Statistical Digest No. 69

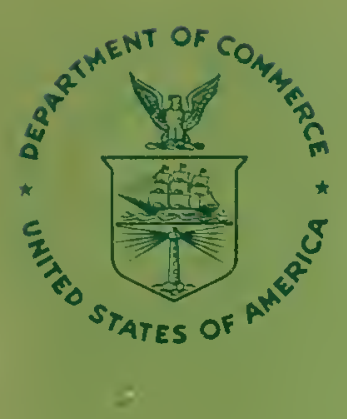

\title{
Fishery Statistics of the United States 1975
}

Washington, D.C.

December 1978

U.S. DEPARTMENT OF COMMERCE National Oceanic and Atmospheric Administration National Marine Fisheries Service 



\section{Statistical Digest No. 69}

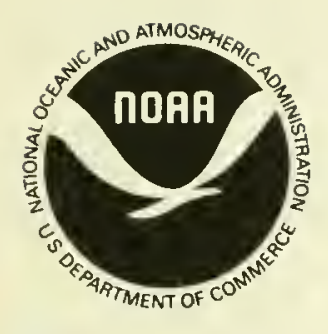

\section{Fishery Statistics of the United States \\ 1975}

Prepared by:

Resource Statistics Division

Joseph Pileggi, Chief

B.G. Thompson, Assistant Chief

Edited by:

Thelma I. Bell and Donald S. FitzGibbon

Washington, D.C.

December 1978

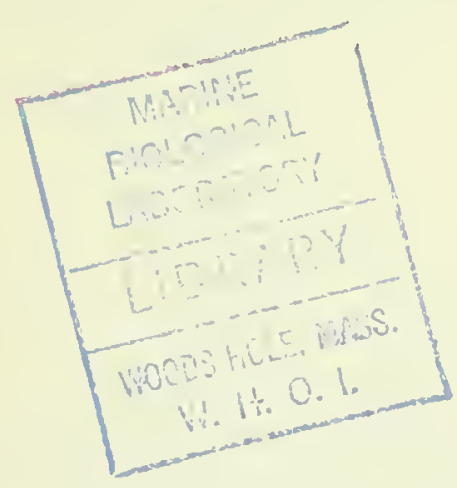

U.S. DEPARTMENT OF COMMERCE

Juanita M. Kreps, Secretary

National Oceanic and Atmospheric Administration

Richard A. Frank, Administrator

National Marine Fisheries Service

Terry L. Leitzell, Assistant Administrator for Fisheries 
For sale by the Superintendent of Documents, U.S. Government Printing Office Washington, D.C. 20402 (paper cover)

Stock Number 003-020-00146-7 


\section{PREFACE}

This report contains a review of U.S. commercial fishery statistics for the calendar year 1975 . These statistics include data on the volume and value of landed catches, employment, quantity of gear operated, and number of fishing craft. Also included are data on the volume and value of production of processed fishery products, freezings and cold storage holdings, and foreign trade in fishery commodities.

Landings data do not include production of artificially cultivated fish or shellfish, except oysters. Landings data include neither the marine or freshwater catches made for sport or personal use including those by Aleuts, Eskimos, and Indians, nor landings by foreign fishing vessels in U.S. ports, nor imports. They include landings made by U.S. fishing vessels at foreign ports for transshipment to the United States under bond or as "Products of American Fisheries."

Unless otherwise noted, landings data are only for the 50 States. Landings in Puerto Rico are shown separately in Section 11. Data on production of processed products are for the 50 States, Puerto Rico, and American Samoa.

Weights in all of the U.S. landings tables in this report, except the one entitled, "U.S. Landings, 1975-Live Weight Besis," are in round (live) weight, excluding weight of shells. Weights shown for univalve and bivalve mollusks (conchs, clams, oysters, scallops, et al.) represent the weights of meats. The weight of shells omitted from the catch in 1975 was about 1.2 billion pounds. It should be noted, however, that the data in the table "World Landings of Fish, Crustaceans, Mollusks, et al., by Countries" are shown on a live weight basis with shell weights included.

Values of the landings are gross dollar returns to the fishermen, and are known as "exvessel prices." The values shown for the processed fishery products are the gross amounts received by the producer at the production point; no deductions are made for commission or expenses.

All appropriate records collected by the various State fishery agencies were used in assembling data on the fisheries. In certain areas, information complete enough to be used by the statistical agents was available from State agencies, and in these States, only partial surveys were made. Information on the means of collecting the data and an explanation of terms used may be found in Section 14 of this publication.

Complete statistical surveys covering the fisheries of the United States were made by the National Marine Fisheries Service in all areas for 1970-75. The first complete survey of the fisheries of the United States was made by the Bureau of Census for 1908. Others were made by the Bureau of Fisheries and the Fish and Wildlife Service for the years 1931, 1950, 1954-60, and 1962-69.

\section{ACKNOWLEDGMENTS}

The data in this edition of "Fishery Statistics of the United States" were collected in cooperation with the various States and tabulated by the staff of the Resource Statistics Division under the direction of Joseph Pileggi and B.G. Thompson. The material was prepared for publication by Thelma I. Bell. Field surveys were supervised by the various regional and area offices. Program leaders in charge of field surveys were: Francis Riley, New England, Middle Atlantic, Chesapeake, Great Lakes and northern Mississippi River States; E. E. Burgess, South Atlantic, Gulf, and southern Mississippi River States; James R. Bybee, California; John K. Bishop, Washington and Oregon; Kaysa A. Stutte, Alaska; and Robert T. B. Iverson, Hawaii.

The cooperation of the many contributors is gratefully acknowledged. Contributors are given credit for their information in the section of the report in which the data appear. 


\section{FISHERY STATISTICS OF THE UNITED STATES, 1975 RESOURCE STATISTICS DIVISION CONTENTS}

SECTION 1. - GENERAL REVIEW

U.S. Summaries

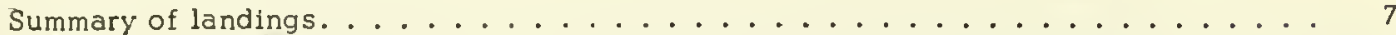

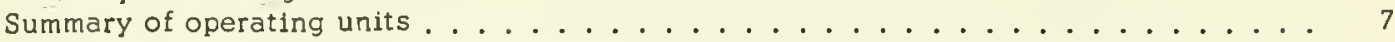

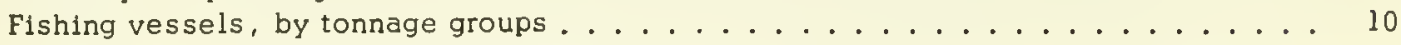

Flshing vessels, by length distribution . . . . . . . . . . . . . 11

Fishing vessels, by year built and region. ................. 12

Fishing vessels, by gear and construction .................. 14

Landings by waters, fishermen, craft, plants, and employment, by States . . . . 16

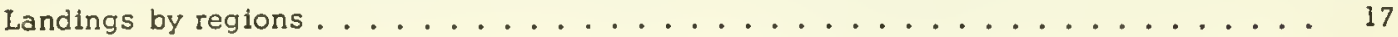

Landings of catch by gear. . . . . . . . . . . . . . . . . . 26

Landings by U.S. fishing craft, by distance caught off U.S. shores and

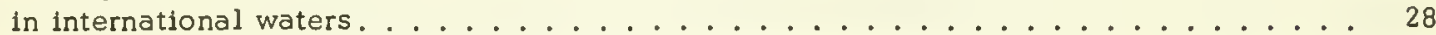

U.S. landings for human food and industrial use. . . . . . . . . . . . . . 31

Relative volume of the landings, by species . . . . . . . . . . . . . . 35

Relative value of the landings, by species. . . . . . . . . . . . . . . 36

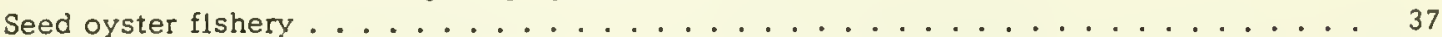

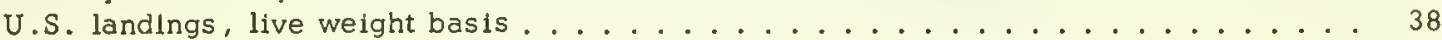

World landings of fish, crustaceans, mollusks, et al., by countries . . . . . . . 39

Processed fishery products . . . . . . . . . . . . . . . . . . . . . 40

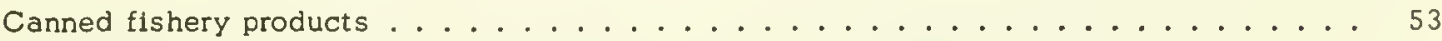

Industrial fishery products . . . . . . . . . . . . . . . . . . . 62

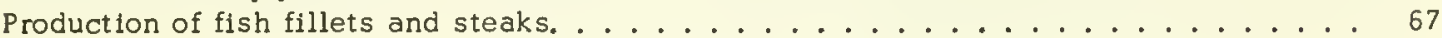

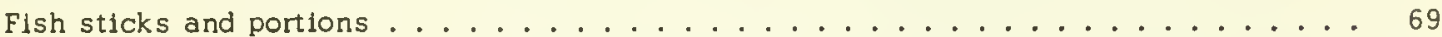

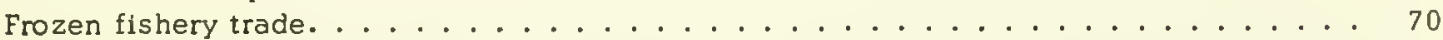

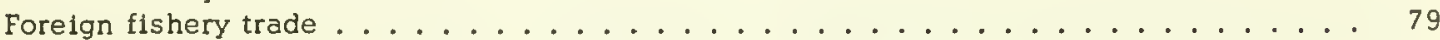

SECTION 2. - NEW ENGLAND FISHERIES 86

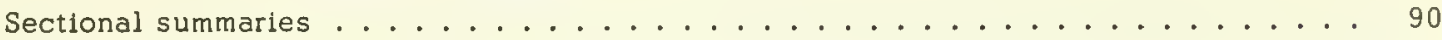

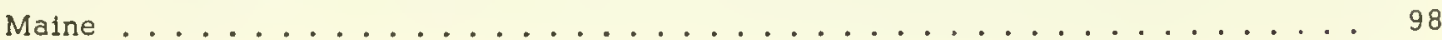

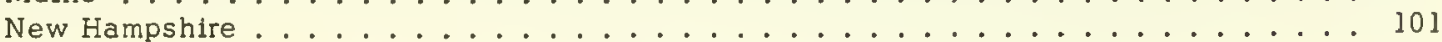

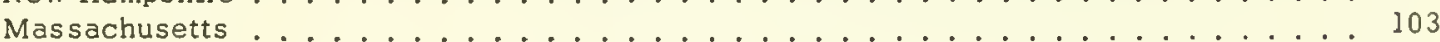

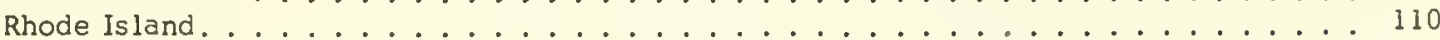

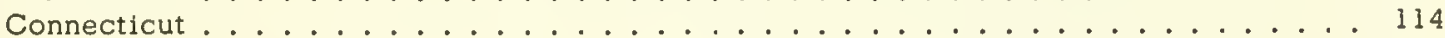

SECTION 3. - MIDDLE ATLANTIC FISHERIES 116

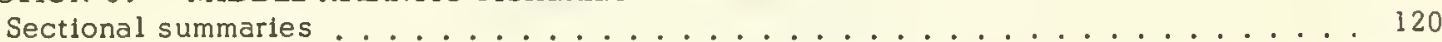

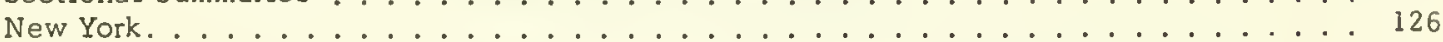

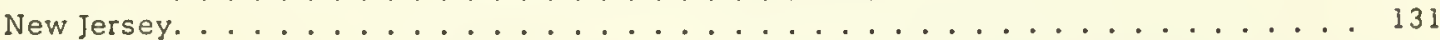

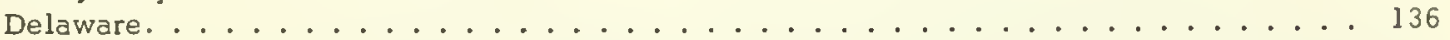

SECTION 4. - CHESAPEAKE FISHERIES 139

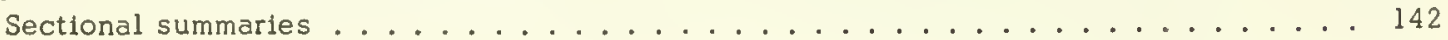

Maryland. . . . . . . . . . . . . . . . . . . . . . 147

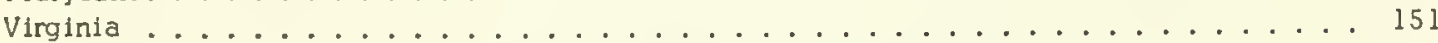

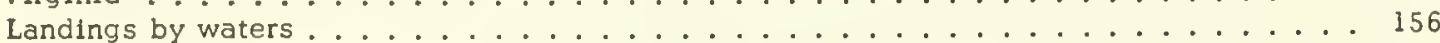




\section{CONTENTS - Continued}

SECTION 5. - SOUTH ATLANTIC FISHERIES 159

Sectional summaries . . . . . . . . . . . . . . . . . . . . . . 162

North Carolina . . . . . . . . . . . . . . . . . . . . . 170

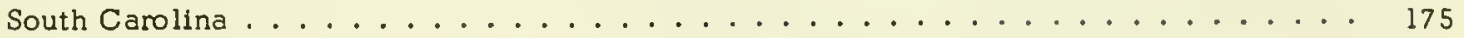

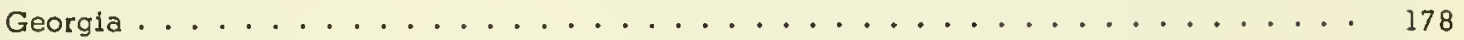

Florida, east coast. . . . . . . . . . . . . . . . . . . . 180

Supplementary surveys:

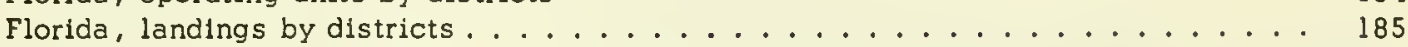

South Atlantic shrimp fishery ...................... 187

SECTICN 6. - GULF FISHERIES 189

Sectional summaries . . . . . . . . . . . . . . . . . . . . . . 192

Florlda, west coast . . . . . . . . . . . . . . . . . . . . 200 200

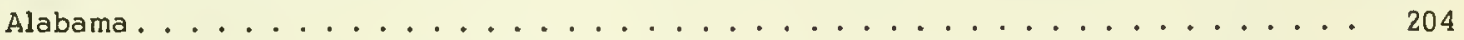

Mississippi. . . . . . . . . . . . . . . . . . . . . . . . . 205

Loulsiana . . . . . . . . . . . . . . . . . . . . . . . 207

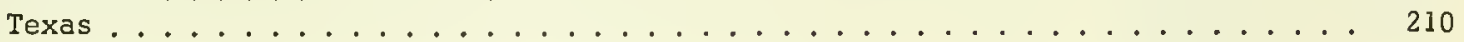

Supplementary survey - Gulf shrimp fishery. . . . . . . . . . . . . . . 212

SECTION 7. - PACIFIC COAST FISHERIES 219

Sectional summaries. . . . . . . . . . . . . . . . . . . . . . . . . 226

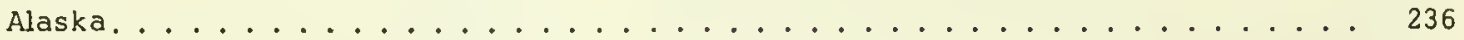

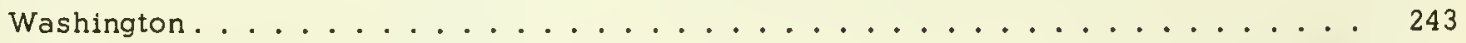

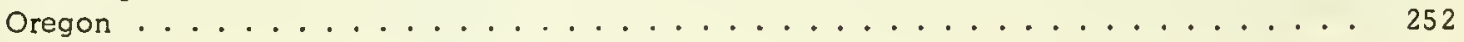

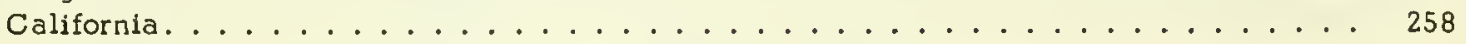

SECTION 8. - GREAT LAKES FISHERIES 278

United States and Canadian landings. . . . . . . . . . . . . . . . . . . . 280

Sectional summaries . . . . . . . . . . . . . . . . . . . . . . . . 283

Operating units and fishing effort, by gear . . . . . . . . . . . . 293

Landings of catch by lake, State, and gear. . . . . . . . . . . . . 298

SECTION 9. - MISSISSIPPI RIVER FISHERIES 305

Sectional summaries . . . . . . . . . . . . . . . . . . . . . . 306

Supplementary survey - Great Lakes and Mississippi River landings

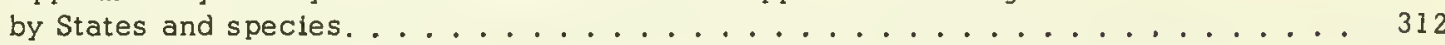

SECTION 10. - HAWAII FISHERIES 316

Sectional summaries . . . . . . . . . . . . . . . . . . . . 317

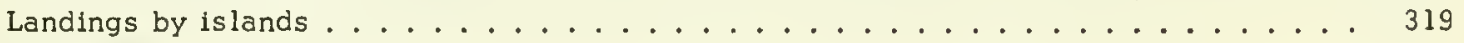

Landings of catch by gear. . . . . . . . . . . . . . . . . . . 322 


\section{CONTENTS - Continued}

SECTION 11. - PUERTO RICO FISHERIES 326

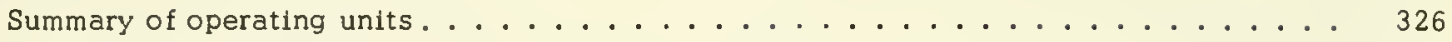

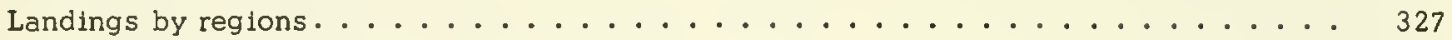

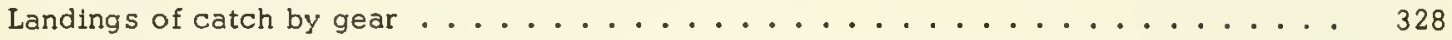

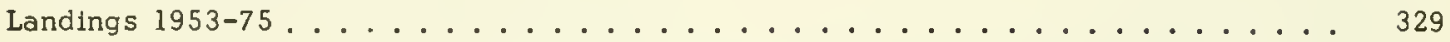

SECTION 12. - REVIEW OF CERTAIN MAJOR FISHERIES 331

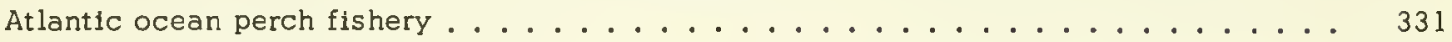

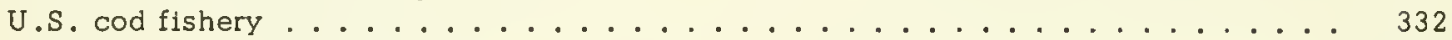

Atlantic coast haddock fishery. . . . . . . . . . . . . . . . 334

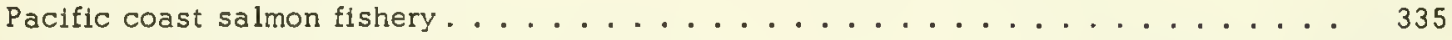

Atlantic coast tuna fishery......................... 341

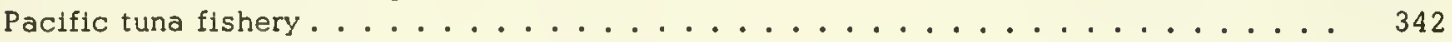

Landings of tuna by U.S. flag vessels, by ocean of capture and species, 1960-75 . . 346

U.S. menhaden fishery . . . . . . . . . . . . . . . . . 347

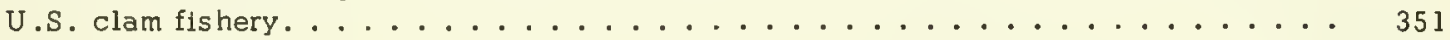

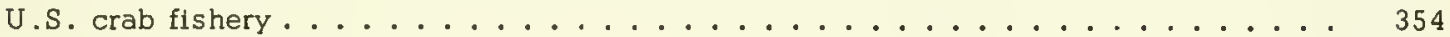

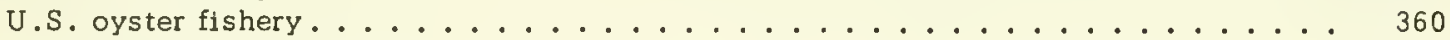

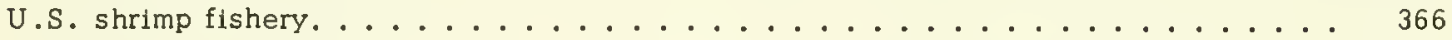

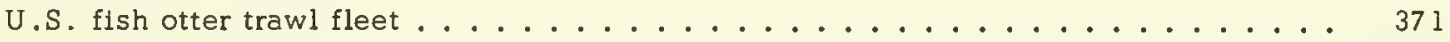

SECTION 13. - STATISTICAL SURVEY PROCEDURE 376

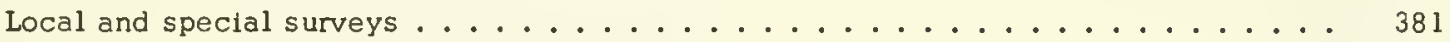

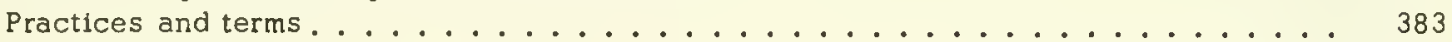

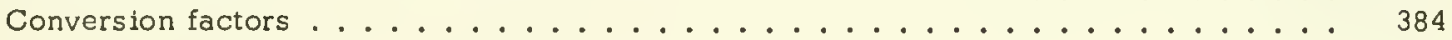

SECTION 14. - GLOSSARY ......................... 388

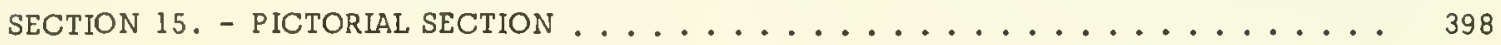

SECTION 16. - STATISTICAL PUbLICATIONS. ............... 416 
In 1975 , commercial fishery landings at U.S. ports were 4.9 billion pounds worth a record $\$ 976.6$ million. The volume landed was 2 percent less than in 1974 , but the value was 5 percent greater than in 1974 and 4 percent greater than in 1973, the former record year. Landings declined for several major species such as menhaden, albacore and yellowfin tuna, shrimp, chum and silver salmon, yellowtail flounder, clams, alewives, and Atlantic ocean perch. However, landings of bluefin tuna, anchovies, whiting, and jack mackerel increased significantly.

U.S.-flag vessels also landed 184.1 million pounds valued at $\$ 52.5$ at ports outside the United States in 1975. These landings consisted principally of tuna at ports in Puerto Rico and shrimp at ports in the Caribbean area.

Fishermen took 931.5 million pounds of shellfish worth $\$ 492.2$ million, an average of 53 cents per pound-10 cents per pound more than in 1974. Shellfish accounted for 50 percent of the value, but only 19 percent of the volume of landings of fish and shellfish in the United States. The value of shellfish landings exceeded the value of finfish landings in the Atlantic, Gulf, and the Pacific. Data on shellfish landings do not include the weight of the shells of clams, oysters, and other mollusks. (See Section 1.-General Review, "U.S. landings, live weight basis.")

Per capita consumption. The per capita consumption of commercially caught fish and shellfish was 12.1 pounds of fish (edible weight) in 1975 , down slightly from the 12.2 pounds in 1974 . For the fourth consecutive year, fish consumption remained above 12 pounds per person.

\section{U.S. PER CAPITA CONSUMPTION OF COMMERCIAL FISH AND SHELLFISH}

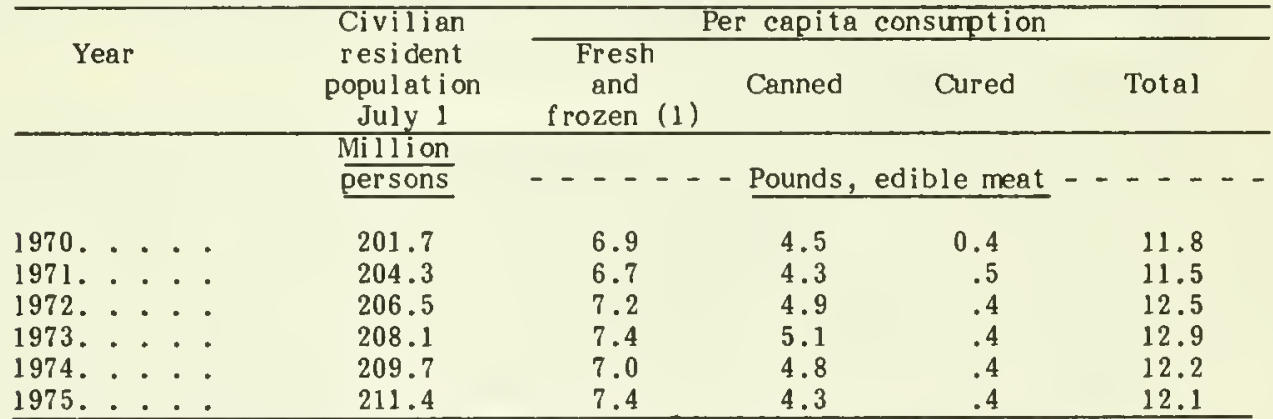

1/ Beginning in 1973, data included consumption of artificially cultivated catfish.

Note:-Per capita consumption represents the pounds consumed of edible U.S. production from both domestically caught and imported fish and shellfish adjusted for the beginning and ending inventories, imports, exports, and military purchases, divided by the civilian resident population of the United States on July 1 of each year. These consumption figures refer only to consumption of fish and shellfish entering commercial channels, and do not include amounts harvested and consumed by recreational fishermen.

Principal States. Louisiana again led the nation in volume of landings with 1.1 billion pounds-23 percent of all U.S. landings. California was second with 875.0 million pounds, followed by Virginia with 444.8 million pounds; Alaska, 444.1 million pounds; Mississippi, 309.6 million pounds; and Massachusetts, 273.8 million pounds.

California led all States in exvessel value of landings with $\$ 134.7$ million-14 percent of the total. Alaska was next with $\$ 129.7$ million; followed by Texas with $\$ 93.6$ million; Louisiana, $\$ 89.0$ million; and Massachusetts, $\$ 82.9$ million.

Principal ports. San Pedro, Calif., led all ports in volume of landings with 606.8 million pounds. Cameron, La., was second with 395.0 million pounds, followed by Pascagoula-Moss Point, Miss., 242.6 million pounds; Dulac-Chauvin, La., 204.2 million pounds; Empire, La., 176.9 million pounds; Morgan City, La., 140.2 million pounds; and Gloucester, Mass., 126.4 million pounds. 
Fishermen and vessels. In the United States, 168,013 fishermen operated 16,211 vessels ( 5 net tons or more) and 86,983 other craft in 1975 . This was an increase of 6,652 fishermen, 320 vessels, and 1,638 other craft compared with 1974 .

Processed products. See "Processed fishery products" in this section.

Alewives. Landings were 58.9 million pounds valued at $\$ 1.2$ million, down 16 percent in volume and 19 percent in value compared with 1974. Production in Lake Michigan of 35.2 million pounds declined 23 percent; Chesapeake, 12.1 million pounds, 18 percent; South Atlantic, 6.0 million pounds, 5 percent; and Middle Atlantic, 25,000 pounds, declined 4 percent. Lendings in the New England States were 5.6 million pounds, up 55 percent from 1974. The Gulf States had no production of alewives in 1975.

Anchovies. See Section 7.-Pacific Coast Fisheries.

Clams. Landings yielded 113.4 million pounds (meat weight) valued at $\$ 43.4$ million,a decrease of 7 percent in

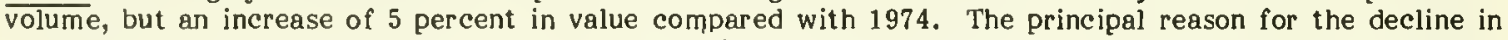
har vest was a decline of 9 million pounds ( 10 percent) in surf clam landings.

Surf clams were 77 percent of the total clam landings but only 29 percent of the value. Virginia led in surf clam landings with 39.1 million pounds, 33 percent less than in 1974 . New Jersey was second with 35.6 million pounds of meats, up 57 percent from the previous year. Virginia and New Jersey accounted for 86 percent of the total surf clam landings in 1975.

Hard clams led in value of landings with 49 percent of the total, but only accounted for 13 percent of the total volume. Surf clams were second in value with 29 percent of the total. Soft clams were third in both volume ( 8 percent) and value $(20$ percent). The remaining 2 percent of clam landings consisted of cockle, geoduck, ocean quahog, razor, and mixed clams. The Middle Atlantic States led in both volume (47 percent) and value ( 51 percent) of landings followed by the Chesapeake States with 41 percent of the total volume and 21 percent of the total value.

Crabs. Landings of all species of crabs were 306.1 million pounds valued at $\$ 81.0$ million, down 8 percent in $\overline{v o l u m}$ and 5 percent in value compared with 1974. Landings of all species of crabs declined except for dungeness, king, and rock crabs. Landings of hard blue crabs were 134.7 million pounds-down 10 percent from 1974, the record year. In the Chesapeake States, landings of hard blue crabs (59.1 million pounds) decreased 10 percent; landings in the South Atlantic States (30.5 million) decreased 20 percent; and landings in the Gulf States (38.7 million pounds) decreased 4 percent. However, landings from the Middle Atlantic States of 6.4 million pounds increased 29 percent over 1974 . Virginia led in production with 34.8 million pounds, followed by Maryland with 24.3 million and Louisiana with 17.1 million pounds. The three States together accounted for 25 percent of the total landings of hard blue crabs. Dungeness crab landings were 18.4 million pounds worth $\$ 11.4$ million-31 percent more in volume and 23 percent more in value than 1974 . Landings of king crab (97.6 million pounds) increased 3 percent, and were the highest since 1968 . The snow crab fishery (46.9 million pounds) showed a 27 -percent decrease in landings in 1975, mainly because of poor market conditions and high inventories in cold storage. A price dispute between fishermen and buyers almost halted snow crab fishing during part of the 1975 fishing season.

Flounders. Landings were 161.6 million pounds valued at $\$ 44.3$ million, a decrease of 815,000 pounds, but an increase of $\$ 8.5$ million compared with 1974 . The value increase was attributed mainly to the scarcity of the yellowtail flounder which caused prices to rise from an average of 25 cents per pound in 1974 to 36 cents per pound in 1975. Landings from the Atlantic States accounted for 64 percent of the total flounder catch, followed by the Pacific Coast States with 35 percent and the Gulf States with 1 percent. Landings of Pacific flounders were 56.6 million pounds worth $\$ 8.6$ million, an increase of 2.1 million pounds in volume and $\$ 517,000$ in value. AImost all of the U.S. catch of Atlantic flounders is taken in waters subject to the regulations by the International Convention for the Northwest Atlantic Fisheries (ICNAF) catch recommendations. The U.S. catch of yellowtail flounder, which has fallen steadily from 72.0 million pounds in 1972 to 42.9 million pounds in 1975 , has been the subject of great concern. The ICNAF has sharply reduced the yellowtail catch quota for all nations and given the United States almost all (99 percent) of the total allowable catch in 1975 and 1976 in waters off the U.S. Atlantic Coast.

Groundfish. Landings of Atlantic groundfish (Atlantic ocean perch, cod, cusk, haddock, hakes, pollock, and whiting) were 182.0 million pounds valued at $\$ 29.5$ million, an increase of 6 percent in volume and 25 percent in value over 1974. Larger landings of haddock (up 97 pel'cent) and whiting (up 43 percent) were responsible for the increase. Cod was the leading groundfish in both volume and value. Landings of Atlantic cod were 
56.1 million pounds valued at $\$ 13.2$ million, down 4 percent in volume but up 17 percent in value compared with 1974. Atlantic ocean perch landings of 32.1 million pounds declined 23 percent compared with 1974 and was the lowest since 1935 .

Landings of Pacific groundfish (cod, Pacific hake, Pacific ocean perch and other rockfishes, pollock, lingcod, and sablefish) were 83.0 million pounds valued at $\$ 10.1$ million, an increase of 1.5 million pounds in volume and $\$ 275,000$ in value. Landings of cod, lingcod, and sablefish increased in 1975 , but landings of all other species declined.

Imports of groundfish fillets (including blocks) were 513.8 million pounds worth $\$ 278.4$ million, up 82.4 million pounds in volume and $\$ 27.9$ million in value compared with 1974 . The available supply (U.S. production plus imports) of groundfish fillets and blocks was 556.0 million pounds, an increase of 71.7 million pounds compared with 1974 .

Halibut. Landings on the Pacific Coast accounted for all but 171,000 pounds landed in New England. (See Section 7.-Pacific Coast Fisheries.)

Jack mackerel. See Section 7.-Pacific Coast Fisheries.

Lobsters, American. Landings were 30.2 million pounds valued at a record $\$ 51.4$ million, an increase of 6 percent in volume and 19 percent in value over 1974. Fishermen received an average exvessel price of $\$ 1.70$ in 1975 compared with $\$ 1.52$ in 1974. Landings increased in the New England States, but declined in the Middle Atlantic and Chesapeake States. In Maine, the principal producing State, landings of 17.0 million pounds were 550,000 pounds more than in 1974. The available supply (U.S. domestic landings of American lobsters plus imports from Canada) were 48.5 million pounds in 1975 compared with 46.1 million pounds in 1974.

Lobsters, spiny. The spiny lobster harvest declined to 7.6 million pounds worth $\$ 10.3$ million, down 31 percent in volume and 25 percent in value from 1974. Florida accounted for 97 percent of the total spiny lobster production. Landings in Florida were 7.4 million pounds in 1975, down 32 percent from 1974. This decrease from 1974 was the result of smaller catch being taken from the Florida Keys and the permanent closing of Bahama waters. The closure of the Bahama waters is expected to curtail the Florida fishing industry for years to come. The California commercial harvest of 201,000 pounds was 5 percent more than in 1974.

Menhaden. Landings were 1.8 billion pounds worth $\$ 49.4 \mathrm{million}$, a decrease of 10 percent in volume and 26 percent in value compared with 1974 . The sharp drop in value reflects a decline in prices for fish meal and fish oil from the abnormally high levels in 1974 .

Landings of Gulf menhaden were 1.2 billion pounds in 1975 , down 99.0 million pounds compared with 1974, but the fourth largest on record. Fishing effort in the Gulf in terms of thousands of vessel ton weeks was the highest on record, but poor fishing weather during the season may have been one factor that held down landings.

Landings of Atlantic menhaden were 606.7 million pounds in 1975, down 14 percent from 1974. Fishing effort was down slightly, and there was a poor showing of fish in New England, Middle Atlantic, and Chesapeake fishing grounds.

About 98 percent of the Atlantic and Gulf landings were used for reduction to fish meal, oil, and solubles in 1975. Most of the rest was used for bait except for a small quantity canned for animal food. Production of menhaden meal (191,400 tons) was down 6 percent, menhaden oil (213,300 pounds) was down 2 percent, and menhaden solubles ( 84,000 tons) was down 18 percent.

Oysters. Landings yielded 53.2 million pounds of meats worth $\$ 45.0$ million, an increase of 6 percent in volume and 10 percent in value over 1974. Production increased in the Middle Atlantic, Gulf, and Pacific Coast States, but declined in the New England, Chesapeake, and South Atlantic States. The Chesapeake States led in production with 22.6 million pounds of meats, followed by the Gulf States with 19.3 million. The Chesapeake and Gulf States accounted for 79 percent of the landings. In the Chesapeake fishery, Maryland was first in production with 16.4 million pounds, down 10 percent comparcd with 1974 . Recruitment in the Maryland fishery has been poor in recent years. In the Gulf States, Louisiana led in production with 13.7 million pounds, up 37 percent over 1974. 
Salmon. Virtually all landings were on the Pacific Coast. (See Section 7.-Pacific Coast Fisheries.)

Scallops. Landings yielded 13.7 million pounds of meats worth $\$ 23.0$ million, a gain of 51 percent in volume and 82 percent in value compared with 1974 . The exvessel price per pound of $\$ 1.68$ increased 29 cents compared with 1974.

Landings of all species of scallops increased. The production of sea scallops were 10.1 million pounds of meats worth a record $\$ 18.3$ million, an increase of 56 percent in volume and 85 percent in value over 1974. New England landings (7.1 million pounds) accounted for 70 percent of the total production. Bay scallop landings were 1.6 million pounds valued at $\$ 3.4$ million, an increase of 10 percent in volume and 62 percent in value compared with 1974. Landings of calico scallops at Florida ports yielded 2.0 million pounds of meats valued at $\$ 1.2$ million, up 76 percent in volume and 102 percent in value over 1974 .

Sea herring. Landings of sea herring were 130.9 million pounds worth $\$ 6.3$ million, up 2 percent in volume, but down 3 percent in value compared with 1974. Landings increased along both the Atlantic and Pacific coasts. The Atlantic catch of 79.7 million pounds valued at $\$ 2.7$ million accounted for 61 percent of the total landings. Maine was the leading State with 38.2 million pounds, Massachusetts followed with 32.2 million pounds. Small landings in Rhode Island, New York, New Jersey, Delaware, Maryland, and Virginia accounted for the rest. Pacific landings were 51.2 million pounds valued at $\$ 3.6$ million. Alaska landings of 35.5 million pounds were 69 percent of the Pacific Coast production.

Shrimp. Landings of 346.7 million pounds (heads-on) were worth a record $\$ 225.7$ million to the fishermen. This was a decline of 7 percent in volume, but an increase of 25 percent in value compared with 1974. The Gulf States accounted for 49 percent of the total volume and 79 percent of the total value. Landings along the Gulf Coast of 170.1 million pounds valued at $\$ 178.3$ million declined 9 percent in volume, but increased 29 percent in value. Similarly, landings in the South Atlantic States of 24.9 million pounds valued at $\$ 30.3$ million declined 8 percent in volume, but increased 65 percent in value. Exvessel prices paid to fishermen in the South Atlantic and Gulf States increased from 73 cents per pound in 1974 to a record \$1.07 in 1975. Shrimp landings in the Pacific Coast States of 140.1 million pounds valued at $\$ 13.9$ million declined 2 percent in volume and 25 percent in value compared with 1974. Alaska led in volume with 99.0 million pounds followed by record landings in Oregon (23.9 million pounds) and Washington ( 10.0 million pounds). New England landings of 11.7 million pounds worth $\$ 3.1$ million declined 34 percent in volume and 45 percent in value compared with 1974. The decline was due to a number of factors including overfishing in the previous seasons, price disputes, and closure by Maine officials of the Maine summer shrimp fishery to help restore depleted stocks.

U.S. imports of shrimp (including fresh or frozen, canned, and cured) were 201.5 million pounds (import weight), a decrease of 27.5 million pounds ( 12 percent) compared with 1974 , the record year. Mexico continued as the leading country exporting shrimp to the United States.

Tuna. Landings in the United States were 392.5 million pounds valued at $\$ 106.8$ million, an increase of 304,000 pounds, but a decline of $\$ 12.4$ million compared with 1974 , the record year in value. Landings in 1975 were the second highest on record. Landings of all species of tuna inereased except albacore and yellowfin. Landings of albacore tuna were 49.0 million pounds, down 11 percent; landings of yellowfin tuna were 242.0 million pounds, down 5 percent from 1974. Landings of bluefin tuna (21.3 million pounds) increased 52 percent, and skipjack tuna $(79.5$ million pounds) increased 16 percent. Landings of bigeye and little tuna also increased.

Landings of tuna in Puerto Rico were a record 177.1 million pounds valued at $\$ 44.4$ million, up 7 percent in volume, but down 3 percent from the record value in 1974 . The greater harvest resulted principally from increased landings of yellowfin tuna ( 99.6 million pounds), up 12 percent. Landings of bluefin tuna $(760,000$ pounds) increased 442,000 pounds, and skipjack tuna ( 76.7 million pounds) increased 616,000 pounds. However, the value of skipjack tuna ( $\$ 17.8$ million) declined 13 percent because exvessel prices dropped from $\$ 2.69$ per pound in 1974 to $\$ 2.32$ per pound in 1975 .

In 1975 the pack of canned tuna, 27.0 million standard cases (529.4 million pounds) valued at $\$ 652.6$ million, was the fourth highest pack on record and the third in value. When compared with the record year 1974, the pack decreased 20 percent and the value 21 percent. Canned tuna available for consumption (U.S. pack from domestic landings plus U.S. pack from imported tuna) was 581.1 million pounds in 1975 compared to a record 713.1 million pounds in 1974 . 
World landings. In 1975, world landings were 69.9 million metric tons (154.1 billion pounds), down 1 percent from the 1974 production of 70.5 million metric tons (155.4 billion pounds). Japan, with 15 percent of the total landings, continues to be the world leader in fishery landings, followed by the U.S.S.R. with 14 percent. The Peoples Republic of China was third with 10 percent; followed by Peru, 5 percent; and the United States, 4 percent. The United States was fifth for the third consecutive year.

Other information. Summaries of landings statistics for certain States have been published previousy in the Current Fishery Statistics series of bulletins. A preliminary review titled "Fisheries of the Unites States," available each April, contains current information on many aspects of the fisheries such as domestic and world landings, per capita consumption, price indexes, foreign trade, and supplies, together with comparative data for the previous year. "Fisheries of the United States" is for sale by the Superintendent of Documents, U.S. Government Printing Office, Washington, D.C. 20402.

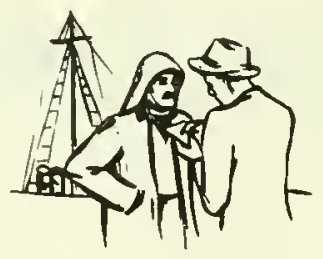


LANDINGS OF FISH AND SHELLFISH, 1945-75

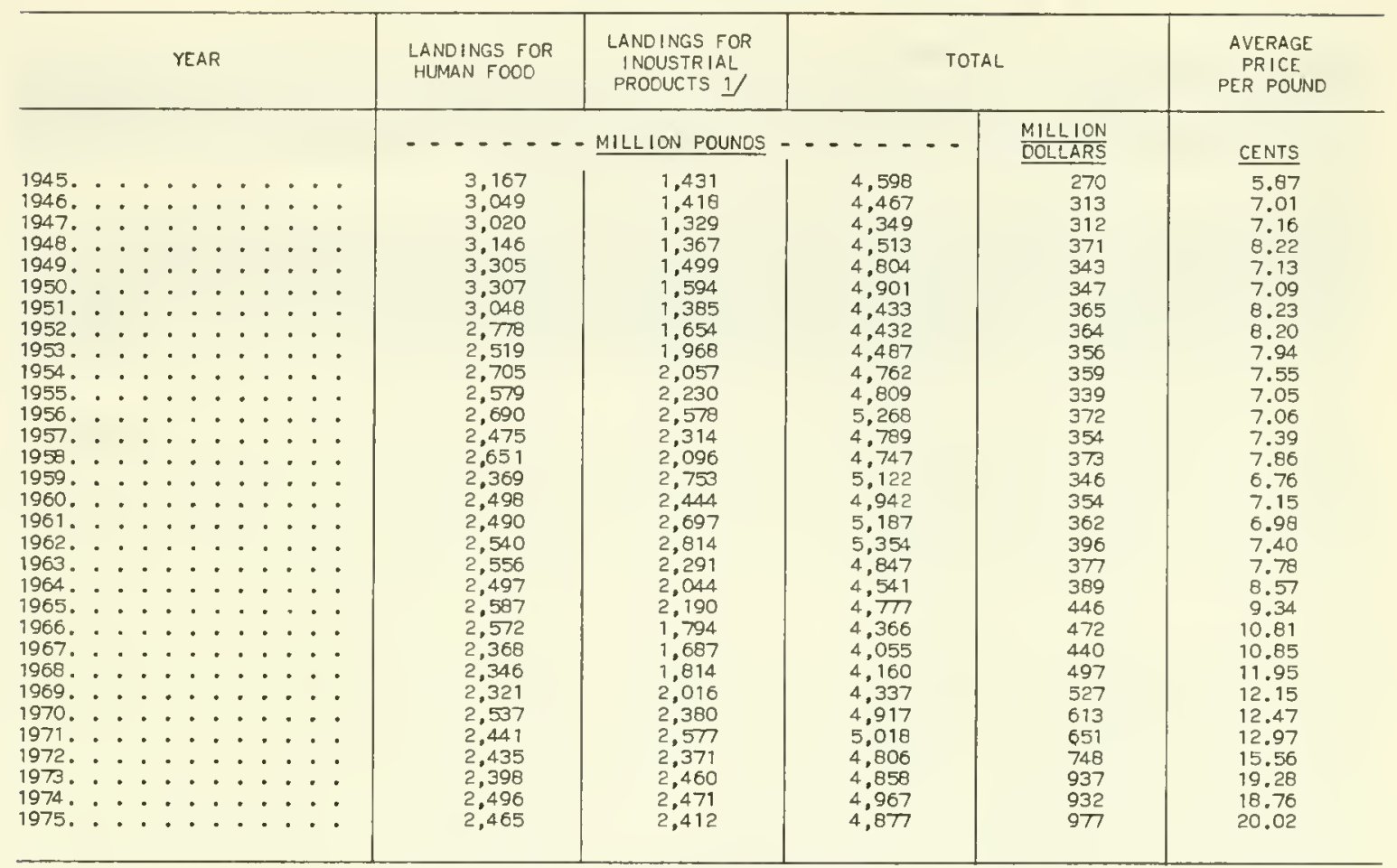

1 MANUFACTUREO INTO MEAL, OIL, FISH SOLUBLES, HOMOGENIZED CONDENSED FISH, SHELL PROOUCTS, AND USEO AS BAIT ANO ANIMAL FOOD.

NOTE:--DOES NOT INCLUDE OATA ON THE HAWAII LANDINGS PRIOR TO 1948.

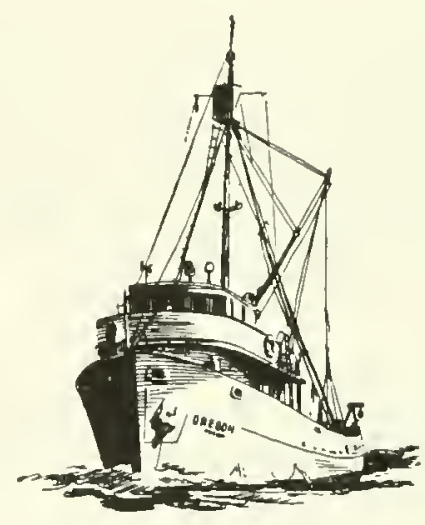


SECTIONAL SUMMARIES

SUMMARY OF LANDINGS, 1975

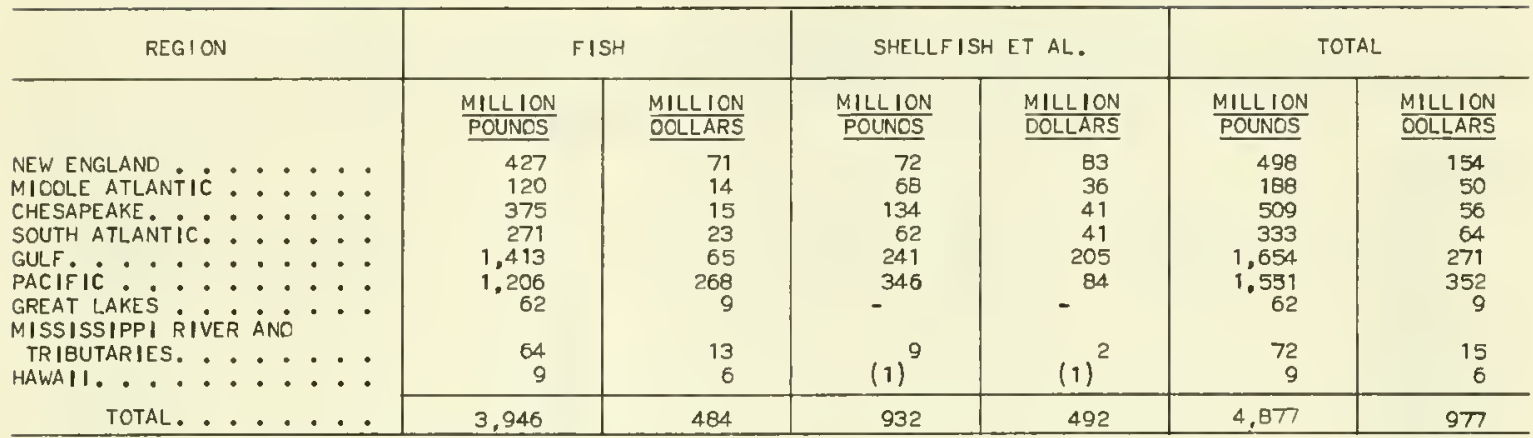

$1 /$ LESS THAN 500,000 POUNDS OR $\$ 500,000$.

NOTE:--TABLE MAY NOT ADO BECAUSE OF ROUNDING.

\section{SUMMARY OF OPERATING UNITS, 1975}

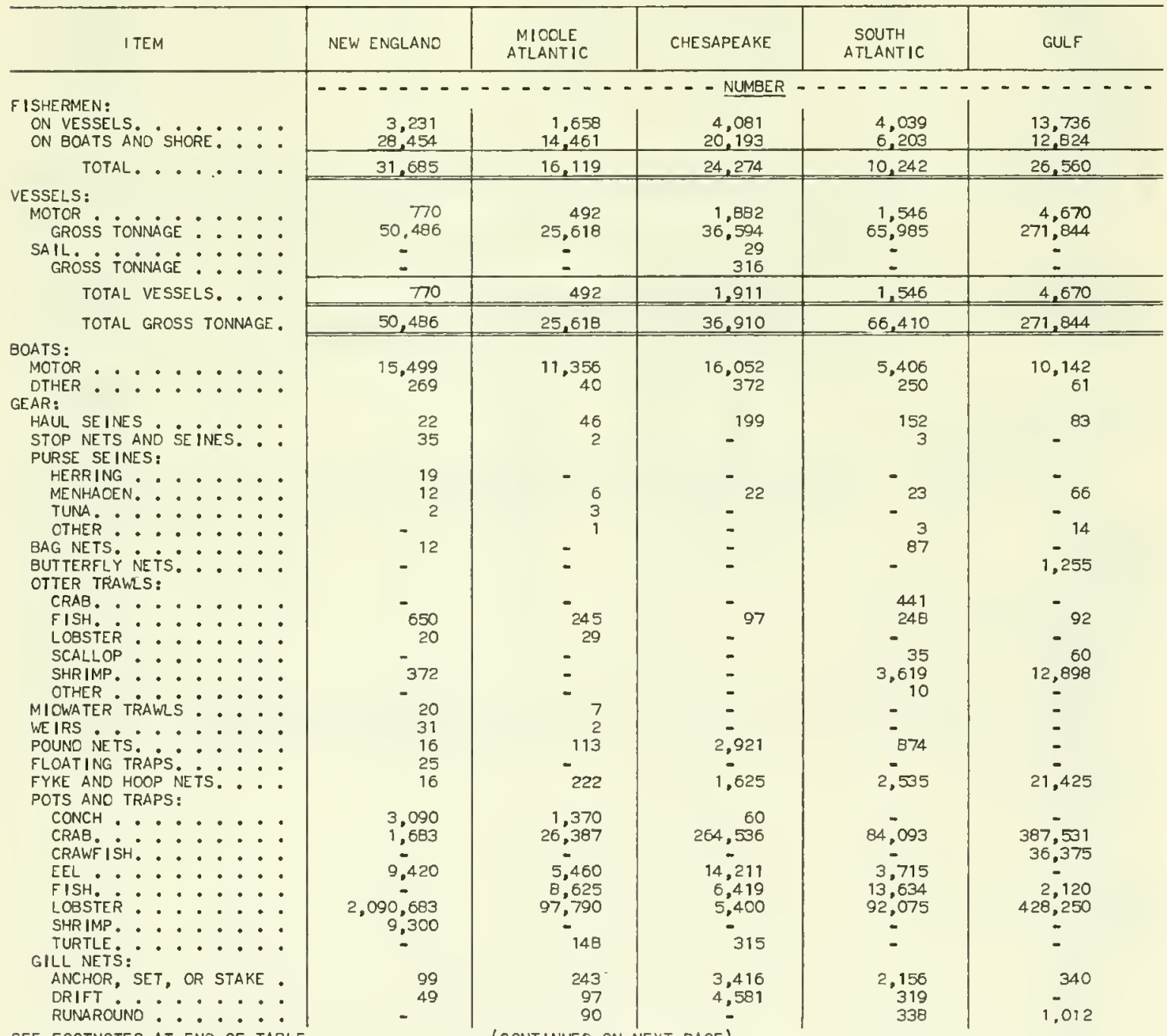

SEE FOOTNOTES AT ENO OF TABLE. 
SUMMARY OF OPERATING UNITS, 1975 - Continued

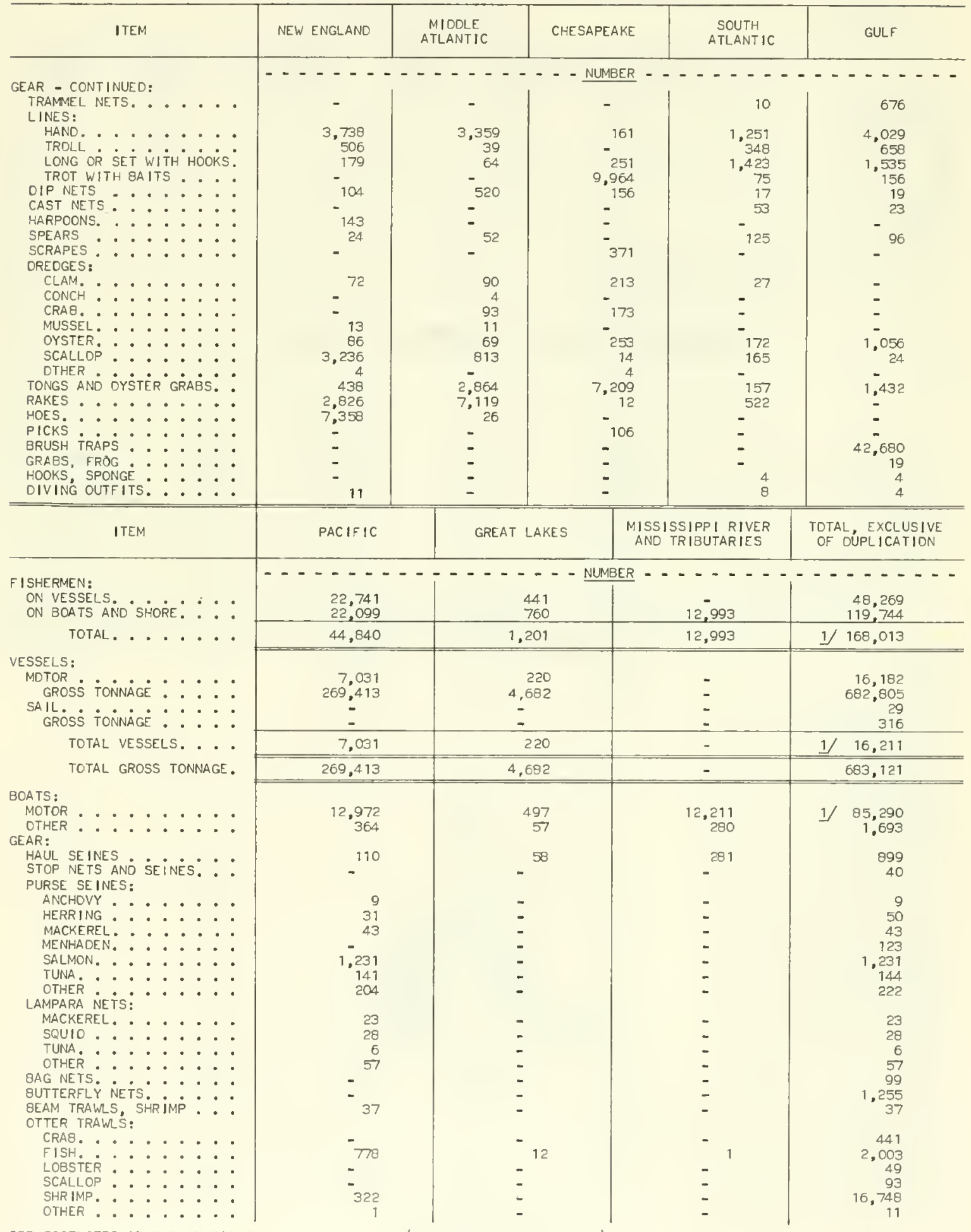




\section{SUMMARY OF OPERATING UNITS, 1975 - Continued}

\begin{tabular}{|c|c|c|c|c|}
\hline ITEM & PACIFIC & GREAT LAKES & $\begin{array}{l}\text { MISSISSIPPI RIVER } \\
\text { AND TRIBUTARIES }\end{array}$ & $\begin{array}{l}\text { TOTAL, EXCLUSIVE } \\
\text { OF DUPLICATION }\end{array}$ \\
\hline 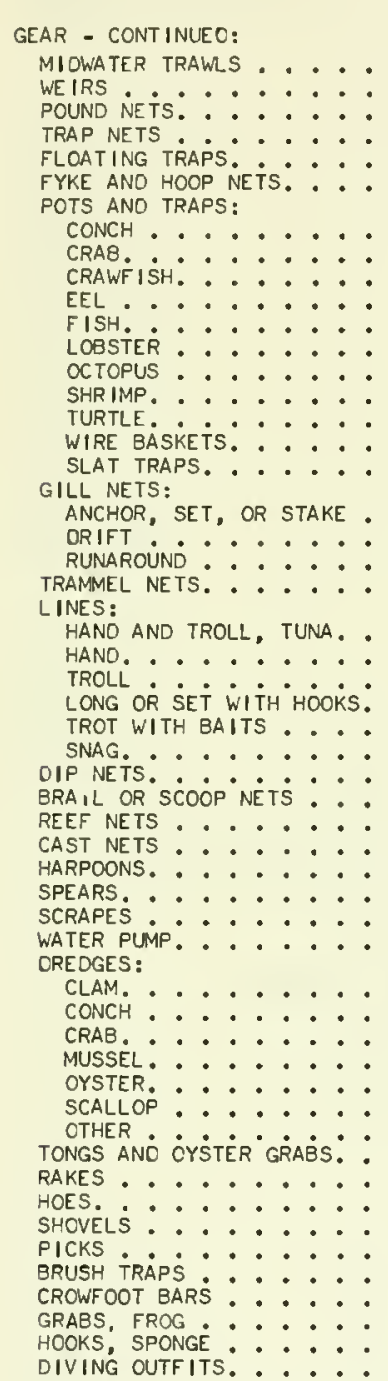 & 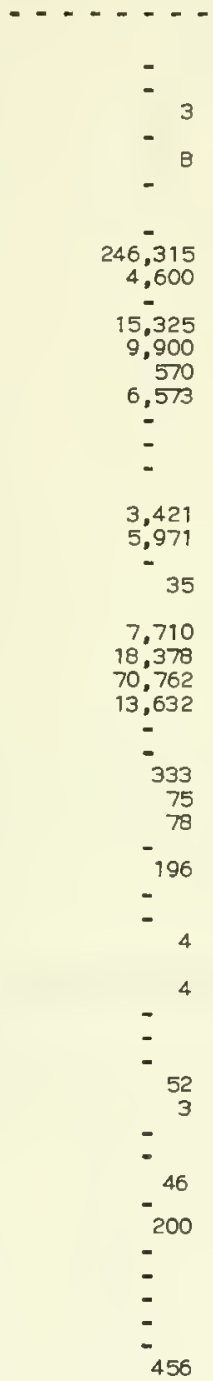 & 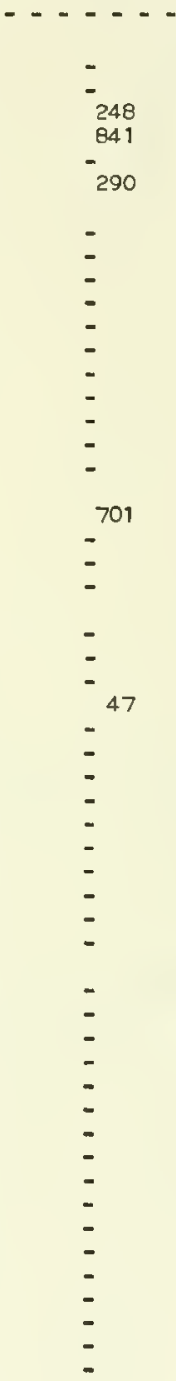 & 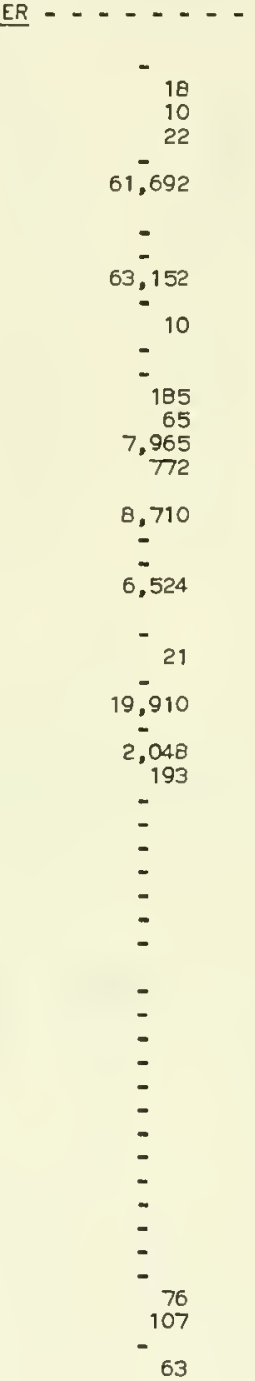 & $\begin{array}{r}27 \\
51 \\
4,179 \\
863 \\
33 \\
87,785 \\
4,520 \\
1,010,545 \\
104,127 \\
32,806 \\
46,133 \\
2,720,748 \\
570 \\
16,058 \\
528 \\
7,965 \\
772 \\
19,086 \\
11,015 \\
1,437 \\
7,245 \\
7,710 \\
30,933 \\
72,313 \\
37,023 \\
10,195 \\
2,048 \\
1,342 \\
75 \\
78 \\
76 \\
339 \\
297 \\
371 \\
4 \\
406 \\
4 \\
4 \\
265 \\
24 \\
1,686 \\
4,250 \\
8 \\
12,100 \\
10,525 \\
7,384 \\
200 \\
106 \\
42,680 \\
76 \\
126 \\
8 \\
542\end{array}$ \\
\hline
\end{tabular}

1/ INCLUOES 2.197 FISHERMEN OPERATING 109 VESSELS ANO 1,278 BOATS IN HAWAII. OATA ON GROSS TONNAGE ANO THE NUMBER OF GEAR OPERATEO IN HAWAII ARE NOT AVAILABLE. 
SUMMARY OF U.S. FISHING VESSELS, BY TONNAGE GROUPS, 1975

\begin{tabular}{|c|c|c|c|c|c|c|c|c|c|c|c|}
\hline & GROSS & TONNAG & & $\begin{array}{c}\text { NEW } \\
\text { ENGLAND }\end{array}$ & $\begin{array}{l}\text { MIOOLE } \\
\text { ATLANT IC }\end{array}$ & $\begin{array}{l}\text { CHESA - } \\
\text { PEAKE } \\
1 /\end{array}$ & $\begin{array}{c}\text { SOUTH } \\
\text { ATLANT IC }\end{array}$ & GULF & PACIFIC & $\begin{array}{l}\text { GREAT } \\
\text { LAKES }\end{array}$ & $\begin{array}{l}\text { TOTAL, } \\
\text { EXCLUSIVE } \\
\text { OF OUPLI - } \\
\text { CATION }\end{array}$ \\
\hline $\begin{array}{r}5 \\
10 \\
20 \\
30 \\
40 \\
50 \\
60 \\
70 \\
80 \\
90\end{array}$ & $\begin{array}{l}-\quad 9 \\
-\quad 19 \\
-\quad 29 \\
-\quad 39 \\
-\quad 49 \\
-\quad 59 \\
-\quad 69 \\
-\quad 79 \\
-\quad 89 \\
-\quad 99\end{array}$ & 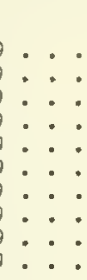 & $\begin{array}{l}: \\
: \\
: \\
: \\
: \\
: \\
:\end{array}$ & $\begin{array}{l}---- \\
15 \\
122 \\
109 \\
88 \\
68 \\
47 \\
40 \\
44 \\
29 \\
37\end{array}$ & $\begin{array}{c}---- \\
36 \\
116 \\
58 \\
48 \\
52 \\
30 \\
27 \\
31 \\
10 \\
26\end{array}$ & $\begin{array}{c}---- \\
1,232 \\
452 \\
56 \\
27 \\
16 \\
10 \\
13 \\
17 \\
10 \\
11\end{array}$ & $\begin{array}{c}---N \\
188 \\
254 \\
220 \\
210 \\
184 \\
110 \\
129 \\
73 \\
52 \\
75\end{array}$ & $\begin{array}{r}\text { ER - - } \\
257 \\
1.076 \\
547 \\
354 \\
270 \\
208 \\
334 \\
211 \\
207 \\
495\end{array}$ & $\begin{array}{c}---- \\
1.251 \\
2.967 \\
919 \\
568 \\
398 \\
218 \\
126 \\
69 \\
52 \\
62\end{array}$ & $\begin{array}{r}-- \\
25 \\
99 \\
57 \\
22 \\
14 \\
-1 \\
-1 \\
-1 \\
-1\end{array}$ & $\begin{array}{r}--- \\
3,000 \\
5,068 \\
1,947 \\
1,276 \\
953 \\
579 \\
608 \\
381 \\
307 \\
634\end{array}$ \\
\hline $\begin{array}{l}100 \\
110 \\
120 \\
130 \\
140 \\
150 \\
160 \\
170 \\
180 \\
190\end{array}$ & $\begin{array}{l}-109 \\
-119 \\
-129 \\
-139 \\
-149 \\
-159 \\
-169 \\
-179 \\
-189 \\
-199\end{array}$ & 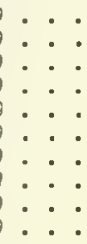 & 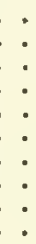 & $\begin{array}{r}18 \\
34 \\
27 \\
22 \\
5 \\
14 \\
10 \\
8 \\
5 \\
19\end{array}$ & $\begin{array}{r}10 \\
12 \\
11 \\
8 \\
5 \\
1 \\
1 \\
-\quad 1 \\
1 \\
3\end{array}$ & $\begin{array}{r}8 \\
6 \\
6 \\
7 \\
3 \\
2 \\
5 \\
1 \\
-\quad 6\end{array}$ & $\begin{array}{r}18 \\
4 \\
5 \\
4 \\
3 \\
-\quad 1 \\
-\quad \\
-\quad \\
-\quad 1\end{array}$ & $\begin{array}{r}200 \\
161 \\
104 \\
112 \\
24 \\
17 \\
17 \\
4 \\
6 \\
4\end{array}$ & $\begin{array}{r}30 \\
37 \\
17 \\
30 \\
16 \\
32 \\
26 \\
8 \\
21 \\
78\end{array}$ & $\begin{array}{ll}- & \\
- & \\
- & 1 \\
- & \\
- & \\
- & \\
- & \end{array}$ & $\begin{array}{r}255 \\
237 \\
154 \\
160 \\
49 \\
66 \\
55 \\
20 \\
30 \\
107\end{array}$ \\
\hline $\begin{array}{l}200 \\
210 \\
220 \\
230 \\
240 \\
250 \\
260 \\
270 \\
280 \\
290\end{array}$ & $\begin{array}{l}-209 \\
-219 \\
-229 \\
-239 \\
-249 \\
-259 \\
-269 \\
-279 \\
-289 \\
-299\end{array}$ & 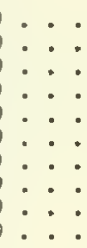 & : & $\begin{array}{l}- \\
- \\
- \\
- \\
- \\
- \\
-\end{array}$ & $\begin{array}{l}- \\
= \\
= \\
- \\
- \\
-2 \\
-\end{array}$ & $\begin{array}{ll}- & \\
- & \\
- & \\
- & \\
& 7 \\
& 5 \\
& 6 \\
- & \\
- & \\
- & \end{array}$ & $\begin{array}{r}1 \\
-\quad \\
-\quad 1 \\
3 \\
1 \\
-\quad 3 \\
-\quad \\
-\quad 2\end{array}$ & $\begin{array}{r}-\quad \\
2 \\
3 \\
1 \\
3 \\
1 \\
1 \\
1 \\
1 \\
7\end{array}$ & 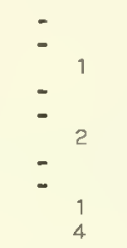 & $\begin{array}{l}- \\
\overline{-} \\
\overline{-} \\
\overline{-} \\
\overline{-} \\
\overline{-} \\
\overline{-}\end{array}$ & $\begin{array}{r}1 \\
2 \\
4 \\
2 \\
6 \\
9 \\
8 \\
3 \\
2 \\
14\end{array}$ \\
\hline $\begin{array}{l}310 \\
320 \\
330 \\
340 \\
350 \\
360 \\
370 \\
380\end{array}$ & $\begin{array}{l}-319 \\
-329 \\
-339 \\
-349 \\
-359 \\
-369 \\
-379 \\
-389\end{array}$ & 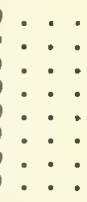 & : & $\begin{array}{l} \\
\quad 2 \\
= \\
= \\
= \\
= \\
=\end{array}$ & 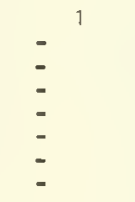 & $\begin{array}{l}- \\
- \\
- \\
- \\
- \\
- \\
-\end{array}$ & $\begin{array}{l}- \\
- \\
= \\
- \\
-\end{array}$ & $\begin{array}{r}1 \\
1 \\
-\quad 1 \\
-\quad \\
-\quad 2 \\
2 \\
2\end{array}$ & $\begin{array}{l}1 \\
3 \\
1 \\
1 \\
2 \\
2 \\
2 \\
1\end{array}$ & $\begin{array}{l}- \\
- \\
- \\
- \\
- \\
-\end{array}$ & $\begin{array}{l}7 \\
6 \\
2 \\
1 \\
2 \\
4 \\
4 \\
4\end{array}$ \\
\hline $\begin{array}{l}410 \\
420 \\
430 \\
440 \\
450 \\
460 \\
470 \\
480 \\
490\end{array}$ & $\begin{array}{l}-419 \\
-429 \\
-439 \\
-449 \\
-459 \\
-469 \\
-479 \\
-489 \\
-499\end{array}$ & 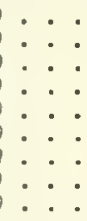 & $\begin{array}{l}: \\
: \\
: \\
: \\
:\end{array}$ & $\begin{array}{l}- \\
- \\
- \\
- \\
- \\
-\end{array}$ & $\begin{array}{l}- \\
\overline{-} \\
\overline{-} \\
\overline{-} \\
\overline{-} \\
\overline{-} \\
\bar{z}\end{array}$ & $\begin{array}{l}- \\
- \\
- \\
\overline{-} \\
\overline{-} \\
\overline{-}\end{array}$ & $\begin{array}{l}- \\
- \\
- \\
- \\
- \\
- \\
-\end{array}$ & $\begin{array}{r}2 \\
-\quad 1 \\
-\quad 1 \\
1 \\
1 \\
3 \\
2 \\
2\end{array}$ & $\begin{array}{r}-1 \\
8 \\
1 \\
1 \\
1 \\
-\quad 1 \\
-\quad 1\end{array}$ & $\begin{array}{l}- \\
- \\
- \\
- \\
- \\
-\end{array}$ & $\begin{array}{l}2 \\
2 \\
9 \\
1 \\
3 \\
2 \\
3 \\
2 \\
4\end{array}$ \\
\hline $\begin{array}{l}510 \\
520 \\
530 \\
540 \\
550 \\
570\end{array}$ & $\begin{array}{l}-519 \\
-529 \\
-539 \\
-549 \\
-559 \\
-579\end{array}$ & 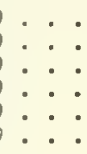 & : & $\begin{array}{l}- \\
- \\
- \\
-\end{array}$ & $\begin{array}{l}- \\
- \\
= \\
- \\
-\end{array}$ & $\begin{array}{l}- \\
- \\
-4 \\
2 \\
-\quad 4\end{array}$ & $\begin{array}{l}- \\
\overline{-} \\
\overline{-} \\
-\end{array}$ & $\begin{array}{r}2 \\
3 \\
12 \\
-\quad 1 \\
-\quad 1\end{array}$ & $\begin{array}{l}- \\
- \\
-\end{array}$ & $\begin{array}{l}- \\
- \\
- \\
- \\
-\end{array}$ & $\begin{array}{r}2 \\
3 \\
17 \\
2 \\
5 \\
1\end{array}$ \\
\hline $\begin{array}{l}600 \\
610 \\
630 \\
640 \\
650 \\
670\end{array}$ & $\begin{array}{l}-609 \\
-619 \\
-639 \\
-649 \\
-659 \\
-679\end{array}$ & 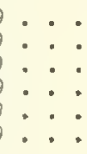 & : & $\begin{array}{l}- \\
- \\
- \\
-\end{array}$ & $\begin{array}{l}-1 \\
-\quad 1 \\
-\quad 1 \\
-\quad 1\end{array}$ & $\begin{array}{l}- \\
\overline{-} \\
- \\
\overline{-}\end{array}$ & $\begin{array}{r}- \\
-1 \\
-1 \\
1\end{array}$ & $\begin{array}{r}1 \\
-\quad 1 \\
-\quad 1 \\
-\quad 1\end{array}$ & $\begin{array}{ll}- & \\
- & 1 \\
- & \\
- & \end{array}$ & $\begin{array}{l}- \\
- \\
- \\
- \\
-\end{array}$ & $\begin{array}{l}1 \\
1 \\
2 \\
2 \\
1 \\
4\end{array}$ \\
\hline $\begin{array}{l}710 \\
720 \\
730 \\
750 \\
760 \\
770\end{array}$ & $\begin{array}{l}-719 \\
\text { - } 729 \\
\text { - } 739 \\
\text { - } 759 \\
-769 \\
-779\end{array}$ & $\begin{array}{l}\cdot: \cdot \\
: \dot{*} \\
: \dot{*} \\
: \dot{*}\end{array}$ & : & $\begin{array}{l}- \\
- \\
- \\
-\end{array}$ & $\begin{array}{l}- \\
- \\
- \\
- \\
-\end{array}$ & $\begin{array}{l}- \\
- \\
- \\
-\end{array}$ & $\begin{array}{l}- \\
- \\
- \\
-\end{array}$ & $\begin{array}{l}- \\
\overline{-} \\
\overline{-} \\
-\end{array}$ & $\begin{array}{l}1 \\
5 \\
1 \\
2 \\
1 \\
1\end{array}$ & $\begin{array}{l}- \\
- \\
- \\
- \\
-\end{array}$ & $\begin{array}{l}1 \\
5 \\
1 \\
2 \\
1 \\
1\end{array}$ \\
\hline
\end{tabular}


SUMMARY OF U.S. FISHING VESSELS, BY TONNAGE GROUPS, 1975 - Continued

\begin{tabular}{|c|c|c|c|c|c|c|c|c|}
\hline GROSS TONNAGE & $\begin{array}{l}\text { NEW } \\
\text { ENGLANO }\end{array}$ & $\begin{array}{c}\text { MIOOLE } \\
\text { ATLANT IC }\end{array}$ & $\begin{array}{c}\text { CHESA- } \\
\text { PEAKE } \\
1 /\end{array}$ & $\begin{array}{c}\text { SOUTH } \\
\text { ATLANTIC }\end{array}$ & GULF & PACIFIC & $\begin{array}{l}\text { GREAT } \\
\text { LAKES }\end{array}$ & $\begin{array}{l}\text { TOTAL, } \\
\text { EXCLUSIVE } \\
\text { OF OUPL I- } \\
\text { CATION } \\
\end{array}$ \\
\hline $\begin{array}{l}800=809: \ldots \\
830=839: \therefore \\
860=869: \vdots \\
870=8790 \\
880=889: \vdots\end{array}$ & $\begin{array}{l}--- \\
- \\
- \\
-\end{array}$ & $\begin{array}{l}--- \\
\vdots \\
\vdots \\
-\end{array}$ & $\begin{array}{l}- \\
- \\
= \\
- \\
-\end{array}$ & $\begin{array}{c}--\cdot \\
\vdots \\
\vdots \\
-\end{array}$ & $\begin{array}{l}\text { ABER } \\
\quad- \\
\quad- \\
\quad-\end{array}$ & $\begin{array}{r}--- \\
1 \\
1 \\
9 \\
1 \\
1\end{array}$ & $\begin{array}{c}-- \\
z \\
z\end{array}$ & $\begin{array}{r}-\cdots \\
1 \\
1 \\
9 \\
1 \\
9\end{array}$ \\
\hline $\begin{array}{l}900=909: \ldots \\
910=919: \therefore \\
920=929 \vdots \vdots \\
970=979 \\
980=989 \\
990=999\end{array}$ & $\begin{array}{l}\overline{-} \\
\overline{5} \\
\overline{-}\end{array}$ & $\begin{array}{l}- \\
\overline{-} \\
\overline{-} \\
-\end{array}$ & $\begin{array}{l}- \\
\overline{-} \\
\overline{-}\end{array}$ & $\begin{array}{l}- \\
\bar{z} \\
\overline{-}\end{array}$ & $\begin{array}{l}\overline{-} \\
\vdots \\
\vdots\end{array}$ & $\begin{array}{l}3 \\
3 \\
2 \\
6 \\
5 \\
3\end{array}$ & $\begin{array}{l}\overline{-} \\
\overline{5} \\
\overline{5}\end{array}$ & $\begin{array}{l}3 \\
3 \\
2 \\
6 \\
5 \\
3\end{array}$ \\
\hline $\begin{array}{l}1060=1069 \\
1070=1079 \\
1090=1099\end{array}: \vdots$ & 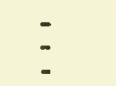 & 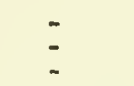 & 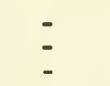 & - & - & $\begin{array}{l}2 \\
4 \\
2\end{array}$ & $\overline{-}$ & $\begin{array}{l}2 \\
4 \\
2\end{array}$ \\
\hline $\begin{array}{l}1110-1119: \therefore \\
1120=1129: \therefore \\
1160=1169: \therefore \\
1180=1189: \therefore \\
1190=1199: \therefore\end{array}$ & $\begin{array}{l}- \\
- \\
-\end{array}$ & $\begin{array}{l}- \\
\vdots \\
-\end{array}$ & $\begin{array}{l}- \\
\overline{-}\end{array}$ & $\begin{array}{l}\text { - } \\
\text { - }\end{array}$ & $\begin{array}{l}- \\
\overline{-} \\
\end{array}$ & $\begin{array}{l}2 \\
1 \\
1 \\
3 \\
1\end{array}$ & $\begin{array}{l}- \\
- \\
-\end{array}$ & $\begin{array}{l}2 \\
1 \\
1 \\
3 \\
1\end{array}$ \\
\hline $1240-1249 \ldots$ & - & - & - & - & - & 2 & - & 2 \\
\hline $1300-1309 . \ldots$ & - & - & - & - & - & 1 & - & 1 \\
\hline \multirow{3}{*}{$\begin{array}{l}1490-1499 \ldots \\
\text { TOTAL VESSELS. } \\
\text { TOTAL GROSS } \\
\text { TONNAGE } .\end{array}$} & - & - & - & - & - & 1 & - & 1 \\
\hline & 770 & 492 & 1,911 & 1,546 & 4,670 & 7,031 & 220 & $2 / 16,211$ \\
\hline & 50,486 & 25,618 & 36,910 & 66,410 & 271,844 & 269,413 & 4.682 & 683,121 \\
\hline
\end{tabular}

1) INCLUDES SAILING VESSELS.

2) TOTAL INCLUDES 109 VESSELS OPERATING IN HAWAII. OATA ON TONNAGE FOR VESSELS IN HAWAII ARE NOT AVAILABLE.

LENGTH DISTRIBUTION OF U.S. FISHING VESSELS, 1975

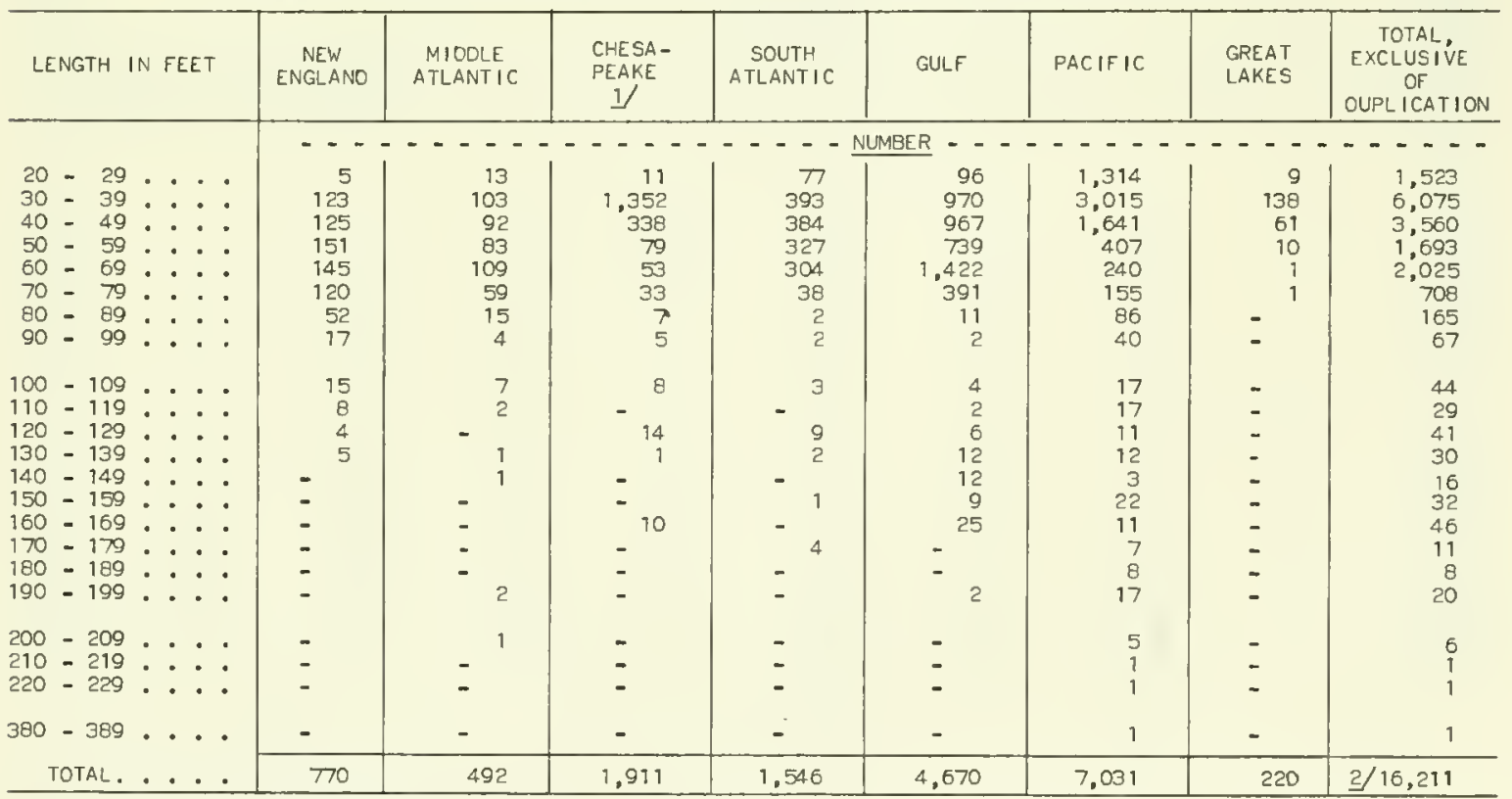

1/. INCLUOES SAILING VESSELS.

2) TOTAL INCLUOES 109 VESSELS OPERATING IN HAWAII. DATA ON LENGTH FOR VESSELS IN HAWA II ARE NOT AVAILABLE. 
U.S. FISHING VESSELS BY YEAR BUILT AND REGION, 1975

\begin{tabular}{|c|c|c|c|c|c|c|c|c|c|c|c|}
\hline & YEAR & BUILT & & $\begin{array}{l}\text { NEW } \\
\text { ENGLAND }\end{array}$ & $\begin{array}{l}\text { MIDOLE } \\
\text { ATLANTIC }\end{array}$ & $\begin{array}{c}\text { CHESA - } \\
\text { PEAKE } \\
1]\end{array}$ & $\begin{array}{l}\text { SOUTH } \\
\text { ATLANTIC }\end{array}$ & GULF & PACIFIC & $\begin{array}{l}\text { GREAT } \\
\text { LAKES }\end{array}$ & $\begin{array}{c}\text { TOTAL, } \\
\text { EXCLUS IVE } \\
\text { OF } \\
\text { OUPL ICATION }\end{array}$ \\
\hline 1849 & $\cdot$ & . & $\cdot$ & $\begin{array}{l}-- \\
-\end{array}$ & $=-\frac{-}{1}$ & $\begin{array}{c}--- \\
-\end{array}$ & $\begin{array}{c}- \\
-\end{array}$ & $\frac{E R}{-}-$ & --- & -- & $\begin{array}{r}-\ldots \\
1\end{array}$ \\
\hline 1852 & $\cdot \cdot$ & . & . & - & 1 & - & - & - & 2 & - & 3 \\
\hline $\begin{array}{l}1865 \\
1866\end{array}$ & $\therefore$ & $\because \vdots$ & : & - & -1 & - & -1 & - & - & - & $\begin{array}{l}1 \\
1\end{array}$ \\
\hline $\begin{array}{l}1872 \\
1873 \\
1875 \\
1876\end{array}$ & $\therefore$ & 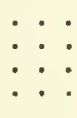 & $:$ & $\begin{array}{l}- \\
-\end{array}$ & $\begin{array}{l}1 \\
1 \\
1 \\
1\end{array}$ & $\begin{array}{l}1 \\
- \\
-\end{array}$ & - & $\overline{-}$ & $\begin{array}{l}- \\
-\end{array}$ & $\begin{array}{l}- \\
= \\
-\end{array}$ & $\begin{array}{l}2 \\
1 \\
1 \\
1\end{array}$ \\
\hline $\begin{array}{l}1883 \\
1885 \\
1886 \\
1887 \\
1888 \\
1889\end{array}$ & $\therefore$ & 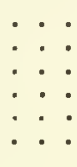 & : & $\begin{array}{l}- \\
- \\
-\end{array}$ & $\begin{array}{ll} & 1 \\
- & \\
- & 1 \\
- & \end{array}$ & $\begin{array}{ll}- & 1 \\
& 1 \\
- & 1 \\
- & \end{array}$ & $\begin{array}{ll}\mathbf{E} & \\
\overline{-} & \\
- & \\
- & 1\end{array}$ & $\begin{array}{ll} & - \\
- & \\
- & \\
- & 1\end{array}$ & $\begin{array}{ll}- & \\
- & 1 \\
- & \end{array}$ & $\begin{array}{l}- \\
= \\
=\end{array}$ & $\begin{array}{l}1 \\
1 \\
1 \\
3 \\
1 \\
1\end{array}$ \\
\hline $\begin{array}{l}1891 \\
1892 \\
1893 \\
1894 \\
1898 \\
1899\end{array}$ & $\therefore$ & $\begin{array}{l}\cdot: \\
:\end{array}:$ & $\begin{array}{l}: \\
\dot{ }\end{array}$ & $\begin{array}{ll}- & 1 \\
- & \\
- & \end{array}$ & $\begin{array}{ll}- & 1 \\
& 1 \\
- & \\
- & 1\end{array}$ & $\begin{array}{l}1 \\
-\quad 1 \\
-\quad 1 \\
-\quad 1\end{array}$ & $\begin{array}{l}- \\
\overline{-} \\
=\end{array}$ & $\begin{array}{l}- \\
- \\
- \\
-\end{array}$ & $\begin{array}{r}1 \\
-\quad 1 \\
-\quad 1 \\
-\quad 1\end{array}$ & $\begin{array}{l}- \\
\overline{-} \\
\text { - }\end{array}$ & $\begin{array}{l}3 \\
2 \\
2 \\
1 \\
1 \\
1\end{array}$ \\
\hline $\begin{array}{l}1900 \\
1901 \\
1902 \\
1903 \\
1904 \\
1905 \\
1906 \\
1907 \\
1908 \\
1909\end{array}$ & & 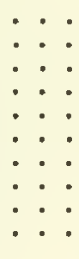 & $\begin{array}{l}\therefore \\
\therefore \\
\therefore \\
:\end{array}$ & 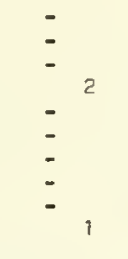 & $\begin{array}{r}1 \\
4 \\
2 \\
4 \\
-\quad 1 \\
1 \\
-\quad 3 \\
-\quad 3\end{array}$ & $\begin{array}{r}1 \\
5 \\
1 \\
-\quad \\
5 \\
3 \\
2 \\
1 \\
2 \\
3\end{array}$ & $\begin{array}{l}- \\
= \\
= \\
= \\
= \\
= \\
=\end{array}$ & $\begin{array}{r}2 \\
2 \\
-\quad 2 \\
2 \\
3 \\
3 \\
4 \\
-\quad 1 \\
\end{array}$ & $\begin{array}{r}1 \\
1 \\
-\quad 1 \\
1 \\
1 \\
2 \\
4 \\
8 \\
4 \\
6\end{array}$ & 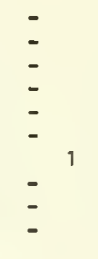 & $\begin{array}{r}5 \\
13 \\
3 \\
9 \\
8 \\
9 \\
14 \\
10 \\
6 \\
15\end{array}$ \\
\hline $\begin{array}{l}1910 \\
1911 \\
1912 \\
1913 \\
1914 \\
1915 \\
1916 \\
1917 \\
1918 \\
1919\end{array}$ & $\therefore:$ & 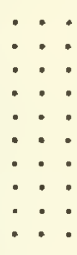 & $\begin{array}{l}\therefore \\
\therefore \\
\therefore\end{array}$ & $\begin{array}{ll} & - \\
\overline{-} & \\
- & 1 \\
= & \\
- & \\
& 4 \\
& 1\end{array}$ & $\begin{array}{r}2 \\
2 \\
-\quad 2 \\
-\quad \\
-\quad 1 \\
1 \\
4 \\
2\end{array}$ & $\begin{array}{l}1 \\
3 \\
3 \\
5 \\
3 \\
2 \\
1 \\
2 \\
6 \\
2\end{array}$ & $\begin{array}{r}2 \\
-\quad \\
1 \\
2 \\
-\quad \\
-\quad 1 \\
-\quad 2 \\
-\quad\end{array}$ & $\begin{array}{r}- \\
-\quad 1 \\
-\quad \\
2 \\
3 \\
1 \\
1 \\
4 \\
2\end{array}$ & $\begin{array}{r}7 \\
18 \\
30 \\
28 \\
31 \\
38 \\
21 \\
70 \\
56 \\
44\end{array}$ & $\begin{array}{ll}- & \\
- & 1 \\
- & 1 \\
- & \\
- & \\
- & \end{array}$ & $\begin{array}{l}10 \\
25 \\
36 \\
37 \\
38 \\
43 \\
24 \\
74 \\
71 \\
49\end{array}$ \\
\hline $\begin{array}{l}1920 \\
1921 \\
1922 \\
1923 \\
1924 \\
1925 \\
1926 \\
1927 \\
1928 \\
1929\end{array}$ & $\begin{array}{l}\therefore \\
\therefore \\
\therefore \\
\therefore\end{array}$ & 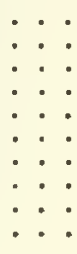 & $\begin{array}{l}\therefore \\
\therefore \\
\therefore\end{array}$ & $\begin{array}{r}2 \\
1 \\
-\quad 1 \\
1 \\
8 \\
7 \\
7 \\
4 \\
5 \\
5\end{array}$ & $\begin{array}{r}2 \\
-\quad 2 \\
2 \\
5 \\
5 \\
2 \\
3 \\
8 \\
4 \\
6\end{array}$ & $\begin{array}{r}5 \\
1 \\
5 \\
10 \\
11 \\
11 \\
12 \\
10 \\
11 \\
9\end{array}$ & $\begin{array}{l}1 \\
4 \\
2 \\
2 \\
3 \\
7 \\
1 \\
8 \\
1 \\
7\end{array}$ & $\begin{array}{r}3 \\
-\quad \\
2 \\
3 \\
13 \\
9 \\
10 \\
11 \\
14 \\
13\end{array}$ & $\begin{array}{r}70 \\
24 \\
13 \\
24 \\
35 \\
69 \\
75 \\
103 \\
117 \\
86\end{array}$ & $\begin{array}{ll}- & \\
- & 1 \\
- & \\
- & \\
- & 3 \\
- & 4\end{array}$ & $\begin{array}{r}83 \\
30 \\
25 \\
45 \\
74 \\
102 \\
111 \\
142 \\
152 \\
129\end{array}$ \\
\hline $\begin{array}{l}1930 \\
1931 \\
1932 \\
1933 \\
1934 \\
1935 \\
1936 \\
1937 \\
1938 \\
1939\end{array}$ & $\begin{array}{l}\therefore \\
\therefore \\
\therefore \\
\therefore\end{array}$ & 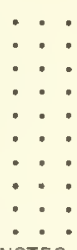 & $\begin{array}{l}\therefore \\
\therefore \\
\therefore\end{array}$ & $\begin{array}{l}9 \\
4 \\
4 \\
4 \\
2 \\
2 \\
6 \\
9 \\
9 \\
6 \\
9\end{array}$ & $\begin{array}{r}6 \\
2 \\
2 \\
-\quad 1 \\
1 \\
1 \\
3 \\
5 \\
4 \\
3\end{array}$ & $\begin{array}{r}12 \\
5 \\
10 \\
6 \\
16 \\
13 \\
14 \\
17 \\
17 \\
26\end{array}$ & $\begin{array}{c}12 \\
4 \\
6 \\
4 \\
3 \\
8 \\
6 \\
7 \\
8 \\
8\end{array}$ & $\begin{array}{r}12 \\
10 \\
4 \\
6 \\
7 \\
19 \\
30 \\
42 \\
35 \\
23\end{array}$ & $\begin{array}{r}56 \\
33 \\
21 \\
18 \\
28 \\
66 \\
39 \\
65 \\
67 \\
103\end{array}$ & $\begin{array}{r}2 \\
1 \\
1 \\
3 \\
4 \\
6 \\
11 \\
11 \\
5 \\
4\end{array}$ & $\begin{array}{r}106 \\
59 \\
48 \\
41 \\
60 \\
115 \\
111 \\
154 \\
141 \\
176\end{array}$ \\
\hline
\end{tabular}


U.S. FISHING VESSELS BY YEAR BUILT AND REGION, 1975 - Continued

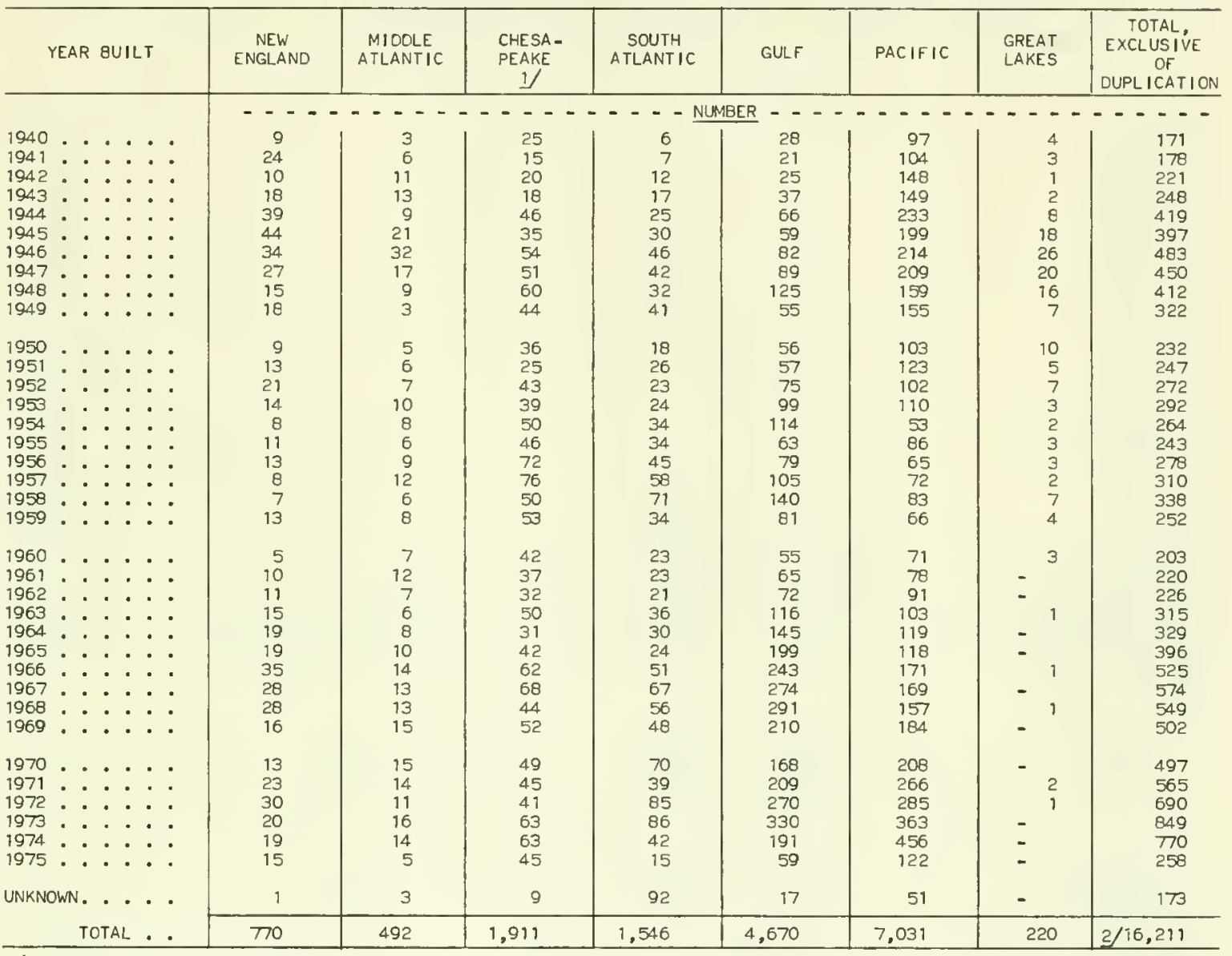

1) INCLUOES SA ILING VESSELS.

2/ TOTAL INCLUOES 109 VESSELS OPERATING IN HAWAII. DATA ON YEAR BUILT FOR VESSELS IN HAWAII ARE NOT AVAILABLE. 


\section{U.S. FISHING VESSELS BY GEAR AND CONSTRUCTION. 1975}

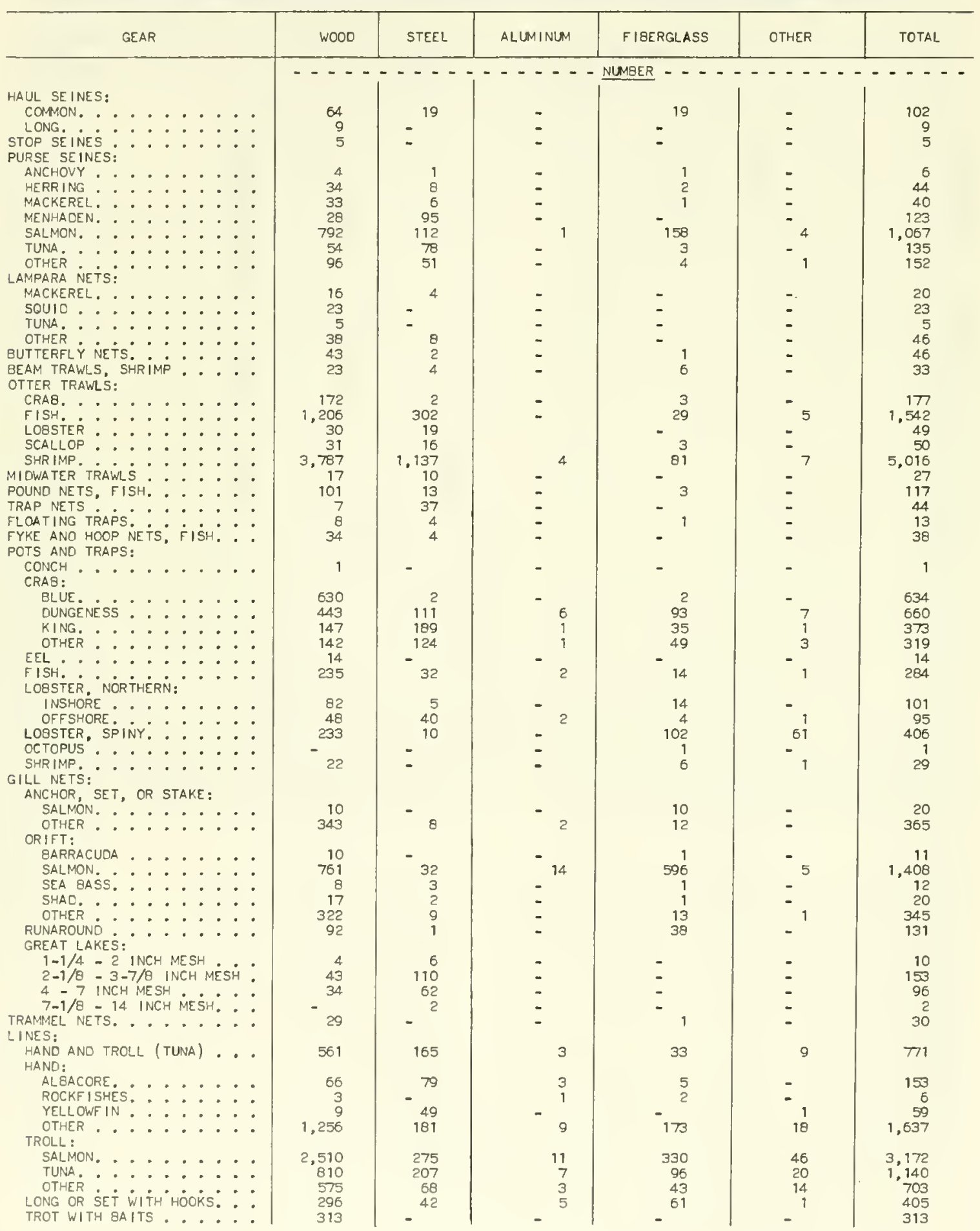

(CONTINUED ON NEXT PAGE) 
U.S. FISHING VESSELS BY GEAR AND CONSTRUCTION, 1975 - Continued

\begin{tabular}{|c|c|c|c|c|c|c|}
\hline GEAR & WOOD & STEEL & ALUMINUM & FIBERGLASS & OTHER & TOTAL \\
\hline 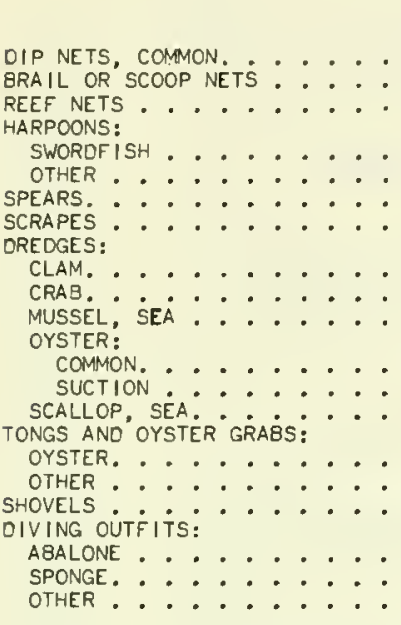 & $\begin{array}{r}223 \\
159 \\
3 \\
542 \\
-\quad 46 \\
1,026 \\
82 \\
2 \\
13 \\
4 \\
52\end{array}$ & 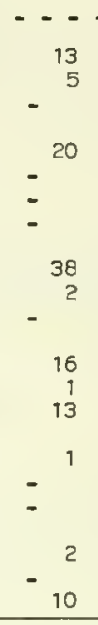 & $\begin{array}{l}- \\
- \\
- \\
= \\
= \\
= \\
= \\
= \\
= \\
- \\
- \\
-\end{array}$ & 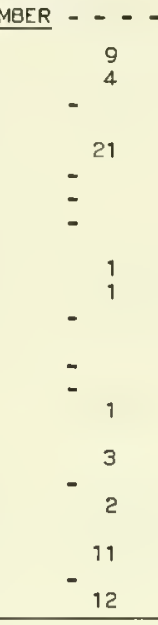 & $\begin{array}{l}- \\
= \\
-1 \\
= \\
- \\
- \\
- \\
- \\
-1 \\
- \\
-\end{array}$ & $\begin{array}{r}r \\
50 \\
16 \\
2 \\
141 \\
2 \\
2 \\
14 \\
262 \\
262 \\
162 \\
3 \\
562 \\
1 \\
61 \\
1,030 \\
82 \\
4 \\
26 \\
4 \\
80 \\
\end{array}$ \\
\hline TOTAL. . . . . . & 19,035 & 3,867 & 81 & 2,116 & 213 & 25,312 \\
\hline
\end{tabular}

NOTE: - INCLUOES DUPLICATION BETWEEN GEARS. 


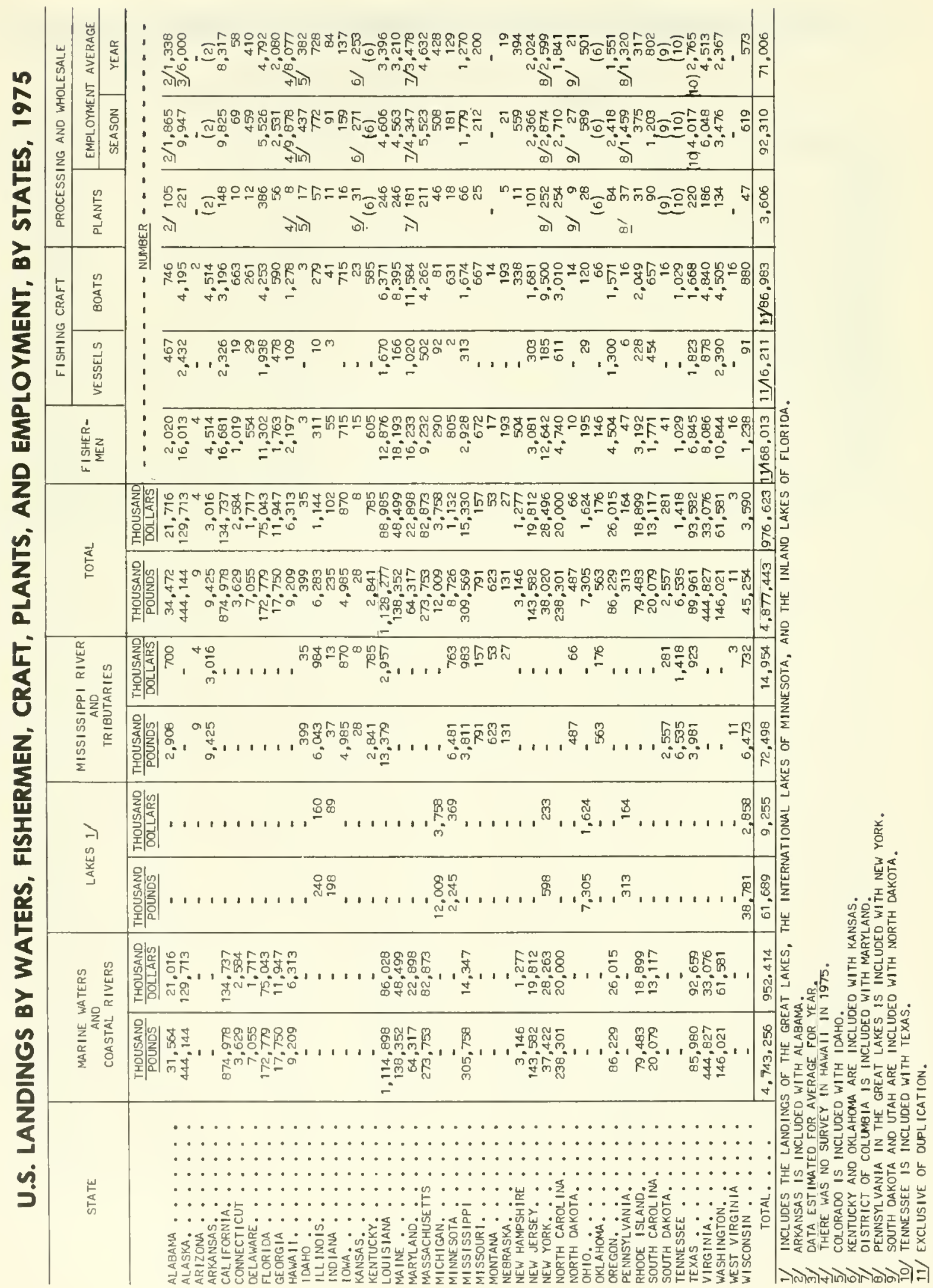


LANDINGS BY REGION, 1975

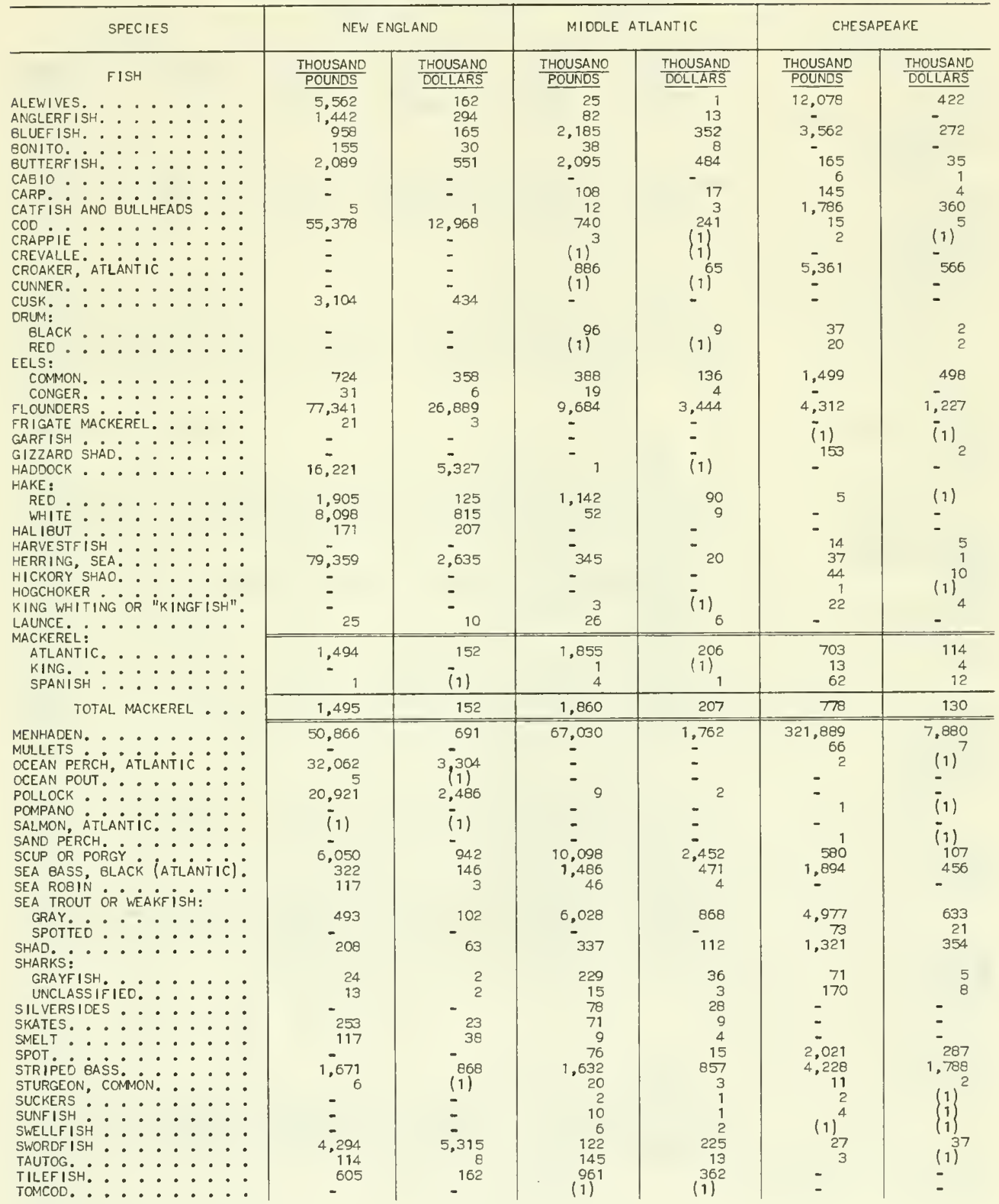

SEE FOOTNOTES AT ENO DF TABLE. 
LANDINGS BY REGION, 1975 - Continued

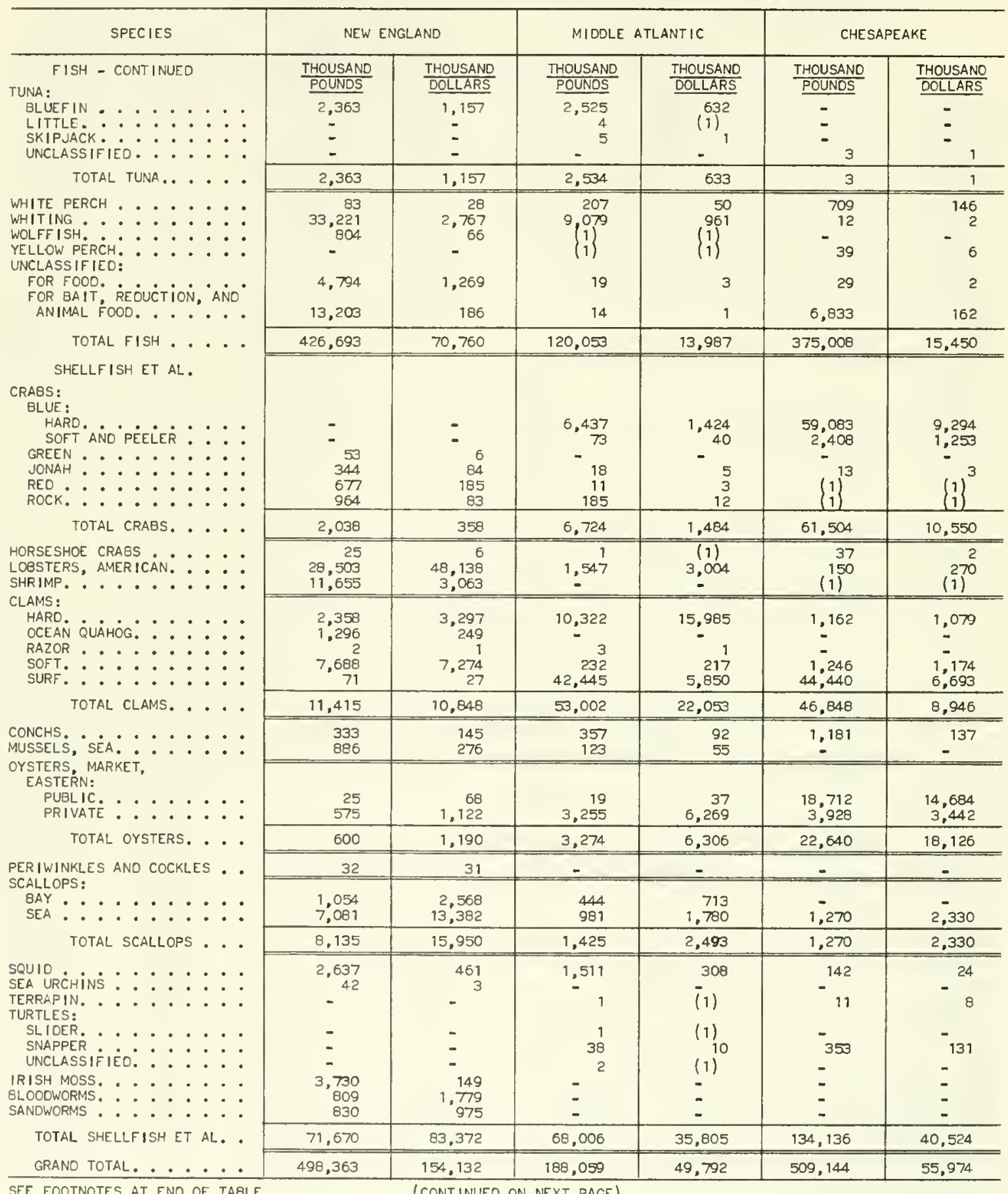

SEE FOOTNOTES AT ENO OF TABLE.

(CONTINUEO ON NEXT PAGE) 
LANDINGS BY REGIONS, 1975 - Continued

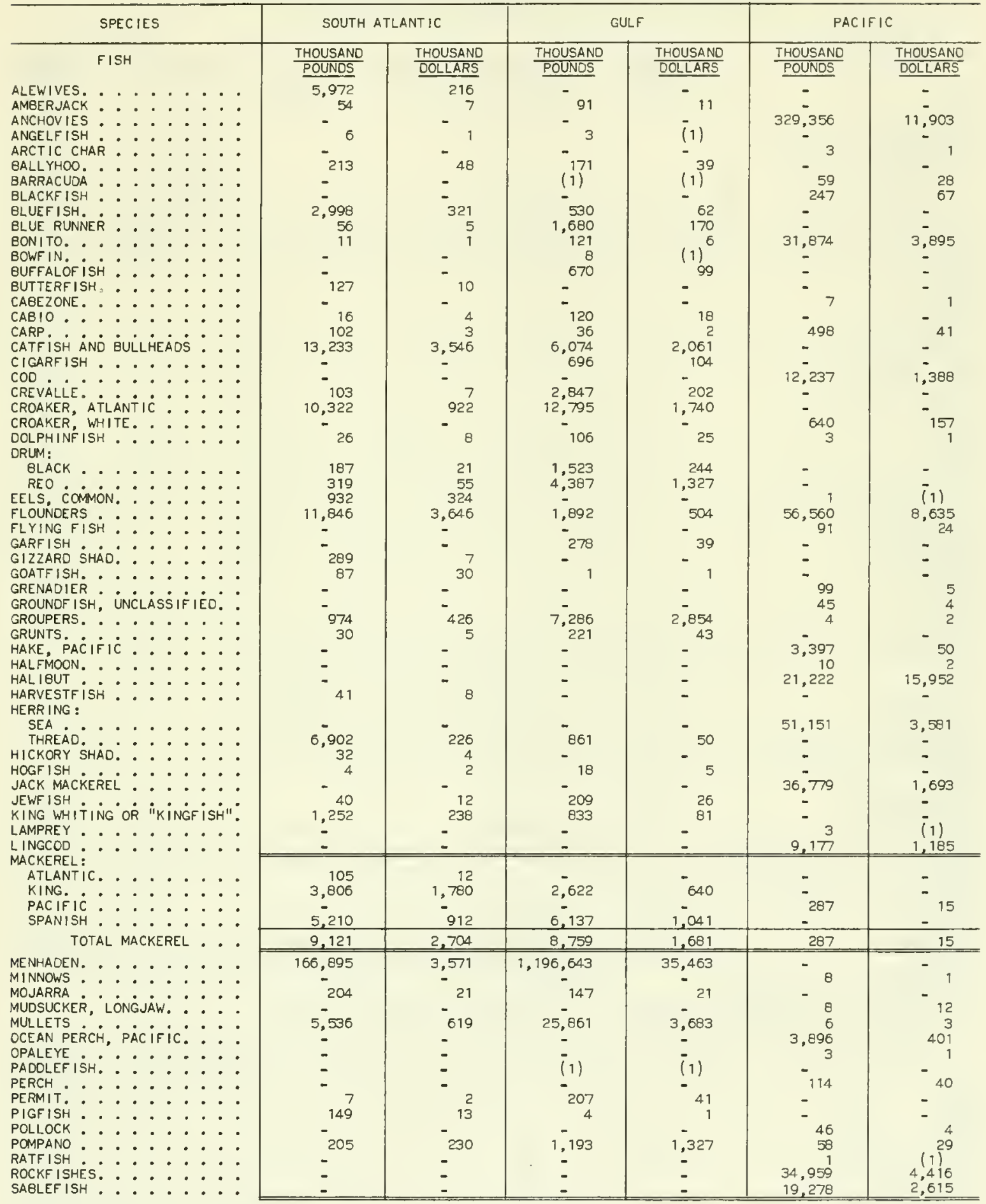

SEE FOOTNOTES AT END OF TABLE.

(CONTINUED ON NEXT PAGE) 
LANDINGS BY REGION, 1975 - Continued

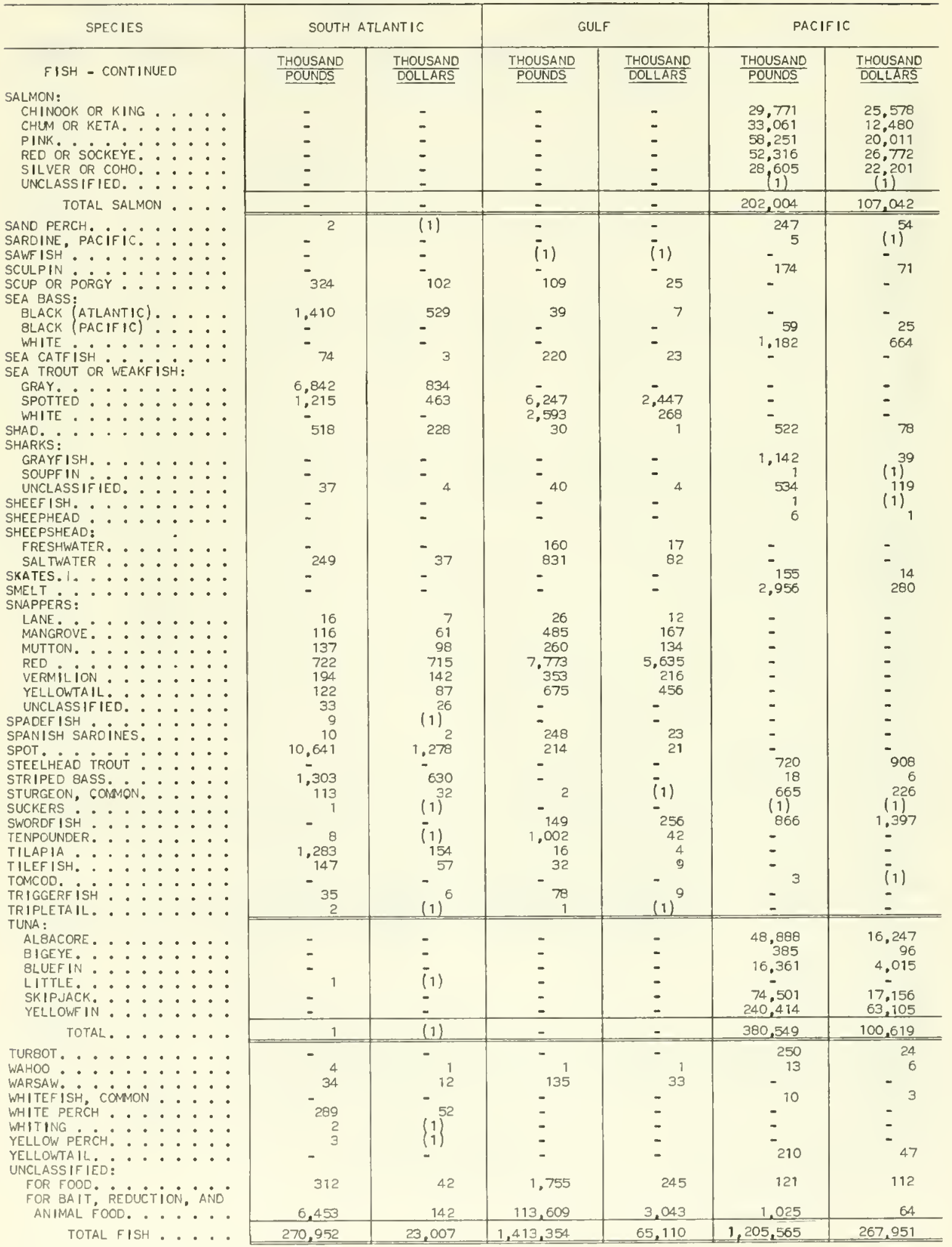




\section{LANDINGS BY REGIONS, 1975 - Continued}

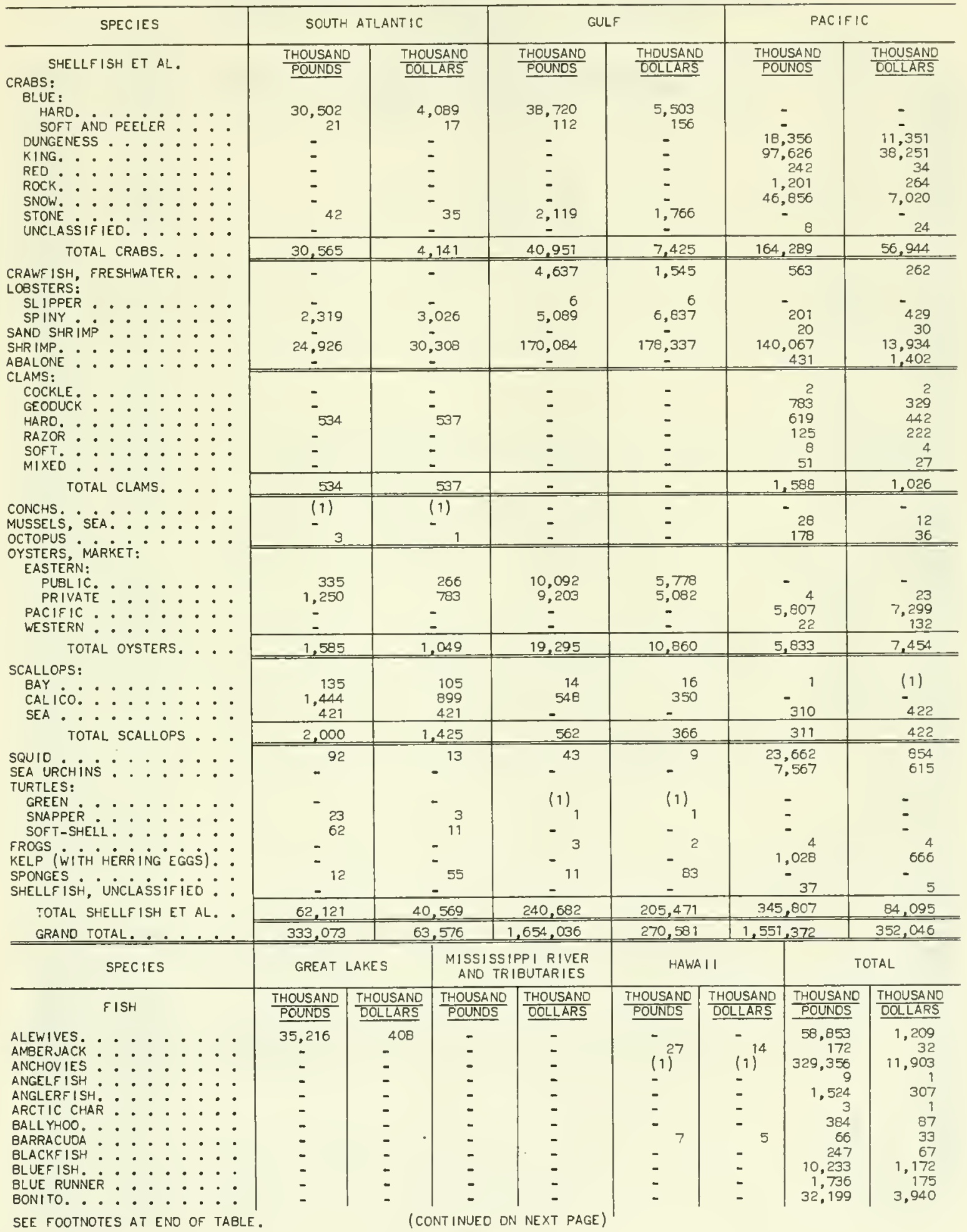


LANDINGS BY REGIONS, 1975 - Continued

\begin{tabular}{|c|c|c|c|c|c|c|c|c|c|c|c|}
\hline & SPECIES & & & GREAT & LAKES & $\begin{array}{l}\text { MISSISSIP } \\
\text { ANO TRIE }\end{array}$ & $\begin{array}{l}\text { PI RIVER } \\
\text { BUTARIES }\end{array}$ & HAV & A 11 & TOT & \\
\hline $\mathrm{FISH}-\mathrm{C}$ & CONTINUED & & & $\frac{\text { THOUSANO }}{\text { POUNDS }}$ & $\frac{\text { THOUSAND }}{\text { DOLLARS }}$ & $\frac{\text { THOUSANO }}{\text { POUNDS }}$ & $\frac{\text { THOUSANO }}{\text { DOLLARS }}$ & $\frac{\text { THOUSAND }}{\text { POUNOS }}$ & $\frac{\text { THOUSAND }}{\text { DOLLARS }}$ & $\frac{\text { THOUSAND }}{\text { POUNDS }}$ & $\frac{\text { THOUSANO }}{\text { DOLLARS }}$ \\
\hline 80WF IN. . & . . . & . • & . & 2 & (1) & 171 & 11 & - & - & 181 & 11 \\
\hline BUFFALOF ISH . & $\therefore: \vdots$ & $:$ & $\therefore$ & 67 & 17 & 23,356 & 4,974 & - & - & 24.093 & 5,090 \\
\hline BURBOT. . & $\therefore$. & . . & . & 488 & 13 & 37 & 2 & - & - & 525 & 15 \\
\hline QUTTERF ISH. . & . . . & $\cdot \cdot$ & $\cdot$ & - & - & - & - & - & - & 4,476 & 1,080 \\
\hline CABEZONE. . & $\cdot \cdot \cdot \cdot$ & $\cdot \cdot$ & : & - & - & - & - & - & - & 7 & 1 \\
\hline $\begin{array}{l}\text { CABIO } \\
\text { CARP }\end{array}$ & $\therefore: \cdot$ & $\therefore$ & : & 6,732 & - & $\overline{15,368}$ & ${ }_{986}$ & - & 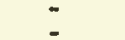 & $\begin{array}{r}142 \\
22,989\end{array}$ & $\begin{array}{r}23 \\
1.434\end{array}$ \\
\hline CATF ISH ANO B & BULLLHEAOŚ & $\therefore$ & $\vdots$ & 757 & 303 & 12,981 & 5,380 & $=$ & $\overline{-}$ & 34,848 & 11,654 \\
\hline CHUBS ... & . . . . & . . & . & 2,444 & 1,629 & (1) & $(1)$ & - & - & 2,444 & 1,629 \\
\hline CIGARFISH. & . . . . & $\cdot \cdot$ & . & - & - & - & - & - & - & 696 & 104 \\
\hline $\mathrm{COO}$ & . . . . & $\cdot \cdot$ & . & - & - & - & - & - & - & 68,370 & 14,602 \\
\hline CRAPPIE . & . · • . & $\cdot \cdot$ & & 89 & 59 & 98 & 38 & & & 192 & 97 \\
\hline CREVALLE. & $\dot{0} \cdot \dot{0}$ &. & . & - & - & - & - & 96 & & 3,046 & 289 \\
\hline CROAKER, ATLA & ANTIC . · & . . & . & - & - & - & - & - & - & 29,364 & 3,293 \\
\hline CROAKER, WHIT & TE. . . . &. & . & - & - & - & - & - & - & 640 & 157 \\
\hline CUNNER. . & . . . . . & . . & . & - & - & - & - & - & - & (1) & (1) \\
\hline CUSK. . . & . . . . & . . & - & - & - & - & - & & & 3,104 & 434 \\
\hline $\begin{array}{l}\text { DOLPHINF ISH } \\
\text { ORUM: }\end{array}$ & $\cdots$ & . & . & - & - & - & - & 85 & 115 & 220 & 149 \\
\hline BLACK ... & . . . . & . . & . & - & - & - & - & - & - & 1,843 & 276 \\
\hline RED ... & . . . . & . . & . & - & - & - & - & - & - & 4.726 & 1,384 \\
\hline $\begin{array}{l}\text { EELS: } \\
\text { COMMON. . }\end{array}$ &... &. & . & 30 & 21 & 3 & (1) & (1) & (1) & $35 \pi$ & \\
\hline CONGER.: & $\therefore: \vdots$ & $\dot{0}$ & : & & - & & - & - & - & $\begin{array}{r}3,5 / 1 \\
50\end{array}$ & $\begin{array}{r}1,331 \\
10\end{array}$ \\
\hline FLOUNDERS . & $\therefore .$. &. & . & - & - & - & - & - & - & 161,635 & 44,345 \\
\hline FLYING FISH: & $\therefore \therefore$ & $\therefore$ & : & - & - & - & - & - & - & & \\
\hline FRIGATE MACKE & EREL. . & $\therefore$ & . & - & - & - & - & - & - & 21 & 3 \\
\hline GARFISH... & $\therefore .$. & $\therefore$ & . & & - & 1,216 & 157 & - & & 1.494 & 196 \\
\hline GIZZARD SHAO. & . . . . &. & & 1 & (1) & 626 & 27 & & & 1,069 & 36 \\
\hline GOATFISH. . & . . . . &. & . & & - & - & - & 67 & 61 & 155 & 92 \\
\hline GOLDFISH. . & . . . . & . . & . & 56 & 3 & - & - & & & 56 & 3 \\
\hline GRENAOIER . . & . . . . & & . & & & - & - & - & - & 99 & 5 \\
\hline GROUNDF ISH, U & UNCLASSIFI & IED. & . & - & - & - & - & - & - & 45 & 4 \\
\hline GROUPERS. . . & . . . . &. & . & - & - & - & - & - & - & 8,264 & 3,282 \\
\hline GRUNTS. : . & $\therefore \therefore$ & . & & - & - & - & - & - & - & 251 & \\
\hline HAODOCK ... & . . . & . . & . & - & - & - & - & - & - & 16,222 & 5,327 \\
\hline HAKE : & & & & & & & & & & & \\
\hline PACIFIC. & $\cdots \cdot \cdot$ & . . & . & - & - & - & - & - & - & 3,397 & 50 \\
\hline REO .... & $\cdot \cdots \cdot$ & . . & • & - & - & - & - & - & - & 3,052 & 215 \\
\hline WHITE . . & . . . . & . $\cdot$ & . & - & - & - & - & - & - & 8,150 & 824 \\
\hline HALFMOON. . & $\cdots$ & $\cdot \cdot$ & . & - & - & - & - & - & - & 10 & 2 \\
\hline HALIBUT . . & . . . . &. & & - & - & - & - & - & - & 21,393 & 16,159 \\
\hline HARVESTF ISH - & . . . . & . & . & - & - & - & - & - & - & 55 & 13 \\
\hline $\begin{array}{l}\text { HERR ING : } \\
\text { LAKE }\end{array}$ & & & & & 40 & - & & & & & \\
\hline${ }_{S E A}^{\text {LAKE . . . }}$ & • • • • & $\cdot \cdot$ & - & 513 & 146 & $\begin{array}{r}5 \\
-\quad 5\end{array}$ & $\begin{array}{r}1 \\
-\end{array}$ & - & - & 518 & 147 \\
\hline SEA ${ }_{\text {THREAO }}^{\circ} \cdot$ & 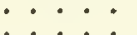 & : & - & $\bar{z}$ & $\overline{-}$ & - & - & $\overline{-}$ & $\overline{-}$ & $\begin{array}{r}130,892 \\
7,763\end{array}$ & 6,237 \\
\hline HICKORY SHAD: & $\therefore \therefore$ & $\therefore$ & : & - & - & - & - & - & - & .76 & 14 \\
\hline HOGCHOKER . & . . . . & . . & . & & & - & - & - & - & & (1) \\
\hline HOGFISH. . & $\therefore .$. & . & . & & & - & - & - & - & 22 & \\
\hline JACK MACKEREL & L . . . . & . & & - & - & - & - & - & - & 36,779 & 1.693 \\
\hline JEWF ISH . . & . . . . & & & & & - & - & - & - & 249 & 38 \\
\hline KING WHITING & $O R$ "KINGF & "isH" & ". & & & - & - & - & - & 2,110 & 323 \\
\hline LAKE TROUT. . & . . . . & . . & . & 456 & 267 & - & - & - & - & 456 & 267 \\
\hline LAMPREY . . & . . . . & . & . & - & - & - & - & - & - & 3 & (1) \\
\hline LAUNCE. . & . . . . & . . & . & - & - & - & - & - & - & 51 & 16 \\
\hline LINGCOO . . & . . . . & . & . & - & - & - & - & - & - & $9,17 \pi$ & 1,185 \\
\hline MACKEREL： & & & & & & & & & & & \\
\hline ATLANTIC. . & .... & . . & . & - & - & - & - & - & - & 4,157 & 484 \\
\hline KING. ... & . . . . & & & - & - & - & - & - & - & 6,442 & 2,424 \\
\hline PACIFIC . & . . . . & . . & : & - & - & - & - & - & - & 287 & 15 \\
\hline SPANISH . & . . . . & . . & . & - & - & - & - & - & $=$ & 11,414 & 1,966 \\
\hline TOTAL & MACKEREL & . & - & - & - & - & - & - & - & 22,300 & 4,889 \\
\hline MACKEREL SCAD & D. . . & . . & . & - & - & - & - & 309 & 247 & 309 & 247 \\
\hline MARL IN. . . & & $\therefore$ & & - & - & - & - & 282 & 152 & 282 & 152 \\
\hline MENHADEN. & $\therefore$. . & $\therefore$ & $\therefore$ & - & - & - & - & - & - & $1,803,323$ & 49,367 \\
\hline MINNOWS & . . . . & . . & & 12 & 14 & - & - & & - & 20 & \\
\hline MOJARRA: : & $\therefore \therefore$ & $\therefore$ & : & - & - & - & - & - & - & 351 & 42 \\
\hline MOONEYE OR GO & OLOEYE. . & . . & . & - & - & 352 & 84 & - & - & 352 & 84 \\
\hline MUOSUCKER, LO & ONGUAW: & $\therefore$ & : & - & - & - & - & - & - & 8 & 12 \\
\hline MULLETS . . & .... & $:$ & : & - & - & - & - & 14 & 23 & 31,483 & 4,335 \\
\hline OCEAN PERCH: & & & & & & & & & & & \\
\hline ATLANTIC. & . . . . & . & . & - & - & - & - & - & - & 32,064 & 3,304 \\
\hline PACIFIC: & . . . . . & . & . & - & - & - & - & - & - & 3,896 & 401 \\
\hline OCEAN POUT. & . . . . . & . . & . & - & - & - & - & - & - & 5 & (1) \\
\hline SEE FOOTNOTES & $S$ AT ENO OI & DF TA & ABLE & & (co & INUEO ON & EXT PAGE) & & & & \\
\hline
\end{tabular}


LANDINGS BY REGION, 1975 - Continued

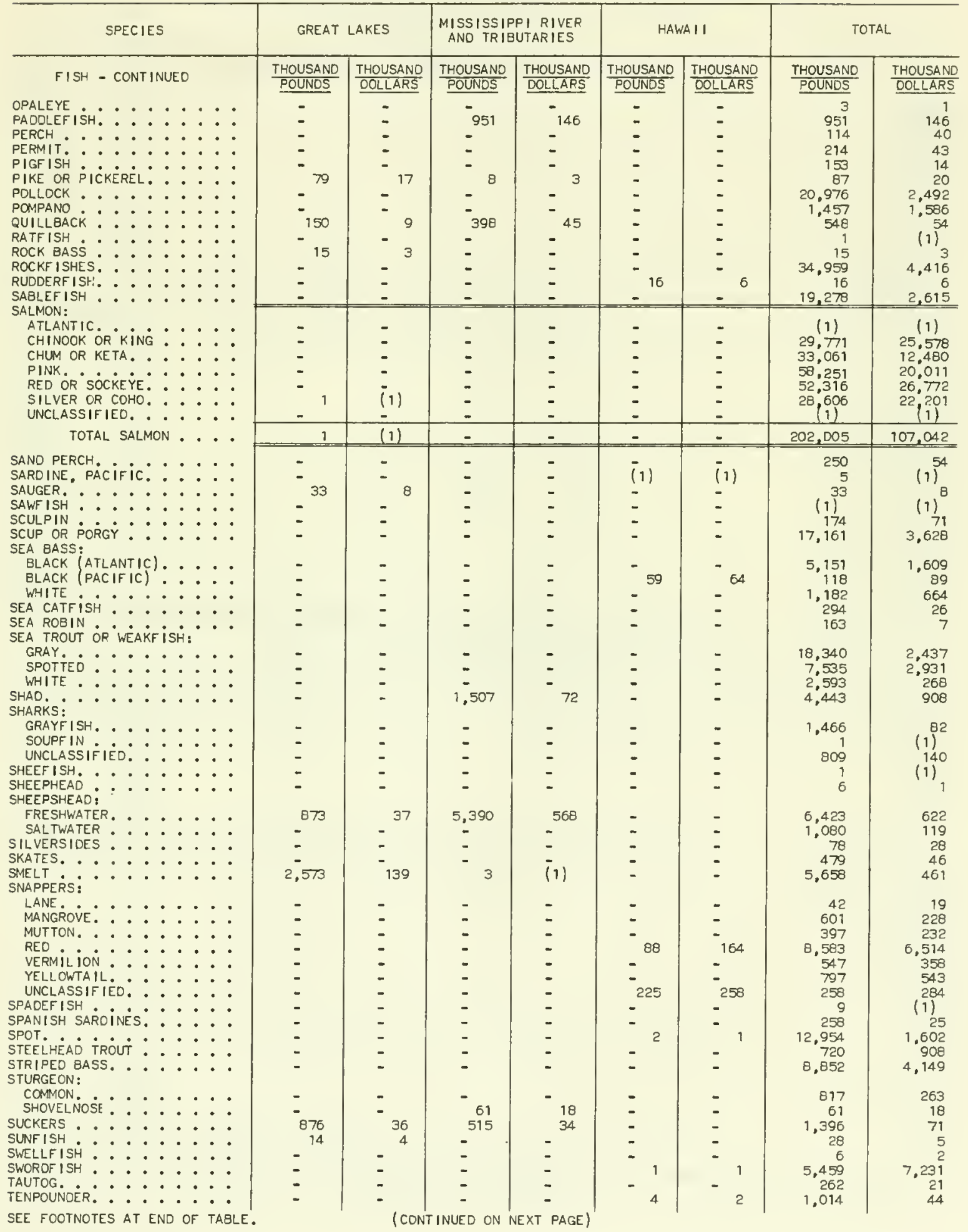




\section{LANDINGS BY REGIONS, 1975 - Continued}

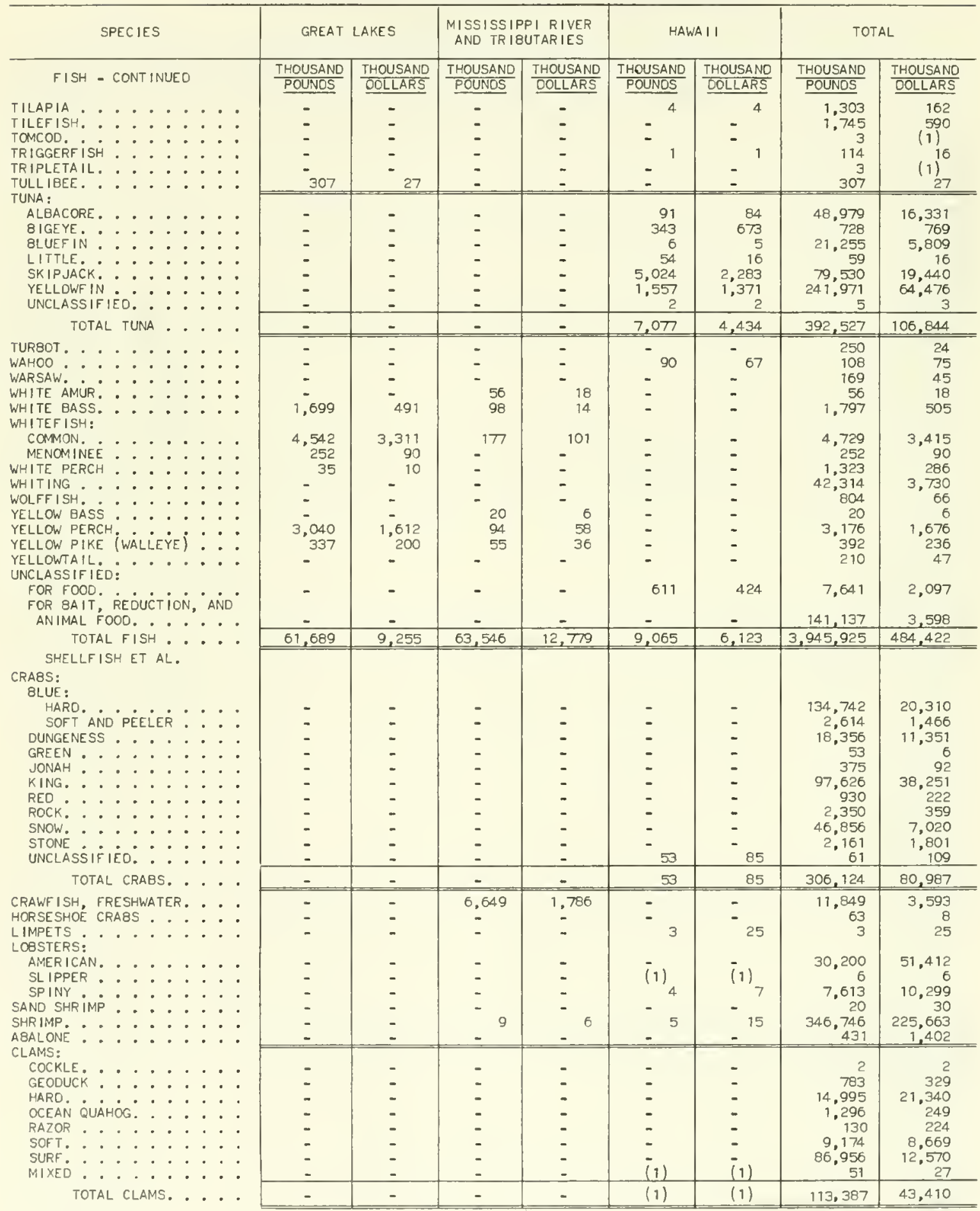

SEE FOOTNOTES AT END OF TABLE. 
LANDINGS BY REGIONS, 1975 - Continued

\begin{tabular}{|c|c|c|c|c|c|c|c|c|}
\hline SPECIES & \multicolumn{2}{|c|}{ GREAT LAKES } & \multicolumn{2}{|c|}{$\begin{array}{c}\text { MISSISSIPPI RIVER } \\
\text { AND TRIBUTARIES }\end{array}$} & \multicolumn{2}{|c|}{ HAWA II } & \multicolumn{2}{|c|}{ TOTAL } \\
\hline SHELLFISH ET AL, - CONTO. & $\frac{\text { THOUSANO }}{\text { POUNOS }}$ & $\frac{\text { THOUSAND }}{\text { DOLLARS }}$ & $\frac{\text { THOUSAND }}{\underline{\text { POUNDS }}}$ & $\frac{\text { THOUSANO }}{\text { DOLLARS }}$ & $\frac{\text { THOUSAND }}{\underline{\text { POUNOS }}}$ & $\frac{\text { THOUSAND }}{\text { DOLLARS }}$ & $\frac{\text { THOUSANO }}{\text { POUNDS }}$ & $\frac{\text { THOUSAND }}{\text { DOLLARS }}$ \\
\hline $\begin{array}{l}\text { CONCHS, }{ }_{\text {MUSSELS, }} \text { SEA }: \vdots: \vdots: \\
\text { MUSSEL SHELLS }: \vdots: \vdots:\end{array}$ & $\begin{array}{l}- \\
- \\
\end{array}$ & $\begin{array}{l}- \\
- \\
\end{array}$ & $\overline{-}$ & $\begin{array}{l}- \\
- \\
- \\
\end{array}$ & $\begin{array}{l}- \\
- \\
\end{array}$ & $\begin{array}{l}- \\
- \\
\end{array}$ & $\begin{array}{r}1,871 \\
1,037 \\
2,077 \\
189 \\
\end{array}$ & $\begin{array}{r}374 \\
343 \\
305 \\
47 \\
\end{array}$ \\
\hline 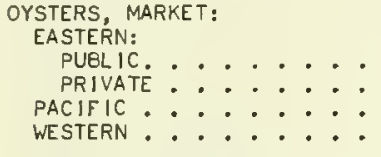 & $\overline{-}$ & - & $\begin{array}{l}- \\
- \\
-\end{array}$ & - & $\begin{array}{l}\overline{-} \\
\overline{-}\end{array}$ & - & $\begin{array}{r}29,183 \\
18,215 \\
5,807 \\
22 \\
\end{array}$ & $\begin{array}{r}20,833 \\
16,721 \\
7,299 \\
132 \\
\end{array}$ \\
\hline TOTAL OYSTERS. . . . & - & - & - & - & - & - & 53,227 & 44,985 \\
\hline PERIWINKLES ANO COCKLES . . & - & - & - & - & - & - & 32 & 31 \\
\hline 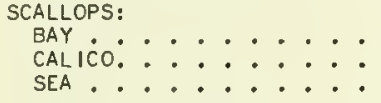 & - & - & $\begin{array}{l}- \\
-\end{array}$ & - & - & - & $\begin{array}{r}1,648 \\
1,992 \\
10,063 \\
\end{array}$ & $\begin{array}{r}3,402 \\
1,249 \\
18,335 \\
\end{array}$ \\
\hline TOTAL SCALLOPS . . & - & - & - & - & - & - & 13,703 & 22,986 \\
\hline 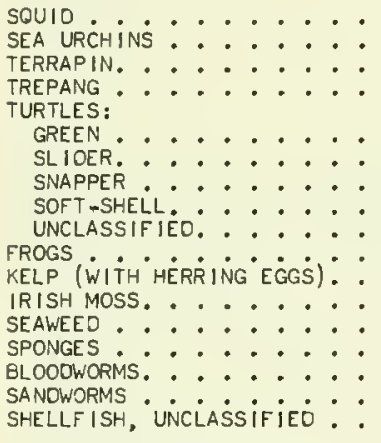 & $\begin{array}{l}- \\
= \\
= \\
= \\
= \\
= \\
= \\
= \\
= \\
=\end{array}$ & $\begin{array}{l}- \\
- \\
- \\
- \\
= \\
= \\
- \\
- \\
- \\
- \\
- \\
-\end{array}$ & $\begin{array}{l}- \\
= \\
= \\
- \\
10 \\
158 \\
11 \\
=38 \\
= \\
= \\
= \\
= \\
=\end{array}$ & $\begin{array}{l}- \\
- \\
- \\
- \\
47 \\
4 \\
- \\
- \\
- \\
- \\
- \\
- \\
\end{array}$ & 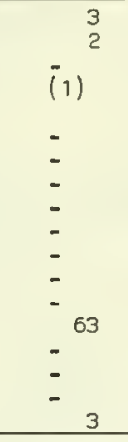 & $\begin{array}{l}{ }^{4} \\
{ }^{2} \\
-1) \\
= \\
= \\
= \\
= \\
= \\
= \\
= \\
- \\
\end{array}$ & $\begin{array}{r}28,090 \\
7,611 \\
112 \\
(1) \\
(1) \\
11 \\
573 \\
73 \\
2 \\
45 \\
1,028 \\
3,730 \\
63 \\
23 \\
809 \\
830 \\
40 \\
\end{array}$ & $\begin{array}{r}1.673 \\
620 \\
8 \\
(1)^{8} \\
(1) \\
1 \\
192 \\
14 \\
(1)^{3} \\
33 \\
666 \\
149 \\
39 \\
138 \\
1,79 \\
975 \\
8 \\
\end{array}$ \\
\hline TOTAL SHELLFISH ET AL. . & - & - & 8,952 & 2,175 & 144 & 190 & 931,518 & 492,201 \\
\hline GRANO TOTAL. . . . . . & 61,689 & 9,255 & 72.498 & 14,954 & 9,209 & 6,313 & $4,877,443$ & 976,623 \\
\hline
\end{tabular}

I LESS THAN 500 POUNOS OR $\$ 500$.

NOTE: --LANDINGS ARE SHOWN IN ROUND (LIVE) WEIGHT EXCEPT FOR SHELL MOLLUSKS. CLAMS, CONCHS, LIMPETS, MUSSELS, OYSTERS, AND PERIWINKLES AND COCKLES ARE REPORTEO IN WEIGHT OF TOTAL MEATS; ABALONE AND SCALLOPS ARE REPORTEO IN WE IGHT OF EOIBLE MEATS. 
LANDINGS OF CATCH BY GEAR, 1975

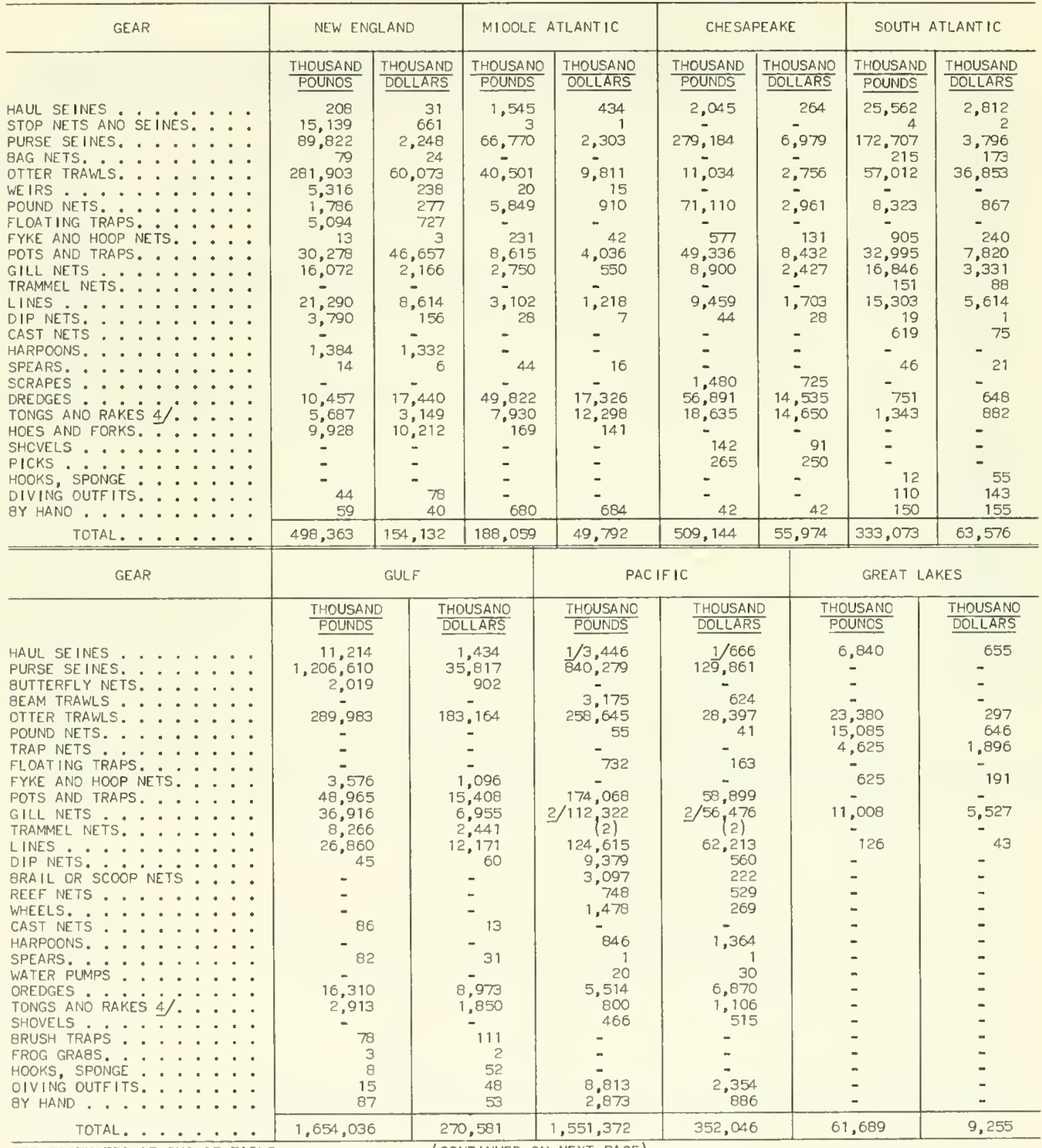

SEE FOOTNOTES AT ENO OF TABLE.

(CONTINUED ON NEXT PAGE) 
LANDINGS OF CATCH BY GEAR, 1975 - Continued

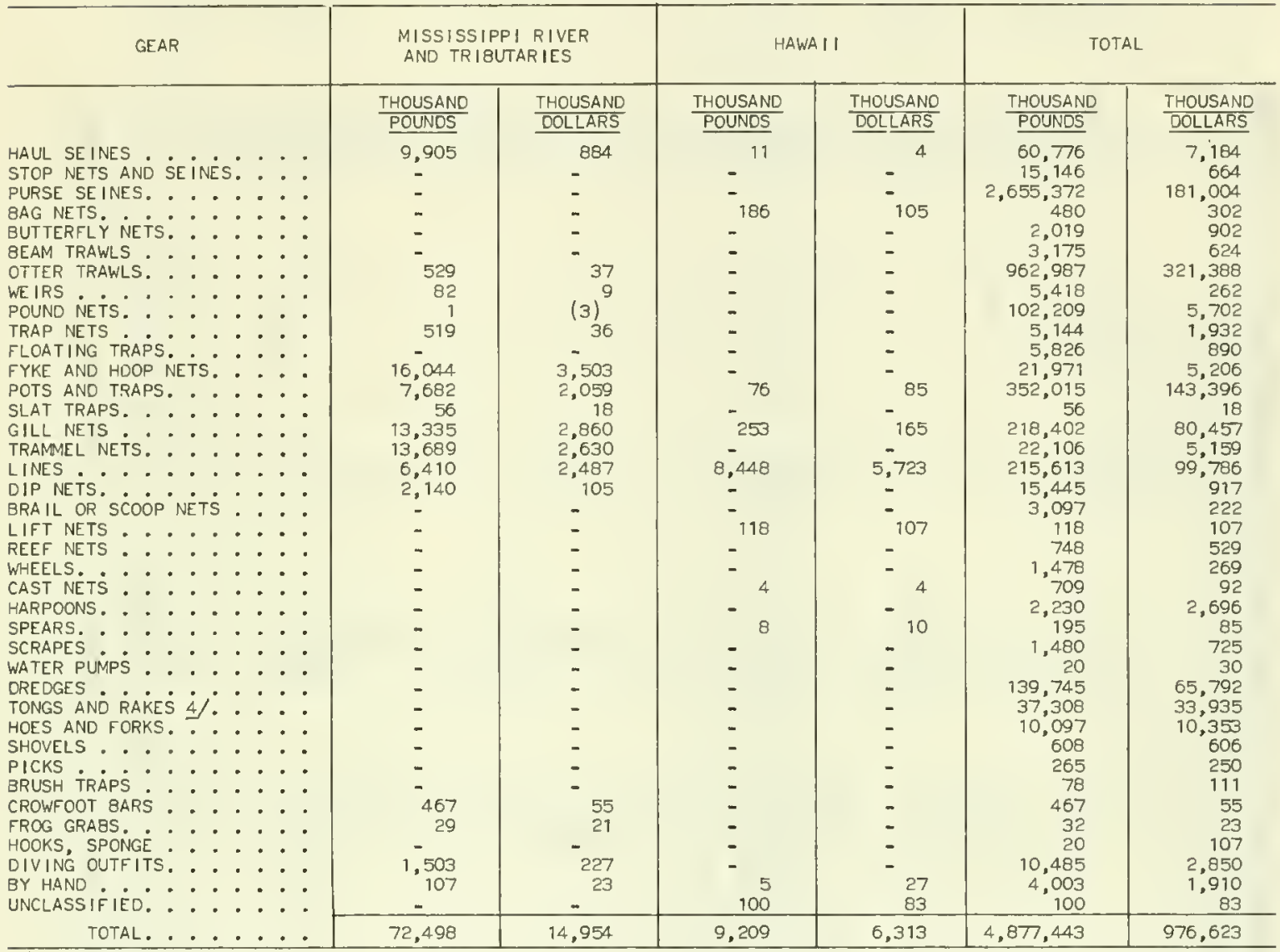

$1 /$ LANDINGS $8 Y$ HAUL SEINES IN ALASKA AND BY LAMPARA NETS IN CALIFORNIA HAVE BEEN INCLUDED WITH PURSE SEINES.

2) LANDINGS BY TRAMMEL NETS IN CALIFORNIA HAVE BEEN INCLUDED WITH GILL NETS.

3 LESS THAN 500 PDUNDS OR \$500.

4) INCLUDES LANDINGS OF OYSTER GRABS. 


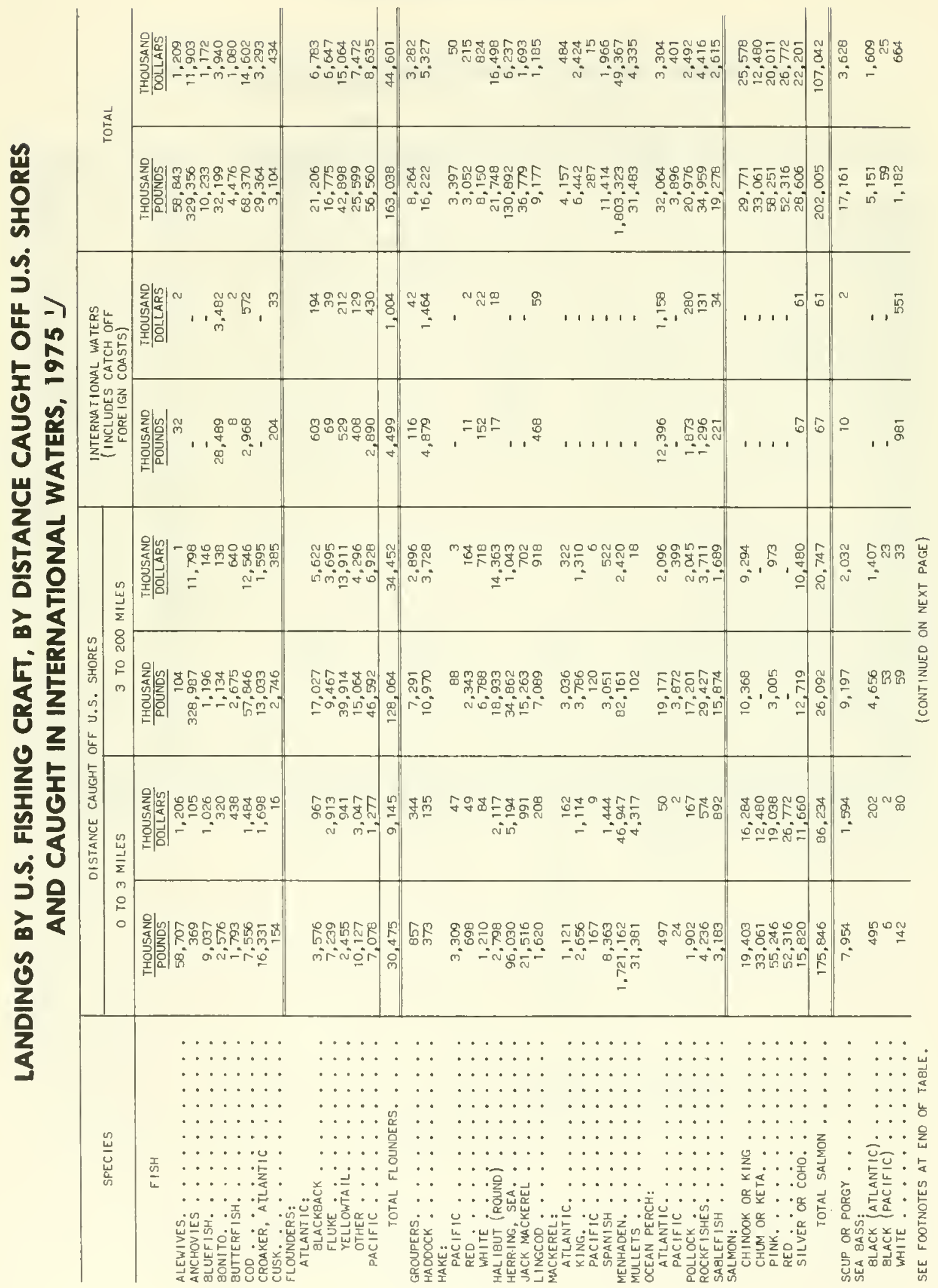




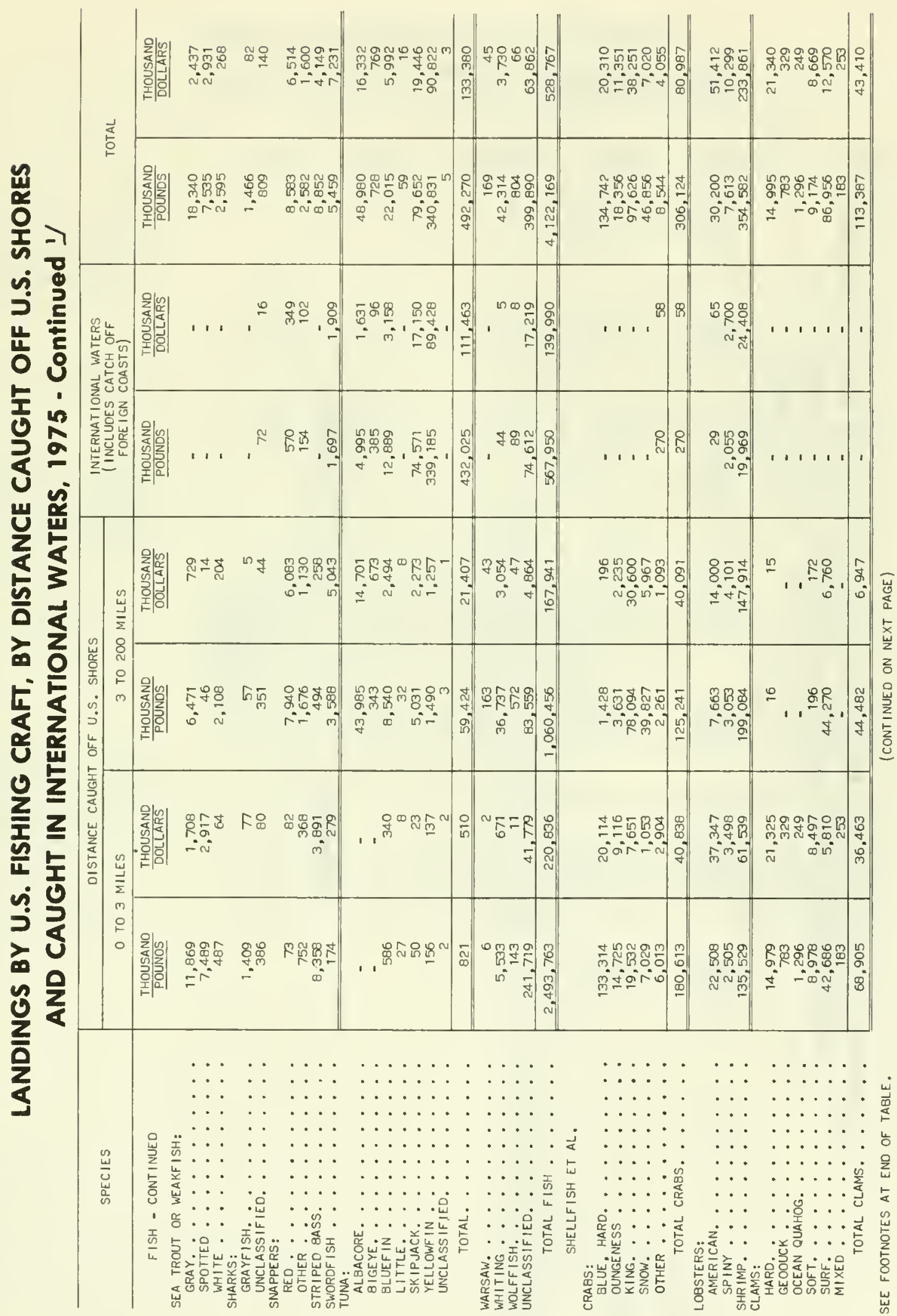



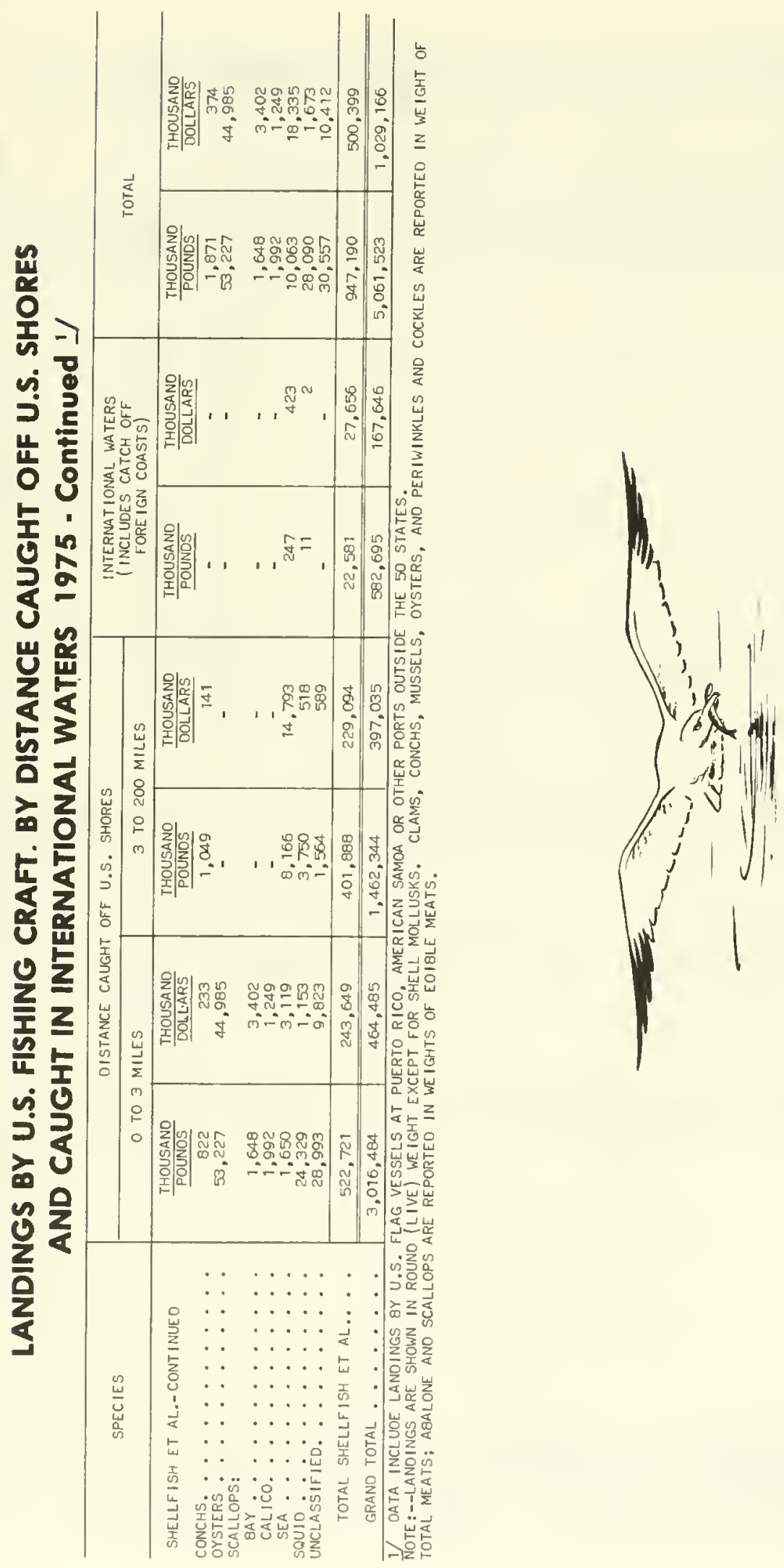


\section{LANDINGS USED FOR HUMAN FOOD AND INDUSTRIAL PRODUCTS, 1975}

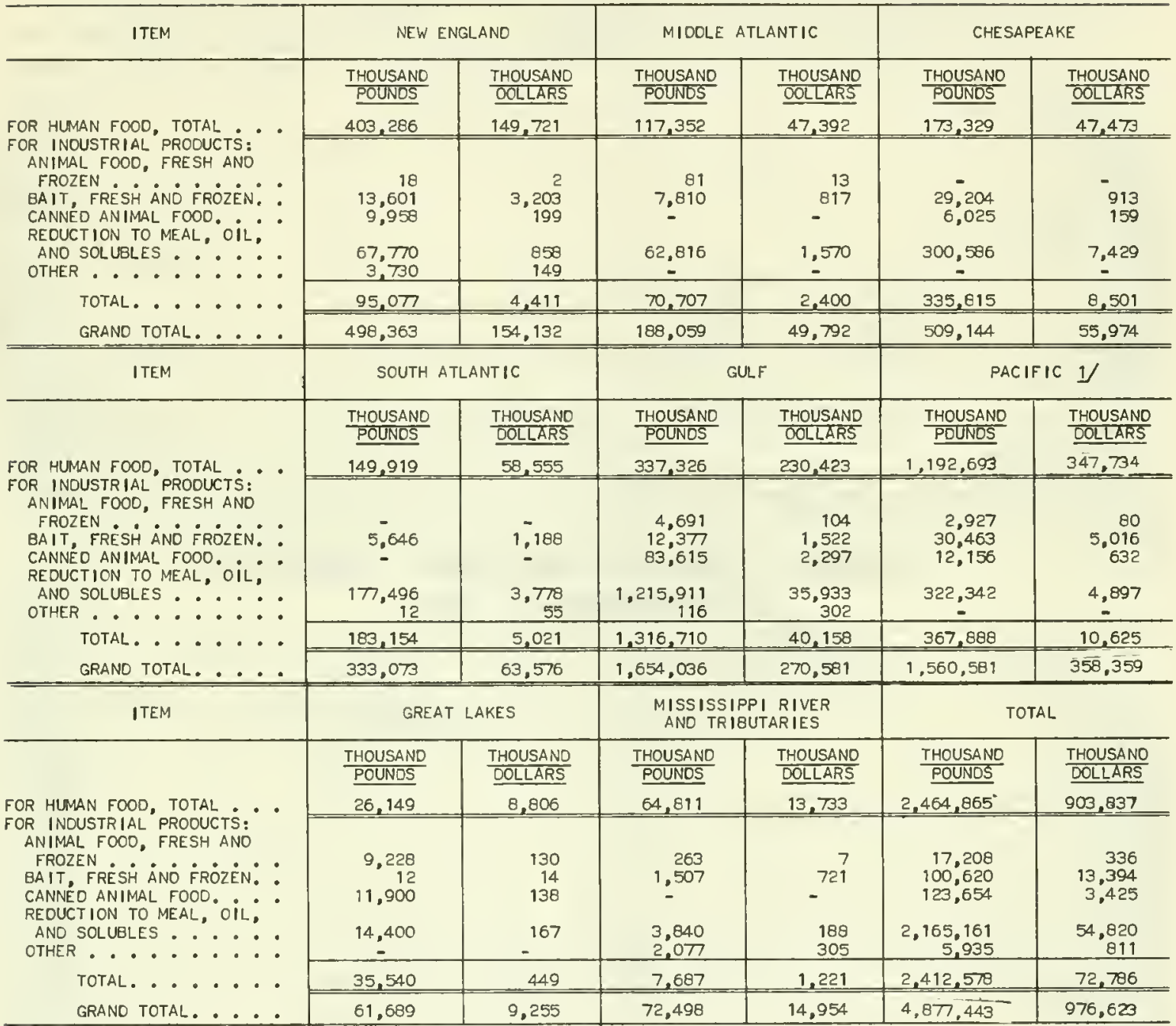

I) INCLUDES HAWAII. 


\section{LANDINGS USED FOR INDUSTRIAL PRODUCTS, BY REGIONS, 1975 - Continued}

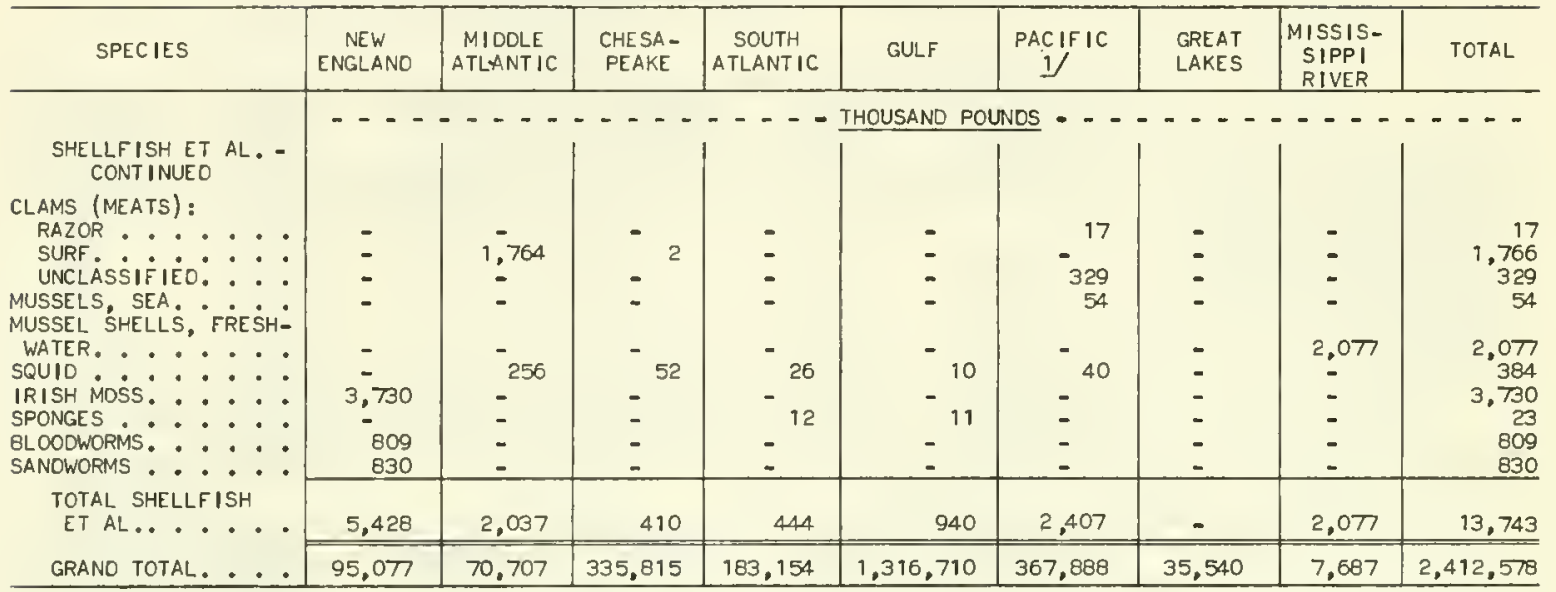

1) INCLUOES HAWAII.

NOTE: - $P A R T L Y$ ESTIMATED. LANOINGS OF CROAKER, COMMON EELS, GIZZARD SHAD, REO HAKE, THREAD HERRING, LAUNCE, MEN HADEN, MUDSUCKER, SEA ROBIN, WHITE SEA TROUT OR WEAKFISH, SKATES, SPANISH SARDINES, SPOT, WHITE CROAKER, GREEN

CRABS, AND UNCLASSIFIED CLAMS AS SHOWN IN THIS TABLE EXCEED THE TABULATION ON LANDINGS BY REGION, PAGE 17.

IN THAT TABLE, THE EXTRA AMOUNTS ARE INCLUDED WITH UNCLASSIFIEO FOR GAIT, REOUCTION, AND ANIMAL FOOD.

\section{LANDINGS USED FOR INDUSTRIAL PRODUCTS, BY COMMODITY, 1975}

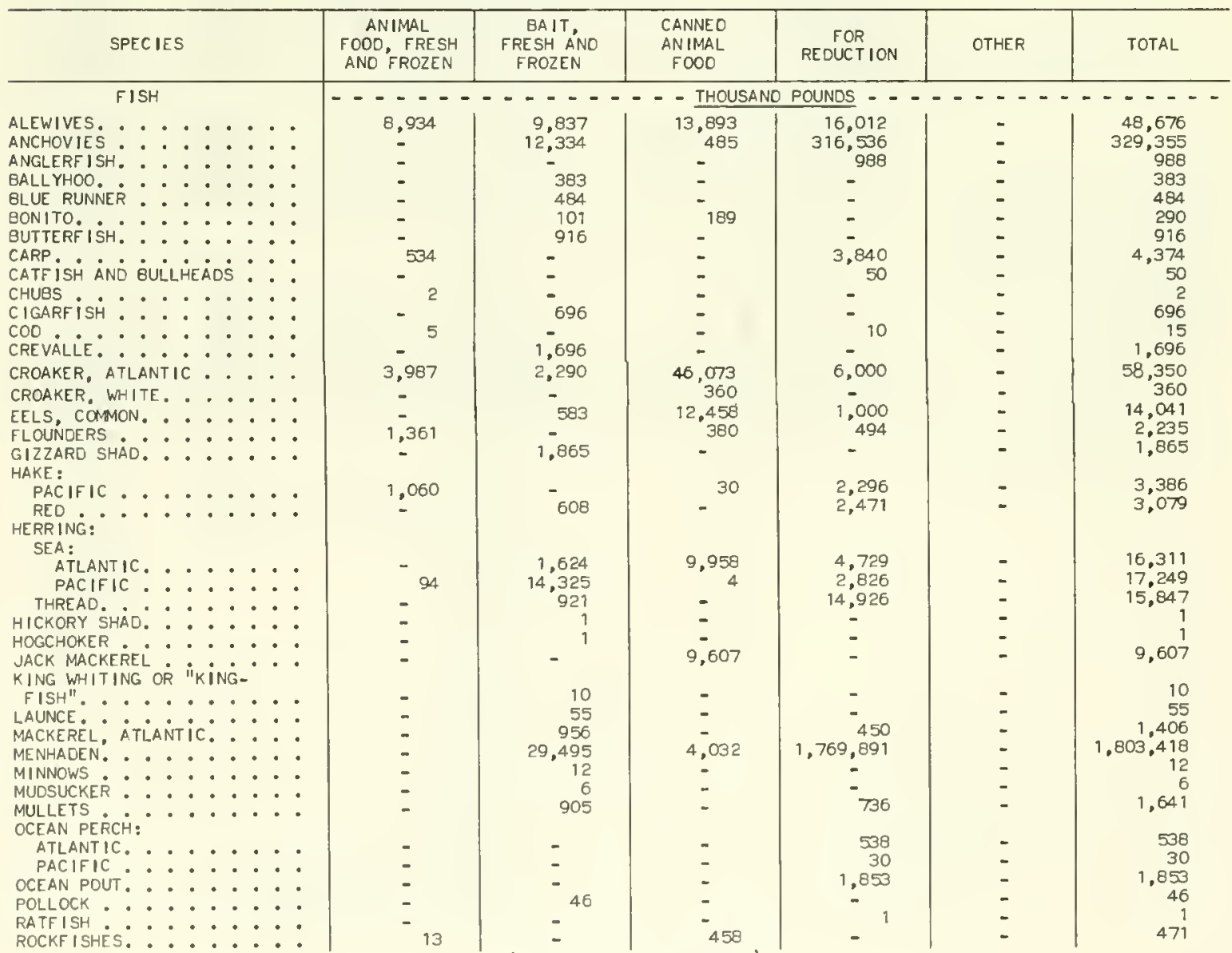


LANDINGS USED FOR INDUSTRIAL PRODUCTS, BY REGIONS, 1975

\begin{tabular}{|c|c|c|c|c|c|c|c|c|c|}
\hline SPECIES & $\begin{array}{l}\text { NEW } \\
\text { ENGLAND }\end{array}$ & $\begin{array}{l}\text { MIDDLE } \\
\text { ATLANTIC }\end{array}$ & $\begin{array}{l}\text { CHESA- } \\
\text { PEAKE }\end{array}$ & $\begin{array}{l}\text { SOUTH } \\
\text { ATLANTIC }\end{array}$ & GULF & $\begin{array}{l}\text { PACIFIC } \\
\end{array}$ & $\begin{array}{l}\text { GREAT } \\
\text { LAKES }\end{array}$ & $\begin{array}{l}\text { MISSIS- } \\
\text { SIPPI } \\
\text { RIVER }\end{array}$ & TOTAL \\
\hline \multirow{2}{*}{\multicolumn{10}{|c|}{ ALEWIVES. . . . }} \\
\hline & & & & & & & & & \\
\hline ANCHOVIES $\cdots \cdots$ & -088 & - & - & - & - & 329,355 & - & - & 329,355 \\
\hline BALLYHOO. : $: \therefore$ &. & - & - & 213 & 170 & - & - & $=$ & 383 \\
\hline $\begin{array}{l}\text { BLUE RUNNER } \cdots \cdots \\
\text { BONITO }\end{array}$ & - & $\overline{-}$ & - & $\begin{array}{l}50 \\
10\end{array}$ & $\begin{array}{r}434 \\
91\end{array}$ & - & - & - & 484 \\
\hline BUTTERFISH. : $: \vdots$ & - & ${ }^{-} 916$ & $\overline{-}$ & -10 & $-\quad 91$ & -189 & $\overline{-}$ & $\overline{-}$ & $\begin{array}{l}290 \\
916\end{array}$ \\
\hline CARP & : & - & 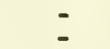 & $\overline{-}$ & & & $=$ & 4,038 & $\begin{array}{r}4.374 \\
50\end{array}$ \\
\hline CHUBS & - & - & - & - & - & - & 1 & 1 & 3 \\
\hline CIGARFISH $\ldots \vdots \vdots \vdots$ & $=$ & z & $\overline{-}$ & 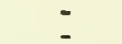 & -696 & $-{ }_{15}$ & $\overline{-}$ & - & $\begin{array}{r}696 \\
15\end{array}$ \\
\hline CREVALLE $:$ : & - & - & - & 78 & 1,618 & -15 & $\overline{-}$ & $=$ & 1,696 \\
\hline $\begin{array}{l}\text { CROAKER, ATLANTIC : } \\
\text { CROAKER, WHITE. : }\end{array}$ & - & - & $=$ & - & 58,350 & $-{ }_{360}$ & $\overline{-}$ & $\overline{-}$ & 58,350 \\
\hline EELS, cOOMMON. $\therefore$ & - & 48 & 85 & - & 13.908 & 74 & - & $\overline{-}$ & 14,041 \\
\hline GLOUNARD SHAOD: $: \vdots \vdots$ & - & $\overline{-}$ & 69 & $-\overline{289}$ & $=$ & 1,741 & 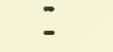 & 1,507 & $\begin{array}{l}2,235 \\
1,865\end{array}$ \\
\hline PACI & $=-0$ & - & - & - & - & 3,386 & - & - & 3,386 \\
\hline HERRING: $\cdots \cdots \cdots$ & 3,079 & - & - & - & - & & - & - & 3,079 \\
\hline SEA: & & & & & & & & & \\
\hline $\begin{array}{l}\text { ATLANTIC. }: \vdots: \\
\text { PACIFIC }:\end{array}$ & 15,932 &.$^{345}$ & 34 & $\overline{-}$ & $=$ & 17.249 & : & $=$ & 16.311 \\
\hline THREAD. $: \therefore \therefore$ & $=$ & $=$ & - & 6,902 & 8,945 & 17,249 & $=$ & $\overline{-}$ & $\begin{array}{l}77,249 \\
15,847\end{array}$ \\
\hline $\begin{array}{l}\text { HICKORY SHAD } \\
\text { HOGCHOKER }: \cdots\end{array}$ & - & $=$ & 1 & - & $=$ & $=$ & $=$ & - & 1 \\
\hline $\begin{array}{l}\text { JACK MACKEREL } \\
\text { KING WHITING OR }\end{array}$ & - & - & - & - & - & 9,607 & - & 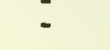 & 9,607 \\
\hline "KINGFISH" ..... & - & - & - & - & 10 & - & - & - & 10 \\
\hline LAUNCE, - ATLAANTIC: : & $\begin{array}{r}29 \\
1,199\end{array}$ & $\begin{array}{r}26 \\
207\end{array}$ & - & - & $=$ & $=$ & 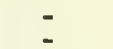 & - & $\begin{array}{r}55 \\
1,406\end{array}$ \\
\hline MENHAOEN. . . . & 50,866 & 67,021 & 321,995 & 166,894 & $1,196,642$ & $\overline{-}$ & $\overline{-}$ & $\overline{-}$ & $1,803,418$ \\
\hline $\begin{array}{l}\text { MINNOOWS } \\
\text { MUOSUCKER }: \cdots \cdots\end{array}$ & : & $=$ & $=$ & & $=$ & & 12 & $\overline{-}$ & $\begin{array}{r}12 \\
6\end{array}$ \\
\hline $\begin{array}{l}\text { MULLET } \\
\text { OCEAN PERCH: } \cdots\end{array}$ & - & - & - & 278 & 1,363 & - & 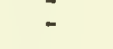 & $\overline{-}$ & 1,641 \\
\hline ATLANTIC. . . . & 538 & - & - & - & - & - & - & - & 538 \\
\hline $\begin{array}{l}\text { PACIFIC } \cdots \cdots \\
\text { OCEAN POUT: } \cdots \cdots\end{array}$ & -853 & $=$ & $\overline{-}$ & : & $=$ & 30 & $=$ & - & 30 \\
\hline 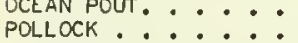 & & - & $=$ & $=$ & $=$ & & $\begin{array}{l}- \\
-\end{array}$ & $=$ & $\begin{array}{l}1,853 \\
46\end{array}$ \\
\hline RATFISH $\therefore \therefore$ & - & - & - & - & - & 1 & - & - & 1 \\
\hline $\begin{array}{l}\text { ROCKF ISHES. } \\
\text { SABLEFISH }: \cdots\end{array}$ & $=$ & $\overline{-}$ & $\overline{-}$ & $=$ & $=$ & $\begin{array}{r}471 \\
16\end{array}$ & $=$ & $=$ & 471 \\
\hline $\begin{array}{l}\text { SABLEFISH } \\
\text { SCULPIN }: \vdots: \vdots\end{array}$ & & & $=$ & $=$ & $=$ & $\begin{array}{r}16 \\
1\end{array}$ & $=$ & $=$ & $\begin{array}{r}16 \\
1\end{array}$ \\
\hline $\begin{array}{l}\text { SEA ROSIN } \\
\text { SEA TROUT OR WEAKF ISH, }\end{array}$ & 769 & 45 & - & - & - & - & - & - & 814 \\
\hline WHITE. ........ & - & - & - & - & 5,750 & - & - & - & 5,750 \\
\hline 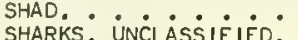 & $=$ & $=$ & - & - & - & 23 & - & - & \\
\hline $\begin{array}{l}\text { SHARKS, UNCLASSIFIED. } \\
\text { SILVERSIDES } . \cdots\end{array}$ & $=$ & 31 & $\begin{array}{c}- \\
-\end{array}$ & -6 & -13 & -631 & $\overline{-}$ & $=$ & $\begin{array}{r}650 \\
31\end{array}$ \\
\hline SKATES. . . . . & 1.060 & - & - & - & - & 15 & $-{ }_{5}$ & - & 1,075 \\
\hline SMELTISH SARDINESS: & $=$ & $=$ & $=$ & & 249 & & -5 & $=$ & $250^{5}$ \\
\hline SPOT. $\ldots \ldots \ldots$ & - & - & - & - & 20,385 & & - & - & 20,385 \\
\hline 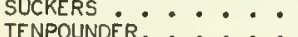 & $=$ & - & - & & - & & - & 64 & 64 \\
\hline NDER. : : : : : & - & - & - & - & 1,003 & 1 & - & $=$ & 1,011 \\
\hline TULL IEEEE & - & - & - & - & $=$ & - & 306 & - & 306 \\
\hline TUNA SKIPJACK. . . & $=-170$ & - & - & - & - & 597 & - & - & 597 \\
\hline UNCLASSIFIEDD: $\because \vdots \vdots$ & $\begin{array}{r}2.470 \\
4.822 \\
\end{array}$ & -31 & 5,829 & 6,453 & 6,093 & 1,427 & $=$ & $=$ & $\begin{array}{r}2,470 \\
25,655\end{array}$ \\
\hline TOTAL FISH. . & 89,649 & 68,670 & 335,405 & 182,710 & $1,315,770$ & 365,481 & 35,540 & 5,610 & $2,398,835$ \\
\hline SHELLFISH ET & & & & & & & & & \\
\hline CRABS: & & & & & & & & & \\
\hline $\begin{array}{l}\text { SOFT AND } \\
R . . .\end{array}$ & & & & & & & & & \\
\hline PREEN $: \vdots:$ & 59 & & - & 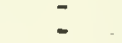 & $\overline{-}$ & & $\overline{-}$ & $=$ & $\begin{array}{r}365 \\
59\end{array}$ \\
\hline UNCLASSIFIE & - & & - & - & - & 8 & - & - & 8 \\
\hline RAWF ISH, FRESHWATER. & $\Xi$ & 8 & $=$ & $=$ & $=$ & -27 & $\overline{-}$ & $\overline{-}$ & $\begin{array}{l}27 \\
8\end{array}$ \\
\hline $\operatorname{MMP} . .$. & - & - & $=$ & - & - & 20 & $=$ & - & \\
\hline SHRIMP. & - & - & - & 406 & 919 & 1,912 & - & - & 3,237 \\
\hline
\end{tabular}




\section{LANDINGS USED FOR INDUSTRIAL PRODUCTS, BY COMMODITY, 1975 - Continued}

\begin{tabular}{|c|c|c|c|c|c|c|}
\hline SPECIES & $\begin{array}{l}\text { ANIMAL } \\
\text { FOOD, FRESH } \\
\text { AND FROZEN }\end{array}$ & $\begin{array}{l}\text { BAIT, } \\
\text { FRESH AND } \\
\text { FROZEN }\end{array}$ & $\begin{array}{l}\text { CANNED } \\
\text { ANIMAL } \\
\text { FOOD }\end{array}$ & $\begin{array}{c}\text { FOR } \\
\text { REOUCT ION }\end{array}$ & OTHER & TOTAL \\
\hline 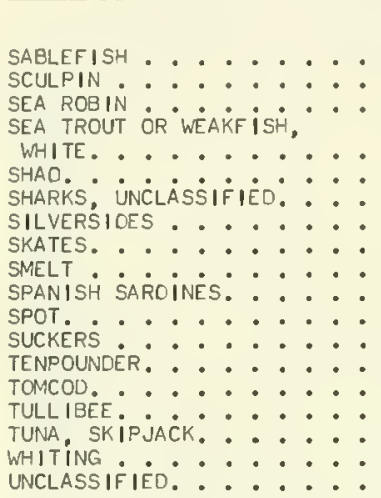 & 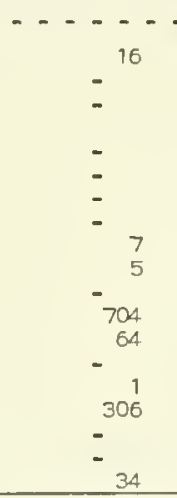 & $\begin{array}{r}1 \\
319 \\
542 \\
1 \\
19 \\
31 \\
566 \\
- \\
259 \\
900 \\
- \\
1,011 \\
- \\
- \\
- \\
- \\
9,094 \\
\end{array}$ & $\begin{array}{c}- \text { THOUS } \\
= \\
- \\
4,208 \\
= \\
= \\
- \\
16,723 \\
- \\
- \\
- \\
-1997 \\
\end{array}$ & $\begin{array}{c}\text { POUNOS }- \\
- \\
- \\
495 \\
1,000 \\
-631 \\
- \\
-502 \\
- \\
2,058 \\
- \\
- \\
- \\
- \\
2,470 \\
12,328\end{array}$ & $\begin{array}{l}- \\
- \\
- \\
- \\
- \\
= \\
- \\
= \\
= \\
= \\
= \\
= \\
- \\
-\end{array}$ & $\begin{array}{r}16 \\
1 \\
814 \\
5,750 \\
1 \\
650 \\
31 \\
1,075 \\
5 \\
259 \\
20,385 \\
64 \\
1,011 \\
1 \\
306 \\
597 \\
2,470 \\
25,655 \\
\end{array}$ \\
\hline TOTAL FISH .... & 17.127 & 92,893 & 123,654 & $2,165,161$ & - & $2,398,835$ \\
\hline 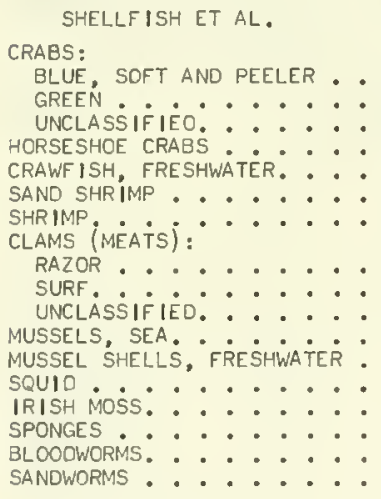 & $\begin{array}{l}- \\
\vdots \\
- \\
- \\
- \\
- \\
= \\
- \\
- \\
- \\
- \\
-\end{array}$ & $\begin{array}{r}365 \\
59 \\
8 \\
8 \\
27 \\
20 \\
3.132 \\
17 \\
1,685 \\
329 \\
54 \\
-\quad \\
-384 \\
- \\
- \\
809 \\
830 \\
\end{array}$ & $\begin{array}{l}- \\
= \\
= \\
= \\
- \\
= \\
= \\
= \\
= \\
= \\
- \\
\end{array}$ & $\begin{array}{l}- \\
- \\
- \\
- \\
- \\
- \\
- \\
- \\
- \\
- \\
-\end{array}$ & $\begin{array}{l}\overline{-} \\
\overline{-} \\
- \\
- \\
105 \\
\bar{z} \\
- \\
- \\
2,077 \\
3,730 \\
- \\
-\end{array}$ & $\begin{array}{r}365 \\
59 \\
8 \\
8 \\
27 \\
20 \\
3,237 \\
17 \\
1,766 \\
329 \\
54 \\
2,077 \\
384 \\
3,730 \\
23 \\
809 \\
830 \\
\end{array}$ \\
\hline TOTAL SHELLFISH ET AL. • & 81 & 7.727 & - & - & 5,935 & 13,743 \\
\hline GRAND TOTAL. . . . . . & 17,208 & 100,620 & 123,654 & $2,165,161$ & 5,935 & $2,412,578$ \\
\hline
\end{tabular}

NOTE :--PARTLY ESTIMATED. LANDINGS OF CROAKER, COMMON EELS, GIZZARD SHAD, RED HAKE, THREAD HERRING, LAUNCE, MENHADEN MUDSUCKER SEA ROBIN, WHITE SEA TROUT OR WEAKFISH, SKATES, SPANISH SARDINES, SPOT, WHTTE CROAKER, GREEN CRÁBS, AND UNCLASSIFIED CLAMS AS SHOWN IN THIS TABLE EXCEED THE TABULATION ON LANDINGS BY REGION, PAGE 17. IN THAT TAELE. THE EXTRA AMOUNTS ARE INCLUDED WITH UNCLASSIFIED FOR BAIT, REDUCTION, AND ANIMAL FOOD.

\section{MONTHLY LANDINGS AND UTILIZATION OF FISH AND SHELLFISH, 1975}

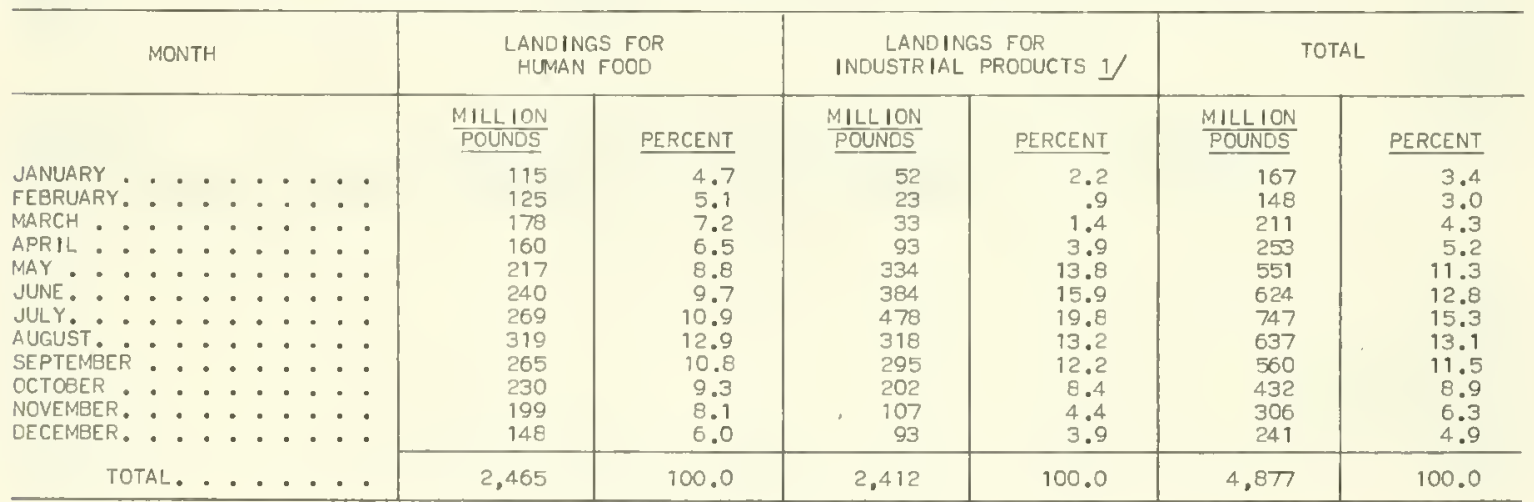

1) USEO FOR MEAL, OIL, SOLUBLES, BAIT, ANIMAL FOOD, AND OTHER NONHUMAN FOOD PRODUCTS. 
RELATIVE VOLUME OF THE LANDINGS, BY SPECIES, 1975

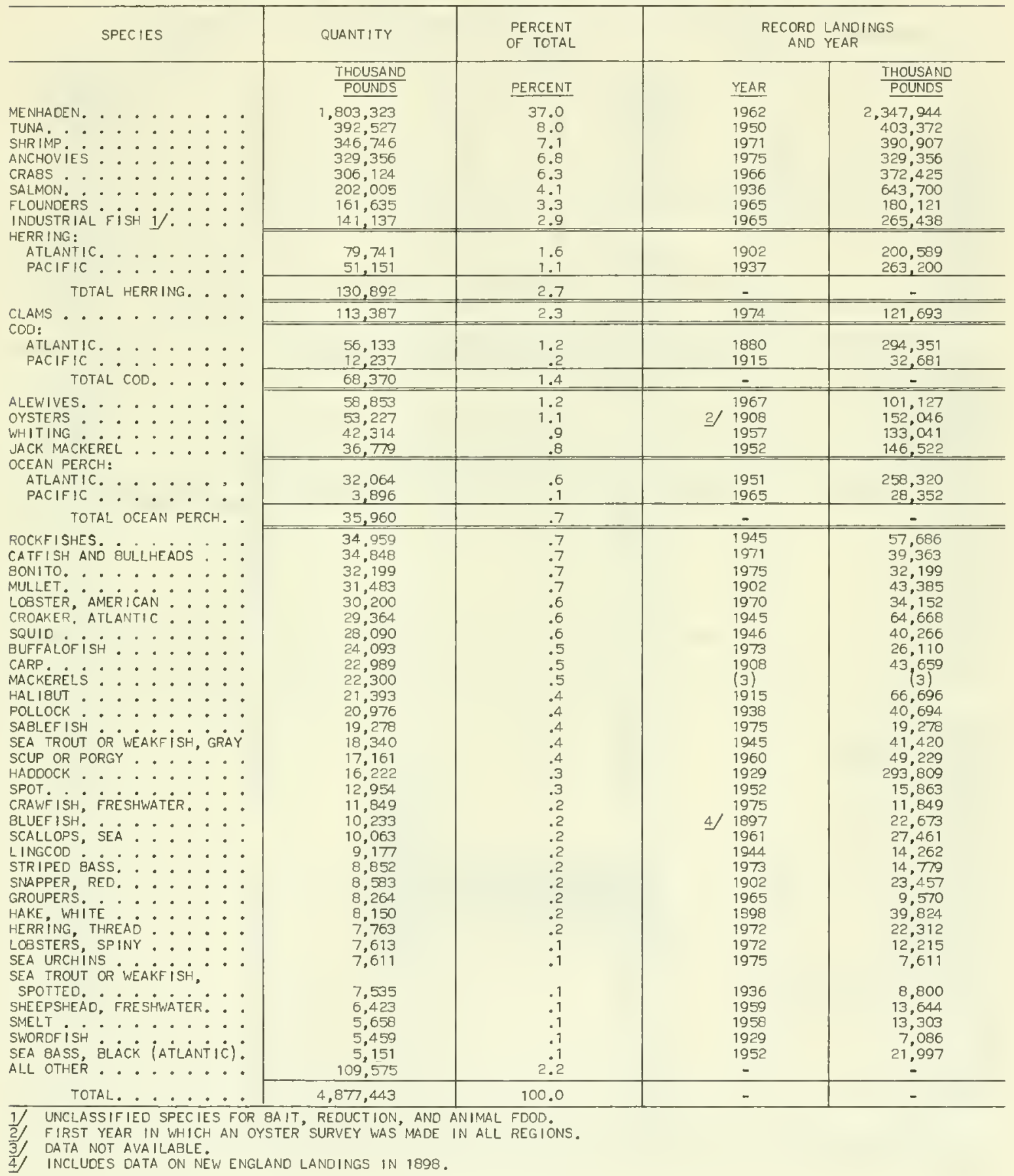




\section{RELATIVE VALUE OF THE LANDINGS, BY SPECIES, 1975}

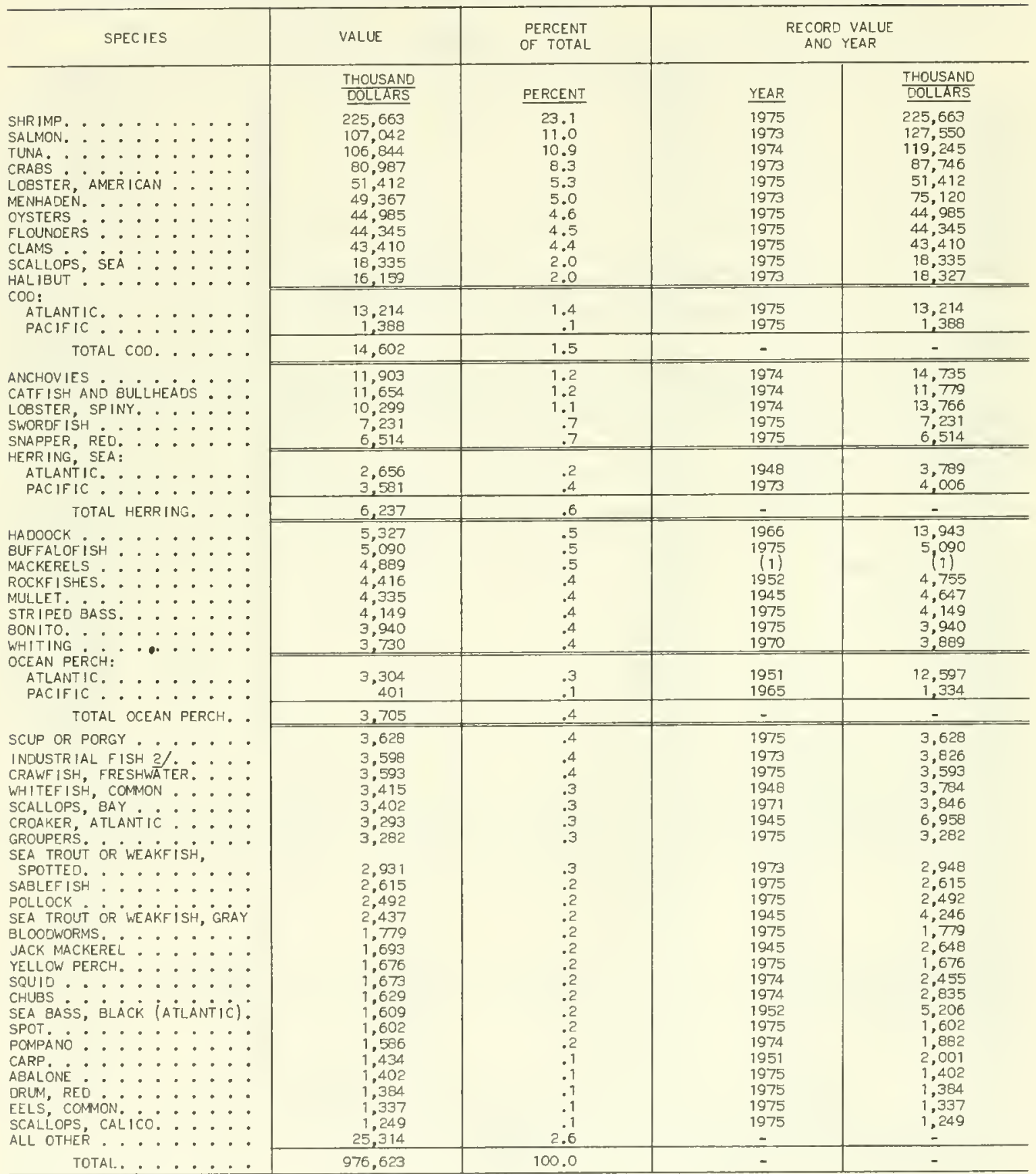

1/ DATA NOT AVA ILABLE.

1. UNCLASSIFIED SPECIES FOR BAIT, REDUCTION, ANO ANIMAL FOOD. 
SEED OYSTER FISHERY, 1975

\begin{tabular}{|c|c|c|c|c|c|c|c|c|c|}
\hline \multicolumn{2}{|l|}{ ITEM } & \multicolumn{2}{|c|}{$\begin{array}{l}\text { NEW ENGLAND, } \\
\text { CONNECT I CUT' }\end{array}$} & \multicolumn{2}{|c|}{$\begin{array}{c}\text { MIODLE ATLANTIC, } \\
\text { DELAWARE }\end{array}$} & \multicolumn{2}{|c|}{$\begin{array}{l}\text { CHESAPEAKE, } \\
\text { VIRGINIA }\end{array}$} & \multicolumn{2}{|c|}{ TOTAL } \\
\hline $\begin{array}{l}\text { OPERATING UNITS } \\
\text { FISHERMEN: } \\
\text { ON VESSELS. } \\
\text { ON } 80 A T S \text { AND SHORE } \\
\text { REGULAR : } \\
\text { CASUAL. }: .:\end{array}$ & $\begin{array}{l}. \\
. \\
. \\
.\end{array}$ & $\cdots$ & $\begin{array}{l}-\cdots-\cdots \\
- \\
\end{array}$ & $\cdots$ & 82 & $E R=-$ & $\begin{array}{c}---- \\
302 \\
182 \\
76\end{array}$ & $\cdots$ & $\begin{array}{c}-\ldots \\
384 \\
336 \\
76\end{array}$ \\
\hline TOTAL .... & . . & & 154 & & 82 & & 560 & & 796 \\
\hline 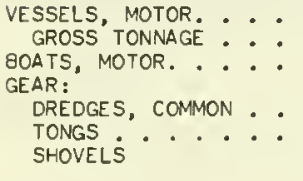 & 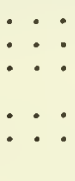 & & $\begin{array}{r}74 \\
- \\
- \\
-\end{array}$ & & $\begin{array}{r}8 \\
304 \\
15\end{array}$ & & $\begin{array}{r}101 \\
707 \\
72 \\
-\quad \\
410 \\
22 \\
\end{array}$ & & $\begin{array}{r}109 \\
1,011 \\
146 \\
\\
62 \\
410 \\
22\end{array}$ \\
\hline LANDINGS & & 8 U.S. & U.S.S. & U.S. & U.S. & U.S. & $\frac{\text { U.S. }}{\text { OOLLARS }}$ & BUSHELS & U.S. \\
\hline 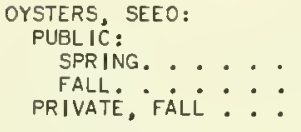 & : : : & $\begin{array}{r}36,800 \\
123,200 \\
-\end{array}$ & $\begin{array}{c}110,400 \\
369,600 \\
-\end{array}$ & $\begin{array}{c}16,625 \\
- \\
\end{array}$ & $\begin{array}{c}23,275 \\
- \\
- \\
\end{array}$ & $\begin{array}{r}245,666 \\
229,853 \\
2,951 \\
\end{array}$ & $\begin{array}{r}461,752 \\
416,764 \\
2,094 \\
\end{array}$ & $\begin{array}{r}299,091 \\
353,053 \\
2,951 \\
\end{array}$ & $\begin{array}{r}595,427 \\
786,364 \\
2,094 \\
\end{array}$ \\
\hline TOTAL. . . . . & $\cdot$. & 160,000 & 480,000 & 16,625 & 23,275 & 478,470 & 880,610 & 655,095 & $1,383,885$ \\
\hline
\end{tabular}

NOTE:--SOME OF THE FISHERMEN ENGAGEO IN HARVEST ING SEED OYSTERS ALSO FISHED FOR MARKET OYSTERS OR OTHER SPECIES.

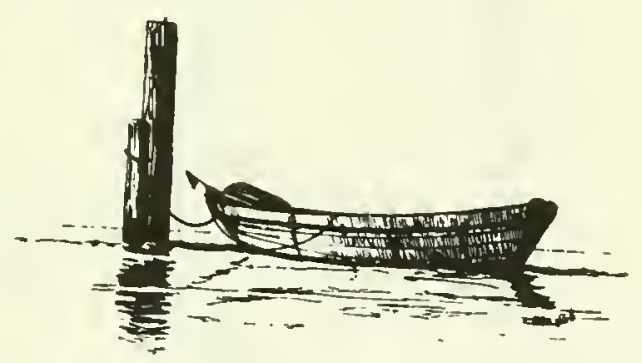




\section{U.S. LANDINGS, 1975 - LIVE WEIGHT BASIS}

In the annual digest it has been the practice of NMFS to show the landings of univalue and bivalve mollusks on the basis of the weight of meats. Insofar as possible, all other fish and shellfish items are shown on a live weight basis.

Since world fishery statistics published by the Food and Agriculture Organization of the United Nations represent the live weight of landings of all items of fish and shellfish, it has been necessary to provide that organization. with information on domestic landings of all species on a live weight basis. Data released by the Food and Agriculture Organization, therefore, indicate that U.S. landings in 1975 were 1.2 billion pounds greater than the figure appearing in NMFS publications. The increase is due to the inclusion of the weight of the shells of univalve and bivalve mollusks in the Food and Agriculture Organization data.

Data are included in the report showing the entire domestic landings on a live weight basis. Information is also included on landings of fishery products in the principal countries of the world so that the relative importance of the domestic fisheries can be determined. Tables contrining these data follows:

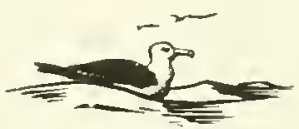

\section{U.S. LANDINGS, 1975 - LIVE WEIGHT BASIS}

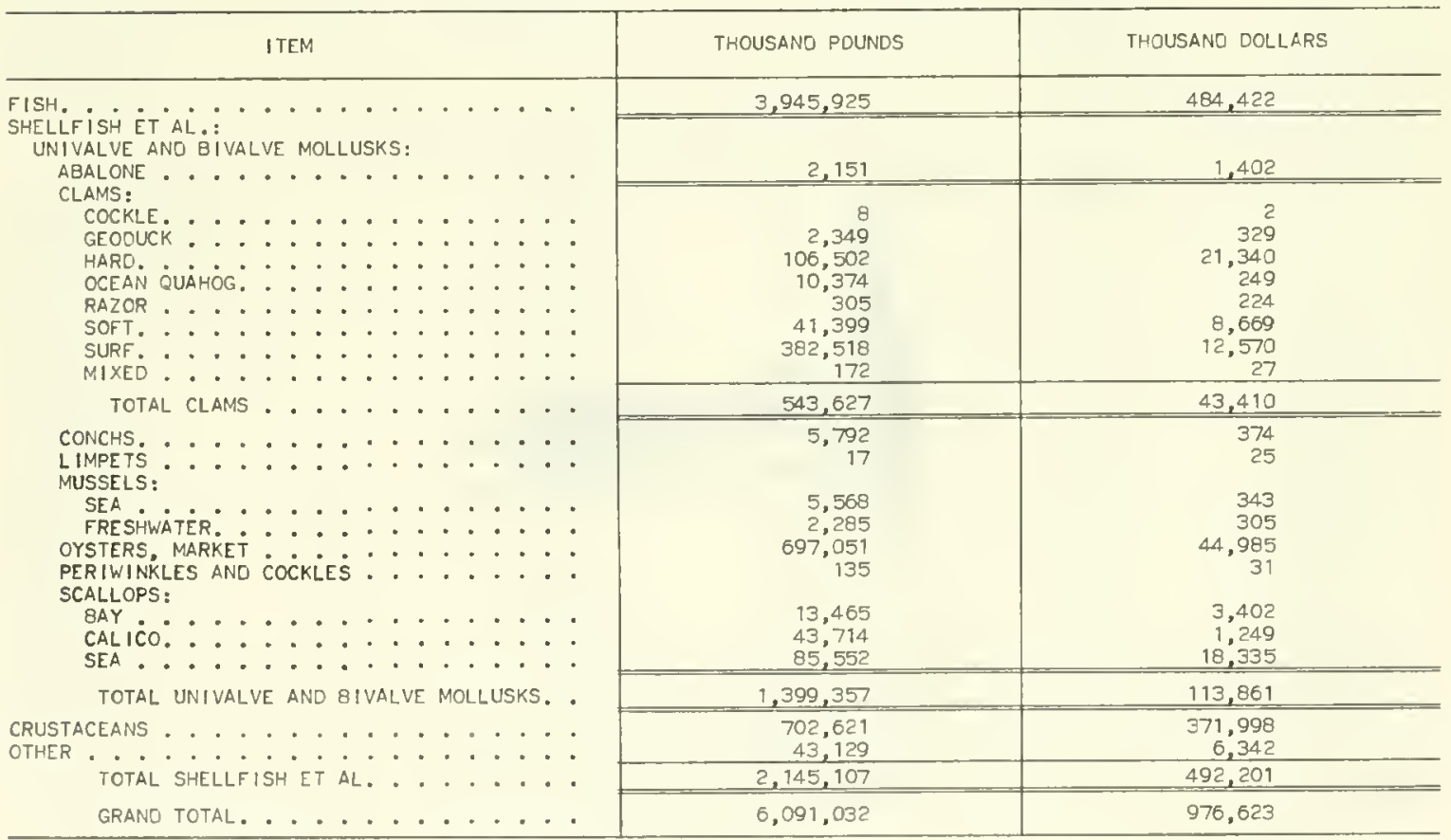




\section{WORLD LANDINGS OF FISH, CRUSTACEANS, MOLLUSKS, ET AL. BY COUNTRIES, 1975}

World landings of fish, crustaceans, mollusks, and other aquatic organisms (live weight) were 154.1 billion pounds-a decrease of 1 percent compared with 1974.

Six countries accounted for 50 percent of the world landings-Japan led with 15.1 percent; followed by the U.S.S.R., 14.2 percent; China, 9.8 percent; Peru, 4.9 percent; the United States, 4.0; and Norway, 3.7 percent.

Among the continents, Asia led with 44.0 percent of the world landings; followed by Europe with 18.1 percent; the U.S.S.R., 14.2 percent; South Africa, 8.4 percent; North and Central America, 6.9 percent; Africa, 6.4 percent; and Ocesnia, 0.4 percent.

\section{WORLD LANDINGS OF FISH, CRUSTACEANS, MOLLUSKS, ET AL. BY COÚNTRIES, 1975}

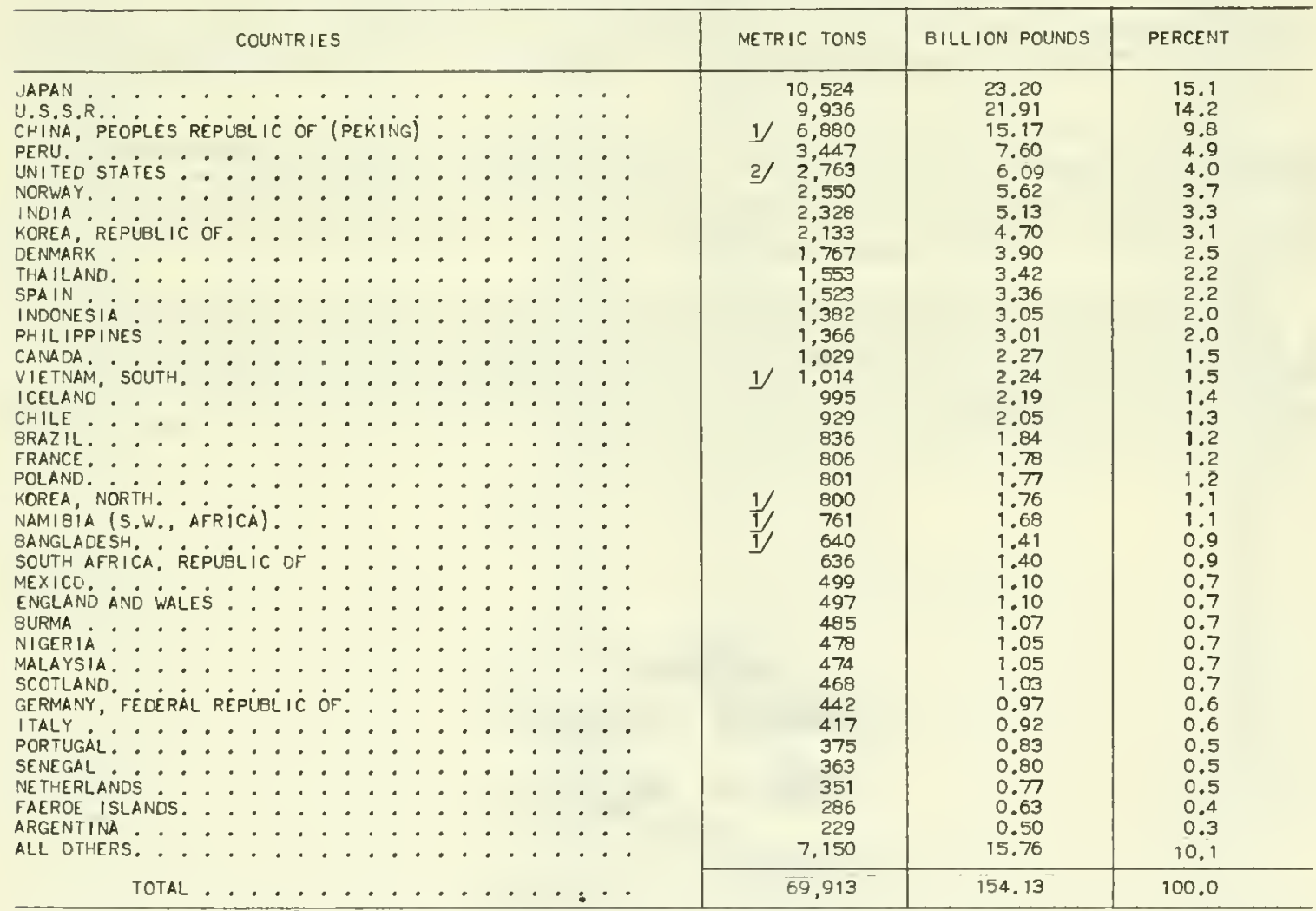

1/ OATA ESTIMATEO BY FAO. 2/ INCLUDES THE WEIGHT DF CLAMS, OYSTERS, SCALLOPS, ANO OTHER UNIVALVE AND BIVALVE MOLLUSK SHELLS. THIS WEIGHT IS NOT INCLUDED IN OTHER UNITED STATES LANDINGS STATISTICS. 


\section{PROCESSED FISHERY PRODUCTS, 1975}

The production of processed fishery products (fresh and frozen, canned, cured, and industrial) in the United States, American Samoa, and Puerto Rico was worth $\$ 2,651.0$ million in 1975 . Fresh and frozen items were 49 percent of the total value; canned, 40 percent; cured, 4 percent; and industrial, the remaining 7 percent. The Pacific Coast States accounted for $\$ 835.2$ million or about 32 percent of the total value of processed fishery products. The Gulf Coast States ranked second with $\$ 418.2$ million or 16 percent, and the New England States, third, with $\$ 391.7$ million or 15 percent. California was the leading State for processed fishery products with $\$ 472.3$ million, followed by Puerto Rico with $\$ 304.3$ million. Canned tuna was by far the most important fishery product produced in both California and Puerto Rico.

The 1975 production of fresh and frozen processed products, mainly fillets, steaks, fish sticks and portions, and breaded shrimp was $\$ 1,309.0$ million, compared with $\$ 1,128.8$ million in 1974 .

The pack of canned fishery products in the United States, American Samoa, and Puerto Rico was 49.0 million standard cases (1,382.4 million pounds), valued at $\$ 1,067.1$ million by the canning companies. Included in the total were 36.8 million standard cases, valued at $\$ 914.8$ million for human consumption, and 12.2 million standard cases valued at $\$ 152.3$ million for bait and animal food. Compared with 1974 , the total output declined 15 percent in quantity and 18 percent in value. The U.S. pack of canned tuna produced from both domestic and imported raw tuna was the leading canned product in 1975.

Production of cured fishery products in 1975 was $\$ 101.5$ million, compared with $\$ 113.7$ in 1974 . The value of salted products was $\$ 43.9$ million; smoked, $\$ 55.7$ million; and sun-dried, $\$ 1.9$ million. The value of salted and smoked fishery products declined by $\$ 5.9$ and $\$ 6.6$ million when compared with 1974 , but the value of sun-dried products increased by $\$ 228,000$ in 1975 .

The value of industrial fish products (including sealskins and other items further processed) was $\$ 173.4$ million in 1975 , compared with $\$ 207.9$ million in 1974 . The quantity of fish meal produced in 1975 was 290,431 tons $-11,000$ tons less than 1974. The production of oil reached 245.7 million pounds, 3 percent more than in 1974 and the highest since 1971. Domestic production of fish solubles was 128,000 tons, down 7 percent in quantity from 137,000 tons produced in 1974 .

A total of 3,606 wholesaling and processing establishments reported selling or processing fishery items in 1975 compared with 3,534 in 1974 . In 1975 , fishery products were processed by 1,700 firms, $-a$ decline of 38 firms from 1974. Peak monthly employment for all firms in 1975 was 92,310 compared with 92,118 in 1974 ; and average monthly employment was 71,006 in 1975 compared with 70,750 in 1974 . Peak monthly employment in the processing segment of the industry was 78,983 in 1975 and 80,666 in 1974; average monthly employment was 60,281 in 1975 compared with 61,114 in 1974 .

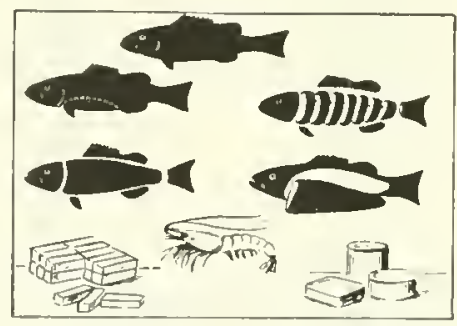


SUMMARY OF PROCESSED PRODUCTS, 1975

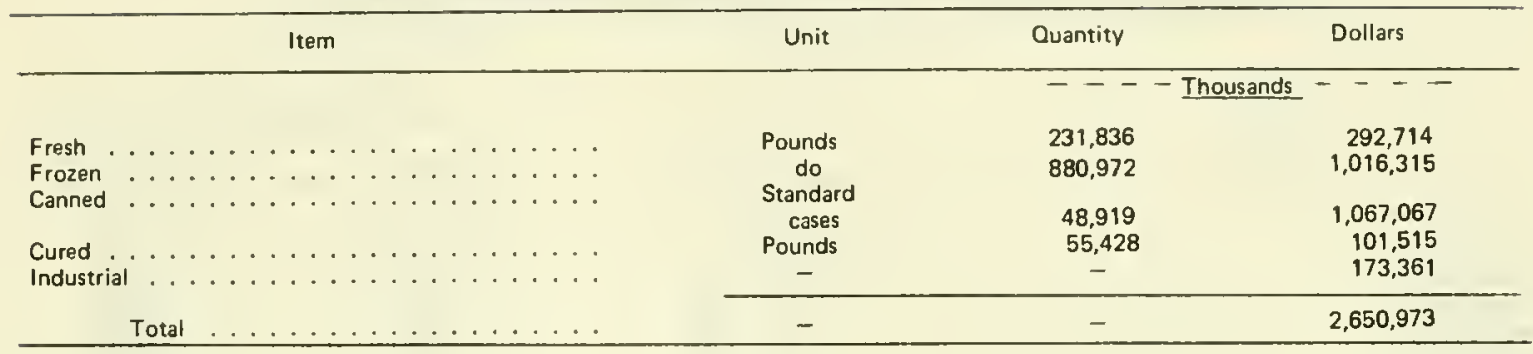

Note:- Totals are correct. Figures may not add to total because of rounding.

\section{VALUE OF PROCESSED PRODUCTS, BY STATES, 1975}

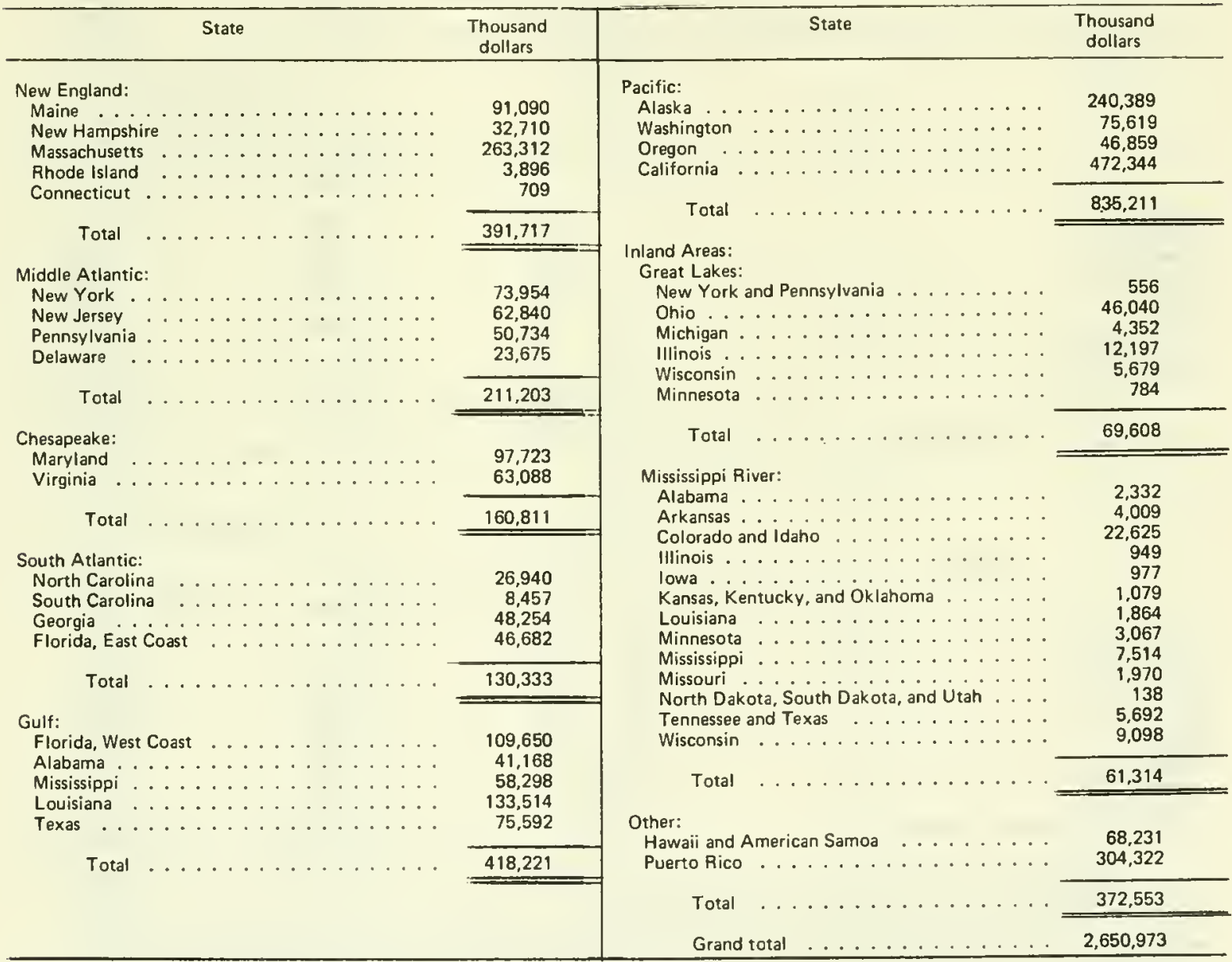

Note:--Totals are correct. Regions and States may not add because of rounding. 


\section{PROCESSING AND WHOLESALE ESTABLISHMENTS AND EMPLOYMENT, 1975}

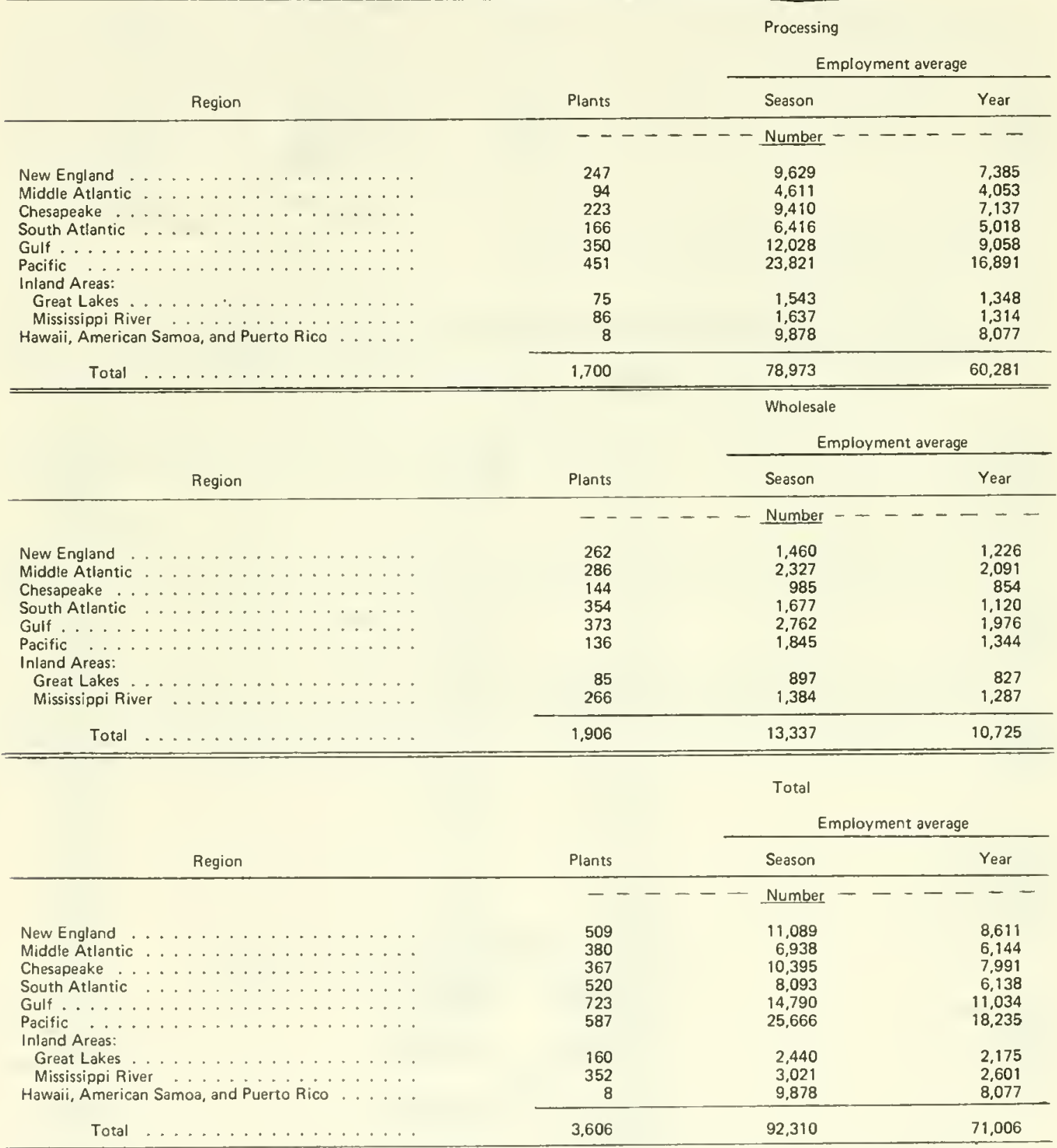

Note:-Date are incomplete. A partial survey was made for Hawail only.

Employment is reported by each plant for each month for the payroll period that includes the 12th of the month. Employment

for the season is based on the greatest number of employees working during the payroll period that included the 12th of each month. Employment for the year is obtained by adding the number of employees recorded as working during the payroll period that included the 12 th of each month, and dividing by 12 . 
PROCESSED FISHERY PRODUCTS, 1975

\begin{tabular}{|c|c|c|c|}
\hline Item & Unit & Quantity & Dollars \\
\hline & & --- & --- \\
\hline \multicolumn{4}{|l|}{ Alewives: } \\
\hline $\begin{array}{l}\text { Fresh and frozen for bait } \ldots \ldots \ldots \ldots \ldots \\
\text { Canned: }\end{array}$ & Pounds & 2,575 & 125 \\
\hline Fish $\ldots \ldots \ldots \ldots \ldots \ldots \ldots$ & Standard & & \\
\hline & cases & 7 & 529 \\
\hline Roe ${ }_{\text {Animal food }} \ldots \ldots \ldots \ldots$ & do & 4 & 86 \\
\hline Animal food $\ldots \ldots \ldots \ldots$ & do & 1,130 & 9,006 \\
\hline 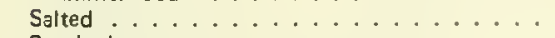 & Pounds & 4,360 & 1,217 \\
\hline 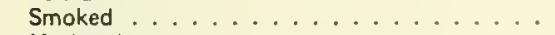 & do & 73 & 43 \\
\hline Meal and scrap $\ldots \ldots \ldots \ldots$ & Tons & (1) & (1) \\
\hline Oil $\ldots \ldots \ldots \ldots \ldots \ldots \ldots$ & Pounds & (1) & (1) \\
\hline \multicolumn{4}{|l|}{ Anchovies: } \\
\hline & (1) \\
\hline Natural $\ldots \ldots \ldots \ldots \ldots$ & Standard & & \\
\hline$\ldots \ldots \ldots \ldots \ldots$ & cases & (1) & (1) \\
\hline Salted $\ldots \ldots \ldots$ & do & 3 & 183 \\
\hline Meal and scrap $\ldots \ldots \ldots$ & Pounds & (1) 28 & $(1)$ \\
\hline 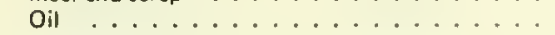 & $\begin{array}{l}\text { Tons } \\
\text { Pounds }\end{array}$ & $\begin{array}{r}28 \\
12,857\end{array}$ & $\begin{array}{l}6,559 \\
1,547\end{array}$ \\
\hline Anglerfish, fresh and frozen, fillets $\ldots \ldots \ldots$ & do & (1) & (1) \\
\hline Ballyhoo, frozen for bait ........... & do & (1) & (1) \\
\hline Barracuda, smoked . . . . . . . . . . & do & (1) & (1) \\
\hline Bluefish, fresh and frozen, fillets and steaks ... & do & 143 & 102 \\
\hline \multicolumn{4}{|l|}{ Buffalofish: } \\
\hline \multicolumn{4}{|l|}{ Fresh and frozen: } \\
\hline 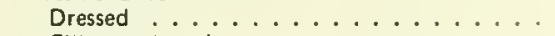 & do & (1) & (1) \\
\hline Fillets and steaks $\ldots \ldots \ldots \ldots \ldots$ & do & 249 & 144 \\
\hline 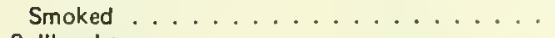 & do & 26 & 29 \\
\hline \multicolumn{4}{|l|}{ 8ullheads: } \\
\hline Fresh and frozen, dressed and skinned $\ldots \ldots$ & do & 15 & 8 \\
\hline 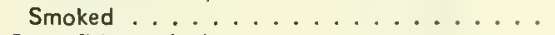 & do & (1) & (1) \\
\hline Butterfish, smoked $\ldots \ldots \ldots \ldots$ & do & 28 & 55 \\
\hline \multicolumn{4}{|l|}{$\begin{array}{l}\text { Carp: } \\
\text { Fresh and frozen: }\end{array}$} \\
\hline 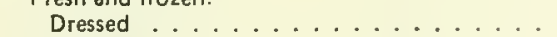 & do & (1) & (1) \\
\hline \multicolumn{4}{|l|}{ Fillets: } \\
\hline 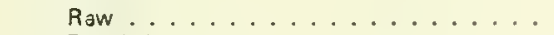 & do & 2,140 & 839 \\
\hline 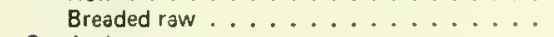 & do & (1) & (1) \\
\hline 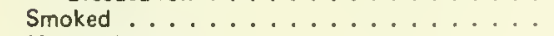 & do & 362 & 231 \\
\hline Meal and scrap $\ldots \ldots \ldots \ldots$ & Tons & (1) & (1) \\
\hline Oil $\ldots \ldots \ldots \ldots \ldots \ldots \ldots \ldots \ldots \ldots$ & Pounds & (1) & (1) \\
\hline \multirow{2}{*}{\multicolumn{4}{|c|}{$\begin{array}{l}\text { Catfish: } \\
\text { Fresh and frozen: }\end{array}$}} \\
\hline \multirow{2}{*}{\multicolumn{4}{|c|}{$\begin{array}{l}\text { Fresh and frozen: } \\
\text { Dressed and skinned: }\end{array}$}} \\
\hline & & & \\
\hline 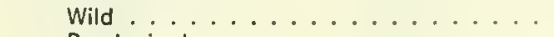 & do & 4,829 & 4,849 \\
\hline Pond raised $\ldots \ldots \ldots \ldots \ldots$ & do & 10,313 & 11,694 \\
\hline Fillets: & & & \\
\hline 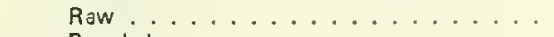 & do & (1) & (1) \\
\hline 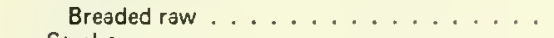 & do & (1) & (1) \\
\hline 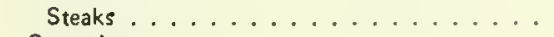 & do & 72 & 96 \\
\hline Canned stews $\ldots \ldots \ldots \ldots \ldots$ & Standard & & \\
\hline & cases & (1) & (1) \\
\hline Smoked . . . . . . . . . . . & Pounds & (1) & (1) \\
\hline Meal and scrap $\ldots \ldots \ldots \ldots$ & Tons & (1) & (1) \\
\hline 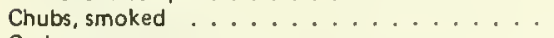 & Pounds & 4,188 & 6,181 \\
\hline Cod: & & & \\
\hline Fresh and frozen: & & & \\
\hline For bait $\ldots \ldots \ldots \ldots \ldots$ & do & (1) & (1) \\
\hline Fillets: & & & \\
\hline 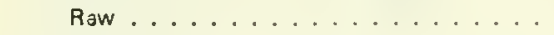 & do & 15,212 & 14,652 \\
\hline Breaded, raw and cooked ........ & do & 1,689 & 1,388 \\
\hline Form pressed $\ldots \ldots \ldots \ldots$ & do & (1) & (1) \\
\hline Steaks: & & & \\
\hline 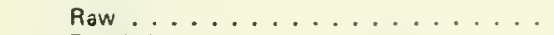 & do & 374 & 216 \\
\hline Breaded raw . . . . . . . . . . . & do & (1) & (1) \\
\hline 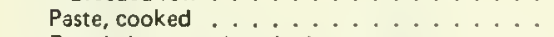 & do & (1) & (1) \\
\hline Breaded, raw and cooked: & & & \\
\hline Cakes $\ldots \ldots \ldots \ldots \ldots$ & do & 288 & 120 \\
\hline Croquettes $\ldots \ldots \ldots \ldots$ & do & (1) & (1) \\
\hline Salted: & & & \\
\hline Fish and bites $\ldots \ldots \ldots \ldots$ & do & 112 & 84 \\
\hline Lutefisk . . . . . . . . . . . . & do & 1,497 & 1,303 \\
\hline 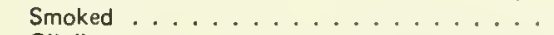 & do & 150 & 240 \\
\hline Oil, liver . . . . . . . . . . . . . . . & do & (1) & (1) \\
\hline See footnotes at end of table. & IContinue & & \\
\hline
\end{tabular}




\section{PROCESSED FISHERY PRODUCTS, 1975 - Continued}

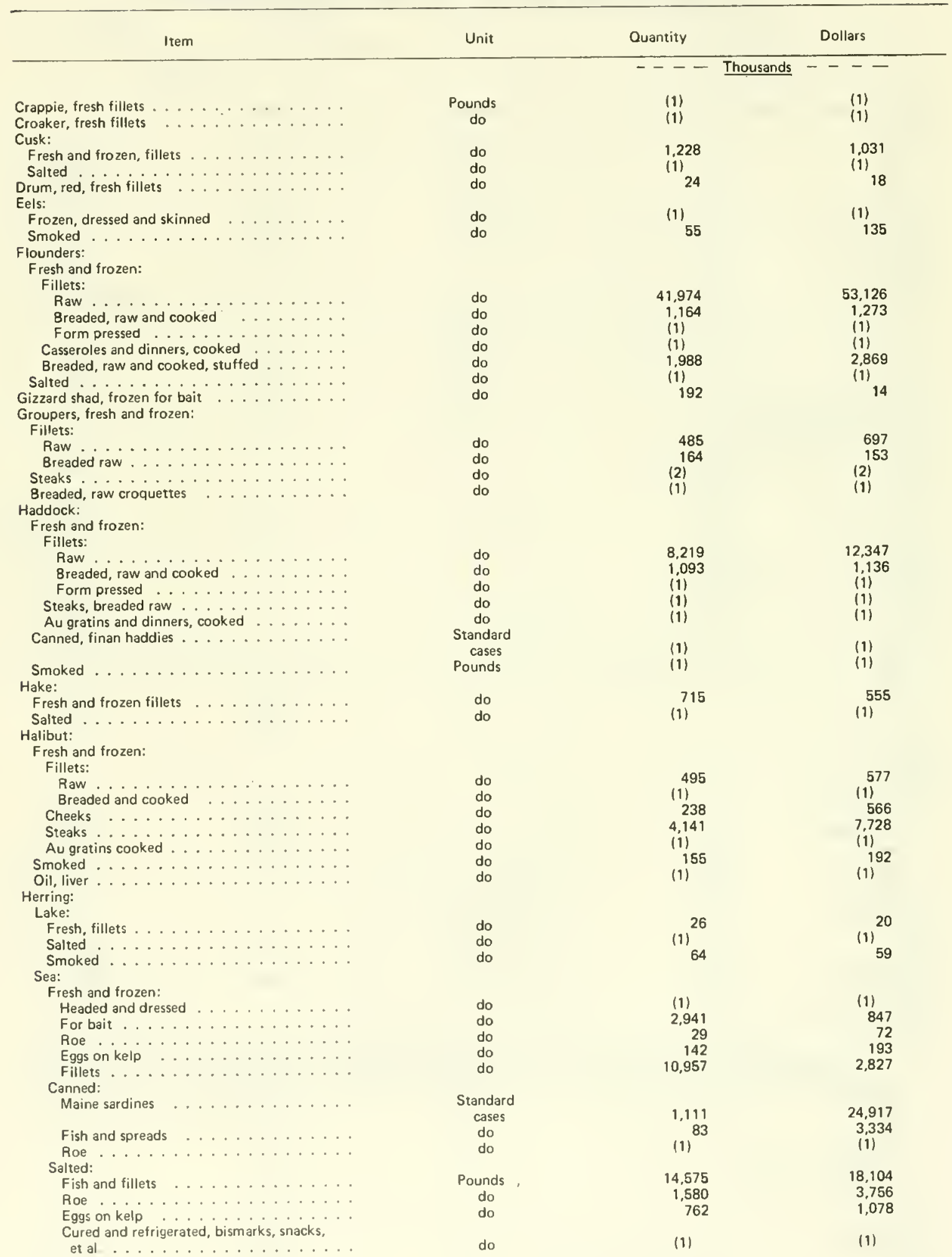


PROCESSED FISHERY PRODUCTS, 1975 - Continued

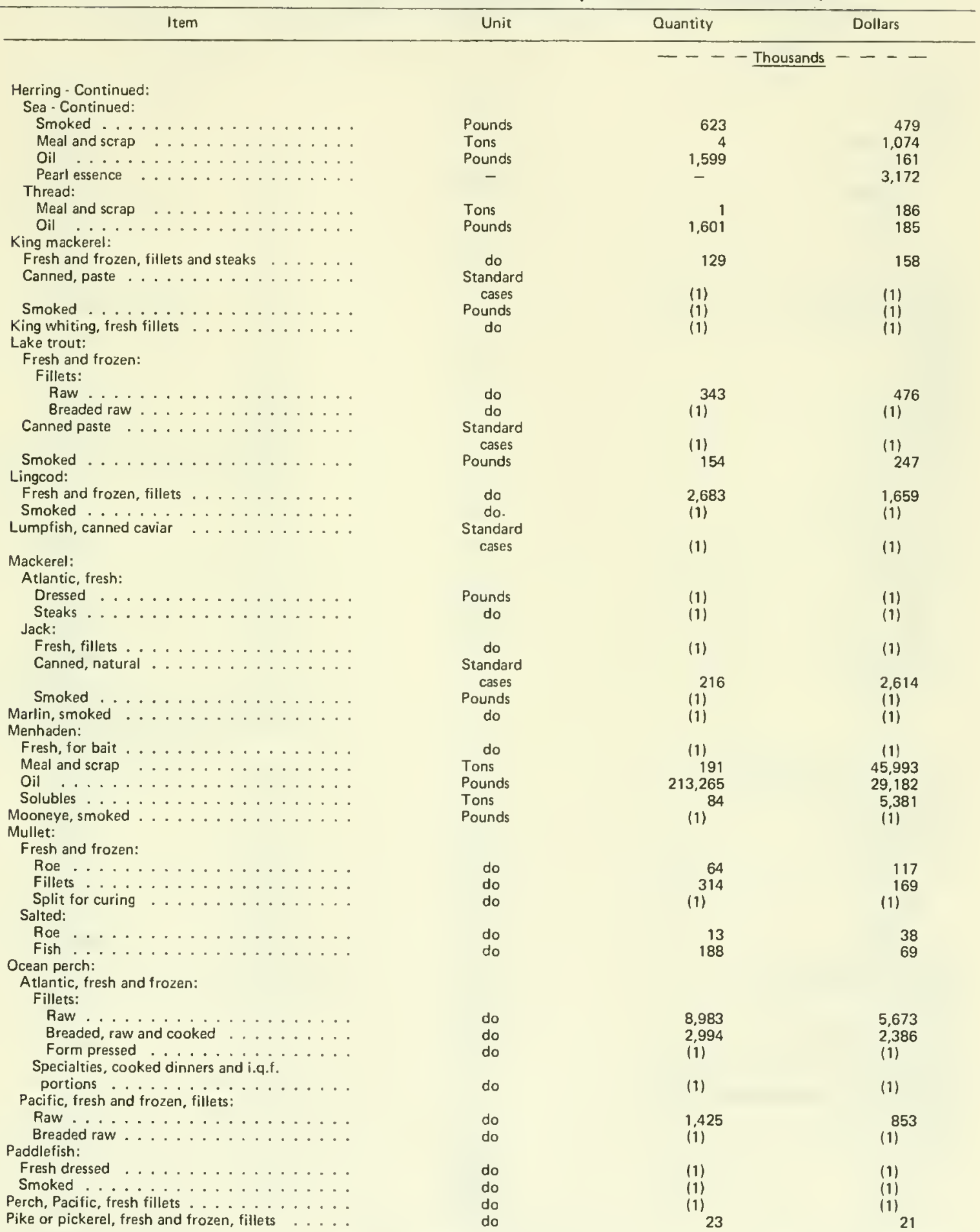

See footnotes at end of table.

(Continued on next page) 


\section{PROCESSED FISHERY PRODUCTS, 1975 - Continued}

\begin{tabular}{|c|c|c|c|}
\hline Item & Unit & Quantity & Dollars \\
\hline & & --- & --- \\
\hline \multicolumn{4}{|l|}{ Pollock: } \\
\hline \multicolumn{4}{|l|}{ Atlantic: } \\
\hline \multirow{2}{*}{\multicolumn{4}{|c|}{$\begin{array}{l}\text { Fresh and frozen: } \\
\text { Fillets: }\end{array}$}} \\
\hline & & & \\
\hline Raw Breaded raw $\ldots \ldots \ldots$ & $\begin{array}{c}\text { Pounds } \\
\text { do }\end{array}$ & $\begin{array}{l}5,631 \\
(1)\end{array}$ & $\begin{array}{l}3,628 \\
\text { (1) }\end{array}$ \\
\hline \multicolumn{4}{|l|}{ 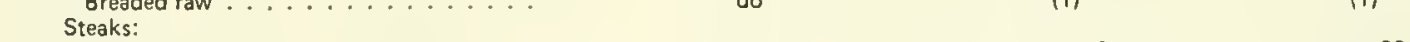 } \\
\hline 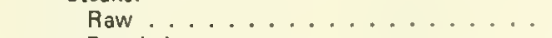 & do & 46 & 20 \\
\hline 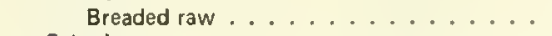 & do & (1) & $(1)^{20}$ \\
\hline 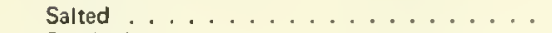 & do & 34 & 19 \\
\hline Smoked . . . . . . . . . . . . . & do & (1) & (1) \\
\hline Pacific, frozen, breaded cooked, fish and chips . & do & (1) & (1) \\
\hline Pompano, frozen fillets $\ldots \ldots \ldots \ldots$ & do & (1) & (1) \\
\hline \multicolumn{4}{|l|}{ Rockfish: } \\
\hline 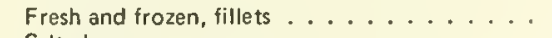 & do & 5,472 & 3,179 \\
\hline Salted $\ldots \ldots \ldots \ldots \ldots \ldots$ & do & (1) & (1) \\
\hline \multicolumn{4}{|l|}{ Sablefish: } \\
\hline Fresh and frozen, fillets .......... & do & 1,448 & 787 \\
\hline 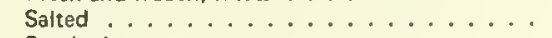 & do & (1) & (1) \\
\hline 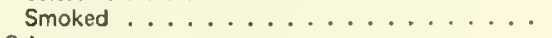 & do & 2,871 & 4,414 \\
\hline \multirow{2}{*}{\multicolumn{4}{|c|}{ Salmon: }} \\
\hline & & & Fresh and frozen: \\
\hline Fillets $\ldots \ldots \ldots \ldots \ldots \ldots$ & do & 4,798 & 7,044 \\
\hline 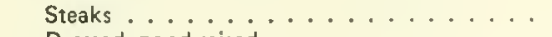 & do & 1,156 & 2,381 \\
\hline Dressed, pond-raised $\ldots \ldots \ldots$ & do & (1) & (1) \\
\hline \multicolumn{4}{|l|}{ Eggs: } \\
\hline For food $\ldots \ldots \ldots \ldots$ & do & 232 & 549 \\
\hline For bait $\ldots \ldots \ldots \ldots \ldots$ & do & $(3)$ & 1 \\
\hline \multirow{2}{*}{\multicolumn{4}{|c|}{$\begin{array}{l}\text { Canned: } \\
\text { Chinook or king . . . . . . . . . }\end{array}$}} \\
\hline \multirow{2}{*}{ Chinook or king . . . . . . . . } & Standard & & \\
\hline & cases & 17 & 1,406 \\
\hline $\begin{array}{l}\text { Pink } \\
\text { Red or sockeye } \ldots \ldots \ldots \ldots\end{array}$ & do & 617 & 40,646 \\
\hline $\begin{array}{l}\text { Red or sockeye } \ldots \ldots \ldots \ldots \\
\text { Silver or coho }\end{array}$ & do & 632 & 51,882 \\
\hline & do & 63 & 4,325 \\
\hline Total $\ldots \ldots \ldots \ldots$ & do & 1,555 & 110,414 \\
\hline Smoked ................... & do & 2 & 351 \\
\hline 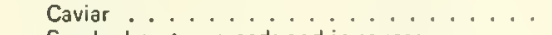 & do & 1 & 545 \\
\hline Smoked paste, spreads,and in sauces .... & do & (3) & 21 \\
\hline Animal food $\ldots \ldots \ldots \ldots \ldots$ & do & (1) & (1) \\
\hline Eggs for bait $\ldots \ldots \ldots \ldots \ldots$ & do & 12 & 4,427 \\
\hline \multicolumn{4}{|l|}{ Salted: } \\
\hline Salted and pickled $\ldots \ldots \ldots \ldots$ & Pounds & 419 & 484 \\
\hline 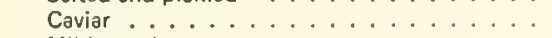 & do & 2,003 & 6,706 \\
\hline Mild cured $\ldots \ldots \ldots \ldots \ldots$ & do & 2,797 & 7,277 \\
\hline \multicolumn{4}{|l|}{ Eggs: } \\
\hline For food $\ldots \ldots \ldots \ldots$ & do & 589 & 2,412 \\
\hline For bait $\ldots \ldots \ldots \ldots \ldots$ & do & 21 & 66 \\
\hline 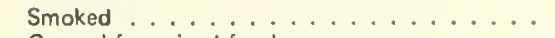 & do & 10,902 & 36,238 \\
\hline 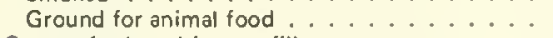 & Tons & (1) & (1) \\
\hline Sauger, fresh and frozen, fillets: & & & \\
\hline 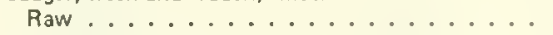 & Pounds & 128 & 196 \\
\hline 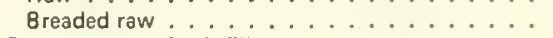 & do & (1) & (1) \\
\hline Scup or porgy, fresh fillets $\ldots \ldots \ldots$ & do & (1) & (i) \\
\hline Sea bass: & & & \\
\hline 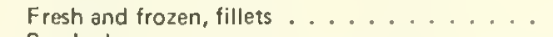 & do & 64 & 104 \\
\hline 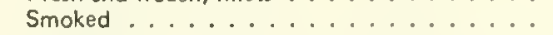 & do & (1) & (1) \\
\hline Sea trout, fresh and frozen, fillets . . . . . . . & do & 335 & 279 \\
\hline Shad: & & & \\
\hline Fresh, fillets, boned . . . . . . . . . & do & 45 & 124 \\
\hline Canned: & & & \\
\hline Roe $\ldots \ldots \ldots \ldots \ldots \ldots$ & $\begin{array}{l}\text { Standard } \\
\text { cases }\end{array}$ & (1) & (1) \\
\hline Smoked . . . . . . . . . . . & $\begin{array}{l}\text { Cases } \\
\text { do }\end{array}$ & (1) & (1) \\
\hline 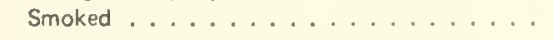 & pounds & 83 & 108 \\
\hline See footnotes at end of table. & (Continue & & \\
\hline
\end{tabular}


PROCESSED FISHERY PRODUCTS, 1975 - Continued

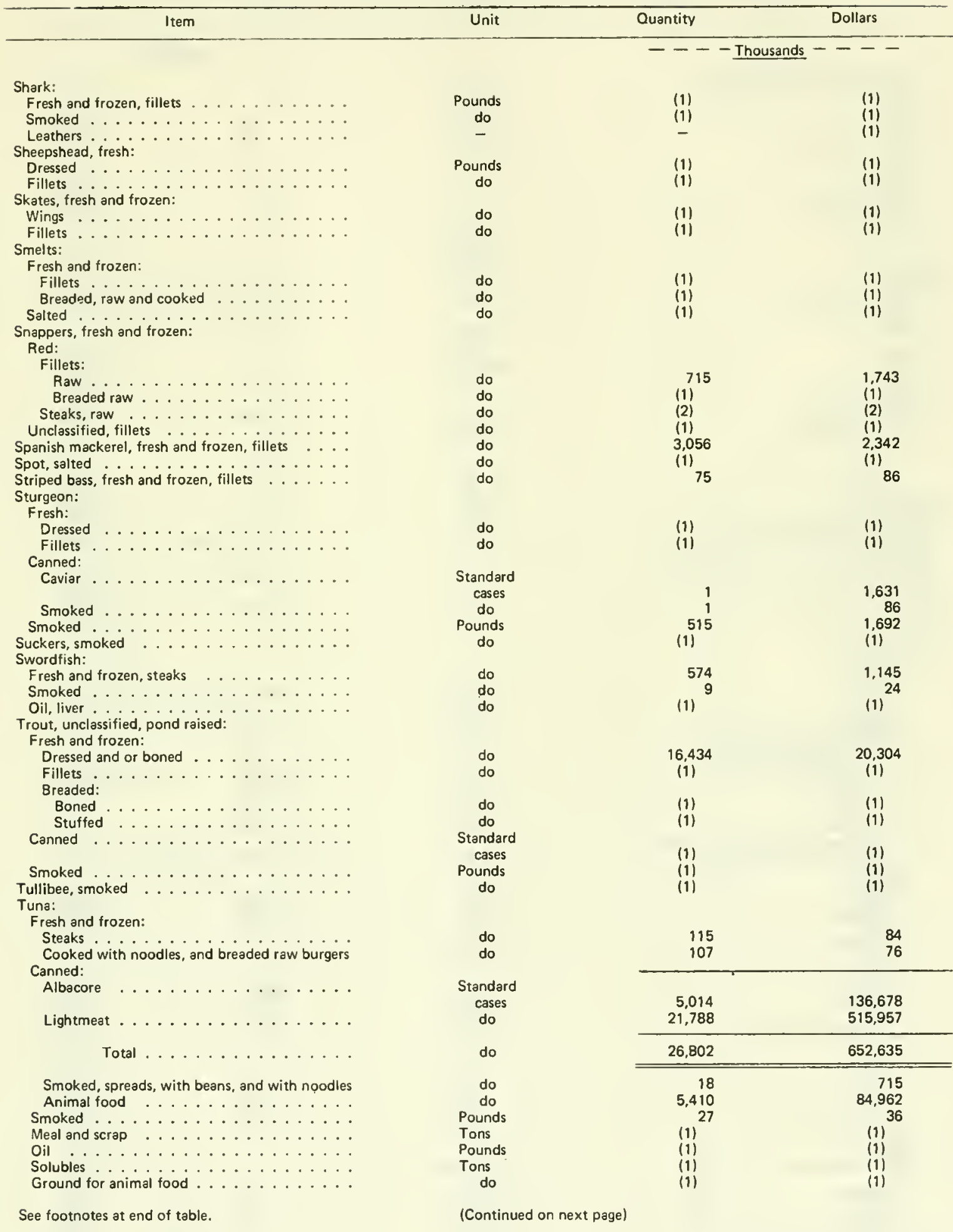




\section{PROCESSED FISHERY PRODUCTS, 1975 - Continued}

\begin{tabular}{|c|c|c|c|}
\hline Item & Unit & Quantity & Dollars \\
\hline & & --- & --- \\
\hline $\begin{array}{l}\text { Tuna like fish, bonito and yellowtail: } \\
\text { Fresh and frozen, fillets and steaks ....... }\end{array}$ & $\begin{array}{l}\text { Pounds } \\
\text { Standard }\end{array}$ & (1) & (1) \\
\hline Canned $\ldots \ldots \ldots \ldots \ldots$ & cases & 661 & 10,067 \\
\hline \multicolumn{4}{|l|}{$\begin{array}{l}\text { Turbot, fresh and frozen: } \\
\text { Fillets: }\end{array}$} \\
\hline $\begin{array}{l}\text { Raw } \\
\text { Raw in casseroles } \\
\text { Raw }\end{array}$ & $\begin{array}{l}\text { do } \\
\text { do } \\
\text { do }\end{array}$ & $(1)^{202}$ & $(1)^{167}$ \\
\hline \multirow{2}{*}{\multicolumn{4}{|c|}{$\begin{array}{l}\text { Wahoo: } \\
\text { Canned } \ldots \ldots \ldots \ldots\end{array} \ldots \ldots \ldots$}} \\
\hline & cases & (1) & (1) \\
\hline $\begin{array}{r}\text { Smoked } \ldots \ldots \ldots \ldots \ldots \ldots \ldots \ldots \ldots \ldots \ldots \\
\text { Whitefish: }\end{array}$ & Pounds & 8 & 17 \\
\hline $\begin{array}{l}\text { Fresh and frozen, fillets . . . . . . . . . . } \\
\text { Canned: }\end{array}$ & do & 1,342 & 1,844 \\
\hline Fish $\ldots \ldots \ldots \ldots \ldots$ & $\begin{array}{l}\text { Standard } \\
\text { cases }\end{array}$ & (1) & (1) \\
\hline 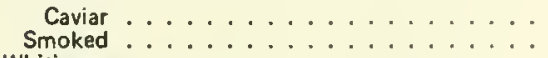 & $\begin{array}{l}\text { do } \\
\text { Pounds }\end{array}$ & 2,608 & $\begin{array}{r}371 \\
4,090\end{array}$ \\
\hline \multicolumn{4}{|l|}{$\begin{array}{l}\text { Whiting: } \\
\text { Fresh and frozen: }\end{array}$} \\
\hline $\begin{array}{l}\text { Fresh and frozen: } \\
\text { Headed and dressed } \ldots \ldots \ldots \ldots \\
\text { Dressed, skins off } \ldots \ldots \ldots \ldots . . . . . .\end{array}$ & $\begin{array}{l}\text { do } \\
\text { do }\end{array}$ & $\begin{array}{l}8,709 \\
\text { (1) }\end{array}$ & $\begin{array}{l}3,069 \\
\text { (i) }\end{array}$ \\
\hline 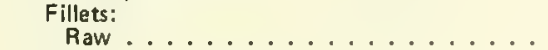 & do & 926 & 613 \\
\hline Breaded, raw and cooked $\ldots$ & do & $(1)^{20}$ & (1) \\
\hline l.q.f. raw $\ldots \ldots \ldots \ldots \ldots$ & do & (1) & \\
\hline 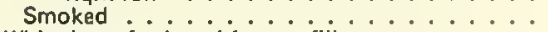 & do & 1,123 & 803 \\
\hline White bass, fresh and frozen, fillets . . . . & do & (i) & (1) \\
\hline \multirow{2}{*}{\multicolumn{4}{|c|}{ Yellow perch, fresh and frozen, fillets: }} \\
\hline & & & \\
\hline Rreaded, raw and cooked $\ldots \ldots$ & $\begin{array}{l}\text { do } \\
\text { do }\end{array}$ & $\begin{array}{l}1,655 \\
1,924\end{array}$ & $\begin{array}{l}3,551 \\
3,990\end{array}$ \\
\hline Yellow pike, fresh and frozen, fillets: & & & \\
\hline Raw ${ }_{\text {Breaded raw }} \ldots \ldots \ldots$ & $\begin{array}{l}\text { do } \\
\text { do }\end{array}$ & $\begin{array}{r}1,053 \\
629\end{array}$ & $\begin{array}{l}1,675 \\
1,220\end{array}$ \\
\hline \multicolumn{4}{|l|}{$\begin{array}{l}\text { Crabs: } \\
\text { Fresh and frozen: }\end{array}$} \\
\hline \multicolumn{4}{|l|}{$\begin{array}{l}\text { Fresh and frozen: } \\
\text { Blue, hard: } \\
\text { Cooked: }\end{array}$} \\
\hline $\begin{array}{l}\text { Meats } \ldots \ldots \\
\text { Claws }\end{array}$ & Pounds & $\begin{array}{r}14,370 \\
77\end{array}$ & $\begin{array}{r}46,691 \\
217\end{array}$ \\
\hline \multicolumn{4}{|l|}{$\begin{array}{c}\text { Claws } \\
\text { Specialties: }\end{array} \ldots \ldots \ldots \ldots \ldots \ldots$} \\
\hline \multicolumn{4}{|l|}{$\begin{array}{l}\text { Cooked, gumbos and soups } \ldots \ldots \ldots \\
\text { Breaded, raw and cooked: }\end{array}$} \\
\hline 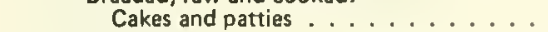 & do & 1,394 & 2,048 \\
\hline 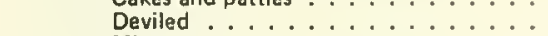 & do & 4,381 & 5,433 \\
\hline Mixes . . . . . . . . . & do & 202 & 219 \\
\hline 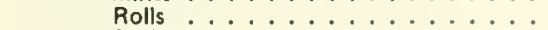 & do & 377 & 295 \\
\hline Stuffed ....... & do & 2,489 & 2,836 \\
\hline $\begin{array}{l}\text { Burgers, croquettes, cutlets, loaves, } \\
\text { sticks, and imperials }\end{array}$ & do & 173 & 165 \\
\hline \multirow{2}{*}{\multicolumn{4}{|c|}{ Dungeness: }} \\
\hline $\begin{array}{l}\text { Dungeness: } \\
\text { Cooked: }\end{array}$ & & & \\
\hline Whole $\ldots \ldots \ldots \ldots \ldots \ldots$ & do & 4,998 & 4,846 \\
\hline Sections $\ldots \ldots$ & do & 310 & 503 \\
\hline Meat $\ldots \ldots \ldots$ & do & 1,321 & 5,467 \\
\hline Cocktails $\ldots \ldots \ldots$ & do & (1) & (i) \\
\hline \multirow{2}{*}{\multicolumn{4}{|c|}{$\begin{array}{l}\text { King: } \\
\text { Cooked: }\end{array}$}} \\
\hline & & & \\
\hline 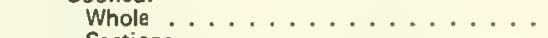 & do & 30,488 & 60,775 \\
\hline Sections . . . . . . . . . . & do & 4,201 & 7,303 \\
\hline Meat $\quad \ldots \ldots$ & do & 4,940 & 12,740 \\
\hline Rock and red, cooked meat $\ldots \ldots \ldots$ & do & 249 & 710 \\
\hline Snow: & & & \\
\hline Cooked: & & & \\
\hline 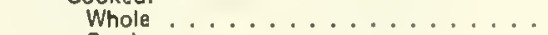 & do & 17,100 & 14,795 \\
\hline Sections . . . . . . . . . . . . & do & 1,086 & 1,780 \\
\hline Meat $\ldots \ldots$ & do & 834 & 2,082 \\
\hline Stone, claws, cooked & do & 54 & 118 \\
\hline \multirow{2}{*}{\multicolumn{4}{|c|}{$\begin{array}{l}\text { Canned: } \\
\text { Natural: }\end{array}$}} \\
\hline & & & \\
\hline Blue, red, and rock . . . . . . . . . & Standard & & \\
\hline Dungeness & cases & 76 & $\begin{array}{r}3,460 \\
69\end{array}$ \\
\hline King $\ldots$ & do & 55 & 4,267 \\
\hline Snow $\ldots$ & do & 36 & 2,282 \\
\hline Deviled, dips, gumbos, spreads, and soups . & do & 4 & 123 \\
\hline Back shells, cleaned and polished ........ & - & - & 326 \\
\hline Meal and scrap $\ldots \ldots \ldots \ldots$ & Tons & 8 & 807 \\
\hline See footnotes at end of table. & (Continue & & \\
\hline
\end{tabular}


PROCESSED FISHERY PRODUCTS, 1975 - Continued

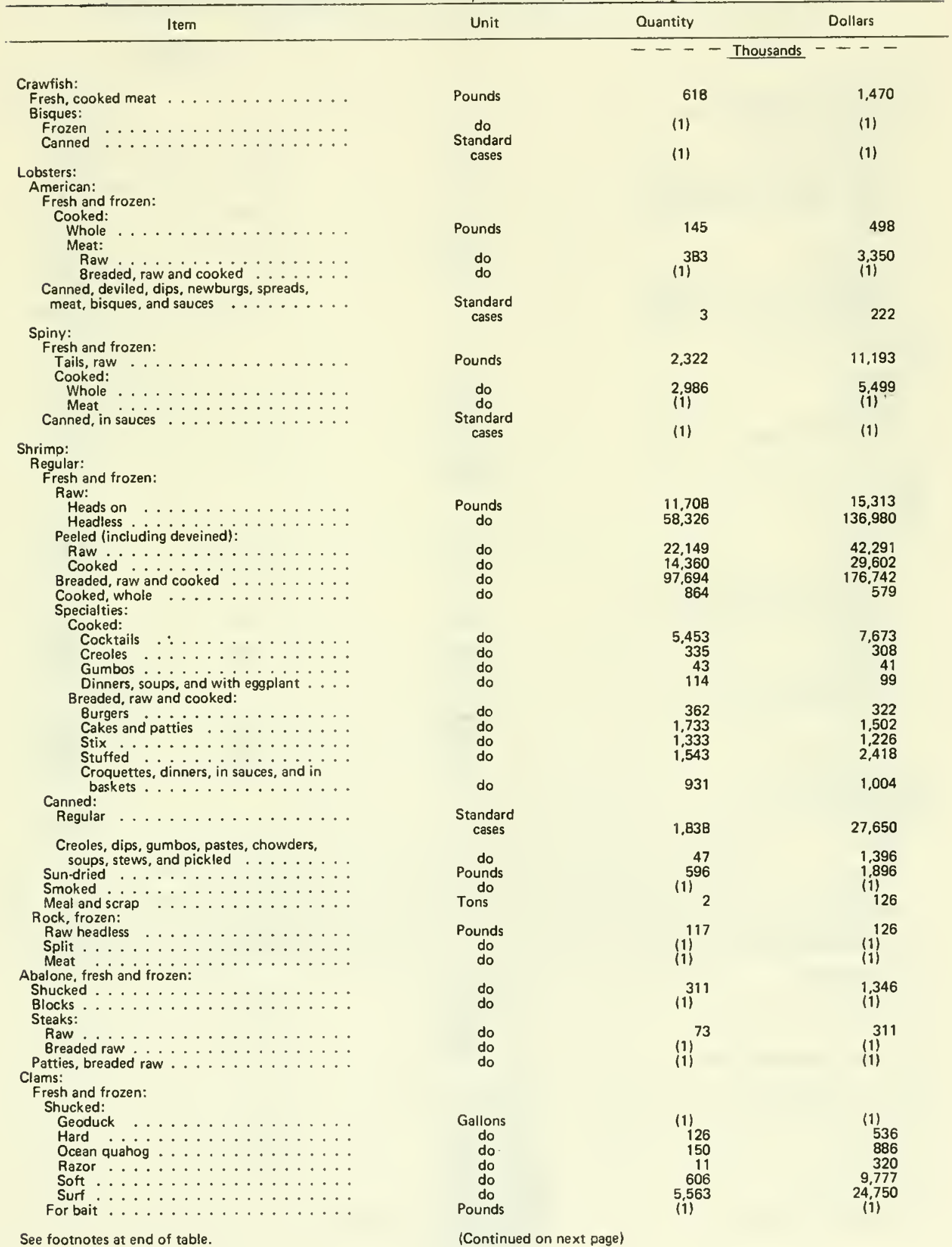




\section{PROCESSED FISHERY PRODUCTS, 1975 - Continued}

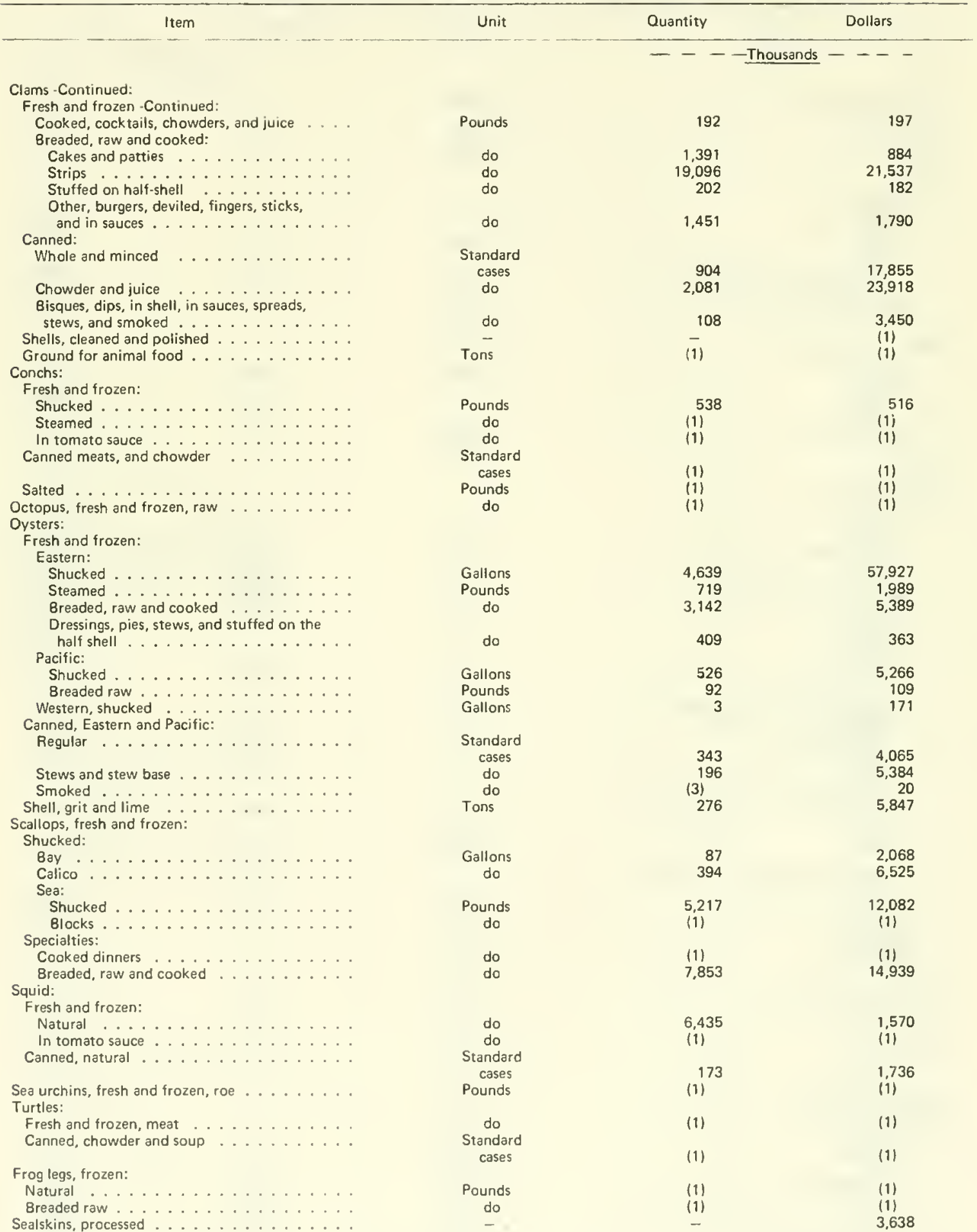

See footnotes at end of table.

(Continued on next page) 
PROCESSED FISHERY PRODUCTS, 1975 - Continued

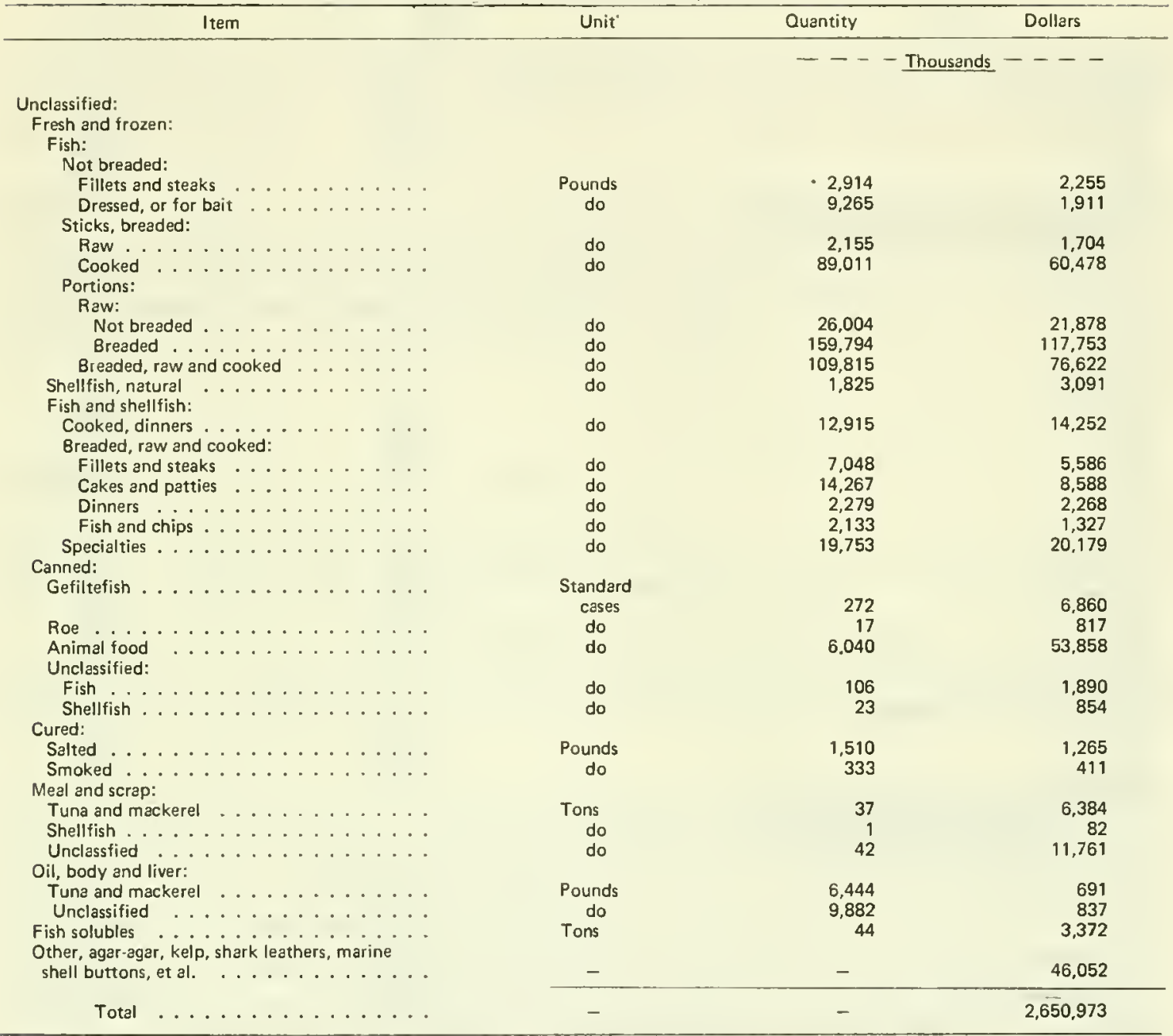

(1) Included with unclassified. (2) Included with fillets. (3) Less than $500 \mathrm{lb}, 500$ standard cases, or 500 tons.

Note:--Totals are correct. Table will not add because of rounding. Some of the above items have been processed from raw products imported from foreign countries; therefore, the production cannot be correlated directly with landings. Certain items, such as salted alewives and mild-cured salmon, are shown in an intermediate and also a more advanced stage of processing. The lime and poultry feed processed shell products were processed from live and reef mollusk shells that are not included in the landings statistics. 


\section{CURED FISHERY PRODUCTS, 1975}

\begin{tabular}{|c|c|c|}
\hline Item & $\begin{array}{l}\text { Thousand } \\
\text { pounds }\end{array}$ & $\begin{array}{l}\text { Thousand } \\
\text { dollars }\end{array}$ \\
\hline \multicolumn{3}{|l|}{ Salted and pickled: } \\
\hline Alewives $\ldots \ldots \ldots \ldots \ldots \ldots$ & 4,360 & 1,217 \\
\hline 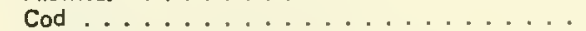 & 1,609 & 1,387 \\
\hline Herring, sea . . . . . . . . . . . & 16,914 & 22,930 \\
\hline 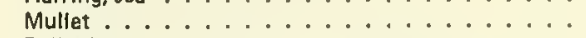 & 201 & 108 \\
\hline 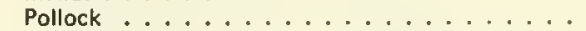 & 34 & 19 \\
\hline 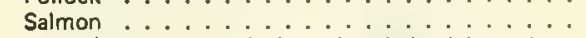 & 5,830 & 16,946 \\
\hline $\begin{array}{l}\text { Other (anchovies, cusk, flounders, hake, lake and } \\
\text { sea herring, rockfishes, sablefish, smelt, spot, }\end{array}$ & & \\
\hline 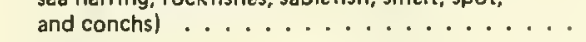 & 1,510 & 1,265 \\
\hline Total $\ldots \ldots \ldots \ldots \ldots$ & 30,457 & 43,872 \\
\hline \multicolumn{3}{|l|}{ Smoked: } \\
\hline Alewives $\ldots \ldots \ldots \ldots \ldots$ & 73 & 43 \\
\hline Buffalofish $\ldots \ldots \ldots$ & 26 & 29 \\
\hline Butterfish . . . . . . . . . . . & 28 & 55 \\
\hline 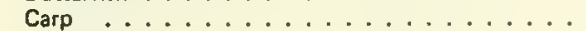 & 362 & 231 \\
\hline Chubs $\ldots$ & 4,188 & 6,181 \\
\hline 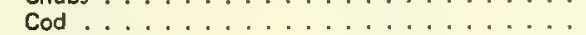 & 150 & 240 \\
\hline Eels $\ldots \ldots \ldots \ldots \ldots$ & 55 & 135 \\
\hline Halibut $\ldots \ldots \ldots \ldots \ldots \ldots$ & 155 & 192 \\
\hline \multicolumn{3}{|l|}{ Herring: } \\
\hline Lake $\ldots \ldots \ldots \ldots \ldots \ldots$ & 64 & 59 \\
\hline Sea $\ldots \ldots \ldots \ldots$ & 623 & 479 \\
\hline Lake trout $\ldots$ & 154 & 247 \\
\hline 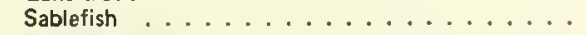 & 2,871 & 4,414 \\
\hline 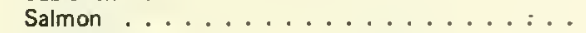 & 10,902 & 36,238 \\
\hline 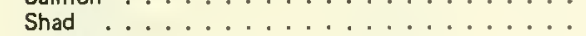 & 83 & 108 \\
\hline Sturgeon $\ldots \ldots \ldots \ldots \ldots \ldots$ & 515 & 1,692 \\
\hline 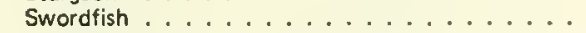 & 9 & 24 \\
\hline Tuna $\ldots \ldots \ldots$ & 27 & 36 \\
\hline Tunalike fish (bonito and yellowtail) ......... & 18 & 27 \\
\hline 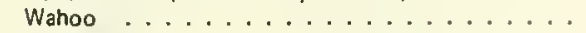 & 8 & 17 \\
\hline 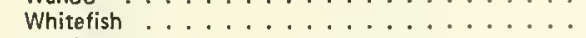 & 2,608 & 4,090 \\
\hline 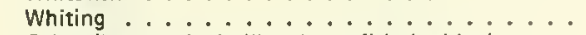 & 1,123 & 803 \\
\hline \multicolumn{3}{|l|}{$\begin{array}{l}\text { Other (barracuda, buliheads, cuttish, haddock, } \\
\text { jack mackerel, king mackerel, lingcod, marlin, } \\
\text { mooneye, paddlefish, pollock, sea bass, shark, } \\
\text { suckers, trout, tullibee, shrimp, and }\end{array}$} \\
\hline 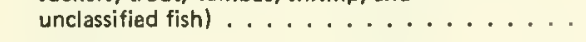 & 333 & 411 \\
\hline Total $\ldots \ldots \ldots \ldots \ldots \ldots$ & 24,376 & 55,748 \\
\hline Sun-dried, shrimp . . . . . . . . . . & 596 & 1,896 \\
\hline Grand total $\ldots \ldots \ldots \ldots \ldots$ & 55,428 & 101,515 \\
\hline
\end{tabular}

Note:--Totals are correct. Table may not add because of rounding. Praducts are shown in an intermediate and also a more advanced stage of processing. 


\section{CANNED FISHERY PRODUCTS, 1975}

The 1975 pack of canned fishery products in the United States, American Samoa, and Puerto Rico was the smallest since 1971. The total pack for human consumption and for bait and animal food was $49.0 \mathrm{million}$ standard cases (1,382.4 million pounds) with a value reported by the canning companies of $\$ 1,067.1$ million, down 15 percent in quantity and 18 percent in value compared with 1974 . The largest declines were in tuna, salmon, clams, and shrimp for human consumption.

Salmon. The 1975 pack of salmon was the smallest since 1906 . The pack was 1.6 million standard cases valued at $\$ 110.7$ million, a decline of 273,588 standard cases and $\$ 26.5$ million compared with 1974 . The pack in Washington and Oregon registered declines in 1975, while the pack in Alaska increased by 40,646 standard cases. Pink salmon registered the only increase in the 1975 pack of salmon, from 527,237 standard cases in 1974 to 616,942 standard cases in 1975 . Chum salmon showed the sharpest decline, 55 percent from 409,446 standard cases in 1974 to 225,659 standard cases in 1975. A better than expected run of reds in Bristol Bay moderated the drop in the pack of red salmon to a 2-percent decline.

Despite the small 1975 pack, exports of canned salmon increased from 8.3 million pounds in 1974 to 22.5 million pounds in 1975 .

Sardines. The pack of Maine sardines (sea herring) was 1.1 million standard cases valued at $\$ 24.9$ million, up 3 percent in quantity and 15 percent in value compared with 1974.

Tuna. In 1975 the domestic pack of tuna was 26.8 million standard casses ( 529.4 million pounds) valued at $\$ 652.6$ million - the fourth highest pack on record and the third in value. The pack was down 20 percent in quant ity and 21 percent in vaiue compared with the record year, 1974.

The pack of white meat (albacore) comprised 19 percent of the pack in 1975, down 39 percent from 1974. The pack of lightmeat tuna (skipjack, yellowfin, bluefin, and bigeye) comprised 81 percent (21.8 million standard cases) in 1975, down 3.4 million cases compared with 1974. The canning plants in Washington, Oregon, California, and Maryland packed 49 percent of the total; the rest was packed by plants in American Samoa, Hawaii, and Puerto Rico.

Canned tuna packed from landings by U.S. fishermen was a record 269.1 million pounds, up 9 percent from 1974. The pack of tuna from imported raw tuna was 260.3 million pounds down 37 percent from 1974. The year 1975 was the first since 1961 that the pack from domestic landings was greater than from imports. The explanation of this was that in order to reduce their inventories of canned tuna, tuna canning companies cut back on their use of imported raw tuna. Inventories toward the end of 1974 had reached record levels, in part because of record U.S. production of canned tuna in that year. Following the cutback on the use of imported raw tuna, prices paid to U.S. fishermen were reduced, beginning in about April 1975; by July inventories has been reduced, and prices of raw tuna had been stabilized at levels appreciably below 1974. In July 1975 the exvessel price of albacore was $\$ 675$ per ton, down 18 percent from December 1975; bluefin, $\$ 480$ per ton, down 14 percent; skipjack, $\$ 450$ per ton, down 17 percent; and yellowfin, $\$ 500$ per ton, down 13 percent. At these prices U.S. tuna fishermen succeeded in landing a record amount of tuna and this prevented any substantial increase in the use of raw tuna imports during the rest of 1975.

Clams. The 1975 pack of clams and clam products was 3.0 million cases valued at $\$ 41.8$ million, 12 percent less in quantity and 3 percent less in value than in 1974. This decline was due to a drop in the pack of canned chowder and juice, which more than offset a small gain in the pack of whole and minced clams.

Shrimp. The 1975 natural pack of shrimp was 1.8 million standard cases valued at $\$ 27.7$ million, down 44 percent in volume and 38 percent in value compared with 1974. This large decline was due to a number of factors, among which were heavy inventories carried over from 1974 and rising costs of operation. In Alaska, which accounts for almost half the U.S. pack, more shrimp was diverted to the frozen product than in the previous year.

Animal (pet) food. In 1975 the pack of pet food (10 pounds of fish per standard case of 48 1-pound cans) was 12.1 million standard cases valued at $\$ 147.8$ million. This was 147,765 standard cases and $\$ 26.8$ million less than in 1974. Tuna trimmings are used in producing a substantial part of the U.S. pack of canned animal (pet) food, and with the production of canned tuna down, the pet food pack was lower also. 


\section{SUMMARY OF PRODUCTION, BY PRODUCTS, 1975}

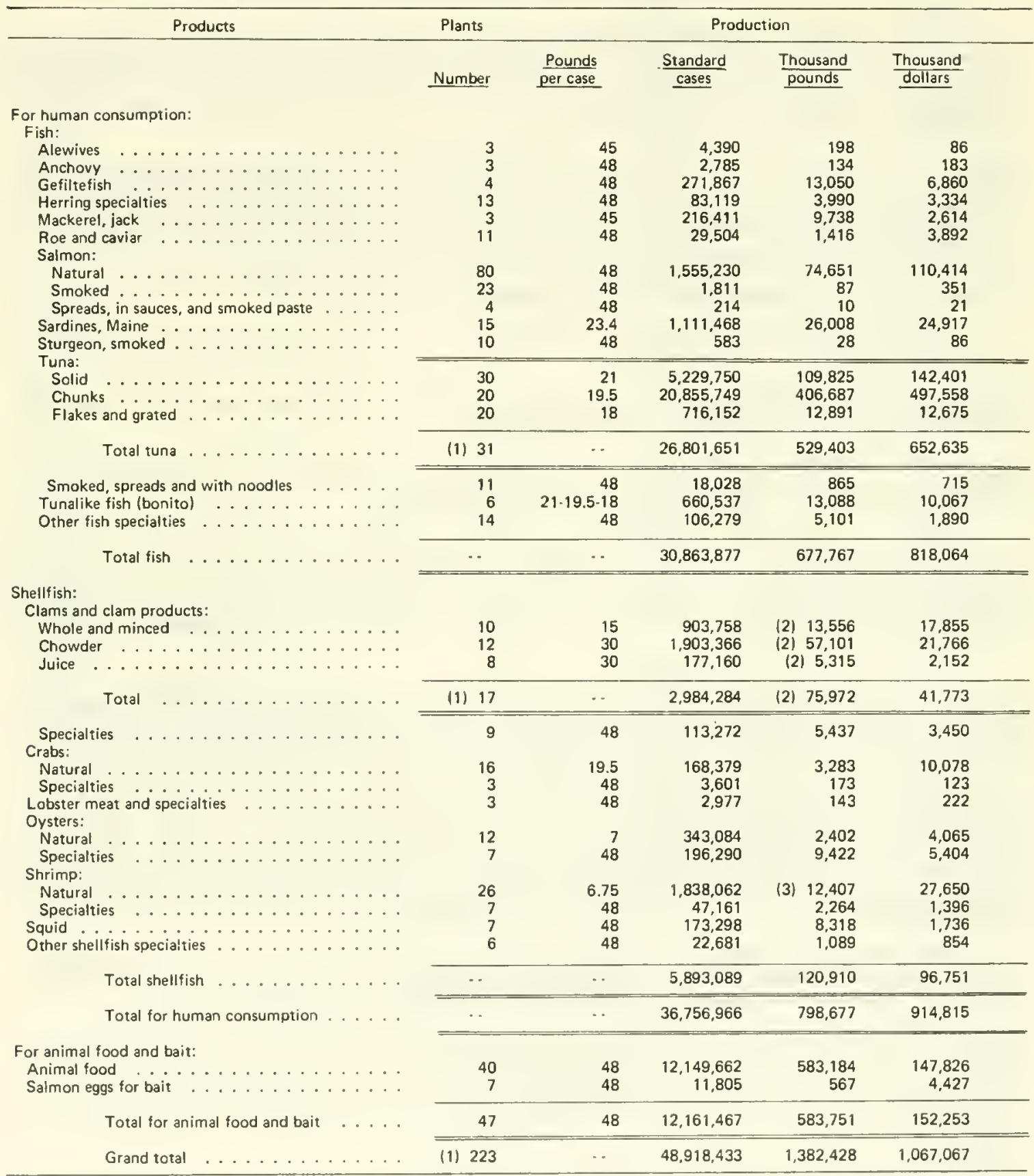

(1) Exclusive of duplication. (2) "Cut out" or "drained" weight of can contents is given for whole or minced clams, and net contents for other clam products. (3) Drained weight.

Note:-*This table will not add because of rounding. 


\section{VALUE OF PRODUCTION, BY STATES, 1975}

\begin{tabular}{|c|c|c|}
\hline State and number of plants & $\begin{array}{l}\text { Standard } \\
\text { cases }\end{array}$ & $\begin{array}{c}\text { Thousand } \\
\text { tollars }\end{array}$ \\
\hline 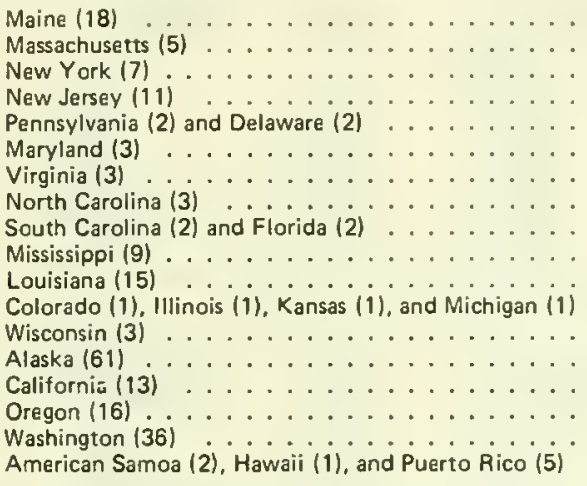 & $\begin{array}{r}2,284,615 \\
1,482,995 \\
283,269 \\
1,358,718 \\
888,888 \\
767,046 \\
78,463 \\
29,078 \\
96,952 \\
3,153,600 \\
1,319,979 \\
599,189 \\
597,959 \\
2,088,055 \\
15,587,409 \\
1,803,878 \\
893,701 \\
15,676,184 \\
\end{array}$ & $\begin{array}{r}41,993 \\
17,578 \\
7,213 \\
25,439 \\
15,274 \\
16,799 \\
793 \\
1,559 \\
2,870 \\
22,837 \\
21,000 \\
3,227 \\
6,255 \\
108,905 \\
342,458 \\
31,623 \\
31,456 \\
369,789\end{array}$ \\
\hline$\ldots \ldots \ldots \ldots$ & $48,989,978$ & $1,067,067$ \\
\hline
\end{tabular}

Note:--Totals are correct. Table may not add because of rounding.

\section{FACTORS USED TO CONVERT STANDARD CASES TO POUNDS}

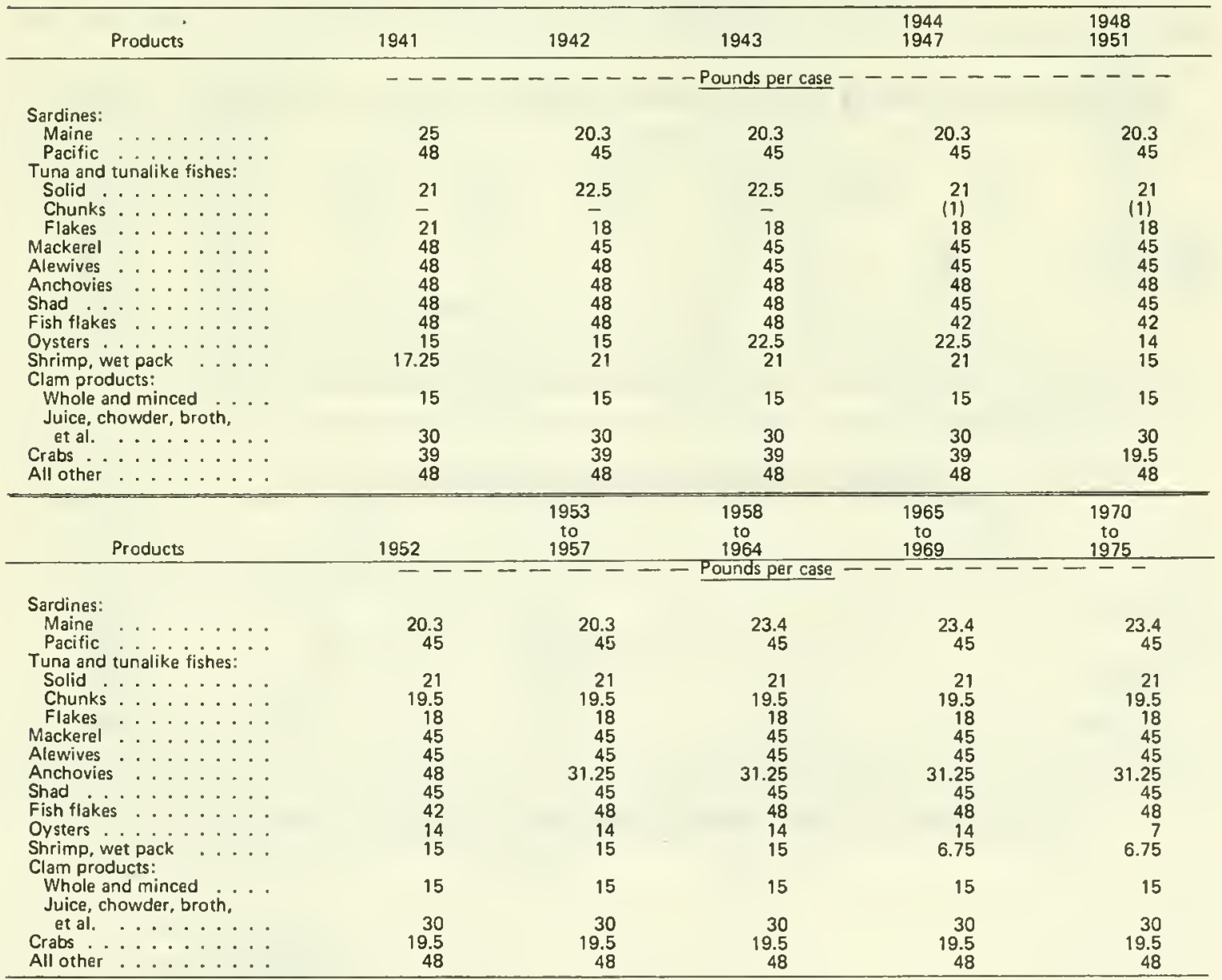

(1) Prior to 1952 chunk pack tuna was included with the flake pack.

Note:- The factors listed above were used in converting standard cases reported in the "Canned Fishery Products" bulletins for the years indicated. 
PACK OF SALMON, BY STATES, 1975

\begin{tabular}{|c|c|c|c|c|c|}
\hline \multicolumn{2}{|r|}{ Species } & \multicolumn{2}{|c|}{ Alaska } & \multicolumn{2}{|c|}{ Washington } \\
\hline & & $\frac{\text { Standard }}{\text { cases }}$ & $\frac{\text { Thousand }}{\text { dollars }}$ & $\frac{\text { Standard }}{\text { cases }}$ & $\frac{\text { Thousand }}{\text { dollars }}$ \\
\hline $\begin{array}{l}\text { Chinook or king } \\
\text { Chum or keta.... } \\
\text { Pink . . . . } \\
\text { Red or sockeve } \\
\text { Silver or coho. }\end{array}$ & ․ & $\begin{array}{r}7,990 \\
221,002 \\
552,555 \\
553,287 \\
49,066\end{array}$ & $\begin{array}{r}696 \\
11,875 \\
36,176 \\
43,383 \\
3,294\end{array}$ & $\begin{array}{r}2,091 \\
4,657 \\
64,387 \\
79,093 \\
11,976\end{array}$ & $\begin{array}{r}177 \\
280 \\
4.470 \\
8.499 \\
867\end{array}$ \\
\hline Total & $\ldots \ldots \ldots \ldots \ldots$ & $1,383,900$ & 95,424 & 162,204 & 14,293 \\
\hline \multicolumn{2}{|r|}{ Species } & \multicolumn{2}{|c|}{ Oregon } & \multicolumn{2}{|c|}{ Total } \\
\hline & & $\frac{\text { Standard }}{\text { cases }}$ & $\frac{\text { Thousand }}{\text { dollars }}$ & $\frac{\text { Standard }}{\text { cases }}$ & $\frac{\text { Thousand }}{\text { dollars }}$ \\
\hline $\begin{array}{l}\text { Chinook or king } \\
\text { Chum or keta. } \\
\text { Pink. . . . } \\
\text { Red or sockeye } \\
\text { Silver or coho. }\end{array}$ & $\begin{array}{l}\ldots \ldots \\
\ldots \\
\ldots\end{array} \ldots$ & (1) $\begin{array}{l}6,754 \\
(2) \\
- \\
- \\
2,372\end{array}$ & $\begin{array}{l}\text { (1) } 533 \\
\text { (2) } \\
- \\
- \\
164\end{array}$ & $\begin{array}{r}16,835 \\
225,659 \\
616,942 \\
632,380 \\
63,414\end{array}$ & $\begin{array}{r}1,406 \\
12,155 \\
40,646 \\
51,882 \\
4,325\end{array}$ \\
\hline Total. & $\ldots \ldots \ldots \ldots \ldots$ & 9,126 & 697 & $1,555,230$ & 110,414 \\
\hline
\end{tabular}

(1) Includes a small pack produced in California. (2) Included with silver or coho.

Note:-"'Standard cases" represent the various size cases converted to the equivalent of 48 1-lb cans of 16 oz each. Salmon were canned in 50 plants in Alaska, 19 plants in Washington, 9 plants in Oregon, and 2 plants in California.

WASHINGTON AND OREGON SALMON PACK, BY DISTRICTS, 1975

\begin{tabular}{|c|c|c|c|c|c|c|c|c|}
\hline \multirow[t]{2}{*}{ Species } & \multicolumn{2}{|c|}{ Puget Sound } & \multicolumn{2}{|c|}{ Columbia River } & \multicolumn{2}{|c|}{ Coastal } & \multicolumn{2}{|c|}{ Total } \\
\hline & $\frac{\text { Standard }}{\text { cases }}$ & $\frac{\text { Thousand }}{\text { dollars }}$ & $\frac{\text { Standard }}{\text { cases }}$ & $\frac{\text { Thousand }}{\text { dollars }}$ & $\frac{\text { Standard }}{\text { cases }}$ & $\begin{array}{l}\text { Thousand } \\
\text { dollars }\end{array}$ & $\frac{\text { Standard }}{\underline{\text { cases }}}$ & $\begin{array}{l}\text { Thousand } \\
\text { dollars }\end{array}$ \\
\hline $\begin{array}{l}\text { Chinook or king } \\
\text { Chum or keta } \\
\text { Pink } \\
\text { Red or sockeye } \\
\text { Silver or coho }\end{array}$ & $\begin{array}{r}1,177 \\
4,657 \\
64,387 \\
79,093 \\
11,623\end{array}$ & $\begin{array}{r}102 \\
280 \\
4.470 \\
8.499 \\
839\end{array}$ & $\begin{array}{l}6,415 \\
(2) \\
(\overline{2)} \\
467\end{array}$ & $\begin{array}{l}508 \\
(2) \\
(2) \\
39\end{array}$ & (1) $\begin{array}{l}1,253 \\
\text { (3) } \\
= \\
2,258\end{array}$ & (1) $\begin{array}{l}100 \\
(3) \\
= \\
- \\
153\end{array}$ & $\begin{array}{r}8,845 \\
4,657 \\
64,387 \\
79,093 \\
14,348 \\
\end{array}$ & $\begin{array}{r}710 \\
280 \\
4,470 \\
8,499 \\
1,031 \\
\end{array}$ \\
\hline Total & 160,937 & 14,190 & 6,882 & 547 & 3,511 & 253 & 171,330 & 14,990 \\
\hline
\end{tabular}

(1) Includes a small pack produced in California. (2) Included with Puget Sound pack. (3) Included with silver or coho.

Note:--"Standard cases" represent the various size cases converted to the equivalent of 48 1-1b cans of 16 oz each.

PUGET SOUND SALMON PACK, 1975

\begin{tabular}{|c|c|c|c|c|}
\hline & Species & $\begin{array}{l}\text { Local } \\
\text { fish }\end{array}$ & $\begin{array}{l}\text { Alaskan } \\
\text { fish }\end{array}$ & Total \\
\hline & & \multicolumn{3}{|c|}{------ Standard cases $---\ldots-\ldots$} \\
\hline $\begin{array}{l}\text { Chinook or king } \\
\text { Chum or keta } \\
\text { Pink . S } \\
\text { Red or sockeye } \\
\text { Silver or coho. }\end{array}$ & $\therefore \therefore \therefore a$ & $\begin{array}{r}1.149 \\
4,135 \\
63,713 \\
78,661 \\
11,473\end{array}$ & $\begin{array}{r}28 \\
522 \\
674 \\
432 \\
150\end{array}$ & $\begin{array}{r}1,177 \\
4,657 \\
64,387 \\
79,093 \\
11,623\end{array}$ \\
\hline Total. & $\ldots \ldots \ldots \ldots \ldots$ & 159,131 & 1,806 & 160,937 \\
\hline
\end{tabular}

Note:--Included a small pack of chum and red produced by Columbia River canneries. "Standard cases" represent the various size cases converted to equivalent of 48 cans to the case, each containing 16 oz each.

\section{PACK OF MISCELLANEOUS SALMON PRODUCTS, 1975}

\begin{tabular}{|c|c|c|c|}
\hline Product & $\begin{array}{l}\text { Standard } \\
\text { cases }\end{array}$ & $\begin{array}{l}\text { Thousand } \\
\text { dollars }\end{array}$ & Location and number of plants \\
\hline 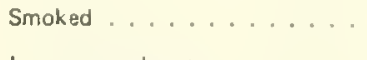 & 1,811 & 351 & $\begin{array}{l}\text { Alaska (7), Oregon (5), and } \\
\text { Washington }(11)\end{array}$ \\
\hline In sauces and pastes ...... & 214 & 21 & $\begin{array}{l}\text { Maine }(1\} \text {, Michigan }(1\} \text {, Oregon (1), } \\
\text { and Washington (1) }\end{array}$ \\
\hline Total .......... & 2,025 & 372 & \\
\hline
\end{tabular}

Note--"Standard cases" represent the various size cases converted to the equivalent of 48 cans to the case, each containing 16 oz net weight. 


\section{PACK OF TUNA, 1975}

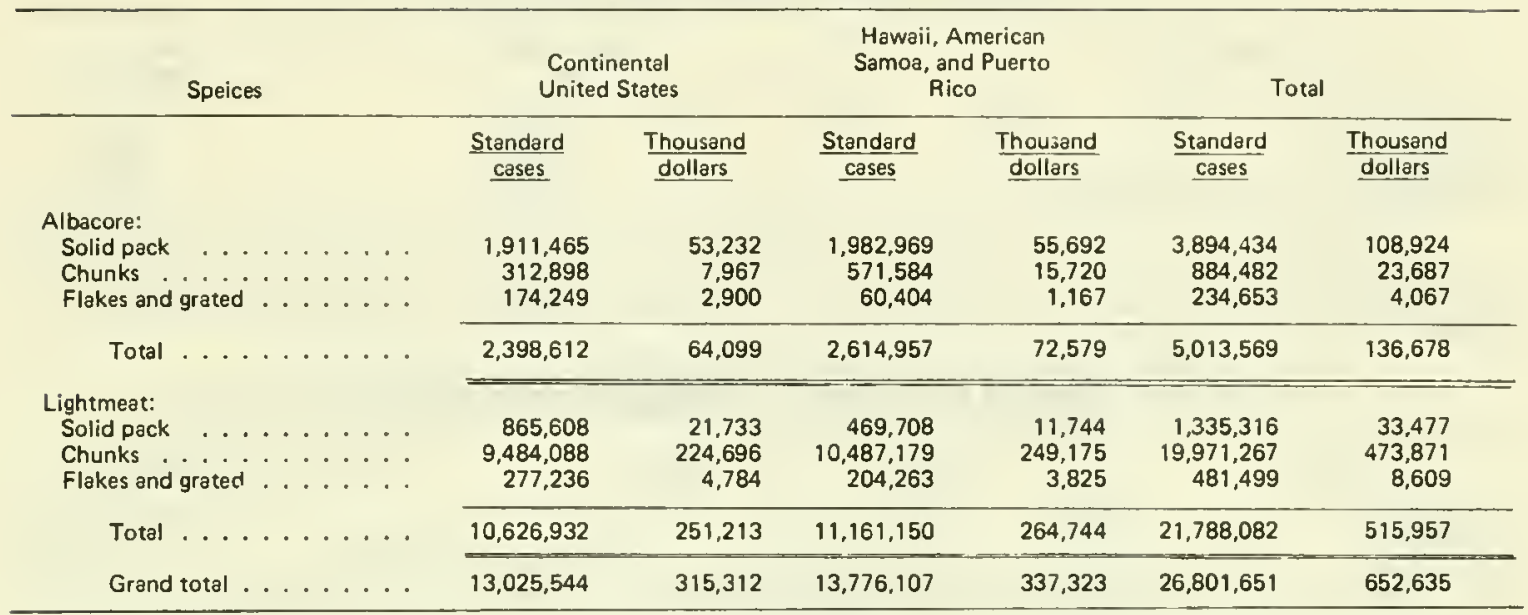

Note:-"Standard cases" represent the various size cases converted to the equivalent of 48 No. $1 / 2$ tuna cans to the case, each containing $7 \mathrm{oz}$ net weight of solid pack, $6 \frac{1}{2} \mathrm{oz}$ net weight of chunks, and 6 oz net weight of flakes grated. The pack of dietetic tuna is included in these totals. Tuna were canned in 8 plants each in California and Oregon, 6 plants in Washington, 5 plants in Puerto Rico, 2 plants in American Samoa, and 1 plant each in Maryland and Hawaii.

PACK OF TUNA, BY CAN SIZE, 1975

\begin{tabular}{|c|c|c|}
\hline Can and case sizes & $\begin{array}{c}\text { Actual } \\
\text { cases }\end{array}$ & $\begin{array}{l}\text { Thousand } \\
\text { dollars }\end{array}$ \\
\hline 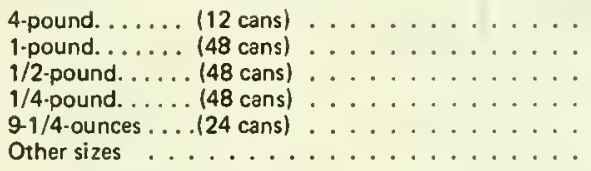 & $\begin{array}{r}401,308 \\
1,698,987 \\
19,383,357 \\
2,107,888 \\
312,319 \\
\text { (1) } 2,114,882\end{array}$ & $\begin{array}{r}20,894 \\
81,347 \\
462,105 \\
30,941 \\
4,805 \\
52,543\end{array}$ \\
\hline Total $\ldots \ldots \ldots \ldots \ldots \ldots$ & $26,018,741$ & 652,635 \\
\hline
\end{tabular}

(1) Converted to standard cases, mostly (307×207 can size).

\section{PACK OF MISCELLANEOUS TUNA PRODUCTS, 1975}

\begin{tabular}{|c|c|c|c|}
\hline Product & Standard & Thousand & Location and number of plants \\
\hline $\begin{array}{l}\text { Smoked , } \ldots \text {. } \\
\text { Spreads, with noodles, and }\end{array}$ & 96 & 12 & Oregon (3), and Washington (4) \\
\hline 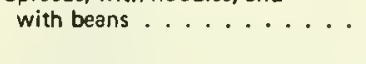 & 17,932 & 703 & $\begin{array}{l}\text { California (2), Maine (1), and } \\
\text { Pennsylvainia (1) }\end{array}$ \\
\hline Total $\ldots \ldots \ldots$ & 18,028 & 715 & \\
\hline
\end{tabular}

Note:-." "Standard cases" represent the various size cases converted to the equivalent of 48 cans to the case, each containing 16 oz net weight.

PACK OF TUNALIKE FISH, 1975

\begin{tabular}{cccc}
\hline Species & $\begin{array}{c}\text { Standard } \\
\text { cases }\end{array}$ & $\begin{array}{c}\text { Thousand } \\
\text { dollars }\end{array}$ \\
\hline 8onito, solid pack, chunk, flakes and grated $\ldots \ldots$ & 660,537 & 10,067 \\
\hline
\end{tabular}

Note:-" "Standard cases" represent the equivalent of 48 No. $1 / 2$ tuna cans to the case, each containing 7 oz net weight of solid pack, $6-1 / 202$ net weight of chunks, and $6 \mathrm{oz}$ net weight of flakes and grated. Tunalike fish were conned in 6 plants in California. 
PACK OF MAINE SARDINES, 1975

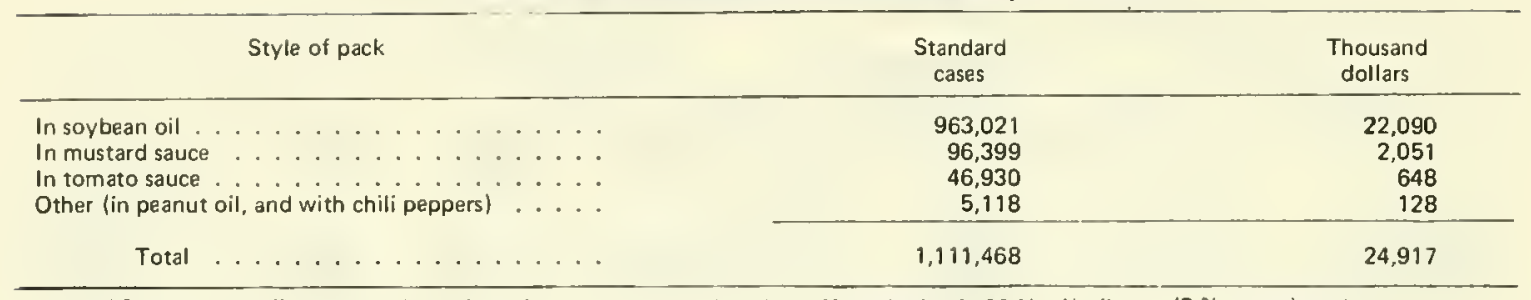

Note:-"Standard cases" represent the various size cases converted to the uniform basis of 100 No. $1 / 4$ oil cans $(3.3 / 4$ oz net) to the case. Sardines were canned in 15 plants in Maine.

\section{PACK OF MISCELLANEOUS HERRING PRODUCTS, 1975}

\begin{tabular}{|c|c|c|c|c|}
\hline Product & $\begin{array}{l}\text { Standard } \\
\text { cases }\end{array}$ & $\begin{array}{l}\text { Thousand } \\
\text { dollars }\end{array}$ & Location ar & $r$ of plants \\
\hline Spreads and fish & 83,119 & 3.334 & Maine (13) & \\
\hline \multicolumn{5}{|c|}{ Note:--"Standard cases" represent the various size cases converted to the equivalent of 48 cans to the case, each containing 16 oz net weight. } \\
\hline State and number of plants & & $\begin{array}{l}\text { Standard } \\
\text { cases }\end{array}$ & & $\begin{array}{l}\text { Thousand } \\
\text { pounds }\end{array}$ \\
\hline North Carolina (2) and Virginia (1) . . . & & 4,390 & & 86 \\
\hline
\end{tabular}

Note:-."Standard cases" represent the various size cases converted to the equivalent of 48 cans of 15 oz each.

PACK OF JACK MACKEREL, 1975

\begin{tabular}{lccc}
\hline State and number of plants & $\begin{array}{c}\text { Standard } \\
\text { cases }\end{array}$ & $\begin{array}{c}\text { Thousand } \\
\text { pounds }\end{array}$ \\
\hline California (3) $\ldots \ldots \ldots \ldots \ldots \ldots \ldots \ldots \ldots$ & 216,411 \\
\hline
\end{tabular}

Note--"Standard cases" represent the various size cases converted to the equivalent of 48 cans of 15 oz each.

\section{PACK OF ANIMAL FOOD FROM FISHERY PRODUCTS, 1975}

\begin{tabular}{|c|c|c|}
\hline State and number of plants & $\begin{array}{l}\text { Standard } \\
\text { cases }\end{array}$ & $\begin{array}{l}\text { Thousand } \\
\text { pounds }\end{array}$ \\
\hline Massachusetts (2) and New Jersey (1) $\ldots \ldots \ldots$ & $1,475,330$ & 17,253 \\
\hline Pennsylvania (1), Maryland (1), and Virginia (1) ... & 176,601 & 1,473 \\
\hline Louisiana $(1)$ and Mississippi $(3) \ldots \ldots \ldots$ & $3,111,390$ & 22,286 \\
\hline Illinois (1), Kansas (1), and Wisconsin (2) & $1,195,758$ & 9,318 \\
\hline California $(8) \ldots \ldots \ldots \ldots \ldots$ & $3,153,792$ & 53,717 \\
\hline Oregon $(6) \ldots \ldots \ldots \ldots \ldots$ & 788,657 & 5,792 \\
\hline Washington $\langle 4| \ldots \ldots \ldots \ldots \ldots$ & 355,463 & 5.765 \\
\hline Puerto Rico $(5) \ldots \ldots \ldots \ldots \ldots$ & $1,646,928$ & 26,662 \\
\hline American Samoa (2) and Hawaii (1) & 245,743 & 5,560 \\
\hline Total $(40) \ldots \ldots \ldots \ldots \ldots \ldots$ & $12,149,662$ & 147,826 \\
\hline
\end{tabular}

Note:- Each standard cases contains 10 or more pounds of fish. An additional pack of $3,372,680$ standard cases valued at $\$ 22,886,716$ had less than $10 \mathrm{lb}$ of fish per case, and is not included in the above pack. "Standard cases" represent the various size cases converted to the equivalent of $4 \mathrm{~B}$ cans of 16 oz each. 
PACK OF CLAMS AND CLAM PRODUCTS, 1975

\begin{tabular}{|c|c|c|c|c|c|c|c|}
\hline \multicolumn{2}{|l|}{ Species } & \multicolumn{2}{|c|}{ Whole and minced } & \multicolumn{2}{|c|}{ Chowder and juice } & \multicolumn{2}{|c|}{ Total } \\
\hline & & $\frac{\text { Standard }}{\text { cases }}$ & $\frac{\text { Thousand }}{\text { pounds }}$ & $\frac{\text { Standard }}{\text { cases }}$ & $\frac{\text { Thousand }}{\text { pounds }}$ & $\frac{\text { Standard }}{\text { cases }}$ & $\frac{\text { Thousand }}{\text { pounds }}$ \\
\hline Hard, soft, surf, and razor & ... & 903,758 & 17,855 & $2,080,526$ & 23,918 & $2,984,284$ & 41,773 \\
\hline
\end{tabular}

Note:--"Standard cases" represent the various size cases converted to the equivalent of 48 No. 1 picnic cans, each can of whole or minced clams containing 5 oz of meat, drained weight, and each can of chowder, juice, broth, nectar, 10 oz net contents. The pack of clams in the shell is not included. Clams were canned in 5 plants in New Jersey, 2 plants each in Delaware, Maine, New York, and Washington, 1 plant each in Maryland, Massachuse tts, Pennsylvania, and South Carolina.

\section{CLAM PRODUCTION, BY TYPE OF PACK, 1975}

\begin{tabular}{|c|c|c|c|}
\hline Production and number of plants & $\begin{array}{l}\text { Standard } \\
\text { cases }\end{array}$ & $\begin{array}{l}\text { Thousand } \\
\text { pounds }\end{array}$ & $\begin{array}{l}\text { Thousand } \\
\text { dollars }\end{array}$ \\
\hline $\begin{array}{l}\text { Whole }(2) \text { and minced }(8) \ldots \ldots \\
\text { Chowder }(12) \ldots \ldots \\
\text { Juice }(\text { includes broth, juice, and nectar }(8) \ldots \ldots\end{array}$ & $\begin{array}{r}903,758 \\
1,903,366 \\
177,160\end{array}$ & $\begin{array}{r}13,556 \\
57,101 \\
5,315\end{array}$ & $\begin{array}{r}17,855 \\
21,766 \\
2,152\end{array}$ \\
\hline Total, exclusive of duplication (17) . . . . & $2,984,284$ & 75,972 & 14,773 \\
\hline
\end{tabular}

\section{PACK OF MISCELLANEOUS CLAM PRODUCTS, 1975}

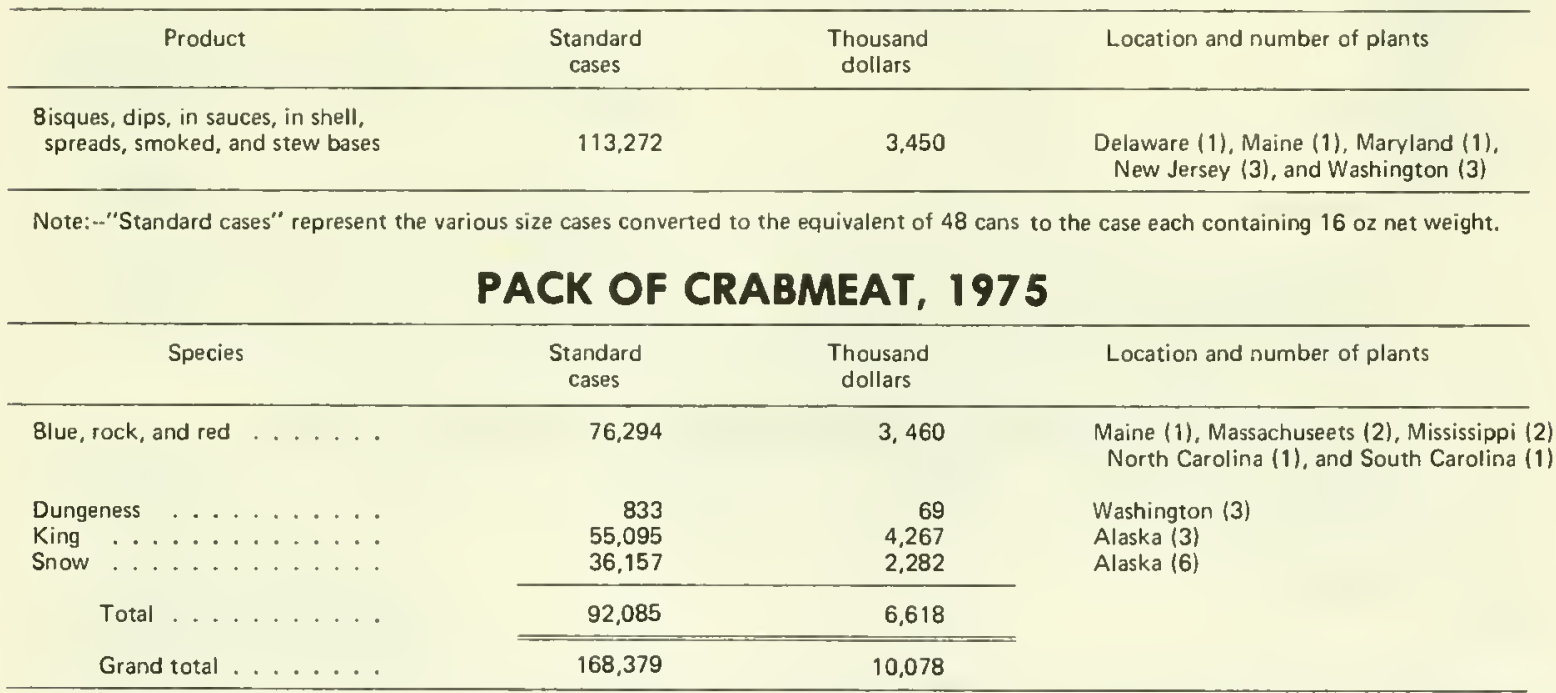

Note:-" Standard cases" represent the various size cases converted to the equivalent of 48 cans to the case each containing 16 oz net weight.

\section{PACK OF CRAB SPECIALTIES, 1975}

\begin{tabular}{lccc}
\hline Product & $\begin{array}{c}\text { Standard } \\
\text { cases }\end{array}$ & $\begin{array}{c}\text { Thousand } \\
\text { dollars }\end{array}$ & Location and number of plants \\
\hline $\begin{array}{c}\text { Bisques, deviled, dips, gumbos, } \\
\text { and spreads . . . . }\end{array}$ & 3,601 & 123 & $\begin{array}{c}\text { Louisiana (1), Maine (1), and } \\
\text { South Carolina (1) }\end{array}$ \\
\hline
\end{tabular}

Note:-." "Standard cases" represent the various size cases converted to the equivalent of 48 cans to the case each containing 16 oz net weight. 
NATURAL PACK OF OYSTERS, 1975

\begin{tabular}{|c|c|c|c|}
\hline State and number of plants & & $\begin{array}{l}\text { Standard } \\
\text { cases }\end{array}$ & $\begin{array}{l}\text { Thousand } \\
\text { dollars }\end{array}$ \\
\hline \multicolumn{2}{|l|}{$\begin{array}{l}\text { Louisiana (5), Mississippi (5), and } \\
\text { South Carolina (2) ............. }\end{array}$} & 343,084 & 4,065 \\
\hline \multicolumn{4}{|c|}{ Note:-"'Standard cases" represent the various size cases converted to the equivalent of 24 cans of $4-2 / 3$ oz of oyster meats. } \\
\hline Product & $\begin{array}{l}\text { Standard } \\
\text { cases }\end{array}$ & $\begin{array}{l}\text { Thousand } \\
\text { dollars }\end{array}$ & Location and number of plants \\
\hline Stews and stew bases $\ldots .$. & 196,153 & 5,384 & $\begin{array}{l}\text { Louisiana (1), New Jersey (1), Oregon (1), } \\
\text { South Carolina (2), and Washington (2) }\end{array}$ \\
\hline 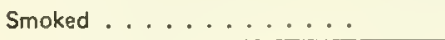 & 137 & 20 & Washington (3) \\
\hline
\end{tabular}

Note:-"Standard cases" represent the various size cases converted to the equivalent of 48 cans to the case each containing 16 oz net weight.

NATURAL PACK OF SHRIMP, 1975

\begin{tabular}{|c|c|c|}
\hline State and number of plants & $\begin{array}{l}\text { Standard } \\
\text { cases }\end{array}$ & $\begin{array}{l}\text { Thousand } \\
\text { dollars }\end{array}$ \\
\hline $\begin{array}{l}\text { Gulf States: } \\
\text { Louisiana }(12) \ldots \ldots \ldots \ldots \ldots \ldots \ldots \ldots \ldots \ldots \ldots \ldots \ldots \ldots \ldots \ldots \ldots \\
\text { Mississippi }(7) \ldots \ldots \ldots \ldots \ldots \ldots\end{array}$ & $\begin{array}{r}946,741 \\
97,243\end{array}$ & $\begin{array}{r}15,470 \\
2,016\end{array}$ \\
\hline Total $(19) \ldots \ldots \ldots$ & $1,043,984$ & 17,486 \\
\hline $\begin{array}{l}\text { Pacific States: } \\
\text { Alaska (2) } \ldots \text { Wregon (3) and Washington (2) } \ldots \ldots \ldots \ldots\end{array}$ & $\begin{array}{l}541,183 \\
252,895\end{array}$ & $\begin{array}{l}6,903 \\
3,261\end{array}$ \\
\hline Total $(7) \ldots \ldots \ldots$ & 794.078 & 10,164 \\
\hline Grand total $(26) \ldots \ldots \ldots$ & $1,838,062$ & 27,650 \\
\hline
\end{tabular}

Note:- "Standard cases" represent the various size cases converted to the equivalent of 24 cans of $4-1 / 2$ oz of shrimp meats.

PACK OF MISCELLANEOUS SHRIMP PRODUCTS, 1975

\begin{tabular}{|c|c|c|c|}
\hline Product & $\begin{array}{l}\text { Standard } \\
\text { cases }\end{array}$ & $\begin{array}{l}\text { Thousand } \\
\text { dollars }\end{array}$ & Location and number of plants \\
\hline $\begin{array}{l}\text { Bisques, dips, chowders, creoles, } \\
\text { gumbos, pickled, paste, and } \\
\text { stews } \ldots \ldots \ldots\end{array}$ & 47,161 & 1,396 & $\begin{array}{l}\text { Louisiana (2), Maine (1), Michigan (1), } \\
\text { New Jersey (1), Oregon (1), and South } \\
\text { Carolina (1) }\end{array}$ \\
\hline
\end{tabular}

Note:-."Standard cases" represent the various size cases converted to the equivalent of 48 cans to the case, each containing 16 oz net weight.

\section{PACK OF MISCELLANEOUS SHELLFISH SPECIALTIES, 1975}

\begin{tabular}{|c|c|c|c|}
\hline Product & $\begin{array}{l}\text { Standard } \\
\text { cases }\end{array}$ & $\begin{array}{l}\text { Thousand } \\
\text { dollars }\end{array}$ & Location and number of plants \\
\hline $\begin{array}{l}\text { American lobster, bisque, dips, } \\
\text { deviled, meat, newburgs, pastes, } \\
\text { sauces, and spreads ...... }\end{array}$ & 2.977 & 222 & $\begin{array}{l}\text { Maine (1), New Jersey (1), and } \\
\text { Michigan (1) }\end{array}$ \\
\hline 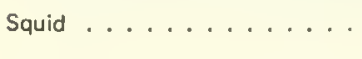 & 173.298 & 1,736 & $\begin{array}{l}\text { California (5), New Jersey (1), and } \\
\text { New York (1) }\end{array}$ \\
\hline $\begin{array}{l}\text { Unclassified, conchs, crawtish, } \\
\text { spiny lobster, and turtle, either } \\
\text { natural pack, or in bisques, } \\
\text { chowders, soups, or in sauces }\end{array}$ & 22,681 & 854 & $\begin{array}{l}\text { Florida (1), Louisiana (2), New } \\
\text { Jersey }(2) \text {, and New York (1) }\end{array}$ \\
\hline
\end{tabular}

Note:-" "Standard cases" represent the various size cases converted to the equivalent of 48 cans to the case, each containing 16 oz net weight. 


\section{PACK OF FISH ROE AND CAVIAR, 1975}

\begin{tabular}{|c|c|c|c|}
\hline Product and number of plants & $\begin{array}{l}\text { Standard } \\
\text { cases }\end{array}$ & $\begin{array}{l}\text { Thousand } \\
\text { dollars }\end{array}$ & State and number of plants \\
\hline Alewife roe (5) & 7,178 & 529 & $\begin{array}{l}\text { Maine (1), North Carolina (2), and } \\
\text { Virginia (2) }\end{array}$ \\
\hline $\begin{array}{l}\text { Salmon caviar (3) } \ldots \ldots \ldots \\
\text { Sturgeon caviar (3) } \ldots \ldots\end{array}$ & $\begin{array}{l}1.184 \\
1.145\end{array}$ & $\begin{array}{r}545 \\
1.631\end{array}$ & $\begin{array}{l}\text { New York (3) } \\
\text { New York }(3)\end{array}$ \\
\hline Whitefish caviar (4) $\ldots \ldots$ & 2,917 & 371 & New York (3) and Wisconsin (1) \\
\hline $\begin{array}{l}\text { Herring roe (1), lumpfish caviar } \\
\text { (2), shad roe (1), and unclassified } \\
\text { roe (1)................... }\end{array}$ & 17,080 & 816 & $\begin{array}{l}\text { Maine (1), Massachusetts (1), New } \\
\text { York (2), and Washington (1) }\end{array}$ \\
\hline $\begin{array}{l}\text { Total, exclusive of } \\
\text { duplication (11) }\end{array}$ & 29,504 & 3,892 & \\
\hline Salmon eggs for bait (7) & 11,805 & 4,427 & Washington (7) \\
\hline Grand total $(18) \ldots \ldots$ & 41,309 & 8,319 & \\
\hline
\end{tabular}

Note:--"Standard cases" represent the various size cases converted to the equivalent of 48 cans of 16 oz each.

\section{PACK OF FISH ROE AND CAVIAR, BY STATES, 1975}

\begin{tabular}{|c|c|c|}
\hline State and number of plants & $\begin{array}{l}\text { Standard } \\
\text { cases }\end{array}$ & $\begin{array}{l}\text { Thousand } \\
\text { dollars }\end{array}$ \\
\hline $\begin{array}{l}\text { New York (3) } \\
\text { North Carolina (2) and Virginia (2) } \ldots \ldots \ldots \\
\text { Maine (1), Massachusetts (1), and Wisconsin (1) } \ldots \\
\text { Washington (8) } \ldots \ldots \ldots \ldots \ldots\end{array}$ & $\begin{array}{r}9,279 \\
6,714 \\
13.487 \\
11,829\end{array}$ & $\begin{array}{r}2,983 \\
507 \\
398 \\
4,431\end{array}$ \\
\hline$\ldots \ldots \ldots \ldots \ldots \ldots$ & 41,309 & 8,319 \\
\hline
\end{tabular}

Note:--"Standard cases" represent the various size cases converted to the equivalent of 48 cans of 16 oz each.

\section{PACK OF MISCELLANEOUS FISHERY PRODUCTS, 1975}

\begin{tabular}{|c|c|c|c|}
\hline Product & $\begin{array}{l}\text { Standard } \\
\text { cases }\end{array}$ & $\begin{array}{l}\text { Thousand } \\
\text { dollars }\end{array}$ & State and number of plants \\
\hline \multirow{2}{*}{$\begin{array}{l}\text { Fish: } \\
\text { Anchovy paste . . . . . . . . } \\
\text { Gefiltefish . . . . } \\
\text { Sturgeon, smoked . } \\
\text { Anchovies, catfish, haddock, king } \\
\text { mackerel, lake trout, wahoo, } \\
\text { whitefish, and unclassified fish, } \\
\text { all the forgoing in various } \\
\text { styles including, natural pack, } \\
\text { chowders, dips, smoked, stews, }\end{array}$} & & & \\
\hline & $\begin{array}{r}2,785 \\
271,867 \\
583\end{array}$ & $\begin{array}{r}183 \\
6,860 \\
86\end{array}$ & $\begin{array}{l}\text { Michigan (1) and New York (2) } \\
\text { New Jersey (3) and New York (1) } \\
\text { Oregon (3) and Washington (7) }\end{array}$ \\
\hline et. al. $\ldots \ldots \ldots$ & 106,279 & 1,890 & $\begin{array}{l}\text { California (1), Colorado (1), Florida (1), } \\
\text { Maine (2), Massachusetts (1), Michigan (1), } \\
\text { New Jersey (3), South Carolina (1), } \\
\text { Washington (1), and American Samoa (2) }\end{array}$ \\
\hline 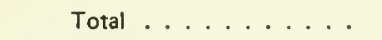 & 381,514 & 9,019 & \\
\hline
\end{tabular}

Note:-."Standard cases" represent the various size cases converted to the equivalent of 48 cans to the case, each containing 16 oz net weight. 


\section{INDUSTRIAL FISHERY PRODUCTS, 1975}

The value of the 1975 production of industrial fishery products in the United States, American Samoa, and Puerto Rico was $\$ 162.3$ million-- $\$ 36.5$ million less than the $\$ 198.8$ million produced in the previous year. In terms of value, the leading producing State was Louisiana ( $\$ 49.8$ million), followed by California ( $\$ 42.1$ million), and Virginis ( $\$ 13.2$ million).

Fish meal and scrap. Domestic production including shellfish meal was 290,431 tons-10,283 tons less than the previous year. Menhaden meal (191,443 tons) accounted for 66 percent of the fish meal production and was 12,416 tons less then the 203,859 tons produced in the previous year. Production of tuna and mackerel meal (a byproduct of canning) was 37,209 tons in 1975 compared with 48,244 tons in 1974. This reduction was attributed to a drop in the production of canned tuna.

Fish oils. The United States production of fish oils reached 245.7 million pounds, 3 percent more than a year earlier and the highest since 1971. A sharp increase in the production of anchovy oil contributed to this improvement.

Fish solubles. Domestic production of fish solubles was 128,000 tons valued at $\$ 8.8$ million, down 7 percent in quantity and 25 percent in value compared with 1974.

Other industrial products. Oyster shell grit and lime were valued at $\$ 5.8$ million in 1975 compared with $\$ 4.7$ million in 1974. The value of other industrial products was $\$ 49.6$ million compared with $\$ 48.9$ million in 1974 . These other industrial products included agar-agar, animal feeds, crab and clam shells processed for food serving, fish pellets, Irish moss extract, kelp products, shark leather, liquid fertilizer, and pearl essence. 
SUMMARY OF PRODUCTION, BY PRODUCTS, 1975

\begin{tabular}{|c|c|c|c|c|}
\hline Product & Plants & Unit & Quantity & Dollars \\
\hline & Number & --- & - Thousands & ----- \\
\hline $\begin{array}{l}\text { Fish and shellfish meal } \ldots \ldots \\
\text { Fish body oils } \ldots \ldots\end{array}$ & $\begin{array}{r}71 \\
40 \\
26 \\
6 \\
35\end{array}$ & $\begin{array}{l}\text { Tons } \\
\text { Pounds } \\
\text { Tons } \\
\text { do } \\
\text { - }\end{array}$ & $\begin{array}{r}290 \\
245,653 \\
128 \\
276 \\
-\quad\end{array}$ & $\begin{array}{r}65,545 \\
32,603 \\
8,753 \\
5,847 \\
49,550\end{array}$ \\
\hline 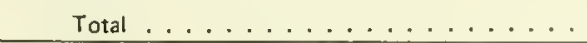 & (1) 115 & - & - & 162,297 \\
\hline
\end{tabular}

(1) Exclusive of duplication. Note:--Totals are correct. This table will not add because of rounding.

VALUE OF PRODUCTION, BY STATES, 1975

\begin{tabular}{|c|c|}
\hline State & Thousand dollars \\
\hline Maine $\ldots \ldots \ldots \ldots \ldots \ldots$ & 21,638 \\
\hline Massachusetts . . . . . . . . . . . . & 2,199 \\
\hline Rhode Island, New York, and Pennsylvania ..... & 436 \\
\hline 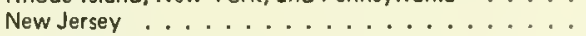 & 2,980 \\
\hline 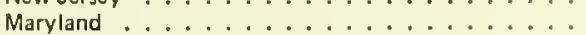 & 1,380 \\
\hline Virginia . . . . . . . . . . & 13,210 \\
\hline North Carolina . . . . . . . . . . . . . . & 6,185 \\
\hline Georgia, Alabama, and Texas . . . . . . . & 4,647 \\
\hline 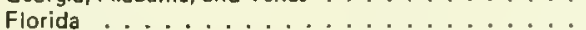 & 480 \\
\hline Mississippi . . . . . . . . . . . . & 10,157 \\
\hline Louisiana . . . . . . . . . . . . . . . . . & 49,799 \\
\hline 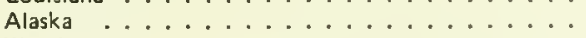 & 400 \\
\hline Washington $\ldots \ldots \ldots \ldots$ & 2.933 \\
\hline Oregon $\ldots \ldots \ldots \ldots \ldots$ & 459 \\
\hline 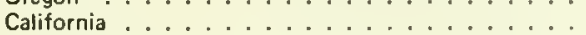 & 42.116 \\
\hline lowa, Michigan, and Wisconsin . . . . . . & 513 \\
\hline American Samoa and Puerto Rico $\ldots \ldots$ & 2,765 \\
\hline 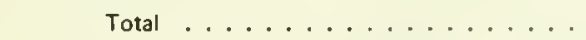 & 162,297 \\
\hline
\end{tabular}

\section{PLANTS PRODUCING INDUSTRIAL FISHERY PRODUCTS, 1975}

\begin{tabular}{|c|c|c|c|}
\hline Area and State & Plants & Area and State & Plants \\
\hline & Number & & Number \\
\hline 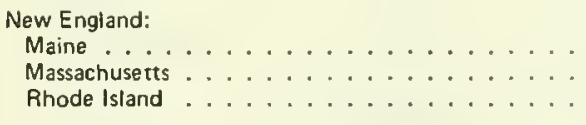 & $\begin{array}{l}7 \\
4 \\
2\end{array}$ & 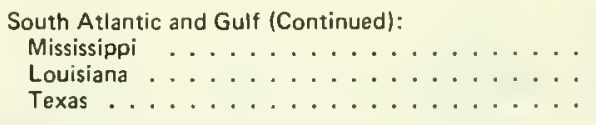 & $\begin{array}{r}6 \\
18 \\
1\end{array}$ \\
\hline Total $\ldots \ldots \ldots \ldots \ldots$ & 13 & Total $\ldots \ldots \ldots \ldots \ldots \ldots$ & 44 \\
\hline 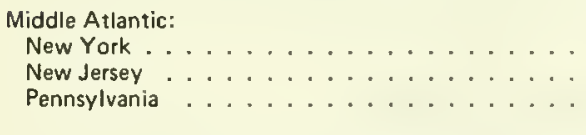 & $\begin{array}{l}2 \\
4 \\
1\end{array}$ & 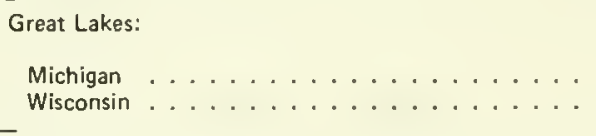 & $\begin{array}{l}1 \\
1\end{array}$ \\
\hline Total $\ldots \ldots \ldots \ldots \ldots$ & 7 & 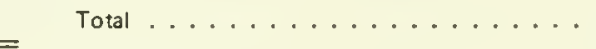 & 2 \\
\hline $\begin{array}{l}\text { Chesapeake: } \\
\text { Maryland } \ldots \ldots \ldots \ldots \ldots \ldots \ldots \ldots \ldots \ldots \ldots\end{array}$ & $\begin{array}{l}3 \\
9\end{array}$ & Mississippi River, lowa $\ldots \ldots \ldots \ldots \ldots$ & 1 \\
\hline Total $\ldots \ldots \ldots \ldots \ldots$ & 12 & $\begin{array}{l}\text { Pacific Coast: } \\
\text { - Alaska } \ldots \ldots \ldots \\
\text { Washington } \ldots \ldots \ldots \ldots\end{array}$ & $\begin{array}{l}4 \\
7 \\
6\end{array}$ \\
\hline $\begin{array}{l}\text { South Atlantic and Gulf: } \\
\text { North Carolina . . . . . . . . . . }\end{array}$ & 12 & 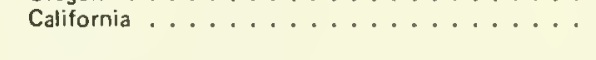 & 13 \\
\hline $\begin{array}{l}\text { Georgia } \ldots \ldots \\
\text { Florida } \ldots \ldots \ldots\end{array}$ & $\begin{array}{l}2 \\
4\end{array}$ & Total . . . . . . . . . . . . & 30 \\
\hline Alabama $\ldots \ldots \ldots \ldots$ & 1 & 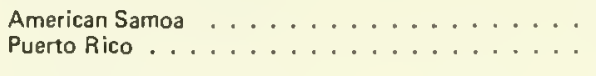 & $\frac{2}{4}$ \\
\hline (Continued) & & Grand total $\ldots \ldots \ldots \ldots \ldots$ & 115 \\
\hline
\end{tabular}


NUMBER OF PLANTS PRODUCING INDUSTRIAL

FISHERY PRODUCTS, BY TYPE PRODUCT, 1975

\begin{tabular}{|c|c|c|c|}
\hline Product & $\begin{array}{l}\text { Atlantic and } \\
\text { Gulf Coasts (1) }\end{array}$ & Pacific Coast (2) & Total \\
\hline & --- & Number - - - & - - \\
\hline \multicolumn{4}{|l|}{ Scrap and meal, dried: } \\
\hline 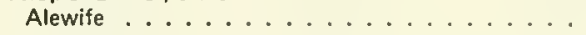 & 3 & - & 3 \\
\hline Anchovy $\ldots \ldots \ldots \ldots \ldots$ & - & 6 & 6 \\
\hline 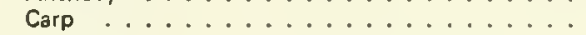 & 1 & - & 1 \\
\hline Herring: $\ldots \ldots \ldots \ldots \ldots \ldots \ldots \ldots \ldots \ldots \ldots$ & 14 & 4 & 18 \\
\hline Sea $\ldots \ldots \ldots \ldots \ldots \ldots$ & 2 & 2 & 4 \\
\hline Thread $\ldots \ldots \ldots$ & 3 & -2 & $\begin{array}{l}4 \\
3\end{array}$ \\
\hline 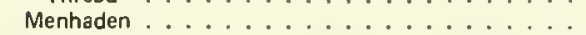 & 22 & - & 22 \\
\hline Shrimp $\ldots \ldots \ldots$ & 10 & 1 & 11 \\
\hline Tuna and mackerel $\ldots \ldots \ldots \ldots$ & - & 12 & 12 \\
\hline Unclassified $\ldots \ldots \ldots \ldots \ldots$ & 16 & 4 & 20 \\
\hline \multicolumn{4}{|l|}{ Oil: $\quad$ n } \\
\hline Alewife $\ldots \ldots \ldots \ldots \ldots \ldots$ & 3 & - & 3 \\
\hline 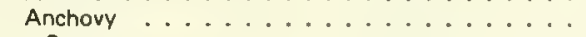 & - & 6 & 6 \\
\hline 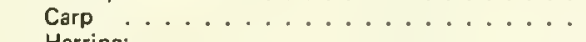 & 1 & - & 1 \\
\hline \multicolumn{4}{|l|}{ Herring: } \\
\hline Sea $\ldots \ldots \ldots \ldots \ldots$ & 2 & 1 & 3 \\
\hline Thread $\ldots \ldots \ldots \ldots \ldots$ & 3 & - & 3 \\
\hline 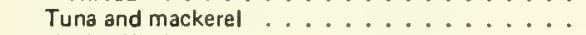 & - & 8 & 8 \\
\hline \multicolumn{4}{|l|}{ Unclassified: } \\
\hline Liver $\ldots \ldots \ldots \ldots \ldots$ & 1 & - & 9 \\
\hline Body $\ldots \ldots \ldots \ldots$ & 6 & 3 & 9 \\
\hline \multicolumn{4}{|l|}{ Shell products: } \\
\hline Clam shells processed for food serving $\ldots \ldots \ldots$ & 3 & - & 3 \\
\hline Crabs shells processed for food serving . . . . . & 3 & - & 3 \\
\hline Marine pearl shell buttons $\ldots \ldots$ & 2 & - & 2 \\
\hline \multicolumn{4}{|l|}{ Oyster shell: } \\
\hline Crushed shell for poultry feed $\ldots \ldots \ldots \ldots$ & 4 & 1 & 5 \\
\hline Lime (burned and unburned) $\ldots \ldots \ldots$ & 2 & 1 & 3 \\
\hline \multicolumn{4}{|l|}{ Seaweed products: } \\
\hline Agar-agar $\ldots \ldots \ldots \ldots$ & - & 1 & 1 \\
\hline Irish moss extracts . . . . . . . . . . & 3 & - & 3 \\
\hline Kelp products . . . . . . & - & 1 & 1 \\
\hline \multicolumn{4}{|l|}{ Miscellaneous: } \\
\hline Animal feeds $\ldots \ldots \ldots \ldots \ldots$ & 6 & 10 & 16 \\
\hline Chitosan $\ldots \ldots \ldots$ & - & 1 & 1 \\
\hline Fish solubles . . . . . . . . . . . & 20 & 6 & 26 \\
\hline Shark leather . . . . . . . . . . . & 1 & - & 1 \\
\hline Liquid fertilizer & - & 1 & 1 \\
\hline Pearl essence . . . . . . . . . . . . . & 3 & - & 3 \\
\hline Total, exclusive of duplication . . . . . . . & 77 & 38 & 115 \\
\hline
\end{tabular}

(1) Includes firms in the Great Lakes and Mississippi River areas. (2) Includes Puerto Rico and American Samoa. 


\section{PRODUCTION OF MARINE ANIMAL MEAL AND SCRAP, 1975}

\begin{tabular}{|c|c|c|c|c|c|c|}
\hline \multirow[t]{2}{*}{ Product } & \multicolumn{2}{|c|}{$\begin{array}{l}\text { Atlantic and } \\
\text { Gulf Coasts }\end{array}$} & \multicolumn{2}{|c|}{$\begin{array}{c}\text { American Samoa, } \\
\text { Pacific Coast, } \\
\text { and Puerto Rico }\end{array}$} & \multicolumn{2}{|c|}{ Total } \\
\hline & $\frac{\text { Thousand }}{\text { tons }}$ & $\frac{\text { Thousand }}{\text { dollars }}$ & $\frac{\text { Thousand }}{\text { tons }}$ & $\frac{\text { Thousand }}{\text { dollars }}$ & $\frac{\text { Thousand }}{\text { tons }}$ & $\frac{\text { Thousand }}{\text { dollars }}$ \\
\hline \multicolumn{7}{|l|}{$\begin{array}{l}\text { Dried scrap and meal: } \\
\text { Fish: }\end{array}$} \\
\hline $\begin{array}{l}\text { Anchovy } \ldots . . \\
\text { Herring: }\end{array}$ & - & - & 28 & 6,559 & 28 & 6,559 \\
\hline Sea ....... & (1) 4 & (1) 1,074 & - & - & 4 & 1,074 \\
\hline Thread ..... & 1 & 186 & - & - & $i$ & 186 \\
\hline Menhaden $\ldots$. & 191 & 45,993 & - & - & 191 & 45,993 \\
\hline Tuna and mackerel & - & - & 37 & 6,384 & 37 & 6,384 \\
\hline Unclassified ... & (2) 17 & (2) 4,083 & 1 & 251 & 18 & 4,334 \\
\hline ... & 213 & 51,336 & 66 & 13,194 & 279 & 64,530 \\
\hline \multicolumn{7}{|l|}{ Shellfish: } \\
\hline Crab ......... & 7 & 723 & 1 & 84 & 8 & 807 \\
\hline Shrimp ..... & 1 & 25 & 1 & 101 & 2 & 126 \\
\hline Unclassified . . . & - & - & 1 & 82 & $\overline{1}$ & 82 \\
\hline . . & 8 & 748 & 3 & 267 & 11 & 1,015 \\
\hline Grand total . . & 221 & 52,084 & 69 & 13,461 & 290 & 65,545 \\
\hline
\end{tabular}

(1) Includes production on the Pacific Coast. (2) Includes production in the Great Lakes and Mississippi River.

PRODUCTION OF MARINE ANIMAL OIL, 1975

\begin{tabular}{|c|c|c|c|c|c|c|}
\hline \multirow[t]{2}{*}{ Product } & \multicolumn{2}{|c|}{$\begin{array}{l}\text { Atlantic and } \\
\text { Gulf Coasts }\end{array}$} & \multicolumn{2}{|c|}{$\begin{array}{c}\text { Pacific Coast } \\
\text { and Puerto Rico }\end{array}$} & \multicolumn{2}{|c|}{ Total } \\
\hline & $\begin{array}{l}\text { Thousand } \\
\text { pounds }\end{array}$ & $\frac{\text { Thousand }}{\text { dollars }}$ & $\frac{\text { Thousand }}{\text { pounds }}$ & $\frac{\text { Thousand }}{\text { dollars }}$ & $\frac{\text { Thousand }}{\text { pounds }}$ & $\frac{\text { Thousand }}{\text { dollars }}$ \\
\hline \multicolumn{7}{|l|}{ Fish oil: } \\
\hline $\begin{array}{l}\text { Anchowy } \ldots \ldots \\
\text { Herring: }\end{array}$ & - & - & 12,857 & 1,547 & 12,857 & 1,547 \\
\hline Sea .......... & 1,598 & 161 & - & - & 1,598 & 161 \\
\hline Thread ....... & 1.601 & 185 & - & - & 1,601 & 185 \\
\hline Menhaden .... & 213,271 & 29,182 & - & - & 213,271 & 29,182 \\
\hline Tuna and mackerel. & - & - & 6,444 & 691 & 6.444 & 691 \\
\hline Unclassified $\ldots$. & (1) 9.186 & (1) 762 & 696 & 75 & 9,882 & 837 \\
\hline$\ldots \ldots$ & 225,656 & 30,290 & 19,997 & 2,313 & 245,653 & 32,603 \\
\hline
\end{tabular}

(1) Includes production in the Great Lakes and Mississippi River area and liver oils.

Note:--To convert oil to gallons divide by 7.75 .

PRODUCTION OF FISH SOLUBLES, 1975

\begin{tabular}{|c|c|c|}
\hline Product, State, and number of plants & $\begin{array}{c}\text { Thousand } \\
\text { tons }\end{array}$ & $\begin{array}{c}\text { Thousand } \\
\text { dollars }\end{array}$ \\
\hline $\begin{array}{l}\text { Fish solubles: } \\
\text { Massachusetts (1) New Jersey (1) Virginia (2) }\end{array}$ & & \\
\hline 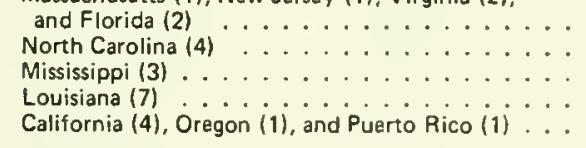 & $\begin{array}{r}37 \\
9 \\
15 \\
27 \\
40\end{array}$ & $\begin{array}{r}2,208 \\
685 \\
911 \\
1,806 \\
3,143\end{array}$ \\
\hline Total $(26) \ldots \ldots \ldots \ldots$ & 128 & 8,753 \\
\hline
\end{tabular}


PRODUCTION OF MENHADEN PRODUCTS, 1975

\begin{tabular}{|c|c|c|c|c|c|c|c|}
\hline \multirow[t]{2}{*}{$\begin{array}{c}\text { State and } \\
\text { number of plants }\end{array}$} & \multicolumn{2}{|c|}{$\begin{array}{l}\text { Dried scrap } \\
\text { and meal }\end{array}$} & \multicolumn{2}{|c|}{ Oil } & \multicolumn{2}{|c|}{ Solubles } & \multirow{2}{*}{$\begin{array}{l}\text { Total } \\
\text { Thousand } \\
\text { do!lars }\end{array}$} \\
\hline & $\frac{\text { Thousand }}{\text { tons }}$ & $\frac{\text { Thousand }}{\text { dollars }}$ & Thousand & $\frac{\text { Thousand }}{\text { dollars }}$ & $\frac{\text { Thousand }}{\text { tons }}$ & $\frac{\text { Thousand }}{\text { dollars }}$ & \\
\hline $\begin{array}{l}\text { Maine (1), Massa- } \\
\text { chusetts (1), New } \\
\text { Jersey }(1) \text {, Virginia (2), } \\
\text { and Florida (1) } \ldots \\
\text { North Carolina (4) } \ldots \\
\text { Mississippi (3) } \ldots \ldots \\
\text { Louisiana (8) . . . . }\end{array}$ & $\begin{array}{r}46 \\
17 \\
24 \\
104\end{array}$ & $\begin{array}{r}11,002 \\
4,357 \\
5,765 \\
24,869\end{array}$ & $\begin{array}{r}24,216 \\
3,319 \\
23,775 \\
161,961\end{array}$ & $\begin{array}{r}2,977 \\
389 \\
3,251 \\
22,564\end{array}$ & $\begin{array}{r}33 \\
9 \\
15 \\
27\end{array}$ & $\begin{array}{r}1,978 \\
686 \\
911 \\
1,806\end{array}$ & $\begin{array}{r}15,957 \\
5,432 \\
9,927 \\
49,239\end{array}$ \\
\hline Total (21) & 191 & 45,993 & 213,271 & 29,181 & 84 & 5,381 & 80,555 \\
\hline
\end{tabular}

Note:--May include a small quantity of other species.

\section{PRODUCTION OF OYSTER SHELL PRODUCTS, 1975}

("Live and reef shells")

\begin{tabular}{|c|c|c|c|c|c|c|}
\hline \multirow[t]{2}{*}{$\begin{array}{c}\text { State and } \\
\text { number of plants }\end{array}$} & \multicolumn{2}{|c|}{ Poultry grit } & \multicolumn{2}{|c|}{$\begin{array}{l}\text { Lime, } \\
\text { burned and unburned }\end{array}$} & \multicolumn{2}{|c|}{ Total } \\
\hline & $\frac{\text { Thousand }}{\text { tons }}$ & $\frac{\text { Thousand }}{\text { dollars }}$ & $\frac{\text { Thousand }}{\text { tons }}$ & $\frac{\text { Thousand }}{\text { dollars }}$ & $\frac{\text { Thousand }}{\text { tons }}$ & $\frac{\text { Thousand }}{\text { dollars }}$ \\
\hline $\begin{array}{l}\text { Alabama (1), Mary- } \\
\text { land (1), Oregon (1), } \\
\text { Pennsylvania (1), } \\
\text { Texas (1), and } \\
\text { Virginia (1)..... }\end{array}$ & 264 & 5,602 & 12 & 245 & 276 & 5,847 \\
\hline
\end{tabular}

\section{PRODUCTION OF MISCELLANEOUS INDUSTRIAL FISHERY PRODUCTS, 1975}

\begin{tabular}{|c|c|c|}
\hline Product & State and number of plants & $\begin{array}{l}\text { Thousand } \\
\text { dollars }\end{array}$ \\
\hline Agar-agar $\ldots \ldots \ldots \ldots \ldots$ & California (1) & \\
\hline Animal feeds and fish feed pellets $\ldots \ldots \ldots$ & $\begin{array}{l}\text { California (2), Michigan (1), New } \\
\text { York (1), North Carolina (1), Oregon (4), } \\
\text { Rhode Island (1), Virginia (2), and } \\
\text { Washington (4) }\end{array}$ & \\
\hline Clam and crab shells (processed for food serving) . . & $\begin{array}{l}\text { Forida (1), Massachusetts (1), Mississippi (2), } \\
\text { North Carolina (1), and Rhode Island (1) }\end{array}$ & \\
\hline Irish moss extracts $\ldots \ldots \ldots \ldots \ldots$ & Maine (2) and Massachusetts (1) & \\
\hline 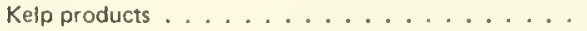 & California (1) & 49.550 \\
\hline Shark leather . . . . . . . . . . . . & New Jersey (1) & \\
\hline Liquid fertilizer . . . . . . . . . . . . . & California (1) & \\
\hline Marine pearl shell buttons ............. & New Jersey (2) & \\
\hline 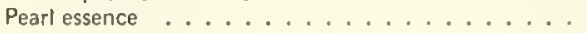 & Maine (3) & \\
\hline Unclassified crab products $\ldots \ldots \ldots \ldots$ & Washington (1) & \\
\hline
\end{tabular}


SUMMARY OF PRODUCTION OF FISH FILLETS AND STEAKS, 1975

\begin{tabular}{|c|c|c|c|c|c|c|c|}
\hline & \multirow[t]{2}{*}{ Item } & \multicolumn{2}{|c|}{ Fillets } & \multicolumn{2}{|c|}{ Steaks } & \multicolumn{2}{|c|}{ Total } \\
\hline & & $\frac{\text { Thousand }}{\text { pounds }}$ & $\frac{\text { Thousand }}{\text { dollars }}$ & $\frac{\text { Thousand }}{\text { pounds }}$ & $\frac{\text { Thousand }}{\text { dollars }}$ & $\frac{\text { Thousand }}{\text { pounds }}$ & $\frac{\text { Thousand }}{\text { dollars }}$ \\
\hline \multirow[t]{2}{*}{$\begin{array}{l}\text { Fresh } \\
\text { Frozen }\end{array}$} & $\ldots \ldots \ldots$ & $\begin{array}{l}97,208 \\
28,218\end{array}$ & $\begin{array}{r}101,512 \\
24,715\end{array}$ & $\begin{array}{l}1,701 \\
4,796\end{array}$ & $\begin{array}{l}2,301 \\
9,395\end{array}$ & $\begin{array}{l}98,909 \\
33,014\end{array}$ & $\begin{array}{r}103,813 \\
34,110\end{array}$ \\
\hline & Total ......... & 125,426 & 126,227 & 6,497 & 11,696 & 131,923 & 137,923 \\
\hline
\end{tabular}

\section{PRODUCTION OF FRESH AND FROZEN FISH FILLETS AND STEAKS, BY SECTIONS, 1975}

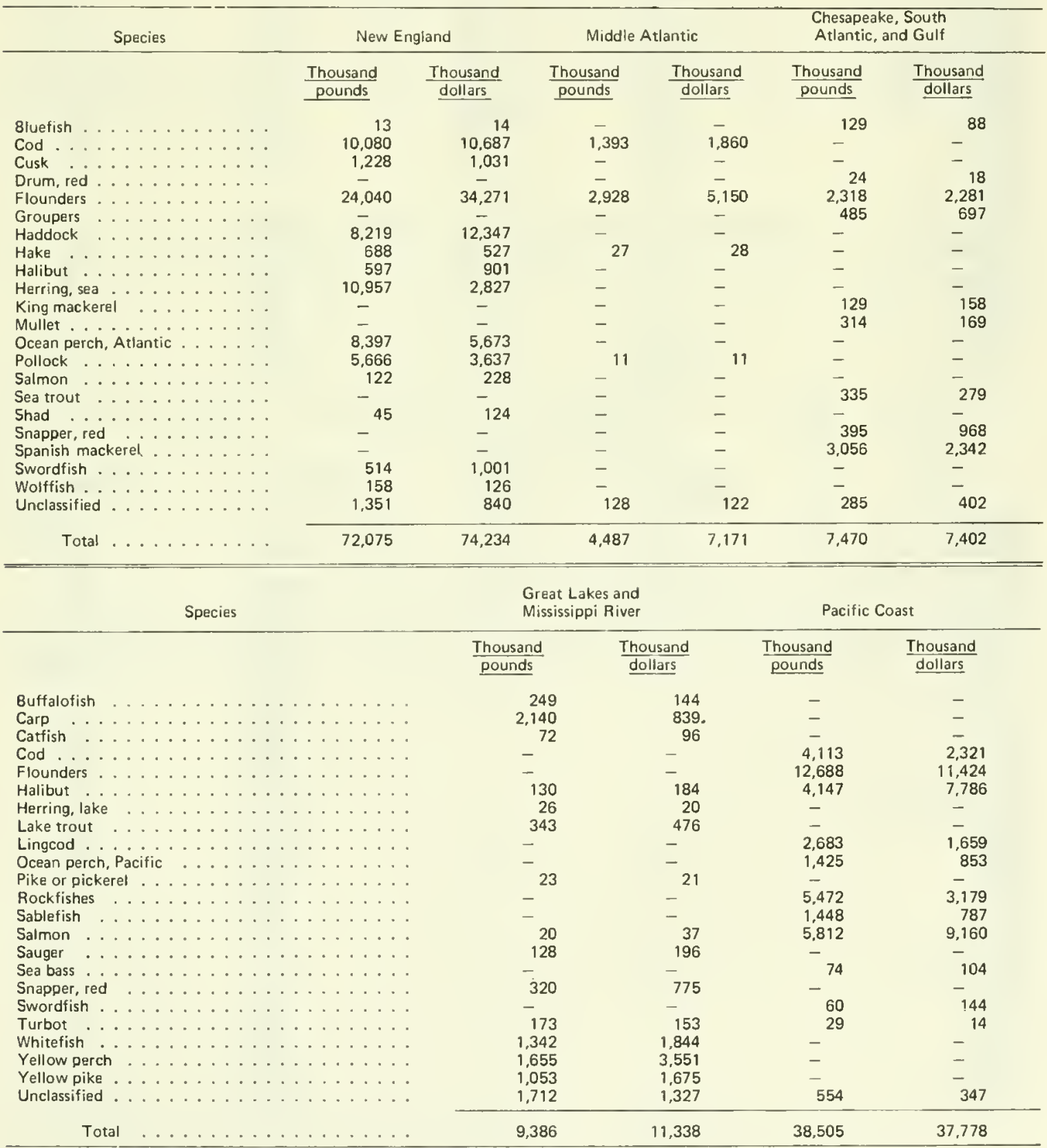


PRODUCTION OF FISH FILLETS AND STEAKS, BY METHOD OF PREPARATION, 1975

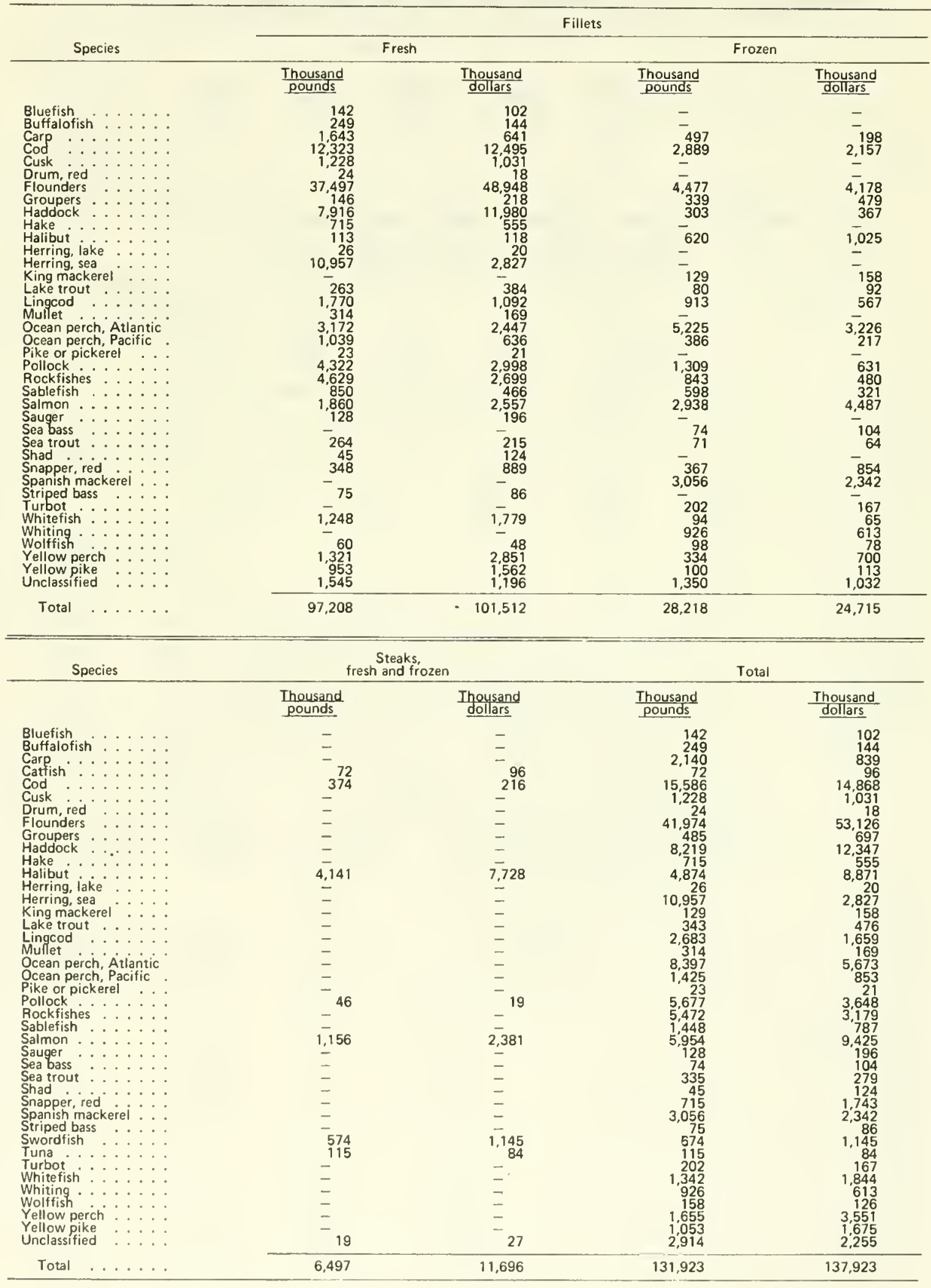


PRODUCTION OF FISH STICKS, 1975

\begin{tabular}{|c|c|c|c|c|c|c|c|c|}
\hline \multicolumn{6}{|c|}{ MONTH } & COOKEO & RAW & TOTAL \\
\hline $\begin{array}{l}\text { JANUARY: } \\
\text { FEBRUARY: } \\
\text { MARCH: } \\
\text { APRIL: } \\
\text { MAY : : } \\
\text { UUNE: : } \\
\text { JULY: : } \\
\text { AUGUST: } \\
\text { SEPTEMBER } \\
\text { OCTOBER : } \\
\text { NOVEMBER: } \\
\text { DECEMBER. }\end{array}$ & $\begin{array}{l}\therefore \\
\therefore \\
\therefore \\
\therefore \\
\therefore \\
:\end{array}$ & $\begin{array}{l}: \\
\vdots \\
\vdots\end{array}$ & $\therefore$ & $\begin{array}{l}\dot{ } \\
\dot{ } \\
\dot{ } \\
\dot{ } \\
\dot{ } \\
\dot{ }\end{array}$ & 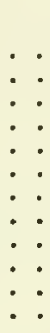 & $\begin{array}{c}\ldots \ldots \\
8,080 \\
9,553 \\
8,331 \\
6,967 \\
6,094 \\
5,417 \\
5,039 \\
6,535 \\
10,087 \\
6,686 \\
7,533 \\
8,689 \\
\end{array}$ & $\begin{array}{r}-\ldots \text { THOUSAND POUNDS } \\
214 \\
184 \\
135 \\
148 \\
168 \\
228 \\
142 \\
155 \\
197 \\
243 \\
214 \\
127 \\
\end{array}$ & $\begin{array}{r}\ldots, \ldots \ldots \\
8,294 \\
9,737 \\
8,466 \\
7,115 \\
6,262 \\
5,645 \\
5,181 \\
6,690 \\
10,284 \\
6,929 \\
7,747 \\
8,816 \\
\end{array}$ \\
\hline TO & & & & & . & 89,011 & 2,155 & 91,166 \\
\hline TOTAL VALL & $E-Y E$ & & & & & $\begin{array}{c}\cdots \cdots, \ldots \\
60,478\end{array}$ & $\cdots-\frac{\text { THOUSANO DOLLARS }}{1,704} \cdots$ & $\begin{array}{c}\ldots 2,182 \\
6\end{array}$ \\
\hline
\end{tabular}

NOTE : - A FISH STICK, GENERALLY CUT FROM A BLOCK OF FILLETS, IS AN ELONGATEO PIECE OF BREADEO FISH FLESH WE IGHING NOT LESS THAN $3 / 4$ OF AN OUNCE ANO NOT MORE THAN $11 / 2$ OUNCES WITH THE LARGEST OIMENSION AT LEAST THREE TIMES THAT OF THE NEXT LARGEST OIMENSION.

PRODUCTION OF FISH PORTIONS, 1975

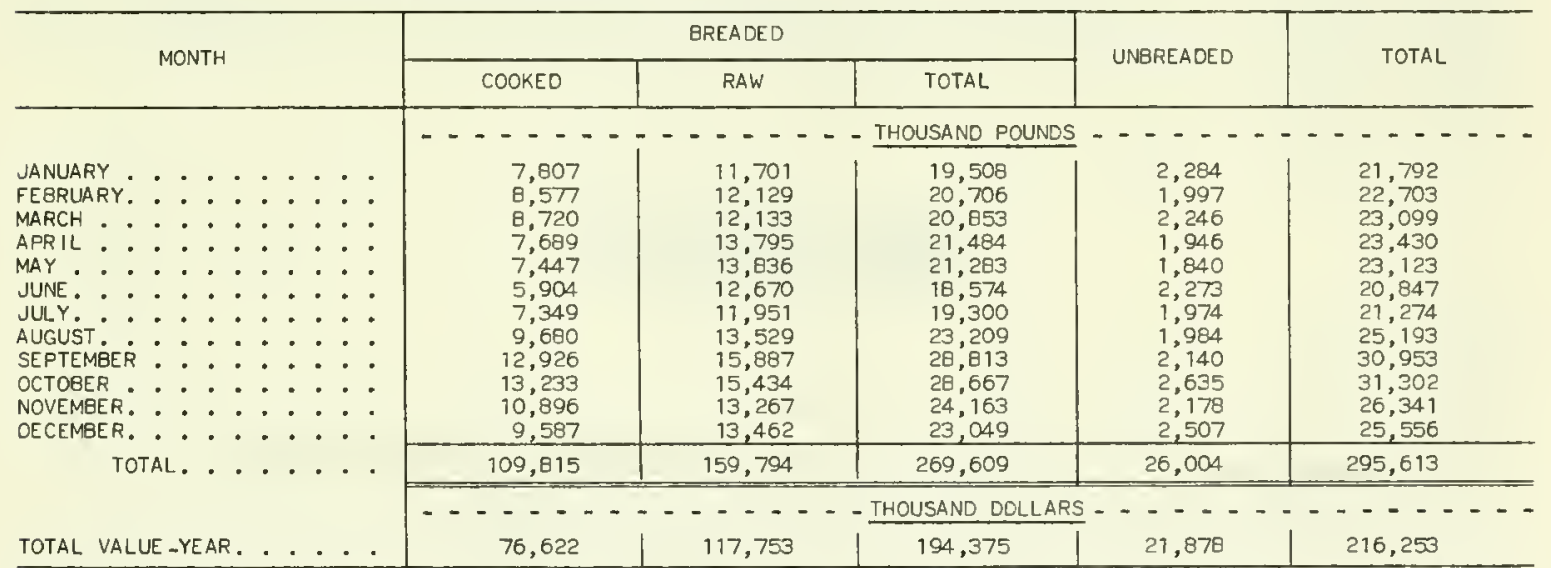

NOTE : - A FISH PORTION, GENERALLY CUT FROM A BLOCK OF FILLETS, IS A PIECCE OF FISH FLESH GENERALLY OF UNIFORM SIZE WITH A THICKNESS OF $3 / 8$ OF AN INCH OR MORE, AND DOES NOT CONFORM TO THE DEFINITION OF A FISH STICK. 


\section{FROZEN FISHERY TRADE}

Freezings. The 1975 production of frozen fish and shellfish by firms reporting to NMFS was 299.7 million pounds-a decline of 12 percent compared with 1974 and well below the record 410.4 million pounds frozen in 1973. The decline was caused primarily by decreased freezings of crabs (down 37 percent) and bait and animal food (down 30 percent). Not included were freezings by firms not reporting to NMFS on a monthly basis and a considerable volume of frozen fillets and steaks produced by firms operating plate freezers at the end of fillet production lines. It is estimated that landings of 468.8 million pounds (live weight) of fish and shellfish were required for the frozen production in 1975.

The New England area led all other areas in freezings with 82.6 million pounds (28 percent of the total); followed by Pacific with 63.7 million and South Central with 61.8 million (21 percent each); South Atlantic with 48.3 million (16 per cent); and Alaska with 28 million pounds ( 9 percent).

Cold Storage Holdings. Monthly holdings of frozen fish and shellfish by cold storage warehouses reporting to NMFS were at a high of 401.8 million pounds on January 31 and a low of 296.4 million pounds on June 30 . Holdings of frozen shrimp products (raw, headless, breaded, peeled, and unclassified) were highest on January 31 when 75.3 million pounds were in storage and lowest on August 31 when 46.7 million pounds were in storage.

Cured Fish Cold-Storage Holdings. Monthly average holdings of salted and smoked fish were $6.1 \mathrm{million}$ pounds. Salted herring ( 4.5 million pounds) and mild-cured salmon $(980,000$ pounds) accounted for 91 percent of the monthly average cold storage inventories of cured fish.

Information on the freezings and holdings of fishery products for 1975 by firms supplying monthly data on their operations and a list of these firms were published previously in Current Fishery Statistics No. 6906. Data on freezings and holdings were also published in preliminary and final monthly reports, Frozen Fishery Products, also in the Current Fishery Statistics Series.

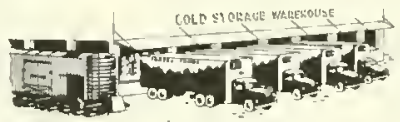

SUMMARY OF FREEZINGS, BY SECTIONS AND MONTHS, 1975

\begin{tabular}{|c|c|c|c|c|c|c|c|c|c|c|c|c|c|c|}
\hline \multicolumn{6}{|c|}{ MONTH } & $\begin{array}{c}\text { NEW } \\
\text { ENGLAND }\end{array}$ & $\begin{array}{l}\text { MIDOLE } \\
\text { ATLANT IC }\end{array}$ & $\begin{array}{c}\text { SOUTH } \\
\text { ATLANTIC }\end{array}$ & $\begin{array}{l}\text { NORTH } \\
\text { CENTRAL, } \\
\text { EAST }\end{array}$ & $\begin{array}{l}\text { NORTH } \\
\text { CENTRAL, } \\
\text { W'EST }\end{array}$ & $\begin{array}{l}\text { SOUTH } \\
\text { CENTRAL. }\end{array}$ & PACIF IC & ALASKA & TOTAL. \\
\hline $\begin{array}{l}\text { JANUARY } \\
\text { FEBRUARY } \\
\text { MARCH : } \\
\text { APRIL : } \\
\text { MAY : } \\
\text { JUNE: : } \\
\text { JULY: : } \\
\text { AUGUST: } \\
\text { SEFTEMBEF } \\
\text { OCTOBER } \\
\text { NOVEMBER } \\
\text { OECEMBER }\end{array}$ & 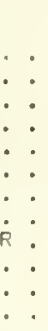 & $\begin{array}{l}\dot{:} \\
\dot{:} \\
\dot{:} \\
\dot{:} \\
\dot{:} \\
\dot{:}\end{array}$ & $\begin{array}{l}\dot{0} \\
\dot{0} \\
\dot{0} \\
\dot{ } \\
\dot{ } \\
\dot{ }\end{array}$ & $\begin{array}{l}\dot{:} \\
\dot{:} \\
\dot{:} \\
\dot{0} \\
\dot{.} \\
\dot{:}\end{array}$ & 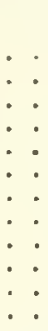 & $\begin{array}{r}--- \\
5,075 \\
5,399 \\
5,808 \\
4,621 \\
7,276 \\
5,141 \\
8,427 \\
7,750 \\
9,137 \\
10,324 \\
8,431 \\
5,221\end{array}$ & $\begin{array}{r}--- \\
1,002 \\
635 \\
626 \\
1,039 \\
1,177 \\
1,111 \\
1,100 \\
1,197 \\
771 \\
538 \\
904 \\
400\end{array}$ & $\begin{array}{r}--- \\
3,039 \\
3,756 \\
4,029 \\
2,790 \\
3,796 \\
3,723 \\
2,815 \\
3,076 \\
4,405 \\
5,066 \\
5,039 \\
5,205\end{array}$ & $\begin{array}{c}-- \text { THC } \\
-240 \\
- \\
- \\
400 \\
420 \\
1,015 \\
785 \\
124 \\
139 \\
750 \\
750\end{array}$ & $\begin{array}{c}\text { SAND POU } \\
- \\
- \\
- \\
= \\
- \\
- \\
- \\
- \\
- \\
-\end{array}$ & $\begin{array}{c}-\cdot= \\
5,790 \\
4,333 \\
4,350 \\
3,630 \\
4,219 \\
5,301 \\
5,217 \\
7,374 \\
5,122 \\
5,524 \\
6,215 \\
4,740\end{array}$ & $\begin{array}{r}-. . \\
3,155 \\
3,114 \\
4,282 \\
5,349 \\
8,371 \\
5,868 \\
6,878 \\
8,567 \\
7,468 \\
5,587 \\
2,566 \\
2,509\end{array}$ & $\begin{array}{r}. \\
664 \\
312 \\
1,065 \\
1,890 \\
3,286 \\
3,687 \\
3,693 \\
3,406 \\
2,524 \\
3,546 \\
3,523 \\
450\end{array}$ & $\begin{array}{l}-\cdot-\cdot \\
18,965 \\
17,549 \\
20,159 \\
19,319 \\
28,527 \\
25,251 \\
29,145 \\
32,957 \\
29,553 \\
31,524 \\
27,420 \\
19,275\end{array}$ \\
\hline To & TAL & . & . & . & . . & 82,610 & 10,500 & 48,340 & 4,623 & 2 & 61,815 & 63,714 & 28,048 & 299,652 \\
\hline
\end{tabular}

FISHING OR TRANSPORTING CRAFT IS NOT INCLUDEO IN THIS TABLE. 


\section{SUMMARY OF FREEZINGS, BY MONTHS, 1975}

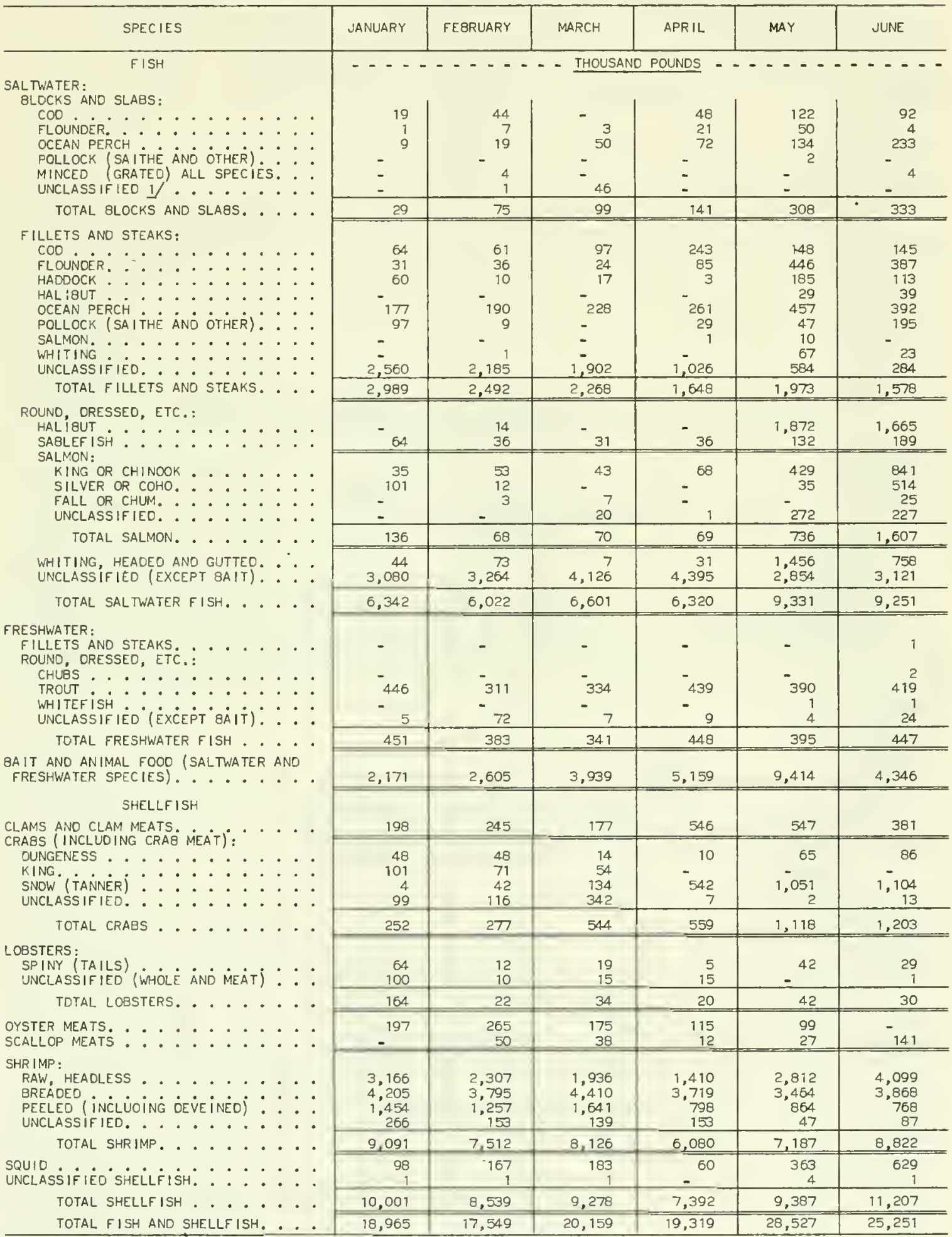

SEE FOOTNOTE AT ENO OF TABLE.

(CONTINUEO ON NEXT PAGE) 


\section{SUMMARY OF FREEZINGS, BY MONTHS, 1975 - Continued}

\begin{tabular}{|c|c|c|c|c|c|c|c|c|c|}
\hline SPECIES & & & JULY & AUGUST & SEPTEMBER & DCTOBER & NOVEMBER & OECEMBER & TOTAL \\
\hline 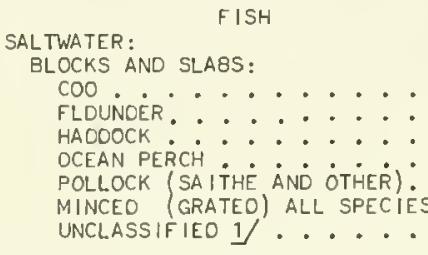 & $\therefore:$ & $\therefore$ & $\begin{array}{r}48 \\
-45 \\
-\quad 122 \\
-\quad 4 \\
-\quad 4 \\
\end{array}$ & $\begin{array}{r}99 \\
10 \\
-\quad 96 \\
96 \\
-\quad 18 \\
-\quad 5 \\
\end{array}$ & $\begin{array}{r}100 \\
13 \\
-\quad 85 \\
81 \\
21 \\
-\quad 4 \\
\end{array}$ & $\begin{array}{r}72 \\
24 \\
-\quad \\
25 \\
1 \\
8 \\
70 \\
\end{array}$ & $\begin{array}{r}69 \\
20 \\
3 \\
59 \\
-\quad \\
12 \\
91 \\
\end{array}$ & $\begin{array}{r}21 \\
-71 \\
-\quad 16 \\
-\quad \\
-\quad 3 \\
\end{array}$ & $\begin{array}{r}734 \\
269 \\
3 \\
920 \\
42 \\
36 \\
216 \\
\end{array}$ \\
\hline TOTAL BLOCKS AND SLABS. . & . & - . & 219 & 228 & 223 & 200 & 254 & 111 & 2,220 \\
\hline 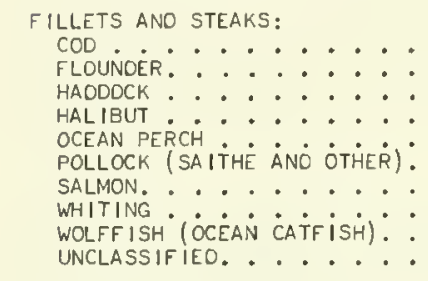 & 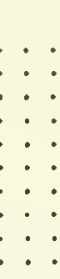 & $\therefore$ & $\begin{array}{r}317 \\
138 \\
73 \\
44 \\
395 \\
71 \\
2 \\
63 \\
-\quad 722 \\
\end{array}$ & $\begin{array}{r}197 \\
187 \\
48 \\
38 \\
439 \\
234 \\
2 \\
34 \\
2 \\
1,556 \\
\end{array}$ & $\begin{array}{r}236 \\
110 \\
11 \\
39 \\
364 \\
112 \\
3 \\
6 \\
-\quad 342 \\
\end{array}$ & $\begin{array}{r}109 \\
54 \\
28 \\
19 \\
337 \\
31 \\
2 \\
23 \\
-\quad \\
3,226 \\
\end{array}$ & $\begin{array}{r}83 \\
46 \\
36 \\
18 \\
174 \\
362 \\
-\quad 19 \\
-\quad 781 \\
\end{array}$ & $\begin{array}{r}153 \\
31 \\
3 \\
33 \\
175 \\
435 \\
4 \\
8 \\
1 \\
1,189 \\
\end{array}$ & $\begin{array}{r}1,853 \\
1,575 \\
587 \\
259 \\
3,589 \\
1,622 \\
24 \\
244 \\
3 \\
21,357 \\
\end{array}$ \\
\hline TOTAL FILLETS ANO STEAKS. & . . & . & 2,825 & 2,737 & $3, \underline{223}$ & 3,829 & 3,519 & 2,032 & 31,113 \\
\hline 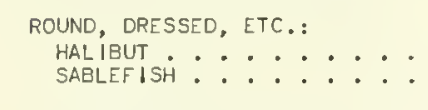 & $\therefore$ & $\therefore$ & $\begin{array}{r}1,711 \\
283\end{array}$ & $\begin{array}{r}1,480 \\
158\end{array}$ & $\begin{array}{l}378 \\
477\end{array}$ & $\begin{array}{l}105 \\
332\end{array}$ & $\begin{array}{l}38 \\
32\end{array}$ & $\begin{array}{l}24 \\
89\end{array}$ & $\begin{array}{l}7.287 \\
1.859\end{array}$ \\
\hline $\begin{array}{l}\text { SALMON: } \\
\text { KING OR CHINOOK }: \vdots: \\
\text { SILVER OR COHO.: } \\
\text { FALL OR CHUM. : }: \vdots: \\
\text { UNCLASSIFIED. }: \vdots:\end{array}$ & $\therefore:$ & $\dot{:}:$ & $\begin{array}{r}1,206 \\
1,324 \\
240 \\
1,389 \\
\end{array}$ & $\begin{array}{l}1,655 \\
1,619 \\
1,145 \\
2,420 \\
\end{array}$ & $\begin{array}{l}1,272 \\
1,862 \\
1,135 \\
1,081 \\
\end{array}$ & $\begin{array}{r}403 \\
1.421 \\
825 \\
78 \\
\end{array}$ & $\begin{array}{r}54 \\
300 \\
444 \\
48 \\
\end{array}$ & $\begin{array}{l}12 \\
45 \\
72 \\
52 \\
\end{array}$ & $\begin{array}{l}6,071 \\
7,233 \\
3,896 \\
5,588 \\
\end{array}$ \\
\hline TOTAL SALMON. . . . & . & . . & 4,159 & 6,839 & 5,350 & 2,727 & 846 & 181 & 22,788 \\
\hline $\begin{array}{l}\text { WHITING, HEAOED AND GUTTEO. } \\
\text { UNCLASSIF IED (EXCEPT } 8 \text { AIT). }\end{array}$ & $\therefore$ & & $\begin{array}{l}2,803 \\
2,644 \\
\end{array}$ & $\begin{array}{l}1,633 \\
3,250 \\
\end{array}$ & $\begin{array}{r}519 \\
5,675 \\
\end{array}$ & $\begin{array}{l}1,452 \\
5,502 \\
\end{array}$ & $\begin{array}{r}508 \\
5,011 \\
\end{array}$ & $\begin{array}{r}67 \\
5,080 \\
\end{array}$ & $\begin{array}{r}9,351 \\
48,002 \\
\end{array}$ \\
\hline TOTAL SALTWATER FISH. . & . $\cdot$ & . & 14,644 & 16,325 & 15,845 & 14,147 & 10,208 & 7,584 & 122,620 \\
\hline 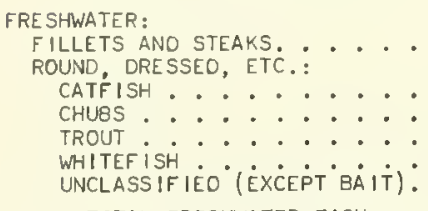 & 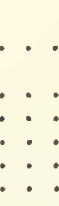 & $\begin{array}{l}. \\
: \\
: \\
: \\
:\end{array}$ & $\begin{array}{l}- \\
- \\
- \\
323 \\
-\quad 23 \\
\end{array}$ & $\begin{array}{r}- \\
2 \\
5 \\
390 \\
2 \\
27 \\
\end{array}$ & $\begin{array}{r}- \\
1 \\
1 \\
339 \\
1 \\
20 \\
\end{array}$ & $\begin{array}{r}- \\
-\quad 4 \\
377 \\
1 \\
34 \\
\end{array}$ & $\begin{array}{l}- \\
- \\
- \\
- \\
-\end{array}$ & $\begin{array}{l}- \\
- \\
- \\
- \\
-\end{array}$ & $\begin{array}{r}1 \\
3 \\
12 \\
4,252 \\
6 \\
225 \\
\end{array}$ \\
\hline TOTAL FRESHWATER FISH . • & $\cdot \cdot$ & . & 346 & 426 & 362 & 416 & 311 & 173 & 4.499 \\
\hline $\begin{array}{l}\text { 8AIT AND ANIMAL FOOD (SALTWATER } \\
\text { FRESHWATER SPECIES). } \cdots\end{array}$ & ANL & ID & 4,400 & 4,125 & 3,455 & 3,154 & 4,276 & 2,655 & 49,699 \\
\hline $\begin{array}{l}\text { SHELLFISH } \\
\text { CLAMS ANO CLAM MEATS. } . \dot{\text { CRABS }} \text { (INCLUOING CRAB MEAT): }\end{array}$ & . & . & 390 & 37 & 223 & 88 & 98 & 175 & 3,445 \\
\hline 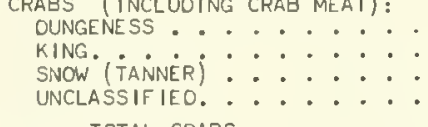 & $\therefore$ & $: \dot{ }$ & $\begin{array}{r}34 \\
-\quad 764 \\
21 \\
\end{array}$ & $\begin{array}{r}24 \\
4 \\
73 \\
35 \\
\end{array}$ & $\begin{array}{r}1 \\
440 \\
34 \\
33 \\
\end{array}$ & $\begin{array}{r}25 \\
1,854 \\
98 \\
17 \\
\end{array}$ & $\begin{array}{r}9 \\
1,450 \\
63 \\
20 \\
\end{array}$ & $\begin{array}{r}236 \\
375 \\
114 \\
17 \\
\end{array}$ & $\begin{array}{r}600 \\
4,349 \\
4,023 \\
722 \\
\end{array}$ \\
\hline TOTAL CRABS . . . . & $\cdot \cdot$ & - & 819 & 136 & 508 & 1,994 & 1,542 & 742 & 9,694 \\
\hline 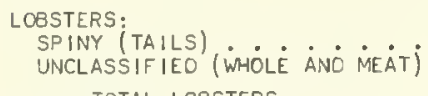 & ; & & -16 & $\begin{array}{r}19 \\
279 \\
\end{array}$ & $\begin{array}{r}20 \\
194 \\
\end{array}$ & $\begin{array}{r}36 \\
141 \\
\end{array}$ & $\begin{array}{l}31 \\
79 \\
\end{array}$ & $\begin{array}{r}6 \\
34 \\
\end{array}$ & $\begin{array}{l}283 \\
884 \\
\end{array}$ \\
\hline TOTAL LOBSTERS. . . . & . & . . & 16 & 298 & 214 & 177 & 110 & 40 & 1,167 \\
\hline $\begin{array}{l}\text { OYSTER MEATS. }: \cdots: \cdots \\
\text { SCALLOP MEATS }: \cdots\end{array}$ & $\therefore$ & & $\begin{array}{l}42 \\
66 \\
\end{array}$ & $\begin{array}{r}65 \\
47 \\
\end{array}$ & $\begin{array}{l}57 \\
42 \\
\end{array}$ & $\begin{array}{r}305 \\
87 \\
\end{array}$ & $\begin{array}{r}287 \\
68 \\
\end{array}$ & $\begin{array}{r}304 \\
77 \\
\end{array}$ & $\begin{array}{r}1.911 \\
655 \\
\end{array}$ \\
\hline 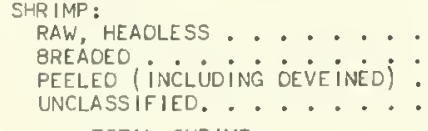 & $\dot{:}:$ & & $\begin{array}{r}3,951 \\
3,719 \\
841 \\
144 \\
\end{array}$ & $\begin{array}{r}5,883 \\
3,576 \\
1,389 \\
136 \\
\end{array}$ & $\begin{array}{r}4,225 \\
3,445 \\
888 \\
76 \\
\end{array}$ & $\begin{array}{r}5,563 \\
3,353 \\
666 \\
403 \\
\end{array}$ & $\begin{array}{r}5,866 \\
3,203 \\
1,009 \\
71 \\
\end{array}$ & $\begin{array}{r}3,963 \\
2,398 \\
1,009 \\
81 \\
\end{array}$ & $\begin{array}{r}45,181 \\
42,555 \\
12,584 \\
1,756 \\
\end{array}$ \\
\hline TOTAL SHRIMP. . . . . & . & & 8,055 & 10,984 & 8,634 & 9,985 & 10,149 & 7,451 & 102,076 \\
\hline $\begin{array}{l}\text { SQUID } \\
\text { UNCLASSIFIE }\end{array}$ & $:$ & & $\begin{array}{r}367 \\
- \\
\end{array}$ & $\begin{array}{r}174 \\
- \\
\end{array}$ & $\begin{array}{r}213 \\
-\end{array}$ & 1.171 & $\begin{array}{r}371 \\
8 \\
\end{array}$ & $\begin{array}{r}66 \\
8 \\
\end{array}$ & $\begin{array}{r}3.862 \\
24 \\
\end{array}$ \\
\hline TOTAL SHELLFISH .... & & & 9,755 & 12,081 & 9,891 & 13,807 & 12,633 & 8,863 & 122,834 \\
\hline TOTAL FISH ANO SHELLFISH. & 1. . & & 29,145 & 32,957 & 29,553 & 31,524 & 27,428 & 19,275 & 299,652 \\
\hline
\end{tabular}

1/ "UNCLASSIFIEO" MAY ALSO INCLUDE BLOCKS ANO SLABS MADE FROM SPECIES LISTED SEPARATELY ANO ALSO MINCEO (GRATEO) FISH 8LOCKS. NOTE:--PROOUCTION OF FISH FROZEN ON U.S. FISHING OR TRANSPDRT ING CRAFT IS NOT INCLUDED IN THIS TABLE. 
SUMMARY OF FREEZINGS, BY SECTIONS, 1975

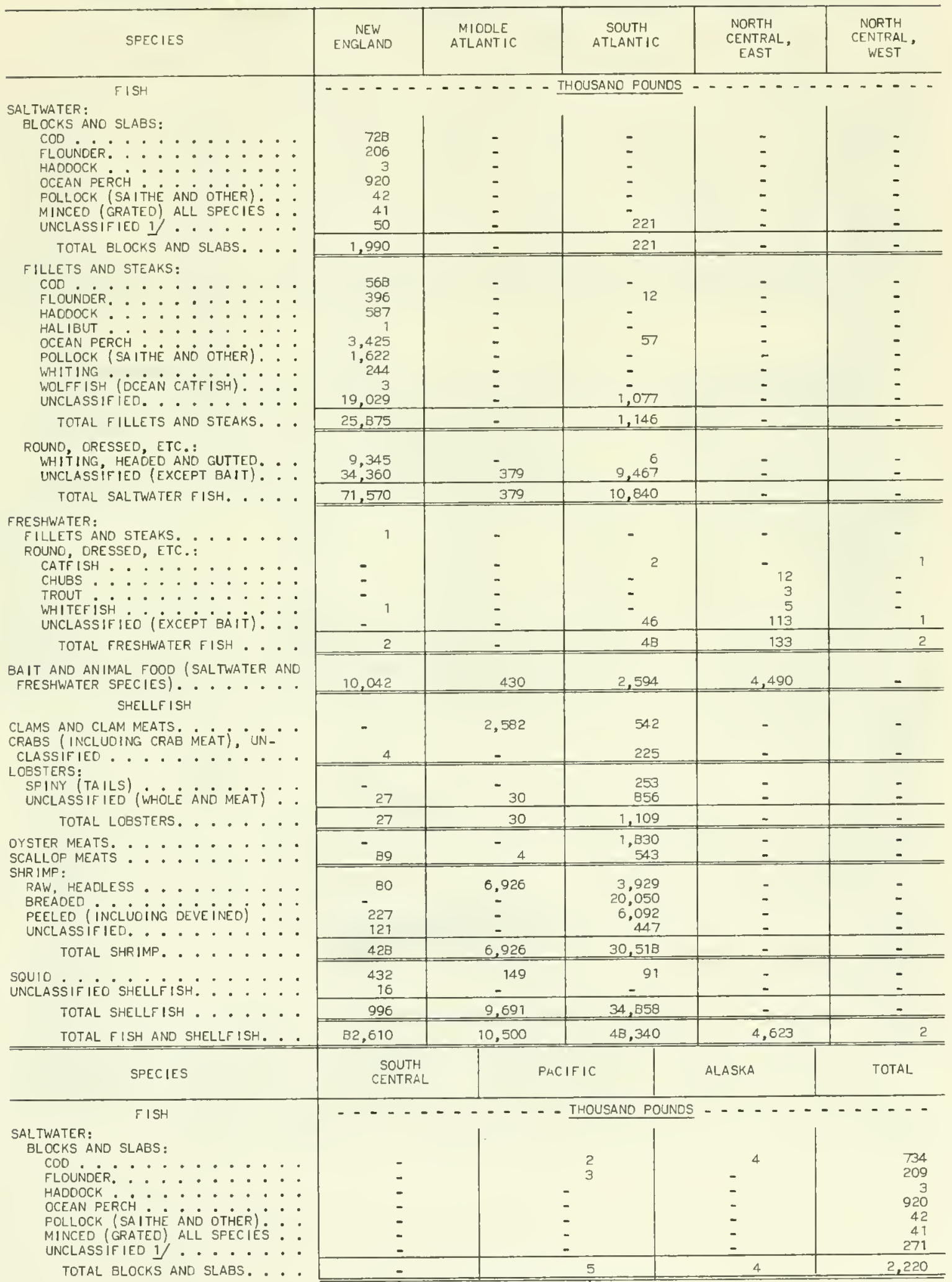




\section{SUMMARY OF FREEZINGS, BY SECTIONS, 1975 - Continued}

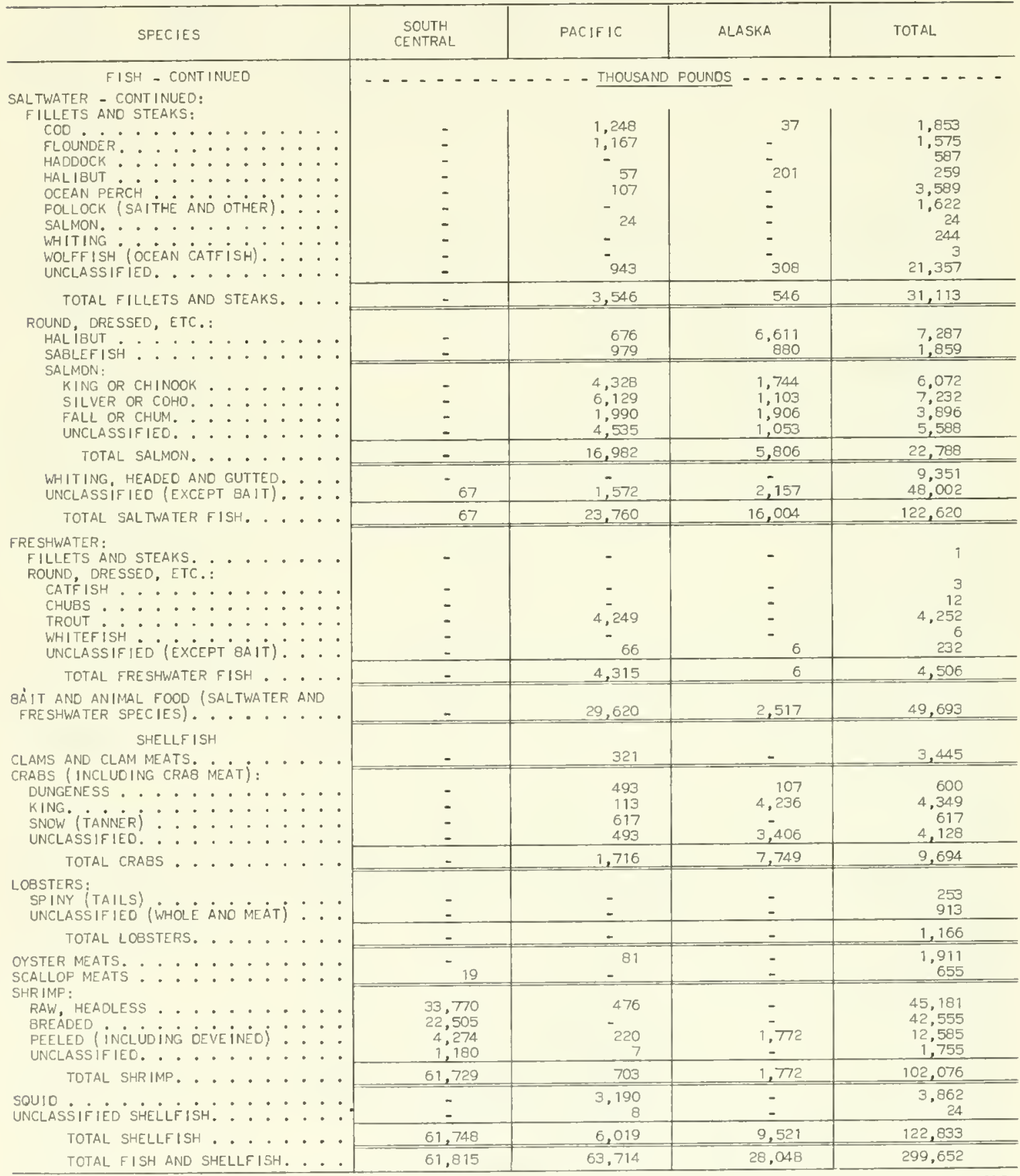

1/ "UNCLASSIFIEO" BLOCKS MAY ALSO INCLUDE BLOCKS ANO SLABS MADE FROM SPECIES LISTED SEPARATELY ANO ALSO MINCEO (GRATEO) FISH BLOCKS. NOTE:---SEE PAGE 7BFDR THE STATES INCLUDED IN THE VARIOUS SECTIONS. 


\section{SUMMARY OF HOLDINGS, BY SECTIONS AND MONTHS, 1975}

\begin{tabular}{|c|c|c|c|c|c|c|c|c|c|c|c|c|}
\hline MONTH & & & & $\begin{array}{c}\text { NEW } \\
\text { ENGLAND }\end{array}$ & $\begin{array}{c}\text { MIDDLE } \\
\text { ATLANT IC }\end{array}$ & $\begin{array}{c}\text { SOUTH } \\
\text { A TLANT IC }\end{array}$ & $\begin{array}{l}\text { NORTH } \\
\text { CENTRAL, } \\
\text { EAST }\end{array}$ & $\begin{array}{l}\text { NORTH } \\
\text { CENTRAL, } \\
\text { WEST }\end{array}$ & $\begin{array}{l}\text { SOUTH } \\
\text { CENTRAL }\end{array}$ & PACIFIC & ALASKA & TOTAL \\
\hline 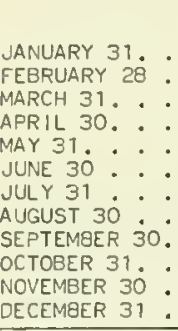 & $\begin{array}{l}\dot{:} \\
\dot{.} \\
\dot{.} \\
\dot{.} \\
\dot{.}\end{array}$ & $\begin{array}{l}\dot{:} \\
\dot{.} \\
\dot{ } \\
\dot{ } \\
\dot{ } \\
\dot{ }\end{array}$ & $\dot{.}$ & $\begin{array}{r}---- \\
131,215 \\
116,995 \\
110,343 \\
101,359 \\
98,508 \\
99,016 \\
100,275 \\
94,264 \\
96,548 \\
108,794 \\
119,123 \\
125,276\end{array}$ & $\begin{array}{r}---- \\
50,314 \\
45,395 \\
39,063 \\
36,946 \\
35,242 \\
33,922 \\
32,131 \\
33,423 \\
31,206 \\
32,338 \\
39,857 \\
41,290\end{array}$ & $\begin{array}{l}42,428 \\
40,044 \\
39,868 \\
34,820 \\
42,219 \\
35,736 \\
35,437 \\
31,584 \\
36,360 \\
40,100 \\
42,821 \\
48,050\end{array}$ & $\begin{array}{l}23,045 \\
17,908 \\
15,852 \\
16,486 \\
15,347 \\
15,277 \\
19,517 \\
21,639 \\
16,914 \\
17,754 \\
18,857 \\
20,280\end{array}$ & $\begin{array}{l}19,160 \\
18,663 \\
14,845 \\
14,031 \\
12,723 \\
13,881 \\
13,615 \\
13,685 \\
13,226 \\
13,910 \\
11,661 \\
11,447\end{array}$ & $\begin{array}{l}25,021 \\
24,355 \\
20,502 \\
16,919 \\
16,101 \\
18,165 \\
18,855 \\
20,823 \\
17,546 \\
19,116 \\
19,895 \\
20,717\end{array}$ & $\begin{array}{l}-\ldots \\
104,607 \\
94,884 \\
86,530 \\
77,905 \\
78,287 \\
73,310 \\
80,990 \\
82,024 \\
91,071 \\
93,961 \\
88,454 \\
84,205\end{array}$ & $\begin{array}{l}--- \\
6,053 \\
8,261 \\
8,487 \\
6,972 \\
6,404 \\
7,088 \\
5,591 \\
8,049 \\
8,138 \\
5,445 \\
6,636 \\
4,943\end{array}$ & $\begin{array}{l}--=- \\
401,843 \\
366,505 \\
335,490 \\
305,438 \\
304,831 \\
296,395 \\
306,411 \\
305,491 \\
311,009 \\
331,418 \\
347,304 \\
356,208\end{array}$ \\
\hline
\end{tabular}

NOTE: --THE STATES INCLUDED IN THE VARIOUS SECTIONS ARE INOICATED ON PAGE 78. HOLDINGS INCLUDE IMPORTEO FROZEN FISH.

\section{SUMMARY OF HOLDINGS OF CURED FISH, BY MONTHS, 1975}

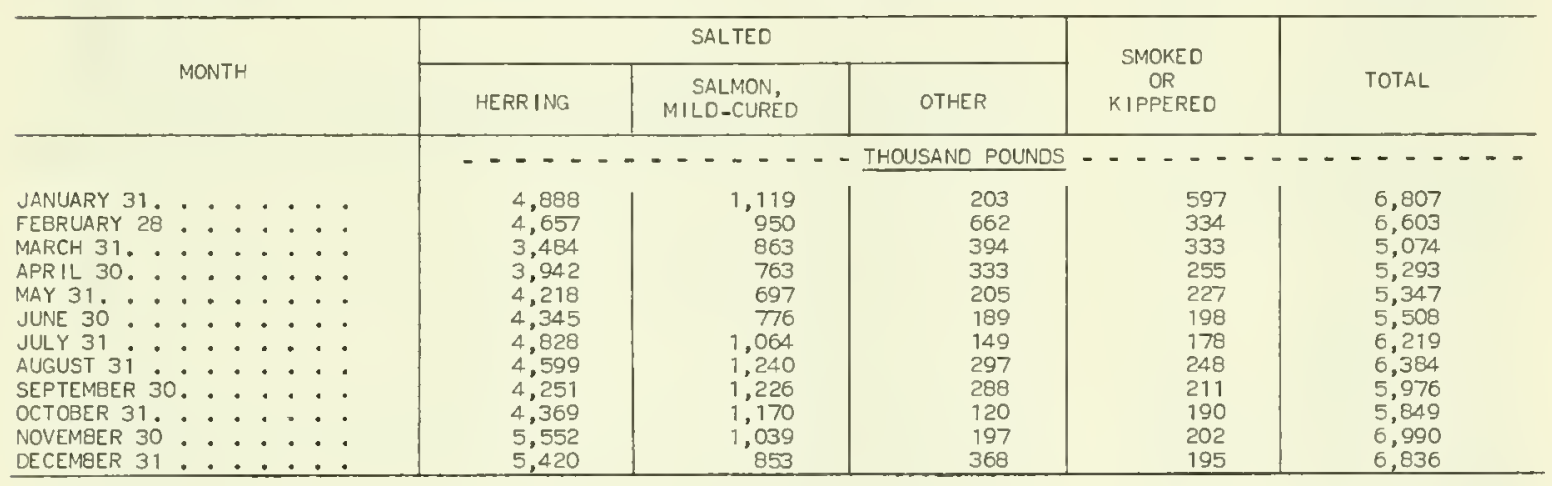




\section{SUMMARY OF HOLDINGS, BY MONTHS, 1975}

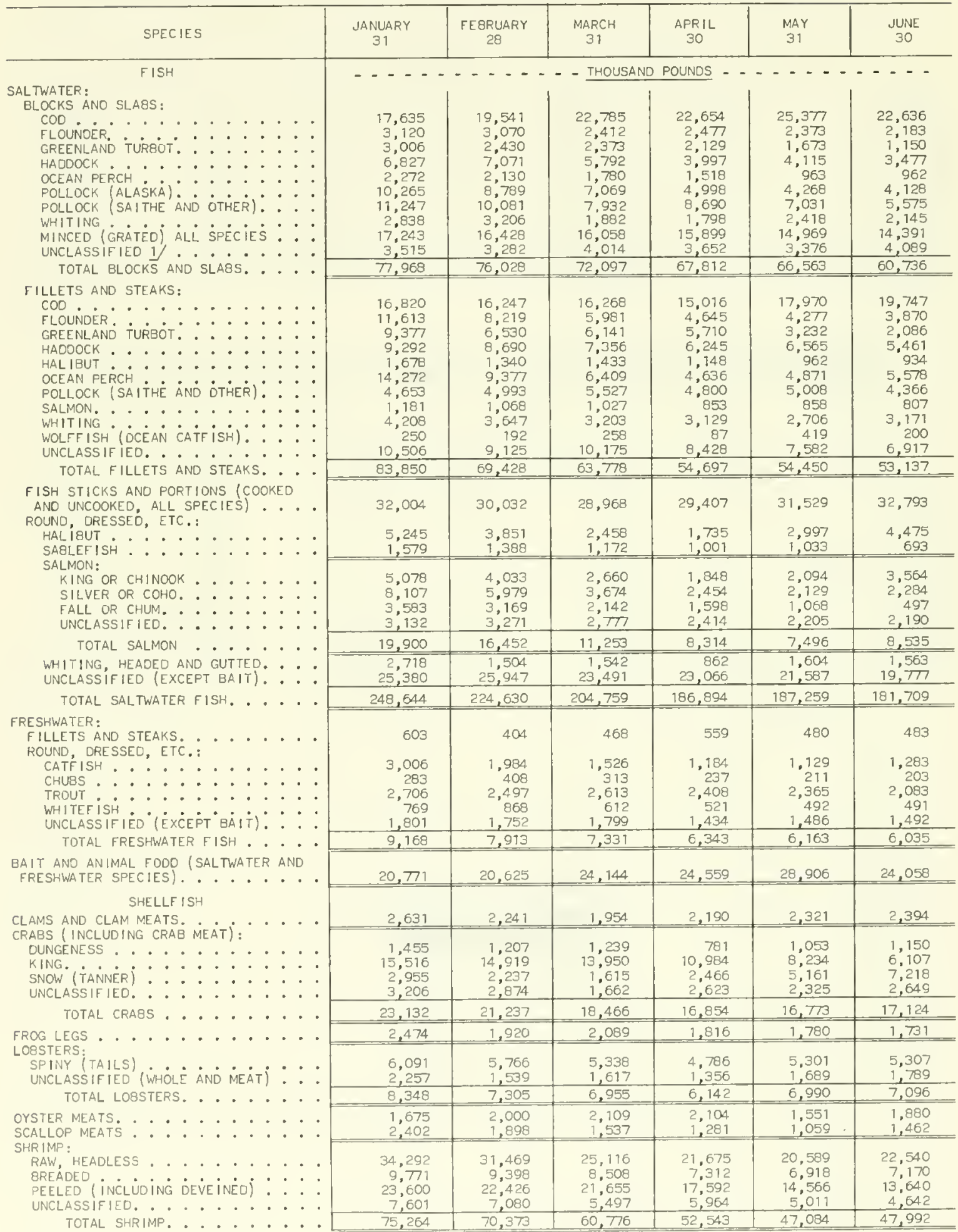




\section{SUMMARY OF HOLDINGS, BY MONTHS, 1975 - Continued}

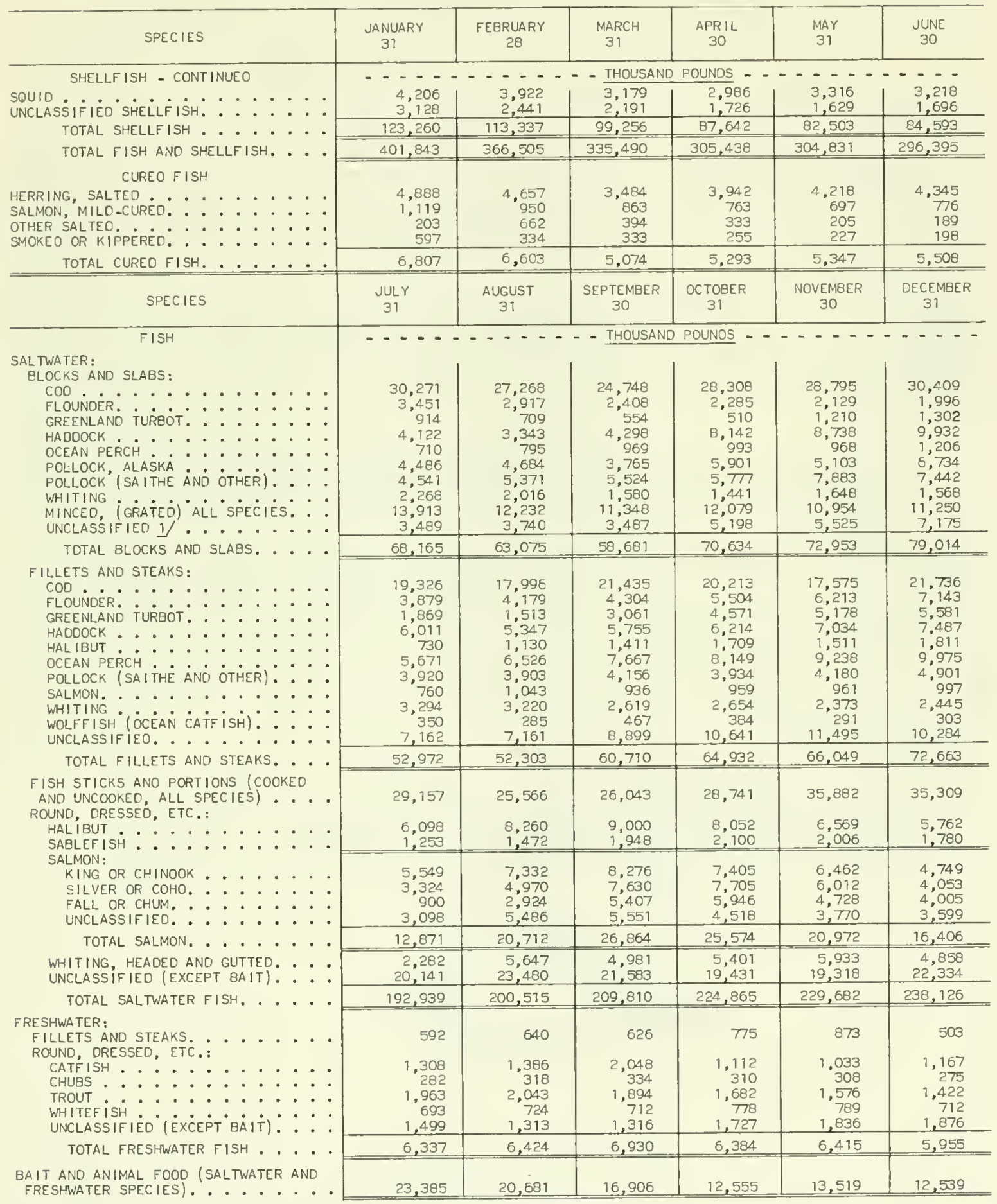

SEE FOOTNOTES AT END DF TABLE.

(CONTINUEO ON NEXT PAGE) 


\section{SUMMARY OF HOLDINGS, BY MONTHS, 1975 - Continued}

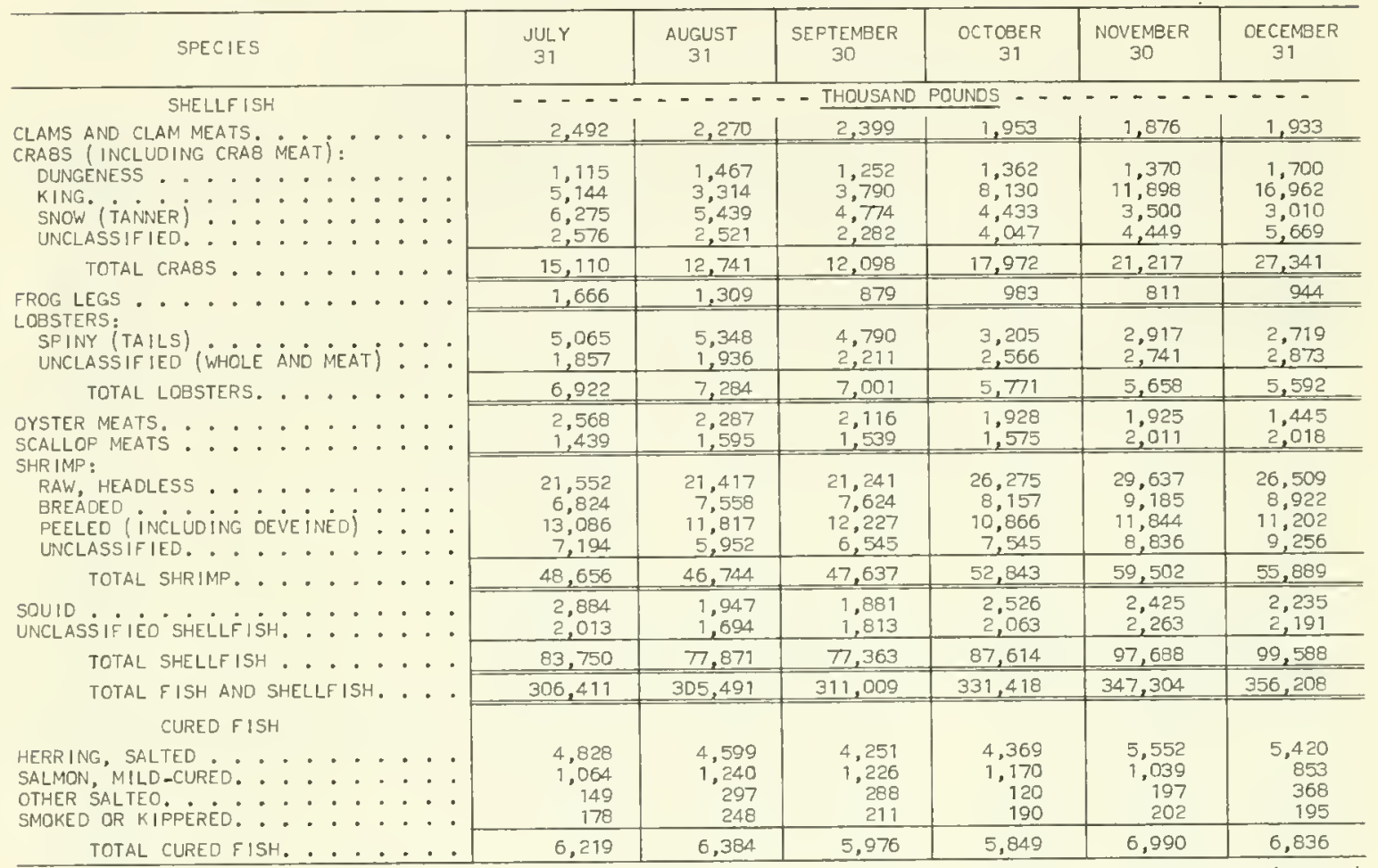

1. "UNCLASSIFIEO" MAY ALSO INCLUDE BLOCKS AND SLABS MAOE FROM SPECIES LISTEO SEPARATELY AND ALSO MINCED (GRATEO) $\bar{F}$ ISH 8LOCKS.

NOTE:-- PRODUCTION OF FISH FROZEN ON U.S. FISHING OR TRANSPORTING CRAFT IS NOT INCLUDED IN THESE TABLES. THERE WERE NO FREEZ INGS DF THE FOLLOWING ITEMS REPORTED TO THE NATIONAL MARINE FISHERIES SERVICE DURING 1975: GREEN-

LAND TURBDT 8LOCKS AND FILLETS, WHITING BLOCKS, AND FROG LEGS.

THE STATES IN EACH SECTION AND THE NUMBER OF PUBL IC ANO PRIVATE FREEZERS AND WAREHOUSES REPORTING TO NMFS

DURING 1975 WERE AS FOLLOWS:

NEW ENGLAND (36) - MAINE, MASSACHUSETTS, RHODE ISLAND, CONNECTICUT, AND NEW HAMPSHIRE,

MIDDLE ATLANTIC (44) - -NÉW YORK, NEW JERSEY, DELAWARE', AND PENNSYLVANIA.

SOUTH ATLANTIC (45) - MMARYAAND, DISTRICT OF' COLUMBIA, VIRGINIA, NORTH CAROLINA, SOUTH CAROLINA, GEORGIA, AND FLORIOA.

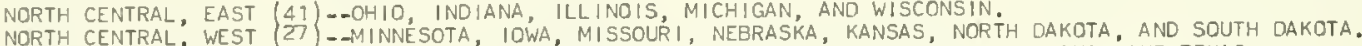

SOUTH CENTRAL (54) - LARKANSAS, OKLAHOMA, TÉNNESSEE, ALABAMA, MISSISSIPPI, LOUISIANA, ANO TEXAS.

PACIFIC (60)-WWASHINGTON, OREGON, CALIFORNIA, ARIZONA, UTAH, COLORADO, MONTANA, IDAHO, AND NEVADA.

ALASKA (13) 


\section{FOREIGN FISHERY TRADE, 1975}

Total U.S. imports (for consumption) of edible and nonedible fishery products were $\$ 1,637.1$ million. A decrease of 4 percent compared with record imports of $\$ 1,710.9$ million in 1974. Exports of domestic fishery products were a record $\$ 304.7$ million in 1975 , an increase of 16 percent over 1974 .

Imports of edible products were $1,913.1$ million pounds valued at $\$ 1,367.2$, down 353.8 million pounds (16 percent) and $\$ 128.2$ million (9 percent) compared with 1974. Decreased receipts of fresh and frozen tuna contributed to much of the loss in the 1974 imports. Imports of fresh and frozen tuna (including loins and discs) were 478.6 million pounds, down 310.8 million pounds ( 39 percent) compared with the 1974 imports of 789.4 million pounds. There were also decreases in total imports of all types of shrimp (10 percent), canned salmon (62 percent), and canned sardines ( 55 percent). Imports of canned tuna dropped slightly ( 2 percent). Imports of fresh and frozen fillets increased to 367.9 million pounds, up 17 percent compared with 1974 , and were the third largest on record. Imports of regular and minced blocks were 313.5 million pounds in 1975, up 18 percent over 1974 , and also were the third largest on record.

Exports of domestic edible fishery products were 218.2 million pounds valued at a record $\$ 267.4$ million-up 23 percent in quantity and 37 percent in value compared with 1974 . Most of this increase was due to increased exports of salmon products. Exports of fresh and frozen salmon were 48.2 million pounds valued at $\$ 66.9$ million, an increase of 72 percent in quantity and 91 percent in value compared with 1974. Exports of canned salmon were 22.5 million pounds valued at $\$ 34.6$ million in 1975 , up 170 percent in quantity and 161 percent in value. These increased exports reflected declines in the 1975 catch of salmon by other salmon exporting countries.

Exports of domestic nonedible products were $\$ 37.4$ million, a decrease of 44 percent compared with 1974. A sharp drop in exports of fish oil was responsible for much of the decline in total exports. A primary factor in this decline was the greater availability of fish oil from competing exporting countries.

Exports of foreign fishery products increased in 1975. Edible products were $\$ 32.3$ million compared with $\$ 21.9$ million in 1974 , and nonedible products were $\$ 467,000$ compared with $\$ 313,000$. Increases occurred in exports of fresh and frozen cod, salmon, and shrimp, and canned salmon and sardines. No. 6905 .

Data on foreign fishery trade for 1974-75 have been published previously in Current Fishery Statistics

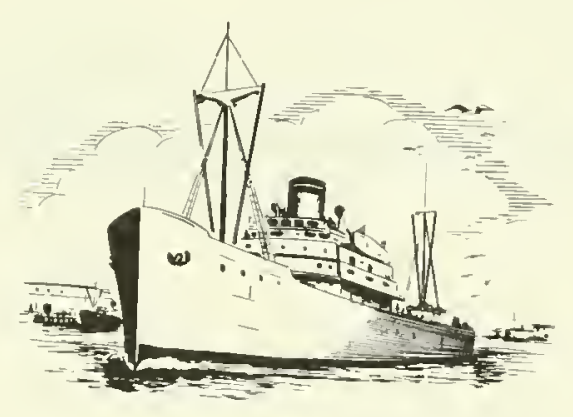


EXPORTS OF DOMESTIC FISHERY PRODUCTS, $1974-75$

\begin{tabular}{|c|c|c|c|c|c|}
\hline \multirow[b]{2}{*}{ EDI8LE FISHERY PRODUCTS: } & & \multicolumn{2}{|c|}{1974} & \multicolumn{2}{|c|}{1975} \\
\hline & Unit & Quantity & $\frac{\text { Thousand }}{\text { dollars }}$ & Quantity & $\frac{\text { Thousand }}{\text { dollars }}$ \\
\hline $\begin{array}{l}\text { Fresh or frozen: } \\
\text { Fish: }\end{array}$ & & & & & \\
\hline 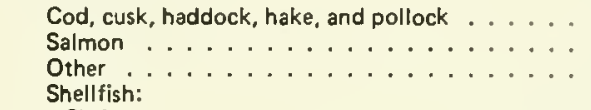 & $\begin{array}{l}1,000 \text { pounds } \\
\text { do } \\
\text { do }\end{array}$ & $\begin{array}{r}1,314 \\
28,067 \\
50,486\end{array}$ & $\begin{array}{r}814 \\
34,924 \\
19,776\end{array}$ & $\begin{array}{r}2,339 \\
48,229 \\
67,624\end{array}$ & $\begin{array}{r}1,347 \\
66,863 \\
24,048\end{array}$ \\
\hline $\begin{array}{l}\text { Shrimp } \ldots \ldots \ldots \ldots \ldots \\
\text { Other } \ldots \ldots \ldots \ldots \ldots \ldots\end{array}$ & $\begin{array}{l}\text { do } \\
\text { do }\end{array}$ & $\begin{array}{l}27,728 \\
21,730\end{array}$ & $\begin{array}{l}47.340 \\
25.447\end{array}$ & $\begin{array}{l}28,078 \\
22,239\end{array}$ & $\begin{array}{l}54,081 \\
27,433\end{array}$ \\
\hline Total fresh and frozen $\ldots \ldots \ldots \ldots$ & do & 129,325 & 128,301 & 158,509 & 173,772 \\
\hline 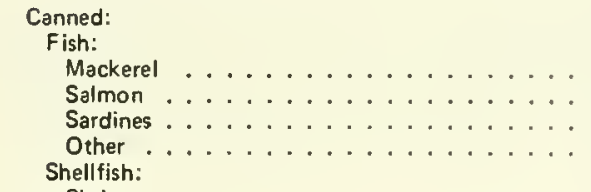 & $\begin{array}{l}\text { do } \\
\text { do } \\
\text { do } \\
\text { do }\end{array}$ & $\begin{array}{r}353 \\
8,320 \\
1,691 \\
10,292\end{array}$ & $\begin{array}{r}76 \\
13,258 \\
1,146 \\
15,553\end{array}$ & $\begin{array}{r}660 \\
22,504 \\
2,161 \\
6,547\end{array}$ & $\begin{array}{r}120 \\
34,552 \\
1,774 \\
7,865\end{array}$ \\
\hline $\begin{array}{l}\text { Shrimp } \ldots \ldots \ldots \ldots \ldots \\
\text { Squid } \ldots \ldots \ldots \ldots \ldots \ldots \ldots \ldots \ldots \ldots \ldots \ldots\end{array}$ & $\begin{array}{l}\text { do } \\
\text { do } \\
\text { do }\end{array}$ & $\begin{array}{l}6,885 \\
8,221 \\
4,594\end{array}$ & $\begin{array}{r}11.830 \\
1,712 \\
4,573\end{array}$ & $\begin{array}{l}6.223 \\
6.759 \\
4.756\end{array}$ & $\begin{array}{r}10,263 \\
1,866 \\
6,726\end{array}$ \\
\hline Total canned $\ldots \ldots \ldots \ldots \ldots$ & do & 40,356 & 48,148 & 49,510 & 63,166 \\
\hline $\begin{array}{l}\text { Cured, pickled, or salted: } \\
\text { Unclassified fish } \ldots \ldots \ldots \ldots \ldots \ldots \ldots \\
\text { Unclassified shellfish } \ldots \ldots \ldots \ldots \ldots\end{array}$ & $\begin{array}{l}\text { do } \\
\text { do }\end{array}$ & $\begin{array}{r}8,178 \\
152\end{array}$ & $\begin{array}{r}18,252 \\
265\end{array}$ & $\begin{array}{r}10,009 \\
124\end{array}$ & $\begin{array}{r}30.153 \\
269\end{array}$ \\
\hline Total cured $\ldots \ldots \ldots \ldots \ldots$ & do & 8,330 & 18,517 & 10,133 & 30,422 \\
\hline Total edible fishery products $\ldots \ldots \ldots$ & do & 178,011 & 194,966 & 218,152 & 267,360 \\
\hline 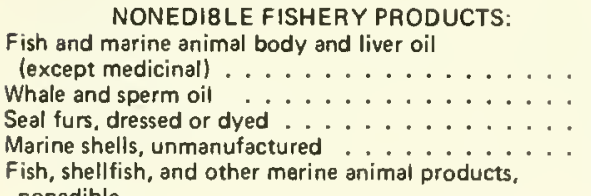 & $\begin{array}{l}\text { do } \\
\text { do } \\
1.000 \text { pieces } \\
1.000 \text { pounds }\end{array}$ & $\begin{array}{r}199,122 \\
3,042 \\
81 \\
5,577\end{array}$ & $\begin{array}{r}39,595 \\
645 \\
5,736 \\
1,573\end{array}$ & $\begin{array}{r}191,843 \\
1,316 \\
47 \\
7,580\end{array}$ & $\begin{array}{r}27,849 \\
288 \\
2,919 \\
1,917\end{array}$ \\
\hline 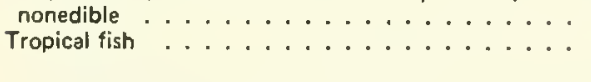 & $\overline{-}$ & - & $\begin{array}{r}18,235 \\
1,382\end{array}$ & $\overline{-}$ & $\begin{array}{l}3,152 \\
1,244 \\
\end{array}$ \\
\hline Total nonedible fishery products $\ldots \ldots \ldots$ & - & - & 67,166 & - & 37,369 \\
\hline Grand total . . . . . . . . . . & - & - & 262,132 & - & 304,729 \\
\hline
\end{tabular}

Note:--In addition to the export figures that are shown, there are quantities of fish oils and concentrates that are exported for medicinal purposes, and other miscellaneous fishery products that cannot be shown because the axport classification covering these products includes other than fishery products. 


\section{EXPORTS OF FOREIGN FISHERY PRODUCTS, 1974.75}

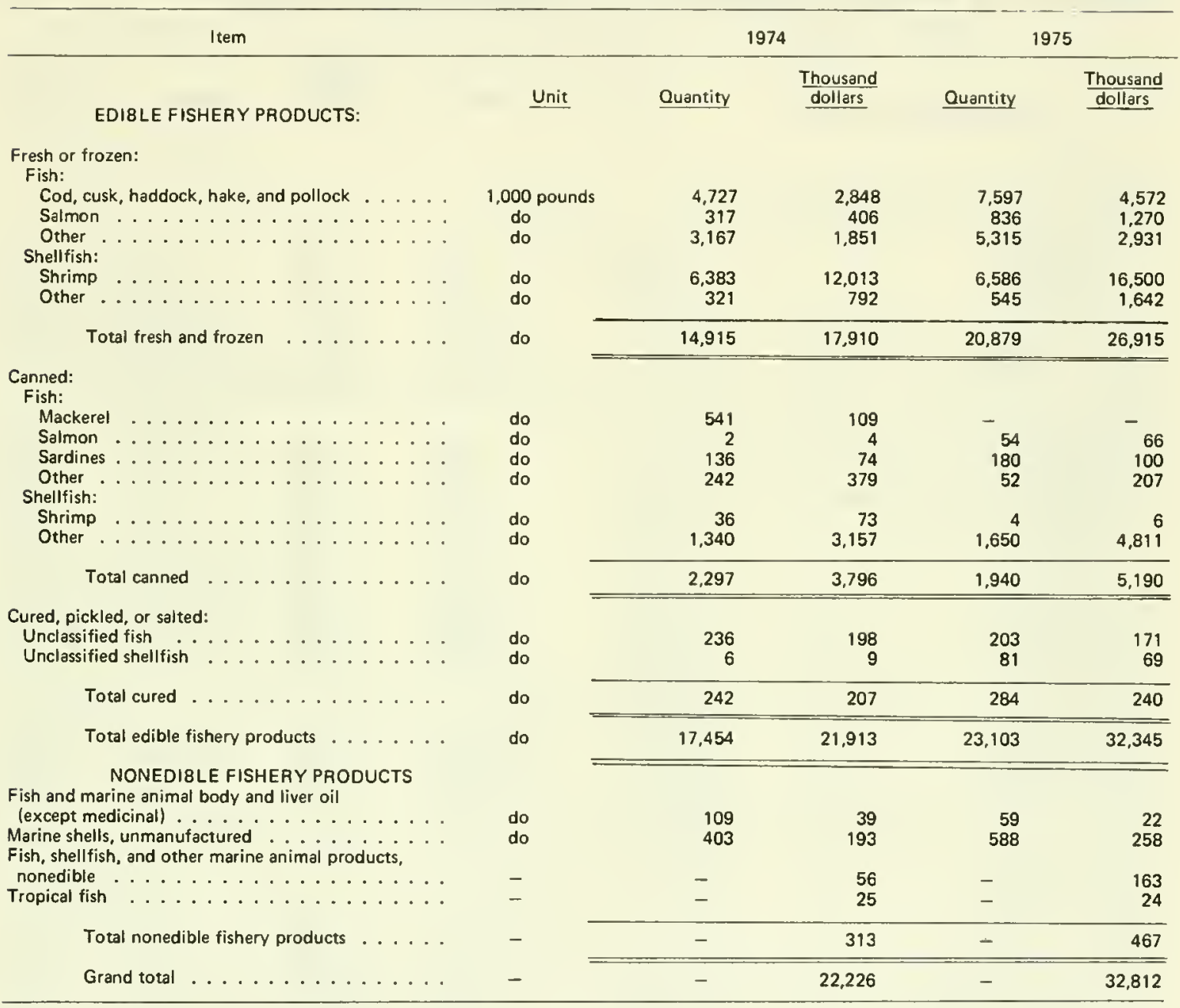




\section{IMPORTS OF FISHERY PRODUCTS ENTERED FOR CONSUMPTION, 1974-75}

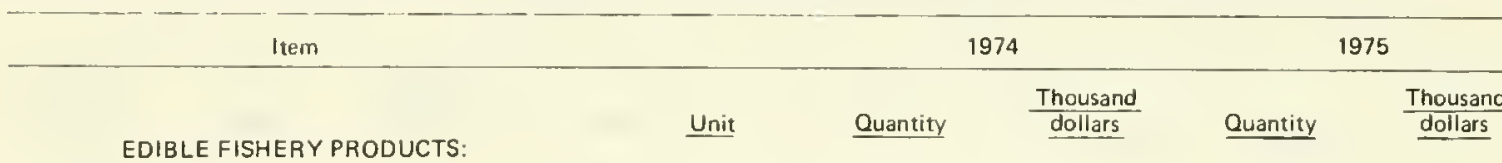

Fresh or frozen:

Fish:

Whether or not whole (except fillets, steaks, and similar products):

Freshwater:

Lake trout

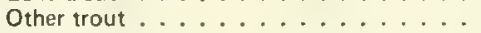

Whitefish .............

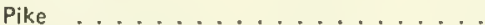

Unclassified ..............

Total freshwater fish

1,000 pounds
do
do
do
do

\begin{tabular}{rrrr}
295 & 280 & 415 & 319 \\
1,663 & 1,606 & 1,204 & 850 \\
7,249 & 4,671 & 8,419 & 5,637 \\
4,181 & 3,063 & 6,667 & 5,521 \\
11,940 & 3,882 & 11,934 & 5,194 \\
& & & \\
\hline 25,328 & 13,502 & 28,639 & 17,521 \\
\hline
\end{tabular}

Saltwater:

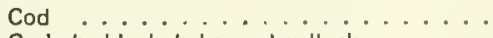

Cusk, haddock, hake, and pollock .....

Eels, shad, and sturgeon .........

Flounders or flatfish (except halibut) ....

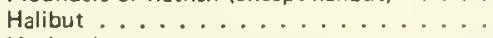

Mackerel:

Fresh ...............

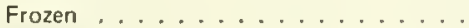

Ocean perch (Atlantic) . . . . . . . .

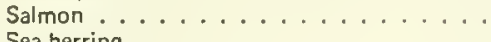

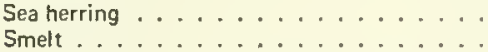

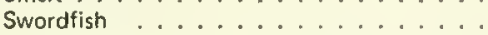

Tuna (whole and other than whole): (3)

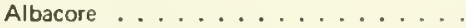

Skipjack ...............

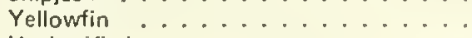

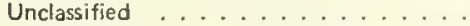

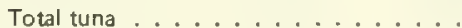

do

do

do

do

(n)

do

do

do

do

do

do

una loins and discs:

Albacore ................

Unclassified .............

Total loins and discs ......... do

Unclassified

Total saltwater fish

do

do

do

do

do

3,166

8,851

582

3,043

5,357

829

3,484
467

2,208

2,208
5,168

5,088

$5,088 \quad 974$

, 399

3,770

1,362

12,483

(1) 86,863

8,755
22

169

809

620

14,031

(1) 4,672

2,805
8

1,309

5,642

3.049

1,225

4,656

8,036

7,956

489

3,415

451

9,250

765

11,469

(2) 99,189

8,775
21

(2) 5,118

3,240

\begin{tabular}{rrrr}
\hline & & & \\
\hline 254,965 & 105,728 & 131,892 & 45,743 \\
378,053 & 81,992 & 190,023 & 35,203 \\
134,914 & 20,795 & 127,191 & 31,861 \\
16,843 & 2,308 & 27,218 & 6,649 \\
\hline 784,775 & 210,823 & 476,324 & 119,456 \\
\hline
\end{tabular}

do

do
do

\begin{tabular}{rrrr}
3,856 & 4,506 & 850 & 715 \\
811 & 739 & 1,460 & 1,065 \\
\hline 4,667 & 5,245 & 2,310 & 1,780 \\
\hline 48,026 & 13,929 & 48,185 & 15,929 \\
\hline 973,121 & 265,267 & 677,431 & 176,403 \\
\hline
\end{tabular}

Blocks, regular and minced:

Cod Flatfish, Greenland turbot .......... . . .

Flatfish, other

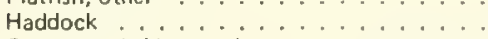

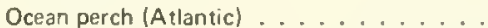

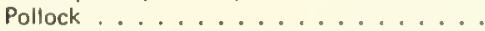

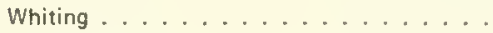

Other regular blocks

Minced blocks

Total, regular and minced blocks

\begin{tabular}{ccrr}
113,162 & 69,714 & 160,857 & 83,963 \\
- & - & 2,776 & 1,214 \\
21,052 & 13,953 & 10,025 & 6,837 \\
80,052 & 32,040 & 36,649 & 19,730 \\
- & - & 7,553 & 3,331 \\
21,083 & 11,857 & 74,831 & 20,908 \\
- & - & 8,727 & 2,696 \\
30,724 & 13,644 & 2,173 & 1,008 \\
- & - & 9,888 & 2,070 \\
\hline 266,073 & 141,208 & 313,479 & 141,757 \\
\hline
\end{tabular}

Fillets and steaks:

Groundfish and ocean perch:

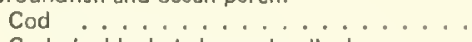

Cusk, haddock, hake, and pollock .....

Ocean perch (Atlantic) .........

Total groundfish and ocean perch

do
do
do

\begin{tabular}{rrrr}
71,553 & 56,945 & 91,017 & 70,770 \\
34,132 & 24,217 & 41,747 & 28,150 \\
59,666 & 28,109 & 67,592 & 37,723 \\
\hline 165,351 & 109,271 & 200,356 & 136,643 \\
\hline
\end{tabular}


IMPORTS OF FISHERY PRODUCTS ENTERED

FOR CONSUMPTION, 1974-75 - Continued

\begin{tabular}{|c|c|c|c|c|c|}
\hline Item & & \multicolumn{2}{|c|}{1974} & \multicolumn{2}{|c|}{1975} \\
\hline EDIBLE FISHERY PRODUCTS: - Continued & $\underline{\text { Unit }}$ & Quantity & $\frac{\text { Thousand }}{\text { dollars }}$ & Quantity & $\frac{\text { Thousand }}{\text { dollars }}$ \\
\hline 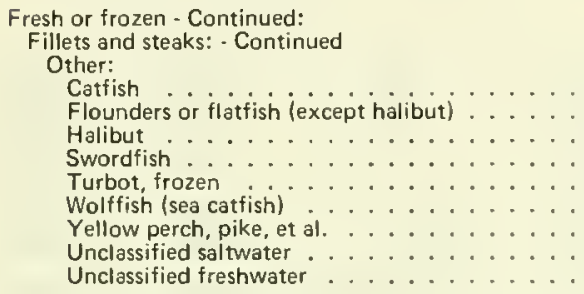 & $\begin{array}{l}1,000 \text { pounds } \\
\text { do } \\
\text { do } \\
\text { do } \\
\text { do } \\
\text { do } \\
\text { do } \\
\text { do } \\
\text { do }\end{array}$ & $\begin{array}{r}8,443 \\
77,531 \\
3,635 \\
66 \\
-\quad \\
6,753 \\
9,649 \\
41,817 \\
2,030\end{array}$ & $\begin{array}{r}3,499 \\
50,293 \\
3,326 \\
29 \\
-\quad \\
4,502 \\
12,300 \\
25,329 \\
1,503\end{array}$ & $\begin{array}{r}10,906 \\
45,953 \\
4,565 \\
5 \\
52,391 \\
7,633 \\
9,045 \\
34,395 \\
2,699\end{array}$ & $\begin{array}{r}4,883 \\
36,568 \\
5,870 \\
5 \\
24,857 \\
5,381 \\
14,234 \\
23,541 \\
1,959\end{array}$ \\
\hline Total, other than groundfish . . . . . . . & do & 149,924 & 100,781 & 167,592 & 117,298 \\
\hline Total fillets and steaks ........... & do & 315.275 & 210,052 & 367.948 & 253,941 \\
\hline Fish sticks and similar products . . . . . . . & do & 1,463 & 1,226 & 413 & 234 \\
\hline Total fish, fresh and frozen $\ldots \ldots$ & do & $1,581,260$ & 631,255 & $1,387,910$ & 589,856 \\
\hline $\begin{array}{l}\text { Shellfish, et al.: } \\
\text { Crabs: } \\
\text { Fresh or frozen (including prepared or } \\
\text { preserved, except canned) } \ldots \ldots \ldots \\
\text { Crab meat (fresh cooked) } \ldots \ldots \ldots \ldots\end{array}$ & $\begin{array}{l}\text { do } \\
\text { do }\end{array}$ & $\begin{array}{l}1,244 \\
2,635\end{array}$ & $\begin{array}{l}1,222 \\
5,275\end{array}$ & $\begin{array}{r}1,374 \\
2,989\end{array}$ & $\begin{array}{r}979 \\
4,294\end{array}$ \\
\hline 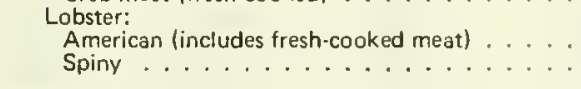 & $\begin{array}{l}\text { do } \\
\text { do }\end{array}$ & $\begin{array}{l}14,991 \\
40,329\end{array}$ & $\begin{array}{r}28,086 \\
150,107\end{array}$ & $\begin{array}{l}15,741 \\
42,329\end{array}$ & $\begin{array}{r}31,460 \\
157,104\end{array}$ \\
\hline $\begin{array}{l}\text { Shrimp: } \\
\text { Breaded . } \\
\text { Peeled, cooked but not breaded } \ldots \ldots \\
\text { Peeled raw } \ldots \ldots \ldots \\
\text { Shell-on } \ldots \ldots \ldots\end{array}$ & $\begin{array}{l}\text { do } \\
\text { do } \\
\text { do } \\
\text { do }\end{array}$ & $\begin{array}{r}953 \\
6,702 \\
83,187 \\
131,962\end{array}$ & $\begin{array}{r}1,466 \\
8,184 \\
129,905 \\
240,211\end{array}$ & $\begin{array}{r}1,190 \\
5,242 \\
76,660 \\
117,247\end{array}$ & $\begin{array}{r}2,053 \\
6,712 \\
113,693 \\
222,094\end{array}$ \\
\hline Total shrimp $\ldots \ldots \ldots \ldots \ldots$ & do & 222,804 & 379,766 & 200,339 & 344,552 \\
\hline $\begin{array}{l}\text { Clams (in shell or shucked) } \\
\text { Frog legs (includes fresh-cooked meat) } \ldots \ldots \\
\text { Oysters: }\end{array}$ & $\begin{array}{l}\text { do } \\
\text { do }\end{array}$ & $\begin{array}{l}1,602 \\
6,021\end{array}$ & $\begin{array}{l}1,188 \\
9,348\end{array}$ & $\begin{array}{l}1,436 \\
3,311\end{array}$ & $\begin{array}{r}919 \\
4,056\end{array}$ \\
\hline $\begin{array}{l}\text { Except seed oysters } \ldots \ldots \ldots \\
\text { Seed oysters } \ldots \ldots \ldots\end{array}$ & $\begin{array}{l}\text { do } \\
\text { do } \\
\text { do } \\
\text { do }\end{array}$ & $\begin{array}{r}2,663 \\
815 \\
18,100 \\
7\end{array}$ & $\begin{array}{r}2.287 \\
625 \\
28,106 \\
8\end{array}$ & $\begin{array}{r}3,399 \\
525 \\
19,737 \\
4\end{array}$ & $\begin{array}{r}2,473 \\
293 \\
37,183 \\
8\end{array}$ \\
\hline $\begin{array}{l}\text { Total shellfish, et al., fresh and frozen } \\
\text { Total fresh and frozen fish, shellfish, et al. }\end{array}$ & $\begin{array}{l}\text { do } \\
\text { do }\end{array}$ & $\begin{array}{r}311,211 \\
1,892,471\end{array}$ & $\begin{array}{r}606,018 \\
1,237,273\end{array}$ & $\begin{array}{r}291,184 \\
1,679,094\end{array}$ & $\begin{array}{r}583,321 \\
1,173,177\end{array}$ \\
\hline
\end{tabular}

Canned:

Fish:

Anchovies:

In oil .................. do

Not in oil ............. do

Herring:

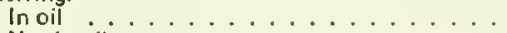

Not in oil ................. do

Salmon:

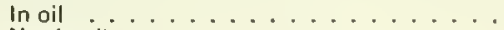

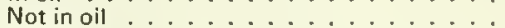

Sardines:

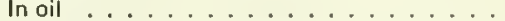

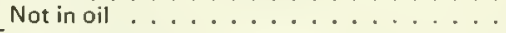

Tuna:

In oil, albacore ............. do

In brine:

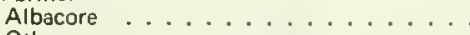

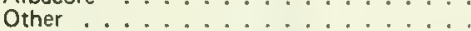

Total in brine ............ do

Bonito and yellowtail:

In oil ................. do d.... d

In brine .............. do

Total bonito and yellowtail ....... do

\begin{tabular}{rrrr}
4,804 & 8,181 & 3,594 & 5,616 \\
1,092 & 542 & 1,294 & 655 \\
179 & 137 & 163 & 129 \\
15,982 & 8,874 & 12,259 & 7,286 \\
7 & 29 & 27 & 45 \\
8,546 & 11,835 & 3,238 & 3,856 \\
29,408 & 22,028 & 18,513 & 16,267 \\
39,729 & 14,858 & 12,593 & 8,640 \\
233 & 343 & 199 & 277 \\
\hline 26,570 & 28,040 & 30,423 & 28,570 \\
25,943 & 22,725 & 21,049 & 17,354 \\
\hline 52,513 & 50,765 & 51,472 & 45,924 \\
\hline
\end{tabular}

\begin{tabular}{rrrr}
282 & 212 & 68 & 95 \\
59 & 34 & 43 & 31 \\
\hline 341 & 246 & 111 & 126 \\
\hline
\end{tabular}

(Continued on next page) 


\section{IMPORTS OF FISHERY PRODUCTS ENTERED FOR CONSUMPTION, $1974-75$ - Continued}

\begin{tabular}{|c|c|c|c|c|c|}
\hline Item & & \multicolumn{2}{|c|}{1974} & & \\
\hline & Unit & Quantity & dollars & Quantity & $\begin{array}{l}\text { Thousano } \\
\text { dollars }\end{array}$ \\
\hline
\end{tabular}

EDIBLE FISHERY PRODUCTS: - Continued

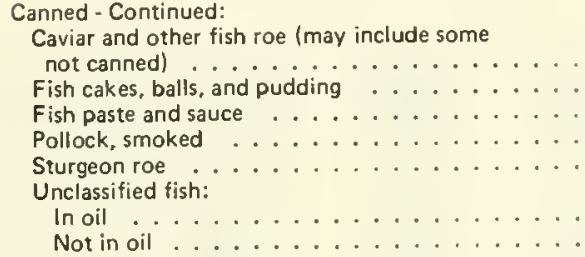

Total canned fish

1,000 pounds
do
do
do
do
do
do

do

Shellfish, et al.:

Abalone (may include fresh or dried, and canned

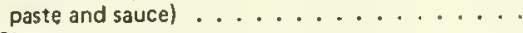

Clams:

Chowder, juice, et al. . . . . . . . . .

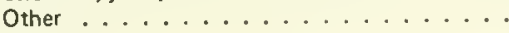

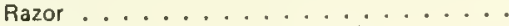

Crab meat (includes paste and sauce) ......

Lobster meat:

American (includes fresh-cooked meat) .....

Spiny ..................

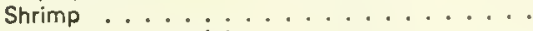

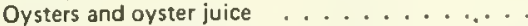

Unclassified (includes shellfish paste and sauce)

Total canned shellfish . . . . . . . .

Total canned fish, shellfish, et al. . . . . . .

Cured:

Dried (unsalted):

Cod, cusk, haddock, hake, and pollock ......

Shark fins .................

Unclassified ..............

Total dried (unsalted) .......... do

Pickled or salted:

Alewives .................. do

Cod, cusk, haddock, hake, and pollock:

Skinned or boned . . . . . . . . . . . .

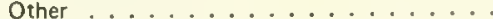

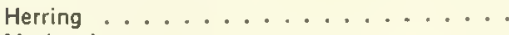

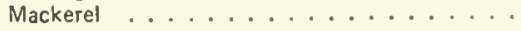

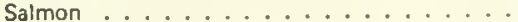

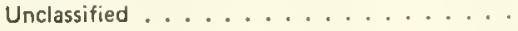

Total pickled or salted

Smoked or kippered:

Cod, cusk, haddock, hake, and pollock:

Fillets, steaks, et al. . . . . . . . . . . .

Whole, beheaded, or eviscerated, or both

Herring:

Whole or beheaded:

Hard dry smoked

Boned and not boned (eviscerated split)

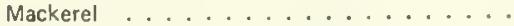

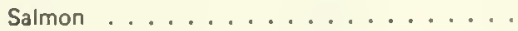

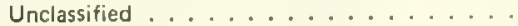

Total smoked or kippered

Total cured . . . . .

Other fish and shellfish, not specially provided for

Total edible fishery products

do

do

do

do

do

do

do

do

do

do

do

do

do

do

do

do

do

do

do

do

do

do

do

do

\begin{tabular}{rrrr}
279 & 287 & 200 & 176 \\
1,125 & 700 & 654 & 489 \\
1,556 & 669 & 2,393 & 825 \\
35 & 46 & 13 & 18 \\
1,262 & 2,613 & 720 & 2,785 \\
2,130 & 1,817 & 1,904 & 1,389 \\
61,845 & 19,526 & 17,660 & 4,065 \\
\hline 221,066 & 143,496 & 127,007 & 98,568 \\
\hline
\end{tabular}

3,676

9,349

4,623

12,092

4589

4,589
5
2,371

4,605

2,371

7
5,234

10
1997

4

4,589
5
2,371

1,593

95
6,107

16,010

8,292

16,764

335

7,570

10,130

1,440

2,087

2,933

51,210

61,876

1,992

10,520

112

1,118

12,363

16,207

1687

8,405

15,735

\begin{tabular}{rrrr}
\hline 51,210 & 61,876 & 39,862 & 53,890 \\
\hline 272,276 & 205,372 & 166,869 & 152,458 \\
\hline
\end{tabular}

\begin{tabular}{rrrr}
282 & 419 & 380 & 690 \\
181 & 473 & 100 & 283 \\
438 & 756 & 454 & 913 \\
\hline 901 & 1,648 & 934 & 1,886 \\
\hline
\end{tabular}

264

89

29

10

10,210

27,560

18.572

1,046

111

826

9,206

20,574

6,008

289

201

896

\begin{tabular}{rr}
10,427 & 9,485 \\
23.191 & 17,293 \\
20.596 & 6,610 \\
1.123 & 341 \\
115 & 184 \\
689 & 747 \\
\hline 56.170 & 34,670 \\
\hline
\end{tabular}

58,589

37.263

56.170

4,670

\begin{tabular}{rrrr}
702 & 473 & 998 & 662 \\
158 & 150 & 62 & 54 \\
& & & \\
45 & 25 & 127 & 60 \\
1,015 & 446 & 821 & 372 \\
1,028 & 660 & 903 & 557 \\
44 & 32 & 6 & 4 \\
76 & 234 & 82 & 286 \\
265 & 171 & 204 & 154 \\
\hline 3,333 & 2,191 & 3,203 & 2,149 \\
\hline 62,823 & 41,102 & 60,307 & 38,705 \\
\hline 39,310 & 11,633 & 6,819 & 2,840 \\
\hline \hline $2,266,880$ & $1,495,380$ & $1,913,089$ & $1,367,180$ \\
\hline \hline
\end{tabular}

(Continued on next page)" 


\section{IMPORTS OF FISHERY PRODUCTS ENTERED FOR CONSUMPTION, $1974-75 \cdot$ Continued}

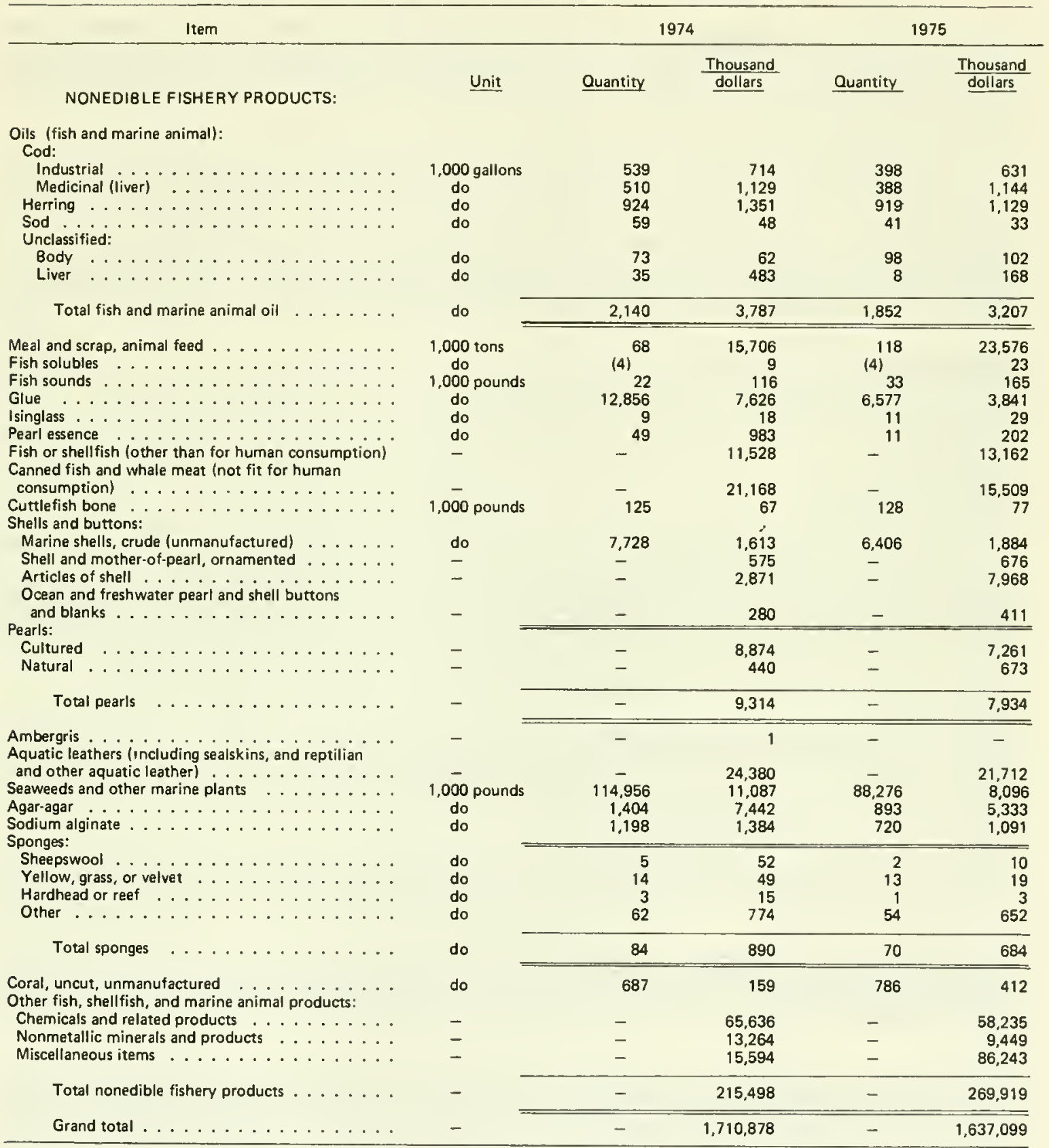

(1) Includes Customs Service data on imports of fresh sea herring into Maine that amounted to 76,979,575 pounds. Bureau of Census data, which did not include most entries valued at less than $\$ 250$, amounted to $70,849,451$ pounds valued at $\$ 4,049,384$. (2) Includes Customs Service data on imports of fresh sea herring into Maine that amounted to 87,238,540 pounds. Bureau of Census data, which did not include most entries valued at less than $\$ 250$, amounted to $83,268,733$ pounds valued at $\$ 4,663,938$. (3) Includes landings of foreign-caught tuna in American Samoa. Such landings are not included in the Bureau of the Census data because of the territorial situation of the possession. (4) Less than 1,000 units or $\$ 1,000$. 
In 1975, commercial fishermen of the New England States (Maine, New Hampshire, Massachusetts, Rhode lsland, and Connecticut) landed 498.4 million pounds of fish and shellfish worth a record $\$ 154.1 \mathrm{million}$. This was a decline of 24.1 million pounds (5 percent), but an increase of $\$ 29.8$ million ( 24 percent) compared with 1974. Landings of yellowtail flounder, ocean perch, menhaden, shrimp, and species used for bait or reduction were significantly less. Species with important increases in landings were alewives, haddock, sea herring, whiting, American lobsters, and sea scallops.

Compared with 1974, landings in New Hampshire and Massachusetts increased slightly, but landings in the other States declined. Massachusetts led all States in volume with 273.8 million pounds (55 percent); followed by Maine, 138.4 million pounds (28 percent); and Rhode lsland, 79.5 million pounds ( 16 percent). Connecticut with 3.7 million pounds and New Hampshire with 3.1 million pounds accounted for 1 percent. The value of landings increased in all States except Connecticut. Massachusetts led in value with $\$ 82.9$ million (54 percent), Maine was second with $\$ 48.5$ million (31 percent), followed by Rhode Island, $\$ 18.9 \mathrm{million}$ (12 percent). New Hampshire with $\$ 1.3$ million and Connecticut with $\$ 2.6$ million accounted for the rest.

Fishermen and vessels. The New England fisheries had 31,685 full-time and part-time fishermen using 770 vessels (5 net tons or more), 15,499 motorboats, and 269 other craft. This was an increase of 2,274 fishermen, 37 vessels, 1,087 motorboats, and 78 other boats over 1974 .

Processed products. The value of processed seafood items was a record $\$ 391.7$ million- $\$ 32.2$ million more than in 1974 and $\$ 20.9$ million more than the record value in 1973 . Massachusetts led with products valued at $\$ 263.3$ million, followed by Maine with $\$ 91.1$; New Hampshire, $\$ 32.7$; Rhode Island, $\$ 3.9$ million, and Connecticut, $\$ 700,000$.

New England Fisheries Development Program. This NMFS program was implemented late in 1973 to use fish and shellfish that were marketed infrequently or discarded at sea by fishermen. It is felt that use of these fish would be substantially profitable and at the same time would enable heavily fished species to be conserved. Use of squid, red crab, ocean quahog, sea mussels, and sand dabs among others has been studied, and plans have been made for marketing them. Squid may prove to be the most feasible of this group, because it is very abundant both on the inshore grounds and offshore grounds during certain seasons. Foreign fleets have caught large quantities of squid in the deeper waters off southern New England and the Middle Atlantic.

International Commission for the Northwest Atlantic Fisheries (ICNAF). The 25th Annual Meeting of ICNAF was held in Edinburgh, Scotland, in June 1975; 175 members attended from all 17 member countries. The main purpose of the meeting was to establish national quotas for 1976 for the major fish stocks in the Northwest Atlantic and to consider improvements to existing regulations relating to the management of fish stocks in the joint enforcement scheme.

Final regulations for 1975 covering fishing on the high seas in the Northwest Atlantic Ocean north of Cape Hatteras became effective in May 1975. The regulations contained provisions for quotas, licensing of fishing vessels, record keeping (logs), and size limitations on certain species of fish.

Catch and effort data as well as length and age frequency samples for major species were collected from the commercial fishing fleet for research programs in the lCNAF areas. Groundfish surveys were carried out in the spring and fall in cooperation with other countries. Data on catch of all species, age and length-frequency samples, hydrographic observations, and plankton samples were routinely taken for about 300 stations.

American lobster. Landings were 28.5 million pounds valued at a record $\$ 48.1$ million to the fishermen compared with the 1974 landings of 26.3 million valued at $\$ 39.4$ million. In Maine, the principal producing area, landings of 17.0 million pounds were 550,000 pounds more than in 1974 . In Massachusetts landings of 6.7 million pounds increased 28 percent and were the second highest on record. The American lobster accounted for 31 percent of the value of all landings in New England making it the area's most valuable species.

The inshore pot catch (from 0 to 12 miles) accounted for 83 percent of the lobster catch; the rest was taken by offshore draggers and off shore pot boats. Lobster draggers work seasonally, but much of their eatch is incidental to finfishing. 
Clams. Landings yielded 11.4 million pounds of meats worth $\$ 10.8$ million-increases of 12 percent in volume and 17 percent in value compared with 1974. Landings increased for all species of clams. Soft clams were 67 percent of the total New England production; hard clams, 21 percent; ocean quahog, 11 percent; and razor and surf were 1 percent.

Soft clams landings of 7.7 million pounds of meats increased 5 percent compared with 1974. Maine was the leading producer of soft clams with 6.5 million pounds of meats (up 11 percent), followed by Massachusetts with 1.1 million pounds (down 15 percent), and Rhode lsland with 18,000 pounds (down 73 percent). There was no production in Connecticut or New Hampshire.

Landings of hard clams yielded 2.4 million pounds of meats, up 15 percent compared with 1974 . Landings of 1.1 million pounds in Rhode Island increased 33 percent. Maine landings (8,000 pounds) also increased; however, Connecticut with 120,000 pounds and Massachusetts with 1.1 million pounds had slight decreases. The average price per pound paid to fishermen was $\$ 1.40$ in 1975 and $\$ 1.45$ in 1974 .

Flounders. Landings were 77.4 million pounds worth $\$ 26.9$ million -3.8 million pounds less than in 1974 , but worth $\$ \overline{6.1}$ million more to the fishermen. Landings were the smallest since 1961 and 15.4 million pounds below the average for the previous 5 years. All species of flounders increased in landings except yellowtail. Landings of yellowtail flounders were 41.5 million pounds, a decline of 22 percent compared with 1974 and the smallest since 1953 .

Almost all of the U.S. catch of Atlantic flounders is taken in waters subject to ICNAF catch recommendations. The declining U.S. catch of yellowtail flounder has been the subject of great concern. ICNAF has sharply reduced the yellowtail catch quota for all nations and given the United States almost all (99 percent) of the total allowable catch in 1975 in waters off the U.S. Atlantic Coast.

Groundfish. Landings of groundfish (cod, cusk, haddock, pollock, white hake, and Atlantic ocean perch) were

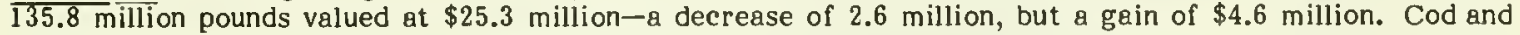
white hake were down slightly, but landings of Atlantic ocean perch had sizable declines. Landings of cusk and pollock had small increases, but haddock increased sharply.

Landings of cod (55.4 million pounds) declined 4 percent compared with 1974 , and landings of white hake ( 8.1 million pounds) declined 3 percent. Atlantic ocean perch landings (32.1 million pounds) declined 23 percent to the lowest level since 1935 .

Landings of cusk (3.1 million pounds) were up 5 percent compared with 1974, and pollock (20.9 million pounds) increased 7 percent with the largest eat ch sinee 1961. Landings of haddock were $16.2 \mathrm{million}$ pounds, an increase of 7.9 million pounds (96 percent) over the record low catch in 1974.

Menhaden. Landings in 1975 of 50.9 million pounds declined 28 million pounds (35 percent), but was still 19 percent above the previous 5-year average. Menhaden purse seiners landed chiefly at the ports of Gloucester, Pt. Judith, and Portland in 1975.

Sea herring. Landings were 79.4 million pounds valued at $\$ 2.6$ million, up 7.9 million pounds and $\$ 69,000$ compared with 1974. The catch of sea herring in New England accounted for 60 percent of the total U.S. landings. Massachusetts landings of 32.2 million pounds increased 83 percent, and Rhode lsland landings of 9.0 million pounds were up 40 percent. Landings in Maine (38.2 million pounds) declined 19 percent and were only 48 percent of the total catch in 1975 compared with 66 percent in 1974 .

In Maine, where small immature sea herrings are used to pack sardines, landings were 48 percent of the total production for all States compared with 66 percent in 1974. The 1975 pack of Maine sardines was 1.1 million standard cases valued at $\$ 24.9$ million, up 3 percent in quantity and 15 percent in value compared with 1974.

Sea scallops. Landings were 7.1 million pounds of edible meats valued at $\$ 13.4$ million-increases of 54 percent in volume and 87 percent in value compared with 1974 . The 1975 production was the largest since 1968 and 62 percent above the average for the previous 5 years. Prices received by fishermen were $\$ 1.89$ per pound in 1975 compared to $\$ 1.56$ in 1974 . About 72 percent of the New England catch was made by 20 vessels fishing out of New Bedford. 
Landings in New Bedford, the leading sea scallop port, were up sharply in 1975, because of increased landings from the Middle Atlantic grounds off New Jersey. These grounds, which in past years provided about 6 months' fishing, were fished for up to 10 months by regular sea scallop vessels in 1975 .

Scallop imports were 19.7 million pounds of meats valued at $\$ 37.2$ million. This was an increase of 1.6 million pounds and $\$ 9.1$ million from the previous year. Most of the imports were from Canada indicating that Georges Bank was very productive.

Northern shrimp. The northern shrimp fishery in Maine, New Hampshire, and Massachusetts continued to have problems as the overall catch declined from 17.5 million pounds valued at $\$ 5.6$ million in 1974 to 11.6 million pounds valued at $\$ 3.1$ million in 1975 . The quantity landed was 53 percent below the average for the previous 5 years. The decline was due to a number of factors, including overfishing in the previous season, price disputes, and closure by Maine officials of the Maine summer shrimp fishery to help restore depleted stocks. The average price per pound paid to fishermen dropped from 31.8 cents per pound in 1974 to 26.3 cents in 1975 , because of the unusually small shrimps.

Maine led other States with a catch of 7.0 million pounds-60 percent of the total, but still 2.8 million pounds less that in 1974. Massachusetts catch was 4.6 million pounds ( 39 percent of the total) compared with 7.7 million pounds in 1974. New Hampshire landings were 65,000 pounds compared with 81,000 in 1974 .

Whiting. Landings of whiting were 33.2 million pounds valued at $\$ 2.8$ million, increases of 12.7 million pounds $(62$ percent) and $\$ 1.1$ million (68 percent) compared with 1974 . Landings in Massachusetts increased 115 percent and were 80 percent of the total New England catch. Landings at Maine ports declined 58 percent, the lowest since 1938. At one time the whiting fishery was one of Maine's most productive fisheries.

Unclassified industrial fish. Landings of unclassified species of fish for processing into industrial products have been trending downward since 1967. In 1975, landings were 13.2 million pounds, a decline of 14.4 million pounds compared with 1974. Most of the industrial fishes is caught incidental to fishing for edible stocks.

Other information. Condensed summary data on the operating units and landings, by States, appearing in the following pages have been published previously in Current Fishery Statistics No. 7405. Additional data may be found in the monthly and annual landings bulletins for Maine, Massachusetts, and Rhode Island published in the Current Fishery Statistics series by the Data Management and Statistics Division in cooperation with the respective States.

Acknowledgements. The following organizations helped collect the data appearing in this section: Maine Department of Marine Resources; New Hampshire Fish and Game Department; Massachusetts Department of Natural Resources, Division of Marine Fisheries; Rhode Island Department of Natural Resources, Division of Conservation; Connecticut State Board of Fisheries and Game; and Connecticut State Shellfish Commission. 


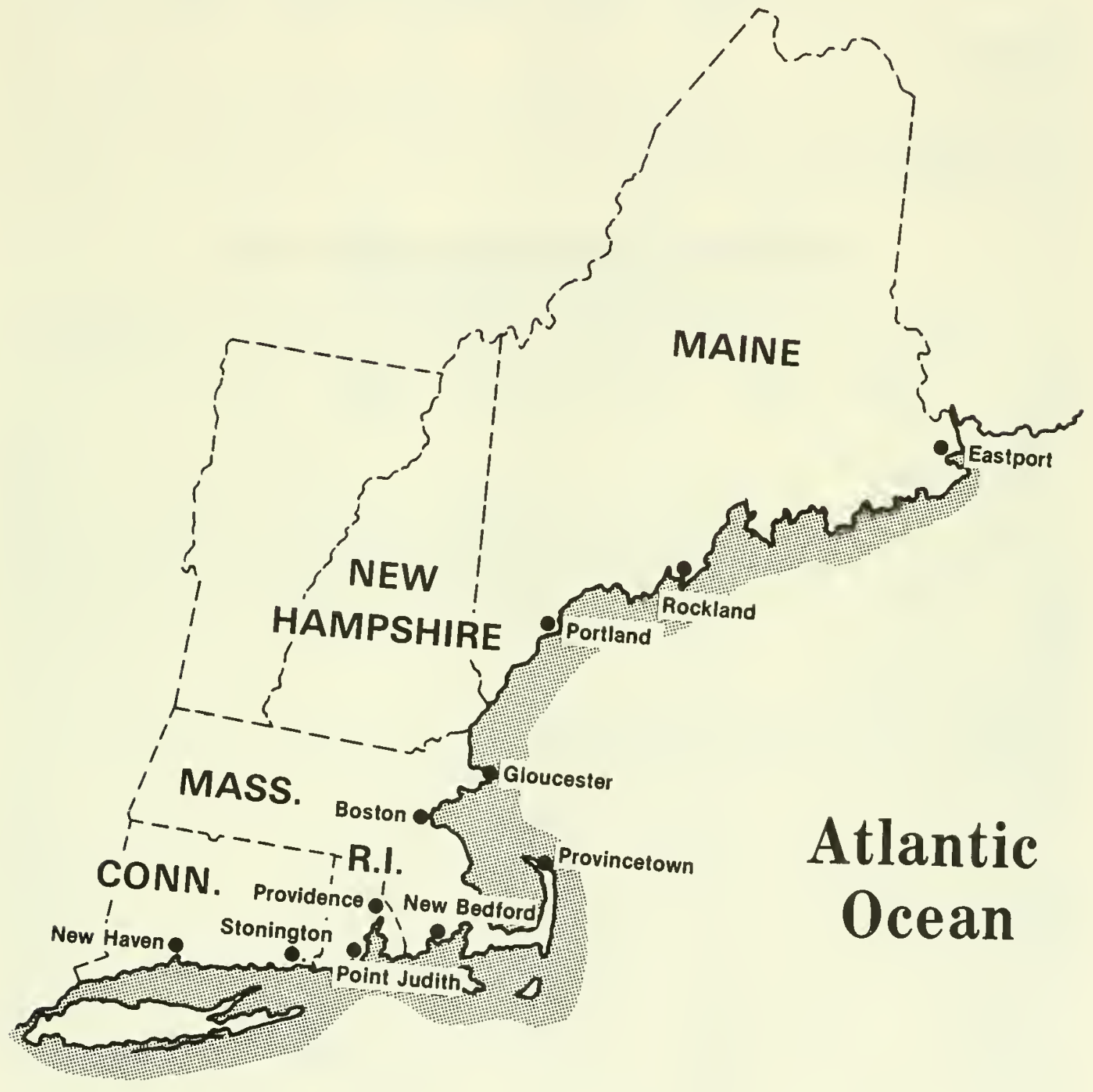


SECTIONAL SUMMARIES

SUMMARY OF LANDINGS, 1975

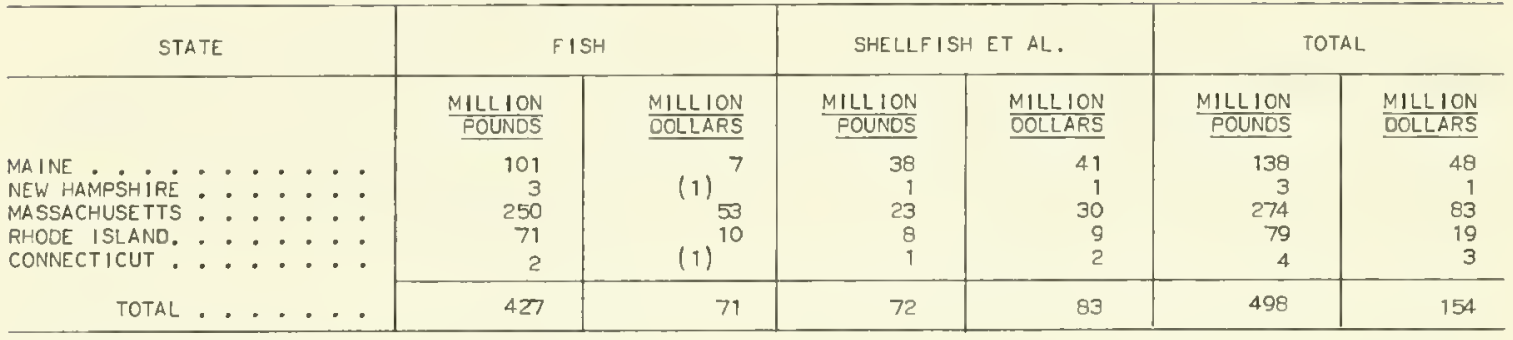

1 LESS THAN $\$ 500,000$.

NOTE:--TABLE MAY NOT AOO BECAUSE OF ROUNDING.

SUMMARY OF OPERATING UNITS, 1975

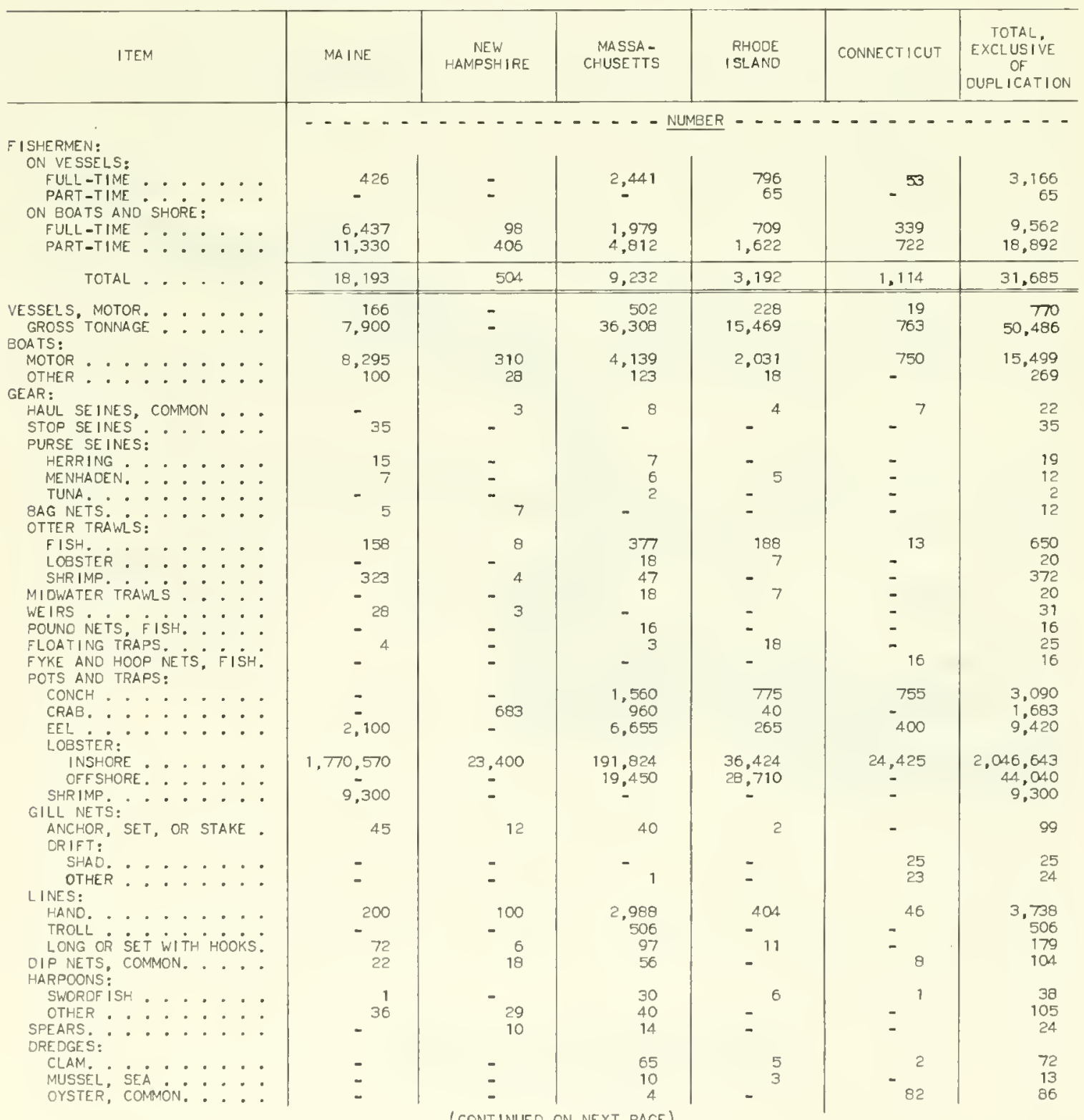


SUMMARY OF OPERATING UNITS, 1975 - Continued

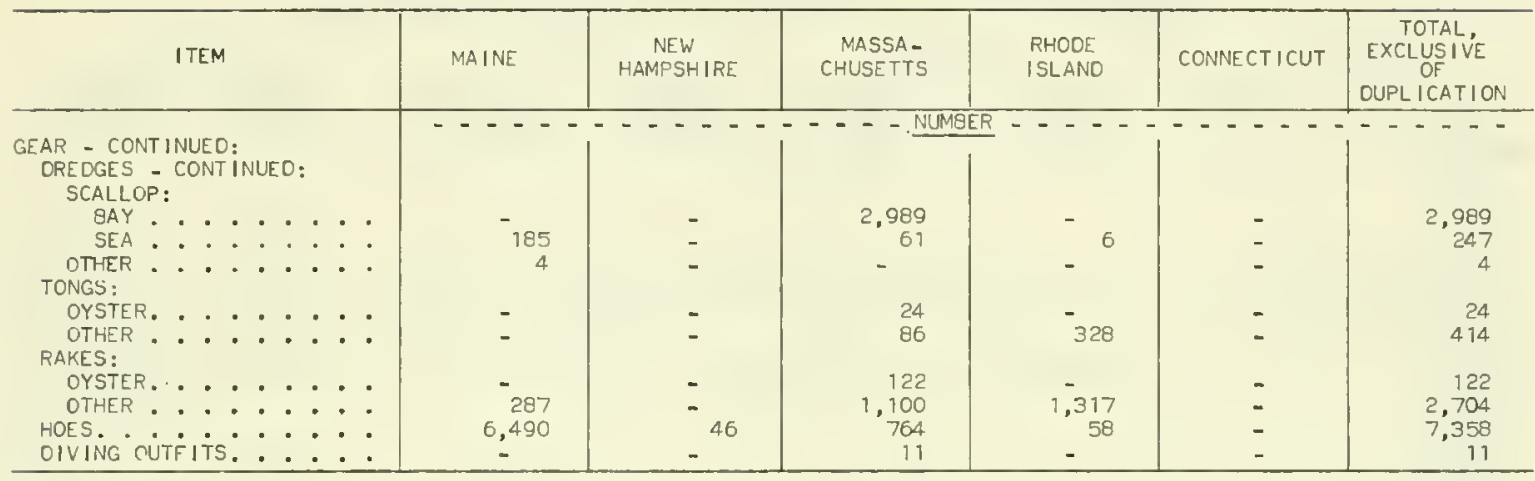

LANDINGS BY STATES, 1975

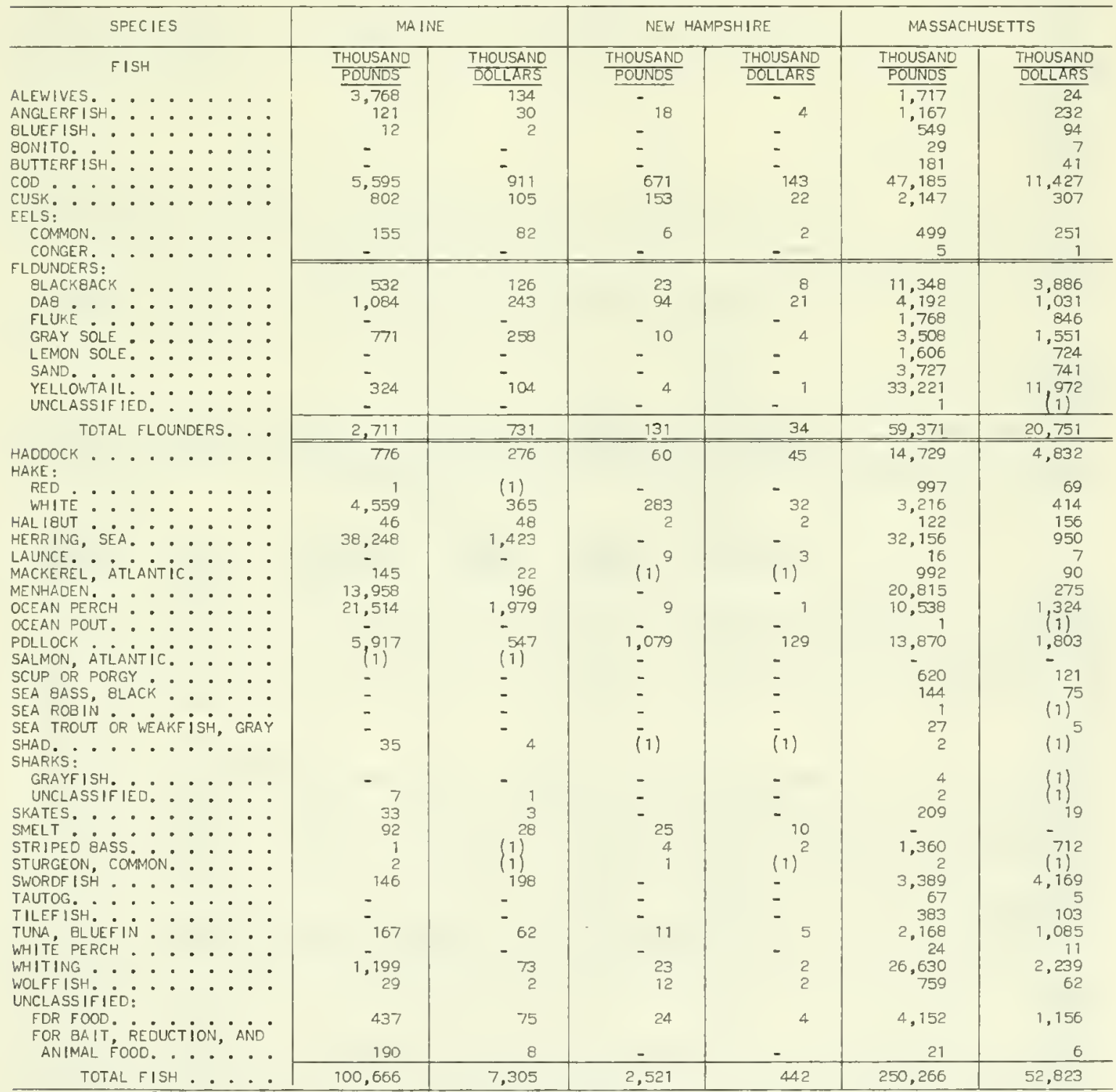


LANDINGS BY STATES, 1975 - Continued

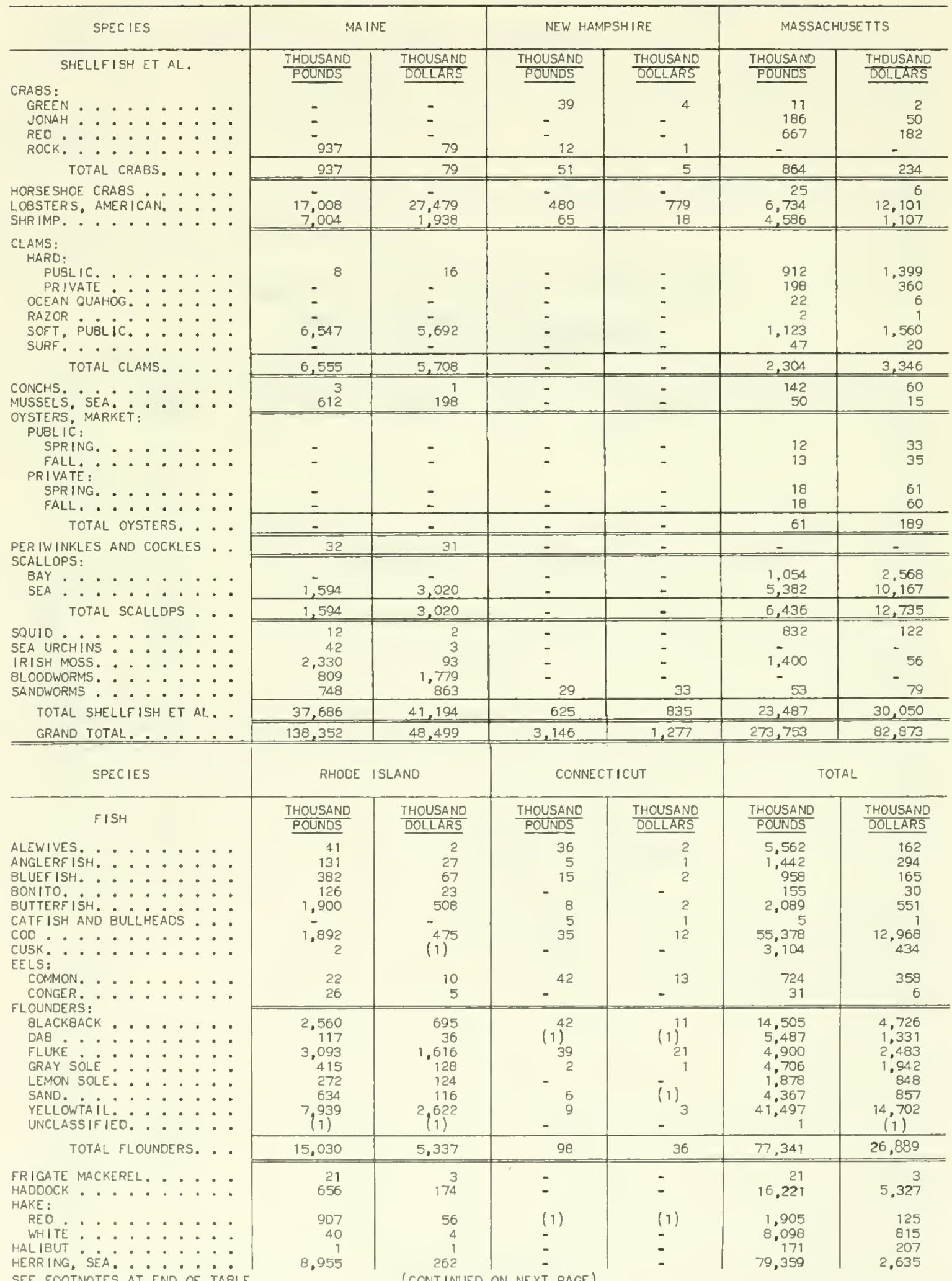


LANDINGS BY STATES, 1975 - Continued

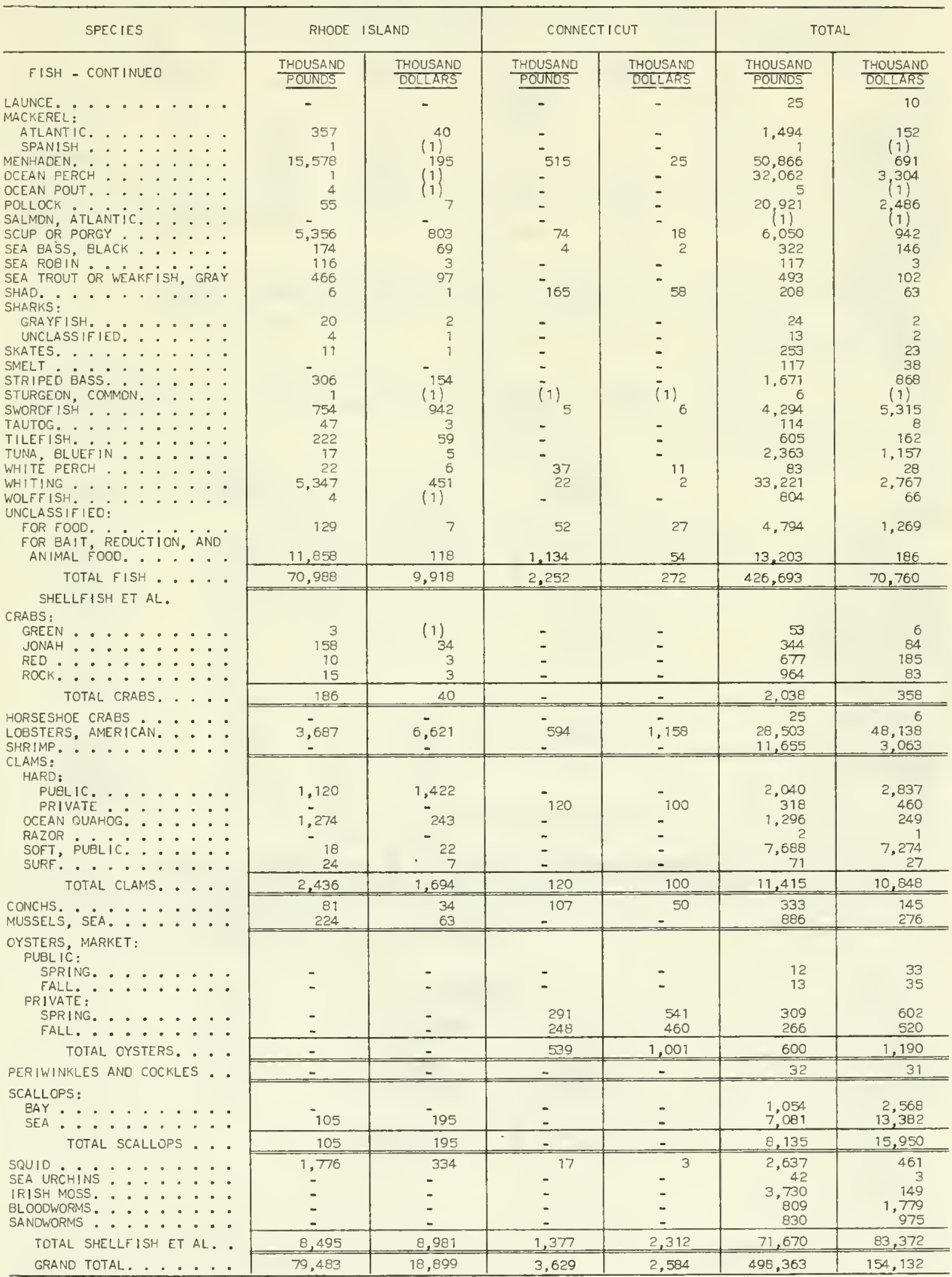


LANDINGS OF CERTAIN SHELLFISH, 1975

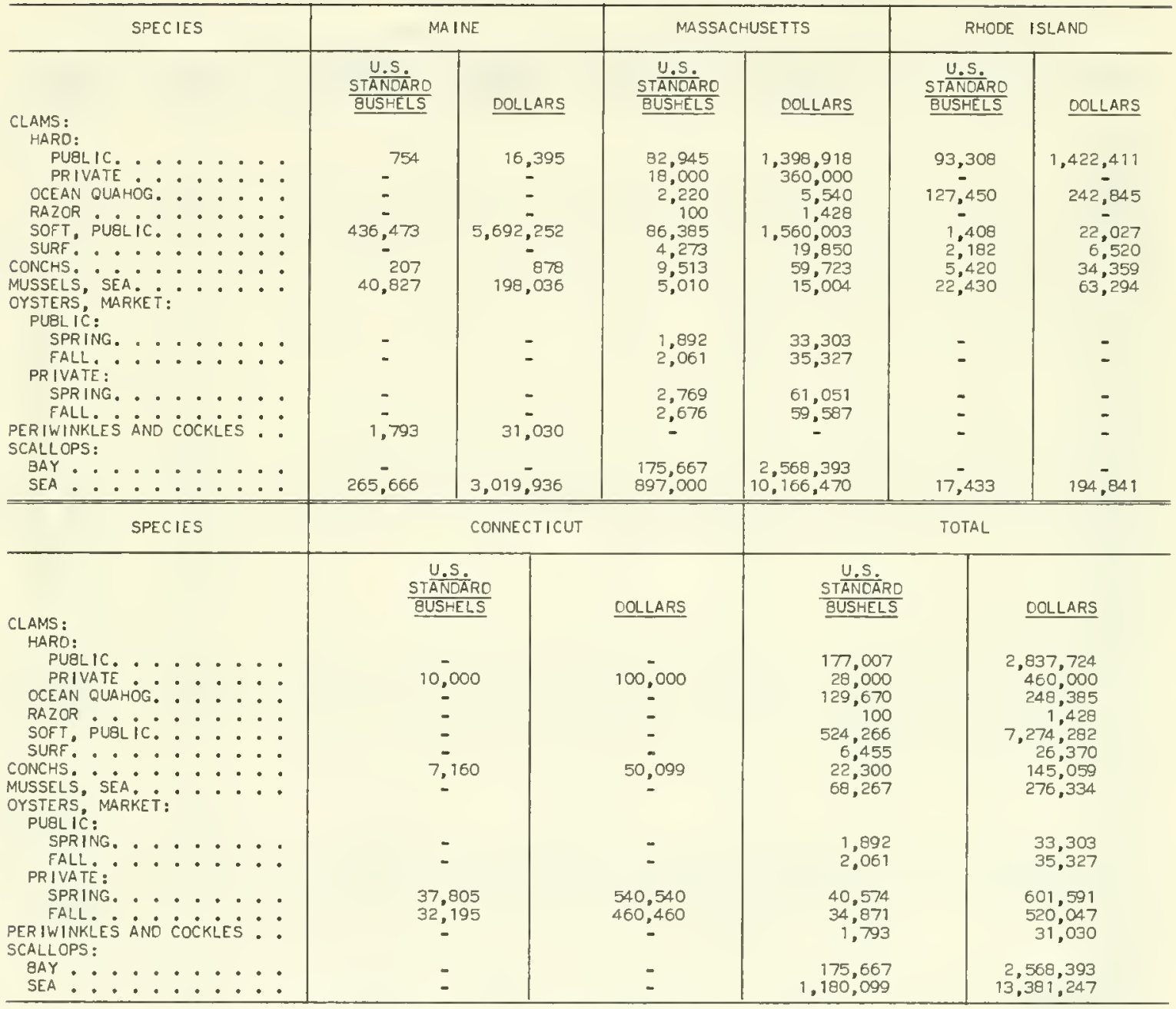

NOTE:--THE CAPACITY OF A U.S. STANDARO BUSHEL IS 2,150.4 CU8IC INCHES.

AVERAGE YIELD OF CERTAIN SHELLFISH, 1975

\begin{tabular}{|c|c|c|c|c|}
\hline SPECIES & MAINE & MASSACHUSETTS & RHODE ISLAND & CONNECTICUT \\
\hline 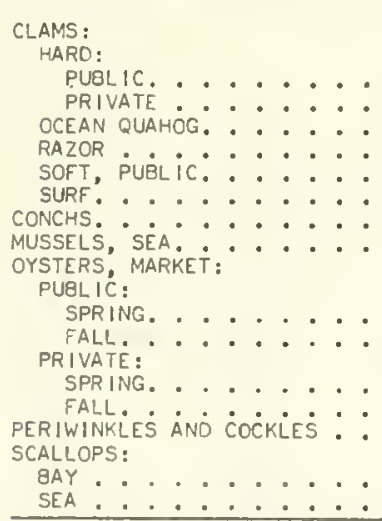 & $\begin{array}{c}11.00 \\
- \\
- \\
15.00 \\
\overline{15.00} \\
15.00 \\
- \\
- \\
\overline{-} \\
18.00 \\
\overline{6} .00\end{array}$ & $\begin{array}{l}11.00 \\
11.00 \\
10.00 \\
16.00 \\
13.00 \\
11.00 \\
15.00 \\
10.00 \\
\\
6.50 \\
6.50 \\
6.50 \\
6.50 \\
-. \\
6.00 \\
6.00\end{array}$ & $\begin{array}{c}12.00 \\
10.00 \\
13.00 \\
11.00 \\
15.00 \\
10.00 \\
= \\
= \\
= \\
- \\
5.00\end{array}$ & $\begin{array}{c}12.00 \\
\vdots \\
\vdots \\
15.00 \\
- \\
- \\
- \\
7.70 \\
7.70\end{array}$ \\
\hline
\end{tabular}

NOTE:- -THE CAPACITY OF A U.S. STANOARO BUSHEL IS 2,150.4 CUBIC INCHES. 
SUMMARY OF PROCESSED PRODUCTS, 1975

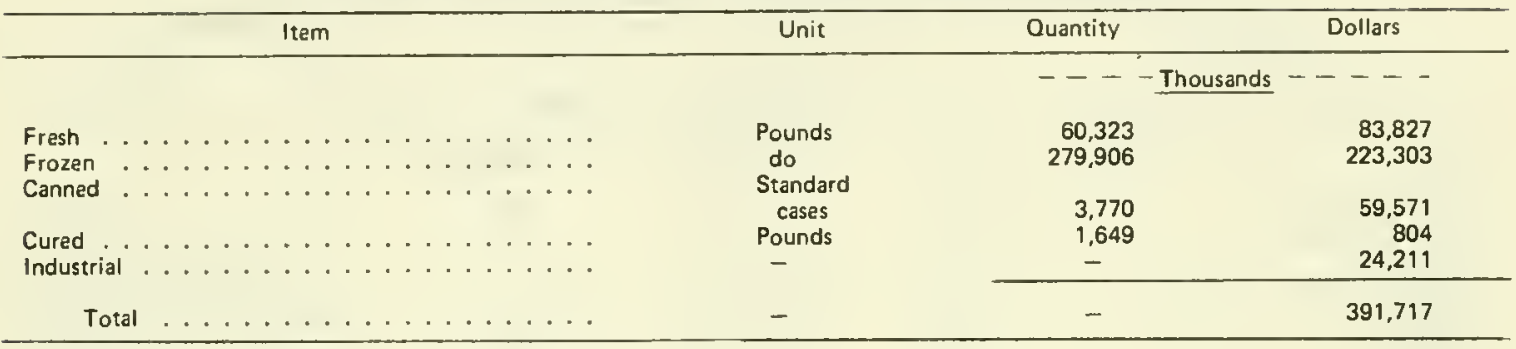

Note:-Table may not add because of rounding. Total is correct.

\section{VALUE OF PROCESSED PRODUCTS, BY STATES, 1975}

\begin{tabular}{|c|c|}
\hline State & Thousand dollars \\
\hline 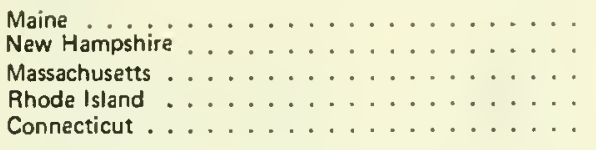 & $\begin{array}{r}91,091 \\
32,710 \\
263,312 \\
3,896 \\
709\end{array}$ \\
\hline Total $\ldots \ldots \ldots \ldots \ldots$ & 391,717 \\
\hline
\end{tabular}

Note:-Table may not add because of rounding. Total is correct.

\section{PROCESSING AND WHOLESALE ESTABLISHMENTS AND EMPLOYMENT, 1975}

\begin{tabular}{|c|c|c|c|c|c|c|c|c|c|}
\hline \multirow[b]{3}{*}{ State } & \multirow[b]{3}{*}{ Plants } & \multicolumn{2}{|c|}{ Processing } & \multicolumn{3}{|c|}{ Wholesale } & \multicolumn{3}{|c|}{ Total } \\
\hline & & \multicolumn{2}{|c|}{ Employment average } & \multirow[b]{2}{*}{ Plants } & \multicolumn{2}{|c|}{ Employment average } & \multirow[b]{2}{*}{ Plants } & \multicolumn{2}{|c|}{ Employment average } \\
\hline & & Season & Year & & Season & Year & & Season & Year \\
\hline & -- & -- & -- & -- & Number & -- & - & $-\ldots$ & - \\
\hline $\begin{array}{l}\text { Maine ....... } \\
\text { New Hampshire } \\
\text { Massachusetts . . } \\
\text { Rhode Island . . } \\
\text { Connecticut . . }\end{array}$ & $\begin{array}{r}99 \\
9 \\
120 \\
15 \\
4\end{array}$ & $\begin{array}{r}4,115 \\
548 \\
4,638 \\
285 \\
43\end{array}$ & $\begin{array}{r}2,874 \\
385 \\
3,845 \\
245 \\
36\end{array}$ & $\begin{array}{r}147 \\
2 \\
91 \\
16 \\
6\end{array}$ & $\begin{array}{r}448 \\
11 \\
885 \\
90 \\
26\end{array}$ & $\begin{array}{r}336 \\
9 \\
787 \\
72 \\
22\end{array}$ & $\begin{array}{r}246 \\
11 \\
211 \\
31 \\
10\end{array}$ & $\begin{array}{r}4,563 \\
559 \\
5,523 \\
375 \\
69\end{array}$ & $\begin{array}{r}3,210 \\
394 \\
4,632 \\
317 \\
58\end{array}$ \\
\hline Total & 247 & 9,629 & 7,385 & 262 & 1,460 & 1,226 & 509 & 11,089 & 8,611 \\
\hline
\end{tabular}

Note:--Employment is reported by each plant for each month for the payroll period that includes the 12th of the month. Employment for the season is based on the greatest number of employees working during the payroll period that included the 12 th of each month. Employment for the year is obtained by adding the number of employeas recorded as working during the payroll period that included the 12 th of each month, and dividing by 12 .

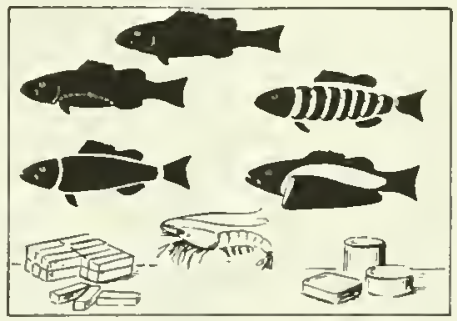


PROCESSED FISHERY PRODUCTS, 1975

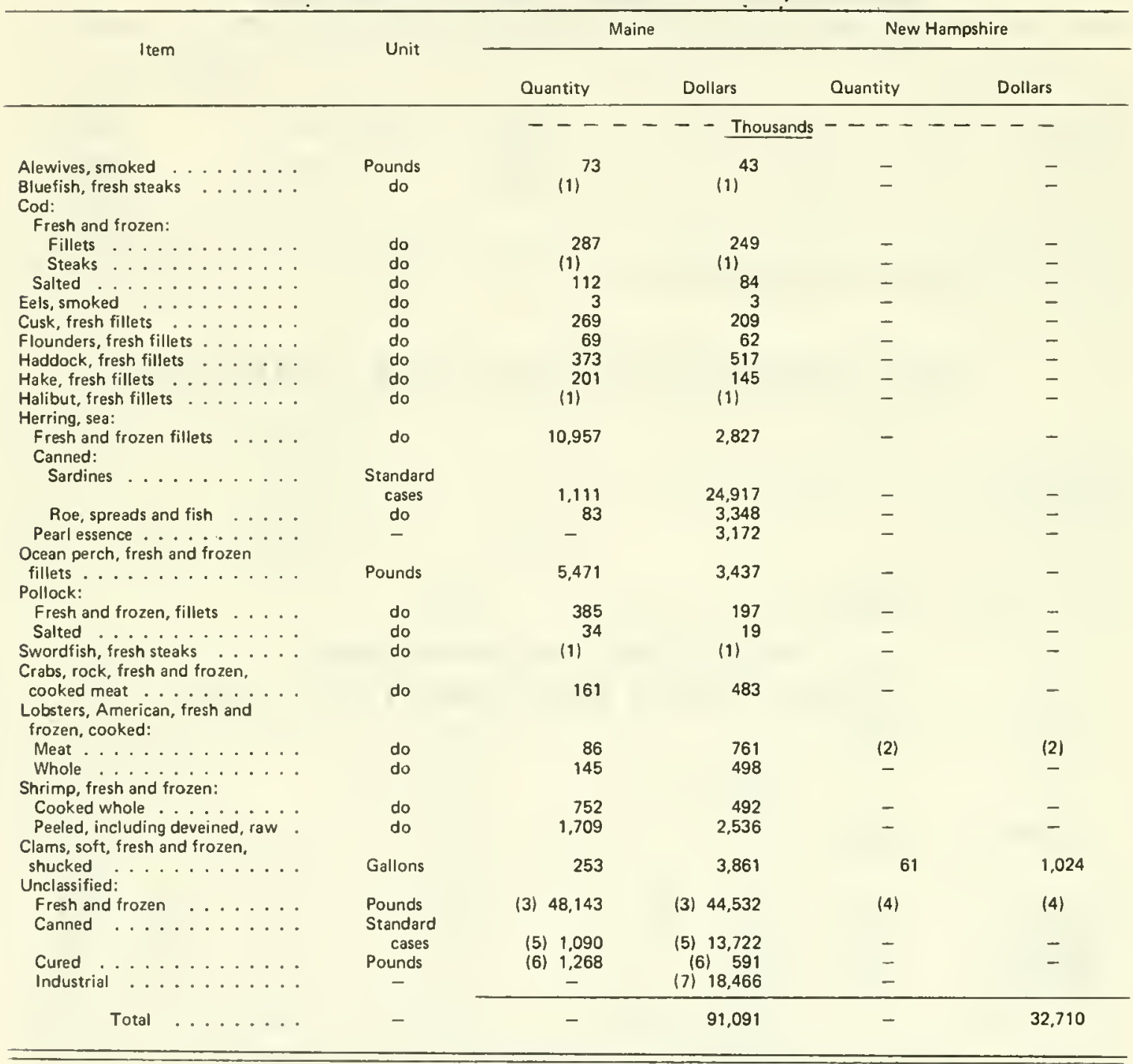

Item

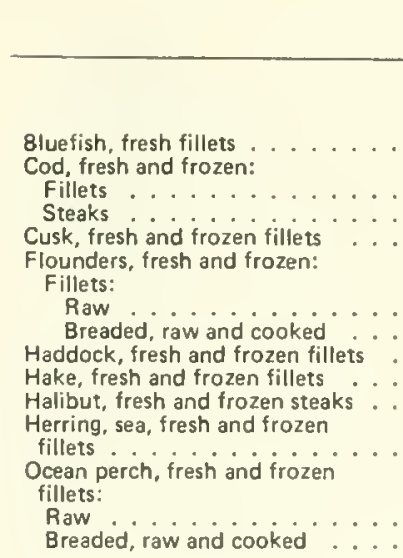

See footnotes at end of table.

8luefish, fresh fillets

Cod, fresh and frozen:

Fillets

usk fresh and froze

lounders, fresh and frozen:

illets:

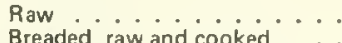

Haddock, fresh and frozen fillets

Hake, fresh and frozen fillets

Herring, sea, fresh and frozen

Ocean perch, fresh and frozen

fillets:

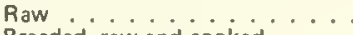

Unit

Massachusetts

Rhode Island and Connecticut

\begin{tabular}{lll} 
Mnit & Massachusetts & $\begin{array}{c}\text { Rhode Island } \\
\text { and Connecticut }\end{array}$ \\
\hline
\end{tabular}

Quantity Dollars Quantity Dollars

$--\ldots-$ Thousands $---\ldots$

\begin{tabular}{|c|c|c|c|c|}
\hline Pounds & 13 & 14 & - & - \\
\hline $\begin{array}{l}\text { do } \\
\text { do } \\
\text { do }\end{array}$ & $\begin{array}{r}9,441 \\
352 \\
959\end{array}$ & $\begin{array}{r}10,249 \\
188 \\
822\end{array}$ & $\overline{-}$ & $\overline{-}$ \\
\hline $\begin{array}{l}\text { do } \\
\text { do } \\
\text { do } \\
\text { do } \\
\text { do }\end{array}$ & $\begin{array}{r}23.569 \\
716 \\
7.846 \\
487 \\
597\end{array}$ & $\begin{array}{r}33.636 \\
777 \\
11.830 \\
381 \\
901\end{array}$ & $\begin{array}{l}401 \\
- \\
- \\
- \\
-\end{array}$ & $\begin{array}{l}573 \\
- \\
- \\
-\end{array}$ \\
\hline do & (8) & (8) & - & - \\
\hline $\begin{array}{l}\text { do } \\
\text { do }\end{array}$ & $\begin{array}{l}2,926 \\
1,394\end{array}$ & $\begin{array}{l}2,235 \\
1,304\end{array}$ & - & - \\
\hline
\end{tabular}

(Continued on next page) 


\section{PROCESSED FISHERY PRODUCTS, 1975 - Continued}

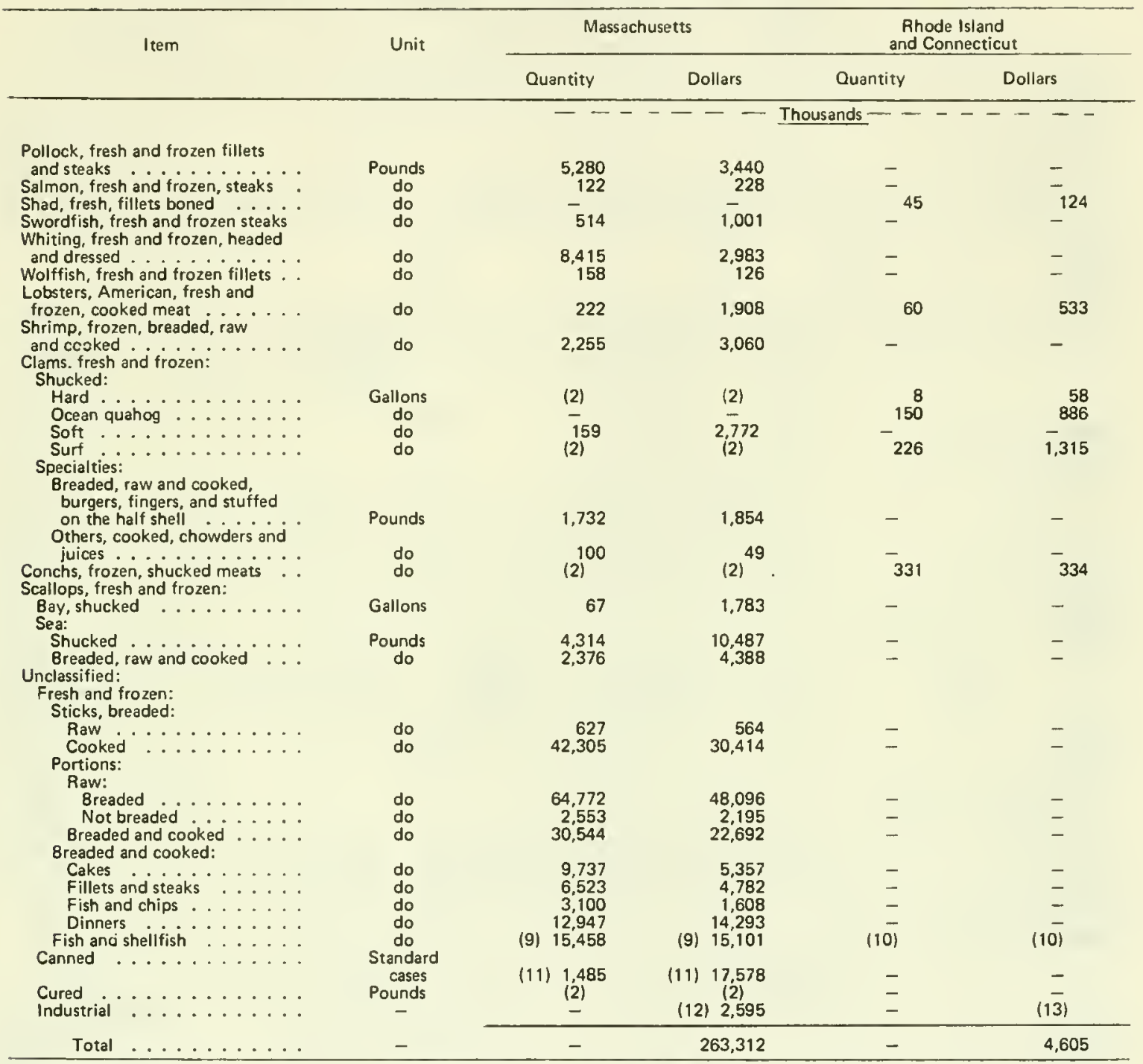

(1) Bluefish, cod, swordfish steaks, and halibut fillets produced in Maine have been included with Massachusetts. (2) Included with unclassified items. (3) Includes tuna and whiting fillets; form pressed cod, flounder, haddock, and ocean perch fillets; breaded cod, flounder, haddock, and ocean perch fillets (raw and cooked); whiting, headed and dressed and i.q.f. fillets; spiny lobster tails repacked; shrimp, raw headless, cooked and peeled, breaded (raw and cooked); fish sticks breaded (raw and cooked); and fish portions, not breaded and breaded (raw), and breaded (cooked). (4) Cod, flounder, haddock, ocean perch, and turbot fillets breaded (raw); langostinos, and spiny lobster tails repacked; shrimp, peeled (cooked), breaded (raw) burgers and sticks; oysters breaded (raw); sea scallops breaded (raw and cooked); fish sticks breaded (raw and cooked); fish portions, not breaded and breaded (raw). breaded (cooked); unclassified bites, cakes, and fish and chips. (5) Includes canned alewife roe; haddock finnan haddies; salmon spreads; tuna spreads; rock crabmeat; American lobster meat and in bisques, deviled, dips, meat, newburgs, spreads and in sauces; shrimp chowders and dips; soft clams, whole, chowder and juices; and unclassified dips and chowders. (6) Includes salted alewives, cusk, hake, sea herring, and conchs; smoked cod, sea herring, and pollock. (7) Includes the value of sea herring. menhaden, and unclassified meal; sea herring, menhaden, and unclassified oil; and Irish moss extract. (8) Sea herring fillets produced in Massachusetts have been included with Maine. (9) Includes anglerfish, skates, striped bass, tuna, turbot, whiting fillets and unclassified minced blocks; sea herring and Atlantic mackerel, headed and dressed; flounder and turbot in casseroles; breaded and cooked smelt; tuna and noodles; cakes and deviled blue crab; red-crab (cooked) meat; American lobster, breaded (raw and cooked) meats; shrimp, cooked whole, peeled, raw and cooked, croquettes, patties, cocktails, cured and refrigerated, creoles, and soups; clams shucked, hard and surf; conchs shucked; oyster stew; sea scallop blocks; squid; unclassifjed bites and salted sea herring. (10) The production of shucked oysters has been included with Massachusetts. (11) Includes canned red crabmeat; clam chowder and juice; unclassified, flakes, cakes, roe, and pet food. (12) Includes the value of cod, halibut and swordfish liver oil; menhaden and unclassified meal, sea herring, menhaden, and unclassified oil; unclassified solubles; dried Irish moss, clams for bait, and clam shells cleaned and polished for food serving. (13) Included with Massachusetts.

Note:--This table will not add. Individual State totals are correct. Some of the products may have been processed from raw products imported from another State or a foreign country; therefore, they cannot be correlated directly with landings within the State. Certain iterns are shown in an intermediate and also a more advanced stage of processing. 


\section{MAINE \\ OPERATING UNITS BY GEAR, 1975}

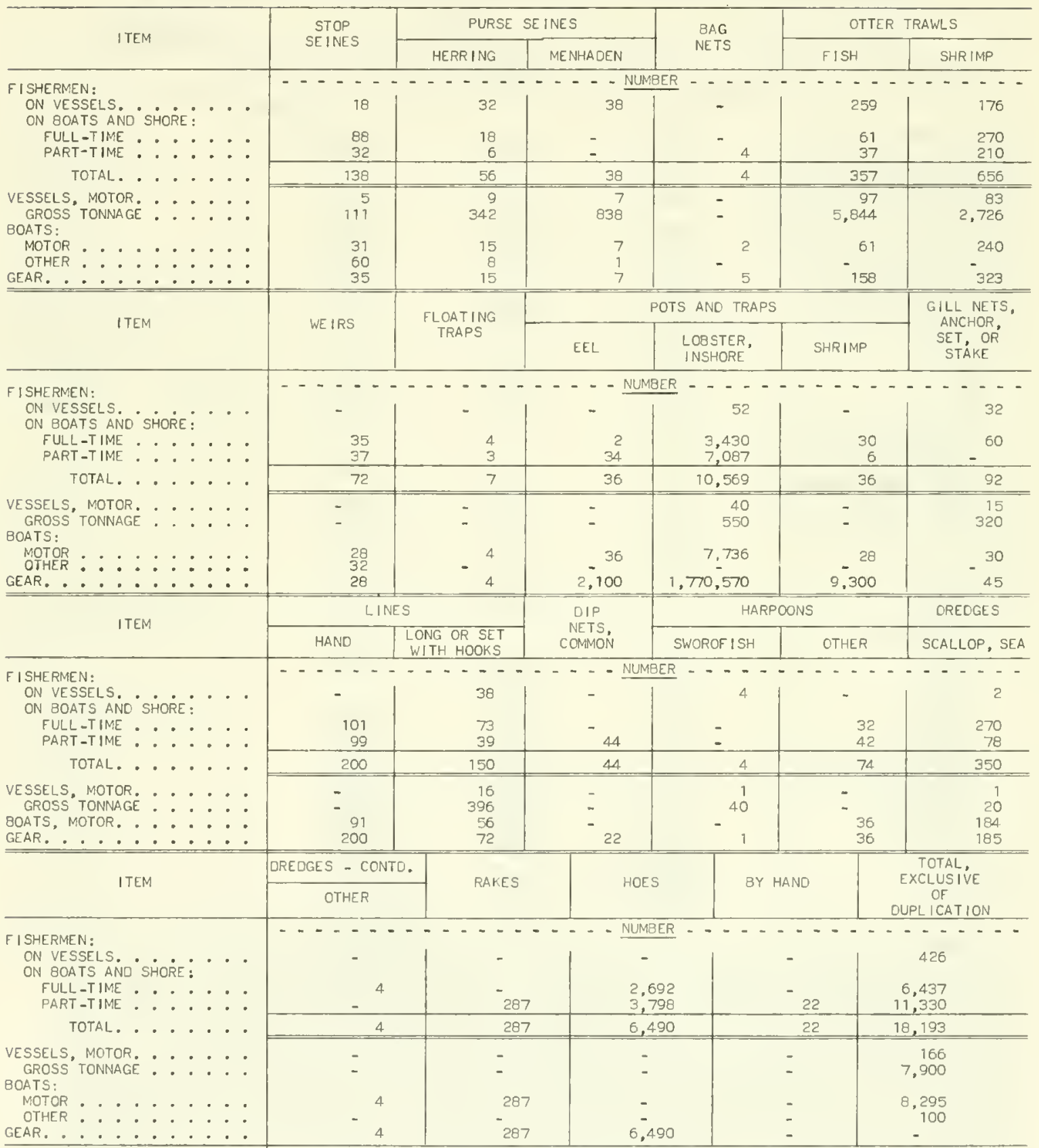


MAINE - LANDINGS OF CATCH BY GEAR, 1975

\begin{tabular}{|c|c|c|c|c|c|c|}
\hline \multirow{2}{*}{ SPECIES } & \multirow{2}{*}{\multicolumn{2}{|c|}{ STOP SEINES }} & \multicolumn{4}{|c|}{ PURSE SE INES } \\
\hline & & & & ING & & DEN \\
\hline 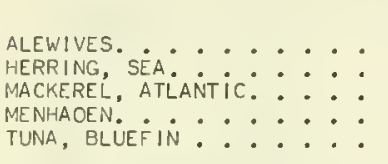 & $\begin{array}{c}\frac{\text { POUNOS }}{-} \\
\begin{array}{c}15,138,400 \\
300 \\
-\end{array} \\
\end{array}$ & $\begin{array}{c}\text { OOLLARS } \\
\begin{array}{c}661,258 \\
- \\
-\end{array} \\
-\end{array}$ & $\begin{array}{r}\text { POUNOS } \\
17,802,800 \\
48,900 \\
- \\
2,400 \\
\end{array}$ & $\begin{array}{c}\text { DULLARS } \\
\begin{array}{c}526,986 \\
5,959 \\
1,590\end{array}\end{array}$ & $\begin{array}{c}\frac{\text { POUNOS }}{39,300} \\
- \\
13,958,300 \\
-\end{array}$ & $\begin{array}{c}\frac{\text { OOLLARS }}{589} \\
- \\
195,416 \\
-\end{array}$ \\
\hline TOTAL. . . . . . . . & $15,138,700$ & 661,308 & $17,854,100$ & 534,535 & $13,997,600$ & 196,005 \\
\hline \multirow{2}{*}{ SPECIES } & \multirow{2}{*}{\multicolumn{2}{|c|}{ BAG NETS }} & \multicolumn{4}{|c|}{ OTTER TRAWLS } \\
\hline & & & \multicolumn{2}{|c|}{ FISH } & \multicolumn{2}{|c|}{ SHR IMP } \\
\hline 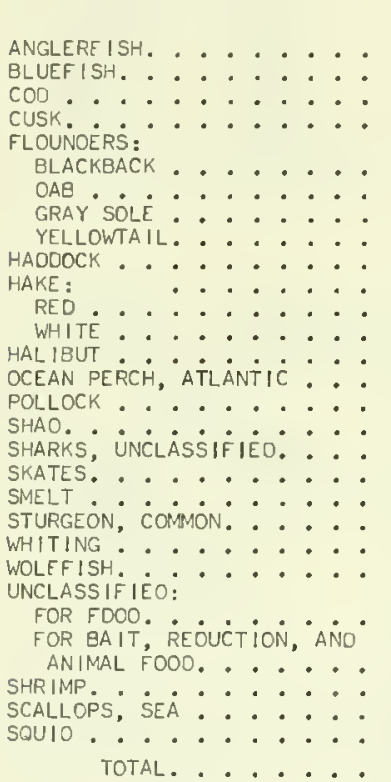 & $\begin{array}{l}\text { POUNOS } \\
- \\
- \\
- \\
- \\
- \\
- \\
- \\
- \\
- \\
- \\
- \\
75,900 \\
- \\
- \\
- \\
- \\
- \\
- \\
\end{array}$ & $\begin{array}{c}\text { DOLLARS } \\
- \\
- \\
- \\
- \\
- \\
- \\
- \\
- \\
- \\
- \\
= \\
- \\
- \\
22,77 \\
- \\
- \\
- \\
- \\
- \\
- \\
\end{array}$ & $\begin{array}{r}\frac{\text { POUNOS }}{74,300} \\
200 \\
2,191,200 \\
185,000 \\
436,800 \\
894,200 \\
715,900 \\
286,300 \\
562,800 \\
900 \\
762,200 \\
27,300 \\
21,364,900 \\
958,700 \\
200 \\
800 \\
14,300 \\
10,700 \\
800 \\
930,400 \\
24,000 \\
185,800 \\
136,000 \\
63,900 \\
9,200 \\
3,400 \\
29,840,200\end{array}$ & $\begin{array}{r}\text { OOLLARS } \\
20,022 \\
33 \\
342,780 \\
21,634 \\
103,440 \\
196,416 \\
237,698 \\
92,073 \\
193,941 \\
\\
53 \\
62,281 \\
28,508 \\
1,966,372 \\
92,125 \\
22 \\
101 \\
1,114 \\
3,279 \\
139 \\
55,585 \\
1,499 \\
36,057 \\
5,886 \\
16,928 \\
20,939 \\
607 \\
3,499,532\end{array}$ & $\begin{array}{r}\text { POUNOS } \\
10,100 \\
812,300 \\
9,900 \\
94,100 \\
17,, 500 \\
51,, 000 \\
38,200 \\
33,000 \\
71,700 \\
1,700 \\
110,500 \\
22,400 \\
- \\
16,300 \\
100 \\
100 \\
250,400 \\
700 \\
101,100 \\
50,000 \\
6,573,500 \\
- \\
1,200 \\
8,726,200\end{array}$ & $\begin{array}{r}\text { DOLLARS } \\
2,038 \\
134,376 \\
1,087 \\
22,112 \\
43,837 \\
19,279 \\
11,994 \\
12,985 \\
12 \\
6,576 \\
1,687 \\
9,187 \\
2,745 \\
- \\
-971 \\
13 \\
27 \\
15,314 \\
66 \\
19,139 \\
2,166 \\
1,901,223 \\
- \\
178 \\
2,207,012\end{array}$ \\
\hline \multirow{2}{*}{ SPECIES } & \multirow{2}{*}{\multicolumn{2}{|c|}{ WE IRS }} & \multirow{2}{*}{\multicolumn{2}{|c|}{ ELOATING TRAPS }} & \multicolumn{2}{|c|}{ POTS AND TRAPS } \\
\hline & & & & & \multicolumn{2}{|c|}{ EEL } \\
\hline \multirow[t]{2}{*}{ 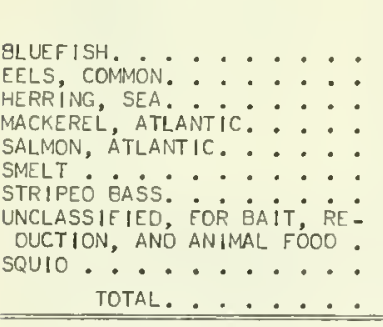 } & $\begin{array}{c}\text { POUNOS } \\
- \\
5,306,600 \\
- \\
- \\
- \\
- \\
-\end{array}$ & $\begin{array}{c}\text { DOLLARS } \\
- \\
234,451 \\
= \\
= \\
- \\
- \\
-\end{array}$ & $\begin{array}{c}\frac{\text { POUNOS }}{3,800} \\
- \\
- \\
95,500 \\
100 \\
100 \\
(1) \\
1,000 \\
7,300\end{array}$ & $\begin{array}{c}\text { DOLLARS } \\
1,209 \\
- \\
15,550 \\
171 \\
20 \\
4 \\
37 \\
1,005 \\
\end{array}$ & $\begin{array}{c}\text { POUNDS } \\
154,-800 \\
= \\
= \\
- \\
- \\
-\end{array}$ & $\begin{array}{c}\text { DOLLARS } \\
82,380 \\
\overline{-} \\
- \\
- \\
- \\
-\end{array}$ \\
\hline & $5,306,600$ & 234,451 & 107,800 & 17,996 & 154,800 & 82,380 \\
\hline SPECIES & \multicolumn{4}{|c|}{ POTS ANO TRAPS - CONTINUEO } & \multicolumn{2}{|c|}{$\begin{array}{c}\text { GILL NETS, } \\
\text { ANCHOR, SET, OR STAKE }\end{array}$} \\
\hline 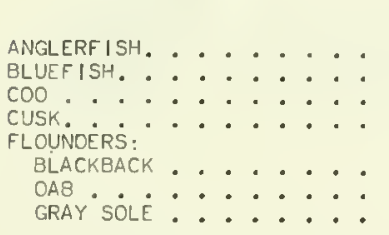 & $\begin{array}{l}\text { POUNOS } \\
- \\
- \\
- \\
- \\
-\end{array}$ & $\begin{array}{c}\text { OOLLARS } \\
- \\
- \\
- \\
- \\
-\end{array}$ & $\begin{array}{c}\text { POUNOS } \\
- \\
- \\
- \\
- \\
-\end{array}$ & $\begin{array}{c}\text { OOLLARS } \\
- \\
- \\
- \\
- \\
- \\
-\end{array}$ & $\begin{array}{r}\frac{\text { POUNOS }}{35,600} \\
7,600 \\
2.067,100 \\
162,800 \\
600 \\
12,200 \\
3,100\end{array}$ & $\begin{array}{r}\text { OOLLARS } \\
7,365 \\
1,132 \\
358,870 \\
19,723\end{array}$ \\
\hline
\end{tabular}


MAINE - LANDINGS OF CATCH BY GEAR, 1975 - Continued

\begin{tabular}{|c|c|c|c|c|c|c|}
\hline \multirow{2}{*}{ SPEC IES } & \multicolumn{4}{|c|}{ POTS AND TRAPS - CONTINUED } & \multirow{2}{*}{\multicolumn{2}{|c|}{$\begin{array}{l}\text { GILL NETS, } \\
\text { ANCHOR, SET, OR STAKE }\end{array}$}} \\
\hline & \multicolumn{2}{|c|}{ LOBSTER, INSHORE } & \multicolumn{2}{|c|}{ SHRIMP } & & \\
\hline \multirow{17}{*}{ 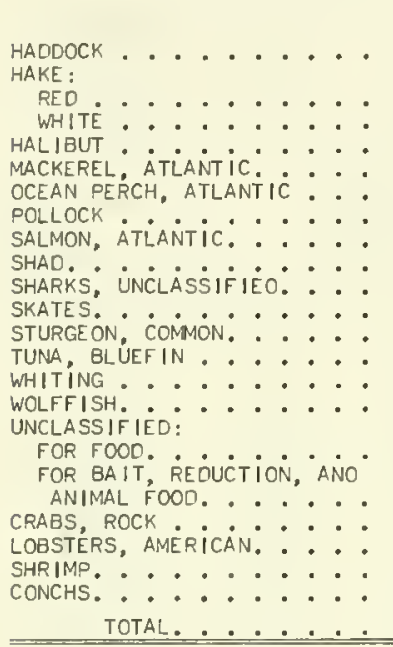 } & POUNDS & DOLLARS & POUNDS & DOLLARS & POUNDS & DOLLARS \\
\hline & - & - & - & - & 115,500 & 42,947 \\
\hline & - & - & - & - & 100 & \\
\hline & - & - & - & - & $2,448,000$ & 203,235 \\
\hline & - & - & - & - & & 889 \\
\hline & - & - & - & - & $\begin{array}{r}100 \\
37,000\end{array}$ & $\begin{array}{r}12 \\
3.637\end{array}$ \\
\hline & - & $\overline{-}$ & - & - & $4,319,600$ & 413,037 \\
\hline & - & - & - & - & 34,200 & 3,432 \\
\hline & - & - & - & - & 3,600 & \\
\hline & $\overline{-}$ & - & - & 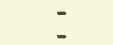 & $\begin{array}{l}700 \\
600\end{array}$ & $\begin{array}{r}67 \\
161\end{array}$ \\
\hline & - & - & - & - & 300 & 80 \\
\hline & $\overline{-}$ & $\overline{-}$ & $\overline{-}$ & $\overline{-}$ & $\begin{array}{r}17,500 \\
4,500\end{array}$ & $\begin{array}{r}1,508 \\
520\end{array}$ \\
\hline & - & - & - & - & 135,700 & 17.726 \\
\hline & - & - & - & - & 1,100 & 39 \\
\hline & $\begin{array}{r}937,300 \\
17,007,500\end{array}$ & $\begin{array}{r}79,392 \\
27,478,713\end{array}$ & - & - & - & \\
\hline & 3,100 & -878 & $\begin{array}{c}67,000 \\
- \\
\end{array}$ & $\begin{array}{r}19,600 \\
- \\
\end{array}$ & - & - \\
\hline & $17,947,900$ & $27,559,043$ & 67,000 & 19,600 & $9,408,400$ & $1,078,868$ \\
\hline \multirow{2}{*}{ SPECIES } & \multicolumn{4}{|c|}{ LINES } & \multirow{2}{*}{\multicolumn{2}{|c|}{$\begin{array}{l}\text { DIP NETS, } \\
\text { COMMON }\end{array}$}} \\
\hline & \multicolumn{2}{|c|}{ HAND } & \multicolumn{2}{|c|}{ LONG OR SET WITH HOOKS } & & \\
\hline & POUNDS & DOLLARS & POUNDS & DOLLARS & POUNDS & DOLLARS \\
\hline ALEWIVES, . . . . . & - & - & - & - & $3,7 \longdiv { 7 2 9 , 0 0 0 }$ & 133,679 \\
\hline ANGLERFISH. . . • • • • & & - & 800 & 182 & - & - \\
\hline $\mathrm{COO} \ldots \ldots . . . .$. & 22,600 & 2,572 & 501,900 & 72,127 & - & - \\
\hline $\begin{array}{l}\text { CUSK } \\
\text { FLOUNDERŚ: }: \cdots \cdots \cdots \cdots\end{array}$ & 2,800 & 145 & 440,900 & 61,874 & - & - \\
\hline 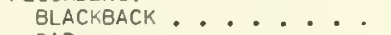 & 500 & 100 & - & - & - & - \\
\hline DAB . . . . . & - & & 200 & 34 & - & - \\
\hline HADOOCK : . . . . . & 300 & 107 & 64,600 & 26,397 & - & - \\
\hline HAKE, WHITE,$\cdot \cdot \cdot \cdot \cdot$ & 3,300 & 146 & $1,273,900$ & 93,005 & - & - \\
\hline OCEAN PERCH, ATLANTIIC: : & -400 & -5 & 1,600 & 14,3100 & - & $\overline{-}$ \\
\hline POLLOCK SALMOATIC $\cdot \cdots \cdot \cdot$ & 6,800 & $\begin{array}{r}304 \\
63\end{array}$ & 609,500 & 39,133 & $\overline{-}$ & 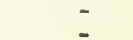 \\
\hline SHAD. : : : : & - & - & 200 & 54 & - & - \\
\hline SHARKS, UNCLASSIFIEO. • • & 400 & 30 & 2.500 & 258 & - & - \\
\hline SKATES. • • • • • • • & 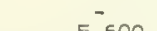 & - & 1.800 & 261 & - & - \\
\hline $\begin{array}{l}\text { SMELT } \\
\text { STRIPED BASSS: }: \cdots: \cdots:\end{array}$ & $\begin{array}{r}5.600 \\
400\end{array}$ & 2,016 & $-\overline{100}$ & $-{ }_{40}$ & $=$ & - \\
\hline STURGEON, COMMON. $: \therefore$ & 100 & & - & - & - & - \\
\hline SWORDF I SH . . . . . & - & - & 142,200 & 193,545 & - & - \\
\hline TUNA, BLUEFIN $\cdot \cdots \cdot \cdot \cdot \cdot$ & 71,200 & 29,425 & $\begin{array}{l}1,700 \\
200\end{array}$ & $\begin{array}{r}392 \\
36\end{array}$ & - & $\overline{-}$ \\
\hline UNCLASSIF́ IÉD; & - & $\overline{-}$ & & & & \\
\hline 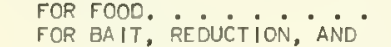 & - & - & 14,600 & 2,068 & - & - \\
\hline ANIMAL FOOD...... & - & - & 2,100 & 76 & - & - \\
\hline TOTAL. . . . . . & 116,500 & 37,666 & $3,072,700$ & 503,919 & $3.729,000$ & 133,679 \\
\hline \multirow{2}{*}{ SPECIES } & \multicolumn{4}{|c|}{ HARPOONS } & \multicolumn{2}{|c|}{ DREDGES } \\
\hline & \multicolumn{2}{|c|}{ SWORDF ISH } & \multicolumn{2}{|c|}{ OTHER } & \multicolumn{2}{|c|}{ SCALLOP, SEA } \\
\hline & POUNOS & DOLLARS & POUNDS & DOLLARS & POUNDS & OOLLARS \\
\hline $\begin{array}{l}\text { SWORDF ISH } \\
\text { TUNA, BLUEFIN }: \vdots: \cdots: \\
\text { SCALLOPS, SEA }: \vdots: \vdots:\end{array}$ & $\begin{array}{l}3,900 \\
- \\
-\end{array}$ & $\begin{array}{l}4,805 \\
-\end{array}$ & 91,100 & $30 . \overline{-} 464$ & $\frac{-}{\overline{7}, 584,800}$ & $\frac{-}{2,998,997}$ \\
\hline TOTAL...... & 3,900 & 4,805 & 91,100 & 30,464 & $1,584,800$ & $2,998,997$ \\
\hline
\end{tabular}

SEE FOOTNOTE AT END OF TABLE.

(CONT INUED ON NEXT PAGE) 


\section{MAINE - LANDINGS OF CATCH BY GEAR, 1975 - Continued}

\begin{tabular}{|c|c|c|c|c|}
\hline \multirow{2}{*}{ SPECIES } & \multicolumn{2}{|c|}{ DREDGES - CONT INUED } & \multirow{2}{*}{\multicolumn{2}{|c|}{ RAKES }} \\
\hline & \multicolumn{2}{|c|}{ OTHER } & & \\
\hline $\begin{array}{l}\text { SEA URCHINS }: \cdots \\
\text { IRISH MOSS. : : }:\end{array}$ & $\begin{array}{c}\frac{\text { POUNOS }}{42,000} \\
-\end{array}$ & $\frac{\text { OOLLARS }}{2,752}$ & $\frac{\text { POUNOS }}{-}$ & $\frac{\text { DOLLARS }}{-}$ \\
\hline 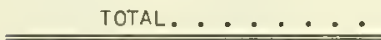 & 42,000 & 2,752 & $2,330,000$ & 93,200 \\
\hline SPECIES & \multicolumn{2}{|c|}{ HOES } & \multicolumn{2}{|c|}{ BY HAND } \\
\hline 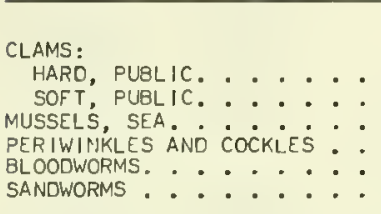 & $\begin{array}{r}\text { POUNOS } \\
8,300 \\
6,547,100 \\
612,400 \\
808,900 \\
748,300\end{array}$ & $\begin{array}{r}\text { DOLLARS } \\
16,395 \\
5,692,252 \\
198,036 \\
1,779,266 \\
862,854\end{array}$ & $\begin{array}{c}\text { POUNOS } \\
\begin{array}{c}- \\
- \\
32,300 \\
-\end{array} \\
-\end{array}$ & $\begin{array}{c}\text { DOLLARS } \\
\begin{array}{c}- \\
- \\
31.030 \\
- \\
-\end{array}\end{array}$ \\
\hline TOTAL. . . . . . & $8,725,000$ & $8,548,803$ & 32,300 & 37,030 \\
\hline
\end{tabular}

1) LESS THAN 500 POUNDS.

\section{NEW HAMPSHIRE OPERATING UNITS BY GEAR, 1975}

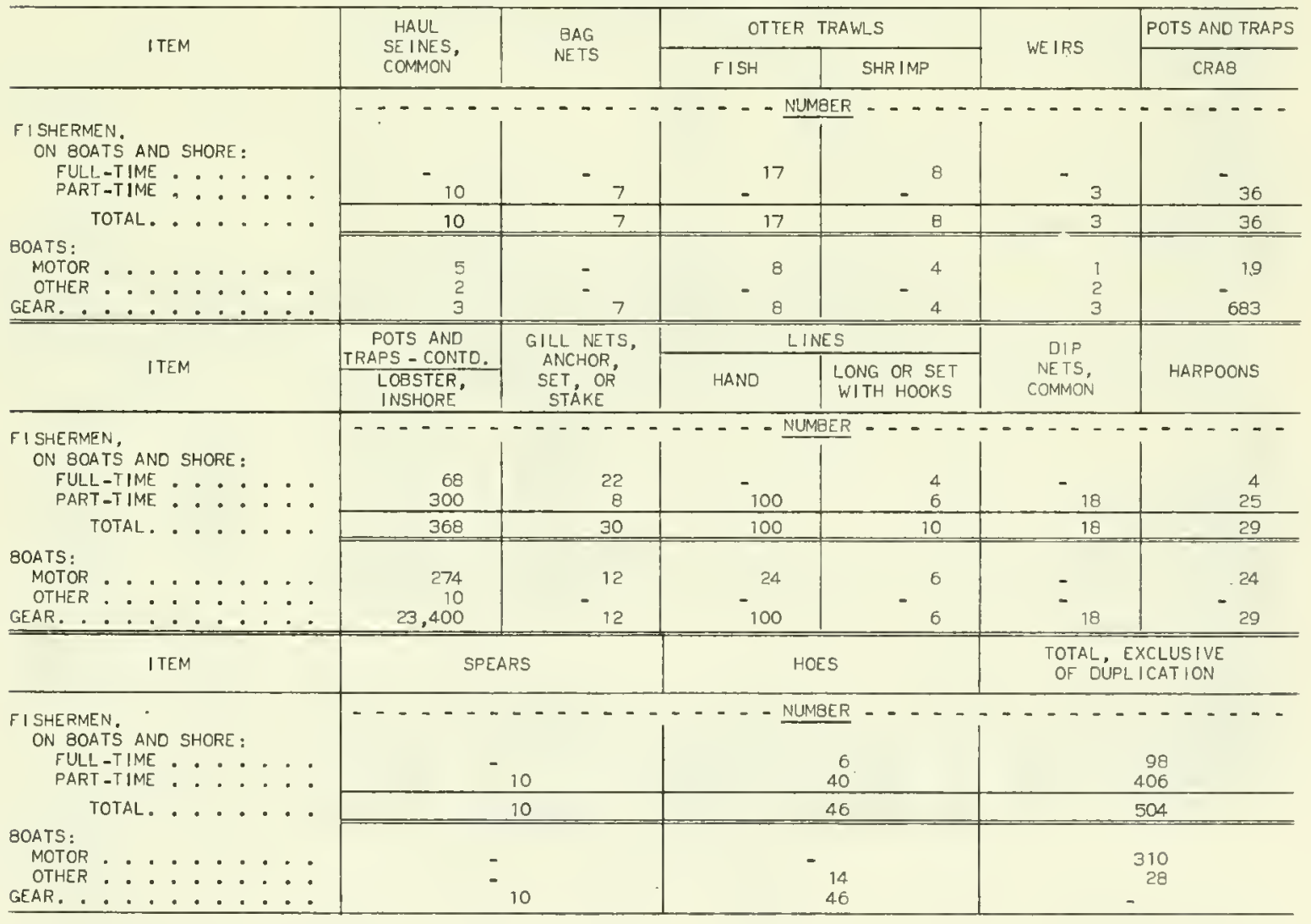


NEW HAMPSHIRE - LANDINGS OF CATCH BY GEAR, 1975

\begin{tabular}{|c|c|c|c|c|c|c|}
\hline \multirow{2}{*}{ SPECIES } & \multirow{2}{*}{\multicolumn{2}{|c|}{ HAUL SEINES, COMMON }} & \multirow{2}{*}{\multicolumn{2}{|c|}{ BAG NETS }} & OTTE & NLS \\
\hline & & & & & \multicolumn{2}{|c|}{ FISH } \\
\hline \multirow{16}{*}{ 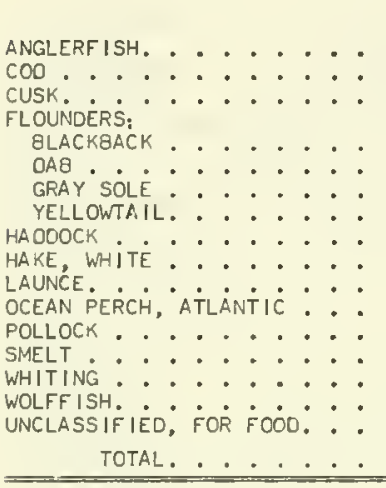 } & POUNOS & OOLLARS & POUNDS & DOLLARS & POUNDS & OOLLARS \\
\hline & - & - & - & - & 1,500 & 345 \\
\hline & - & - & - & - & $\begin{array}{l}93,200 \\
16,800\end{array}$ & 20,103 \\
\hline & - & 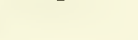 & 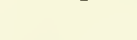 & 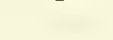 & 10,000 & $2,4 \pi c$ \\
\hline & - & - & - & - & 22,300 & 7,310 \\
\hline & - & - & - & - & 84,600 & 18,900 \\
\hline & - & - & - & - & 9,100 & 4.154 \\
\hline & - & - & - & $\overline{-}$ & $\begin{array}{l}3,200 \\
6,200\end{array}$ & $\begin{array}{l}1.043 \\
4.661\end{array}$ \\
\hline & -700 & -7 & - & - & 40,600 & 4.551 \\
\hline & 8,700 & 2,746 & - & - & 5,800 & - \\
\hline & - & - & - & - & 74,300 & 8,871 \\
\hline & - & - & 3,100 & 1,204 & - & - \\
\hline & - & - & - & - & 22,300 & 1,840 \\
\hline & - & - & - & - & 1,800 & 274 \\
\hline & & & & & & -76005 \\
\hline & 8,700 & 2,746 & 3,100 & 1.204 & 392,200 & 10,805 \\
\hline \multirow{2}{*}{ SPECIES } & \multicolumn{2}{|c|}{ OTTER TRAWLS - CONTINUEO } & \multirow{2}{*}{\multicolumn{2}{|c|}{ WEIRS }} & \multicolumn{2}{|c|}{ POTS AND TRAPS } \\
\hline & \multicolumn{2}{|c|}{ SHRIMP } & & & \multicolumn{2}{|c|}{ CRAB } \\
\hline \multirow{14}{*}{$\begin{array}{l}\text { ANGLERFISH. } \\
\text { COD }::\end{array}$} & POUNDS & DOLLARS & POUNDS & DOLLARS & POUNOS & DOLLARS \\
\hline & 900 & 194 & - & - & - & - \\
\hline & 3,200 & 686 & - & - & - & - \\
\hline & 300 & 46 & 3800 & - & - & - \\
\hline & - & - & 3,800 & 1,544 & - & - \\
\hline & 800 & 300 & - & - & - & - \\
\hline & 2,900 & 637 & - & - & - & - \\
\hline & $\begin{array}{l}400 \\
800\end{array}$ & $\begin{array}{l}159 \\
267\end{array}$ & - & $=$ & $\overline{-}$ & - \\
\hline & 200 & 157 & - & & - & - \\
\hline & 600 & 69 & - & - & - & - \\
\hline & 2.900 & - & 5,400 & 2,131 & - & - \\
\hline & 1,200 & 193 & - & - & - & - \\
\hline & 64,800 & 17,593 & - & - & 38,600 & 3,860 \\
\hline & 79,000 & 20,748 & 9,200 & 3.675 & 38,600 & 3,860 \\
\hline \multirow{2}{*}{ SPECIES } & \multicolumn{2}{|c|}{ POTS AND TRAPS - CONTINUED } & \multirow{2}{*}{\multicolumn{2}{|c|}{$\begin{array}{l}\text { GILL NETS, } \\
\text { ANCHOR, SET, } \\
\text { OR STAKE }\end{array}$}} & \multicolumn{2}{|c|}{ LINES } \\
\hline & \multicolumn{2}{|c|}{ LOBSTER, INSHORE } & & & \multicolumn{2}{|c|}{ HAND } \\
\hline & POUNDS & DOLLARS & POUNDS & DOLLARS & POUNDS & DOLLARS \\
\hline ANGLERFISH. . . . . . & - & - & 15,200 & 3,390 & - & - \\
\hline $\mathrm{COO} \ldots \ldots$ & - & - & 494,300 & 105.486 & 21,400 & 4,610 \\
\hline cusk, . . . . . . & - & - & 32,800 & 4.784 & 12,200 & 1,782 \\
\hline $\begin{array}{l}\text { FLOUNDERS, DAB } \\
\text { HADOOCK, UNCLASSIFIED: }\end{array}$ & - & $=$ & $\begin{array}{r}6,200 \\
42,300\end{array}$ & $\begin{array}{r}1,385 \\
31,645\end{array}$ & $\begin{array}{r}800 \\
600\end{array}$ & $\begin{array}{l}179 \\
219\end{array}$ \\
\hline HAKE, WHITE . . : : & $\overline{-}$ & $\overline{-}$ & 215,600 & 24,169 & 3,900 & 433 \\
\hline MACKEREL, ATLANTIC. . . & - & - & - & - & 300 & \\
\hline OCEAN PERCH, ATLANTIC... & - & - & 2,300 & 280 & - & - \\
\hline POLLOCK . . . . . . . & - & - & 978,300 & 116,804 & 14.400 & 1,717 \\
\hline $\mathrm{SHAO}_{*} \cdot \cdots \cdot \cdots \cdot \cdots$ & - & - & 500 & 50 & - & - \\
\hline SMELT & - & $\overline{-}$ & - & - & $\begin{array}{r}12,000 \\
3,800\end{array}$ & $\begin{array}{l}4.738 \\
1.698\end{array}$ \\
\hline STURGEON, COMMON. $: \therefore$ & $\overline{-}$ & - & 500 & 146 & $:$ & - \\
\hline WHITING : . . . . . & - & - & 900 & & - & - \\
\hline WOLFFISH. • • • • • • & - & - & 6,600 & 1,001 & - & - \\
\hline UNCLASSIFIEO, FOR FOOO. • • & $y^{-}$ & - & 8.200 & 1,281 & 1,500 & 234 \\
\hline $\begin{array}{l}\text { CRABS, ROCK } \\
\text { LOBSTERS, AMERICAN: }: \vdots:\end{array}$ & 480,000 & 799,184 & - & - & - & $\overline{-}$ \\
\hline TOTAL. . . . . . . & 492,000 & 780,384 & $1,803,700$ & 290,494 & 71,900 & 16.635 \\
\hline
\end{tabular}

(CONT INUED ON NEXT PAGE) 


\section{NEW HAMPSHIRE - LANDINGS OF CATCH BY GEAR, 1975 - Continued}

\begin{tabular}{|c|c|c|c|c|c|c|}
\hline \multirow{2}{*}{ SPECIES } & \multicolumn{2}{|c|}{ LINES - CONT INUEO } & \multirow{2}{*}{\multicolumn{2}{|c|}{ DIP NETS, COMMON }} & \multirow{2}{*}{\multicolumn{2}{|c|}{ HARPODNS }} \\
\hline & \multicolumn{2}{|c|}{ LONG OR SET WITH HOOKS } & & & & \\
\hline $\begin{array}{l}\text { COO }:: \vdots: \\
\text { CUSK } \\
\text { HAOOOCK }::\end{array}$ & $\begin{array}{c}\text { POUNDS } \\
58,800 \\
91,400 \\
9,200 \\
22,700 \\
2,100 \\
12,400 \\
- \\
- \\
7,700 \\
3,800 \\
\end{array}$ & $\begin{array}{c}\text { DOLLARS } \\
12,669 \\
13,320 \\
6,853 \\
2,542 \\
2,368 \\
1,481 \\
- \\
- \\
105 \\
596 \\
\end{array}$ & $\begin{array}{c}\text { POUNDS } \\
= \\
= \\
= \\
= \\
4= \\
= \\
=\end{array}$ & $\begin{array}{c}\text { DOLLARS } \\
- \\
- \\
- \\
- \\
1, \pi T \\
- \\
-\end{array}$ & $\begin{array}{c}= \\
= \\
= \\
11,200 \\
=\end{array}$ & $\begin{array}{c}\text { DOLLARS } \\
- \\
\vdots \\
\vdots \\
- \\
5,310 \\
- \\
\end{array}$ \\
\hline TOTAL. . . . . . . & 201,100 & 39,934 & 4,500 & 1.77 & 11,200 & 5,310 \\
\hline SPECIES & \multicolumn{3}{|c|}{ SPEARS্ } & \multicolumn{3}{|c|}{ HOES } \\
\hline $\begin{array}{l}\text { EELS, COMMON. }: \cdots: \therefore \\
\text { SANOWORMS }:: \therefore:\end{array}$ & \multicolumn{2}{|c|}{$\frac{\text { POUNOS }}{1,800}$} & $\begin{array}{c}\text { DOLLARS } \\
732 \\
-\end{array}$ & \multicolumn{2}{|c|}{$\begin{array}{l}\frac{\text { POUNOS }}{-} \\
28,700\end{array}$} & $\begin{array}{c}\frac{\text { DOLLARS }}{-} \\
33,160\end{array}$ \\
\hline TOTAL. . . . . . . & \multicolumn{2}{|c|}{1,800} & 732 & \multicolumn{2}{|c|}{28,700} & 33,160 \\
\hline
\end{tabular}

\section{MASSACHUSETTS OPERATING UNITS BY GEAR, 1975}

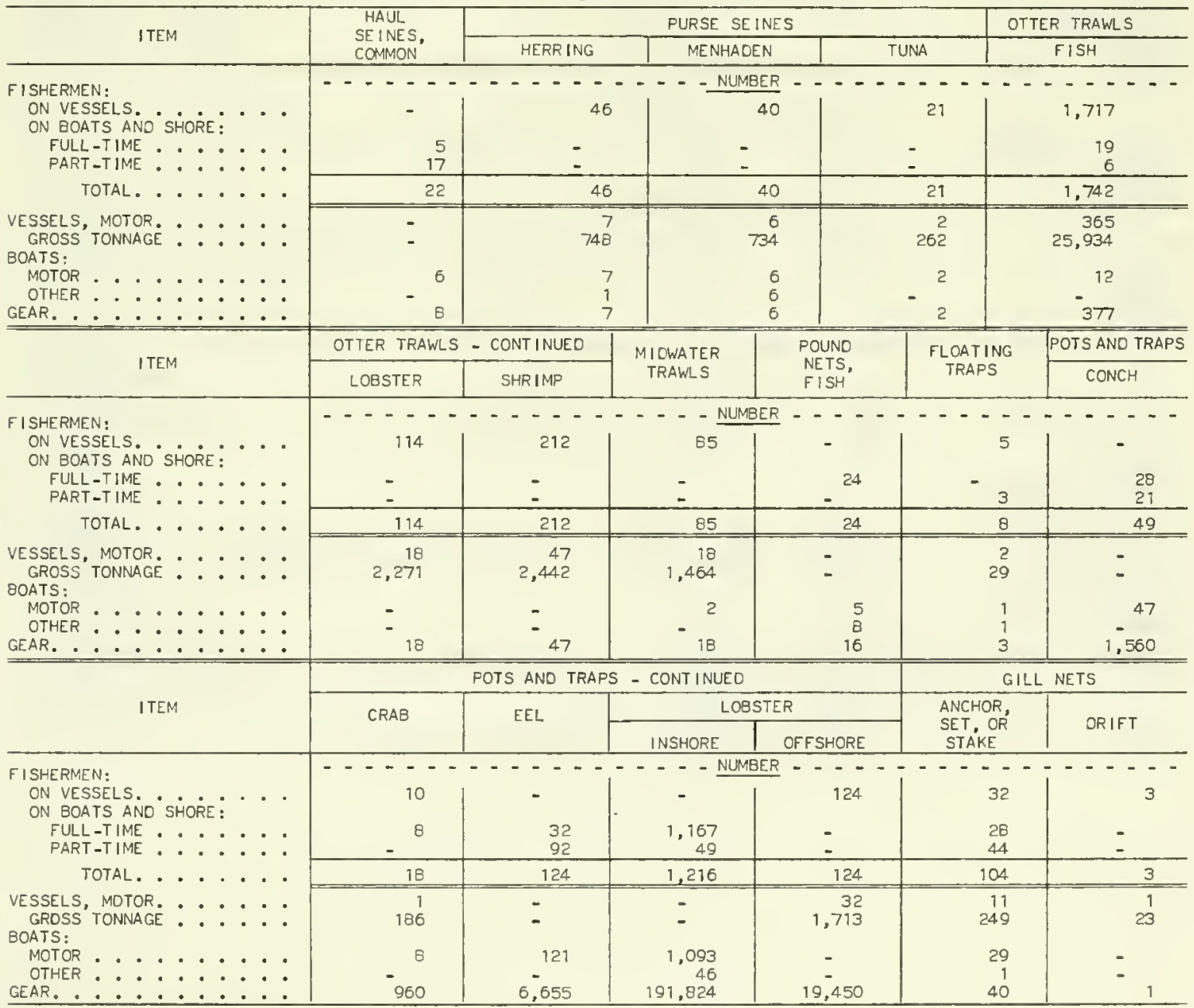


MASSACHUSETTS - OPERATING UNITS BY GEAR, 1975 - Continued

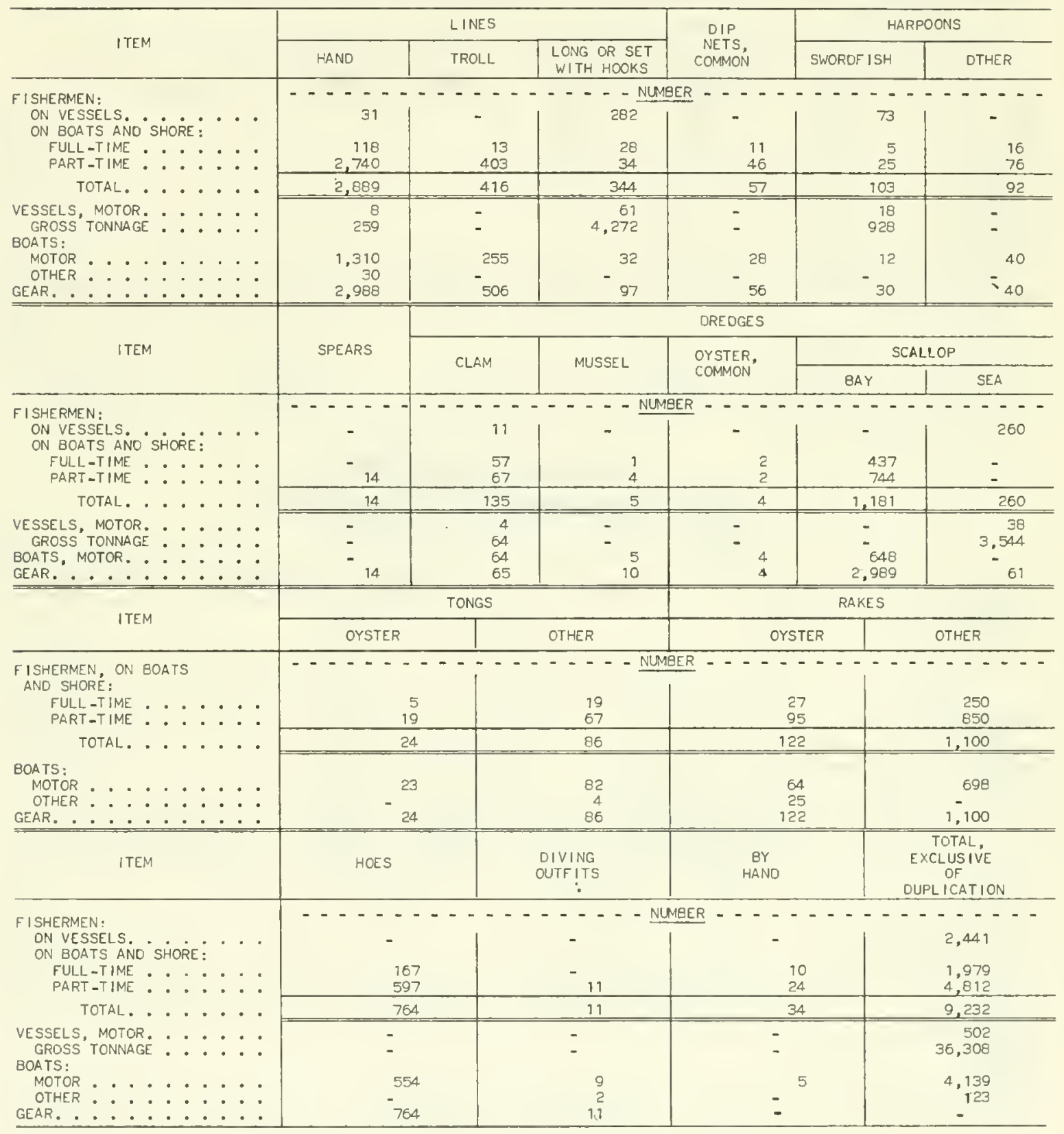




\section{MASSACHUSETTS - LANDINGS OF CATCH BY GEAR, 1975}

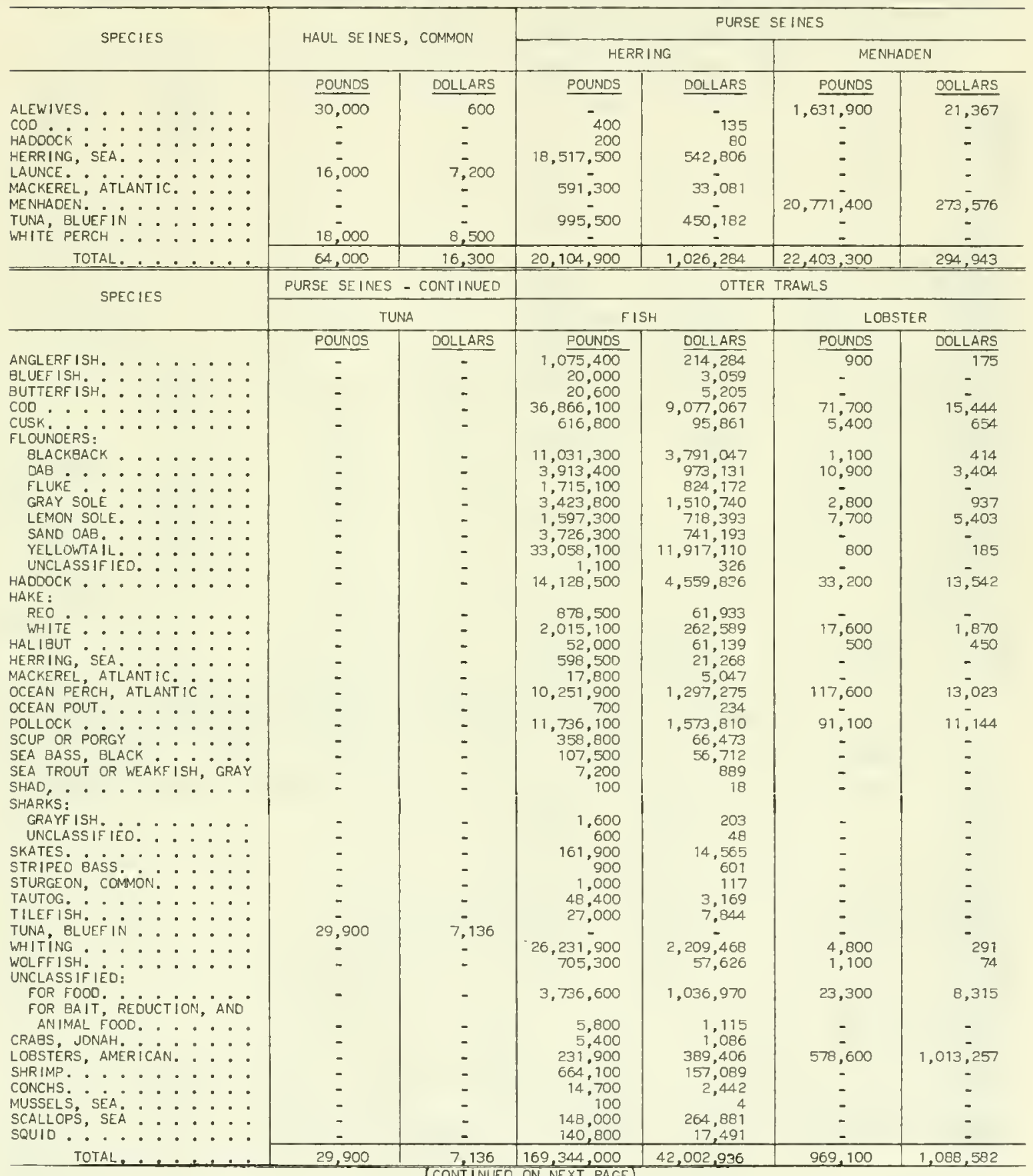




\section{MASSACHUSETTS - LANDINGS OF CATCH BY GEAR, 1975 - Continued}

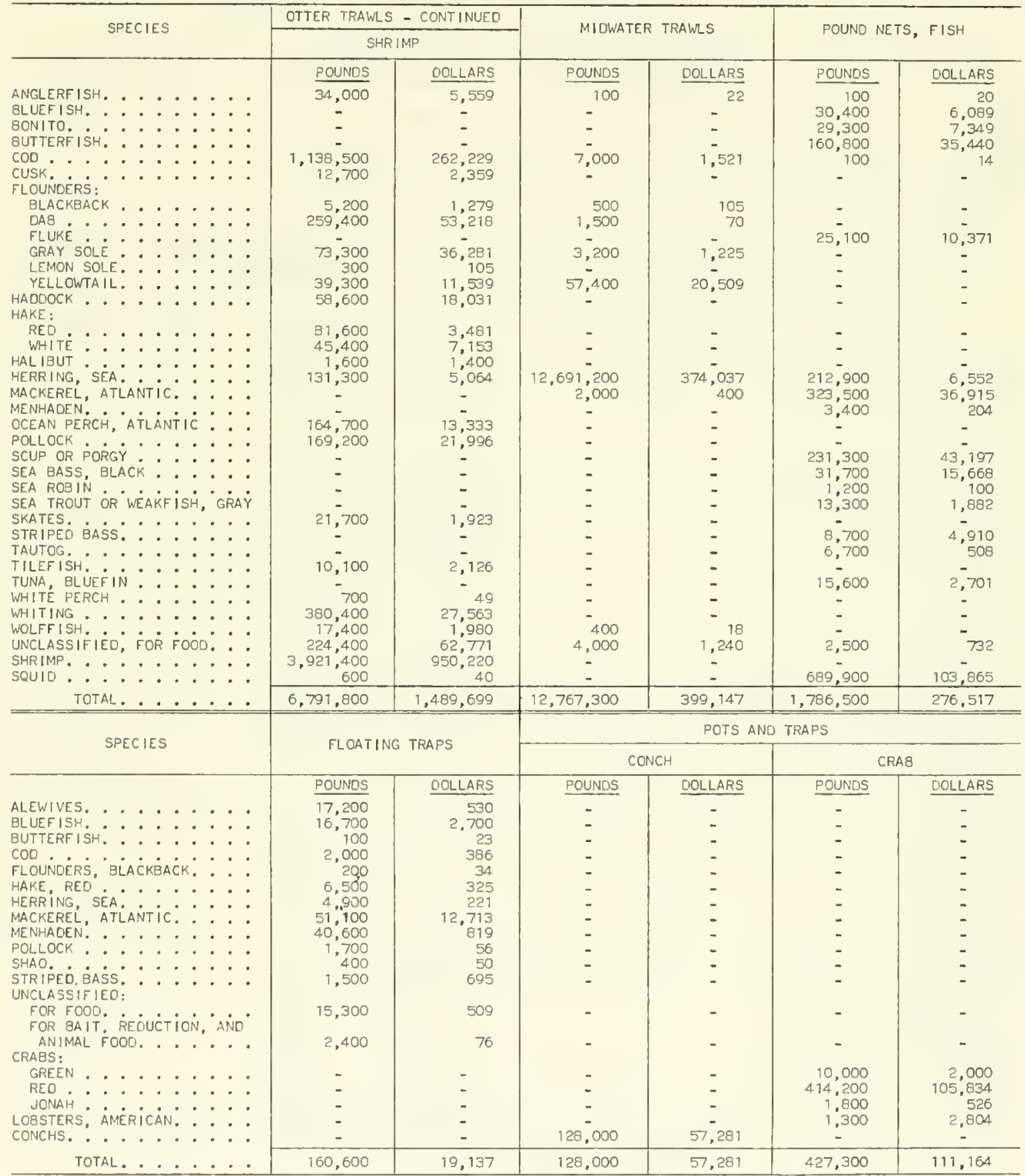

(CONT INUEO ON NEXT PAGE) 


\section{MASSACHUSETTS - LANDINGS OF CATCH BY GEAR, 1975 - Continued}

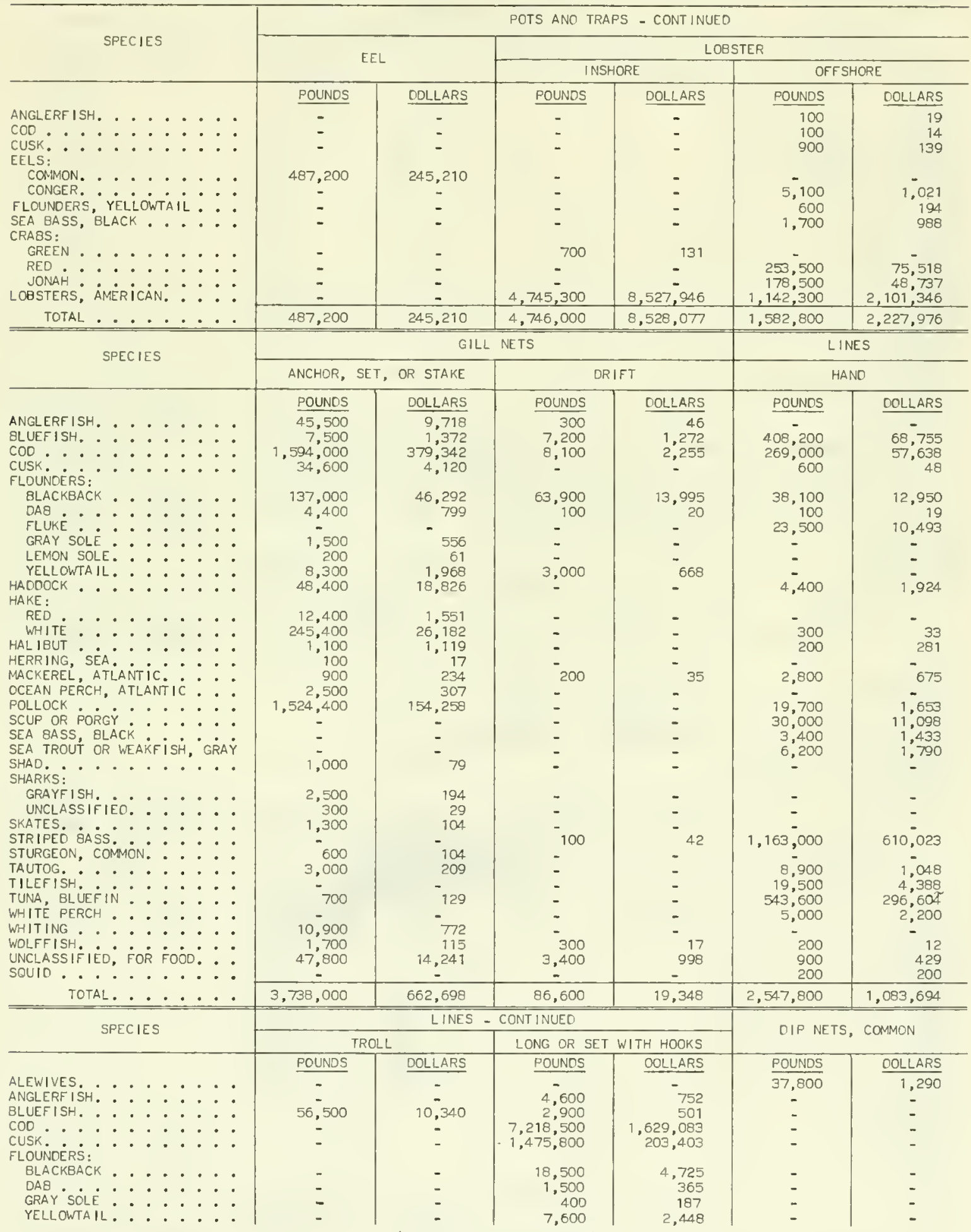

(CONTINUED ON NEXT PAGE) 


\section{MASSACHUSETTS - LANDINGS OF CATCH BY GEAR, 1975 - Continued}

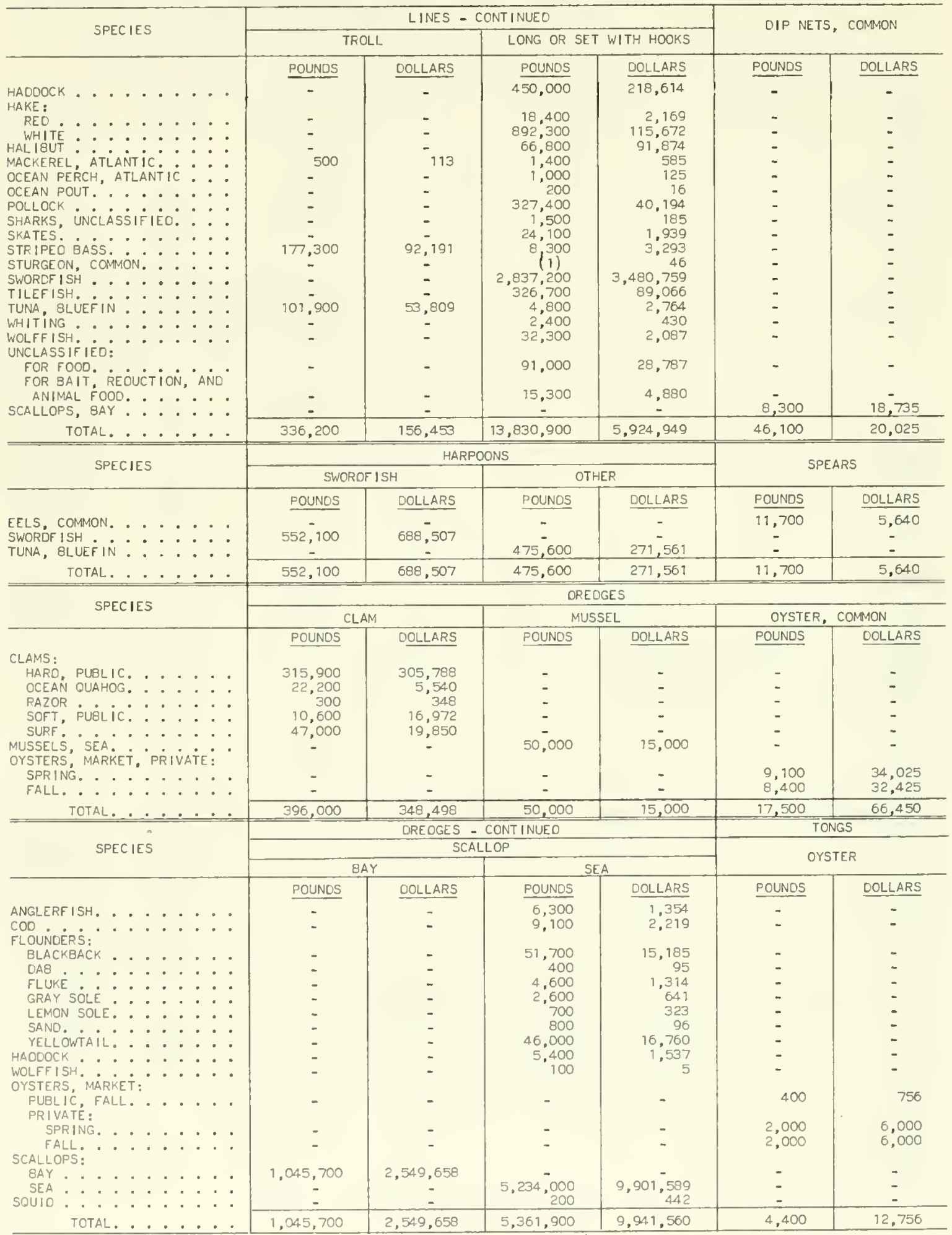


NEW ENGLAND FISHERIES

109

MASSACHUSETTS - LANDINGS OF CATCH BY GEAR, 1975 - Continued

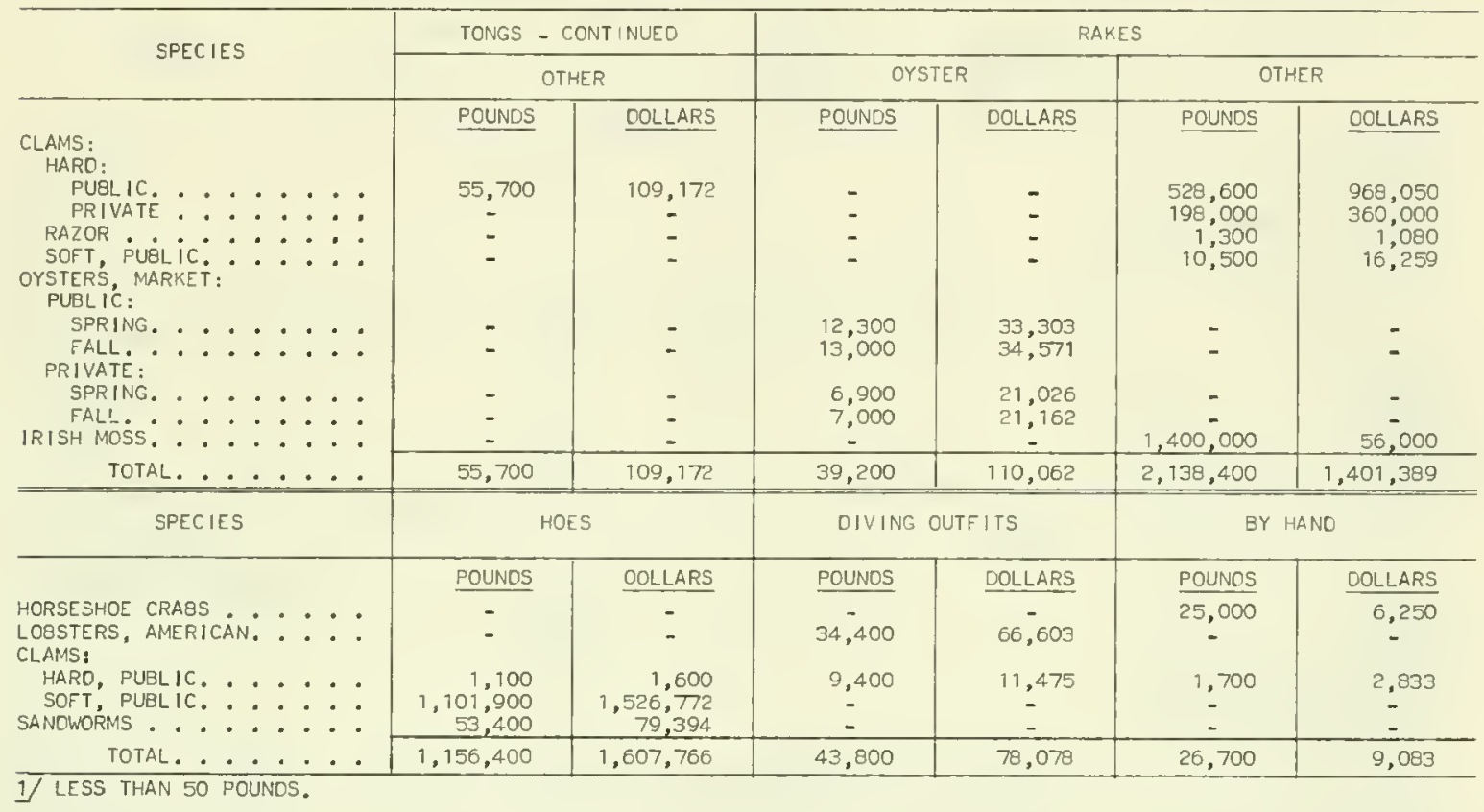




\section{RHODE ISLAND OPERATING UNITS BY GEAR, 1975}

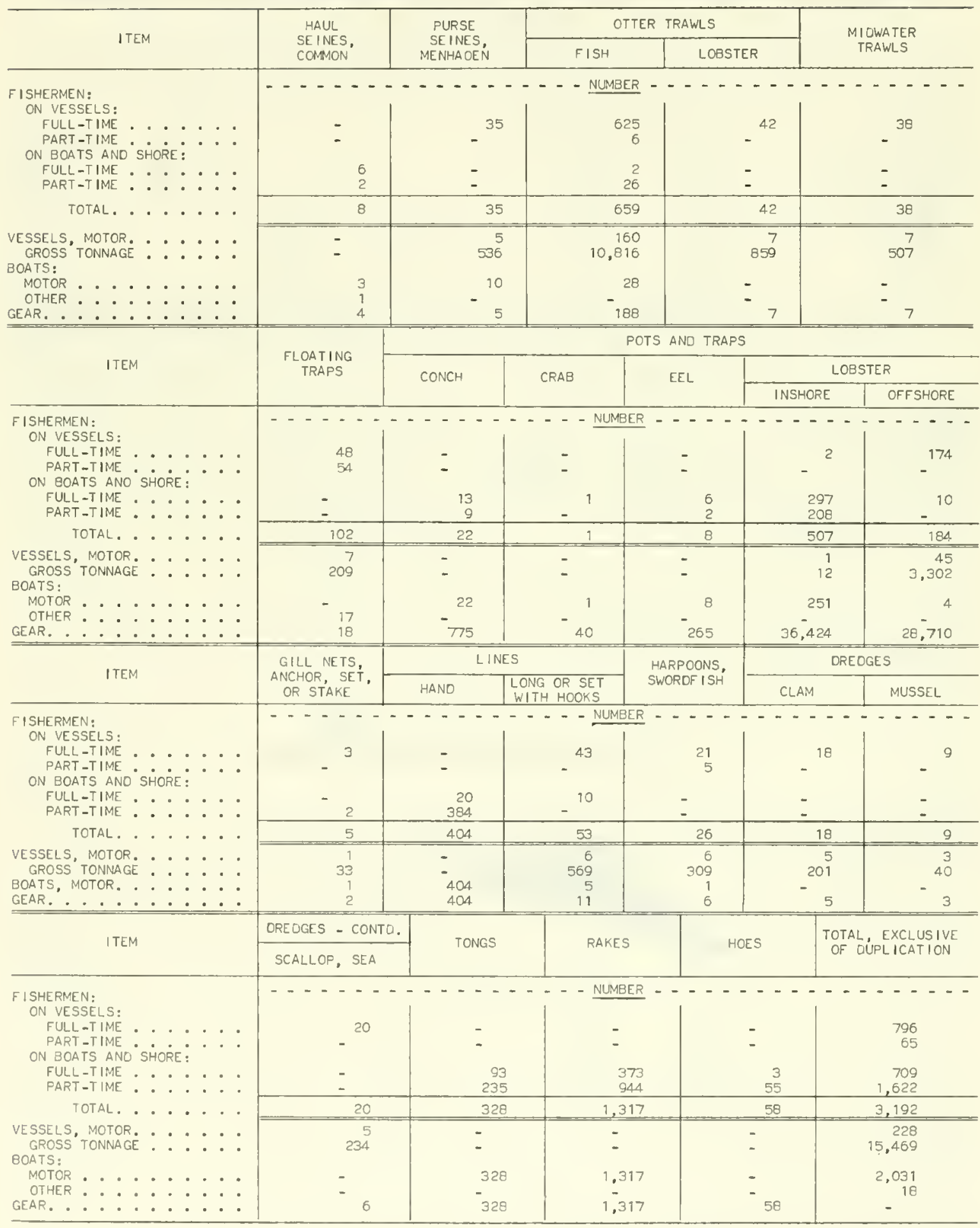


RHODE ISLAND - LANDINGS OF CATCH BY GEAR, 1975

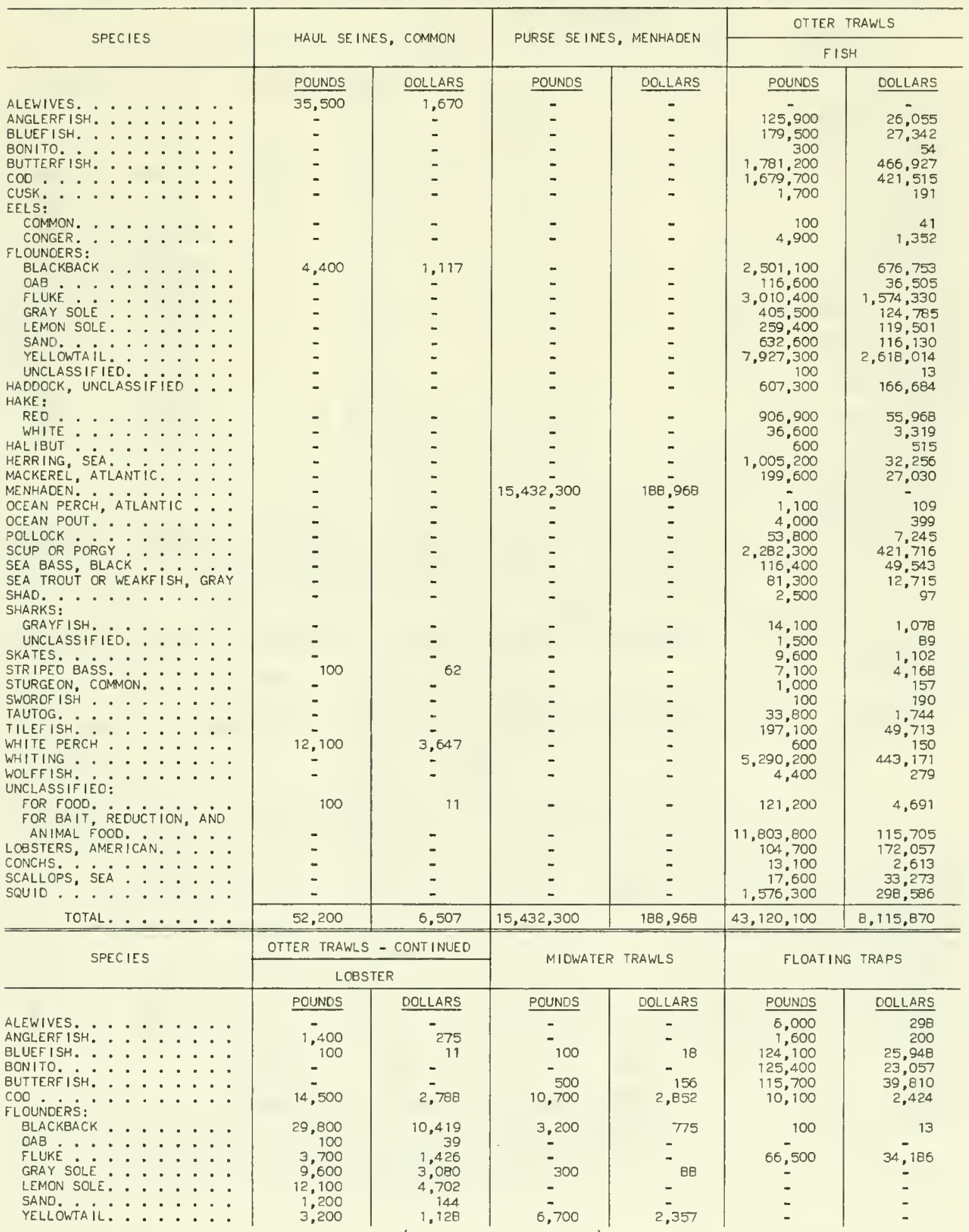




\section{RHODE ISLAND - LANDINGS OF CATCH BY GEAR, 1975 - Continued}

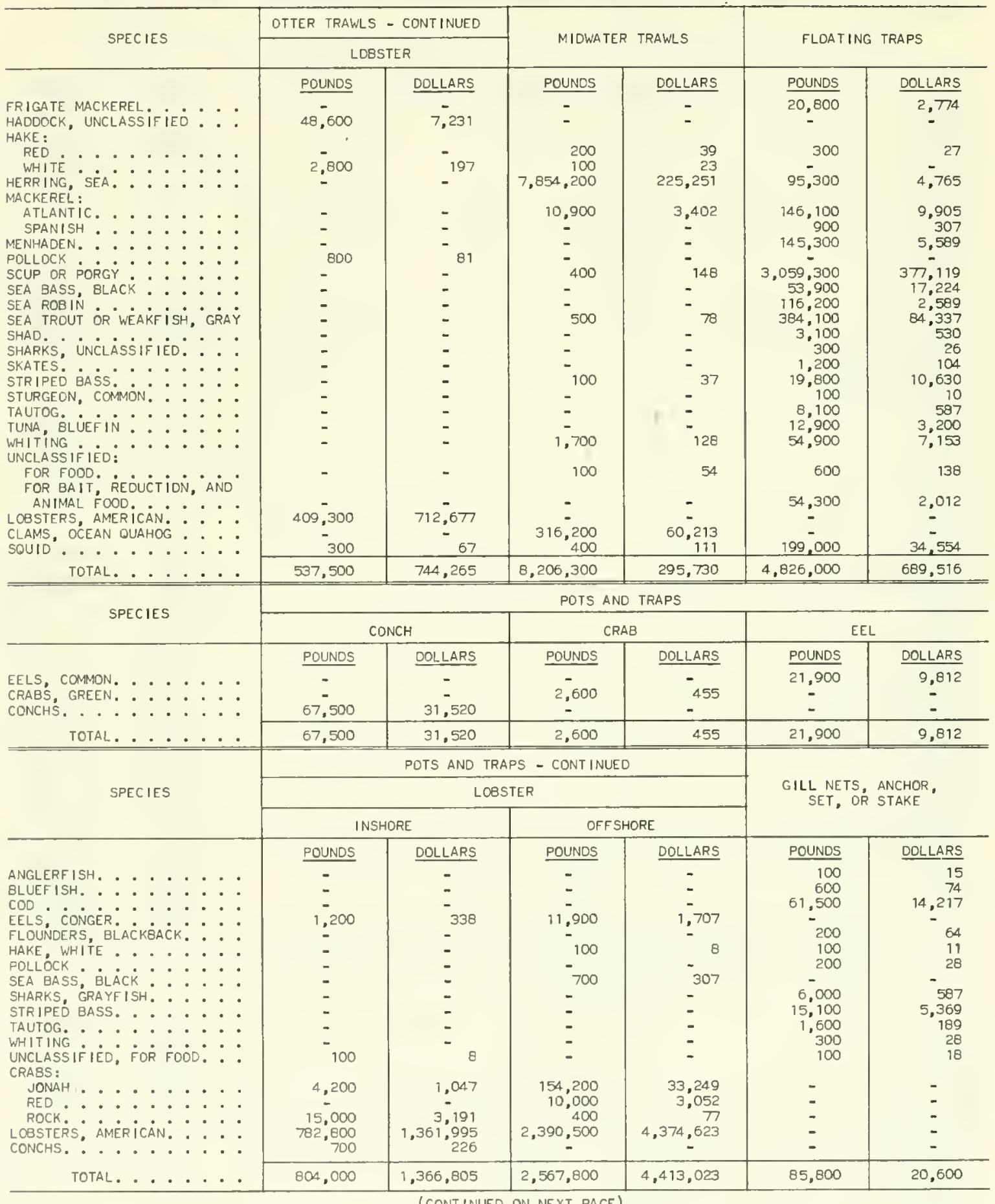


RHODE ISLAND - LANDINGS OF CATCH BY GEAR, 1975 - Continued

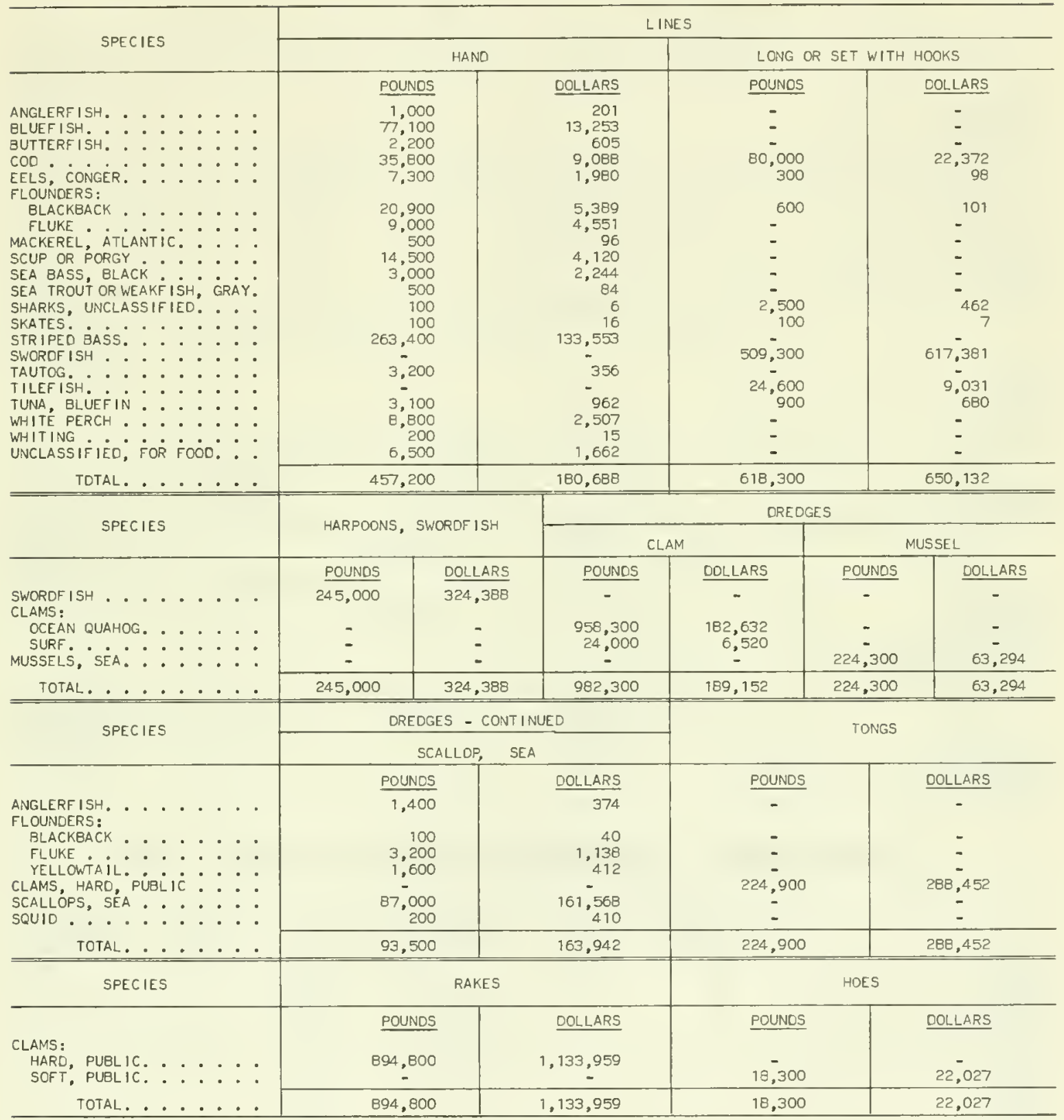




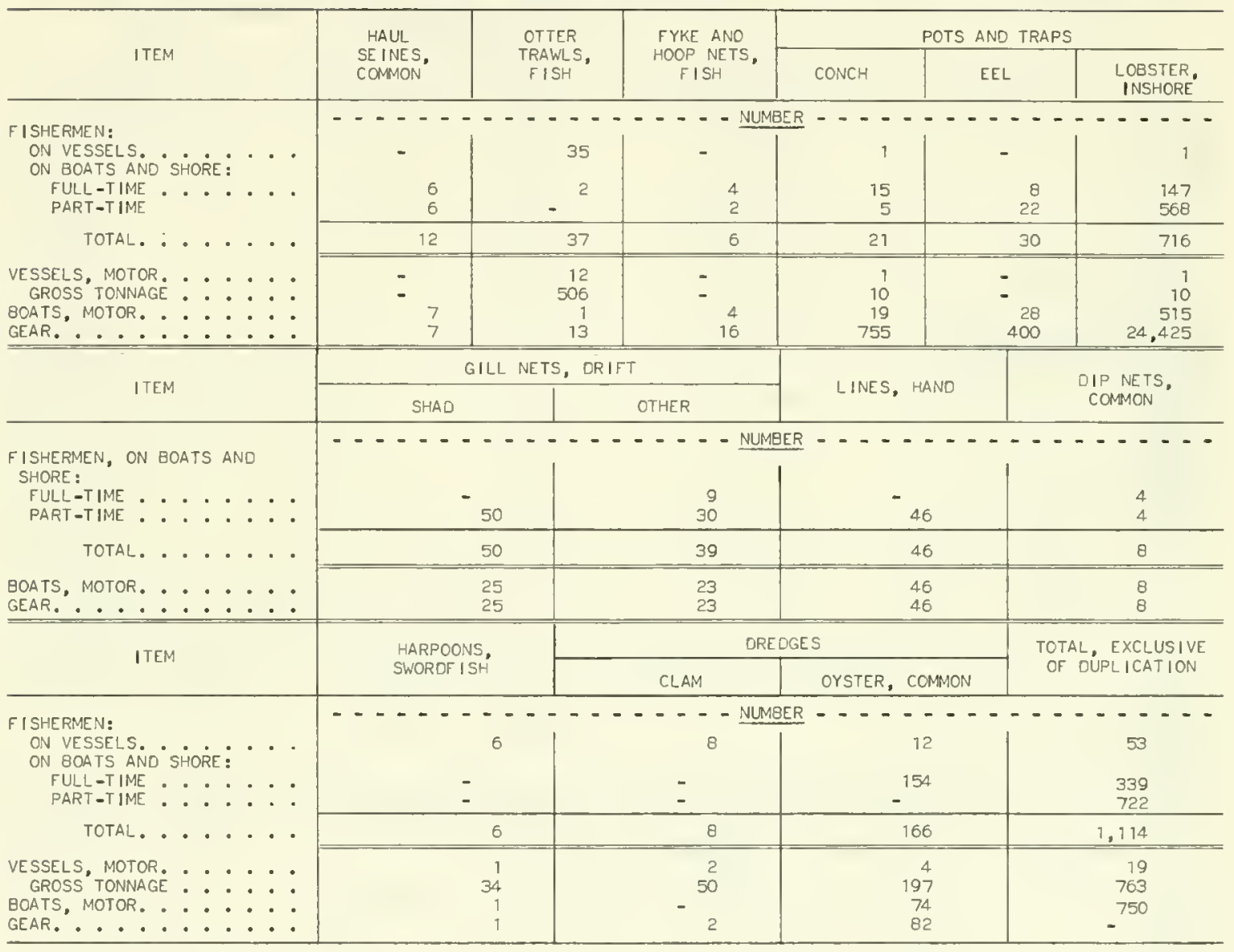

\section{CONNECTICUT - LANDINGS OF CATCH BY GEAR, 1975}

\begin{tabular}{|c|c|c|c|c|c|c|}
\hline SPECIES & HAUL SE & COMMON & OTTER T & FISH & FYKE ANO & NETS, FISH \\
\hline & POUNDS & DOLLARS & POUNDS & DOLLARS & POUNDS & DOLLARS \\
\hline ALEWIVES........ & 20,000 & 925 & - & - & 1.200 & 72 \\
\hline 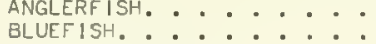 & - & - & $\begin{array}{l}4,600 \\
5,200\end{array}$ & $\begin{array}{l}715 \\
988\end{array}$ & $=$ & $=$ \\
\hline BUTTERF ISH. CATFISH & - & - & 7,900 & 1,967 & - & 110 \\
\hline COD & $=$ & - & 35,500 & 12,164 & - & - \\
\hline FLOUNOERS: & $x^{2}$ & 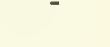 & 1.400 & 700 & & \\
\hline $\begin{array}{l}\text { BLACKBACK }: \therefore: \\
\text { DAB }: \cdots\end{array}$ & 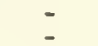 & 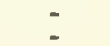 & $\begin{array}{r}42,000 \\
300\end{array}$ & $\begin{array}{r}10,652 \\
93\end{array}$ & $\overline{-}$ & $\overline{-}$ \\
\hline 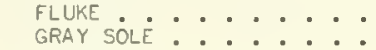 & - & - & $\begin{array}{r}38,400 \\
1,900\end{array}$ & 20,728 & - & - \\
\hline 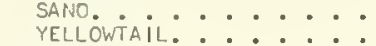 & 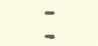 & - & $\begin{array}{l}5,700 \\
9,400\end{array}$ & $\begin{array}{r}229 \\
3,047\end{array}$ & $\overline{-}$ & - \\
\hline HAKE, REO . . . . . & 15.000 & - & -100 & -6 & - & - \\
\hline $\begin{array}{l}\text { SCUP OR PORGY } \\
\text { SEA OASS, BLACK }: \vdots: \vdots\end{array}$ & $=$ & $=$ & $\begin{array}{r}73,800 \\
4,000\end{array}$ & $\begin{array}{r}18,031 \\
1.646\end{array}$ & 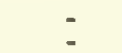 & $=$ \\
\hline $\begin{array}{l}\text { STURGEON COMMON: }: \vdots \vdots \\
\text { WH!TE PERCH } \\
\text { WHITING }\end{array}$ & 6,000 & 2,031 & $\begin{array}{r}300 \\
24,300 \\
22,700\end{array}$ & $\begin{array}{r}56 \\
7,086 \\
1,749\end{array}$ & 7,00 & 2,17 \\
\hline $\begin{array}{l}\text { FOR FOO. } \\
\text { FOR BAIT REOUCTION ANO }\end{array}$ & - & - & 23,900 & 8.797 & - & - \\
\hline $\begin{array}{l}\text { ANIMAL FOOO. } \because \cdots \\
\text { SQUID } \cdots\end{array}$ & 42,000 & 1,800 & $\begin{array}{r}811,600 \\
76,900\end{array}$ & $\begin{array}{r}40,580 \\
2,886\end{array}$ & 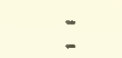 & $\overline{-}$ \\
\hline TOTAL. $\ldots \ldots$ & 83,000 & 5.442 & $1,129,300$ & 132,687 & 13,200 & 3,352 \\
\hline
\end{tabular}


CONNECTICUT - LANDINGS OF CATCH BY GEAR, 1975 - Continued

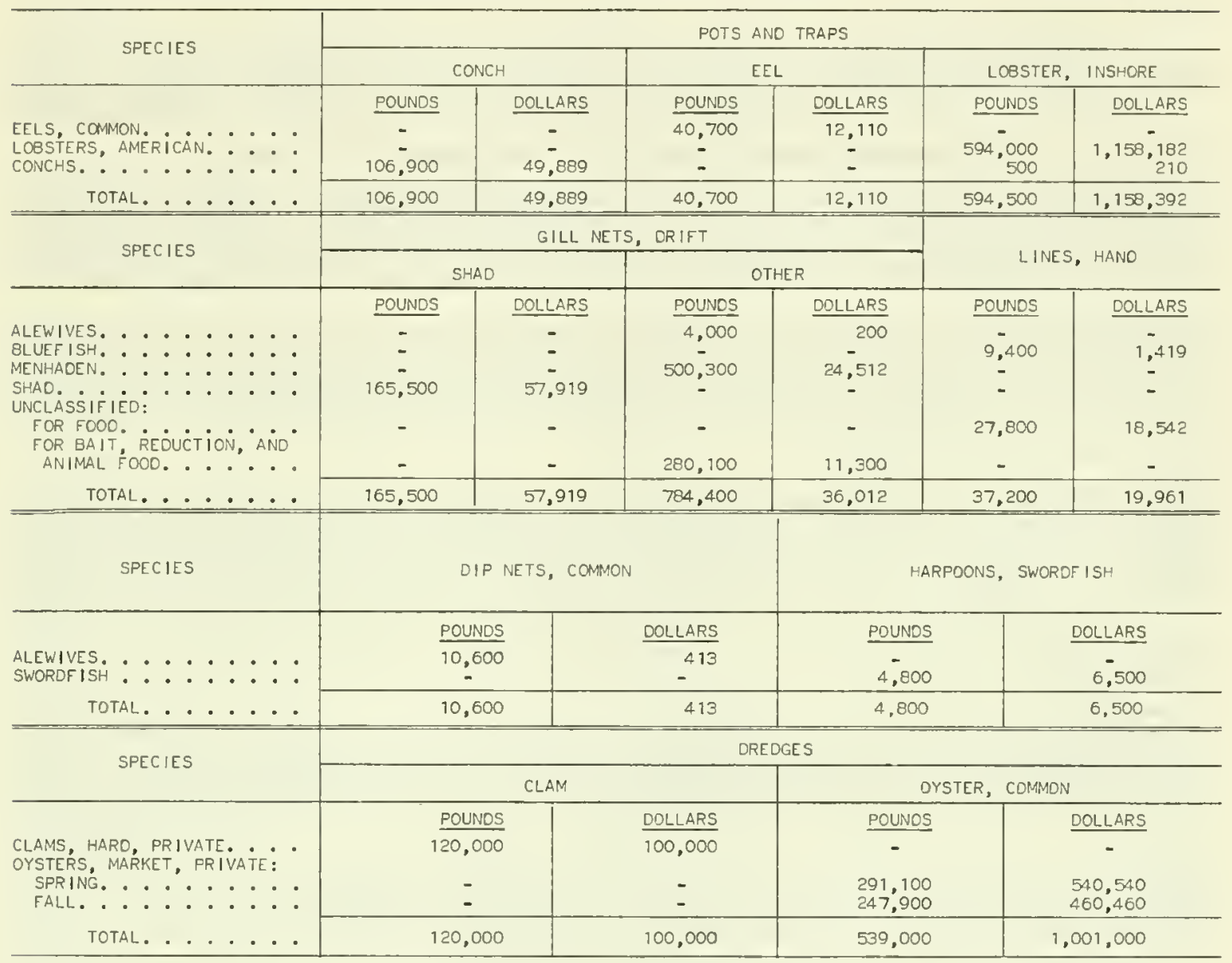




\section{MIDDLE ATLANTIC FISHERIES}

Commercial landings of fish and shellfish at ports in the Middle Atlantic States (New York, New Jersey, and Delaware) during 1975 were 188.1 million pounds valued at $\$ 49.8$ million at dockside. This was a 11 -percent decrease in volume, but a 14-percent increase in value compared with 1974 . Principal cause of the decline in landings was reduced menhaden catches in New Jersey. Among the species that had increased landings were fluke flounder, gray sea trout, scup, whiting, hard blue crabs, and surf clams.

Fishermen and vessels. There were 16,119 full-time and part-time commercial fishermen operating 492 vessels (5 net tons or more), 11,356 motorboats, and 40 other boats. This was an increase of 421 fishermen, 32 vessels, 306 motorboats, and 3 other boats compared with 1974. New York led in number of fishermen $(12,561)$ and motorboats $(9,452)$. New Jersey had the largest number of vessels $(303)$ and other boats (24).

Processed products. The total value of processed fishery products in the Middle Atlantic area (including Pennsylvania) was $\$ 221.2$ million-a decrease of $\$ 20.1$ million (9 percent) compared with 1974 . New York led with products valued at $\$ 74.0$ million, followed by New Jersey with $\$ 62.8$ million; Pennsylvania, $\$ 50.7$ million; and Delaware, $\$ 23.7$ million. An average of 6,144 persons a month were employed in 380 processing and wholesaling establishments operating in the four States-a decrease of 7 employees, but an increase of 3 seafood establishments over 1974.

Clams. Hard clams are the most valuable species of either shellfish or finfish in the Middle Atlantic States. Landings of hard clams yielded 10.3 million pounds of meats worth a record $\$ 16.0$ million-increases of 5 percent in both volume and value over 1974. New York accounted for 84 percent of the area total with landings of 8.7 million pounds of meats valued at $\$ 14.3$ million. This represented increases of 8 percent in volume and 7 percent in value over 1974. Great South Bay on Long lsland provided 90 percent of the New York landings and 76 percent of the Middle Atlantic landings. New Jersey landings yielded 1.6 million pounds, down 7 percent in volume from 1974. Landings were the smallest since 1963 and 26 percent below the average for the previous 5 years.

Surf clam landings yielded 42.4 million pounds of meats valued at $\$ 5.8$ million-increases of 31 percent in volume and 32 percent in value compared with 1974. New Jersey accounted for 84 percent of the landings with 35.6 million pounds-up 57 percent compared with 1974. During the latter half of the year many vessels that had been clamming off southern Virginia returned to New Jersey waters because of reduced landings in Virginia. Most New Jersey surf clams (81 percent) were taken within 3 miles off the beach in an area south of Atlantic City. New York landings of 4.6 million pounds increased 16 percent to the largest landings since 1949. All the New York landings were taken within 3 miles of the beach. Delaware landings were 2.3 million pounds in 1975 , down 60 percent from the previous year and 31 percent below the 1970-74 average. Vessels made only intermittent landings there this year, because they began to land more trips in New Jersey.

Soft clam landings yielded 232,000 pounds of meats valued at $\$ 217,000$-increases of 23 percent in volume and 17 percent in value over the 1974 production. New Jersey landings increased 94 percent in volume compared to 1974 , because of the operation of a new depuration plant allowing the harvesting of soft clams from impure waters. New York landings $(63,000$ pounds) declined 38 percent compared with 1974 .

Hard blue crabs. Landings reached 6.4 million pounds valued at a record $\$ 1.4$ million-gains of 29 percent in quantity and 33 percent in value over the 1974 catch. Landings were the largest since 1950 and 85 percent above the average for the previous 5 years. Landings in all three States were higher than they had been for years. Delaware with 3.6 million pounds increased 58 percent, the highest landings since 1957. New Jersey landings of 2.9 million pounds increased 5 percent over the 1974 total, the highest since 1939. New York landings were 16,000 pounds in 1975 compared with 3,000 pounds in 1974 . The average price per pound paid to fishermen declined 2 cents per pound in New Jersey and 8 cents in New York, but increased 4 cents in Delaware.

Other Species. Landings of sea trout were 6.0 million pounds valued at $\$ 868,000-$ increases of 37 percent in volume and 21 percent in value over 1974. New Jersey fishermen landed 72 percent of the catch in the area. Trawlers landing at Cape May accounted for 68 percent of the New Jersey sea trout landings. Bluefish landings, 2.2 million pounds valued at $\$ 352,000$, increased 5 percent in volume and 34 percent in value compared with 1974. New Jersey with 1.3 million pounds or 59 percent of the total bluefish landings increased 28 percent in volume; New York with 889,000 pounds declined 17 percent. Landings in Delaware 
increased from 6,000 pounds to 15,000 pounds. Landings of butterfish were 2.1 million pounds valued at $\$ 484,000$ an 18 -percent increase in volume and 11 percent in value over 1974. Landings of Atlantic mackerel of 1.9 million pounds valued at $\$ 206,000$ were up 69 percent in volume and 39 percent in value compared with 1974. Striped bass landings were 1.6 million pounds valued at $\$ 857,000-$ a 30 -percent decline in volume, but an 11-percent increase in value compared with 1974. Squid landings, 1.5 million pounds valued at $\$ 308,000$, declined 33 percent in volume and 26 percent in value compared with 1974.

Flounders. Landings of all species of flounders were 9.7 million pounds valued at $\$ 3.4$ million, up 10 percent in quantity and 36 percent in value compared with 1974. Fluke or summer flounder was 78 percent of the total flounder landings in the area. Landings were a record 7.6 million pounds worth $\$ 2.9$ million-increases of 26 percent in quantity and 47 percent in value over 1974. Landings of yellowtail flounder were 1.4 million pounds valued at $\$ 364,000-$ down 32 percent in quantity and 12 percent in value compared with 1974 . From 1967 to 1973 yellowtail had been the most prominent species of flounder landed in the Middle Atlantic region.

American lobsters. Landings were 1.5 million pounds valued at $\$ 3.0$ million-declines of 21 percent in volume and 11 percent in value compared with 1974. Landings were the lowest since 1966. New Jersey landings (851,000 pounds) declined 29 percent below 1974 and 39 percent below the previous 5-year average. New York lobster landings $(669,000$ pounds) declined 8 percent.

Menhaden. Landings of 67.0 million pounds were 40.9 million pounds ( 38 percent) less than in 1974 . For the past 3 years (1972-74), landings had averaged over 100 million pounds of menhaden a year. New Jersey with 65.9 million pounds accounted for 98 percent of the production, mostly by purse seines. The New Jersey fishery had six purse seiners in 1975, three less than the previous year. Landings in New York (1.1 million pounds) increased 87 percent. Pound nets took 76 percent of the landings in New York, the rest were taken by gill nets. The 20,000 pounds landed in Delaware were taken by gill nets. Menhaden landed in New York and Delaware are used mostly for bait.

Oysters. Total landings yielded 3.3 million pounds of meats valued at $\$ 6.3$ million. Compared with 1974 , this was an increase of 20 percent in volume and 28 percent in value. Landings increased 36 percent in New York and 11 percent in Delaware, but declined 4 percent in New Jersey. New York with 2.1 million pounds of meats accounted for 64 percent of the volume and 82 percent of the value in the area. This is the eighth year of increased oyster production in New York attributed to aquaculture operations. New Jersey oyster landings of 972,000 pounds of meats was a 4-percent decline in volume and 12 percent in value from 1974 . A shortage of seed oysters is contributing to reduced landings. Landings of seed oysters in Delaware decreased 68 percent in quantity.

Scallops. Landings of bay scallops yielded 444,000 pounds of meats valued at $\$ 713,000-a$ decline of 36 percent in volume and 18 percent in value compared with 1974. New York was the only State which had a production of bay scallops in 1975. Mast of the landings were made from Gardiners and Peconic Bays by dredgers. Fishermen received $\$ 1.70$ to $\$ 2.00$ per pound (of meats) in the fall and $\$ 1.25$ to $\$ 1.40$ in the spring.

Landings of sea scallops yielded 981,000 pounds of meats worth $\$ 1.8$ million-increases of 84 percent in volume and 118 percent in value over 1974. New Jersey vessels accounted for 72 percent of the total catch in 1975 compared with 61 percent in 1974. The practice of catching the scallops by trawler and landing them in the shell to be shucked ashore contributed to the rise in New Jersey landings. About 52 percent of the New Jersey sea scallops were taken by trawler in 1975 compared with only 2 percent in 1974 . The New York landings were all by dredge vessels at New York City.

Scup. Landings were 10.1 million pounds valued at $\$ 2.5$ million, a 4 -percent increase in quantity and 42 percent in value over 1974. Landings were the largest since 1965 and 79 percent higher than the average for the previous 5 years. Average exvessel prices rose from 18 cents per pound in 1974 to 24 cents in 1975 . New Jersey landings (6.3 million pounds) increased 4 percent over 1974 and New York landings ( 3.8 million pounds) increased 5 percent.

Tuna. Landings of all species were 2.5 million pounds valued at $\$ 633,000$, increases of 184 percent in volume and 167 percent in value over 1974. Landings were the second best harvest since the inception of the tuna purse seine fishery in 1963. Of the total landings, 99 percent were bluefin tuna. Three purse seine vessels made 13 trips this year, 1 more trip than in 1974, with all landings made at Cape May, New Jersey. 
Whiting. Landings were 9.1 million pounds worth $\$ 961,000$, a 1 -percent gain in volume and 15 percent in value over 1974. New Jersey with 6.5 million pounds or 71 percent of the total landings declined 8 percent. The leading ports in New Jersey for whiting were Point Pleasant (59 percent of the catch) and Belford (28 percent). Landings in New York (2.6 million pounds) increased 33 percent compared with 1974; Delaware increased from 8,000 pounds to 13,000 pounds.

Other information. Condensed summary data on the operating units and landings, by States, appearing on the following pages, have been published previously in Current Fishery Statistics No. 7406. Additional data may be found in the monthly and annual landings bulletins for New York and New Jersey published in the Current Fishery Statistics series by the Data Management and Statistics Division in cooperation with the respective States.

Acknowledgments. The following organizations helped collect the data appearing in the section: New York Department of Environmental Conservation, Division of Marine and Coastal Resources; New Jersey Department of Environmental Protection, Division of Fish, Game, and Shellfisheries; and Delaware Department of Natural Resources and Environmental Control, Division of Fish and Game.

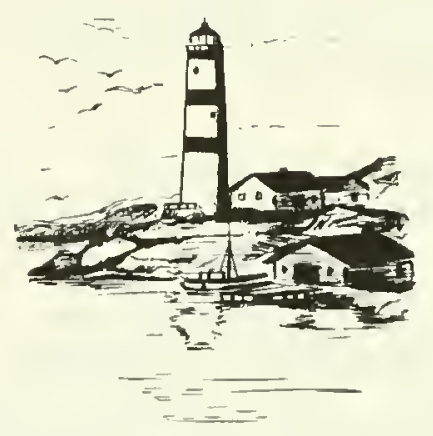



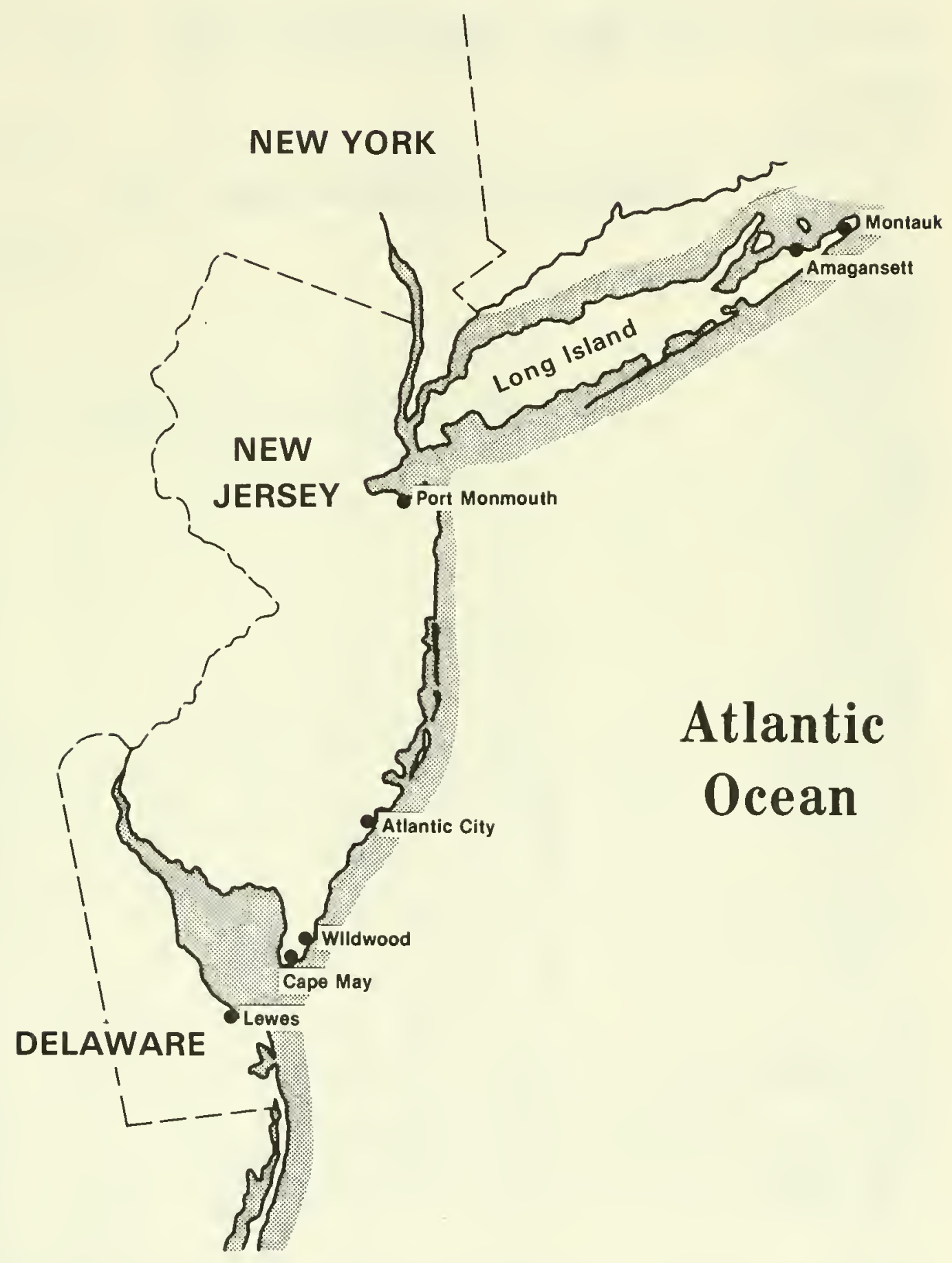
SECTIONAL SUMMARIES

SUMMARY OF LANDINGS, 1975

\begin{tabular}{|c|c|c|c|c|c|c|c|}
\hline \multicolumn{2}{|c|}{ STATE } & \multicolumn{2}{|c|}{ FISH } & \multicolumn{2}{|c|}{ SHELLF ISH ET AL. } & \multicolumn{2}{|c|}{ TOTAL } \\
\hline & & $\frac{\text { MTLL ION }}{\text { POUNOS }}$ & $\frac{\text { MILL I ON }}{\text { DOLLARS }}$ & $\frac{\text { MILL ION }}{\text { POUNDS }}$ & $\frac{\text { MILL ION }}{\text { DOLLARS }}$ & $\frac{\text { MILLION }}{\text { POUNOS }}$ & $\frac{\text { MILLLION }}{\text { DOLLARS }}$ \\
\hline $\begin{array}{l}\text { NEW YORK. } \\
\text { NEW JERSEY. } \\
\text { OELAWARE. }\end{array}$ & 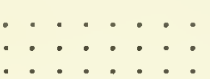 & $\begin{array}{r}20 \\
99 \\
1\end{array}$ & $(1)^{9}$ & $\begin{array}{r}18 \\
44 \\
6 \\
\end{array}$ & $\begin{array}{r}23 \\
11 \\
2\end{array}$ & $\begin{array}{r}37 \\
144 \\
7\end{array}$ & $\begin{array}{r}28 \\
20 \\
2\end{array}$ \\
\hline TOTAL &.. .5. & 120 & 14 & 68 & 36 & 188 & 50 \\
\hline
\end{tabular}

1) LESS THAN $\$ 500,000$. NOTE:--TABLE MAY NOT ADD 8ECAUSE OF ROUNOING.

\section{SUMMARY OF OPERATING UNITS, 1975}

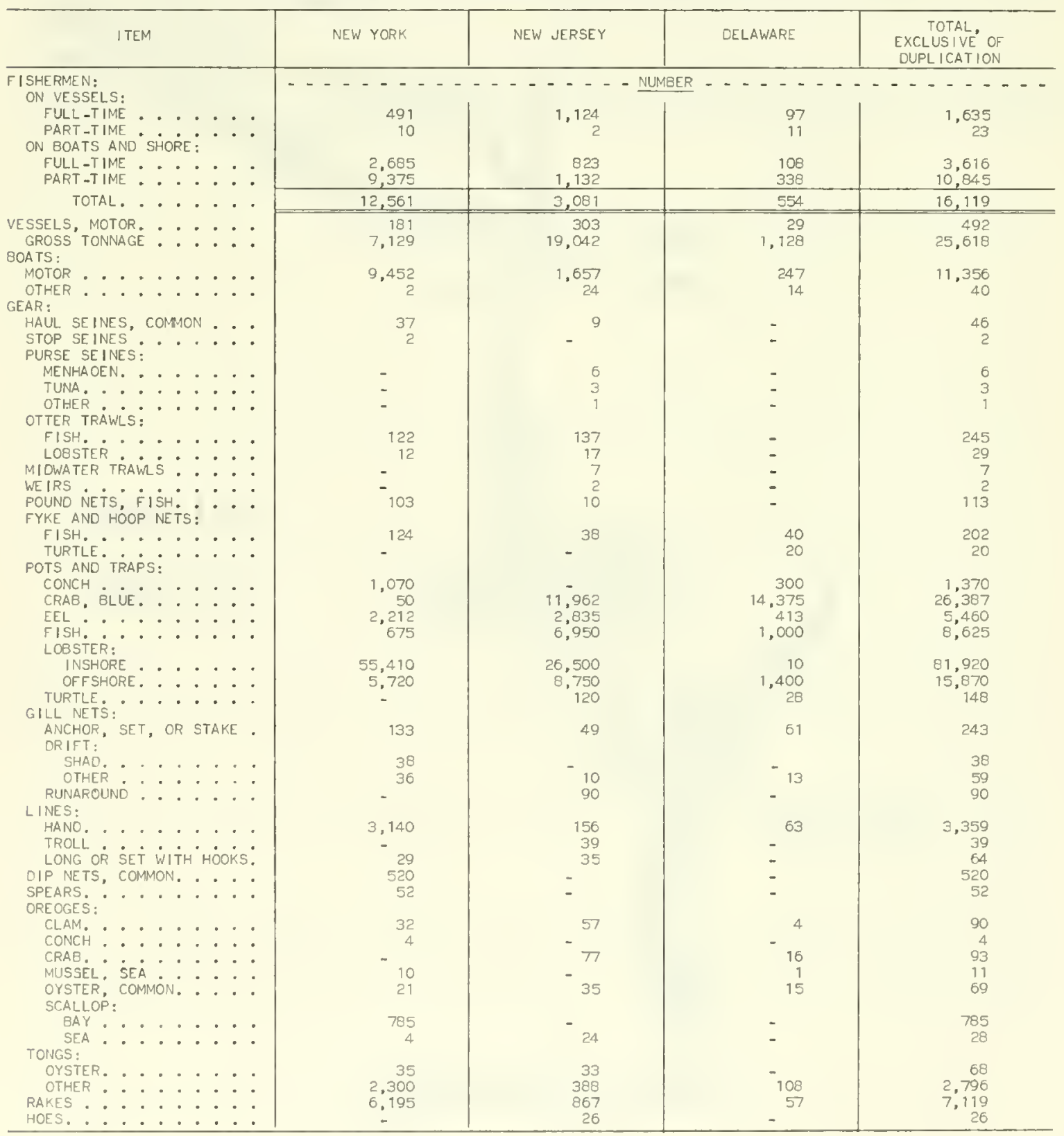


LANDINGS BY STATES, 1975

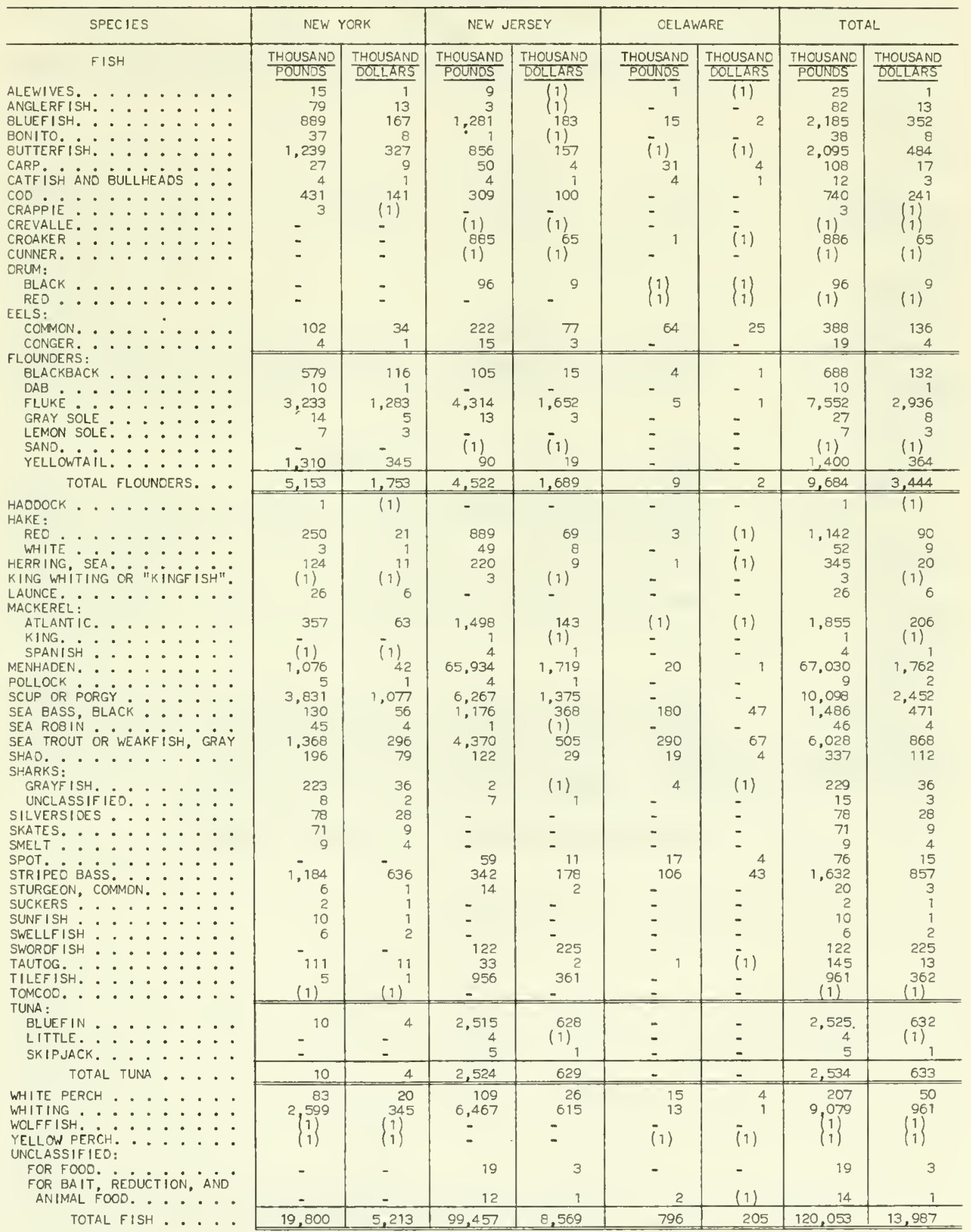

SEE FOOTNOTES AT END DF TAELE. 
LANDINGS BY STATES, 1975 - Continued

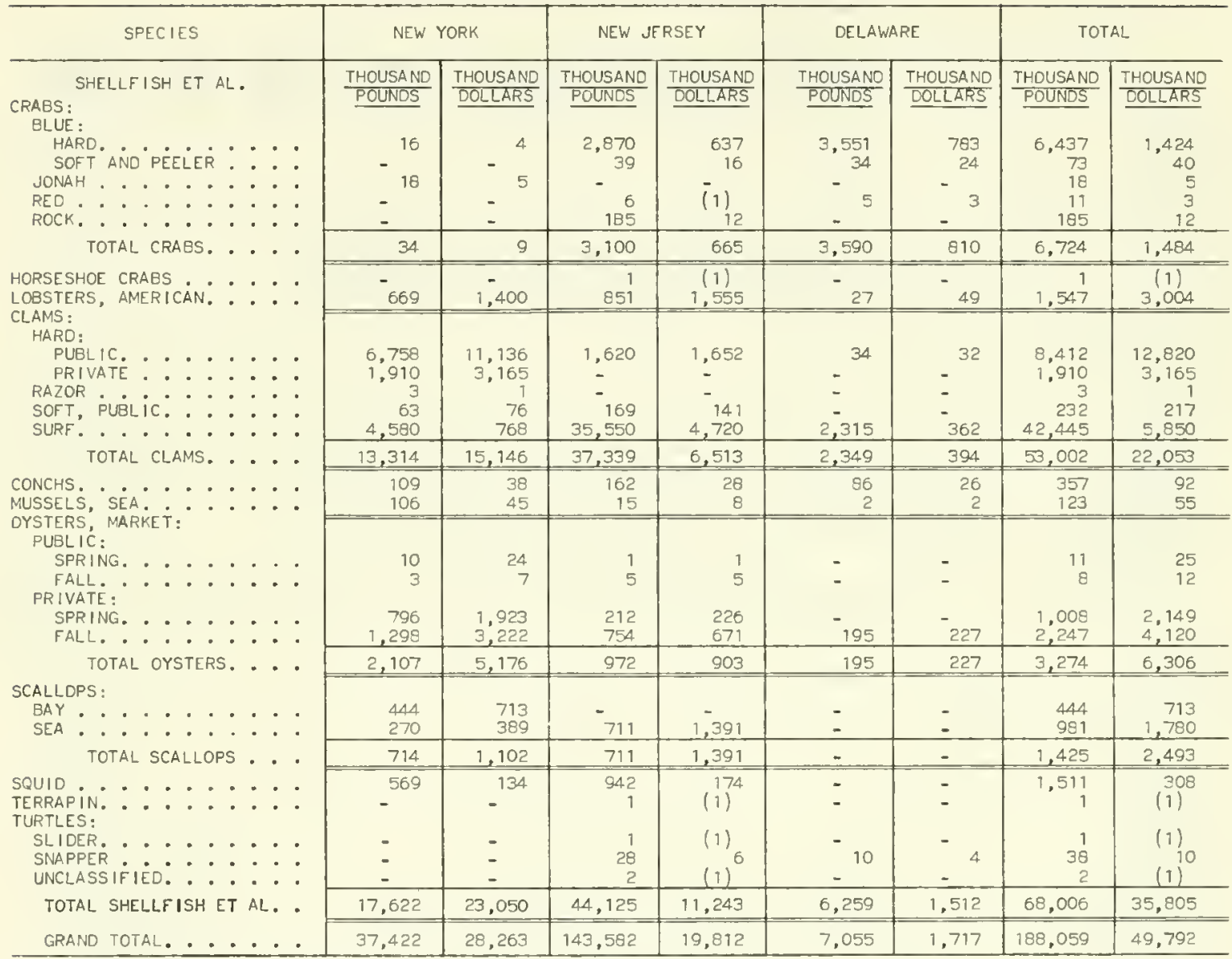

1 LESS THAN 500 POUNDS OR $\$ 500$.

NOTE:--LANOINGS ARE SHOWN IN ROUND (LIVE) WEIGHT EXCEPT FOR SHELL MOLLUSKS. CLAMS, CONCHS, MUSSELS, AND OYSTERS ARE REPORTED IN WEIGHT DF TOTAL MEATS; SCALLOPS ARE REPORTED IN WEIGHT OF EDIBLE MEATS. 
LANDINGS OF CERTAIN SHELLFISH, 1975

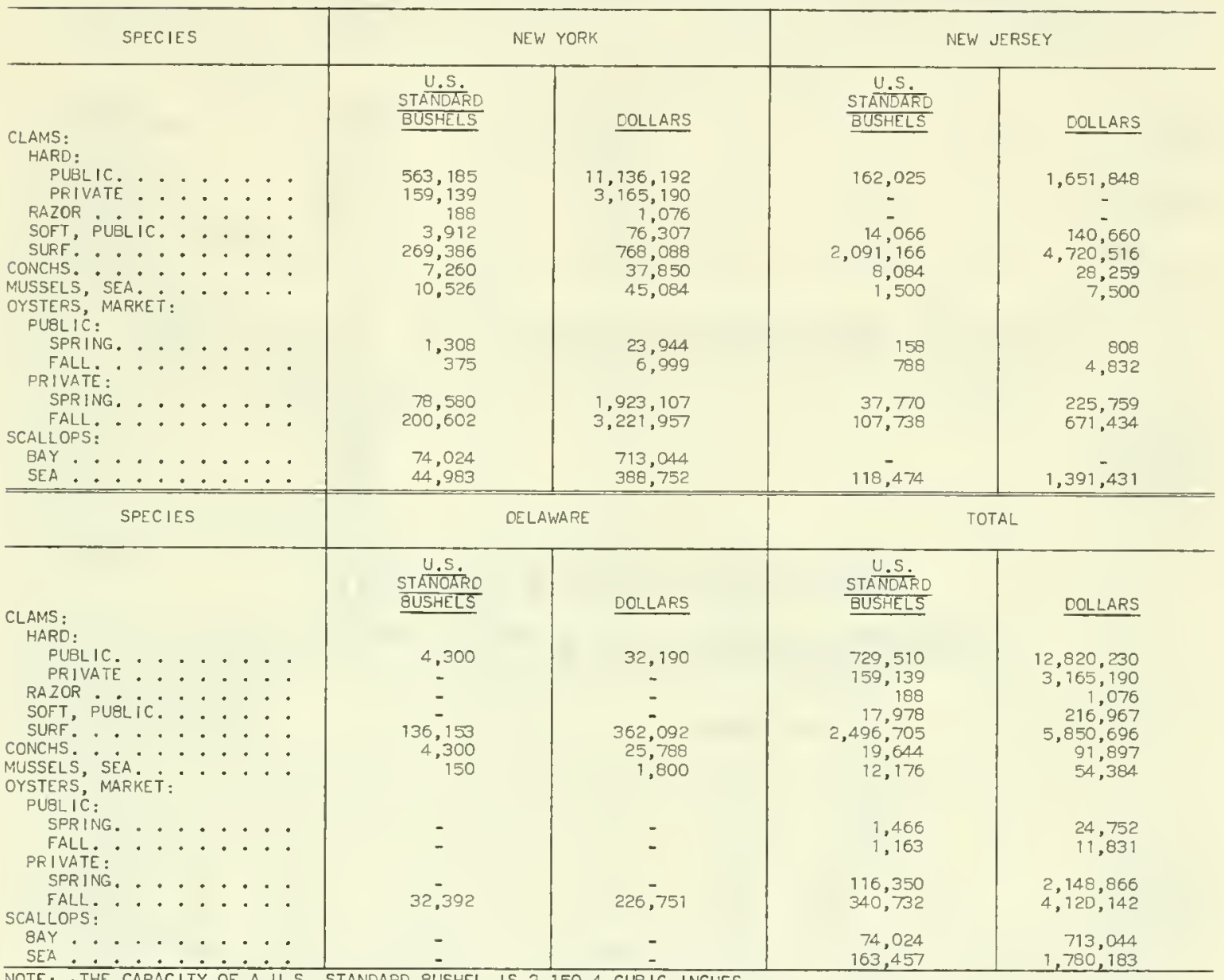

AVERAGE YIELD OF CERTAIN SHELLFISH, 1975

\begin{tabular}{|c|c|c|c|}
\hline SPECIES & NEW YORK & NEW JERSEY & DELAWARE \\
\hline 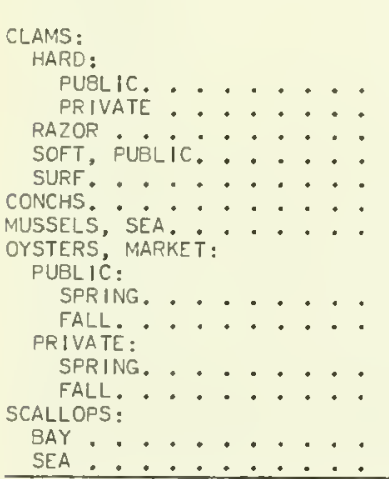 & $\begin{array}{l}12.00 \\
12.00 \\
16.00 \\
16.00 \\
17.00 \\
15.00 \\
10.00 \\
\\
7.50 \\
7.50 \\
7.50 \\
7.50 \\
6.00 \\
6.00\end{array}$ & $\begin{array}{l}\text { ATS PER U.S. } \\
10.00 \\
- \\
12.00 \\
17.00 \\
20.00 \\
10.00 \\
\\
5.70 \\
7.00 \\
5.70 \\
7.00 \\
- \\
6.00\end{array}$ & $\begin{array}{l}8.00 \\
\vdots \\
17.00 \\
20.00 \\
10.00 \\
\vdots \\
- \\
\overline{6} .02 \\
\vdots\end{array}$ \\
\hline
\end{tabular}

NOTE: --THE CAPACITY OF A U.5. STANDARD BUSHEL IS 2,150.4 CUBIC INCHES. 


\section{SUMMARY OF PROCESSED PRODUCTS, 1975}

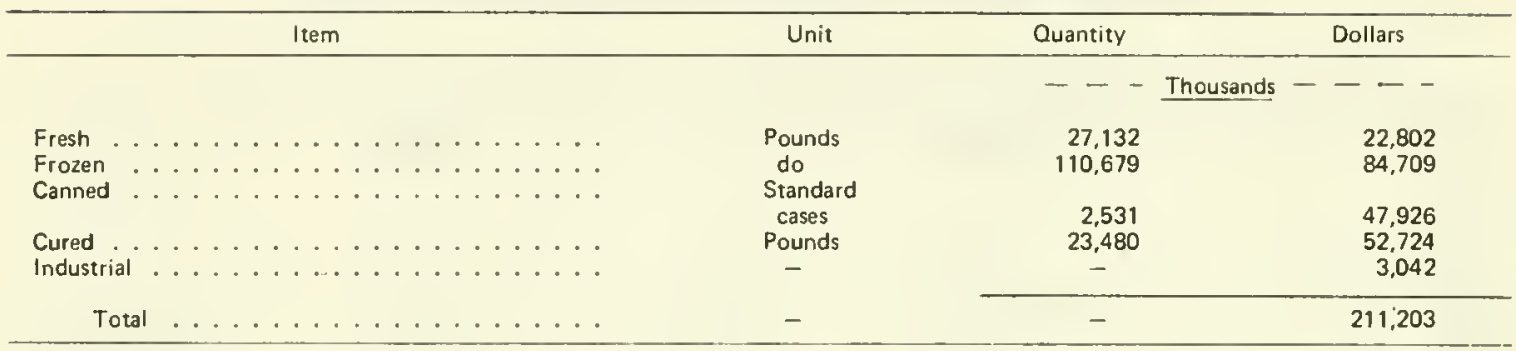

\section{VALUE OF PROCESSED PRODUCTS, BY STATES, 1975}

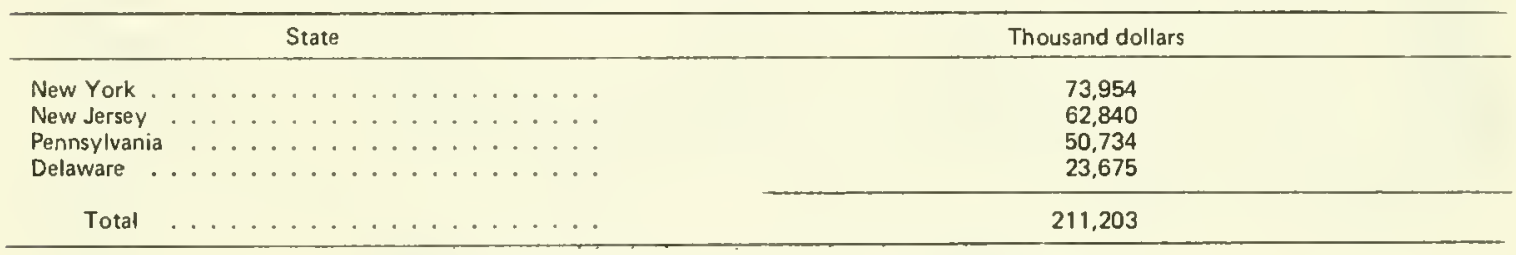

\section{PROCESSING AND WHOLESALE} ESTABLISHMENTS AND EMPLOYMENT, 1975

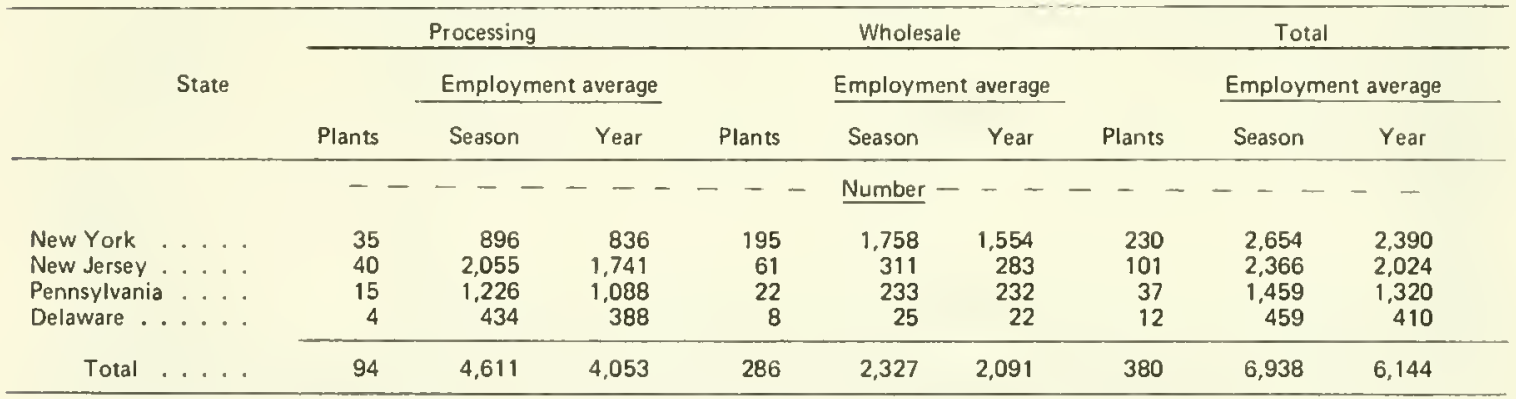

Note:--Employment is reported by each plant for each month for the payroll period that includes the 12 th of the month. Employment for the season is based on the greatest number of employees working during the payroll period that included the 12 th of each month. Employment for the year is obtained by adding the number of employees recorded as working during the payroll period that included the 12 th of each month, and dividing by 12 .

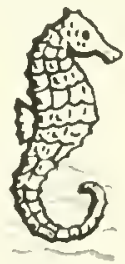


PROCESSED FISHERY PRODUCTS, 1975

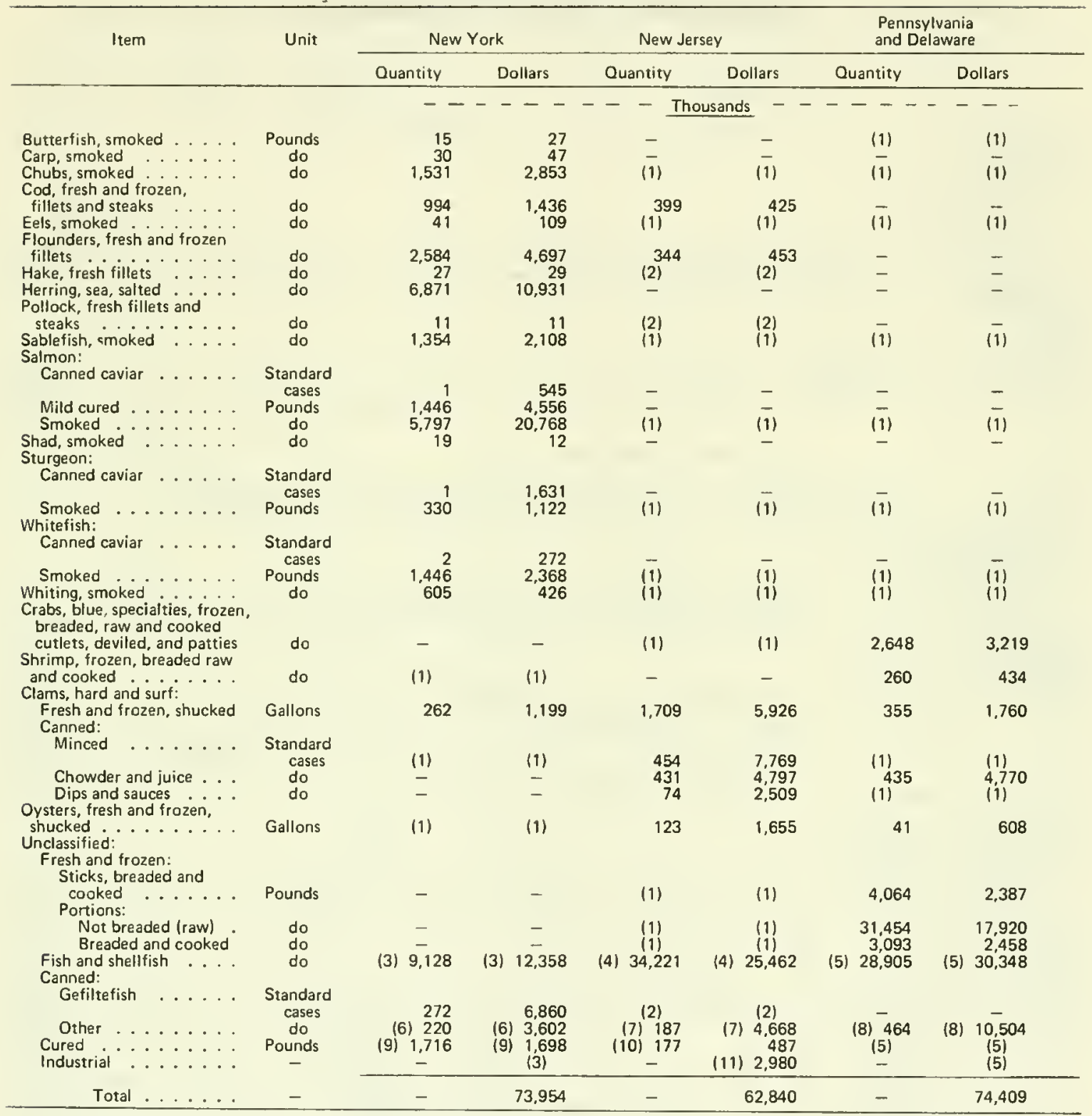

(1) Included with unclassified items. (2) New Jersey production of hake fillets, pollock fillets and steaks, and gefiltefish has been included with New York. (3) Includes (cooked) halibut au gratins; cooked shrimp, peeled and deveined, breaded shrimp (raw and cooked), cocktails cured and refrigerated; clam cakes, patties, deviled, breaded (raw and cooked), and refrigerated cock tails; conch meats, natural and in tornato sauce; oysters, shucked and stuffed on the half shell; squid natural; and unclassified meal. (4) Includes bluefish, ocean perch, red snappers, striped bass, and whiting fillets; crab cakes, breaded (cooked); clam cakes, breaded (raw and cooked), and juice (cooked); conch meats natural; oyster pies (cooked); fish sticks, breaded (cooked); fish portions, breaded (cooked), and not breaded; and unclassified specialties. (5) Includes cod cakes, flounder and haddock fillets breaded (raw): shrimp, breaded (cooked), cakes and patties; clam, breaded, raw and cooked patties; oysters breaded (cooked); scallops, breaded (raw and cooked); fish sticks, breaded (raw); fish portions, breaded (raw); unclassified fish and shellfish; smoked butterfish, chubs, eels, sea herring, lake trout, sablefish, salmon, sturgeon, whitefish and whiting; salmon, mild cured; and the value of unclassified fish meal. (6) Includes canned anchovy paste, lumpfish caviar, minced clams, clam chowder, conch meat, and squid. (7) Includes canned, whitefish bites. American lobster bisque, spiny lobster and shrimp soup; conch meat; oyster soup: squid and unclassified chowders. (8) Includes canned pet food, tuna with noodles, minced clams, dips, and sauces. (9) Includes smoked buffalofish, cod, haddock, lake trout, and unclassified fish; sea herring, cured and refrigerated in wine and cream sauces. (10) Includes smoked chubs, eels, sablefish, salmon, sturgeon, tuna, whitefish, and whiting. (11) Includes the value of menhaden meal, oil, solubles; shark leathers; and marine shell buttons.

Note:--This table will not add. Individual State totals are correct. Some of the products may have been processed from raw products imported from another State or foreign country, therefore, they cannot be correlated directly with landings within the State. Certain items are shown in an intermediate and also a more advanced stage of processing. 


\section{NEW YORK \\ OPERATING UNITS BY GEAR, 1975}

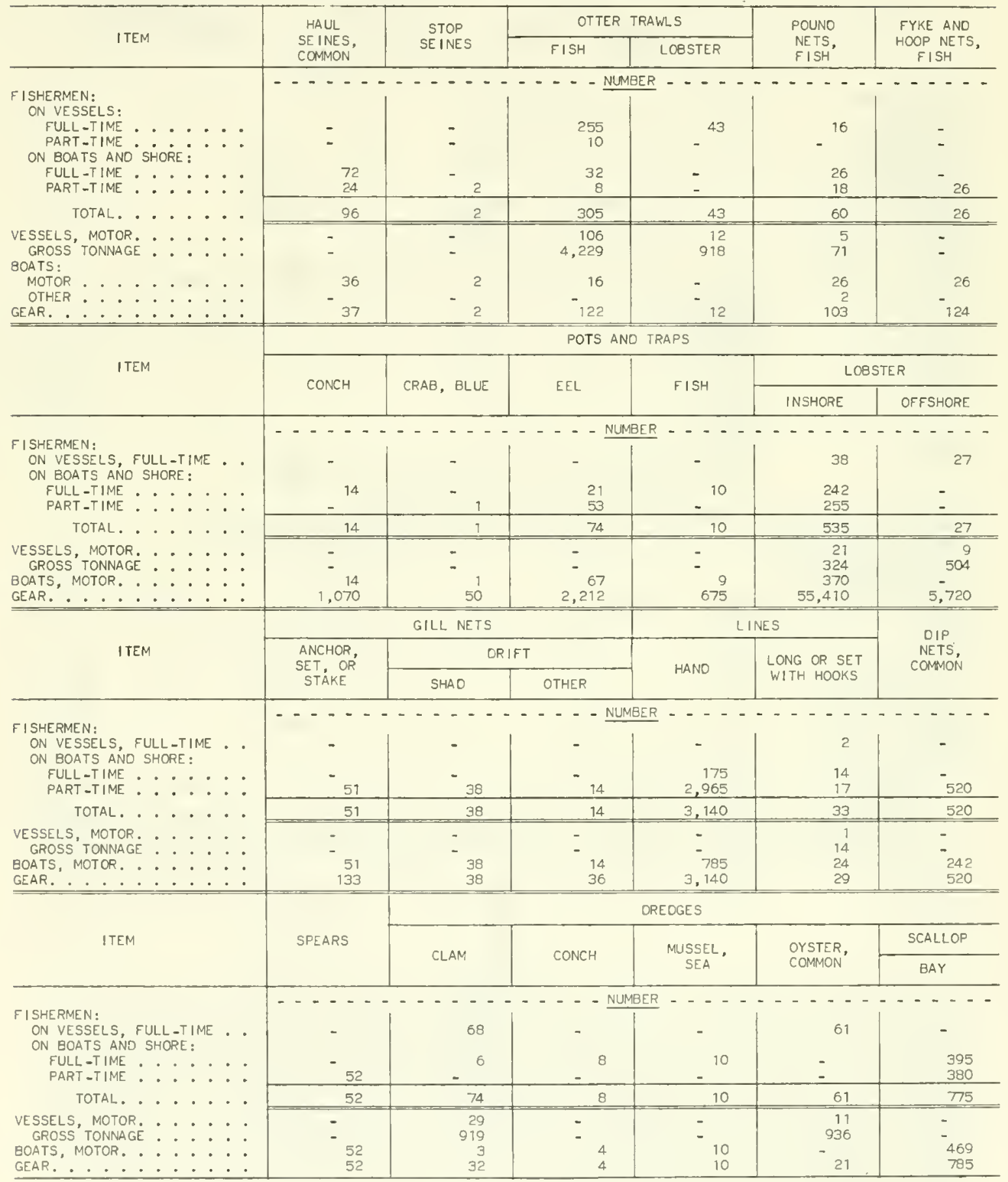

(CONT I NUEO ON NEXT PAGE) 
NEW YORK - OPERATING UNITS BY GEAR, 1975 - Continued

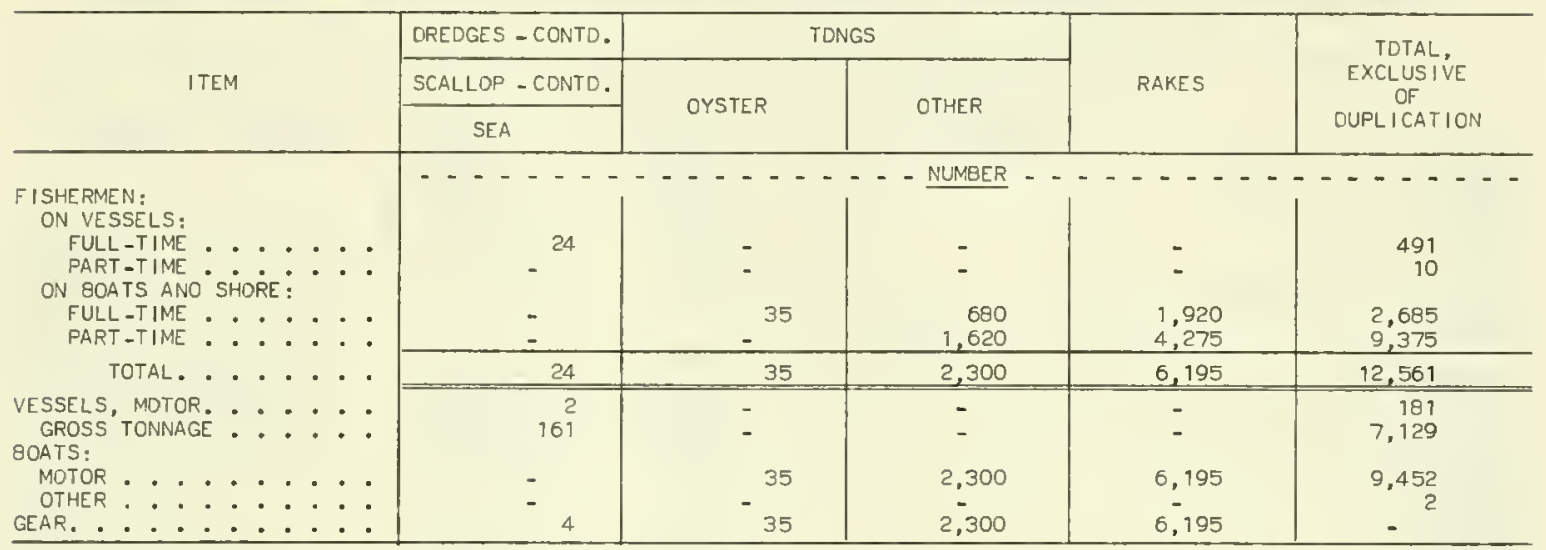

NEW YORK - LANDINGS OF CATCH BY GEAR, 1975

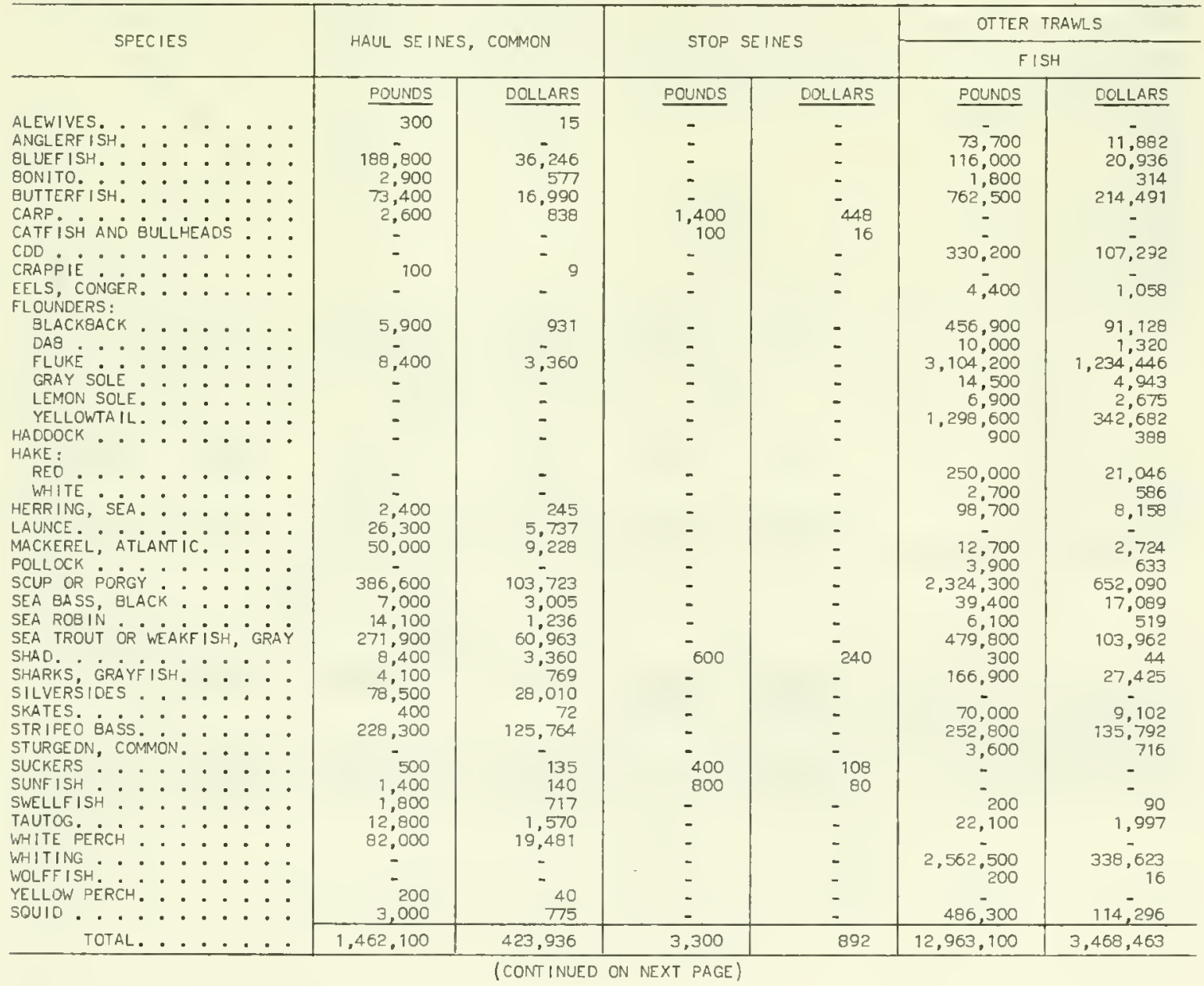


NEW YORK - LANDINGS OF CATCH BY GEAR, 1975 - Continued

\begin{tabular}{|c|c|c|c|c|c|c|}
\hline \multirow{2}{*}{ SPECIES } & OTTER TRAW & ONT INUED & \multirow{2}{*}{\multicolumn{2}{|c|}{ POUNO NETS, FISH }} & \multirow{2}{*}{\multicolumn{2}{|c|}{ FYKE ANO HOOP NETS, FISH }} \\
\hline & \multicolumn{2}{|c|}{ LOBSTER } & & & & \\
\hline \multirow{13}{*}{ 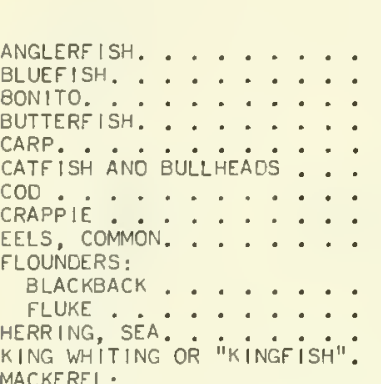 } & POUNOS & DOLLARS & POUNDS & DOLLARS & POUNOS & OOLLARS \\
\hline & - & - & 5,200 & 860 & - & - \\
\hline & - & - & 141,400 & 25,540 & - & - \\
\hline & - & - & 5,000 & 889 & - & - \\
\hline & - & - & 402,500 & 95,121 & - & \\
\hline & - & - & - & - & 1,300 & 416 \\
\hline & - & - & $8-300$ & $3^{-}-540$ & 1,200 & 192 \\
\hline & - & - & - & 2, & 1,400 & 126 \\
\hline & - & - & 22,200 & 8,359 & - & - \\
\hline & - & - & 63,800 & 12,727 & 18,300 & 3.919 \\
\hline & - & - & 43,800 & 76,641 & - & - \\
\hline & - & - & 21,500 & 2,264 & - & - \\
\hline & - & - & 100 & 25 & - & - \\
\hline \multirow{7}{*}{ 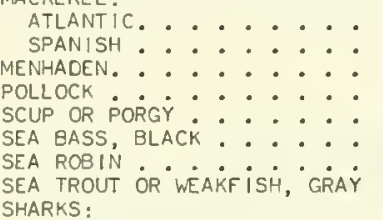 } & - & - & 254,900 & 43,541 & - & - \\
\hline & - & - & 400 & & - & - \\
\hline & - & - & 815,400 & 32,907 & - & - \\
\hline & - & - & & $\begin{array}{r}36 \\
786\end{array}$ & - & - \\
\hline & - & $\overline{-}$ & $\begin{array}{r}681,400 \\
15,400\end{array}$ & $\begin{array}{r}181,706 \\
6,556\end{array}$ & $\overline{-}$ & $\begin{array}{l}- \\
-\end{array}$ \\
\hline & - & - & 21,100 & 1,814 & - & - \\
\hline & - & - & 414,800 & 86,880 & - & - \\
\hline \multirow{14}{*}{ 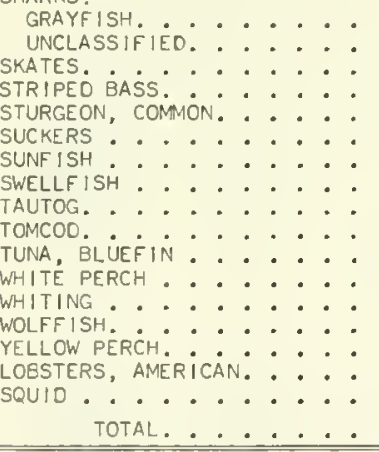 } & - & - & 48,300 & 7,575 & - & - \\
\hline & $\overline{-}$ & $\overline{-}$ & 1,100 & $\begin{array}{r}70 \\
165\end{array}$ & $\overline{-}$ & - \\
\hline & - & - & 224,000 & $\begin{array}{r}115,930 \\
26\end{array}$ & - & - \\
\hline & - & 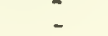 & - & - & 300 & \\
\hline & - & - & - & - & 5,000 & 500 \\
\hline & - & - & 3,400 & 1.429 & - & - \\
\hline & - & - & 13,400 & 1,307 & - & \\
\hline & - & - & 600 & 193 & - & \\
\hline & - & - & - & - & 100 & \\
\hline & - & - & 36,800 & 6,232 & - & - \\
\hline & - & - & -300 & -24 & - & $-{ }^{-} 40$ \\
\hline & 79,800 & 169,725 & -700 & - & - & - \\
\hline & - & - & $-19,600$ & 18,999 & & \\
\hline & 79,800 & 169,725 & $3,331,600$ & 670,496 & 28,000 & 5.320 \\
\hline \multirow{2}{*}{ SPECIES } & \multicolumn{6}{|c|}{ POTS ANO TRAPS } \\
\hline & \multicolumn{2}{|c|}{$\mathrm{CONCH}$} & \multicolumn{2}{|c|}{ CRAB, BLUE } & \multicolumn{2}{|c|}{ EEL } \\
\hline \multirow{5}{*}{ 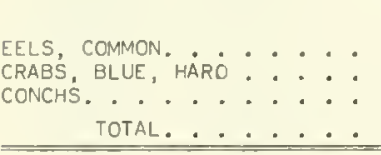 } & POUNOS & DOLLARS & POUNDS & DOLLARS & POUNOS & OOLLARS \\
\hline & - & - & - & - & $\overline{33,200}$ & $\overline{8,815}$ \\
\hline & - & - & 16,000 & 4,000 & - & - \\
\hline & 51,000 & 17,444 & - & & - & - \\
\hline & 51,000 & 17,444 & 16,000 & 4,000 & 33,200 & 8,815 \\
\hline \multirow{3}{*}{ SPECIES } & \multicolumn{6}{|c|}{ POTS AND TRAPS - CONT IINUED } \\
\hline & \multirow{2}{*}{\multicolumn{2}{|c|}{ FISH }} & \multicolumn{4}{|c|}{ LOESTER } \\
\hline & & & \multicolumn{2}{|c|}{ INSHORE } & \multicolumn{2}{|c|}{ OFFSHORE } \\
\hline & POUNOS & DOLLARS & POUNDS & DOLLARS & POUNOS & DOLLARS \\
\hline SCUP OR PORGY . . . . . & 59,900 & 17.551 & - & - & - & - \\
\hline SEA BASS, BLACK $\cdots \cdots$ & 46,800 & 20,118 & - & - & $18 \overline{-} 000$ & 5.400 \\
\hline LOBSTERS, AMERICAN: : & - & - & 282,400 & 586,186 & 307,100 & 643,885 \\
\hline TOTAL. ...... & 106,700 & 37,669 & 282,400 & 586,186 & 325,100 & 649,285 \\
\hline
\end{tabular}

(CONTINUEO ON NEXT PAGE) 
NEW YORK - LANDINGS OF CATCH BY GEAR, 1975 - Continued

\begin{tabular}{|c|c|c|c|c|c|c|}
\hline \multirow{3}{*}{ SPECIES } & \multicolumn{6}{|c|}{ GILL NETS } \\
\hline & \multirow{2}{*}{\multicolumn{2}{|c|}{ ANCHOR, SET, OR STAKE }} & \multicolumn{4}{|c|}{ ORIFT } \\
\hline & & & \multicolumn{2}{|c|}{ SHAD } & \multicolumn{2}{|c|}{ OTHER } \\
\hline $\begin{array}{l}\text { ALEWIVES. } \\
\text { BLUEFISH, } \\
\text { RUTTERF ISH: } \\
\text { CARP } \\
\text { CATF ISH ANO }\end{array}$ & $\begin{array}{r}\text { POUNOS } \\
1,300 \\
58,500 \\
500 \\
14,200 \\
900 \\
-\quad 300 \\
100 \\
1,600 \\
100 \\
5,500 \\
261,000 \\
500 \\
3,500 \\
59,500 \\
120,900 \\
200 \\
76,000 \\
2,200 \\
- \\
300 \\
\end{array}$ & $\begin{array}{r}\text { DOLLARS } \\
117 \\
10,982 \\
180 \\
4,536 \\
136 \\
-\quad 165 \\
27 \\
191 \\
38 \\
1,102 \\
9,228 \\
193 \\
580 \\
13,212 \\
48,347 \\
35 \\
40,965 \\
484 \\
-\quad 72 \\
\end{array}$ & $\begin{array}{c}\text { POUNOS } \\
- \\
- \\
5,000 \\
- \\
1,100 \\
- \\
- \\
- \\
- \\
- \\
- \\
60,100 \\
- \\
1,900 \\
- \\
500 \\
-\end{array}$ & $\begin{array}{c}\text { OOLLARS } \\
- \\
- \\
- \\
1,600 \\
-99 \\
= \\
= \\
- \\
- \\
- \\
- \\
24,028 \\
- \\
- \\
-583 \\
-\end{array}$ & $\begin{array}{c}\text { POUNOS } \\
- \\
- \\
1,100 \\
100 \\
300 \\
= \\
= \\
= \\
- \\
= \\
- \\
- \\
5,200 \\
- \\
2,100 \\
100 \\
400 \\
300 \\
\end{array}$ & $\begin{array}{c}\text { OOLLARS } \\
- \\
- \\
352 \\
16 \\
- \\
- \\
- \\
- \\
- \\
- \\
- \\
- \\
2,480 \\
- \\
1,127 \\
22 \\
40 \\
58 \\
\end{array}$ \\
\hline TOTAL. ....... & 607,100 & 130,590 & 68,600 & 26,760 & 10,600 & 4,122 \\
\hline \multirow{2}{*}{ SPECIES } & \multicolumn{4}{|c|}{ LINES } & \multirow{2}{*}{\multicolumn{2}{|c|}{ DIP NETS, COMMON }} \\
\hline & \multicolumn{2}{|c|}{ HAND } & \multicolumn{2}{|c|}{ LONG OR SET WITH HOOKS } & & \\
\hline 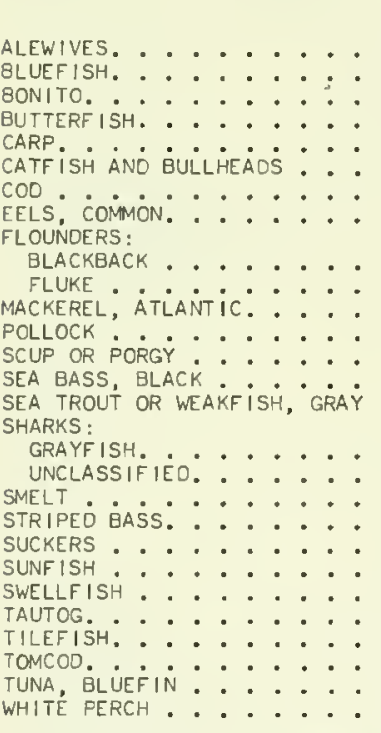 & $\begin{array}{c}\text { POUNOS } \\
384,800 \\
27,300 \\
- \\
- \\
47,700 \\
- \\
22,400 \\
75,000 \\
33,700 \\
366,500 \\
21,900 \\
141,700 \\
3,600 \\
7,300 \\
- \\
398,600 \\
- \\
= \\
200 \\
62,400 \\
5,000 \\
- \\
9,300 \\
-\end{array}$ & $\begin{array}{c}\text { DOLLARS } \\
- \\
\text { T3,225 } \\
6,270 \\
- \\
- \\
15,644 \\
- \\
4,850 \\
27,828 \\
6,481 \\
135 \\
120,286 \\
9,257 \\
31,301 \\
665 \\
1,538 \\
- \\
215,564 \\
- \\
- \\
6,098 \\
1,356 \\
- \\
3,365 \\
-\end{array}$ & $\begin{array}{c}\text { POUNOS } \\
- \\
- \\
300 \\
400 \\
1,000 \\
44,400 \\
700 \\
- \\
- \\
= \\
= \\
= \\
- \\
- \\
- \\
- \\
- \\
- \\
- \\
- \\
- \\
\end{array}$ & $\begin{array}{c}\text { OOLLARS } \\
- \\
- \\
772 \\
128 \\
159 \\
15,058 \\
386 \\
= \\
= \\
= \\
- \\
- \\
- \\
= \\
= \\
- \\
- \\
- \\
- \\
- \\
- \\
-\end{array}$ & $\begin{array}{c}\text { POUNDS } \\
13,700 \\
- \\
100 \\
7500 \\
600 \\
- \\
800 \\
- \\
= \\
- \\
- \\
- \\
- \\
- \\
- \\
8,800 \\
- \\
400 \\
1,500 \\
- \\
- \\
- \\
- \\
100 \\
\end{array}$ & $\begin{array}{c}\text { OOLLARS } \\
1,249 \\
- \\
426 \\
459 \\
\quad 98 \\
-\quad 481 \\
- \\
- \\
- \\
- \\
- \\
- \\
- \\
-023 \\
- \\
112 \\
150 \\
- \\
- \\
- \\
- \\
\end{array}$ \\
\hline TOTAL. . . . . . . & $1,608,100$ & 523.947 & 46,900 & 15,835 & 27,600 & 6,632 \\
\hline \multirow{2}{*}{ SPECIES } & \multirow{2}{*}{\multicolumn{2}{|c|}{ SPEARS }} & \multicolumn{4}{|c|}{ OREOGES } \\
\hline & & & \multicolumn{2}{|c|}{ CLAM } & \multicolumn{2}{|c|}{$\mathrm{CONCH}$} \\
\hline 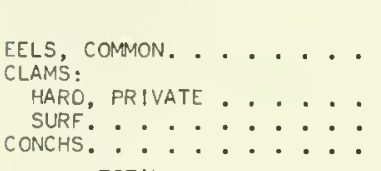 & $\begin{array}{c}\begin{array}{c}\text { POUNDS } \\
44,400 \\
- \\
-\end{array}\end{array}$ & $\begin{array}{c}\text { DOLLARS } \\
15,944 \\
- \\
-\end{array}$ & $\begin{array}{c}\text { POUNOS } \\
- \\
1,909,600 \\
4,579,600 \\
\end{array}$ & $\begin{array}{c}\frac{\text { OOLLARS }}{-} \\
\begin{array}{c}3,165,190 \\
768,088 \\
-\end{array}\end{array}$ & $\begin{array}{c}\text { POUNOS } \\
- \\
- \\
43,600\end{array}$ & $\begin{array}{c}\text { OOLLARS } \\
- \\
- \\
15.491\end{array}$ \\
\hline TOTAL. . . . . . & 44,400 & 15,944 & $6,489,200$ & $3,933,278$ & 43,600 & 15,491 \\
\hline
\end{tabular}




\section{NEW YORK - LANDINGS OF CATCH BY GEAR, 1975 - Continued}

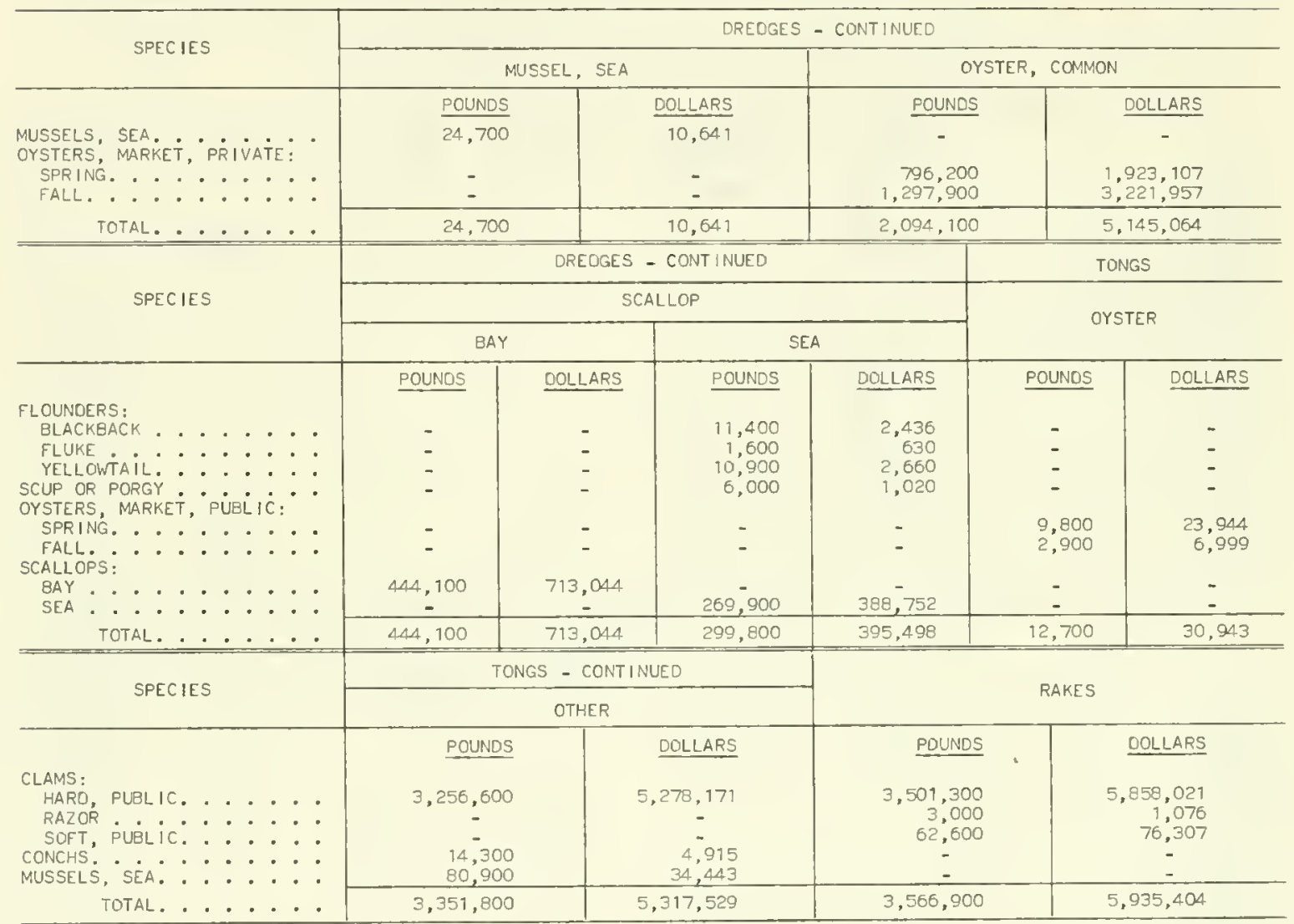




\section{NEW JERSEY \\ OPERATING UNITS BY GEAR, 1975}

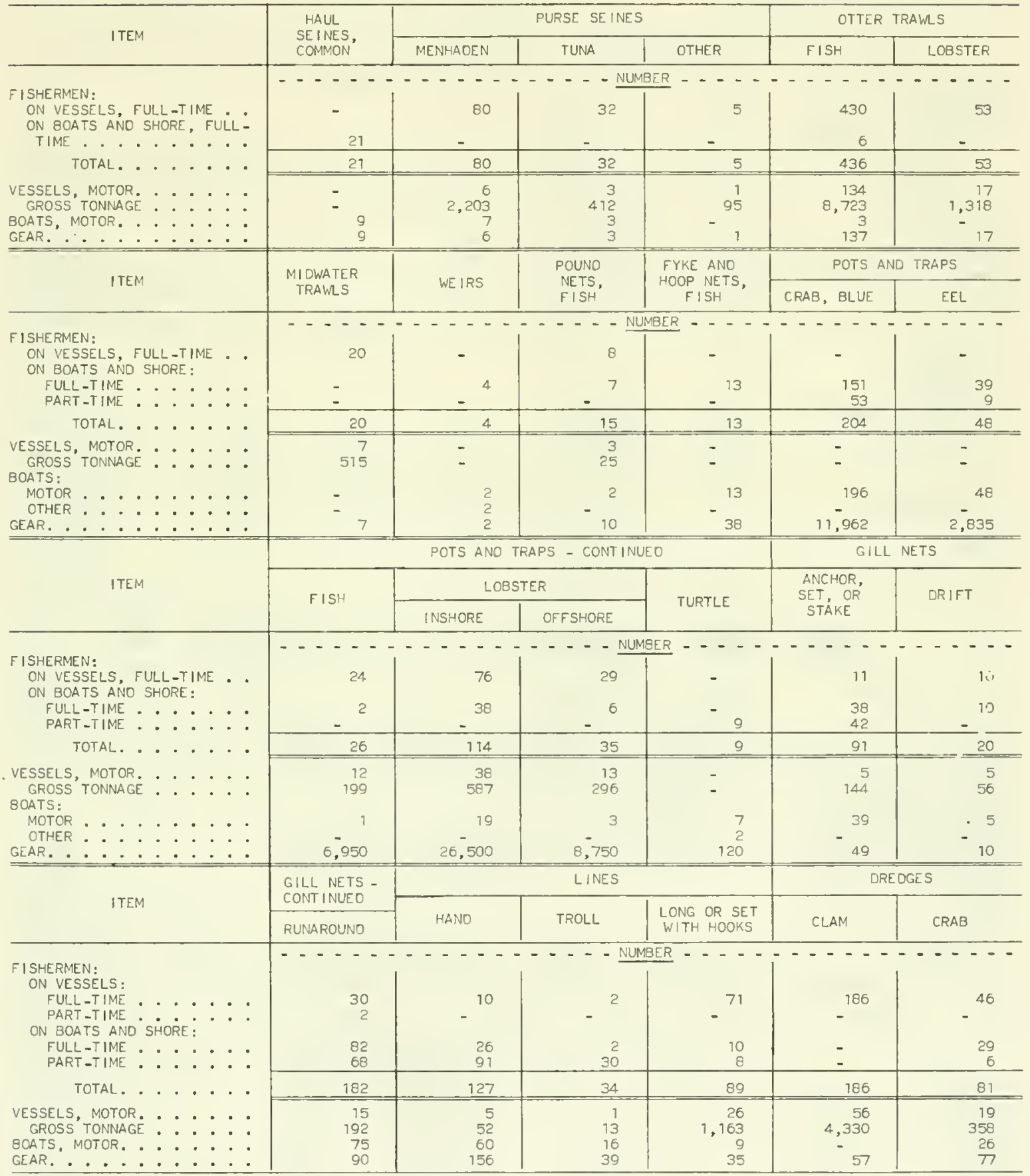

(CONTINUEO ON NEXT PAGE) 


\begin{tabular}{|c|c|c|c|c|}
\hline \multirow{2}{*}{ ITEM } & \multicolumn{2}{|c|}{ OREOGES - CONT INUEO } & \multicolumn{2}{|c|}{ TONGS } \\
\hline & OYSTER, COMMON & SCALLOP, SEA & OYSTER & DTHER \\
\hline $\begin{array}{l}\text { FISHERMEN: } \\
\text { ON VESSELS, FULL-TIME } . . \\
\text { ON BOATS AND SHORE: } \\
\text { FULL-TIME }: \cdots: \ldots \\
\text { PART -TIME }: \ldots . .\end{array}$ & $\begin{array}{r}\ldots . . . \\
96 \\
-\quad 6 \\
\end{array}$ & $\begin{array}{r}140 \\
-\quad 4 \\
\end{array}$ & $\begin{array}{r}-\cdots \\
- \\
18 \\
15 \\
\end{array}$ & $\begin{array}{c}\ldots \ldots \\
- \\
173 \\
215 \\
\end{array}$ \\
\hline TOTAL. . . . . . & 102 & 144 & 33 & 388 \\
\hline $\begin{array}{l}\text { VESSELS, MOTOR. } \ldots: \cdots \\
\text { GROSS TONNAGE }\end{array}$ & $\begin{array}{r}16 \\
606 \\
3 \\
35 \\
\end{array}$ & $\begin{array}{r}12 \\
1,372 \\
1 \\
24 \\
\end{array}$ & $\begin{array}{l}- \\
- \\
27 \\
33 \\
\end{array}$ & $\begin{array}{r}- \\
- \\
388 \\
388 \\
\end{array}$ \\
\hline ITEM & RAKES & HOES & BY HAND & $\begin{array}{l}\text { TOTAL, EXCLUSIVE OF } \\
\text { OUPL ICATION }\end{array}$ \\
\hline 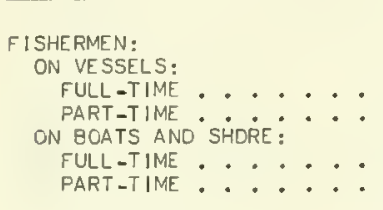 & $\begin{array}{l}- \\
405 \\
462 \\
\end{array}$ & $\begin{array}{r}- \\
19 \\
7 \\
\end{array}$ & $\begin{array}{r}\cdots \\
- \\
370 \\
755 \\
\end{array}$ & $\begin{array}{r}0 \ldots \\
1,124 \\
2 \\
823 \\
1,132 \\
\end{array}$ \\
\hline TOTAL...... & 867 & 26 & 1,125 & 3,081 \\
\hline 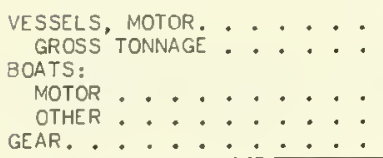 & $\begin{array}{l}- \\
- \\
867 \\
- \\
867\end{array}$ & $\begin{array}{l}- \\
- \\
- \\
26\end{array}$ & $\begin{array}{l}- \\
- \\
1,020 \\
-\quad 20 \\
\end{array}$ & $\begin{array}{r}303 \\
19,042 \\
1.657 \\
-\quad 24 \\
\end{array}$ \\
\hline
\end{tabular}

NEW JERSEY - LANDINGS OF CATCH BY GEAR, 1975

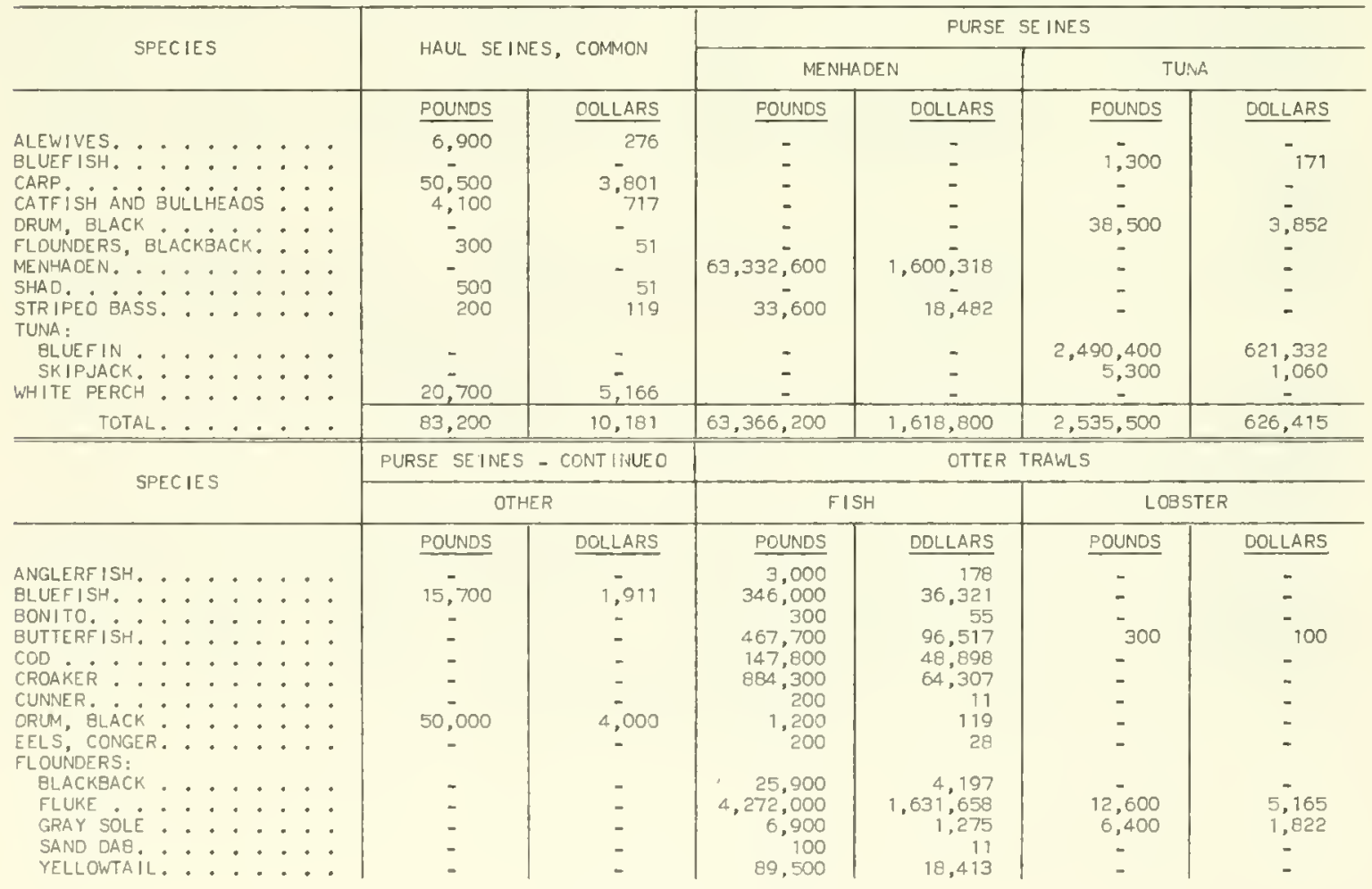


NEW JERSEY - LANDINGS OF CATCH BY GEAR, 1975 - Continued

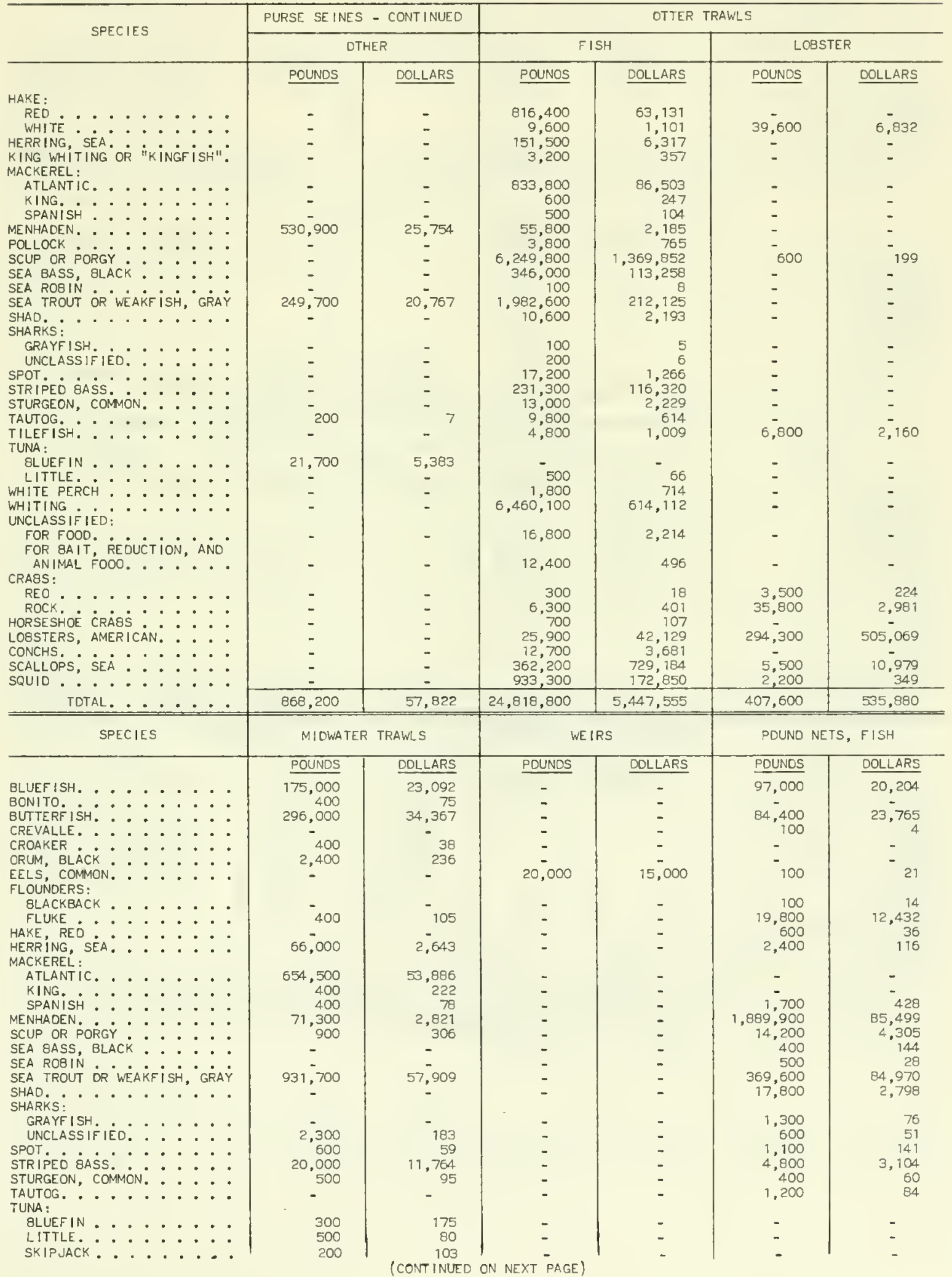




\section{NEW JERSEY - LANDINGS OF CATCH BY GEAR, 1975 - Continued}

\begin{tabular}{|c|c|c|c|c|c|c|}
\hline SPECIES & \multicolumn{2}{|c|}{ MIOWATER TRAWLS } & \multicolumn{2}{|c|}{ WE IRS } & \multicolumn{2}{|c|}{ POUND NETS, FISH } \\
\hline \multirow{3}{*}{ 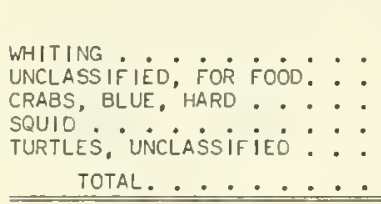 } & POUNDS & DOLLARS & POUNDS & DOLLARS & POUNDS & OOLLARS \\
\hline & $\begin{array}{r}700 \\
200 \\
- \\
6,600 \\
- \\
\end{array}$ & $\begin{array}{r}79 \\
-24 \\
-\quad 282 \\
-\end{array}$ & $\begin{array}{l}- \\
- \\
- \\
-\end{array}$ & $\begin{array}{l}- \\
- \\
-\end{array}$ & $\begin{array}{r}5,000 \\
600 \\
2,400 \\
-, 400 \\
1,400\end{array}$ & $\begin{array}{r}700 \\
101 \\
593 \\
-\quad 182 \\
\end{array}$ \\
\hline & $2,231,700$ & 189,622 & 20,000 & 15,000 & $2,517,400$ & 239,856 \\
\hline \multirow{2}{*}{ SPECIES } & \multirow{2}{*}{\multicolumn{2}{|c|}{ FYKE AND HOOP NETS, FISH }} & \multicolumn{4}{|c|}{ POTS AND TRAPS } \\
\hline & & & \multicolumn{2}{|c|}{ CRA8, BLUE } & \multicolumn{2}{|c|}{ EEL } \\
\hline \multirow[t]{2}{*}{ 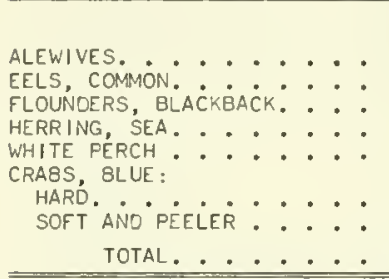 } & $\begin{array}{r}\text { POUNOS } \\
2,400 \\
- \\
78,800 \\
300 \\
79,900 \\
- \\
-\end{array}$ & $\begin{array}{r}\text { DOLLARS } \\
\begin{array}{r}36 \\
10,773 \\
18,362 \\
- \\
-\end{array} \\
\end{array}$ & $\begin{array}{c}\text { POUNDS } \\
- \\
- \\
- \\
2,331,700 \\
38,800\end{array}$ & $\begin{array}{c}\text { OOLLARS } \\
- \\
- \\
- \\
- \\
492,976 \\
16,045\end{array}$ & $\begin{array}{c}\text { POUNOS } \\
201,500 \\
- \\
- \\
- \\
-\end{array}$ & $\begin{array}{c}\text { DOLLARS } \\
\begin{array}{c}- \\
61,879 \\
- \\
- \\
- \\
-\end{array}\end{array}$ \\
\hline & 161,400 & 29,243 & $2,370,500$ & 509,021 & 201,500 & 61,879 \\
\hline \multirow{3}{*}{ SPECIES } & \multicolumn{6}{|c|}{ POTS ANO TRAPS - CONTINUED } \\
\hline & \multirow{2}{*}{\multicolumn{2}{|c|}{$\mathrm{FISH}$}} & \multicolumn{4}{|c|}{ LOBSTER } \\
\hline & & & \multicolumn{2}{|c|}{ INSHORE } & \multicolumn{2}{|c|}{ OFFSHDRE } \\
\hline 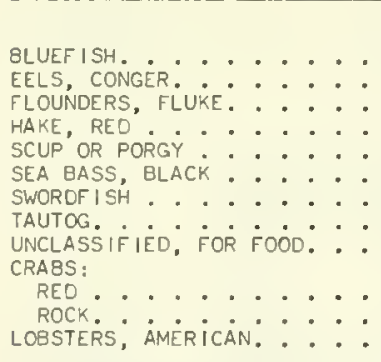 & $\begin{array}{r}\text { POUNDS } \\
100 \\
5,600 \\
100 \\
34,400 \\
1,900 \\
814,100 \\
- \\
8,500 \\
200 \\
- \\
900 \\
3,900\end{array}$ & $\begin{array}{r}\text { DOLLARS } \\
10 \\
1,117 \\
26 \\
1,598 \\
325 \\
249,804 \\
-\quad \\
623 \\
18 \\
-\quad 57 \\
7,750 \\
\end{array}$ & $\begin{array}{c}\text { POUNDS } \\
- \\
- \\
37,100 \\
- \\
14,100 \\
- \\
13,500 \\
- \\
- \\
66,200 \\
273,800\end{array}$ & $\begin{array}{c}\text { DOLLARS } \\
- \\
- \\
4,065 \\
- \\
4,595 \\
-715 \\
- \\
- \\
4.158 \\
516,351\end{array}$ & 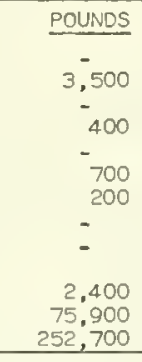 & $\begin{array}{c}\text { DOLLARS } \\
- \\
-798 \\
-70 \\
- \\
335 \\
290 \\
- \\
- \\
4,803 \\
483,591 \\
\end{array}$ \\
\hline 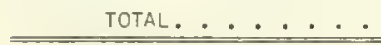 & 869,700 & 261,328 & 404,700 & 529,884 & 335,800 & 489,958 \\
\hline \multirow{2}{*}{ SPECIES } & \multicolumn{2}{|c|}{ PDTS AND TRAPS - CONTINUEO } & \multicolumn{4}{|c|}{ GILL NETS } \\
\hline & \multicolumn{2}{|c|}{ TURTLE } & \multicolumn{2}{|c|}{ ANCHOR, SET, OR STAKE } & \multicolumn{2}{|c|}{ DRIFT } \\
\hline 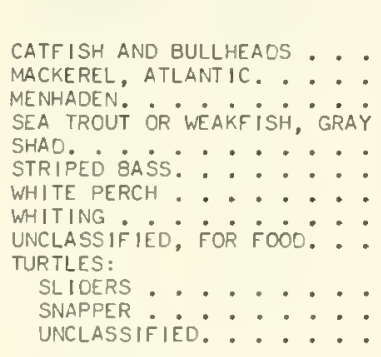 & $\begin{array}{c}\text { POUNDS } \\
- \\
z \\
z \\
= \\
= \\
- \\
600 \\
26,500 \\
900\end{array}$ & $\begin{array}{c}\text { DOLLARS } \\
- \\
- \\
- \\
- \\
- \\
- \\
- \\
55 \\
5,629 \\
60 \\
\end{array}$ & $\begin{array}{r}\text { POUNDS } \\
-100 \\
- \\
13,300 \\
23,100 \\
82,700 \\
27,100 \\
3,800 \\
400 \\
500 \\
- \\
- \\
-\end{array}$ & $\begin{array}{r}\text { DOLLARS } \\
20 \\
- \\
628 \\
4,589 \\
22,095 \\
14,408 \\
925 \\
76 \\
62 \\
- \\
- \\
-\end{array}$ & $\begin{array}{c}\text { POUNDS } \\
- \\
9,000 \\
13,400 \\
- \\
100 \\
200 \\
- \\
- \\
- \\
- \\
-\end{array}$ & $\begin{array}{c}\text { DOLLARS } \\
- \\
2,167 \\
667 \\
-\quad 25 \\
128 \\
-\quad 83 \\
- \\
- \\
- \\
-\end{array}$ \\
\hline 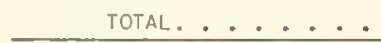 & 28,000 & 5,744 & 151,000 & 42,803 & 23,300 & 3,070 \\
\hline
\end{tabular}


NEW JERSEY - LANDINGS OF CATCH BY GEAR, 1975 - Continued

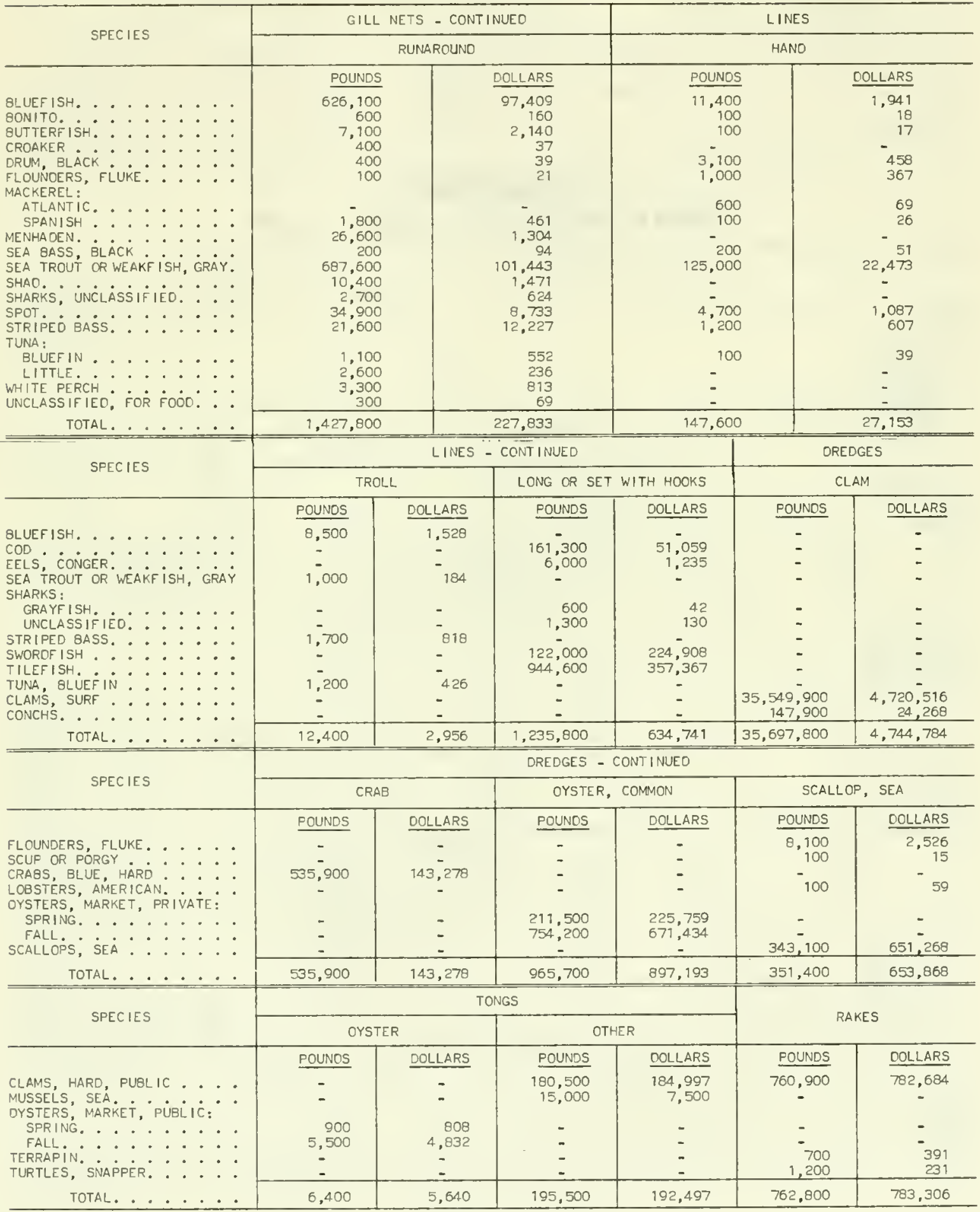

(CONTINUEO ON NEXT PAGE) 


\section{NEW JERSEY - LANDINGS OF CATCH BY GEAR, 1975 - Continued}

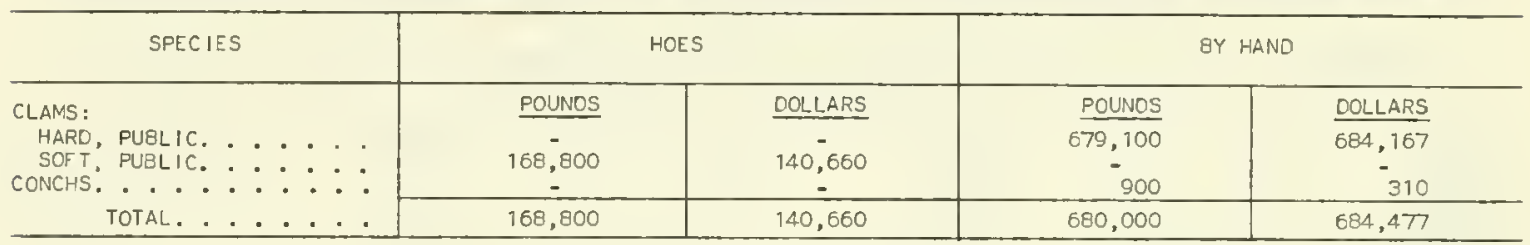

DELAWARE

OPERATING UNITS BY GEAR, 1975

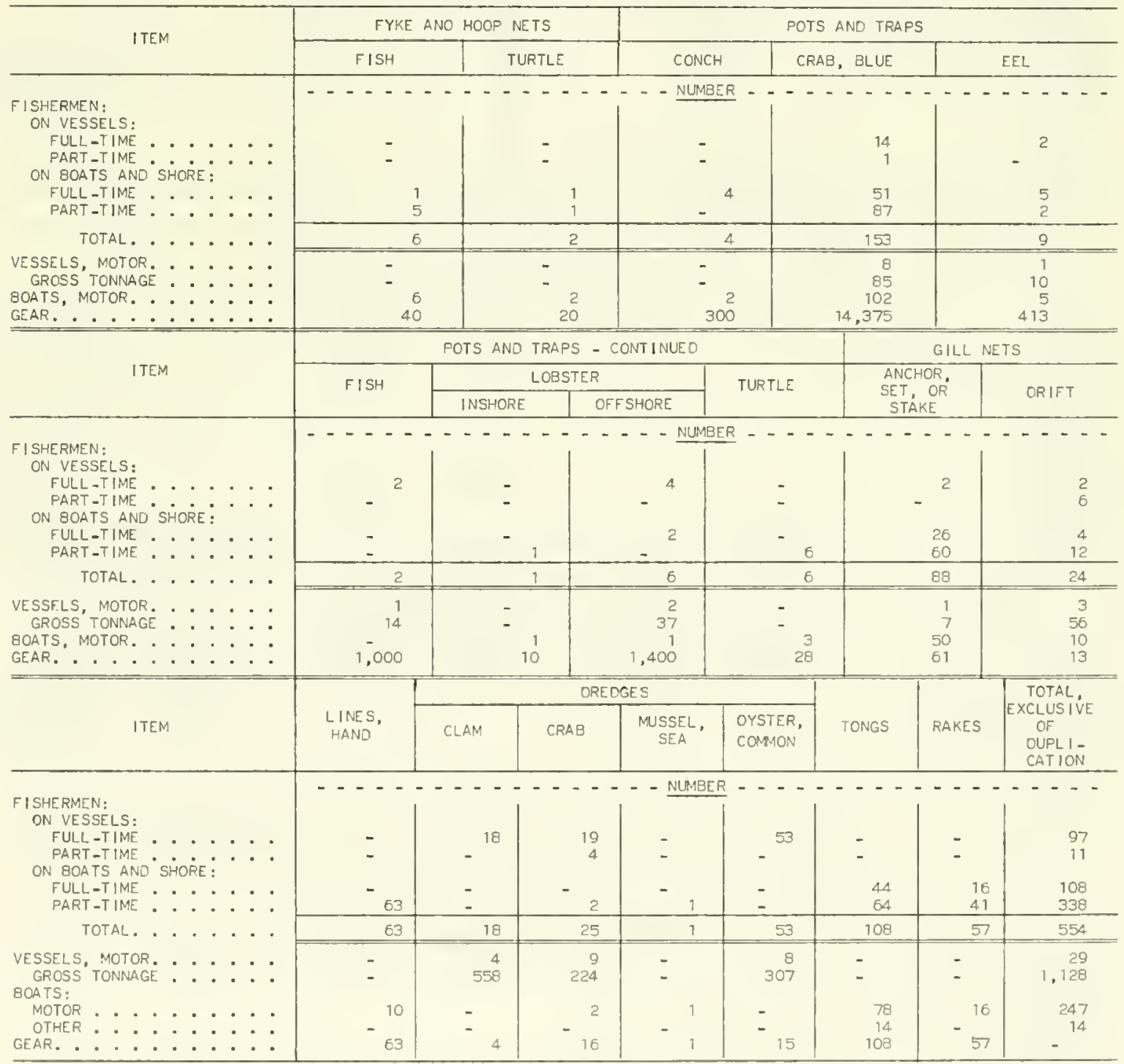


DELAWARE - LANDINGS OF CATCH BY GEAR, 1975

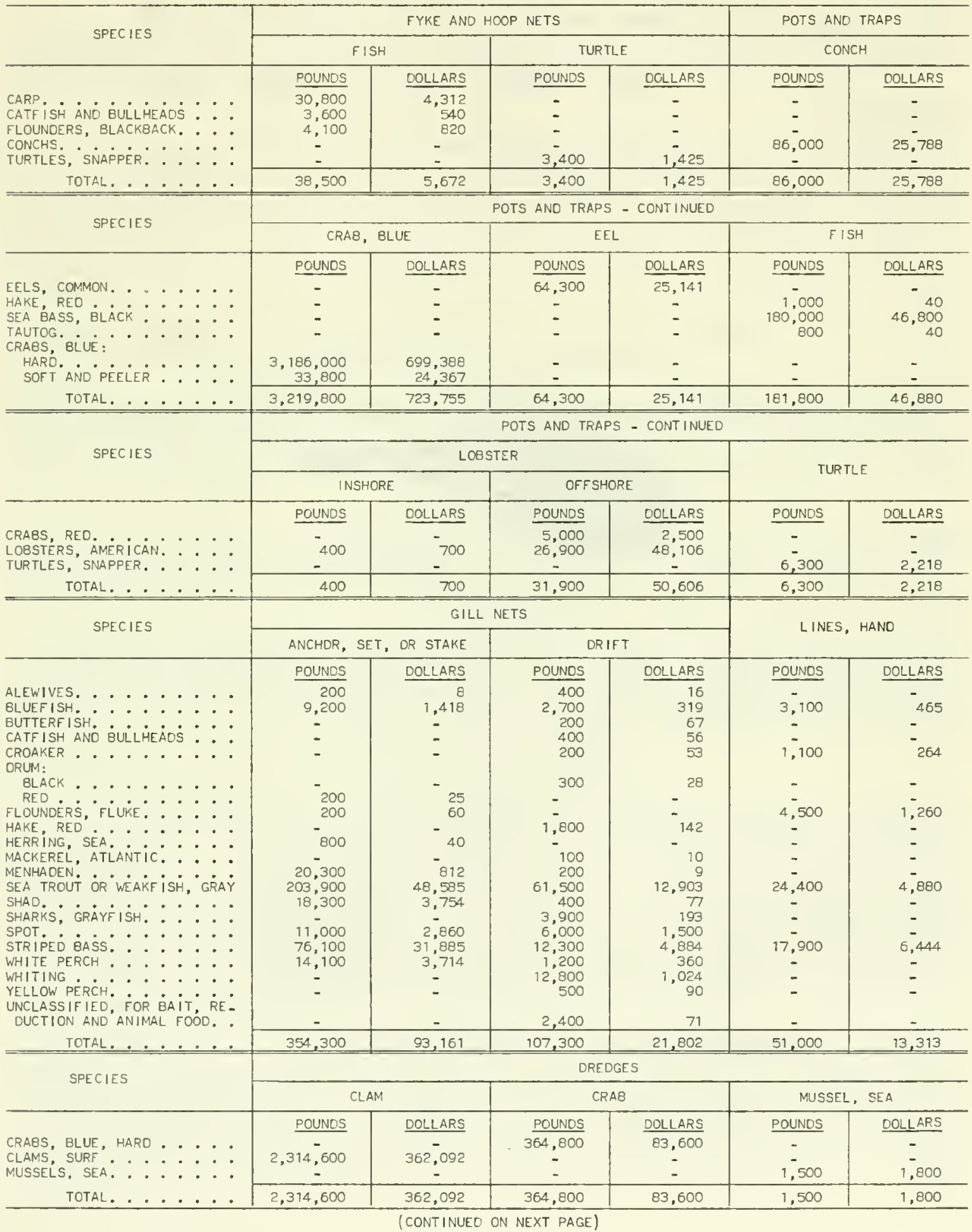




\section{DELAWARE - LANDINGS OF CATCH BY GEAR, 1975 - Continued}

\begin{tabular}{|c|c|c|c|c|c|c|}
\hline \multirow{2}{*}{ SPECIES } & \multicolumn{2}{|c|}{ DREDGES - CONTINUEO } & \multirow{2}{*}{\multicolumn{2}{|c|}{ TONGS }} & \multirow{2}{*}{\multicolumn{2}{|c|}{ RAKES }} \\
\hline & \multicolumn{2}{|c|}{ OYSTER, COMMON } & & & & \\
\hline \multirow{4}{*}{$\begin{array}{l}\text { CLAMS, HARO, PUBLIC ... } \\
\text { OYSTERS, MARKET, } \\
\text { PRIVATE, FALL'.... } \\
\text { TDTAL. ..... }\end{array}$} & POUNDS & DOLLARS & POUNDS & DOLLARS & POUNOS & OOLLARS \\
\hline & - & - & 16,700 & 15,698 & 17,700 & 16,492 \\
\hline & 195,000 & 226,751 & - & - & - & - \\
\hline & 195,000 & 226,751 & 16,700 & 15,698 & 17,700 & 16,492 \\
\hline
\end{tabular}

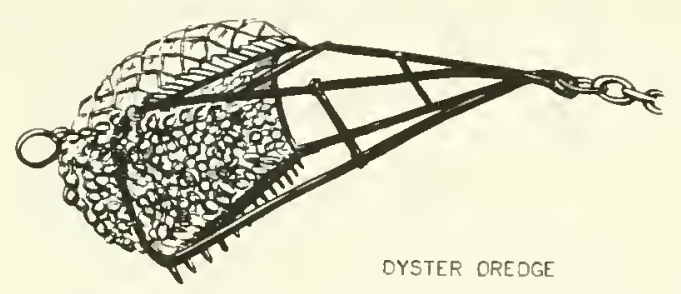




\section{SECTION 4 CHESAPEAKE FISHERIES}

The commercial landings of fish and shellfish in the Chesapeake States (Maryland and Virginia) were 509.1 million pounds valued at $\$ 56.0$ million-a decline of 88.1 million pounds (15 percent) and $\$ 2.1$ million (4 percent) compared with 1974. Reduced landings of alewives, menhaden, surf clams, blue crabs, and oysters were the principal cause of the decline in volume. There were moderate increases, however, in landings of croaker, fluke flounder, gray sea trout, sea bass, and sea scallops.

Virginia landings of $\mathbf{4 4 4 . 8}$ million pounds worth $\$ 33.1$ million were 87 percent of the volume and 59 percent of the value in the Chesapeake area. Menhaden was 71 percent of the volume in Virginia and 23 percent of the value; surf clams were 9 percent of the volume; and hard blue crabs, 8 percent of the volume. Maryland landings were 64.3 million pounds valued at $\$ 22.9$ million. In Maryland hard blue crabs accounted for 38 percent of the total volume; oysters, 26 percent; menhaden, 9 percent; and surf clams, 8 percent. ln December the entire James River in Virginia was closed to all finfishing and shellfishing, because of the presence of kepone, an insecticide that a chemical firm had discharged into the upper river at Hopewell. These discharges were made over a number of years.

Fishermen and vessels. There were 24,274 full-time and part-time fishermen operating 1,911 vessels of 5 net tons or over, 16,052 motorboats, and 372 other boats. Compared with 1974, this was an increase of 1,088 fishermen, 13 vessels, and 719 motorboats, but a decline of 333 other boats.

Processed products. The value of processed fishery products in the Chesapeake States was $\$ 160.8 \mathrm{million}-$ an increase of $\$ 10.8$ million compared with 1974. Maryland firms packed processed products valued at $\$ 97.7$ million-61 percent of the area total. In Virginia, processed products were worth $\$ 63.1 \mathrm{million}$. In Maryland, Virginia, and the District of Columbia, 367 processing and wholesaling establishments employed a monthly average of 7,991 persons.

Alewives. Landings of 12.1 million pounds valued at $\$ 422,000$ declined 18 percent in volume and 9 percent in value compared with 1974. The Virginia production of 11.4 million pounds (down 15 percent) was 94 percent of the Chesapeake landings. Maryland landings of 718,000 pounds were 48 percent less than 1974 , and the smallest on record.

Clams. Landings of surf clams were 44.4 million pounds of meats valued at $\$ 6.7$ million-declines of 30 $\overline{\text { percent }}$ in volume and 14 percent in value compared with 1974, the record year for volume and value. Virginia led the Nation for the fourth consecutive year in surf clam landings with 39.1 million pounds of meats or 45 percent of the U.S. total production. In 1974, surf clam landings in Virginia were a record $58.2 \mathrm{million}$ pounds or 61 percent of the total U.S. production. The once highly productive area east of the Virginia Capes has become depleted owing to extensive fishing. In 1975, the vessels were required to take longer trips to land the same number of clams as in previous years. The Maryland surf clam fishery declined only 1 percent in volume from the previous year; the size of the fleet has remained stable.

Landings of hard clams were 1.2 million pounds of meats valued at $\$ 1.1$ million-decreases of 22 percent in quantity and 21 percent in value compared with 1974 . Virginia fishermen landed 94 percent of the total, 1.1 million pounds of meats. Seaside bays off the Atlantic Ocean yielded 35 percent of the Virginia total; the James River, 32 percent; the York River, 26 percent; and the Chesapeake Bay, 7 percent. The Maryland catch was made from two areas, Chincoteague Bay and Pocomoke Sound. The soft clam fishery, which is in Maryland waters, had landings of 1.2 million pounds of meats valued at $\$ 1.2$ million-down 41 percent in volume and 34 percent in value from the 1974 landings. During the first 6 months of the year, soft clamming was fair, and exvessel prices stable at $\$ 10$ per bushel. In July and August the vessels were hard put to reach their 15-bushel-per-day limit on landings. Many vessels could only bring in 5 to 8 bushels per day. Exvessel prices were $\$ 18$ to $\$ 20$ per bushel. In December the discovery of an untapped bed of mostly largesized soft clams discovered in Pocomoke Sound brought a rush of boats to that area.

Crabs. Landings of hard blue crabs were 59.1 million pounds valued at $\$ 9.3$ million-a decline of 10 percent in volume, but an increase of 12 percent in value compared with 1974. Virginia crabbers caught 59 percent of the total with 34.8 million pounds landed. Pot fishermen landed 30.2 million pounds or 87 percent of the Virginia total. Dredge vessels in the winter fishery took most of the remainder. Maryland landings, 24.3 million pounds, valued at $\$ 4.3$ million, declined 2 percent in volume and increased 5 percent in value compared with 1974. Maryland crab pots took about 64 percent of the catch; trot lines took most of the rest. The average exvessel price for hard blue crabs was 17.6 cents per pound in Maryland and 14.4 cents per pound in Virginia. 
Lobsters, American. Landings were 150,000 pounds valued at $\$ 270,600$-declines of 52 percent in both quantity and value compared with 1974. The quantity landed was the smallest since 1968. Virginia landings declined from 274,000 in 1974 to 91,000 in 1975; however, Maryland landings $(59,000$ pounds) increased 59 percent. Virginia fishermen landed 61 percent of the total, taken almost exclusively by pots. Vessels in Virginia made 44 trips during 1975 compared to 83 trips in 1974 . The major company in this fishery had sold the last of $i$ ts vessels and ceased operations by the end of 1975 .

Menhaden. Landings of 321.9 million pounds declined 16 percent compared with 1975 and were 30 percent below the average of the previous 5 years. The value of menhaden landings was $\$ 7.9$ million -31 percent less than in 1974. Purse seines took 87 percent of the landings; pound nets caught most of remaining landings. Purse seines operated mostly in Chesapeake Bay, but worked in the Atlantic Ocean in the fall. About 16 percent of the purse seine catch was taken in the ocean.

Other finfish. Landings of bluefish were 3.6 million pounds valued at $\$ 272,000-$ declines of 4 percent in quantity and 11 percent in value compared with the record landings in 1974 . These were the second largest landings on record for bluefish in this area. Croaker landings, 5.4 million pounds valued at $\$ 565,900$, increased 231 percent in quantity and 154 percent in value over 1974. After many years of reduced landings the fishery for this species appears to be coming back to its for mer quantities. Striped bass landings were 4.2 million pounds valued at $\$ 1.8$ million in 1975. Compared with 1974 , this was a 30 -percent decrease in volume, but a 17-percent increase in value. The average price per pound at dockside increased from 25 cents in 1974 to 42 cents in 1975 . Landings of 5.0 million pounds of gray sea trout valued at $\$ 633,000$ increased 43 percent in volume and 21 percent in value over the previous year. Fluke landings, 4.3 million pounds valued at $\$ 1.2$ million, increased 13 percent in quantity and 30 percent in value compared with 1974 . Shad landings were 1.3 million pounds valued at $\$ 354,000$, a 26 -percent decline in quantity, but a 29 -percent increase in value. Shad landings are the lowest on record for this area.

Oysters. Landings were 22.6 million pounds valued at $\$ 18.1$ million-a 10 -percent decrease in volume, but a 3 -percent increase in value compared with 1974. The volume was the smallest since 1965. Oyster landings in Maryland (16.4 million pounds) declined 10 percent compared with 1974 . This drop in volume can be attributed to a very poor spat fall in 1972 due to the effects of tropical storm Agnes' dumping too much freshwater and silt into the bay at the height of the spawning season. That year class would have entered the fishery in the fall of this year. Virginia landings of 6.2 million pounds declined 7 percent in quantity, but increased 3 percent in value. The reduced catches are reflected in the increase in exvessel prices. ln the fall, exvessel bushel prices rose $\$ 1$ to $\$ 2$ above the spring prices and averaged $\$ 5$ to $\$ 7$ per bushel. Wholesale gallon prices also increased an average of $\$ 2$ per gallon in the fall and averaged $\$ 12.50$ for standard oysters.

The Virginia seed oyster fishery harvested 478,470 bushels valued at $\$ 880,610$. Compared with 1974 , this was a 2 -percent decrease in quantity and 20 -percent in value.

Sea scallops. Landings of 1.3 million pounds of meats valued at $\$ 2.3$ million increased 46 percent in volume and 83 percent in value compared with 1974 . Almost all the scallops were landed in Virginia, where dredge vessels made 116 trips and took 70 percent of the catch and trawl vessels made 61 trips and caught 30 percent.

Other information. Condensed summary data on the operating units and landings by States appearing on the following pages have been published previously in Current Fishery Statistics No. 8485. Landings of fish and shellfish in the bay and ocean areas of Maryland and Virginia are shown at the end of this section. Additional data may be found in the monthly and annual landings bulletins for Maryland and Virginia published by the Data Management and Statistics Division in cooperation with the respective States.

Acknowledgments. The following organizations helped collect the data appearing in this section: Fisheries Administration, Maryland Department of Natural Resources; Virginia Marine Fisheries Commission; Virginia lnstitute of Marine Science; and Potomac River Fisheries Commission. 


\section{CHESAPEAKE FISHERIES}

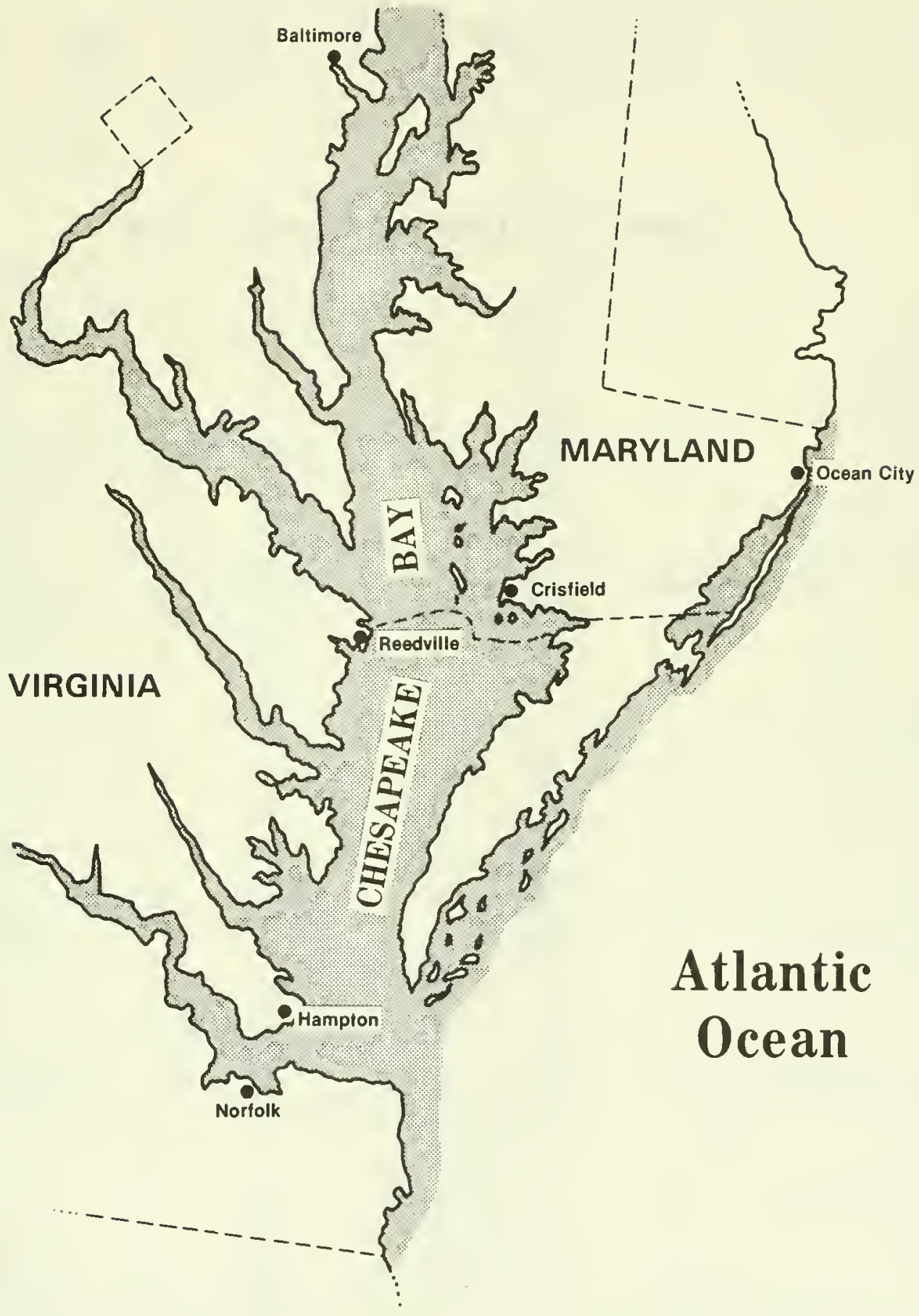

CHESAPEAKE STATES 
SECTIONAL SUMMARIES

SUMMARY OF LANDINGS. 1975

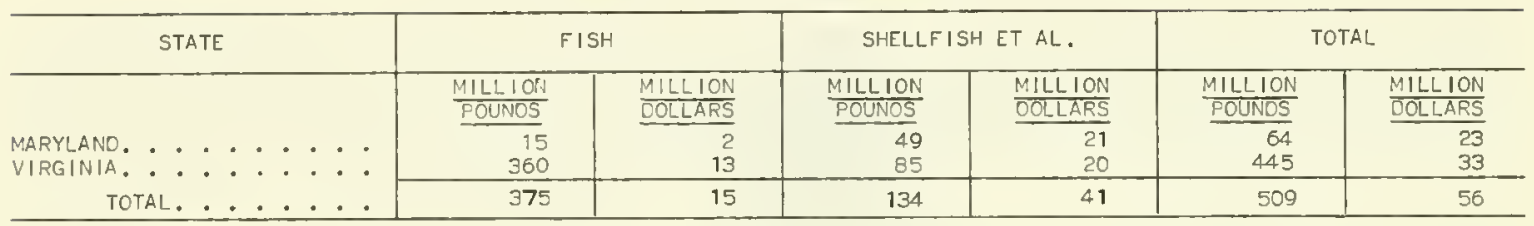

\section{SUMMARY OF OPERATING UNITS, 1975}

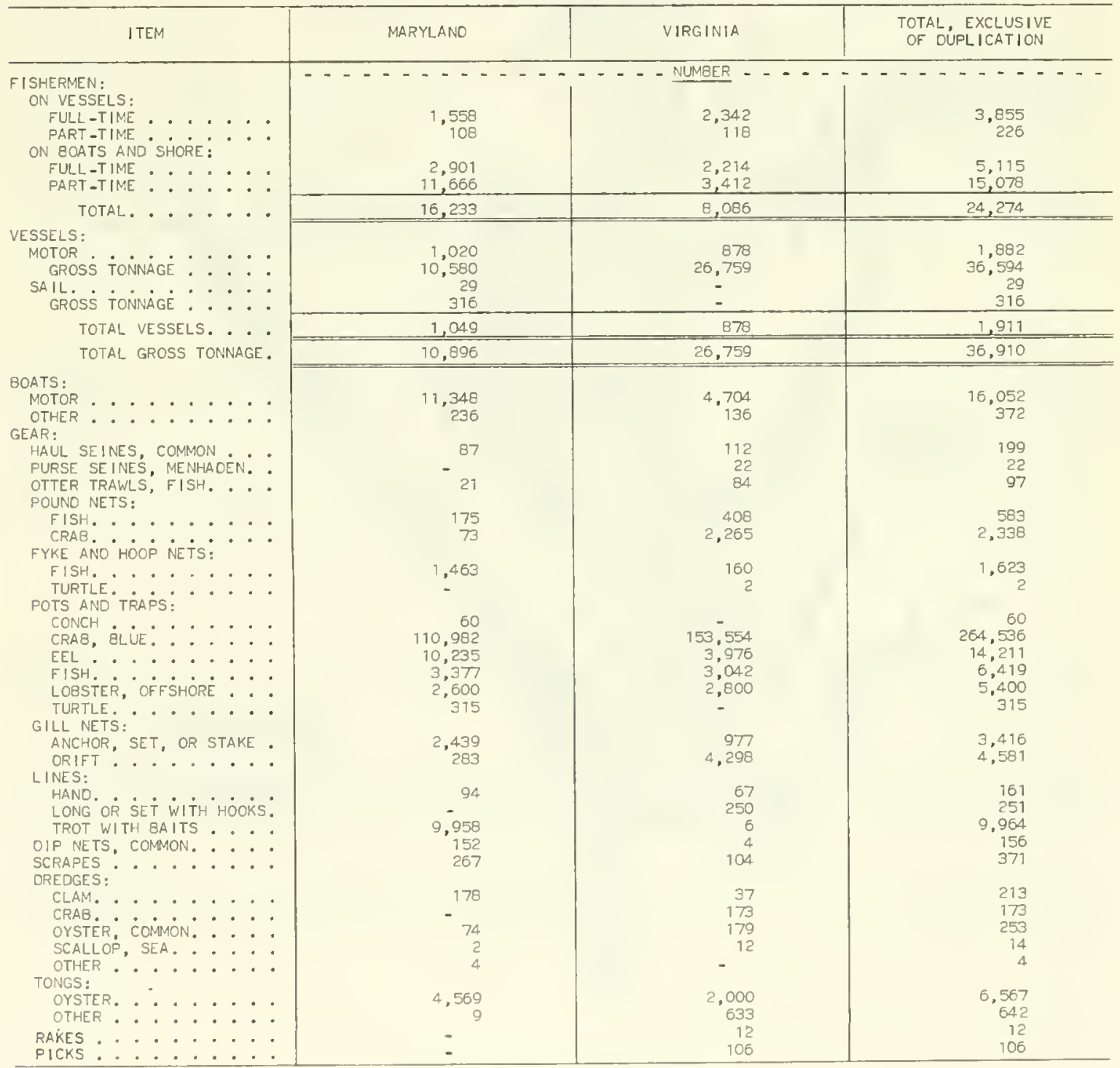


LANDINGS BY STATES, 1975

\begin{tabular}{|c|c|c|c|c|c|c|}
\hline SPECIES & \multicolumn{2}{|c|}{ MARYLAND } & \multicolumn{2}{|c|}{ VIRGINIA } & \multicolumn{2}{|c|}{ TOTAL } \\
\hline & $\frac{\text { THOUSAND }}{\text { POUNDS }}$ & $\frac{\text { THOUSAND }}{\text { DOLLARS }}$ & $\frac{\text { THOUSAND }}{\text { POUNOS }}$ & $\frac{\text { THOUSANO }}{\text { DOLLARS }}$ & $\frac{\text { THOUSANO }}{\text { POUNOS }}$ & $\frac{\text { THOUSAND }}{\text { OOLLARS }}$ \\
\hline ALEWIVES. . . • • • • & 718 & 14 & 11,360 & 408 & $\overline{12,078}$ & 422 \\
\hline QLUEF ISH. . . . . . . & 277 & 26 & 3,285 & 246 & 3,562 & 272 \\
\hline BUTTERF ISH. . . . . . & 22 & 5 & 143 & 30 & 165 & 35 \\
\hline $\mathrm{CABIO} \cdot \cdot \cdot \cdot \cdot \cdot \cdot \cdot$ & & - & 6 & 1 & 6 & 1 \\
\hline $\begin{array}{l}\text { CARP } \\
\text { CATFISH ÁND QULLLHEAOS }: \therefore\end{array}$ & $\begin{array}{l}115 \\
264\end{array}$ & $\begin{array}{r}2 \\
31\end{array}$ & $\begin{array}{r}30 \\
1,522\end{array}$ & $\begin{array}{r}2 \\
329\end{array}$ & $\begin{array}{r}145 \\
1,786\end{array}$ & $\begin{array}{r}4 \\
360\end{array}$ \\
\hline coo & 15 & 5 & (1) & $(1)$ & 15 & 5 \\
\hline 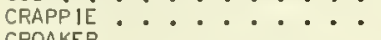 & 2 & (1) & - & - & & $(1)$ \\
\hline $\begin{array}{l}\text { CROAKER } \cdot \cdot \cdot \cdot \cdot \cdot \cdot \cdot \\
\text { DRUM: }\end{array}$ & 640 & 53 & 4,721 & 513 & 5,361 & 566 \\
\hline 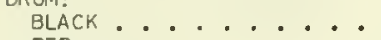 & 30 & 2 & 7 & (1) & 37 & 2 \\
\hline REO & - & - & 20 & 2 & 20 & 2 \\
\hline $\begin{array}{l}\text { EELS, COMMON. } \cdot \cdots \cdot \cdots \cdot \cdot \cdot \\
\text { FLOUNDERS: }\end{array}$ & 205 & 70 & 1,294 & 428 & 1,499 & 498 \\
\hline BLACKBACK ........ & (1) & (1) & (1) & (1) & $(1)$ & (1) \\
\hline $\mathrm{OAB} \cdot \cdots \cdot \cdot \cdot \cdots \cdot \cdot$ & - & - & 1 & (1) & 1 & (1) \\
\hline $\begin{array}{l}\text { FLUKE } \\
\text { UNCLASSIFIIED: }: \vdots: \vdots:\end{array}$ & ${ }^{893}$ & 269 & 3,418 & (1) & ${ }^{4}, 311$ & 1,227 \\
\hline GARFISH & & - & (1) & (1) & (1) & (1) \\
\hline GIZZARO SHAO. . . . . & 94 & 1 & 59 & & 153 & \\
\hline $\begin{array}{l}\text { HAKE, RED } \\
\text { HARVESTFISH : }:: \vdots:\end{array}$ & -5 & (1) & (1) 14 & (1) 5 & $\begin{array}{r}5 \\
14\end{array}$ & $(1)_{5}$ \\
\hline HERRING, SEA: : : : & 31 & 1 & 6 & $(1)^{2}$ & 37 & \\
\hline HICKCRY SHAD. . . . . & 13 & $2^{2}$ & 31 & 8 & 44 & 10 \\
\hline $\begin{array}{l}\text { HOGCHOKER } \\
\text { KING WHITING OR "KINGFISH": }\end{array}$ & $\begin{array}{l}1 \\
4\end{array}$ & (1) & -18 & -3 & $\begin{array}{r}1 \\
22\end{array}$ & (1) \\
\hline MACKEREL: & & & & & $2<$ & \\
\hline ATLANTIC, . . . . • & 205 & 33 & 498 & 81 & 703 & 114 \\
\hline KING. : . . . . . & - & & 13 & 4 & 13 & 4 \\
\hline SPANISH. . . . . . . & (1) & (1) & 62 & 12 & 62 & 12 \\
\hline MENHADEN. $\cdot \cdot \cdot \cdot \cdot \cdot \cdot$ & 6,106 & 163 & 315,783 & 7,717 & 321,889 & 7,880 \\
\hline $\begin{array}{l}\text { MULLET, BLACK (LISA) } \cdot \cdot \cdots \\
\text { OCEAN PERCH, ATLANTIC : }\end{array}$ & $-{ }^{2}$ & (1) & $\begin{array}{r}64 \\
2\end{array}$ & $(1)^{7}$ & $\begin{array}{r}66 \\
2\end{array}$ & $(1)^{7}$ \\
\hline 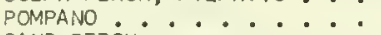 & - & - & 1 & 1) & 1 & (1) \\
\hline SAND PERCH. . . . . . & & & 1 & (1) & 1 & (1) \\
\hline SCUP OR PORGY ...... & 171 & 36 & 409 & 71 & 580 & 107 \\
\hline $\begin{array}{l}\text { SEA BASS, OLACK } \\
\text { SEA TROUT OR WEAKFISH: } \cdots\end{array}$ & 348 & 89 & 1,546 & 367 & 1,894 & 456 \\
\hline 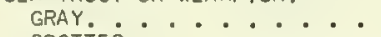 & 887 & 79 & 4,090 & 554 & 4,977 & 633 \\
\hline SPOTTEO . . . . . . & & & 73 & 21 & 73 & 21 \\
\hline SHAO $\cdot \cdots \cdot \cdots \cdot \cdots \cdot$ & 184 & 45 & 1,137 & 309 & 1,321 & 354 \\
\hline $\begin{array}{l}\text { SHARKS: } \\
\text { GRAYFISH......... }\end{array}$ & 6 & (1) & 65 & & 71 & 5 \\
\hline UNCLASSIFIED: : : : & 169 & 8 & 1 & $(1)^{2}$ & 170 & 8 \\
\hline SPOT......... & 103 & & 1,918 & 276 & 2,021 & 287 \\
\hline STRIPED BASS. . . . . . & 2,897 & 1,146 & 1,331 & 642 & 4,228 & 1.788 \\
\hline STURGEON, COMMON, .... & & 1 & & 1 & 11 & 2 \\
\hline $\begin{array}{l}\text { SUCKERS } \cdot \cdot \cdot \cdot \cdot \cdot \cdot \cdot \\
\text { SUNEISH }\end{array}$ & $\begin{array}{l}1 \\
4\end{array}$ & $\left\{\begin{array}{l}1 \\
1\end{array}\right\}$ & $\begin{array}{r}1 \\
-\end{array}$ & (1) & $\begin{array}{l}2 \\
4\end{array}$ & $\left(\begin{array}{l}1 \\
1\end{array}\right)$ \\
\hline $\begin{array}{l}\text { SUNF ISH } \\
\text { SWELLFISH: }:: \vdots:\end{array}$ & $\begin{array}{r}4 \\
-\end{array}$ & (1) & i1) & (1) & $(1)^{4}$ & $1\}$ \\
\hline 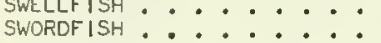 & - & - & 27 & 37 & 27 & 37 \\
\hline $\begin{array}{l}\text { TAUTOG } \\
\text { TUNA } \\
\text { UNCLASSSI|F|E் }\end{array}$ & 1 & (1) & $\begin{array}{l}2 \\
3\end{array}$ & (1) & 3 & $(1)$ \\
\hline & -527 & $-\overline{107}$ & 182 & $\begin{array}{r}1 \\
39\end{array}$ & 709 & $\begin{array}{r}1 \\
146\end{array}$ \\
\hline 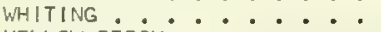 & 5 & 1 & 7 & 1 & 12 & 2 \\
\hline $\begin{array}{l}\text { YELLOW PERCH: } \cdots \cdots \cdot \cdots \cdot \\
\text { UNCLASSIFIED: }\end{array}$ & 38 & 6 & 1 & (1) & 39 & 6 \\
\hline $\begin{array}{l}\text { FOR FOOO. :EंUCTION, 'ANO' } \\
\text { FOR BAIT, REDUCT }\end{array}$ & 5 & (1) & 24 & 2 & 29 & 2 \\
\hline 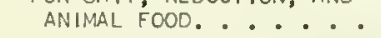 & 7 & (1) & 6,826 & 162 & 6,833 & 162 \\
\hline TOTAL FISH . . . & 15,000 & 2,207 & 360,008 & 13,243 & 375,008 & 15,450 \\
\hline SHELLFISH ET AL. & & & & & & \\
\hline $\begin{array}{l}\text { CRABS: } \\
\text { GLUE: }\end{array}$ & & & & & & \\
\hline 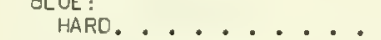 & 24,264 & & & & & \\
\hline SOFT AND PEELER . . . & 1,654 & 869 & 754 & 384 & 2,408 & 1,253 \\
\hline JONAH $\cdot \cdots \cdot \cdots \cdot \cdots \cdot$ & - & - & 13 & $(-)^{3}$ & 13 & $(-)^{3}$ \\
\hline REO . . . . . . . . & - & - & (1) & (1) & (1) & (1) \\
\hline 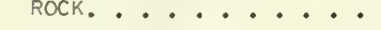 & $=$ & - & (1) & (1) & (1) & (1) \\
\hline TOTAL CRABS. . • • & 25,918 & 5,145 & 35,586 & 5,405 & 61,504 & 10,550 \\
\hline $\begin{array}{l}\text { HORSESHOE CRABS } \\
\text { LOBSTERS, AMERICAN: }: \cdot: \\
\text { SHRIMP. }\end{array}$ & $\begin{array}{l}37 \\
59\end{array}$ & $\begin{array}{r}2 \\
106\end{array}$ & $(1)^{1}$ & $\begin{array}{l}- \\
164 \\
(1)\end{array}$ & $\begin{array}{l}37 \\
150 \\
(1)\end{array}$ & ${ }^{270}$ \\
\hline
\end{tabular}

SEE FOOTNOTES AT END OF TABLE.

(CONTINUEO ON NEXT PAGE) 
LANDINGS BY STATES, 1975 - Continued

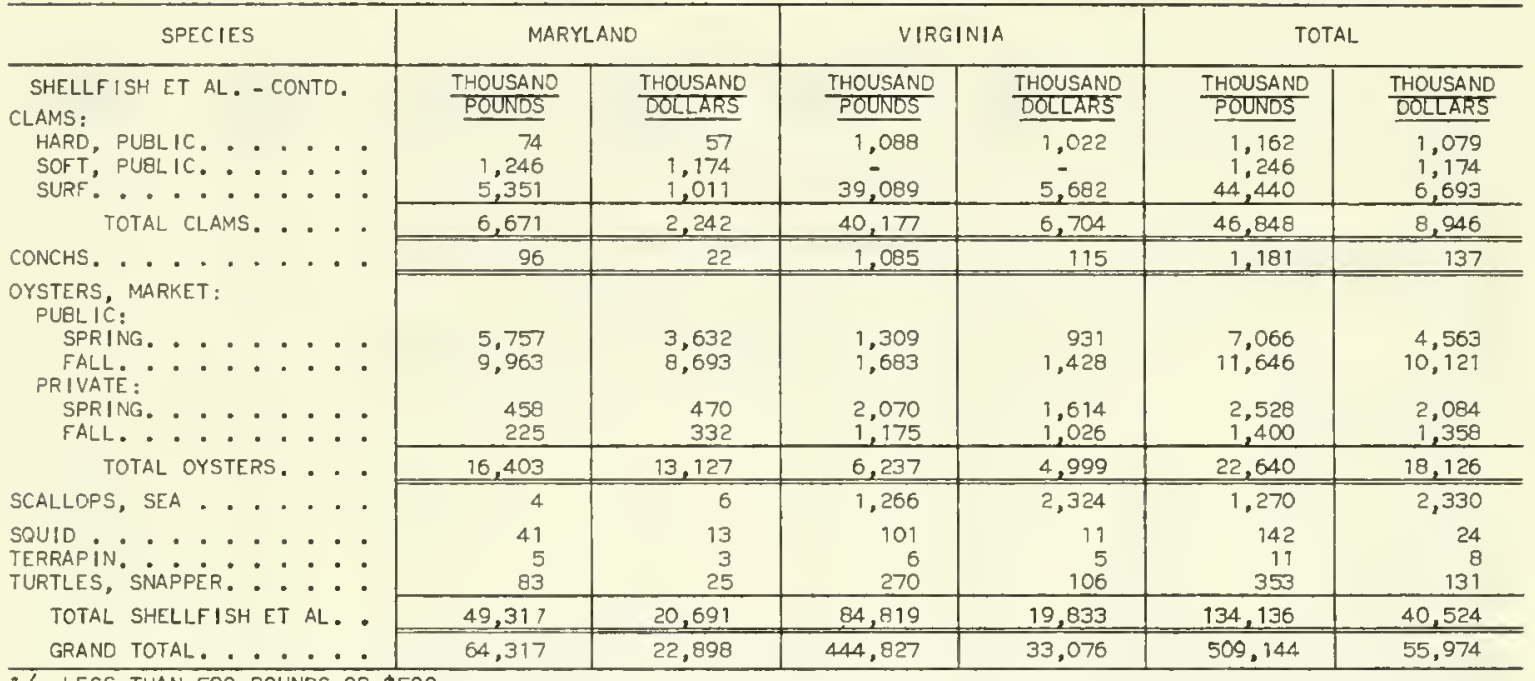

1/ LESS THAN 500 POUNOS OR $\$ 500$.

NOTE:--LANDINGS ARE SHDWN IN ROUND (LIVE) WEIGHT EXCEPT FOR MOLLUSKS. CLAMS, CONCHS, ANO OYSTERS ARE REPORTED IN WEIGHT DF TDTAL MEATS; SCALLOPS, IN WEIGHT OF EDIBLE MEATS.

LANDINGS OF CERTAIN SHELLFISH, 1975

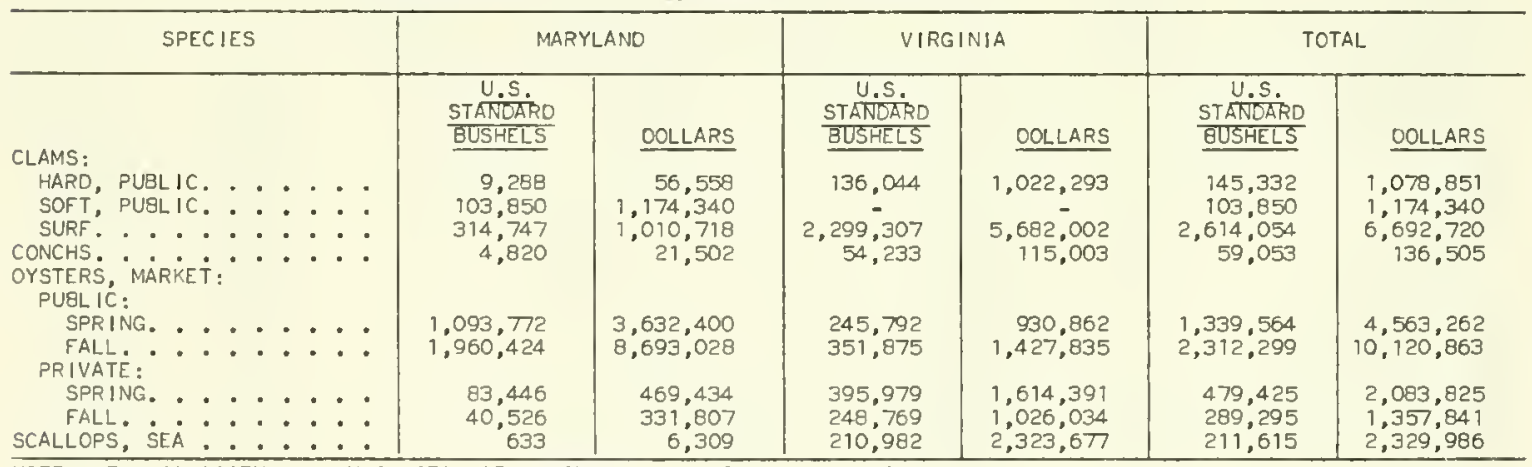

NOTE: --THE CAPACITY OF A U.S. STANDARD BUSHEL IS 2, 150.4 CUBIC INCHES.

AVERAGE YIELD OF CERTAIN SHELLFISH, 1975

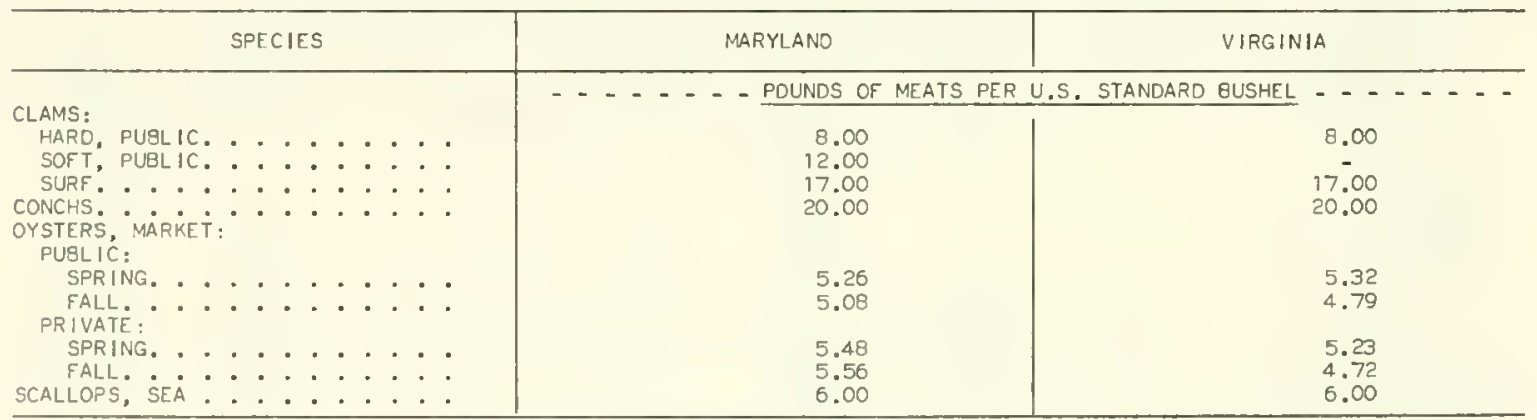

NDTE :- -THE CAPACITY OF A U.S. STANOARO BUSHEL IS 2,150.4 CUBIC INCHES. 
SUMMARY OF PROCESSED PRODUCTS, 1975

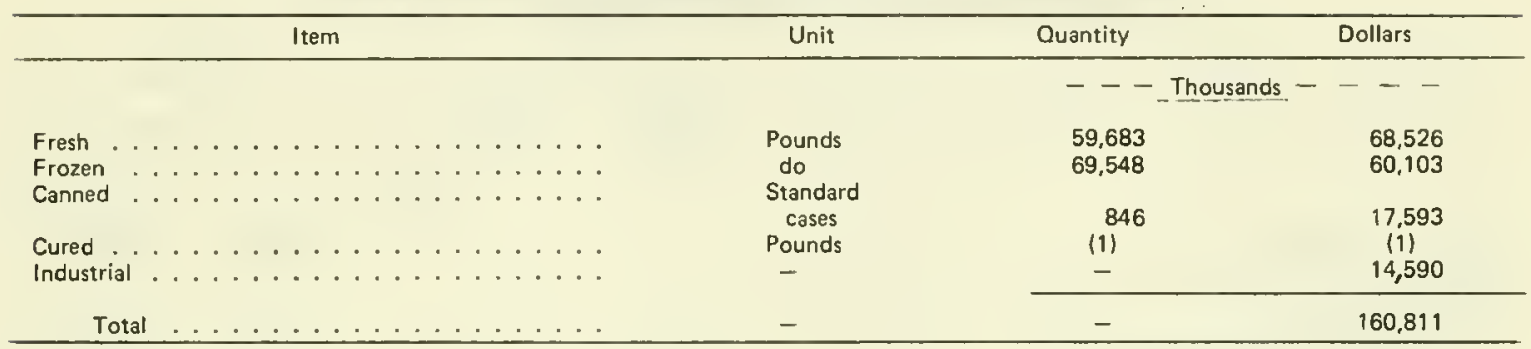

(1) Included with fresh items.

Note:-Table may not add because of rounding. Total is correct.

\section{VALUE OF PROCESSED PRODUCTS, BY STATES, 1975}

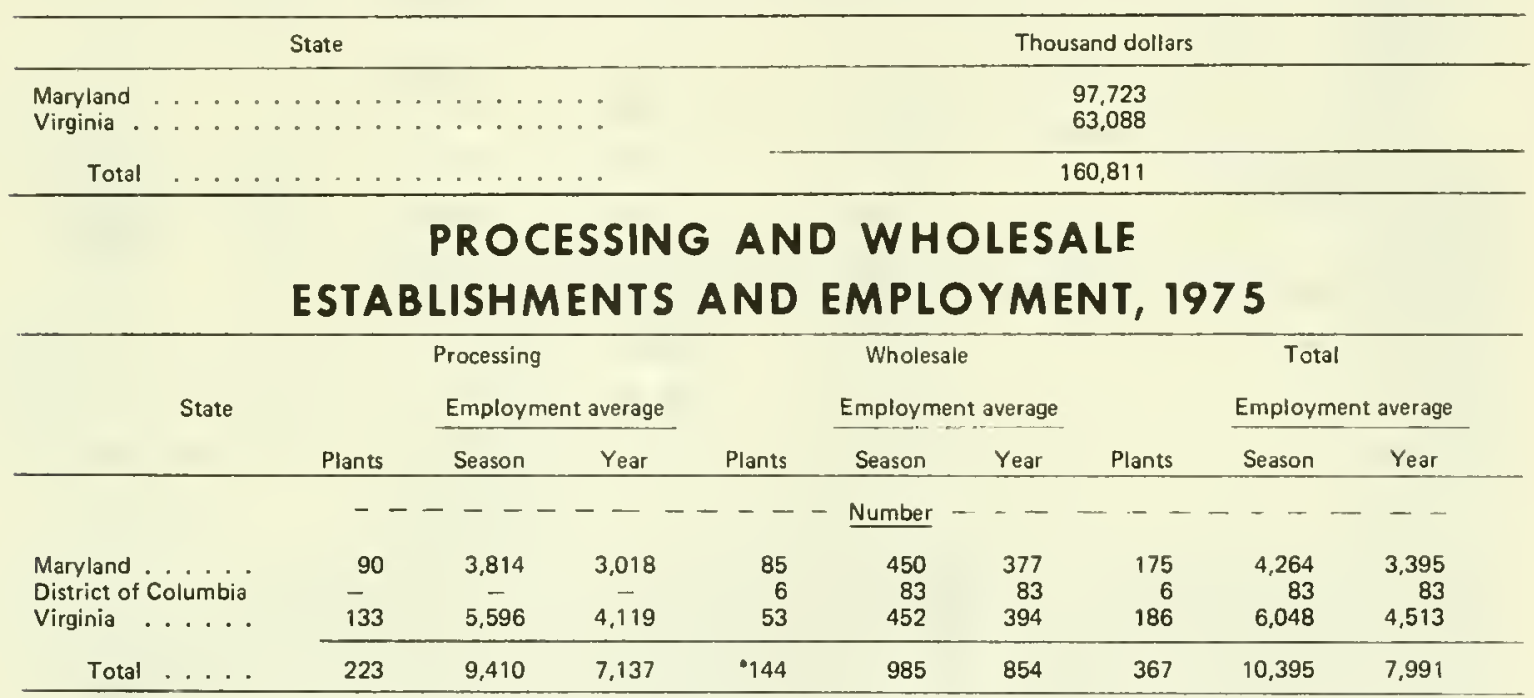

Note:-Employment is reported by each plant for each month for the payroll period that includes the 12th of the month. Employment for the season is based on the greatest number of employees working during the payroll period that included the 12th of each month. Employment for the year is obtained by adding the number of employees recorded as working during the payroll period that included the 12 th of each month, and dividing by 12 . 
PROCESSED FISHERY PRODUCTS, 1975

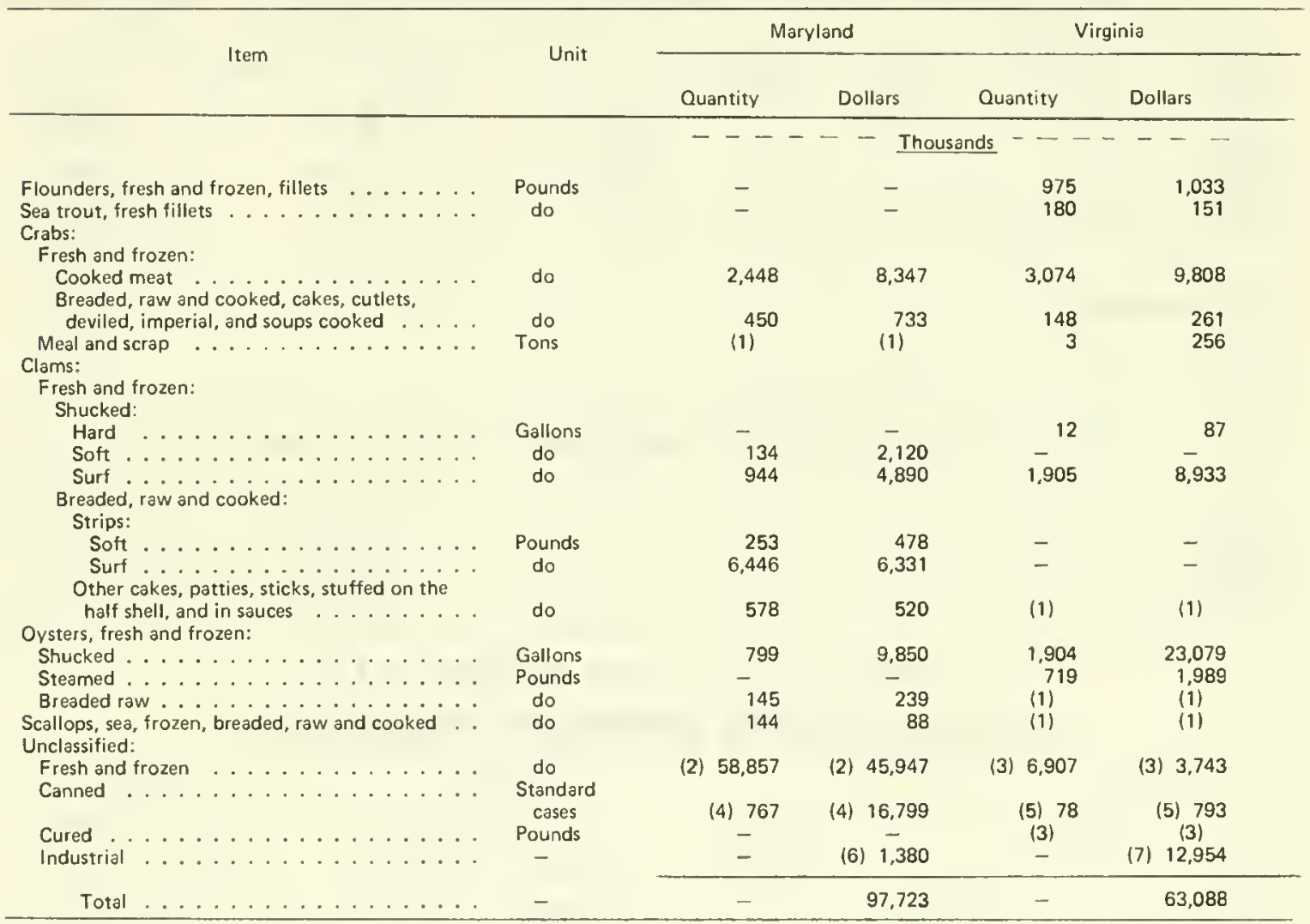

(1) Included with unclassified items. (2) Includes flounders, breaded (raw) stuffed, breaded (cooked), cakes and sticks; conch meat, bay scallops, breaded (raw and cooked), sticks breaded (raw and cooked), portions breaded (raw), breaded (cooked) and not breaded (raw), and unclassified cakes breaded (cooked). (3) Includes alewives and menhaden, frozen, for bait; bluefish, Spanish mackerel, and striped bass fillets; flounder fillets breaded (raw) and breaded (raw) stuffed; dressed and skinned pond-raised trout; shrimp breaded (raw); clam cakes, breaded (raw) and stuffed on the half shell; conchs (steamed); oysters, sea scallop portions breaded (raw); unclassified dinners breaded (raw); and salted and pickled alewives. (4) Includes canned albacose and lightmeat tuna: pet food; soft clam, juice and steamed in the shell. (5) Includes canned, alewives natural and roe; and pet food. (6) Includes the value of crabmeat and ovster sheli grit. (7) Includes the value of menhaden meal, oil, and solubles; unclassified meal, oil, and solubles; and ground fish for animal feeds.

Note:- This table will not add. Individual State totals are correct. Some of the products may have been processed from raw products imported from another State or foreign country; therefore, they cannot be correlated directly with landings within the State, Certain items are shown in an intermediate and also a more advanced stage of processing.

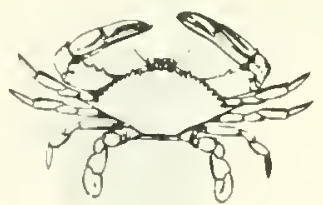




\section{CHESAPEAKE FISHERIES}

\section{MARYLAND \\ OPERATING UNITS BY GEAR, 1975}

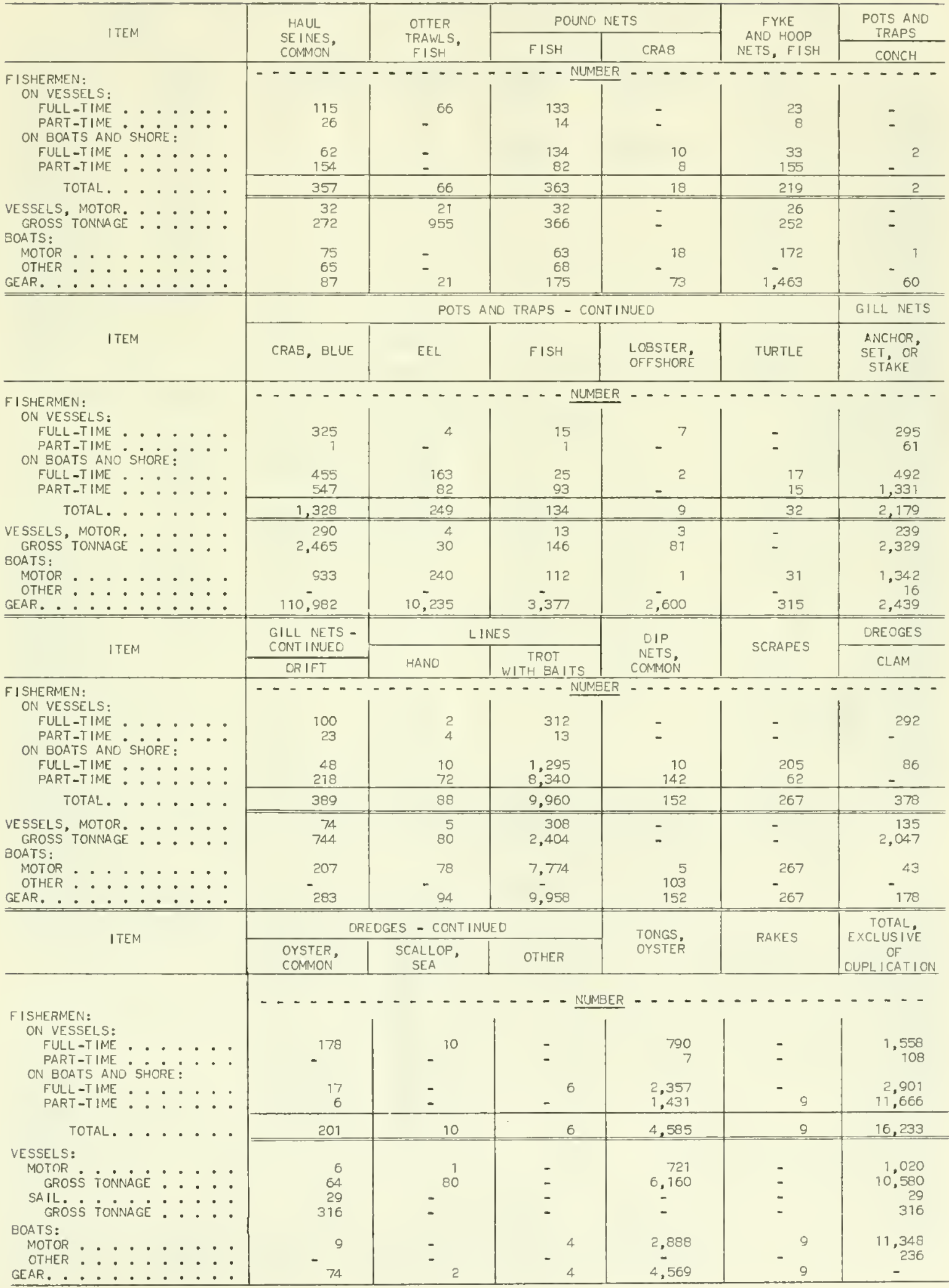


MARYLAND - LANDINGS OF CATCH BY GEAR, 1975

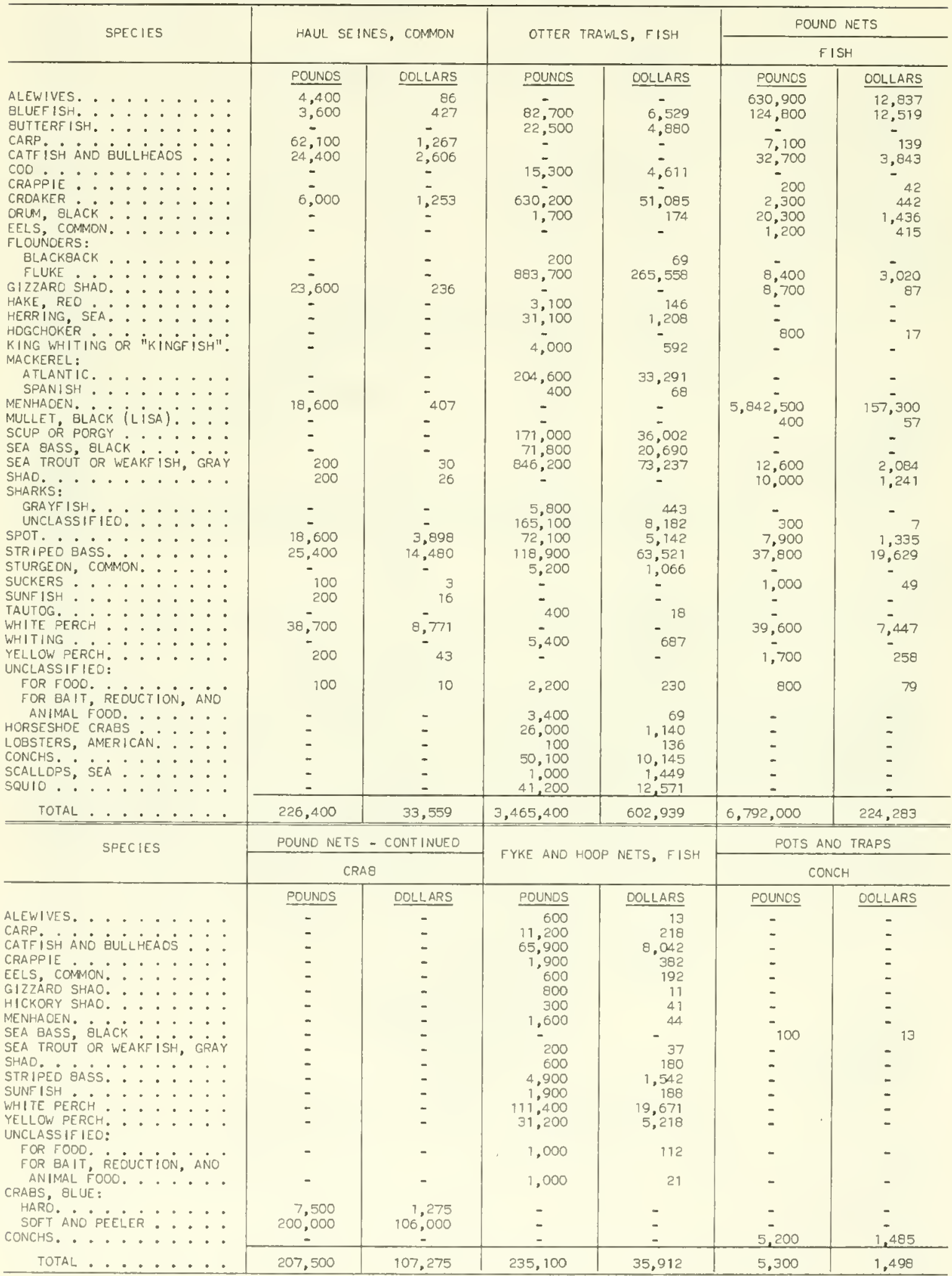


MARYLAND - LANDINGS OF CATCH BY GEAR, 1975 - Continued

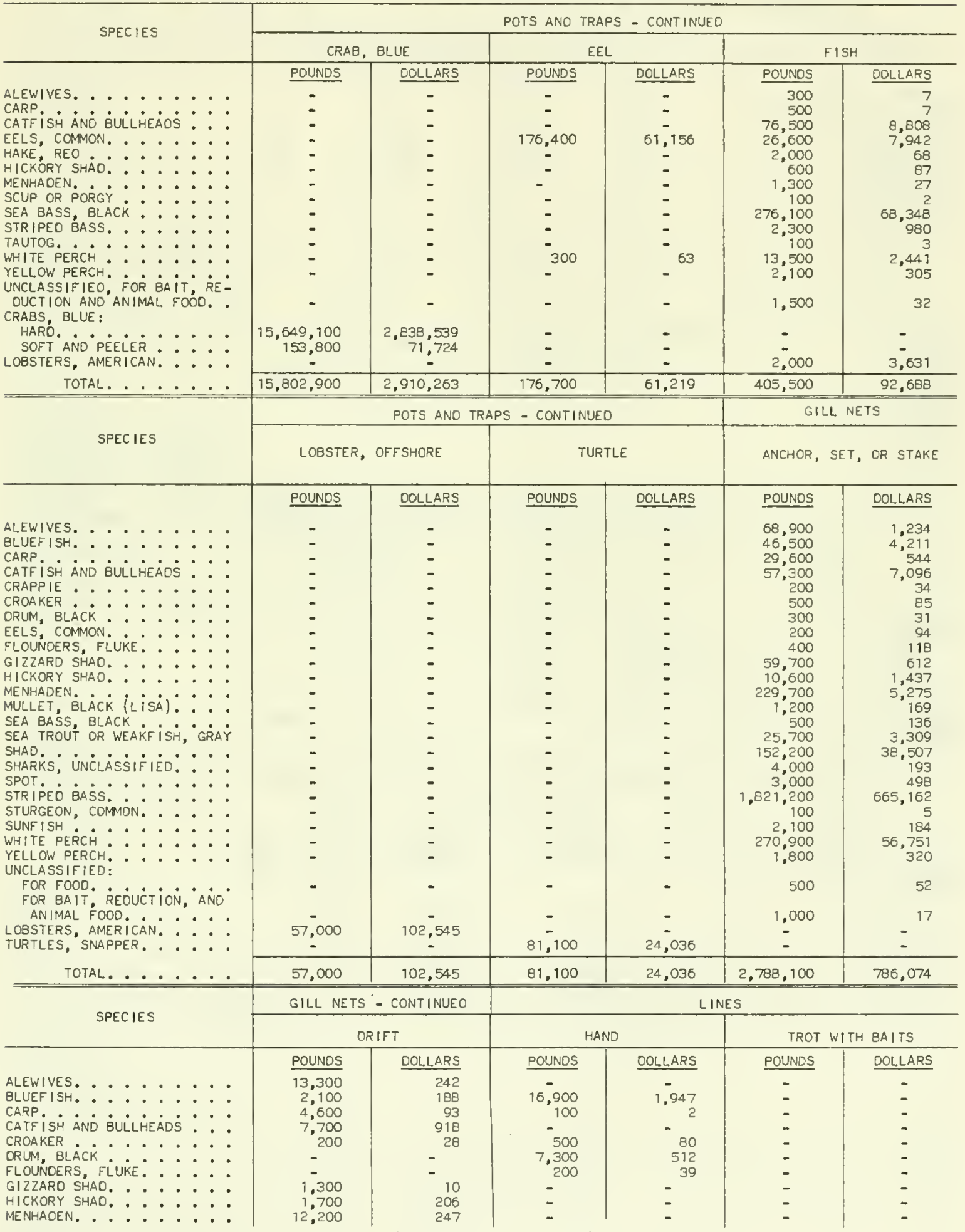

(CONTINUED ON NEXT PAGE) 


\section{MARYLAND - LANDINGS OF CATCH BY GEAR, 1975 - Continued}

\begin{tabular}{|c|c|c|c|c|c|c|}
\hline \multirow{2}{*}{ SPECIES } & \multirow{2}{*}{\multicolumn{2}{|c|}{$\begin{array}{c}\text { GILL NETS - CONTINUEO } \\
\text { ORIFT }\end{array}$}} & \multicolumn{4}{|c|}{ LINES } \\
\hline & & & \multicolumn{2}{|c|}{ HANO } & \multicolumn{2}{|c|}{ TROT WITH GAITS } \\
\hline \multirow[t]{2}{*}{ 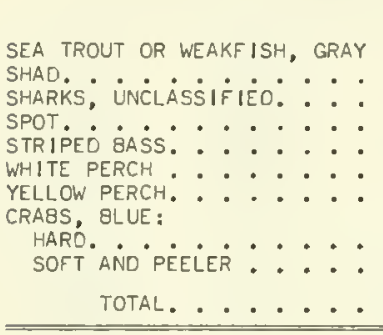 } & $\begin{array}{r}\text { POUNDS } \\
500 \\
20,600 \\
1,700 \\
873,200 \\
51,700 \\
200 \\
- \\
-\end{array}$ & $\begin{array}{r}\text { DOLLARS } \\
73 \\
4,597 \\
- \\
115 \\
373,144 \\
11,254 \\
23 \\
- \\
-\end{array}$ & $\begin{array}{r}\text { POUNOS } \\
1,100 \\
- \\
100 \\
200 \\
13,100 \\
700 \\
300 \\
= \\
= \\
\end{array}$ & $\begin{array}{r}\text { OOLLARS } \\
-\quad 211 \\
-\quad 11 \\
27 \\
7,727 \\
118 \\
43 \\
- \\
-\end{array}$ & $\begin{array}{r}\text { POUNOS } \\
- \\
= \\
= \\
= \\
8,499,000 \\
47,800 \\
\end{array}$ & $\begin{array}{c}\text { OOLLARS } \\
- \\
- \\
- \\
- \\
- \\
1,417,716 \\
26,499\end{array}$ \\
\hline & 990,500 & 391,138 & 40.500 & 10,717 & $8,546,800$ & $1,444,215$ \\
\hline \multirow[t]{2}{*}{ SPECIES } & \multirow{2}{*}{\multicolumn{2}{|c|}{ OIP NETS, COMMON }} & \multirow{2}{*}{\multicolumn{2}{|c|}{ SCRAPES }} & \multicolumn{2}{|c|}{ DREOGES } \\
\hline & & & & & \multicolumn{2}{|c|}{ CLAM } \\
\hline 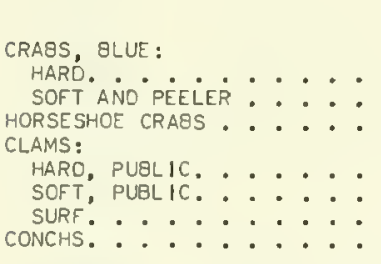 & $\begin{array}{l}\text { POUNDS } \\
15,400 \\
20,700 \\
- \\
= \\
= \\
-\end{array}$ & 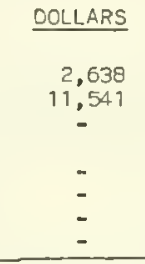 & $\begin{array}{r}\text { POUNDS } \\
93,000 \\
1,231,600 \\
- \\
= \\
- \\
\end{array}$ & $\begin{array}{c}\text { OOLLARS } \\
\begin{array}{c}15,630 \\
652,752 \\
- \\
- \\
- \\
-\end{array}\end{array}$ & $\begin{array}{c}\text { POUNOS } \\
- \\
11,100 \\
72,700 \\
1,246,200 \\
5,350,700 \\
41,100 \\
\end{array}$ & $\begin{array}{r}\text { OOLLARS } \\
- \\
- \\
477 \\
55,221 \\
1,174,340 \\
1,010,718 \\
9,872\end{array}$ \\
\hline TOTAL. ...... & 36,100 & 14,179 & $1,324,600$ & 668,382 & $6,721,800$ & $2.250,628$ \\
\hline \multirow{2}{*}{ SPECIES } & \multicolumn{6}{|c|}{ OREOGES - CONTINUEO } \\
\hline & \multicolumn{2}{|c|}{ OYSTER, COMMON } & \multicolumn{2}{|c|}{ SCALLOP, SEA } & \multicolumn{2}{|c|}{ OTHER } \\
\hline \multirow[t]{2}{*}{ 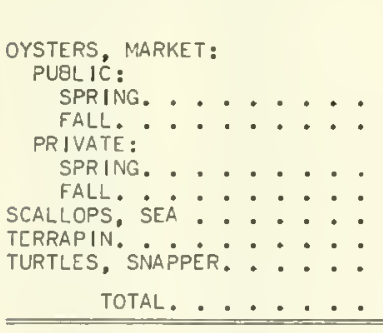 } & $\begin{array}{l}635,600 \\
648,300 \\
309,300 \\
180,400 \\
- \\
- \\
-\end{array}$ & $\begin{array}{l}449.947 \\
667,206 \\
363.930 \\
288,325 \\
= \\
=\end{array}$ & $\begin{array}{l}- \\
- \\
- \\
2,800 \\
-\end{array}$ & 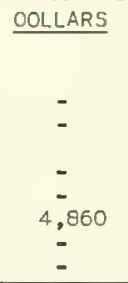 & $\begin{array}{l}- \\
- \\
- \\
5,100 \\
2,000\end{array}$ & $\begin{array}{l}- \\
- \\
= \\
= \\
3.319 \\
608\end{array}$ \\
\hline & $1,773,600$ & $1,769,408$ & 2,800 & 4,860 & 7,100 & 3,927 \\
\hline SPECIES & \multicolumn{3}{|c|}{ TONGS, OYSTER } & \multicolumn{3}{|c|}{ RAKES } \\
\hline 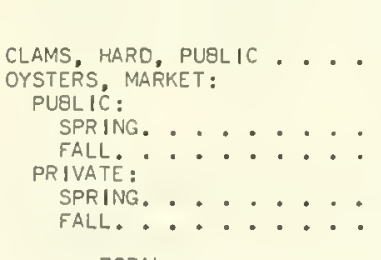 & $\begin{array}{l}5,12 \\
9,31\end{array}$ & & $\begin{array}{r}3,182,453 \\
8,025,822 \\
105,504 \\
43,482 \\
\end{array}$ & $\frac{\text { POUN }}{1,8}$ & & $\begin{array}{l}\text { OOLLARS } \\
1,337 \\
- \\
- \\
-\end{array}$ \\
\hline TOTAL. . . . . . . & 14,62 & & $11,357.261$ & 1,6 & & 1,337 \\
\hline
\end{tabular}




\section{VIRGINIA \\ OPERATING UNITS BY GEAR, 1975}

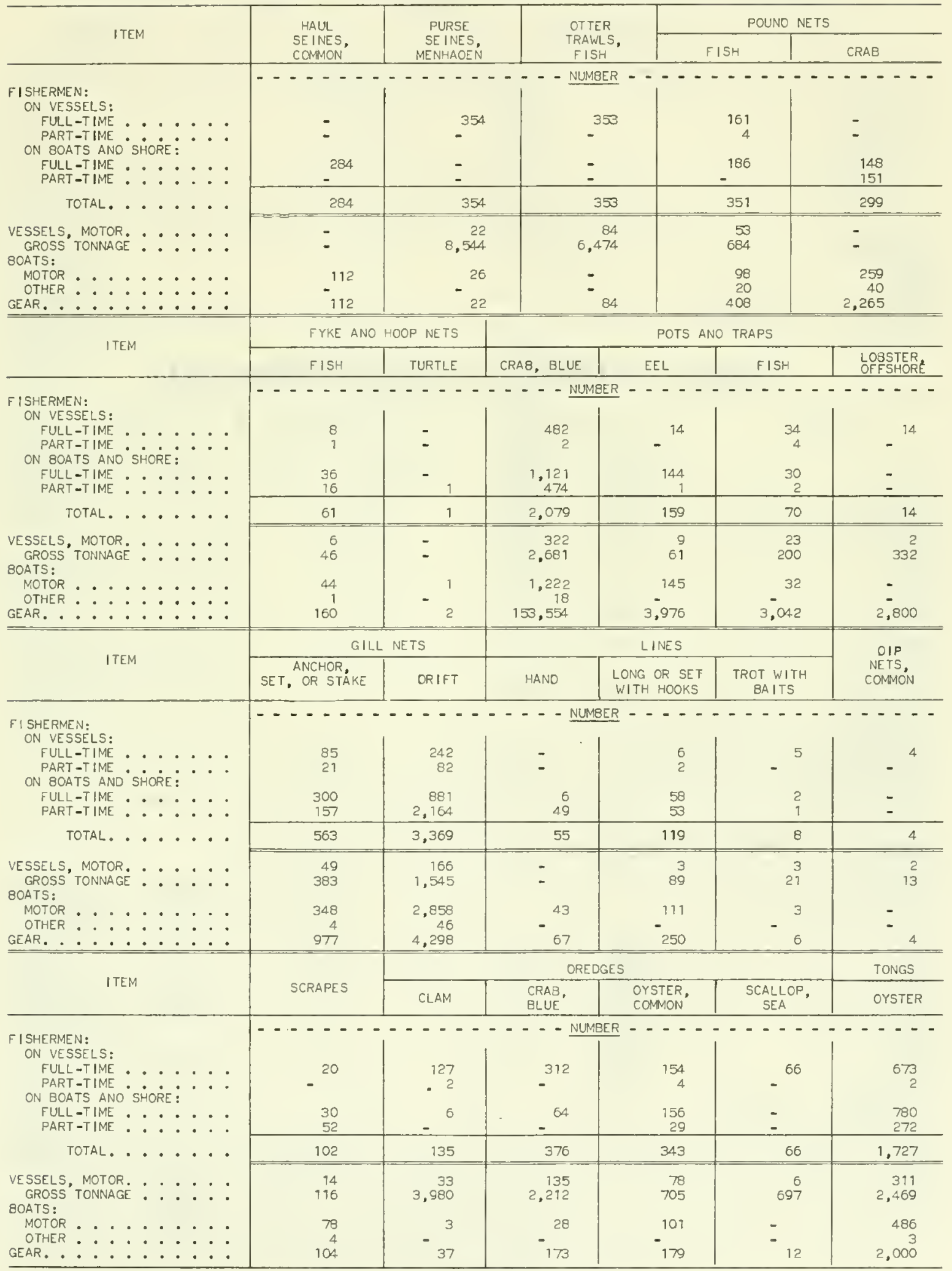




\section{VIRGINIA - OPERATING UNITS BY GEAR, 1975 - Continued}

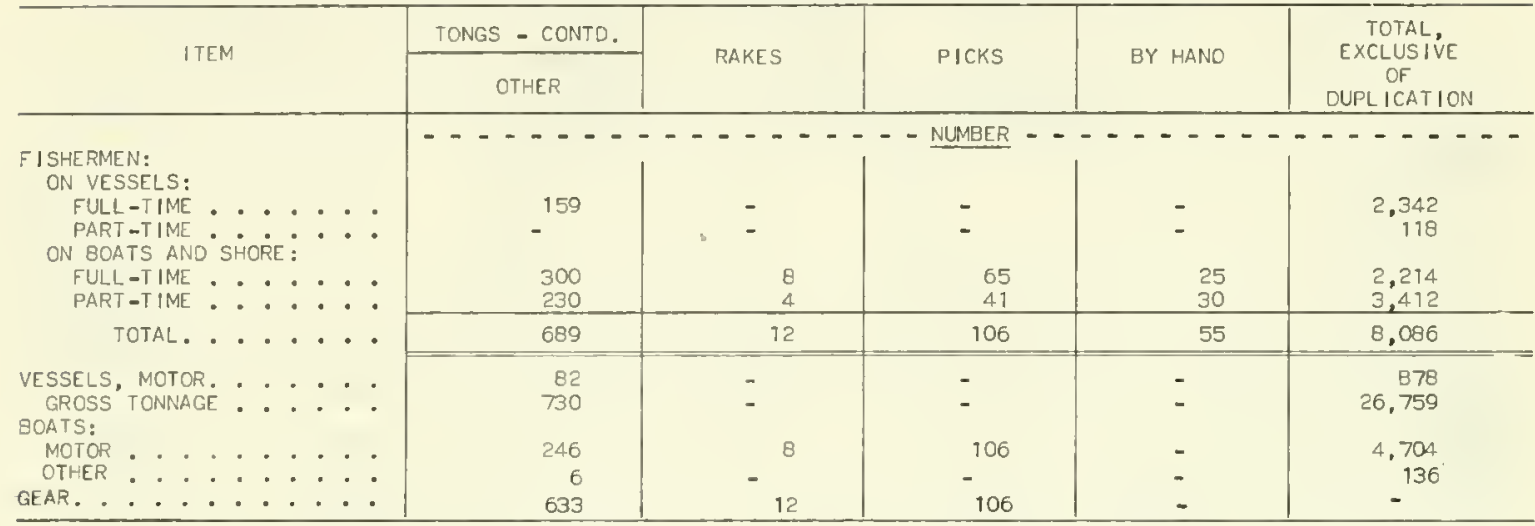

\section{VIRGINIA - LANDINGS OF CATCH BY GEAR, 1975}

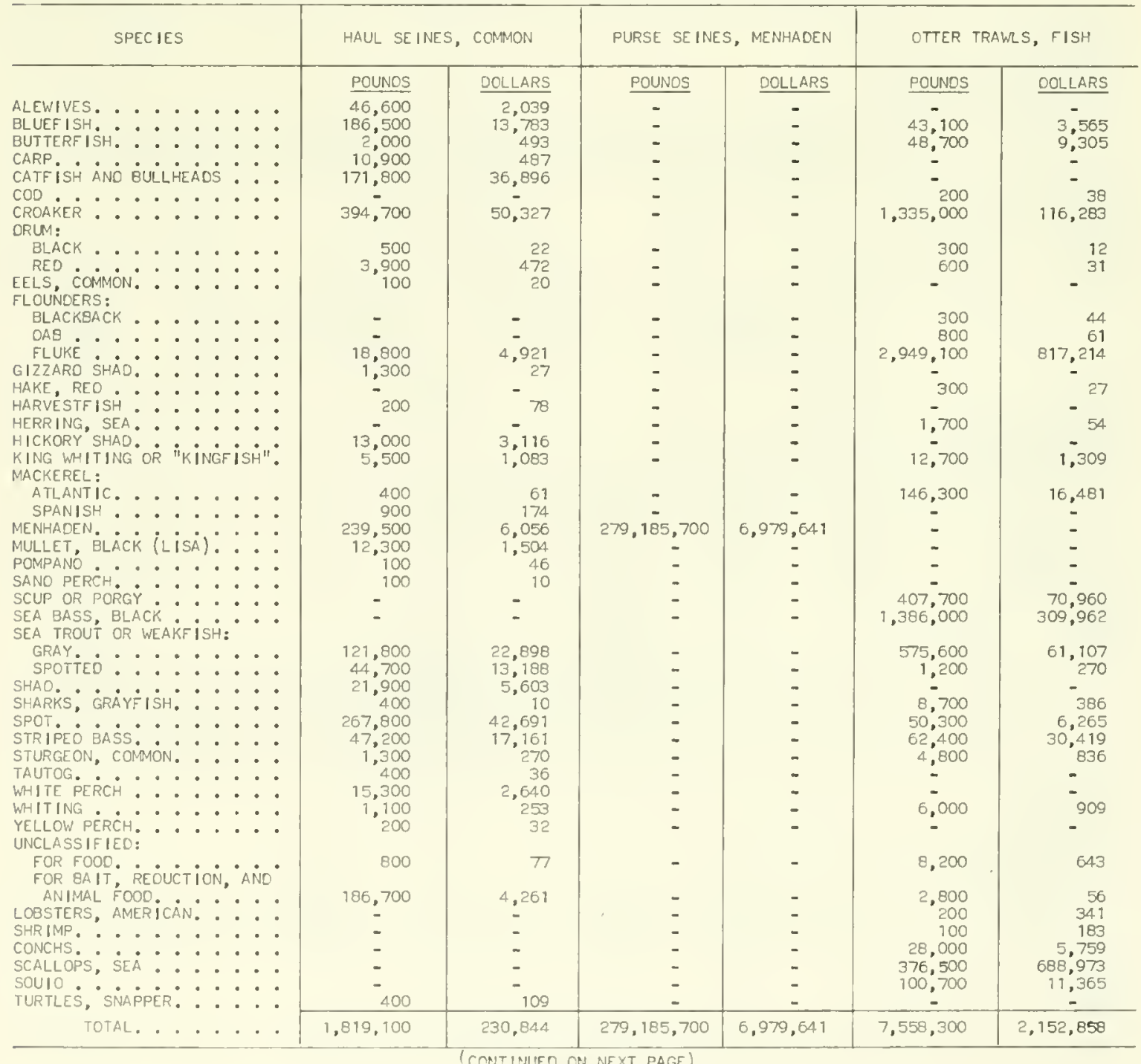


VIRGINIA - LANDINGS OF CATCH BY GEAR, 1975 - Continued

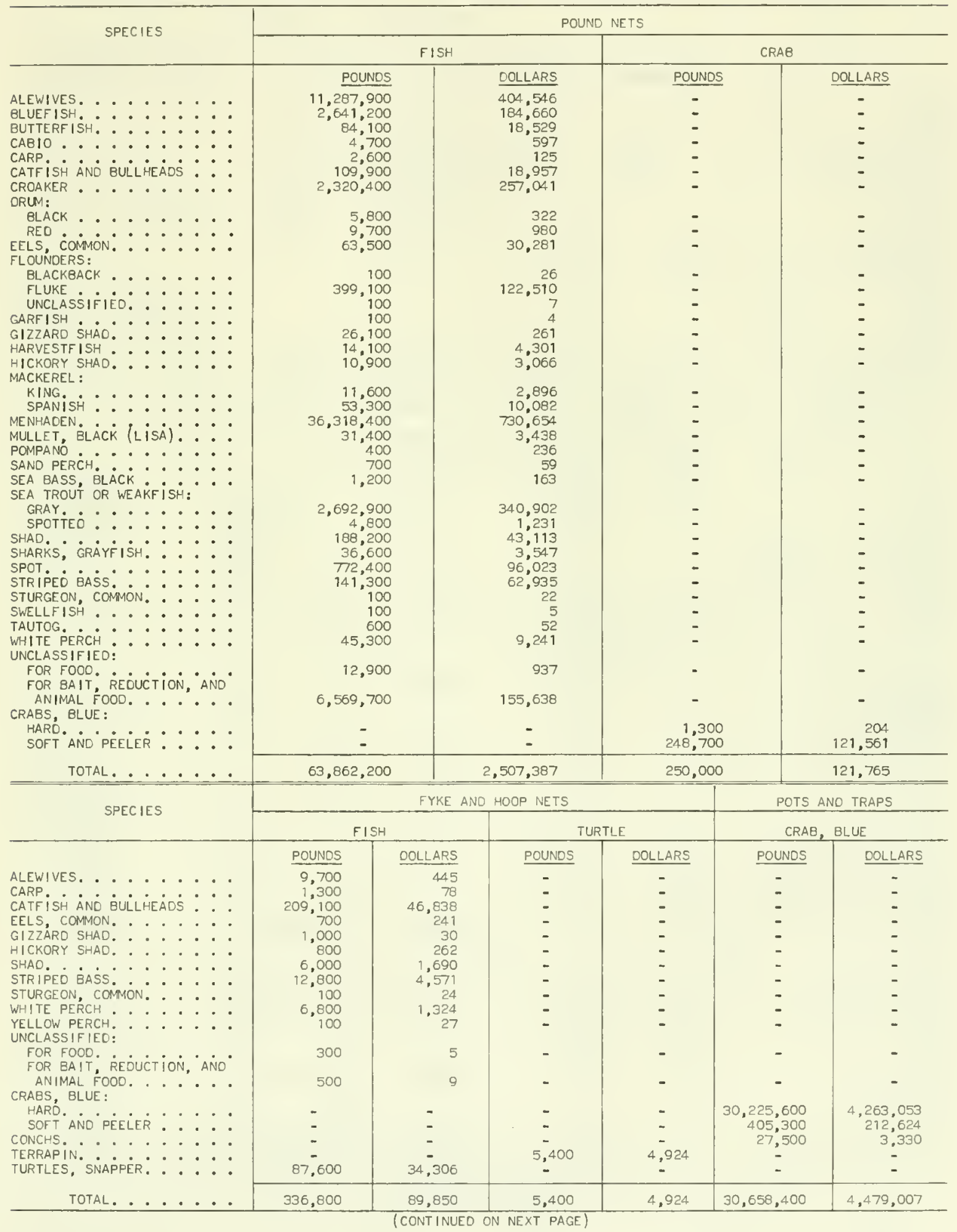


VIRGINIA - LANDINGS OF CATCH BY GEAR, 1975 - Continued

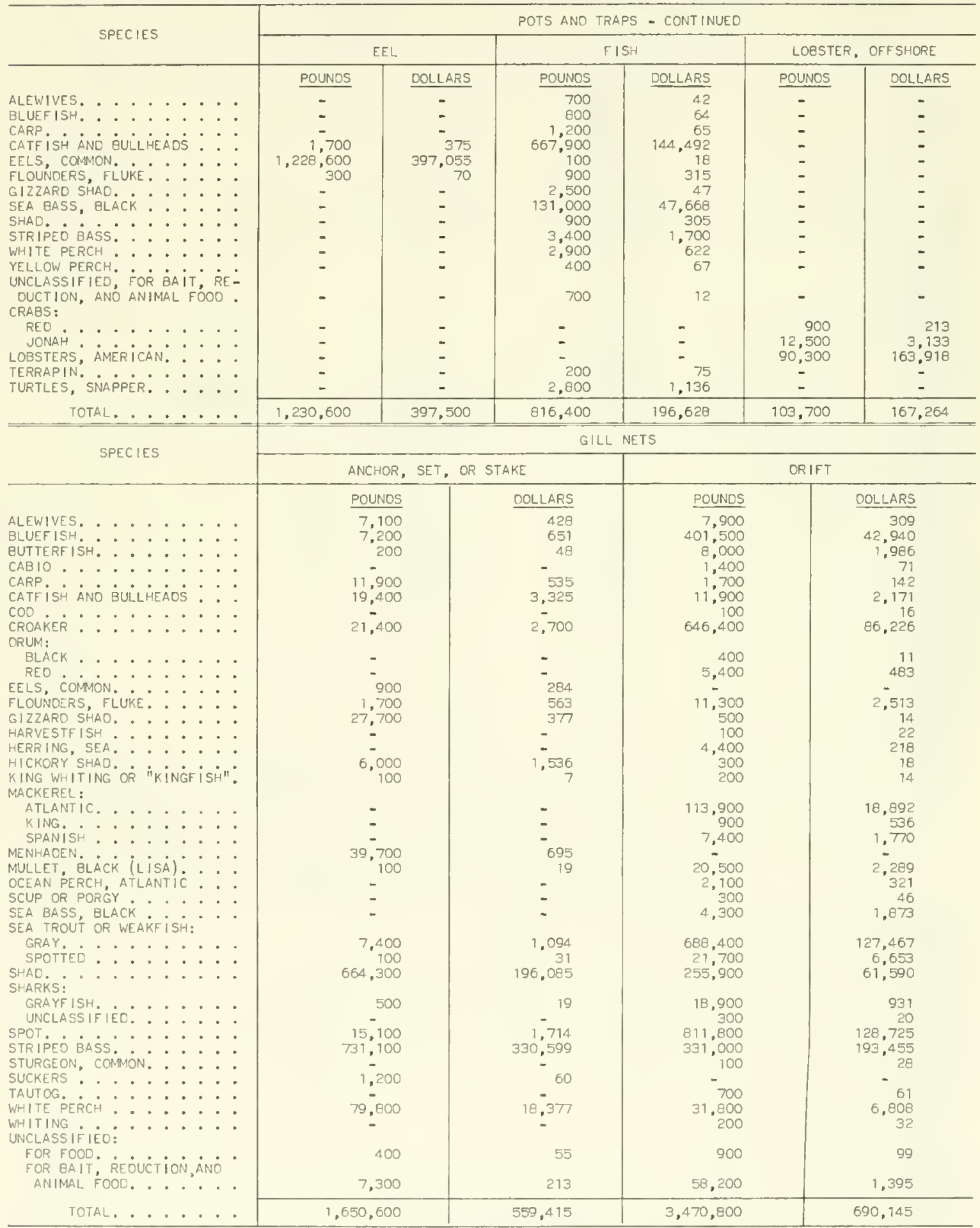


VIRGINIA - LANDINGS OF CATCH BY GEAR, 1975 - Continued

\begin{tabular}{|c|c|c|c|c|c|c|}
\hline \multirow{2}{*}{ SPECIES } & \multicolumn{6}{|c|}{ LINES } \\
\hline & \multicolumn{2}{|c|}{ HAND } & \multicolumn{2}{|c|}{ LONG OR SET WITH HOOKS } & \multicolumn{2}{|c|}{ TROT WITH BAITS } \\
\hline \multirow[t]{2}{*}{ 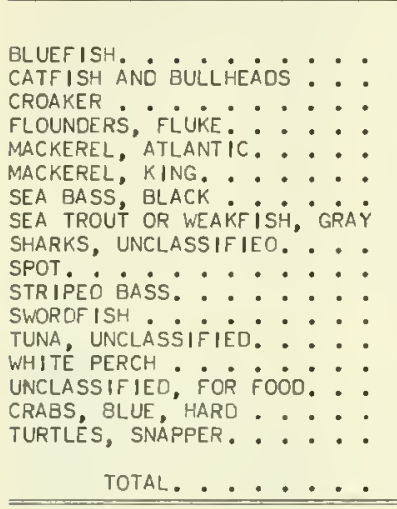 } & $\begin{array}{r}\frac{\text { POUNDS }}{4,900} \\
- \\
3,400 \\
1,900 \\
237,700 \\
400 \\
23,200 \\
3,900 \\
=, 000 \\
2,700 \\
= \\
= \\
= \\
179,300\end{array}$ & $\begin{array}{r}\frac{\text { DOLLARS }}{554} \\
- \\
329 \\
473 \\
45,785 \\
223 \\
7,533 \\
574 \\
- \\
208 \\
1,061 \\
= \\
= \\
= \\
70,845\end{array}$ & 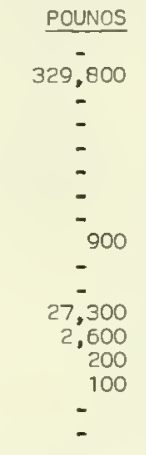 & $\begin{array}{c}\text { DOLLARS } \\
75,420 \\
\vdots \\
\vdots \\
- \\
- \\
- \\
- \\
37,285 \\
1,226 \\
41 \\
12 \\
-\end{array}$ & $\begin{array}{l}\text { POUNOS } \\
\vdots \\
\vdots \\
\vdots \\
\vdots \\
\vdots \\
\vdots \\
\vdots \\
\vdots \\
\vdots \\
53,400 \\
-\end{array}$ & $\begin{array}{c}\text { OOLLARS } \\
- \\
\vdots \\
\vdots \\
\vdots \\
\vdots \\
\vdots \\
\vdots \\
\vdots \\
\vdots \\
\vdots \\
\vdots \\
-564\end{array}$ \\
\hline & 457,800 & 127,585 & 360,900 & 114,137 & 53,400 & 6,564 \\
\hline \multirow{2}{*}{ SPECIES } & \multirow{2}{*}{\multicolumn{2}{|c|}{ DIP NETS, COMMON }} & \multirow{2}{*}{\multicolumn{2}{|c|}{ SCRAPES }} & \multicolumn{2}{|c|}{ DREOGES } \\
\hline & & & & & \multicolumn{2}{|c|}{ CLAM } \\
\hline \multirow[t]{2}{*}{ 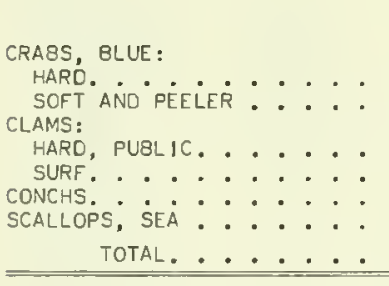 } & $\begin{array}{c}\frac{\text { POUNOS }}{-} \\
- \\
- \\
\overline{-} \\
8,400\end{array}$ & $\begin{array}{c}\text { OOLLARS } \\
- \\
- \\
- \\
13,809\end{array}$ & $\begin{array}{r}\text { POUNOS } \\
55,600 \\
100,300 \\
= \\
- \\
\end{array}$ & $\begin{array}{c}\text { DOLLARS } \\
6,573 \\
49,654 \\
- \\
- \\
-\end{array}$ & $\begin{array}{r}\text { POUNOS } \\
21,600 \\
- \\
55,400 \\
39,088,300 \\
7,027,900 \\
\end{array}$ & $\begin{array}{r}\text { DOLLARS } \\
3,240 \\
50,485 \\
5,682,002 \\
104,027 \\
\end{array}$ \\
\hline & 8,400 & 13,809 & 155,900 & 56,327 & $40,187,200$ & $5,839,754$ \\
\hline \multirow{2}{*}{ SPECIES } & \multicolumn{6}{|c|}{ DREDGES - CONTINUED } \\
\hline & \multicolumn{2}{|c|}{ CRAB, BLUE } & \multicolumn{2}{|c|}{ OYSTER, COMMON } & \multicolumn{2}{|c|}{ SCALLOP, SEA } \\
\hline 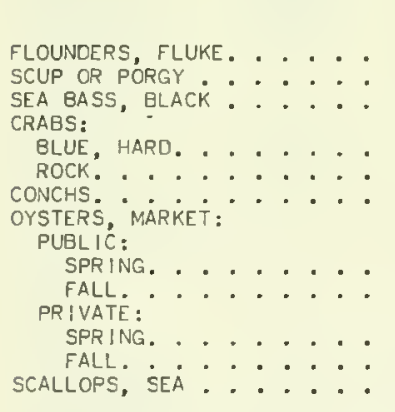 & $\begin{array}{c}\frac{\text { POUNOS }}{-} \\
- \\
4,461,500 \\
300 \\
7,500\end{array}$ & $\begin{array}{c}\frac{\text { DOLLARS }}{-} \\
- \\
737,817 \\
32 \\
1,887\end{array}$ & $\begin{array}{c}\text { POUNOS } \\
- \\
= \\
= \\
= \\
39,100 \\
5,300\end{array}$ & $\begin{array}{r}29,235 \\
5,026 \\
1,545,997 \\
716,385 \\
\end{array}$ & $\begin{array}{r}\frac{\text { POUNOS }}{34,400} \\
500 \\
600 \\
- \\
-\end{array}$ & $\begin{array}{c}\frac{\text { DOLLARS }}{9,158} \\
158 \\
138 \\
= \\
- \\
- \\
- \\
- \\
- \\
\end{array}$ \\
\hline 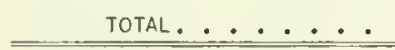 & $4,469,300$ & 739,736 & $2,813,900$ & $2,296,643$ & 916,400 & $1,630,349$ \\
\hline SPECIES & \multicolumn{4}{|c|}{ TONGS } & \multicolumn{2}{|c|}{ RAKES } \\
\hline 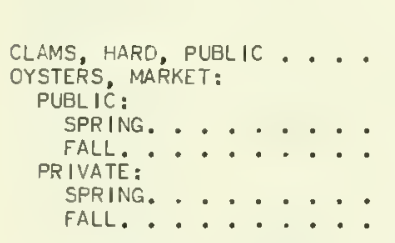 & $\begin{array}{r}1,269,700 \\
1,636,800 \\
91,400 \\
384,200 \\
\end{array}$ & $\begin{array}{r}901,627 \\
1,385,436 \\
68,394 \\
309,649 \\
\end{array}$ & $\frac{\text { POUNDS }}{710,000}$ & $\frac{\text { DOLLARS }}{666,252}$ & $\frac{\text { POUNOS }}{15,200}$ & $\frac{\text { DOLLARS }}{13,808}$ \\
\hline TOTAL. . . . . . & $3,382,100$ & $2,665,106$ & 751,200 & 703,625 & 15.200 & 13,808 \\
\hline SPECIES & & PICKS & & & BY HANO & \\
\hline $\begin{array}{l}\text { CLAMS, HARD, PUBLIC } \ldots \ldots \\
\text { TOTAL. } \ldots \ldots\end{array}$ & $\frac{\frac{P O U}{265}}{265}$ & & $\frac{\text { DOLLARS }}{249,894}$ & $\frac{\frac{P O U N}{42,7}}{42,7}$ & & $\frac{\text { OLLARS }}{\frac{41,854}{41,854}}$ \\
\hline
\end{tabular}




\section{CHESAPEAKE STATES - LANDINGS OF CATCH BY WATERS, 1975}

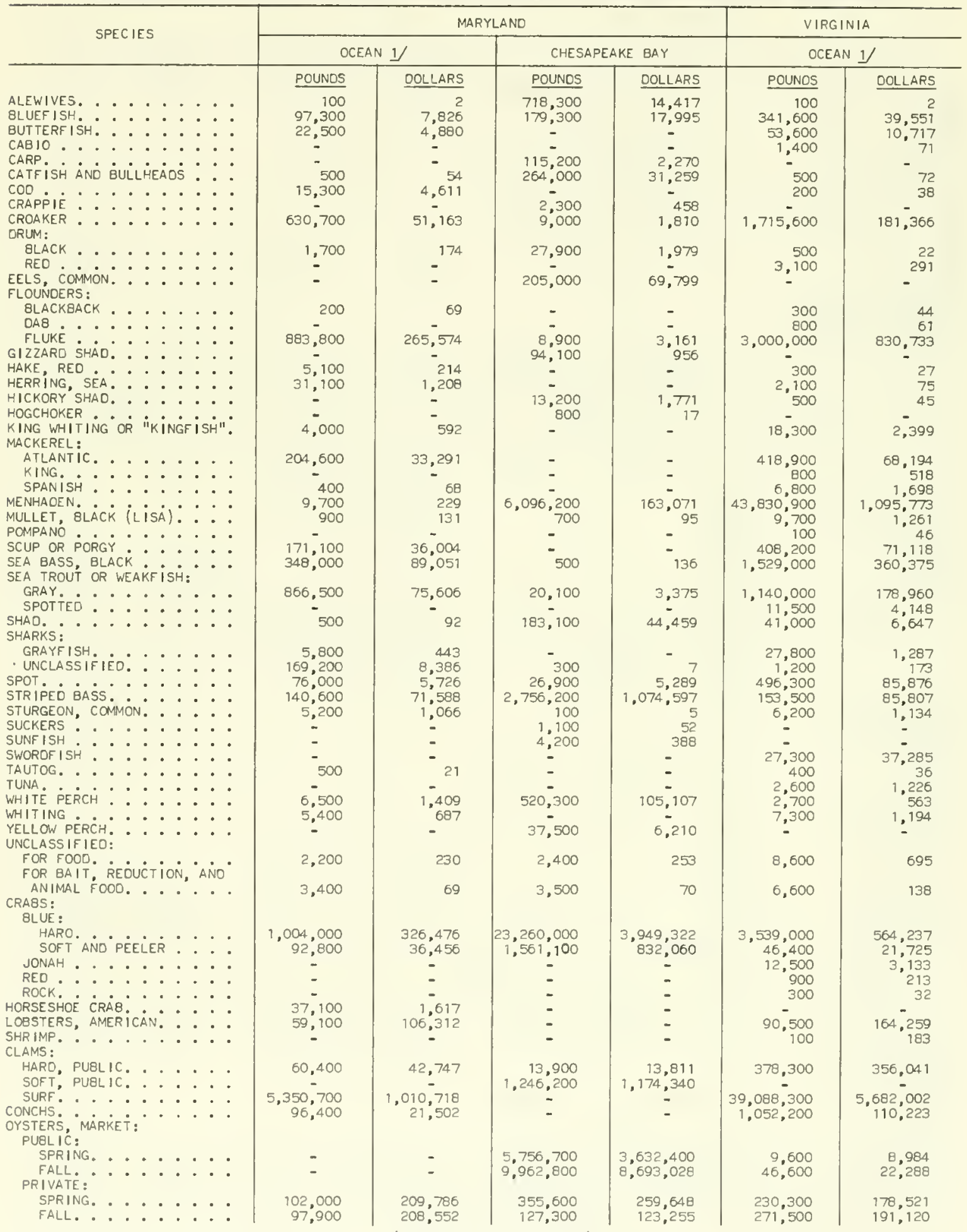

SEE FOOTNOTE AT ENO OF TABLE. 
CHESAPEAKE STATES - LANDINGS OF CATCH BY WATERS, 1975 - Continued

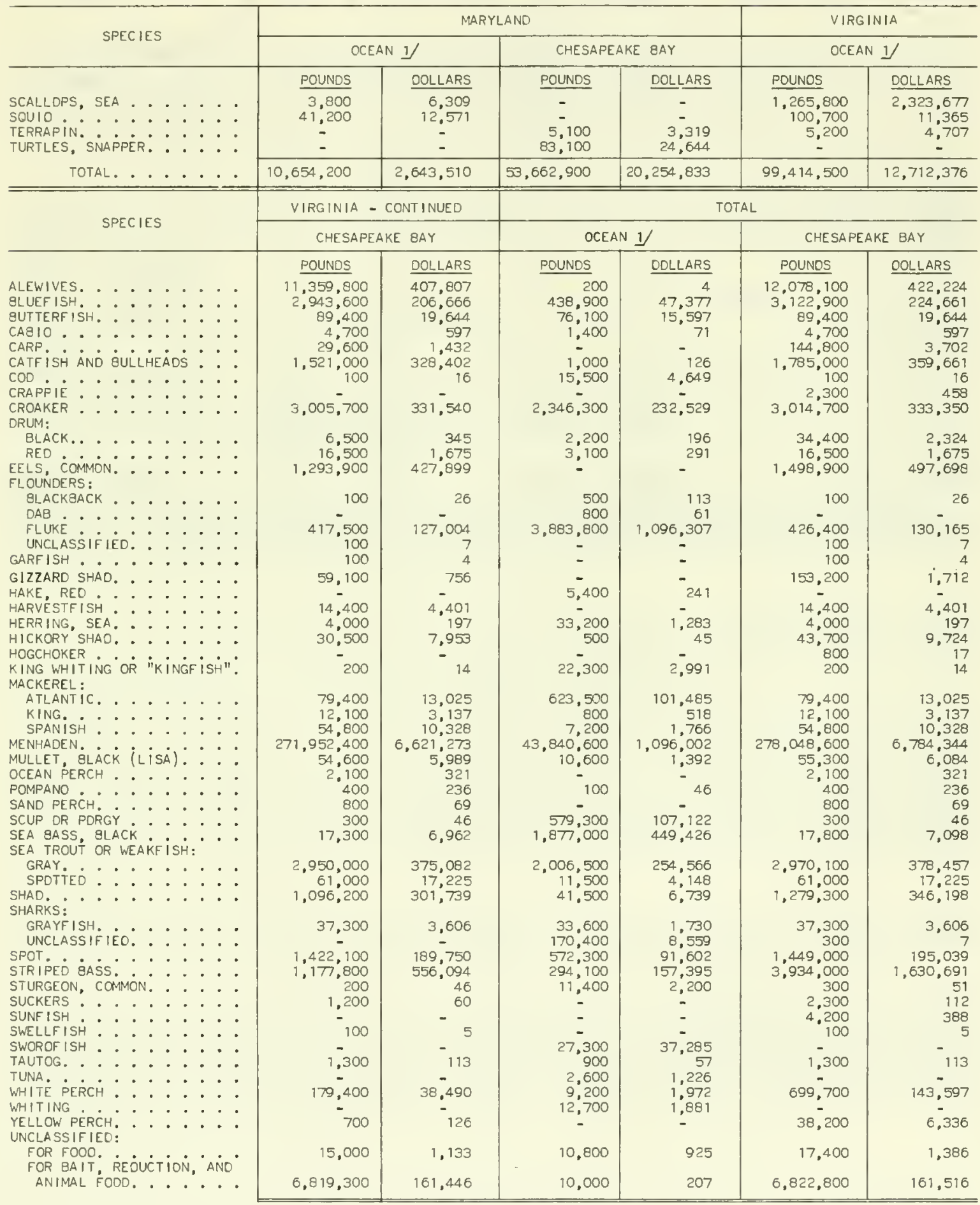

SEE FOOTNOTE AT END OF TABLE.

(CONT I NUED ON NEXT PAGE) 


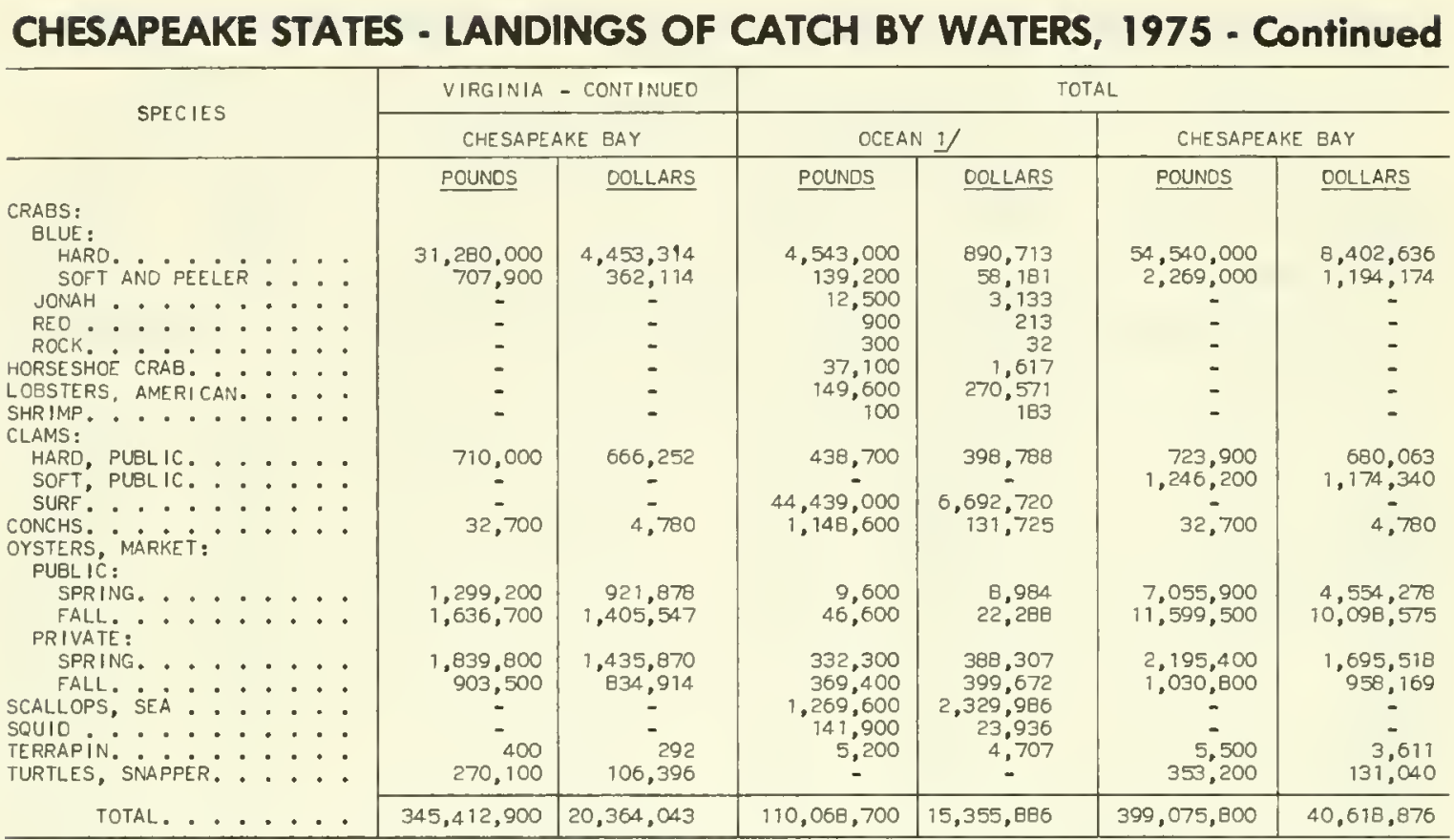

1) INCLUOES BAYS ANO CREEKS, EXCLUSIVE OF CHESAPEAKE BAY, WHICH DRAIN INTO THE ATLANTIC OCEAN. 


\section{SECTION 5 \\ SOUTH ATLANTIC FISHERIES}

Commercial landings of fish and shellfish at ports of the South Atlantic States (North Carolina, South Carolina, Georgia, and the East Coast of Florida, including freshwater areas of Florida) were 333.1 million pounds worth a record $\$ 63.6$ million. The quantity landed was the largest since 1968 and 22 percent above the average of the previous 5 years. The larger volume was caused principally by heavier landings of menhaden. Landings of croaker, spanish mackerel, spot, and thread herring also increased significantly. The 25-percent increase in value was caused by higher exvessel prices paid for shrimp in all four States.

North Carolina led all States with landings of 238.3 million pounds, 15 percent higher than the previous year and 42 percent higher than the 5-year average for 1970-74. Landings in South Carolina (20.1 million pounds) increased 6 percent, but landings in Georgia (17.7 million pounds) declined 2 percent, and Florida, East Coast ( 56.9 million pounds) declined 6 percent. Florida, East Coast was the only State that had a decline in value compared with 1974 .

Fishermen and Vessels. There were 10,242 full-time and part-time fishermen operating 1,546 vessels of 5 gross tons or over, 5,406 motorboats, and 250 other boats. Compared with 1974, this was an increase of 251 fishermen, 23 vessels, 290 motorboats, and 74 other boats.

Processed products. The value of processed fishery products was $\$ 130.3$ million, an increase of $\$ 14.3$ million compared with 1974. Georgia led with products valued at $\$ 48.3$ million, followed by Florida, East Coast with $\$ 46.7$ million; North Carolina, $\$ 26.9$ million; and South Carolina, $\$ 8.5$ million. The four States had a monthly average of 6,138 persons employed in 520 wholesaling and processing plants.

Hard blue crabs. Landings of 30.5 million pounds valued at $\$ 4.1$ million decreased 20 percent in volume and 10 percent in value compared with 1974 , the record year for value. The volume landed was the smallest since 1956 and 19 percent below the average of the previous 5 years. Landings declined in all four States. North Carolina landings of 11.1 million pounds were down 16 percent; South Carolina, 6.4 million, down 15 percent; Georgia, 8.9 million, down 12 percent; and Florida, East Coast, 4.2 million pounds, down 44 percent. The value of landings declined in all States except North Carolina.

North Carolina landings were the lowest since 1956, but the value was 6 percent above the previous year. Crabs were generally in short supply with good demand. Exvessel prices averaged a record 13 cents per pound in 1975 compared with 10 cents in 1974. Wholesale and retail prices for crabmeat and other products from hard blue crabs also reached record highs in North Carolina during the year.

Food finfish. Landings of edible finfish were 88.2 million pounds, an increase of 6.3 million pounds compared with 1974. Several major species including alewives, catfish and bullheads, flounders, and black mullet declined in volume. Landings of alewives were the smallest on record. Flounder landings were 11.8 million pounds, 2 percent below the record catch in 1974; black mullet, 5.2 million pounds, declined 9 percent. Species with notable increases in 1975 were croaker (up 67 percent); gray sea trout (up 11 percent); spanish mackerel (up 115 percent); and spot (up 38 percent). Croaker and spot had record landings, and spanish mackerel had the third largest landings on record. Alewives, croaker, and spanish mackerel had lower exvessel prices in 1975. Flounder landings, which had dropped to the lowest exvessel price since 1970, increased 7 cents a pound in 1975 .

Spiny lobsters. Landings were 2.3 million pounds valued at $\$ 3.0$ million, a decline of 1.8 million pounds and $\$ 2.0$ million compared with 1974 . The quantity landed was the smallest since 1967 and 51 percent below the previous 5-year average. All landings were made at Florida, East Coast ports.

Menhaden. Landings were 166.9 million pounds, an increase of 33.1 million pounds (25 percent) compared with 1974. North Carolina with 92 percent of the total landings had 153.8 million pounds-an increase of 27 percent compared with 1974. Biological studies by NMFS indicate that fishing effort for Atlantic menhaden is excessive relative to current stock size. Also, the capture of juvenile menhaden is reducing the contribution these small fish could make towards improved landings in the next few years. Intense effort and the capture of juveniles have reduced current levels of production for the entire Atlantic fishery to about one-half the maximum sustainable yield. 
Oysters. Landings yielded 1.6 million pounds of meats worth $\$ 1.0$ million, a decline of 14 percent in both volume and value compared with 1974. Landings and value declined in all States, and the total quantity landed was the smallest since 1880. South Carolina, the leading producer, declined 7 percent; North Carolina, 24 percent; Florida, East Coast, 19 percent; and Georgia, 32 percent. Georgia landings were the smallest on record, and Florida, East Coast landings were the lowest since 1962. The average price per pound remained about the same in North Carolina and South Carolina, but increased 4 cents a pound in Georgia and 10 cents a pound along the east coast of Florida.

Calico scallops. Landings yielded 1.4 million pounds of meats worth $\$ 899,000-$ an increase of 313,000 pounds and $\$ 280,000$ compared with 1974. Florida, East Coast accounted for the entire production. North Carolina, usually the leading producer, had no calico scallop production in 1974 and 1975.

Shrimp. Landings of 24.9 million pounds (heads-on) valued at a record $\$ 30.3$ million were 2.2 million pounds less, but $\$ 12.0$ million more than in 1974. Excellent consumer demand combined with the moderate catch kept prices high and made 1975 a good year for the shrimp fishery. Fishermen received an average price of a record $\$ 1.22$ per pound compared with 68 cents in 1974 .

South Carolina led with 8.9 million pounds, an increase of 19 percent compared with 1974. Landings in Georgia ( 8.1 million pounds) increased 12 percent, but Florida, East Coast ( 2.8 million pounds) and North Carolina ( 5.2 million pounds) declined 30 and 39 percent, respectively. The average price per pound for shrimp increased 43 cents in North Carolina; 57 cents in South Carolina; 53 cents in Georgia; and 59 cents in Florida, East Coast.

A comparison of the species composition in the South Atlantic catch in 1974 and 1975 (heads-off) shows a substantial decrease in landings of brown shrimp, down 2.7 million pounds; pink shrimp, down 58,500 pounds; and rock shrimp, down 167,500 pounds. Landings of white shrimp increased 1.6 million pounds and royal red shrimp, 25,900 pounds. Landings of brown shrimp were 26 percent of the total landings compared to 40 percent in 1974 , and white shrimp were 65 percent compared to 50 percent. Pink, royal red, and rock shrimp remained about the same.

Other information. Condensed summary data on the operating units and landings, by States, appearing in the following pages have been published previously in Current Fishery Statistics No. 7408. Additional data may be found in the monthly and annual landings bulletins for North Carolina, South Carolina, Georgia, and Florida published in the Current Fishery Statistics series by the Data Management and Statistics Division in cooperation with the respective States.

Acknowledgments. The following organizations helped collect the data appearing in this section: North Carolina Department of Natural and Economic Resources, Division of Commercial and Sports Fisheries; South Carolina Wildlife Resources Department, Division of Marine Resources; Georgia State Game and Fish Commission, Coastal Fisheries Division; and Florida Department of Natural Resources. 


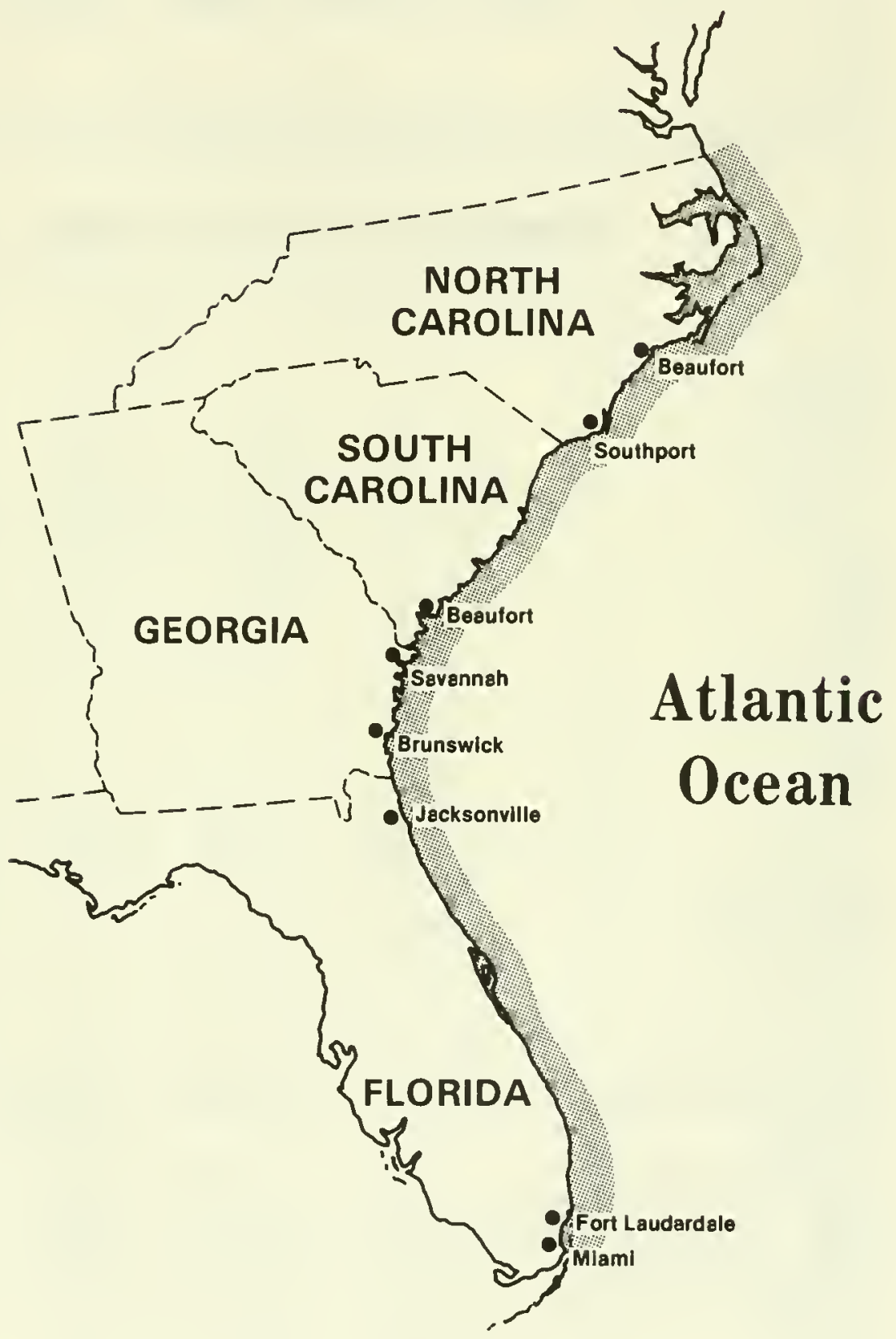

SOUTH ATLANTIC STATES 
SECTIONAL SUMMARIES

SUMMARY OF LANDINGS, 1975

\begin{tabular}{|c|c|c|c|c|c|c|}
\hline STATE & \multicolumn{2}{|c|}{ FISH } & \multicolumn{2}{|c|}{ SHELLFISH ET AL. } & \multicolumn{2}{|c|}{ TOTAL } \\
\hline & $\frac{\text { MILLLION }}{\text { POUNOS }}$ & $\begin{array}{l}\text { MILLION } \\
\text { DOLLARS }\end{array}$ & $\frac{\text { MILLION }}{\text { POUNDS }}$ & $\begin{array}{l}\text { M!LLION } \\
\text { DOLLARS }\end{array}$ & $\frac{\text { MILLION }}{\text { POUNDS }}$ & $\begin{array}{l}\text { MILLION } \\
\text { DOLLARSS }\end{array}$ \\
\hline 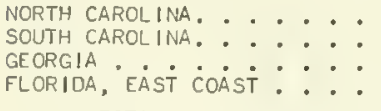 & $\begin{array}{r}221 \\
4 \\
1 \\
46 \\
\end{array}$ & $(1)_{10}^{12}$ & $\begin{array}{l}18 \\
16 \\
17 \\
11 \\
\end{array}$ & $\begin{array}{r}\mathrm{B} \\
12 \\
12 \\
9 \\
\end{array}$ & $\begin{array}{r}238 \\
20 \\
18 \\
57 \\
\end{array}$ & $\begin{array}{r}20 \\
13 \\
12 \\
19 \\
\end{array}$ \\
\hline TOTAL........ & 271 & 23 & 62 & 41 & 333 & 64 \\
\hline
\end{tabular}

9 LESS THAN $\$ 500,000$. NOTE:--TABLE MAY NOT AOO BECAUSE OF ROUNDING. LANOINGS FOR THE INLAND LAKES OF FLORIDA ARE INCLUDED WITH THE LANDINGS FOR THE EAST COAST OF FLORIDA. FOR THE PURPOSE OF THIS REPORT THE "EAST COAST OF FLORIOA" INCLUDES THE COASTAL COUNTIES FROM NASSAU TO DADE, INCLUSIVE.

\section{SUMMARY OF OPERATING UNITS, 1975}

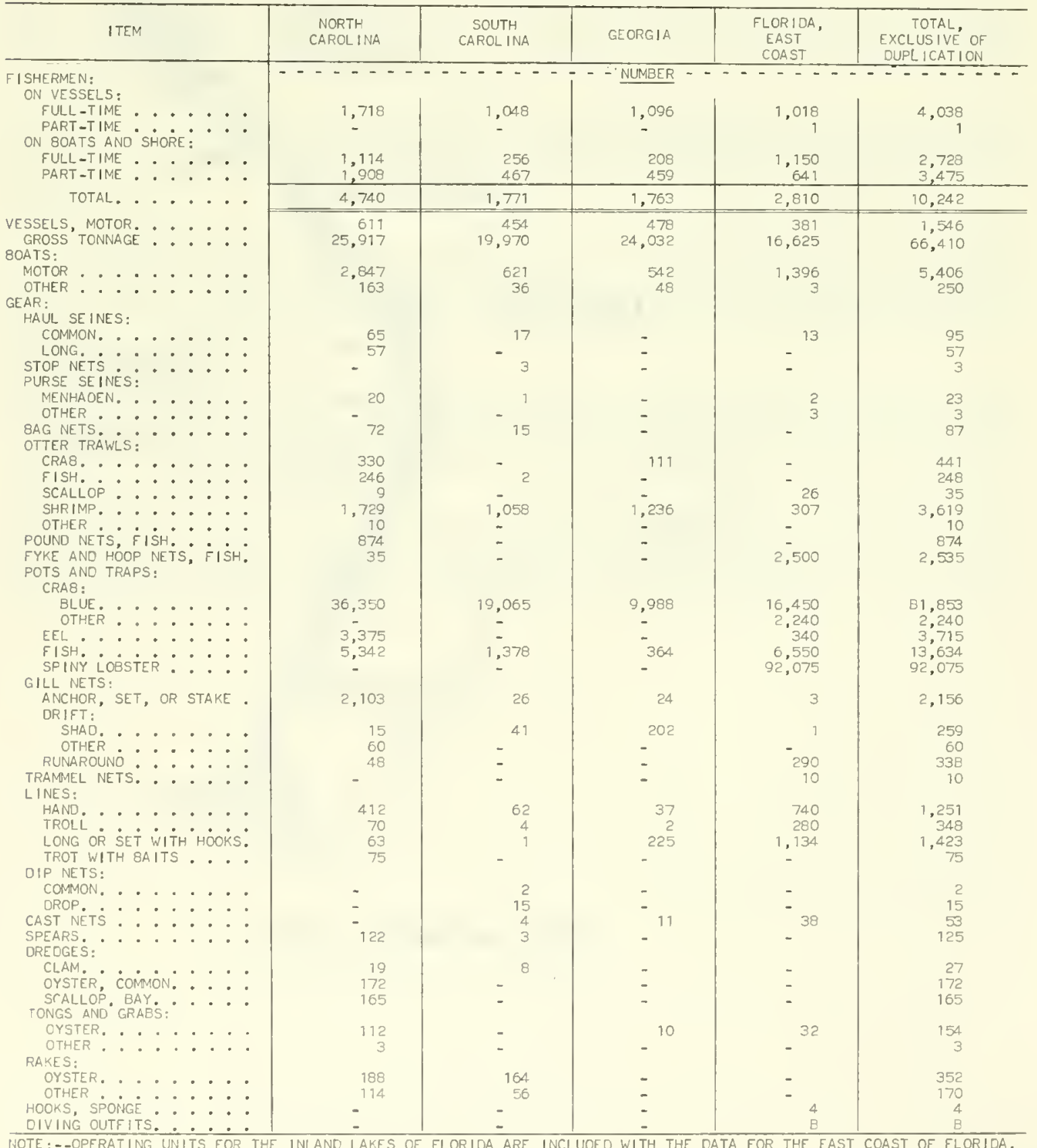


LANDINGS BY STATES, 1975

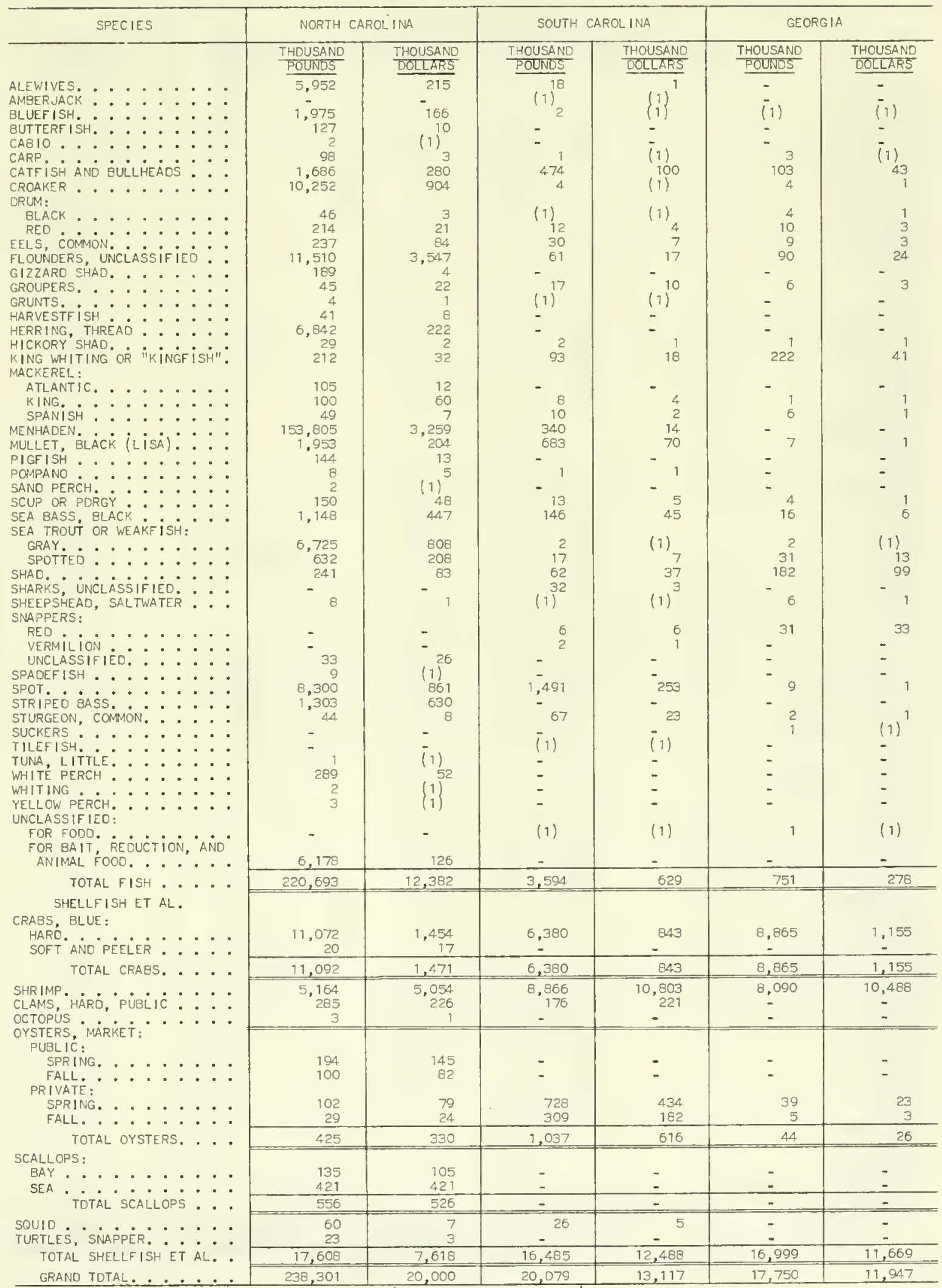


LANDINGS BY STATES, 1975 - Continued

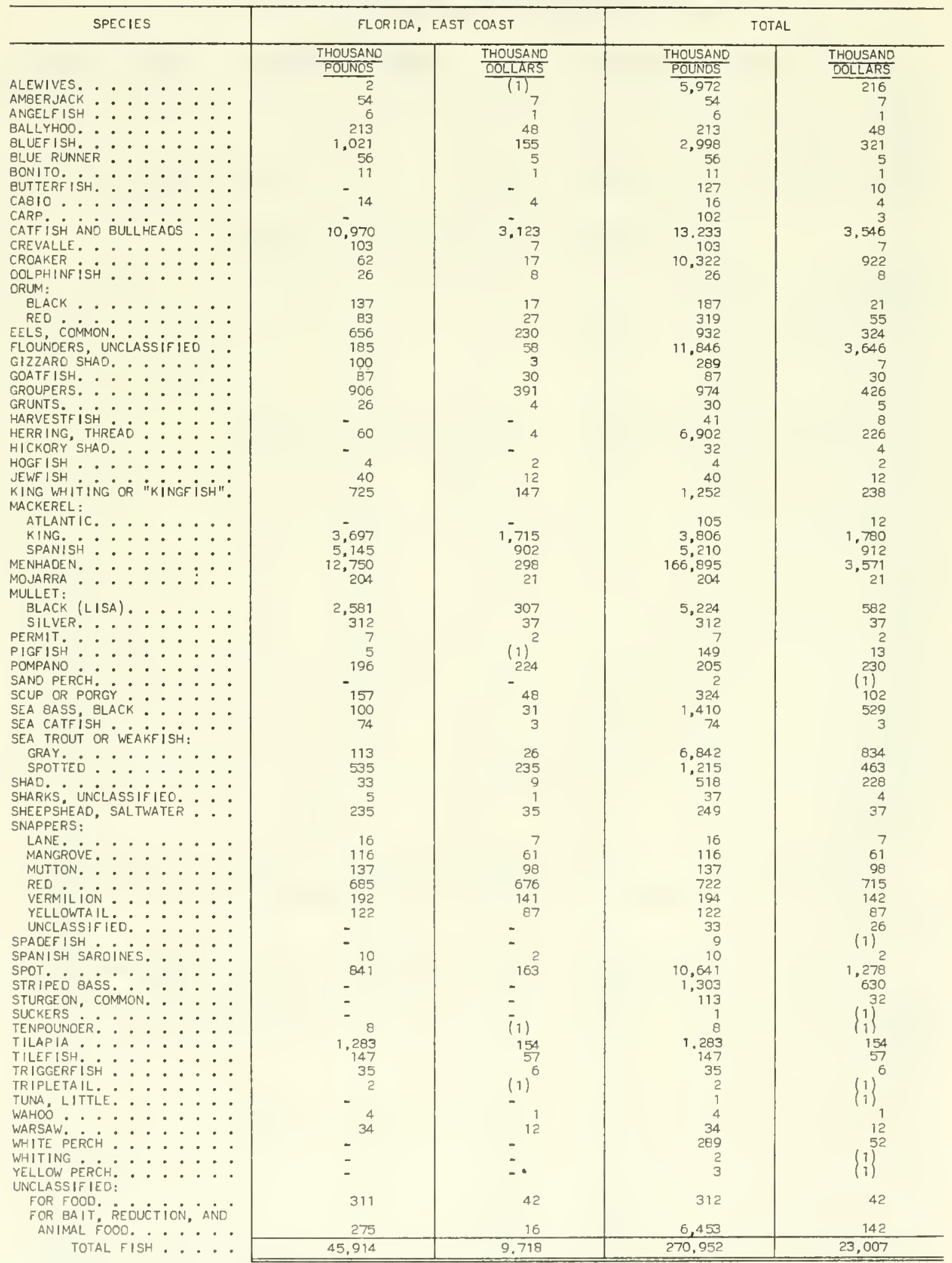




\section{LANDINGS BY STATES, 1975 - Continued}

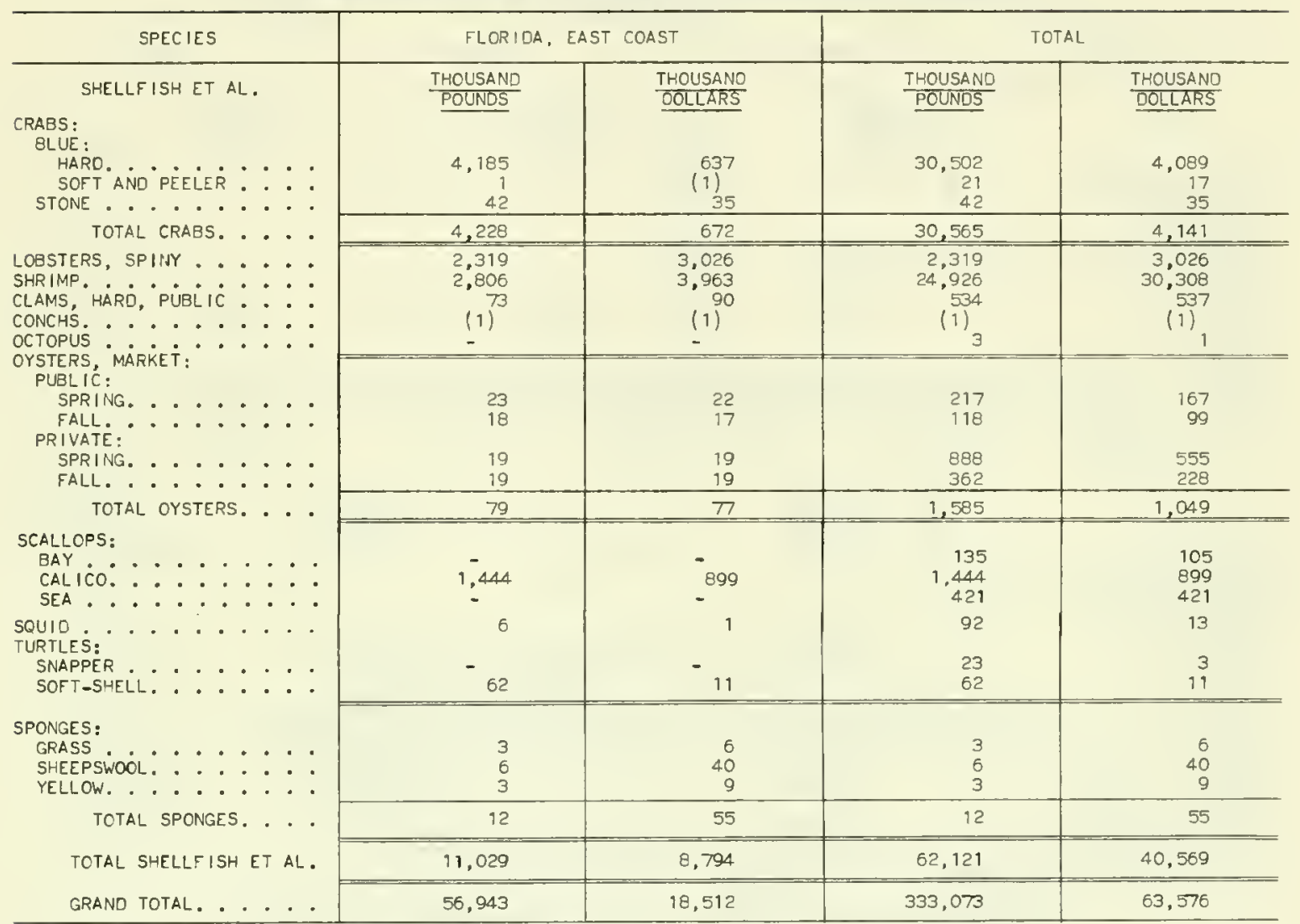

1) LESS THAN 500 POUNOS OR \$500.

NOTE:--LANDINGS ARE SHOWN IN ROUNO (LIVE) WEIGHT EXCEPT FOR SHELL MOLLUSKS. CLAMS, CONCHS, ANO OYSTERS ARE REPORTED IN WE IGHT OF TOTAL MEATS; SCALLOPS, IN WEIGHT OF EDIBLE MEATS. LANOINGS FOR THE INLAND LAKES OF FLORIDA ARE INCLUDEO WITH THE LANDINGS FOR THE EAST COAST OF FLORIDA. 
LANDINGS OF CERTAIN SHELLFISH, 1975

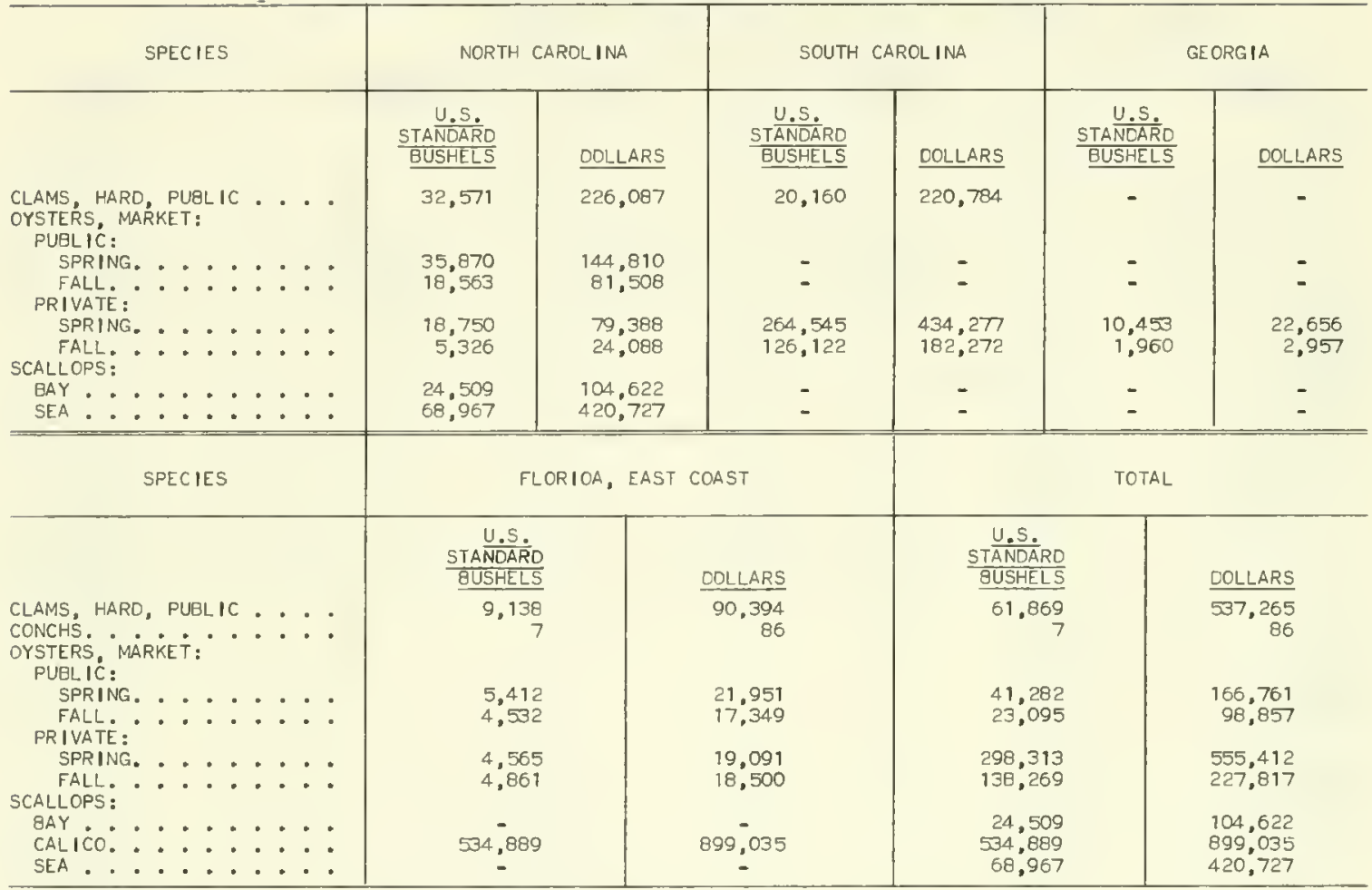

NOTE:--THE CAPACITY OF A U.S. STANDARO BUSHEL IS 2,150.4 CUBIC INCHES.

AVERAGE YIELD OF CERTAIN SHELLFISH, 1975

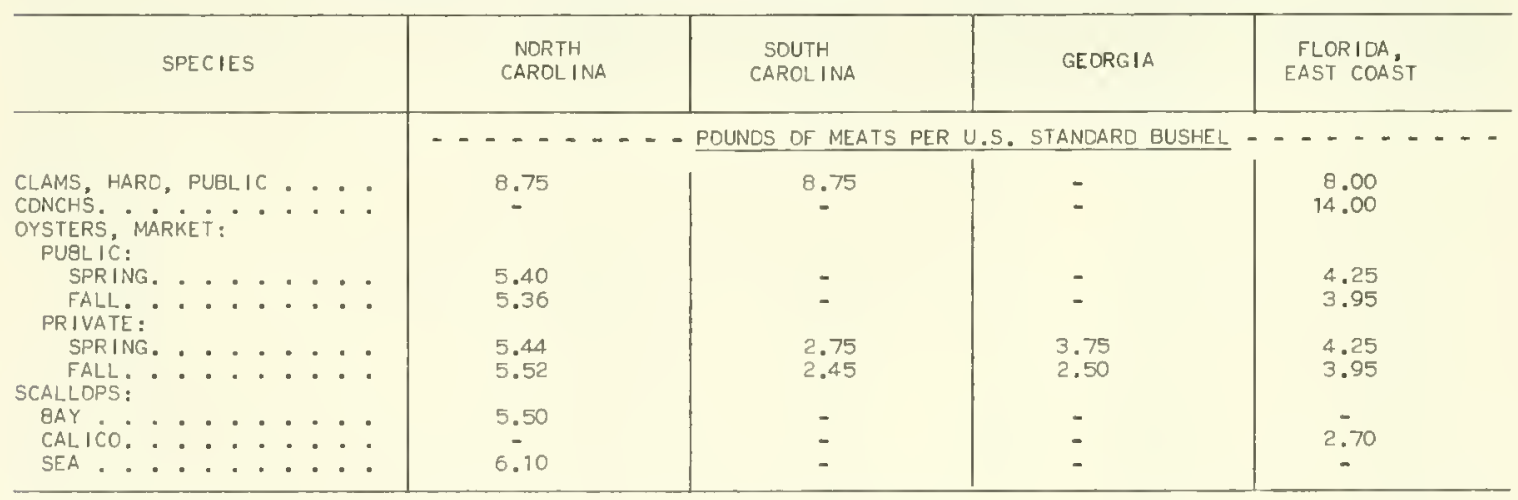

NOTE:--THE CAPACITY OF A U.S. STANDARO BUSHEL $152,150.4$ CUEIC INCHES. 
SUMMARY OF PROCESSED PRODUCTS, 1975

\begin{tabular}{|c|c|c|c|c|}
\hline & Item & Unit & Quantity & Dollars \\
\hline & & & --- & --- \\
\hline $\begin{array}{l}\text { Fresh : } \\
\text { Frozen : } \\
\text { Canned : }\end{array}$ & a & $\begin{array}{l}\text { Pounds } \\
\text { do } \\
\text { Standard }\end{array}$ & $\begin{array}{l}11,496 \\
51,872\end{array}$ & $\begin{array}{l}25,124 \\
83,671\end{array}$ \\
\hline $\begin{array}{l}\text { Cured . } \\
\text { Industrial }\end{array}$ & $\ldots \ldots \ldots \ldots \ldots$ & $\begin{array}{l}\text { cases } \\
\text { Pounds } \\
-\end{array}$ & $\begin{array}{r}118 \\
4,256 \\
-\end{array}$ & $\begin{array}{r}4,198 \\
4,313 \\
13,027\end{array}$ \\
\hline Total & $\ldots \ldots \ldots \ldots \ldots \ldots$ & - & - & 130,333 \\
\hline
\end{tabular}

\section{VALUE OF PROCESSED PRODUCTS, BY STATES, 1975}

\begin{tabular}{|c|c|}
\hline State & Thousand dollars \\
\hline $\begin{array}{l}\text { North Carolina } \ldots \ldots \ldots \ldots \\
\text { South Carolina } \ldots \ldots \ldots \ldots \\
\text { Georgia } \\
\text { Florida, East Coast } \ldots \ldots \ldots \ldots\end{array}$ & $\begin{array}{r}26,940 \\
8,457 \\
48,254 \\
46,682\end{array}$ \\
\hline Total $\ldots \ldots \ldots \ldots \ldots$ & 130,333 \\
\hline
\end{tabular}

\section{PROCESSING AND WHOLESALE}

ESTABLISHMENTS AND EMPLOYMENT, 1975

\begin{tabular}{|c|c|c|c|c|c|c|c|c|c|}
\hline \multirow{3}{*}{ State } & \multirow[b]{3}{*}{ Plants } & \multicolumn{2}{|l|}{ Processing } & \multicolumn{3}{|c|}{ Wholesale } & \multirow[b]{3}{*}{ Plants } & \multicolumn{2}{|c|}{ Total } \\
\hline & & \multicolumn{2}{|c|}{ Employment average } & & \multicolumn{2}{|c|}{ Employment average } & & \multicolumn{2}{|c|}{ Employment average } \\
\hline & & Season & Year & Plants & Season & Year & & Season & Year \\
\hline & -- & --- & -- & --- & Number & -- & -- & -- & -- \\
\hline $\begin{array}{l}\text { North Carolina ... } \\
\text { South Carolina ... } \\
\text { Georgia } \\
\text { Florida, East Coast . }\end{array}$ & $\begin{array}{l}87 \\
21 \\
13 \\
45\end{array}$ & $\begin{array}{r}2,111 \\
710 \\
2,162 \\
1,433 \\
\end{array}$ & $\begin{array}{r}1,420 \\
544 \\
1,841 \\
1,213 \\
\end{array}$ & $\begin{array}{r}167 \\
69 \\
43 \\
75\end{array}$ & $\begin{array}{l}599 \\
493 \\
369 \\
216\end{array}$ & $\begin{array}{l}421 \\
258 \\
239 \\
202\end{array}$ & $\begin{array}{r}254 \\
90 \\
56 \\
120\end{array}$ & $\begin{array}{l}2,710 \\
1,203 \\
2,531 \\
1,649\end{array}$ & $\begin{array}{r}1,841 \\
802 \\
2,080 \\
1,415\end{array}$ \\
\hline Total ... & 166 & 6,416 & 5,018 & 354 & 1,677 & 1,120 & 520 & 8,093 & 6,138 \\
\hline
\end{tabular}

Note:--Employment is reported by each plant for each month for the payroll period that includes the 12th of the month. Employment for the season is based on the greatest number of employees working during the payroll period that included the 12 th of each month. Employment for the year is obtained by adding the number of employees recorded as working during the payroll period that included the 12 th of each month, and dividing by 12 .

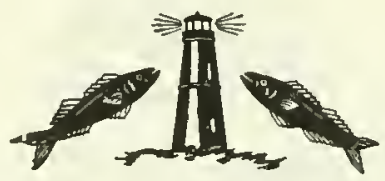




\section{PROCESSED FISHERY PRODUCTS, 1975}

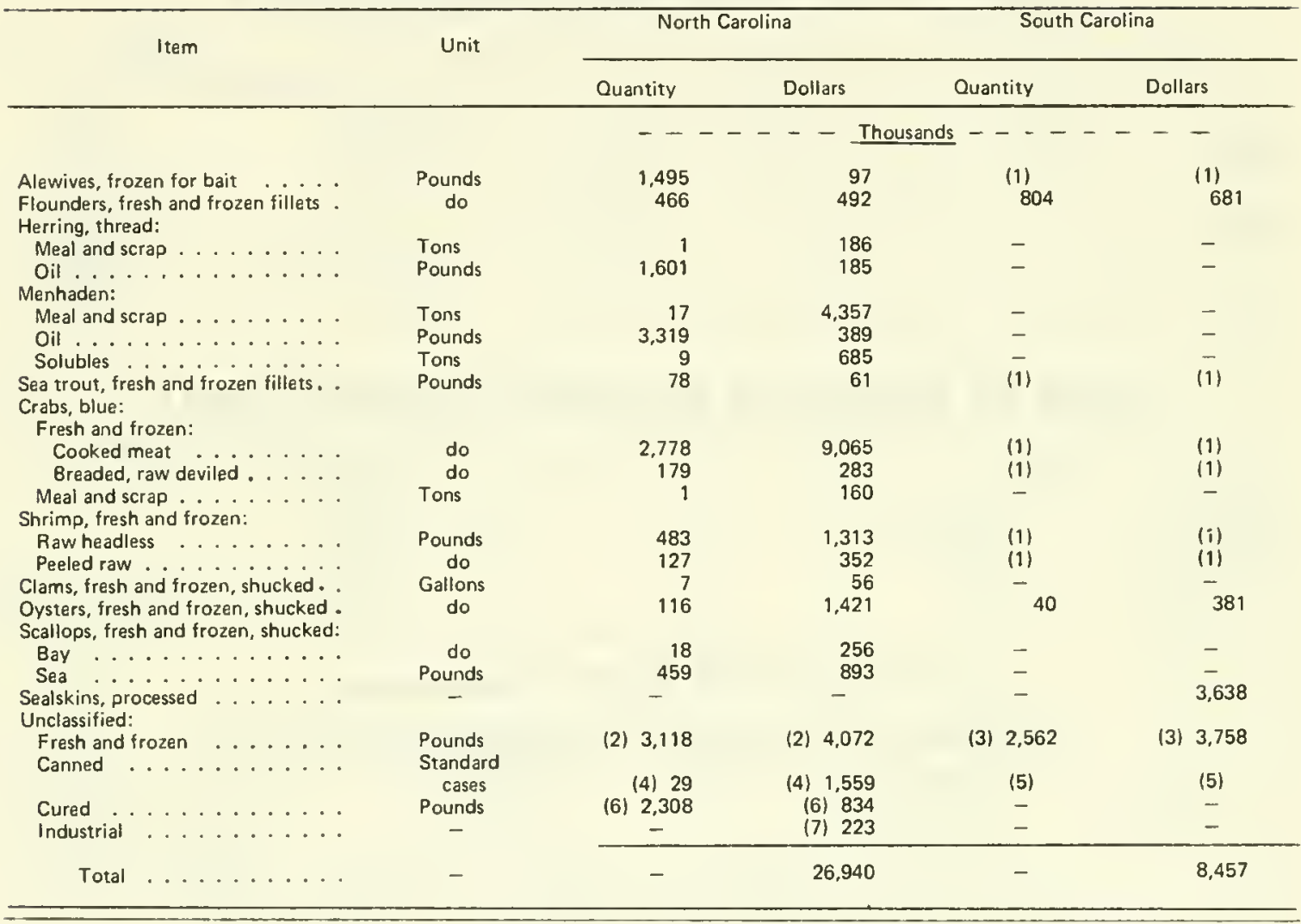

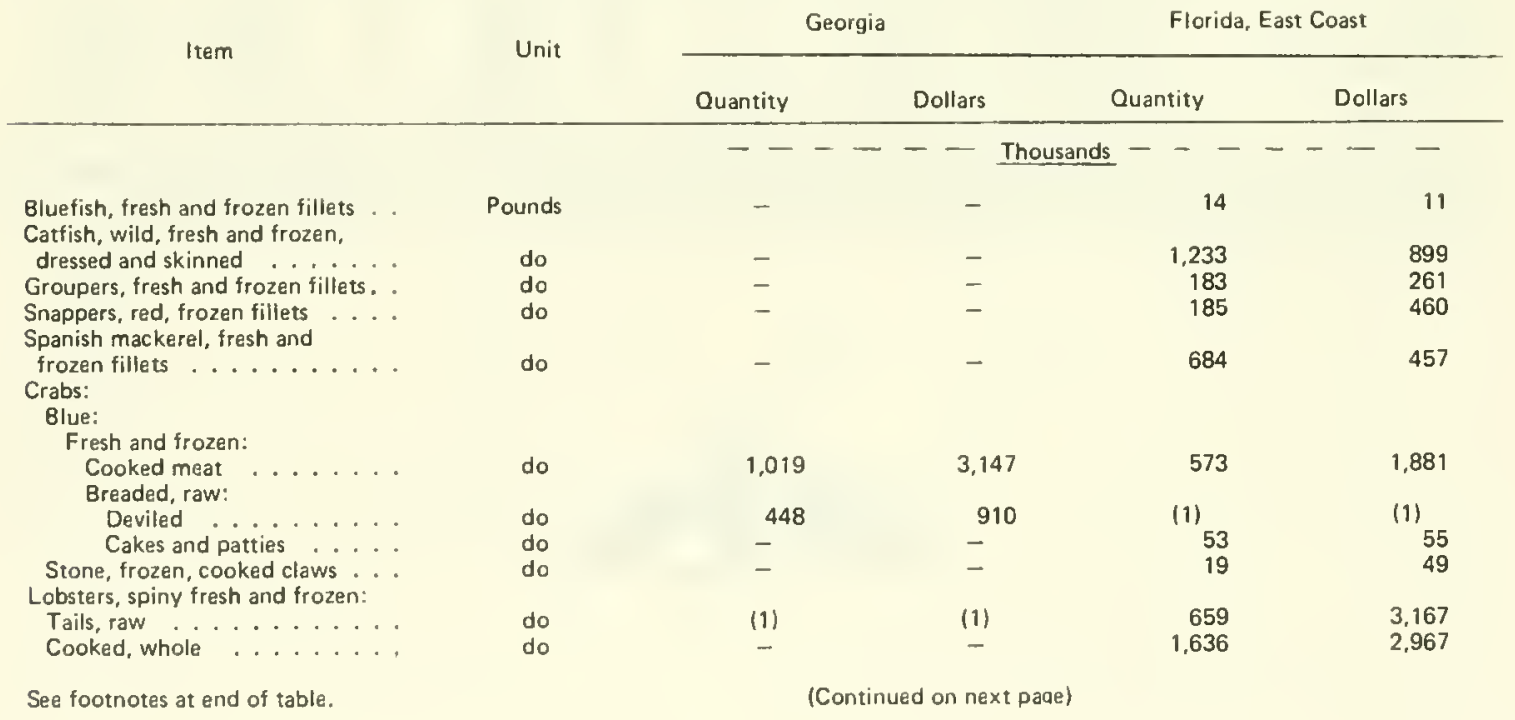




\section{PROCESSED FISHERY PRODUCTS, 1975 - Continued}

\begin{tabular}{|c|c|c|c|c|c|c|}
\hline \multirow{2}{*}{ Item } & \multirow{2}{*}{ Unit } & \multicolumn{2}{|c|}{ Georgia } & \multicolumn{3}{|c|}{ Florida, East Coast } \\
\hline & & Quantity & Dollars & Quantity & \multicolumn{2}{|c|}{ Dollars } \\
\hline \multicolumn{7}{|l|}{ Shrimp, fresh and frozen: } \\
\hline 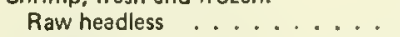 & Pounds & 590 & 1,277 & 156 & & 384 \\
\hline Peeled raw . . . . . . . . . & do & 840 & 2.189 & - & & - \\
\hline $\begin{array}{l}\text { Breaded, raw } \\
\text { Breaded, raw, burgers, stuffed, }\end{array}$ & do & 15,947 & 30,178 & 10,852 & & 19,914 \\
\hline in baskets, and in sauces .... & do & - & - & 491 & & 825 \\
\hline Oysters, fresh and frozen, shucked . & Gallons & (1) & (1) & 5 & & 78 \\
\hline \multicolumn{7}{|l|}{ Calico: } \\
\hline 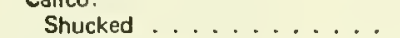 & do & _- & - & 195 & & 3,114 \\
\hline Breaded raw . . . . . . . & Pounds & - & - & 277 & & 519 \\
\hline Sea, breaded, raw and cooked .. & do & 812 & 1,607 & - & & - \\
\hline Unclassified: & & & & & & \\
\hline Fresh and frozen $\ldots \ldots \ldots$ & do & (8) 8,219 & (8) 8,946 & (9) 6,064 & (9) & 11,641 \\
\hline Canned $\ldots \ldots \ldots \ldots$ & $\begin{array}{l}\text { Standard } \\
\text { cases }\end{array}$ & - & - & (5) & & (5) \\
\hline Cured $\ldots \ldots \ldots \ldots$ & Pounds & - & - & (5) & & (5) \\
\hline Industrial $\ldots \ldots \ldots$ & - & - & (5) & - & & (5) \\
\hline$\ldots \ldots \ldots$ & - & - & 48.254 & - & & 46,682 \\
\hline
\end{tabular}

(1) Included with unclassified items. (2) Includes bluefish, mullet, and striped bass fillets; dressed and skinned catfish; flounders, stuffed breaded (raw); gizzard shad frozen (for bait); mullet (roe); breaded raw crab cakes, oysters, and unclassified dinners; shucked, calico scallops; sea scallops, breaded (raw and cooked); turtle meat (raw); and unclassified fish for bait. (3) Includes alewives and menhaden (for bait); dressed and skinned catfish and eels; sea trout fillets (raw); cooked crab meat, and deviled crabs; shrimp, raw headless, peeled (raw), canned, catfish (stew); (natural) crab meat; crab and shrimp (soup); clam (chowder); oysters (natural and stews). (4) Includes canned, alewives and roe; and natural crab meat. (5) Included with unclassified fresh and frozen. (6) Includes salted alewives, mullet, and spot. (7) Includes the value of alewife, catfish, and unclassified meal; alewife and unclassified oil; clam shells cleaned and polished for food serving; and fish ground for animal feed. (8) Includes flounder fillets (raw); ocean perch fillets, breaded (raw); spiny lobster tails repacked; shrimp, (cooked and peeled), cocktails, cured and refrigerated, creoles cooked; shucked oysters, and breaded (raw) oysters; fish sticks breaded (raw and cooked); and fish portions, not breaded and breaded (raw), and breaded (cooked), and the value of crab meal. (9) Includes ballyhoo (for bait); dressed and skinned pond-raised catfish; flounder, mullet, pompano, sea trout, and unclassified fillets; king mackerel fillets and steaks; flounders stuffed, grouper fillets, deviled crabs, breaded (raw); spiny lobster meat (cooked); rock shrimp, raw headless, split, and cooked meat; shucked clams; oysters breaded (raw); fish sticks and fish portions breaded (raw); canned king mackerel (paste); smoked butterfish, chubs, sea herring, king mackerel, sablefish, salmon, sturgeon, and whitefish, and salted sea herring; the value of menhaden and unclassified meal; menhaden oil and solubles.

Note:-This table will not add because of rounding. Individual State totals are correct. Some of the products may have been processed from raw products imported from another State or a foreign country; therefore, they cannot be correlated directly with landings within the State. Certain items are shown in an intermediate and also a more advanced stage of processing.

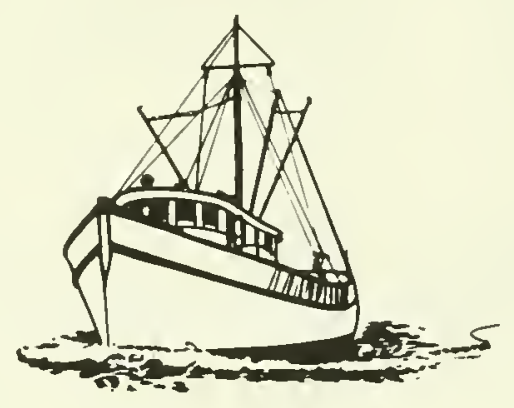




\section{NORTH CAROLINA OPERATING UNITS BY GEAR, 1975}

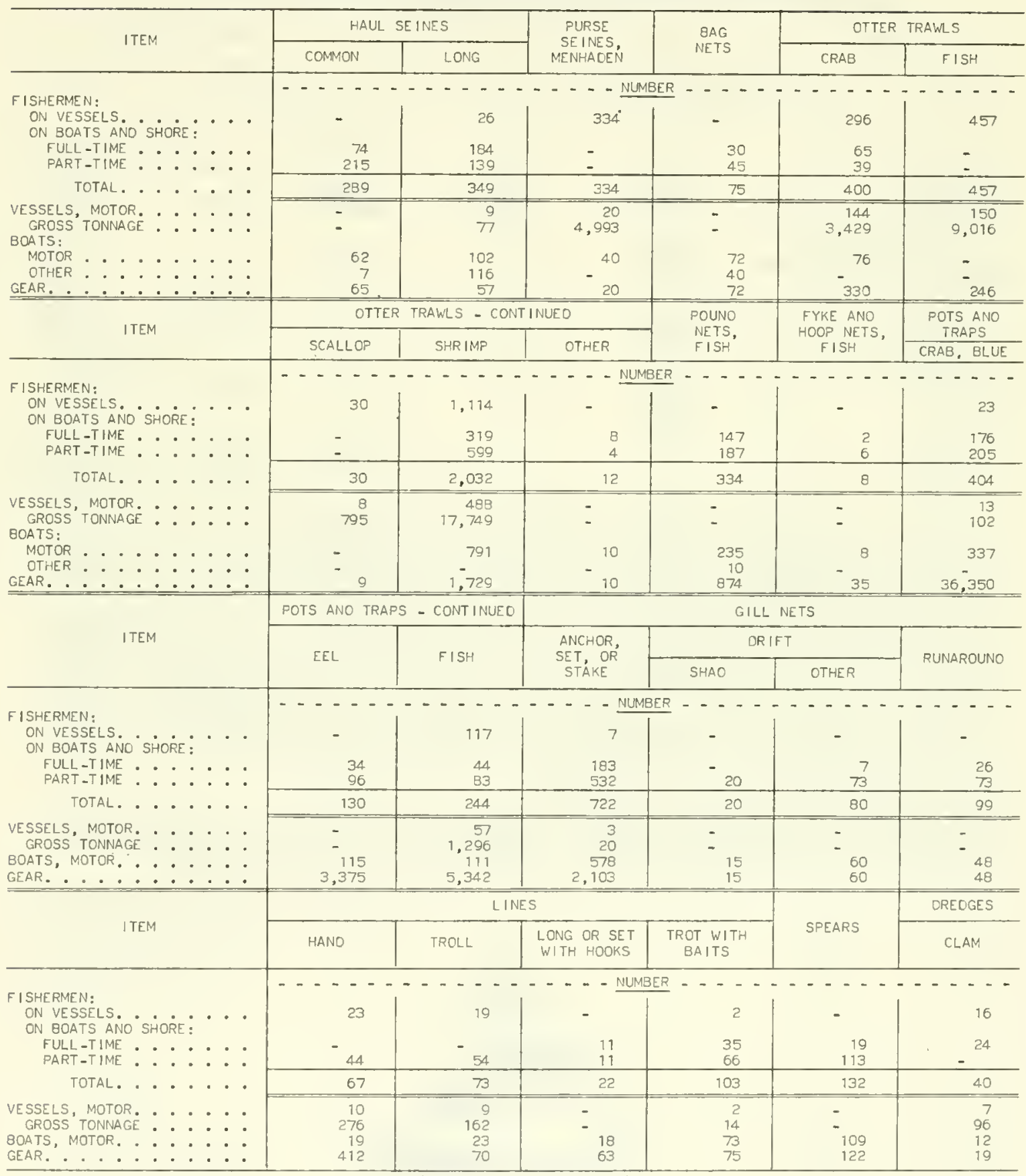

(CONTINUEO ON NEXT PAGE) 


\section{NORTH CAROLINA - OPERATING UNITS BY GEAR, 1975 - Continued}

\begin{tabular}{|c|c|c|c|c|}
\hline \multirow{2}{*}{ ITEM } & \multicolumn{2}{|c|}{ DREOGES - CONTINUEO } & \multicolumn{2}{|c|}{ TONGS AND GRABS } \\
\hline & OYSTER, COMMON & SCALLOP, BAY & OYSTER & OTHER \\
\hline \multirow{3}{*}{ 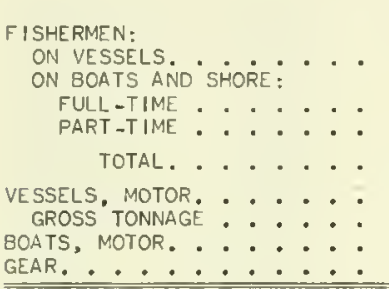 } & $\begin{array}{r}49 \\
92 \\
71 \\
\end{array}$ & $\begin{array}{r}\cdots \cdots \\
-\cdots \\
60 \\
105 \\
\end{array}$ & $\begin{array}{r}-\cdots \\
- \\
36 \\
84 \\
\end{array}$ & 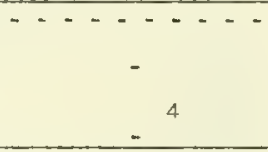 \\
\hline & 212 & 165 & 120 & 4 \\
\hline & $\begin{array}{r}35 \\
296 \\
137 \\
172 \\
\end{array}$ & $\begin{array}{l}- \\
137 \\
165 \\
\end{array}$ & $\begin{array}{l}- \\
110 \\
112 \\
\end{array}$ & $\begin{array}{r}- \\
- \\
3 \\
\end{array}$ \\
\hline \multirow{2}{*}{ ITEM } & \multicolumn{2}{|c|}{ RAKES } & \multirow{2}{*}{$\begin{array}{c}\text { BY } \\
\text { HANO, } \\
\text { OYSTER }\end{array}$} & \multirow{2}{*}{$\begin{array}{l}\text { TOTAL, EXCLUSIVE OF } \\
\text { DUPLICATION }\end{array}$} \\
\hline & OYSTER & OTHER & & \\
\hline \multirow{3}{*}{ 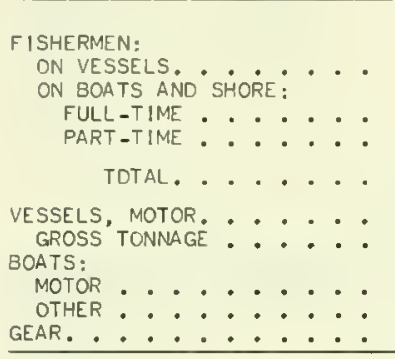 } & $\begin{array}{r}- \\
59 \\
127 \\
\end{array}$ & $\begin{array}{r} \\
\quad \cdots \\
84 \\
80 \\
\end{array}$ & $\begin{array}{r}\cdots \\
- \\
6 \\
20 \\
\end{array}$ & $\begin{array}{r}\ldots \ldots \\
1,718 \\
1,114 \\
1,908 \\
\end{array}$ \\
\hline & 186 & 114 & 26 & 4,740 \\
\hline & $\begin{array}{l}- \\
- \\
165 \\
3 \\
188\end{array}$ & $\begin{array}{l}- \\
109 \\
2 \\
114\end{array}$ & $\begin{array}{l}- \\
-\end{array}$ & $\begin{array}{r}611 \\
25,917 \\
2,847 \\
163 \\
-\end{array}$ \\
\hline
\end{tabular}

NORTH CAROLINA - LANDINGS OF CATCH BY GEAR, 1975

\begin{tabular}{|c|c|c|c|c|c|c|}
\hline \multirow{4}{*}{ SPECIES } & \multicolumn{4}{|c|}{ HAUL SE INES } & \multirow{2}{*}{\multicolumn{2}{|c|}{$\begin{array}{l}\text { PURSE SE INES, } \\
\text { MENHADEN }\end{array}$}} \\
\hline & \multicolumn{2}{|c|}{ COMMON } & \multicolumn{2}{|c|}{ LONG } & & \\
\hline & POUNDS & DOLLARS & POUNOS & OOLLARS & POUNDS & OOLLARS \\
\hline & $\begin{array}{r}39,600 \\
266,700\end{array}$ & $\begin{array}{r}1,420 \\
27,276\end{array}$ & $\begin{array}{r}87,900 \\
847,300\end{array}$ & $\begin{array}{r}3,294 \\
53,785\end{array}$ & - & - \\
\hline BUTTERFISH: : : : $:$ & $\begin{array}{r}266,700 \\
200\end{array}$ & $\begin{array}{r}27.276 \\
12\end{array}$ & $\begin{array}{r}847,300 \\
2,300\end{array}$ & $\begin{array}{r}53,785 \\
214\end{array}$ & - & - \\
\hline 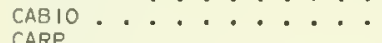 & - & - & 1,900 & 88 & - & - \\
\hline 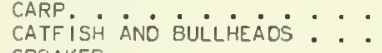 & - & - & $\begin{array}{r}76,000 \\
47,900\end{array}$ & $\begin{array}{l}2,308 \\
7,191\end{array}$ & 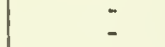 & - \\
\hline $\begin{array}{l}\text { CROAKER } \cdots \cdots \cdots \cdots \\
\text { DRUM: }\end{array}$ & 14,000 & 1,412 & $6,470,000$ & 555,211 & - & - \\
\hline${ }_{\text {RED }}^{B L A C K}: \cdots: \cdots$ & $\begin{array}{r}900 \\
36.800\end{array}$ & $\begin{array}{r}50 \\
4,528\end{array}$ & $\begin{array}{l}29,800 \\
66,600\end{array}$ & $\begin{array}{l}1,531 \\
7,025\end{array}$ & - & - \\
\hline $\begin{array}{l}\text { FLOUNOERS, UNCLASSIFIED }: \\
\text { HARVESTF ISH }\end{array}$ & 9,000 & 2,807 & $\begin{array}{l}56,800 \\
20,300\end{array}$ & $\begin{array}{r}19,324 \\
3,983\end{array}$ & - & - \\
\hline $\begin{array}{l}\text { HERR ING, THREAD } \\
\text { HICKORY SHAD } \\
\text { KING WHITING OR "KINGF ISH": }\end{array}$ & $\overline{23,300}$ & $\overline{3,941}$ & $\begin{array}{r}500 \\
15,500\end{array}$ & $\begin{array}{r}- \\
36 \\
2,627\end{array}$ & $\begin{array}{c}6,842,100 \\
:\end{array}$ & $\begin{array}{c}222,374 \\
-\end{array}$ \\
\hline $\begin{array}{l}\text { KING } \\
\text { SPANISH : }: \vdots::\end{array}$ & - & - & $\begin{array}{r}100 \\
20,600\end{array}$ & $\begin{array}{r}30 \\
2,661\end{array}$ & 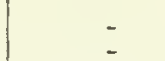 & - \\
\hline $\begin{array}{l}\text { MENHAOEN, } \\
\text { MULLET, BLACK }(\text { LISA) }: \because \because\end{array}$ & $1,221,200$ & 122,096 & 1,100 & -128 & $153,805,200$ & 3.258 .977 \\
\hline $\begin{array}{l}\text { PIGFISH } \\
\text { POMPANO } \\
\text { SEA TROUT OR WEAKKFISH }\end{array}$ & 2,000 & 1.251 & $\begin{array}{r}128,400 \\
5,200\end{array}$ & $\begin{array}{r}11,520 \\
2,928\end{array}$ & - & - \\
\hline GRAY. . . . . . & 22,900 & 4,009 & $1,301,600$ & 164,653 & - & - \\
\hline $\begin{array}{l}\text { SPOTTEO }: \therefore: \therefore \\
\text { SHAD. }\end{array}$ & 73,400 & 23,566 & 389,400 & $\begin{array}{l}127.613 \\
328\end{array}$ & - & - \\
\hline $\begin{array}{l}\text { SHEEPSHEAD, SALTWATER : } \\
\text { SPADEFISH }: \cdots\end{array}$ & - & -78 & $\begin{array}{l}5,200 \\
6,400\end{array}$ & $\begin{array}{l}325 \\
292\end{array}$ & - & - \\
\hline SPOT & $\begin{array}{l}148,600 \\
409,200\end{array}$ & $\begin{array}{r}21,416 \\
272,814\end{array}$ & $\begin{array}{r}6,717,500 \\
32,000\end{array}$ & $\begin{array}{r}717,894 \\
11,810\end{array}$ & $=$ & - \\
\hline 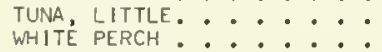 & 7,400 & 135 & $43^{-} 900$ & 8,215 & - & - \\
\hline $\begin{array}{l}\text { YELLOW PERCH } \\
\text { UNCLASSIFIED } \\
\text { FOR }\end{array}$ & & & & & - & - \\
\hline DUCT ION AND ANIMAL FOCD. & - & - & $3,099,600$ & 64,889 & - & - \\
\hline TOTAL. ................ & $2,269,600$ & 486,751 & $19,475,100$ & $1,769,966$ & $160,647,300$ & $3,481,351$ \\
\hline
\end{tabular}


NORTH CAROLINA - LANDINGS OF CATCH BY GEAR, 1975 - Continued

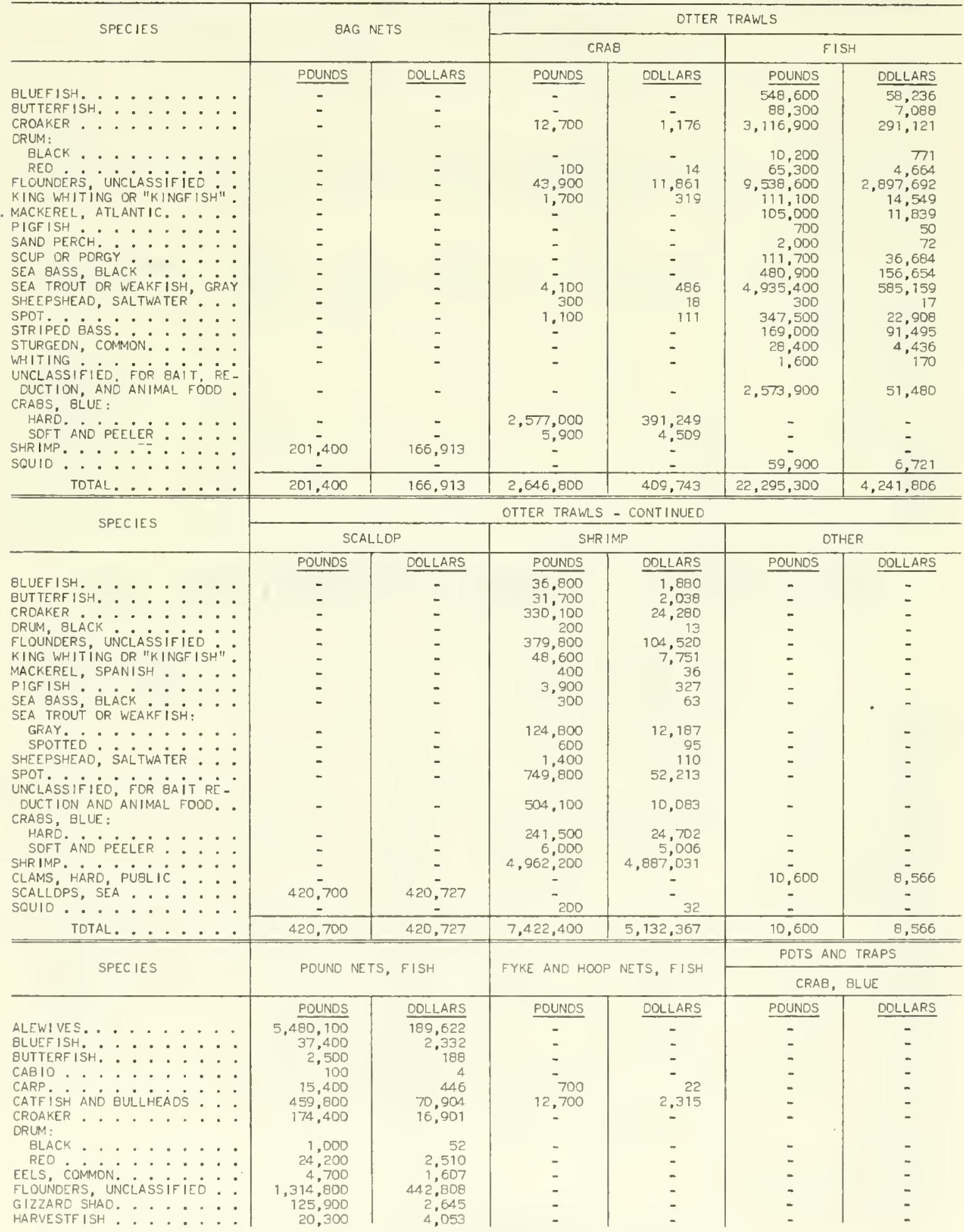

(CONT INUED ON NEXT PAGE) 
NORTH CAROLINA - LANDINGS OF CATCH BY GEAR, 1975 - Continued

\begin{tabular}{|c|c|c|c|c|c|c|}
\hline \multirow{2}{*}{ SPECIES } & \multirow{2}{*}{\multicolumn{2}{|c|}{ POUNO NETS, FISH }} & \multirow{2}{*}{\multicolumn{2}{|c|}{ FYKE ANO HODP NETS, FISH }} & \multicolumn{2}{|c|}{ POTS AND TRAPS } \\
\hline & & & & & \multicolumn{2}{|c|}{ CRAB, BLUE } \\
\hline & POUNDS & DOLLARS & PDUNDS & DOLLARS & POUNDS & DDLLARS \\
\hline HICKDRY SHAO. ${ }^{\circ} \cdot$ & 23,300 & 1,945 & - & - & - & - \\
\hline $\begin{array}{l}\text { KING WHITING OR "KINGF ISH". } \\
\text { MACKEREL: }\end{array}$ & 500 & 97 & - & - & - & - \\
\hline KING. . . . . . & 1,400 & 524 & - & - & - & - \\
\hline SPANISH : : & 6,200 & 903 & - & - & - & - \\
\hline MULLET, BLACK $(L I S A), \cdots$ & 9,000 & 916 & - & - & - & - \\
\hline $\begin{array}{l}\text { POMPAND } \\
\text { SAND PERCH. }: \vdots: \cdots\end{array}$ & $\begin{array}{l}600 \\
500\end{array}$ & $\begin{array}{r}389 \\
18\end{array}$ & $\begin{array}{l}- \\
-\end{array}$ & $\begin{array}{l}- \\
-\end{array}$ & - & 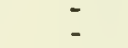 \\
\hline $\begin{array}{l}\text { SEA TROUT OR WEAKF ISH: } \\
\text { GRAY. }\end{array}$ & $2 \uparrow 6,200$ & 24,116 & - & - & _- & - \\
\hline SPOTTED : : : : : & 25,600 & 8,417 & - & - & - & - \\
\hline SHAO . . . . . & 114,100 & 39,013 & - & - & - & - \\
\hline SPADEFISH $\cdot \cdots \cdot \cdot \cdot$ & $\begin{array}{r}2,200 \\
43,500\end{array}$ & $\begin{array}{r}79 \\
4.363\end{array}$ & - & - & - & - \\
\hline STRRIPED BASS: $: \cdots$ & $\begin{array}{l}43,500 \\
65,000\end{array}$ & $\begin{array}{r}4,363 \\
23,354\end{array}$ & -800 & -288 & - & - \\
\hline $\begin{array}{l}\text { STURGEON, COMMON. }::: \\
\text { WHITE PERCH }\end{array}$ & $\begin{array}{r}1,400 \\
152,700\end{array}$ & 28,692 & 7,300 & $-3,329$ & - & - \\
\hline $\begin{array}{l}\text { WELLDW PERCH. }: \vdots: \cdots \\
\text { YRABS, BLUE }: \cdots\end{array}$ & 300 & $\begin{array}{r}20.02 \\
46\end{array}$ & - & - & - & - \\
\hline $\begin{array}{l}\text { HARD } \\
\text { SDFT AND PEELLER }: \cdots:\end{array}$ & 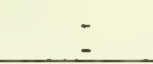 & - & - & - & $\begin{array}{r}7,879,200 \\
8,200 \\
\end{array}$ & $\begin{array}{r}992,973 \\
7,481 \\
\end{array}$ \\
\hline 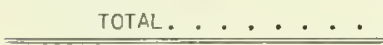 & $8,323,100$ & 867,144 & 21,500 & 3,954 & $7,887,400$ & $1,000,454$ \\
\hline \multirow{2}{*}{ SPECIES } & \multicolumn{4}{|c|}{ POTS AND TRAPS - CONTINUEO } & \multicolumn{2}{|c|}{ GILL NETS } \\
\hline & \multicolumn{2}{|c|}{ EEL } & \multicolumn{2}{|c|}{ FISH } & \multicolumn{2}{|c|}{ ANCHDR, SET, OR STAKE } \\
\hline & PDUNOS & DOLLARS & POUNDS & OOLLARS & POUNDS & DOLLARS \\
\hline ALEWIVES. . . . . . . & - & - & - & - & $1 \overline{17.000}$ & 6,901 \\
\hline BLUEFISH. . . . . . . & - & - & - & - & 212,300 & 19,255 \\
\hline 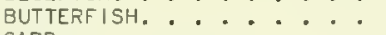 & - & - & - & - & 2.200 & 247 \\
\hline CARP & - & - & $757^{-} .400$ & $128^{-}, 154$ & $\begin{array}{r}5.600 \\
321.300\end{array}$ & $\begin{array}{r}196 \\
55.466\end{array}$ \\
\hline 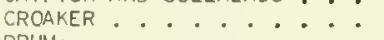 & - & - & - & - & 131.200 & 13,886 \\
\hline 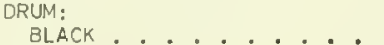 & - & - & & 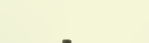 & & \\
\hline REO : : : : : : & - & - & - & - & $\begin{array}{r}4,000 \\
19,600\end{array}$ & 2,580 \\
\hline EELS, COMMON & 230,000 & 81,832 & 2,800 & 717 & - & - \\
\hline $\begin{array}{l}\text { FLOUNDERS, UNCLASSIFIEO }: \cdot \\
\text { GIZZARO SHAD. }\end{array}$ & - & & - & - & 127,200 & 46,544 \\
\hline $\begin{array}{l}\text { GIZZARO SHAD }:: \cdots: \\
\text { GRDUPERS. }\end{array}$ & - & - & - & -313 & 63.300 & 991 \\
\hline GRUNTS. $:: \therefore:$ & - & - & 4,000 & 550 & - & - \\
\hline HARVESTFISH : : & - & - & - & - & 200 & \\
\hline HICKORY SHAD. & - & - & - & - & 4,600 & 432 \\
\hline $\begin{array}{l}\text { KING WHITING DR "KINGFISH". } \\
\text { MACKEREL: }\end{array}$ & - & - & - & - & 11,700 & 2,351 \\
\hline KING. . . . . . . & - & - & - & - & 4,100 & 744 \\
\hline SPANISH : & - & - & - & - & 21,500 & 3,200 \\
\hline & - & - & - & - & 370,100 & 40,078 \\
\hline PIGFISH $\ldots \ldots \ldots$ & - & - & 3,400 & 366 & 6,800 & 729 \\
\hline POMPANO & - & $=$ & 39,900 & $\overline{9} 257$ & 100 & 56 \\
\hline $\begin{array}{l}\text { SCUP OR PORGY } \\
\text { SEA BASS, BLACK }: \cdots: \cdots\end{array}$ & - & - & 653,100 & 282,976 & $=$ & - \\
\hline $\begin{array}{l}\text { SEA TROUT DR WEAKF ISH: } \\
\text { GRAY, }\end{array}$ & - & - & - & - & 118.100 & 17.039 \\
\hline SPOTTEO : : : : : & - & - & - & $\overline{-}$ & 108,900 & 36,337 \\
\hline 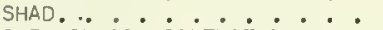 & - & - & - & - & 103,200 & 35,608 \\
\hline SHEEPSHEAD, SALTWATER : : & - & - & - & - & 600 & 58 \\
\hline SNAPPER, UNCLASSIFIED . . & - & - & 2,100 & 959 & - & \\
\hline & - & - & $=$ & 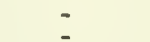 & $\begin{array}{l}266,900 \\
606,900\end{array}$ & $\begin{array}{r}37,689 \\
2 ? 1,560\end{array}$ \\
\hline $\begin{array}{l}\text { STRIPED BASS. } \\
\text { STURGEON, CDMMDN } \cdot \cdot \cdot \cdot \cdot\end{array}$ & - & $\overline{-}$ & - & - & $\begin{array}{r}606,900 \\
14,300\end{array}$ & $\begin{array}{r}221,560 \\
3,330\end{array}$ \\
\hline WHITE PERCH. . : : : & - & & - & - & 84,700 & 13,655 \\
\hline YELLOW PERCH. . . . . . & - & - & 5800 & - & 2,200 & 339 \\
\hline OCTOPUS $\cdots \cdots \cdot \cdots \cdot \cdot$ & - & - & 2,800 & 1,163 & - & - \\
\hline TOTAL....... & 230,000 & 81,832 & $1,458,900$ & 424,455 & $2,722,600$ & 559,629 \\
\hline
\end{tabular}




\section{NORTH CAROLINA - LANDINGS OF CATCH BY GEAR, 1975 - Continued}

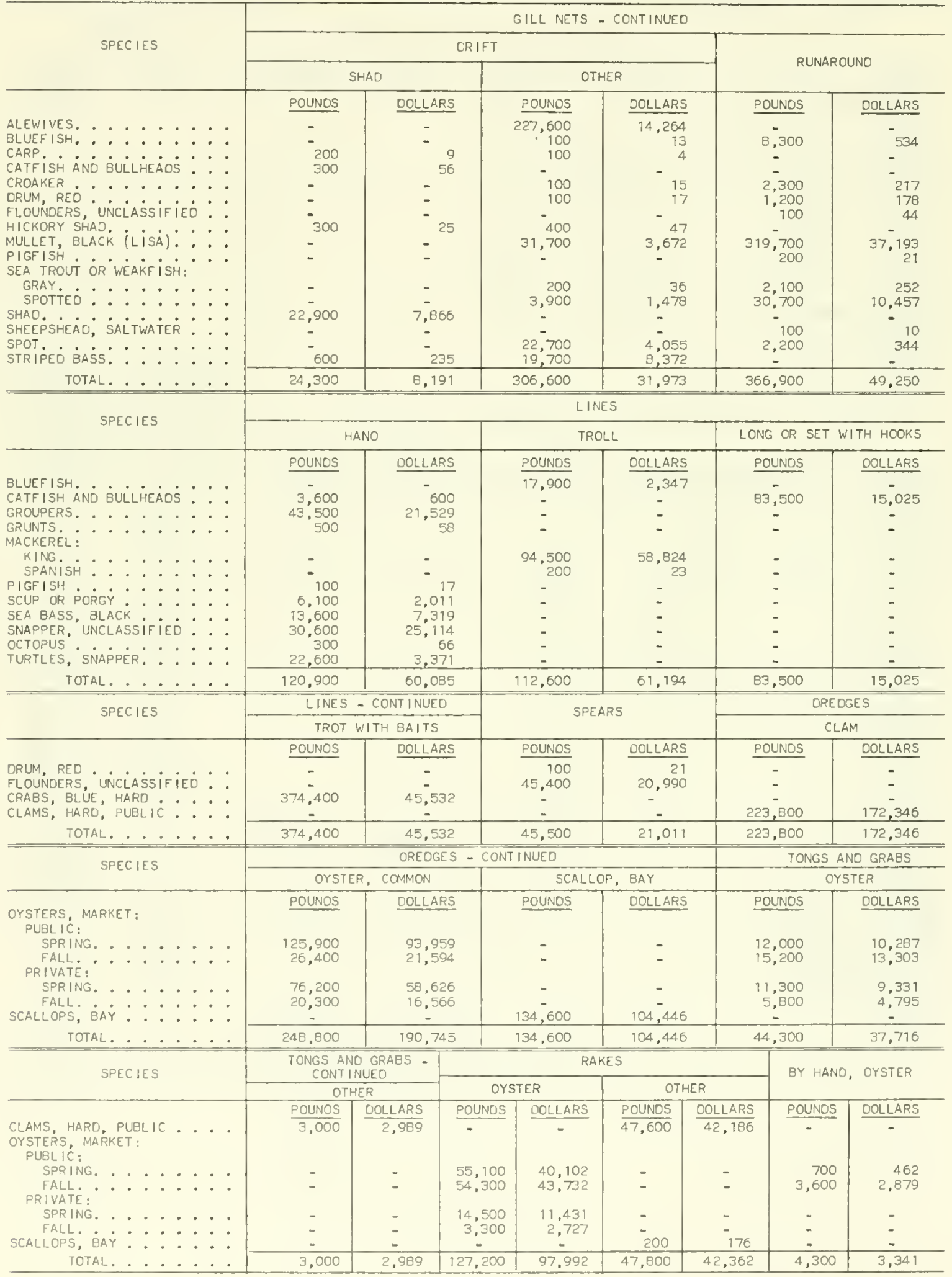


SOUTH CAROLINA

OPERATING UNITS BY GEAR, 1975

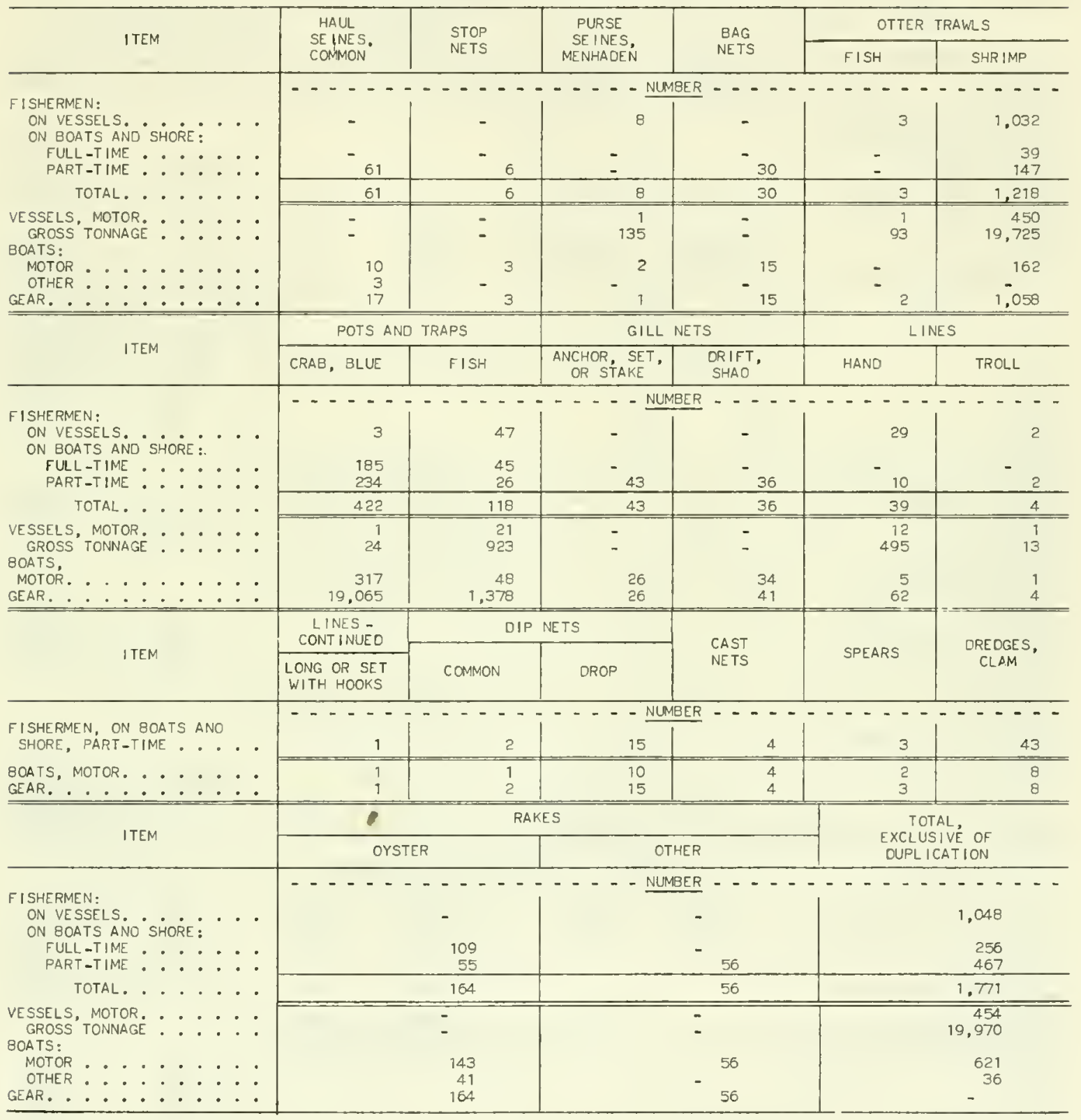


SOUTH CAROLINA - LANDINGS OF CATCH BY GEAR, 1975

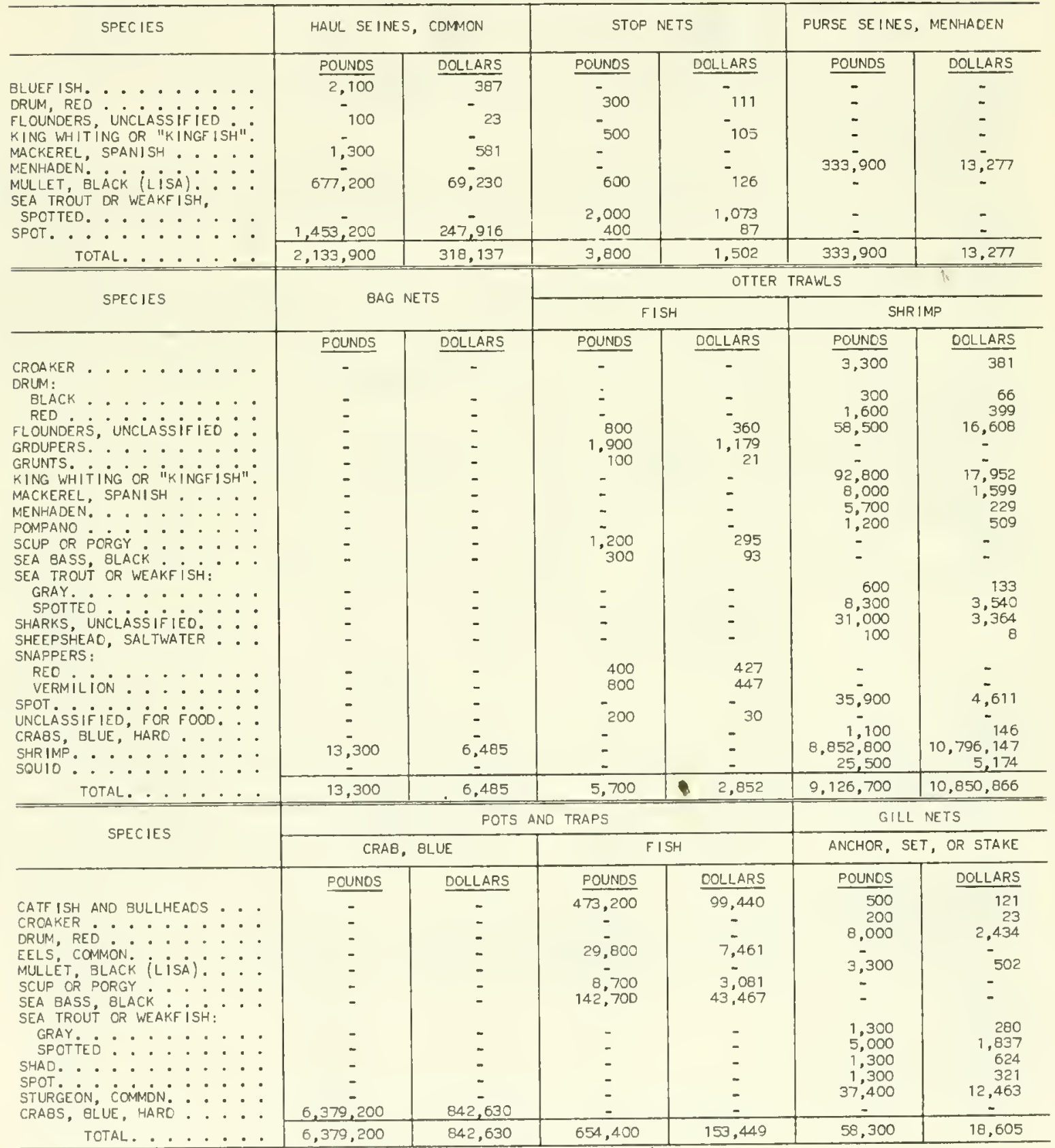

(CONT INUEO ON NEXT PAGE) 
SOUTH CAROLINA - LANDINGS OF CATCH BY GEAR, 1975 - Continued

\begin{tabular}{|c|c|c|c|c|c|c|}
\hline \multirow{2}{*}{ SPECIES } & \multicolumn{2}{|c|}{$\begin{array}{l}\text { GILL NETS - } \\
\text { CONT INUEO }\end{array}$} & \multicolumn{4}{|c|}{ LINES } \\
\hline & \multicolumn{2}{|c|}{ DRIFT, SHAO } & \multicolumn{2}{|c|}{ HAND } & \multicolumn{2}{|c|}{ TROLL } \\
\hline & POUNOS & ODLLARS & POUNOS & DOLLARS & POUNOS & OOLLARS \\
\hline AMBERJACK ....... & & - & 100 & 50 & - & - \\
\hline CARP & 300 & 30 & - & - & - & - \\
\hline DRUM, REO • & - & - & 2,300 & $\begin{array}{l}678 \\
279\end{array}$ & - & - \\
\hline $\begin{array}{l}\text { FLOUNOERS, UNCLASSIFIEO : } \\
\text { GROUPERS. }\end{array}$ & $=$ & - & $\begin{array}{r}1,100 \\
15,100\end{array}$ & $\begin{array}{r}279 \\
8,593\end{array}$ & - & - \\
\hline HICKORY SHAO : & 2,100 & 747 & -2 & - & - & - \\
\hline $\begin{array}{l}\text { KING WHITING OR "KINGF ISH". } \\
\text { MACKEREL: }\end{array}$ & - & - & 200 & 65 & - & - \\
\hline KING. $\cdot \ldots \ldots \ldots$ & - & - & - & - & 7,800 & 4,429 \\
\hline $\begin{array}{l}\text { SPANISH }:: \vdots: \vdots: \\
\text { POMPANO }:\end{array}$ & $\overline{-}$ & 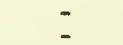 & $-\overline{100}$ & - & -500 & $\dot{-}^{132}$ \\
\hline SCUP OR PORGY $: \therefore \vdots:$ & $\overline{-}$ & - & 3,300 & 1,258 & - & - \\
\hline $\begin{array}{l}\text { SEA BASS, BLACK } \\
\text { SEA TROUT OR WEAKF ISH, } \cdots\end{array}$ & - & - & 3,500 & 1,126 & - & - \\
\hline SPOTTEO. . . . . . & - & - & 1.600 & 634 & - & - \\
\hline SHAO . . . . & 61,100 & 36,092 & - & - & - & - \\
\hline $\begin{array}{l}\text { SHARKS, UNCLASSIFIEO. } \cdot \cdot \cdot \\
\text { SNAPPERS: }\end{array}$ & - & - & 600 & 103 & - & - \\
\hline REO & - & - & 5,200 & 5,370 & - & - \\
\hline $\begin{array}{l}\text { VERMILION } \\
\text { STURGEON, COMMON. }: \cdots: \cdots\end{array}$ & 30,000 & $10 \overline{-} 291$ & 1,000 & -758 & $\overline{-}$ & $\overline{-}$ \\
\hline TILEFISH. * : : : & 50,0 & & 200 & 70 & $\dot{-}$ & - \\
\hline 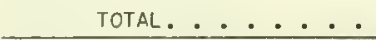 & 93.500 & 47,154 & 34,300 & 19,009 & 8,300 & 4,561 \\
\hline \multirow{2}{*}{ SPECIES } & \multicolumn{2}{|c|}{ LINES - CONTINUEO } & \multicolumn{4}{|c|}{ OIP NETS } \\
\hline & \multicolumn{2}{|c|}{ LONG OR SET WITH HOOKS } & \multicolumn{2}{|c|}{ COMMON } & \multicolumn{2}{|c|}{ DROP } \\
\hline \multirow{4}{*}{$\begin{array}{l}\text { ALEWIVES. } \\
\text { CARP. } \\
\text { CATF ISH ANO BULLHEAOS : } \\
\text { TOTAL. } . .\end{array}$} & POUNDS & DOLLARS & POUNOS & DOLLARS & POUNDS & DOLLARS \\
\hline & - & - & - & & 18,300 & 1,100 \\
\hline & 100 & 24 & - & - & - & $=$ \\
\hline & 100 & 24 & 400 & 54 & 18,300 & 1,100 \\
\hline SPECIES & \multicolumn{2}{|c|}{ CAST NETS } & \multicolumn{2}{|c|}{ SPEARS } & \multicolumn{2}{|c|}{ OREDGES, CLAM } \\
\hline \multirow{5}{*}{$\begin{array}{l}\text { ORUM, REO } \\
\text { MULLET, BLACK (LISA): } \\
\text { SEA TROUT OR WEAKFISH, } \\
\text { SPOTTED, } \\
\text { CLAMS, HARD, PUBLIIC : } \\
\text { TOTAL. } \cdots\end{array}$} & POUNOS & OOLLARS & POUNOS & DOLLARS & POUNDS & DOLLARS \\
\hline & $\overline{1,900}$ & - & $-^{200}$ & ${ }^{-70}$ & $=$ & - \\
\hline & - & - & 200 & 68 & - & 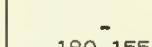 \\
\hline & $=$ & & & & 144,200 & 180,155 \\
\hline & 1,900 & 301 & 400 & 138 & 144,200 & 180,155 \\
\hline \multirow{2}{*}{ SPECIES } & \multicolumn{6}{|c|}{ RAKES } \\
\hline & \multicolumn{3}{|c|}{ OYSTER } & \multicolumn{3}{|c|}{ OTHER } \\
\hline \multirow{4}{*}{ 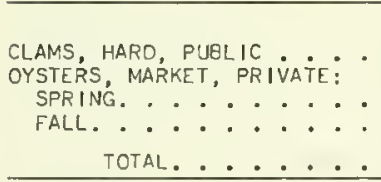 } & \multirow{3}{*}{\multicolumn{2}{|c|}{$\begin{array}{c}\text { POUNDS } \\
- \\
727,500 \\
309,000\end{array}$}} & DOLLARS & \multicolumn{2}{|c|}{ POUNOS } & DOLLARS \\
\hline & & & - & 32 , & & 40,629 \\
\hline & & & $\begin{array}{l}434,277 \\
182,272\end{array}$ & 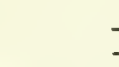 & & - \\
\hline & 1,036 , & & 616,549 & 32 , & & 40,629 \\
\hline
\end{tabular}


GEORGIA

OPERATING UNITS BY GEAR, 1975

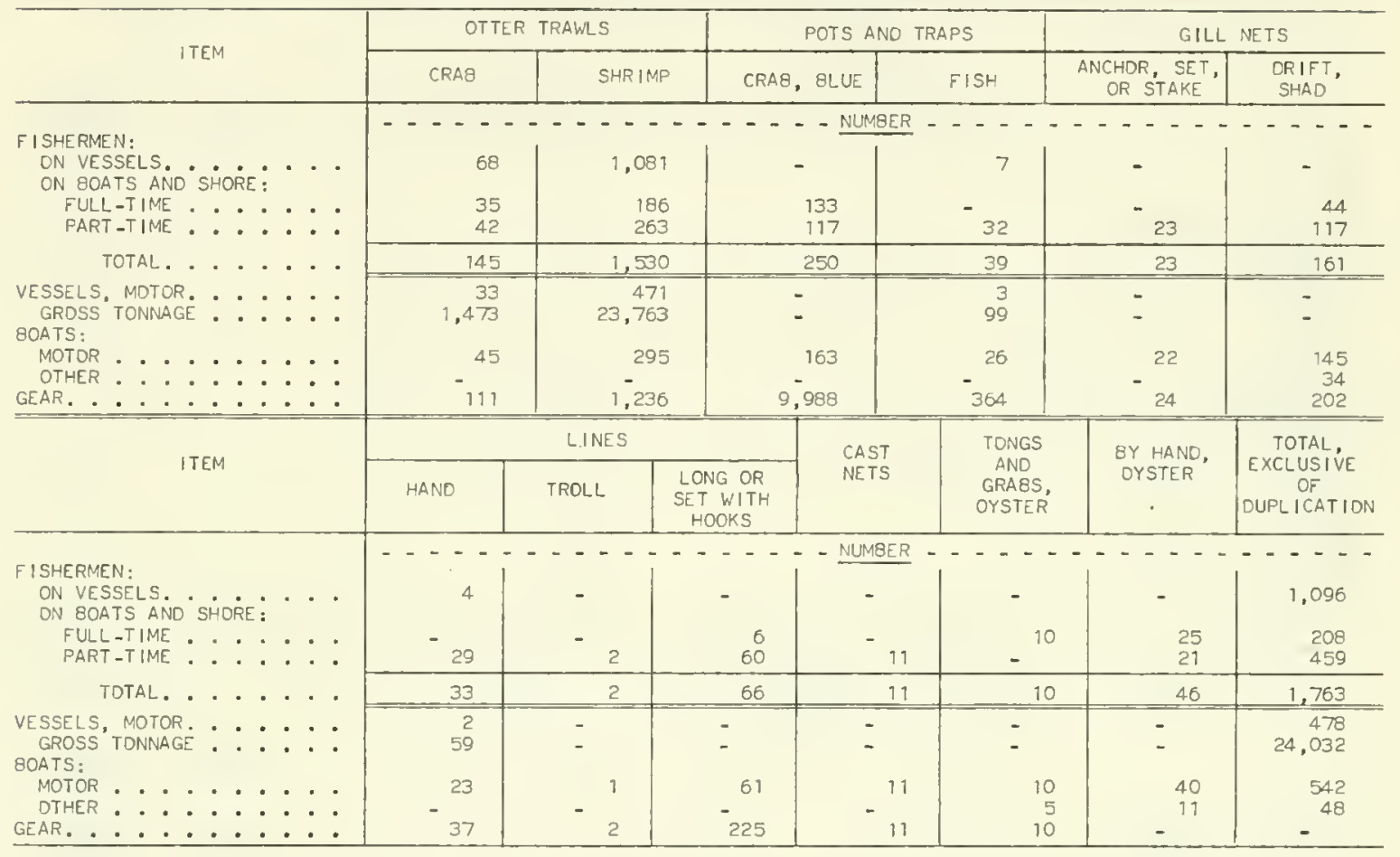

\section{GEORGIA - LANDINGS OF CATCH BY GEAR, 1975}

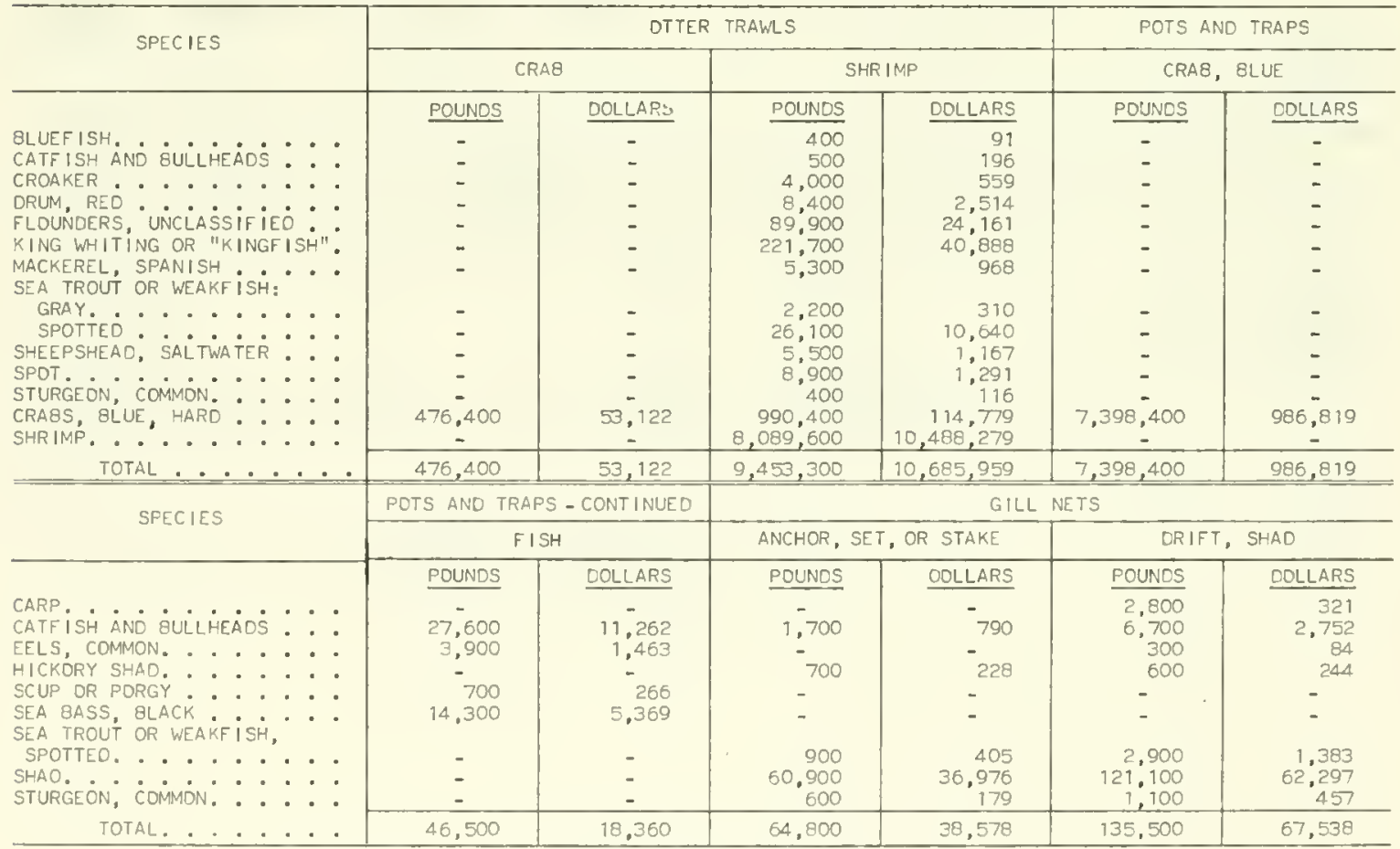


SOUTH ATLANTIC FISHERIES

179

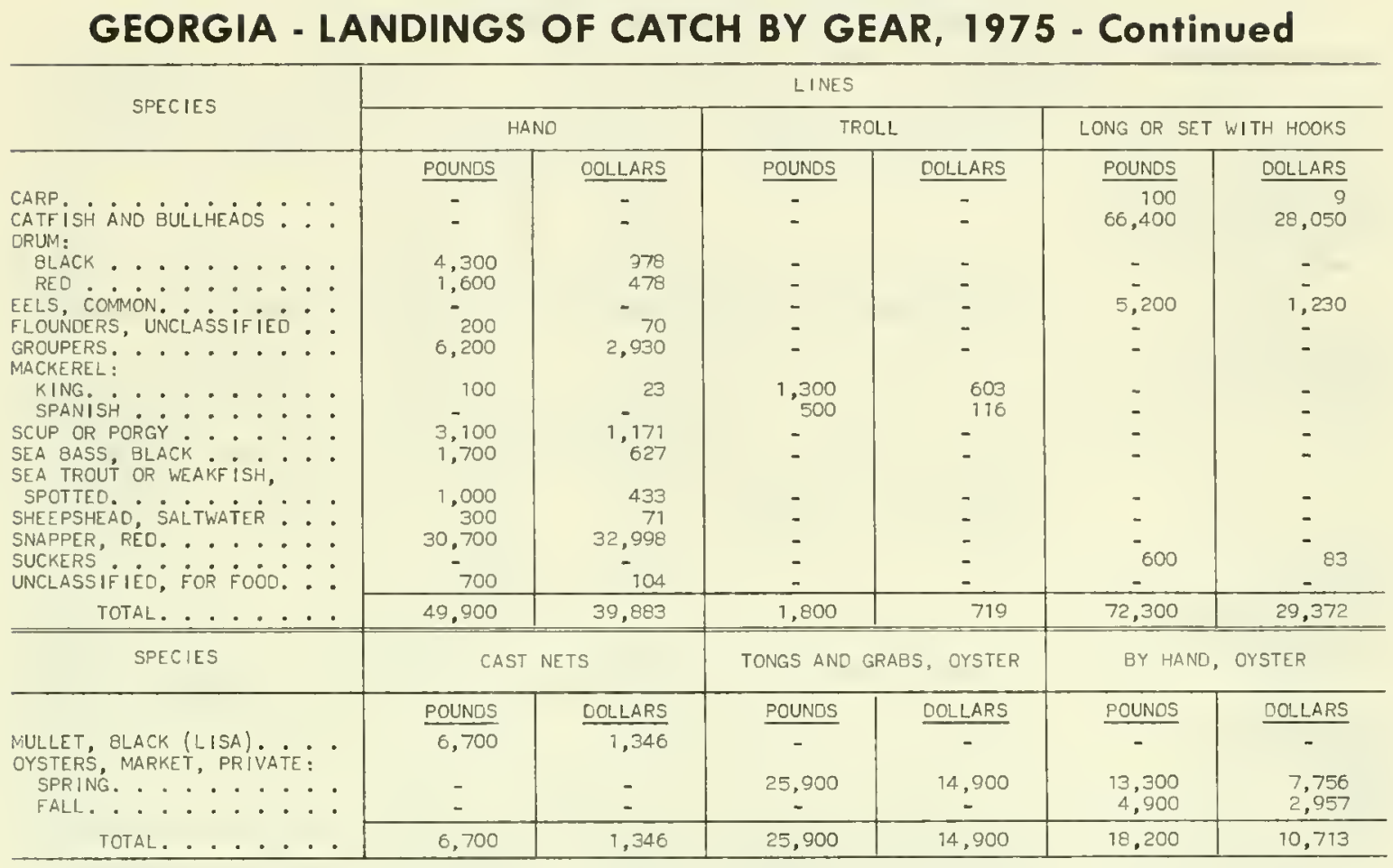




\section{FLORIDA. EAST COAST \\ OPERATING UNITS BY GEAR, 1975}

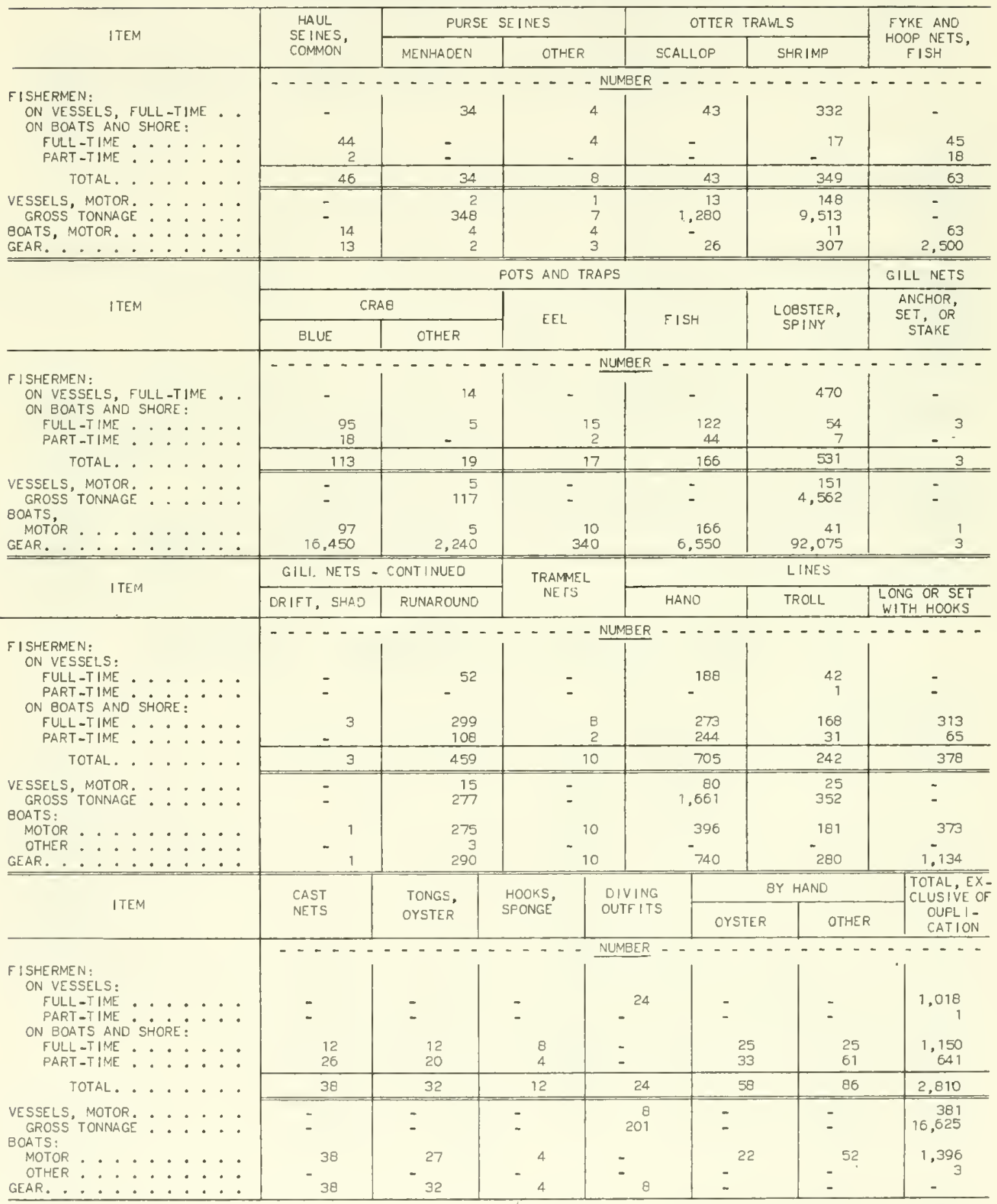

NOTE:--INCLUOES OPERATING UNITS FOR THE INLANO LAKES OF FLORIOA. 
FLORIDA, EAST COAST - LANDINGS OF CATCH BY GEAR, 1975

\begin{tabular}{|c|c|c|c|c|c|c|}
\hline \multirow{2}{*}{ SPECIES } & \multirow{2}{*}{\multicolumn{2}{|c|}{ HAUL SEINES, COMMON }} & \multicolumn{4}{|c|}{ PURSE SE INES } \\
\hline & & & \multicolumn{2}{|c|}{ MENHAOEN } & \multicolumn{2}{|c|}{ DTHER } \\
\hline \multirow{23}{*}{ 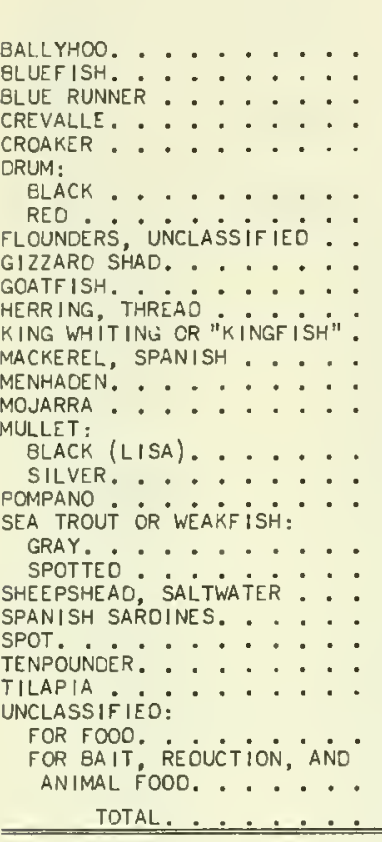 } & POUNOS & COLLARS & POUNDS & OOLLARS & POUNOS & DOLLARS \\
\hline & - & - & - & - & 213,000 & 47.777 \\
\hline & 418,200 & 63,895 & - & - & - & - \\
\hline & $\begin{array}{l}13,700 \\
25,700\end{array}$ & $\begin{array}{l}1,286 \\
1,944\end{array}$ & $\overline{-}$ & - & - & $=$ \\
\hline & 19,100 & 5,243 & $\overline{-}$ & - & - & - \\
\hline & 6,200 & 917 & - & - & - & - \\
\hline & 5,900 & 2,101 & $\overline{-}$ & - & - & - \\
\hline & 5,700 & 2,041 & - & - & - & - \\
\hline & $\begin{array}{r}100,000 \\
5,200\end{array}$ & $\begin{array}{l}3,000 \\
1,892\end{array}$ & - & - & $=$ & - \\
\hline & 56,800 & 3,809 & - & - & 2,600 & 312 \\
\hline & $\begin{array}{l}73,600 \\
76,400\end{array}$ & $\begin{array}{r}14,926 \\
2,748\end{array}$ & - & - & - & - \\
\hline & 3,200 & 166 & $11,510,600$ & 253,232 & - & - \\
\hline & 32,900 & 3,386 & - & - & - & - \\
\hline & $\begin{array}{l}63,600 \\
19,600\end{array}$ & $\begin{array}{l}6,709 \\
2,720\end{array}$ & - & - & - & - \\
\hline & 13,700 & 14,747 & - & - & - & - \\
\hline & 14,300 & 3,401 & - & - & - & - \\
\hline & $\begin{array}{r}13,600 \\
9,600\end{array}$ & $\begin{array}{l}6,544 \\
1,423\end{array}$ & : & - & $=$ & $\overline{-}$ \\
\hline & 10,200 & 2,300 & - & - & - & - \\
\hline & $\begin{array}{r}31,300 \\
600\end{array}$ & $\begin{array}{r}6,358 \\
37\end{array}$ & - & $\vdots$ & - & - \\
\hline & 682,500 & 81,964 & - & - & - & - \\
\hline & 15,200 & 1,761 & - & - & - & - \\
\hline & 26,400 & 1,858 & - & - & $\therefore$ & - \\
\hline & $1,683,200$ & 237,256 & $11,510,600$ & 253,232 & 215,600 & 48,089 \\
\hline \multirow{2}{*}{ SPECIES } & \multicolumn{4}{|c|}{ OTTER TRAWLS } & \multirow{2}{*}{ FYKE ANO } & \multirow{2}{*}{ HOOP NE } \\
\hline & \multicolumn{2}{|c|}{ SCALLOP } & \multicolumn{2}{|c|}{ SHRIMP } & & \\
\hline \multirow{15}{*}{ 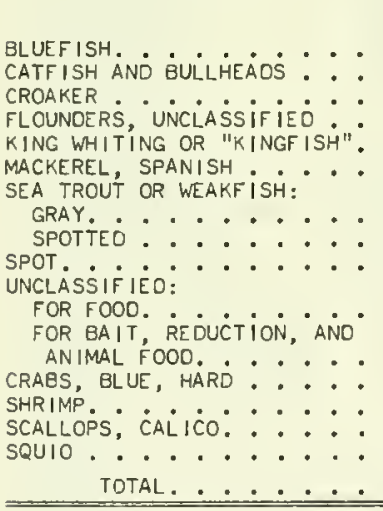 } & POUNOS & DOLLARS & POUNDS & OOLLARS & POUNOS & DOLLARS \\
\hline & - & - & 20,800 & 2,574 & - & - \\
\hline & - & - & - & - & 883,400 & 235,556 \\
\hline & - & $\overline{-}$ & 152,800 & 49,061 & - & $\therefore$ \\
\hline & - & - & 555,900 & 112,097 & - & - \\
\hline & - & - & 600 & 105 & - & - \\
\hline & - & $\overline{-}$ & $\begin{array}{r}34,800 \\
2,700\end{array}$ & 8,272 & - & - \\
\hline & $\overline{-}$ & - & $\begin{array}{l}2,700 \\
3,000\end{array}$ & $\begin{array}{r}1,343 \\
597\end{array}$ & - & - \\
\hline & - & - & 3,000 & & - & - \\
\hline & - & - & 100 & 29 & - & - \\
\hline & - & - & 95,000 & 5,194 & - & - \\
\hline & - & - & $\begin{array}{r}29,500 \\
2806,400\end{array}$ & $\begin{array}{r}5,601 \\
3,962,607\end{array}$ & 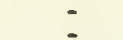 & $\overline{-}$ \\
\hline & $1,444,200$ & $899^{-}, 035$ & $2,806,400$ & $3,962,607$ & $\overline{-}$ & $\because$ \\
\hline & - & - & 0,400 & .893 & Pחר & - \\
\hline & $1,444,200$ & 899,035 & $3,709,800$ & $4,148,918$ & 883,400 & 235,556 \\
\hline \multirow{3}{*}{ SPECIES } & \multicolumn{6}{|c|}{ POTS ANO TRAPS } \\
\hline & \multicolumn{4}{|c|}{ CRAB } & \multirow{2}{*}{\multicolumn{2}{|c|}{ EEL }} \\
\hline & \multicolumn{2}{|c|}{ BL.UE } & \multicolumn{2}{|c|}{ OTHER } & & \\
\hline & POUNOS & OOLLARS & PDUNDS & OOLLARS & POUNOS & OOLLARS \\
\hline EELS, COMMON. . . . . . & - & - & - & - & 656,100 & 229,477 \\
\hline BLUE: & & & & & & \\
\hline HARO & $4,155,300$ & $\begin{array}{r}630,816 \\
326\end{array}$ & 600 & 200 & $\overline{-}$ & 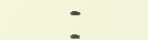 \\
\hline $\begin{array}{l}\text { SOFT ANO PEELER }: \cdots \\
\text { STONE } . \cdot \cdots\end{array}$ & $\begin{array}{r}400 \\
5,800\end{array}$ & $\begin{array}{r}326 \\
3,613\end{array}$ & 36,200 & 37,854 & $\overline{-}$ & - \\
\hline TOTAL. . . . . . & $4,161,500$ & 634,755 & 36,800 & 32,054 & 656,100 & 229,477 \\
\hline
\end{tabular}




\section{FLORIDA, EAST COAST - LANDINGS OF CATCH BY GEAR, 1975 - Continued}

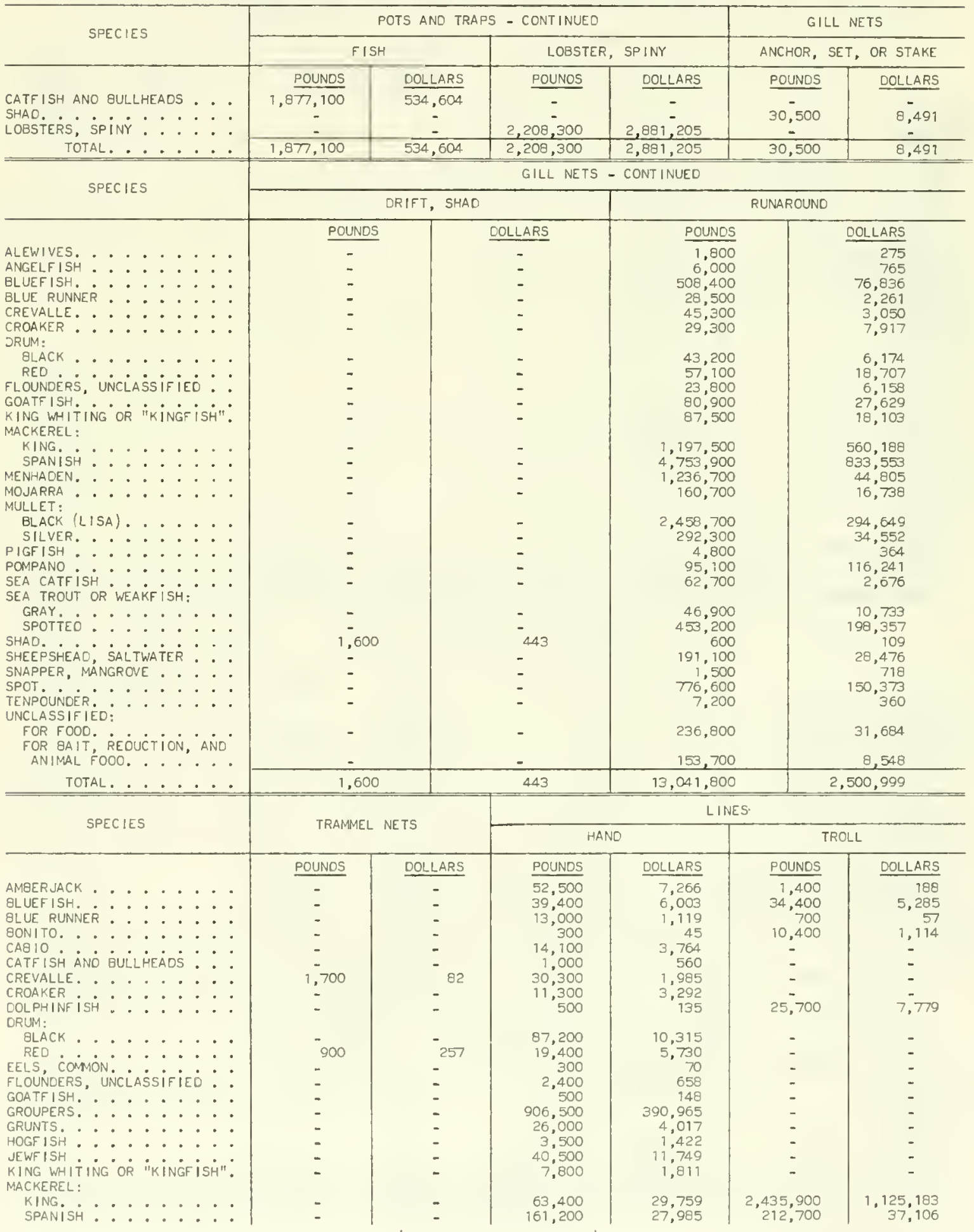

SEE NOTE AT ENO OF TABLE.

(CONTINUEO ON NEXT PAGE) 


\section{FLORIDA, EAST COAST - LANDINGS OF CATCH BY GEAR, 1975 - Continued}

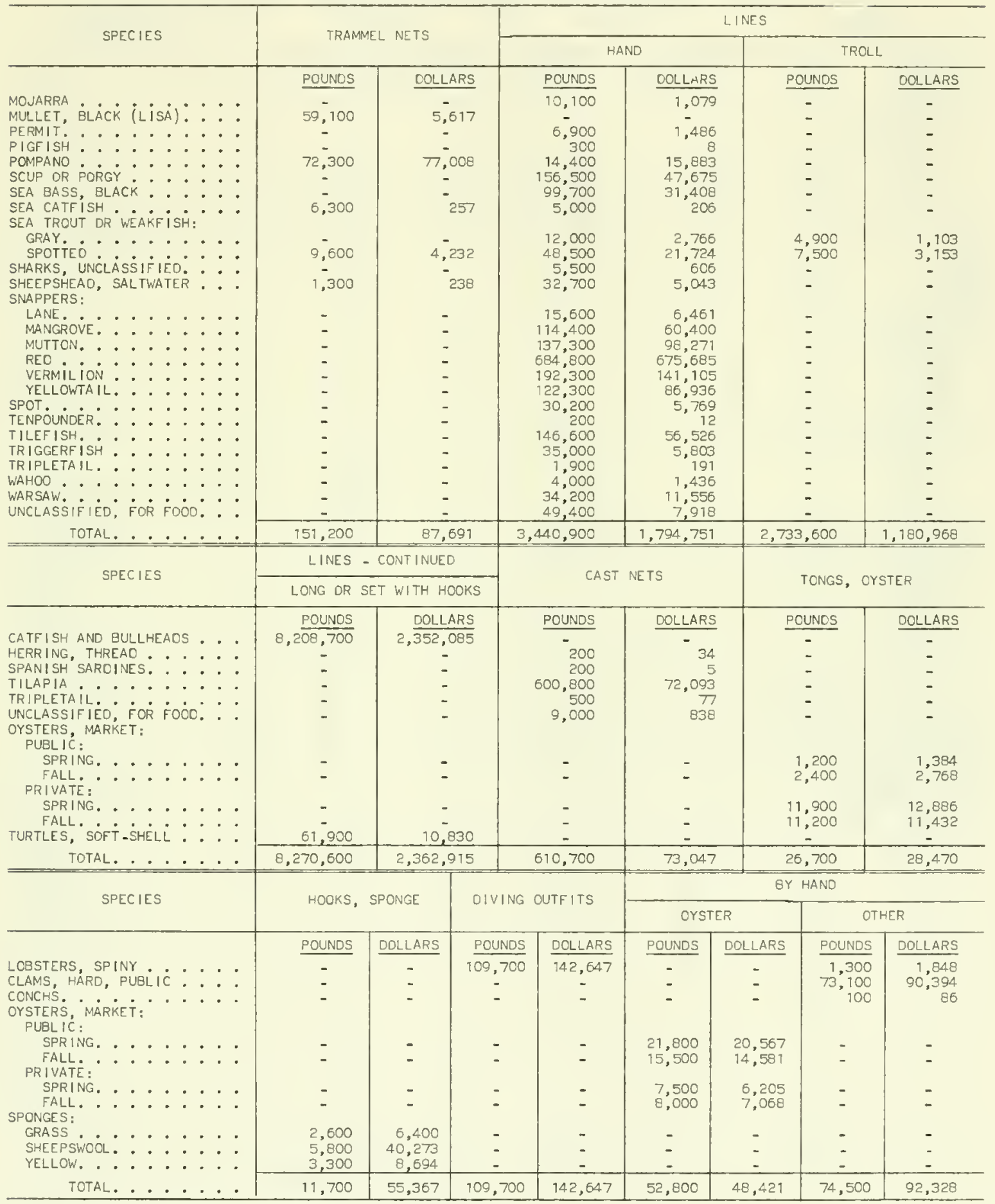

NOTE: - INCLUDES LANOINGS FOR THE INLANO LAKES OF FLORIOA. 
SUPPLEMENTARY TABLES

FLORIDA - OPERATING UNITS BY DISTRICTS, 1975

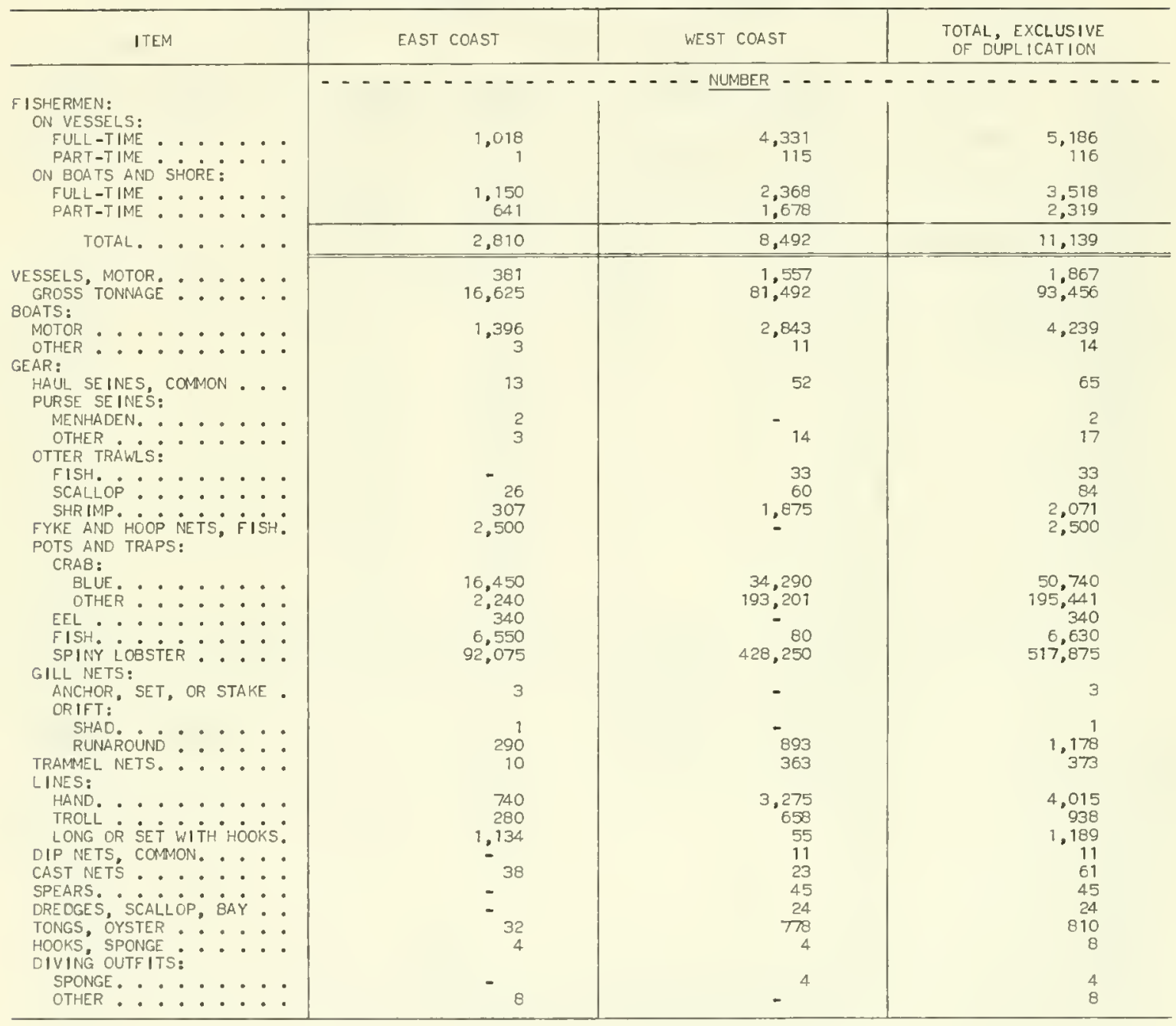


FLORIDA - LANDINGS BY DISTRICTS, 1975

\begin{tabular}{|c|c|c|c|c|c|c|c|c|c|}
\hline \multicolumn{4}{|c|}{ SPECIES } & \multicolumn{2}{|c|}{ EAST COAST } & \multicolumn{2}{|c|}{ WEST COASTT } & \multicolumn{2}{|c|}{ TOTAL } \\
\hline & FISH & & & $\frac{\text { THOUSAND }}{\text { POUNOS }}$ & $\frac{\text { THOUSANO }}{\underline{\text { OOLLARS }}}$ & $\frac{\text { THOUSANO }}{\text { POUNOS }}$ & $\frac{\text { THOUSAND }}{\text { DOLLARS }}$ & $\frac{\text { THOUSANO }}{\text { POUNDS }}$ & $\begin{array}{l}\text { THOUSAND } \\
\text { DOLLARS }\end{array}$ \\
\hline ALEWIVES. & . . . & . . . & . . . & 2 & (1) & - & - & 2 & (1) \\
\hline AMBERJACK & . . . . & . . . . & $\therefore$ & 54 & 7 & 91 & 11 & 145 & 18 \\
\hline ANGELF ISH - & . . . & - . . & . . & 6 & 1 & 3 & (1) & 9 & 1 \\
\hline BALLYHOO. - & . . . & . . . & . . & 213 & 48 & 171 & 39 & 384 & 87 \\
\hline OARRACUOA - & • : & & $\cdot \cdot \cdot$ & 1.021 & & $\begin{array}{l}(1) \\
436\end{array}$ & $(1)_{48}$ & $\begin{array}{l}\text { (1) } \\
457\end{array}$ & (1) \\
\hline $\begin{array}{l}\text { BLUEF I SH. } \\
\text { BLUE RUNNER }\end{array}$ & $\dot{R}: \dot{P}$ & $\therefore:$ & $\therefore$ : & $\begin{array}{r}1,0<1 \\
56\end{array}$ & $\begin{array}{r}155 \\
5\end{array}$ & $\begin{array}{r}430 \\
1,680\end{array}$ & $\begin{array}{r}48 \\
170\end{array}$ & 1,736 & $\begin{array}{l}203 \\
175\end{array}$ \\
\hline BONITO. . & $\therefore$ & $\therefore:$ & $\therefore$ & 11 & 1 & 121 & 6 & 132 & 7 \\
\hline CABIO & . . & . & . . & 14 & 4 & 84 & 13 & 98 & 17 \\
\hline CREVALLE. & $\therefore:$ & $\therefore:$ & $\therefore$ & 103 & -7 & $\begin{array}{r}696 \\
2,825\end{array}$ & $\begin{array}{l}104 \\
200\end{array}$ & $\begin{array}{r}696 \\
2,928\end{array}$ & $\begin{array}{l}104 \\
207\end{array}$ \\
\hline CROAKER - & $\therefore \cdot \cdot$ & . . . & . . & 62 & 17 & 2.126 & 329 & 2,188 & 346 \\
\hline $\begin{array}{l}\text { OOLPHINF ISH } \\
\text { ORUM: }\end{array}$ & H . . & • • & $\cdot \cdot$ & 26 & 8 & 106 & 25 & 132 & 33 \\
\hline 8LACK . & . . & . . . & • . . & 137 & 17 & 35 & 4 & 172 & 21 \\
\hline REO - - & $\therefore \cdot \cdot$ & . • • & $\cdot \cdot \cdot$ & 83 & 27 & 759 & 181 & 842 & 208 \\
\hline EELS, COMMO & ON. & SSIFiE: & $\dot{0} \cdot$ & $\begin{array}{l}656 \\
185\end{array}$ & 230 & & & 656 & 230 \\
\hline $\begin{array}{l}\text { FLOUNDERS, } \\
\text { GIZZARO SHA }\end{array}$ & $\begin{array}{l}\text { UNCLA } \\
\text { AD. }\end{array}$ & $\begin{array}{l}\text { ASSIFIED } \\
. .\end{array}$ & D: & $\begin{array}{l}185 \\
100\end{array}$ & $\begin{array}{r}58 \\
3\end{array}$ & $\begin{array}{r}219 \\
-\end{array}$ & -69 & 404 & 127 \\
\hline $\begin{array}{l}\text { GIZZARO SHA } \\
\text { GOATFISH. }\end{array}$ & : : & 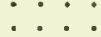 & $\therefore:$ & $\begin{array}{r}100 \\
87\end{array}$ & $\begin{array}{r}3 \\
30\end{array}$ & -1 & -1 & $\begin{array}{r}100 \\
88\end{array}$ & $\begin{array}{r}3 \\
31\end{array}$ \\
\hline GROUPERS. & . : & . . . & . . & 906 & 391 & 7,007 & 2,787 & 7,913 & 3,178 \\
\hline GRUNTS. . . & $\therefore$. & . . . & . . . & 26 & 4 & 221 & 43 & 247 & \\
\hline HERR ING, TH & HREAD & . . • & •. • & 60 & 4 & 861 & 50 & 921 & 54 \\
\hline HOGF ISH . - & . . . & . . . & . . • & 4 & 2 & 18 & 5 & 22 & 7 \\
\hline JEWF ISH & ix - : & ikivis & & 40 & 12 & 186 & 22 & 226 & 34 \\
\hline $\begin{array}{l}\text { KING WHITIN } \\
\text { MACKEREL: }\end{array}$ & NG OR & "KINGF I & ISH". & 725 & 147 & 148 & 13 & 873 & 160 \\
\hline KING. & . . . & . . . & . . & 3,697 & 1,715 & 2,622 & 640 & 6,319 & 2,355 \\
\hline SPANISH. & $\therefore$ & . . . . & . . . & 5,145 & 902 & 5,621 & 962 & 10,766 & 1,864 \\
\hline MENHAOEN. - & . . & . . . & . $\cdot$ & 12,750 & 298 & 466 & 17 & 13,216 & 315 \\
\hline MOJARRA • • & $\cdot \cdot \cdot$ & . . . & $\cdot \cdot \cdot$ & 204 & 21 & 147 & 21 & 351 & 42 \\
\hline $\begin{array}{l}\text { MULLET: } \\
\text { BLACK (LI) }\end{array}$ & $|S A|$ & . . . & . . & 2,581 & 307 & 23,167 & 3,381 & 25,748 & 3,688 \\
\hline SILVER. & . . & $\therefore$ & $\therefore$ & 312 & 37 & 532 & 96 & 844 & $\begin{array}{r}.008 \\
133\end{array}$ \\
\hline PERMIT. . & $\cdot \cdot$ & . . . & . • • & 7 & $2^{2}$ & 207 & 41 & 214 & 43 \\
\hline PIGFISH. & . . & . . . & - . . & 5 & (1) & 4 & 1 & 9 & 1 \\
\hline POMPANO . & ... & . . . & •. & 196 & 224 & 1,133 & 1,266 & 1.329 & 1,490 \\
\hline SCUP OR POF & RGG . & . . . & . . • & 157 & 48 & 109 & 25 & 265 & \\
\hline SEA BASS, E & BLACK & . . . & . . . & 100 & 31 & 39 & 7 & 139 & 38 \\
\hline $\begin{array}{l}\text { SEA CATF ISH } \\
\text { SEA TROUT }\end{array}$ & $O R$ WEA & AKF isH: & $\cdot \cdot \cdot$ & 74 & 3 & 25 & 2 & 99 & 5 \\
\hline GRAY. & . . & . . . & •. . & 113 & 26 & - & - & 113 & 26 \\
\hline SPOTTEO & . . & . . . . & . . . & 535 & 235 & 2,769 & 921 & 2,704 & 1,156 \\
\hline WHITE & . . & ... & . . . & - & - & 176 & 24 & 176 & 24 \\
\hline SHAO ${ }^{\circ}$ & $\dot{\dot{r}} \dot{\mathrm{s} \dot{s}}$ & $\dot{E} \dot{F} \cdot \cdot$ & . . . & 33 & 9 & 5 & (1) & 38 & 9 \\
\hline SHARKS, UNC & ICLASSI & IFIED. • & . . & 5 & 1 & 13 & 1 & 18 & 2 \\
\hline $\begin{array}{l}\text { SHEEPSHEAO, } \\
\text { SNAPPERS. }\end{array}$ & , SALT & TWATER . & • · & 235 & 35 & 268 & 36 & 503 & 71 \\
\hline $\begin{array}{l}\text { SNAPPERS: } \\
\text { LANE. }\end{array}$ & . . . & . . . & . . . & 16 & 7 & 26 & 12 & 42 & 19 \\
\hline MANGROVE & $\therefore$ & . . . & . . & 116 & 61 & 485 & 167 & 601 & 228 \\
\hline MUTTON. & . . & . . . . & . . . & 137 & 98 & 260 & 134 & 397 & 232 \\
\hline RED . . & & . . . & $\therefore$ & 685 & 676 & 4,453 & 3,720 & 5,138 & 4,396 \\
\hline VERMILIOI & ON. & . . . & . . . & 192 & 141 & 353 & 216 & 545 & 357 \\
\hline YELLOWTA & IL. & . . . & . . . & 122 & 87 & 675 & 456 & 797 & 543 \\
\hline SPANISH SAF & RDINES & 5.... & . . . & 10 & 2 & 248 & 23 & 258 & 25 \\
\hline $\begin{array}{l}\text { SPOT. } \\
\text { STURGEON }\end{array}$ & - & - *. & • · & 841 & $-_{-}^{163}$ & $\begin{array}{r}136 \\
2\end{array}$ & $(1)^{16}$ & 977 & 179 \\
\hline $\begin{array}{l}\text { STURGEON, } \\
\text { SWORDFISH }\end{array}$ & COMMON & N. : & $::$ & $=$ & - & 131 & 226 & 131 & $\begin{array}{l}(1) \\
226\end{array}$ \\
\hline $\begin{array}{l}\text { SWORDF ISH } \\
\text { TENPOUNOER }\end{array}$ & $\therefore:$ & $: \vdots:$ & $: \vdots:$ & 8 & (1) & 1,002 & 42 & 1,010 & 42 \\
\hline TILAPIA. & $\therefore$ & $\therefore$. & $\therefore$ & 1,283 & 154 & 16 & 4 & 1,299 & 158 \\
\hline TILEFISH. & $\therefore \cdot$ & . . . & . . . & 147 & 57 & 32 & 9 & 179 & 66 \\
\hline TRIGGERF IS & SH. & . . . . & . . . & 35 & 6 & 78 & 9 & 113 & 15 \\
\hline TRIPLETAIL & ・. & . . & . . & 2 & (1) & 1 & (1) & 3 & (1) \\
\hline WAHOO . . & $\cdot \cdot$ & . . . & . . & 4 & 1 & 1 & 1 & 5 & 2 \\
\hline $\begin{array}{l}\text { WARSAW. } \\
\text { UNCLASS }|\dot{F}| \mid\end{array}$ & $\dot{E} 0:$ & $\cdots \cdot$ & $\cdot \cdot$ & 34 & 12 & 135 & 33 & 169 & 45 \\
\hline $\begin{array}{l}\text { FOR FOOD } \\
\text { FOR BAIT }\end{array}$ & $\dot{R} \dot{B C U}$ & ICTION, & A ANO $^{\circ}$ & 311 & 42 & 1,447 & 213 & 1,758 & 255 \\
\hline ANIMAL & Fooo. & $\cdots$ & $\cdot$. & 275 & 16 & 810 & 41 & 1,085 & 57 \\
\hline TOT & TAL FIS & SH $\cdot$ & $\cdot \cdot \cdot$ & 45,914 & 9,718 & 64,821 & 15,897 & 110,735 & 26.615 \\
\hline
\end{tabular}

SEE FOOTNOTES AT ENO OF TABLE.

(CONTINUED ON NEXT PAGE) 
FLORIDA - LANDINGS BY DISTRICTS, 1975 - Continued

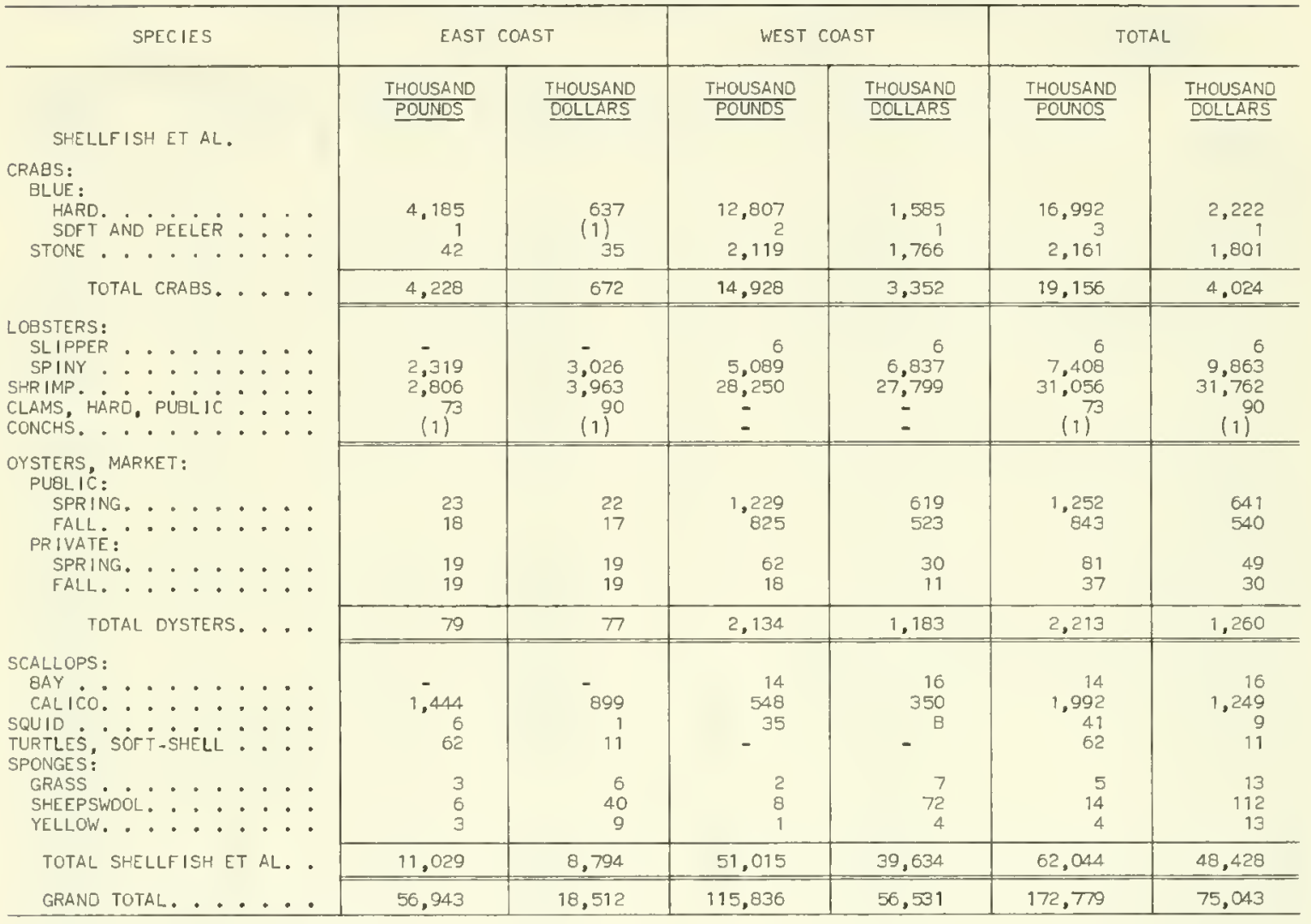

1 LESS THAN 500 POUNDS OR $\$ 500$

NOTE:--THF LANDINGS OF $9,698,100$ POUNDS OF CATFISH AND BULLHEAOS (VALUED AT \$2,782,473), 100,000 POUNDS DF GIZZARD SHAD (VALUED AT $\$ 3,000), 1,281,100$ POUNDS OF TILAPIA (VALUED AT \$153,735), AND 61,900 POUNDS OF SOFT - SHELL TURTLES (VALUED AT $\$ 10,830$ ) TAKEN FROM THE INLANO LAKES ARE INCLUOEO WITH THE EAST COAST OF FLORIOA. FOR THE PURPOSE OF THIS REPORT THE "EAST COAST OF FLORIDA" INCLUDES THE COASTAL COUNTIES FRDM NASSAU TO DADE, INCLUSIVE, WHILE THE "WEST COAST OF FLORIOA" INCLUOES THOSE FROM MONROE TO ESCAMBIA, INCLUSIVE. 


\section{SOUTH ATLANTIC SHRIMP FISHERY \\ SUMMARY OF SHRIMP LANDINGS, 1975}

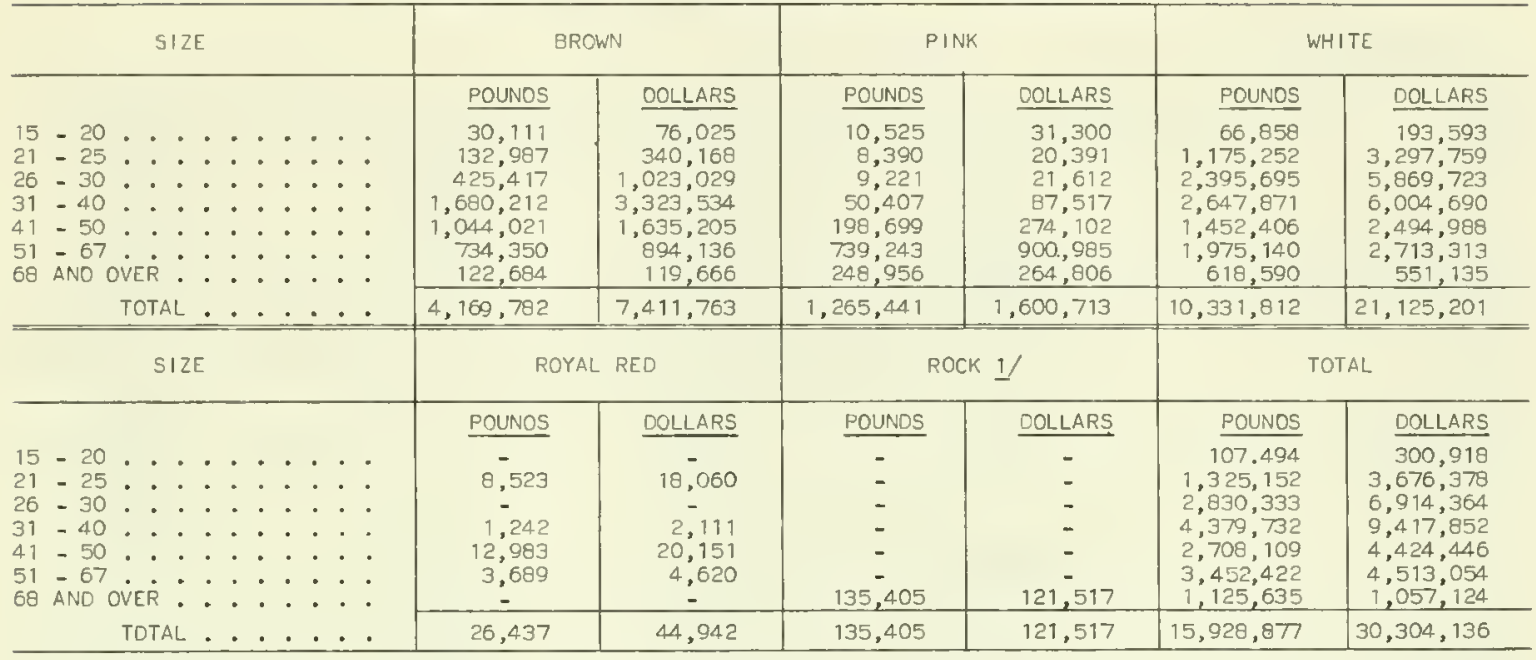

1) NOT MARKETEO BY COUNT SIZE.

NOTE:- -ALL WE IGHTS ARE ON HEADS-OFF BASIS AND ARE NOT OIRECTLY COMPARABLE WITH THE VOLUME DATA PUBLISHED IN THE GENERAL REVIEW AND REGIONAL TABLES, WHICH REPRESENT THE ROUND WEIGHT OF THE CATCH. THE POUNOS OF HEADS -OFF SHRIMP MAY BE CONVERTED TO HEAOS-ON (ROUND) WEIGHT BY MULTIPLYING BROWN SHRIMP BY 1.61, PINK 8Y 1.60, WHITE BY 1.54 ,

ROYAL RED OY 1.80 , ANO ROCK BY 1.67 .

\section{SOUTH ATLANTIC SHRIMP LANDINGS, BY SPECIES AND SIZE, 1975}

\begin{tabular}{|c|c|c|c|c|c|c|}
\hline SPECIES AND SIZE & \multicolumn{2}{|c|}{ NORTH CAROLINA } & \multicolumn{2}{|c|}{ SOUTH CARDLINA } & \multicolumn{2}{|c|}{ GEORGIA } \\
\hline 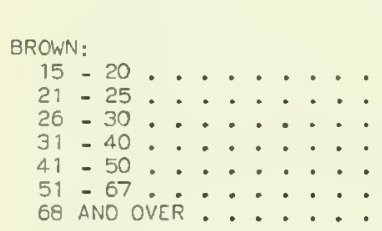 & $\begin{array}{r}\text { POUNDS } \\
- \\
51,079 \\
241,807 \\
712,891 \\
311,602 \\
209,638 \\
64,249 \\
\end{array}$ & $\begin{array}{r}\text { DOLLARS } \\
154,656 \\
57,493 \\
1,431,911 \\
485,770 \\
238,602 \\
68,424 \\
\end{array}$ & $\begin{array}{r}\text { PCUNOS } \\
275 \\
15,002 \\
84,597 \\
463,313 \\
464,980 \\
395,069 \\
55,607\end{array}$ & $\begin{array}{r}\text { DOLLARS } \\
789 \\
42,197 \\
215,688 \\
964,989 \\
740,128 \\
489,513 \\
49,320 \\
\end{array}$ & $\begin{array}{r}\text { POUNDS } \\
2,977 \\
16,329 \\
51,797 \\
410,878 \\
243,078 \\
79,581 \\
324 \\
\end{array}$ & $\begin{array}{r}\text { ODLLARS } \\
8,196 \\
41,299 \\
118,921 \\
742,001 \\
371,452 \\
97,175 \\
161\end{array}$ \\
\hline TOTAL ...... & $1,601,266$ & $2,956,856$ & $1,478,843$ & $2,501,618$ & 804,964 & $1,379,275$ \\
\hline 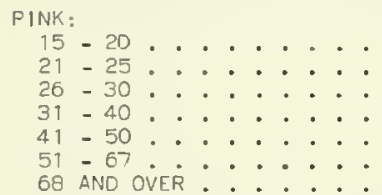 & $\begin{array}{c}- \\
- \\
- \\
43,274 \\
195,291 \\
7377,372 \\
247,448\end{array}$ & $\begin{array}{c}- \\
- \\
\overline{-} \\
74,315 \\
269,505 \\
898,027 \\
263,067\end{array}$ & $\begin{array}{r}4 \\
716 \\
4,752 \\
1,497 \\
730 \\
60 \\
8\end{array}$ & $\begin{array}{r}10 \\
1,770 \\
11,926 \\
3,309 \\
309 \\
86 \\
9\end{array}$ & $\begin{array}{l}2,604 \\
1,955 \\
-845 \\
116 \\
-\end{array}$ & $\begin{array}{l}7.160 \\
4,985 \\
- \\
7.625 \\
214 \\
-\end{array}$ \\
\hline TDTAL . . . . & $1,223,385$ & $7,505,714$ & 7,161 & 17,419 & 5,520 & 13,984 \\
\hline 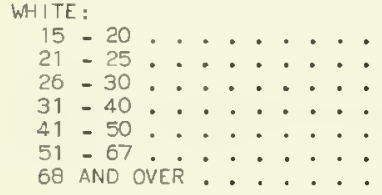 & $\begin{array}{c}- \\
- \\
2,145 \\
75,658 \\
263,454 \\
66,643\end{array}$ & $\begin{array}{c}- \\
- \\
4,612 \\
124,031 \\
383,162 \\
79,569 \\
\end{array}$ & $\begin{array}{r}904 \\
127,484 \\
655,932 \\
1,451,972 \\
632,230 \\
1,045,792 \\
289,403 \\
\end{array}$ & $\begin{array}{r}2,466 \\
358,762 \\
1,666,131 \\
3,430,960 \\
1,129,812 \\
1,443,019 \\
252,499 \\
\end{array}$ & $\begin{array}{r}28,252 \\
582,895 \\
1,393,940 \\
938,206 \\
632,890 \\
562,349 \\
241,496 \\
\end{array}$ & $\begin{array}{r}82,844 \\
.638,063 \\
3,339,831 \\
2,010,792 \\
1,053,045 \\
739,071 \\
193,519 \\
\end{array}$ \\
\hline . . . & 407,900 & 591,374 & $4,203,717$ & $8,283,649$ & $4,380,028$ & $9,057,165$ \\
\hline $\begin{array}{l}\text { ROYAL RED: } \\
21=250: \therefore \\
41=50: \therefore \\
51-67: \therefore:\end{array}$ & : & ! & $\Xi$ & - & $\begin{array}{r}7,048 \\
10,558 \\
2,649 \\
\end{array}$ & $\begin{array}{r}14,800 \\
16,364 \\
3,391 \\
\end{array}$ \\
\hline TOTAL . . . . & - & - & - & - & 20,255 & 34,475 \\
\hline GRANO TDTAL .... & $3,232,551$ & $5,053,944$ & $5,689,721$ & $10,802,686$ & $5,210,767$ & $10,484,899$ \\
\hline
\end{tabular}

SEE NOTE AT ENO OF TABLE.

(CONT INUED ON NEXT PAGE) 


\section{SOUTH ATLANTIC SHRIMP LANDINGS, BY SPECIES AND SIZE, 1975 - Continued}

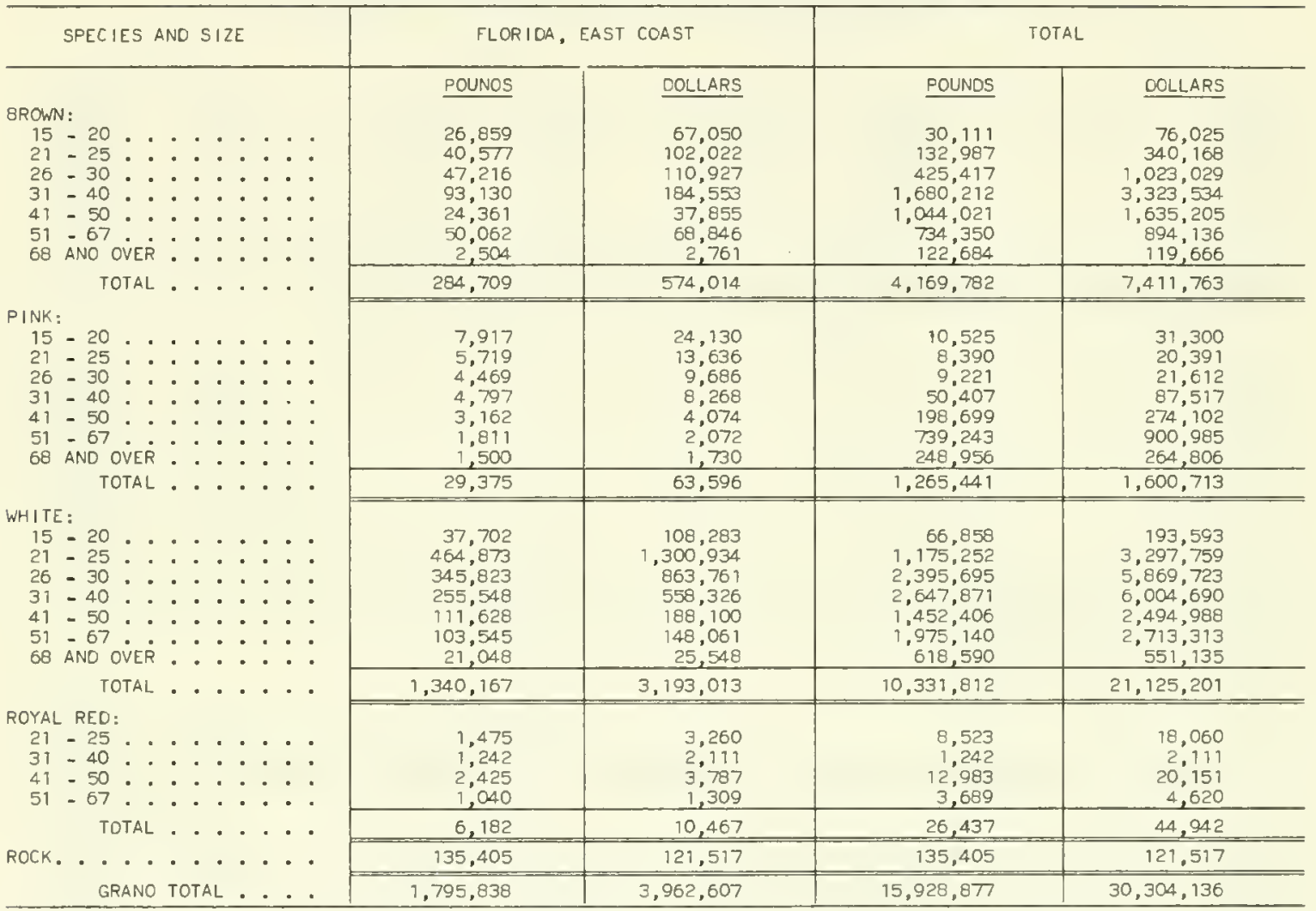

NOTE:--ALL WE IGHTS ARE ON HEADS-OFF 8ASIS. THE SIZE INOICATES THE NUMBER OF HEADS-OFF SHRIMP TO THE POUNO. TO CONVERT TO HEADS-ON WEIGHT MULTIPLY 8Y 1.61 FOR BROWN, 1.60 FOR PINK, 1.54 FOR WHITE, 1.80 FOR ROYAL RED, AND 1.67 FOR ROCK. THE STATES LISTED REPRESENT THE STATES WHERE THE SHR IMP WERE LANDED REGAROLESS OF WHERE CAUGHT. THE NAMES OF THE SPECIES USEO IN THESE TABLES ARE AS FOLLOWS: WHITE SHRIMP (MOSTLY PENAEUS SETIFERUS), BROWN SHRIMP (MOSTLY PENAEUS AZTECUS), PINK SHRIMP (MOSTLY PENAEUS DUORARUM), ROYAL RED (MOSTLY HYMENOPENAEUS ROBUSTUS) ANO ROCK SHRTMP (MOSTLY SICYONIA SPP. THE VALUE REPORTED IS THE AMOUNT RECE IVED $8 Y$ THE OWNERS OR OPERATORS OF THE VESSELS FOR THE FIRST SALE AT THE DOCK. ANY EXPENSES INVOLVED IN HANDL ING OR PROCESSING ASHORE ARE NOT INCLUDED, EVEN THOUGH CHARGEABLE TO THE VESSELS. THE SIZE REPORTED GENERALLY IS THAT USED AS OF THE FIRST SALE. SIZE GRADING IN VARYING DEGREES OF UNIFORMITY MAY OR MAY NOT OCCUR AT, OR PRIOR TO, THE TIME FIRST SALES ARE MADE. IF GRADING IS NDT DONE AT THIS TIME. THE SIZE REPORTED IS AN AVERAGE SIZE AND MAY INCLUOE SEVERAL SIZE CLASSIFICATIONS. 
Total commercial landings of fish and shellfish at ports in the Gulf States (West Coast of Florida, Alabama, Mississippi, Louisiana, and Texas) were 1.7 billion pounds worth a record $\$ 270.6$ million, a decrease of 7 percent in quantity, but an increase of 12 percent in value compared with 1974 . Smaller landings of menhaden and shrimp was the principal reason for the volume decline. The increased value resulted from the record exvessel prices that fishermen received for shrimp in 1975 .

The Gulf States had 34 percent of the volume and 28 percent of the value of U.S. landings and exceeded all other areas in volume. Louisiana led in volume of landings with 1.1 billion pounds (67 percent); followed by Mississippi with 305.8 million (18 percent); Florida, West Coast, 115.8 milion ( 7 percent); Texas, 86.0 million ( 5 percent); and Alabama, 31.6 million pounds ( 2 percent). Compared with 1975, landings declined in all States except Mississippi, which had a 2-percent increase in volume.

Fishermen and vessels. The Gulf States had 26,560 full-time and part-time fishermen operating 4,670 vessels ( 5 net tons or more), 10,142 motorboats, and 61 other boats. Compared with 1974, this was an increase of 1,071 fishermen, 693 motorboats, and 3 other boats, and a decrease of 11 vessels.

According to records of the U.S. Department of Transportation, 121 vessels with home ports in the Gulf of Mexico received first documents as fishing vessels in 1975 compared with 245 vessels in 1974.

Processed products. In 1975 the value of processed seafood at the plant level was $\$ 418.2$ million, a decrease of $\$ 16$ million compared with 1974. Frozen packaged items accounted for 65 percent of the total value of processed products - an increase of 8 percent over the previous year. Louisiana led with products valued at $\$ 133.5$ million; followed by Florida, West Coast, $\$ 109.6$ million; Texas, $\$ 75.6$ million; Mississippi, $\$ 58.3$ million; and Alabama, $\$ 41.2$ million. The five States had a monthly average of 11,034 persons employed in 723 wholesaling and processing plants.

Hard blue crabs. Landings of 38.7 million pounds valued at a record $\$ 5.5$ million decreased 1.6 million pounds, but increased $\$ 179,000$ compared with 1974 . Landings increased in Florida, West Coast, but declined in all other States. Florida, West Coast landings were 12.8 million pounds, up 26 percent from 1974. Louisiana landings were 17.1 million pounds (down 17 percent); Texas, 6.0 million (down 2 percent); Alabama, 1.6 million (down 10 percent); and Mississippi, 1.1 million pounds (down 32 percent).

Food finfish. Compared with 1974, landings of most major species decreased. Landings of black mullet were 25.3 million pounds (down 9 percent); croaker, 12.8 million (down 12 percent); king mackerel, $2.6 \mathrm{million}$ (down 57 percent); spanish mackerel, 6.1 million (down 28 percent); spotted sea trout, 6.2 million (down 11 percent); and red snapper, 7.8 million pounds (down 8 percent). Landings of groupers ( 7.3 million pounds) increased 13 percent, and catfish and bullheads ( 6.1 million pounds) increased 22 percent.

Spiny lobster. Landings of 5.1 million pounds valued at $\$ 6.8$ million declined 24 percent in volume and 18 percent in value compared with 1974, the record year for value. All but 100 pounds were landed at Florida, West Coast ports. Fishermen received an average price of $\$ 1.34$ per pound, 10 cents more than in 1974 .

Menhaden. Landings of 1.2 billion pounds worth $\$ 35.5$ million were down 99.0 million pounds (8 percent) and $\$ 12.9$ million (27 percent) compared with 1974. Fishing eff ort in the Gulf in terms of thousands of vessel-ton weeks was the highest on record, but poor fishing weather during the season may have been one factor that held landings down. Louisiana landings (984.1 million pounds) declined 9 percent; Mississippi (212.1 million pounds), 2 percent; and Florida, West Coast (466,000 pounds), 34 percent. The Gulf menhaden fishery had 66 purse seines operating in 1975, the same number that operated in 1974.

Oysters. The production of 19.3 million pounds of shucked oyster meats valued at $\$ 10.9$ million increased 30 percent in volume and 11 percent in value compared with 1974. The harvest was the best since 1971 . Landings increased 291 percent in Mississippi, 37 percent in Lousiana, and 41 percent in Texas. Landings declined 20 percent along the west coast of Florida and 13 percent in Alabama.

Louisiana had 71 percent of the total oyster landings with a record 13.7 million pounds. Most of the catch was taken from private bottom and used by the fresh oyster trade. The canned oyster pack was 27 percent above 1974, but well below the record pack of 1961 . 
Shrimp. Landings of 170.1 million pounds valued at a record $\$ 178.3$ million decreased 9 percent in volume, but increased 29 percent in value compared with 1974. The quantity landed was the lowest since 1962 and 20 percent below the average of the previous 5 years. The Gulf States accounted for 49 percent of the total shrimp landings and 79 percent of the total value in 1975. Brown shrimp, the mainstay of the industry in recent years, declined 12.0 million pounds (17 percent) compared with 1974 . Gulf States biologists said that flood waters, which caused low salinity and abnormally low water temperatures during the postlarval stage, were responsible for the low survival of the juvenile brown shrimp. Short supplies caused exvessel prices to increase steadily throughout the year. Fishermen received an average price of $\$ 1.05$ per pound compared with 74 cents in 1974. Because many raw shrimp processors increased their processing capability to meet the increasing demand for small peeled shrimp, the market became more competitive at the fishermen level. In the past, canning plants were the primary volume users of sinall shrimp.

Landings declined in all five States in 1975. Texas with 70.6 million pounds was down 10 percent; Louisiana, 53.1 million, down 11 percent; and Mississippi, 4.0 million pounds, down 25 percent. Landings of 28.2 million pounds in Florida, West Coast, and 14.1 million pounds in Alabama were down less than 1 percent.

Fishing declined on most major grounds. The Sanibel and Tortugas grounds yielded 11.0 million pounds (down 9 percent from 1974); Pensacola to Mississippi River, 9.2 million (down 5 percent); Mississippi River to Texas, 38.6 million (down 10 percent); Texas Coast, 35.3 million (down 8 percent); off Mexican Coast west of long. $94^{\circ}, 5.6$ million (down 14 percent); and off Obregon and Campeche, 1.8 million pounds (down 50 percent). Increases occurred in waters off the Apalachicola area, 5.5 million pounds (up 1.5 million pounds); and Atlantic Ocean, 13,500 pounds (up 11,200 pounds).

The species composition was much the same as in 1974. Brown shrimp was 54 percent of the total landings; white shrimp, 26 percent; pink shrimp, 15 percent; sea bobs, 4 percent; and royal red and rock shrimp together, 1 percent.

Other information. Condensed summary data on the operating units and landings, by States, appearing in the following pages have been published previously in Current Fishery Statistics No. 7409. Additional data may be found in the monthly and annual landings bulletins for Florida, Alabama, Mississippi, Louisiana, and Texas published in the Current Fishery Statistics series by the Data Management and Statistics Division in cooperation with the respective States.

Acknowledgments. The following organizations helped collect the data appearing in this section: Florida Department of Natural Resources, Alabama Department of Conservation and Natural Resources, Mississippi Marine Conservation Commission, Louisiana Wild Life and Fisheries Commission, and Texas Parks and Wildlife Department. 


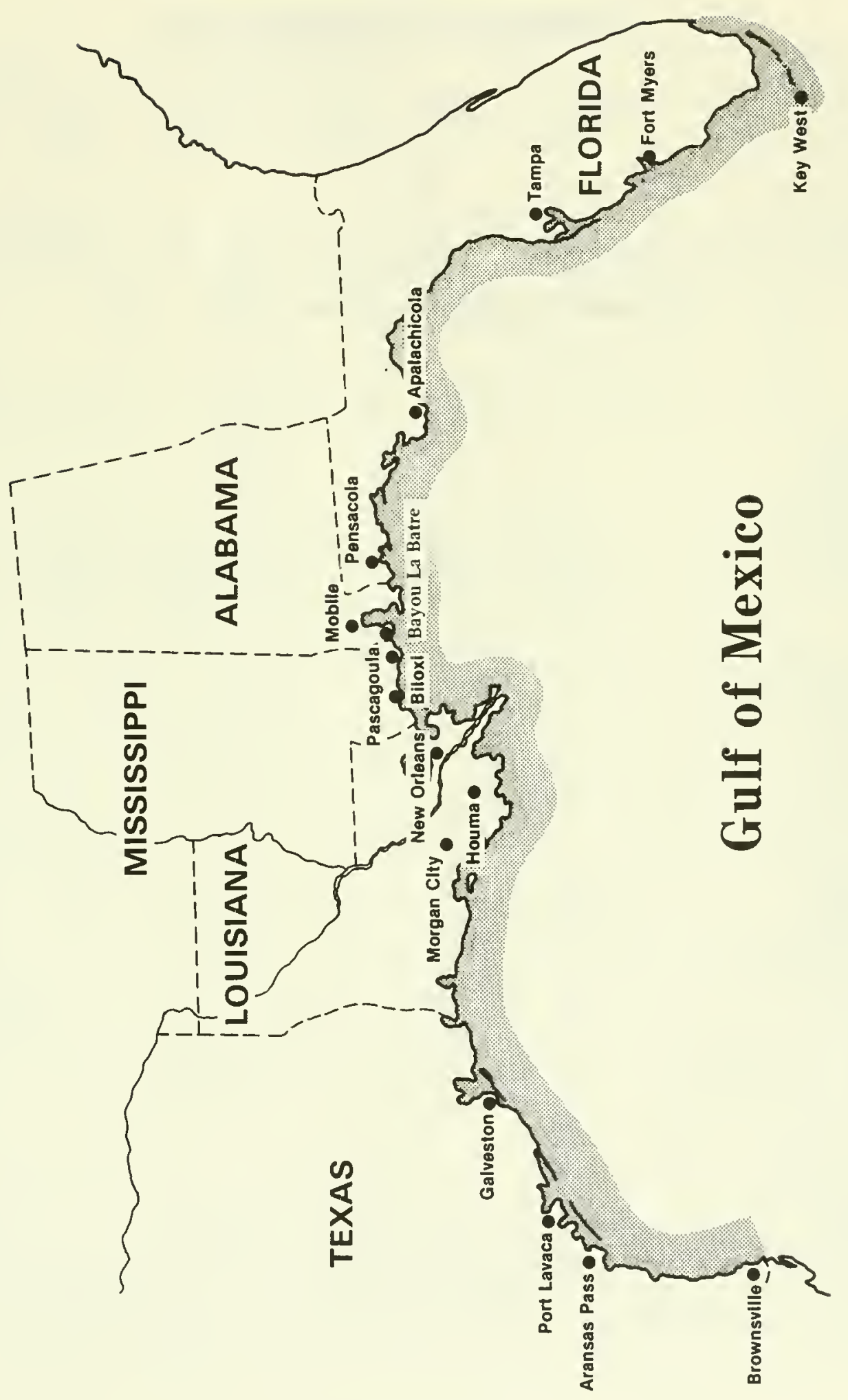

GULF STATES 
SECTIONAL SUMMARIES

SUMMARY OF LANDINGS, 1975

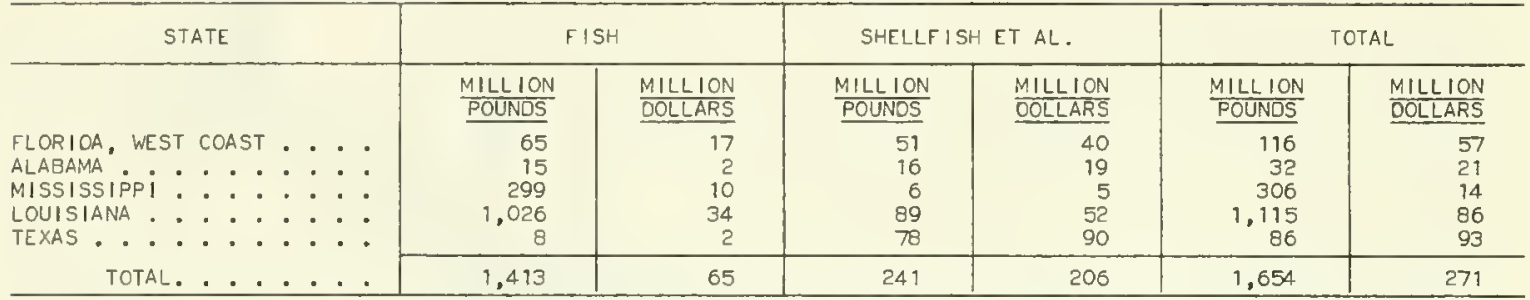

NOTE: - TABLE MAY NOT ADO BECAUSE OF ROUNDING. FOR THE PURPOSE OF THIS REPORT THE "WEST COAST OF FLORIDA" INCLUOES

THE COASTAL COUNTIES FROM MONROE TO ESCAMBIA, INCLUSIVE.

\section{SUMMARY OF OPERATING UNITS, 1975}

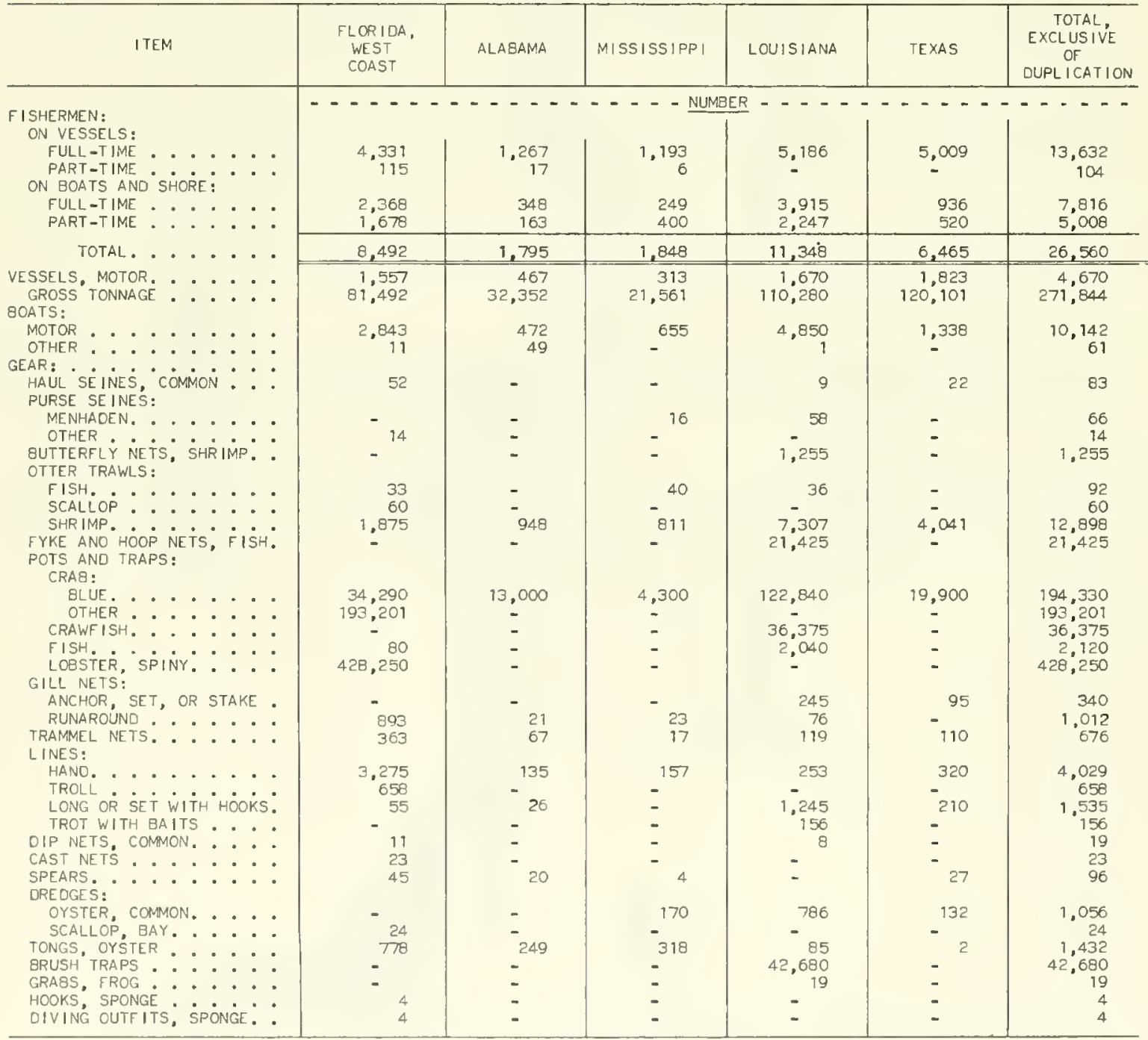

NOTE:--A TOTAL OF 420 FISHERMEN USING 411 MOTORBOATS F ISHED 3 HAUL SEINES, 6,000 FISH POTS, 984 LONG OR SET LINES, AND 34 CAST NETS IN THE INLAND LAKES OF FLORIOA. THESE OPERATING UNITS ARE INCLUDED WITH THOSE OF THE EAST COAST OF FLORIOA. 
LANDINGS BY STATES, 1975

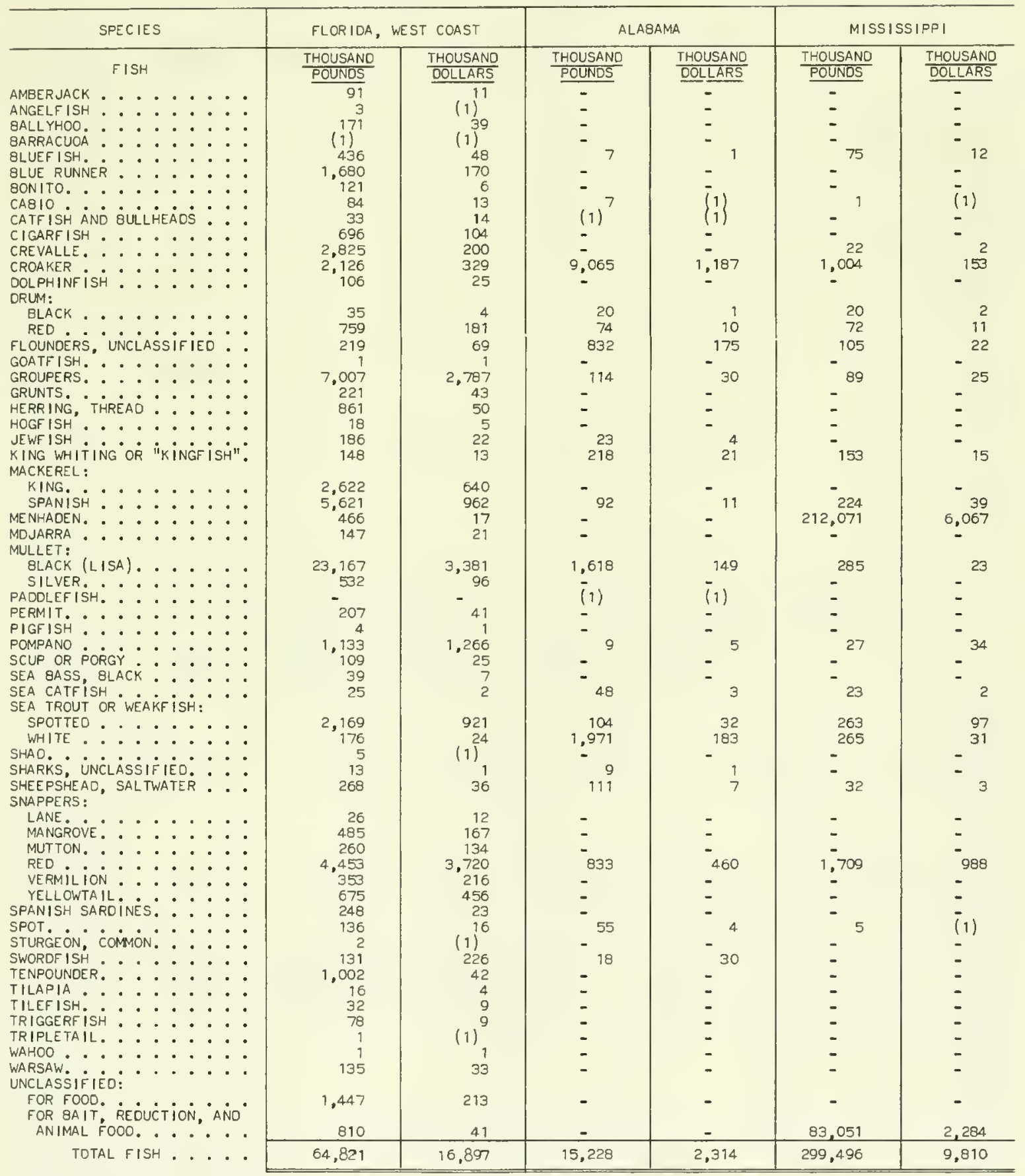

SEE FOOTNOTES AT ENO OF TABLE.

(CONTINUEO ON NEXT PAGE) 
LANDINGS BY STATES, 1975 - Continued

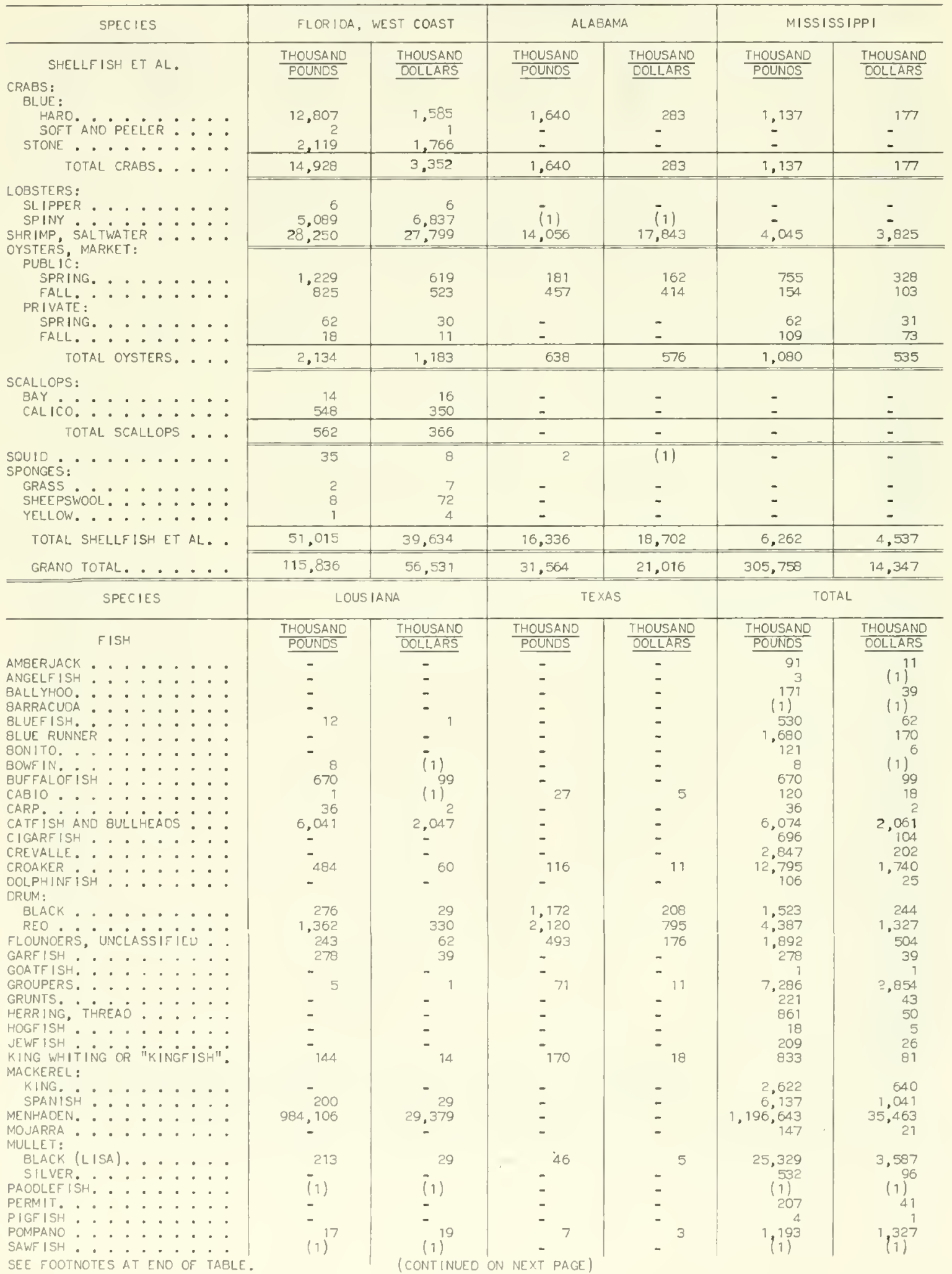


LANDINGS BY STATES, 1975 - Continued

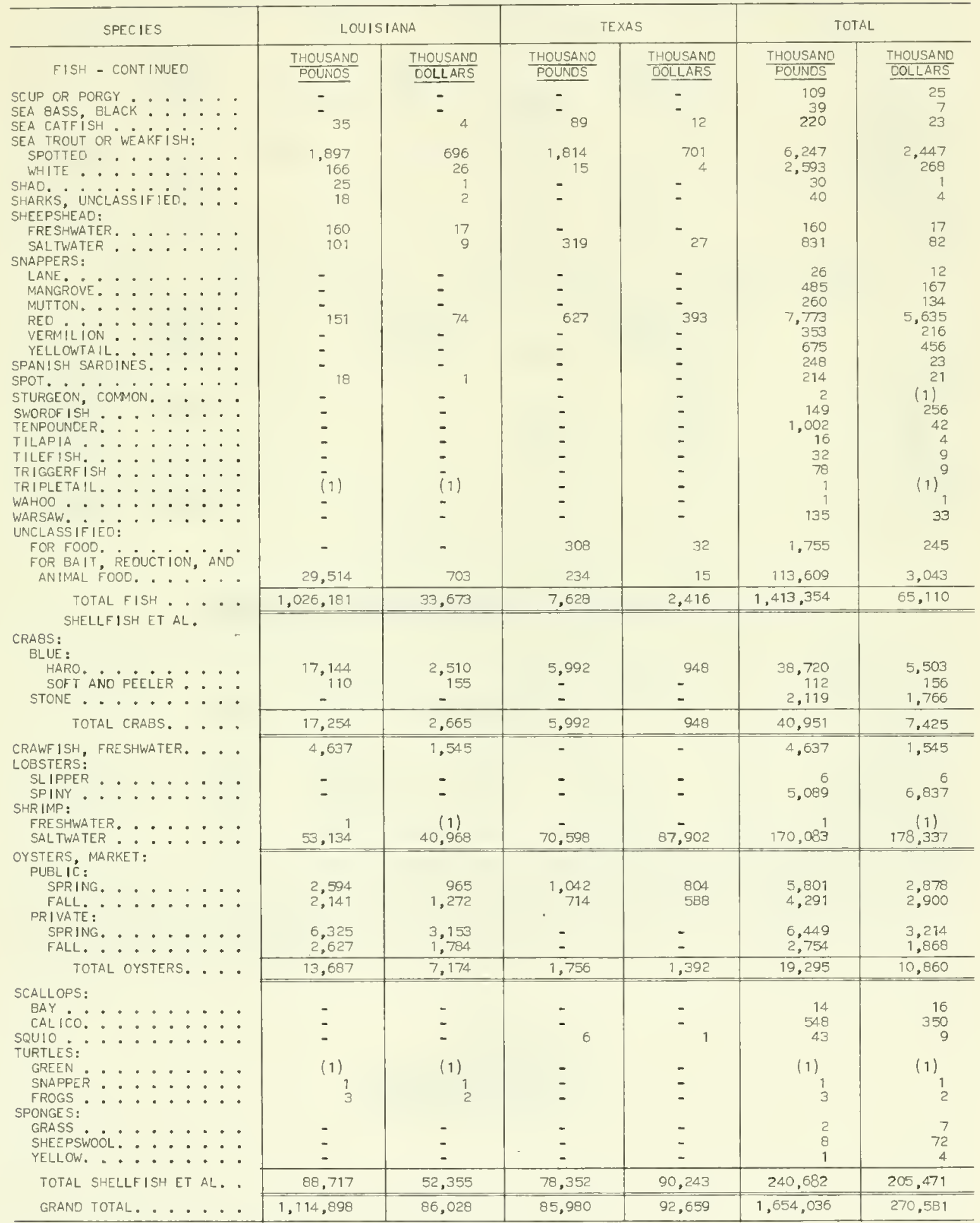

1) LESS THAN 500 POUNDS OR \$500.

NOTE:--LANOINGS ARE SHOWN IN ROUNO (LIVE) WEIGHT EXCEPT FOR MOLLUSKS. OYSTERS ARE REPORTEO IN WEIGHT OF TOTAL MEATS; SCALLOPS IN WEIGHT OF EOIBLE MEATS. 
LANDINGS OF CERTAIN SHELLFISH, 1975

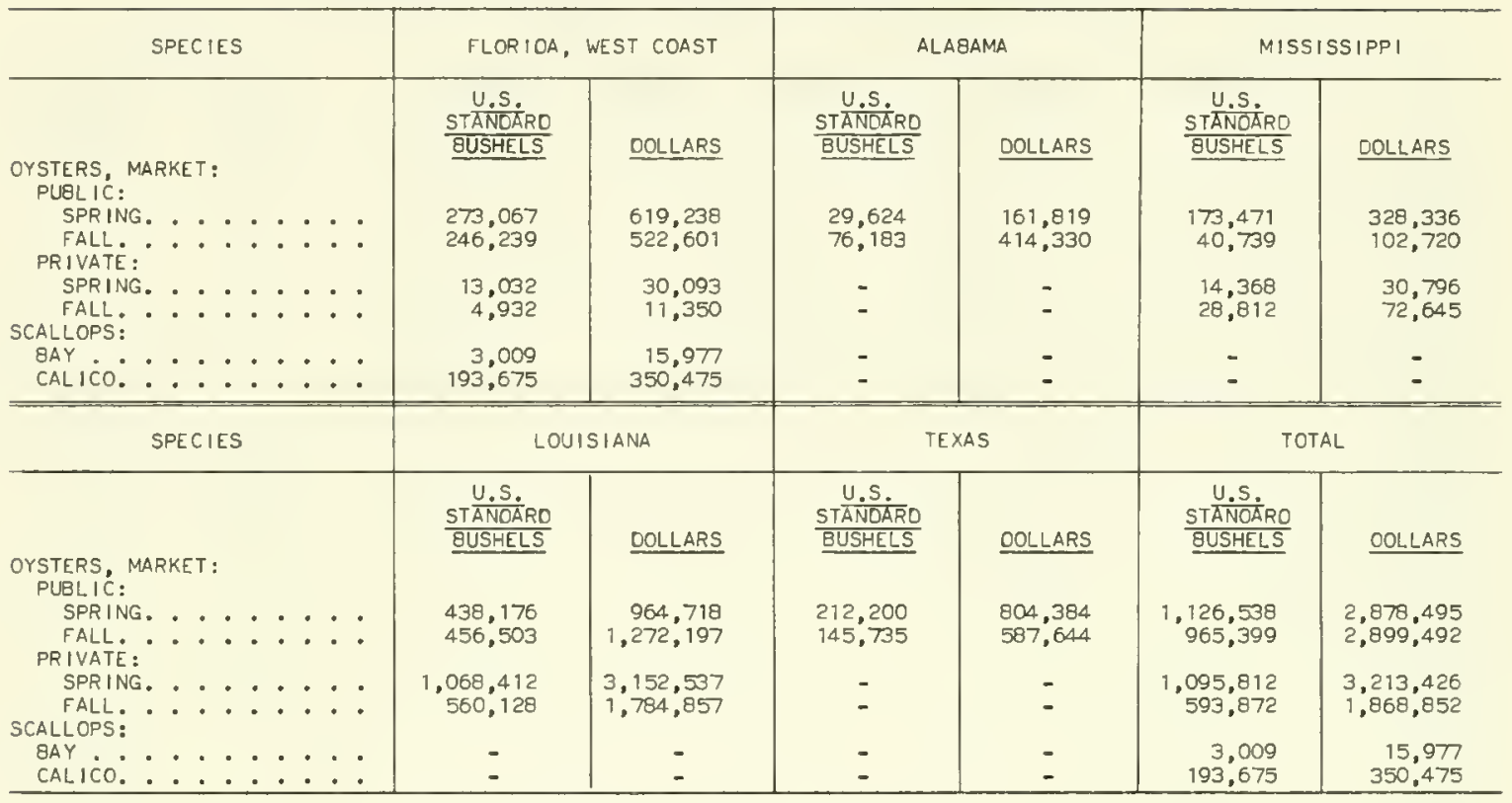

NOTE:--THE CAPACITY OF A U.S. STANOARO BUSHEL IS $2,150.4$ CUBIC INCHES.

AVERAGE YIELD OF CERTAIN SHELLFISH, 1975

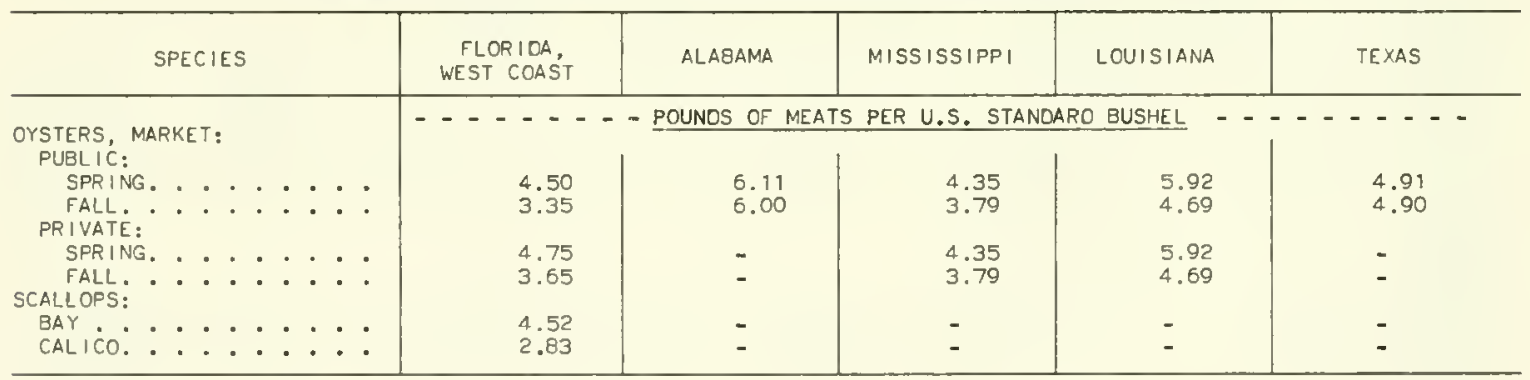

NOTE:--THE CAPACITY OF A U.S. STANOARO BUSHEL IS $2,150.4$ CUBIC INCHES. 
SUMMARY OF PROCESSED PRODUCTS, 1975

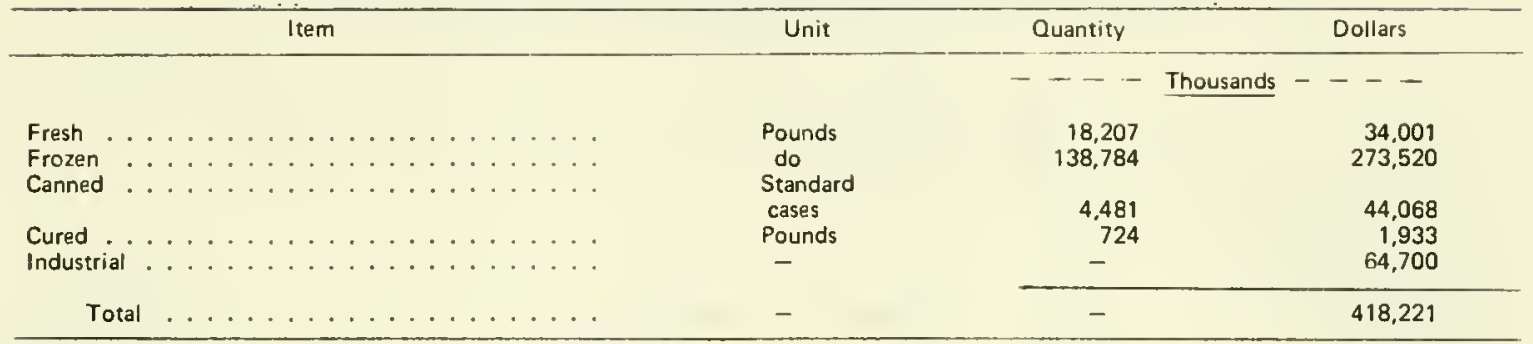

Note:-Table may not add because of rounding. Total is correct.

\section{VALUE OF PROCESSED PRODUCTS, BY STATES, 1975}

\begin{tabular}{|c|c|}
\hline State & Thousand dollars \\
\hline 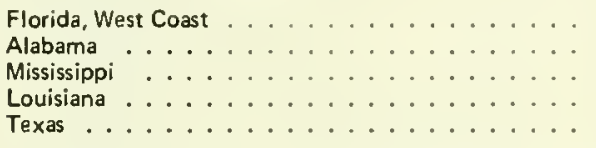 & $\begin{array}{r}109,650 \\
41,168 \\
58,298 \\
133,514 \\
75,592\end{array}$ \\
\hline 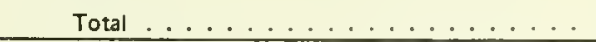 & 418,221 \\
\hline
\end{tabular}

Note:-Table may not add because of rounding. Total is correct.

\section{PROCESSING AND WHOLESALE ESTABLISHMENTS AND EMPLOYMENT, 1975}

\begin{tabular}{|c|c|c|c|c|c|c|c|c|c|}
\hline \multirow[t]{2}{*}{ State } & \multirow[b]{2}{*}{ Plants } & \multicolumn{2}{|c|}{$\begin{array}{l}\text { Processing } \\
\text { Employment average }\end{array}$} & \multirow[b]{2}{*}{ Plants } & \multicolumn{2}{|c|}{$\begin{array}{l}\text { Wholesale } \\
\text { Employment average }\end{array}$} & \multirow[b]{2}{*}{ Plants } & \multicolumn{2}{|c|}{$\begin{array}{l}\text { Total } \\
\text { Employment average }\end{array}$} \\
\hline & & Season & Year & & Season & Year & & Season & Year \\
\hline &.-- & -- & -- & -- & - Number & $-\quad-$ & -- & -- & -- \\
\hline $\begin{array}{l}\text { Florida, West Coast } \\
\text { Alabama } \\
\text { Mississippi . . . } \\
\text { Louisiana } \\
\text { Texas . . . . . }\end{array}$ & $\begin{array}{r}106 \\
43 \\
37 \\
104 \\
60\end{array}$ & $\begin{array}{l}3,319 \\
1,419 \\
1,468 \\
3,780 \\
2,042\end{array}$ & $\begin{array}{l}2,860 \\
1,005 \\
1,035 \\
2,733 \\
1,425\end{array}$ & $\begin{array}{r}160 \\
15 \\
14 \\
101 \\
83\end{array}$ & $\begin{array}{r}558 \\
167 \\
110 \\
460 \\
1,467\end{array}$ & $\begin{array}{r}517 \\
95 \\
80 \\
396 \\
888\end{array}$ & $\begin{array}{r}266 \\
58 \\
51 \\
205 \\
143\end{array}$ & $\begin{array}{l}3,877 \\
1,586 \\
1,578 \\
4.240 \\
3,509\end{array}$ & $\begin{array}{l}3,377 \\
1,100 \\
1,115 \\
3,129 \\
2,313\end{array}$ \\
\hline Total ..... & 350 & 12,028 & 9,058 & 373 & 2,762 & 1.976 & 723 & 14,790 & 11,034 \\
\hline
\end{tabular}

Note:--Employment is reported by each plant for each month for the payroll period that includes the 12 th of the month. Employment for the season is based on the greatest number of employees working during the payroll period that included the $12 \mathrm{th}$ of each month. Employment for the year is obtained by adding the number of employees recorded as working during the payroll period that included the 12 th of each month, and dividing by 12 . 


\section{PROCESSED FISHERY PRODUCTS, 1975}

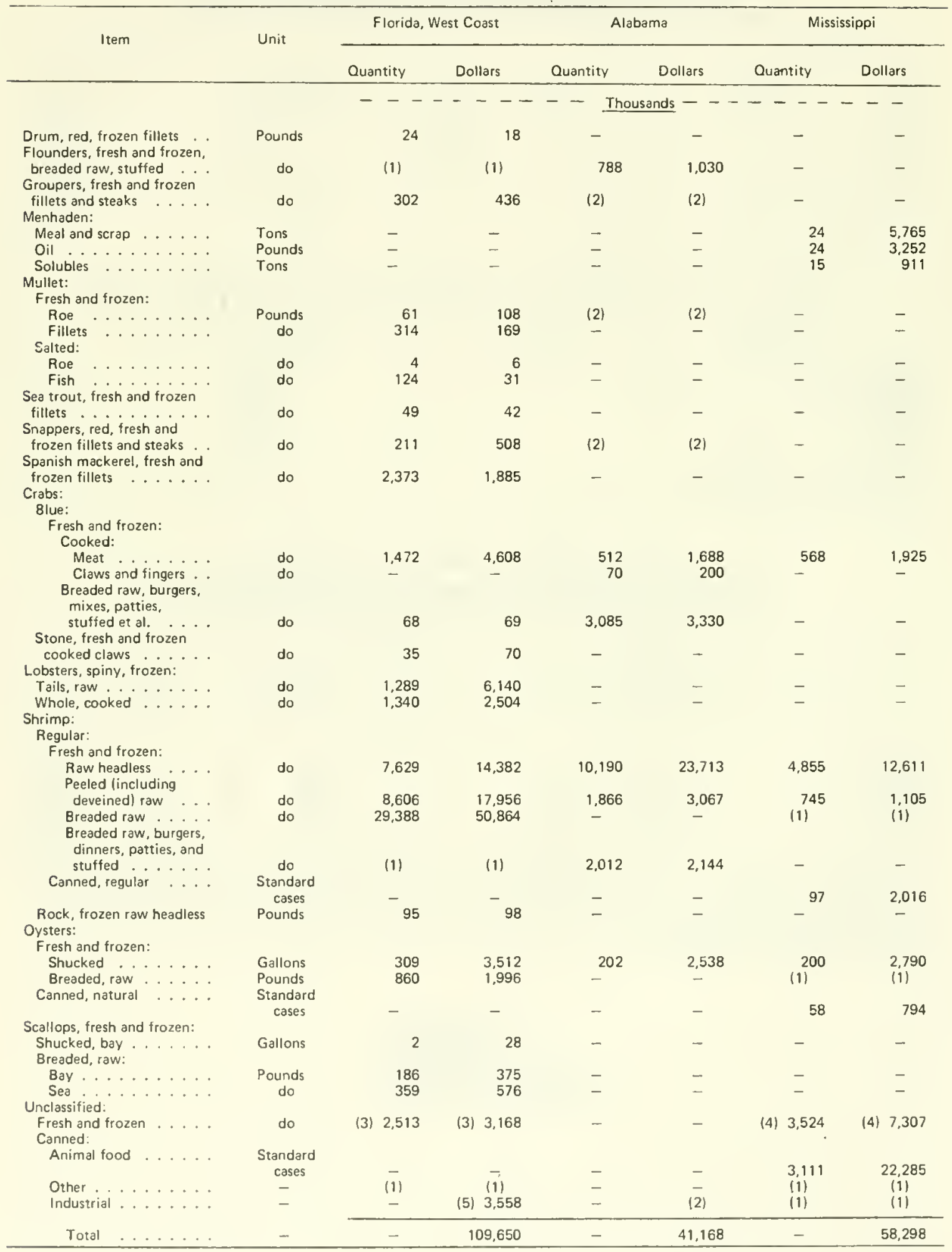


PROCESSED FISHERY PRODUCTS, 1975 - Continued

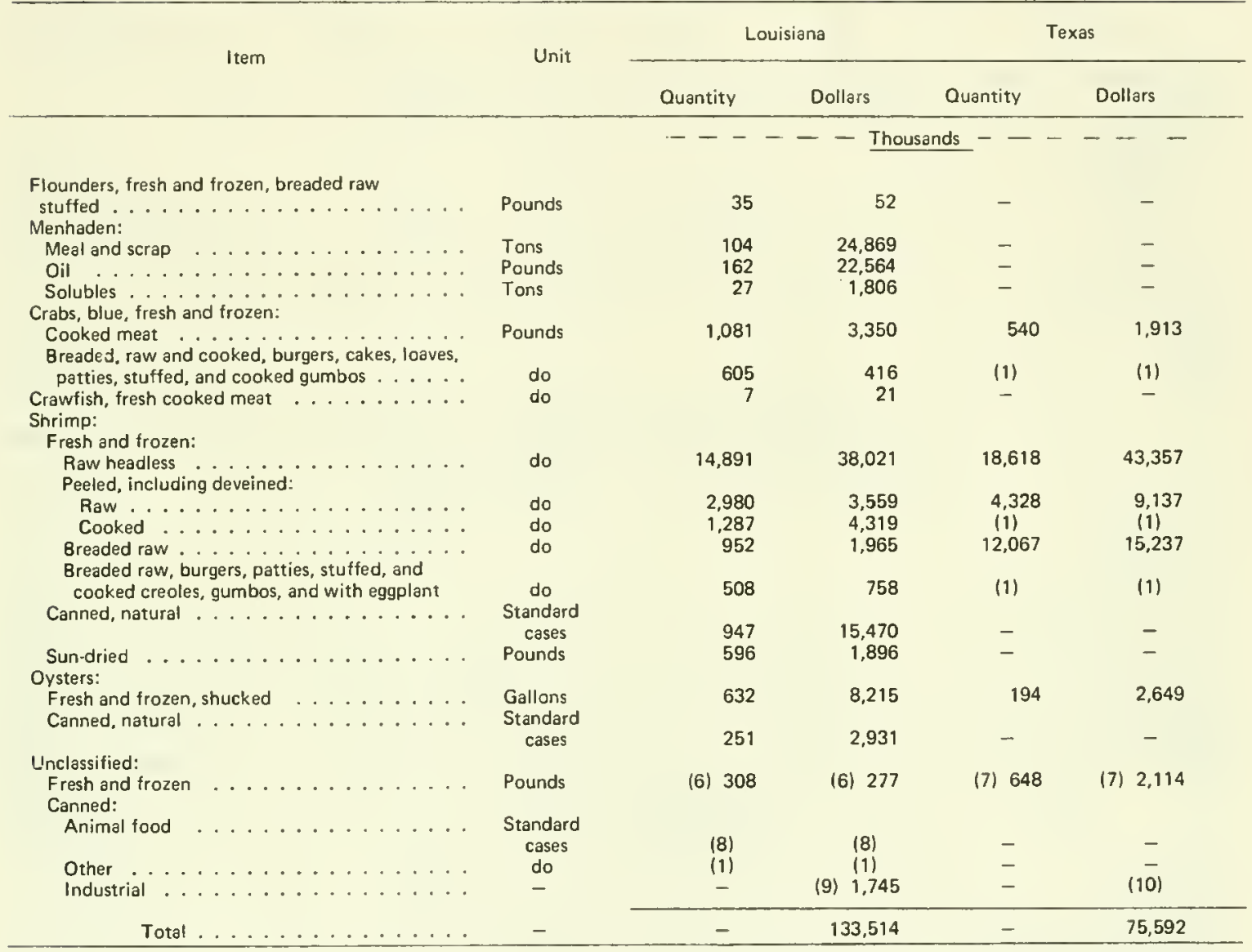

(1) Included with fresh and frozen items. (2) Grouper and red snapper fillets and steaks; mullet roe; the value of oyster shell grit and lime produced in Alabama has been inciuded with the West Coast of Florida. (3) Includes breaded (raw) cod and grouper croquettes; flounder and unclassified snapper fillets; halibut, king mackerel, and salmon steaks; flounder, grouper, ocean perch fillets, stuffed flounders, breaded (raw); mullet split for curing; shrimp, cooked and peeled, stuffed breaded (raw), cocktails, cured and refrigerated; rock shrimp split; oysters and calico scallop meats breaded (raw); shucked sea scallop meats; unclassified dinners and fish cakes breaded (raw); canned conch and turtle chowder. (4) Includes shrimp and oysters breaded (raw); canned (natural) crab meat; the value of crab shells cleaned and polished for food serving, and crab meal. (5) Includes the value of crab shells cleaned and polished for food serving; and shrimp and crab meal. (6) Includes dressed and skinned catfish; frozen crawtish bisques; canned, crawfish bisques; oyster stews; shrimp creoles, gumbos, and stews; and turtle soup. (7) Crabs breaded (raw) stuffed; shrimp creoles and gumbos; and oysters breaded (raw). (8) Included with Mississippi. (9) Includes the value of shrimp and unclassified meal, and oyster shell grit and lime. (10) Included with Louisiana.

Note:--This table will not add because of rounding. Individual State totals are correct. Some of the products may have been processed from raw products imported from another State or a foreign country; therefore, they cannot be correlated directly with landings within the State. Certain items are shown in an intermediate and also a more advanced stage of processing.

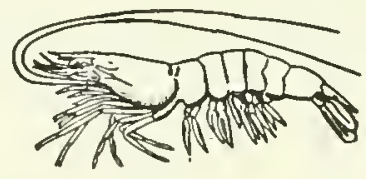




\section{FLORIDA, WEST COAST}

OPERATING UNITS BY GEAR, 1975

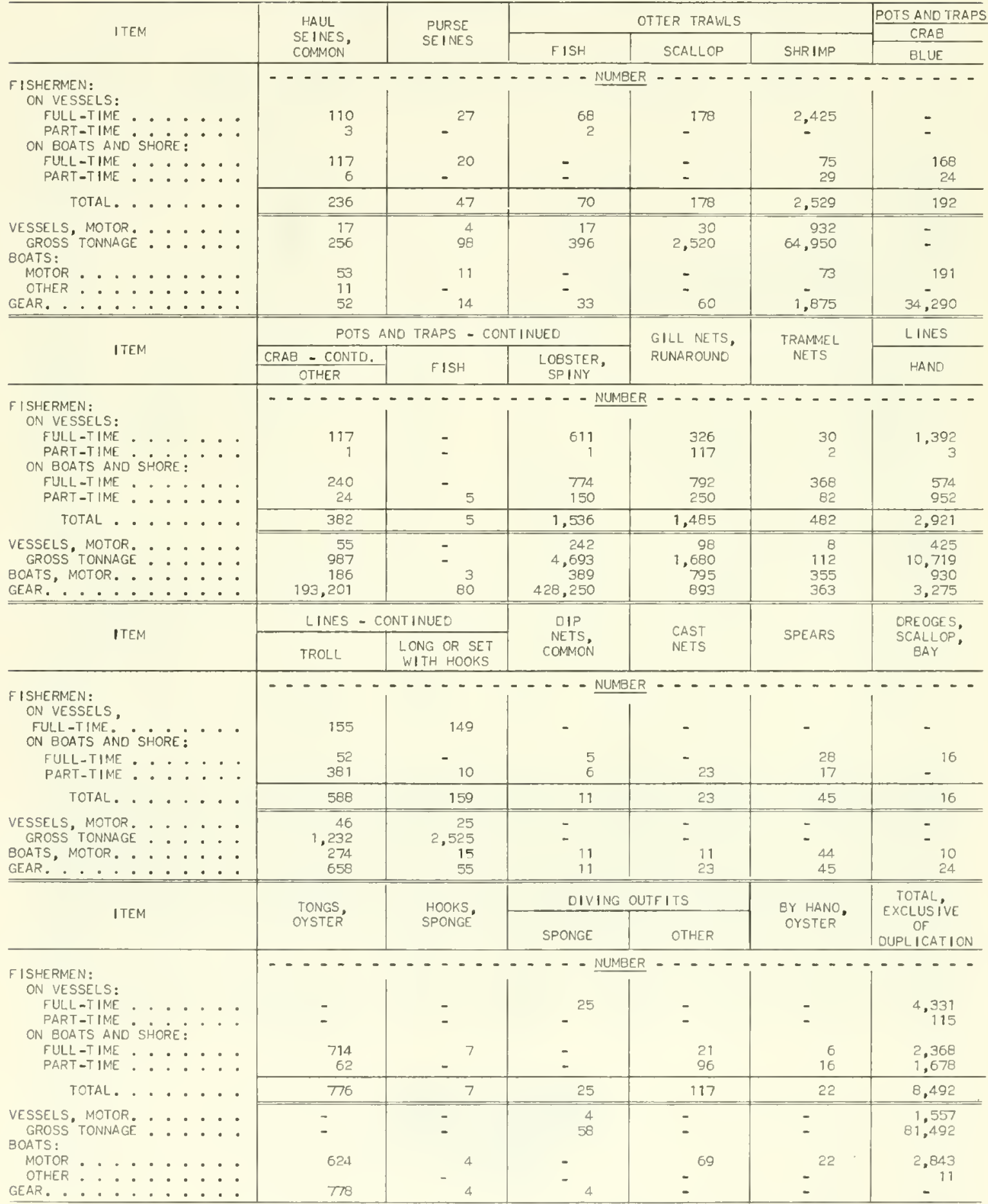




\section{FLORIDA, WEST COAST - LANDINGS OF CATCH BY GEAR, 1975}

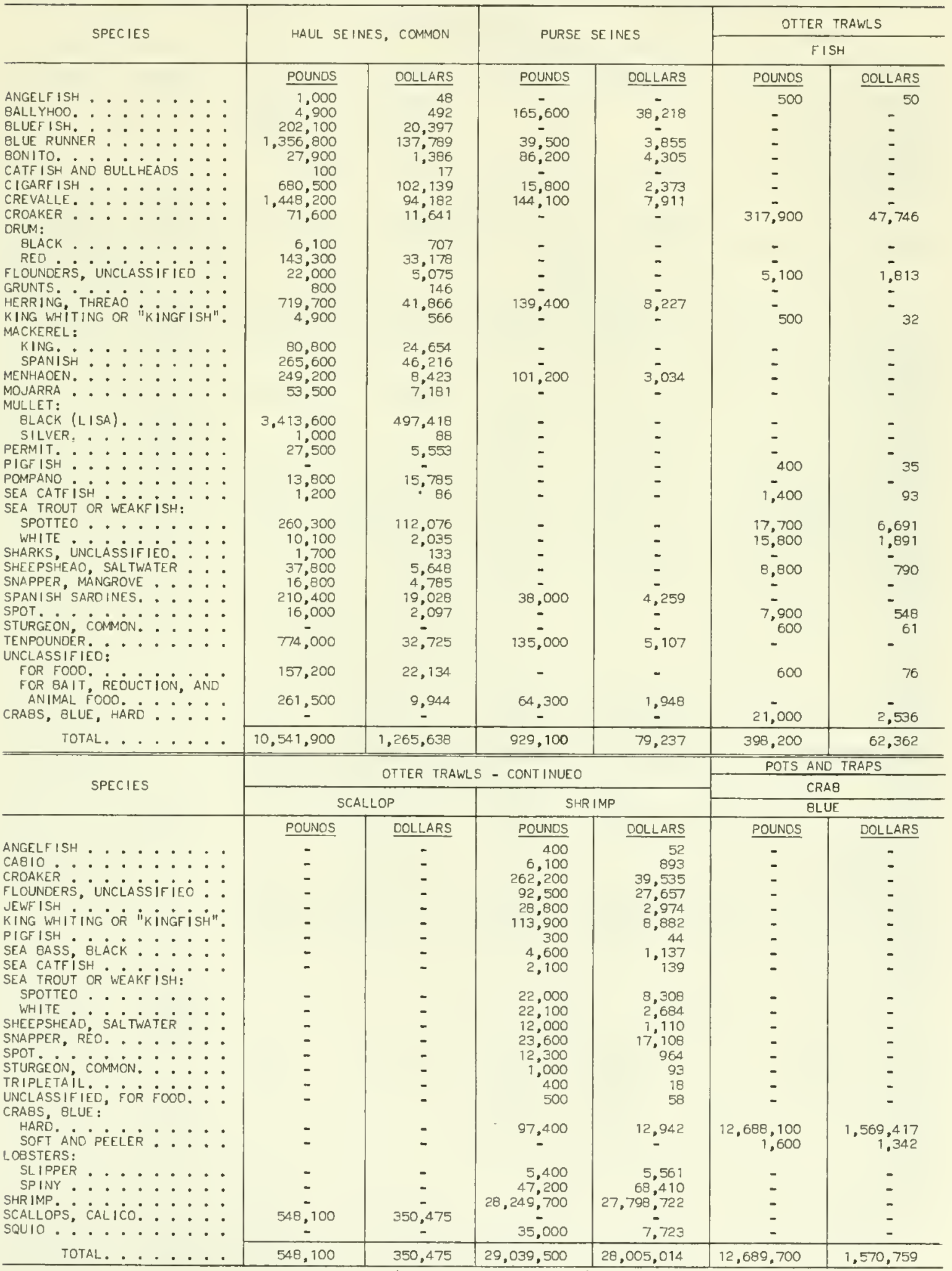


FLORIDA, WEST COAST - LANDINGS OF CATCH BY GEAR, 1975 - Continued

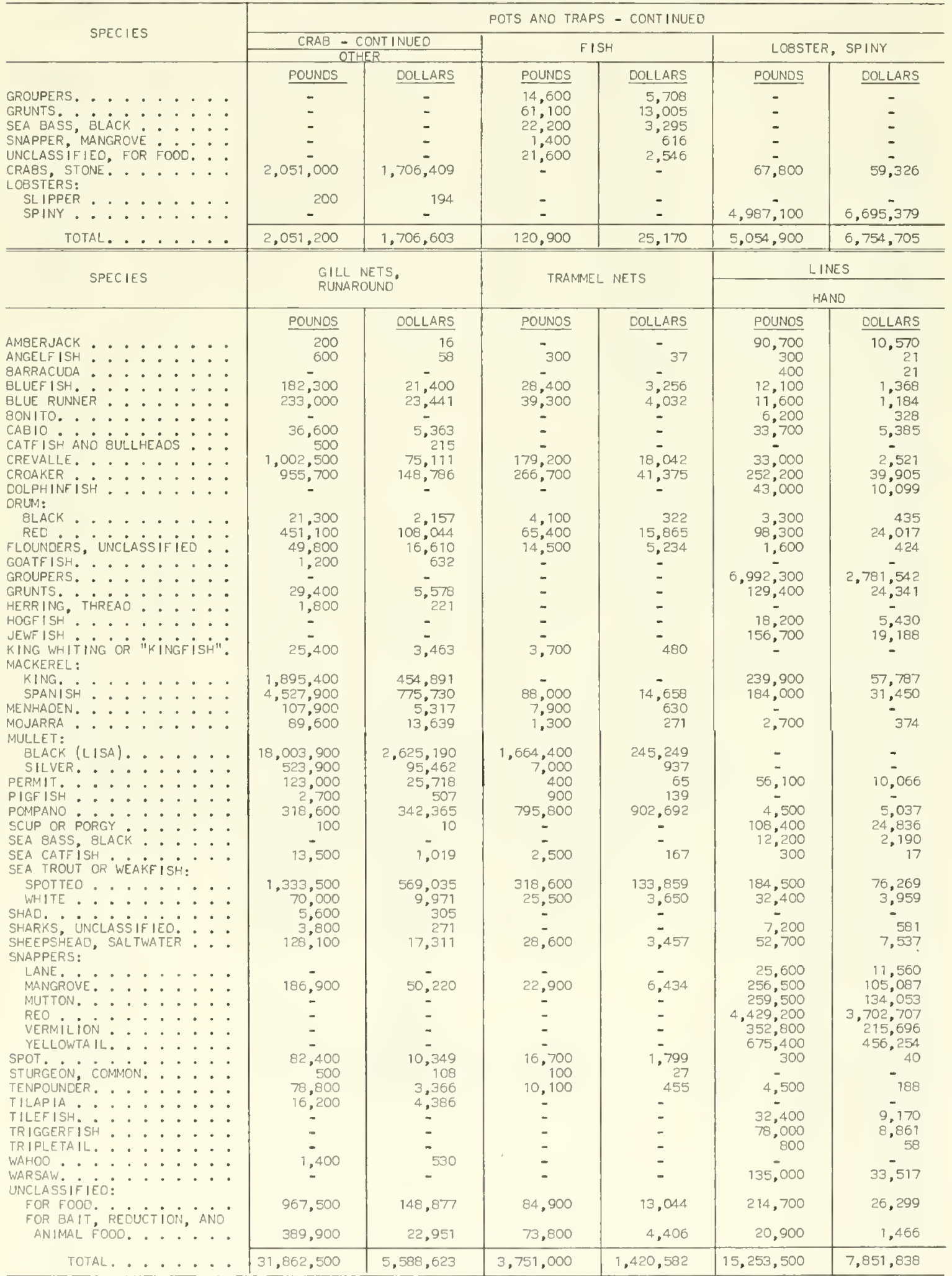


FLORIDA, WEST COAST - LANDINGS OF CATCH BY GEAR, 1975 - Continued

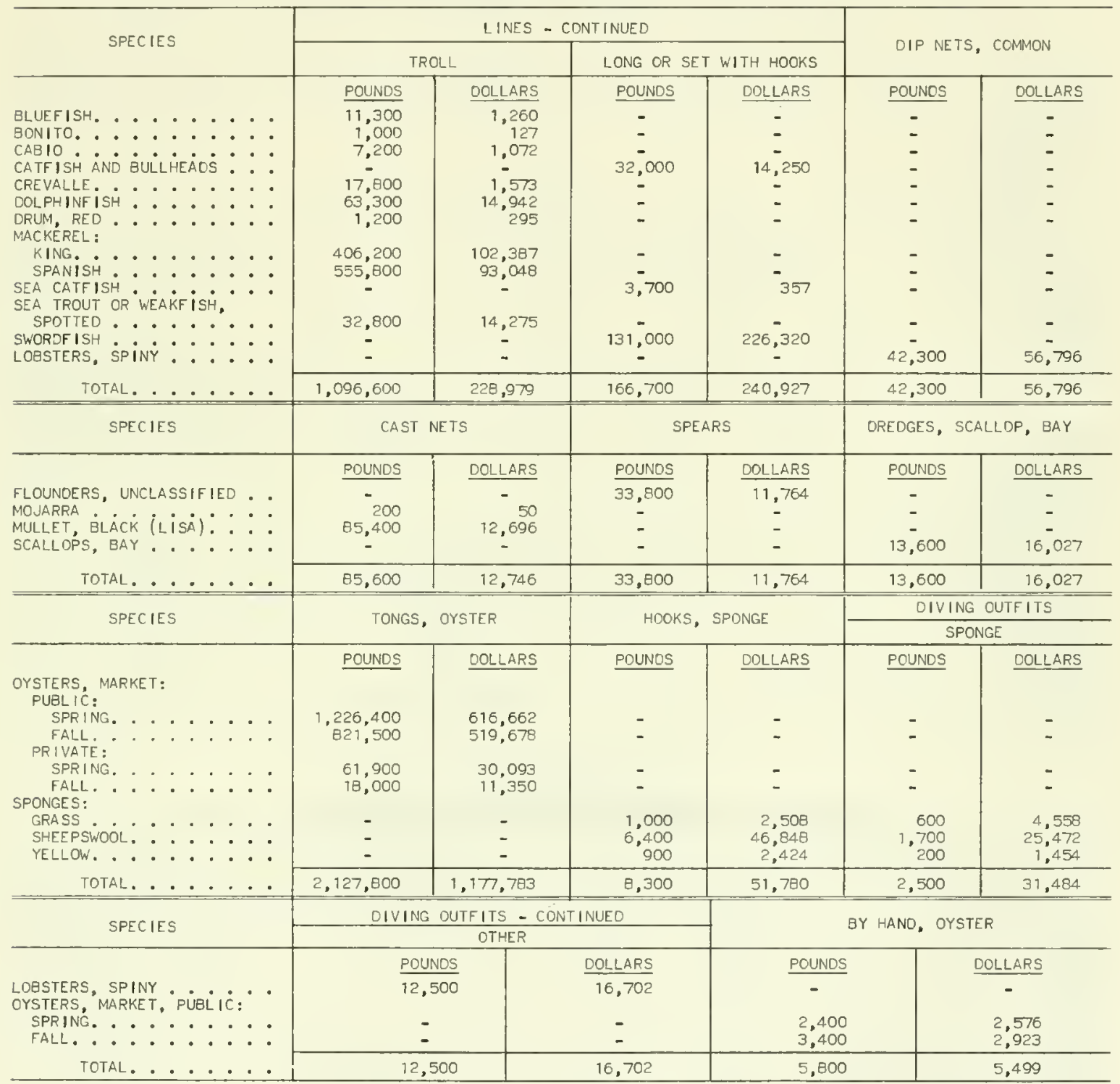




\section{ALABAMA \\ OPERATING UNITS BY GEAR, 1975}

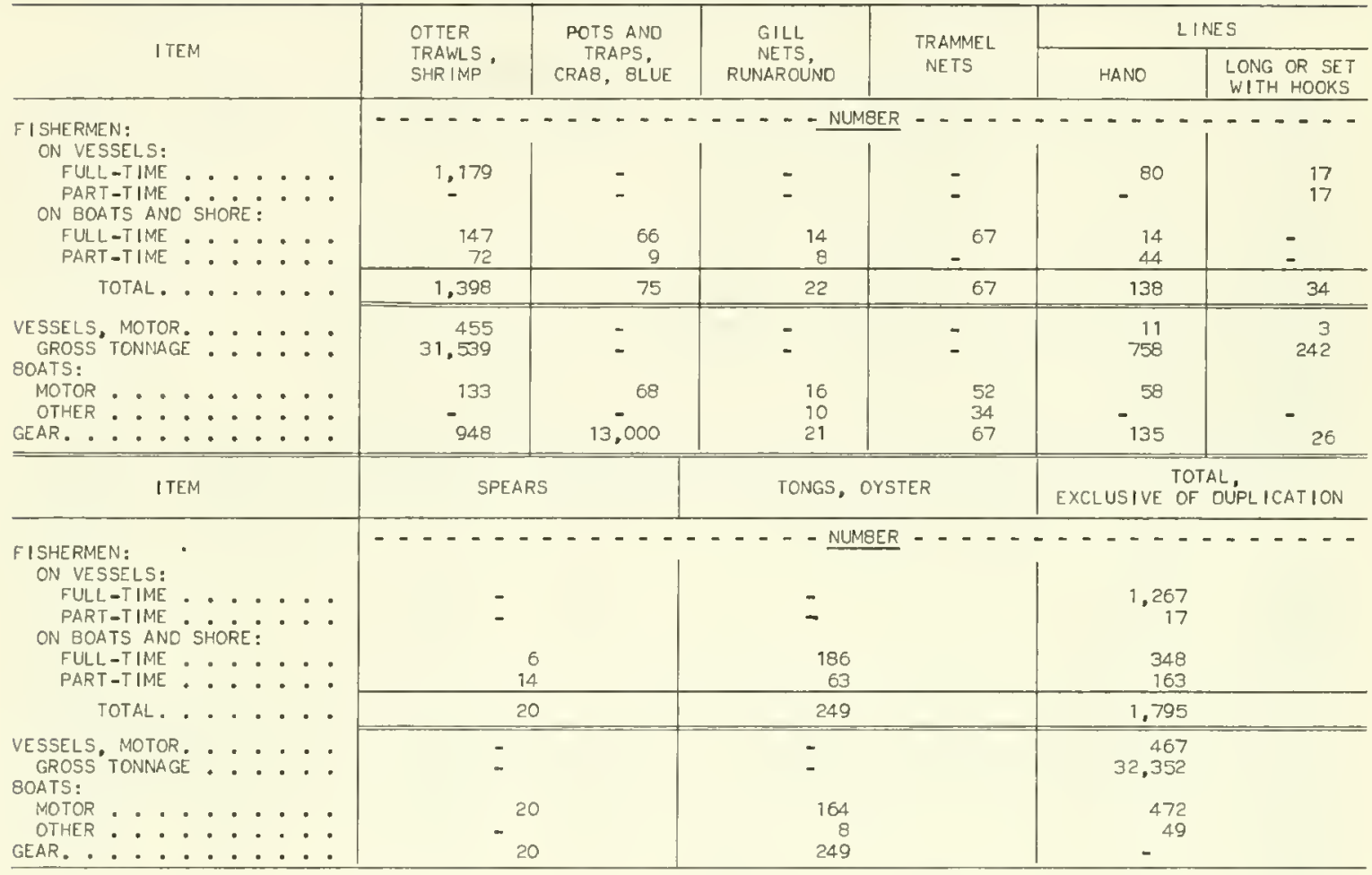

\section{ALABAMA - LANDINGS OF CATCH BY GEAR, 1975}

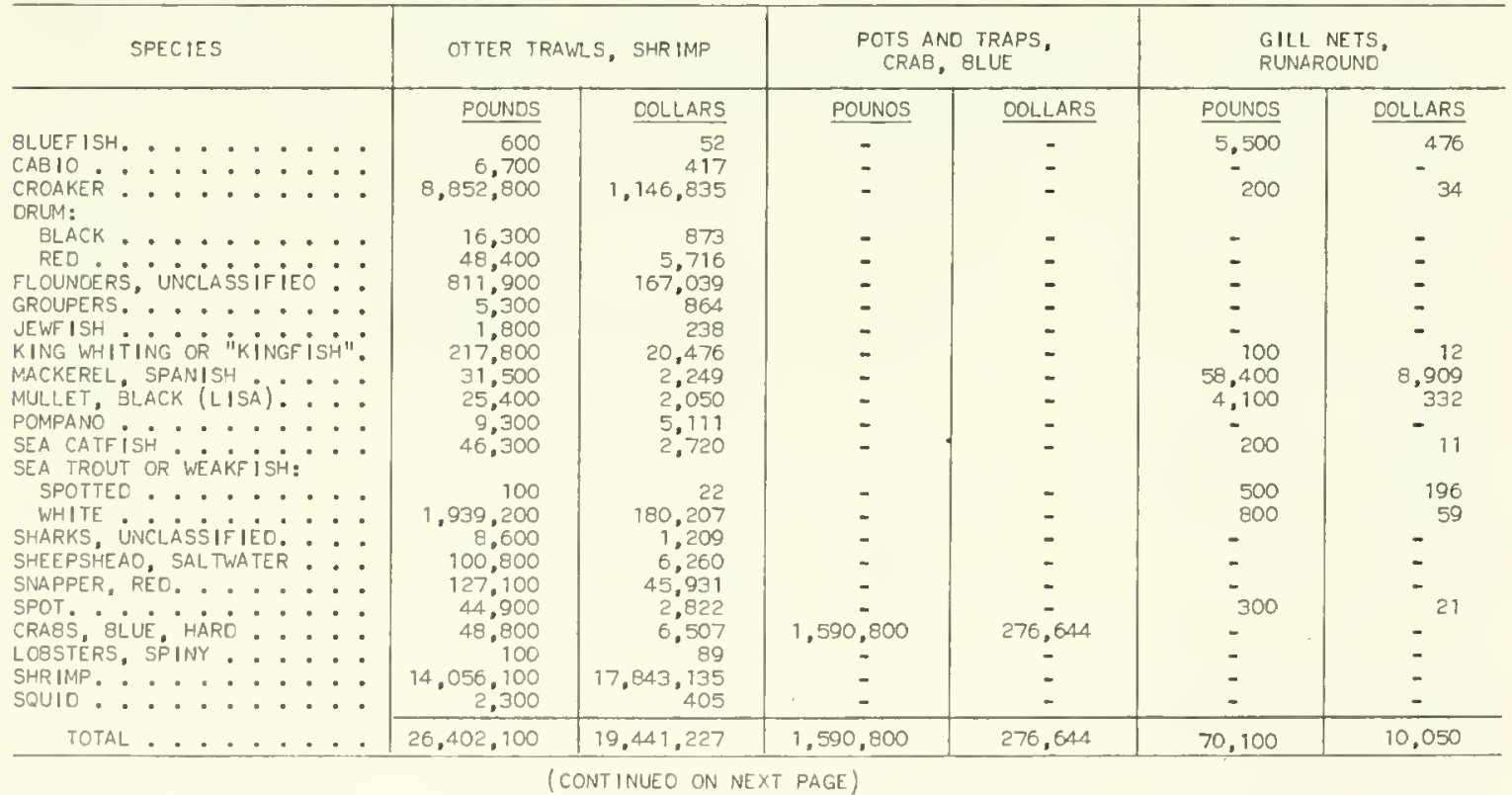


ALABAMA - LANDINGS OF CATCH BY GEAR, 1975 - Continued

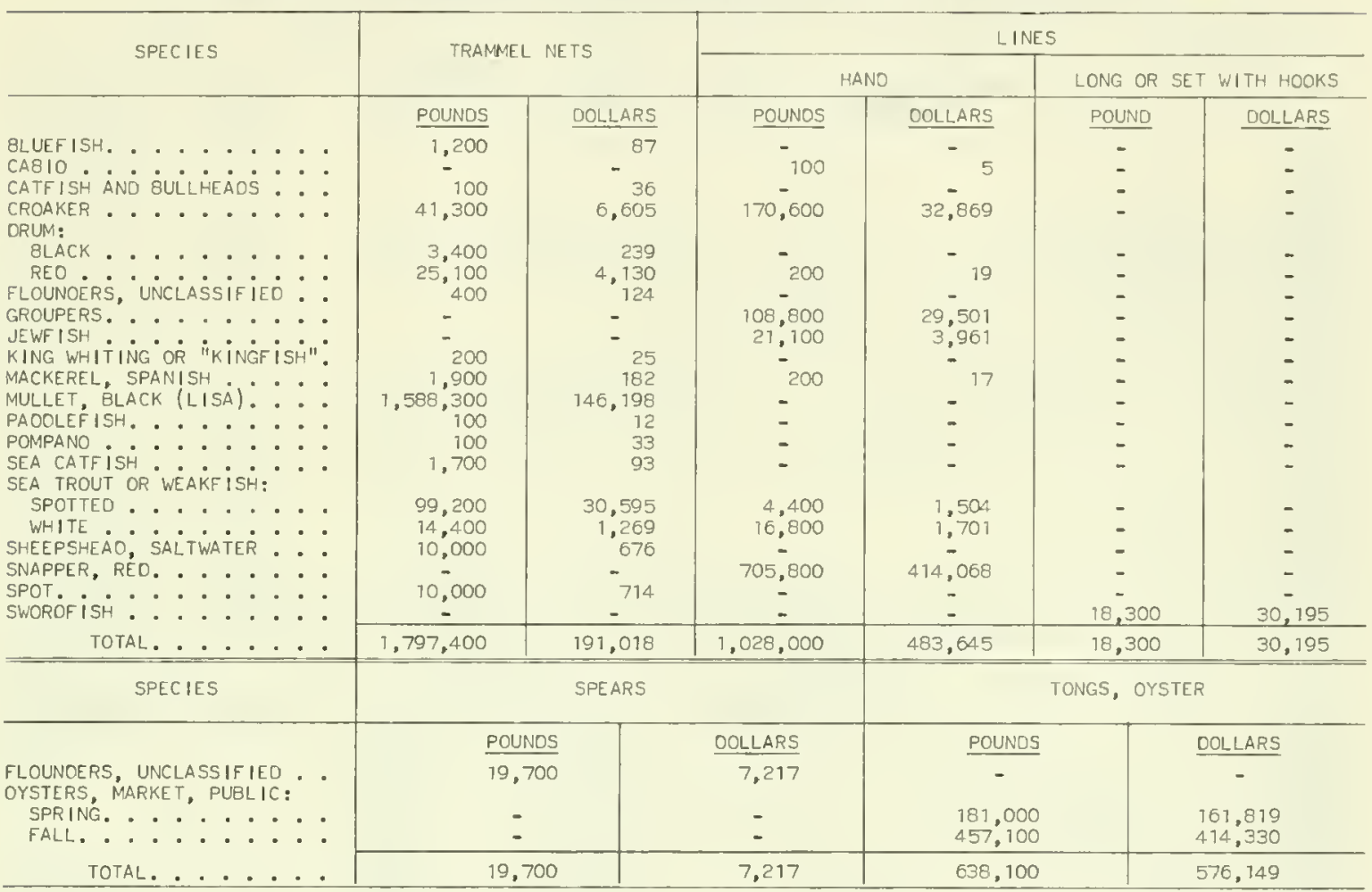

\section{MISSISSIPPI \\ OPERATING UNITS BY GEAR, 1975}

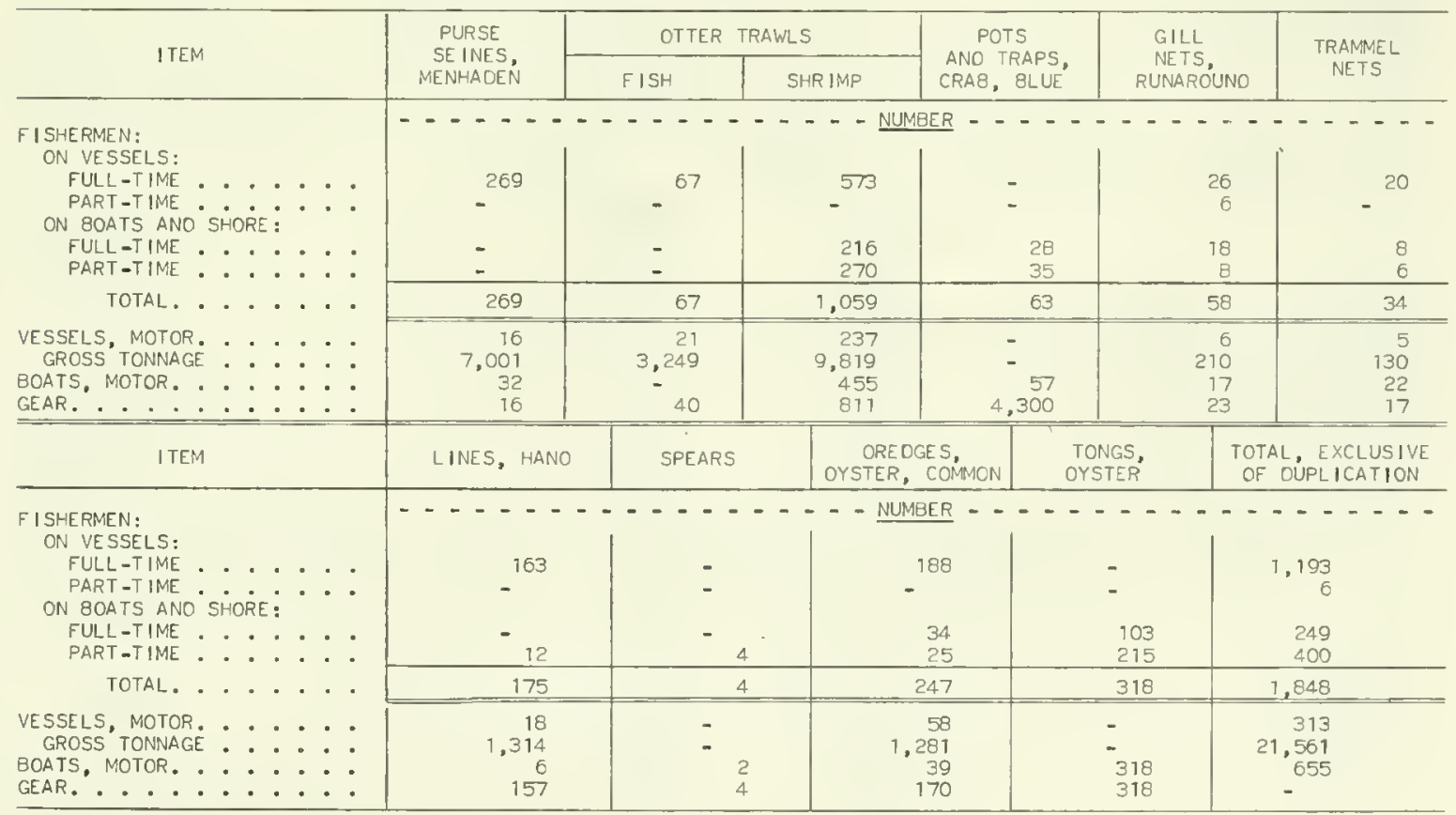


MISSISSIPPI - LANDINGS OF CATCH BY GEAR, 1975

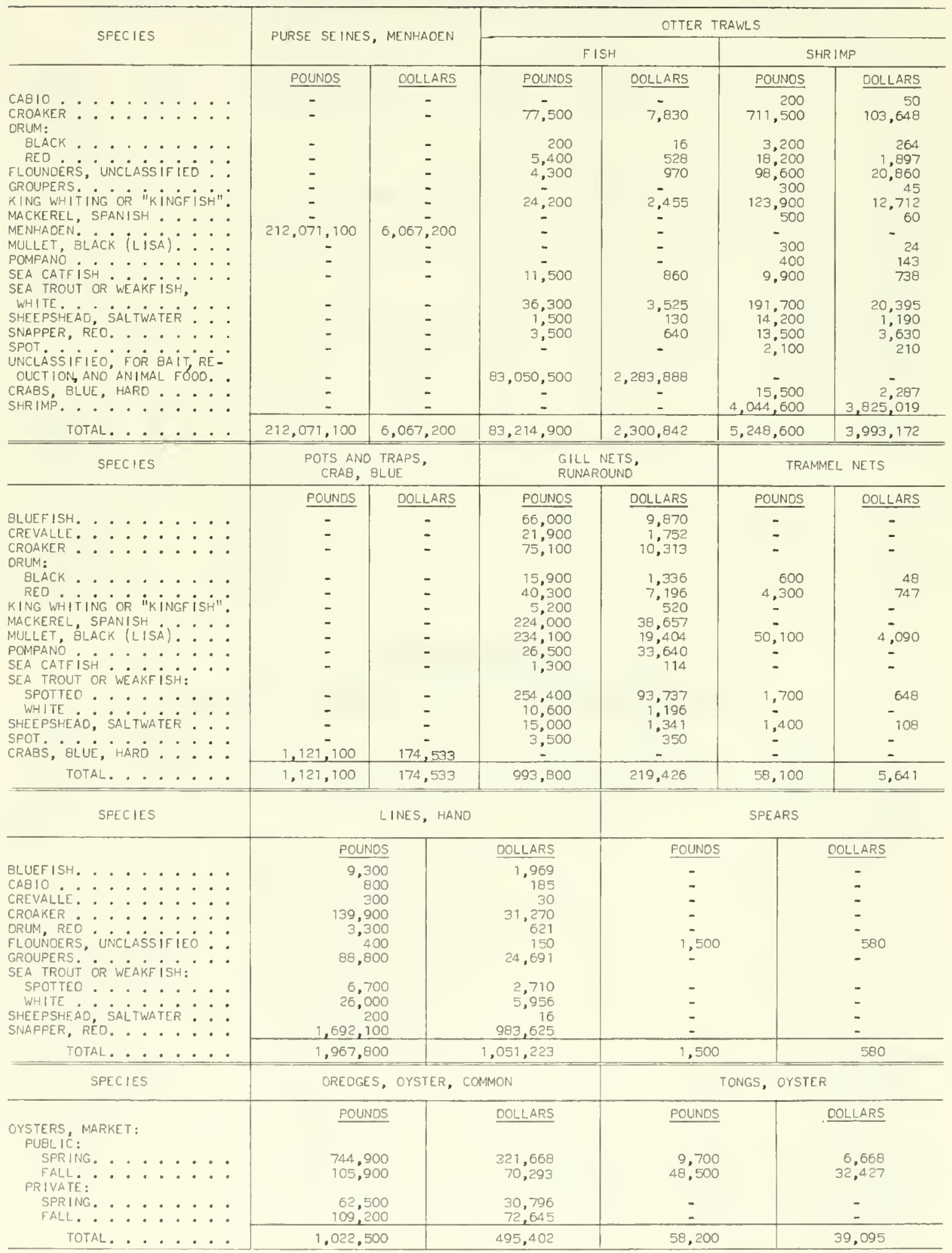




\section{GULF FISHERIES}

LOUISIANA

OPERATING UNITS BY GEAR, 1975

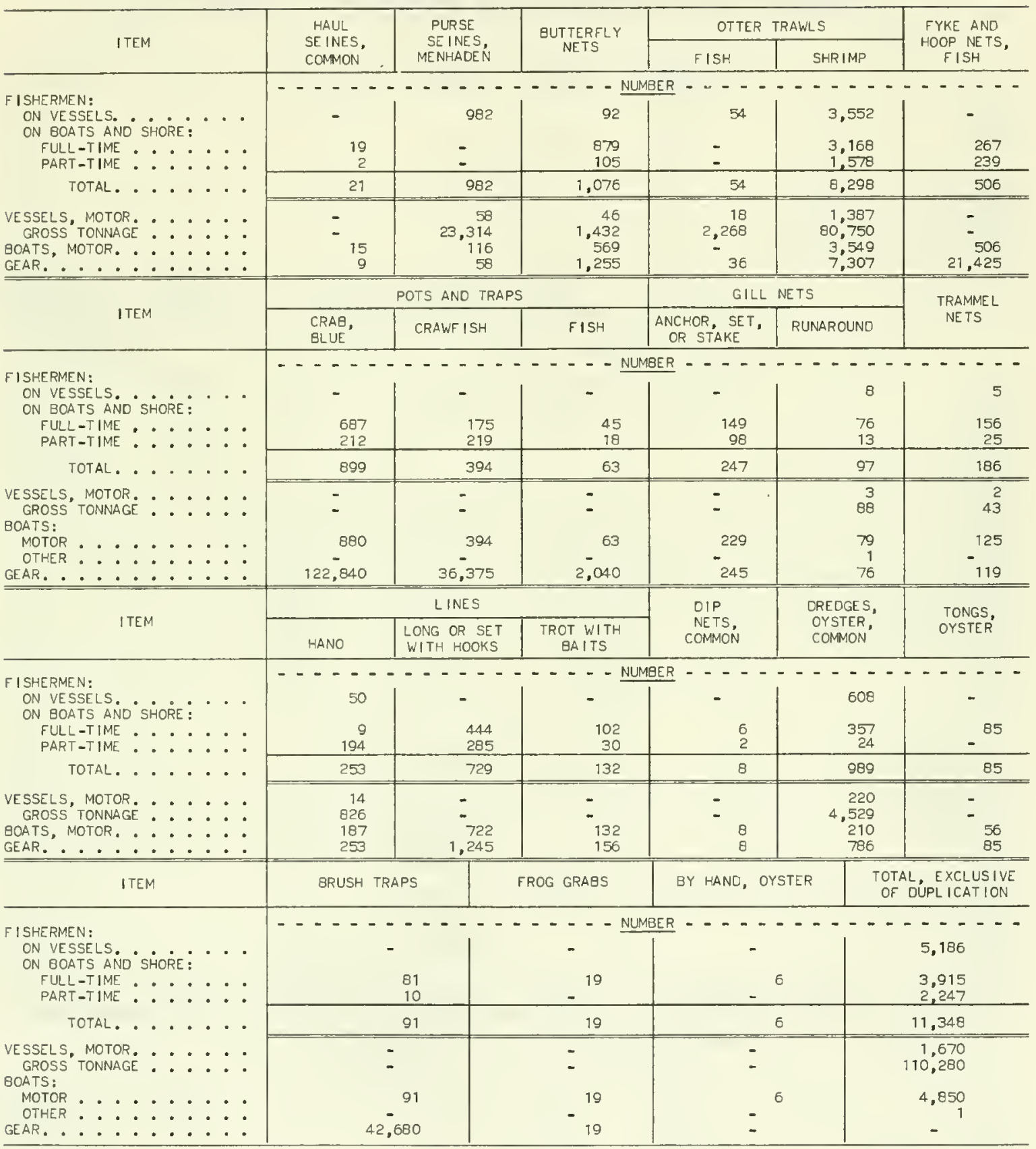


LOUISIANA - LANDINGS OF CATCH BY GEAR, 1975

\begin{tabular}{|c|c|c|c|c|c|c|}
\hline SPECIES & \multicolumn{2}{|c|}{ HAUL SEINES, COMMON } & \multicolumn{2}{|c|}{ PURSE SEINES, MENHAOEN } & \multicolumn{2}{|c|}{ BUTTERFLY NETS } \\
\hline 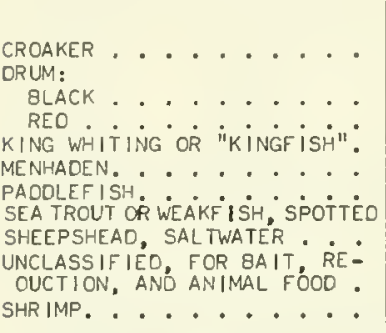 & $\begin{array}{r}\frac{\text { POUNOS }}{200} \\
2,700 \\
36,200 \\
300 \\
- \\
100 \\
28,500 \\
500 \\
102,800 \\
\end{array}$ & $\begin{array}{r}\text { DOLLARS } \\
22 \\
384 \\
10,000 \\
-\quad 50 \\
8,254 \\
58 \\
3,035 \\
-\quad \\
\end{array}$ & $\begin{array}{c}\text { POUNOS } \\
- \\
- \\
984,105,500 \\
- \\
- \\
9,504,700 \\
-\end{array}$ & $\begin{array}{c}\frac{\text { OOLLARS }}{-} \\
- \\
- \\
29.379,379 \\
- \\
- \\
290,758 \\
-\end{array}$ & $\begin{array}{c}\text { POUNOS } \\
- \\
\overline{-} \\
\overline{-} \\
- \\
- \\
- \\
- \\
\end{array}$ & $\begin{array}{c}\text { DOLLARS } \\
- \\
- \\
- \\
= \\
- \\
- \\
901,563\end{array}$ \\
\hline 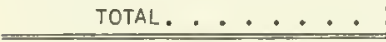 & 171,300 & 21,816 & $993.610,200$ & $29,670,077$ & $2,019,400$ & 901,563 \\
\hline SPECIES & \multicolumn{4}{|c|}{ OTTER TRAWLS } & \multicolumn{2}{|c|}{$\begin{array}{l}\text { FYKE ANO HOOP } \\
\text { NETS, FISH }\end{array}$} \\
\hline 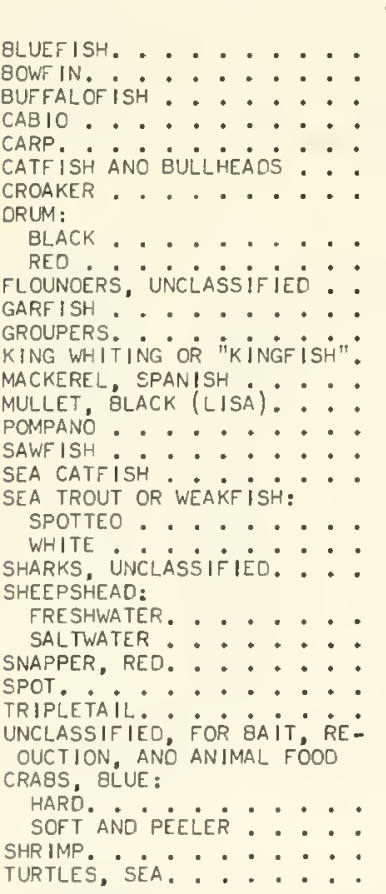 & $\begin{array}{c}\text { POUNDS } \\
- \\
- \\
- \\
- \\
- \\
- \\
- \\
- \\
- \\
- \\
- \\
- \\
- \\
- \\
- \\
- \\
- \\
- \\
- \\
- \\
- \\
- \\
- \\
1975,300 \\
- \\
- \\
- \\
-\end{array}$ & 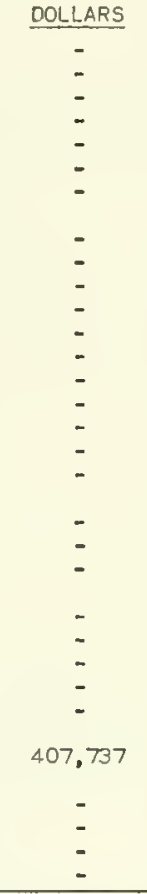 & $\begin{array}{c}\text { POUNOS } \\
10,100 \\
- \\
-600 \\
- \\
- \\
455,800 \\
3,500 \\
10,200 \\
237,900 \\
- \\
5,300 \\
143,600 \\
94,000 \\
8,000 \\
17,300 \\
100 \\
20,800 \\
300 \\
109,900 \\
15,700 \\
- \\
36,500 \\
113,200 \\
18,200 \\
1,700 \\
31,000 \\
266,200 \\
2,200 \\
51,114,200 \\
100 \\
\end{array}$ & $\begin{array}{c}\text { DOLLARS } \\
1,212 \\
- \\
- \\
- \\
56,148 \\
495 \\
2,953 \\
61,012 \\
- \\
14,348 \\
14,968 \\
657 \\
18,525 \\
10 \\
2.111 \\
19,079 \\
1,337 \\
- \\
3,823 \\
58,710 \\
1,407 \\
104 \\
1,240 \\
37.771 \\
703 \\
066,192 \\
27 \\
\end{array}$ & $\begin{array}{c}\text { POUNDS } \\
= \\
8,000 \\
452,500 \\
24,600 \\
2,964,600 \\
= \\
= \\
= \\
12,100 \\
= \\
= \\
= \\
- \\
- \\
= \\
114,200 \\
= \\
= \\
- \\
- \\
-\end{array}$ & 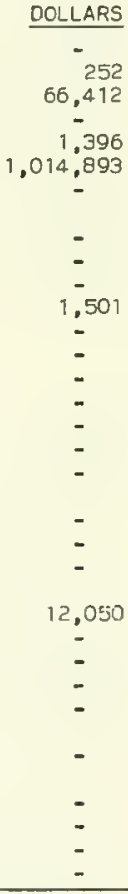 \\
\hline TOTAL. . . . . . . & $19,875,300$ & 407.737 & $52,715,800$ & $40,363,766$ & $3,576,000$ & $1,096,504$ \\
\hline \multirow{2}{*}{ SPECIES } & \multicolumn{6}{|c|}{ POTS ANO TRAPS } \\
\hline & \multicolumn{2}{|c|}{ CRAB, BLUE } & \multicolumn{2}{|c|}{ CRAWF ISH } & \multicolumn{2}{|c|}{$\mathrm{FISH}$} \\
\hline $\begin{array}{l}\text { CATF ISH ANO BULLHEADS } \cdot \cdots \\
\text { CRABS, BLUE: } \\
\text { HARO. } \\
\text { SOFT ANO PEEELER }: \vdots: \\
\text { CRAWF ISH, FRESHWATER: }:\end{array}$ & $\begin{array}{r}\text { POUNOS } \\
1,200 \\
15,788,400 \\
28,400 \\
-\end{array}$ & $\begin{array}{r}\frac{\text { DOLLARS }}{420} \\
2,332,017 \\
39,858 \\
-\end{array}$ & $\begin{array}{c}\text { POUNOS } \\
- \\
= \\
4,636,800\end{array}$ & $\begin{array}{c}\text { DOLLARS } \\
- \\
- \\
1,545,327\end{array}$ & $\begin{array}{c}\text { POUNDS } \\
\begin{array}{c}194,800 \\
- \\
-\end{array}\end{array}$ & $\begin{array}{c}\text { DOLLARS } \\
67,855 \\
- \\
-\end{array}$ \\
\hline TOTAL. . . . . . . . & $15,818,000$ & $2,372,295$ & $4,636,800$ & $1,545,327$ & 194.800 & 67,855 \\
\hline
\end{tabular}

(CONTINUEO ON NEXT PAGE) 


\section{LOUISIANA - LANDINGS OF CATCH BY GEAR, 1975 - Continued}

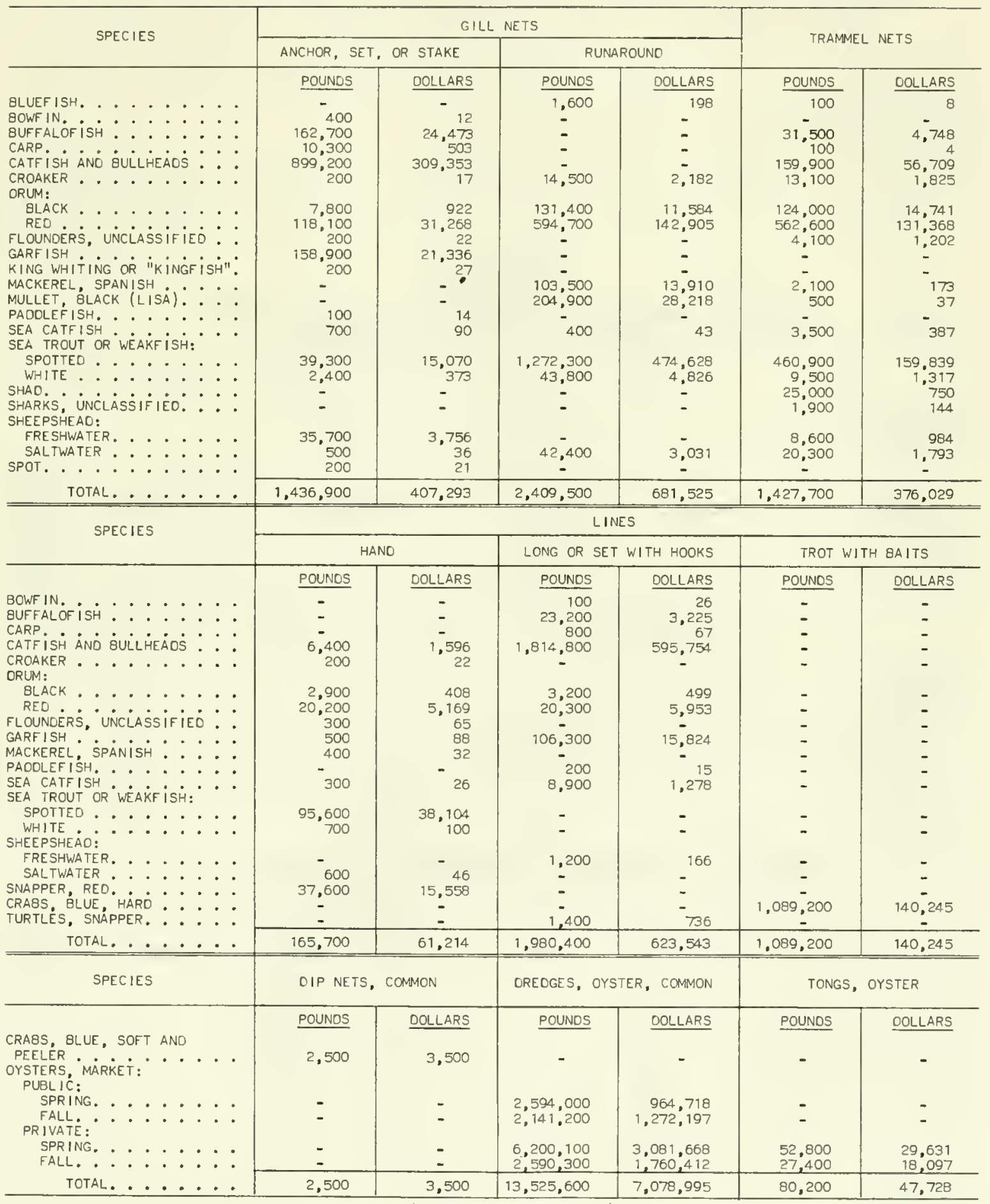

(CONTINUED ON NEXT PAGE) 


\section{LOUISIANA - LANDINGS OF CATCH BY GEAR, 1975 - Continued}

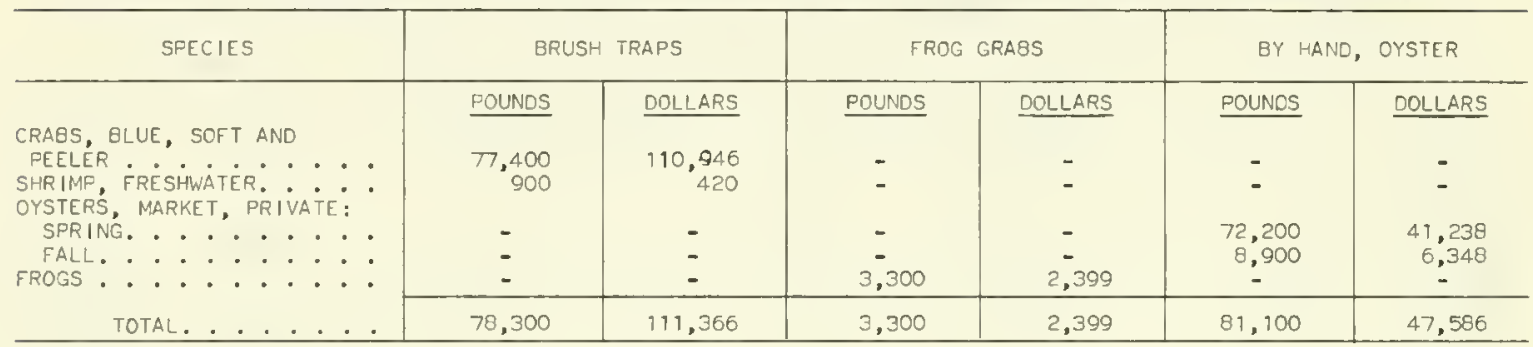

\section{TEXAS}

TEXAS - OPERATING UNITS BY GEAR, 1975

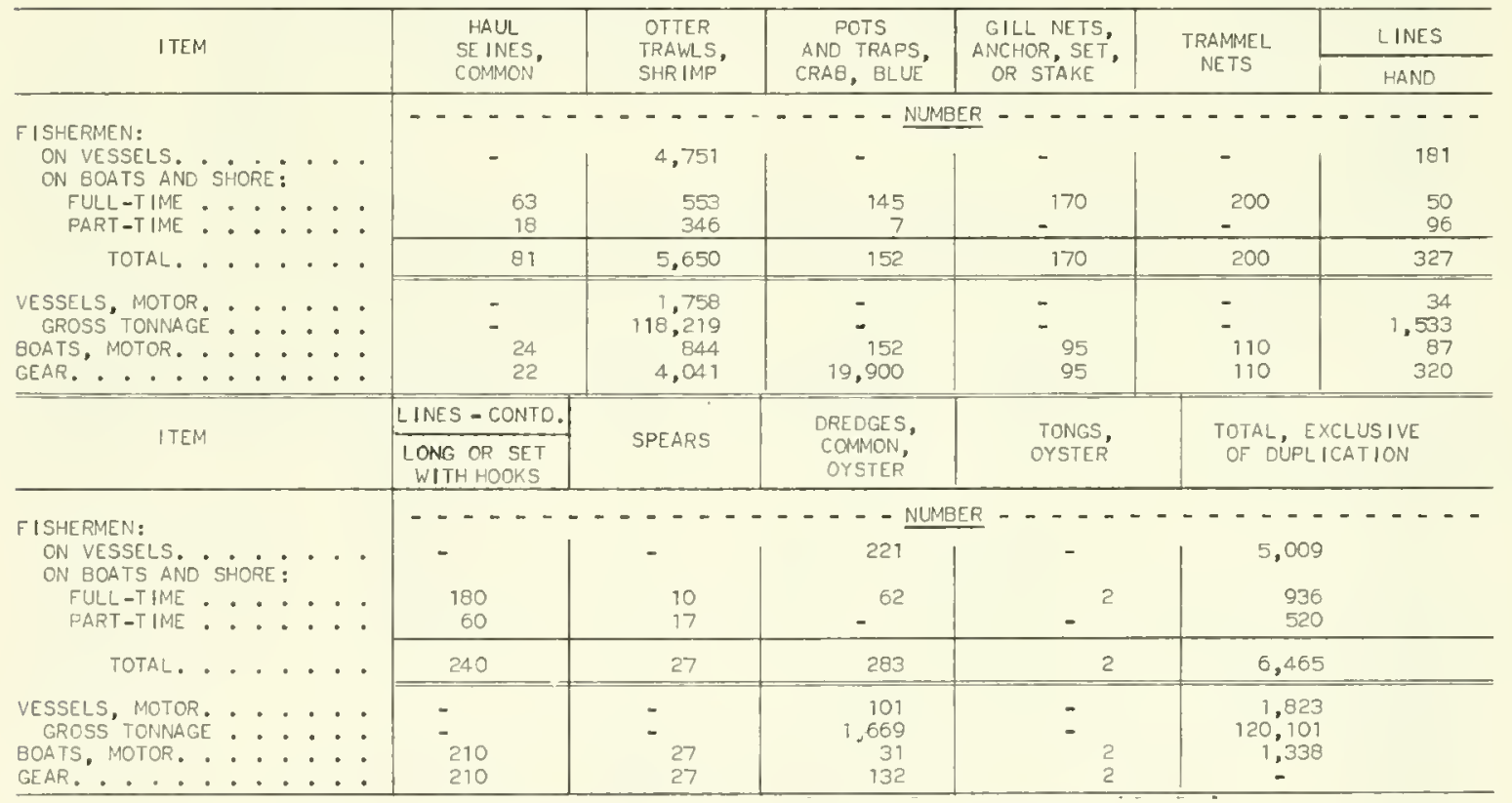

TEXAS - LANDINGS OF CATCH BY GEAR, 1975

\begin{tabular}{|c|c|c|c|c|c|c|}
\hline \multirow[t]{2}{*}{ SPECIES } & \multicolumn{2}{|c|}{ HAUL SEINES, COMMON } & \multicolumn{2}{|c|}{ DTTER TRAWLS, SHRIMP } & \multicolumn{2}{|c|}{ POTS ANO TRAPS, CRAB, BLUE } \\
\hline & $\frac{\text { POUNDS }}{3,300}$ & $\frac{\text { DOLLARS }}{276}$ & $\frac{\text { PDUNOS }}{91.000}$ & $\frac{\text { OOLLARS }}{9.321}$ & $\frac{\text { POUNOS }}{-}$ & $\frac{\text { DOLLARS }}{-}$ \\
\hline \multirow{10}{*}{ 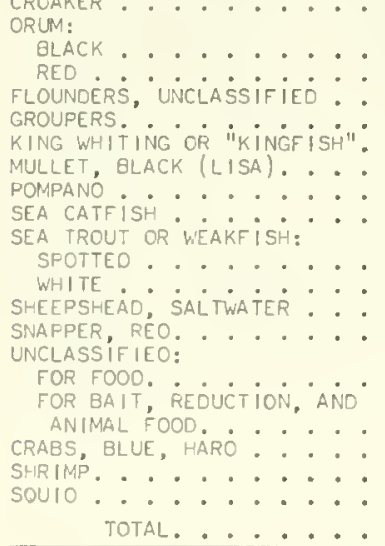 } & & & & & & \\
\hline & $\begin{array}{r}45,700 \\
70,400 \\
3,600\end{array}$ & $\begin{array}{r}4,077 \\
26,420 \\
900\end{array}$ & $\begin{array}{r}47,100 \\
29,900 \\
429,700\end{array}$ & $\begin{array}{r}8,580 \\
10,380 \\
152,324\end{array}$ & $=$ & $\bar{z}$ \\
\hline & $\begin{array}{c}- \\
31,500\end{array}$ & $-\overline{3,609}$ & $\begin{array}{r}5,600 \\
138,200\end{array}$ & $\begin{array}{r}819 \\
14.035\end{array}$ & $\overline{-}$ & $\overline{-}$ \\
\hline & $\begin{array}{l}6,400 \\
1,600 \\
5,600\end{array}$ & & $\begin{array}{l}39,000 \\
79,700\end{array}$ & $\begin{array}{c}3,794 \\
10,149\end{array}$ & $\overline{-}$ & $\overline{-}$ \\
\hline & 246,800 & 100,700 & 8.200 & 3,131 & - & - \\
\hline & $\begin{array}{l}4,400 \\
4,400 \\
-\end{array}$ & $\begin{array}{r}1,689 \\
-537 \\
-\quad\end{array}$ & $\begin{array}{r}600 \\
254,900 \\
42,700\end{array}$ & $\begin{array}{r}236 \\
22,036 \\
26,539\end{array}$ & $\overline{-}$ & E \\
\hline & 22.500 & 2,698 & 284,400 & 29,483 & - & - \\
\hline & 54,700 & 3,576 & $\begin{array}{l}179,600 \\
304.500\end{array}$ & $\begin{array}{r}11.373 \\
33.988\end{array}$ & $5,687.000$ & 913,706 \\
\hline & $=$ & $=$ & $\begin{array}{r}70,598,400 \\
6,500\end{array}$ & $\begin{array}{r}87,902,299 \\
1,423 \\
\end{array}$ & - & - \\
\hline & 500,900 & 146,558 & $72,540,000$ & $88,239,910$ & $5,687,000$ & 913,706 \\
\hline
\end{tabular}




\section{TEXAS - LANDINGS OF CATCH BY GEAR, 1975 - Continued}

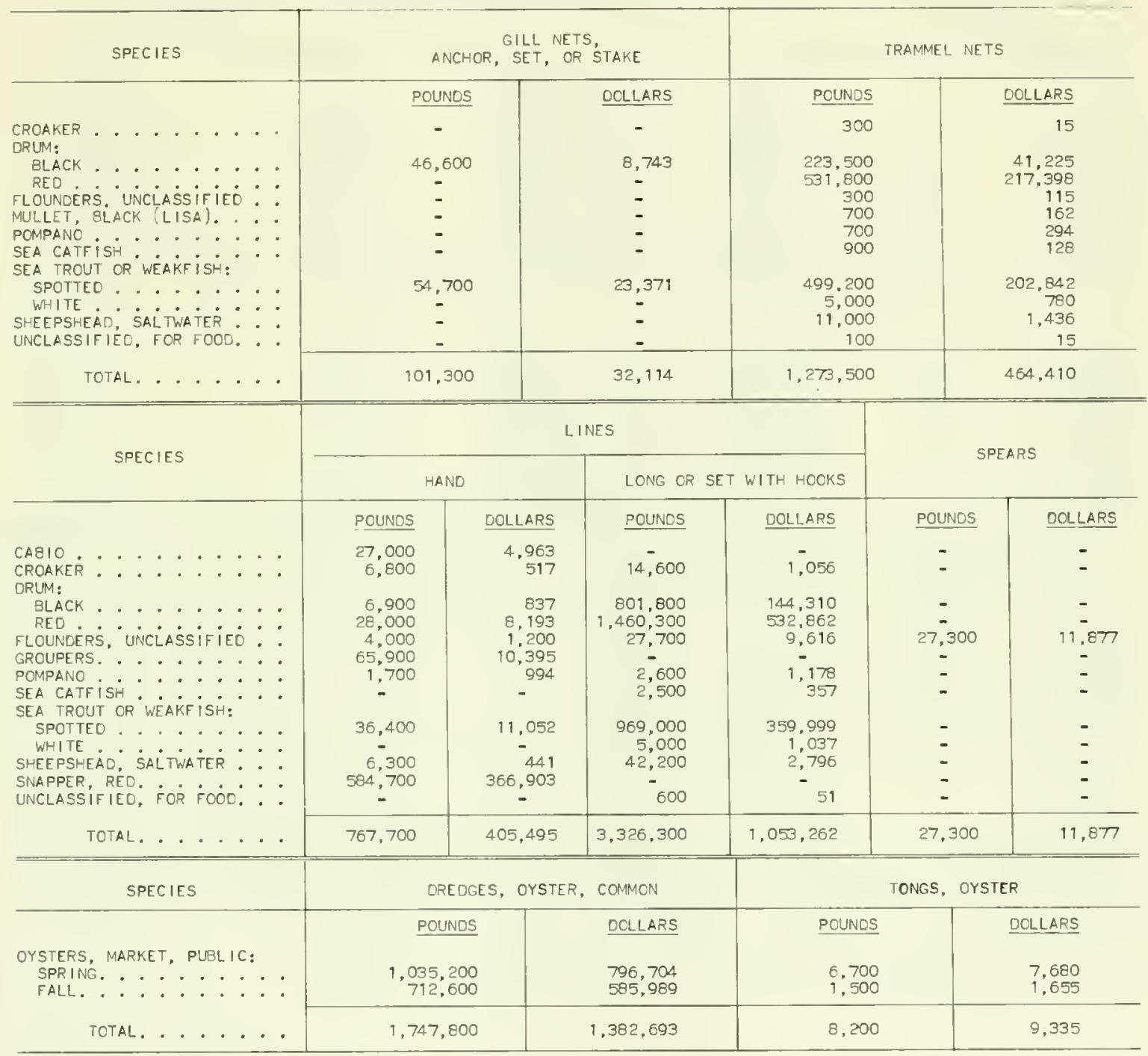




\section{GULF SHRIMP FISHERY \\ SUMMARY OF GULF SHRIMP LANDINGS, 1975}

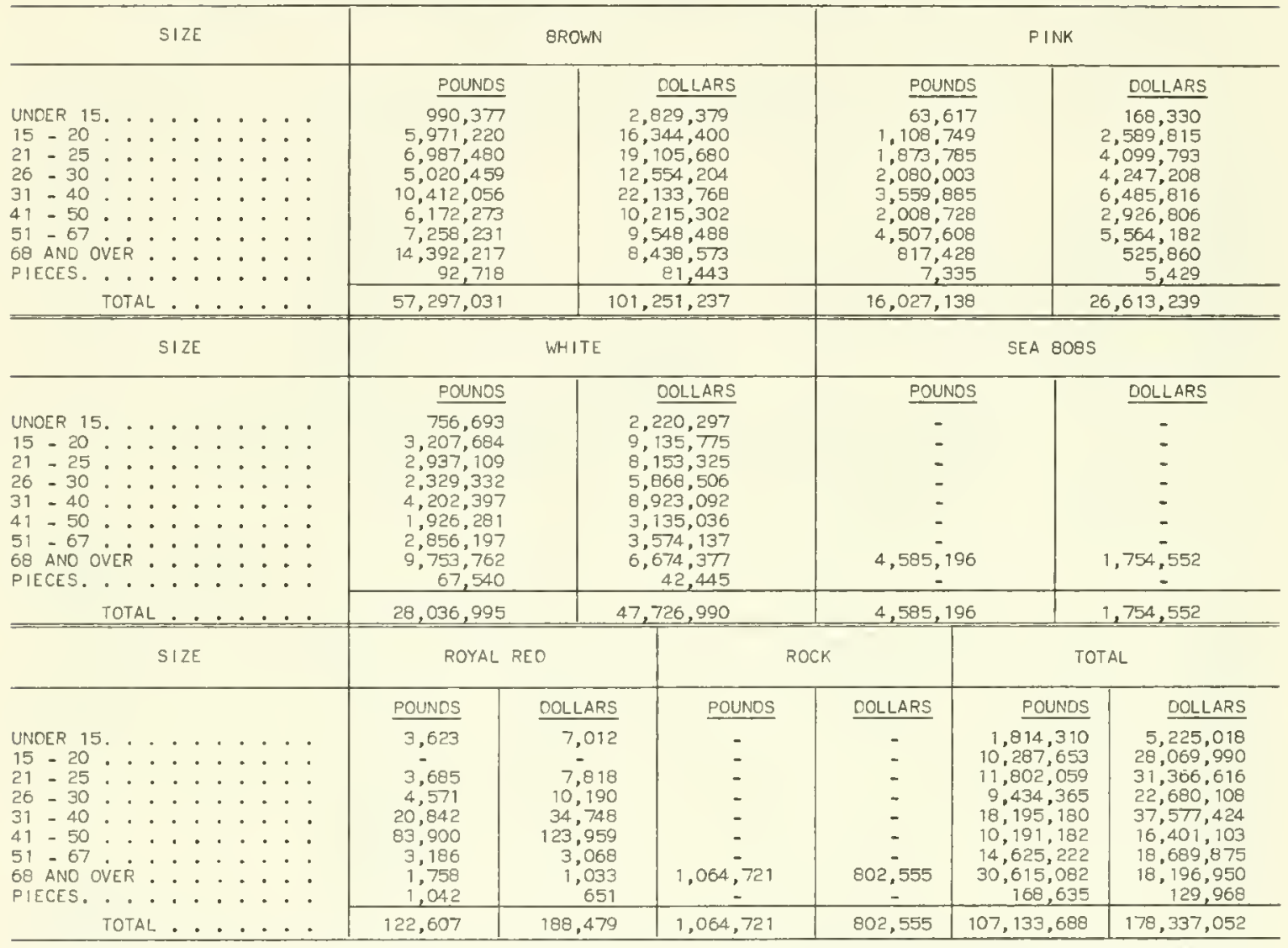

NOTE: - -ALL WEIGHTS ARE ON A HEADS_OFF 8ASIS. LANOINGS FIGURES REPRESENT THE HEAOS-OFF WE IGHT ANO, THEREFORE, ARE NOT DIRECTLY COMPARABLE WITH THE HEAOS-ON (LIVE WEIGHT) OUANTITIES PUBLISHEO IN THE GENERAL REVIEW ANO REGIONAL TABLES. POUNDS OF HEAOS-OFF SHRIMP MAY EE CONVERTEO TO HEADS -ON (ROUNO) WEIGHT BY MULTIPLYING BROWN SHRIMP WEIGHT BY 1.61; PINK, BY 1.60; WHITE, 8Y 1.54; SEA 8OBS, BY 1.53; ROYAL RED, BY 1.80; AND ROCK SHRIMP, BY 1.67. 
GULF SHRIMP LANDINGS BY SPECIES AND SIZE, 1975

\begin{tabular}{|c|c|c|c|c|c|c|c|c|c|c|c|}
\hline SPECIES & AND & \multicolumn{4}{|c|}{ SIZE } & \multicolumn{2}{|c|}{ FLORIOA, WEST COAST } & \multicolumn{2}{|c|}{ ALABAMA } & \multicolumn{2}{|c|}{ MISSISSIPPI } \\
\hline 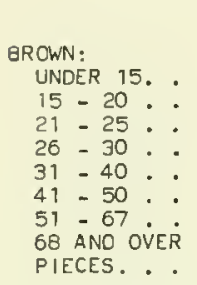 & 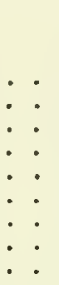 & 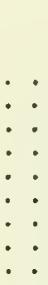 & $\begin{array}{l}\dot{:} \\
\dot{:} \\
\dot{ } \\
\dot{ }\end{array}$ & $\begin{array}{l}\dot{:} \\
\dot{:} \\
\dot{:} \\
\dot{:}\end{array}$ & $\begin{array}{l}: \\
: \\
: \\
: \\
:\end{array}$ & $\begin{array}{r}\text { POUNDS } \\
9,540 \\
65,233 \\
111.791 \\
47,376 \\
113,907 \\
87,487 \\
253,505 \\
80,762 \\
-\end{array}$ & $\begin{array}{c}\text { DOLLARS } \\
27,676 \\
176,803 \\
274,301 \\
118,623 \\
240,913 \\
142,958 \\
301,945 \\
69,952 \\
-\end{array}$ & $\begin{array}{r}\text { POUNDS } \\
149,438 \\
843,446 \\
745,366 \\
657,513 \\
1,465,770 \\
695,890 \\
1,298,314 \\
982,560 \\
9,562 \\
\end{array}$ & $\begin{array}{r}\text { OOLLARS } \\
399,938 \\
2,228,392 \\
2,031,402 \\
1,682,509 \\
3,392,902 \\
1,210,370 \\
1,672,573 \\
839,783 \\
7,626 \\
\end{array}$ & $\begin{array}{r}\text { POUNOS } \\
712 \\
52,135 \\
61,128 \\
89,487 \\
307,025 \\
320,368 \\
637,835 \\
503,467 \\
68 \\
\end{array}$ & $\begin{array}{r}\text { DOLLARS } \\
2,109 \\
120,795 \\
168,872 \\
220,948 \\
650,150 \\
538,714 \\
727,940 \\
374,015 \\
54 \\
\end{array}$ \\
\hline TOTAL & - . & - $\cdot$ & - & $\cdot$ & - & 769,601 & $1,353,171$ & $6,847,967$ & $13,465,495$ & $1,972,225$ & $2,803,597$ \\
\hline $\begin{array}{l}\text { PINK: } \\
\text { UNOER } 15: \\
15-20: \dot{ } \\
21-25: \\
26-30: \\
31-40: \\
41-50: \\
51-67: \\
68 \text { AND DVER } \\
\text { PIECES. }\end{array}$ & 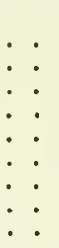 & 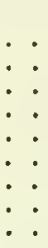 & $\begin{array}{l}\dot{ } \\
\dot{.} \\
\dot{.} \\
\dot{.}\end{array}$ & $\begin{array}{l}\dot{:} \\
\dot{:} \\
\dot{:} \\
\dot{.}\end{array}$ & : & $\begin{array}{r}45,193 \\
936,726 \\
1,679,001 \\
1,897,690 \\
3,263,539 \\
1,892,888 \\
4,343,310 \\
719,091 \\
1,995 \\
\end{array}$ & $\begin{array}{r}119,240 \\
2,172,022 \\
3,673,528 \\
3,861,614 \\
5,921,639 \\
2,743,044 \\
5,376,653 \\
456,337 \\
778 \\
\end{array}$ & $\begin{array}{r}4,432 \\
22,294 \\
37,416 \\
37,774 \\
82,542 \\
52,877 \\
109,634 \\
96,532 \\
255 \\
\end{array}$ & $\begin{array}{r}11,256 \\
56,983 \\
91,361 \\
84,786 \\
161,606 \\
82,227 \\
110,094 \\
67,696 \\
205 \\
\end{array}$ & $\begin{array}{r}- \\
3,334 \\
4,677 \\
5,915 \\
25,895 \\
8,856 \\
18,283 \\
400 \\
-\end{array}$ & $\begin{array}{r}8,701 \\
12,367 \\
13,200 \\
49,601 \\
14,407 \\
23,162 \\
480 \\
-\end{array}$ \\
\hline TOTAL & - . & - $\cdot$ & - & - & - & $14,779,433$ & $24,324,855$ & 443,756 & 666,214 & 67,360 & 121,998 \\
\hline 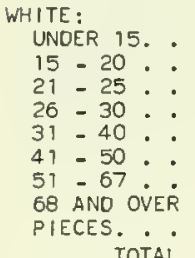 & 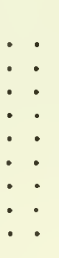 & 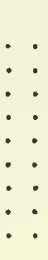 & $\begin{array}{l}\dot{:} \\
\dot{:} \\
\dot{.}\end{array}$ & : & $\begin{array}{l}\dot{5} \\
\dot{5} \\
\dot{5} \\
\dot{ }\end{array}$ & $\begin{array}{r}3,934 \\
28,750 \\
71,557 \\
29,145 \\
93,393 \\
68,956 \\
286,100 \\
273,864 \\
\end{array}$ & $\begin{array}{r}11,228 \\
76,261 \\
190,798 \\
71,238 \\
185,586 \\
111,287 \\
340,177 \\
201,676 \\
-\end{array}$ & $\begin{array}{r}70,220 \\
440,707 \\
317,861 \\
195,446 \\
211,934 \\
97,788 \\
103,804 \\
32,640 \\
1,859 \\
\end{array}$ & $\begin{array}{r}196,301 \\
1,255,977 \\
886,393 \\
491,542 \\
490,736 \\
166,565 \\
148,513 \\
31,666 \\
1,608 \\
\end{array}$ & $\begin{array}{r}- \\
80,755 \\
38,073 \\
70,632 \\
54,282 \\
43,566 \\
51,930 \\
105,766 \\
550 \\
\end{array}$ & $\begin{array}{r}217,736 \\
106,295 \\
176,937 \\
118,497 \\
81,994 \\
77,170 \\
100,392 \\
204\end{array}$ \\
\hline TOTAL & $\cdot \cdot$ & - & - & & & 855,699 & $1,186,251$ & $1,472,259$ & $3,669,301$ & 444,956 & 879,225 \\
\hline SEA BOBS. . . & - $\cdot$ & - $\cdot$ & - & - & - & 120,739 & 36,416 & - & - & 49,790 & 20,199 \\
\hline $\begin{array}{l}\text { RDYAL REO: } \\
15-20: \cdot \\
21-25: \cdot \\
26-30: \cdot \\
31-40: \cdot \\
41-50: \dot{ } \\
51-67: \\
68 \text { ANO OVER } \\
\text { PIECES. } .\end{array}$ & 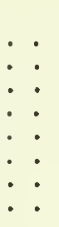 & 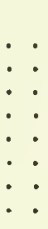 & $\begin{array}{l}\dot{:} \\
\dot{.} \\
\dot{.}\end{array}$ & $\begin{array}{l}\dot{ } \\
\dot{:} \\
\dot{ } \\
\dot{ }\end{array}$ & & $\begin{array}{c}- \\
- \\
15,256 \\
79,849 \\
346 \\
- \\
-\end{array}$ & $\begin{array}{c}- \\
- \\
- \\
26,239 \\
119,393 \\
103 \\
- \\
- \\
\end{array}$ & $\begin{array}{l}3,623 \\
3,190 \\
4,531 \\
5,121 \\
3,551 \\
2,565 \\
1,683 \\
902 \\
\end{array}$ & $\begin{array}{r}7,012 \\
6,432 \\
10,090 \\
7,526 \\
3,816 \\
2,541 \\
992 \\
581 \\
\end{array}$ & $\begin{array}{l}- \\
- \\
- \\
- \\
- \\
-\end{array}$ & $\begin{array}{l}- \\
- \\
- \\
- \\
- \\
-\end{array}$ \\
\hline TOTAL & . . & - . & - & - & . & 95,451 & 145,815 & 25,166 & 38,990 & - & - \\
\hline ROCK. . . . . & - $\cdot$ & - & - & - & - & $1,011,529$ & 750,214 & 5,056 & 3,135 & - & - \\
\hline GRANO & TOTA & $L$ & . & • & - & $17,632,452$ & $27,798,722$ & $8,794,204$ & $17,843,135$ & $2,534,331$ & $3,825,019$ \\
\hline SPECIES & ANO & $\mathrm{Siz}$ & & & & LOUI & ANA & & & & \\
\hline 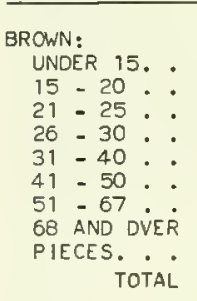 & 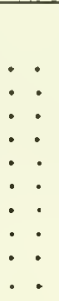 & 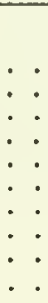 & $\begin{array}{l}\dot{:} \\
\dot{\dot{ }} \\
\dot{\dot{ }} \\
\dot{.}\end{array}$ & $\begin{array}{l}\dot{:} \\
\dot{:} \\
\dot{:} \\
\dot{:} \\
\dot{.}\end{array}$ & $\begin{array}{l}\dot{.} \\
\dot{.} \\
\dot{.} \\
\dot{.} \\
\dot{.}\end{array}$ & $\begin{array}{r}\text { POUNDS } \\
344,604 \\
488,116 \\
568,129 \\
408,995 \\
802,632 \\
545,347 \\
498,999 \\
10,385,402 \\
34,955 \\
14,077,179 \\
\end{array}$ & $\begin{array}{r}\text { DOLLARS } \\
955,101 \\
1,356,360 \\
1,496,782 \\
998,580 \\
1,695,234 \\
856,022 \\
608,576 \\
5,438,449 \\
23,557 \\
13,429,661 \\
\end{array}$ & $\begin{array}{r}\text { POUNOS } \\
486,083 \\
4,522,290 \\
5,501,066 \\
3,817,088 \\
7,722,714 \\
4,523,181 \\
4,569,578 \\
2,440,026 \\
48,033 \\
33,630,059\end{array}$ & $\begin{array}{r}\text { OOLLARS } \\
1,444,555 \\
12,462,050 \\
15,134,323 \\
9,533,544 \\
16,154,569 \\
7,467,238 \\
6,237,454 \\
1,716,374 \\
50,206 \\
70,200,313\end{array}$ & $\begin{array}{r}\text { POUNDS } \\
990,377 \\
5,971,220 \\
6,987,480 \\
5,020,459 \\
10,412,056 \\
6,172,273 \\
7,258,231 \\
14,392,217 \\
92,718 \\
57,297,031 \\
\end{array}$ & $\begin{array}{r}\text { DOLLARS } \\
2,829,379 \\
16,344,400 \\
19,105,680 \\
12,554,204 \\
22,133,768 \\
10,215,302 \\
9,548,488 \\
8,438,573 \\
81,443 \\
101,251,237 \\
\end{array}$ \\
\hline $\begin{array}{l}\text { PINK: } \\
\text { UNDER 15. } \\
15-20: \cdot \\
21-25: \cdot \\
26=30: \dot{ } \\
31=40: \cdot \\
41-50: \cdot \\
51-67: \\
68 \text { AND DVER } \\
\text { PIECES. }\end{array}$ & 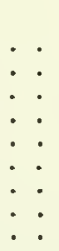 & 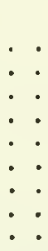 & $\begin{array}{l}\dot{:} \\
\dot{.} \\
\dot{:} \\
\dot{.}\end{array}$ & $\begin{array}{l}\dot{:} \\
\dot{.} \\
\dot{.} \\
\dot{.}\end{array}$ & & $\begin{array}{r}225 \\
8,855 \\
10,704 \\
15,665 \\
13,305 \\
5,095 \\
2,200 \\
805 \\
600 \\
\end{array}$ & $\begin{array}{r}577 \\
23,175 \\
24,413 \\
33,803 \\
21,697 \\
6,508 \\
2,450 \\
777 \\
577 \\
\end{array}$ & $\begin{array}{r}13,767 \\
137,540 \\
141,987 \\
122,959 \\
174,604 \\
49,012 \\
34,181 \\
600 \\
4,485 \\
\end{array}$ & $\begin{array}{r}37,257 \\
328,934 \\
298,124 \\
253,805 \\
331,273 \\
80,540 \\
51,823 \\
570 \\
3,869 \\
\end{array}$ & $\begin{array}{r}63,617 \\
1,108,749 \\
1,873,785 \\
2,080,003 \\
3,559,685 \\
2,008,728 \\
4,507,608 \\
817,428 \\
7,335 \\
\end{array}$ & $\begin{array}{r}168,330 \\
2,589,815 \\
4,099,793 \\
4,247,208 \\
6,485,816 \\
2,926,806 \\
5,564,182 \\
525,860 \\
5,429 \\
\end{array}$ \\
\hline TOTAL & - & - . & - & - & & 57,454 & 113,977 & 679,135 & $1,386,195$ & $16,027,138$ & $26,613,239$ \\
\hline
\end{tabular}

SEE NOTE AT END OF TAQLE.

(CONT INUED ON NEXT PAGE) 


\section{GULF SHRIMP LANDINGS BY SPECIES AND SIZE, 1975 - Continued}

\begin{tabular}{|c|c|c|c|c|c|c|c|c|c|c|}
\hline SPECIES A & ANO & \multicolumn{3}{|c|}{ SIZE } & \multicolumn{2}{|c|}{ LOUISIANA } & \multicolumn{2}{|c|}{ TEXAS } & \multicolumn{2}{|c|}{ TOTAL } \\
\hline $\begin{array}{l}\text { WHITE: } \\
\text { UNDER } 15:: \\
15=20:: \\
21=25: \\
26=30: \\
31=40: \\
41=50: \\
51=67 \vdots \\
68 \text { ANO OVER } \\
\text { PIECES. }\end{array}$ & 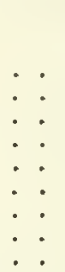 & 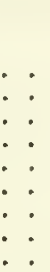 & 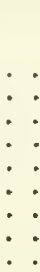 & $\therefore$ & $\begin{array}{r}\text { POUNDS } \\
533,732 \\
1,669,681 \\
1,603,576 \\
1,052,824 \\
1,949,388 \\
935,004 \\
1,248,668 \\
6,721,001 \\
55,750\end{array}$ & $\begin{array}{r}\text { OOLLARS } \\
1,591,290 \\
4,956,104 \\
4,568,299 \\
2,689,562 \\
4,166,171 \\
1,549,201 \\
1,609,554 \\
4,669,662 \\
36,600\end{array}$ & $\begin{array}{r}\text { POUNOS } \\
148,807 \\
988,391 \\
906,042 \\
981,285 \\
1,893,400 \\
780,965 \\
1,165,695 \\
2,620,491 \\
9,381\end{array}$ & $\begin{array}{r}\text { DOLLARS } \\
421,478 \\
2,629,697 \\
2,401,540 \\
2,439,227 \\
3,962,102 \\
1,233,989 \\
1,398,723 \\
1,670,981 \\
4,033\end{array}$ & $\begin{array}{r}\text { POUNOS } \\
756,693 \\
3,207,684 \\
2,937,109 \\
2,329,332 \\
4,202,397 \\
1,926,287 \\
2,856,797 \\
9,753,762 \\
67,540\end{array}$ & $\begin{array}{r}\text { OOLLARS } \\
2,220,297 \\
9,135,775 \\
8,153,325 \\
5,868,506 \\
8,923,092 \\
3,135,036 \\
3,574,137 \\
6,674,377 \\
42,445\end{array}$ \\
\hline TOTAL & . . & . . & . $\cdot$ & . & $15,769,624$ & $25,828,443$ & $9,494,457$ & $76,761,770$ & $28,036,995$ & $47,726,990$ \\
\hline SEA 808S. . & . & . . & . $\cdot$ & . & $3,978,835$ & $1,592,227$ & 435,832 & 105,710 & $4,585,196$ & $7,754,552$ \\
\hline $\begin{array}{l}\text { ROYAL REO: } \\
15=20: \\
21=25: \\
26=30: \\
31=40: \\
41=50: \\
51=67: \\
68 \text { ANO OVER } \\
\text { PIECES.: }\end{array}$ & $\begin{array}{l}: \\
: \\
: \\
: \\
: \\
:\end{array}$ & $\therefore$ & $\begin{array}{l}\dot{:} \\
\dot{.} \\
\dot{.} \\
\dot{.}\end{array}$ & : & $\begin{array}{r}- \\
495 \\
40 \\
465 \\
500 \\
275 \\
75 \\
140 \\
\end{array}$ & $\begin{array}{r}- \\
7,386 \\
100 \\
983 \\
750 \\
344 \\
41 \\
70 \\
\end{array}$ & $\begin{array}{l}- \\
\vdots \\
\vdots \\
-\end{array}$ & $\begin{array}{l}\overline{-} \\
\overline{-} \\
\overline{-} \\
\overline{-}\end{array}$ & $\begin{array}{r}3,623 \\
3,685 \\
4,571 \\
20,842 \\
83,900 \\
3,186 \\
1,758 \\
1,042\end{array}$ & $\begin{array}{r}7,012 \\
7,818 \\
10,790 \\
34,748 \\
123,959 \\
3,068 \\
1,033 \\
651\end{array}$ \\
\hline TOTAL & . . & . . & & . & 1,990 & 3,674 & - & - & 122,607 & 188,479 \\
\hline ROCK..... & . . & . . & . $\cdot$ & - & 943 & 773 & 47,193 & 48,433 & $1,064,721$ & 802.555 \\
\hline GRAND & TOTA & L. & . $\cdot$ & . & $33,886,025$ & $40,967,755$ & $44,286,676$ & $87,902,421$ & $107,133,688$ & $178,337,052$ \\
\hline
\end{tabular}

NOTE: - ALL WE IGHTS ARE ON A HEADS OFF BASIS. LANDINGS FIGURES REPRESENT THE HEADS -OFF WE IGHT AND, THEREFORE, ARE NOT DIRECTLY COMPARABLE WITH THE HEADS -ON (LIVE WEIGHT) QUANTITIES PUBL ISHED IN THE GENERAL REVIEW ANO REGIONAL TABLES. POUNOS OF HEAOS -OFF SHRIMP MAY BE CONVERTED TO HEADS-ON (ROUNO) WE IGHT BY MULTIPLYING BROWN SHRIMP WEIGHT BY 1.61; PINK, 8Y 1.60; WHITE, 8Y 1.54; SEA 8OBS, 8Y 1.53; ROYAL RED, 8Y 1.80; AND ROCK SHRIMP, 8Y 1.67.

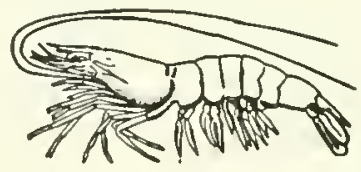


SOUTH ATLANTIC AND GULF COAST SHRIMP LANDINGS, 1975

\begin{tabular}{|c|c|c|c|c|c|c|c|c|c|c|c|c|}
\hline \multirow[t]{2}{*}{ SPECIES } & \multirow[t]{2}{*}{ ANO } & \multicolumn{5}{|c|}{ SIZE } & \multicolumn{2}{|c|}{ SOUTH ATLANTIC } & \multicolumn{2}{|c|}{ GULF } & \multicolumn{2}{|c|}{ TOTAL } \\
\hline & & & & & & & POUNOS & OOLLARS & POUNOS & OOLLARS & POUNOS & OOLLARS \\
\hline 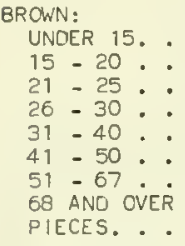 & 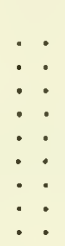 & $\begin{array}{l}\dot{ } \\
\dot{ } \\
\dot{ } \\
\dot{ } \\
\dot{ }\end{array}$ & $\dot{\dot{0}} \dot{.}$ & : & $\dot{:}$. & $\dot{\dot{:}} \dot{\dot{ }} \dot{\dot{ }}$ & $\begin{array}{r}30,111 \\
132,987 \\
425,417 \\
1,680,212 \\
1,044,021 \\
734,350 \\
122,684 \\
-\end{array}$ & $\begin{array}{r}- \\
76,025 \\
340,168 \\
1,023,029 \\
3,323,534 \\
1,635,205 \\
894,136 \\
119,666 \\
.\end{array}$ & $\begin{array}{r}990,377 \\
5,971,220 \\
6,987,480 \\
5,020,459 \\
10,412,056 \\
6,172,273 \\
7,258,231 \\
14,392,217 \\
92,718 \\
\end{array}$ & $\begin{array}{r}2,829,379 \\
16,344,400 \\
19,105,680 \\
12,554,204 \\
22,133,768 \\
10,215,302 \\
9,548,488 \\
8,438,573 \\
81,443 \\
\end{array}$ & $\begin{array}{r}990,377 \\
6,001,331 \\
7,120,467 \\
5,445,876 \\
12,092,268 \\
7,216,294 \\
7,992,581 \\
14,514,901 \\
92,718 \\
\end{array}$ & $\begin{array}{r}2,829,379 \\
16,420,425 \\
19,445,848 \\
13,577,233 \\
25,457,302 \\
11,850,507 \\
10,442,624 \\
8,558,239 \\
81,443 \\
\end{array}$ \\
\hline TOTAL & • • & - & - & - & - & - & $4,169,782$ & $7,411,763$ & $57,297,031$ & $101,251,237$ & $61,466,813$ & $108,663,000$ \\
\hline $\begin{array}{l}\text { PINK: } \\
\text { UNOER 15. } \\
15-20: \dot{ } \\
21-25: \cdot \\
26=30: \\
31-40: \dot{ } \\
41-50: \\
51-67: \\
68 \text { ANO OVER } \\
\text { PIECES. }\end{array}$ & 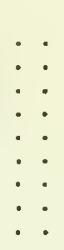 & $\begin{array}{l}\dot{ } \\
\dot{ } \\
\dot{ } \\
\dot{ } \\
\dot{ }\end{array}$ & $\begin{array}{l}\dot{:} \\
\dot{5} \\
\dot{5} \\
\dot{5}\end{array}$ & $\begin{array}{l}: \\
: \\
: \\
: \\
:\end{array}$ & : & $\dot{\dot{.}} \dot{.}$ & $\begin{array}{r}- \\
10,525 \\
8,390 \\
9,221 \\
50,407 \\
198,699 \\
739,243 \\
248,956 \\
-\end{array}$ & $\begin{array}{r}31,300 \\
20,391 \\
21,612 \\
87,517 \\
274,102 \\
900,985 \\
264,806 \\
-\end{array}$ & $\begin{array}{r}63,617 \\
1,108,749 \\
1,873,785 \\
2,080,003 \\
3,559,885 \\
2,008,728 \\
4,507,608 \\
817,248 \\
7,335 \\
\end{array}$ & $\begin{array}{r}168,330 \\
2,589,815 \\
4,099,793 \\
4,247,208 \\
6,485,816 \\
2,926,806 \\
5,564,182 \\
525,860 \\
5,429 \\
\end{array}$ & $\begin{array}{r}63,617 \\
1,119,274 \\
1,882,175 \\
2,089,224 \\
3,610,292 \\
2,207,427 \\
5,246,851 \\
1,066,384 \\
7,335 \\
\end{array}$ & $\begin{array}{r}168,330 \\
2,621,115 \\
4,120,184 \\
4,268,820 \\
6,573,333 \\
3,200,908 \\
6,465,167 \\
790,666 \\
5,429 \\
\end{array}$ \\
\hline TOTAL & $\cdot \cdot$ & - & - & - & - & - & $1,265,441$ & $1,600,713$ & $16,027,138$ & $26,613,239$ & $17,292,579$ & $28,213,952$ \\
\hline 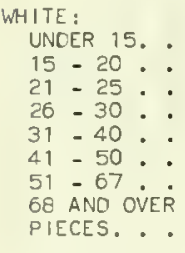 & 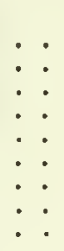 & $\begin{array}{l}\dot{ } \\
\dot{ } \\
\dot{ } \\
\dot{ } \\
\dot{ }\end{array}$ & $\dot{\dot{:}} \dot{\dot{ }}$ & $\begin{array}{l}\text { : } \\
: \\
: \\
: \\
\text { : }\end{array}$ & $\begin{array}{l}\dot{:} \\
\dot{:} \\
\dot{:} \\
\dot{ }\end{array}$ & $\begin{array}{l}\dot{:} \\
\dot{.} \\
\dot{.} \\
\dot{.}\end{array}$ & $\begin{array}{r}66,858 \\
1,175,252 \\
2,395,695 \\
2,647,871 \\
1,452,406 \\
1,975,140 \\
618,590 \\
-\end{array}$ & $\begin{array}{c}193,593 \\
3,297,759 \\
5,869,723 \\
6,004,690 \\
2,494,988 \\
2,713,313 \\
551,135 \\
-\end{array}$ & $\begin{array}{r}756,693 \\
3,207,684 \\
2,937,109 \\
2,329,332 \\
4,202,397 \\
1,926,281 \\
2,856,197 \\
9,753,762 \\
67,540 \\
\end{array}$ & $\begin{array}{r}2,220,297 \\
9,135,775 \\
8,153,325 \\
5,868,506 \\
8,923,092 \\
3,135,036 \\
3,574,137 \\
6,674,377 \\
42,445 \\
\end{array}$ & $\begin{array}{r}756,693 \\
3,274,542 \\
4,712,361 \\
4,725,027 \\
6,850,268 \\
3,378,687 \\
4,831,337 \\
10,372,352 \\
67,540 \\
\end{array}$ & $\begin{array}{r}2,220,297 \\
9,329,368 \\
11,451,084 \\
11,738,229 \\
14,927,782 \\
5,630,024 \\
6,287,450 \\
7,225,512 \\
42,445 \\
\end{array}$ \\
\hline TOTAL & • & - & - & - & - & - & $10,331,812$ & $21,125,201$ & $28,036,995$ & $47,726,990$ & $38,368,807$ & $68,852,191$ \\
\hline SEA BOBS. . . & • & - & - & - & . & . & - & - & $4,585,196$ & $1,1754,552$ & $4,585,196$ & $1,754,552$ \\
\hline 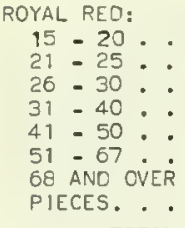 & 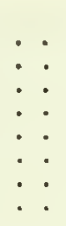 & $\begin{array}{l}\dot{:} \\
\dot{:} \\
\dot{\cdot} \\
\dot{\cdot}\end{array}$ & $\begin{array}{l}\dot{.} \\
\dot{.} \\
\dot{.} \\
\dot{.} \\
\dot{.}\end{array}$ & $\begin{array}{l}\dot{:} \\
\dot{.} \\
\dot{.} \\
\dot{.}\end{array}$ & $\begin{array}{l}\dot{\bullet} \\
\dot{:} \\
\dot{-} \\
\dot{\cdot}\end{array}$ & $\begin{array}{l}\dot{:} \\
\dot{.} \\
\dot{.} \\
\dot{.}\end{array}$ & $\begin{array}{c}- \\
8,523 \\
1,242 \\
12,983 \\
3,689 \\
= \\
=\end{array}$ & $\begin{array}{c}18,060 \\
2,111 \\
20,151 \\
4,620 \\
= \\
=\end{array}$ & $\begin{array}{r}3,623 \\
3,685 \\
4,571 \\
20,842 \\
83,900 \\
3,786 \\
1,758 \\
1,042 \\
\end{array}$ & $\begin{array}{r}7,012 \\
7,818 \\
10,190 \\
34,748 \\
123,959 \\
3,068 \\
1,033 \\
651 \\
\end{array}$ & $\begin{array}{r}3,623 \\
12,208 \\
4,571 \\
22,084 \\
96,883 \\
6,875 \\
1,758 \\
1,042 \\
\end{array}$ & $\begin{array}{r}7,012 \\
25,878 \\
10,190 \\
36,859 \\
144,110 \\
7,688 \\
1,033 \\
651 \\
\end{array}$ \\
\hline TOTAL & • & - & - & - & $\cdot$ & & 26,437 & 44,942 & 122,607 & 188.479 & 149,044 & 233,421 \\
\hline ROCK. . . . & $\cdot \cdot$ & - & - & - & - & - & 135,405 & 121,517 & $1,064,721$ & 802,555 & $1,200,126$ & 924,072 \\
\hline GRAND & TOTA & & . & - & - & - & $15,928,877$ & $30,304,136$ & $107,133,688$ & $178,337,052$ & $123,062,565$ & $208,641,188$ \\
\hline
\end{tabular}

NOTE :--ALL WEIGHTS ARE ON HEAOS-OFF BASIS. THE SIZE INDICATES THE NUMBER OF HEAOS-OFF SHRIMP TO THE POUNO. TO CONVERT TO HEADS-ON WE IGHT MULTIPLY BY 1.61 FOR EROWN, 1.60 FOR PINK, 1.54 FOR WHITE, 1.53 FOR SEA BOBS, 1.80 FOR ROYAL RED. ANO 1.67 FOR ROCK SHRIMP. THE STATES LISTEO REPRESENT THE STATES WHERE THE SHRIMP WERE LANOEO REGAROLESS OF WHERE CAUGHT. THE NAMES OF THE SPECIES USEO IN THESE TABLES ARE AS FOLLOWS: WHITE SHRIMP (MOSTLY PENAEUS SETIFERUS); BROWN SHRIMP (MOSTLY PENAEUS AZTECUS), PINK SHRIMP (MOSTLY PENAEUS DUORARUM), SEA BOBS (MOSTLY XIPHOPENAEUS KROYERI), ROYAL REO SHRIMP (MOSTLY HYMENOPENAEUS ROBUSTUS), ANO ROCK SHRIMP (MOSTLY SICYONIA SPP I. THE VALUE REPORTEO IS THE AMOUNT RECE IVEO BY THE OWNERS OR OPERATORS OF THE VESSELS FOR THE FIRST SALE AT THE DOCK. ANY EXPENSES INVOLVED IN HANOLING OR PROCESSING ASHORE ARE NOT INCLUOED, EVEN THOUGH CHARGEABLE TO THE VESSEL. THE SIZE REPORTED GENERALLY IS THAT USEO AS OF THE FIRST SALE. SIZE GRADING IN VARYING OEGREES OF UNIFORMITY MAY OR MAY NOT OCCUR AT, OR PRIOR TO, THE TIME FIRST SALES ARE MAOE. IF GRAOING IS NOT OONE AT THIS TIME, THE SIZE REPORTEO IS AN AVERAGE SIZE AND MAY INCLUOE SEVERAL SIZE CLASSIFICATIONS. 


\section{GULF FISHERIES}

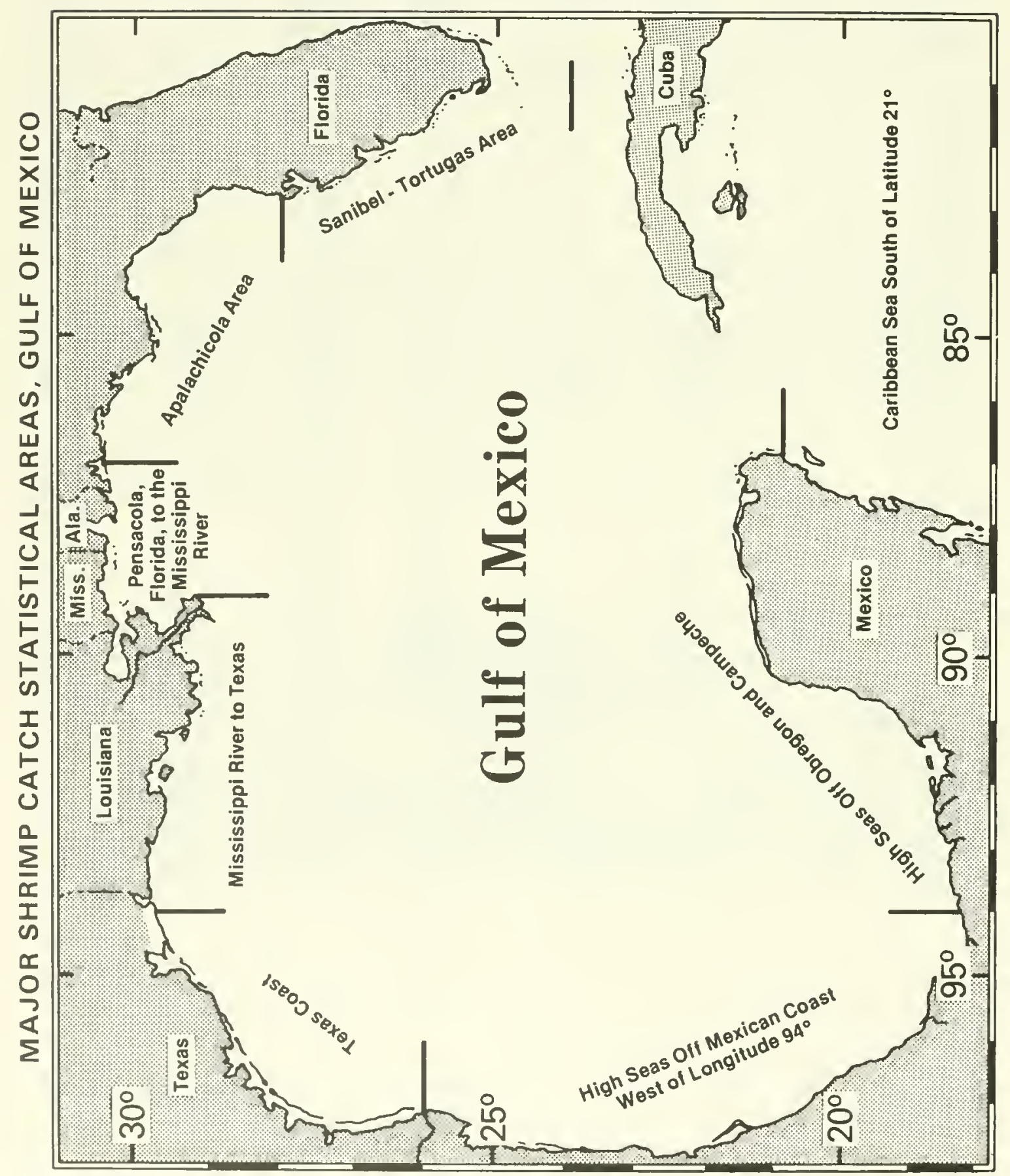




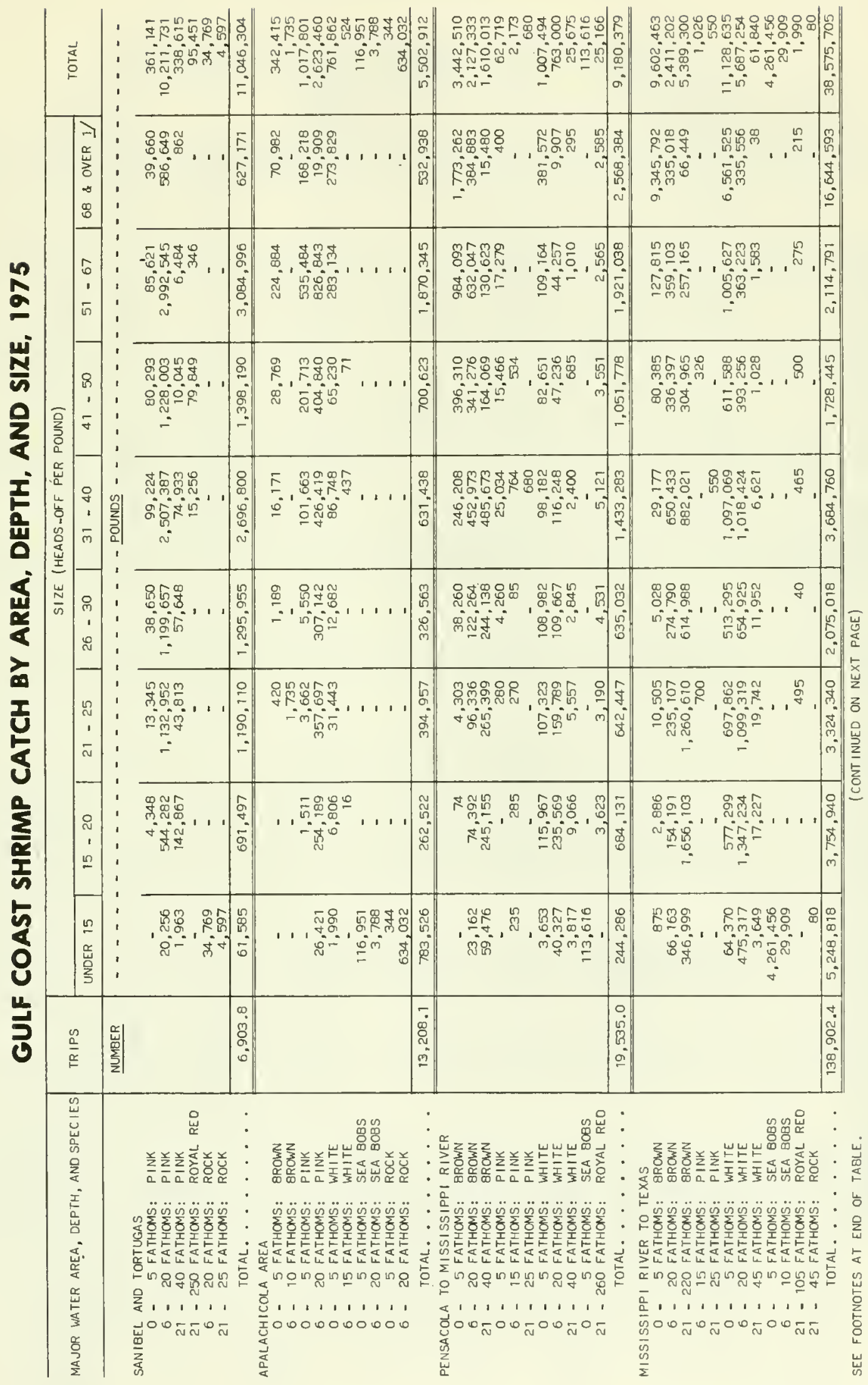




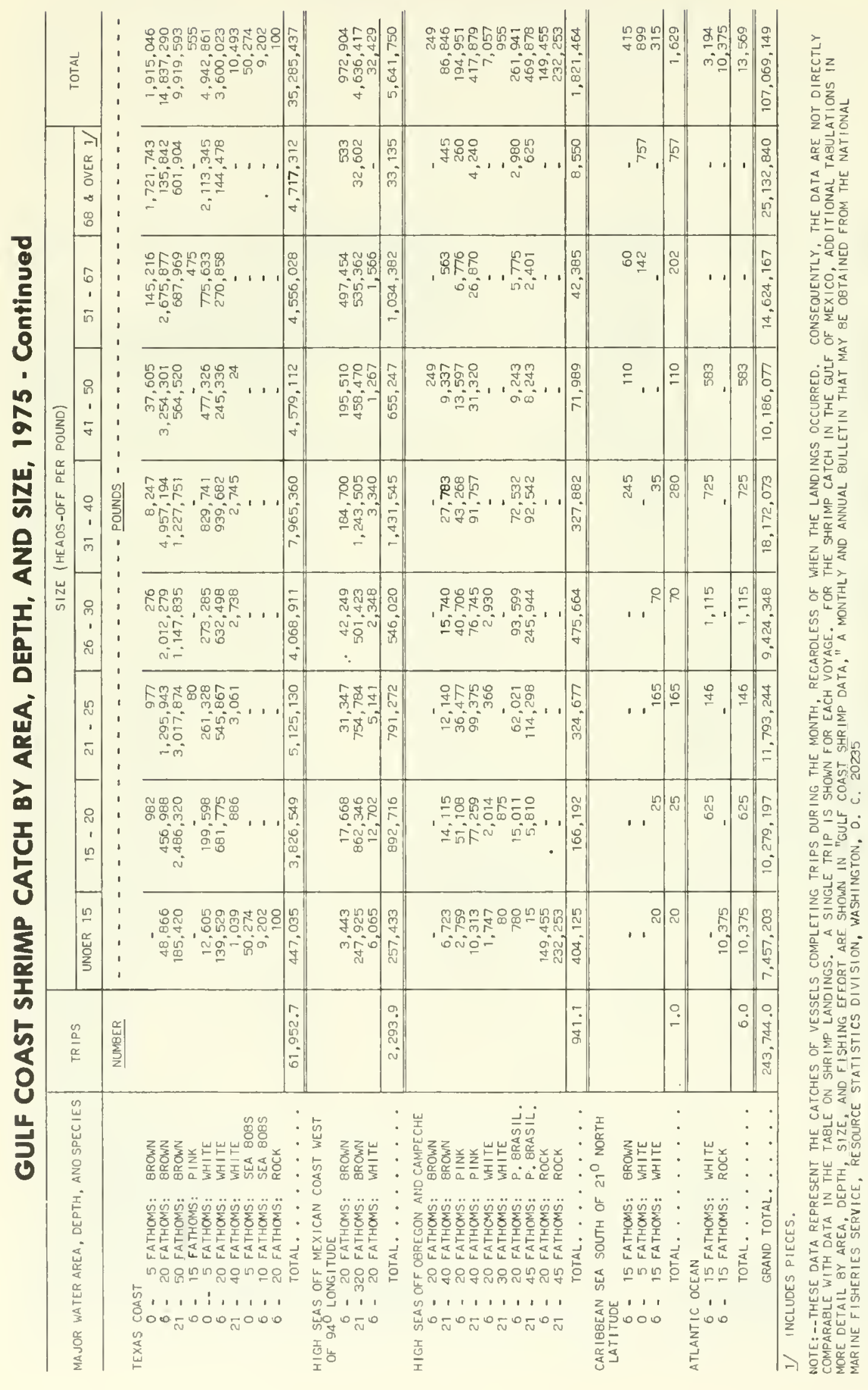




\section{PACIFIC COAST FISHERIES}

Landings by U.S. commercial fishermen in the Pacific Coast States of Alaska, California, Oregon, and Washington were 1.6 billion pounds valued at $\$ 352$ million in 1975 , up 12 percent in quantity, but down 8 percent in value compared with 1974. The increase in quantity mainly was due to record landings of anchovies in California. The decrease in value primarily was caused by depressed exvessel prices for most species.

Alaska led the other States in value of landings with $\$ 129.7$ million, followed closely by California with $\$ 134.7$ million. Washington landings were $\$ 61.6$ million, and Oregon landings were $\$ 26.0$ million. In terms of quantity, however, California led with 875.0 million pounds; followed by Alaska, 444.1 million pounds; Washington, 146.0 million pounds; and Oregon, 86.2 million pounds.

Tuna was the leading species in terms of quantity, but second to salmon in value. Landings of tuna were 380.5 million pounds valued at $\$ 100.6$ million. Landings of salmon were 202.0 million pounds valued at $\$ 107.0$ million. Salmon ranked third in quantity behind anchovies ( 329.4 million pounds).

The total foreign catch in 1975 from Pacific Coast waters was 2.0 million metric tons (4.4 billion pounds), down 11 percent from 1974, but still almost three times the domestic catch. This was the fourth year that foreign catches have declined since 1971, the peak year. The catch of all foreign countries declined; and the catch declined in all areas except the Gulf of Alaska where it increased slightly.

Two factors have been at work to reduce foreign catches in recent years. The first, and probably most important, was a market reduction in abundance of Alaska pollock and other target species. The second factor was the decision by various foreign governments to reduce fishing. In part this decision was a result of reduced catches caused by low abundance and in part a result of international agreements between the fishing nations and the United States to reduce fishing to preserve the stocks.

In 1975, Japan was the leading nation, accounting for 66 percent of the foreign catch off Pacific Coast States; the U.S.S.R. accounted for 31 percent; Poland, 3 percent; and Canada, South Korea, and China (Taiwan) for less than 1 percent. Catches from waters off Alaska accounted for almost 89 percent of the foreign eatch off Pacific Coast States; catches off California, Oregon, and Washington accounted for the remainder.

Alaska pollock was the leading species in the foreign catch, accounting for more tonnage than all other species combined. In 1975, the foreign catch of Alaska pollock was 2.9 billion pounds (1,295,000 metric tons). The catch of Pacific hake was 434 million pounds (197,000 metric tons); flounders, turbots, and other flatfish, except halibut, 299 million pounds (136,000 metric tons); rockfishes, except ocean perch, 129 million pounds ( 58,000 metric tons); cod, 128 million pounds (58,000 metric tons); Pacific ocean perch, 103 million pounds (47,000 metric tons); atka mackerel, 92 million pounds (42,000 metric tons); sablefish, 72 million pounds (33,000 metric tons); sea herring, 38 million pounds (17,000 metric tons); and snow (tanner) crab, 22 million pounds (10,000 metric tons). The bulk of the remainder consisted of miscellaneous groundfish species. Catches of salmon and shrimp were negligible.

Fishermen and craft. The Pacific Coast fleet of fishing vessels (craft of 5 net tons or over) continued to increase in number and total tonnage, a trend unbroken since 1964. The number of fishing boats (craft of less than 5 net tons) and fishermen on boats and shore, however, declined for the second year in a row.

In 1975 , the number of fishing vessels was 7,031 with a total tonnage of 269,413 , up 5 percent in number and 2 percent in tonnage over 1974. The number of fishermen aboard these vessels in 1975 rose to 22,741 , up 7 percent compared with the previous year. The number of boats declined to 13,336 in 1975 , down 10 percent from 1974. The number of fishermen on boats and shore in the Pacific Coast States declined to 22,099 in 1975 , down 5 percent from 1974.

Processed products. Pacific Coast production of processed fishery products was $\$ 835.2$ million in 1975 , down 8 percent from 1974 . California accounted for over half of the total with $\$ 472.3$ million; Alaska was next with $\$ 240.4$ million; Washington, $\$ 75.6$ million; and Oregon, $\$ 46.9$ million. The production of canned products, mainly tuna and salmon, was $\$ 514.4$ million in 1975 and accounted for 62 percent of the total. Of the total value, frozen products accounted for 25 percent; industrial, 6 percent; fresh, 4 percent; and cured, 3 percent of the total. 
The decline in the total value of processed products in the Pacific Coast States was due to a 20 percent decline in canned production, mainly tuna.and salmon, which more than offset increases in the value of fresh or frozen edible products and industrial products.

The Pacific Coast States had 451 processing plants in 1975 employing 16,891 persons on a regular basis and 23,821 at the season's peak. In the same year, 136 wholesale establishments employed 1,344 persons on a regular basis. Compared with 1974, the number of processing plants declined by 26 , but the number of wholesale establishments increased by 18 .

Anchovy. In 1975, Pacific Coast landings of anchovy (northern anchovy) were a record 329.4 million pounds valued at $\$ 11.9$ million-an increase of 86 percent in quantity, but a decrease of 19 percent in value compared with 1974. Virtually all U.S. landings of anchovy are caught in California waters and are primarily reduced to fish meal and oil; a small amount (5-8 percent) is used for bait. Anchovy fishing for reduction is closely controlled by the State of California. In 1975, the 1974-75 season ended May 15; landings were 13,000 tons short of the extended 130,000 -ton quota.

The 1975-76 season opened August 1, 1975, in the nor thern area (north of Point Conception) and September 15, 1975, in the southern area (south of Point Conception). The overall quota was set at 115,000 tons, equal to the initial quota set the previous season. Prices at the beginning of the season were $\$ 35$ per ton, but declined to $\$ 29.50$ by the end of the season.

Bonito. Record landings of bonito in California totaled 31.9 million pounds valued at $\$ 3.9$ million, surpassing the 1970-74 average annual landings by 62 percent in quantity and 52 percent in value. The previous high of 30.8 million pounds was in 1973. All landings were made at California ports, although 28.5 million pounds were caught in waters south of Calif ornia.

Prices dropped for fish over 4 pounds-from $\$ 270$ per ton in 1974 to $\$ 240$ per ton in 1975 . For fish under 4 pounds, prices went from $\$ 185$ to $\$ 240$ per ton in 1974 to $\$ 210$ per ton in 1975 . This price decrease is attributed to increased supply.

Flounders. Landings of Pacific flounders and turbot were 56.8 million pounds valued at $\$ 8.7 \mathrm{million}$ in 1975 , up 4 percent in quantity and 6 percent in value compared with 1974. Over 94 percent of the landings consisted of "sole", namely dover sole, english sole, petrale sole, and rex sole. The most important of these is dover sole. California was the principal State, accounting for 62 percent of the total flounder and turbot landings. Oregon was second with 22 percent. Washington had 16 percent, and Alaska, less than 1 percent.

Halibut. Landings of Pacific halibut were 21.6 million pounds (live weight) valued at $\$ 16.3$ million in 1975 , up

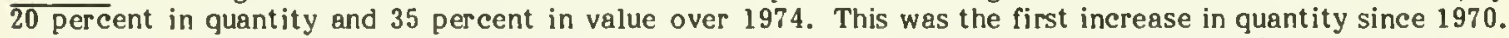
Landings in Alaska accounted for 93 percent of the total, and landings in Washington for almost all the remainder. The highlight of the 1975 halibut season was the exvessel price, which averaged almost 90 cents a pound (dressed weight), for the year, and reached a record high of $\$ 1.38$ for large halibut during the latter part of the season.

Management of the Pacific halibut fishery of the United States and Canada is coordinated through the International Pacific Halibut Commission (IPHC). Halibut stocks have been in a depleted condition for a number of years, and IPHC had reduced catch quotas to remedy this. The large incidental catch of foreign vessels using otter trawl nets has been an important cause of this depletion. In 1973, Japan agreed to keep its fishermen out of an important Bering Sea nursery ground for 3 months. This was raised to 5-1/2 months in 1975. The U.S.S.R. agreed for the first time in 1975 to limit trawling in the Gulf of Alaska during certain critical months.

Jack mackerel. Pacific Coest landings of jack mackerel were 36.8 million pounds valued at $\$ 1.7 \mathrm{million}$ in

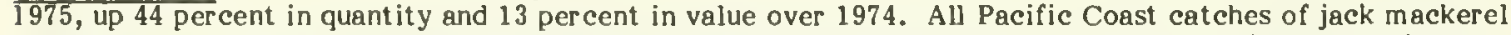
are made at California ports and consist of fish taken near these ports. A large majority of these landings are canned, primarily for human consumption, but a substantial share also is canned for use as pet food. The increase in landings probably was due largely to the rebuilding of a major canning plant in San Pedro that was severely damäged by fire in 1973.

Lingcod. Pacific Coast landings of lingeod were 9.2 million pounds valued at $\$ 1.2$ million in 1975 , up 3 $\overline{\text { percent }}$ in quantity, but down 6 pecent in value compared with 1974 . Washington was the leading State with 46 percent of the total; California was next with 35 percent; then Oregon, 18 percent; and Alaska, 1 percent. 
This is the third year in a row that landings have been above those of most previous years. The 1975 landings were the highest since 1948 .

Pacific cod. U.S. landings of Pacific cod were 12.2 million pounds valued at $\$ 1.4 \mathrm{million}$ in 1975 , up 22 percent in quantity and 10 percent in value over 1974. Washington led the other States with 92 percent of the total; Oregon accounted for 5 percent and Alaska 3 percent. The great bulk of the Washington landings were caught in waters off British Columbia and landed at Puget Sound ports.

The foreign catch of Pacific cod off U.S. shores was 128 million pounds in 1975 , down 8 percent from 1974. All or almost all of the foreign eatch was taken in Alaska waters, principally the Bering Sea and Aleutians area. Japan was the principal catching nation.

Pacific hake. U.S. landings of Pacific hake were 3.4 million pounds valued at $\$ 50,000$ in 1975 , down 35 percent in quantity and 54 percent in value compared with 1974 . This quantity was the lowest since 1965. Almost 99 percent of the total landings in 1975 were made at Washington ports. As in other recent years almost all the landings were sold directly for animal food or processed into meal and oil.

Foreign catches of hake principally off Oregon and Washington, were 434.2 million pounds. The U.S.S.R. was the principal catching nation with 79 percent of the total; Poland followed with 21 percent.

Pacific ocean perch and other rockfishes. Total U.S. landings of Pacific ocean perch and other rockfishes were 38.9 million pounds valued at $\$ 4.8 \mathrm{~m}$ illion in 1975 , down 6 percent in quantity and 4 percent in value compared with 1974. Landings of other rockfishes, although down slightly compared with 1974, were above the average for the previous 5 years. Landings of Pacific ocean perch, on the other hand, have declined in recent years and in 1975 were the lowest since 1951. California was the principal landings State for other rockfishes; and Washington was the principal State for Pacific ocean perch.

The foreign catch of Pacific ocean perch and other rockfishes was 231.5 million pounds in 1975 , down 20 percent compared with 1974. Japan was the principal taking nation with 55 percent of the total; followed by the U.S.S.R., 40 percent; Republic of Korea, 3 percent; Poland, 2 percent; and Canada, less than 1 percent.

Sea herring. U.S. landings of Pacific sea herring were 51.2 million pounds valued at $\$ 3.6 \mathrm{million}$ in 1975 , down 9 percent in quantity and 6 percent in value compared with 1974 , but substantially above the average of 31.1 million pounds for the previous 5 years. Of the total, Alaska accounted for 69 percent; Washington, 26 percent; and California, 5 percent. About 66 percent of Pacific sea herring landings was used for human consumption. The remainder was used as bait in other fisheries.

The foreign catch of sea herring off U.S. Pacifjc shores was 37.8 million pounds in 1975. Japan and the U.S.S.R. were the only catching nations. All the foreign catch was taken from the Bering Sea and Aleutian area, whereas almost all domestic landings were caught in the Gulf of Alaska area.

Sablefish. U.S. landings of sablefish (black cod) were 19.3 million pounds valued at $\$ 2.6$ million in 1975 , up 23 percent in both quantity and value compared with 1974. Both quantity and value in 1975 were a record. Landings of sablefish have been at a relatively high level since 1972, because of heavy landings in California. Of the 1975 landings, California accounted for 73 percent of the total; Alaska, 13 percent; Washington, 10 percent; and Oregon, 4 percent. About half of the California catch is made by a greatly expanded pot fishery. The market in California, which has been exceptionally good in recent years, has been strengthened by large exports to Japan of prime-quality frozen sablefish.

Foreign catches of sablefish off the U.S. Pacific Coast were 72.0 million pounds in 1975 , down 6 percent from 1974. Catches in the Gulf of Alaska were 54.0 million pounds; in Bering Sea and Aleutians, 9 million pounds; and in Washington, Oregon, and California, 9 million pounds. Of the total, Japan accounted for 81 percent; Republic of Korea, 18 percent; and Poland, 1 percent.

Salmon. Domestic landings of Pacific salmon were 202.0 million pounds valued at $\$ 107.0$ million in 1975 , up less than 1 percent in quantity, but down 11 percent in value compared with 1974 . The decrease in value was due to lower prices, chiefly in Alaska. Alaska accounted for 68 percent of the total landings; Washington, 23 percent; Oregon, 6 percent; and California, 3 percent. 
Salmon landings in Alaska were 137.5 million pounds valued at $\$ 55.6$ million in 1975 , up 4 percent in quantity, but down $\$ 9.8$ million (15 percent) in value. Southeast Alaska, an area that in the past 5 years has contributed 35 percent of the total annual Alaska landings, had its lowest salmon landings since the turn of the century. The State, for the first time, closely regulated the troll fishery in the Southeast. The gill net and purse seine fisheries, which take mainly pinks and chums, were closed for most of the season, but were opened after August 8 when late runs improved. Bristol Bay, which had been declared a disaster area in 1974, had the highest catch since $1971-5.2$ million salmon. The most encouraging aspect of the 1975 season was the sockeye escapement to the spawning grounds.

Tuna. Pacific Coast landings of all species of tuna were 380.5 million pounds valued at $\$ 100.6$ million for 1975, down less than 1 percent in quantity and 12 percent in value from 1974 , and just 9.4 million pounds below the record of 389.9 million pounds in 1950. California has 90 percent of the total Pacific Coast landings; followed by Oregon, 6 percent; and Washington, 4 percent.

Although fluctuating by 50 million pounds or more, landings have been at or near record levels since 1969, averaging 355.2 million pounds from 1969 to 1975 . The 25-year average for 1944 to 1968 was 288.3 million pounds. These near-record landings were mainly attributable to increased landings of yellowfin. In 1975, yellowfin (including bigeye) accounted for 63 percent of the Pacific Coast landings; followed by skipjack and black skipjack, 20 percent; albacore, 13 percent; and bluefin, 4 percent.

Albacore tuna landings were 48.9 million pounds, valued at $\$ 16.2$ million in 1975 , down 11 percent in quantity from 1974 and just 7 percent above the 25-year average. For the fourth consecutive year, most of the albacore was caught off Oregon and Washington. Previously, California usually received the bulk of Pacific Coast albacore landings. In 1975, landings in Oregon were the largest with 17.2 million pounds, followed by Washington with 16.3 million pounds, and California with 15.4 million pounds. The season began in June, but fishermen and buyers had a price disagreement that kept many vessels in port. Fishing began in earnest on July 8 after a price of $\$ 675$ per ton was agreed on. The 1975 price was 18 percent below the price of $\$ 820$ a ton prevailing in 1974 .

Bluefin tuna landings were 16.4 million pounds, valued at $\$ 4.0$ million, up 41 percent in quantity and 22 percent in value from 1974, but about average compared with recent years. The 25-year average for landings of bluefin tuna on the Pacific Coast was 17.1 million pounds. Prices decreased from $\$ 555$ per ton in 1974 to $\$ 480$ per ton in 1975. As in other years, catches were made by purse seine vessels and landed at California ports. The fish were caught in waters off Mexico ( 74 percent) and Calif ornia ( 26 percent).

Landings of skipjack and black skipjack tuna at Pacific Coast ports were 74.5 million pounds, up 22 percent from 1974, but still 12.3 million pounds below the 25-year average. Landings of yellowfin at Pacific Coast ports were 240.4 million pounds, a decrease of 5 percent from last year's record 252.8 million pounds. Exvessel prices for skipjack and yellowfin decreased about 15 percent and 8 percent, respectively, from 1974 levels. Skipjack started the year at $\$ 540$ per ton, ranged between $\$ 450$ and $\$ 540$ per ton in April, and fell to $\$ 450$ per ton in June, where it remained for the rest of the year. Similarly, skipjack under 5 pounds fell from $\$ 518$ to $\$ 432$ per ton and yellowfin declined from $\$ 580$ to $\$ 500$ per ton. The average price for black skipjack in 1975 was $\$ 107$ per ton.

In accordance with recommendations by the Inter-American Tropical Tuna Commission (IATTC), yellowfin tuna fishing by U.S. fishermen is closely regulated by NMFS and the U.S. Coast Guard in a major producing area of the eastern Pacific Ocean known as the Commission's Yellowfin Regulatory Area (CYRA). In CYRA, the quota for all countries was 175,000 short tons with allowances for two 10,000 -ton increments should data from the fishery warrant such increases. Fishermen of member nations easily reached this quota. The season was closed on March 13,1975. The U.S. share of the CYRA catch was 61.5 percent of the yellowfin catch and 52.8 percent of the skipjack catch. Thirteen other countries reported landings of tuna caught in CYRA.

Crabs, dungeness. Pacific Coast landings of dungeness crabs were 18.4 million pounds valued at $\$ 11.4$ million in 1975, up 31 percent in quantity and 23 percent in value compared with 1974. Landings of dungeness crabs in the last 3 years (1973-75) have been at very low levels compared with landings from 1968 to 1972 when they averaged 45.3 million pounds.

Crabs, king. U.S. landings of king crabs were 97.6 million pounds valued at $\$ 38.3$ million in 1975 , up 3 percent in quantity, but down 2 percent in value because of lower prices received by fishermen. The 1975-76 Alaska season opened on August 15, 1975, but because of a strike for higher prices by central and westward 
Alaska fishermen, king crab vessels were tied up until September 15, 1975. Fishermen and processors reached a price settlement of 42 cents per pound at Kodiak and 38 cents at Bering Sea ports.

Crabs, snow (tanner). U.S. landings were 46.9 million pounds valued at $\$ 7.0$ million in 1975 , down 27 percent in quantity and 46 percent in value compared with 1974. Depressed market conditions in 1974 left large inventories at the beginning of the 1975 season. In January, February, and March, the United States and Japanese market demand was poor. As a consequence, fewer Alaska fishermen and vessels entered the fishery than in 1974. The number of pots used in this fishery dropped from about 48,000 in 1974 to 37,000 in 1975.

The foreign catch of snow crabs in U.S. waters off Alaska was 22.5 million pounds in 1975, down sharply from the 34 million pounds taken in 1974. In both years Japan was the only taking nation.

Oysters. The yield of oyster meats in the Pacific Coast States in 1975 was 5.8 million pounds valued at $\$ 7.5$ million, up 15 percent in quantity and 23 percent in value over 1974 . The increase in quantity was attributable to greater production in Washington, the principal producing State.

Shrimp. Landings of Pacific Coast shrimp (excluding brine shrimp and sand shrimp) were 138.3 million pounds valued at $\$ 13.6$ million in 1975 , down 2 percent in quantity and 26 percent in value compared with 1974 . The quantity was the third highest on record. Sharply lower exvessel prices in Alaska were responsible for the decline in value. Landings in Washington, Oregon, and California increased in 1975, but not enough to offset the decrease in Alaska, the leading producing State. Alaska landings in 1975 were 99.0 million pounds, down 9 percent; Washington landings were 10.0 million pounds, up 8 percent; Oregon landings were 23.9 million pounds, up 18 percent; and California landings were 5.3 million pounds, up 97 percent.

Pacific Coast production of brine shrimp was 1.8 million pounds valued at $\$ 330,000$ in 1975 , up 11 percent in quantity and 41 percent in value compared with 1974. California was the only producing State. Pacific Coast landings of sand shrimp, fished commercially only in Oregon, were 20,000 pounds valued at $\$ 30,000$.

Acknowledgments. The following organizations collected data or supplied narrative material for this section: Alaska Department of Fish and Game, Washington Department of Fisheries, Oregon Fish Commission, Calif ornia Department of Fish and Game, and the Pacific Marine Fisheries Commission. 


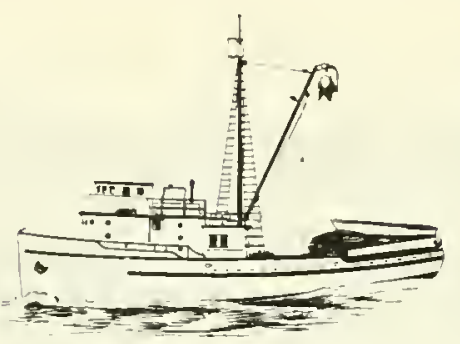

PACIFIC COAST STATES

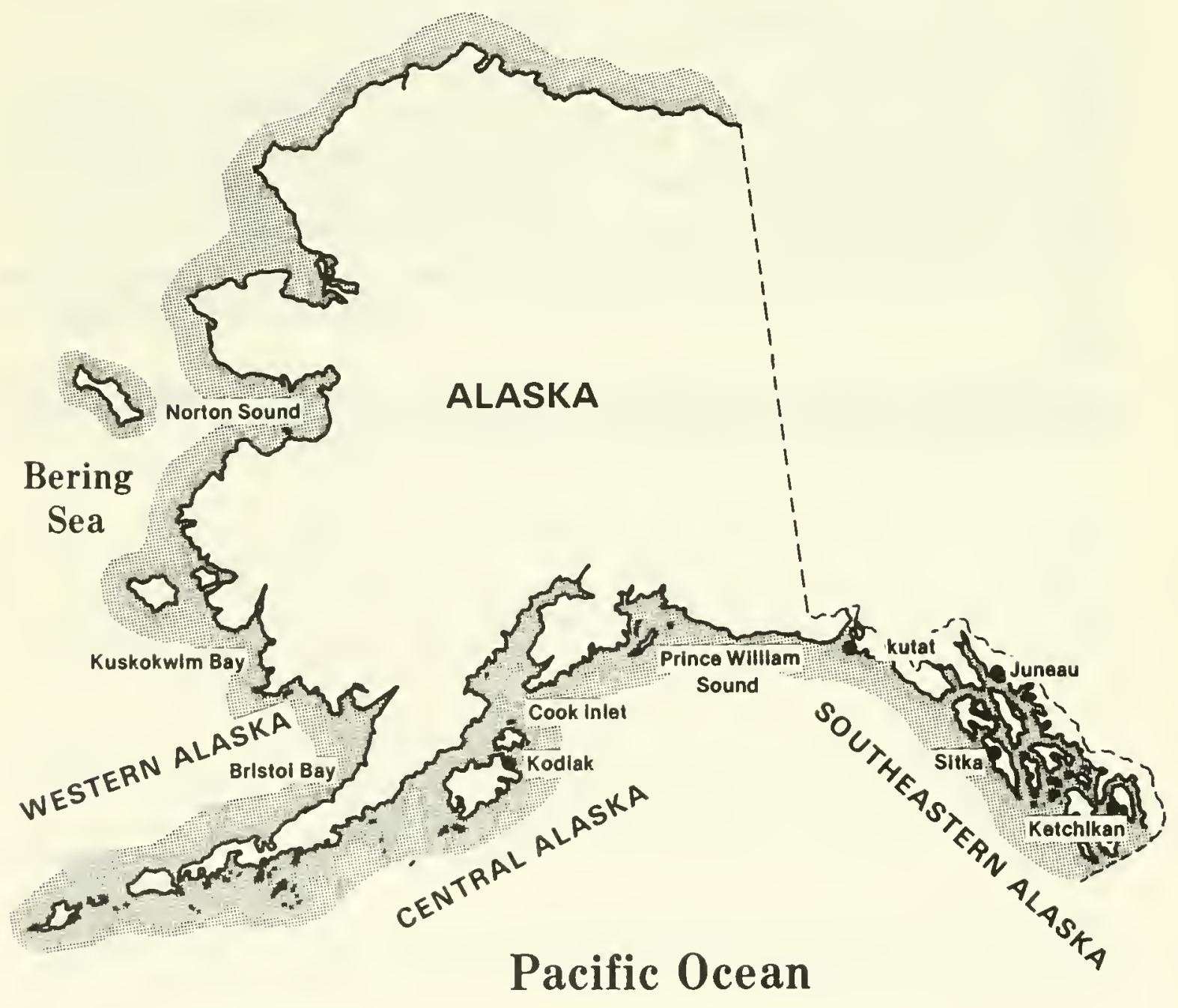




\section{PACIFIC COAST FISHERIES}

\section{PACIFIC COAST STATES - Continued}

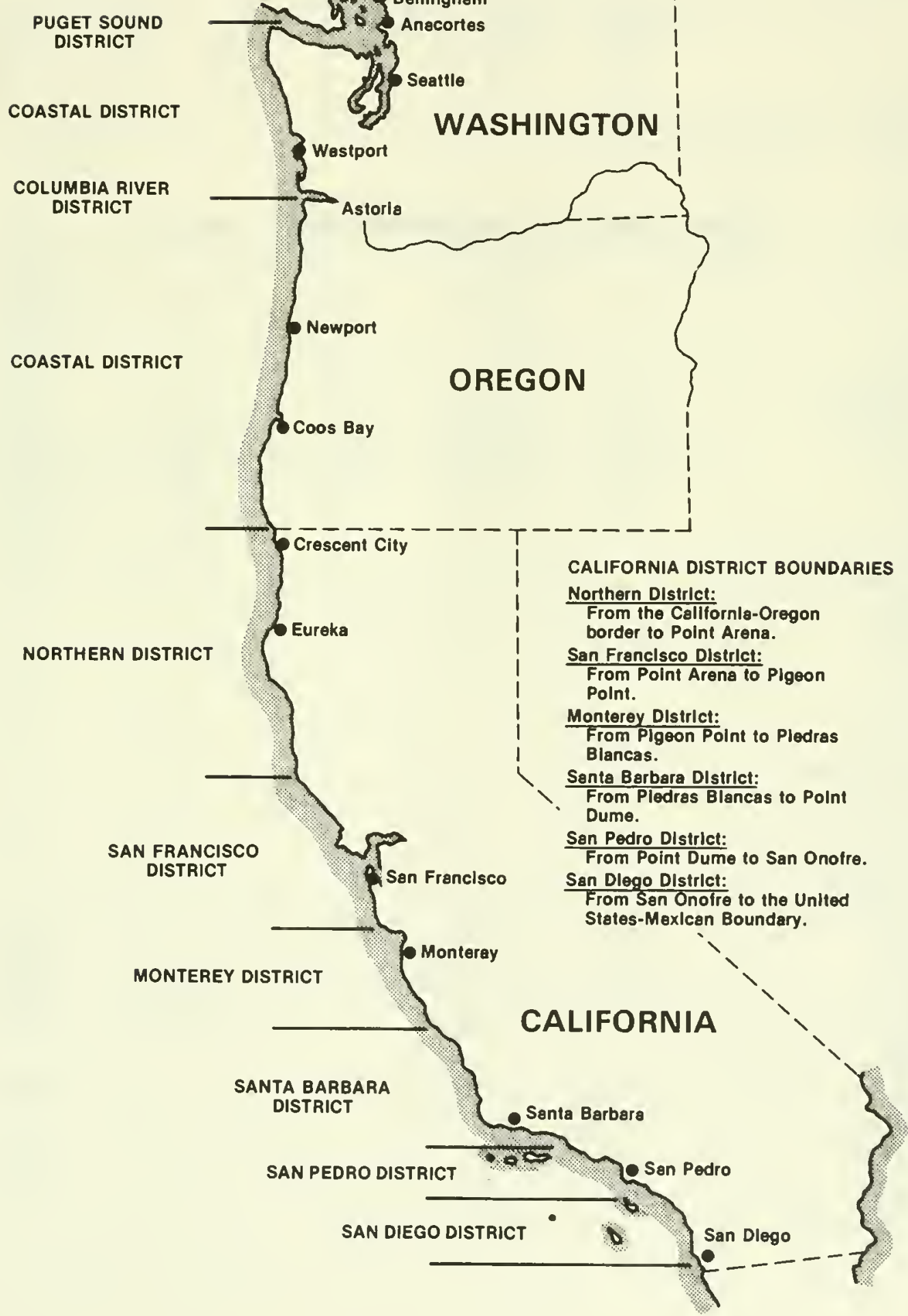


SECTIONAL SUMMARIES

SUMMARY OF LANDINGS, 1975

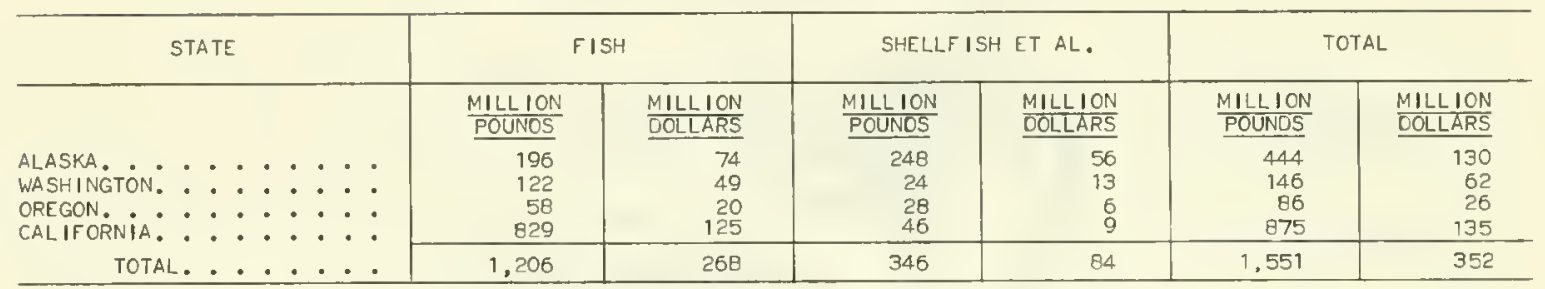

NOTE: TAELES MAY NOT ADO BECAUSE OF ROUNOING.

\section{SUMMARY OF OPERATING UNITS, 1975}

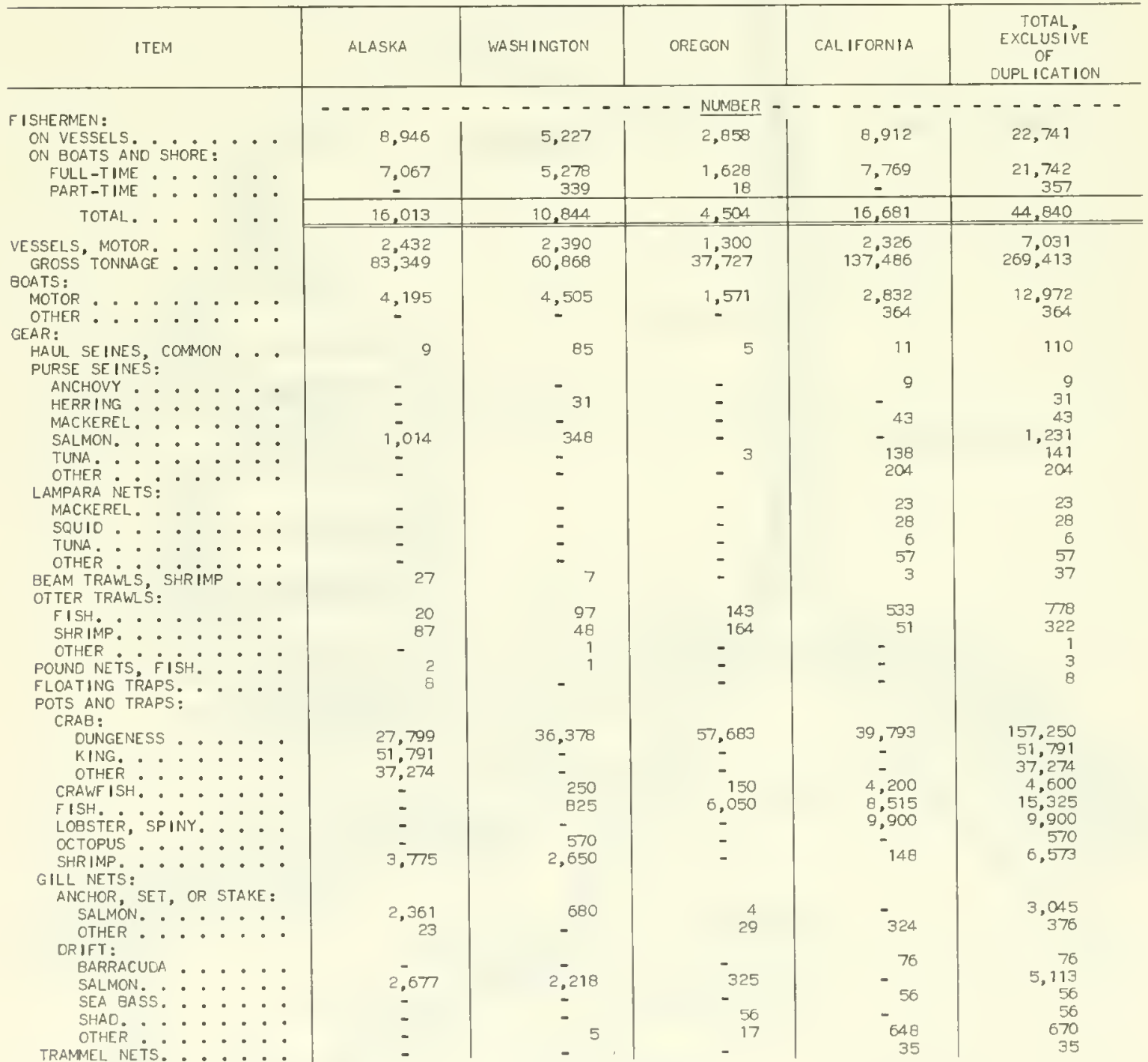

SEE FOOTNOTE AT ENO OF TABLE.

(CONT INUEO ON NEXT PAGE) 
SUMMARY OF OPERATING UNITS, 1975 - Continued

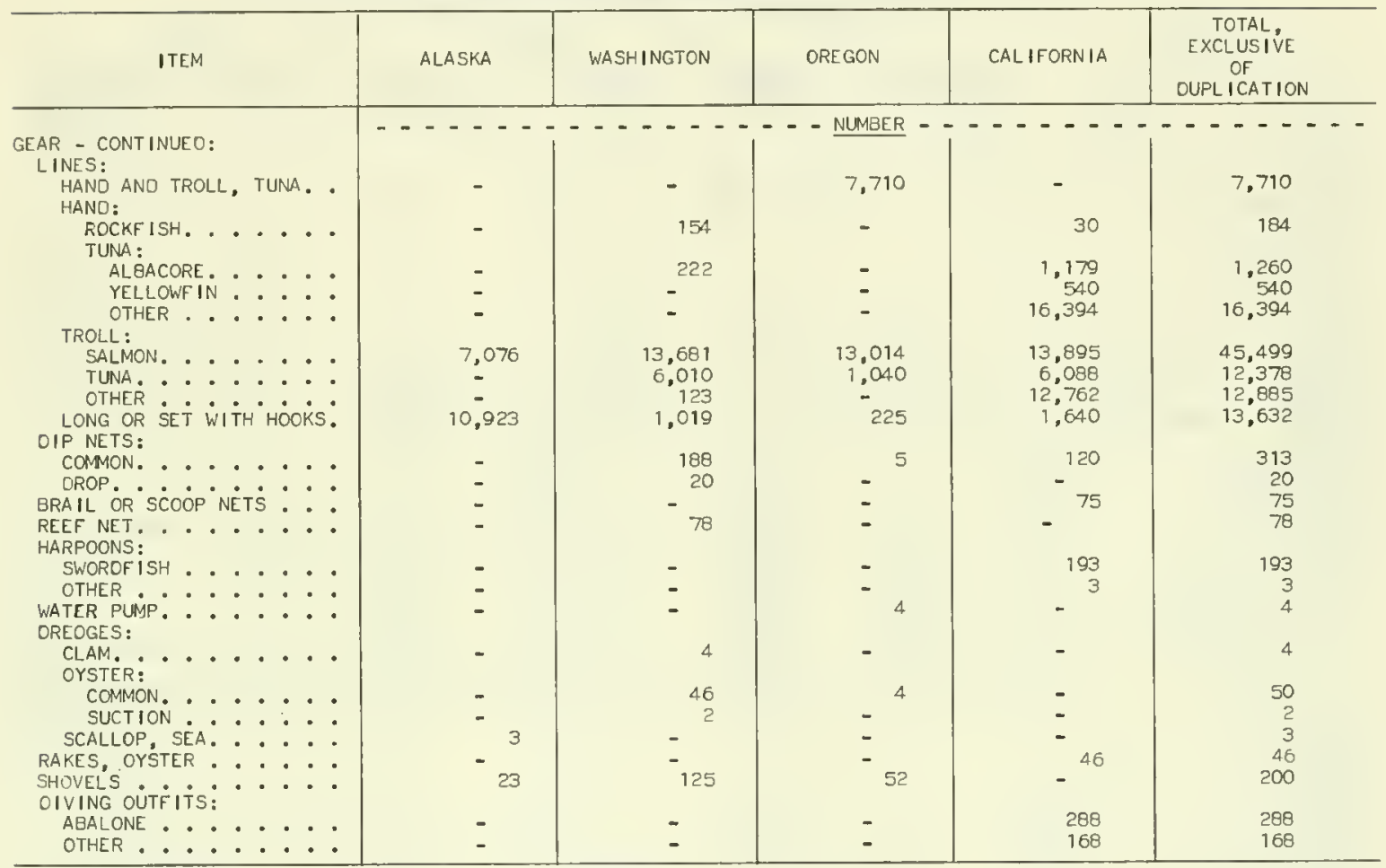

NOTE:--HAUL SE INES IN ALASKA HAVE OEEN INCLUOEO WITH PURSE SEINES. 
LANDINGS BY STATES, 1975

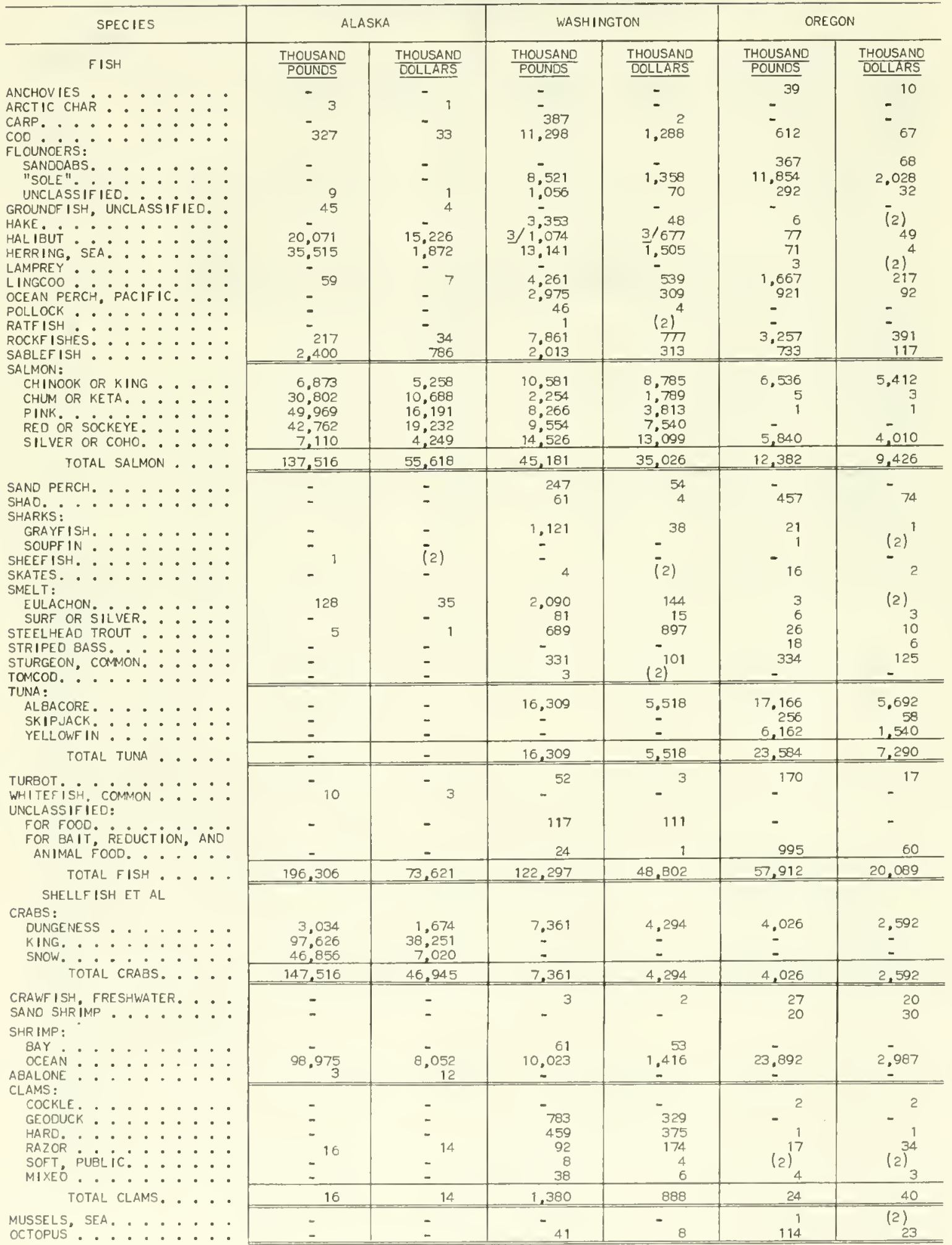


LANDINGS BY STATES, 1975 - Continued

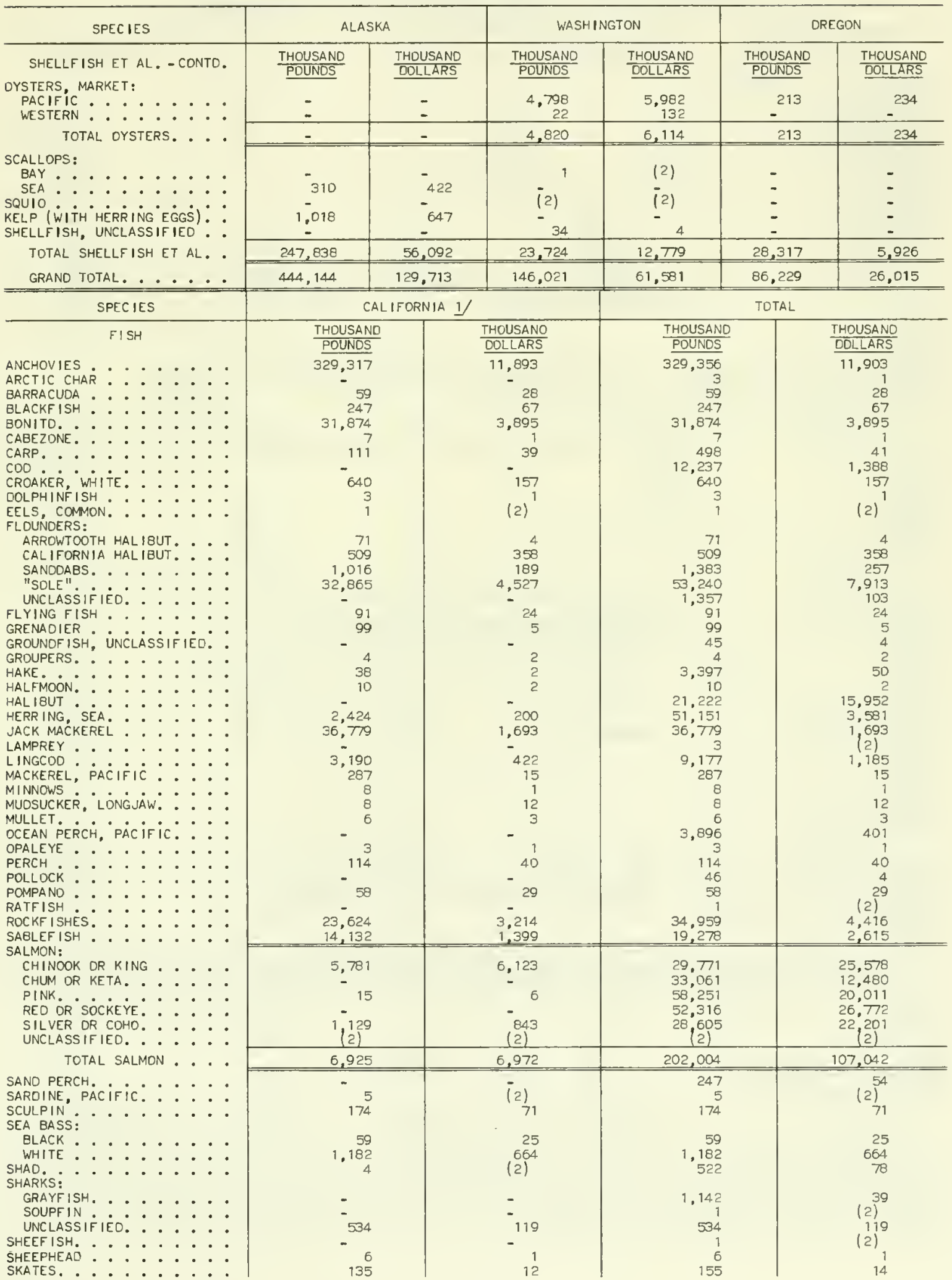


LANDINGS BY STATES, 1975 - Continued

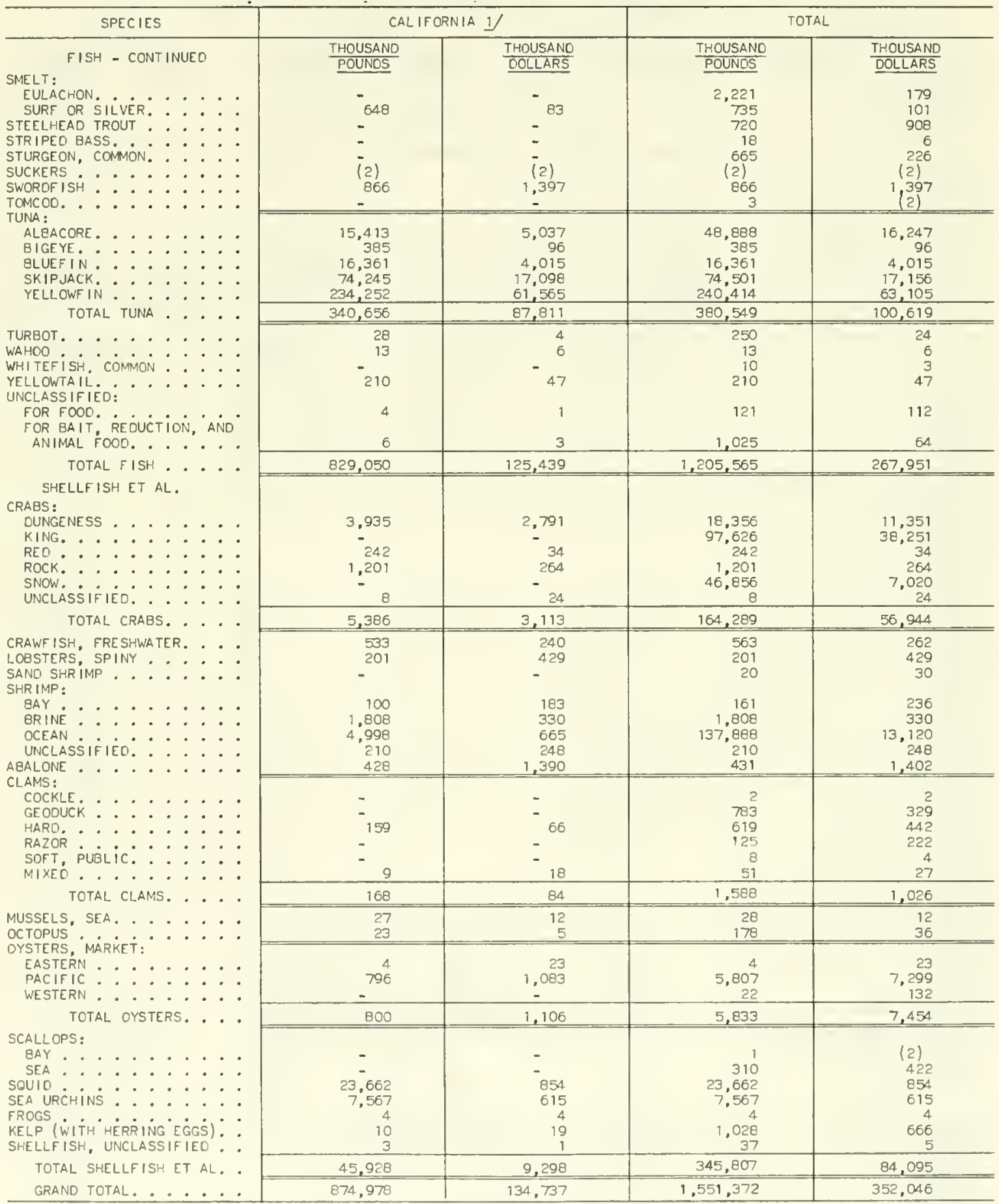

$1 /$ INCLUOES THE CATCH TAKEN OFF LATIN AMERICA AND LANOEO AT, CALIFORNIA PORTS. 2/ LESS THAN 500 POUNOS OR \$5OO. 3) HALIBUT IN WASHINGTON IS SHOWN IN ORESSED WEIGHT (ROUNO WE IGHT IS $1,428,000$ POUNDS VALUED AT \$1,015,902). NOTE:--CATCH STATISTICS FOR ALASKA, WASHINGTON, ANO OREGON ARE SHOWN IN ROUNO WE IGHT. WHILE THOSE FOR CALIFORNIA ARE SHOWN IN WEIGHTS AS LANDEO, EXCEPT FOR SHELL MOLLUSKS. IN ALL STATES, ABALONE, CLAMS, OYSTERS, ANO SCALLOPS ARE REPORTEO IN WEIGHT OF TOTAL MEATS. ALASKA DATA INCLUDE THE CATCH OF HALIBUT, ROCKFISHES, AND SABLEFISH LANDEO BY U.S. VESSELS AT BRITISH COLUMEIA PORTS. 
SUMMARY OF PROCESSED PRODUCTS, 1975

\begin{tabular}{|c|c|c|c|c|}
\hline & Item & Unit & Quantity & Doliars \\
\hline \multirow{3}{*}{$\begin{array}{l}\text { Fresh } \\
\text { Frozen } \\
\text { Canned }\end{array}$} & & & - - Thousands & $-\quad--$ \\
\hline & - & $\begin{array}{l}\text { Pounds } \\
\text { do }\end{array}$ & $\begin{array}{r}38,900 \\
139,952\end{array}$ & $\begin{array}{r}37,223 \\
206,260\end{array}$ \\
\hline & 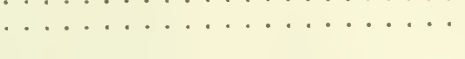 & $\begin{array}{l}\text { Standard } \\
\text { cases }\end{array}$ & 20,302 & 514.441 \\
\hline \multirow[t]{2}{*}{$\begin{array}{l}\text { Cured } \\
\text { Industrial }\end{array}$} & 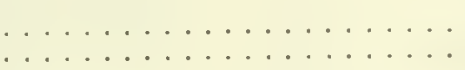 & $\begin{array}{l}\text { Pounds } \\
\text { - }\end{array}$ & 10,497 & $\begin{array}{l}26,774 \\
50,514\end{array}$ \\
\hline & Total $\ldots \ldots \ldots \ldots \ldots$ & - & - & 835,211 \\
\hline
\end{tabular}

Note: Totals are correct; figures do not add because of rounding.

VALUE OF PROCESSED PRODUCTS, BY STATES, 1975

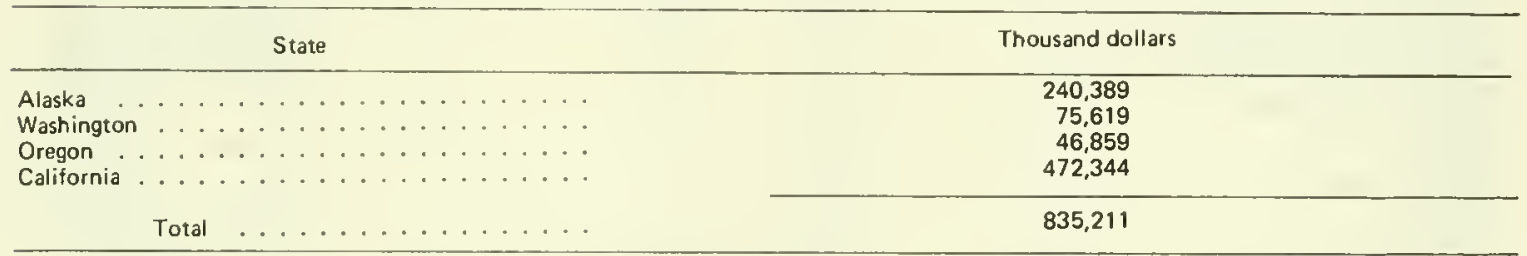

\section{PROCESSING AND WHOLESALE ESTABLISHMENTS AND EMPLOYMENT, 1975}

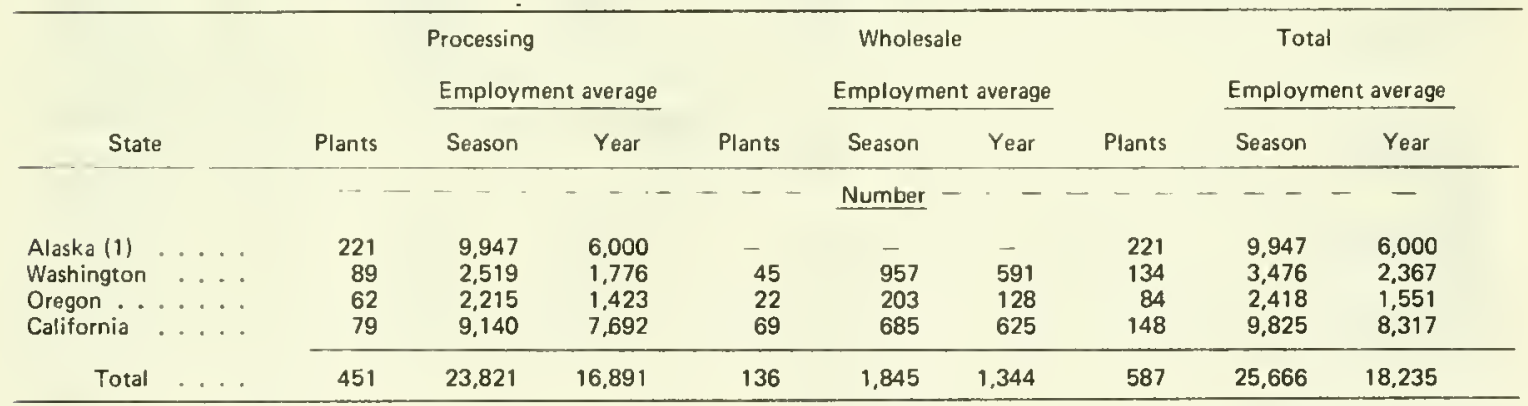

(1) Data estimated for average for year.

Note:--Employment is reported by each plant for each month for the payroll period that includes the 12th of the month. Employment for the season is based on the greatest number of employees working during the payroll period that included the 12th of each month. Employment for the year is obtained by adding the number of employees recorded as working during the payroll period that included the 12th of each month, and dividing by 12 . 
PROCESSED FISHERY PRODUCTS, 1975

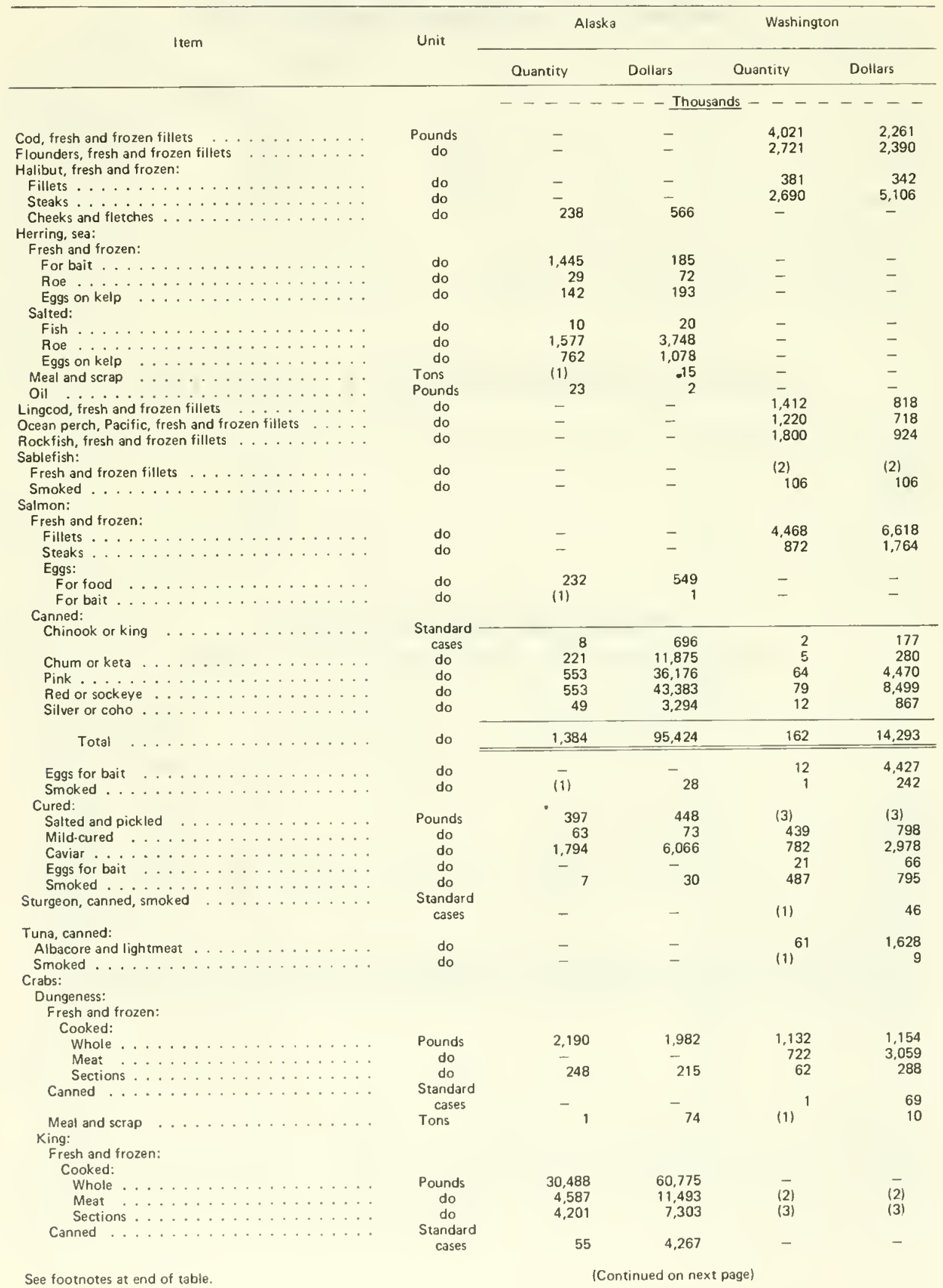


PROCESSED FISHERY PRODUCTS, 1975 - Continued

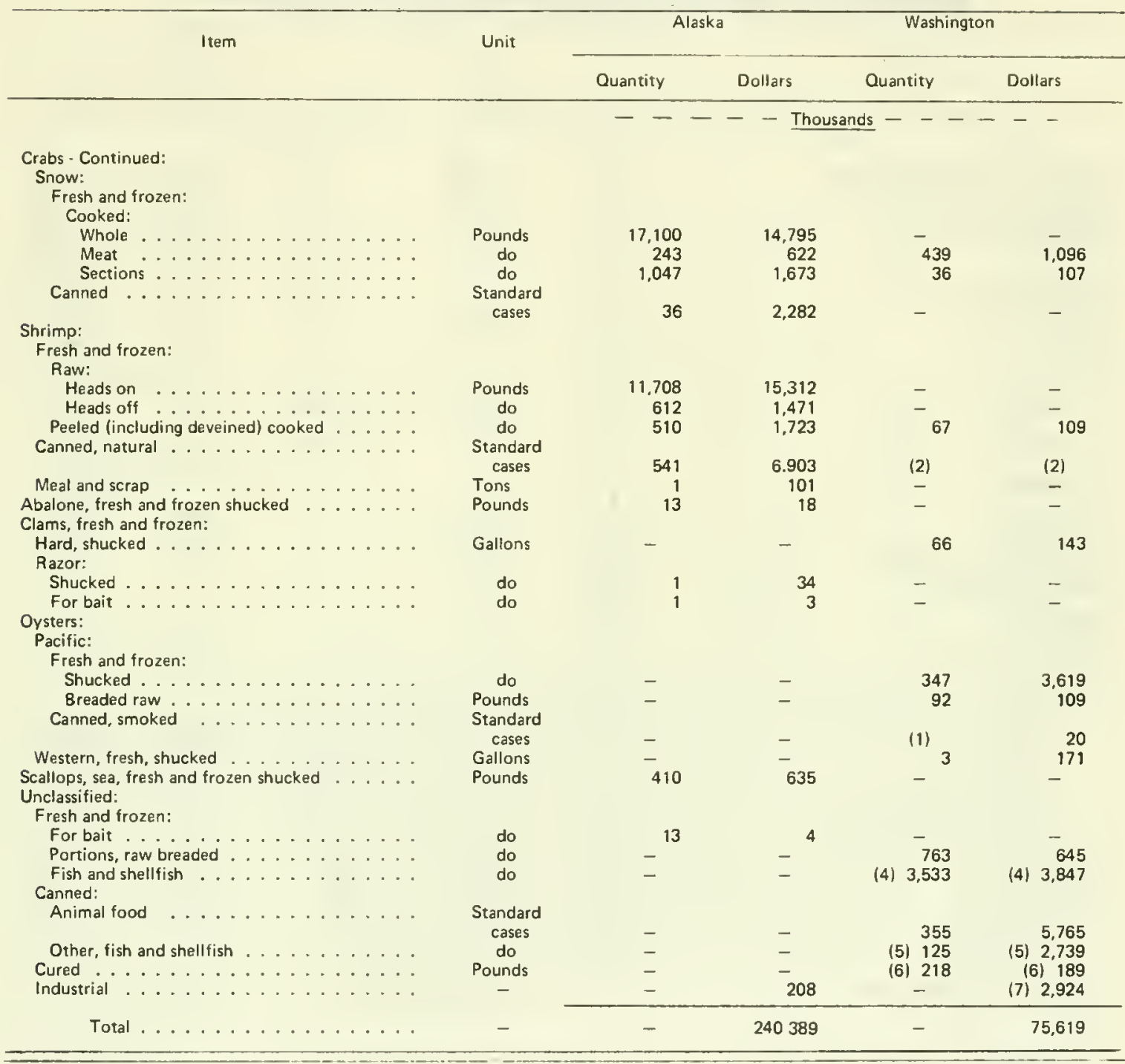

Item

Anchovy:

Meal and scrap .................. Tons

Cod, fresh and frozen fillets

Flounders, fresh and frozen fillets

Halibut, fresh and frozen:

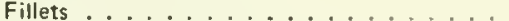

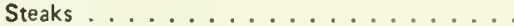

Smoked

Herring sea, fresh and frozen, for bait

Lingcod, fresh and frozen fillets

Mackerel, jack, canned natural
Unit

Oregon

California

Quantity Dollars Quantity Dollars

See footnotes at end of table.

\section{Pounds}

do
do
do
do
do
do
do
Standard
cases

$\begin{array}{ll}- & - \\ -92 & - \\ 3,214 & 39117 \\ (8) & (8) \\ (8) & (8) \\ - & - \\ - & - \\ 514 & 373 \\ - & -\end{array}$

28
12,857
-
6,753
64
773
44
1,049
757
216

6.559

1,547

$-$

155

1,617

77

215

468

(Continued on next page) 


\section{PROCESSED FISHERY PRODUCTS, 1975 - Continued}

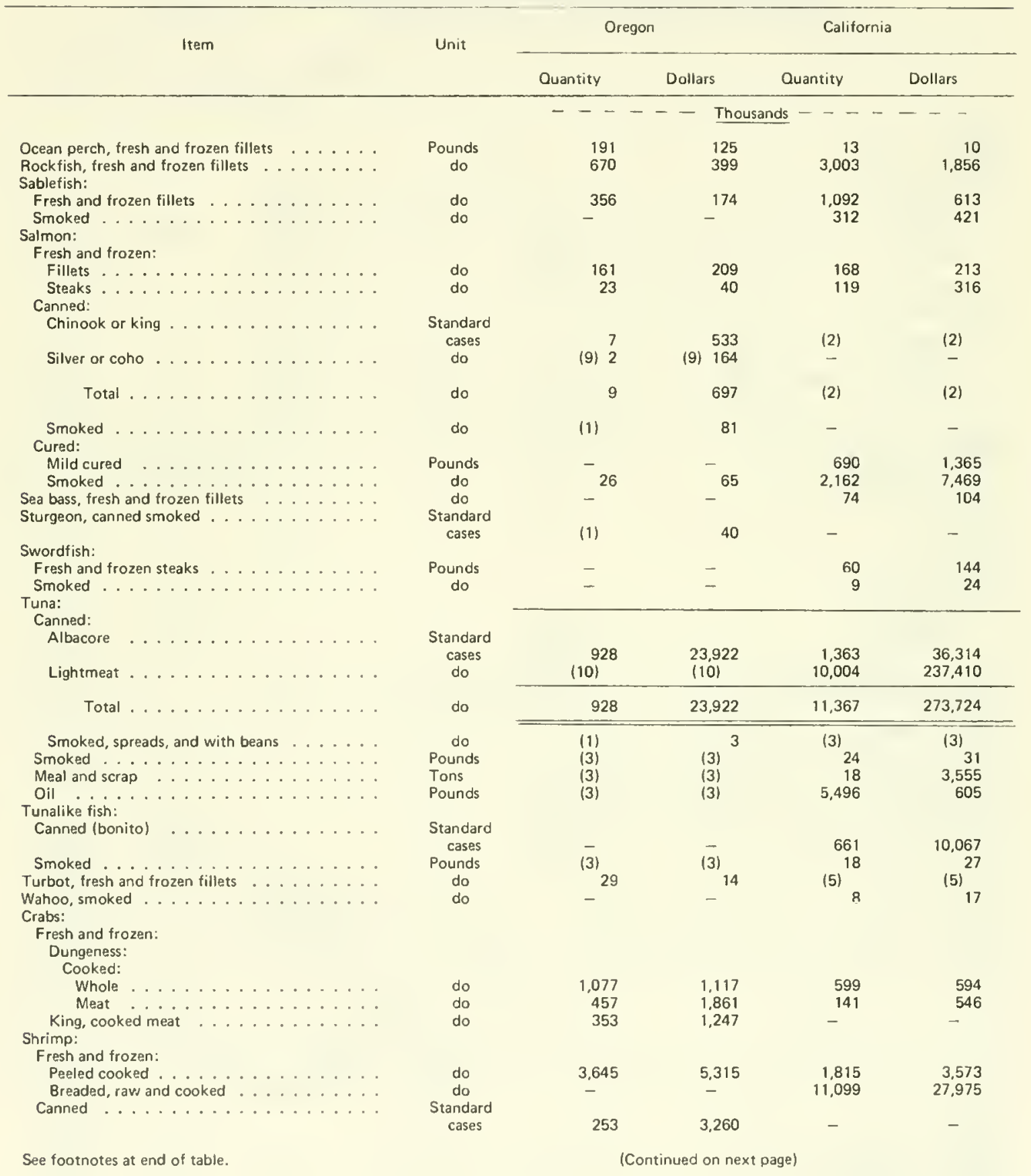


PROCESSED FISHERY PRODUCTS, 1975 - Continued

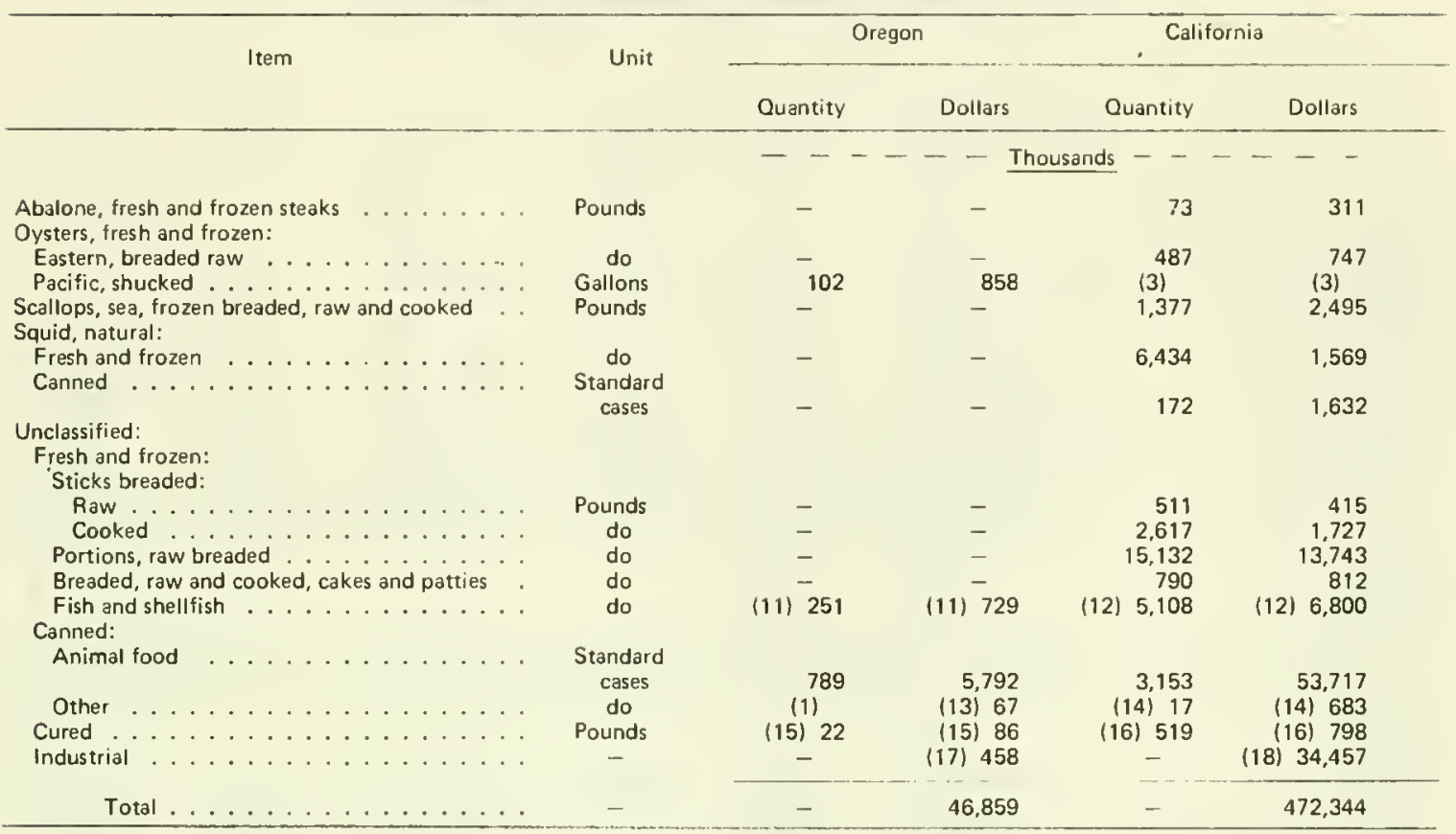

(1) Less than $500 \mathrm{lb}, 500$ tons, or 500 standard cases. (2) Included with Oregon. (3) Included with unclassified. (4) Includes shark fillets: dressed, pond-raised salmon and trout; king crab sections; shrimp, (cooked whole), and breaded (raw); shucked geoduck clams; sea scallop meats breaded (raw and cooked); fish sticks breaded (raw and cooked); fish portions breaded (cooked) and unbreaded; and unclassified patties (cooked). (5) Includes canned salmon (paste); shad (smoked), and (roes); clam (chowder), and (in the shell); razor clams, (whole, minced and smoked); and oyster (stews). (6) Includes salted cod, sablefish, salmon, and halibut (smoked). (7) Includes the value of herring, and unclassified meal, unclassified oil; salmon, tuna, and unclassified fish ground for animal feed, fish pellets and crab chitosan and chitisin. (8) Included with Washington. (9) includes a small production of chum salmon. (10) The production of lightmeat has been included with albacore. (11) Includes sturgeon fillets; tuna steaks; king crab and snow crab (meat) and shucked razor clams. (12) Includes buffalofish, catfish, king croaker, jack mackerel, Pacific perch, shark, striped bass, sturgeon, turbot, and yellowtail fillets; tuna steaks; anchovies and cod for bait; cod paste (surimi); breaded (raw) smelt; skate wings; crab cocktails (refrigerated); spiny lobsters (cooked whole) and tails (raw); shrimp, raw headless, peeled (raw and cooked), cocktails (refrigerated); shucked abalone, breaded (raw) steaks and patties; dressed octopus; shucked Eastern and Pacific oysters; fish portions breaded cooked; unclassified fish and shellfish in lemon butter sauce, as burgers, fish and chips and cocktails (refrigerated). (13) Includes canned saimon in sauce, pickled shrimp, and oyster stews. (14) Includes canned anchovies and tuna specialties. (15) Includes salmon salted and salmon caviar; smoked sturgeon and tuna. (16) includes salted anchovies, flounders, rockfish and smelt; smoked baraccuda, cod, lingcod, jack mackerel, marlin, sea bass, shad, shark, sturgeon, whitefish, shrimp, and unclassified fish. (17) Includes tuna meal and oil; oyster shell grit and lime; unclassified solubles; and fish ground for animal meat. (18) Includes unclassified meal, tuna and unclassified solubles; liquid fertilizer; fish ground for animal feed; kelp and seaweed products.

Note:--This table will not add because of rounding. Individual State totals are correct. Some of the products may have been processed from raw products imported from another State or a foreign country; therefore, they cannot be correlated directly with landings within the State. Certain items are shown in an intermediate and also a more advanced stage of processing.

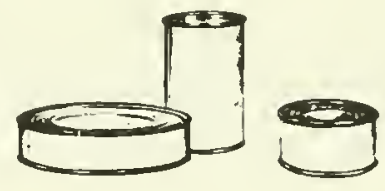


ALASKA

LANDINGS BY DISTRICTS, 1975

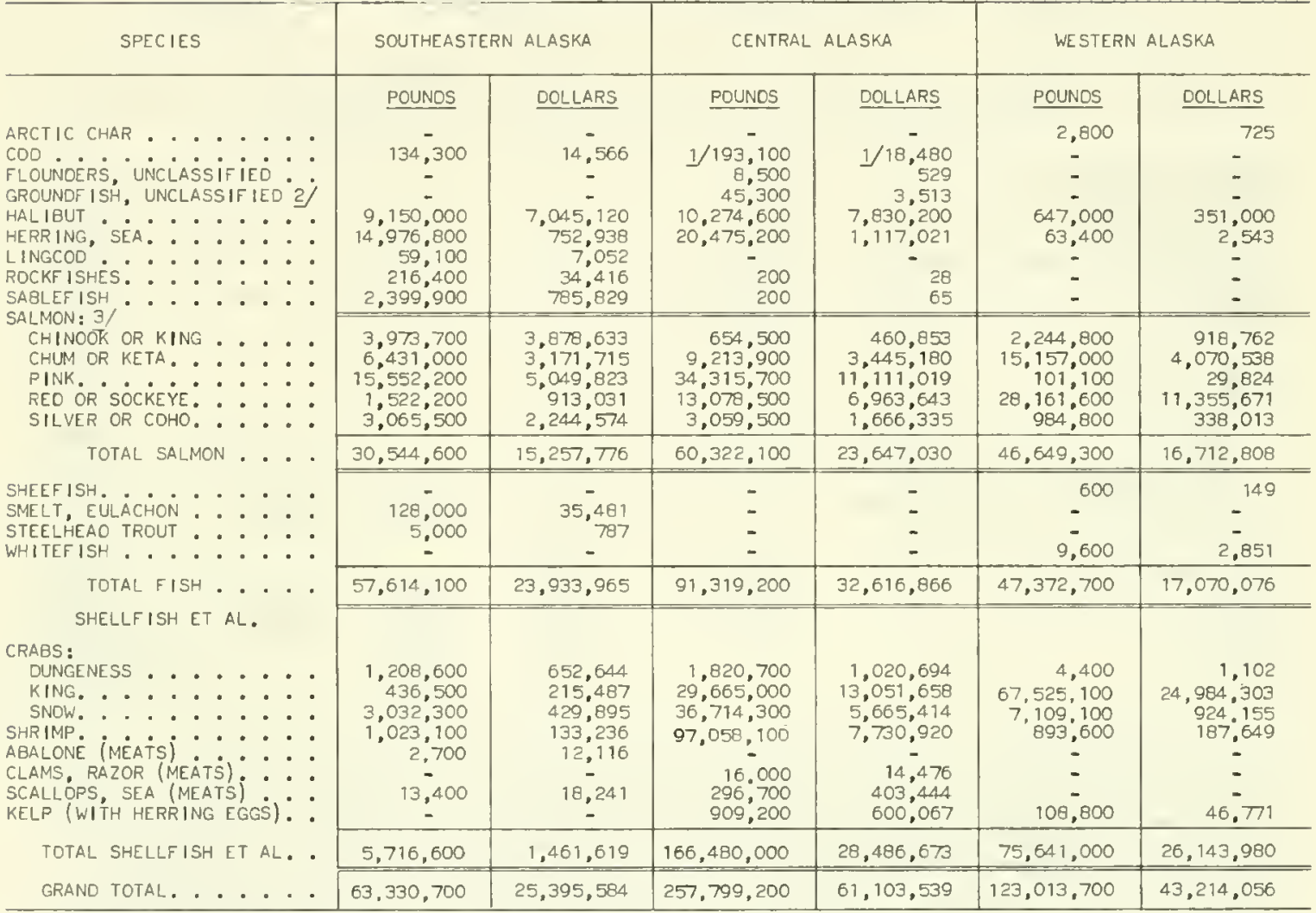

1/ INCLUDES LINGCOD AND TRUE COD.

2) INCLUDES DOVER "SOLE", GULLHEADS, AND MISCELLANEOUS UNINDENTIFIEO SPECIES.

3) THE ROUND WE IGHTS USED IN THE LANDINGS TABLES WERE OBTAINED BY MULTIPLYING NUMEER OF FISH BY THE IR AVERAGE WE IGHT.

NDTE:--THE ABOVE DATA INCLUOE LANOINGS OF HALIBUT, SABLEF ISH, LINGCOD. AND ROCKFISHES BY VESSELS OF U.S. REGISTRY AT BRITISH COLUMBIA PORTS. ROUNO WEIGHTS OF FISH TAKEN BY HALIBUT VESSELS WERE OBTAINED BY MULTIPLYING REPORTED

WE IGHTS, REPRESENT ING POUNDAGE OF FISH EVISCERATED AND WITH HEADS -DFF, BY THE FOLLOWING FACTORS: HALIBUT, 1.33;

SABLEFISH AND ROCKFISHES, 1.43. 


\section{SOUTHEASTERN REGION OF ALASKA OPERATING UNITS BY GEAR, 1975}

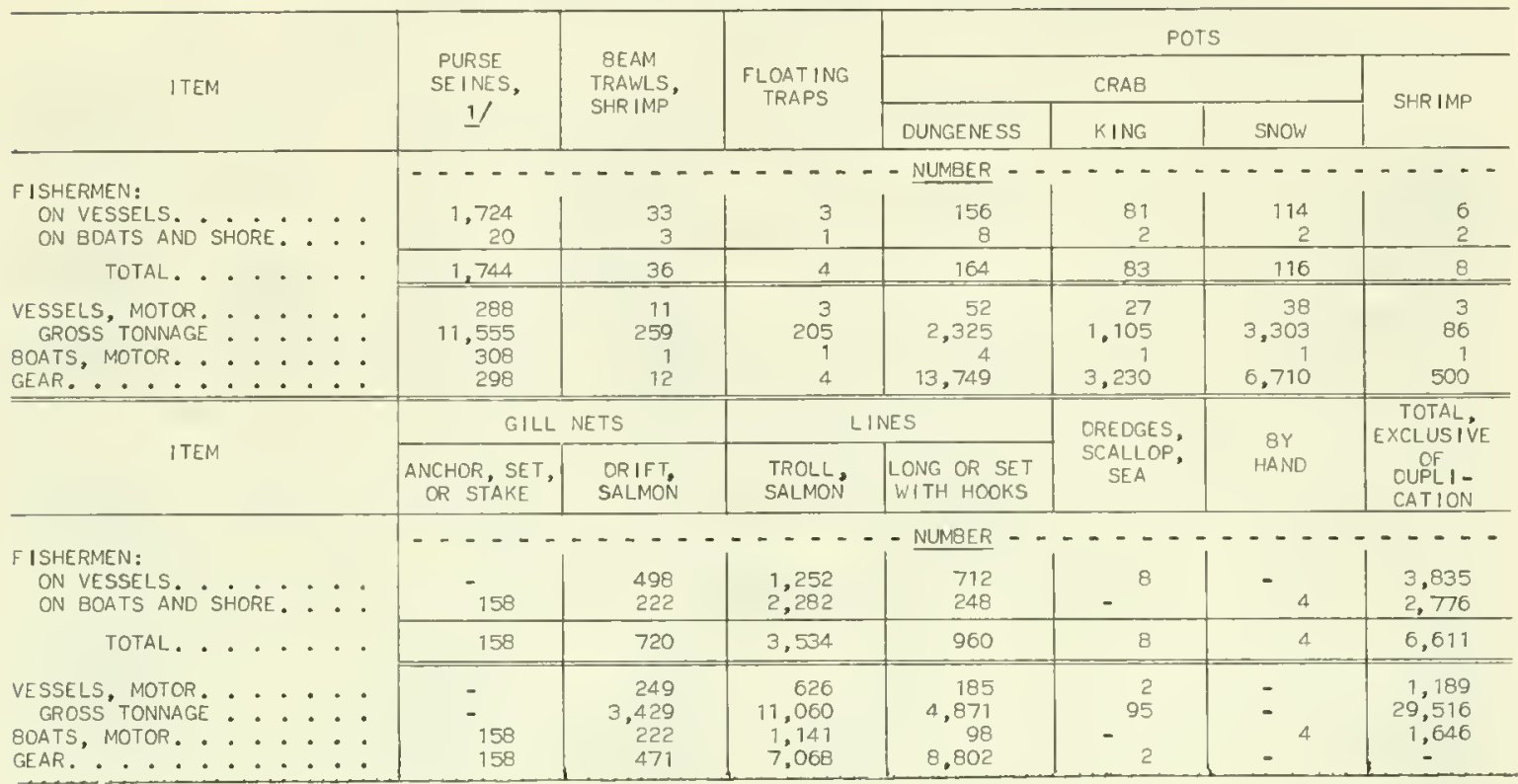

1) INCLUdES HAUL (BEACH) SEINES.

\section{SOUTHEASTERN REGION OF ALASKA LANDINGS OF CATCH BY GEAR, 1975}

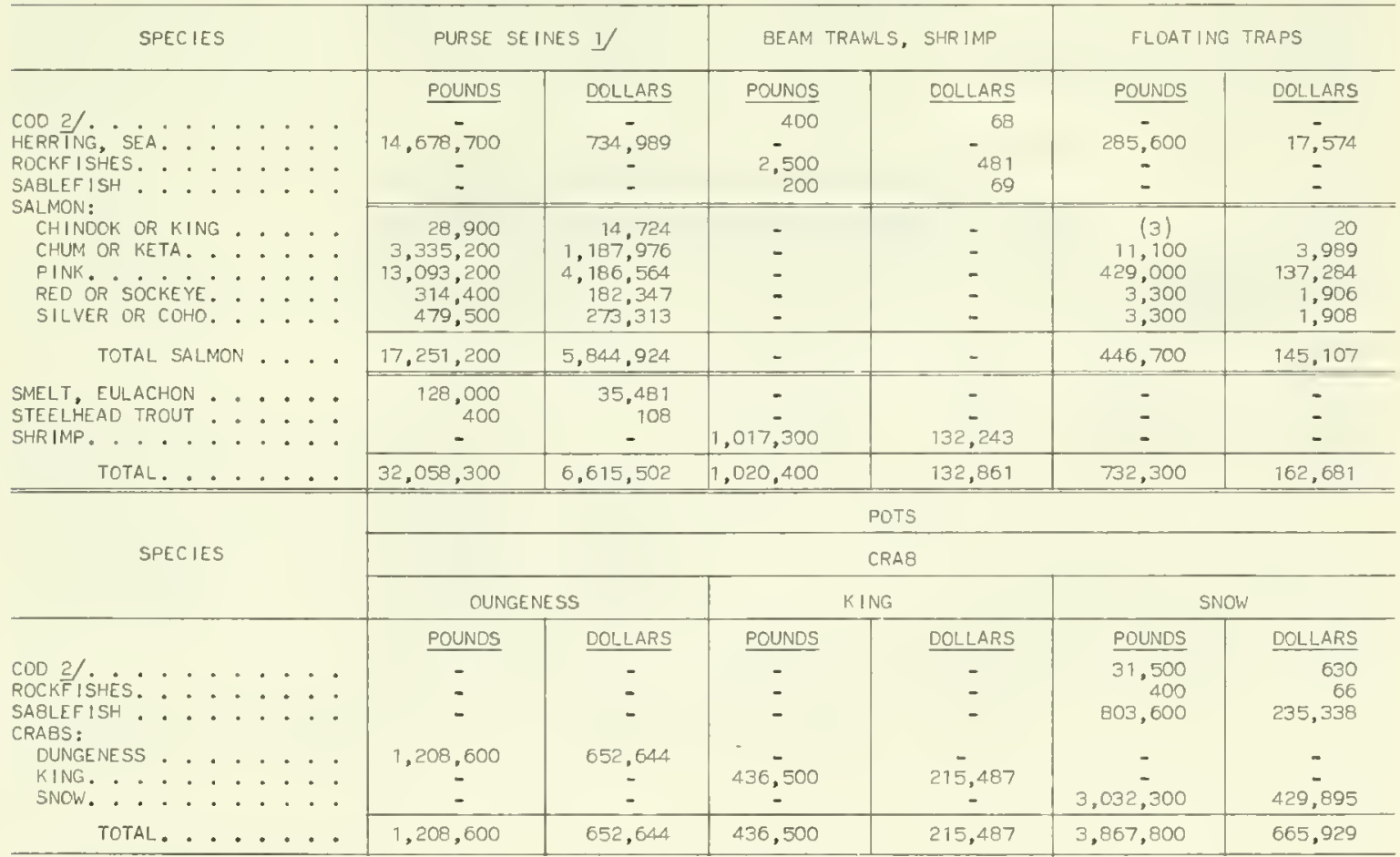




\section{SOUTHEASTERN REGION OF ALASKA} LANDINGS OF CATCH BY GEAR, 1975 - Continued

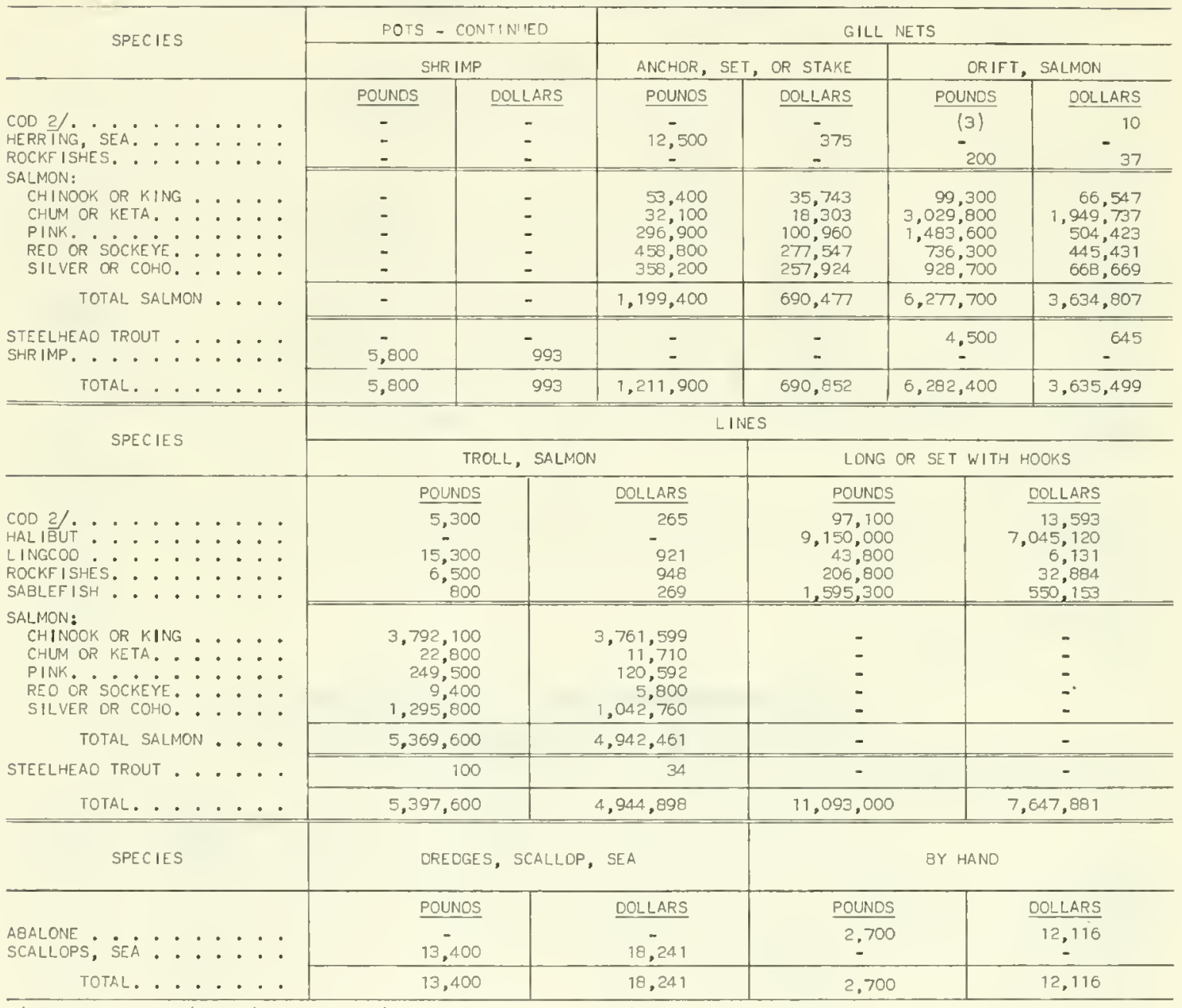

1) INCLUDES HAUL (BEACH) SEINES. 2/ INCLUDES TRUE COO. 3/ LESS THAN 50 POUNDS. 


\section{PACIFIC COAST FISHERIES}

\section{CENTRAL REGION OF ALASKA \\ OPERATING UNITS BY GEAR, 1975}

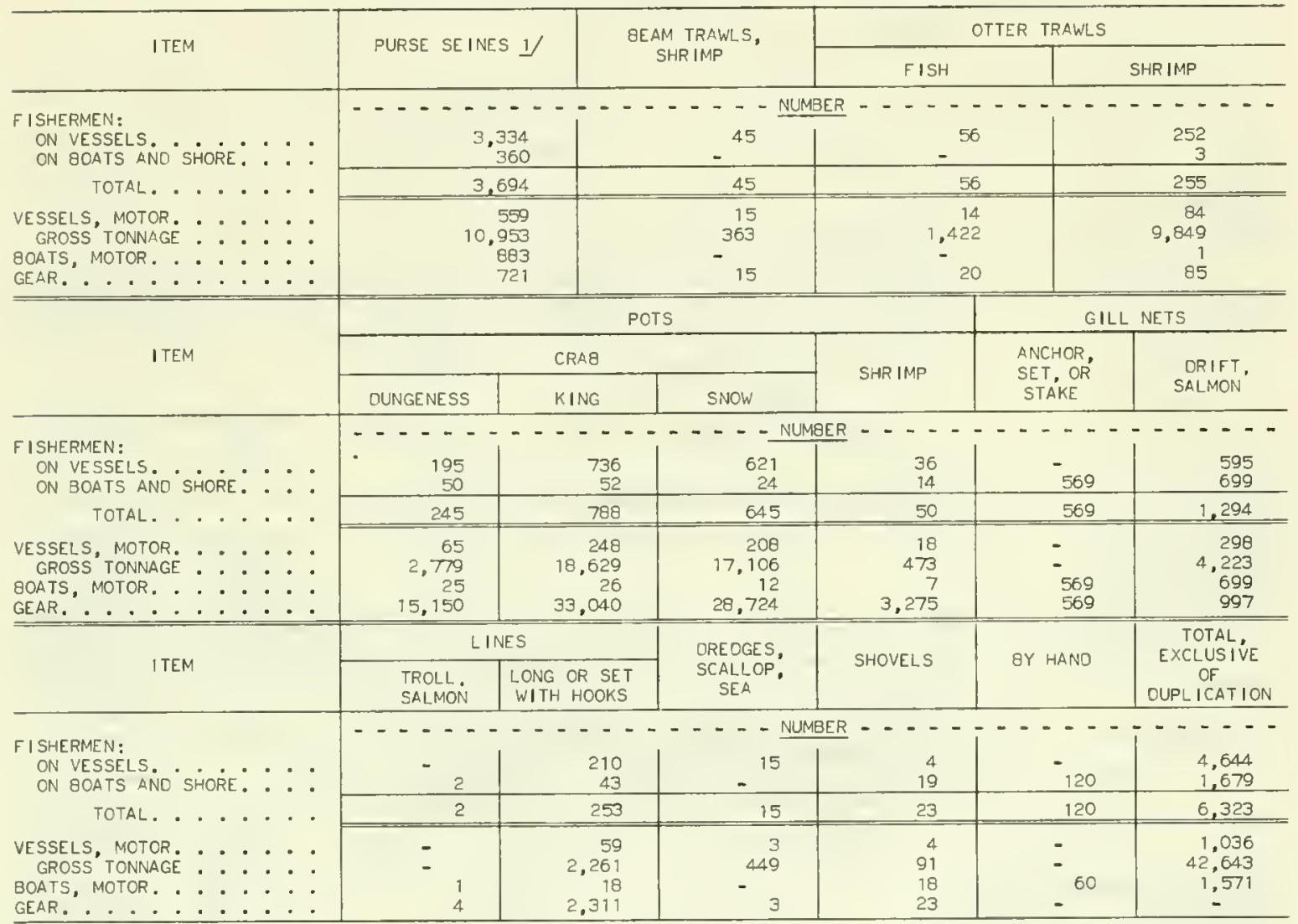

1) INCLUDES HAUL (BEACH) SEINES.

CENTRAL REGION OF ALASKA LANDINGS OF CATCH BY GEAR, 1975

\begin{tabular}{|c|c|c|c|c|c|c|}
\hline \multirow{2}{*}{ SPECIES } & \multirow{2}{*}{\multicolumn{2}{|c|}{ PURSE SEINES $1 /$}} & \multirow{2}{*}{\multicolumn{2}{|c|}{ BEAM TRAWLS, SHRIMP }} & \multicolumn{2}{|c|}{ OTTER TRAWLS } \\
\hline & & & & & \multicolumn{2}{|c|}{ FISH } \\
\hline & POUNDS & DOLLARS & POUNOS & DOLLARS & POUNOS & OOLLARS \\
\hline 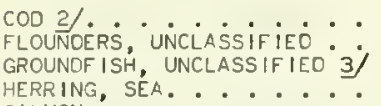 & $20,46 \overline{\bar{z}}, 700$ & $\begin{array}{c}- \\
\vdots \\
1,116,771\end{array}$ & $\begin{array}{r}800 \\
800 \\
2,200 \\
- \\
\end{array}$ & $\begin{array}{r}145 \\
145 \\
423 \\
-\quad \\
\end{array}$ & $\begin{array}{r}95,400 \\
7,700 \\
24,400 \\
- \\
\end{array}$ & $\begin{array}{r}4.769 \\
384 \\
1,222 \\
- \\
\end{array}$ \\
\hline $\begin{array}{l}\text { CHINOOK OR KING }: \cdots \\
\text { CHUM OR KETA. } \\
\text { PINK }: \vdots: \\
\text { REO OR SOCKEYE: } \\
\text { SILVER OR COHO.: }: \vdots:\end{array}$ & $\begin{array}{r}31,600 \\
1,803,000 \\
31,056,300 \\
3,914,700 \\
744,600\end{array}$ & $\begin{array}{r}15,872 \\
703,149 \\
10,006,932 \\
1,931,695 \\
363,064\end{array}$ & $\begin{array}{l}\overline{-} \\
\overline{-} \\
-\end{array}$ & $\begin{array}{l}\bar{z} \\
\bar{z} \\
-\end{array}$ & $\begin{array}{l}- \\
- \\
-\end{array}$ & $\begin{array}{l}\overline{-} \\
\overline{-}\end{array}$ \\
\hline TOTAL SALMON $\cdot \cdots$ & $37,550,200$ & $13,020,712$ & - & - & - & - \\
\hline SHRIMP. . . . . . & - & - & $2,022,100$ & 290,128 & - & - \\
\hline TOTAL. . . . . . & $58,012,900$ & $14,137,483$ & $2,025,900$ & 290.841 & 127,500 & 6,375 \\
\hline
\end{tabular}




\section{CENTRAL REGION OF ALASKA LANDINGS OF CATCH BY GEAR, 1975 - Continued}

\begin{tabular}{|c|c|c|c|c|c|c|}
\hline \multirow{3}{*}{ SPECIES } & \multicolumn{2}{|c|}{ OTTER TRAWLS - CONTINUED } & \multicolumn{4}{|c|}{ Pots } \\
\hline & \multirow{2}{*}{\multicolumn{2}{|c|}{ SHRIMP }} & \multicolumn{4}{|c|}{ CRAB } \\
\hline & & & \multicolumn{2}{|c|}{ OUNGENESS } & \multicolumn{2}{|c|}{ KING } \\
\hline \multirow{3}{*}{$\begin{array}{l}\text { CRABS: } \\
\text { DUNGENESS }: \cdots: \therefore: \\
\text { KING. }: \vdots: \vdots \vdots: \\
\text { SHRIMP: }: \cdots\end{array}$} & POUNOS & OOLLARS & POUNOS & OOLLARS & POUNDS & DOLLARS \\
\hline & $\frac{-}{94,795,000}$ & $7,423,919$ & $\begin{array}{c}1,820,700 \\
- \\
-\end{array}$ & $\begin{array}{c}1,020,694 \\
-\end{array}$ & $29,66 \overline{-}, 000$ & $13,051,658$ \\
\hline & $94,795,000$ & $7,423,919$ & $1,820,700$ & $1,020,694$ & $29,665,000$ & $13,059,658$ \\
\hline \multirow{3}{*}{ SPECIES } & \multicolumn{4}{|c|}{ POTS - CONTINUED } & \multicolumn{2}{|c|}{ GILL NETS } \\
\hline & \multicolumn{2}{|c|}{ CRAB - CONTINUED } & \multirow{2}{*}{\multicolumn{2}{|c|}{ SHRIMP }} & \multirow{2}{*}{\multicolumn{2}{|c|}{ ANCHOR, SET, OR STAKE }} \\
\hline & \multicolumn{2}{|c|}{ SNOW } & & & & \\
\hline $\begin{array}{l}\text { HERR ING, SEA. } \cdot \cdots \cdot \cdots \\
\text { CRABS, SNOW }: \cdot \cdots\end{array}$ & $\frac{\text { POUNDS }}{36,71 \overline{4}, 300}$ & $\begin{array}{l}\frac{\text { DOLLARS }}{-} \\
5,66 \overline{5}, 414\end{array}$ & $\begin{array}{c}\text { POUNOS } \\
- \\
-\end{array}$ & $\begin{array}{c}\text { DOLLARS } \\
- \\
-\end{array}$ & $\begin{array}{c}\frac{\text { POUNDS }}{12.500} \\
-\end{array}$ & $\begin{array}{c}\text { DOLLARS } \\
-\end{array}$ \\
\hline $\begin{array}{l}\text { SALMON: } \\
\text { CHINOOK OR KING }: \vdots: \\
\text { CHUM OR KETA.: } \\
\text { PINK }: \vdots: \text { : } \\
\text { REO OR SOCKEYE: }: \vdots: \\
\text { SILVER OR COHO: }: \therefore:\end{array}$ & $\begin{array}{l}\overline{-} \\
z \\
-\end{array}$ & $\begin{array}{l}- \\
- \\
-\end{array}$ & $\begin{array}{l}= \\
= \\
=\end{array}$ & $\begin{array}{l}- \\
\overline{-} \\
-\end{array}$ & $\begin{array}{r}117,700 \\
569,800 \\
1,998,000 \\
2,375,300 \\
1,009,100\end{array}$ & $\begin{array}{r}57,075 \\
207,881 \\
686,321 \\
7,455,245 \\
551,336\end{array}$ \\
\hline TOTAL SALMON $\ldots$ & - & - & - & - & $6,061,900$ & $2,957,858$ \\
\hline \multirow{2}{*}{$\underset{\text { TOTAL }}{\text { SHRIMP. . . } \ldots \cdots}$} & - & - & 241,000 & 16,873 & - & - \\
\hline & $36,714,300$ & $5,665,414$ & 241,000 & 16,873 & $6,074,400$ & $2,958,108$ \\
\hline \multirow{2}{*}{ SPECIES } & \multicolumn{2}{|c|}{ GILL NETS - CONTINUED } & \multicolumn{4}{|c|}{ LINES } \\
\hline & \multicolumn{2}{|c|}{ DRIFT, SALMON } & \multicolumn{2}{|c|}{ TROLL, SALMON } & \multicolumn{2}{|c|}{ LONG OR SET WITH HOOKS } \\
\hline \multirow{3}{*}{ 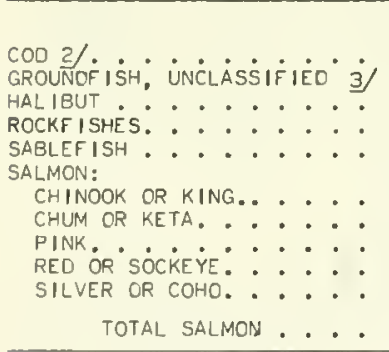 } & $\begin{array}{l}\text { POUNOS } \\
- \\
- \\
- \\
-\end{array}$ & $\begin{array}{c}\text { DOLLARS } \\
- \\
- \\
- \\
-\end{array}$ & $\begin{array}{l}\text { POUNOS } \\
100 \\
- \\
-\end{array}$ & $\begin{array}{c}\text { DOLLARS } \\
- \\
- \\
-\end{array}$ & $\begin{array}{r}\text { POUNOS } \\
96,800 \\
18,700 \\
10,274,600 \\
100 \\
200 \\
\end{array}$ & $\begin{array}{r}\text { DOLLARS } \\
13,556 \\
1,868 \\
7,830,200 \\
16 \\
65 \\
\end{array}$ \\
\hline & $\begin{array}{r}505,200 \\
6,849,100 \\
1,261,400 \\
6,788,500 \\
1,304,800 \\
\end{array}$ & $\begin{array}{r}387,906 \\
2,534,150 \\
417,766 \\
3.576,703 \\
751,256 \\
\end{array}$ & $\begin{array}{l}- \\
= \\
1.000 \\
\end{array}$ & $\begin{array}{l}= \\
= \\
679\end{array}$ & $\begin{array}{l}= \\
= \\
-\end{array}$ & $\begin{array}{l}= \\
= \\
=\end{array}$ \\
\hline & $16,709,000$ & $7,667,781$ & 1,200 & 701 & $10,390,400$ & $7.845,705$ \\
\hline SPECIES & \multicolumn{2}{|c|}{ DREOGES, SCALLOP, SEA } & \multicolumn{2}{|c|}{ SHOVELS } & \multicolumn{2}{|c|}{ BY HAND } \\
\hline 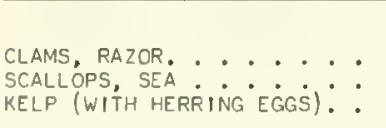 & $\begin{array}{l}\text { POUNDS } \\
29 \overline{-}, 700 \\
-\end{array}$ & $\frac{\text { DOLLARS }}{40 \overline{3}, 444}$ & $\begin{array}{c}\text { POUNOS } \\
16.000 \\
=\end{array}$ & $\begin{array}{c}\text { DOLLARS } \\
\begin{array}{c}14.476 \\
-\end{array}\end{array}$ & $\begin{array}{c}\text { POUNOS } \\
- \\
909,200\end{array}$ & $\begin{array}{c}\frac{\text { OOLLARS }}{-} \\
- \\
600,067\end{array}$ \\
\hline TOTAL. . . . . & 296,700 & 403,444 & 16,000 & 14,476 & 909,200 & 600,067 \\
\hline
\end{tabular}

1) INCLUDES hAUL (BEACH) SEINES. 2) INCLUOES LINGCOD ANO TRUE COD. 3/ INCLUOES DOVER "SOLE", BULLHEADS, AND MISCELLANEOUS UNIOENTIFIED SPECIES. 


\section{WESTERN REGION OF ALASKA OPERATING UNITS BY GEAR, 1975}

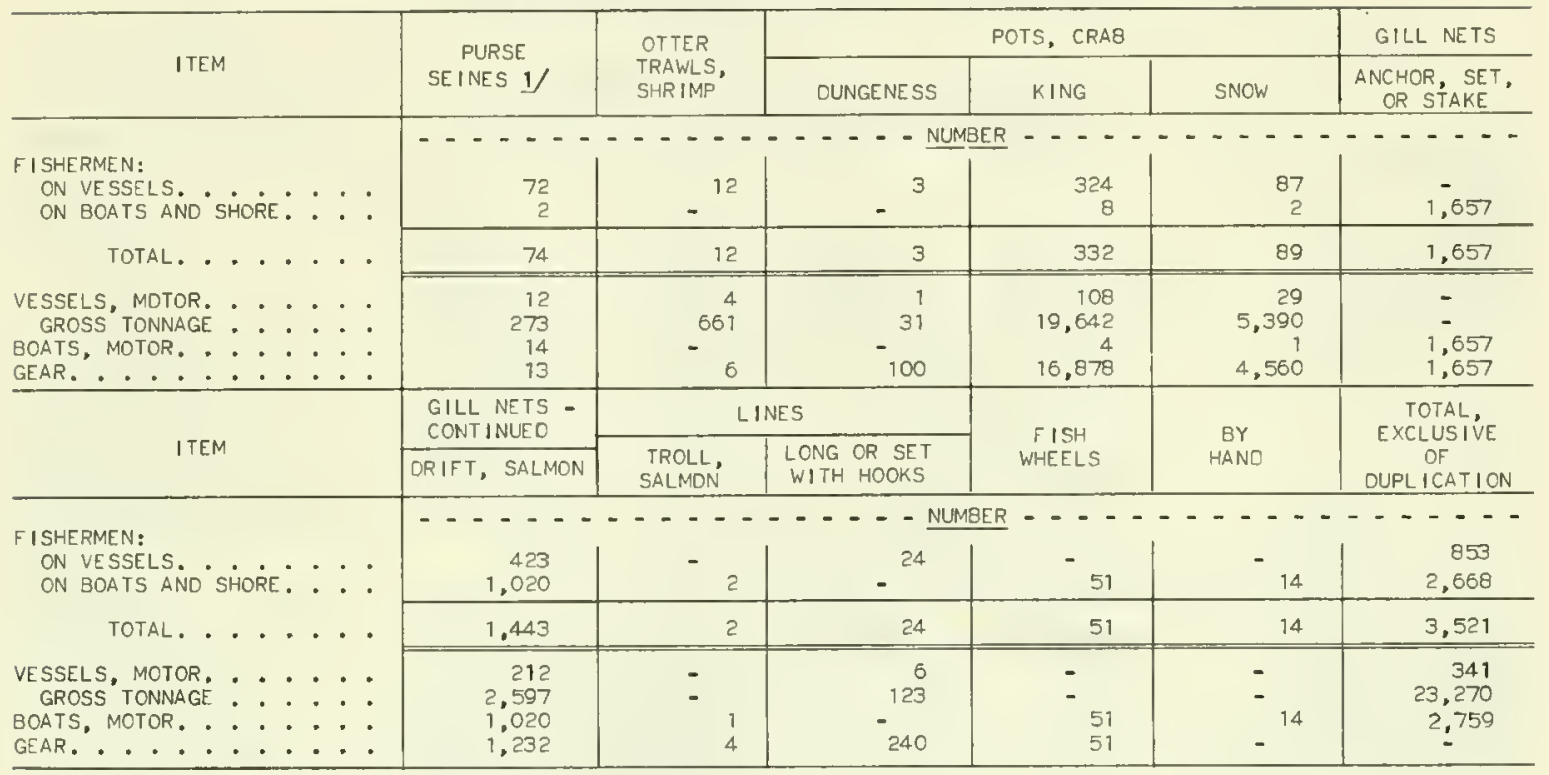

1 inCludes haNo PURSE SEINES AND haUl (BEACH) SEINES.

\section{WESTERN REGION OF ALASKA LANDINGS OF CATCH BY GEAR, 1975}

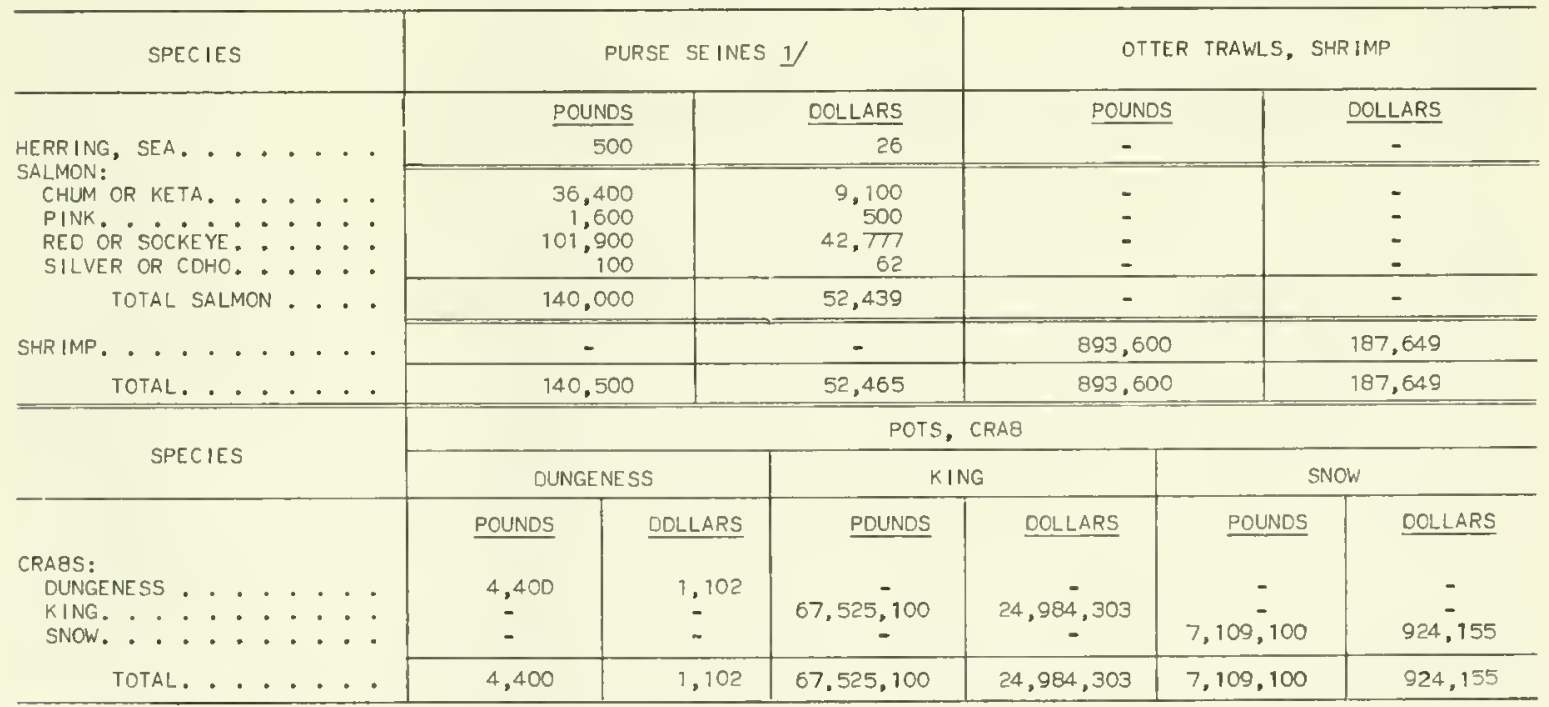


WESTERN REGION OF ALASKA

LANDINGS OF CATCH BY GEAR, 1975 - Continued

\begin{tabular}{|c|c|c|c|c|c|c|c|c|}
\hline \multirow{2}{*}{\multicolumn{3}{|c|}{ SPECIES }} & \multicolumn{4}{|c|}{ GILL NETS } & \multicolumn{2}{|c|}{ LINES } \\
\hline & & & \multicolumn{2}{|c|}{ ANCHOR, SET, OR STAKE } & \multicolumn{2}{|c|}{ DRIFT, SALMON } & \multicolumn{2}{|c|}{ TROLL, SALMON } \\
\hline \multirow{2}{*}{$\begin{array}{l}\text { ARCTIC CHAR : }: \text { : } \\
\text { HERRING, SEA: } \\
\text { SALMON: } \\
\text { CHIINOOK OR KING } \\
\text { CHUM OR KETA.: } \\
\text { PINK . } \text {. } \\
\text { REO OR SOCKEYE: } \\
\text { SILVER OR COHO: }\end{array}$} & \multirow{2}{*}{ 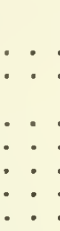 } & \multirow{2}{*}{$\begin{array}{l}\therefore: \\
\therefore: \\
\therefore:\end{array}$} & $\frac{\text { POUNDS }}{2,700}$ & $\frac{\text { OOLLARS }}{697}$ & $\begin{array}{r}\text { POUNDS } \\
62,900\end{array}$ & $\begin{array}{r}\text { DOLLARS } \\
28 \\
2.517\end{array}$ & $\frac{\text { POUNOS }}{-}$ & $\frac{\text { DOLLARS }}{-}$ \\
\hline & & & $\begin{array}{r}928,800 \\
9,794,100 \\
95,800 \\
2,661,800 \\
211,000 \\
\end{array}$ & $\begin{array}{r}380,073 \\
2,714,583 \\
28,010 \\
1,052,379 \\
71,918 \\
\end{array}$ & $\begin{array}{r}1,302,300 \\
3,861,800 \\
3,700 \\
25,397,900 \\
77,600 \\
\end{array}$ & $\begin{array}{r}533,207 \\
1,083,206 \\
1,314 \\
10,260,515 \\
265,997 \\
\end{array}$ & $\begin{array}{l}- \\
- \\
(2)\end{array}$ & $\begin{array}{l}- \\
- \\
-\end{array}$ \\
\hline \multirow{3}{*}{\multicolumn{3}{|c|}{ 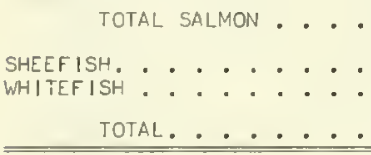 }} & $13,691,500$ & $4,246,963$ & $31,339,300$ & $12,144,239$ & $(2)$ & 18 \\
\hline & & & $\begin{array}{l}200 \\
600 \\
\end{array}$ & $\begin{array}{r}28 \\
168 \\
\end{array}$ & $\begin{array}{r}400 \\
9,000 \\
\end{array}$ & $\begin{array}{r}121 \\
2,683 \\
\end{array}$ & - & - \\
\hline & & & $13,695,000$ & $4,247,856$ & $31,411,700$ & $12,149,588$ & (2) & 18 \\
\hline \multicolumn{3}{|l|}{ SPECIES } & \multicolumn{2}{|c|}{ LINES - CONTINUED } & \multicolumn{2}{|c|}{ FISH WHEELS } & \multicolumn{2}{|c|}{ BY HANO } \\
\hline HAL IOUT $\cdot \cdots \cdot \cdot$ & $\cdot \cdot \cdot$ & - . & $\frac{\text { POUNDS }}{647,000}$ & $\frac{\text { DOLLARS }}{351,000}$ & $\frac{\text { POUNDS }}{-}$ & $\frac{\text { DOLLARS }}{-}$ & $\frac{\text { POUNOS }}{-}$ & $\frac{\text { DOLLARS }}{-}$ \\
\hline $\begin{array}{l}\text { CHINOOK OR KING } \\
\text { CHUM OR KETA. } \\
\text { SILVER OR COHO. }\end{array}$ & $\because: \vdots$ & $\therefore$ & - & - & $\begin{array}{r}13,700 \\
1.464,700 \\
100 \\
\end{array}$ & $\begin{array}{r}5,482 \\
263,649 \\
18 \\
\end{array}$ & $\overline{-}$ & $\overline{-}$ \\
\hline TOTAL SALMON. & $\cdots \cdot$ & . & - & - & $1,478,500$ & 269,149 & - & - \\
\hline KELP (WITH HERRING & EGGS) & . & - & - & - & - & 108,800 & 46,771 \\
\hline TOTAL. $\cdot \cdot \cdot$ & $\cdot \cdot \cdot \cdot$ & - $\cdot$ & 647,000 & 351,000 & $1,478,500$ & 269,149 & 108,800 & 46,771 \\
\hline
\end{tabular}

$1 /$ INCLUDES HANO PURSE SE INES AND HAUL (BEACH) SEINES.
2 LESS THAN 50 POUNOS. 
WASHINGTON

LANDINGS BY DISTRICTS, 1975

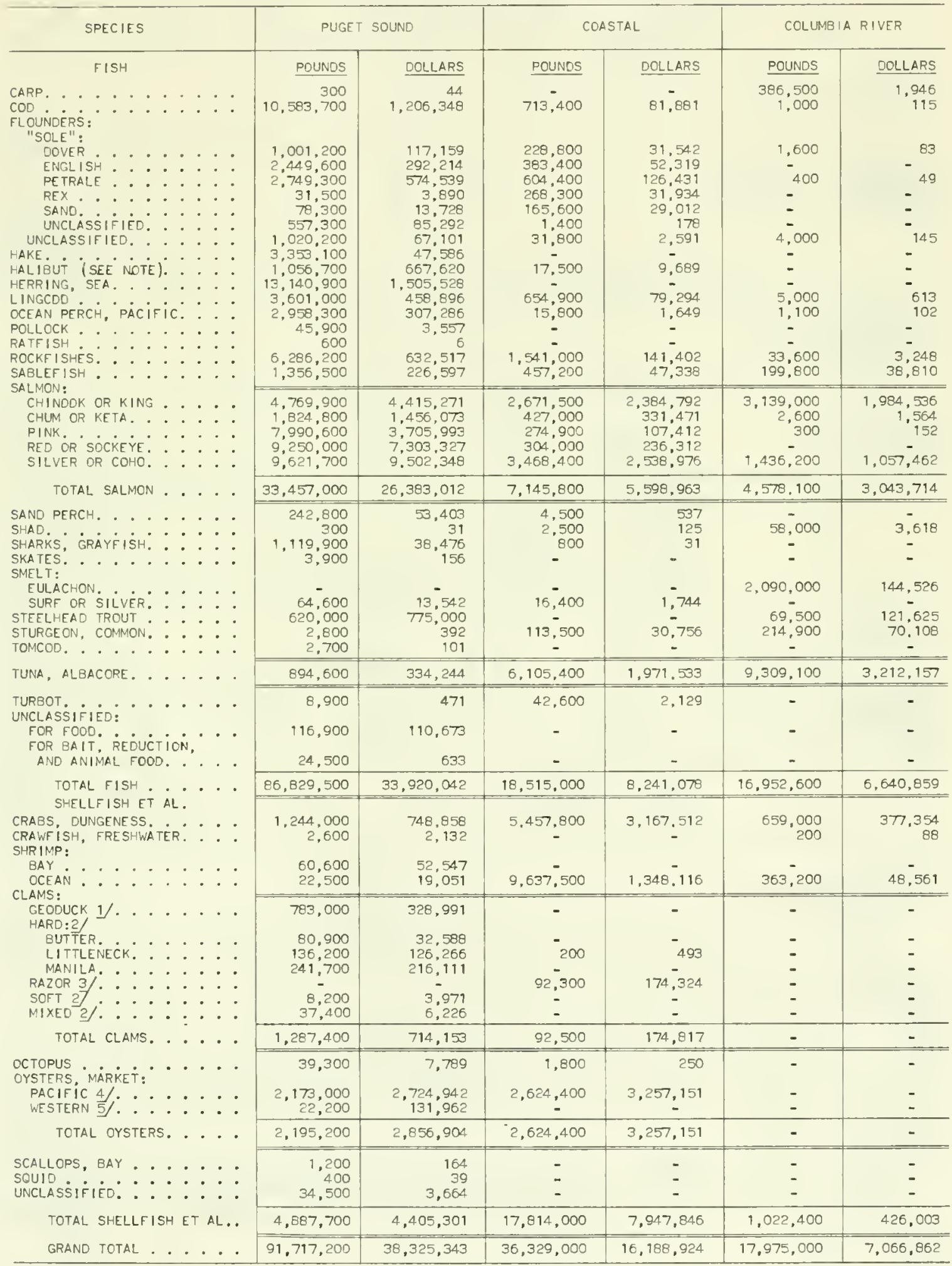

1/ BASEO ON A YIELO OF 33 PERCENT MEATS. 2/ BASED ON A YIELO OF 25 PERCENT MEATS. $3 /$ BASED ON A YIELD OF 42 PERCENT MEATS. 4/. BASED ON A YIELD OF 10 PERCENT MEATS IN PUGET SOUND DISTRICT AND 12 PERCENT MEATS IN COASTAL DISTRICT: 5 / BASEO ON A YIELO OF 18 PERCENT MEATS.

NOTE:--HALIBUT IS SHOWN IN ORESSED WEIGHT. SEE LANOINGS OF CATCH BY GEAR TABLES FOR ROUND WEIGHT OF MALIBUT. 


\section{PUGET SOUND DISTRICT OF WASHINGTON OPERATING UNITS, 1975}

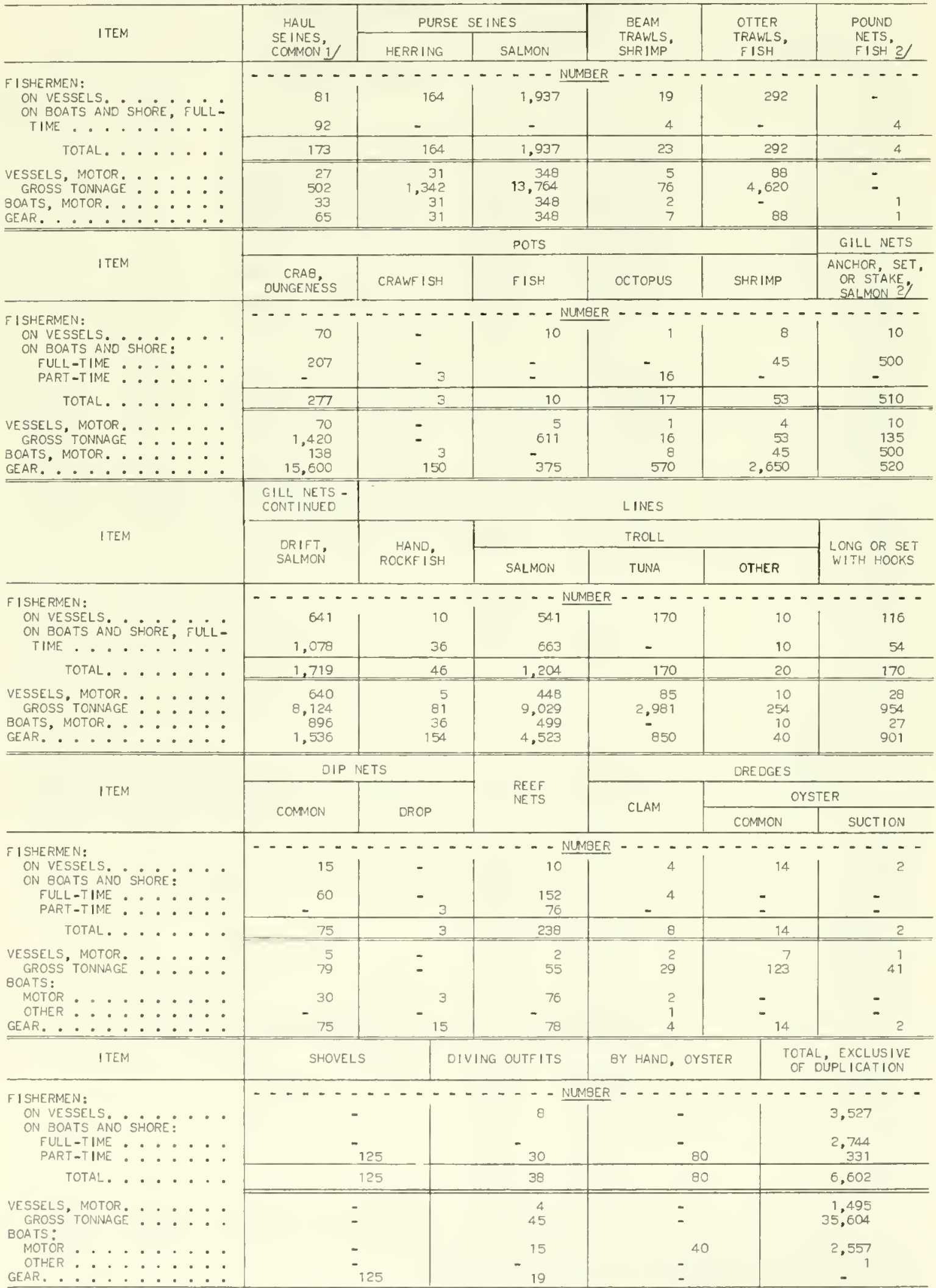




\section{PUGET SOUND DISTRICT OF WASHINGTON LANDINGS OF CATCH BY GEAR, 1975}

\begin{tabular}{|c|c|c|c|c|c|c|}
\hline \multirow{2}{*}{ SPECIES } & \multirow{2}{*}{\multicolumn{2}{|c|}{ HAUL SEINES, COMMON $1 /$}} & \multicolumn{4}{|c|}{ PURSE SEINES } \\
\hline & & & \multicolumn{2}{|c|}{ HERR ING } & \multicolumn{2}{|c|}{ SALMON } \\
\hline \multirow[t]{2}{*}{ 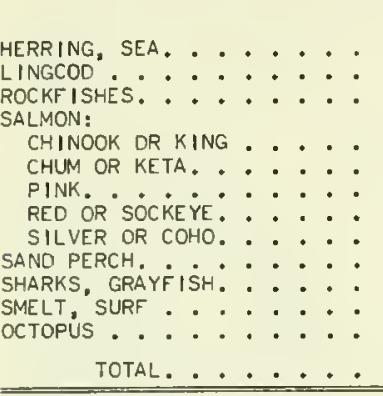 } & $\begin{array}{r}\text { POUNOS } \\
1,953,800 \\
-100 \\
5,300 \\
400 \\
56,500 \\
- \\
19,200 \\
240,800 \\
64,400 \\
-\end{array}$ & $\begin{array}{c}\text { DOLLARS } \\
454,639 \\
31 \\
5,140 \\
349 \\
29,734 \\
- \\
16,244 \\
53,116 \\
- \\
13,474 \\
-\end{array}$ & $\begin{array}{c}\text { POUNOS } \\
6.758,000 \\
= \\
= \\
= \\
= \\
= \\
= \\
=\end{array}$ & 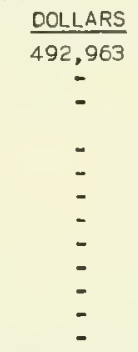 & $\begin{array}{c}\frac{\text { POUNOS }}{-} \\
- \\
1,200 \\
42,500 \\
4,89,100 \\
5,891,500 \\
2,081,100 \\
-086,300 \\
- \\
- \\
- \\
2000\end{array}$ & $\begin{array}{r}\frac{\text { OOLLARS }}{-} \\
- \\
1,030,375 \\
402,246 \\
2,643,040 \\
3,880,880 \\
2,093,287 \\
-\quad 36 \\
-\quad 29\end{array}$ \\
\hline & $2,340,500$ & 572,727 & $6,758,000$ & 492,963 & $14,781,100$ & $10,066,005$ \\
\hline SPECIES & \multicolumn{2}{|c|}{ GEAM TRAWLS, SHRIMP } & \multicolumn{2}{|c|}{ OTTER TRAWLS, FISH } & \multicolumn{2}{|c|}{ POUND NETS, FISH $2 /$} \\
\hline 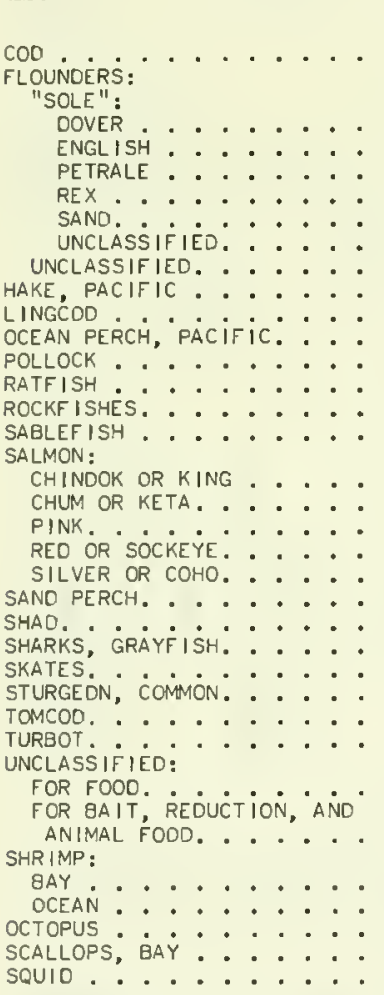 & $\begin{array}{l}- \\
- \\
- \\
- \\
- \\
- \\
- \\
- \\
- \\
- \\
- \\
- \\
- \\
- \\
- \\
- \\
- \\
- \\
- \\
- \\
- \\
- \\
- \\
- \\
- \\
- \\
-\end{array}$ & $\begin{array}{c}- \\
- \\
- \\
- \\
- \\
- \\
- \\
- \\
- \\
- \\
- \\
- \\
- \\
- \\
- \\
- \\
- \\
- \\
- \\
- \\
- \\
- \\
- \\
- \\
-\end{array}$ & $\begin{array}{r}\text { POUNOS } \\
10,455,200 \\
1,001,200 \\
2,449,000 \\
2,749,000 \\
31,500 \\
78,700 \\
55,, 100 \\
1,020,000 \\
3,353,100 \\
3,340,700 \\
2,958,300 \\
45,900 \\
600 \\
5,988,000 \\
343,500 \\
- \\
- \\
- \\
- \\
- \\
2,000 \\
100 \\
1,036,900 \\
3,900 \\
2,400 \\
2,700 \\
8,900 \\
400 \\
24,500 \\
- \\
- \\
27,500 \\
1,200 \\
400 \\
\end{array}$ & $\begin{array}{r}\text { DOLLARS } \\
1,193,217 \\
117,159 \\
292,128 \\
574,480 \\
3,890 \\
13,728 \\
85,268 \\
67,068 \\
47,586 \\
399,780 \\
307,286 \\
3,557 \\
6 \\
578,655 \\
41,504 \\
- \\
- \\
- \\
- \\
- \\
287 \\
4 \\
34,573 \\
156 \\
292 \\
101 \\
471 \\
52 \\
633 \\
- \\
3,935 \\
164 \\
39 \\
\end{array}$ & 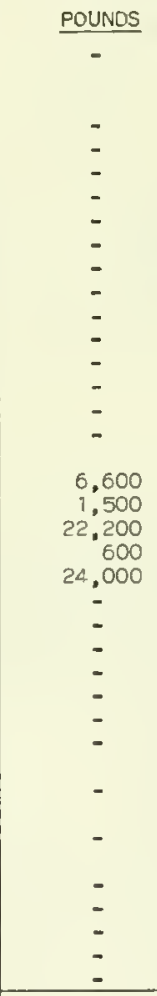 & 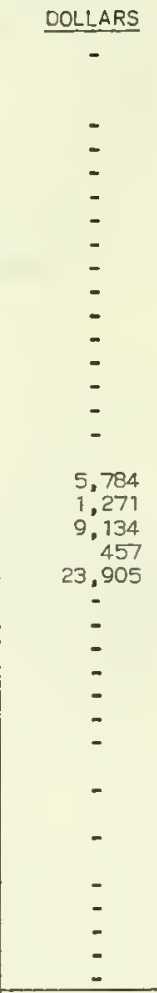 \\
\hline 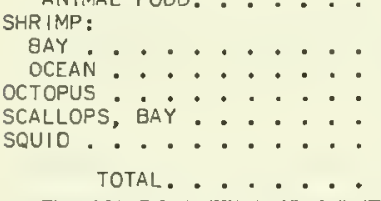 & 30,000 & 18,621 & $35,481,500$ & $3,766,019$ & 54,900 & 40,551 \\
\hline \multirow{2}{*}{ SPECIES } & \multicolumn{6}{|c|}{ POTS } \\
\hline & \multicolumn{2}{|c|}{ CRAB, DUNGENESS } & \multicolumn{2}{|c|}{ CRAWFISH } & \multicolumn{2}{|c|}{ FISH } \\
\hline 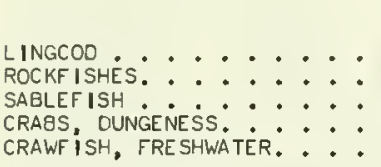 & $\begin{array}{c}\text { POUNDS } \\
\overline{-} \\
1,243,900 \\
-\end{array}$ & $\begin{array}{c}\text { DOLLARS } \\
\overline{-} \\
748,765 \\
-\end{array}$ & $\begin{array}{c}\text { POUNDS } \\
- \\
- \\
\overline{-} \\
2,600\end{array}$ & $\begin{array}{c}\text { OOLLARS } \\
- \\
- \\
\overline{2} \\
\overline{2}\end{array}$ & $\begin{array}{r}\text { POUNDS } \\
400 \\
4,700 \\
641,700 \\
- \\
-\end{array}$ & $\begin{array}{r}\text { OOLLARS } \\
55 \\
329 \\
104,582 \\
-\end{array}$ \\
\hline TOTAL. . . . . & $1,243,900$ & 748,765 & 2,600 & 2,132 & 646,800 & 104,966 \\
\hline
\end{tabular}

SEE FOOTNOTES AT END OF TABLE.

(CONTINUED ON NEXT PAGE) 


\section{PUGET SOUND DISTRICT OF WASHINGTON} LANDINGS OF CATCH BY GEAR, 1975 - Continued

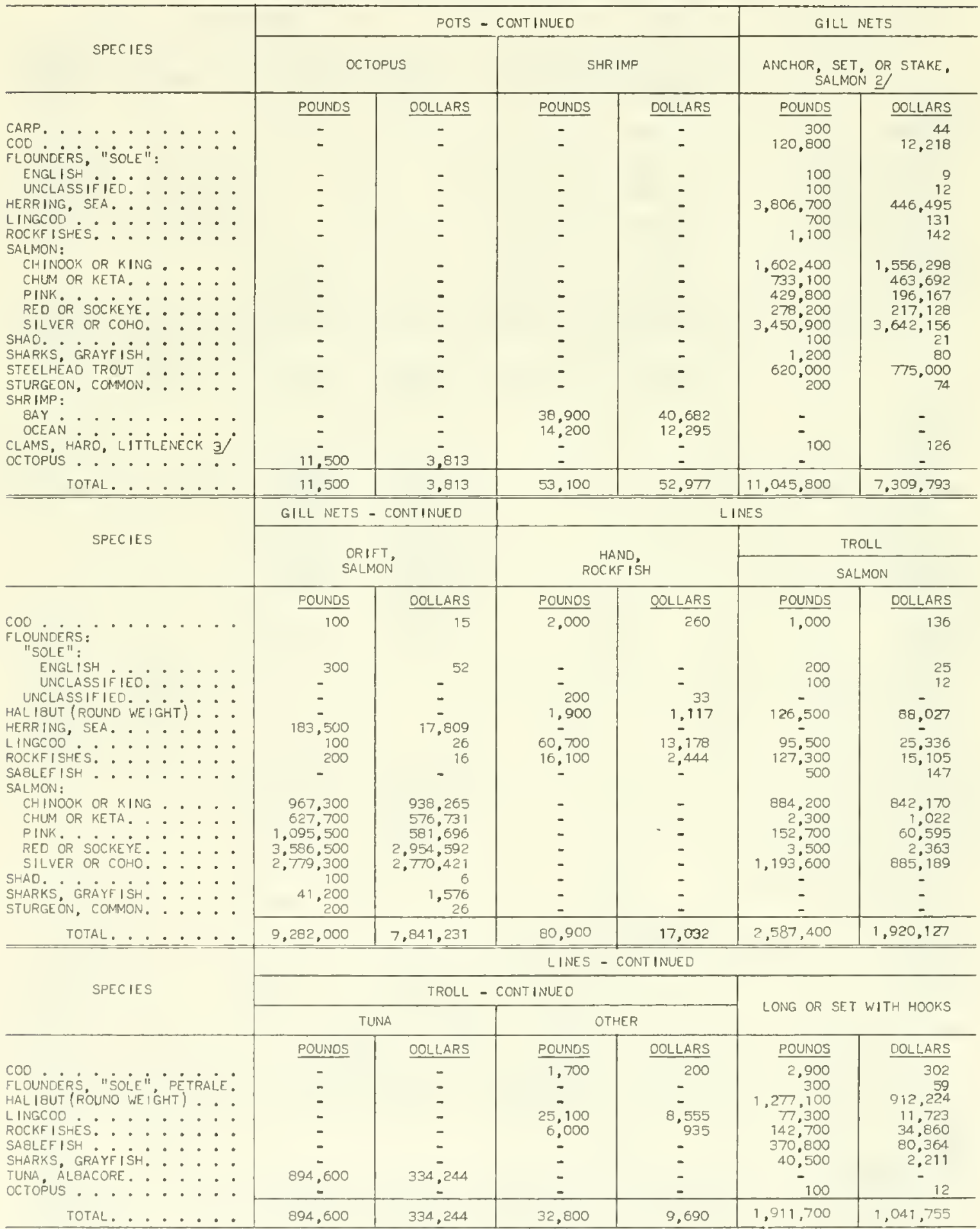




\section{PUGET SOUND DISTRICT OF WASHINGTON LANDINGS OF CATCH BY GEAR, 1975 - Continued}

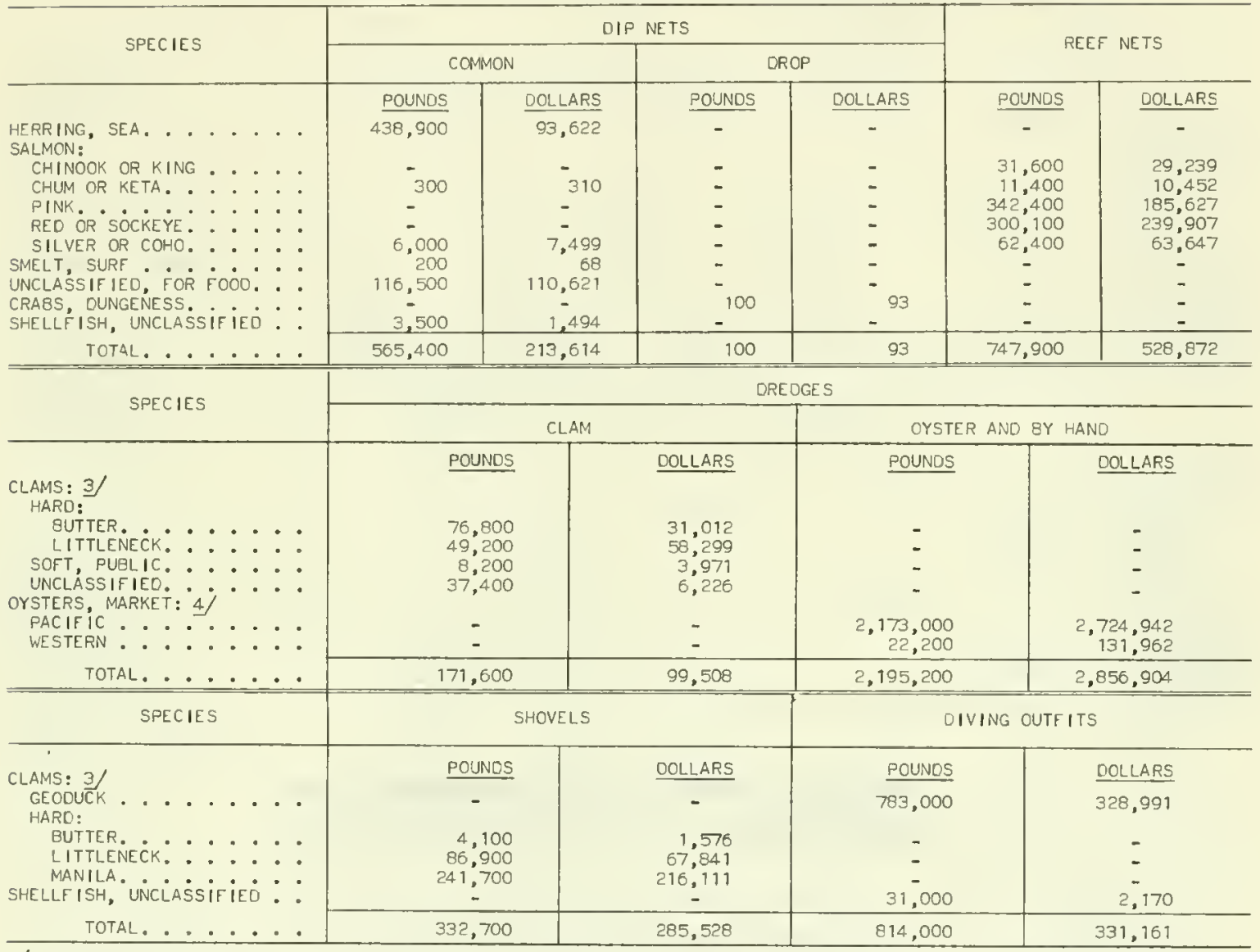

$1 /$ SALMON CAUGHT BY HAUL SE INES WERE TAKEN ON INDIAN RESERVATIONS BY INDIAN FISHERMEN. $2 /$ FISHEO ON INDIAN RESERVATIONS BY INDIAN FISHERMEN. 3/ BASED ON A YIELO OF 33 PERCENT MEATS FOR GEODUCK CLAMS ANO 25 PERCENT FOR HARO CLAMS. 4' BASED ON A YIELD OF 10 PERCENT MEATS FOR PACIFIC OYSTERS AND 18 PERCENT FOR WESTERN OR NATIVE OYSTERS. NOTE:--HALIBUT IS SHOWN IN ROUNO WEIGHT; IN OTHER TABLES, HALIBUT IS SHOWN IN DRESSED WEIGHT IN WÄŚHINGTON.

\section{COASTAL DISTRICT OF WASHINGTON OPERATING UNITS, 1975}

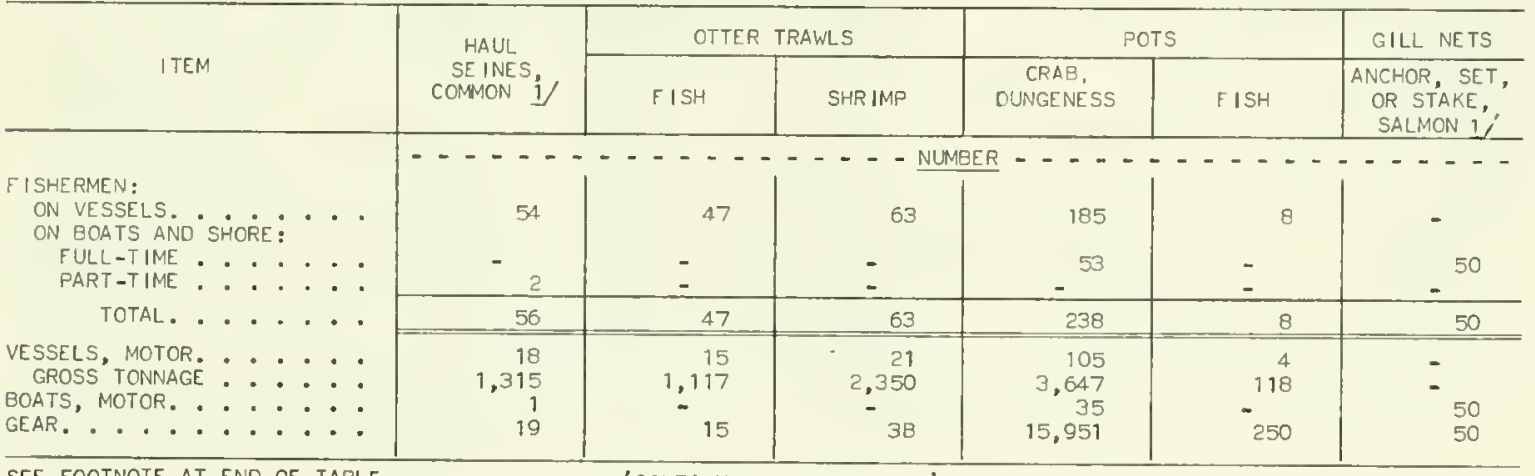

SEE FOOTNOTE AT END OF TABLE.

(CONTINUED ON NEXT PAGE) 
COASTAL DISTRICT OF WASHINGTON
OPERATING UNITS, 1975 - Continued

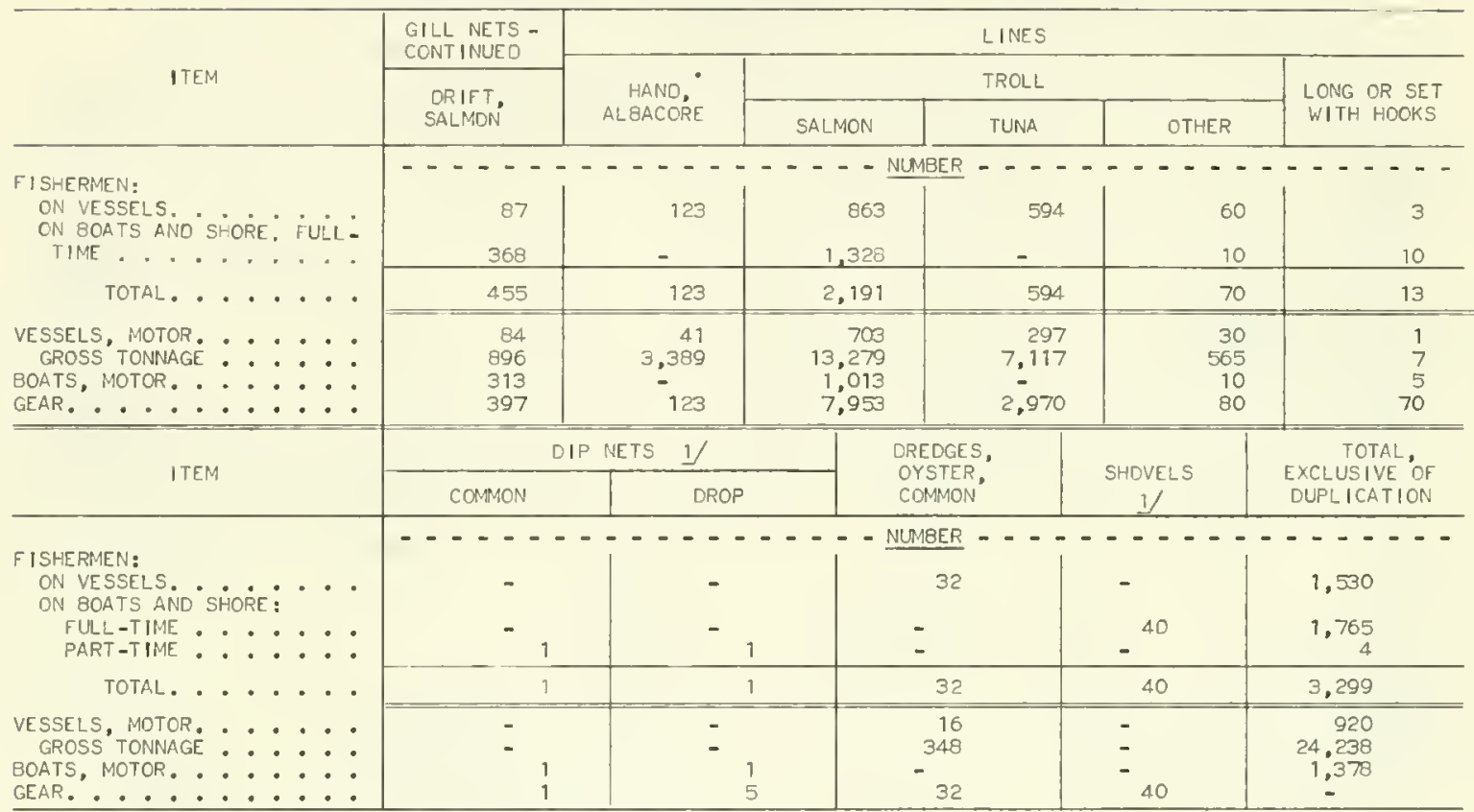

1) OPERATEO DN INDIAN RESERVATIONS BY INDIAN FISHERMEN.

\section{COASTAL DISTRICT OF WASHINGTON LANDINGS OF CATCH BY GEAR, 1975}

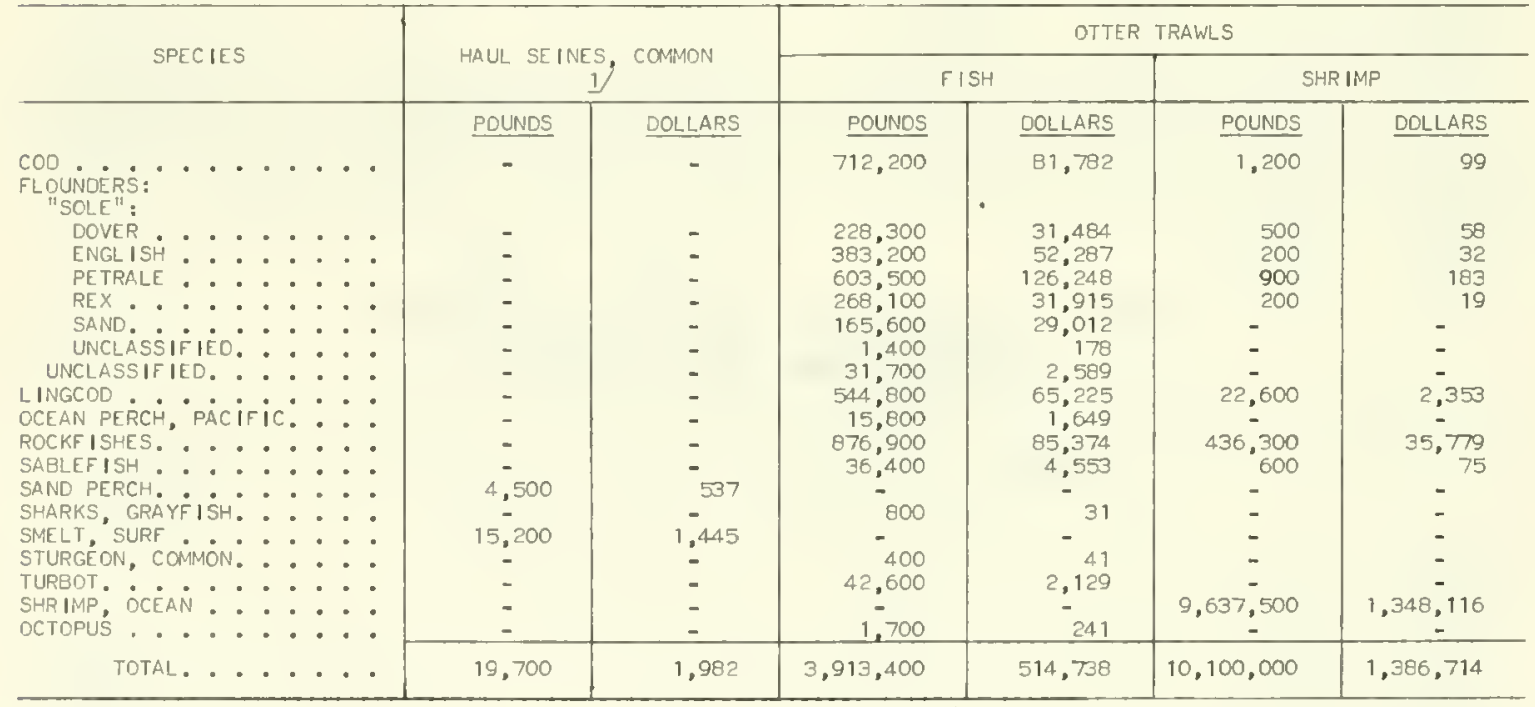

SEE FOOTNOTES AT ENO OF TABLE.

(CONT INUED ON NEXT PAGE) 


\section{COASTAL DISTRICT OF WASHINGTON LANDINGS OF CATCH BY GEAR, 1975 - Continued}

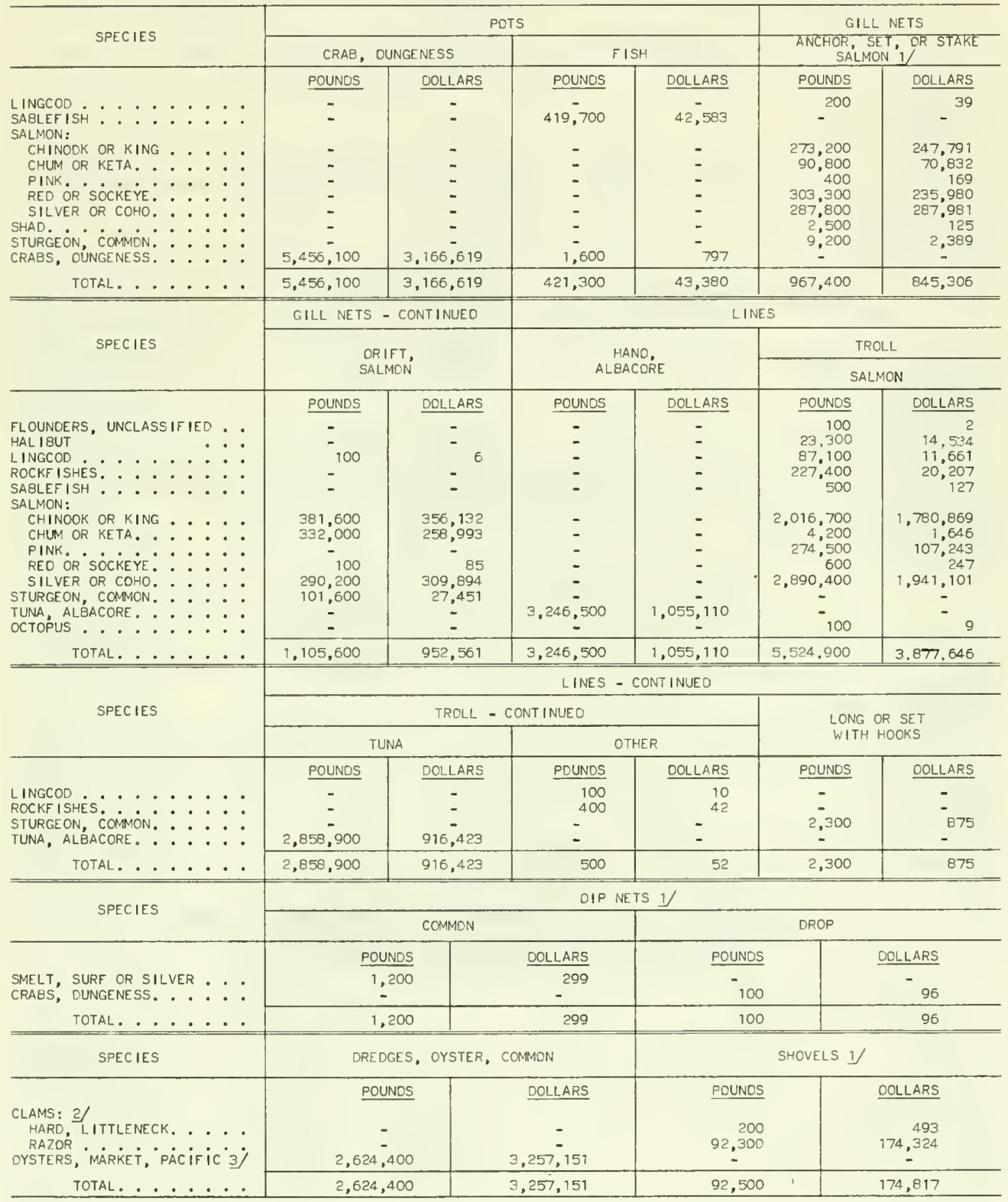

1 FISHEO ON INOIAN RESERVATIONS BY INOIAN FISHERMEN. 2/ GASEO ON A YIELD OF 25 PERCENT MEATS FOR HARD CLAMS AND 42 PERCENT MEATS FOR RAZOR CLAMS. $3 /$ BASED ON A YIELD OF 12 PERCENT MEATS.

NOTE:--HALIBUT IS SHOWN IN ROUND WEIGHT; IN OTHER TABLES, HALIBUT IS SHOWN IN DRESSEO WEIGHT IN WASHINGTON. 


\section{COLUMBIA RIVER DISTRICT OF WASHINGTON OPERATING UNITS, 1975}

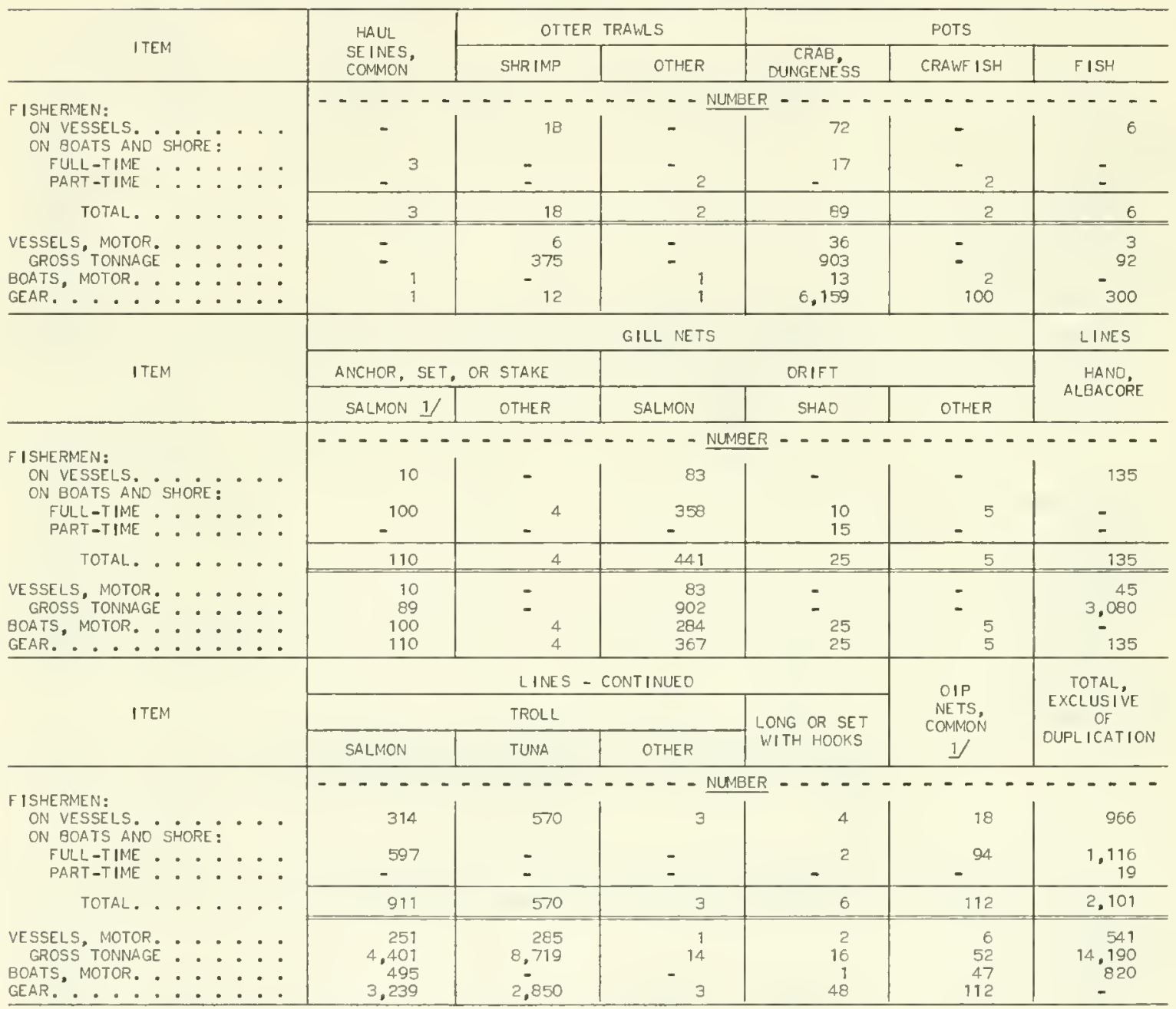

1 OPERATED ON INDIAN RESERVATIONS BY INDIAN FISHERMEN.

\section{COLUMBIA RIVER DISTRICT OF WASHINGTON LANDINGS OF CATCH BY GEAR, 1975}

\begin{tabular}{|c|c|c|c|c|c|c|}
\hline \multirow{2}{*}{ SPECIES } & \multirow{2}{*}{\multicolumn{2}{|c|}{ HAUL SEINES, COMMON }} & \multicolumn{4}{|c|}{ OTTER TRAWLS } \\
\hline & & & \multicolumn{2}{|c|}{ SHRIMP } & \multicolumn{2}{|c|}{ OTHER } \\
\hline 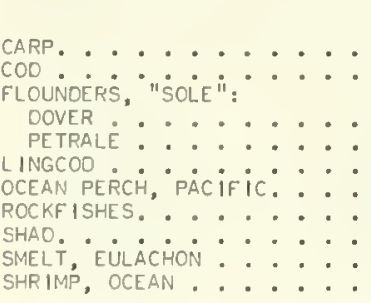 & 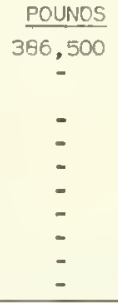 & $\begin{array}{c}\text { OOLLARS } \\
1,946 \\
= \\
= \\
= \\
- \\
- \\
-\end{array}$ & $\begin{array}{c}\text { POUNOS } \\
- \\
1,000 \\
1.600 \\
400 \\
3,000 \\
1.100 \\
9,600 \\
200 \\
- \\
363,200\end{array}$ & $\begin{array}{c}\text { DOLLARS } \\
- \\
115 \\
83 \\
49 \\
360 \\
102 \\
866 \\
-11 \\
48,561\end{array}$ & $\begin{array}{c}\text { POUNOS } \\
- \\
- \\
- \\
= \\
= \\
- \\
\overline{-} .900\end{array}$ & $\begin{array}{c}\text { OOLLARS } \\
- \\
- \\
= \\
\overline{-} \\
- \\
1,264\end{array}$ \\
\hline 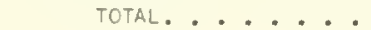 & 386,500 & 1,946 & 380,100 & 50,147 & 7.900 & 1,264 \\
\hline
\end{tabular}




\section{COLUMBIA RIVER DISTRICT OF WASHINGTON LANDINGS OF CATCH BY GEAR, 1975 - Continued}

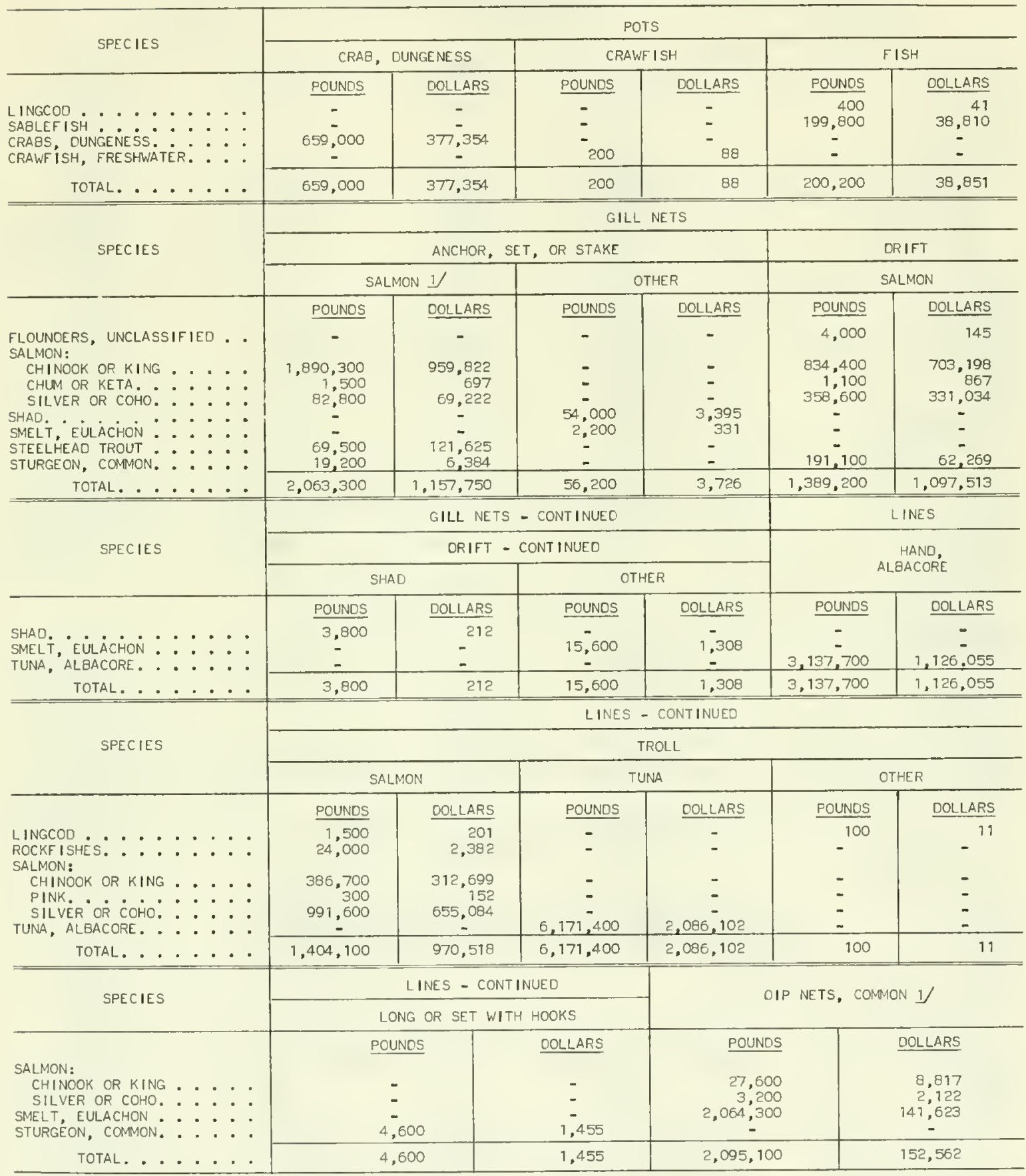

1) FISHEO ON INOIAN RESERVATIONS BY INDIAN FISHERMEN. 
OREGON

LANDINGS BY DISTRICTS, 1975

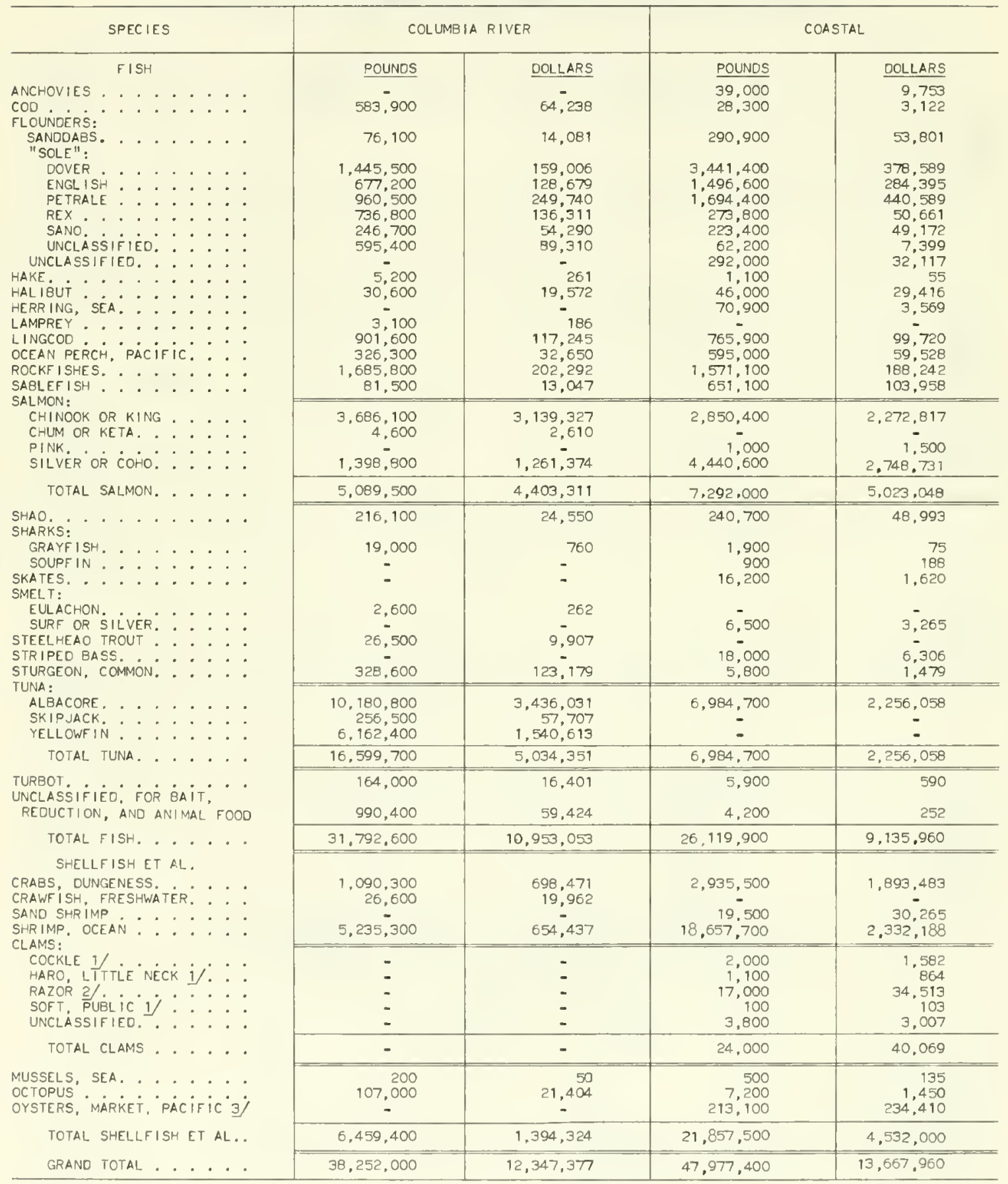

1 BASED ON A YIELD OF 25 PERCENT MEATS. 2/ 8 ASEO ON A YIELD OF 42 PERCENT MEATS. $3 /$ BASED ON A YIELD OF 12 PERCENT MEATS. 


\section{COLUMBIA RIVER DISTRICT OF OREGON OPERATING UNITS, 1975}

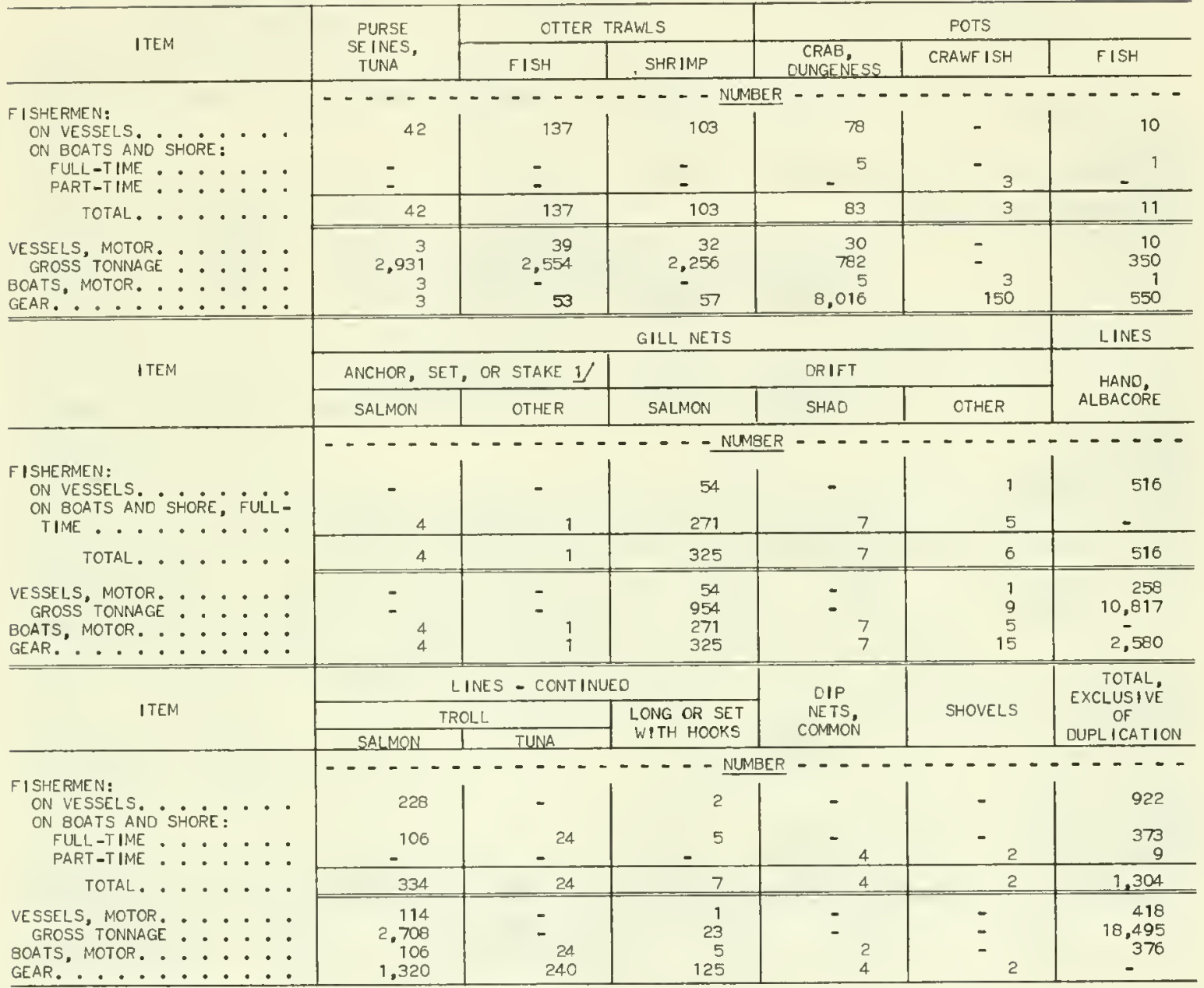

1 OPERATEO ON INDIAN RESERVATIONS BY INOIAN FISHERMEN.

\section{COLUMBIA RIVER DISTRICT OF OREGON LANDINGS OF CATCH BY GEAR, 1975}

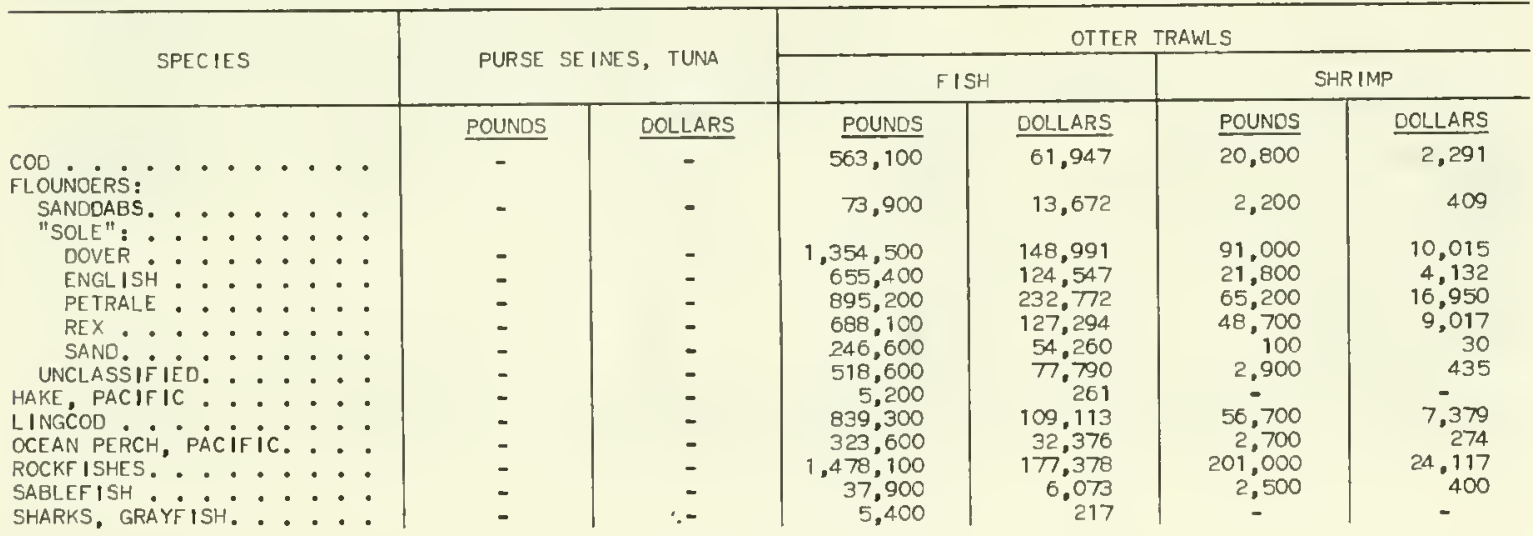

(CONTINUED ON NEXT PAGE) 


\section{COLUMBIA RIVER DISTRICT OF OREGON LANDINGS OF CATCH BY GEAR, 1975 - Continued}

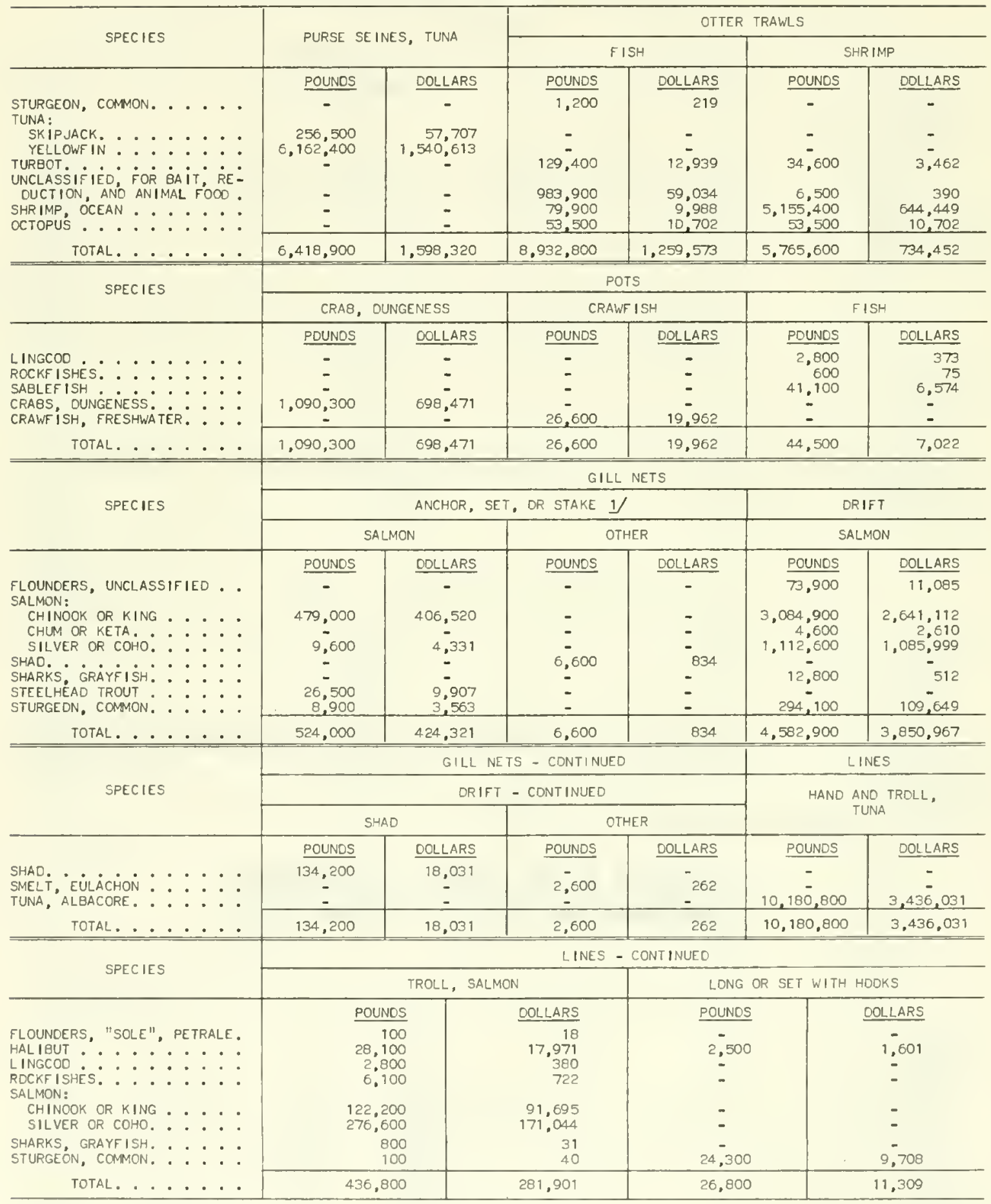


COLUMBIA RIVER DISTRICT OF OREGON LANDINGS OF CATCH BY GEAR, 1975 - Continued

\begin{tabular}{|c|c|c|c|c|}
\hline SPECIES & \multicolumn{2}{|c|}{ DIP NETS, COMMON } & \multicolumn{2}{|c|}{ SHOVELS } \\
\hline $\begin{array}{l}\text { LAMPREY }:: \vdots: \therefore: \\
\text { SHAO }: \dot{:}: \dot{:}:\end{array}$ & $\begin{array}{l}\text { POUNDS } \\
\begin{array}{c}3,100 \\
75,300 \\
-\end{array}\end{array}$ & $\begin{array}{r}\text { OOLLARS } \\
\begin{array}{r}186 \\
5,685 \\
-\end{array} \\
\end{array}$ & $\begin{array}{c}\text { POUNOS } \\
- \\
200\end{array}$ & $\begin{array}{c}\text { OOLLARS } \\
- \\
- \\
50\end{array}$ \\
\hline TOTAL. . . . . . & 78,400 & 5,871 & 200 & 50 \\
\hline
\end{tabular}

1 FISHEO ON INOIAN RESERVATIONS BY INDIAN FISHERMEN.

\section{COASTAL DISTRICT OF OREGON OPERATING UNITS, 1975}

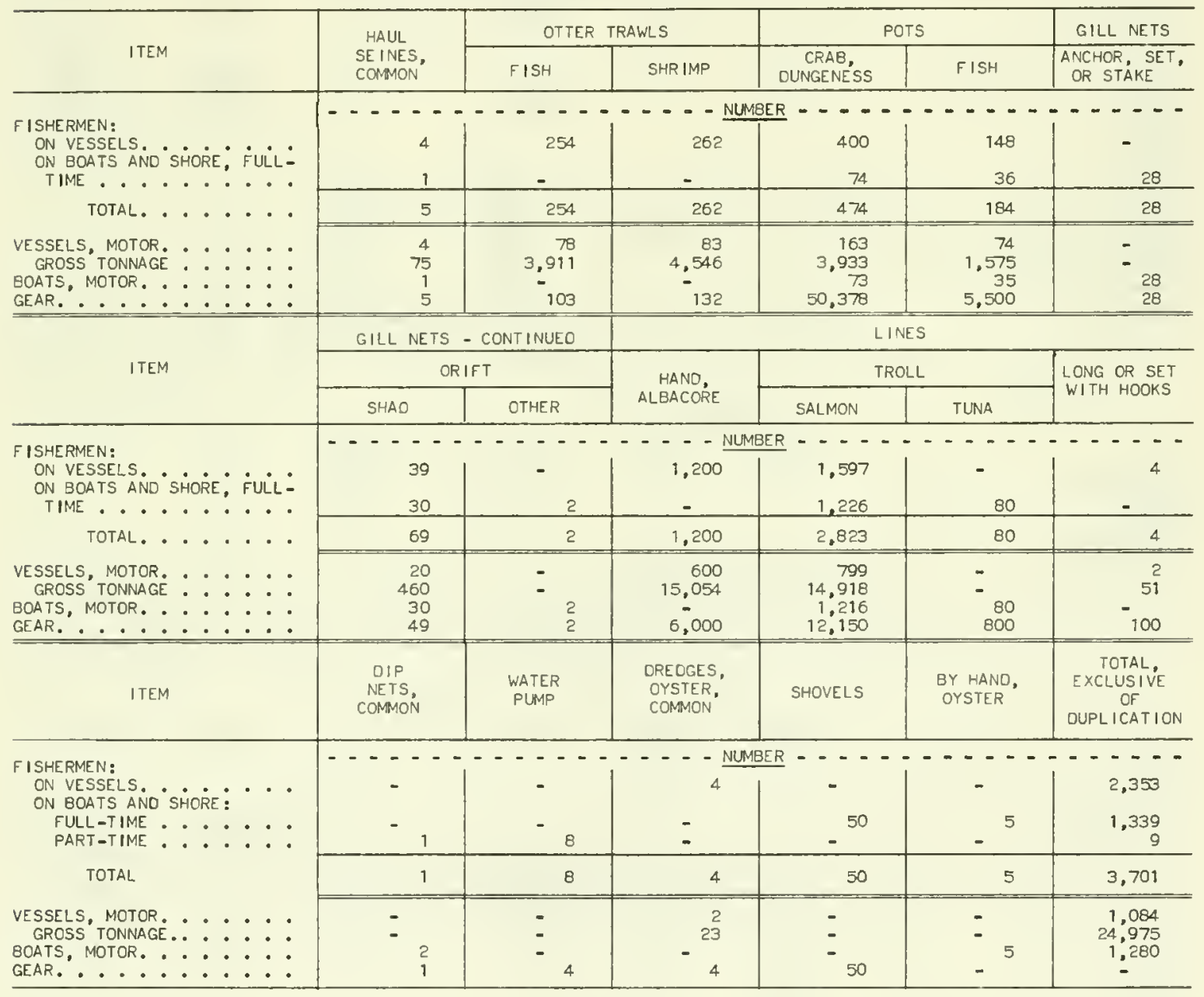


COASTAL DISTRICT OF OREGON LANDINGS OF CATCH BY GEAR, 1975

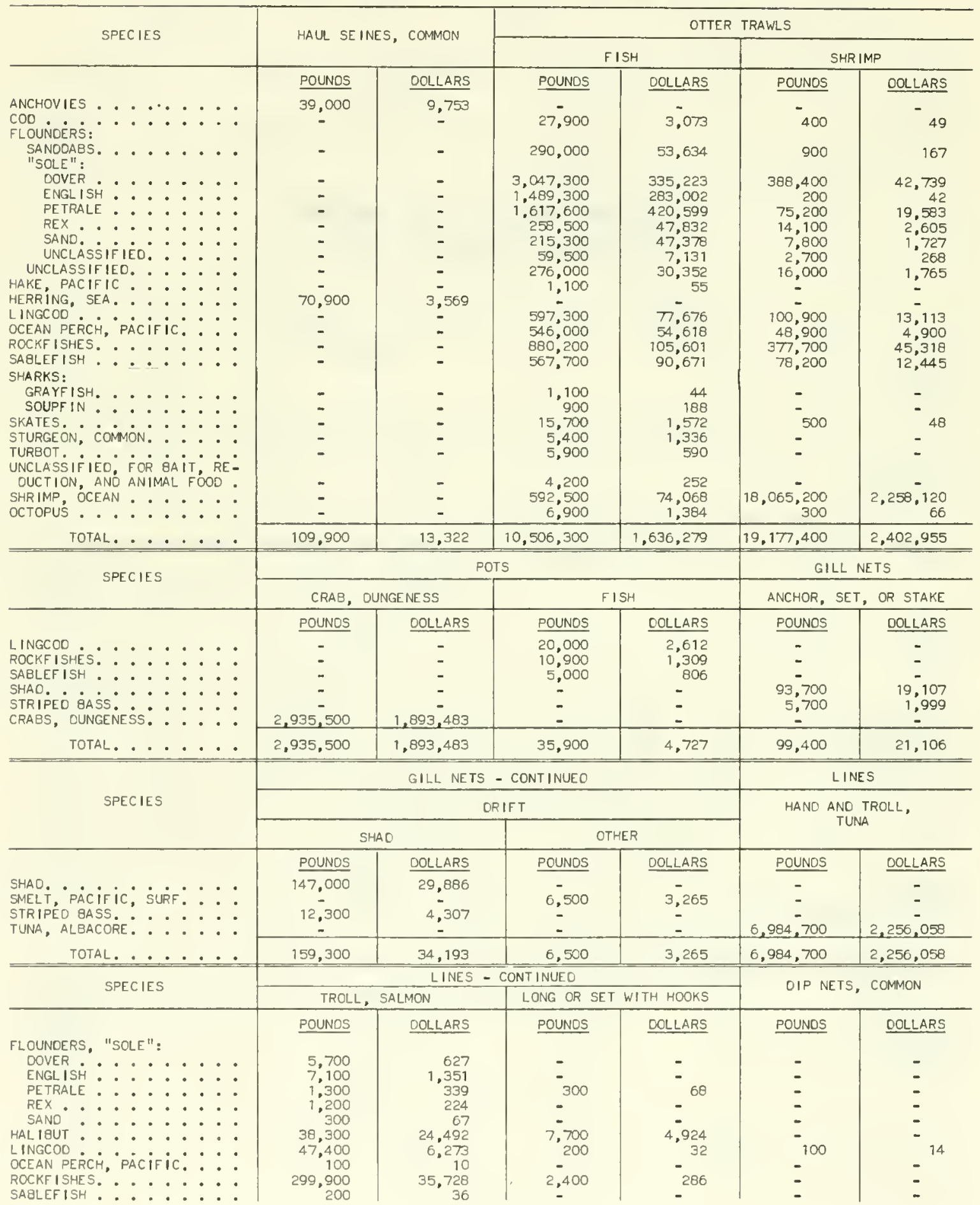




\section{PACIFIC COAST FISHERIES}

COASTAL DISTRICT OF OREGON LANDINGS OF CATCH BY GEAR, 1975 - Continued

\begin{tabular}{|c|c|c|c|c|c|c|}
\hline \multirow{2}{*}{ SPECIES } & \multicolumn{4}{|c|}{ LINES - CONTINUED } & \multirow{2}{*}{\multicolumn{2}{|c|}{ DIP NETS, COMMON }} \\
\hline & \multicolumn{2}{|c|}{ TROLL, SALMON } & \multicolumn{2}{|c|}{ LONG OR SET WITH HOOKS } & & \\
\hline $\begin{array}{l}\text { SALMON: } \\
\text { CHINOOK OR KING }: \cdots: \\
\text { PINK, } \\
\text { SILVER OR COHO: }: \vdots: \\
\text { SHARKS, GRAYFISH. }: \vdots: \\
\text { STURGEON, COMMON. }: \cdots:\end{array}$ & $\begin{array}{r}\text { POUNDS } \\
2,850,400 \\
1,000 \\
4,440,600 \\
800 \\
400 \\
\end{array}$ & $\begin{array}{r}\text { DOLLARS } \\
2,272,817 \\
1,500 \\
2,748,731 \\
31 \\
143\end{array}$ & $\begin{array}{l}\text { POUNOS } \\
= \\
= \\
= \\
=\end{array}$ & $\begin{array}{l}\text { DOLLLARS } \\
= \\
= \\
= \\
=\end{array}$ & $\begin{array}{l}\text { POUNOS } \\
= \\
= \\
=\end{array}$ & $\begin{array}{c}\text { OOLLARS } \\
= \\
- \\
-\end{array}$ \\
\hline TOTAL........ & $7,694,700$ & $5,092,369$ & 10,600 & 5,310 & 100 & 14 \\
\hline SPECIES & \multicolumn{2}{|c|}{ WATER PUMP } & \multicolumn{2}{|c|}{$\begin{array}{l}\text { DREDGES, OYSTER, } \\
\text { AND BY HAND }\end{array}$} & \multicolumn{2}{|c|}{ SHOVELS } \\
\hline 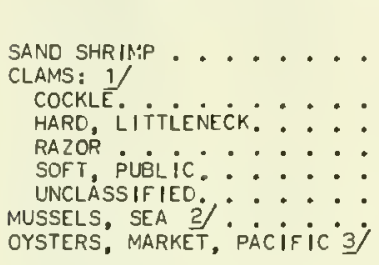 & $\begin{array}{c}\text { POUNDS } \\
\begin{array}{c}19,500 \\
- \\
- \\
- \\
- \\
- \\
-\end{array}\end{array}$ & $\begin{array}{c}\text { DOLLARS } \\
30,265 \\
= \\
= \\
= \\
= \\
-\end{array}$ & $\begin{array}{c}\text { POUNOS } \\
\overline{-} \\
\overline{-} \\
\overline{-} \\
\overline{-} \\
213,100\end{array}$ & $\begin{array}{c}\text { DOLLARS } \\
- \\
- \\
- \\
- \\
234,410\end{array}$ & $\begin{array}{r}\text { POUNOS } \\
- \\
2,000 \\
1,100 \\
17,000 \\
100 \\
3,800 \\
500 \\
-\end{array}$ & $\begin{array}{r}\text { DOLLARS } \\
- \\
1,582 \\
964 \\
34,513 \\
103 \\
3,007 \\
135 \\
-\end{array}$ \\
\hline TOTAL. . . . . . & 19,500 & 30,265 & 213,100 & 234,410 & 24,500 & 40,204 \\
\hline
\end{tabular}

1\% GASEO ON A YIELO OF 25 PERCENT MEATS FOR COCKLE, HARO, AND SOFT CLAMS, AND 42 PERCENT MEATS FOR RAZOR CLAMS.

2f GASED ON A YIELD OF 25 PERCENT MEATS. 3/ BASED ON A YIELD OF 12 PERCENT MEATS. 
CALIFORNIA

LANDINGS BY DISTRICTS, 1975

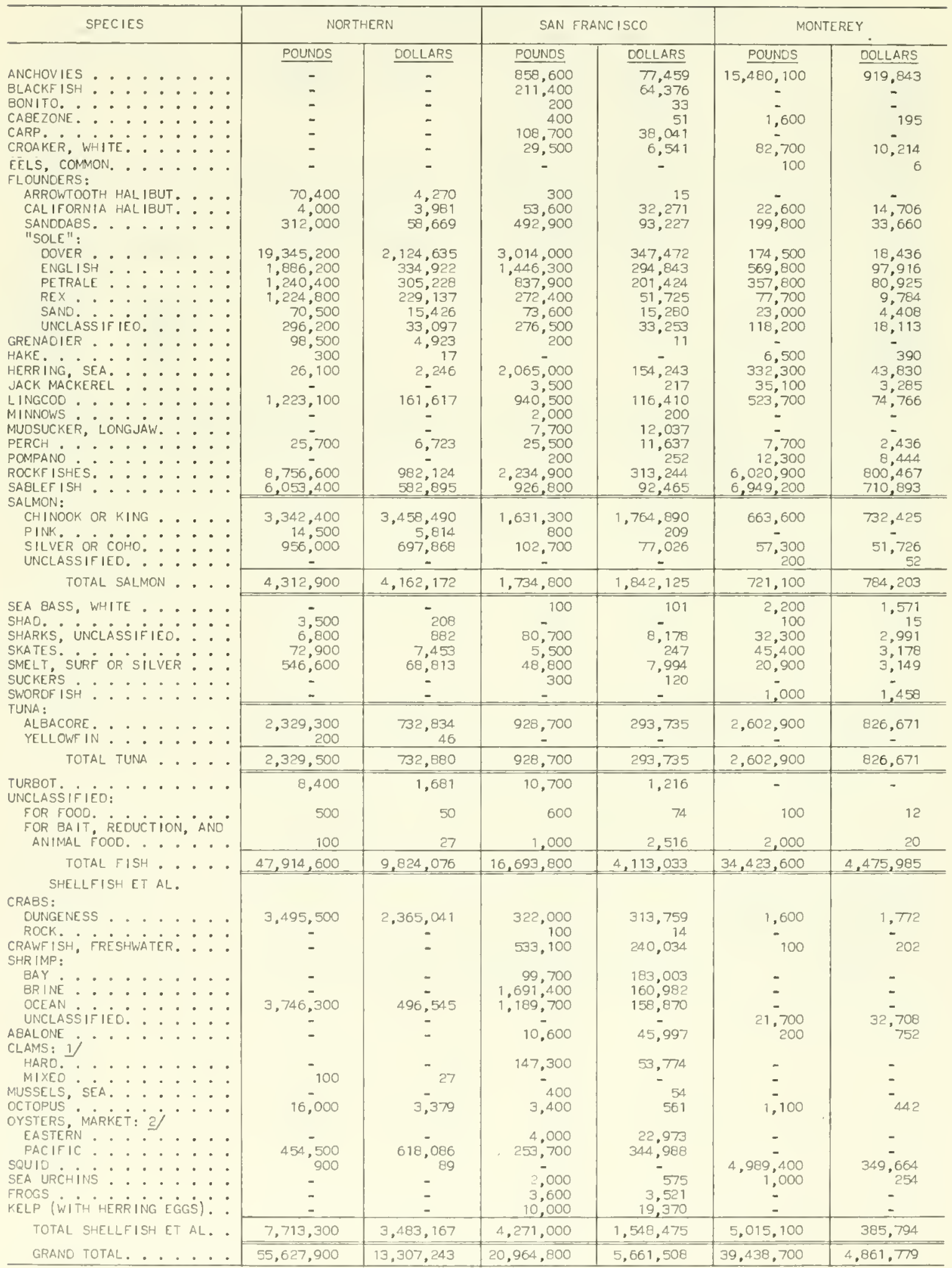


CALIFORNIA - LANDINGS BY DISTRICTS, 1975 - Continued

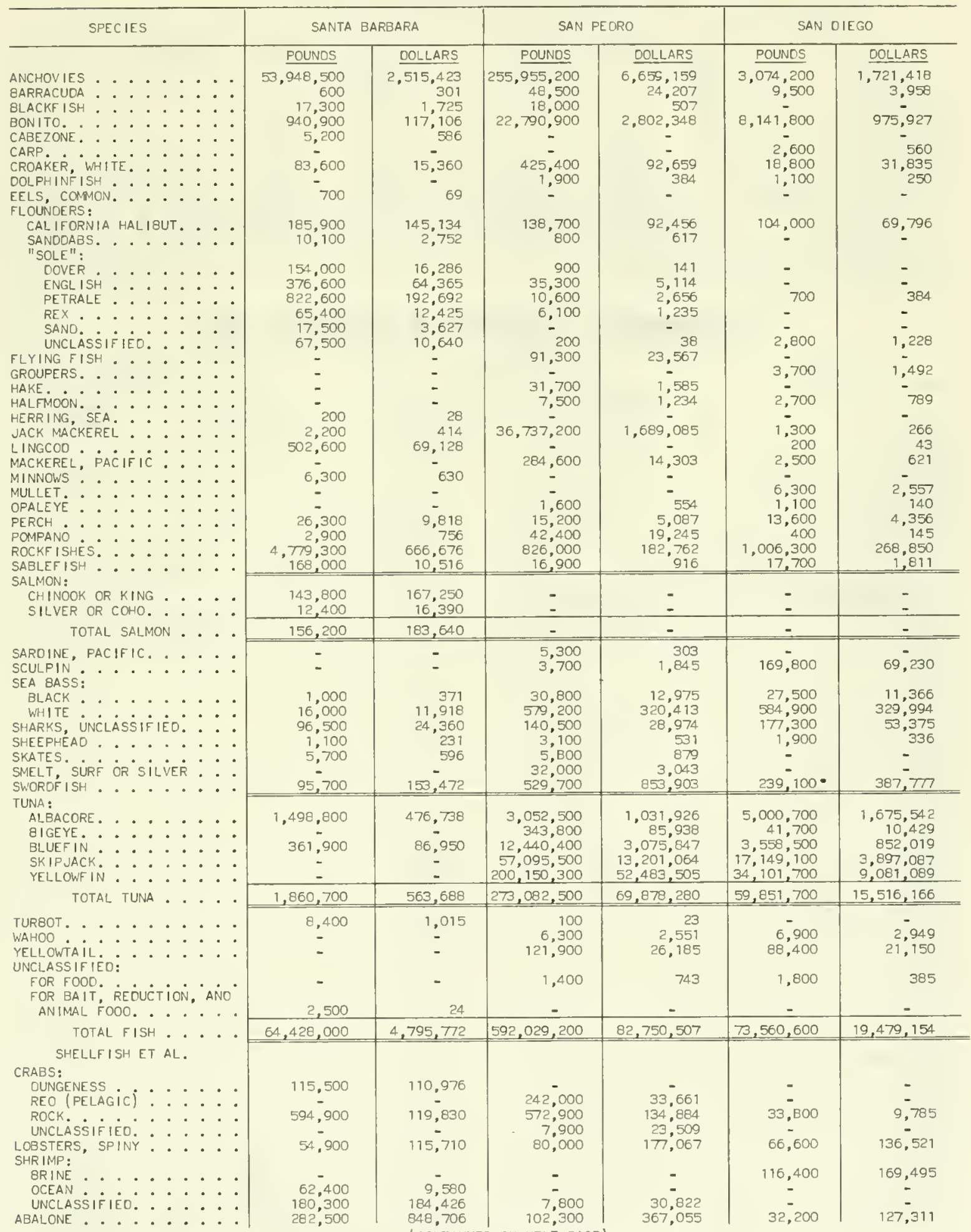

(CONTINUEO ON NEXT PAGE) 
CALIFORNIA - LANDINGS BY DISTRICTS, 1975 - Continued

\begin{tabular}{|c|c|c|c|c|c|c|}
\hline SPECIES & \multicolumn{2}{|c|}{ SANTA BARBARA } & \multicolumn{2}{|c|}{ SAN PEDRO } & \multicolumn{2}{|c|}{ SAN DIEGO } \\
\hline 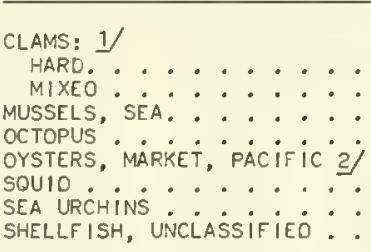 & $\begin{array}{r}\text { POUNDS } \\
- \\
- \\
2,600 \\
87,900 \\
5,119,000 \\
7,195,300 \\
900 \\
\end{array}$ & $\begin{array}{c}\text { DOLLARS } \\
- \\
- \\
555 \\
119,457 \\
109,457 \\
581,212 \\
292 \\
\end{array}$ & $\begin{array}{c}\text { POUNOS } \\
- \\
8,900 \\
24,300 \\
- \\
- \\
13,495,400 \\
220,700 \\
2,100 \\
\end{array}$ & $\begin{array}{c}\text { OOLLARS } \\
- \\
18,109 \\
10,930 \\
- \\
365,218 \\
17,934 \\
780\end{array}$ & $\begin{array}{c}\text { POUNOS } \\
11,300 \\
2,200 \\
- \\
57,200 \\
148,100 \\
300\end{array}$ & $\begin{array}{c}\text { DOLLARS } \\
11,733 \\
- \\
-750 \\
- \\
29,934 \\
14,632 \\
109\end{array}$ \\
\hline TOTAL SHELLFISH ET AL. . & $13,696,200$ & $2,200,201$ & $14,764,300$ & $1.179,969$ & 468,100 & 500,270 \\
\hline GRAND TOTAL. ...... & $78,124,200$ & $6,995,973$ & $606,793,500$ & $83,930,476$ & $74,028,700$ & $19,979,424$ \\
\hline
\end{tabular}

1) BASEO ON A YIELD OF 25 PERCENT MEATS. 2/ BASEO ON A YIELD OF 10.9 PERCENT MEATS FOR EASTERN OYSTERS AND 15.5 PERCENT MEATS FOR PACIFIC OYSTERS.

CALIFORNIA - LANDINGS BY WATERS, 1975

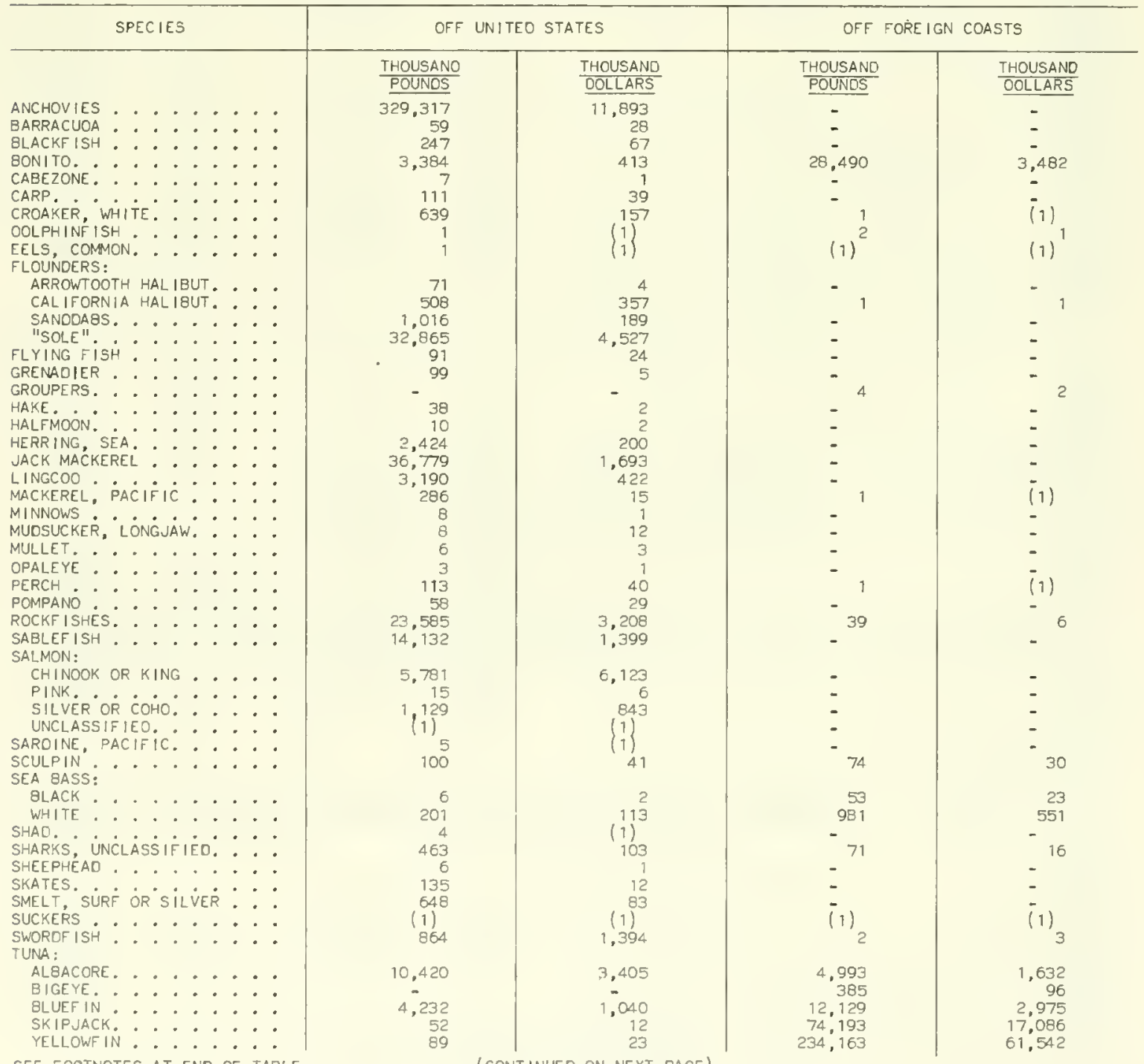


PACIFIC COAST FISHERIES

261

CALIFORNIA - LANDINGS BY WATERS, 1975 - Continued

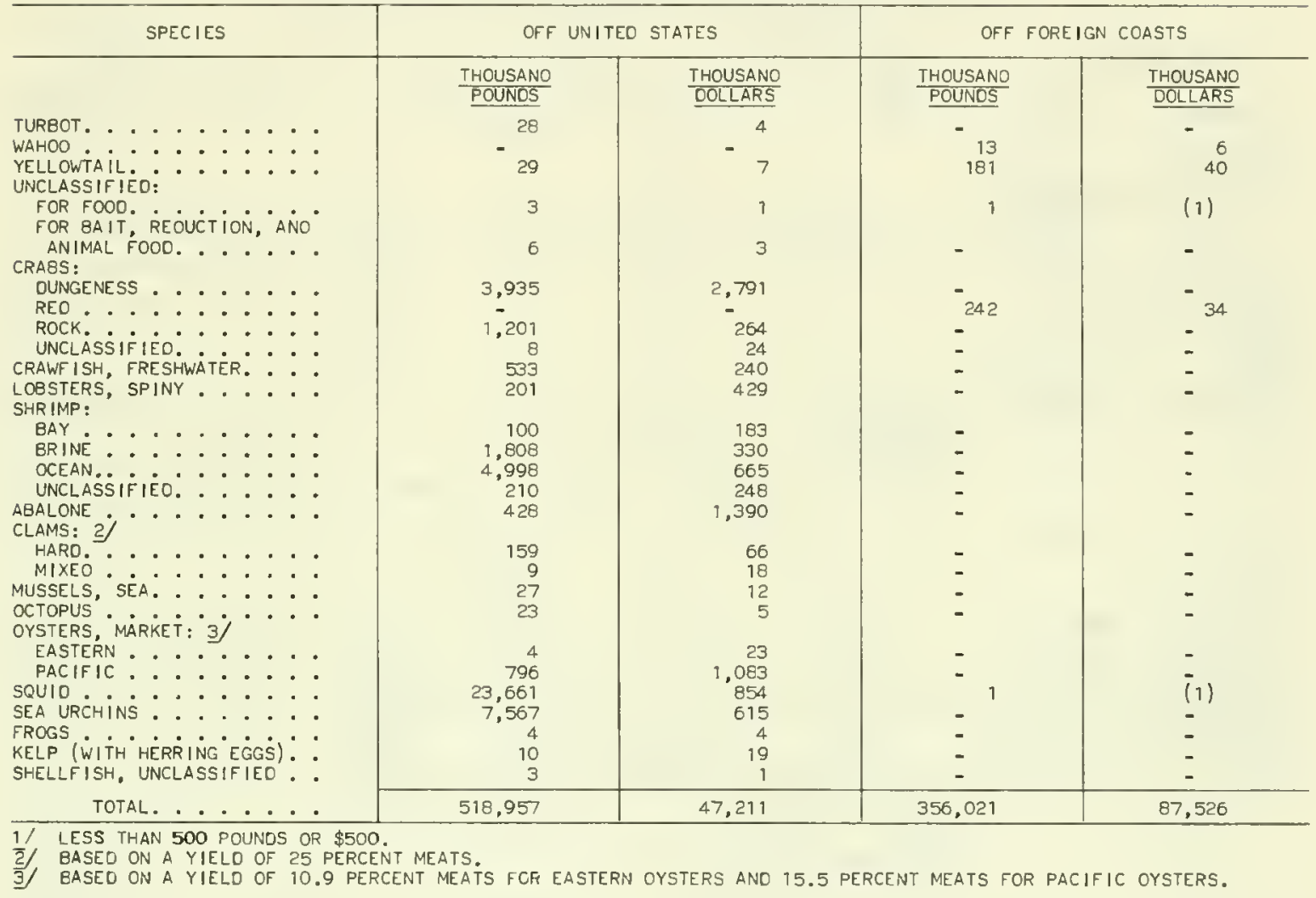




\section{NORTHERN DISTRICT OF CALIFORNIA OPERATING UNITS, 1975}

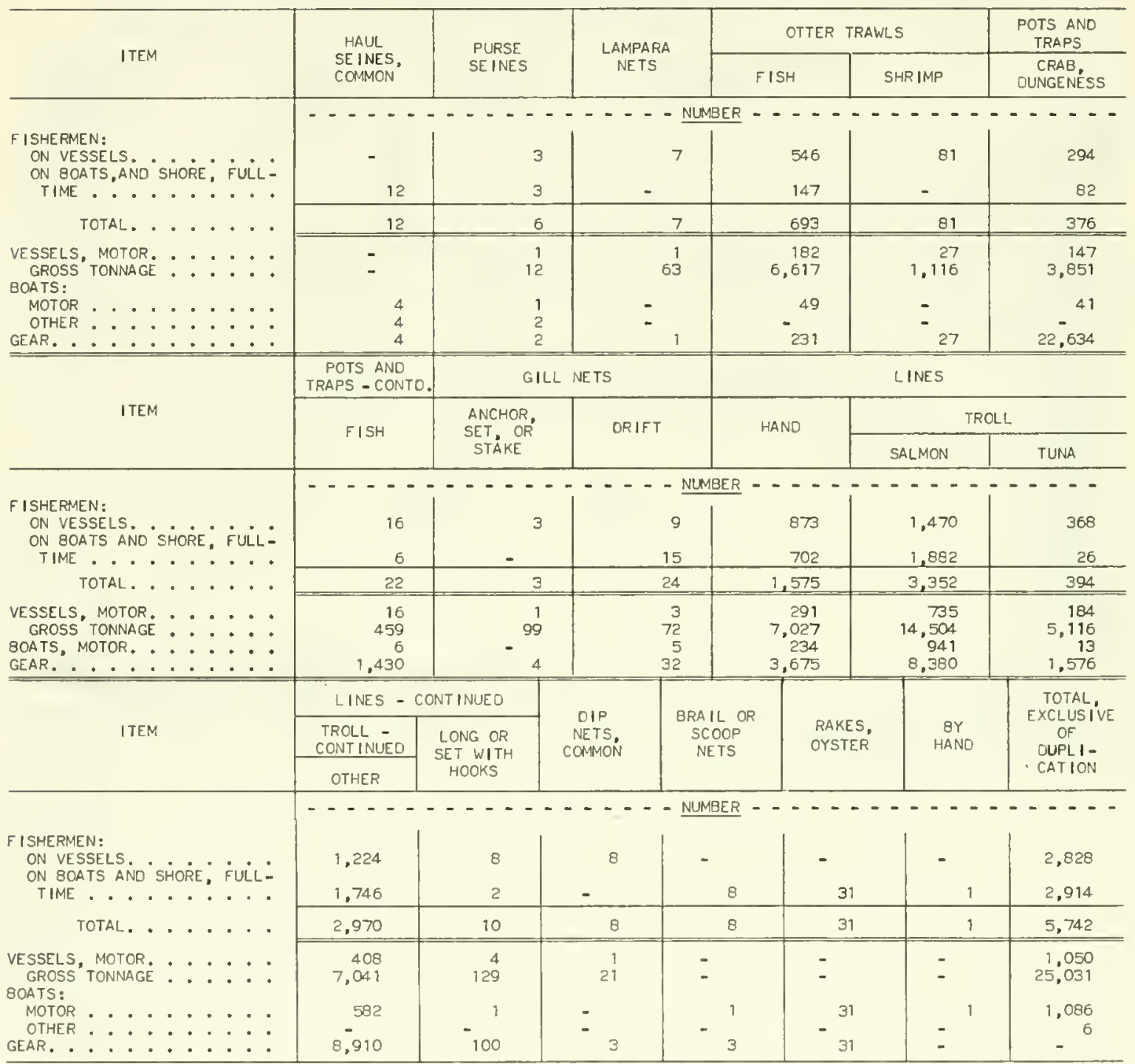




\section{NORTHERN DISTRICT OF CALIFORNIA LANDINGS OF CATCH BY GEAR, 1975}

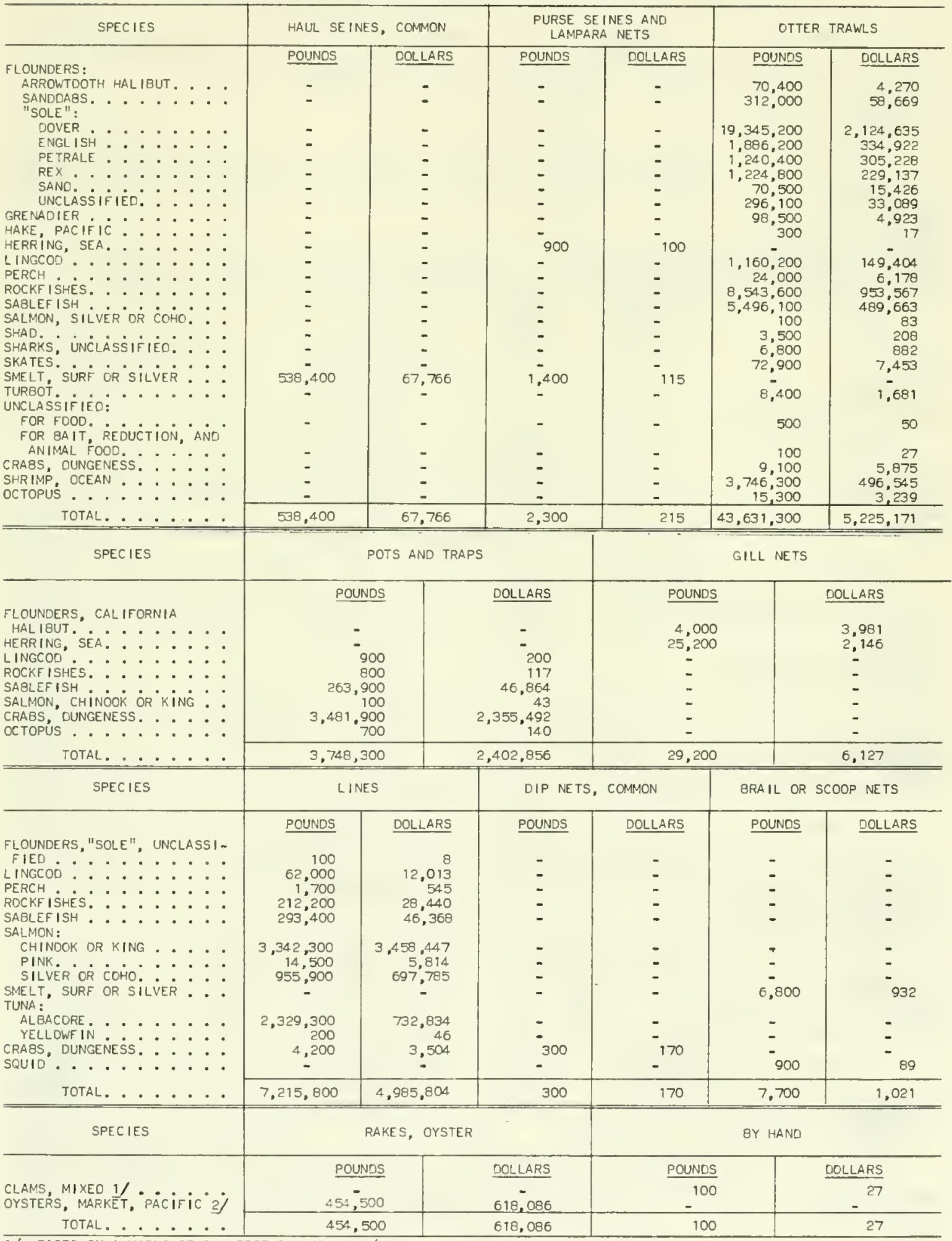

If BASED ON A YIELD OF 25 PERCENT MEATS. 2/ BASED ON A YIELD DF 15.5 PERCENT MEATS. 


\section{SAN FRANCISCO DISTRICT OF CALIFORNIA OPERATING UNITS, 1975}

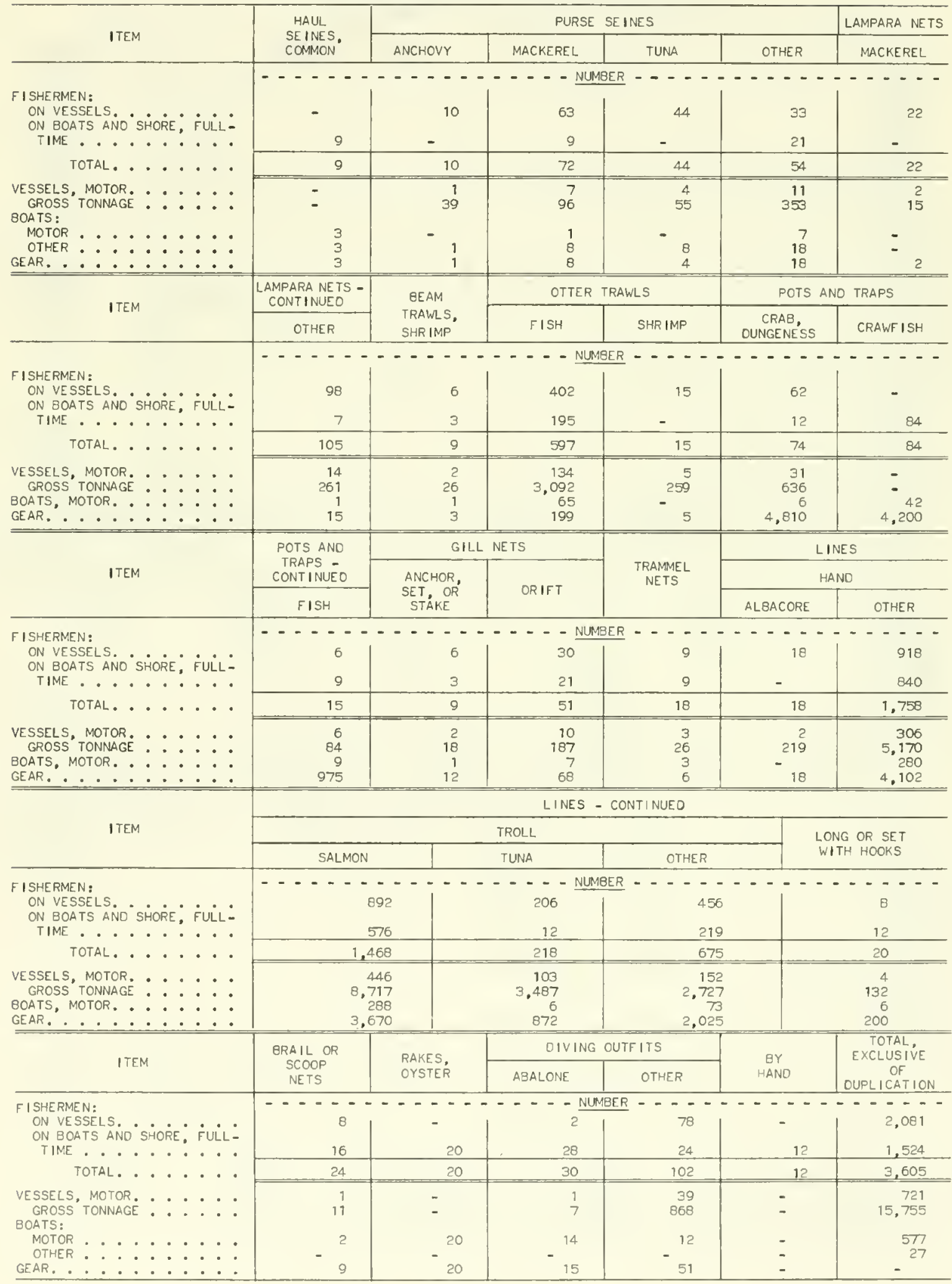




\section{SAN FRANCISCO DISTRICT OF CALIFORNIA LANDINGS OF CATCH BY GEAR, 1975}

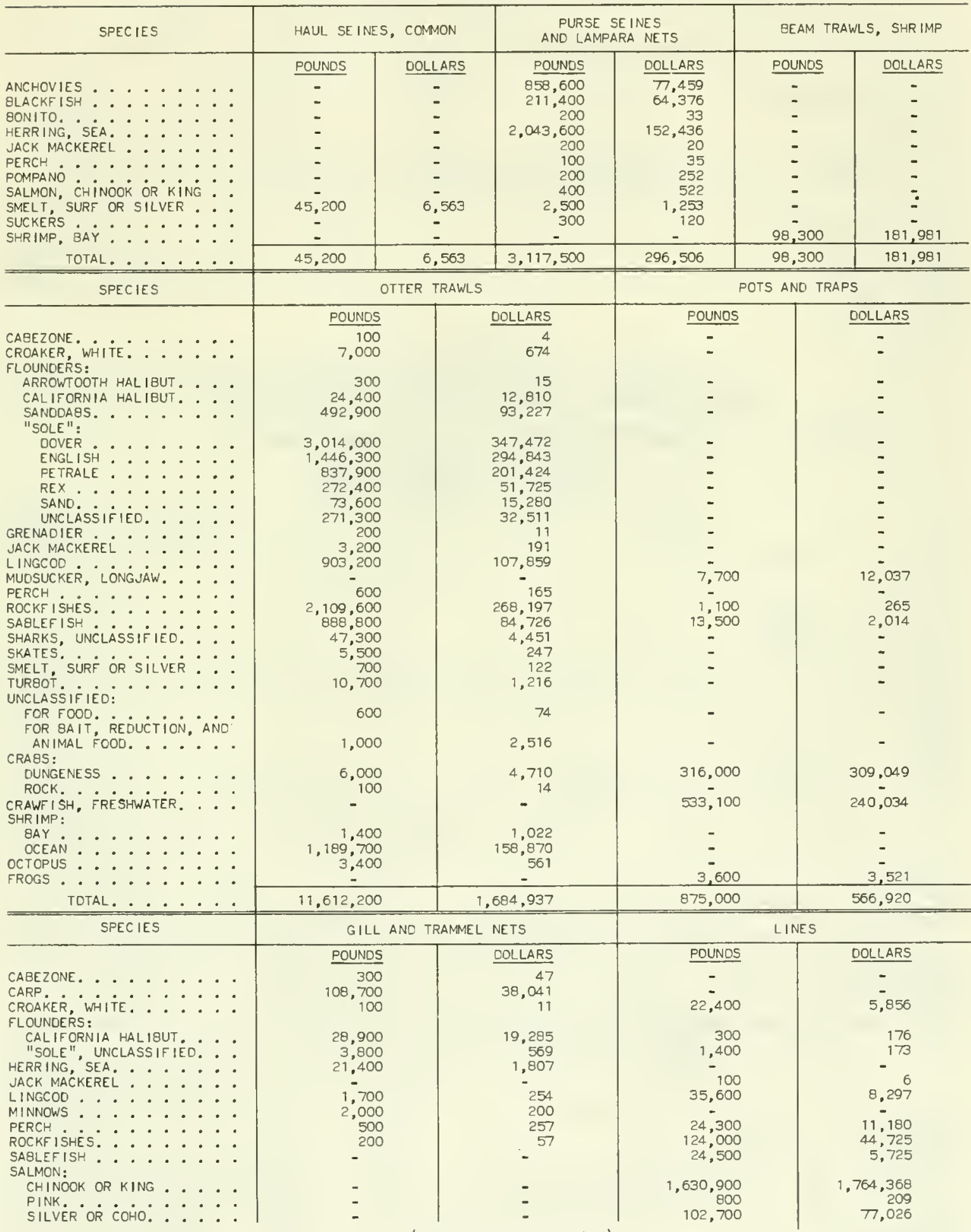




\section{SAN FRANCISCO DISTRICT OF CALIFORNIA LANDINGS OF CATCH BY GEAR, 1975 - Continued}

\begin{tabular}{|c|c|c|c|c|c|c|c|c|}
\hline SPECIES & \multicolumn{4}{|c|}{ GILL AND TRAMMEL NETS } & \multicolumn{4}{|c|}{ LINES } \\
\hline $\begin{array}{l}\text { SEA 8ASS, WHITE } \\
\text { SHARKS, UNCLASSIFIED: }: \\
\text { SMELT, SURF OR SILVER : } \\
\text { TUNA, ALBACORE. }\end{array}$ & \multicolumn{2}{|c|}{$\begin{array}{r}\text { POUNDS } \\
30,900 \\
200 \\
-\end{array}$} & \multicolumn{2}{|c|}{$\begin{array}{r}\text { DOLLARS } \\
\begin{array}{r}101 \\
3.328 \\
26\end{array} \\
\end{array}$} & \multicolumn{2}{|c|}{$\begin{array}{c}\text { POUNDS } \\
\overline{-}, 500 \\
928,700\end{array}$} & \multicolumn{2}{|c|}{$\begin{array}{c}\frac{\text { DOLLARS }}{-} \\
399 \\
293,735\end{array}$} \\
\hline 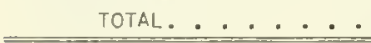 & \multicolumn{2}{|c|}{198,800} & \multicolumn{2}{|c|}{63,983} & \multicolumn{2}{|c|}{$2,898,200$} & \multicolumn{2}{|c|}{$2,211,875$} \\
\hline \multirow[t]{2}{*}{ SPECIES } & \multicolumn{2}{|c|}{$\begin{array}{c}\text { BRAIL OR SCDOF } \\
\text { NETS }\end{array}$} & \multicolumn{2}{|c|}{ RAKES, OYSTER } & \multicolumn{2}{|c|}{ DIVING OUTF ITS } & \multicolumn{2}{|c|}{ BY HAND } \\
\hline & POUNOS & DOLLARS & POUNDS & DOLLARS & POUNDS & DOLLARS & POUNOS & DOLLARS \\
\hline $\begin{array}{l}\text { KELP (WITH HERR ING EGGS). } \\
\text { SMELT, SURF OR SILVER }\end{array}$ & - & -30 & - & - & 10,000 & 19,370 & - & - \\
\hline SHRIMP, BRINE ...: : & - & - & - & - & - & - & $1,691,400$ & 160,982 \\
\hline 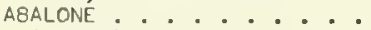 & - & - & - & - & 10,600 & 45,997 & & \\
\hline CLAMS, HARD $1 / \ldots$ & - & - & - & - & - & - & 147,300 & 53,774 \\
\hline $\begin{array}{l}\text { MUSSELS, SEA } \\
\text { OYSTERS, MARKET: } \dot{2} ; \cdots \cdot \cdot\end{array}$ & - & - & - & - & - & - & 400 & \\
\hline 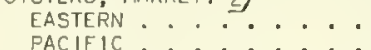 & - & - & 4.000 & 22,973 & - & - & - & - \\
\hline SEA URCHINS $: \vdots \therefore: \vdots$ & $=$ & 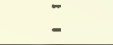 & $253,-700$ & $\begin{array}{c}344,988 \\
-\end{array}$ & 2,000 & -575 & - & - \\
\hline TOTAL. ...... & 200 & 30 & 257,700 & 367,961 & 22,600 & 65,942 & $1,839,100$ & 214.810 \\
\hline
\end{tabular}

1/ 8ASED ON A YIELD OF 25 PERCENT MEATS. 2/ BASED ON A YIELD OF 10.9 PERCENT MEATS FOR EASTERN OYSTERS AND 15.5 PERCENT MEATS FOR PACIFIC OYSTERS.

\section{MONTEREY DISTRICT OF CALIFORNIA OPERATING UNITS, 1975}

\begin{tabular}{|c|c|c|c|c|c|c|}
\hline \multirow{2}{*}{ ITEM } & \multirow{2}{*}{$\begin{array}{l}\text { HAUL } \\
\text { SE INES, } \\
\text { COMMON }\end{array}$} & \multicolumn{2}{|c|}{ PURSE SEINES } & \multicolumn{3}{|c|}{ LAMPARA NETS } \\
\hline & & ANCHOVY & OTHER & MACKEREL & SQUID & OTHER \\
\hline $\begin{array}{l}\text { FISHERMEN: } \\
\text { ON VESSELS. } \\
\text { ON BOATS AND SHORE; FULL: } \\
\text { TIME . . . . . . }\end{array}$ & $\begin{array}{c}\cdots \cdots \\
- \\
9 \\
\end{array}$ & ${ }^{20}$ & $\ldots \ldots-N$ & 7 & 136 & 98 \\
\hline TOTAL. ...... & 9 & 20 & 63 & 110 & 176 & 147 \\
\hline $\begin{array}{l}\text { VESSELS, MOTOR. }: \vdots: \\
\text { GROSS TONNAGE }: \\
\text { BOATS: } \\
\text { MOTOR }: \vdots: \vdots: \vdots \\
\text { OTHER }: \vdots: \vdots:\end{array}$ & $\begin{array}{l}3 \\
3 \\
3 \\
\end{array}$ & $\begin{array}{r}2 \\
30 \\
-\quad \\
2 \\
2 \\
\end{array}$ & $\begin{array}{r}12 \\
475 \\
9 \\
21 \\
21 \\
\end{array}$ & $\begin{array}{r}7 \\
113 \\
-\quad 3 \\
-\quad 10 \\
\end{array}$ & $\begin{array}{r}17 \\
385 \\
-\quad 5 \\
\end{array}$ & $\begin{array}{r}14 \\
324 \\
-\quad 7 \\
-\quad 21 \\
\end{array}$ \\
\hline \multirow[b]{2}{*}{ ITEM } & \multicolumn{2}{|c|}{ OTTER TRAWLS } & \multicolumn{3}{|c|}{ POTS AND TRAPS } & GILL NETS \\
\hline & FISH & SHR IMP & $\begin{array}{c}\text { CRAB, } \\
\text { DUNGENESS }\end{array}$ & FISH & SHR IMP & $\begin{array}{c}\text { ANCHOR, SET, } \\
\text { OR STAKE }\end{array}$ \\
\hline \multirow[t]{2}{*}{ 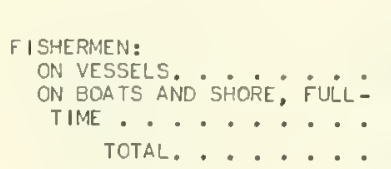 } & $\begin{array}{c}-\cdots \\
69 \\
9\end{array}$ & $\begin{array}{r}-\cdots \\
- \\
-\end{array}$ & $\begin{array}{r}-\cdots \\
4 \\
2 \\
\end{array}$ & $\begin{array}{r}15 \\
15 \\
1\end{array}$ & $\begin{array}{r}--- \\
- \\
-\end{array}$ & $\begin{array}{c}-\cdots \\
9 \\
-\end{array}$ \\
\hline & 78 & 9 & 6 & 16 & 8 & 9 \\
\hline $\begin{array}{l}\text { VESSELS, MOTOR. } \\
\text { GROSS TONNAGE : }: \vdots: \\
\text { BOATS, MOTOR. : }: \vdots:\end{array}$ & $\begin{array}{r}23 \\
836 \\
3 \\
26 \\
\end{array}$ & $\begin{array}{r}3 \\
-\quad 25 \\
-\quad 3 \\
\end{array}$ & $\begin{array}{r}2 \\
28 \\
1 \\
390 \\
\end{array}$ & $\begin{array}{r}15 \\
285 \\
1 \\
1,040 \\
\end{array}$ & $\begin{array}{r}4 \\
-\quad 32 \\
148\end{array}$ & $\begin{array}{r}3 \\
-\quad 39 \\
-\quad 12 \\
\end{array}$ \\
\hline \multirow{3}{*}{ ITEM } & $\begin{array}{l}\text { GILL NETS - } \\
\text { CONT I NUED }\end{array}$ & \multirow{3}{*}{$\begin{array}{l}\text { TRAMMEL } \\
\text { NETS }\end{array}$} & \multicolumn{4}{|c|}{ LINES } \\
\hline & \multirow{2}{*}{ ORIFT } & & \multicolumn{2}{|c|}{ HAND } & \multicolumn{2}{|c|}{ TROLL } \\
\hline & & & ALBACORE & OTHER & SALMON & TUNA \\
\hline $\begin{array}{l}\text { FISHERMEN: } \\
\text { ON VESSELS. } \\
\text { ON } 80 A T S \text { AND SHORE: 'FULL- } \\
\text { TIME } . \cdots \cdots . . . .\end{array}$ & $\begin{array}{r}\cdots \cdots \\
45 \\
21 \\
\end{array}$ & $\begin{array}{r}\cdots \\
15 \\
30 \\
\end{array}$ & $-\ldots-\frac{N}{9}$ & $\begin{array}{r}R-\cdots \\
399 \\
729 \\
\end{array}$ & $\begin{array}{r}--- \\
432 \\
666 \\
\end{array}$ & $\begin{array}{r}\ldots .- \\
450 \\
52 \\
\end{array}$ \\
\hline TOTAL. ..... & 66 & 45 & 9 & 1.128 & 1,098 & 502 \\
\hline $\begin{array}{l}\text { VESSELS, MOTOR. }:: \vdots: \\
\text { GROSS TONNAGE }: \vdots: \vdots:\end{array}$ & $\begin{array}{r}15 \\
244 \\
7 \\
88\end{array}$ & $\begin{array}{r}5 \\
109 \\
10 \\
15\end{array}$ & $\begin{array}{r}1 \\
-\quad 4 \\
9\end{array}$ & $\begin{array}{r}133 \\
2,749 \\
243 \\
2,632\end{array}$ & $\begin{array}{r}216 \\
3,838 \\
333 \\
2,745\end{array}$ & $\begin{array}{r}225 \\
5,564 \\
26 \\
2,008\end{array}$ \\
\hline
\end{tabular}




\section{MONTEREY DISTRICT OF CALIFORNIA OPERATING UNITS, 1975 - Confinued}

\begin{tabular}{|c|c|c|c|c|c|c|c|}
\hline \multirow[b]{2}{*}{ ITEM } & \multicolumn{2}{|c|}{ LINES - CONTINUEO } & \multirow{2}{*}{$\begin{array}{l}\text { BRAIL } \\
\text { OR } \\
\text { SCOOP } \\
\text { NETS }\end{array}$} & \multirow[b]{2}{*}{$\begin{array}{l}\text { HARPOONS, } \\
\text { SWORDF I SH }\end{array}$} & \multicolumn{2}{|c|}{ OIVING OUTFITS } & \multirow{2}{*}{$\begin{array}{l}\text { TOTAL, } \\
\text { EXCLUSIVE } \\
\text { DF } \\
\text { OUPLI- } \\
\text { CATION }\end{array}$} \\
\hline & $\begin{array}{c}\text { TROLL } \\
\text { CONTINUEDD } \\
\text { OTHER }\end{array}$ & $\begin{array}{l}\text { LONG OR SET } \\
\text { WITH HOOKS }\end{array}$ & & & ABALONE & OTHER & \\
\hline $\begin{array}{l}\text { FISHERMEN: } \\
\text { ON VESSELS. } \\
\text { ON BOATS AND SHORE; FULL: } \\
\text { TIME } . \ldots . . .\end{array}$ & $\begin{array}{r}\ldots \\
210 \\
273\end{array}$ & $\begin{array}{r}-\cdots \\
12 \\
26 \\
\end{array}$ & -- & $\begin{array}{c}-\frac{\text { NUMBER }}{-} \\
2\end{array}$ & $\begin{array}{c}--\cdot- \\
-\end{array}$ & $\begin{array}{c}--- \\
-\end{array}$ & $\begin{array}{l}1,266 \\
1,272\end{array}$ \\
\hline TOTAL. . . . . & 483 & 38 & 32 & 2 & 4 & 6 & 2,538 \\
\hline 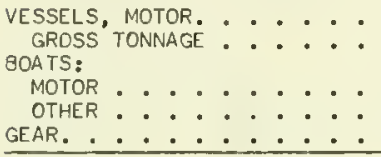 & $\begin{array}{r}70 \\
1.221 \\
-\quad 91 \\
1.449 \\
\end{array}$ & $-\quad 13$ & $\begin{array}{r}1 \\
12 \\
-\quad 3 \\
-\quad 12\end{array}$ & $\begin{array}{l}- \\
- \\
- \\
1\end{array}$ & $\begin{array}{l}- \\
- \\
- \\
2\end{array}$ & $\begin{array}{l}- \\
- \\
-\quad 3 \\
\end{array}$ & $\begin{array}{r}460 \\
10,641 \\
459 \\
13\end{array}$ \\
\hline
\end{tabular}

\section{MONTEREY DISTRICT OF CALIFORNIA} LANDINGS OF CATCH BY GEAR, 1975

\begin{tabular}{|c|c|c|c|c|c|c|}
\hline \multirow[t]{2}{*}{ SPECIES } & \multicolumn{2}{|c|}{ HAUL SEINES, COMMON } & \multicolumn{2}{|c|}{$\begin{array}{l}\text { PURSE SEINE AND } \\
\text { LAMPARA NETS }\end{array}$} & \multicolumn{2}{|c|}{ OTTER TRAWLS } \\
\hline & POUNDS & DOLLARS & POUNDS & DOLLARS & FOUNOS & DOLLARS \\
\hline ANCHOVIES & - & - & $15,4 \overline{80,100}$ & 919,843 & - & - \\
\hline \multirow{21}{*}{ 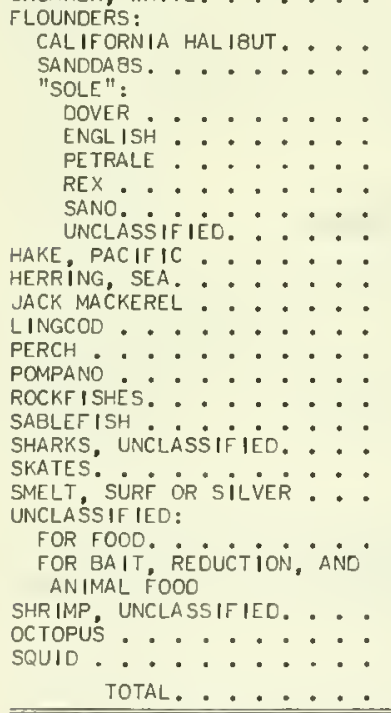 } & - & - & 42,500 & 4,334 & 9,300 & 648 \\
\hline & - & - & - & - & 2,900 & 1.740 \\
\hline & - & - & - & - & 176,000 & 27.945 \\
\hline & - & - & - & - & 174,500 & 18,436 \\
\hline & - & - & - & - & 569,800 & 97.916 \\
\hline & - & - & - & - & 357,600 & 80,874 \\
\hline & - & - & - & - & 77,700 & 9,784 \\
\hline & $\overline{-}$ & - & $\overline{-}$ & - & $\begin{array}{l}22,800 \\
60,800\end{array}$ & $\begin{array}{l}4.359 \\
7,272\end{array}$ \\
\hline & - & - & -3 & -830 & 6.500 & 390 \\
\hline & $\overline{-}$ & 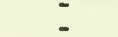 & $\begin{array}{r}332,300 \\
25,500\end{array}$ & $\begin{array}{r}43,830 \\
2,956\end{array}$ & 9,000 & 257 \\
\hline & - & - & 20 & -900 & 193,800 & 27.175 \\
\hline & $\overline{-}$ & $\overline{-}$ & $12^{-}, 100$ & $8-312$ & 1,500 & -178 \\
\hline & - & - & $\begin{array}{r}12,100 \\
1,400\end{array}$ & $\begin{array}{r}8,312 \\
169\end{array}$ & $3,583,200$ & 429,738 \\
\hline & - & - & - & - & 378,300 & 26,139 \\
\hline & $\overline{-}$ & $\overline{-}$ & - & $=$ & 19,900 & 1,662 \\
\hline & 5,800 & 1,300 & 14,200 & 1,698 & 24,300 & 1,900 \\
\hline & - & - & 100 & 12 & - & - \\
\hline & - & - & - & - & 3000 & 20 \\
\hline & - & - & - & - & 500 & 725 \\
\hline & - & - & $4,9 \pi, 300$ & 348,782 & $-^{100}$ & $-\quad 11$ \\
\hline & 5,800 & 1,300 & $20,885,500$ & $1,329,936$ & 5.670 .500 & 737.231 \\
\hline SPECIES & \multicolumn{2}{|c|}{ POTS AND TRAPS } & \multicolumn{2}{|c|}{ GILL ANO TRAMMEL NETS } & \multicolumn{2}{|c|}{ LINES } \\
\hline & POUNOS & DOLLARS & POUNOS & OOLLARS & POUNDS & DOLLARS \\
\hline 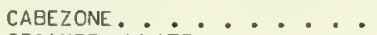 & - & - & 900 & 131 & 700 & \\
\hline CROAKER, WHITE. . . . & - & - & 25,000 & 4.041 & 5,900 & 1,191 \\
\hline $\begin{array}{l}\text { EELS, COMMON. . . . . } \\
\text { FLOUNDERS: }\end{array}$ & - & - & - & - & 100 & \\
\hline CAL IFORNIA HALIBUT. . . & - & - & 19,400 & 12,730 & 300 & 236 \\
\hline $\begin{array}{l}\text { SANOOABS. } \cdots \cdots \cdot \cdots \cdot \\
\text { "SOLE": }\end{array}$ & - & - & - & - & 23,800 & 5,715 \\
\hline PETRÁLE . . . . . . . & _ & _ & - & - & 200 & 51 \\
\hline SANO. $\therefore \therefore$ & - & - & - & - & 200 & 49 \\
\hline UNCLASSIFIEO. . . & - & - & 56,300 & 10,584 & 1,100 & 257 \\
\hline JACK MACKEREL ....... & - & - & 300 & & 300 & 40 \\
\hline 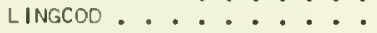 & 100 & 13 & 308,500 & 43,676 & 21,300 & 3,902 \\
\hline
\end{tabular}


MONTEREY DISTRICT OF CALIFORNIA LANDINGS OF CATCH BY GEAR, 1975 - Continued

\begin{tabular}{|c|c|c|c|c|c|c|}
\hline SPECIES & \multicolumn{2}{|c|}{ POTS AND TRAPS } & \multicolumn{2}{|c|}{ GILL AND TRAMMEL NETS } & \multicolumn{2}{|c|}{ LINES } \\
\hline 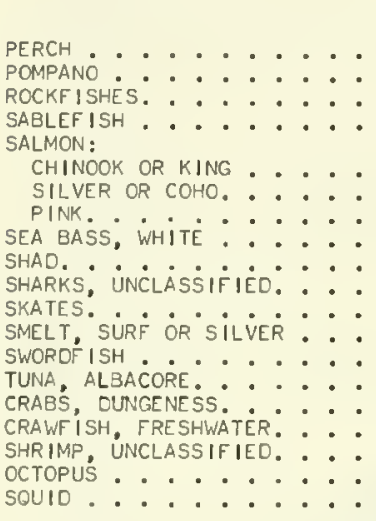 & $\begin{array}{c}\frac{\text { POUNOS }}{-} \\
\overline{-} \\
6,452,800 \\
= \\
= \\
= \\
= \\
\overline{-} \\
- \\
1,600 \\
100 \\
21,200 \\
700 \\
-\end{array}$ & $\begin{array}{c}\frac{\text { DOLLARS }}{-} \\
\vdots \\
672,127 \\
= \\
\vdots \\
= \\
\vdots \\
\vdots \\
= \\
1.772 \\
202 \\
31.983 \\
313 \\
=\end{array}$ & $\begin{array}{r}\frac{P O U N D S}{3,000} \\
200 \\
2,104,500 \\
6,100 \\
- \\
= \\
2,200 \\
11,700 \\
14,500 \\
= \\
= \\
= \\
= \\
=\end{array}$ & $\begin{array}{r}\text { DOLLARS } \\
993 \\
132 \\
272,001 \\
631 \\
= \\
= \\
1,571 \\
1,268 \\
878 \\
=46 \\
= \\
= \\
= \\
-\end{array}$ & $\begin{array}{r}\text { POUNDS } \\
3,200 \\
331,800 \\
112,000 \\
663,600 \\
57,300 \\
-200 \\
- \\
700 \\
6,600 \\
300 \\
600 \\
2,602,900 \\
= \\
- \\
-300 \\
500 \\
\end{array}$ & $\begin{array}{r}\text { DOLLARS } \\
1,265 \\
98.559 \\
11,996 \\
732,425 \\
51,726 \\
-52 \\
- \\
61 \\
338 \\
67 \\
897 \\
826,671 \\
- \\
- \\
-118 \\
69\end{array}$ \\
\hline TOTAL $\ldots \ldots \ldots$ & $6,476,500$ & 706,410 & 2.553 .200 & 348,729 & $3.833,900$ & $1,735,755$ \\
\hline SPECIES & \multicolumn{2}{|c|}{ BRAIL OR SCOOP } & \multicolumn{2}{|c|}{ HARPOONS } & \multicolumn{2}{|c|}{ OIVING OUTFITS } \\
\hline $\begin{array}{l}\text { SMELT, SURF } \\
\text { SWOROF ISH }: \vdots: \therefore: \\
\text { ABALONE }: \vdots:\end{array}$ & $\begin{array}{c}\frac{\text { POUNDS }}{100} \\
- \\
11,600 \\
\end{array}$ & $\begin{array}{c}\frac{\text { DOLLARS }}{38} \\
- \\
- \\
-\end{array}$ & $\begin{array}{l}\frac{\text { POUNDS }}{-} \\
-400 \\
- \\
-\end{array}$ & $\begin{array}{c}\frac{\text { DOLLARS }}{-} \\
-561 \\
\vdots \\
\end{array}$ & $\begin{array}{c}\frac{\text { POUNDS }}{-} \\
- \\
- \\
1,000\end{array}$ & $\begin{array}{c}\text { DOLLARS } \\
- \\
- \\
-752 \\
-254\end{array}$ \\
\hline 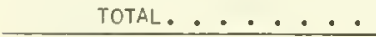 & 11,700 & 851 & 400 & 561 & 1,200 & 1,006 \\
\hline
\end{tabular}

\section{SANTA BARBARA DISTRICT OF CALIFORNIA OPERATING UNITS, 1975}

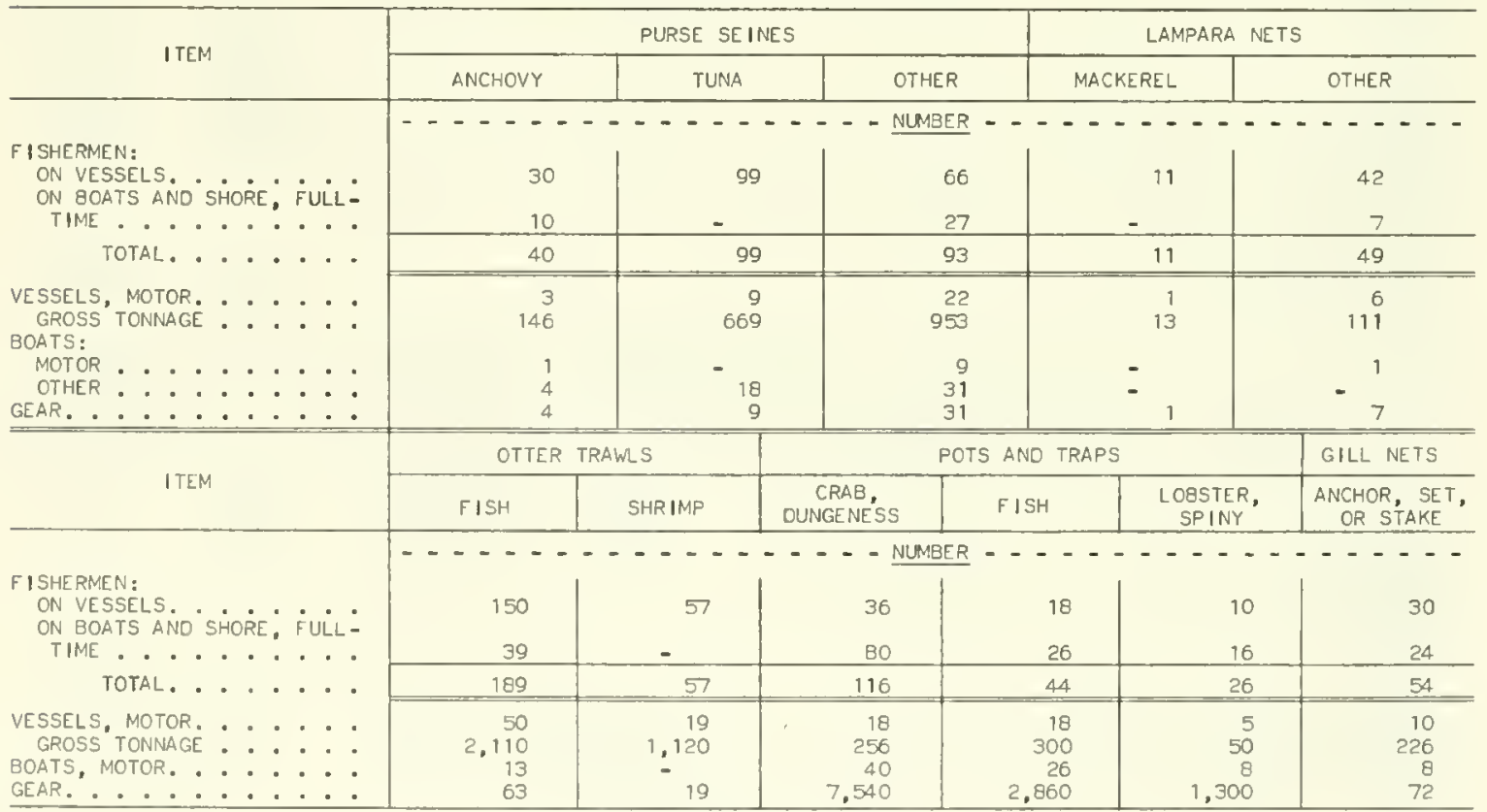

(CONTINUED ON NEXT PAGE) 


\section{SANTA BARBARA DISTRICT OF CALIFORNIA OPERATING UNITS, 1975 - Continued}

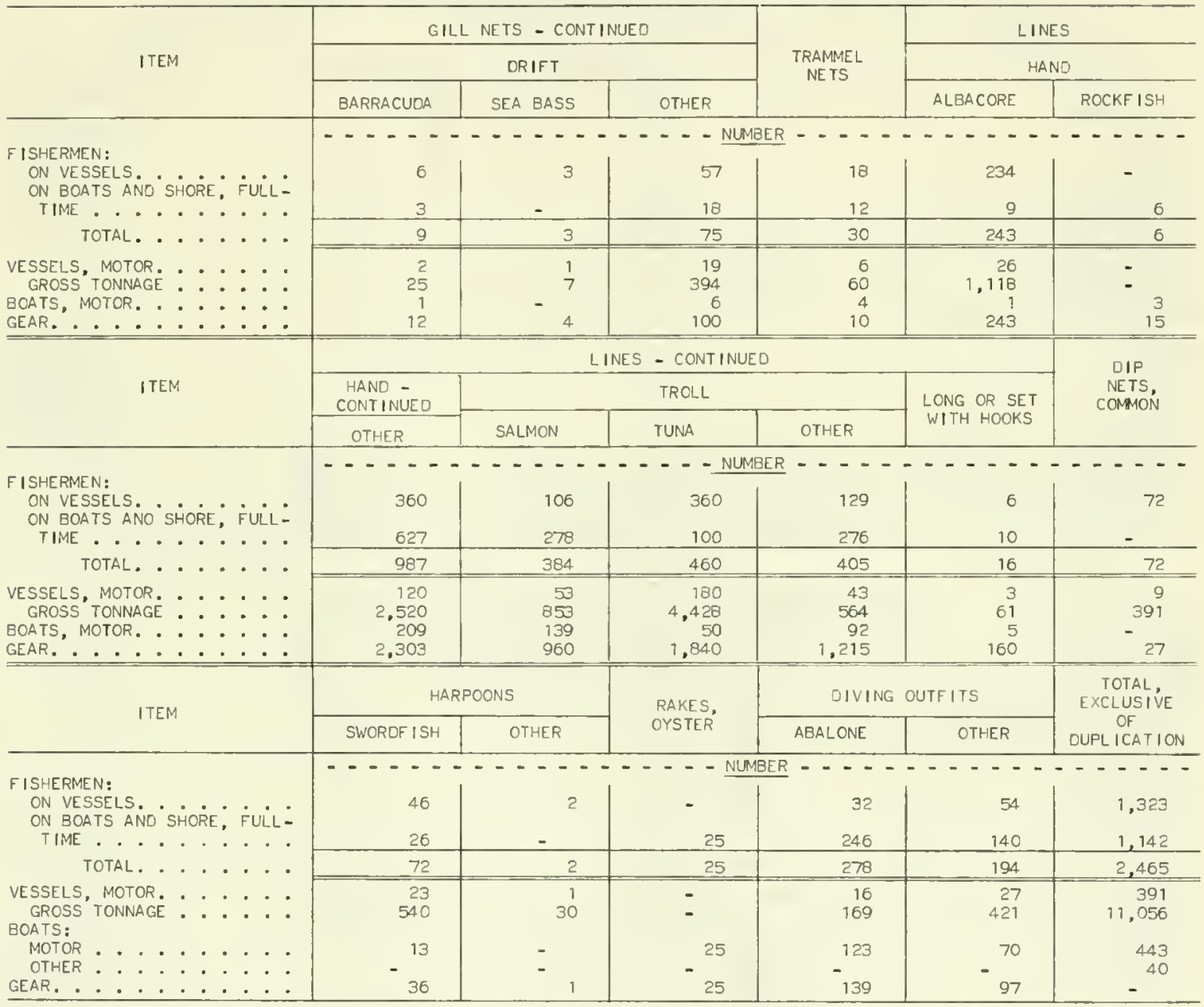

\section{SANTA BARBARA DISTRICT OF CALIFORNIA LANDINGS OF CATCH BY GEAR, 1975}

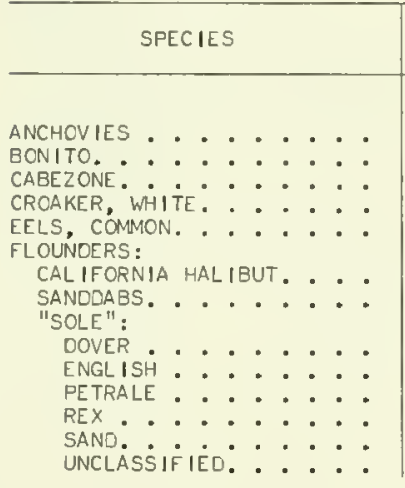

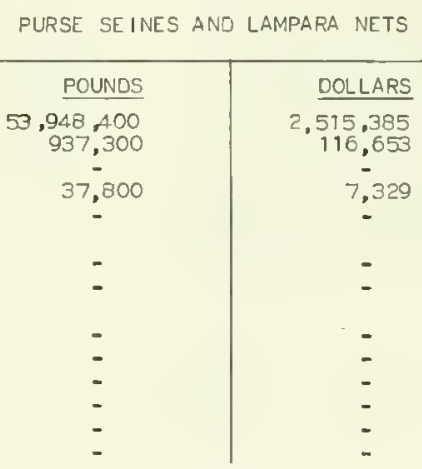

(CONTINUED ON NEXT PAGE)
OTTER TRAWLS

POUNOS
-
-
500
5,400
600
73,400
10,100
154,000
376,600
822,600
65,400
17,500
50,800

DOLLARS

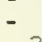

35
796

56,967

2, 752

16,286

64,365

192,692

12,425

3,627
7,301 
SANTA BARBARA DISTRICT OF CALIFORNIA LANDINGS OF CATCH BY GEAR, 1975 - Continued

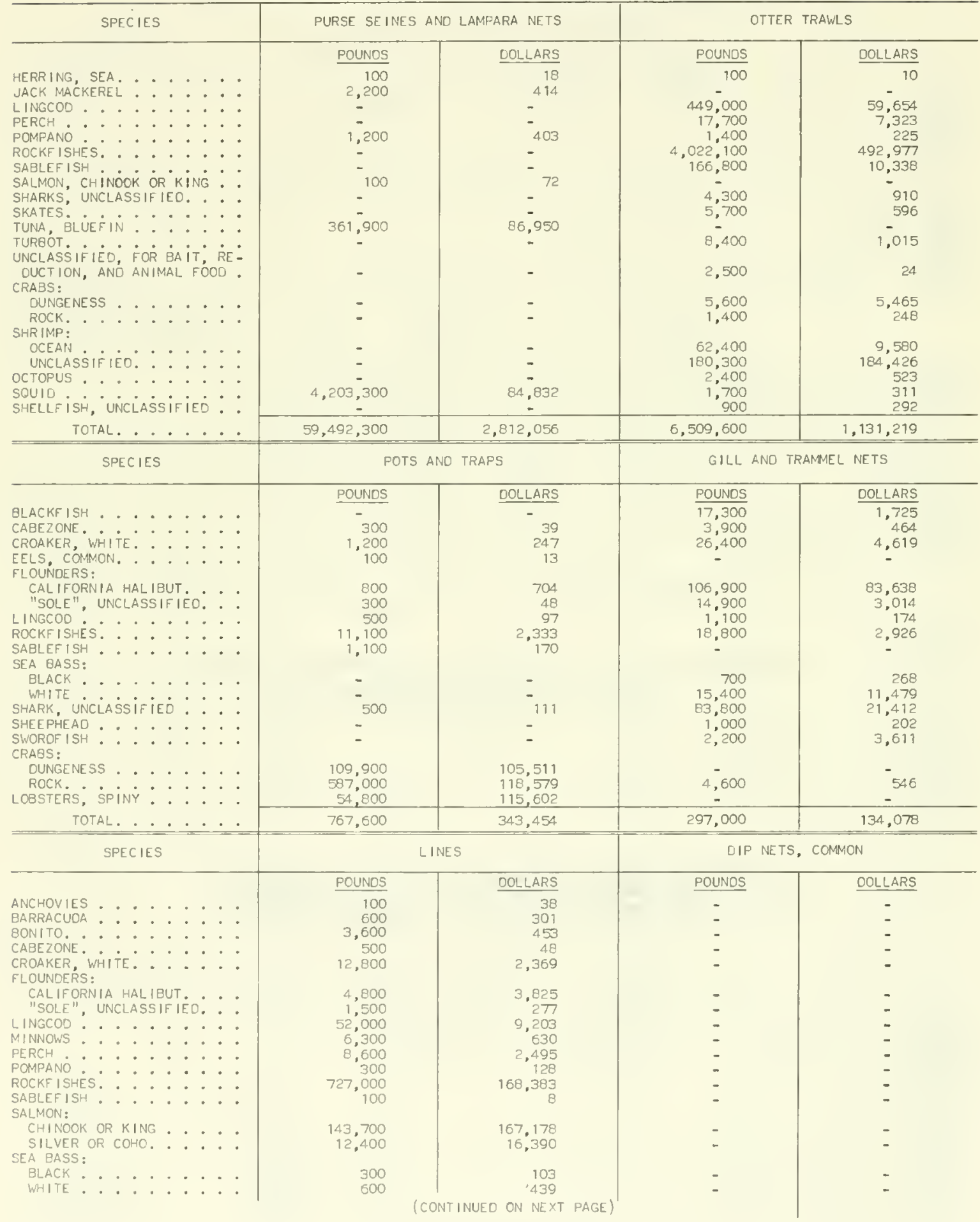


SANTA BARBARA DISTRICT OF CALIFORNIA LANDINGS OF CATCH BY GEAR, 1975 - Continued

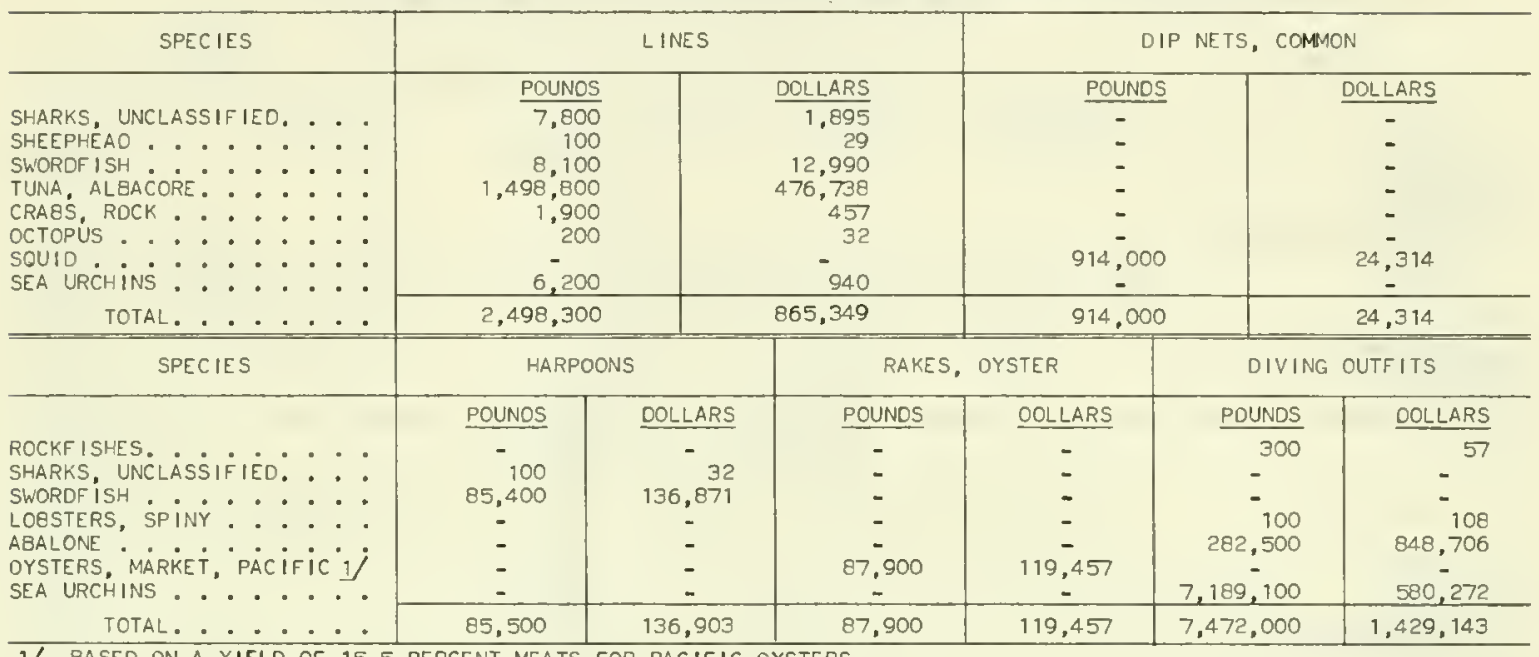

1\% BASED DN A YIELD OF 15.5 PERCENT MEATS FOR PACIFIC OYSTERS.

\section{SAN PEDRO DISTRICT OF CALIFORNIA OPERATING UNITS, 1975}

\begin{tabular}{|c|c|c|c|c|c|c|}
\hline \multirow{2}{*}{ ITEM } & \multicolumn{3}{|c|}{ PURSE SEINES } & \multicolumn{3}{|c|}{ LAMPARA NETS } \\
\hline & MACKEREL & TUNA & OTHER & MACKEREL & SQUID & TUNA \\
\hline $\begin{array}{l}\text { FISHERMEN: } \\
\text { ON VESSELS. } \\
\text { ON BOATS ANO SHORE; } \dot{F} U L L \text { - } \\
\text { TIME } \ldots \ldots \ldots\end{array}$ & $\begin{array}{c}\ldots \ldots \\
288 \\
18\end{array}$ & $\begin{array}{r}1,276 \\
44\end{array}$ & $\begin{array}{r}-\ldots \\
210 \\
39\end{array}$ & 110 & $\begin{array}{r}-\cdots \\
- \\
-\end{array}$ & $\begin{array}{r}\cdots \\
5 \\
1\end{array}$ \\
\hline TOTAL. . ..... & 306 & 1,320 & 249 & 110 & 48 & 6 \\
\hline 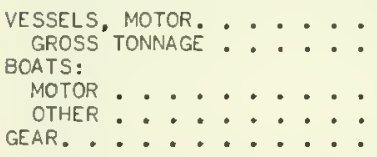 & $\begin{array}{r}32 \\
2,573 \\
2 \\
34 \\
34\end{array}$ & $\begin{array}{r}116 \\
63,888 \\
4 \\
240 \\
120\end{array}$ & $\begin{array}{r}70 \\
6.949 \\
13 \\
83 \\
83\end{array}$ & $\begin{array}{r}10 \\
322 \\
- \\
-\quad 10\end{array}$ & $\begin{array}{r}6 \\
132 \\
-\quad \\
-\quad 6\end{array}$ & $\begin{array}{r}5 \\
100 \\
-\quad 1 \\
-\quad 6\end{array}$ \\
\hline \multirow{2}{*}{ ITEM } & $\begin{array}{c}\text { LAMPARA NETS - } \\
\text { CONT INUED }\end{array}$ & \multirow{2}{*}{$\begin{array}{l}\text { DTTER } \\
\text { TRAWLS, } \\
\text { FISH }\end{array}$} & \multicolumn{3}{|c|}{ POTS AND TRAPS } & GILL NETS \\
\hline & OTHER & & $\begin{array}{c}\text { CRAB, } \\
\text { DUNGENE'SS }\end{array}$ & $\mathrm{FISH}$ & $\begin{array}{l}\text { LOBSTER. } \\
\text { SPINY }\end{array}$ & $\begin{array}{l}\text { ANCHOR, SET, } \\
\text { OR STAKE }\end{array}$ \\
\hline $\begin{array}{l}\text { FISHERMEN: } \\
\text { ON VESSELS. } \\
\text { ON BOATS ANO SHORE; FULL: } \\
\text { TIME } . . . .\end{array}$ & $\begin{array}{c}\ldots \ldots \\
112\end{array}$ & 39 & $--\frac{\mathrm{NU}}{--18}$ & $\begin{array}{r}--- \\
6 \\
18\end{array}$ & $\begin{array}{r}--- \\
16\end{array}$ & $\begin{array}{c}-\ldots \\
12 \\
12\end{array}$ \\
\hline TOTAL. . . . . & 126 & 75 & 64 & 24 & 82 & 24 \\
\hline $\begin{array}{l}\text { VESSELS, MOTOR. }: \vdots: \\
\text { GROSS TONNAGE }: \vdots: \vdots \\
\text { BOATS, MOTOR. } \\
\text { GEAR. }: \vdots:\end{array}$ & $\begin{array}{r}16 \\
607 \\
2 \\
18\end{array}$ & $\begin{array}{r}13 \\
361 \\
12 \\
25\end{array}$ & $\begin{array}{r}9 \\
105 \\
23 \\
4,160\end{array}$ & $\begin{array}{r}6 \\
74 \\
18 \\
1,560\end{array}$ & $\begin{array}{r}8 \\
114 \\
33 \\
4,100\end{array}$ & $\begin{array}{r}4 \\
125 \\
4 \\
32\end{array}$ \\
\hline
\end{tabular}

(CONTINUED ON NEXT PAGE) 


\section{SAN PEDRO DISTRICT OF CALIFORNIA OPERATING UNITS, 1975 - Continued}

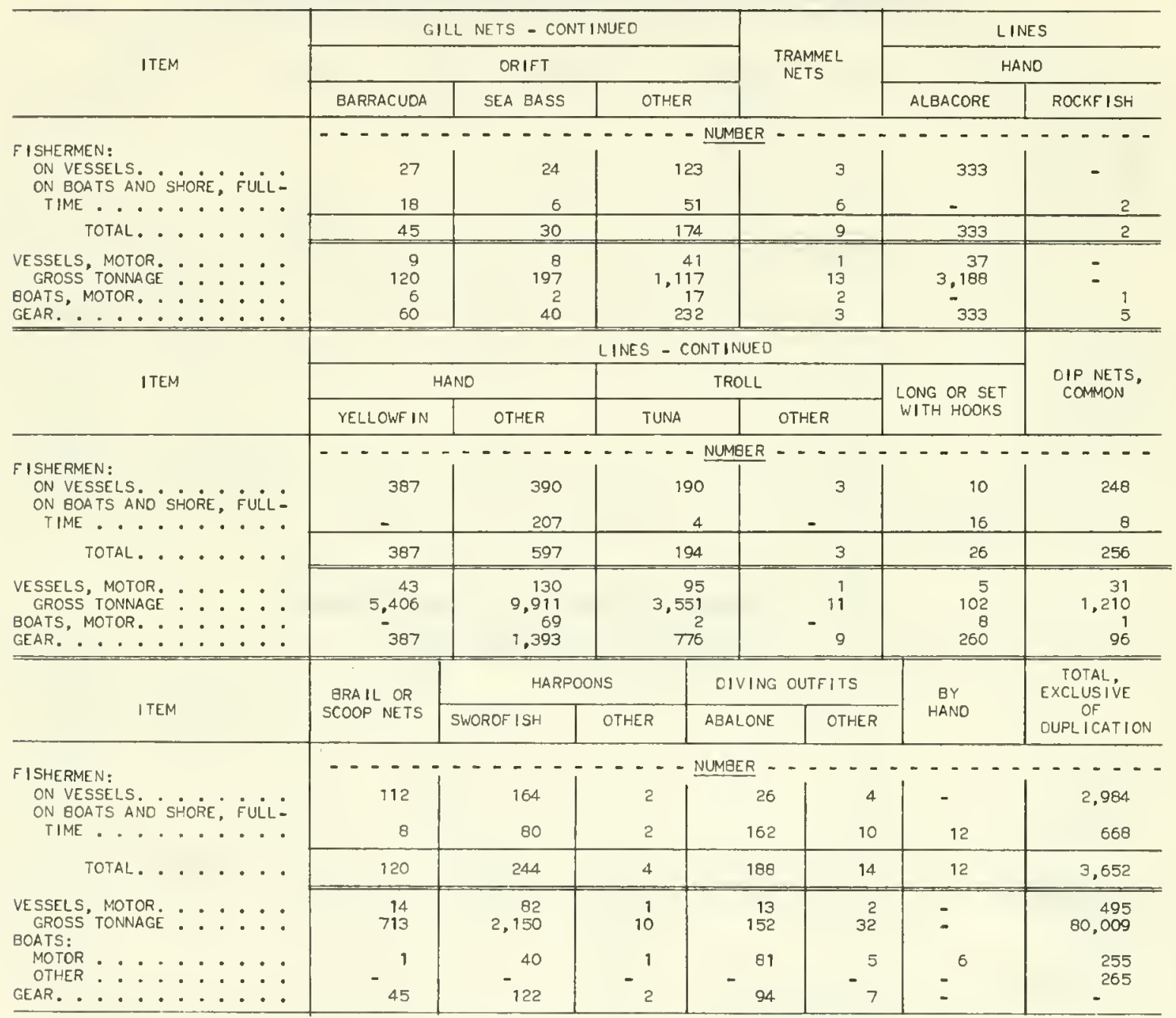

\section{SAN PEDRO DISTRICT OF CALIFORNIA LANDINGS OF CATCH BY GEAR, 1975}

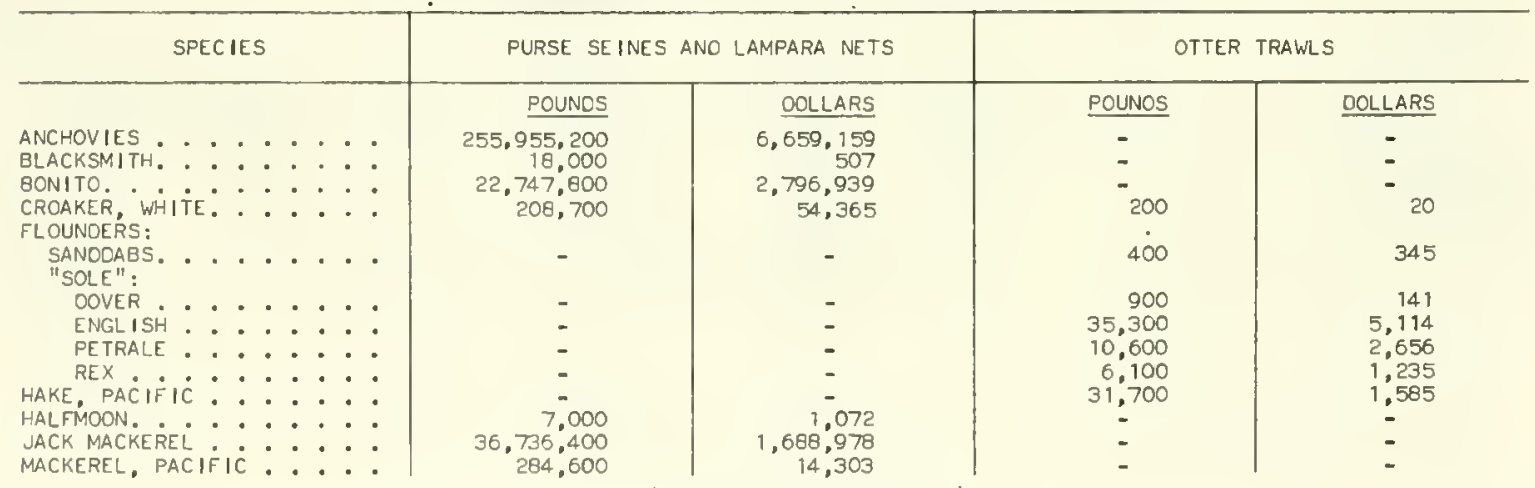


SAN PEDRO DISTRICT OF CALIFORNIA LANDINGS OF CATCH BY GEAR, 1975 - Continued

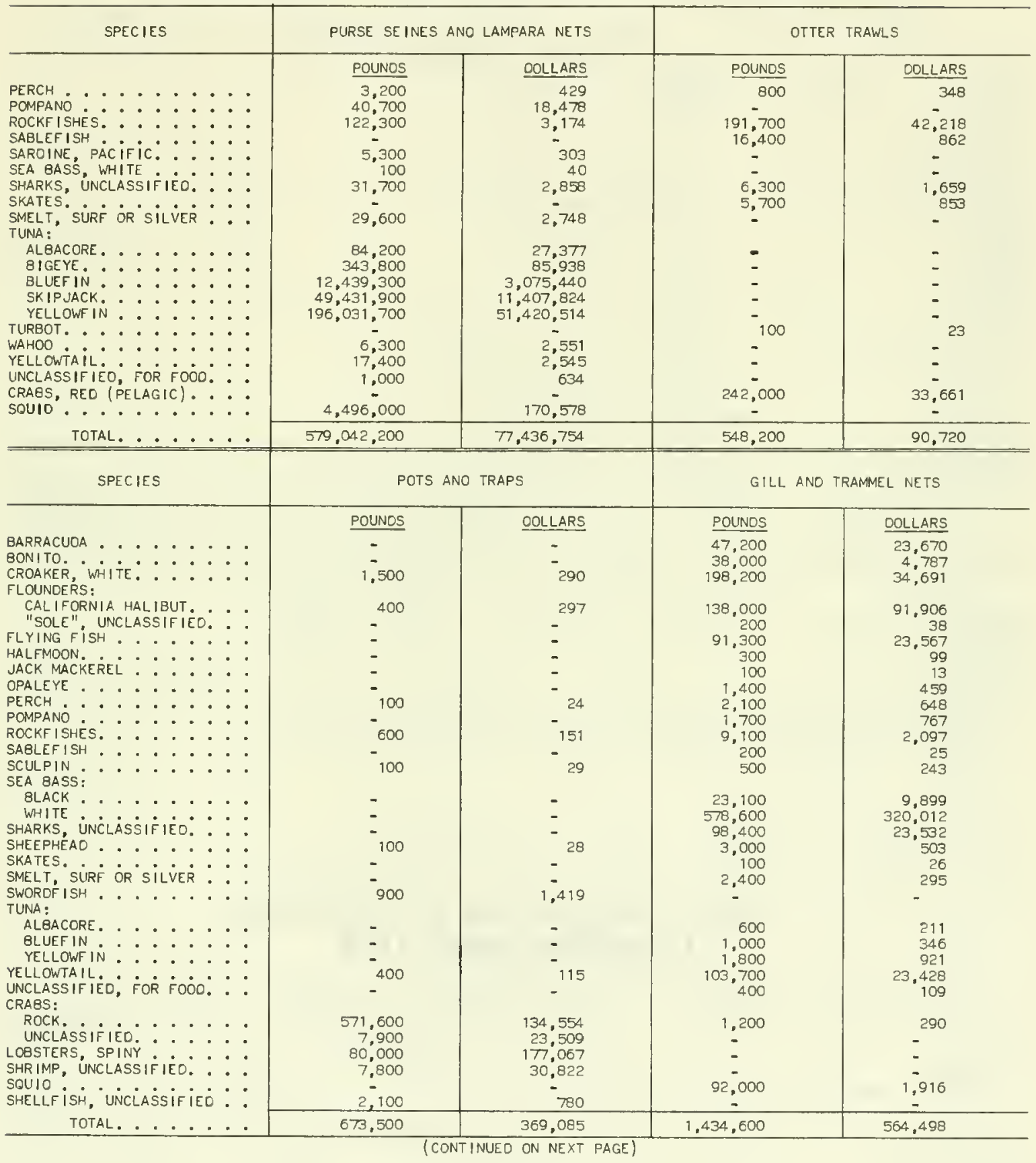




\section{SAN PEDRO DISTRICT OF CALIFORNIA} LANDINGS OF CATCH BY GEAR, 1975 - Continued

\begin{tabular}{|c|c|c|c|c|c|c|}
\hline SPECIES & \multicolumn{2}{|c|}{ LINES } & \multicolumn{2}{|c|}{ DIP NETS, COMMON } & \multicolumn{2}{|c|}{ BRAIL OR SCOOP NETS } \\
\hline \multirow{18}{*}{ 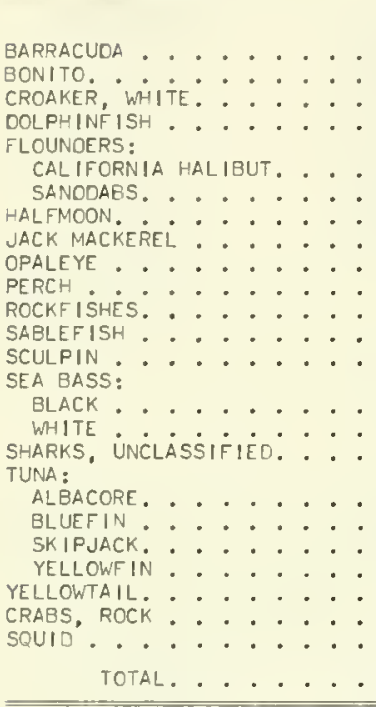 } & POUNDS & DOLLARS & POUNOS & DOLLARS & POUNDS & DOLLARS \\
\hline & 1,300 & 537 & - & - & - & - \\
\hline & $\begin{array}{r}5,100 \\
16,800\end{array}$ & $\begin{array}{r}622 \\
3,293\end{array}$ & $=$ & $\because$ & - & - \\
\hline & 1,900 & 384 & - & - & - & - \\
\hline & 300 & 253 & - & - & - & - \\
\hline & 400 & 272 & - & - & - & - \\
\hline & & & $\overline{-}$ & $\overline{-}$ & $=$ & $\overline{-}$ \\
\hline & $\begin{array}{r}200 \\
9,000\end{array}$ & $\begin{array}{r}95 \\
3.638\end{array}$ & - & - & $\overline{-}$ & - \\
\hline & $\begin{array}{r}502,300 \\
300\end{array}$ & $\begin{array}{r}135,122 \\
29\end{array}$ & - & - & : & - \\
\hline & 3,100 & 1,573 & - & - & - & - \\
\hline & $\begin{array}{r}7,700 \\
500\end{array}$ & $\begin{array}{r}3.076 \\
361\end{array}$ & - & - & - & - \\
\hline & 3,900 & 868 & - & - & - & - \\
\hline & $2,967,700$ & $1,004,338$ & - & - & - & - \\
\hline & $\begin{array}{r}100 \\
7663600\end{array}$ & $1,793,240$ & $=$ & - & - & - \\
\hline & $4,116,800$ & $1,062,070$ & - & - & - & \\
\hline & 400 & 97 & - & - & - & - \\
\hline & 269,000 & 5,380 & $5,690,100$ & 135,405 & $2,948,300$ & 51,939 \\
\hline & $15,571,400$ & $4,015,506$ & $5,690,100$ & 135,405 & $2,948,300$ & 51,939 \\
\hline SPECIES & \multicolumn{2}{|c|}{ HARPOONS } & \multicolumn{2}{|c|}{ DIVING OUTFITS } & \multicolumn{2}{|c|}{ BY HANO } \\
\hline \multirow{6}{*}{$\begin{array}{l}\text { SHARKS, UNCLASSIFIEO } \\
\text { SWORDFISH } \\
\text { ABALONE }\end{array}$} & POUNDS & DOLLARS & POUND & DOLLARS & POUNDS & DOLLARS \\
\hline & $\begin{array}{r}200 \\
528,800\end{array}$ & $\begin{array}{r}57 \\
852.484\end{array}$ & - & $\overline{-}$ & $=$ & - \\
\hline & - & 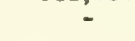 & 102,300 & 367,055 & - & \\
\hline & - & $=$ & - & - & 24,300 & 10.930 \\
\hline & - & - & 220,700 & 17,934 & & \\
\hline & 529,000 & B52,541 & 323,000 & 384,989 & 33,200 & 29,039 \\
\hline
\end{tabular}

1) BASEO ON A YIELO OF 25 PERCENT MEATS.

\section{SAN DIEGO DISTRICT OF CALIFORNIA OPERATING UNITS, 1975}

\begin{tabular}{|c|c|c|c|c|c|c|}
\hline \multirow{2}{*}{ ITEM } & \multicolumn{4}{|c|}{ PURSE SE INES } & \multirow{2}{*}{$\begin{array}{l}\text { OTTER } \\
\text { TRAWLS, } \\
\text { FISH }\end{array}$} & \multirow{2}{*}{ 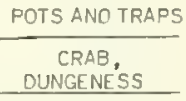 } \\
\hline & ANCHOVIES & MACKEREL & TUNA & OTHER & & \\
\hline $\begin{array}{l}\text { FISHERMEN: } \\
\text { ON VESSELS. } \\
\text { ON BOATS ANO SHORE: FULL: } \\
\text { TIME } \ldots . . . .\end{array}$ & $\begin{array}{c}-\cdots \\
-\cdots \\
20\end{array}$ & $\begin{array}{r}-\cdots \\
9\end{array}$ & $\begin{array}{r}264 \\
55\end{array}$ & $\begin{array}{r}-=- \\
126 \\
57\end{array}$ & $\begin{array}{r}-\ldots \\
18\end{array}$ & $\begin{array}{r}\ldots \\
6 \\
32 \\
\end{array}$ \\
\hline TOTAL. ...... & 20 & 9 & 319 & 183 & 36 & 38 \\
\hline 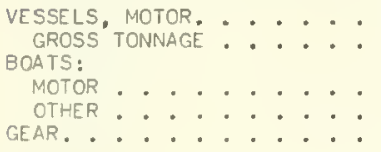 & $\begin{array}{l}2 \\
2 \\
2\end{array}$ & $\begin{array}{r}31 \\
-\quad \\
1 \\
1\end{array}$ & $\begin{array}{r}24 \\
12,832 \\
5 \\
58 \\
29\end{array}$ & $\begin{array}{r}42 \\
21,213 \\
19 \\
61 \\
61\end{array}$ & $\begin{array}{r}6 \\
94 \\
-\quad 6 \\
-12\end{array}$ & $\begin{array}{r}3 \\
41 \\
-\quad 16 \\
2,470\end{array}$ \\
\hline
\end{tabular}


SAN DIEGO DISTRICT OF CALIFORNIA

\section{OPERATING UNITS, 1975 - Continued}

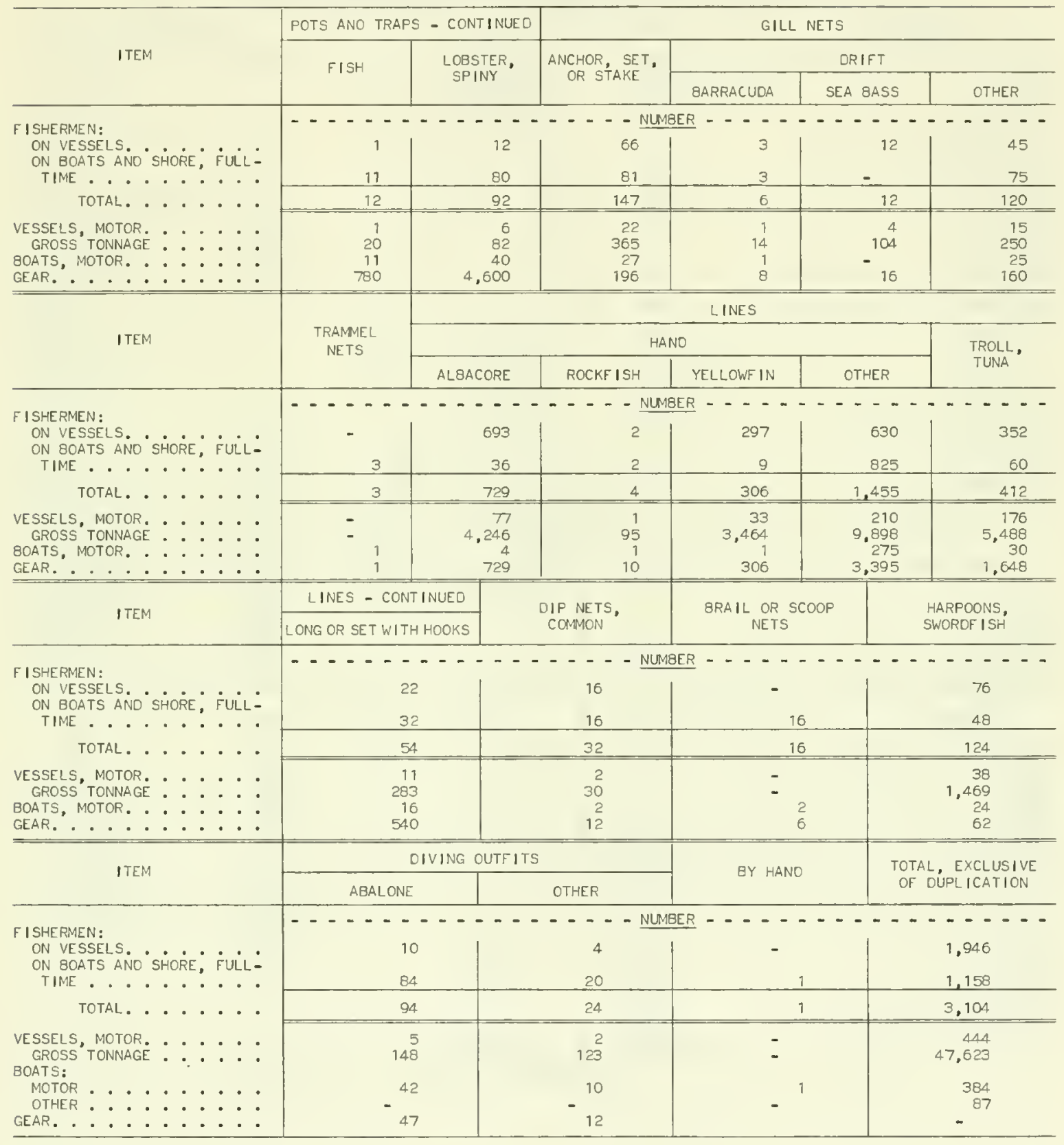


SAN DIEGO DISTRICT OF CALIFORNIA

LANDINGS OF CATCH BY GEAR, 1975

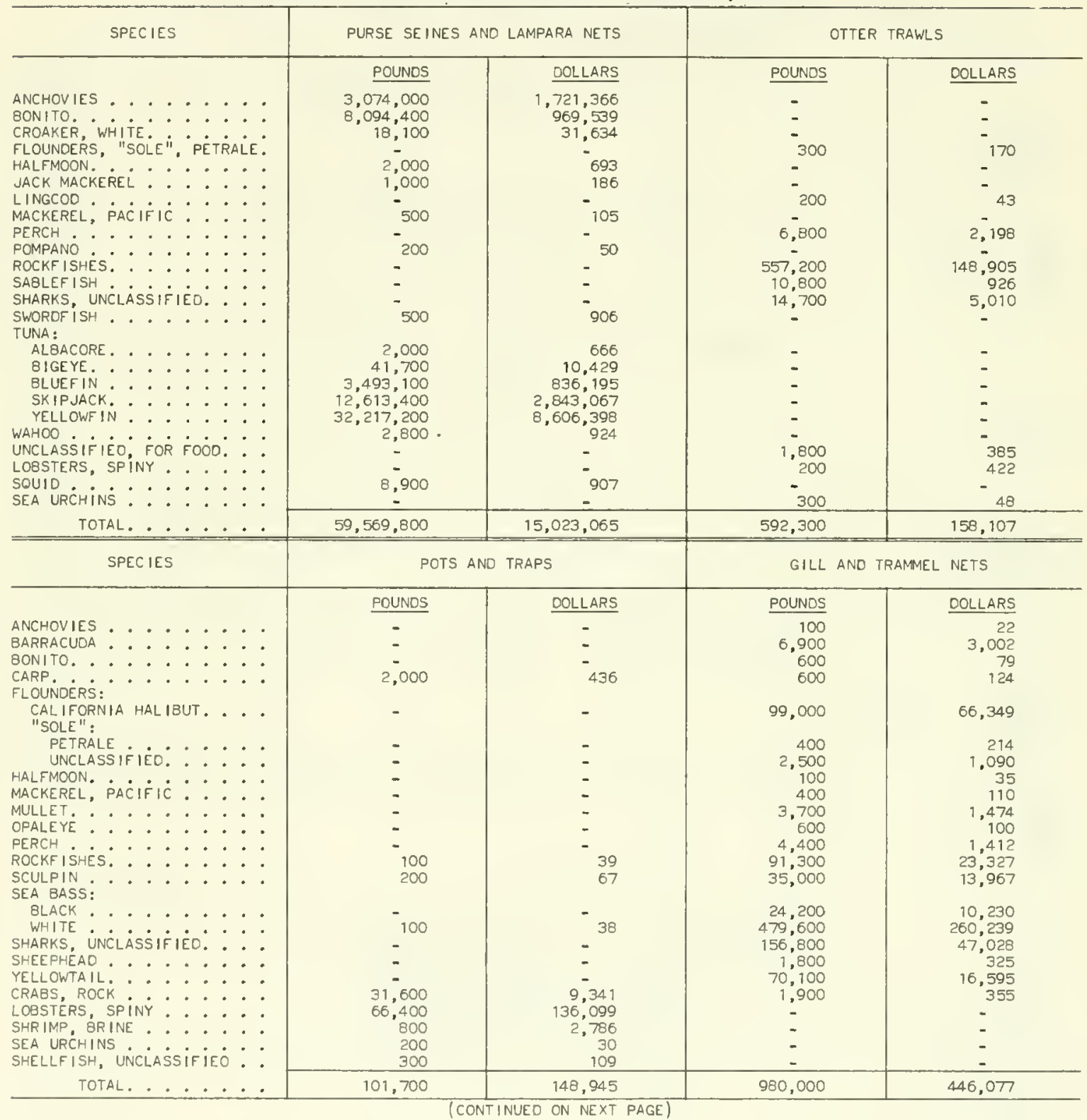


SAN DIEGO DISTRICT OF CALIFORNIA LANDINGS OF CATCH BY GEAR, 1975 - Continued

\begin{tabular}{|c|c|c|c|c|c|c|}
\hline SPECIES & \multicolumn{2}{|c|}{ LINES } & \multicolumn{2}{|c|}{ OIP NETS, COMMON } & \multicolumn{2}{|c|}{ BRAIL OR SCOOP NETS } \\
\hline & POUNOS & DOLLARS & POUNOS & OOLLARS & POUNDS & OOLLARS \\
\hline ANCHOVIES $\ldots \ldots \ldots$ & 100 & & - & - & - & - \\
\hline BARRACUDA $\ldots \ldots \ldots$ & 2.600 & 956 & - & - & - & - \\
\hline BONITO, WHITE: : : : & 46,800 & $\begin{array}{r}6,309 \\
201\end{array}$ & - & $=$ & - & - \\
\hline DOLPHINFISH $: \therefore:$ & 1,100 & 250 & $\overline{-}$ & $\overline{-}$ & - & - \\
\hline $\begin{array}{l}\text { FLOUNOERS: } \\
\text { CALIFORNIA HALIBUT. }\end{array}$ & 5.000 & 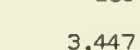 & - & - & - & - \\
\hline $\begin{array}{l}\text { CALIFORNIA HAL IBUT, }: \vdots \\
\text { "SOLE", UNCLASSIFIED: }\end{array}$ & 300 & $\begin{array}{r}3.44 \\
138\end{array}$ & $\overline{-}$ & $=$ & $\overline{-}$ & $=$ \\
\hline GROUPERS. . . . . . . & 3.700 & 1.492 & - & - & - & - \\
\hline HALFMOON HACK $_{\cdots A C K E R E I} \cdots \cdots \cdot$ & $\begin{array}{r}600 \\
300\end{array}$ & $\begin{array}{r}61 \\
00\end{array}$ & $=$ & $=$ & $=$ & $=$ \\
\hline MACKEREL, PACIFIC $: \therefore$ & 1,600 & 406 & $=$ & $=$ & $=$ & - \\
\hline MULLET & 2,600 & 1,083 & - & - & - & - \\
\hline$\therefore \therefore \therefore: \therefore$ & 2,400 & 746 & - & $=$ & $=$ & $=$ \\
\hline POMPANO $:: \therefore$ & 100 & 64 & 100 & 31 & - & - \\
\hline $\begin{array}{l}\text { ROCKFISHES } \\
\text { SABLEFISH }:: \therefore:\end{array}$ & 6,900 & $\begin{array}{r}96.579 \\
885\end{array}$ & $=$ & $=$ & $=$ & $\begin{array}{c}- \\
-\end{array}$ \\
\hline$\therefore \therefore \therefore$ & 134.600 & 55,196 & - & - & - & - \\
\hline 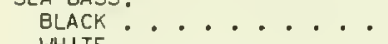 & 3.300 & 1.136 & - & - & - & - \\
\hline WHITE & 105.200 & 69,717 & - & - & - & - \\
\hline SHARKS, UNCLASSIFIED. . . & 5.800 & 1,337 & - & - & - & - \\
\hline $\begin{array}{l}\text { SHEEPHEAO } \\
\text { SWORDF ISH }: \therefore:\end{array}$ & 7.200 & 11.675 & $=$ & $=$ & $\Xi$ & $\overline{-}$ \\
\hline 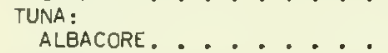 & $4,998,700$ & $1,674,876$ & - & - & - & - \\
\hline BLUEFIN $\ldots$ & 65,400 & 15,824 & - & - & - & - \\
\hline SKIPJACK.$\cdots$ & $4,535,700$ & 1.054 .020 & - & - & - & - \\
\hline YELLOWFIN $\ldots \ldots \ldots$ & $1,884.500$ & 474,691 & - & - & - & - \\
\hline WAHOO WTA $^{\prime} \cdots \cdots \cdot$ & 4,100 & 2,025 & $=$ & - & $\overline{-}$ & - \\
\hline $\begin{array}{l}\text { YELLOWTAIL } \cdots \\
\text { CRAES, ROCK }: \cdots\end{array}$ & 18,300 & $\begin{array}{r}4,555 \\
89\end{array}$ & $=$ & = & - & \\
\hline SHR IMP, QRINE $: \therefore$ & - & - & - & $=$ & 115,600 & 166,709 \\
\hline SQU10 . . . . . . & & & & 28,216 & 5,900 & \\
\hline TOTAL........ & $12,196,700$ & $3,477,963$ & 42,000 & 28,247 & 121,500 & 167,476 \\
\hline SPECIES & \multicolumn{2}{|c|}{ HARPOONS } & \multicolumn{2}{|c|}{ DIVING OUTFITS } & \multicolumn{2}{|c|}{ BY HANO } \\
\hline & POUNOS & ODLLARS & POUNOS & DOLLARS & POUNDS & DOLLARS \\
\hline SWORDFISH ....... & 231,400 & 375.196 & - & - & - & \\
\hline $\begin{array}{l}\text { CLAMS, HARD } \cdots \cdots \cdots \\
\text { ABALONE }\end{array}$ & $=$ & $=$ & $32-200$ & 127311 & 11.3 & 11,733 \\
\hline MUSSELS, SEA. $\therefore$. & - & - & & & 2,2 & 7 \\
\hline SEA URCHINS & - & - & 147,600 & 14,554 & - & - \\
\hline TOTAL. ...... & 231,400 & 375,196 & 179,800 & 141,865 & 13,500 & $12,4 \mathrm{~B} 3$ \\
\hline
\end{tabular}


United States and Canadian commercial fishermen, operating in the five Great Lakes and in three of the five International Lakes of northern Minnesota and Canada, landed 104.6 million pounds of freshwater fish in 1975-a decrease of 23.8 million pounds compared with 1974. Most of the decrease was in Lake Erie (down 19 percent) and Lake Michigan (down 24 percent). In the United States, production from the International Lakes decreased 14 percent; in Canada, landings increased 3 percent.

Canada produced 42.9 million pounds of fish during 1975 , a decrease of 7.3 million pounds compared with the previous year. This catch constituted 41 percent of the total production from both countries. As in previous years, smelt and yellow perch dominated the Canadian catch, accounting for 62 percent of the total landings in 1975.

The U.S. landings of 61.7 million pounds valued at $\$ 9.3$ million decreased 16.5 million pounds and $\$ 1.5$ million compared with 1974 . In 1975 , U.S. fishermen received an average price of 15.0 cents per pounda gain of 1.3 cents compared with 1974. Alewives, taken only in Lake Michigan, were 57 percent of the total U.S. catch. Landings of this species were 35.2 million pounds, 10.3 million pounds below the record harvest in 1974. Decreases for other major species were carp, down 5 percent; chubs, 50 percent; lake herring, 12 percent; smelt, 33 percent, suckers, 19 percent; white bass, 42 percent; and yellow perch, down 23 percent. Increases for the more important species were burbot, up 14 percent; lake trout, 25 percent; sheepshead, 22 percent; and whitefish (common), up 3 percent. U.S. landings from Lake Michigan were 45.3 million pounds; followed by Lake Erie, 8.5 million; Lake Superior, 4.7 million; Lake Huron, 1.9 million; International Lakes, 1.0 million pounds; and Lake Ontario, 232,600 pounds. Wisconsin, with 38.8 million pounds, led in volume of landings followed by Michigan with 12.0 million; Ohio, 7.3 million; Minnesota, 2.2 million pounds; New York, 598,100 pounds; Pennsylvania, 312,400; 1llinois, 240,100; and Indiana, 198,400 pounds.

Fishermen and vessels. In 1975, 1,201 fishermen operated 220 vessels ( 5 net tons or more) and 554 smaller craft in the U.S. commercial fisheries of the Great Lakes and International Lakes. Compared with 1974, this was a decrease of 188 fishermen, 20 vessels, and 114 small craft.

Processed products. The value of processed seafood items was $\$ 69.6$ million, an increase of $\$ 13.0$ million compared with 1974. Ohio led with products valued at $\$ 46.0$ million; followed by lllinois, $\$ 12.2$ million; Wisconsin, $\$ 5.7$ million; and Michigan $\$ 4.4$ million. New York, Pennsylvania, and Minnesota supplied the remaining $\$ 1.3$ million. The 160 wholesaling and processing plants in the eight States employed 2,175 persons.

\section{U.S. landings by lake.}

Lake Ontario. The 1975 production of 232,600 pounds was 91,100 pounds lower than in 1974 . Landings were the smallest since 1965 when 217,000 pounds were produced. Landings of bullheads, eels, and white and yellow perch were 76 percent of the total harvest. The average price per pound for all species in 1975 was 42.4 cents compared with 36.0 cents in 1974.

Lake Erie. Landings were 8.5 million pounds worth $\$ 2.0$ million, a decrease of 1.3 million

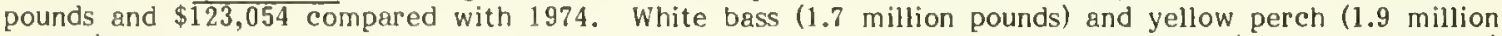
pounds) declined 1.2 million pounds and 464,300 pounds, respectively. Landings of carp (3.2 million pounds) increased 110,600 pounds and sheepshead $(853,800$ pounds) was up 161,100 pounds. U.S. landings accounted for 22 percent of the Lake Erie production. Canada has outproduced the United States since 1954.

Lake Michigan. Landings were 45.3 million pounds worth $\$ 4.6$ million, a decrease of 14.2 million pounds and $\$ 1.7$ miltion compared with the record volume and value in 1974 . Alewives constituted 78 percent of the entire lake's landings. Compared with 1974, landings of several major species had significant declines in production: alewives ( 35.2 million pounds), down 23 percent; earp ( 2.9 million), down 11 per cent; chubs (924,300 pounds), down 72 percent; smelt (1.2 million pounds), down 33 percent; suckers $(340,800$ pounds), down 33 percent; and yellow perch (793,900 pounds), down 39 percent. Landings of whitefish (3.6 million pounds) have been increasing since 1966; however, for the first time in 10 years the production of this species decreased, but only by 91,400 pounds. Biologists state that the abundance of this species is still high. Since 1971, the coho salmon fishery has been closed, because contaminants DDT and PCB (polychlorinated byphenyl-a DDT-like compound) were present. The fishery began in 1967 as a result of the State of Michigan's propagation efforts. In 1967 the production of this species was 1.5 million pounds; by 1970, 2.2 million pounds were harvested.

Lake Superior. Landings of 4.7 million pounds valued at $\$ 1.8$ million declined 14 percent in volume, but increased 14 percent in value compared with 1974 . Landings of chubs (1.5 million pounds) 
declined 6 percent; lake herring (509,900), 11 percent; smelt (1.4 million), 34 percent; and suckers (51,000), 66 percent. Lake herring production has been steadily decreasing since 1941, when nearly 18 million pounds were caught. The average price per pound for all species in 1975 was 37.9 cents; a 9.4 cents per pound increase compared with 1975.

Commercial fishing for yellow pike has been banned in Ohio and Michigan since April 1970 because of polluted waters in their areas of the lake. Production from the State of Michigan resulted from test netting operations to monitor the mercury content of fish.

Lake Huron. Commercial fishermen landed 1.9 million pounds valued at $\$ 629,665-$ an increase of 139,700 pounds and $\$ 166,129$ compared with 1974 . The production was 8 percent above the all-time low harvest of 1974. Carp was the only major species that declined in 1975. Landings declined 55,000 pounds to the lowest level since 1930 . Whitefish (common) landings of 405,100 pounds increased 50 percent compared with 1974 and was more than double the 10-year average (1965-74). Landings of yellow perch (269,000 pounds) increased 17 percent and catfish (282,900 pounds) increased 4 percent compared with 1974 . It is illegal to take chubs in Lake Huron. Since 1961, when 3.2 million pounds were landed, catches of this species have been declining. The average price per pound for all species increased from 27.0 cents in 1974 to 33.9 cents in 1975 .

International lakes. In 1975, 95 percent of the total landings from these waters came from Lake of the Woods. Burbot; suckers, tullibee, and yellow pike constituted 88 percent of the catch. The average price per pound is 20.0 cents compared to 15.0 cents in the Great Lakes.

Factors affecting the fisheries. Biologists reveal that in 1975 Lake Erie had a very good hatch of yellow pike, but a very poor one for yellow perch. The outlook for yellow perch is not good. Consideration is being given to raising the size limit from 8 to $8-1 / 2$ inches. About 400,000 pounds annually are caught in Lake Ontario with Canada landings over 75 percent. It is not known when and if this species will be allowed to be caught commercially.

Lake Michigar ins a partial ban on chub fishing. According to biologists, chubs are at a very low level of abundance (about 2 percent of the 1960-61 level). However, the average weight of chubs in 1975 has doubled since 1960-61.

Other information. Condensed summary data on the landings by Lakes and States appearing in the following pages have been published previously in Current Fishery Statistics No. 7410.

Acknowledgments. The following organizations assisted in collecting the data appearing in this section: Ministry of Natural Resources of Canada; lllinois Department of Conservation, Division of Fisheries; Indiana Department of Natural Resources, Division of Fish and Game, Section of Fish Management; Michigan Department of Natural Resources, Fisheries Division, Great Lakes Fisheries; Minnesota Department of Natural Resources, Division of Fish and Game, Section of Fisheries; New York State Department of Environmental Conservation, Great Lakes Fisheries Station; Ohio Department of Natural Resources, Division of Wildlife, Section of Fish Management; Pennsylvania Fish Commission; Wisconsin Department of Natural Resources, Fish Management Division; and the U.S. Fish and Wildlife Service, Great Lakes Fishery Laboratory, Ann Arbor, Mich. 
SUMMARY OF UNITED STATES AND CANADIAN LANDINGS, 1975

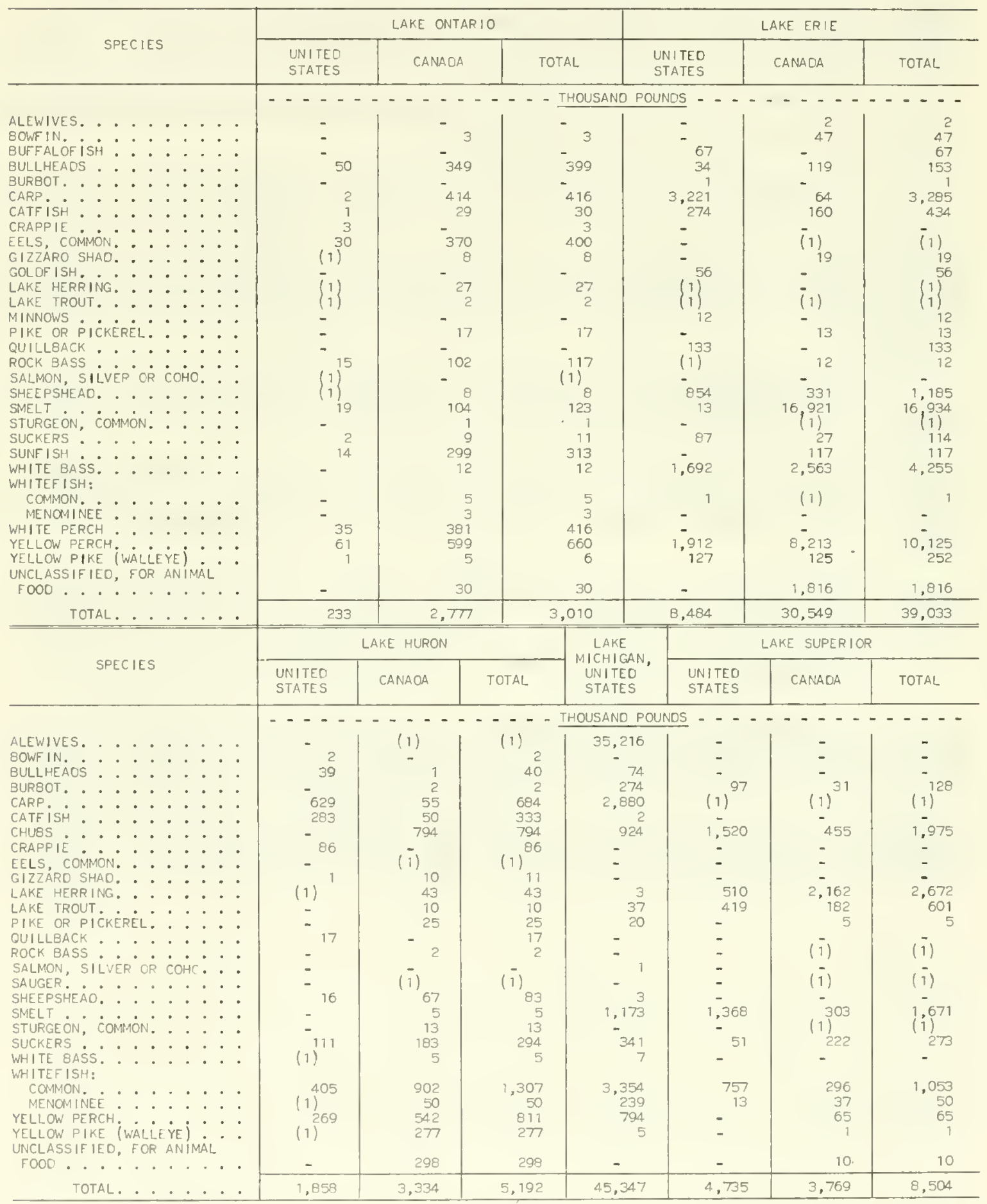


SUMMARY OF UNITED STATES AND CANADIAN LANDINGS, 1975 - Continued

\begin{tabular}{|c|c|c|c|c|c|c|}
\hline \multirow{2}{*}{ SPECIES } & \multicolumn{3}{|c|}{ TOTAL GREAT LAKES } & \multicolumn{3}{|c|}{ LAKE OF THE WOODS } \\
\hline & $\begin{array}{l}\text { UNITEO } \\
\text { STATES }\end{array}$ & CANAOA & TOTAL & $\begin{array}{l}\text { UNITEO } \\
\text { STATES }\end{array}$ & CANADA & TOTAL \\
\hline 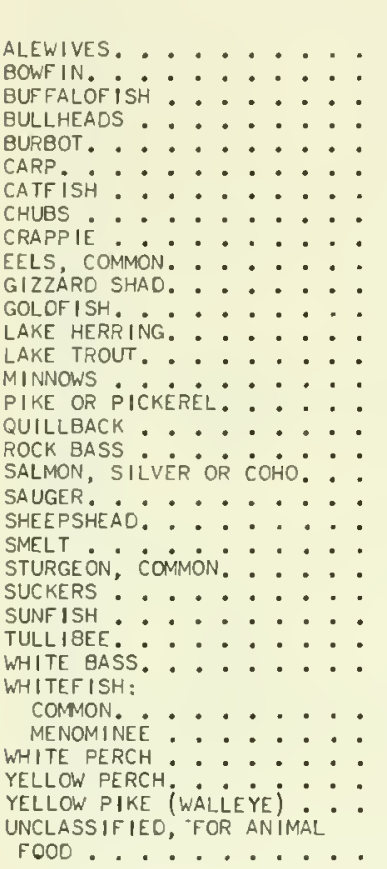 & $\begin{array}{r}- \\
35,216 \\
2 \\
67 \\
197 \\
372 \\
6,732 \\
560 \\
2,444 \\
89 \\
30 \\
1 \\
56 \\
513 \\
456 \\
12 \\
20 \\
150 \\
15 \\
1 \\
- \\
873 \\
2,573 \\
- \\
592 \\
14 \\
- \\
1,699 \\
4,517 \\
252 \\
35 \\
3,036 \\
133\end{array}$ & $\begin{array}{r}2 \\
-\quad 50 \\
469 \\
33 \\
533 \\
239 \\
1,249 \\
-370 \\
37 \\
-\quad 32 \\
2,232 \\
194 \\
-\quad 60 \\
-\quad \\
116 \\
i 1) \\
406 \\
17,333 \\
44 \\
441 \\
416 \\
- \\
2,580 \\
1,203 \\
90 \\
381 \\
9,419 \\
408 \\
2,154 \\
\end{array}$ & $\begin{array}{r}- \text { THOUSA } \\
35,218 \\
52 \\
67 \\
666 \\
405 \\
7,265 \\
799 \\
3,693 \\
89 \\
400 \\
38 \\
56 \\
2,745 \\
650 \\
12 \\
80 \\
150 \\
131 \\
1 \\
11) \\
1,279 \\
19,906 \\
14 \\
1,033 \\
430 \\
- \\
4,279 \\
5,720 \\
342 \\
416 \\
12,455 \\
541 \\
2,154 \\
\end{array}$ & $\begin{array}{c}\text { POUNDS } \\
- \\
- \\
(1) \\
115 \\
- \\
- \\
- \\
- \\
- \\
- \\
- \\
- \\
- \\
- \\
- \\
- \\
-33 \\
- \\
- \\
283 \\
- \\
- \\
(106 \\
- \\
- \\
189 \\
- \\
\end{array}$ & 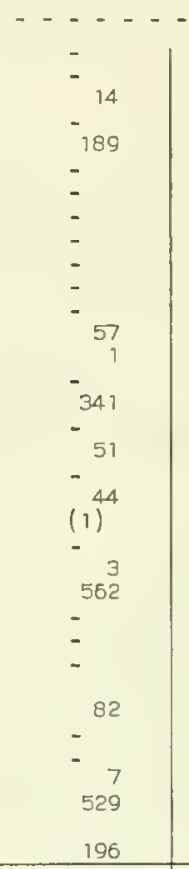 & $\begin{array}{l}- \\
- \\
- \\
(1)^{14} \\
304 \\
- \\
- \\
- \\
- \\
- \\
57 \\
-1 \\
394 \\
-51 \\
-77 \\
(1) \\
-3 \\
845 \\
-306 \\
- \\
-82 \\
-\quad 11 \\
718 \\
196 \\
\end{array}$ \\
\hline 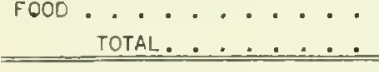 & 60,657 & 40,429 & 101,086 & 983 & 2,076 & 3,059 \\
\hline \multirow[b]{2}{*}{ SPECIES } & \multicolumn{3}{|c|}{ NAMAKAN LAKE } & \multicolumn{3}{|c|}{ RA INY LAKE } \\
\hline & $\begin{array}{l}\text { UNI TED } \\
\text { STATES }\end{array}$ & CANADA & TOTAL & $\begin{array}{l}\text { UNITEO } \\
\text { STATES }\end{array}$ & CANAOA & TOTAL \\
\hline \multirow[t]{4}{*}{ 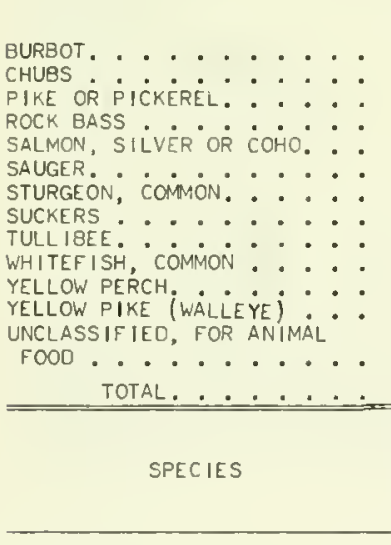 } & $\begin{array}{r}--- \\
- \\
- \\
- \\
= \\
- \\
= \\
- \\
- \\
- \\
-\end{array}$ & $\begin{array}{r}-\cdots \\
\\
(1)^{2} \\
5 \\
(1) \\
-\quad 14 \\
-\quad 6 \\
\end{array}$ & $\begin{array}{r}-\frac{\text { THOUS }}{6} \\
5 \\
(1)^{2} \\
(1) \\
-14 \\
-\quad 18 \\
-\end{array}$ & 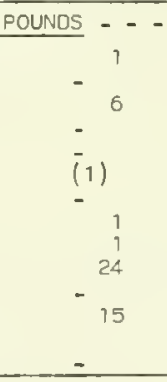 & $\begin{array}{c}\cdots \\
46 \\
18 \\
66 \\
2 \\
(1) \\
-133 \\
-37 \\
(1)^{37} \\
3 \\
\end{array}$ & $\begin{array}{c}\cdots \\
47 \\
18 \\
72 \\
2 \\
(1) \\
-\quad 134 \\
1 \\
61 \\
(1)^{2} \\
52 \\
3\end{array}$ \\
\hline & 1 & 50 & 51 & 48 & 342 & 390 \\
\hline & \multicolumn{3}{|c|}{ TOTAL, INTERNATIONAL LAKES } & \multicolumn{3}{|c|}{ GRANO TOTAL, ALL LAKES } \\
\hline & $\begin{array}{l}\text { UNITED } \\
\text { STATES }\end{array}$ & CANADA & TOTAL & $\begin{array}{l}\text { UNITED } \\
\text { STATES }\end{array}$ & CANAOA & TOTAL. \\
\hline 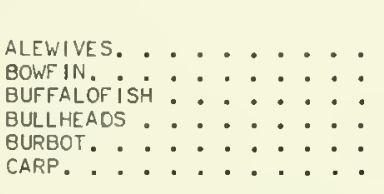 & $\begin{array}{c}\cdots \\
- \\
\overline{(3)} \\
{ }^{116}\end{array}$ & $\begin{array}{l}- \\
- \\
- \\
241 \\
24\end{array}$ & 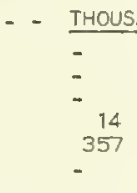 & $\begin{array}{r}\text { POUNOS - - } \\
35,215 \\
2 \\
67 \\
197 \\
488 \\
6,732\end{array}$ & $\begin{array}{r}2 \\
50 \\
-\quad- \\
483 \\
274 \\
533\end{array}$ & $\begin{array}{r}--.-- \\
35,218 \\
52 \\
67 \\
680 \\
762 \\
7,265\end{array}$ \\
\hline
\end{tabular}

SEE FOOTNOTES AT ENO OF TABLE.

(CONTINUEO ON NEXT PAGE) 
SUMMARY OF UNITED STATES AND CANADIAN LANDINGS, 1975 - Continued

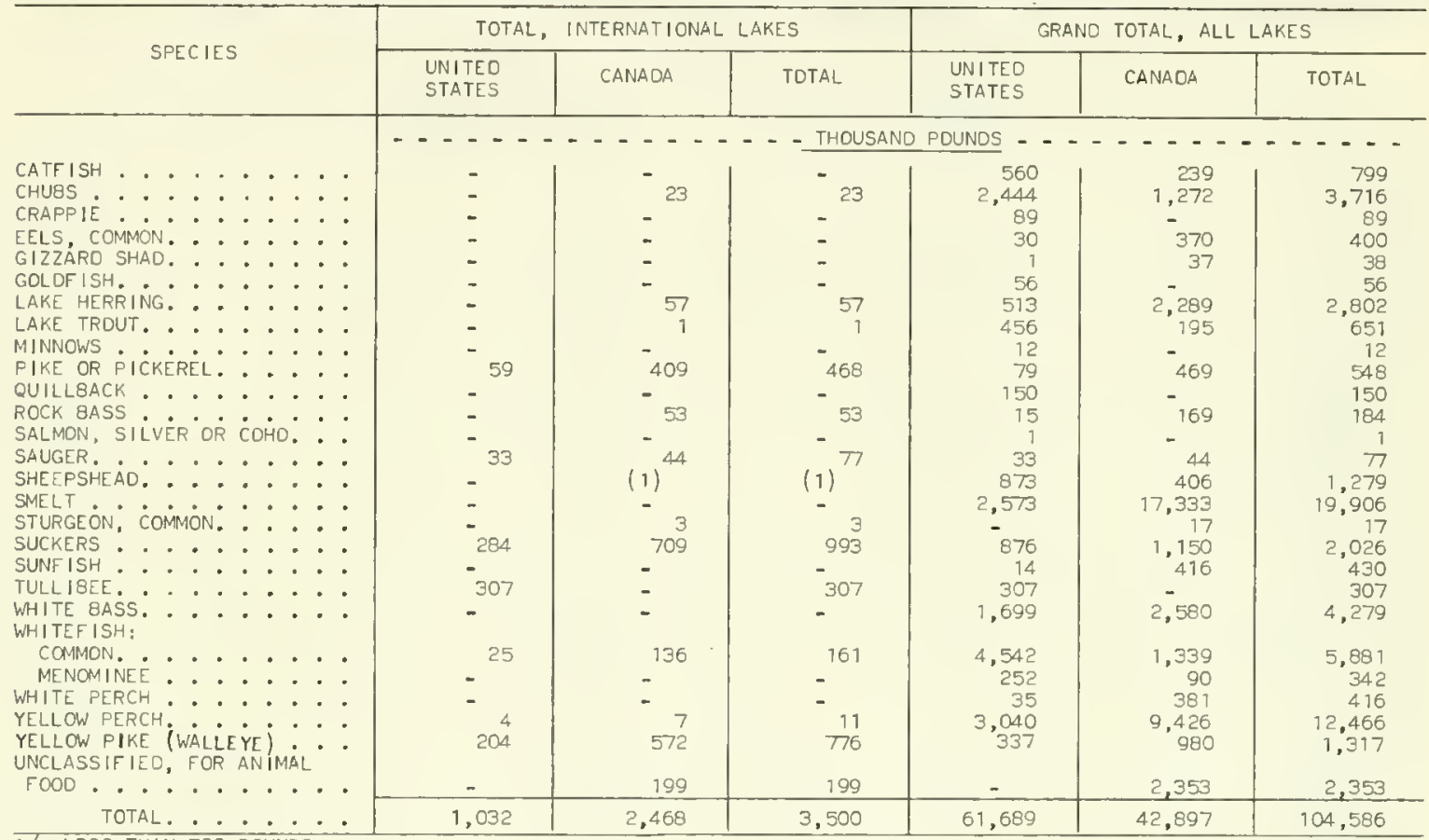

1) LESS THAN 500 POUNDS.

NOTE:- IN CANADA THE LANDINGS OF CRAPPIE HAVE BEEN INCLUDED WITH ROCK BASS.

SUMMARY OF U. S. LANDINGS, 1975

\begin{tabular}{|c|c|c|}
\hline \multirow[t]{2}{*}{ STATE } & \multicolumn{2}{|c|}{ TOTAL } \\
\hline & $\frac{\text { THOUSAND }}{\text { POUNOS }}$ & $\frac{\text { THOUSANO }}{\text { DOLLARS }}$ \\
\hline 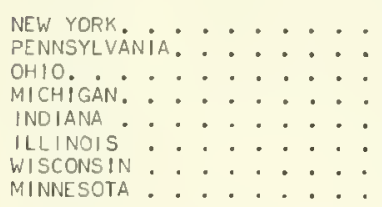 & $\begin{array}{r}598 \\
313 \\
7,305 \\
12,009 \\
198 \\
240 \\
38,781 \\
2,245\end{array}$ & $\begin{array}{r}233 \\
164 \\
1,624 \\
3,758 \\
89 \\
160 \\
2,858 \\
369\end{array}$ \\
\hline TOTAL . . . . . & 61.689 & 9,255 \\
\hline
\end{tabular}




\section{GREAT LAKES FISHERIES \\ SECTIONAL SUMMARIES \\ SUMMARY OF U.S. OPERATING UNITS AND \\ FISHING EFFORT, BY LAKES, 1975}

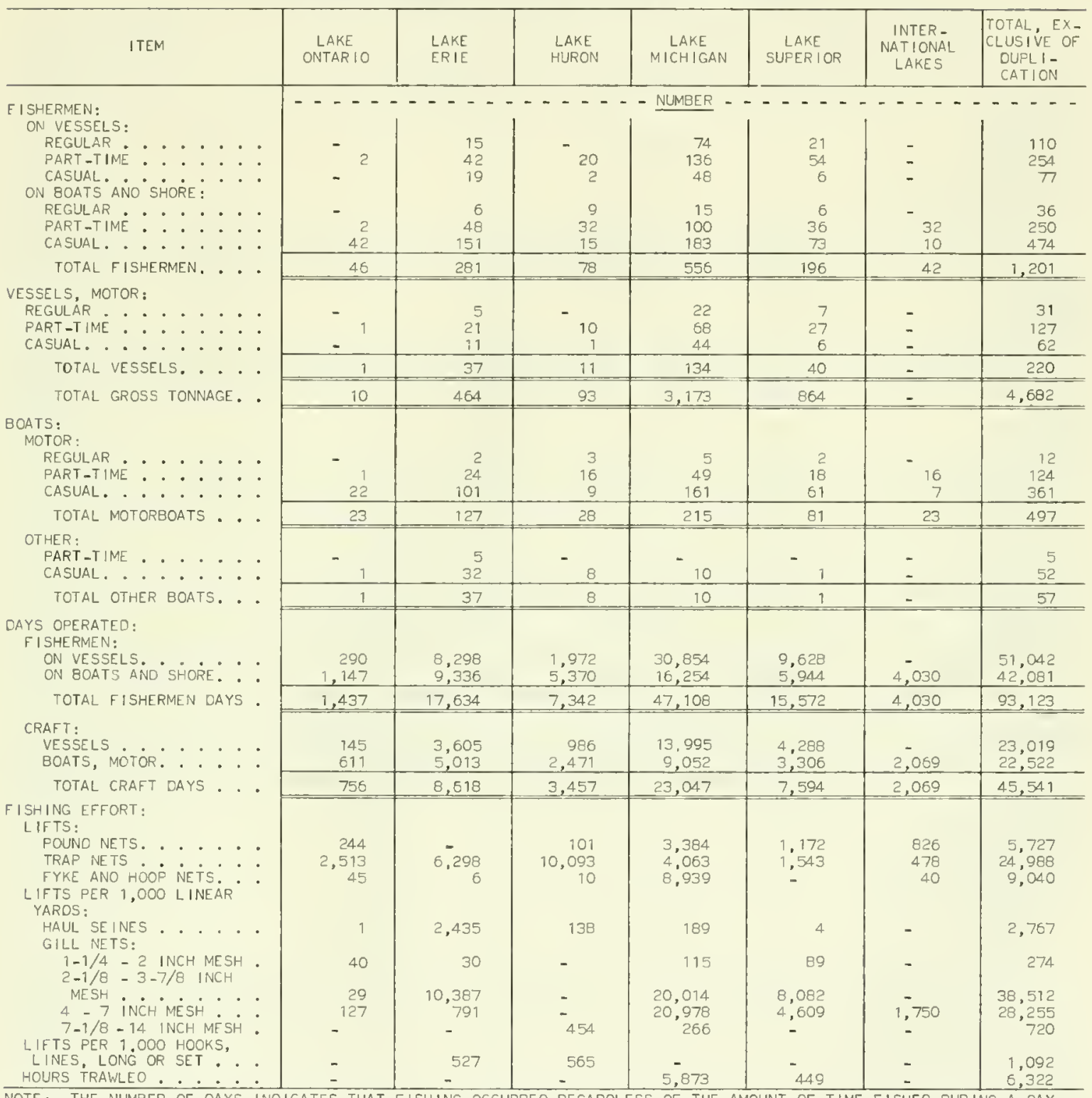

NOTE:--THE NUMBER OF OAYS INOICATES THAT FISHING OCCURREO REGARDLESS OF THE AMOUNT OF TIME FISHEO DURING A OAY. THE NUMBER OF FISHERMEN AND CRAFT OPERATING AS REGULAR, PART-TIME, ANO CASUAL IS BASEO ON DAYS OF OPERATION AS

FOLLOWS: REGULAR_-MORE THAN 151 OAYS, PART-TIME--54 TO 161 OAYS (INCLUSIVE), ANO CASUAL-- LESS THAN 54 DAYS. 


\section{SUMMARY OF U.S. OPERATING UNITS AND FISHING EFFORT, BY STATES, 1975}

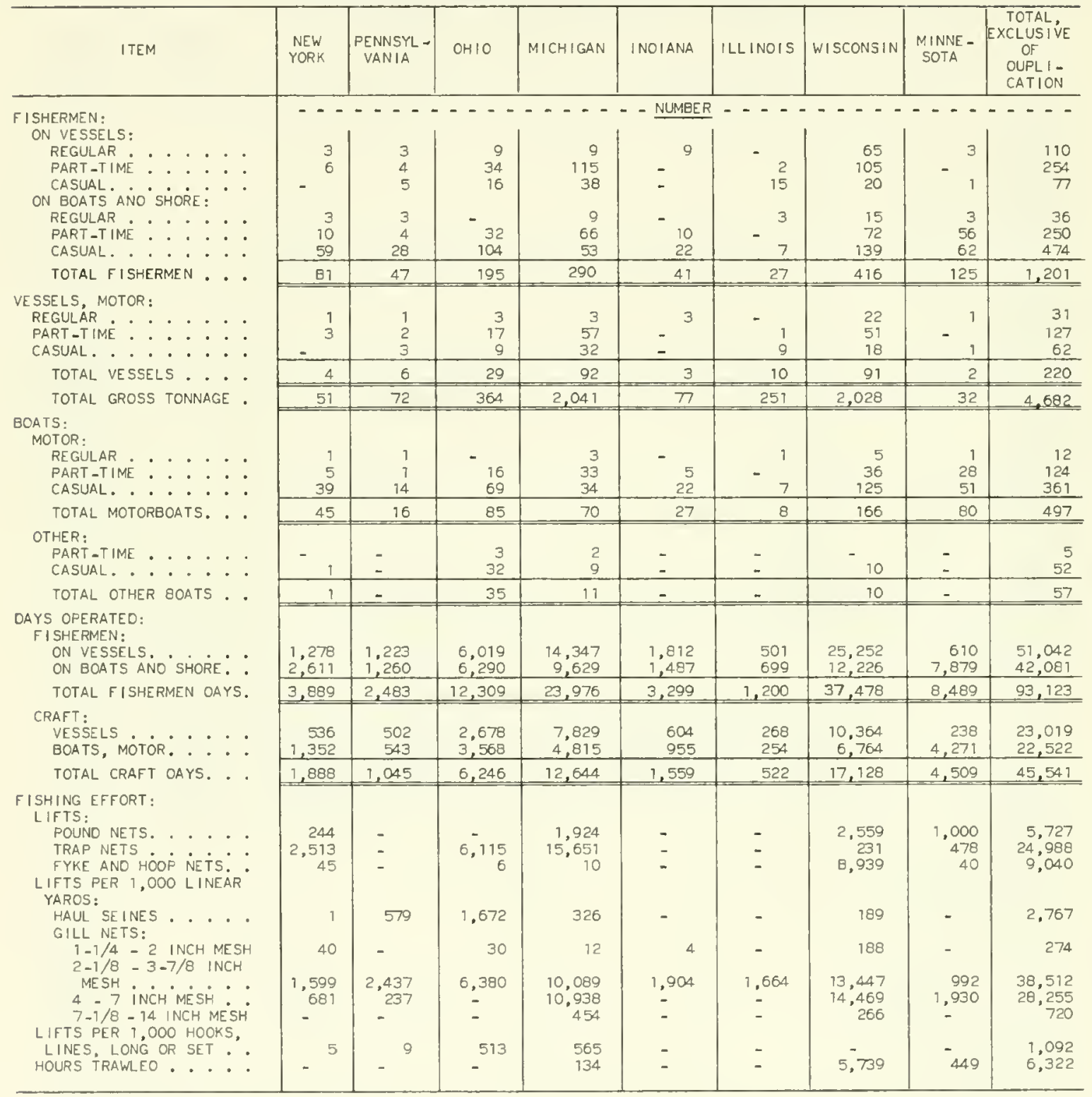

SEE NOTE ON PAGE 283. 


\section{GREAT LAKES FISHERIES}

\section{SUMMARY OF U.S. OPERATING UNITS AND}

FISHING EFFORT, BY STATES AND LAKES, 1975

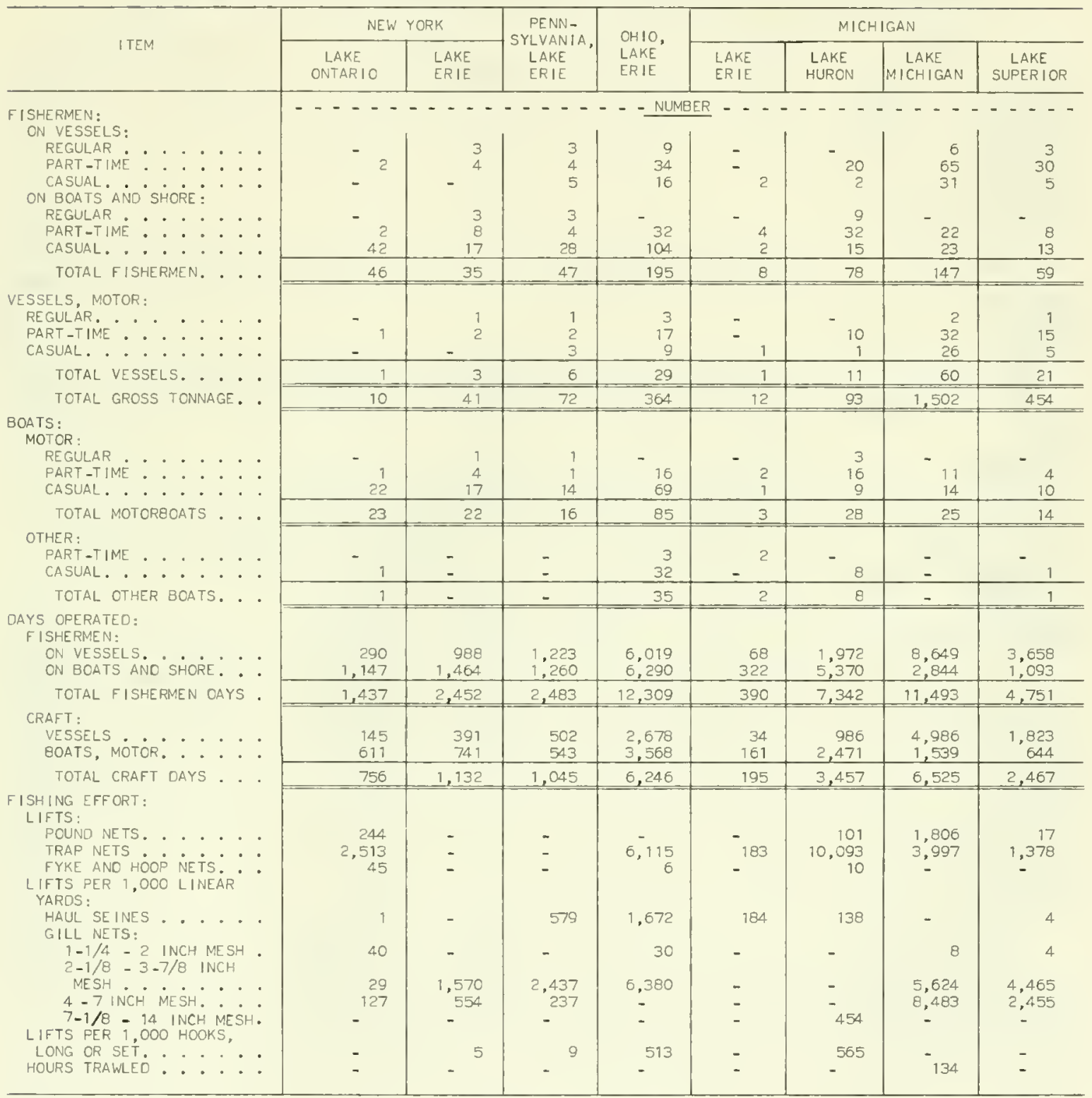


SUMMARY OF U.S. OPERATING UNITS AND FISHING EFFORT, BY STATES AND LAKES, 1975 - Continued

\begin{tabular}{|c|c|c|c|c|c|c|c|}
\hline \multirow{2}{*}{\multicolumn{2}{|c|}{ ITEM }} & \multirow{2}{*}{$\begin{array}{l}\text { INOIANA, } \\
\text { IAKE } \\
\text { MICHIGAN }\end{array}$} & \multirow{2}{*}{$\begin{array}{l}\text { ILLINOIS, } \\
\text { LAKE } \\
\text { MICHIGAN }\end{array}$} & \multicolumn{2}{|c|}{ WISCONSIN } & \multicolumn{2}{|c|}{ MINNESOTA } \\
\hline & & & & $\begin{array}{l}\text { LAKE } \\
\text { MICHIGAN }\end{array}$ & $\begin{array}{l}\text { LAKE } \\
\text { SUPERIOR }\end{array}$ & $\begin{array}{l}\text { LAKE } \\
\text { SUPERIOR }\end{array}$ & $\begin{array}{l}\text { I NTERNA T I ONAL } \\
\text { LAKES }\end{array}$ \\
\hline 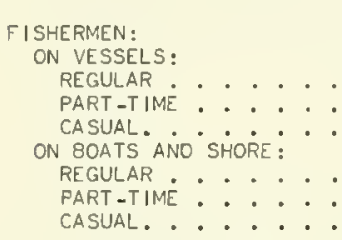 & : & $\begin{array}{rr}\cdots & - \\
& 9 \\
& - \\
& \\
& \\
& 10 \\
22 & \\
\end{array}$ & $\begin{array}{r}- \\
-\quad \\
15 \\
3 \\
-\quad 7 \\
\end{array}$ & $\begin{array}{r}50 \\
81 \\
20 \\
17 \\
68 \\
131 \\
\end{array}$ & $\begin{array}{r}15 \\
24 \\
-\quad \\
3 \\
4 \\
8 \\
\end{array}$ & $\begin{array}{r}\cdots \\
-\quad 3 \\
3 \\
24 \\
52 \\
\end{array}$ & $\begin{array}{c}-\ldots \\
- \\
- \\
- \\
32 \\
10 \\
\end{array}$ \\
\hline TOTAL FISHERMEN. . & . & 41 & 27 & 367 & 54 & 83 & 42 \\
\hline $\begin{array}{l}\text { VESSELS, MOTOR: } \\
\text { REGULAR }: \therefore: \vdots \\
\text { PART-TIME }: \therefore: \vdots \\
\text { CASUAL. }: \vdots\end{array}$ & : & $\begin{array}{l} \\
- \\
-\end{array}$ & $\begin{array}{r}- \\
9 \\
9\end{array}$ & $\begin{array}{l}17 \\
39 \\
18 \\
\end{array}$ & $\begin{array}{r}5 \\
-\quad 12 \\
-\end{array}$ & $\begin{array}{r}1 \\
-\quad 1 \\
\end{array}$ & $\overline{-}$ \\
\hline TOTAL VESSELS. ... & . & 3 & 10 & 74 & 17 & 2 & - \\
\hline TOTAL GROSS TONNAGE. & . & $\pi$ & 251 & 1,650 & 378 & 32 & - \\
\hline $\begin{array}{l}\text { 8OATS: } \\
\text { MOTOR: } \\
\text { REGULAR }: \cdots: \\
\text { PART_TIME }: \vdots: \therefore \\
\text { CASUAL. }: \therefore .:\end{array}$ & $\therefore$ & $\begin{array}{r}- \\
5 \\
22 \\
\end{array}$ & $\begin{array}{r}1 \\
-\quad 7 \\
\end{array}$ & $\begin{array}{r}4 \\
34 \\
118 \\
\end{array}$ & $\begin{array}{l}1 \\
2 \\
7 \\
\end{array}$ & $\begin{array}{r}1 \\
12 \\
44 \\
\end{array}$ & $\begin{array}{r}- \\
16 \\
7 \\
\end{array}$ \\
\hline TOTAL MOTORBOATS . . & . & 27 & 8 & 156 & 10 & 57 & 23 \\
\hline OTHER, CASUAL . . . & · & - & - & 10 & - & - & - \\
\hline TOTAL OTHER BOATS. - & . & - & - & 10 & - & - & - \\
\hline $\begin{array}{l}\text { DAYS OPERATED: } \\
\text { FISHERMEN: } \\
\text { ON VESSELS. . . . } \\
\text { ON BOATS AND SHORE: }\end{array}$ & & $\begin{array}{l}1,812 \\
1,487 \\
\end{array}$ & $\begin{array}{l}501 \\
699 \\
\end{array}$ & $\begin{array}{l}19,892 \\
11,224 \\
\end{array}$ & $\begin{array}{l}5,360 \\
1,002 \\
\end{array}$ & $\begin{array}{r}610 \\
3,849 \\
\end{array}$ & 4,030 \\
\hline TOTAL FISHERMEN OAYS & . & 3,299 & 1,200 & 37,116 & 6,362 & 4,459 & 4,030 \\
\hline $\begin{array}{l}\text { CRAFT: } \\
\text { VESSELS, } . . . \\
\text { BOATS, MOTOR. }\end{array}$ & $\dot{0}$ & $\begin{array}{r}604 \\
955 \\
\end{array}$ & $\begin{array}{r}268 \\
254 \\
\end{array}$ & $\begin{array}{l}8,137 \\
6,304 \\
\end{array}$ & $\begin{array}{r}2,227 \\
460 \\
\end{array}$ & $\begin{array}{r}238 \\
2,202 \\
\end{array}$ & 2,069 \\
\hline TOTAL CRAFT DAYS . & . & 1,559 & 522 & 14,441 & 2,687 & 2,440 & 2,069 \\
\hline 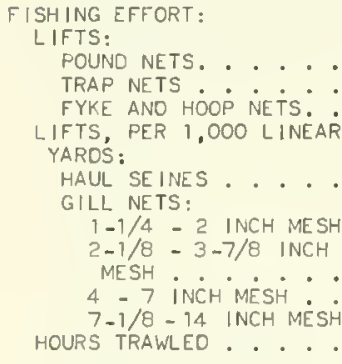 & : & $\begin{array}{l}- \\
\\
\\
1,904 \\
= \\
-\end{array}$ & $\begin{array}{l}- \\
- \\
- \\
- \\
1.664 \\
- \\
-\end{array}$ & $\begin{array}{r}1,578 \\
66 \\
8,939 \\
\\
189 \\
103 \\
10,822 \\
12,495 \\
266 \\
5,739\end{array}$ & $\begin{array}{l}981 \\
- \\
- \\
- \\
\\
\quad 85 \\
\\
2,625 \\
1,974 \\
- \\
-\end{array}$ & $\begin{array}{l}174 \\
- \\
- \\
- \\
992 \\
780 \\
-449\end{array}$ & $\begin{array}{l}826 \\
478 \\
40 \\
- \\
- \\
- \\
1.750 \\
- \\
-\end{array}$ \\
\hline
\end{tabular}

SEE NOTE ON PAGE 283. 
LANDINGS BY STATES, 1975

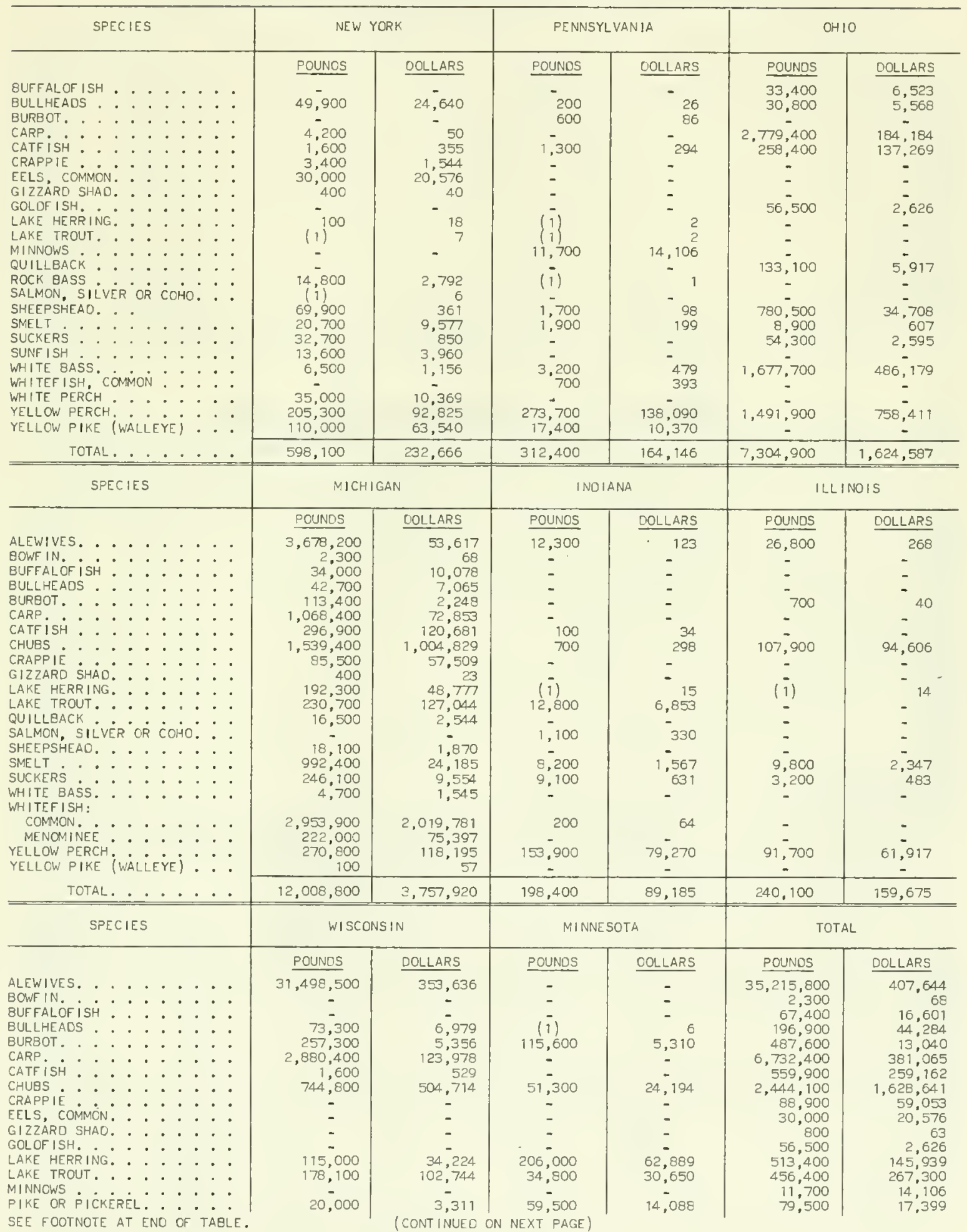


LANDINGS BY STATES, 1975 - Continued

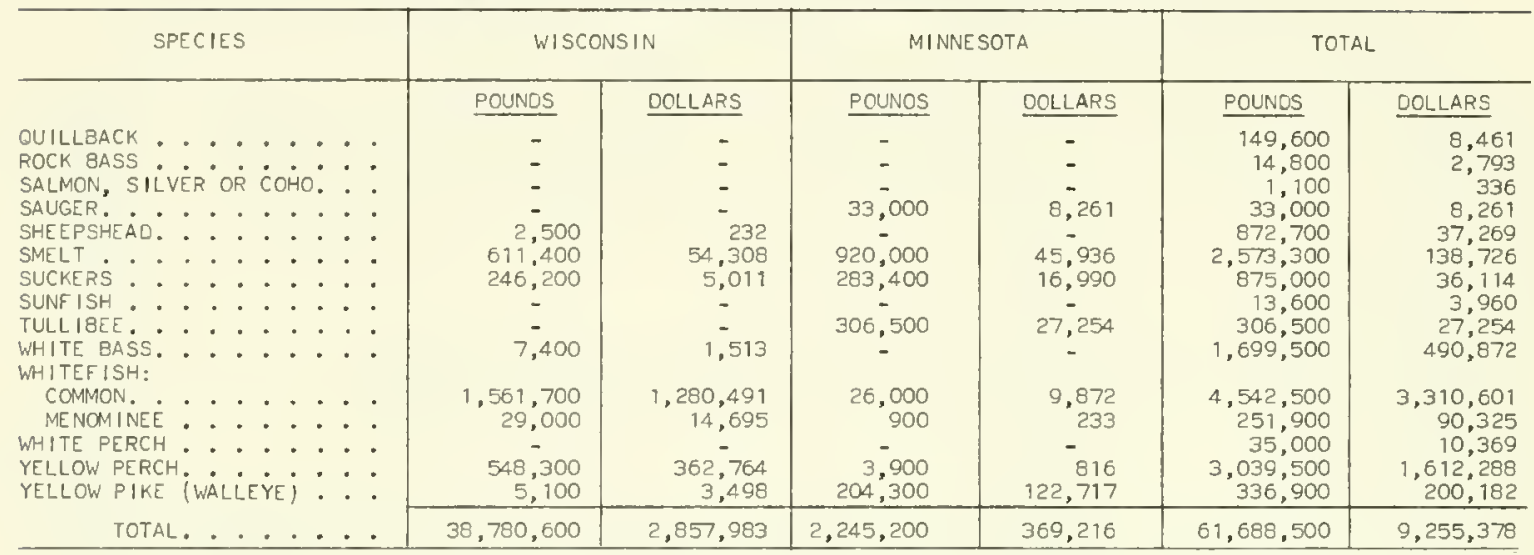

1) LESS THAN 50 POUNOS.

LANDINGS BY LAKES AND STATES, 1975

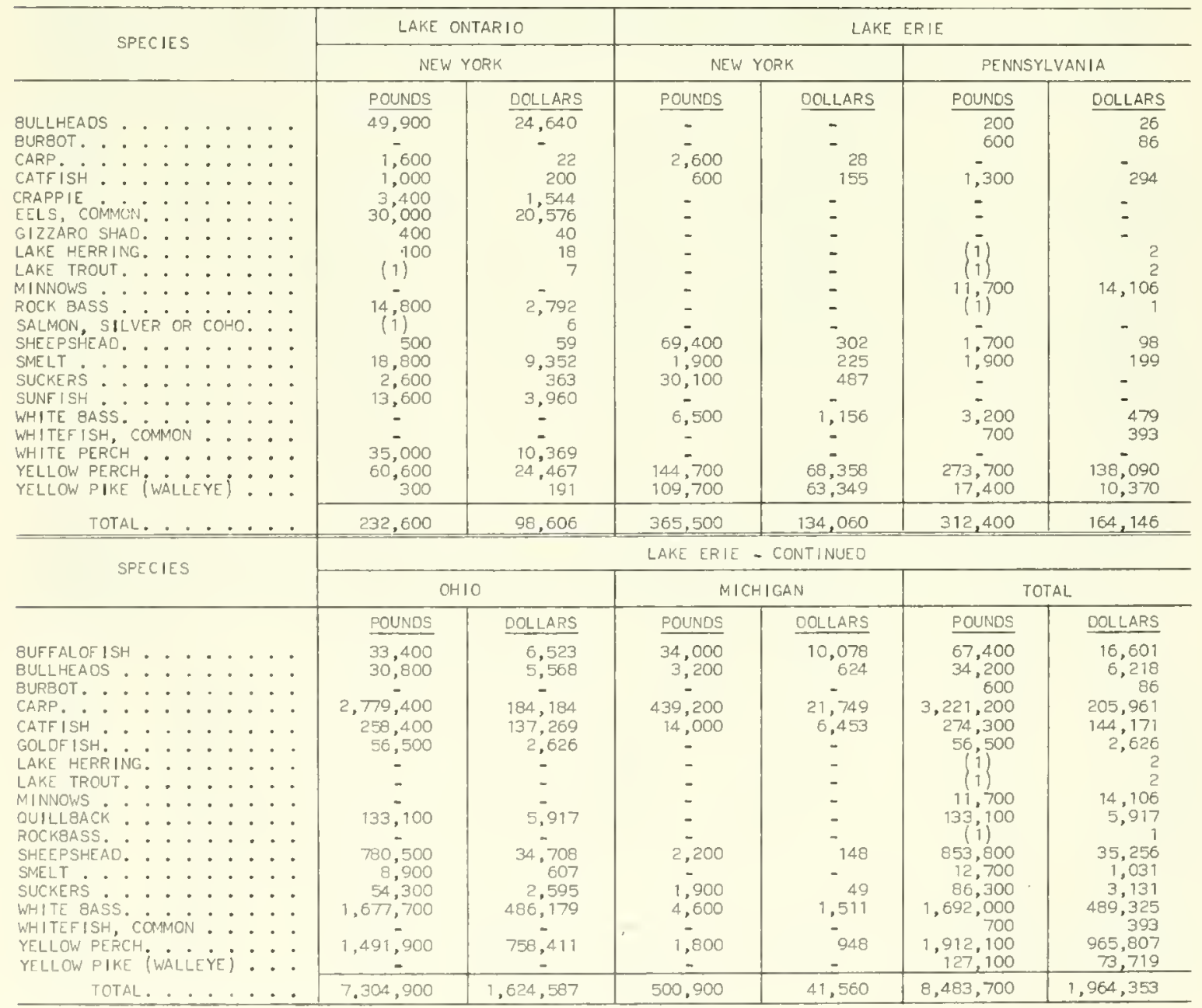


LANDINGS BY LAKES AND STATES, 1975 - Continued

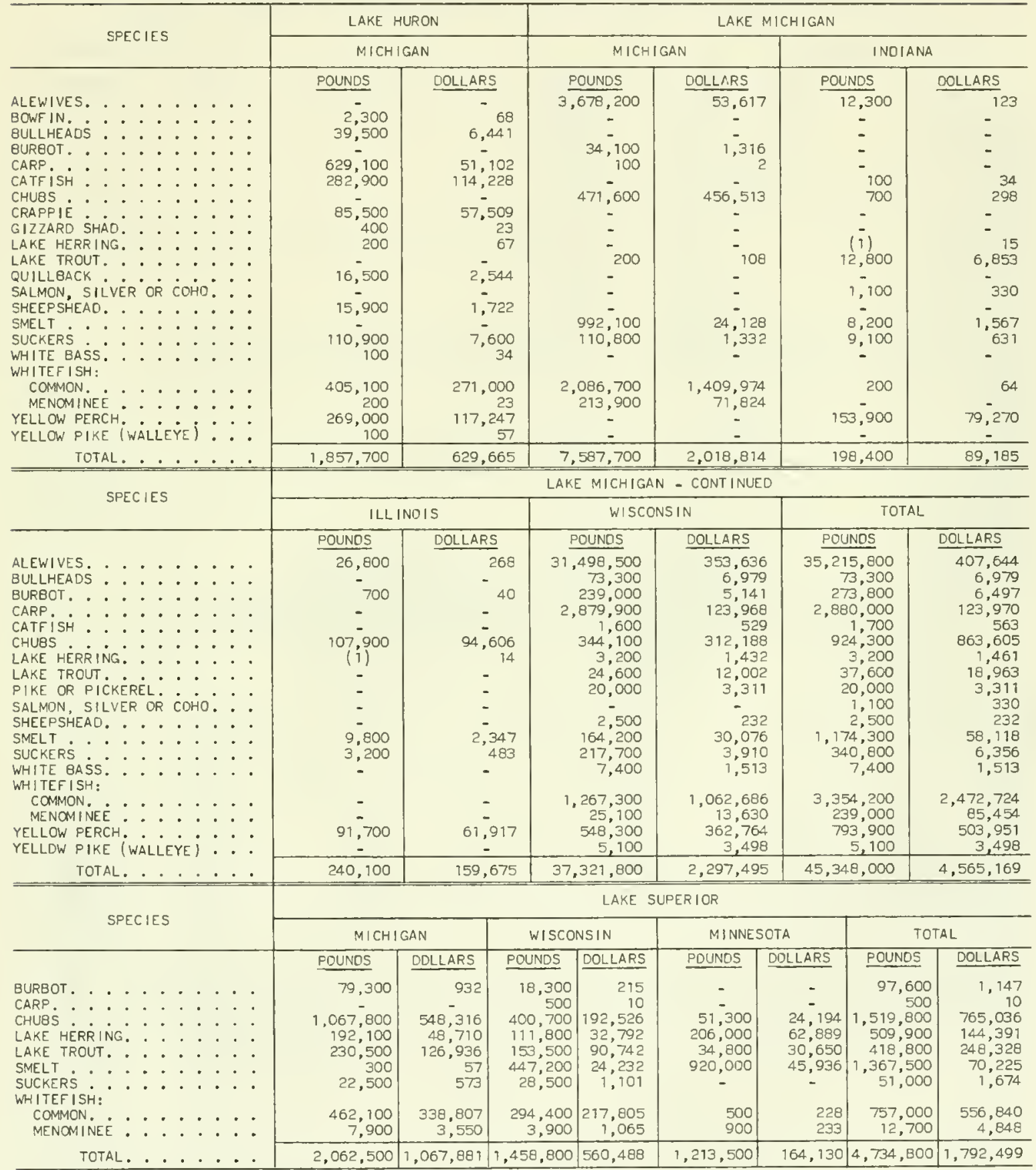

SEE FOOTNOTE AT ENO OF TABLE.

(CONT INUEO ON NEXT PAGE) 
LANDINGS BY LAKES AND STATES, 1975 - Continued

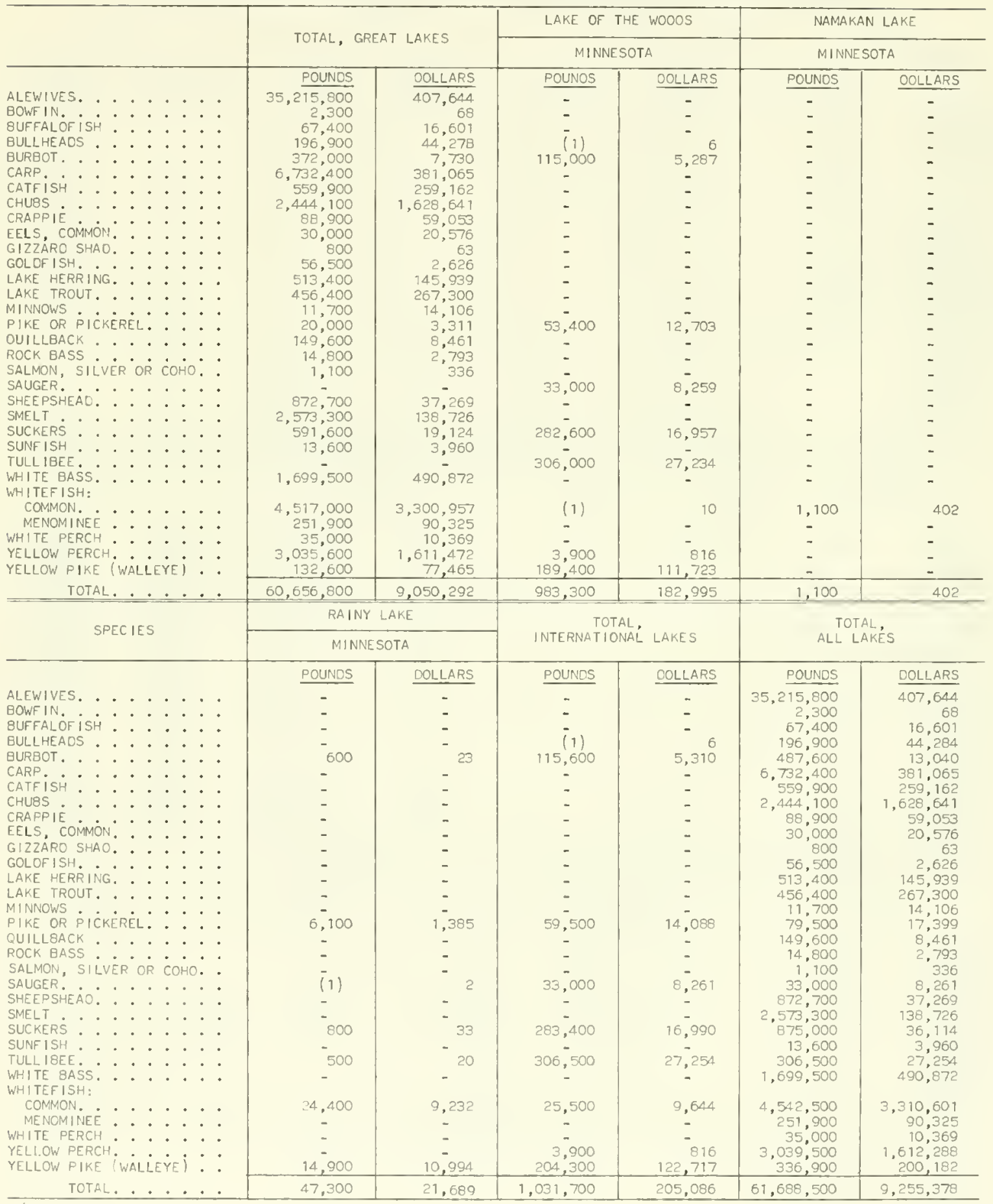

1) LESS THAN 50 POUNOS. 


\section{SUMMARY OF PROCESSED PRODUCTS, 1975}

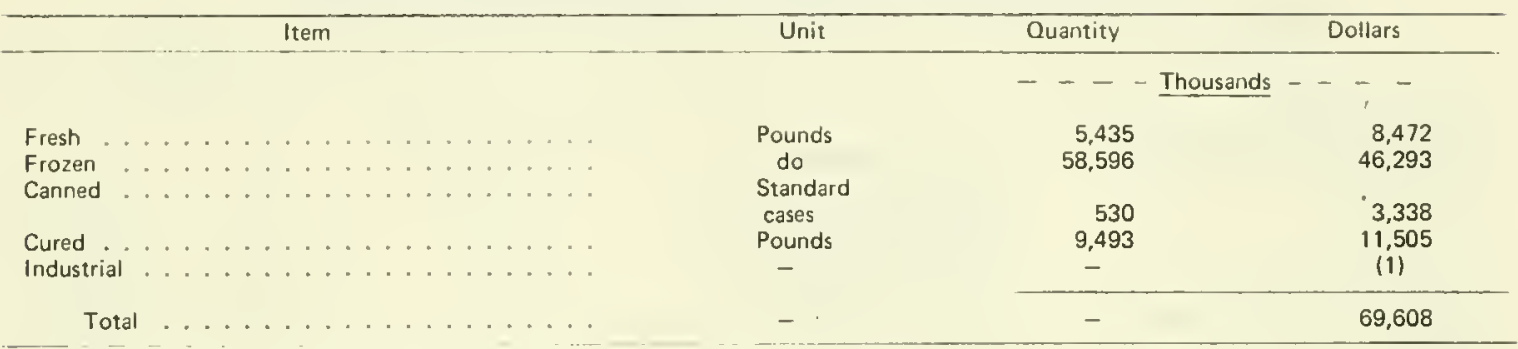

(1) Included with canned. Total is correct. Table does not add because of rounding.

\section{VALUE OF PROCESSED PRODUCTS, BY STATES, 1975}

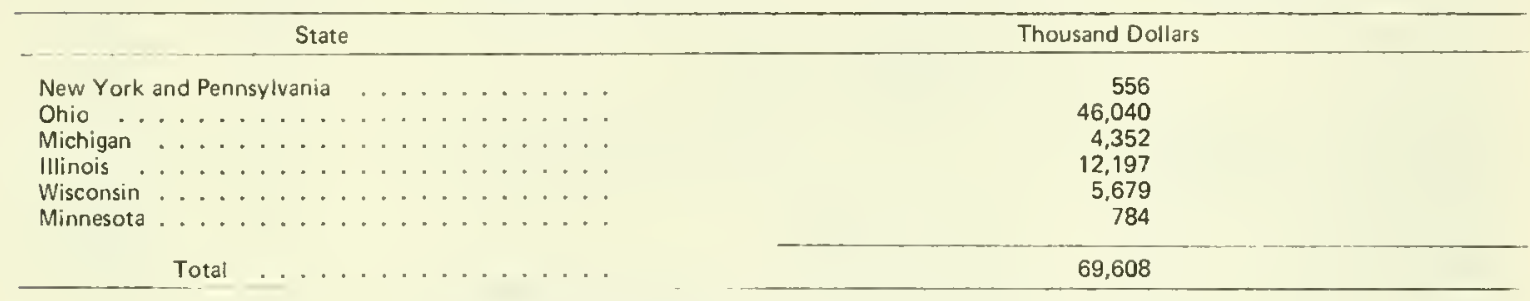

\section{PROCESSING AND WHOLESALE ESTABLISHMENTS AND EMPLOYMENT, 1975}

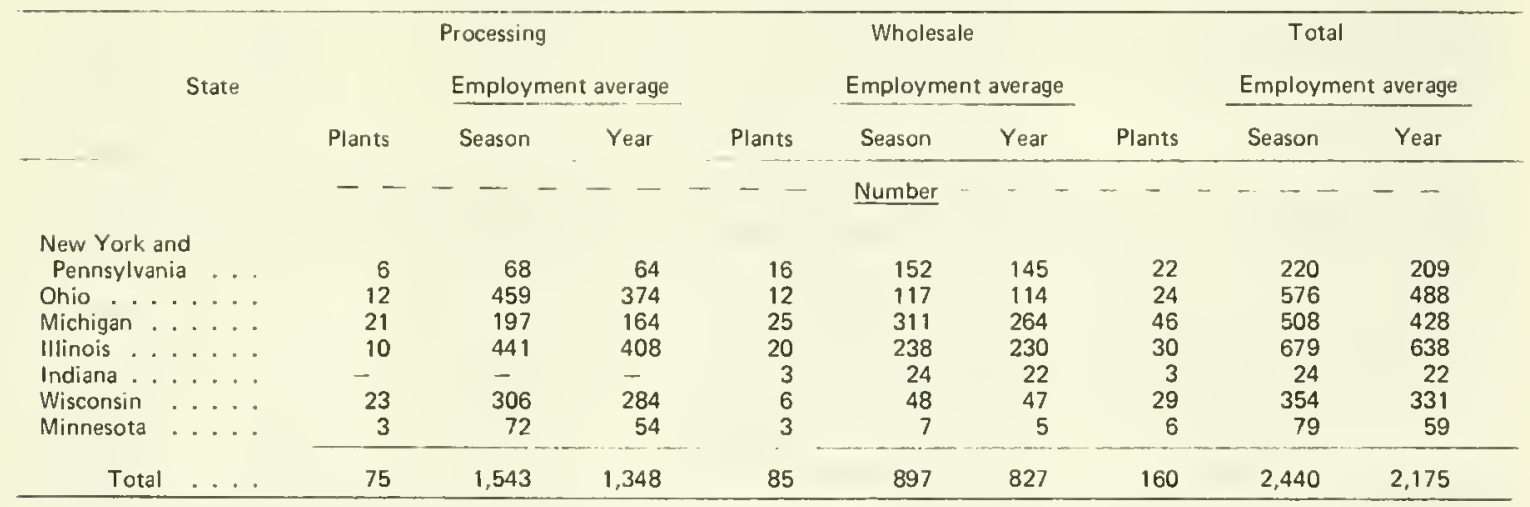

Note:-- Employment is reported by each plant for each month for the payroll period that includes the 12th of the month. Employment for the season is based on the greatest number of employees working during the payroll period that included the 12th of each month. Employment for the year is obtained by adding the number of employees recorded as working during the payroll period that included the 12th of each month, and dividing by 12 . 
PROCESSED FISHERY PRODUCTS, 1975

\begin{tabular}{|c|c|c|c|c|}
\hline Item & State & Unit & Quantity & Dollars \\
\hline & & & $-\cdots I$ & iands $-\cdots$ \\
\hline \multicolumn{5}{|l|}{8 uffalofish, fresh and frozen fillets } \\
\hline & Wisconsin & Pounds & 170 & 105 \\
\hline Carp, smoked $\ldots \ldots \ldots \ldots \ldots$ & $\begin{array}{l}\text { Illinois, Michigan, Minnesota, } \\
\text { Ohio, and Wisconsin }\end{array}$ & do & 79 & 45 \\
\hline Chubs, smoked $\ldots \ldots \ldots \ldots$ & $\begin{array}{l}\text { Illinois, Michigan, Minnesota, } \\
\text { Ohio, and Wisconsin }\end{array}$ & & & \\
\hline Halibut, fresh and frozen fillets and & & & 2,201 & 2,564 \\
\hline steaks $\ldots \ldots \ldots \ldots \ldots$ & $\begin{array}{l}\text { Illinois, New York, and } \\
\text { Wisconsin }\end{array}$ & do & 130 & 184 \\
\hline \multicolumn{5}{|l|}{ Herring: } \\
\hline $\begin{array}{l}\text { Lake: } \\
\text { Fresh fillets . . . . . . . . }\end{array}$ & Michigan and Minnesota & do & 26 & 20 \\
\hline 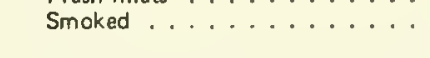 & $\begin{array}{l}\text { Michigan, Minnesota, Ohio, } \\
\text { and Wisconsin }\end{array}$ & do & 50 & 52 \\
\hline Sea, salted and pickled $\ldots \ldots$ & Illinois, Michigan, and & & & \\
\hline Lake trout: & Wisconsin & do & 5,012 & 5,151 \\
\hline $\begin{array}{l}\text { Lake trout: } \\
\text { Fresh and frozen fillets ....... }\end{array}$ & $\begin{array}{l}\text { Illinois, Michigan, Minnesota, } \\
\text { and Wisconsin }\end{array}$ & do & 343 & 476 \\
\hline Smoked $\ldots \ldots \ldots \ldots$ & $\begin{array}{l}\text { Illinois, Michigan, Minnesota, } \\
\text { and Wisconsin }\end{array}$ & do & 145 & 229 \\
\hline $\begin{array}{l}\text { Ocean perch, frozen, breaded raw } \\
\text { fillets } \ldots \ldots \ldots \ldots \ldots \ldots\end{array}$ & Illinois, Ohio, and Wisconsin & do & 698 & 474 \\
\hline $\begin{array}{l}\text { Pike or pickerel, fresh and frozen } \\
\text { fillets } \ldots \ldots \ldots\end{array}$ & Michigan and Wisconsin & do & 23 & 21 \\
\hline Sablefish, smoked ... . . . . & Illinois, Michigan, Ohio, & & & \\
\hline & and Wisconsin & do & 548 & 938 \\
\hline $\begin{array}{l}\text { Salmon: } \\
\text { Fresh and frozen, fillets and steaks. }\end{array}$ & & & & \\
\hline Fresh and frozen, fillets and steaks & $\begin{array}{l}\text { Illinois, Michigan, and } \\
\text { Wisconsin }\end{array}$ & do & 21 & 37 \\
\hline Smoked $\ldots \ldots \ldots \ldots \ldots$ & $\begin{array}{l}\text { Illinois, Michigan, Ohio, } \\
\text { and Wisconsin }\end{array}$ & do & 396 & 1,475 \\
\hline Sauger, fresh and frozen fillets .... & Ohio and Wisconsin & do & 128 & 196 \\
\hline Snapper, red, fresh and frozen fillets. & Illinois, Michigan, and Ohio & do & 320 & 775 \\
\hline Turbot, fresh and frozen fillets .... & Illinois and Michigan & do & 173 & 153 \\
\hline Whitefish: & & & & \\
\hline Fresh and frozen fillets $\ldots \ldots$ & $\begin{array}{l}\text { Illinois, Michigan, Minnesota, } \\
\text { New York, Ohio, and Wisconsin }\end{array}$ & do & 1,344 & 1,847 \\
\hline 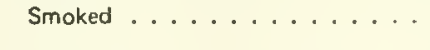 & Illinois, Michigan, New York, & & & \\
\hline Whiting, smoked ... . . . . . & $\begin{array}{l}\text { Ohio, and Wisconsin } \\
\text { Illinois, Michigan, and Wisconsin }\end{array}$ & $\begin{array}{l}\text { do } \\
\text { do }\end{array}$ & 288 & 410 \\
\hline Yellow perch, fresh and frozen fillets: & & do & 150 & 115 \\
\hline Raw $\ldots \ldots \ldots \ldots$ & $\begin{array}{l}\text { Illinois, Michigan, Ohio, } \\
\text { Pennsylvania, and Wisconsin }\end{array}$ & do & 1,652 & 3,549 \\
\hline Breaded, raw and cooked & $\begin{array}{l}\text { Illinois, Michigan, Ohio, } \\
\text { and Wisconsin }\end{array}$ & do & 1,123 & 2,311 \\
\hline Yellow pike, fresh and frozen fillets . & $\begin{array}{l}\text { Illinois, Michigan, New York, } \\
\text { Ohio, Pennsylvania, and }\end{array}$ & & & \\
\hline & Wisconsin & do & 1.053 & 1,675 \\
\hline $\begin{array}{l}\text { Shrimp, frozen breaded raw . . . . . } \\
\text { Unclassified: }\end{array}$ & Illinois, Ohio, and Wisconsin & do & 389 & 541 \\
\hline Fresh and frozen $\ldots \ldots \ldots$ & $\begin{array}{l}\text { Illinois, Michigan, Minnesota, } \\
\text { New York, Ohio, and Wisconsin }\end{array}$ & do & (1) 56,438 & (1) 42,403 \\
\hline Canned ....... & Illinois, Michigan, and Wisconsin & $\begin{array}{l}\text { Standard } \\
\text { cases }\end{array}$ & (2) 530 & (2) 3,338 \\
\hline Cured $\ldots \ldots \ldots \ldots$ & $\begin{array}{l}\text { Illinois, Michigan, Minnesota, and } \\
\text { Wisconsin }\end{array}$ & Pounds & (3) 624 & (3) 526 \\
\hline Industrial $\ldots \ldots \ldots$ & Michigan and Wisconsin & - & - & (1) \\
\hline Total & & - & - & 69,608 \\
\hline
\end{tabular}

(1) Includes anglerfish, bluefish, carp, cod, crappie, croaker, grouper, mullet, Atlantic ocean perch, scup or porgy, sea bass, sea trout, smelt, striped bass, white bass, and whiting fillets; catfish. Atlantic mackerel, swordfish, and tuna steaks; bullheads and catfish, dressed and skinned; cod, haddock, pollock, sauger, and yellow pike fillets, breaded raw or cooked; oyster meat, sea scallop meat, and frog legs breaded (raw); fish sticks breaded (raw and cooked); fish portions, not breaded and breaded (raw), and breaded cooked, and unclassified breaded (raw) fillets. (2) Includes canned anchovy, lake trout, salmon, lobster, and shrimp pastes: whitefish caviar, pet food, and the value of alewife meal and oil, and animal feeds. (3) Includes dried cod (lutefisk) salted lake herring; smoked eels, mooneye, tullibee, and sturgeon.

Note:-- Some of the products may have been processed from raw products imported from another State or a foreign country: therefore, they cannot be correlated directly with landings within the State. Certain items are shown in an intermediate and aiso a more advanced stage of processing. Total is correct. Table may not add because of rounding. 


\section{LAKE ONTARIO - OPERATING UNITS \\ AND FISHING EFFORT BY GEAR, 1975}

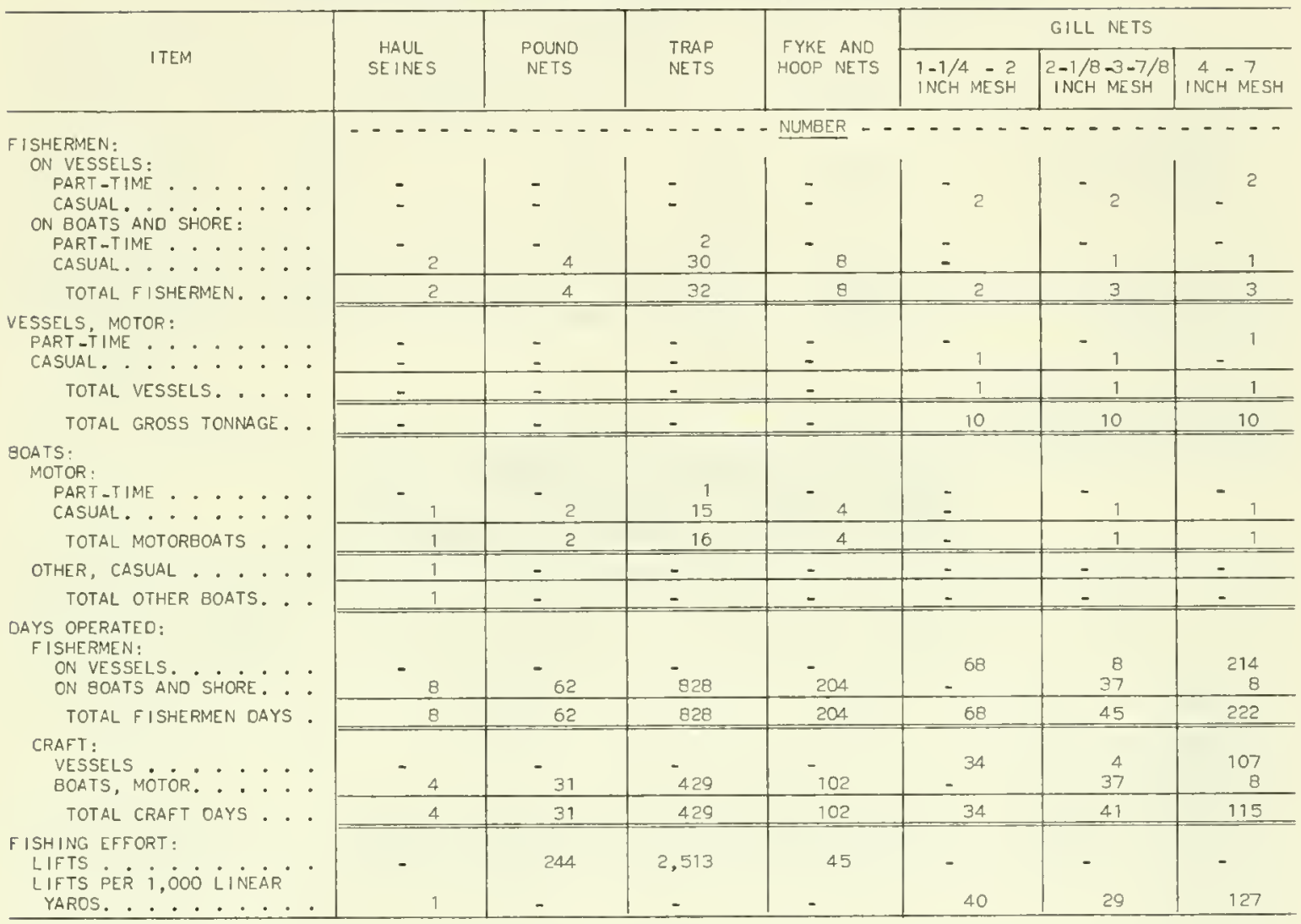

SEE NOTE ON PAGE 283.

\section{LAKE ERIE - OPERATING UNITS AND FISHING EFFORT BY GEAR, 1975}

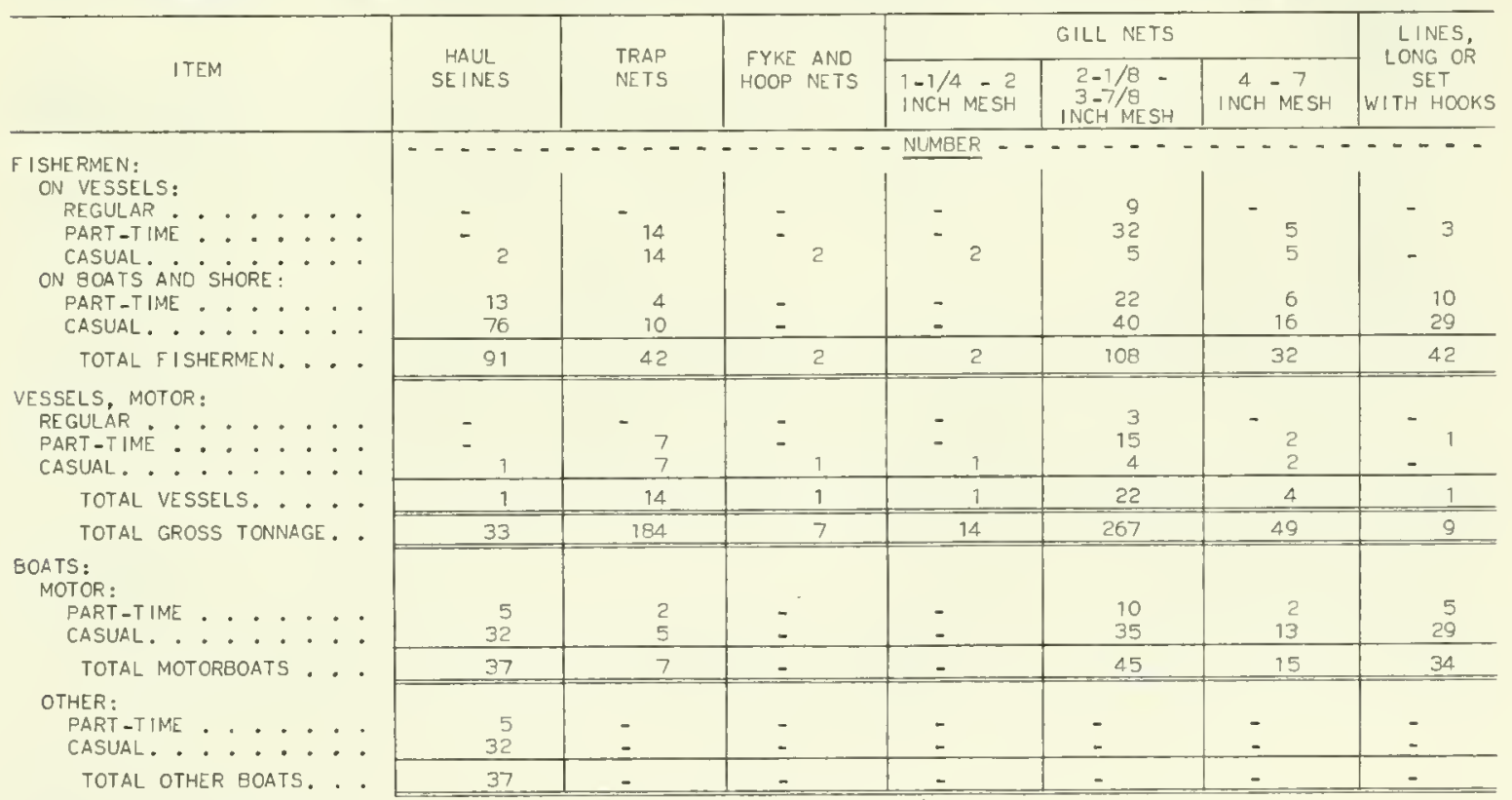




\section{GREAT LAKES FISHERIES}

\section{LAKE ERIE - OPERATING UNITS AND}

FISHING EFFORT BY GEAR, 1975 - Continued

\begin{tabular}{|c|c|c|c|c|c|c|c|}
\hline \multirow{2}{*}{ ITEM } & \multirow{2}{*}{$\begin{array}{l}\text { HAUL } \\
\text { SE INES }\end{array}$} & \multirow{2}{*}{$\begin{array}{l}\text { TRAP } \\
\text { NETS }\end{array}$} & \multirow{2}{*}{$\begin{array}{l}\text { FYKE ANO } \\
\text { HOOP NETS }\end{array}$} & \multicolumn{3}{|c|}{ GILL NETS } & \multirow{2}{*}{$\begin{array}{l}\text { LINES, } \\
\text { LONG OR } \\
\text { SET WITH } \\
\text { HOOKS }\end{array}$} \\
\hline & & & & $\begin{array}{l}1-1 / 4=2 \\
\text { INCH MESH }\end{array}$ & $\begin{array}{l}2-1 / 8- \\
3-7 / 8 \text { - } \\
1 \mathrm{NCH} / M E S H\end{array}$ & $\begin{array}{l}4-7 \\
\text { I NCH MESH }\end{array}$ & \\
\hline $\begin{array}{l}\text { OAYS OPERATED: } \\
\text { FISHERMEN: } \\
\text { ON VESSELS. } . . . \\
\text { ON BOATS AND SHORE: . }\end{array}$ & $\begin{array}{r}-\ldots \\
80 \\
3,316 \\
\end{array}$ & $\begin{array}{r}-\ldots \\
1,812 \\
446 \\
\end{array}$ & $\begin{array}{r}-\cdots \\
-2 \\
\end{array}$ & - NUMBER & $\begin{array}{r}-\ldots \\
5,537 \\
3,147 \\
\end{array}$ & $\begin{array}{r}-\cdots \\
501 \\
777 \\
\end{array}$ & $\begin{array}{r}-\ldots \\
336 \\
1,641 \\
\end{array}$ \\
\hline TOTAL FISHERMEN OAYS - & 3,396 & 2,258 & 2 & 30 & 8,684 & 1,278 & 1,977 \\
\hline 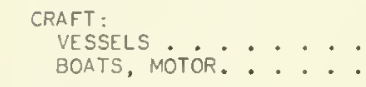 & $\begin{array}{r}40 \\
1,667 \\
\end{array}$ & $\begin{array}{r}906 \\
223 \\
\end{array}$ & - & $\begin{array}{r}15 \\
-\quad \\
\end{array}$ & $\begin{array}{l}2,340 \\
1,650 \\
\end{array}$ & $\begin{array}{r}191 \\
331 \\
\end{array}$ & $\begin{array}{r}112 \\
1,134 \\
\end{array}$ \\
\hline TOTAL CRAFT DAYS . . & 1,707 & 1,129 & 1 & 15 & 3,998 & 522 & 1,246 \\
\hline 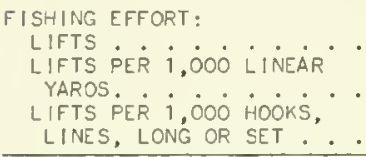 & $\begin{array}{l}- \\
2,435 \\
-\end{array}$ & $\begin{array}{l}6,298 \\
- \\
-\end{array}$ & - & 30 & $\begin{array}{c}- \\
10,387 \\
-\end{array}$ & $\begin{array}{r}- \\
791 \\
- \\
\end{array}$ & $\begin{array}{l}- \\
- \\
527\end{array}$ \\
\hline
\end{tabular}

SEE NOTE ON PAGE 283.

\section{LAKE HURON - OPERATING UNITS AND FISHING EFFORT BY GEAR, 1975}

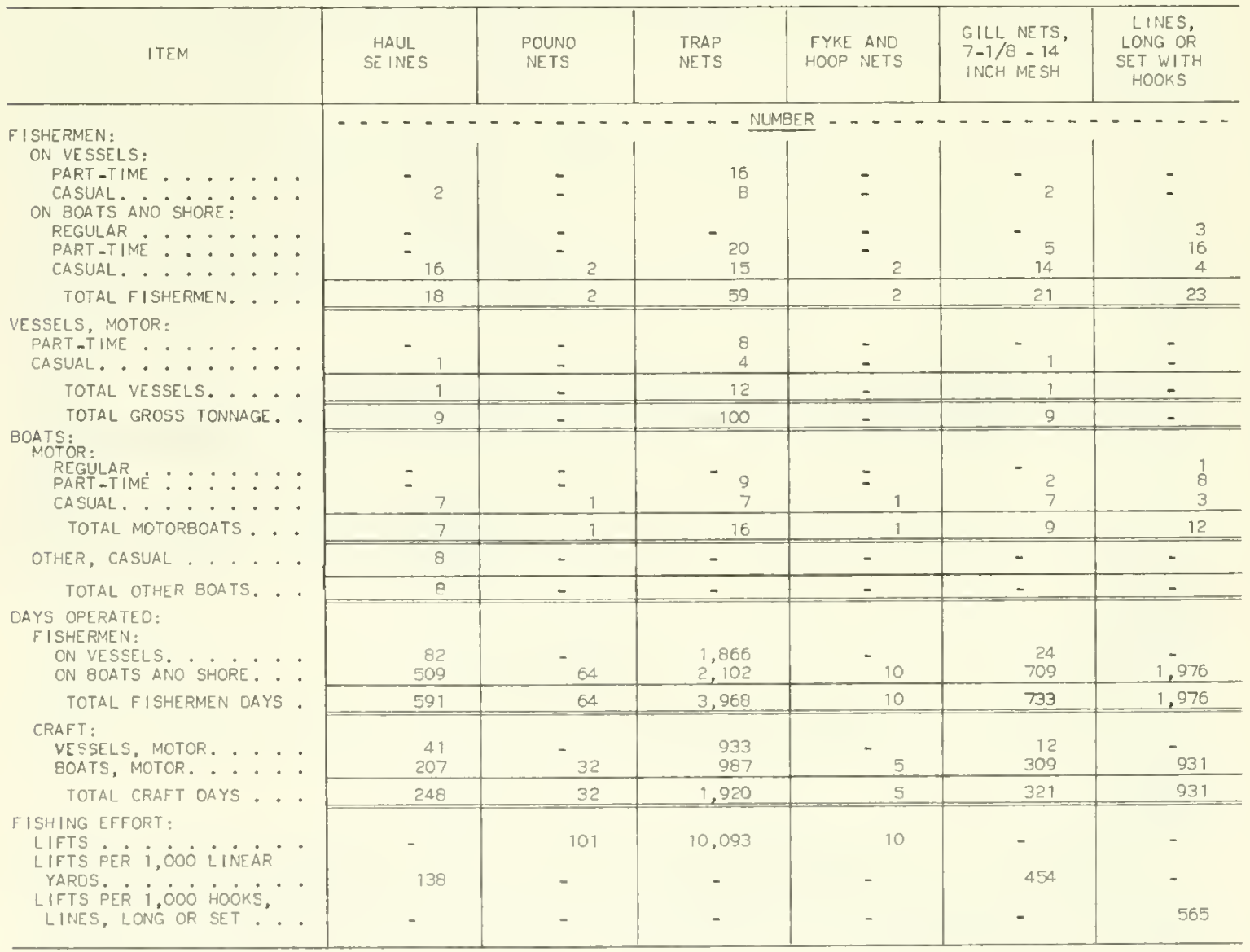

SEE NOTE ON PAGE ZE3. 


\section{LAKE MICHIGAN - OPERATING UNITS AND FISHING EFFORT BY GEAR, 1975}

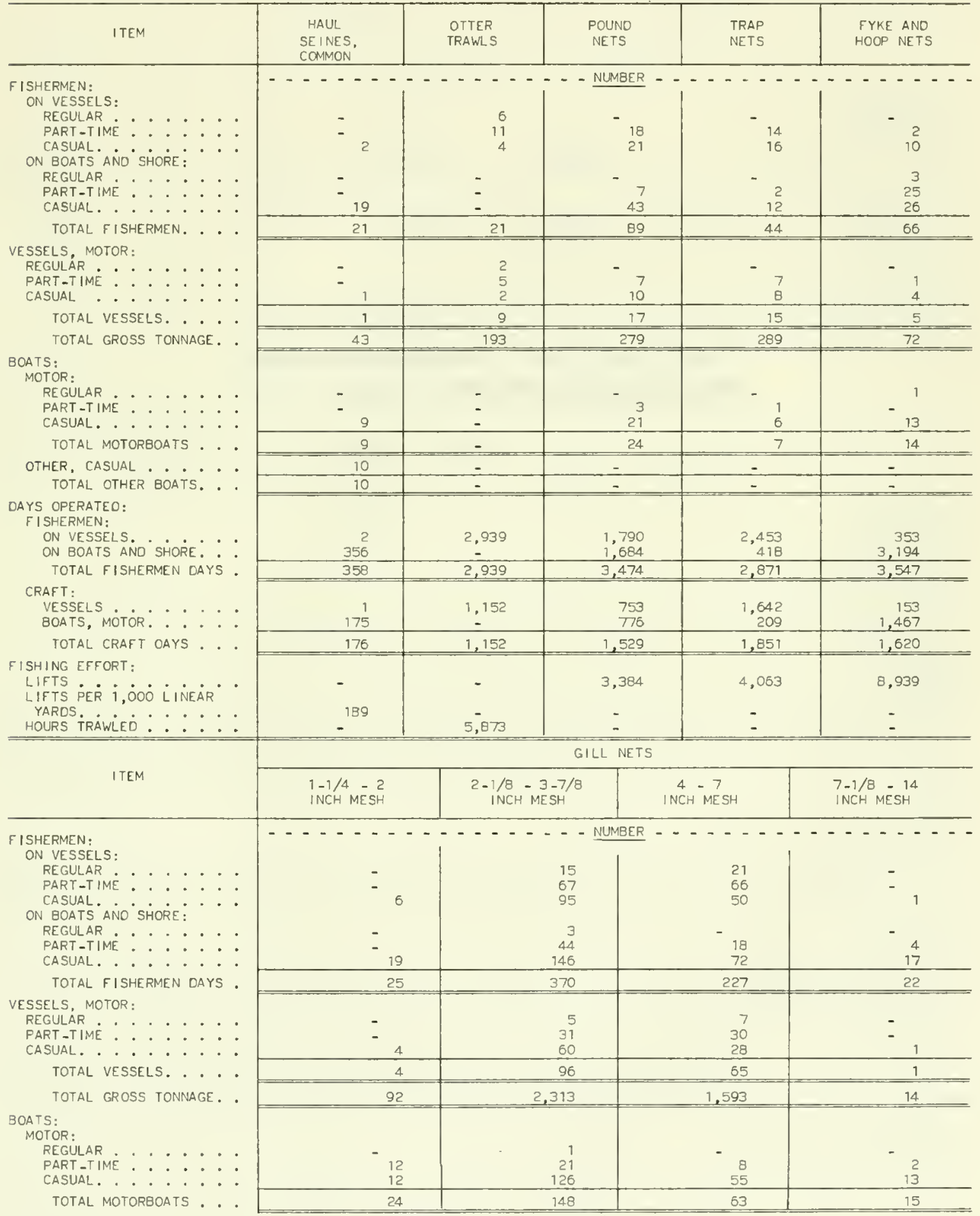




\section{LAKE MICHIGAN - OPERATING UNITS AND FISHING EFFORT BY GEAR, 1975 - Continued}

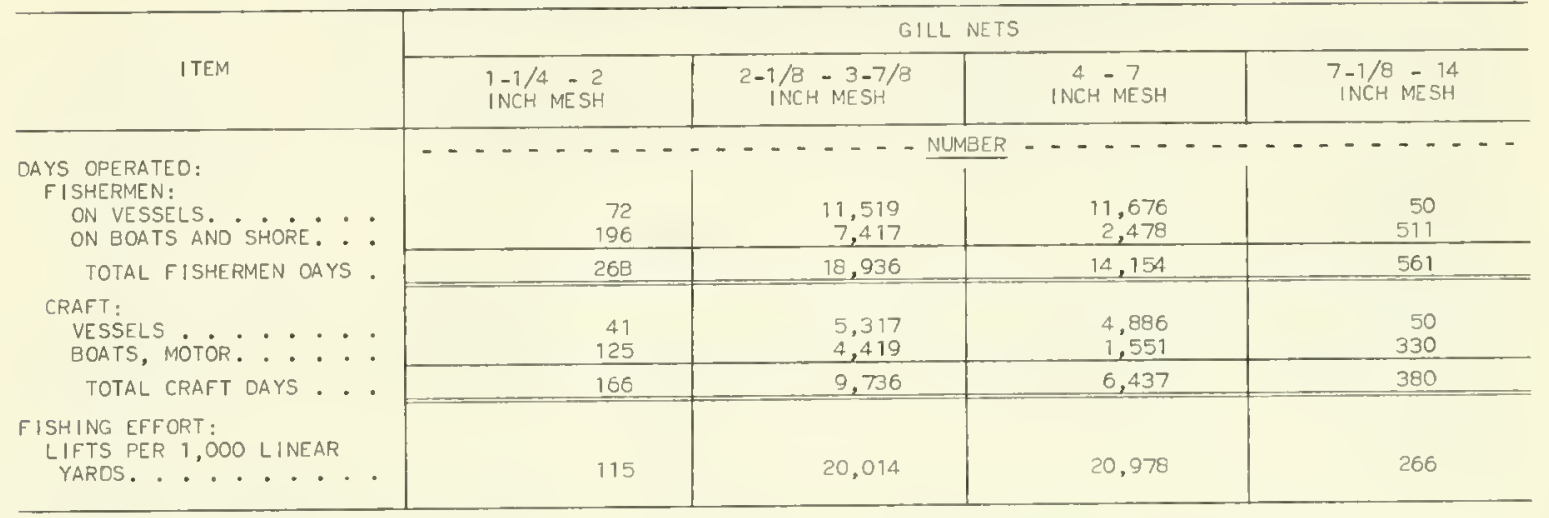

SEE NOTE ON PAGE 283.

\section{LAKE SUPERIOR - OPERATING UNITS AND FISHING EFFORT BY GEAR, 1975}

\begin{tabular}{|c|c|c|c|c|c|c|c|}
\hline \multirow[b]{2}{*}{ ITEM } & \multirow[b]{2}{*}{$\begin{array}{l}\text { HAUL } \\
\text { SEINES }\end{array}$} & \multirow[b]{2}{*}{$\begin{array}{l}\text { OTTER } \\
\text { TRAWLS }\end{array}$} & \multirow[b]{2}{*}{$\begin{array}{l}\text { POUNO } \\
\text { NETS }\end{array}$} & \multirow[b]{2}{*}{$\begin{array}{l}\text { TRAP } \\
\text { NETS }\end{array}$} & \multicolumn{3}{|c|}{ GILL NETS } \\
\hline & & & & & $\begin{array}{l}1-1 / 4-2 \\
\text { INCH MESH }\end{array}$ & $\begin{array}{l}2-1 / 8- \\
3-7 / 8- \\
\text { INCH MESH }\end{array}$ & $\begin{array}{c}4 \\
\text { INCH }\end{array}$ \\
\hline $\begin{array}{l}\text { FISHERMEN: } \\
\text { ON VESSELS: } \\
\text { REGULAR } \\
\text { PART TIME } \\
\text { CASUAL. } \\
\text { ON SOATS ANO SHORE } \vdots \\
\text { REGGLAR } \\
\text { PART TIME } \\
\text { CASUAL. }\end{array}$ & $\begin{array}{l}- \\
- \\
- \\
- \\
\end{array}$ & $\begin{array}{l}- \\
- \\
- \\
-\end{array}$ & $\begin{array}{r}3 \\
9 \\
-\quad \\
-\quad 16 \\
\end{array}$ & $\begin{array}{r}-7 \\
2 \\
-\quad \\
-\quad 2 \\
8 \\
\end{array}$ & $\begin{array}{l}- \\
-11 \\
-\quad \\
2 \\
6\end{array}$ & $\begin{array}{r}- \\
43 \\
33 \\
3 \\
24 \\
46 \\
\end{array}$ & $\begin{array}{r}21 \\
40 \\
-\quad \\
2 \\
29 \\
\end{array}$ \\
\hline TOTAL FISHERMEN. $\cdots$ & 2 & 7 & 31 & 19 & 19 & 149 & 92 \\
\hline $\begin{array}{l}\text { VESSELS, MOTOR: } \\
\text { REGULAR } \\
\text { PART-TIMË }: \vdots \vdots \vdots \vdots \\
\text { CASUAL. }: \vdots \vdots\end{array}$ & $\overline{-}-$ & $\mathbf{-}^{1}$ & & $\begin{array}{r}- \\
3 \\
1 \\
\end{array}$ & $\overline{-}_{5}$ & $\begin{array}{r}- \\
19 \\
18 \\
\end{array}$ & $\begin{array}{r}9 \\
20 \\
\end{array}$ \\
\hline TOTAL VESSELS. . . . . & $=$ & 1 & 5 & 4 & 5 & 37 & 29 \\
\hline TOTAL GROSS TONNAGE. . & $=$ & 17 & 99 & 116 & 102 & 808 & 645 \\
\hline $\begin{array}{l}\text { 8OATS: } \\
\text { MOTOR: } \\
\text { REGULAR }: \cdots: \therefore \\
\text { PART-TIME }: \therefore: \therefore \\
\text { CASUAL. }: \cdots\end{array}$ & - & $\begin{array}{l}- \\
- \\
\end{array}$ & $\begin{array}{r}1 \\
-\quad 8 \\
\end{array}$ & $\begin{array}{l}1 \\
4 \\
\end{array}$ & $\begin{array}{r}- \\
1 \\
6 \\
\end{array}$ & $\begin{array}{r}1 \\
12 \\
40 \\
\end{array}$ & $\begin{array}{r}- \\
20 \\
\end{array}$ \\
\hline TOTAL MOTORBOATS $\ldots$ & 1 & 2 & 9 & 5 & 7 & 53 & 21 \\
\hline $\begin{array}{l}\text { OTHER, CASUAL } \cdots \cdots \\
\text { TOTAL OTHER SOATS. } \cdots\end{array}$ & 1 & - & - & - & - & - & - \\
\hline TOTAL OTHER BOATS. . & 1 & $=$ & - & - & - & - & - \\
\hline $\begin{array}{l}\text { OAYS OPERATEO: } \\
\text { FISHERMEN: } \\
\text { ON VESSELS. }{ }^{\circ} \text { ON BOATS ANO SHORE. }: \cdots\end{array}$ & $\begin{array}{r}- \\
- \\
\end{array}$ & $\begin{array}{r}498 \\
62 \\
\end{array}$ & $\begin{array}{l}490 \\
751 \\
\end{array}$ & $\begin{array}{r}643 \\
358 \\
\end{array}$ & $\begin{array}{l}185 \\
227 \\
\end{array}$ & $\begin{array}{l}4,974 \\
3,552 \\
\end{array}$ & $\begin{array}{r}2,838 \\
966 \\
\end{array}$ \\
\hline TOTAL FISHERMEN DAYS • & 28 & 560 & 1,241 & 1,001 & 412 & 8,526 & 3,804 \\
\hline $\begin{array}{l}\text { CRAFT: } \\
\text { VESSELS } \\
\text { BOATS, MOTOR. } \cdots \cdots\end{array}$ & $-{ }^{-} 14$ & $\begin{array}{r}166 \\
31 \\
\end{array}$ & $\begin{array}{l}188 \\
278 \\
\end{array}$ & $\begin{array}{l}275 \\
179 \\
\end{array}$ & $\begin{array}{r}88 \\
170 \\
\end{array}$ & $\begin{array}{l}2,317 \\
1,991 \\
\end{array}$ & $\begin{array}{r}1.254 \\
643 \\
\end{array}$ \\
\hline TOTAL CRAFT DAYS . . & 14 & 197. & 466 & 454 & 258. & 4,308 & 1,897 \\
\hline $\begin{array}{l}\text { FISHING EFFORT: } \\
\text { LIFTS } \\
\text { LIFTS PER } \dot{\dagger}, \dot{0} 0 \dot{\text { Y }} \text { YAROS }: \\
\text { HOURS TRAWLEO }\end{array}$ & $\begin{array}{l}- \\
-\end{array}$ & $\bar{i}_{499}$ & $\begin{array}{l}1,172 \\
:-\end{array}$ & $\begin{array}{l}1.543 \\
-\end{array}$ & -89 & 8.082 & 4.609 \\
\hline
\end{tabular}




\section{LAKE OF THE WOODS, NAMAKAN LAKE, AND RAINY LAKE OPERATING UNITS AND FISHING EFFORT BY GEAR, 1975}

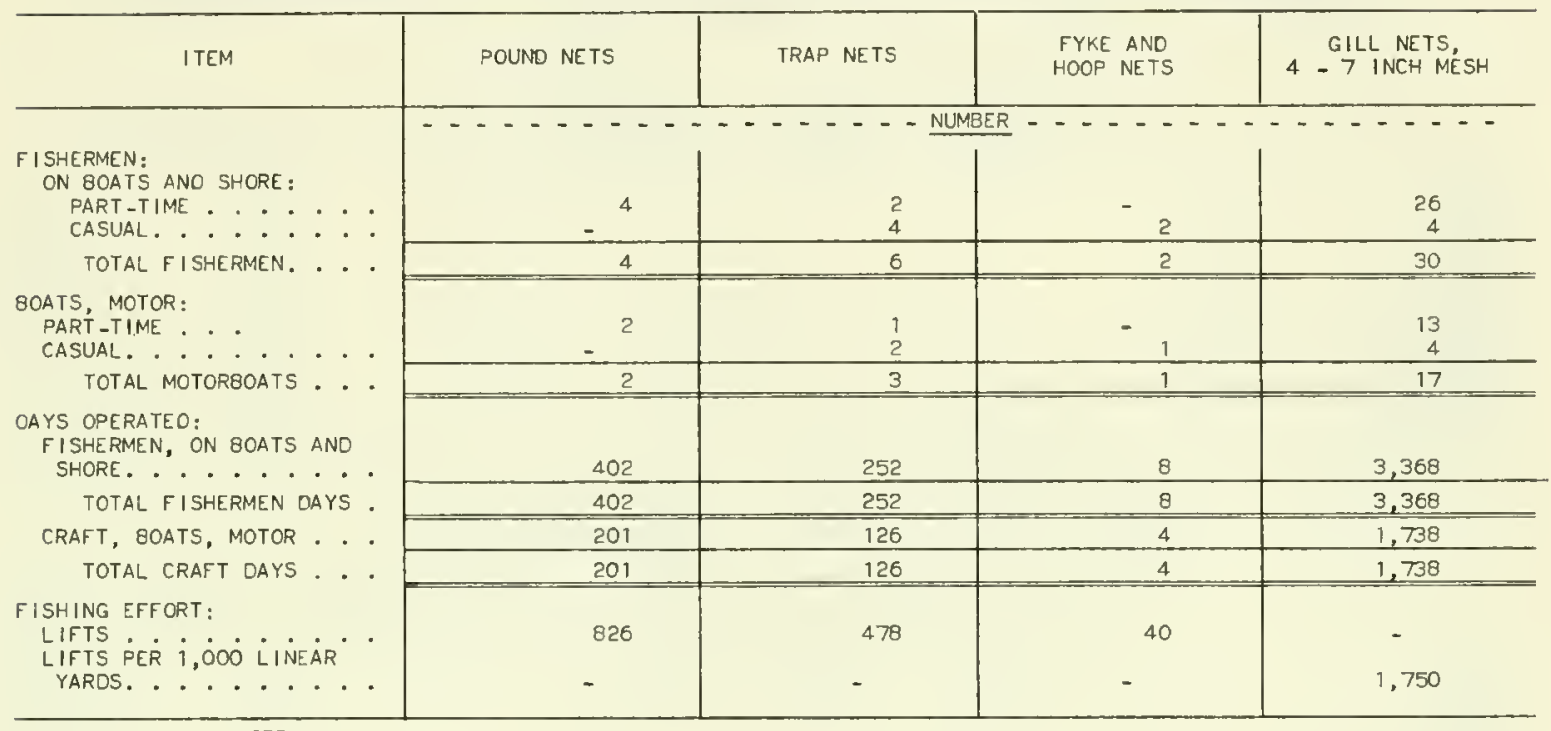

SEE NOTE ON PAGE 283. 
LANDINGS BY LAKE, STATE, AND CATCH BY GEAR, 1975

\begin{tabular}{|c|c|c|c|c|c|c|c|}
\hline \multirow{3}{*}{\multicolumn{2}{|c|}{ SPECIES }} & \multicolumn{6}{|c|}{ LAKE ONTARIO } \\
\hline & & \multicolumn{6}{|c|}{ NEW YORK } \\
\hline & & \multicolumn{2}{|c|}{ HAUL SEINES, COMMON } & \multicolumn{2}{|c|}{ POUNO NETS } & \multicolumn{2}{|c|}{ TRAP NETS } \\
\hline \multirow{3}{*}{ 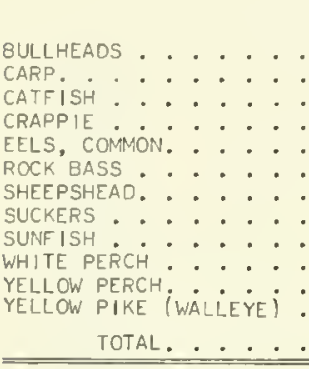 } & \multirow{3}{*}{$\therefore:$} & POUNOS & DOLLARS & POUNOS & OOLLARS & POUNDS & DOLLARS \\
\hline & & $\begin{array}{l}1,700 \\
- \\
- \\
- \\
- \\
- \\
- \\
- \\
- \\
-\end{array}$ & $\begin{array}{l}\text {,026 } \\
= \\
- \\
- \\
- \\
- \\
- \\
- \\
-\end{array}$ & $\begin{array}{l}1,200 \\
- \\
100 \\
100 \\
2,600 \\
1,100 \\
- \\
- \\
300 \\
2,000 \\
5,000 \\
- \\
\end{array}$ & $\begin{array}{r}696 \\
-\quad 18 \\
19 \\
1,336 \\
86 \\
-\quad \\
-\quad 68 \\
298 \\
-775 \\
\end{array}$ & $\begin{array}{r}46,400 \\
1,600 \\
800 \\
3,100 \\
27,400 \\
8,600 \\
300 \\
1,400 \\
13,200 \\
5,500 \\
21,300 \\
300 \\
\end{array}$ & $\begin{array}{r}22,695 \\
22 \\
157 \\
1,483 \\
19,235 \\
1,462 \\
37 \\
57 \\
3,877 \\
1,188 \\
4,605 \\
178 \\
\end{array}$ \\
\hline & & 1,700 & 1,026 & 12,400 & 3,296 & 129,900 & 54,997 \\
\hline \multirow{4}{*}{\multicolumn{2}{|c|}{ SPECIES }} & \multicolumn{6}{|c|}{ LAKE ONTARIO - CONTINUEO } \\
\hline & & \multicolumn{6}{|c|}{ NEW YORK - CONTINUEO } \\
\hline & & \multirow{2}{*}{\multicolumn{2}{|c|}{ FYKE ANO HOOP NETS }} & \multicolumn{4}{|c|}{ GILL NETS } \\
\hline & & & & $1-1 / 4-$ & $\mathrm{CH}$ MESH & $2-1 / 8-3$ & INCH MESH \\
\hline \multirow{3}{*}{ 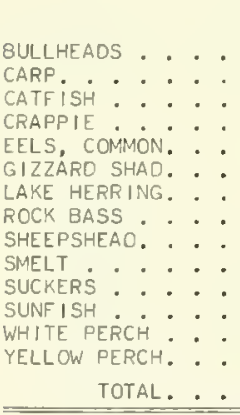 } & & POUNOS & DOLLARS & POUNDS & DOLLARS & POUNOS & OOLLARS \\
\hline & 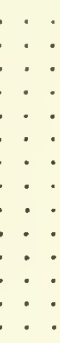 & $\begin{array}{l}600 \\
(1) \\
- \\
200 \\
(1) \\
- \\
- \\
- \\
- \\
100 \\
100 \\
600 \\
100 \\
\end{array}$ & 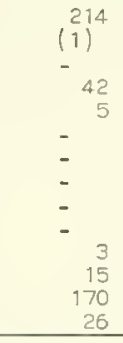 & $\begin{array}{l}- \\
- \\
- \\
- \\
- \\
- \\
- \\
17,900 \\
- \\
- \\
- \\
-\end{array}$ & $\begin{array}{l}- \\
- \\
- \\
- \\
- \\
- \\
- \\
8,808 \\
- \\
- \\
-\end{array}$ & $\begin{array}{l}- \\
- \\
- \\
- \\
400 \\
100 \\
5,100 \\
200 \\
900 \\
1,000 \\
- \\
26,800 \\
34,200 \\
\end{array}$ & $\begin{array}{r}- \\
- \\
- \\
- \\
40 \\
18 \\
1,242 \\
22 \\
544 \\
290 \\
- \\
8,679 \\
19,055 \\
\end{array}$ \\
\hline & . & 1,700 & 475 & 17,900 & 8,808 & 68.800 & 29,915 \\
\hline \multirow{4}{*}{\multicolumn{2}{|c|}{ SPECIES }} & \multicolumn{4}{|c|}{ LAKE ONTARIO - CONTINUEO } & \multicolumn{2}{|c|}{ LAKE ERIE } \\
\hline & & \multicolumn{4}{|c|}{ NEW YORK - CONTINUEO } & \multicolumn{2}{|c|}{ NEW YORK } \\
\hline & & \multicolumn{2}{|c|}{ GILL NETS - CONT I NUEO } & \multirow{2}{*}{\multicolumn{2}{|c|}{ TOTAL }} & \multicolumn{2}{|c|}{ GILL NETS } \\
\hline & & $4-7$ & MESH & & & $2-1 / 8-3$ & INCH MESH \\
\hline 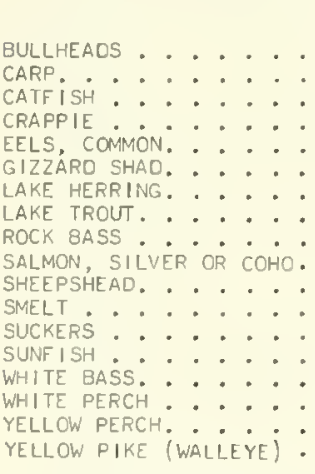 & $\therefore$ & 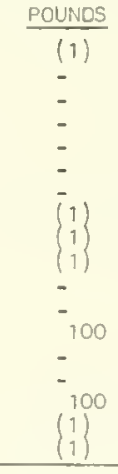 & $\begin{array}{l}\text { DOLLARS } \\
- \\
- \\
- \\
- \\
- \\
-7 \\
2 \\
- \\
- \\
- \\
- \\
- \\
34 \\
6 \\
13 \\
\end{array}$ & $\begin{array}{r}\text { POUNOS } \\
49,900 \\
1,600 \\
1,000 \\
3,400 \\
30,000 \\
400 \\
100 \\
(1) \\
14,800 \\
(1) \\
500 \\
18,800 \\
2,600 \\
13,600 \\
35,000 \\
60,600 \\
300 \\
\end{array}$ & $\begin{array}{r}\frac{\text { OOLLARS }}{24,640} \\
22 \\
200 \\
1,544 \\
20,576 \\
40 \\
18 \\
7 \\
2,792 \\
6 \\
59 \\
9,352 \\
363 \\
3,960 \\
- \\
10,369 \\
24,467 \\
191\end{array}$ & $\begin{array}{c}\text { POUNOS } \\
- \\
800 \\
400 \\
- \\
= \\
- \\
- \\
- \\
14,200 \\
1,000 \\
16,200 \\
- \\
3,700 \\
139,100 \\
32,000\end{array}$ & 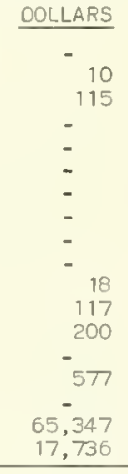 \\
\hline TOTAL..... & . . & 200 & 89 & 232,600 & 98,606 & 207,400 & 84,120 \\
\hline
\end{tabular}

SEE FOOTNOTE AT ENO OF TABLE.

(CONTINUED ON NEXT PAGE) 
LANDINGS BY LAKE, STATE AND CATCH BY GEAR, 1975 - Continued

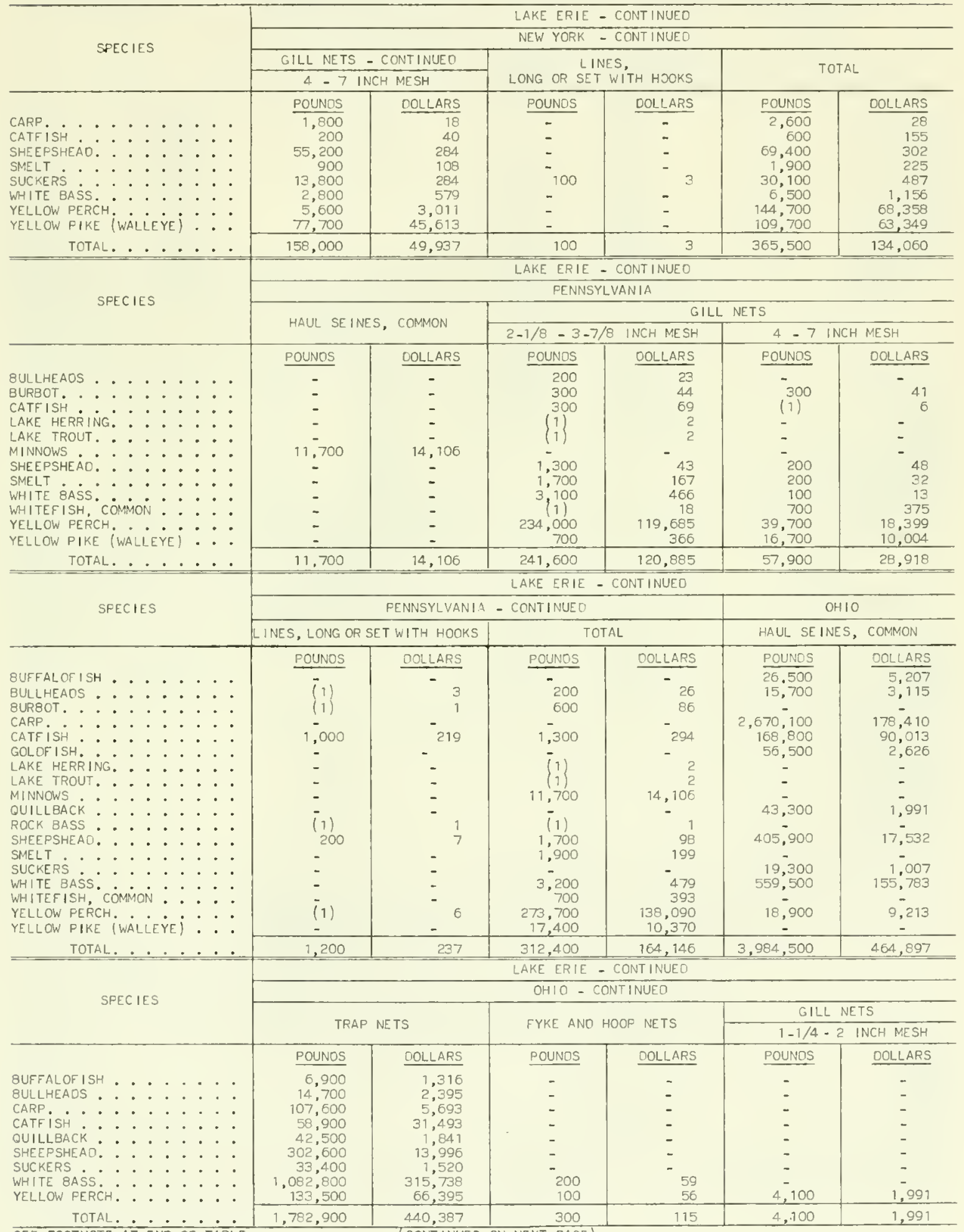




\section{LANDINGS BY LAKE, STATE, AND CATCH BY GEAR, 1975 - Continued}

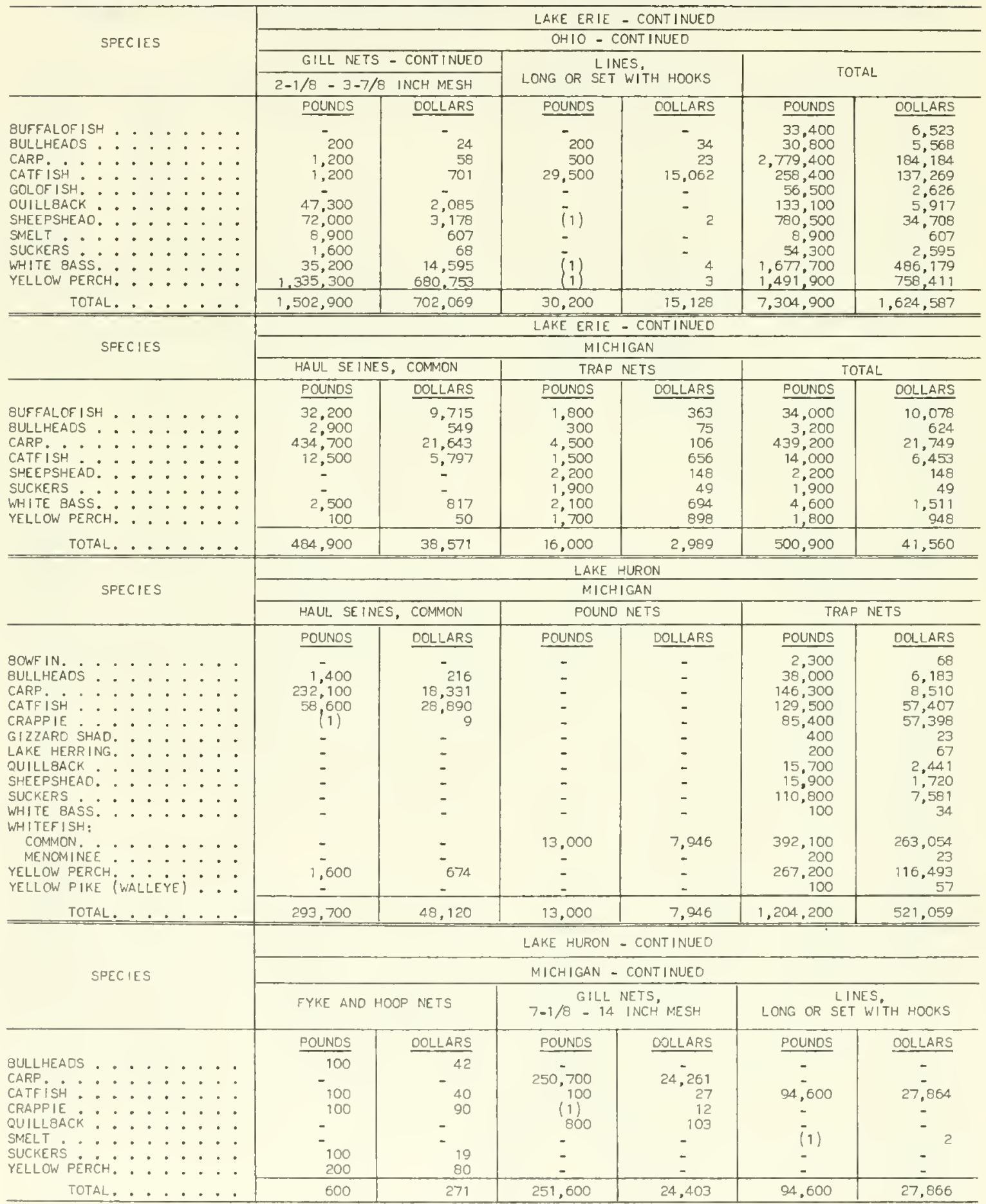




\section{LANDINGS BY LAKE, STATE, AND CATCH BY GEAR, 1975 - Continued}

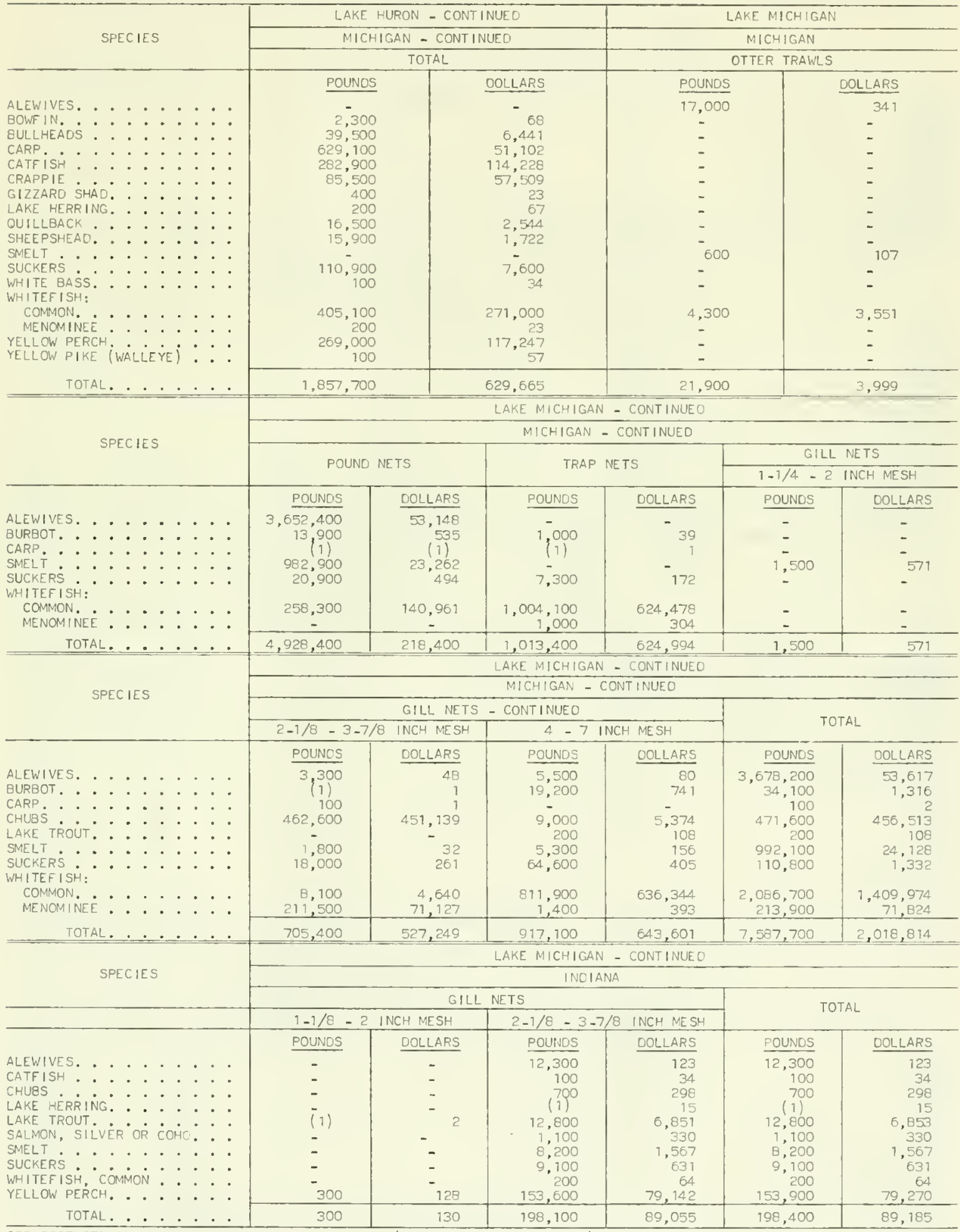

SEE FOOTNOTE AT END OF TABLE.

(CONTINUED ON NEXT PAGE) 
LANDINGS BY LAKE, STATE, AND CATCH BY GEAR, 1975 - Continued

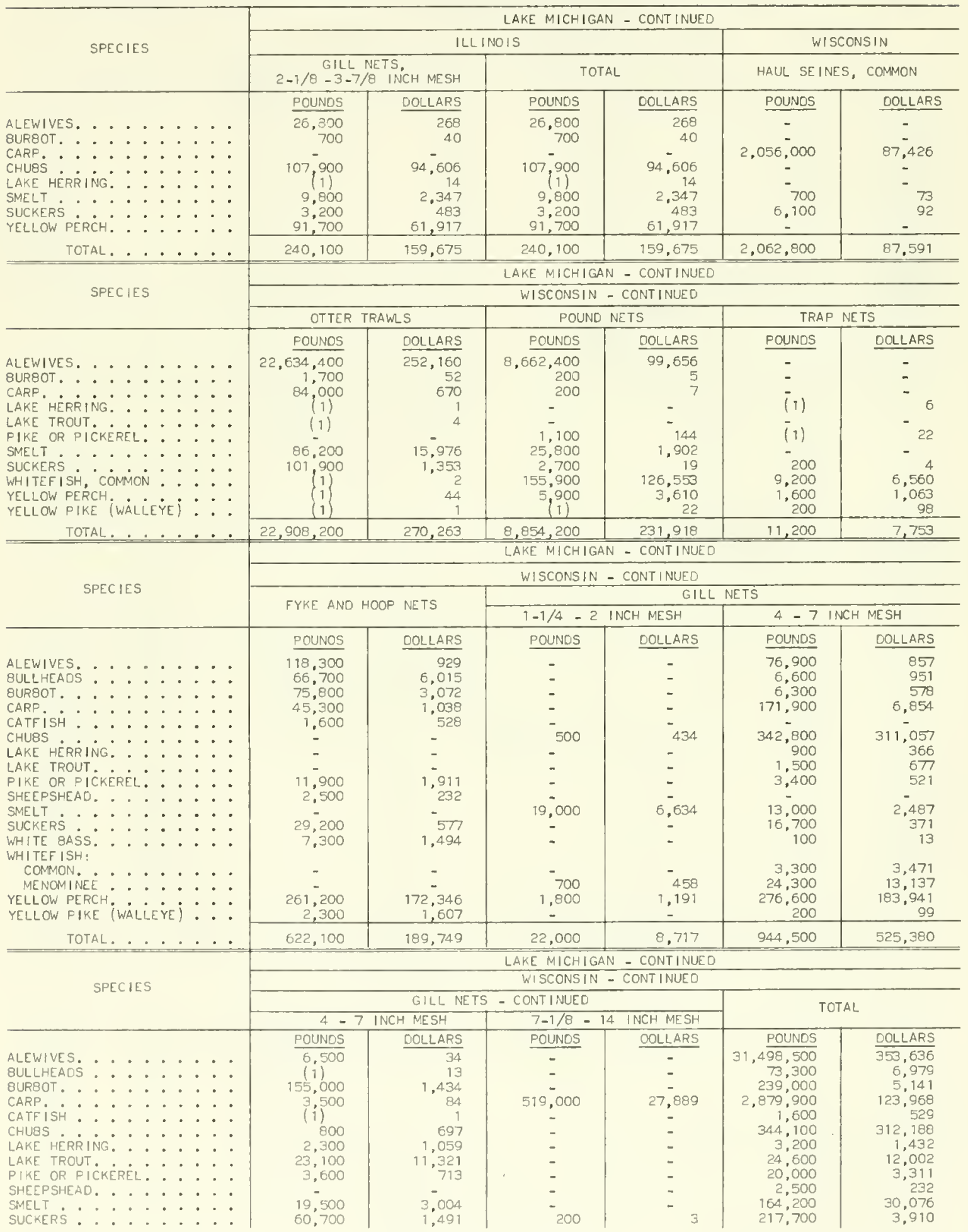

SEE FOOTNOTE AT ENO OF TABLE.

(CONTINUEO ON NEXT PAGE) 


\section{LANDINGS BY LAKE, STATE, AND CATCH BY GEAR, 1975 - Continued}

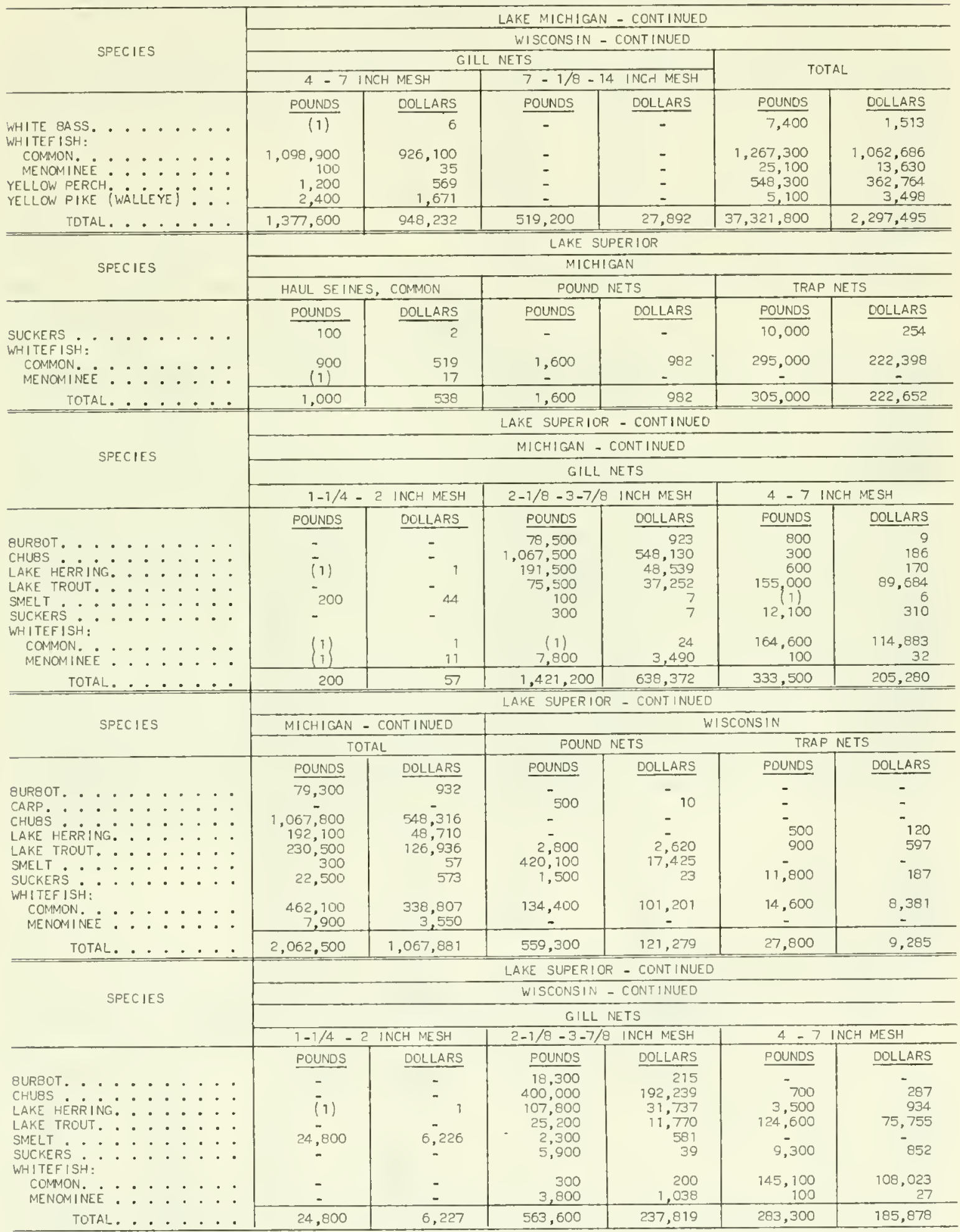

SEE FOOTNOTE AT END OF TABLE.

(CONT INUED DN NEXT PAGE) 
LANDINGS BY LAKE, STATE, AND CATCH BY GEAR, 1975 - Continued

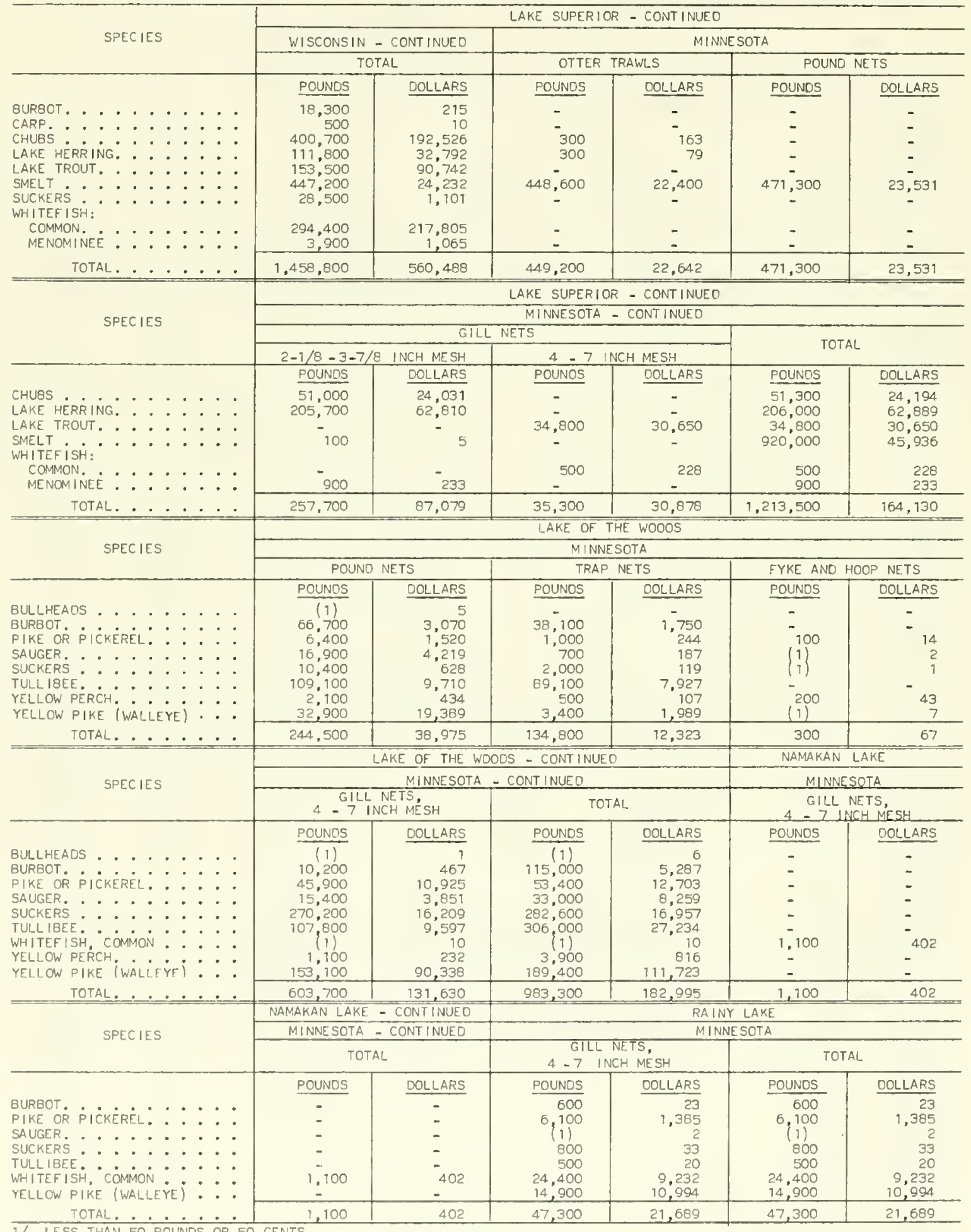




\section{MISSISSIPPI RIVER FISHERIES}

Commercial landings of fish and shellfish from the waters of the Mississippi River and tributaries were 72.5 million pounds valued at $\$ 15.0$ million, a decrease of 2.9 million pounds and $\$ 700,000$ compared with 1974. Landings decreased for mast major species of fish and shellfish. Landings of buffalofish (23.4 million pounds) decreased 7 percent; carp (15.4 million), 9 percent; catfish and bullheads (13.0 million), 8 percent; sheepshead (5.4 million), 11 percent; and mussel shells (2.1 million pounds), 37 percent. Landings of crawfish (6.6 million pounds) increased 85 percent compared with 1975.

Buffalofish, carp, catfish and bullheads, sheepshead, crawfish, and mussel shells accounted for 91 percent of the volume and 94 percent of the value. The landings were made by 12,993 fishermen, using 12,211 motorboats and 280 other boats. This was a decrease of 58 fishermen and 65 motorboats, but an increase of 21 other boats compared with 1974.

Louisiana was the leading State in volume with 13.4 million pounds, followed by Arkansas (9.4 million) and Tennessee ( 6.5 million pounds). Arkansas led in value of landings with $\$ 3.0$ million, followed by Louisiana ( $\$ 2.9$ million) and Tennessee with ( $\$ 1.4$ million).

The value of processed products was $\$ 61.3$ million $-\$ 20.2$ million (49 percent) more than in 1974 . Frozen packaged fishery products valued at $\$ 38.5$ million were 63 percent of the total value of processed items. There were 2,601 persons employed in 352 wholesaling and processing plants in 22 States in 1975.

Other information. This report contains summary tables on operating units and landings in the Mississippi River Fisheries. Complete statistics by State on operating units, landings of catch by gear, and landings by waters are on file in the Washington Office of the Data Management and Statistics Division. Summary data appearing on the following pages have been published previously in Current Fishery Statistics No.7233.

Acknowledgments. The following organizations helped collect the data appearing in this section; Alabama Department of Conservation, Division of Game and Fish; Arizona Game and Fish Department; Arkansas Game and Fish Commission, Division of Fisheries; Idaho Fish and Game Department; lllinois Department of Conservation, Division of Fisheries; Indiana Department of Conservation, Division of Fish and Game, Section of Fish Management; lowa State Conservation Commission, Division of Fish and Game; Kansas Forestry, Fish and Game Commission, Fisheries Division; Kentucky Department of Fish and Wildlife Resources; Louisiana Wild Life and Fisheries Commission; Minnesota Department of Conservation, Division of Game and Fish, Section of Fisheries; Mississippi Game and Fish Commission; Missouri Conservation Commission; Montana Deparment of Fish and Game, Fisheries Management; Nebraska Game, Forestation and Parks Commission, Fishery Division; North Dakota Game and Fish Department, Fisheries Division; Ohio Department of Natural Resources, Division of Wildlife, Section of Fish Management; Oklahom a Department of Wildlife Conservation, Division of Fisheries; South Dakota Department of Game, Fish and Parks; Tennessee Game and Fish Commission, Fish Management Division; Texas Game and Fish Commission, Inland Fisheries; West Virginia Department of Natural Resources; Wisconsin Conservation Department, Fish Management Division; and the Tennessee Valley Authority, Fish and Game Branch. 
SECTIONAL SUMMARIES

SUMMARY OF LANDINGS, 1975

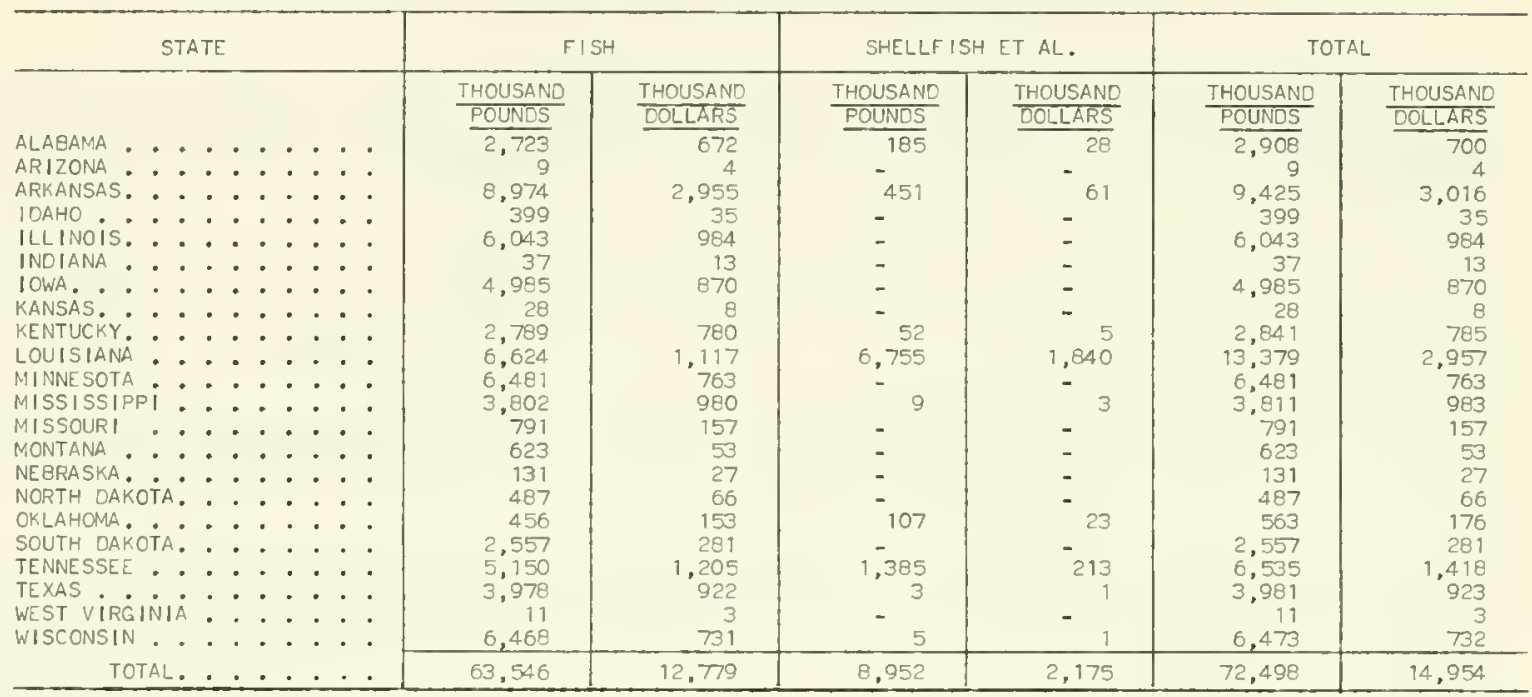

\section{SUMMARY OF OPERATING UNITS, 1975}

\begin{tabular}{|c|c|c|c|c|c|c|c|c|}
\hline ITEM & ALABAMA & ARIZONA & ARKANSAS & IDAHO & ILLINOIS & INDIANA & IOWA & KANSAS \\
\hline 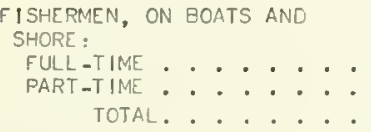 & $\begin{array}{r}125 \\
125 \\
100 \\
225 \\
\end{array}$ & $\begin{array}{r}-4 \\
4\end{array}$ & $\begin{array}{r}648 \\
3,866 \\
4,514 \\
\end{array}$ & $\begin{array}{r}-\quad-\frac{N U R}{3} \\
-\quad 3 \\
\end{array}$ & $\begin{array}{r}65 \\
219 \\
284\end{array}$ & $\begin{array}{r}-\cdots \\
-\quad-14 \\
14\end{array}$ & $\begin{array}{l}187 \\
528 \\
715\end{array}$ & $\begin{array}{r}-\cdots \\
- \\
15\end{array}$ \\
\hline 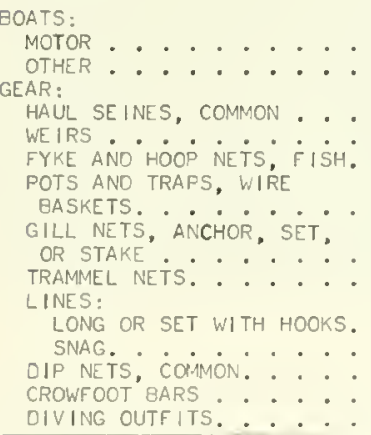 & $\begin{array}{l}- \\
- \\
- \\
- \\
613 \\
696 \\
138 \\
1,633 \\
407 \\
6 \\
-\quad 6\end{array}$ & $\begin{array}{l} \\
- \\
- \\
- \\
- \\
- \\
\\
11 \\
- \\
- \\
- \\
-\end{array}$ & $\begin{array}{c}4.514 \\
- \\
- \\
10,253 \\
- \\
1.994 \\
2.079 \\
3.565 \\
676 \\
- \\
50 \\
20\end{array}$ & $\begin{array}{l} \\
- \\
- \\
- \\
- \\
- \\
- \\
- \\
- \\
- \\
-\end{array}$ & $\begin{array}{r}234 \\
37 \\
18 \\
-\quad 150 \\
4,040 \\
10 \\
172 \\
212 \\
- \\
- \\
-\end{array}$ & $\begin{array}{l}- \\
- \\
- \\
- \\
- \\
- \\
- \\
- \\
= \\
- \\
- \\
-\end{array}$ & $\begin{array}{r}625 \\
90 \\
\\
34 \\
4 \\
3,946 \\
5,884 \\
652 \\
688 \\
2,176 \\
- \\
- \\
-\end{array}$ & 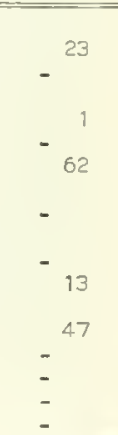 \\
\hline | TEM & KENTUCKY & LOUISIANA & $\begin{array}{l}\text { MINNE - } \\
\text { SOTA }\end{array}$ & $\begin{array}{l}\text { MISSIS- } \\
\text { SIPPI }\end{array}$ & MISSOURI & MONTANA & NEBRASKA & $\begin{array}{l}\text { NORTH } \\
\text { OAKOTA }\end{array}$ \\
\hline 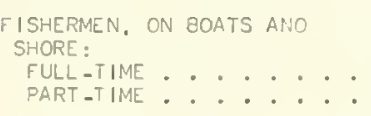 & $\begin{array}{l}101 \\
504\end{array}$ & $\begin{array}{r}351 \\
1,17 \\
\end{array}$ & $\begin{array}{l}111 \\
569 \\
\end{array}$ & $\begin{array}{l}175 \\
905 \\
\end{array}$ & $\begin{array}{r}52 \\
620 \\
\end{array}$ & $-\cdots$ & $\begin{array}{r}10 \\
183 \\
\end{array}$ & $\begin{array}{r}--- \\
4 \\
6\end{array}$ \\
\hline TOTAL. . . . . & 605 & 1.528 & 680 & 1,080 & 672 & 17 & 193 & 10 \\
\hline 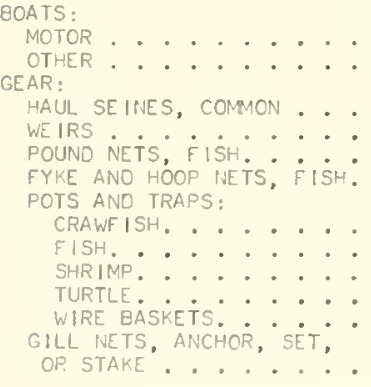 & $\begin{array}{l}505 \\
- \\
- \\
- \\
624 \\
= \\
= \\
= \\
260\end{array}$ & $\begin{array}{c}1,520 \\
- \\
- \\
- \\
26,965 \\
63,152 \\
-\quad \begin{array}{r}185 \\
-65 \\
1,192\end{array}\end{array}$ & $\begin{array}{r}459 \\
92 \\
94 \\
-14 \\
3,233 \\
-\quad 10 \\
- \\
- \\
- \\
175\end{array}$ & $\begin{array}{r}1,017 \\
2 \\
= \\
= \\
4,920 \\
= \\
= \\
= \\
- \\
1,015\end{array}$ & $\begin{array}{r}640 \\
27 \\
= \\
=10 \\
2,126 \\
= \\
= \\
- \\
- \\
37\end{array}$ & $\begin{array}{r}9 \\
5 \\
-\quad 4 \\
-\quad 10 \\
- \\
= \\
= \\
= \\
= \\
= \\
- \\
-\end{array}$ & $\begin{array}{r}172 \\
21 \\
\\
-\quad 21 \\
- \\
-271 \\
= \\
- \\
- \\
- \\
-\end{array}$ & $\begin{array}{rr}12 \\
2 \\
\\
2 \\
-\quad 2 \\
- & \\
& 87 \\
- & \\
- & \\
- & \\
- & \\
& 15\end{array}$ \\
\hline
\end{tabular}




\section{SUMMARY OF OPERATING UNITS, 1975 - Continued}

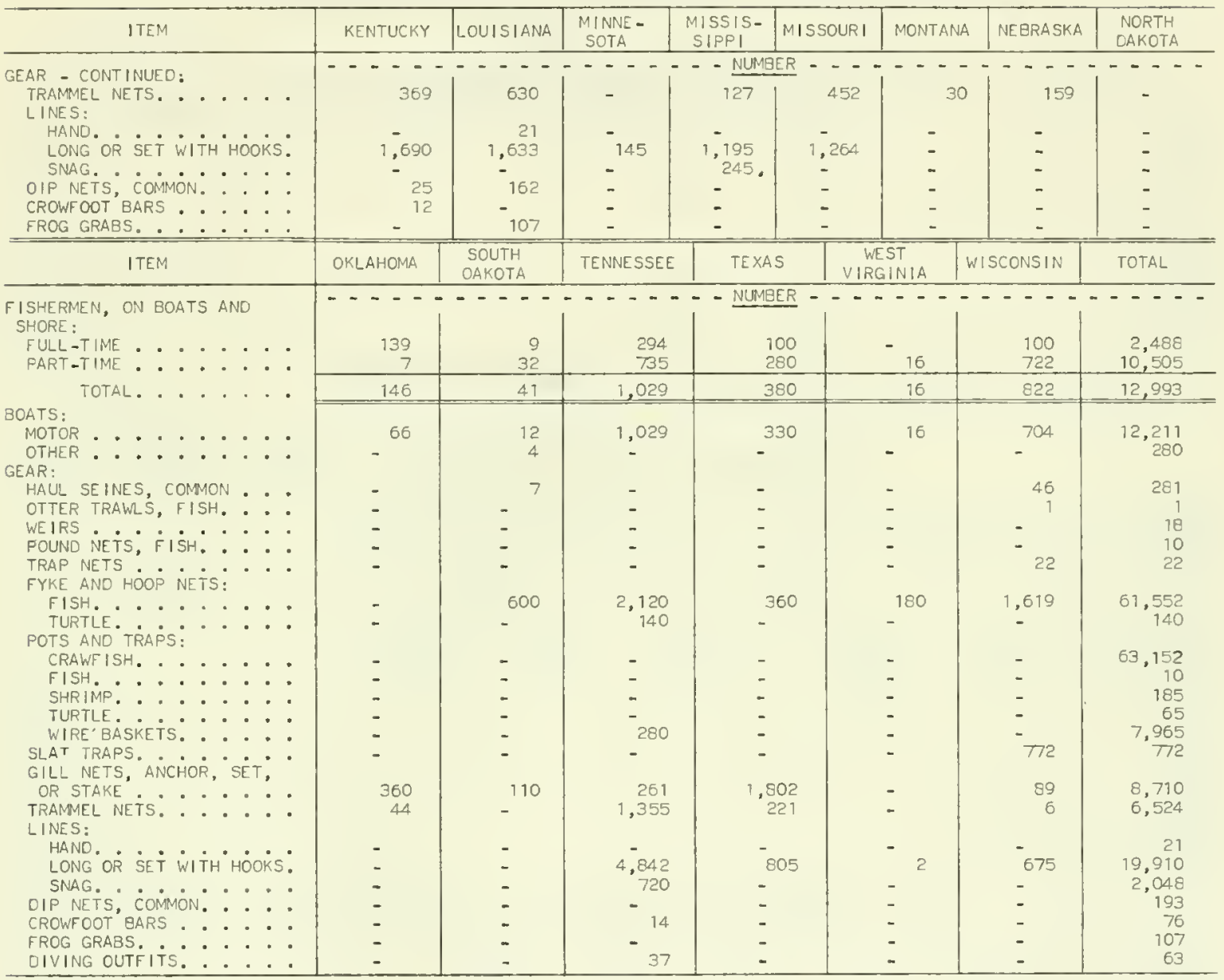

\section{LANDINGS BY STATES, 1975}

\begin{tabular}{|c|c|c|c|c|c|c|c|c|}
\hline SPECIES & \multicolumn{2}{|c|}{ ALABAMA } & \multicolumn{2}{|c|}{ ARIZONA } & \multicolumn{2}{|c|}{ ARKANSAS } & \multicolumn{2}{|c|}{ IDAMO } \\
\hline 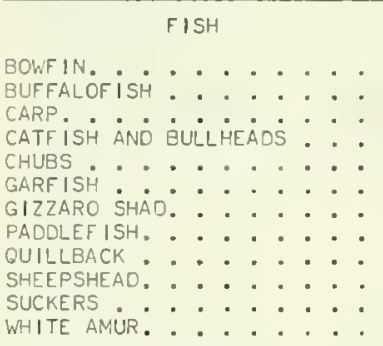 & $\begin{array}{c}\frac{\text { THOUSAND }}{\text { POUNDS }} \\
- \\
, 207 \\
300 \\
7.091 \\
-\quad 7 \\
4 \\
47 \\
-73 \\
-7 \\
- \\
\end{array}$ & $\begin{array}{c}\text { THOUSAND } \\
\text { DOLLARS } \\
-208 \\
17 \\
440 \\
-(1) \\
1\} \\
-5 \\
-2 \\
- \\
\end{array}$ & 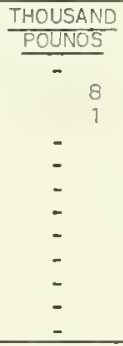 & $\begin{array}{c}\frac{\text { THOUSAND }}{\text { OOLLARS }} \\
- \\
(1)^{4} \\
\vdots \\
\vdots \\
\vdots \\
- \\
-\end{array}$ & $\begin{array}{c}\text { THOUSAND } \\
\text { POUNDS } \\
53 \\
3,934 \\
7,267 \\
7,969 \\
- \\
564 \\
- \\
117 \\
263 \\
636 \\
115 \\
56 \\
\end{array}$ & $\begin{array}{c}\frac{\text { THOUSANO }}{\text { DOLLARS }} \\
1.25 \\
1,253 \\
108 \\
1,300 \\
-\quad 76 \\
-\quad 31 \\
36 \\
119 \\
10 \\
18 \\
\end{array}$ & $\begin{array}{c}\text { THOUSAND } \\
\text { POUNDS } \\
- \\
- \\
-297 \\
(1) \\
- \\
- \\
- \\
- \\
-\end{array}$ & $\begin{array}{c}\frac{\text { THOUSAND }}{\text { DOLLARS }} \\
- \\
- \\
-25 \\
-11 \\
- \\
- \\
- \\
- \\
-\end{array}$ \\
\hline TOTAL FISH.... & 2,723 & 672 & 9 & 4 & 8,974 & 2,955 & 399 & 35 \\
\hline $\begin{array}{l}\text { SHELLFISH ET AL. } \\
\text { MUSSEL SHELLS } . \cdots \\
\text { TURTLES: } \\
\text { SNAPPER } \ldots . \cdots \\
\text { SOFT-SHELL. } . . \cdots\end{array}$ & 185 & 28 & - & - & $\begin{array}{l}66 \\
11 \\
\end{array}$ & $\begin{array}{r}17 \\
3\end{array}$ & - & - \\
\hline TOTAL SHELLFISH ET AL. . & 185 & 28 & - & - & 451 & 61 & - & - \\
\hline GRAND TOTAL...... & $2, \overline{908}$ & 700 & 9 & 4 & 9.425 & 3,016 & 399 & 35 \\
\hline
\end{tabular}




\section{LANDINGS BY STATES, 1975 - Continued}

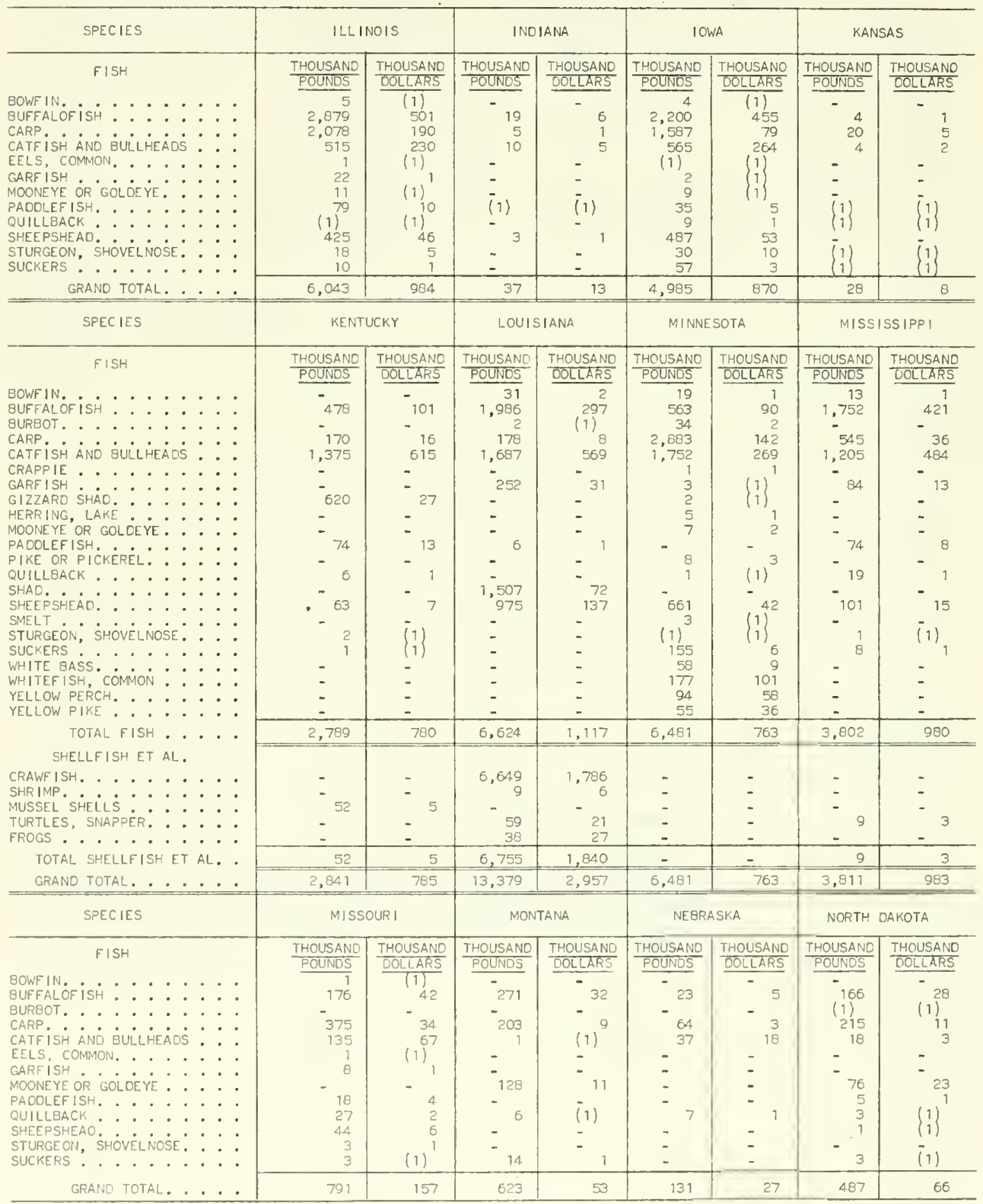




\section{LANDINGS BY STATES, 1975 - Continued}

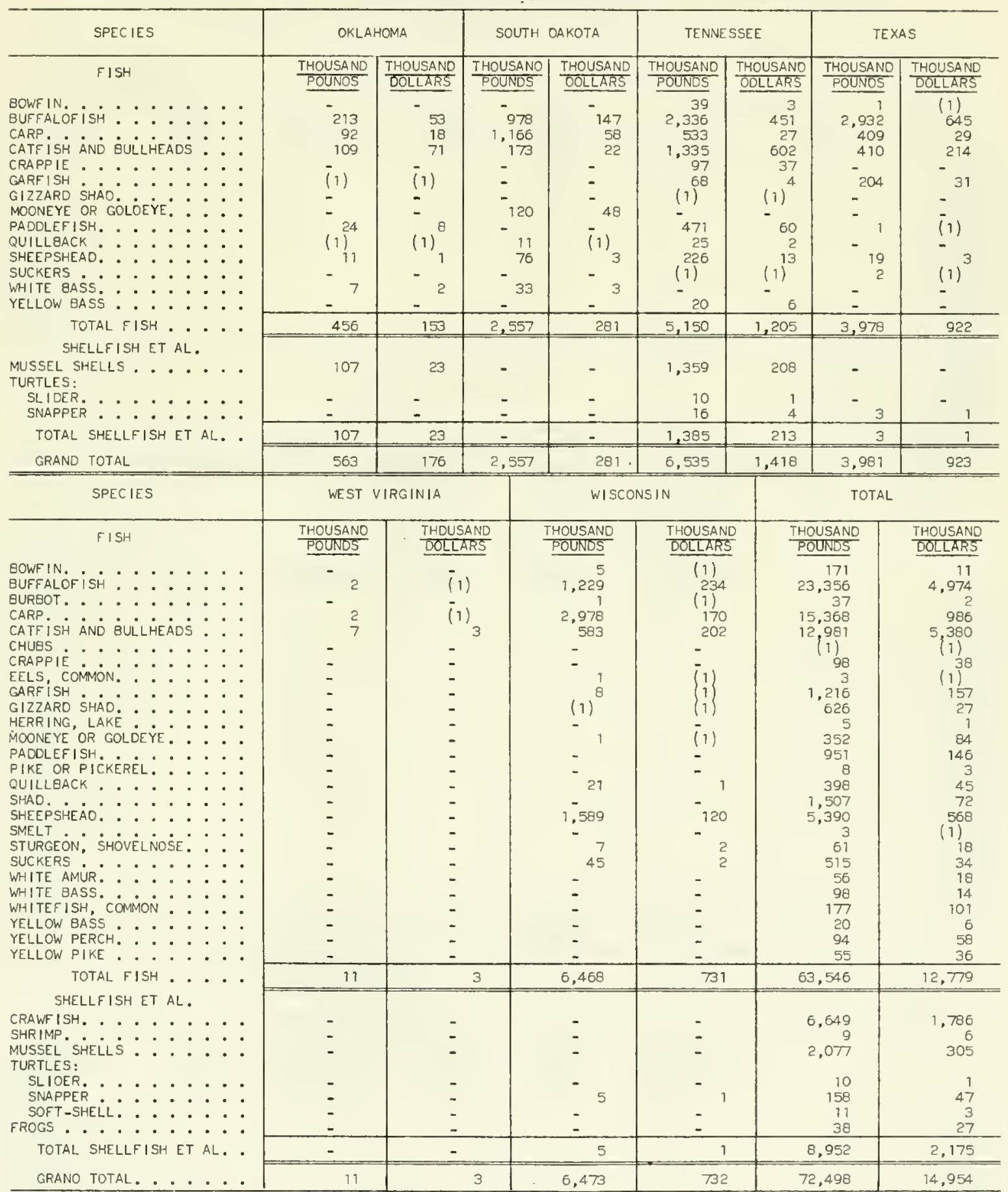

$1 /$ LESS THAN $50 D$ POUNDS OR $\$ 500$. 


\section{SUMMARY OF LANDINGS FROM MAJOR WATERS OF CERTAIN INLAND DRAINAGE AREAS, 1975}

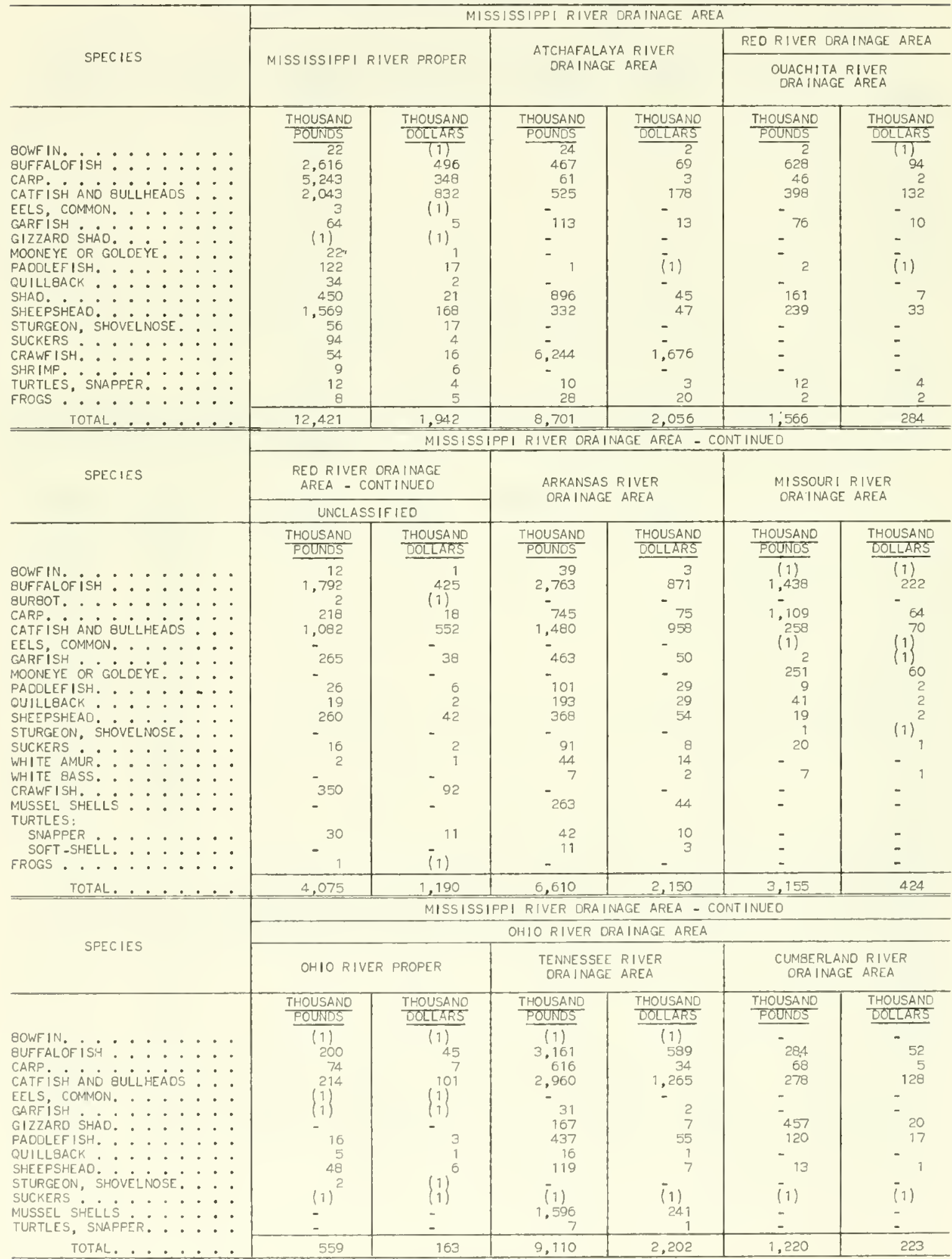




\section{SUMMARY OF LANDINGS FROM MAJOR WATERS OF CERTAIN INLAND DRAINAGE AREAS, 1975 - Continued}

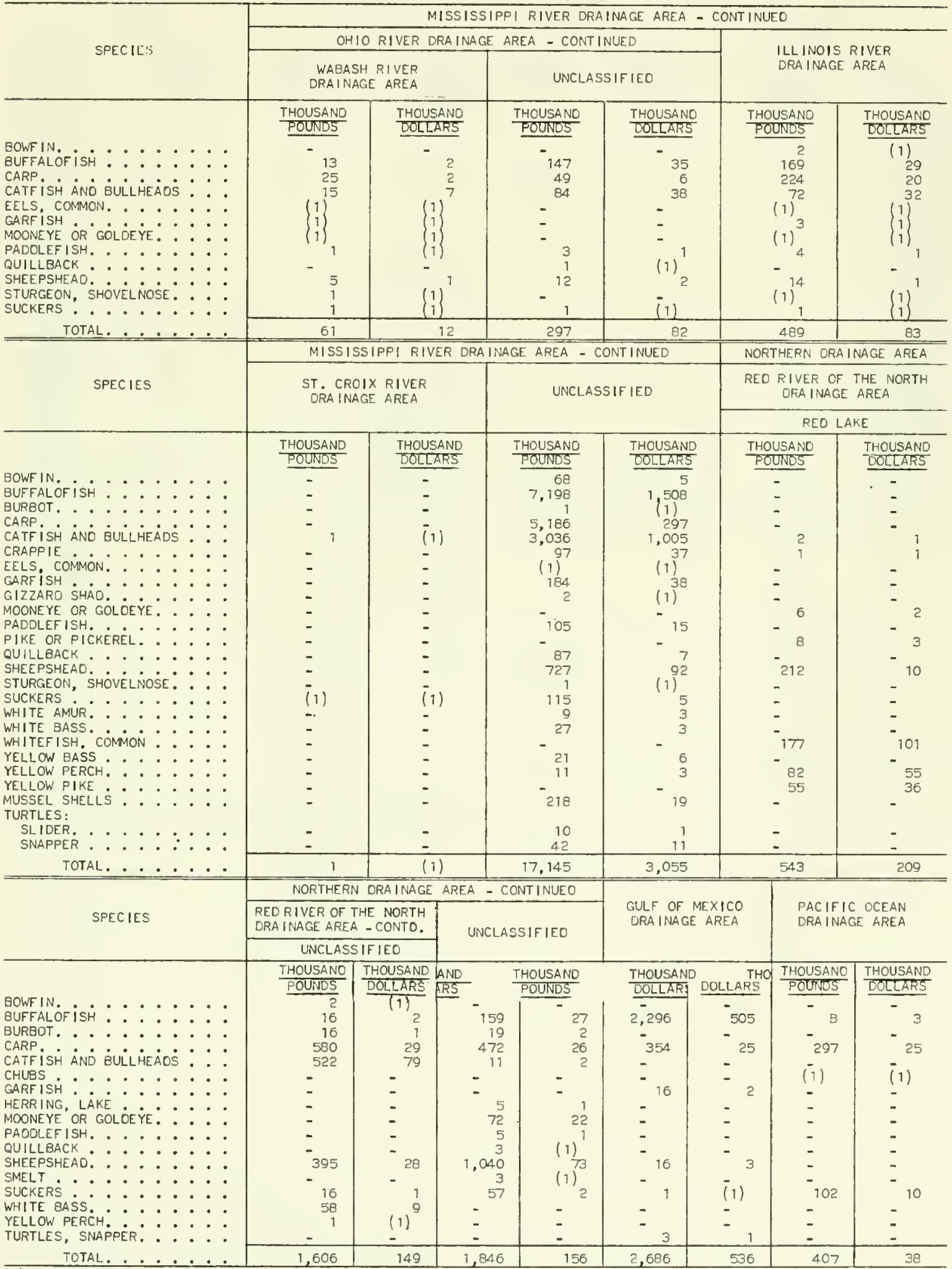


GREAT LAKES AND MISSISSIPPI RIVER LANDINGS, BY STATES, 1975

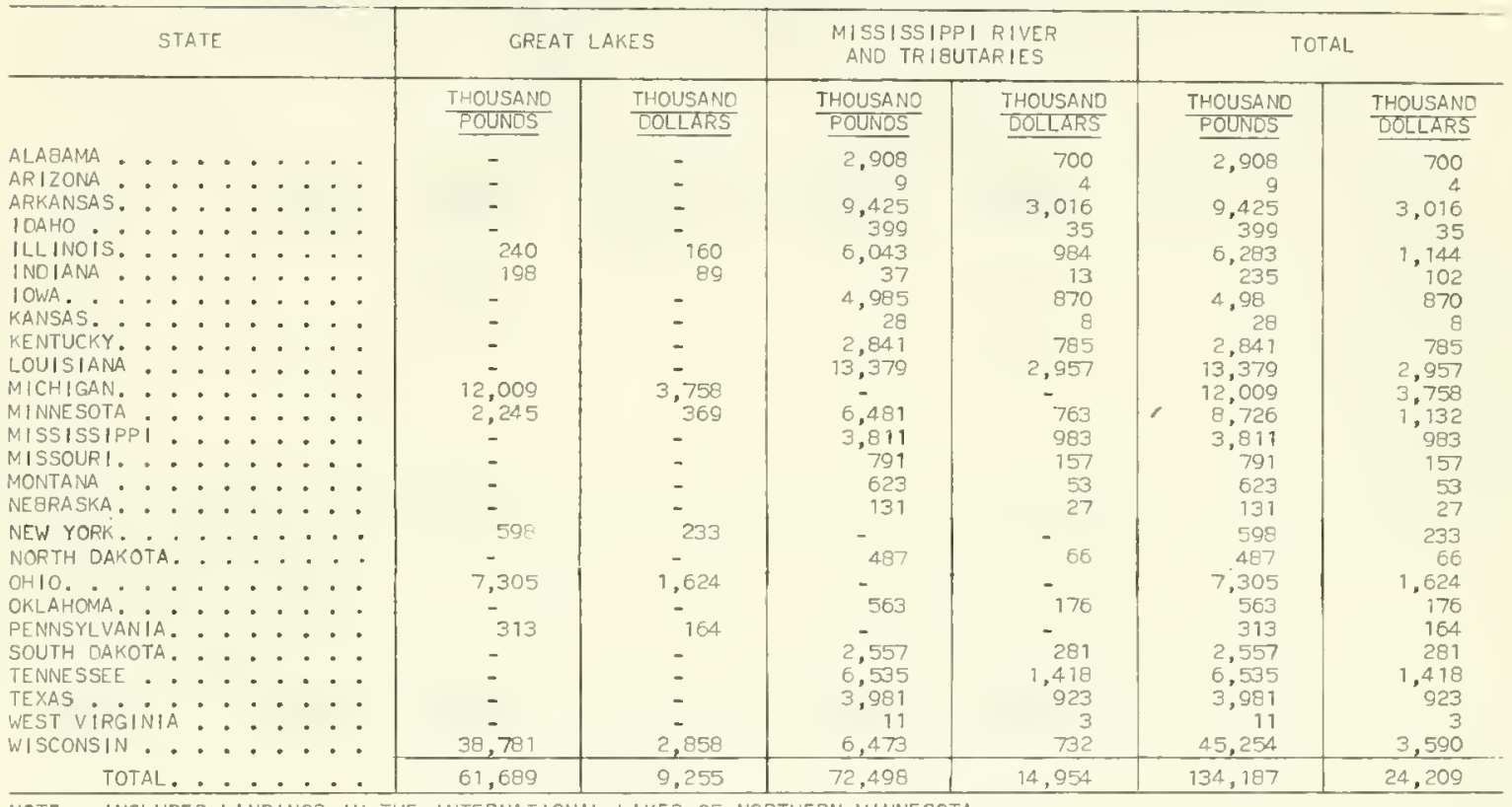

\footnotetext{
NOTE: .. INCLUDES LANOINGS IN THE INTERNATIONAL LAKES OF NORTHERN MINNESOTA.
} 


\section{GREAT LAKES AND MISSISSIPPI RIVER LANDINGS, BY SPECIES, 1975}

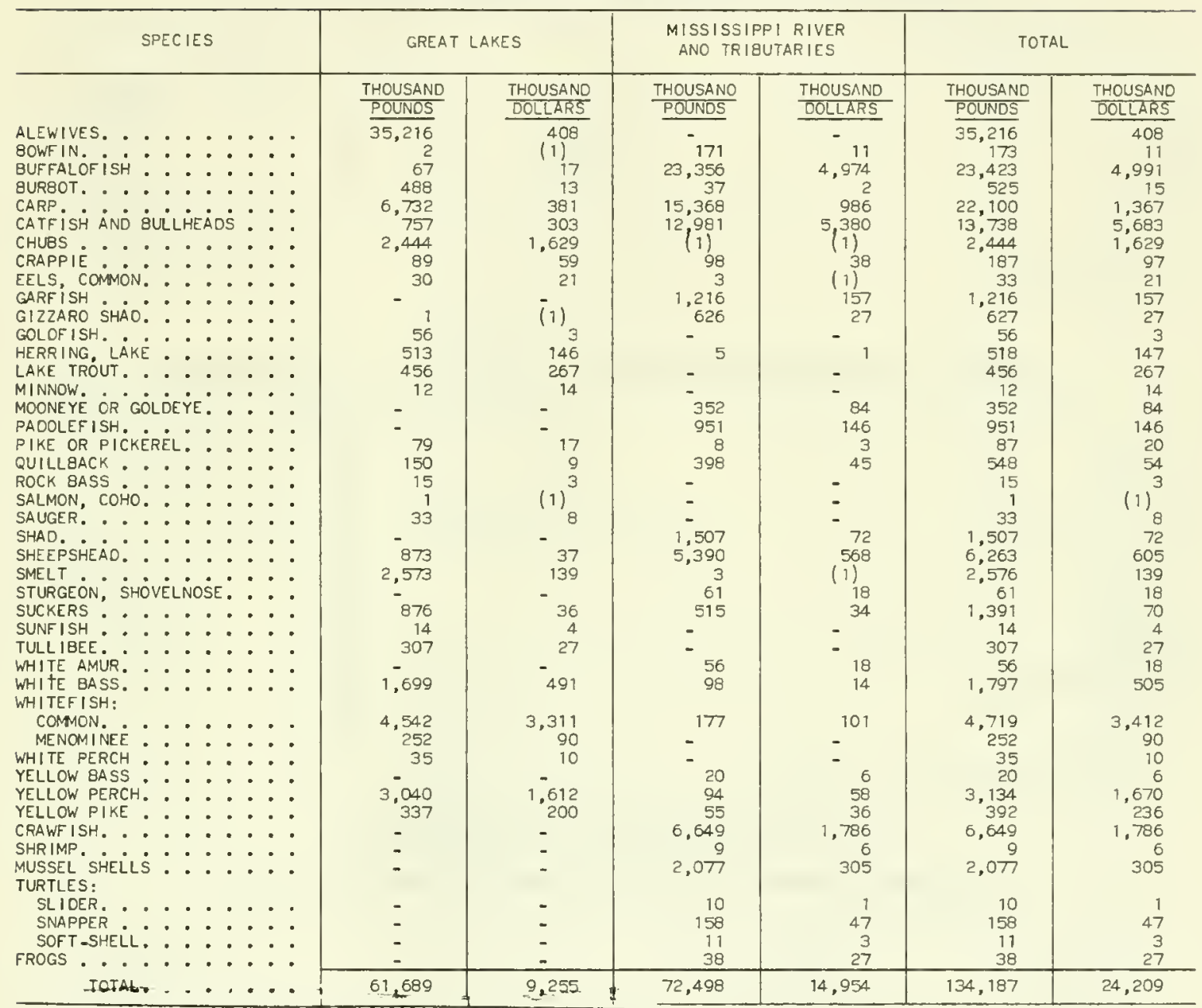

1) LESS THAN 500 ROUNOS OR $\$ 500$.

NOTE:-- INCLUOES LANOINGS IN THE INTERNATIONAL LAKES OF NORTHERN MINNESOTA. 
SUMMARY OF PROCESSED PRODUCTS, 1975

\begin{tabular}{|c|c|c|c|c|}
\hline & Item & Unit & Quantity & Dollars \\
\hline & & & $-\ldots$ Thousands - & $-\ldots-$ \\
\hline $\begin{array}{l}\text { Fresh . } \\
\text { Frozen } \\
\text { Canned }\end{array}$ & $\cdots$ & $\begin{array}{l}\text { Pounds } \\
\text { do } \\
\text { Standard }\end{array}$ & $\begin{array}{l}11,831 \\
31,712\end{array}$ & $\begin{array}{l}13,085 \\
38,455\end{array}$ \\
\hline $\begin{array}{l}\text { Cured . . } \\
\text { Industrial }\end{array}$ & $\ldots \ldots \ldots$ & $\begin{array}{l}\text { cases } \\
\text { Pounds } \\
\text { - }\end{array}$ & $\begin{array}{r}667 \\
3.517 \\
-\end{array}$ & $\begin{array}{l}6,657 \\
3,117 \\
\text { (1) }\end{array}$ \\
\hline Total & $\ldots \ldots \ldots \ldots$ & - & - & 61,314 \\
\hline
\end{tabular}

(1) Included with canned.

\section{VALUE OF PROCESSED PRODUCTS, BY STATES, 1975}

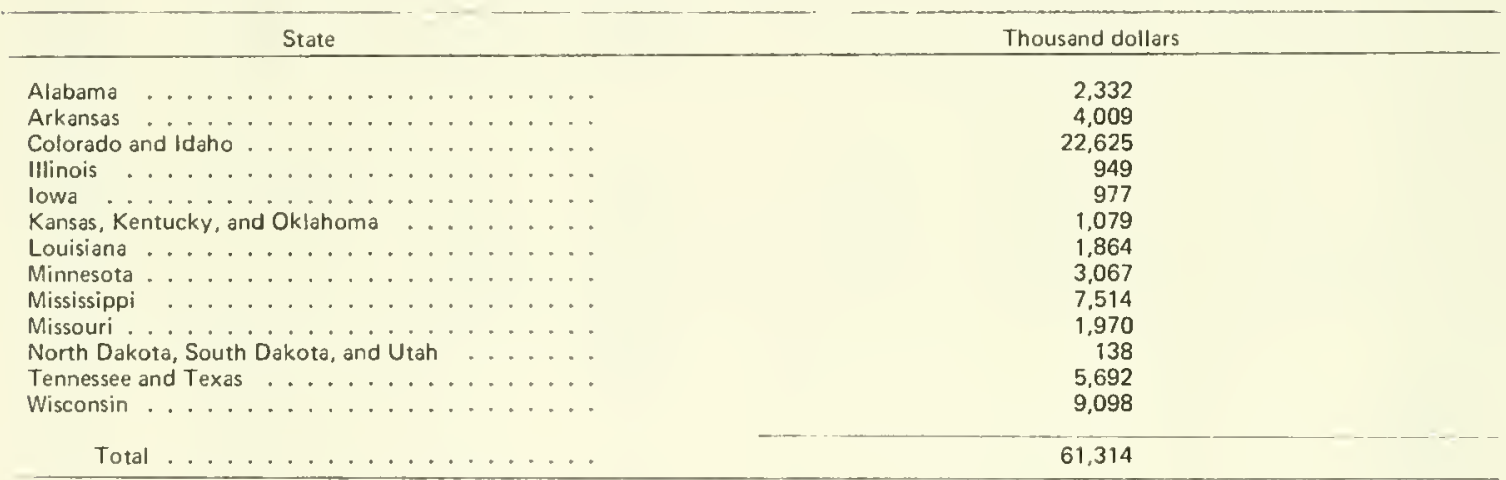

Note:--State totals do not add because of rounding.

\section{PROCESSING AND WHOLESALE}

\section{ESTABLISHMENTS AND EMPLOYMENT, 1975}

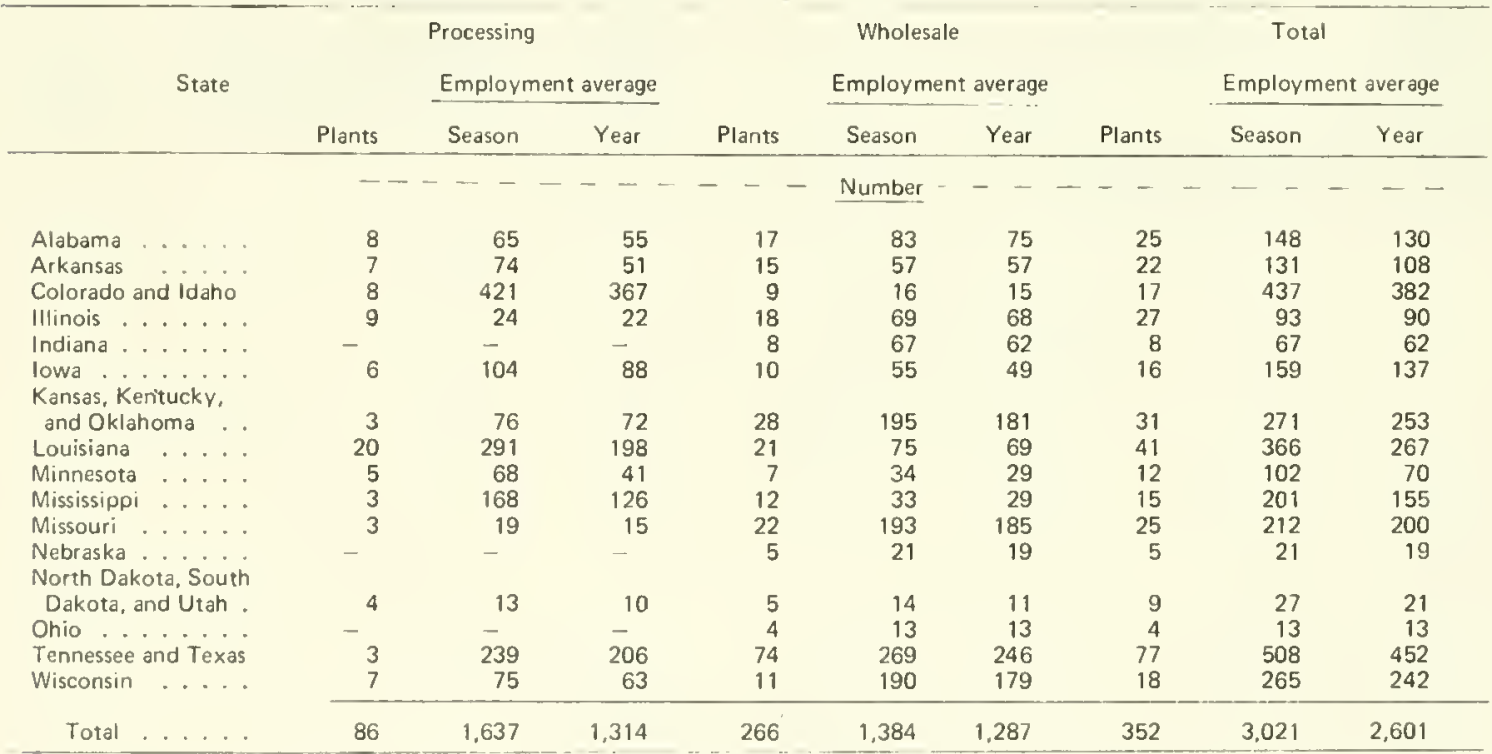

Note:--Employment is reported by each plant for each month for the payroll period that includes the 12th of the month. Employment for the season is based on the greatest number of emplovees working during the payroll period that included the 12th of each month. Emplovment for the vear is obtained by adding the number of employees recorded as working during the payroll period that included the $12 \mathrm{th}$ of each month, and dividing by 12 . 
PROCESSED FISHERY PRODUCTS, 1975

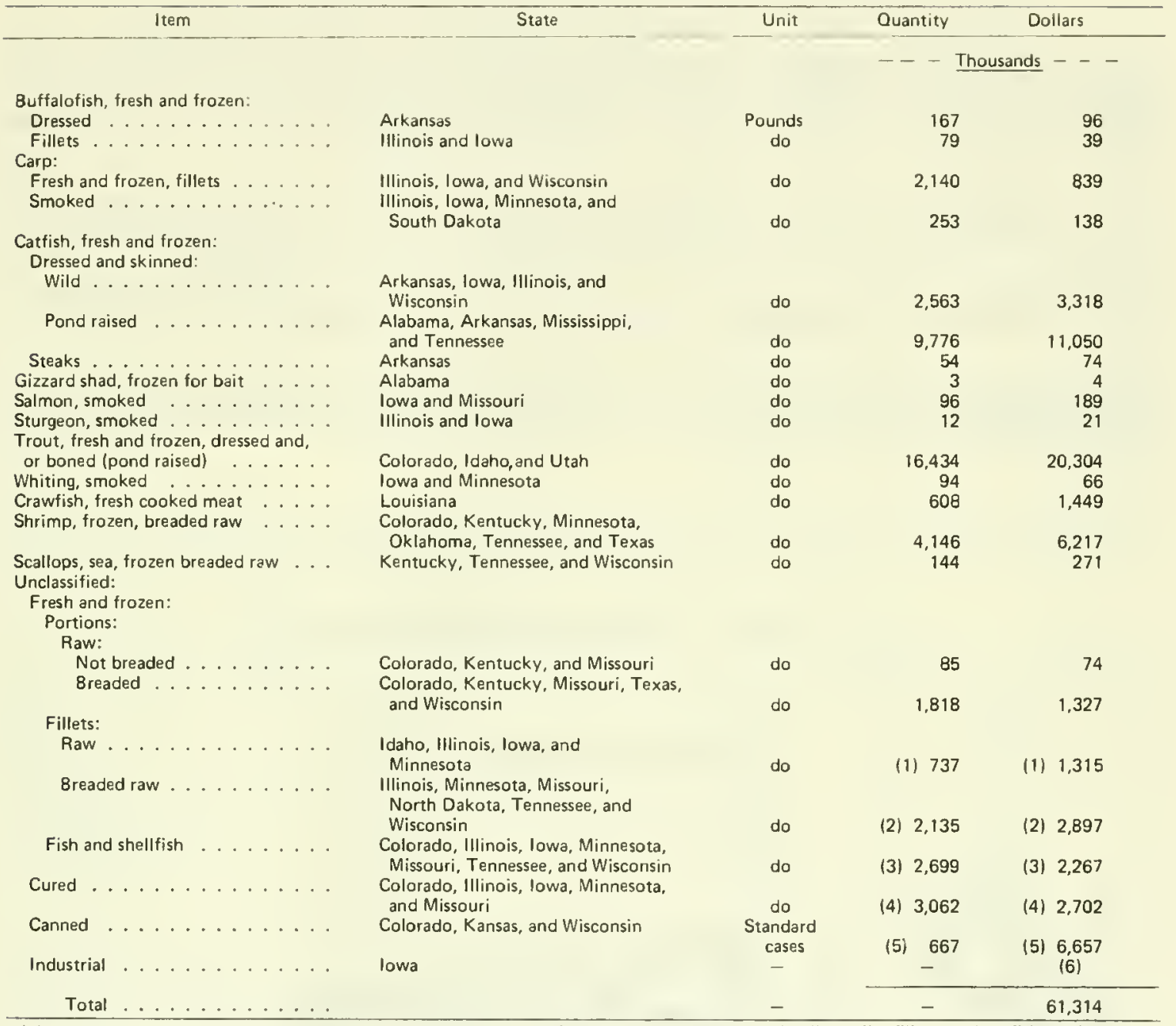

(1) Includes ocean perch, pike or pickerel, sheepshead, unclassified trout, yellow perch and yellow pike fillets; and catfish steaks. (2) Includes carp, catfish, cod, flounders, halibut, lake trout, acean perch, whiting, yellow perch, yellow pike fillets, breaded raw: and unclassified breaded raw steaks. (3) Includes dressed or skinned, bullheads, carp, paddlefish, sheepshead, sturgeon, and whiting; cod cakes breaded (raw), unclassified trout (breaded and stuffed); crabmeat cooked, crabs breaded (raw) deviled, lobster meat breaded (raw); shrimp, raw or cooked and peeled; oysters, breaded (raw): turtle steaks (raw), frog legs frozen, and unclassified dinners. (4) Includes buffalofish, bullheads, chubs, catfish, lake trout, paddlefish, sablefish, suckers, unclassified trout, and whitefish, smoked; lake herring and sea herring salted, and dried cod (lutefisk). (5) Includes canned, unclassified trout, animal food, the value of carp meal and oil. (6) Included in canned.

Note:-- Some of the products may have been processed from raw products imported from another State or a foreign country; therefore, they cannot be correlated directly with landings within the State. Certain items are shown in an intermediate and also a more advanced stage of processing. Total is correct. Table may not add because of rounding. 
Landings of commercially caught fish and shellfish in the State of Hawaii were 9.2 million pounds worth $\$ 6.3$ million, a decline of 1.8 million pounds (16 percent), but an increase of $\$ 284,000$ ( 5 percent) compared with 1974. Landings were the smallest since 1970 and 35 percent below the average for the previous 4 years (1971-74). A smaller harvest of skipjack tuna was the principal reason for the decline. Landings of skipjack was 5.0 million pounds in 1975-32 percent less than in 1974. Landings of bigeye also declined moderately, but landings of albacore, bluefin, little, and yellowfin increased.

Fish and shellfish were landed at six of the eight principal islands in the State of Hawaii. Oaluu led the islands with a production of 6.2 million pounds. Hawail was next with 2.2 million pounds, followed by Maui with 456,000 pounds. The rest of the landings were made at Kauai, Molokai, and Lanai.

Other lnformation. Condensed summary data on the operating units and landings of the State of Hawaii, by islands, appearing in the following pages have been published previously in Current Fishery Statistics No. 7412 .

Acknowledgments. The data in this section were assembled and prepared for publication by NMFS area office, Honolulu, Hawaii, largely from information collected by the Hawaii Department of Land and Natural Resources, Division of Fish and Game.

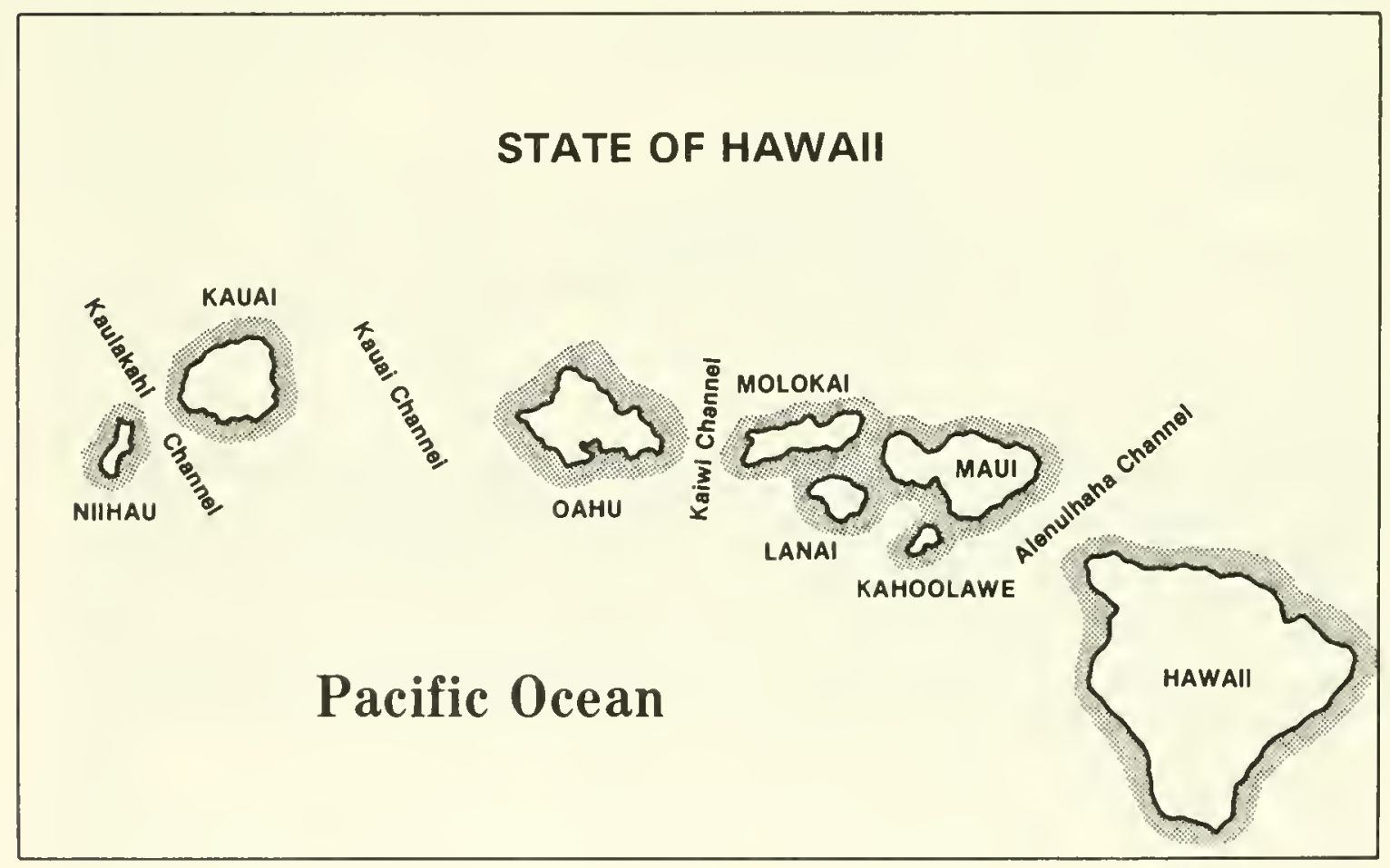




\section{HAWAII FISHERIES}

SECTIONAL SUMMARIES

SUMMARY OF LANDINGS, 1975

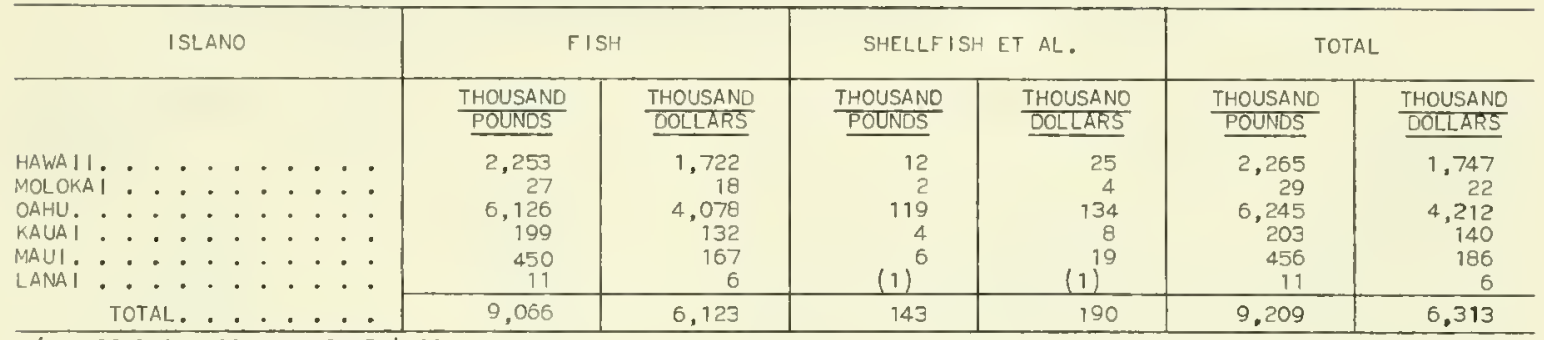

1) LESS THAN 500 POUNDS OR $\$ 500$.

SUMMARY OF OPERATING UNITS, 1975

\begin{tabular}{|c|c|c|c|c|c|c|c|c|c|}
\hline & ITEM & & HAWA I I & MOLOKAI & OAHU & KAUA I & MAUI & LANA I & TOTAL \\
\hline $\begin{array}{l}\text { FISHERMEN } \\
\text { VESSELS } \\
\text { BOATS } .\end{array}$ & $: \div:$ & $\therefore: \therefore:$ & $\begin{array}{c}-.-- \\
671 \\
29 \\
475\end{array}$ & $\begin{array}{l}---- \\
23 \\
-\quad 19\end{array}$ & $\begin{array}{c}\cdots,-- \\
1,115 \\
74 \\
515\end{array}$ & $\begin{array}{c}-\frac{\text { NUMBER }}{145} \\
1 \\
119\end{array}$ & $\begin{array}{r}---\cdots \\
228 \\
5 \\
141\end{array}$ & $\begin{array}{c}---\cdots \\
-15 \\
9\end{array}$ & $\begin{array}{r}-\cdots \\
2,197 \\
109 \\
1,278\end{array}$ \\
\hline
\end{tabular}

NOTE:--COMPLETE DATA ARE NOT AVAILABLE ON OPERATING UNITS BY ISLAND AND ON THE NUMBER OF GEAR USED IN THE HAWAII FISHERIES. THERE WERE 42 FISHERY WHOLESAL ING AND PROCESSING ESTABLISHMENTS IN THE STATE OF HAWAII IN 1975.

\section{HAWAII - LANDINGS BY SPECIES, 1975}

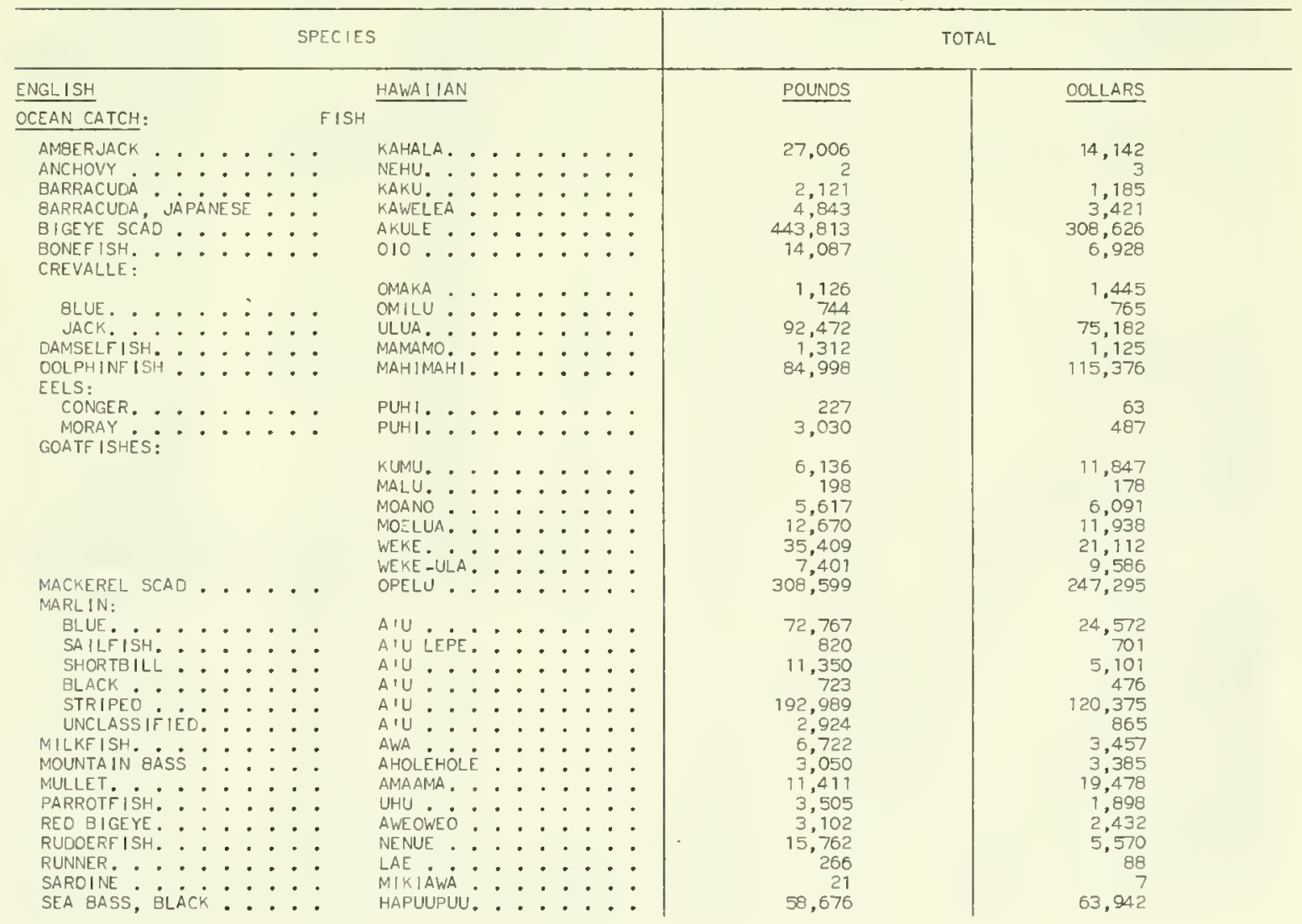


HAWAII - LANDINGS BY SPECIES, 1975 - Continued

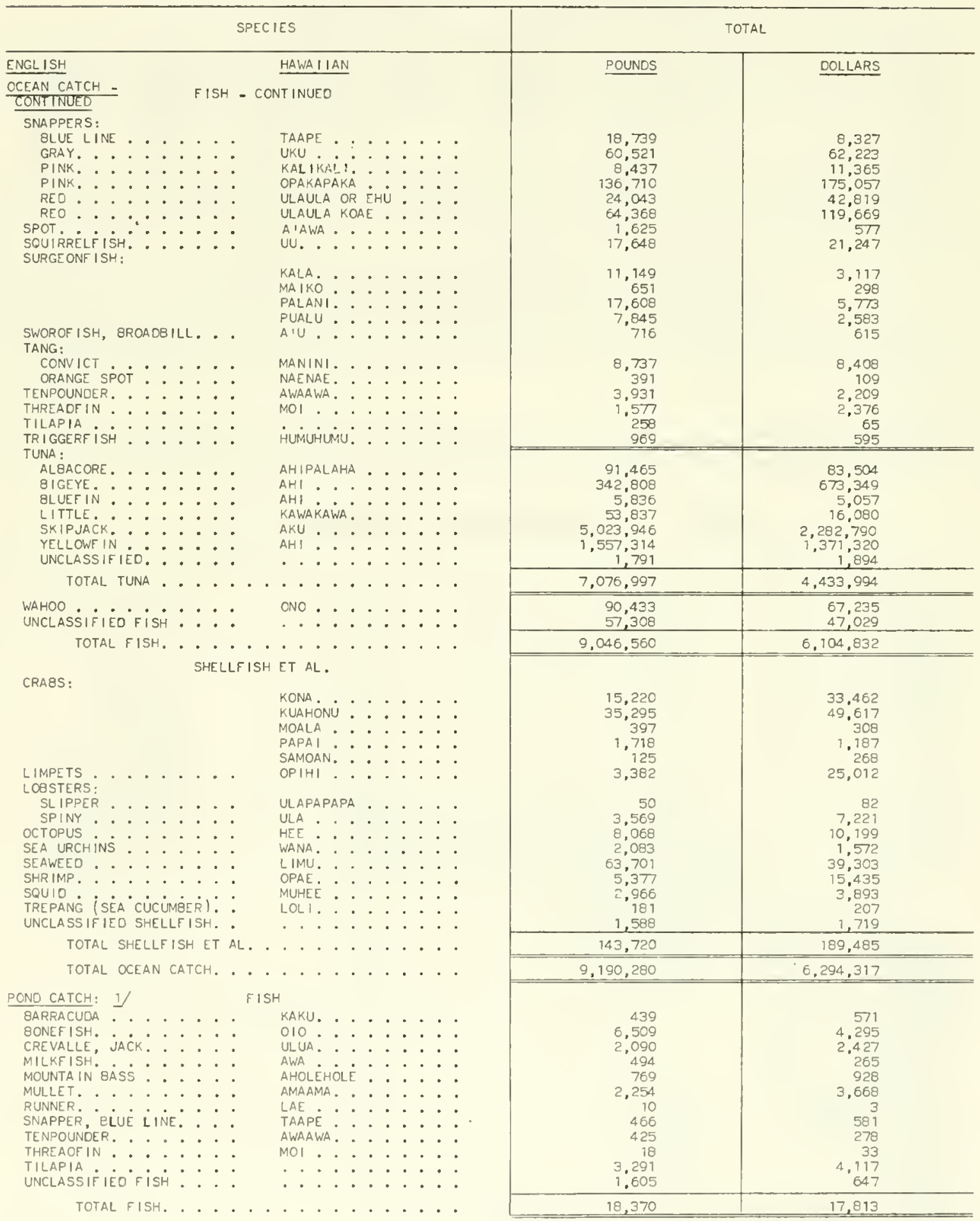

SEE FOOTNOTES AT END OF TABLE.

(CONT I NUED ON NEXT PAGE) 
HAWAII - LANDINGS BY SPECIES, 1975 - Continued

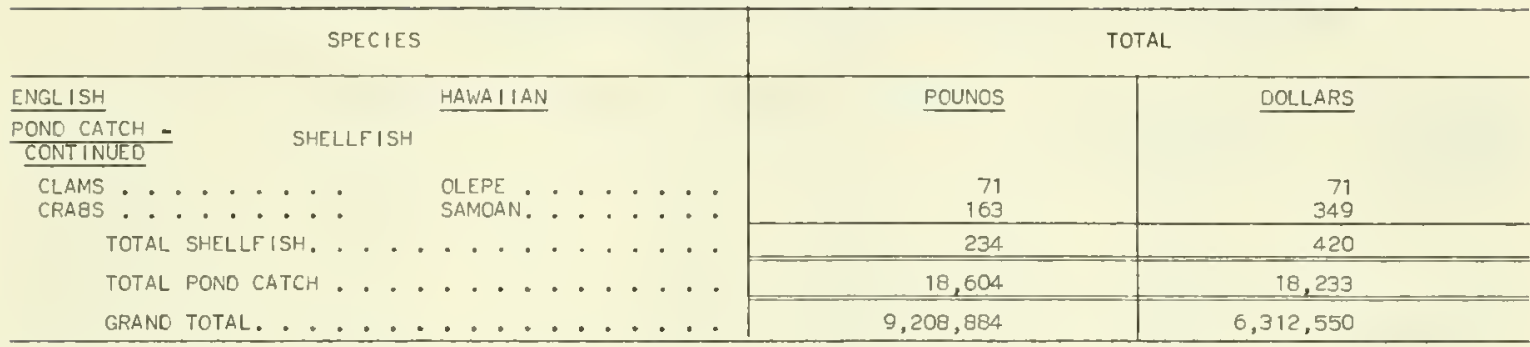

1) SALTWATER.

NOTE:--LANOINGS OF FISH, CRUSTACEANS. ANO SUCH MOLLUSKS AS OCTOPUS ANO SQUIO ARE SHOWN IN ROUNO (LIVE) WEIGHT. DATA ON LIMPETS AND CLAMS REPRESEN' THE WE IGHT OF MEATS EXCLUDING THE SHELL. THE WEIGHT OF MEATS FOR LIMPETS IS BASEO ON A YIELO OF 20 PERCENT.

HAWAII - LANDINGS BY ISLANDS, 1975

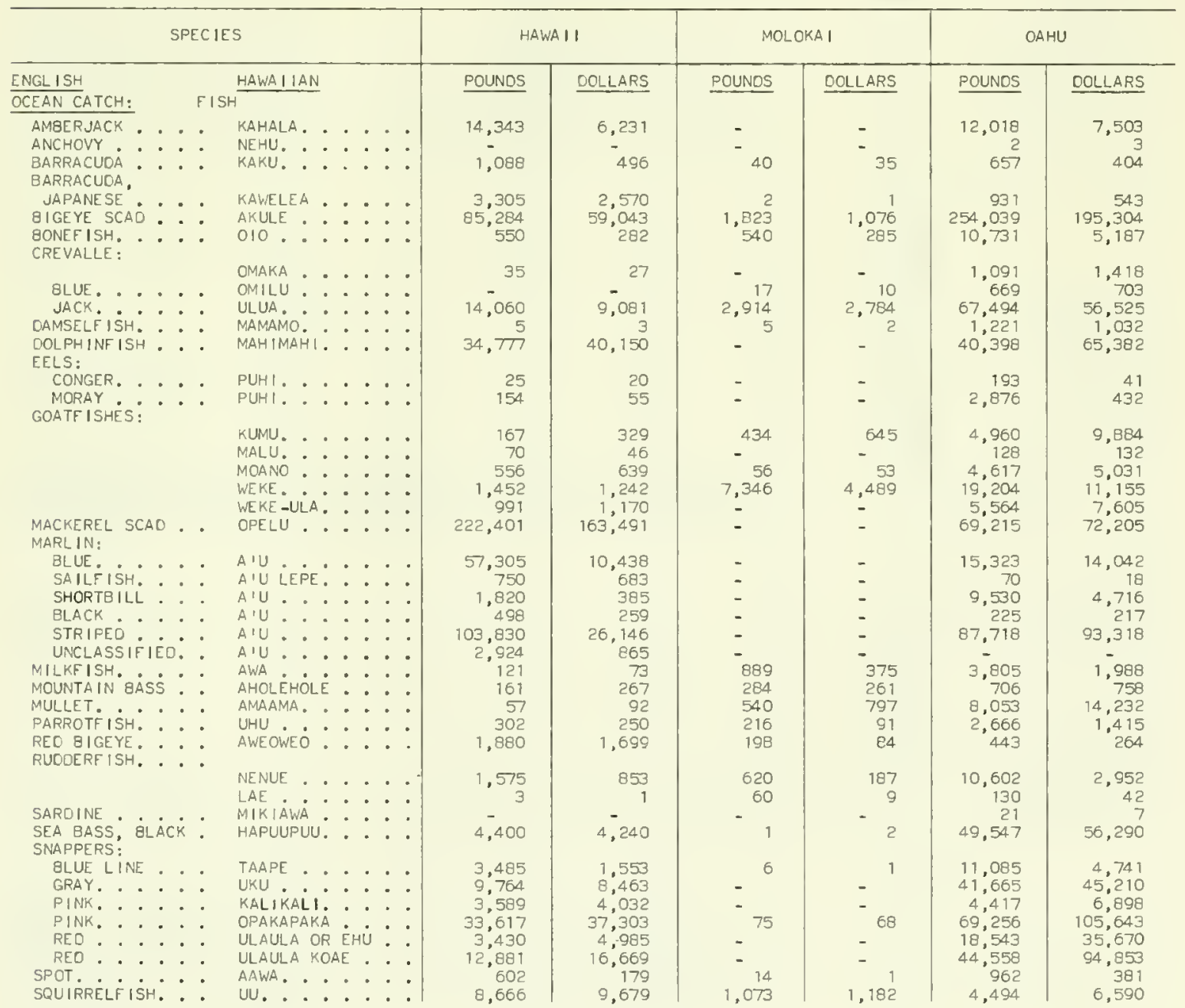


HAWAII - LANDINGS BY ISLANDS, 1975 - Continued

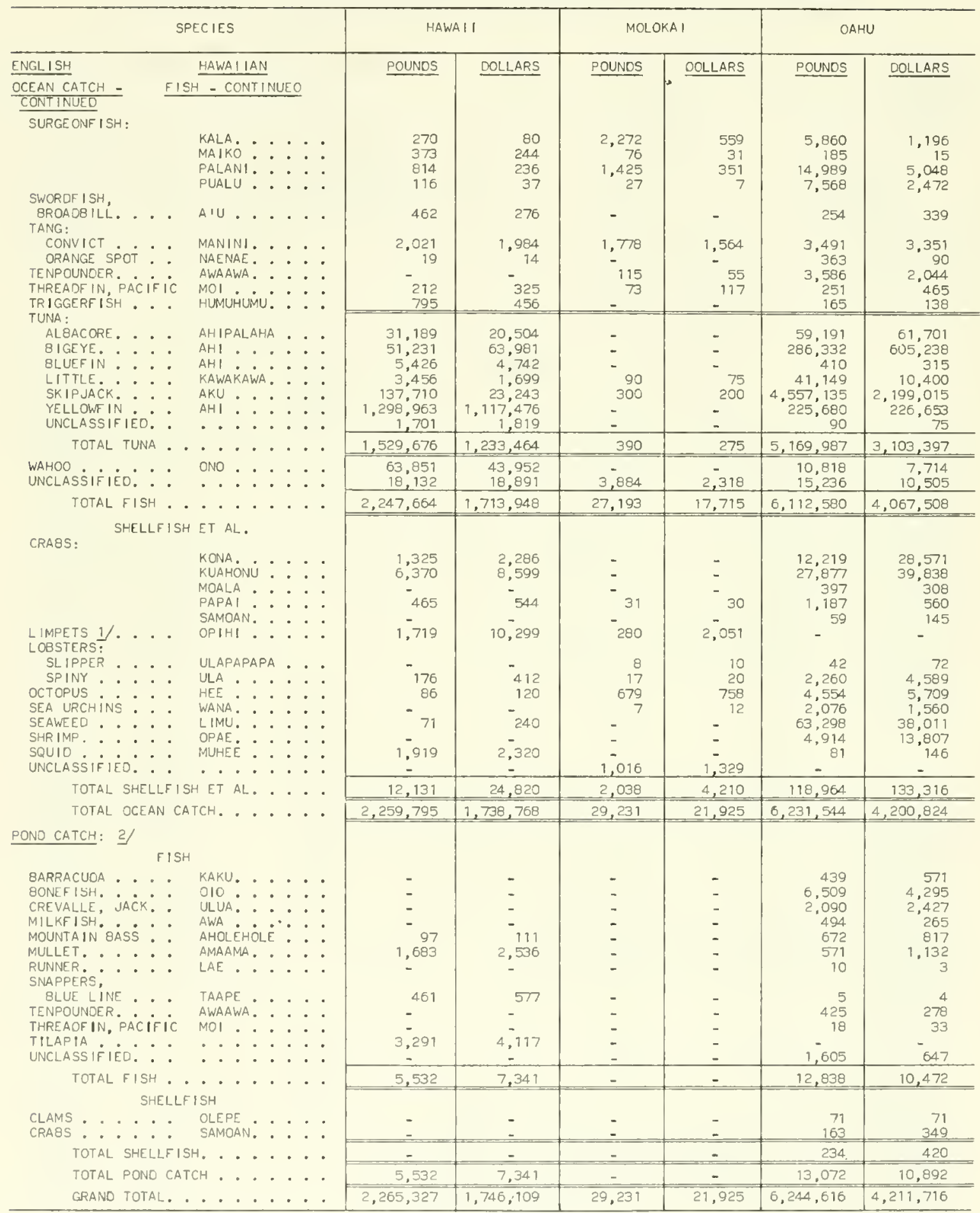

SEE FOOTNOTES AT END OF TABLE.

(CONTINUEO ON NEXT PAGE) 
HAWAII - LANDINGS BY ISLANDS, 1975 - Continued

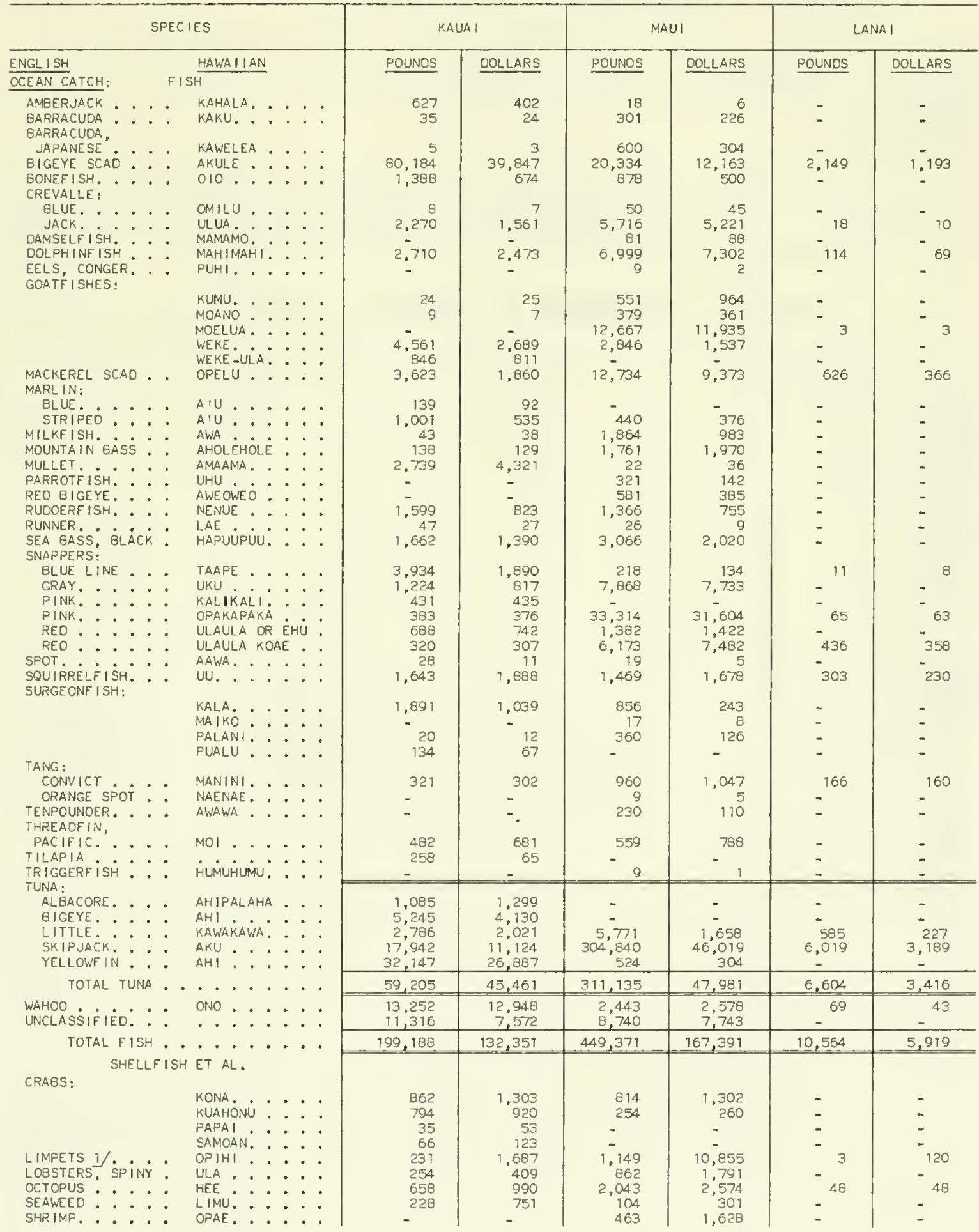

SEE FOOTNOTES AT ENO OF TABLE.

(CONT INUED ON NEXT PAGE) 
HAWAII - LANDINGS BY ISLANDS, 1975 - Continued

\begin{tabular}{|c|c|c|c|c|c|c|c|}
\hline \multicolumn{2}{|c|}{ SPECIES } & \multicolumn{2}{|c|}{ KAUA I } & \multicolumn{2}{|c|}{ MAUI } & \multicolumn{2}{|c|}{ LANAI } \\
\hline$\frac{\text { ENGL ISH }}{\text { OCEAN CATCH }}=$ & $\begin{array}{l}\text { HAWA IIAN } \\
\text { SHELLFISH ET AL. - } \\
\text { CONT INUED }\end{array}$ & POUNDS & DOLLARS & POUNDS & OOLLARS & POUNDS & DOLLARS \\
\hline 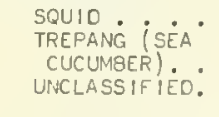 & $\begin{array}{l}\text { MUHEE } \ldots \\
\text { LOLI. } \ldots\end{array}$ & $\begin{array}{r}181 \\
-\quad \\
\end{array}$ & $\begin{array}{r}1,427 \\
207 \\
- \\
\end{array}$ & $\begin{array}{l}- \\
- \\
5>2 \\
\end{array}$ & $\begin{array}{l}- \\
- \\
\end{array}$ & - & - \\
\hline TOTAL SHE & LFISH ET AL. . . & 4,275 & 7,870 & 6,261 & 19,101 & 51 & 168 \\
\hline TOTAL OCE & $\mathrm{N} \mathrm{CATCH} \ldots \ldots$ & 203,463 & 140,221 & 455,632 & 186,492 & 10,615 & 6,087 \\
\hline GRANO TOT & L. . . . & 203,463 & 140,221 & 455,632 & 186,492 & 10,615 & 6,087 \\
\hline
\end{tabular}

HAWAII - LANDINGS OF CATCH BY GEAR, 1975

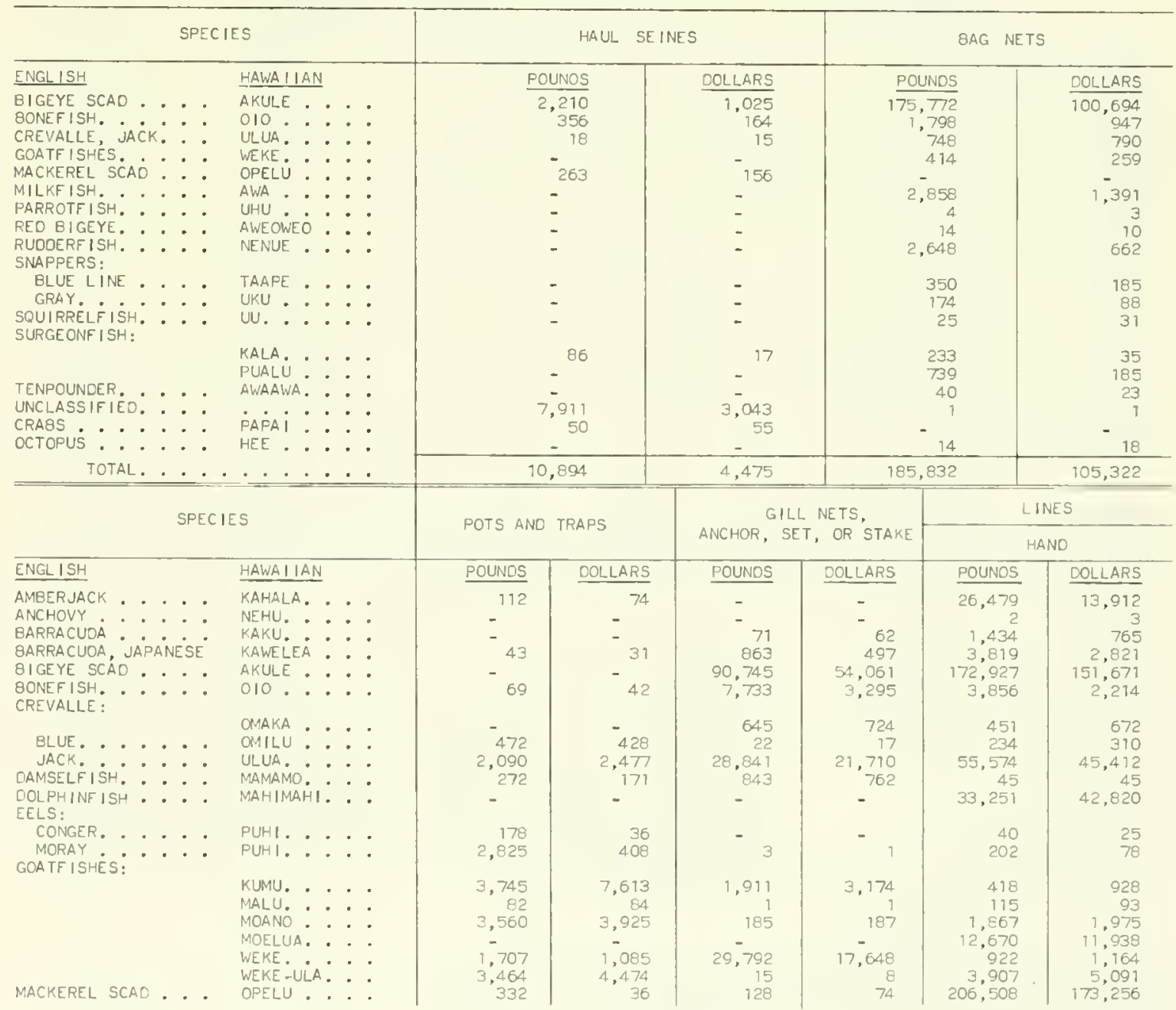




\section{HAWAII - LANDINGS OF CATCH BY GEAR, 1975 - Continued}

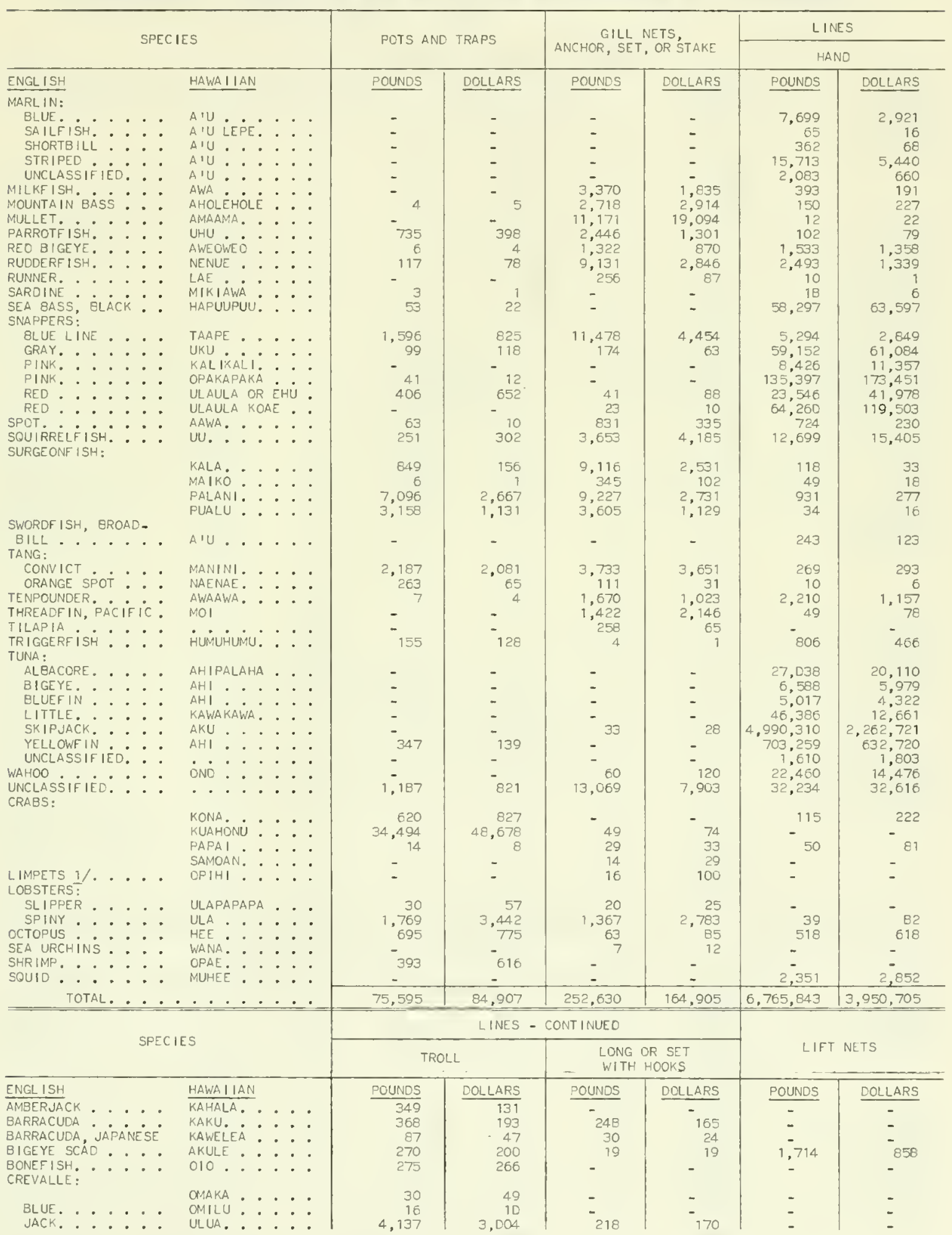


HAWAII - LANDINGS OF CATCH BY GEAR, 1975 - Continued

\begin{tabular}{|c|c|c|c|c|c|c|c|c|c|c|c|}
\hline \multirow[b]{3}{*}{ ENGL ISH } & \multirow{2}{*}{\multicolumn{5}{|c|}{ SPECIES }} & \multicolumn{4}{|c|}{ LINES - CONTINUED } & \multirow{2}{*}{\multicolumn{2}{|c|}{ LIFT NETS }} \\
\hline & & & & & & \multicolumn{2}{|c|}{ TROLL } & \multicolumn{2}{|c|}{$\begin{array}{l}\text { LONG OR SET } \\
\text { WITH HOOKS }\end{array}$} & & \\
\hline & & & \multicolumn{3}{|l|}{ HAWA IIAN } & POUNDS & OOLLARS & POUNOS & DOLLARS & POUNOS & DOLLARS \\
\hline OAMSELFISH. . & - & - $\cdot$ & MAMAMO. & . $\cdot$ & . & 3 & 4 & 57 & 43 & - & - \\
\hline \multirow{4}{*}{$\begin{array}{l}\text { DOLPH! I } \\
\text { GOATF ISHES: }\end{array}$} & - & - & MAHIMAHI. & - & . & 40,207 & 53,944 & 11,460 & 18,544 & - & - \\
\hline & & & KUMU. . . & - . & . & 12 & 23 & 1 & 1 & - & - \\
\hline & & & $\begin{array}{l}\text { MOANO }: \vdots \\
\text { WEKE. }\end{array}$ & $\therefore$ & & $-_{38}$ & $-{ }_{44}$ & ${ }^{-}$ & -93 & $\begin{array}{r}2 \\
1,396\end{array}$ & $\begin{array}{r}1 \\
354\end{array}$ \\
\hline & & & WEKE-ULA. & . & $\therefore$ & & & 3 & & - & - \\
\hline MACKEREL SCAD & - & - & OPELU . . & - . & - & 1.794 & 1,275 & 687 & $1, \overline{163}$ & 97,528 & 70,277 \\
\hline \multicolumn{12}{|c|}{ MARL IN: } \\
\hline SAILFISH. & ; & : & AIU LEPE. & $\therefore$ & : & 174 & 412 & 581 & 273 & - & - \\
\hline SHORTBILL . & - & - . & A'U... & $\therefore$ & - & 1.548 & 398 & 9,440 & 4.635 & - & 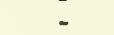 \\
\hline $8 \angle A C K . .$. & - & & $A^{\prime} U$... & . & . & 342 & 87 & 381 & 389 & - & - \\
\hline $\begin{array}{l}\text { STRIPEO } \\
\text { UNCLASSIFIEED }\end{array}$ & - & - $\cdot$ & $A^{\prime} U$. . & - $\cdot$ & $\cdot$ & 91,395 & 26,571 & 85,881 & 88,364 & - & - \\
\hline MOUNTA IN BASS & : & $:$ : & AHOLE் $\dot{H} \dot{O L} \dot{E}$ & $\therefore$ & $\therefore$ & - & - & - & - & -16 & 17 \\
\hline MULLET . . . & - & - . & AMAAMA. . & . & . & 3 & 5 & - & - & 99 & 149 \\
\hline PARROTFISH. . & - & . . & UHU . : . & - . & . & & & 52 & 18 & & - \\
\hline REO BIGEYE. . & - & - . & AWE OWEO - & . . & & - & - & & - & 45 & \\
\hline RUDDERF ISH. & & - . & NENUE & . $\cdot$ & . & - & - & 99 & 36 & 10 & 7 \\
\hline $\begin{array}{l}\text { SEA BASS, BLACH } \\
\text { SNAPPERS: }\end{array}$ & & - • & AHPUUPUU. & $\cdot \cdot$ & $\cdot$ & 268 & 293 & 57 & 28 & - & - \\
\hline \multirow{9}{*}{$\begin{array}{l}\text { SNAPPERS: } \\
\text { BLUE LINE } \\
\text { GRAY. }: \\
\text { PINK: } \\
\text { PINK: } \\
\text { RED : } \\
\text { REO : }: \\
\text { SPOT. } \\
\text { SOUIRRELF ISH: } \\
\text { SURGEONF ISH: }\end{array}$} & - & - . & TAAPE $\cdots$ & - . & .. & 15 & 9 & - & - & - & - \\
\hline & - & - & UKU $: \cdot$ & - & - $\cdot$ & 807 & 784 & $\begin{array}{r}115 \\
4\end{array}$ & 86 & - & - \\
\hline & - & • · & KAL IKAL I & $\cdot \cdot$ & & 1.7 & $\begin{array}{r}5 \\
1.463\end{array}$ & $\begin{array}{r}4 \\
167\end{array}$ & 3 & - & - \\
\hline & : & - & $\begin{array}{l}\text { OPAKAPAKA } \\
\text { ULAULA OR }\end{array}$ & $\dot{E} H \dot{U}$ & : & $\begin{array}{r}1,705 \\
38\end{array}$ & $\begin{array}{r}1,463 \\
91\end{array}$ & $\begin{array}{r}167 \\
11\end{array}$ & $\begin{array}{r}131 \\
6\end{array}$ & $\overline{-}$ & - \\
\hline & : & $\therefore$ & ULAULA KOAE & E. & . & 69 & 139 & 16 & 17 & - & $\overline{-}$ \\
\hline & - & - . & AAWA. . . & . & . & 5 & 1 & & - & - & - \\
\hline & - . & - $\cdot$ & UU. $\cdot \cdot$ & - $\cdot$ & . & $4 \pi$ & 722 & 164 & 157 & 220 & 268 \\
\hline & & & KALA. . . & . $\cdot$ & - . & - & - & - & - & 16 & 3 \\
\hline & & & MAIKO . . & - . & . & - & - & & & 24 & 10 \\
\hline \multicolumn{3}{|c|}{ SWOROF ISH, BROAO- } & PALANI. . & $\cdot \cdot$ & - & 2 & 1 & 276 & 70 & - & - \\
\hline BILL . . & - & -. & $A^{\prime} U \ldots$ & . & . & 254 & 339 & 219 & 153 & & \\
\hline TANG, CONVICT & & & MANINI. . & . . & $\therefore$ & - & - & 18 & 18 & 8 & \\
\hline THREAOF IN, PACI & $|F|$ & C. & $\mathrm{MOI} . .$. & . & . & - & - & - & - & 42 & 48 \\
\hline TUNA : & & & & & & & & & & & \\
\hline ALBACORE . & - & - . & AHIPALAHA & . & . & 1,023 & 1,243 & 63,404 & 62,151 & - & - \\
\hline 8IGEYE. • • & - & · . & $\mathrm{AHI} \cdot \cdot \cdot$ & - $\cdot$ & - & 5,391 & 4,240 & 330,829 & 663,130 & - & - \\
\hline BLUEF IN . . & - & - . & $\mathrm{AHI} \cdot \ldots$ & . . & & 651 & 525 & 168 & 210 & - & - \\
\hline LITTLE. • : & - & - . & KAWAKAWA. & . & . & 7,428 & 3.411 & - & - & - & - \\
\hline SKIPJACK. • & . & - . & $A K U \cdot \cdot \cdot$ & . . & . & 33,523 & 20,000 & - & - & - & - \\
\hline YELLOWF IN & & . . & $\mathrm{AHI} \cdot \cdot$ & . & - . & 625,585 & 482,200 & 225, 084 & 254,296 & - & - \\
\hline UNCLASSIFIED & & - . & $\dot{0} \cdot \cdot \cdot$ & - $\cdot$ & - $\cdot$ & 181 & 91 & - & - & - & - \\
\hline WAHOO ${ }^{\circ}$ ' & - & - $\cdot$ & ONO . . . & - $\cdot$ & · & 61,045 & 48,470 & 6,650 & 4,060 & - & - \\
\hline $\begin{array}{l}\text { UNCLASSIF TEO. } \\
\text { CRABS: }\end{array}$ & & & $\cdots \cdot \cdot$ & $\cdot \cdot$ & $\cdot$ & 730 & 719 & 839 & 697 & 133 & 122 \\
\hline & & & KONA. . & . & . & - & - & - & - & 14,376 & 32,086 \\
\hline & & & KUAHONU • & . . & & - & - & - & - & 751 & 864 \\
\hline & & & MOALA . . & . . & & - & - & - & - & 382 & 295 \\
\hline & & & PAPAI: . & . . & . & - & - & - & - & 1.575 & 1,010 \\
\hline & & & SAMOAN. . & . & & - & - & - & - & 111 & 239 \\
\hline OCTOPUS . . & . & . . & HEE . . • & . . & . & 165 & 208 & 2 & 2 & - & - \\
\hline TOTAL. & . & . . & ....... & . . & - . & 935,458 & 664,361 & 747,121 & $1,108,177$ & 118,448 & 106,642 \\
\hline & & SPE & IES & & & CAST & ETS & & & $8 Y$ & NO \\
\hline ENGL I SH & & & HAWA I IAN & & & POUNOS & DOLLARS & POUNOS & DOLLARS & POUNDS & DOLLARS \\
\hline AMBERJACK . . & . & . . & KAHALA . . & . . & & - & - & 38 & 19 & - & - \\
\hline OAMSELF ISH. - & - & - . & MAMAMO. & . & - & 50 & 50 & 5 & 4 & - & - \\
\hline Go Ir & & & KUMU. . • & . . & . . & 9 & 10 & 5 & 10 & - & - \\
\hline & & & MOANO : . & . & . & 3 & 3 & - & - & - & - \\
\hline & & & $\begin{array}{l}\text { WEKE } \\
\text { WEKE } \text { YUIA: }\end{array}$ & $\therefore$ & : & $\begin{array}{r}27 \\
8\end{array}$ & $\begin{array}{r}14 \\
4\end{array}$ & - & - & - & - \\
\hline MACKEREL SCAD & . & . . & WERE TULA. & $\therefore$ & $\therefore$ & - & - & 10 & & - & $\overline{-}$ \\
\hline MOUNTAIN BASS & . & . . & AHOLEHOLE & $\therefore$ & & 49 & 62 & 12 & 12 & 19. & 17 \\
\hline MULLET. . . & : & $\therefore$ & AMAAMA. & $\therefore$ & $\therefore$ & 91 & 137 & - & - & - & - \\
\hline PARROTFISH. . & - & - • & UHU ... & . & & 40 & 18 & 43 & 26 & - & - \\
\hline RED \&IGEYE. . & - & . & AWE OWEO . & . . & $\therefore$ & 85 & 94 & - & - & & - \\
\hline RUDOERF ISH : & $\dot{k}$ & & NENUE : & $\cdot \cdot$ & - $\cdot$ & 261 & 197 & - & - & $\begin{array}{l}6 \\
1\end{array}$ & $\begin{array}{l}2 \\
2\end{array}$ \\
\hline $\begin{array}{l}\text { SEA BASS, BLAC } \\
\text { SPOT. }\end{array}$ & . & : & $\begin{array}{l}\text { HAPUUPUU. } \\
\text { AAWA. }\end{array}$ & $\therefore$ & $\therefore$ & -2 & $\begin{array}{l}-1 \\
1\end{array}$ & - & - & - & - \\
\hline
\end{tabular}

SEE FOOTNOTES AT ENO OF TABLE.

(CONT INUEO ON NEXT PAGE) 
HAWAII - LANDINGS OF CATCH BY GEAR, 1975 - Continued

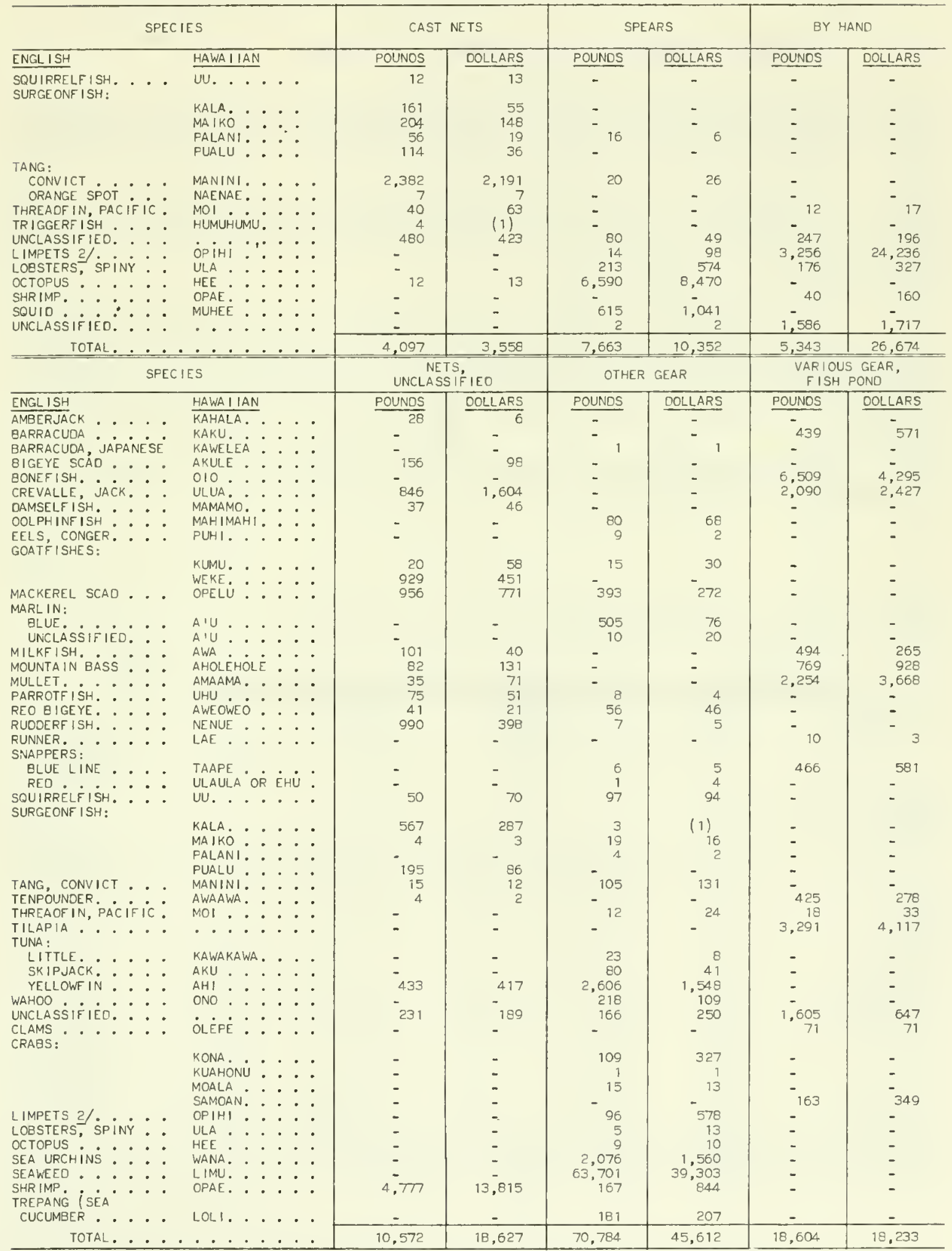


Landings in Puerto Rico are not included in the United States landings table in the General Review or Review of Certain Major Fisheries sections.

Puerto Rico landings were a record 181.1 million pounds worth $\$ 46.8$ million-an increase of 12.6 million pounds ( 7 percent) but a decline of $\$ 986,000$ ( 2 percent) compared with 1974 . The increase in volume resulted principally from record landings of tuna, the most important species landed in Puerto Rico. The value of tuna landings ( $\$ 44.4$ million) declined 3 percent compared with the record value in 1974 .

Tuna landings of 177.1 million pounds were 12.1 million (7 percent) more than in 1974 . Yellowfin tuna predominated with landings of 99.6 million pounds-compared with 88.6 million in 1974. Landings of yellowfin tuna were 56 percent of the total tuna production. Landings of skipjack tuna were 76.7 million pounds-a gain of 616,000 pounds compared with 1974. Bluefin tuna landings of 760,000 pounds increased 442,000 pounds compared with 1974 .

Landings made by local fishermen, consisting largely of marine fish and shellfish, were 4.0 million pounds worth $\$ 2.3$ million-an increase of 14 percent in volume and 29 percent in value compared with 1974. Fish were 86 percent of the total local landings. At least 1,230 fishermen operated 865 boats, an increase of 48 fishermen and 30 boats compared with the previous year. The fishing gear consisted principally of fish pots ( 57 percent), and hand and troll lines (29 percent). The pot fishery was concentrated mainly in the western region. Cabo Rojo, the fishing center with the most fish pots, was also the area showing the greatest production.

Data on local Puerto Rico fisheries are from statistics published by the Commonwealth of Puerto Rico, Department of Agriculture.

\section{PUERTO RICO - SUMMARY OF OPERATING UNITS, 1975}

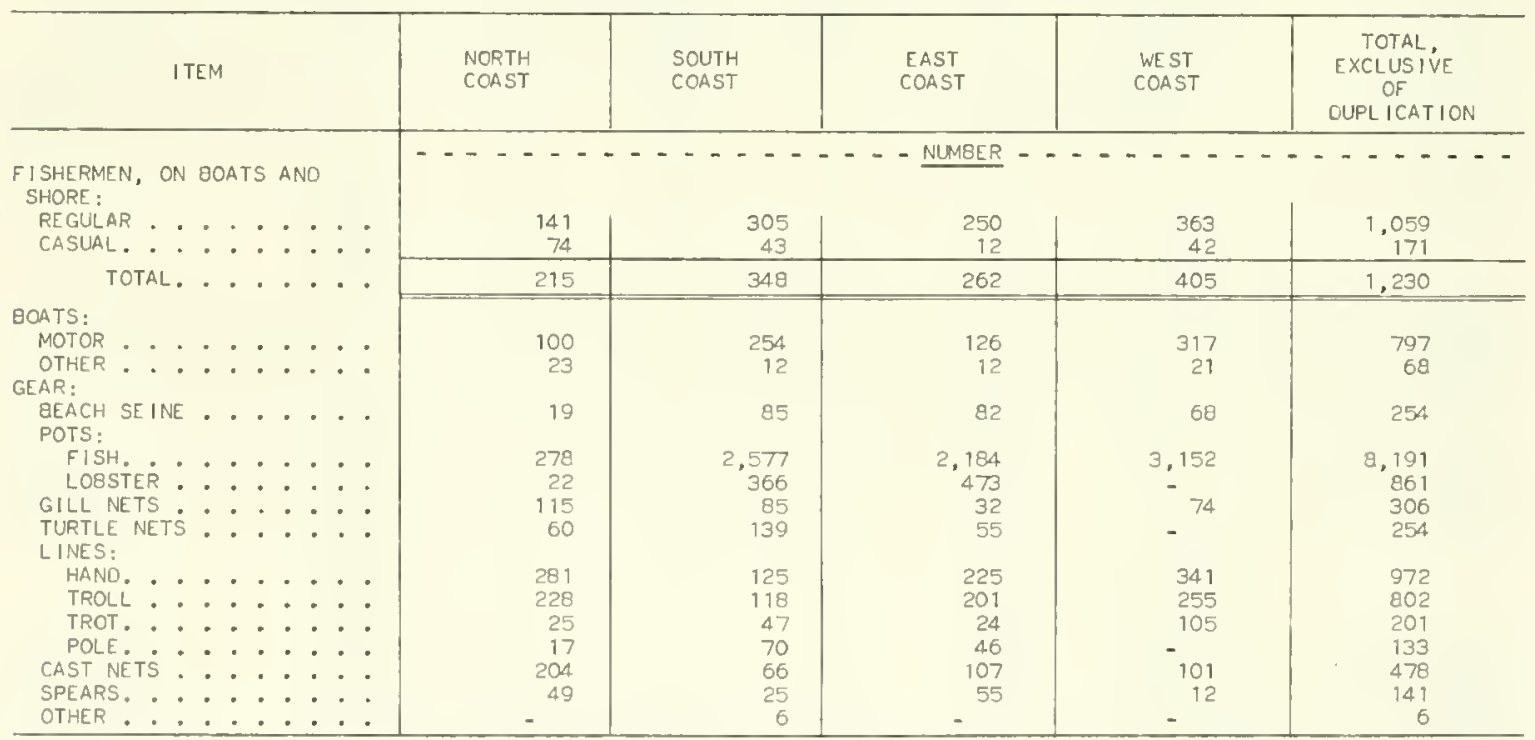

NOTE:--INCLUOES ONLY LOCAL CRAFT. DOES NOT INCLUOE VESSELS IN TUNA FLEET. 
PUERTO RICO - LANDINGS BY REGIONS, 1975

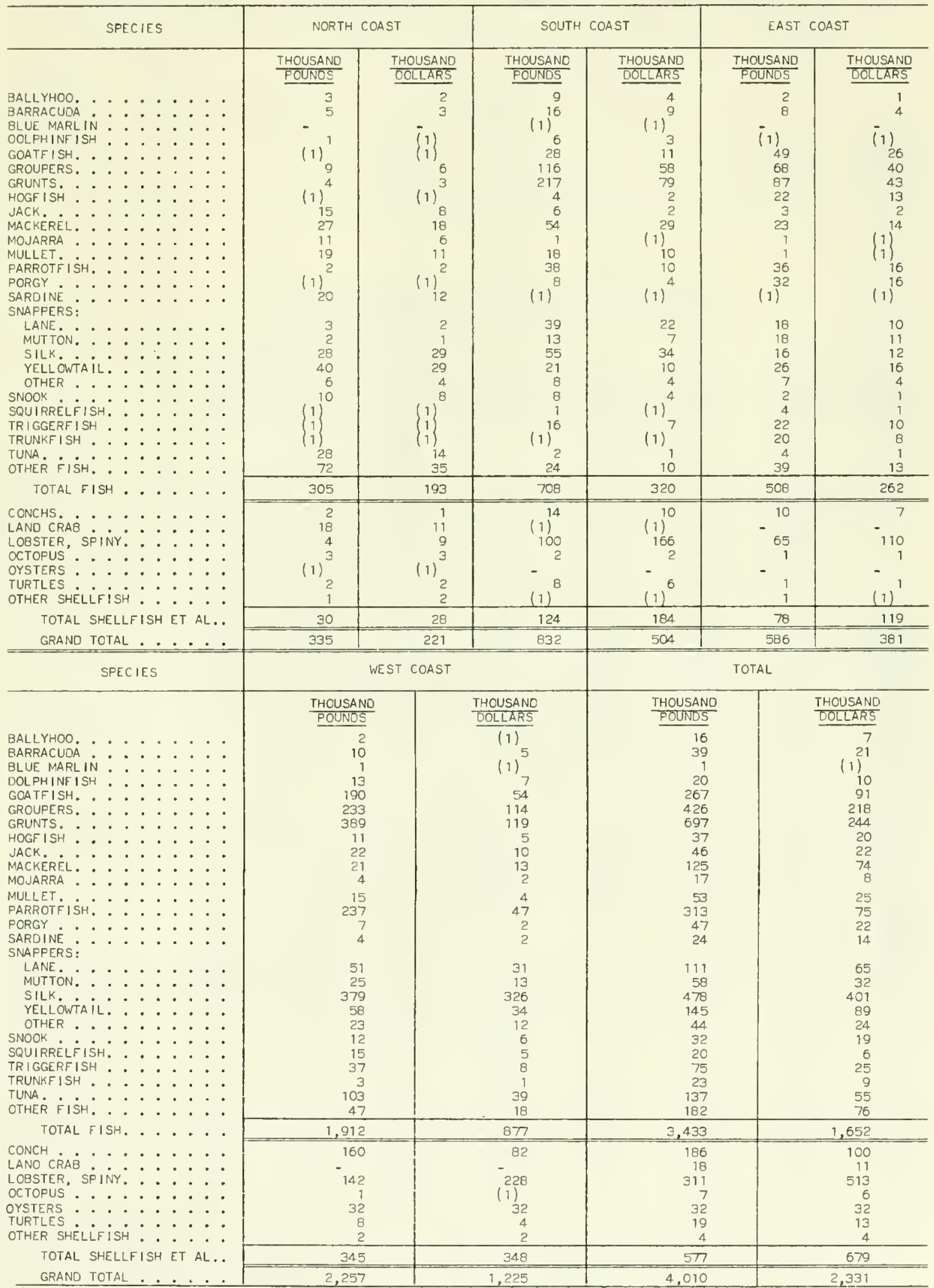




\section{PUERTO RICO - LANDINGS OF CATCH BY GEAR, 1975}

\begin{tabular}{|c|c|c|c|c|c|c|c|c|c|c|c|c|c|c|}
\hline \multirow{2}{*}{\multicolumn{7}{|c|}{ SPECIES }} & \multirow{2}{*}{\multicolumn{2}{|c|}{ BEACH SEINES }} & & \multicolumn{5}{|c|}{ POTS } \\
\hline & & & & & & & & & & \multicolumn{2}{|c|}{ FISH } & \multicolumn{3}{|c|}{ LOBSTER, SPINY } \\
\hline & & & & & & & POUNDS & DOLLARS & ARS & POUNOS & OOLLARS & \multicolumn{2}{|r|}{ POUNDS } & DOLLARS \\
\hline $\begin{array}{l}\text { BALLYHOO. } \\
\text { BARRACUOA }\end{array}$ & . & . & - · & . . & . & . & 7,000 & \multirow{10}{*}{\multicolumn{2}{|c|}{$\begin{array}{r}3,111 \\
7,060 \\
- \\
1,007 \\
3,352 \\
- \\
9,713 \\
10,245 \\
5,505 \\
283 \\
1,096 \\
900\end{array}$}} & - & - & \multicolumn{2}{|r|}{-} & - \\
\hline $\begin{array}{l}\text { BARRACUOA } \\
\text { GOATF ISH. }\end{array}$ & . . & - & - . & - . & . & - & 13,000 & & & 26700 & - & & - & - \\
\hline $\begin{array}{l}\text { GOATF ISH.: } \\
\text { GROUPERS. }\end{array}$ & $\therefore$ & : & $\therefore$ & • & : & : & 2,000 & & & $\begin{array}{l}267,000 \\
336,000\end{array}$ & $\begin{array}{r}97,861 \\
171,671\end{array}$ & \multirow{2}{*}{\multicolumn{2}{|c|}{ - }} & - \\
\hline GRUNTS. - . & . & . & $\therefore$ & . & $\dot{0}$ & : & 9,000 & & & 635,000 & 222,651 & & & - \\
\hline HOGF ISH . & . & & $\therefore$ & $\therefore$ & : & . & - & & & 35,000 & 19,518 & \multirow{2}{*}{\multicolumn{2}{|c|}{ - }} & - \\
\hline JACK. • • • & . & - & . . & . . & : & . & 19,000 & & & 4,000 & 1,540 & - & & - \\
\hline $\begin{array}{l}\text { MACKEREL. : } \\
\text { MULLET. }\end{array}$ & $\cdot$ & : & - $\cdot$ & $\cdot \cdot$ & • & · & $\begin{array}{l}18,000 \\
12,000\end{array}$ & & & - & - & \multicolumn{2}{|r|}{-} & $\overline{-}$ \\
\hline PARROTFISISH: & $:$ : & : & $\therefore$ & $\therefore$ & : & $\dot{0}$ & 1,000 & & & 307,000 & 73.227 & \multirow{2}{*}{\multicolumn{2}{|c|}{ 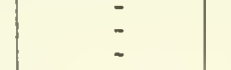 }} & - \\
\hline $\begin{array}{l}\text { PORGY } \\
\text { SAROINE: }:\end{array}$ & $:$ : & : & $\therefore$ & $\therefore$ & : & : & $\begin{array}{l}3,000 \\
3,000\end{array}$ & & & 27,000 & $\begin{array}{c}12.968 \\
-\end{array}$ & & & - \\
\hline $\begin{array}{l}\text { SNAPPERS: } \\
\text { LANE. }\end{array}$ & . & . & 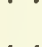 & 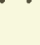 & 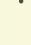 & 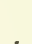 & 2,000 & & & 66,000 & 38,504 & & - & - \\
\hline $\begin{array}{l}\text { LANE. : } \\
\text { MUTTON. : }\end{array}$ & $\because:$ & : & $\therefore$ & $\therefore$ & : & : & $\begin{array}{l}2,000 \\
1,000\end{array}$ & \multicolumn{2}{|c|}{$\begin{array}{l}815 \\
835\end{array}$} & 50,000 & 27,057 & & 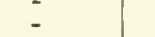 & - \\
\hline SILK. : & . . & : & $\therefore$ & $\therefore$ & : & : & - & - & & 50,000 & 47,543 & & - & - \\
\hline YELLOWTA IL & L. . & - & - & - . & - & - & 5,000 & 2.4 & & 69,000 & 39,625 & & - & - \\
\hline $\begin{array}{l}\text { OTHER }: \cdots \\
\text { SNOOK }: \therefore\end{array}$ & $\cdot \cdot$ & : & $\cdot \cdot$ & - . & : & : & $\begin{array}{l}4,000 \\
9,000\end{array}$ & $\begin{array}{l}2,1 \\
4,7\end{array}$ & & $\begin{array}{r}19,000 \\
3,000\end{array}$ & $\begin{array}{r}9,585 \\
1,389\end{array}$ & & - & - \\
\hline SQUIRRE $\dot{F}|\dot{S}|$ & H: & & $\therefore$ & $\therefore$ & $\dot{0}$ & : & - & - & & 20,000 & 5,564 & & 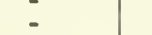 & - \\
\hline TRIGGERF ISH & . . & . & . . & . & . & . & - & - & & 72,000 & 23,670 & & - & - \\
\hline TRUNKF ISH. & . & . & . . & . . & . & . & $23-000$ & - & & 23,000 & 8.955 & & - & - \\
\hline $\begin{array}{l}\text { TUNA. : } \\
\text { LOBSTER: }\end{array}$ & $\therefore$ & : & $\therefore$ & $\therefore$ & : & : & 23,000 & 10,6 & & 292,000 & 471,191 & & $\overline{1,000}$ & $\overline{1,409}$ \\
\hline $\begin{array}{l}\text { OCTOPUS } \\
\text { OTHER SHELL }\end{array}$ & Fisi & . & & $\therefore$ & : & : & - & - & & $\begin{array}{l}2,000 \\
4,000\end{array}$ & $\begin{array}{l}1,321 \\
4,280 \\
\end{array}$ & & $=$ & - \\
\hline TOTAL . & . . & . & . . & . . & . & - & 131,000 & 63,9 & & $.281,000$ & $1,272,120$ & & 1,000 & 1,409 \\
\hline & CDES & & & & & & c14 & METS & & & LIN & NES & & \\
\hline & Srec & & & & & & GTLL & TVL T & & HAND & TROL & & TR & \\
\hline & & & & & & & POUNOS & OOLLARS & POUNOS & DOLLARS & POUNOS & DOLLARS & POUNOS & DOLLARS \\
\hline BALLYHOO. . & . . & - & . & & & - & 9,000 & 3,643 & - & - & - & - & - & - \\
\hline $\begin{array}{l}\text { BARRACUDA } \\
\text { OOLPHINF ISH }\end{array}$ & . $\cdot$ & - & - . & - $\cdot$ & - & - & - & & - & - & 26,000 & 14,000 & - & - \\
\hline OOLPHINF ISH & - & - & . . & - $\cdot$ & - & . & - & - & - & - & 20,000 & 9,565 & - & - \\
\hline BLUE MARL IN & . . & . & . & .. & . & & - & - & - & - & 2,000 & 820 & - & - \\
\hline GROUPERS. . & . & : & : & $\therefore$ & : & - & 49.000 & - & 88,000 & 45,235 & - & - & - & - \\
\hline GRUNTS. . . & . & - & . . & - . & . & - & $\begin{array}{c}49,000 \\
-\end{array}$ & 17,681 & 4,000 & 1,552 & - & - & - & - \\
\hline HOGF ISH : & . & - & . & . . & - & $\cdot$ & 7,000 & - & 1,000 & 421 & - & - & - & - \\
\hline $\begin{array}{l}\text { MACKEREL.: } \\
\text { MOJARRI: }\end{array}$ & $\therefore$ & : & • & $\cdot$ & : & : & $\begin{array}{r}7,000 \\
17,000\end{array}$ & $\begin{array}{r}557 \\
8.165\end{array}$ & - & - & 106,000 & 62,961 & - & - \\
\hline MULLET.: & $\therefore$ & : & $:$ & $\therefore$ & $\dot{0}$ & . & 40,000 & 18,971 & - & - & - & - & $\overline{-}$ & - \\
\hline PARROTF ISH. & $\therefore$ & • & $:$ & $\therefore$ & : & - & 1,000 & 475 & 3,000 & 924 & - & - & - & - \\
\hline $\begin{array}{l}\text { PORGY } \cdot \cdots \\
\text { SAROINE }:\end{array}$ & · & - & - & - $\cdot$ & . & - & - & - & 17,000 & 7,467 & - & - & - & - \\
\hline $\begin{array}{l}\text { SARDINE : } \\
\text { SNAPPERS: }\end{array}$ & $\cdot \cdot$ & - & . & $\cdot \cdot$ & - & · & 3,000 & 1,379 & - & - & - & - & - & - \\
\hline LANE. - & . & . & . & . . & . & . & - & - & 34,000 & 19,137 & - & - & 9,000 & 7.096 \\
\hline MUTTON. - & - & - & . & - . & . & . & 1,000 & 331 & 6.000 & 3.557 & - & - & - & - \\
\hline $\begin{array}{l}\text { SILK. } \\
\text { YELLOWTA }\end{array}$ & - & · & $\cdot \cdot$ & • & . & - & - & - & $\begin{array}{r}428,000 \\
69,000\end{array}$ & $\begin{array}{r}352,183 \\
44.619\end{array}$ & - & $\overline{-}$ & 2,000 & -751 \\
\hline OTHER . . & . & $\dot{.}$ & $\dot{0}$ & $\therefore$ & $\therefore$ & : & 1,000 & 657 & 20,000 & $\begin{array}{r}44,619 \\
11,793\end{array}$ & $\overline{-}$ & $\overline{-}$ & 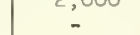 & - \\
\hline SNOOK . . & . & - & . & . . & - & . & 16,000 & 10,088 & 4,000 & 2,065 & - & - & - & - \\
\hline SQUIRRELF ISH & H. . & . & - & . . & . & . & - & - & - & - & - & - & - & - \\
\hline TR I GGERF I SH & . & - & - & - $\cdot$ & - & . & - & - & 3.000 & 1,080 & $114^{-} 000$ & 44.140 & - & $\overline{-}$ \\
\hline TUNA $\dot{\text { OTHE }} \dot{F}$ S & $\cdot$ & $\dot{9}$ & : & & • & : & - & - & - & - & 182,000 & 75,820 & $\overline{-}$ & - \\
\hline TURTLE. . & $:$ & : & $\vdots$ & & $\therefore$ & $\therefore$ & 19.000 & 13,300 & - & - & - & - & - & - \\
\hline TOTAL & AL. & . & - & . . & . . & - . & 164,000 & 78,291 & 693,000 & 498,196 & 450,000 & 207,306 & 11,000 & 8,847 \\
\hline
\end{tabular}


PUERTO RICO - LANDINGS OF CATCH BY GEAR, 1975 - Continued

\begin{tabular}{|c|c|c|c|c|c|c|}
\hline SPECIES & \multicolumn{2}{|c|}{ CAST NETS } & \multicolumn{2}{|c|}{ SPEARS } & \multicolumn{2}{|c|}{ BY HA!ID } \\
\hline 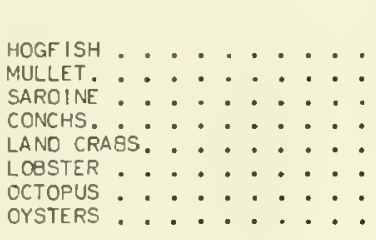 & $\begin{array}{c}\frac{\text { POUNDS }}{1,000} \\
18,000 \\
\vdots \\
\vdots \\
\end{array}$ & $\begin{array}{c}\frac{\text { OOLLARS }}{-} \\
175 \\
11,64 ! \\
= \\
= \\
- \\
\end{array}$ & $\begin{array}{l}\text { POUNOS } \\
1,000 \\
= \\
= \\
4,000 \\
1,000 \\
-\end{array}$ & $\begin{array}{c}\frac{\text { DOLLARS }}{781} \\
\vdots \\
- \\
7,419 \\
811 \\
- \\
\end{array}$ & $\begin{array}{c}\frac{\text { POUNDS }}{-} \\
\overline{-} \\
186,000 \\
18,000 \\
14,000 \\
4,000 \\
32,000\end{array}$ & $\begin{array}{c}\frac{\text { DOLLARS }}{-} \\
- \\
100,308 \\
11,160 \\
32,984 \\
3,329 \\
32,000\end{array}$ \\
\hline TOTAL. . . . . & 19,000 & 12,116 & 6,000 & 9,011 & 254,000 & 179,781 \\
\hline
\end{tabular}

PUERTO RICO LANDINGS, 1953-75

\begin{tabular}{|c|c|c|c|c|c|c|c|c|}
\hline \multirow{2}{*}{ YEAR } & \multicolumn{8}{|c|}{ TUNA } \\
\hline & \multicolumn{2}{|c|}{ BLUEF IN } & \multicolumn{2}{|c|}{ SKIPJACK } & \multicolumn{2}{|c|}{ YELLOWF IN } & \multicolumn{2}{|c|}{ TOTAL } \\
\hline $\begin{array}{l}1953 . \cdots \\
1954: \vdots \vdots \\
1955,: \vdots \\
1956 \\
1957: \vdots \vdots \\
1958 .\end{array}$ & $\begin{array}{c}\frac{\text { THOUSAND }}{\text { POUNDS }} \\
\left\{\begin{array}{l}1 \\
1 \\
1 \\
1 \\
1 \\
1 \\
1 \\
1 \\
1\end{array}\right\} \\
1,676 \\
2,494 \\
4,324 \\
2,346 \\
1,286 \\
1,360 \\
- \\
- \\
1,004 \\
1,858 \\
1,528 \\
58 \\
318 \\
760\end{array}$ & 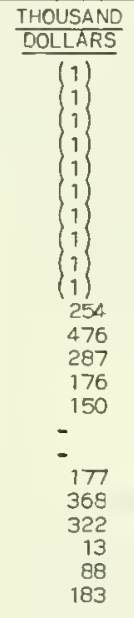 & $\begin{array}{c}\frac{\text { THOUSAND }}{\text { POUNDS }} \\
\left.\begin{array}{r}1 \\
1 \\
1 \\
1 \\
1 \\
1 \\
1\end{array}\right) \\
5,692 \\
10,392 \\
20,086 \\
30,454 \\
30,447 \\
42,064 \\
37,962 \\
77,702 \\
46,672 \\
28,014 \\
23,948 \\
84,630 \\
41,044 \\
63,616 \\
76,128 \\
76,744\end{array}$ & $\begin{array}{c}\frac{\text { THOUSAND }}{\text { DDLLARS }} \\
\left\{\begin{array}{l}1 \\
1 \\
1 \\
1 \\
1 \\
1 \\
1 \\
1 \\
1 \\
1\end{array}\right\} \\
2,966 \\
2,816 \\
4,417 \\
4,881 \\
7,343 \\
6,096 \\
3,847 \\
3,835 \\
15,741 \\
8,249 \\
14,646 \\
20,457 \\
17,821\end{array}$ & 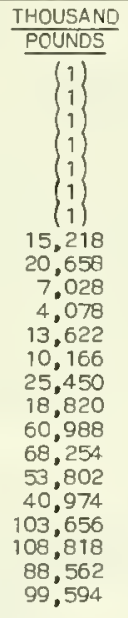 & 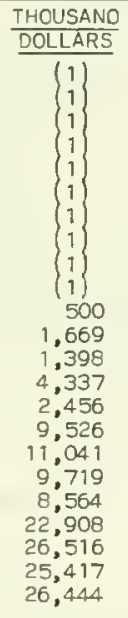 & $\begin{array}{r}\text { THOUSAND } \\
\text { POUNDS } \\
2,704 \\
6,389 \\
9,549 \\
12,000 \\
18,393 \\
16,652 \\
22,090 \\
20,910 \\
37,050 \\
28,790 \\
37,026 \\
48,393 \\
54,576 \\
64,698 \\
97,882 \\
107,660 \\
96,268 \\
78,754 \\
127,462 \\
4 / 146,320 \\
172,492 \\
165,008 \\
4 / 177,100\end{array}$ & 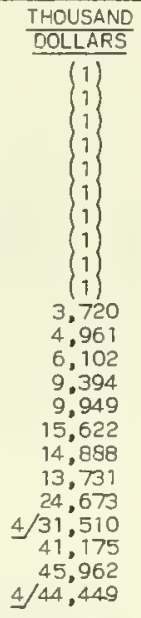 \\
\hline \multirow{2}{*}{ YEAR } & \multicolumn{8}{|c|}{ OTHER } \\
\hline & \multicolumn{2}{|c|}{ FRESHWATER FISH } & \multicolumn{2}{|c|}{ UNCLASSIFIED FISH } & \multicolumn{2}{|c|}{ CRUSTACEANS } & \multicolumn{2}{|c|}{ MOLLUSKS } \\
\hline 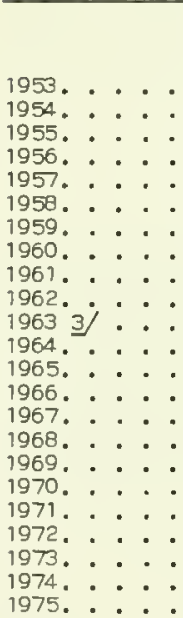 & $\begin{array}{r}\frac{\text { THOUSAND }}{\text { POUNDS }} \\
441 \\
441 \\
441 \\
441 \\
441 \\
441 \\
441 \\
441 \\
441 \\
441 \\
441 \\
441 \\
441 \\
441 \\
441 \\
441 \\
441 \\
441 \\
441 \\
441 \\
441 \\
441 \\
441\end{array}$ & 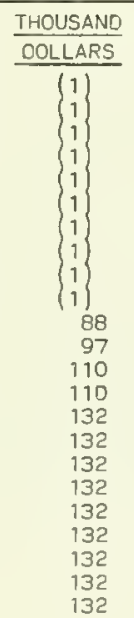 & $\begin{array}{c}\text { THOUSAND } \\
\text { POUNDS } \\
4,409 \\
4,630 \\
4,630 \\
4,850 \\
4,850 \\
5,071 \\
5,291 \\
5,512 \\
5,952 \\
6,614 \\
7,496 \\
8,378 \\
9,039 \\
9,039 \\
8,598 \\
8,598 \\
2,866 \\
3,748 \\
2,864 \\
2,668 \\
2,475 \\
2,593 \\
2,992\end{array}$ & $\begin{array}{c}\frac{\text { THOUSAND }}{\text { DOLLARS }} \\
\left\{\begin{array}{l}1 \\
1 \\
1 \\
1 \\
1 \\
1 \\
1 \\
1 \\
1\end{array}\right. \\
1,357 \\
1,843 \\
2,079 \\
2,079 \\
1,934 \\
1,711 \\
1,654 \\
1,069 \\
903 \\
963 \\
922 \\
1,138 \\
1,520\end{array}$ & $\begin{array}{c}\text { THOUSAND } \\
\text { POUNDS } \\
441 \\
441 \\
661 \\
661 \\
661 \\
661 \\
661 \\
667 \\
661 \\
667 \\
1,102 \\
1,102 \\
1,323 \\
7,323 \\
1.984 \\
1,764 \\
220 \\
441 \\
354 \\
313 \\
298 \\
268 \\
329\end{array}$ & 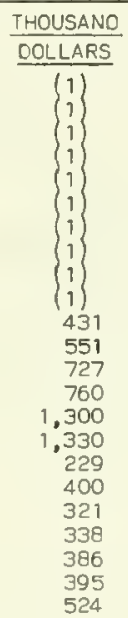 & 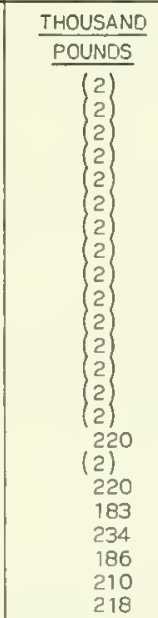 & 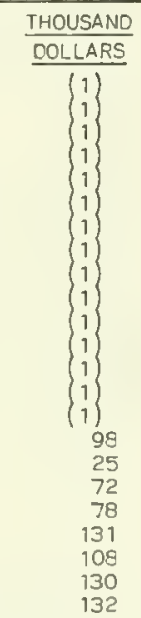 \\
\hline
\end{tabular}




\section{PUERTO RICO LANDINGS, 1953-75 - Continued}

\begin{tabular}{|c|c|c|c|c|c|c|c|c|c|c|c|c|c|}
\hline \multirow{2}{*}{\multicolumn{8}{|c|}{ YEAR }} & \multicolumn{4}{|c|}{ OTHER - CONTINUEO } & \multirow{2}{*}{\multicolumn{2}{|c|}{ GRANO TOTAL }} \\
\hline & & & & & & & & \multicolumn{2}{|c|}{$\begin{array}{l}\text { MISCELLANEOUS } \\
\text { SHELLFISH ET AL. }\end{array}$} & \multicolumn{2}{|c|}{ TOTAL } & & \\
\hline 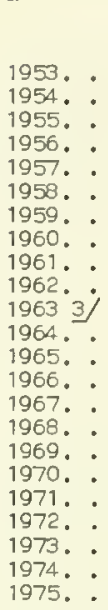 & $\begin{array}{l}: \\
: \\
: \\
: \\
: \\
: \\
: \\
: \\
: \\
:\end{array}$ & 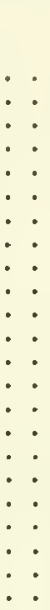 & $\begin{array}{l}: \\
: \\
: \\
: \\
: \\
: \\
: \\
: \\
: \\
: \\
:\end{array}$ & 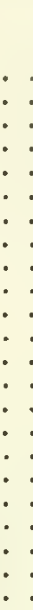 & $\therefore:$ & $\begin{array}{l}: \\
: \\
: \\
: \\
: \\
: \\
: \\
: \\
: \\
:\end{array}$ & 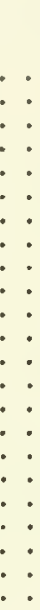 & $\begin{array}{c}\frac{\text { THOUSANO }}{\text { POUNOS }} \\
\left(\begin{array}{l}2 \\
2 \\
2 \\
2 \\
2 \\
2 \\
2\end{array}\right\} \\
220 \\
220 \\
(2) \\
220 \\
220 \\
220 \\
220 \\
220 \\
220 \\
2 \\
2 \\
2 \\
39 \\
25 \\
22 \\
15 \\
30\end{array}$ & 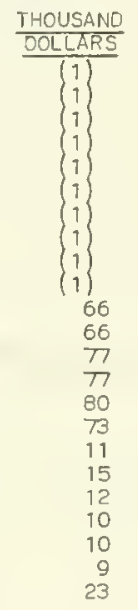 & $\begin{array}{c}\text { THOUSANO } \\
\text { POUNOS } \\
5,291 \\
5,512 \\
5,732 \\
5,952 \\
5,952 \\
6,173 \\
6,393 \\
6,834 \\
7,274 \\
7,716 \\
9,259 \\
10,141 \\
11,023 \\
11,023 \\
11,243 \\
11,243 \\
3,527 \\
4,850 \\
3,881 \\
3,681 \\
3,422 \\
3,527 \\
4,010\end{array}$ & $\begin{array}{c}\frac{\text { THOUSAND }}{\text { DOLLARS }} \\
\left(\begin{array}{l}1 \\
1 \\
1 \\
1 \\
1 \\
1 \\
1 \\
1 \\
1 \\
1\end{array}\right) \\
1,942 \\
2,557 \\
2,993 \\
3,026 \\
3,446 \\
3,404 \\
1,051 \\
1,688 \\
1,446 \\
1,574 \\
1,558 \\
1,804 \\
2,331\end{array}$ & $\begin{array}{r}\text { THOUSAND } \\
\frac{\text { POUNOS }}{7,995} \\
11,900 \\
15,281 \\
17,952 \\
24,345 \\
22,825 \\
28,483 \\
27,744 \\
38,324 \\
36,506 \\
46,285 \\
58,534 \\
65,599 \\
75,721 \\
109,125 \\
118,903 \\
99,795 \\
83,504 \\
131,343 \\
4 / 150,001 \\
175,914 \\
168,535 \\
4 / 181,110\end{array}$ & $\begin{array}{c}\text { THOUSANO } \\
\text { OOLLARS } \\
\left\{\begin{array}{l}1 \\
1 \\
1 \\
1 \\
1 \\
1 \\
1 \\
1 \\
1 \\
1\end{array}\right) \\
5,662 \\
7,518 \\
9,095 \\
12,420 \\
13,395 \\
19,026 \\
15,939 \\
15,419 \\
26,119 \\
4 / 33,084 \\
42,733 \\
47,766 \\
4 / 46,780\end{array}$ \\
\hline
\end{tabular}

1) NOT AVA ILABLE.

2) NEGLIGIBLE.

3) AODITIONAL LANOINGS OF BLUEFIN (640,000 POUNOS) ANO SKIPJACK (596,000 POUNOS) TUNA WERE MADE AT U.S. ATLANTIC COAST PORTS AND TRANSSHIPPEO TO PUERTO RICO.

4) INCLUDES 92,000 POUNDS OF ALBACORE VALUEO AT \$31,000 IN 1972, AND 2,000 POUNDS VALUED AT \$1,000 IN 1975. NOTE:---DATA FOR 1953-71 ON PUERTO RICO LANDINGS MADE GY LOCAL F ISHERMEN ARE FROM THE YEAREOOK OF FISHERY STATISTICS (VARIOUS YEARS). FOOD ANO AGRICULTURE ORGANIZATION OF THE UNITED NATIONS. METRIC TONS HAVE BEEN CONVERTED TO POUNDS BY MULTIPLYING GY 2,204.6. THE 1972-75 LANOINGS ANO VALUE TOTALS ARE FROM TABULATIONS PREPAREO BY THE PUERTO RICO OEPARTMENT OF AGRICULTURE, COMMERCIAL FISHERIES LABORATORY. DATA ON TUNA LANOINGS IN PUERTO RICO BY U.S. FISHERMEN WERE OBTA INEO BY THE NÁTIONAL MARINE FISHERIES SERVICE.

\section{ATLANTIC AND PACIFIC OCEANS, $1953-75$ PUERTO RICO TUNA LANDINGS}

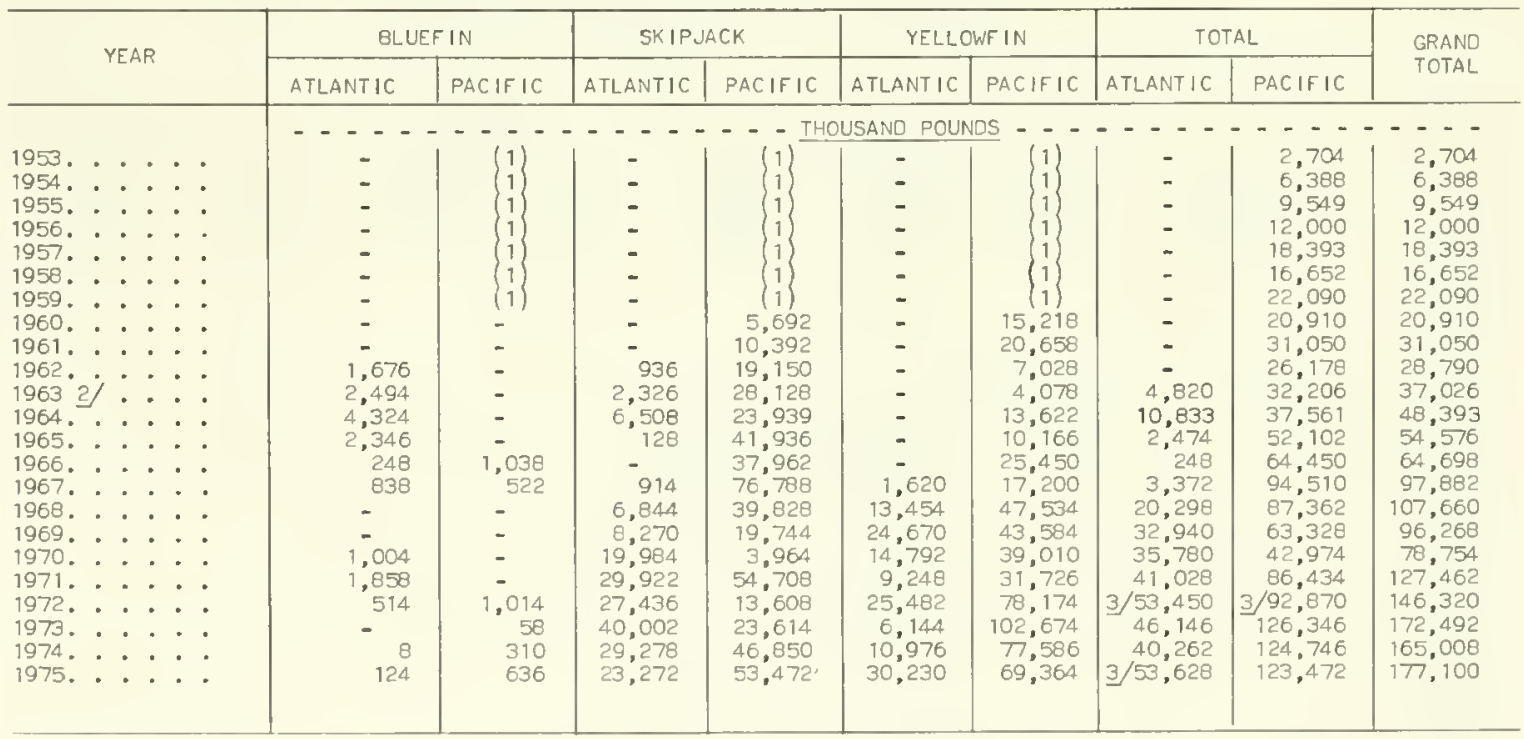

1/ NOT AVAILABLE.

2) AOOITIONAL LANOINGS OF BLUEFIN (640,000 POUNOS) ANO SKIPJACK (596,000 POUNOS) TUNA WERE MADE AT U.S. ATLANTIC COAST PORTS ANO TRANSSHIPPED TO PUERTO RICO. IN THE ATLANTIC ANO 74,000 POUNOS TAKEN IN THE PACIFIC OCEAN IN I972 ANO 2,000 POUNOS OF ALBACORE TAKEN IN THE ATLANTIC IN 1975. 


\section{SECTION 12

In this Section, there are complete data on the commercial landings of certain major species of fish and shellfish taken in the U.S. fisheries. Additional information is presented on the operating units for many of these fisheries. Most of the major species are taken by several types of fishing gear operated in two or more States; because of this, the casual reader of the digest may have difficulty in locating complete data. The information contained in this Section includes operating units and the volume and value of the catch by types of gear, by States, or by districts.

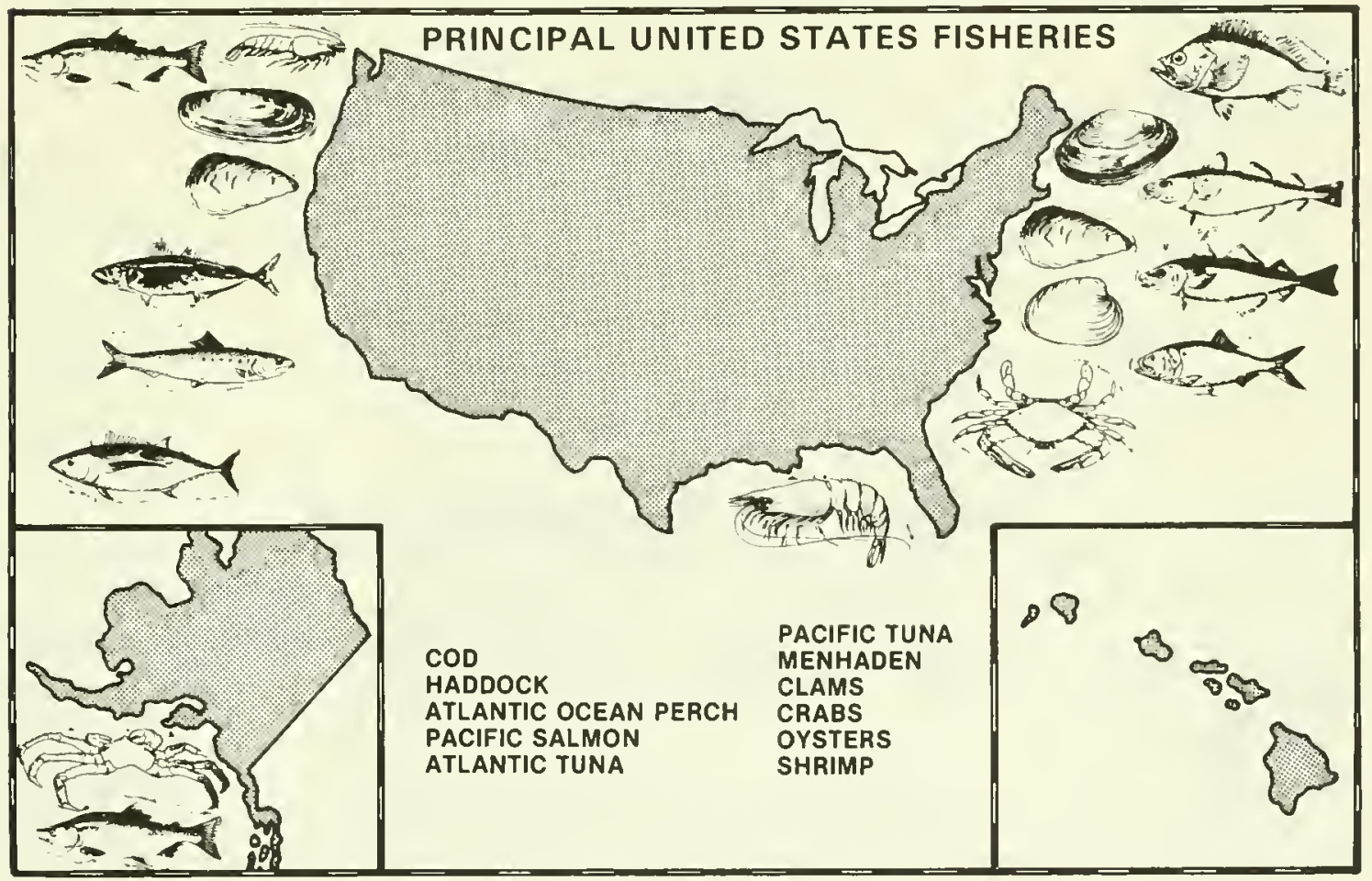

\section{ATLANTIC OCEAN PERCH FISHERY, 1975}

Landings of Atlantic ocean perch were 32.1 million pounds worth $\$ 3.3$ million, a decline of 9.4 million pounds and $\$ 44,000$. The production was the smallest since 1935 and 20.0 million pounds below the average for the previous 5 years.

Maine landings of 21.5 million pounds valued at $\$ 2.0$ million was 67 percent of the volume and 60 percent of the value. Massachusetts accounted for 10.5 million pounds worth $\$ 1.3$ million. The remainder was landed in Rhode Island, New Hampshire, and Virginia.

Ninety-nine percent of the cat ch was taken by fish otter trawls. The rest were taken by shrimp and lobster otter trawls, gill nets, and lines. 


\section{U.S. COD FISHERY, 1975}

Landings of cod were 68.4 million pounds valued at $\$ 14.6$ million-a decline of 300,000 pounds, but an increase of $\$ 2.0$ million compared with 1974. Landings at Massachusetts ports were 69 percent of the total, followed by Washington with 17 percent; Maine, 8 percent; and Rhode lsland, 3 percent. The remainder was landed in eight other Atlantic and Pacific Coast States.

Eighty-one percent of the catch was taken by otter trawls, 13 percent by lines, 6 percent by gill nets, and the remainder was taken by purse seines, midwater trawls, pound nets, beam trawls, floating traps, pots and traps, and dredges.

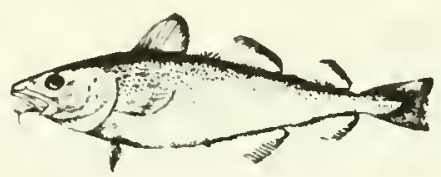

SUMMARY OF COD LANDINGS, 1975

\begin{tabular}{|c|c|c|c|c|c|c|c|c|c|c|}
\hline \multirow[t]{2}{*}{ AREA ANO } & \multicolumn{4}{|c|}{ STATE } & \multicolumn{2}{|c|}{ PURSE SE INES } & \multicolumn{2}{|c|}{ OTTER TRAWLS } & \multicolumn{2}{|c|}{ MIOWATER TRAWLS } \\
\hline & & & & & $\frac{\text { THOUSAND }}{\text { POUNOS }}$ & $\begin{array}{l}\text { THOUSAND } \\
\text { DOLLARS }\end{array}$ & $\frac{\text { THOUSAND }}{\text { POUNDS }}$ & $\frac{\text { THOUSANO }}{\text { OOLLARS }}$ & $\frac{\text { THOUSAND }}{\text { POUNOS }}$ & $\frac{\text { THOUSANO }}{\text { OOLLARS }}$ \\
\hline $\begin{array}{l}\text { NEW ENGLANO: } \\
\text { MA INE } \\
\text { NEW HAMPSH IRE } \\
\text { MASSACHUSETTS } \\
\text { RHOOE ISLANO. } \\
\text { CONNECT ICUT . }\end{array}$ & $\begin{array}{l}: \\
: \\
:\end{array}$ & $\begin{array}{l}: \\
: \\
:\end{array}$ & : & $\dot{\dot{ }}$ & $\begin{array}{l}- \\
(1) \\
-\end{array}$ & $\begin{array}{l}- \\
(1) \\
-\end{array}$ & $\begin{array}{r}3,003 \\
96 \\
38,077 \\
1,694 \\
35\end{array}$ & $\begin{array}{r}477 \\
21 \\
9.355 \\
425 \\
12 \\
\end{array}$ & $\begin{array}{r}- \\
-7 \\
-\quad 11 \\
\end{array}$ & $\begin{array}{r}- \\
- \\
-\quad 3 \\
\end{array}$ \\
\hline TOTAL. . & . . & . . & . & . & (1) & (1) & 42,905 & 10.290 & 18 & 4 \\
\hline $\begin{array}{l}\text { MIODLE ATLANTIC: } \\
\text { NEW YORK. } \\
\text { NEW JERSEY. }\end{array}$ & : & $\dot{:}$ & $\therefore$ & : & - & - & $\begin{array}{l}330 \\
148\end{array}$ & $\begin{array}{r}107 \\
49\end{array}$ & - & - \\
\hline TOTAL. . & . $\cdot$ & - . & •. & - & - & - & 478 & 156 & - & - \\
\hline $\begin{array}{l}\text { CHESAPEAKE: } \\
\text { MARYLANO: : } \\
\text { VIRGINIA: : }\end{array}$ & $\dot{0}$ & $\therefore$ & $\therefore$ & : & - & - & $(1)^{15}$ & $(1)^{5}$ & $\overline{-}$ & - \\
\hline TOTAL. . & . & - . & •. & . & - & - & 15 & 5 & - & - \\
\hline $\begin{array}{l}\text { PACIFIC COAST: } \\
\text { ALASKA. - : } \\
\text { WASHINGTON. : } \\
\text { OREGON. : : }\end{array}$ & 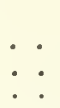 & $\begin{array}{l}. \\
: \\
.\end{array}$ & : & $\dot{.}$ & - & $\overline{-}$ & $\begin{array}{r}95 \\
11,169 \\
612 \\
\end{array}$ & $\begin{array}{r}5 \\
1,276 \\
67 \\
\end{array}$ & $\overline{-}$ & - \\
\hline TOTAL . . & $\cdot \cdot$ & . . & . & - & - & - & 11,876 & 1,348 & - & - \\
\hline GRAND TOT. & TAL. & . . & . . & . & (1) & (1) & 55.274 & 11.799 & 18 & 4 \\
\hline
\end{tabular}




\section{SUMMARY OF COD LANDINGS, 1975 - Continued}

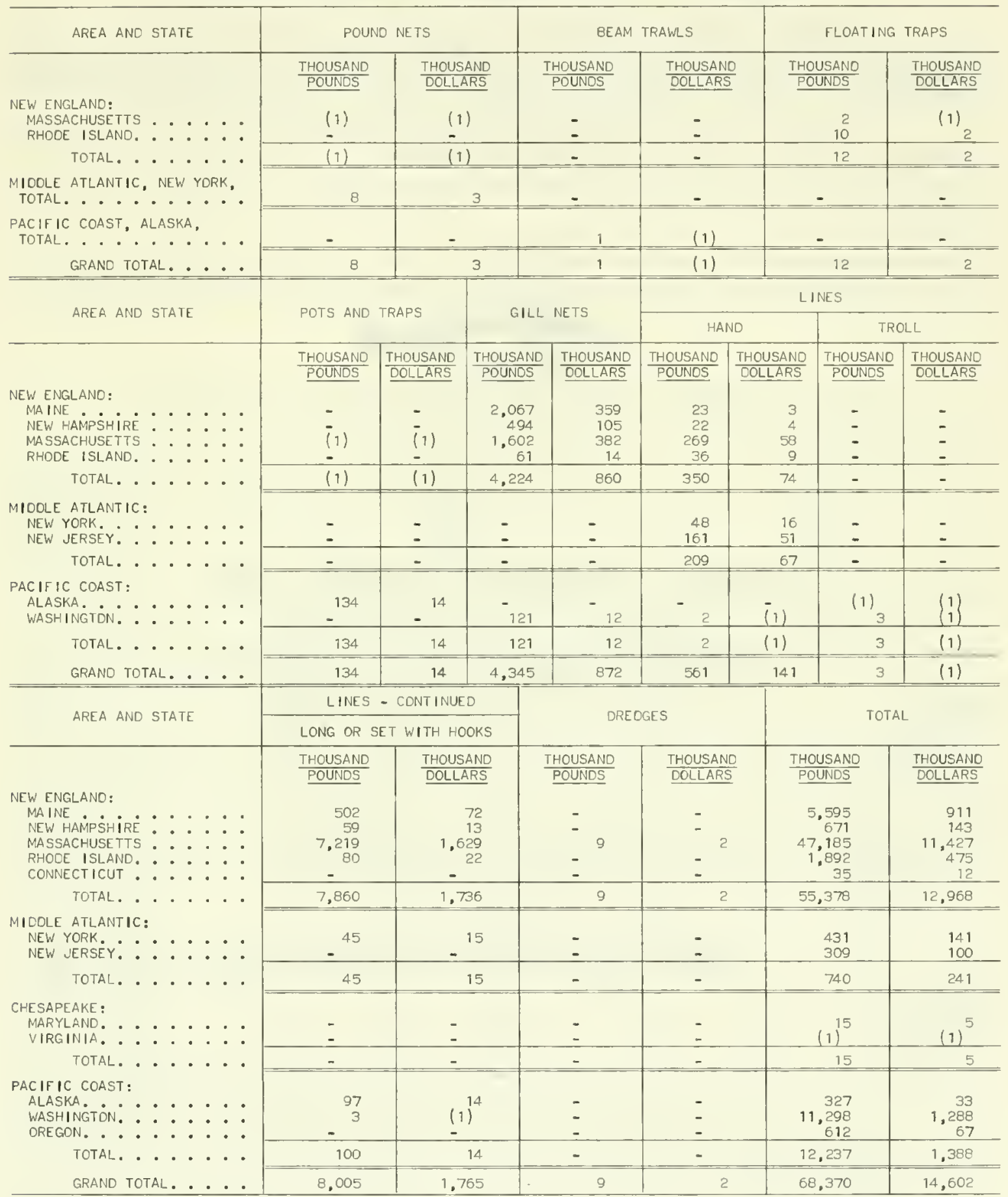

1) LESS THAN 500 POUNDS OR $\$ 500$. 


\section{ATLANTIC COAST HADDOCK FISHERY, 1975}

Haddock landings of 16.2 million pounds valued at $\$ 5.3$ mijlion increased 8.0 million pounds (97 percent) and $\$ 2.3$ million (76 percent) over 1974 . Landings for the past 3 years (1972-74) averaged $9.4 \mathrm{million}$ pounds, and in 1974 landings were the smallest on record. In 1975, Massachusetts accounted for 14.7 million pounds (91 percent) of the total harvest.

Fishermen took 96 percent of the total volume with otter trawls and 3 percent with lines. The remaining 1 percent was taken by purse seines, gill nets, and dredges.

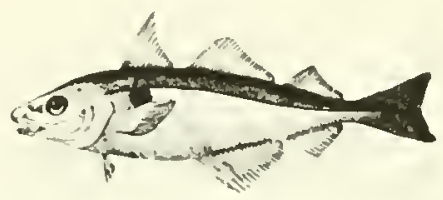

SUMMARY OF HADDOCK LANDINGS, 1975

\begin{tabular}{|c|c|c|c|c|c|c|c|c|}
\hline AREA AND STATE & \multicolumn{3}{|c|}{ PURSE SE INES } & \multicolumn{3}{|c|}{ OTTER TRAWLS } & \multicolumn{2}{|c|}{ GILL NETS } \\
\hline & $\frac{\text { THOUSAND }}{\text { PDUNDS }}$ & \multicolumn{2}{|c|}{$\frac{\text { THDUSANO }}{\text { DOLLARS }}$} & $\frac{\text { THOUSAND }}{\text { POUNDS }}$ & $\frac{\text { THOUSANO }}{\text { DOLLARS }}$ & \multicolumn{2}{|c|}{$\frac{\text { THDUSANO }}{\text { POUNDS }}$} & $\frac{\text { THOUSANO }}{\text { DOLLARS }}$ \\
\hline $\begin{array}{l}\text { MA INE } \\
\text { NEW HAMPSHIRE : }: \vdots: \\
\text { MASSACHUSETTS : }: \vdots: \\
\text { RHODE ISLANO. }: \vdots:\end{array}$ & (1) & \multicolumn{2}{|r|}{ (1) } & $\begin{array}{r}596 \\
7 \\
14,220 \\
656 \\
\end{array}$ & $\begin{array}{r}207 \\
5 \\
4.591 \\
174 \\
\end{array}$ & \multicolumn{2}{|c|}{$\begin{array}{r}115 \\
42 \\
-\quad 49 \\
\end{array}$} & $\begin{array}{r}43 \\
32 \\
-\quad 19 \\
\end{array}$ \\
\hline 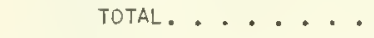 & (1) & \multicolumn{2}{|c|}{ (1) } & 15,479 & \multicolumn{2}{|l|}{4.97} & 206 & 94 \\
\hline $\begin{array}{l}\text { MIOOLE ATLANTIC, NEW YORK, } \\
\text { TOTAL. . . . . }\end{array}$ & - & \multicolumn{2}{|c|}{-} & 1 & (1) & \multicolumn{2}{|c|}{ - } & - \\
\hline GRAND TOTAL..... & (1) & \multicolumn{2}{|c|}{ (i) } & 15,480 & 4.977 & \multicolumn{2}{|r|}{206} & 94 \\
\hline & \multicolumn{4}{|c|}{ LINES } & \multirow{2}{*}{\multicolumn{2}{|c|}{ OREOGES }} & \multirow{2}{*}{\multicolumn{2}{|c|}{ TOTAL }} \\
\hline AREA ANO STATE & \multicolumn{2}{|c|}{ HAND } & \multicolumn{2}{|c|}{$\begin{array}{l}\text { LONG OR SET } \\
\text { WITH HOOKS }\end{array}$} & & & & \\
\hline & $\frac{\text { THOUSANO }}{\text { POUNDS }}$ & $\frac{\text { THOUSAND }}{\text { DOLLARS }}$ & $\frac{\text { THOUSAND }}{\text { POUNDS }}$ & $\frac{\text { THDUSANO }}{\text { DOLLARS }}$ & $\frac{\text { THOUSAND }}{\text { POUNDS }}$ & $\frac{\text { THOUSAND }}{\text { DOLLARS }}$ & $\frac{\text { THOUSAND }}{\text { POUNDS }}$ & $\frac{\text { THOUSAND }}{\text { OOLLARS }}$ \\
\hline 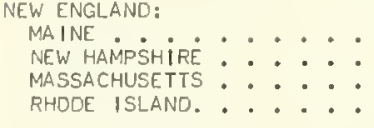 & $\begin{array}{r}1 \\
2 \\
-\quad 5 \\
\end{array}$ & $\begin{array}{r}1 \\
1 \\
-\quad 2 \\
\end{array}$ & $\begin{array}{r}65 \\
9 \\
450 \\
-\quad \\
\end{array}$ & $\begin{array}{r}26 \\
7 \\
219 \\
-\quad\end{array}$ & $\begin{array}{l}- \\
- \\
-\end{array}$ & -1 & $\begin{array}{r}776 \\
50 \\
14.729 \\
656\end{array}$ & $\begin{array}{r}276 \\
45 \\
4,832 \\
174 \\
\end{array}$ \\
\hline TDTAL. . . . . & 7 & 3 & 524 & 252 & 5 & 1 & 16,221 & 5,327 \\
\hline $\begin{array}{l}\text { MIOOLE ATLANTIC, NEW YORK, } \\
\text { TOTAL. } \cdots \cdots \cdots \cdots\end{array}$ & - & - & - & $=$ & - & - & 1 & $(1)$ \\
\hline GRANO TOTAL. .... & 7 & 3 & 524 & 252 & 5 & 1 & 16.222 & 5,327 \\
\hline
\end{tabular}

1 LESS THAN 500 POUNOS OR $\$ 500$. 


\section{PACIFIC COAST SALMON FISHERY, 1975}

Landings of salmon at Pacific Coast ports were 202.0 million pounds worth $\$ 107.0$ million, an increase of 530,000 pounds but a decline of $\$ 13.2$ million. The harvest was the second smallest since 1915 and 76.4 million pounds below the previous 5-year average. Landings of pink salmon increased 45 percent; red salmon, 7 percent; and chinook salmon increased 5 percent. The increase in these three species offset the 22percent decline in chum and the 32-percent decline in silver salmon.

Landings in Alaska (137.5 million pounds) increased 4 percent and Washington (45.2 million pounds) increased 2 percent. Landings in Oregon (12.4 million pounds) declined 19 percent, and California with 6.9 million pounds declined 21 percent.

Gill nets took 100.6 million pounds of the landings of Pacific salmon ( 50 percent); purse seines, 69.7 million pounds ( 35 percent); and lines, 28.8 million pounds ( 14 percent). The remaining 1 percent was taken by haul seines, otter trawls, pound nets, floating traps, pots, dip nets, reef nets, and wheels.

\section{SUMMARY OF SALMON LANDINGS BY SPECIES, 1975}

\begin{tabular}{|c|c|c|}
\hline SPECIES & THOUSANO POUNOS & THOUSANO DOLLARS \\
\hline 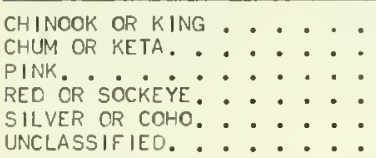 & $\begin{array}{l}29,771 \\
33,061 \\
58,251 \\
52,316 \\
20,605 \\
(1)\end{array}$ & $\begin{array}{l}25,578 \\
12,480 \\
20,011 \\
26,772 \\
22,201 \\
(1)\end{array}$ \\
\hline TOTAL. . . . . & 202,004 & 107,042 \\
\hline
\end{tabular}

\section{SUMMARY OF PACIFIC COAST SALMON PURSE SEINE OPERATING UNITS, 1975}

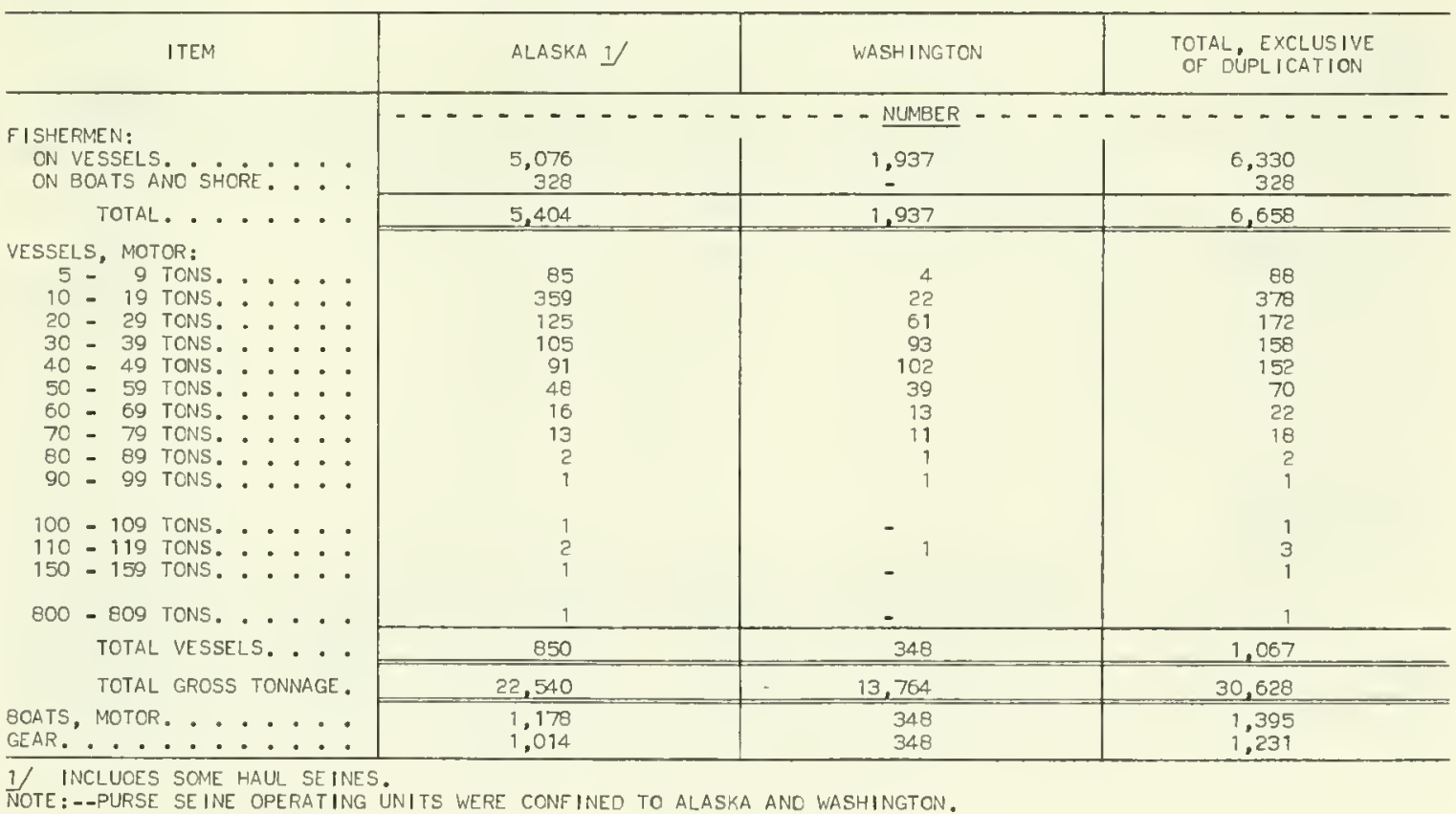




\section{SUMMARY OF PACIFIC COAST SALMON} GILL NET OPERATING UNITS, 1975

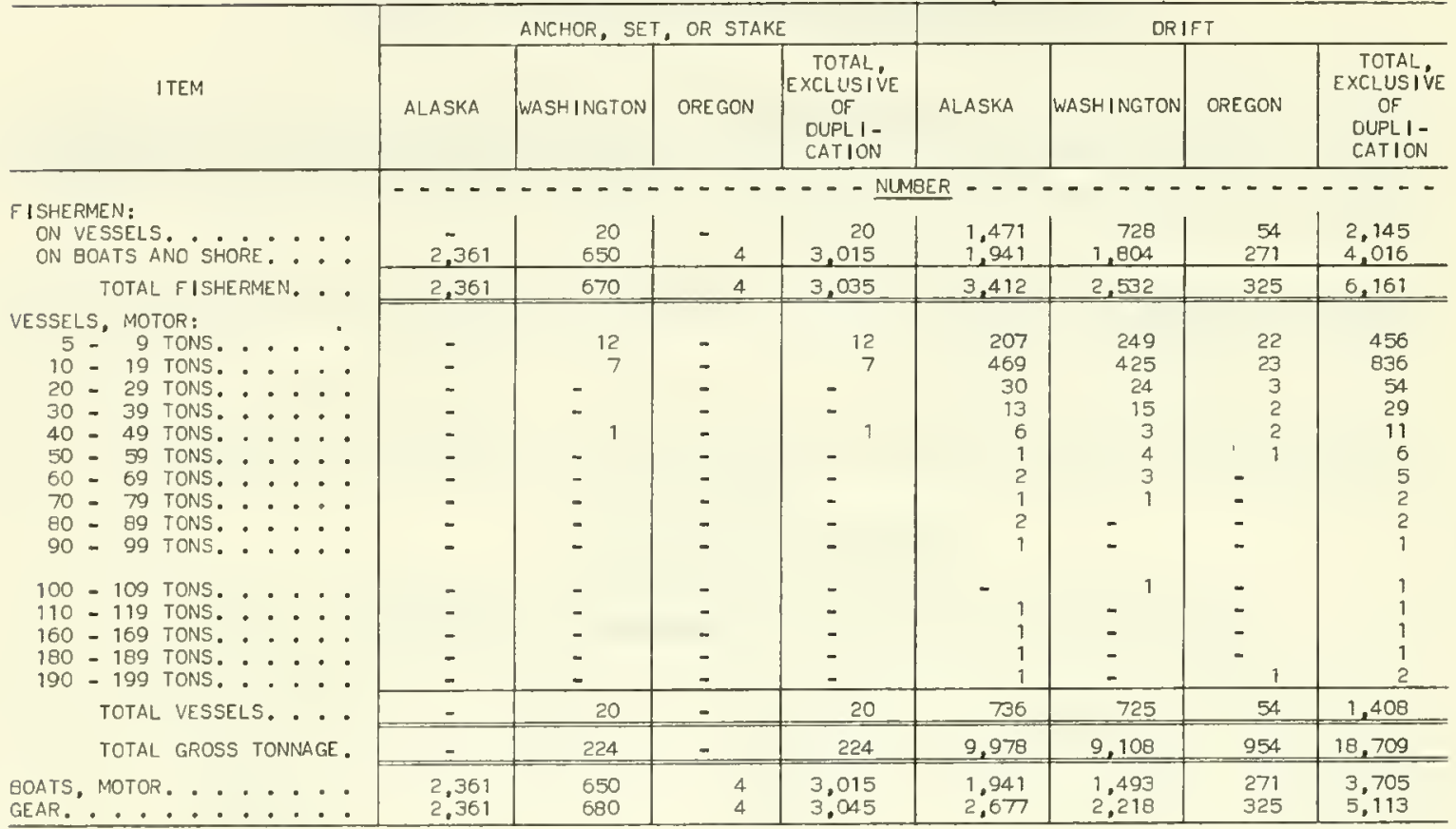

\section{SUMMARY OF PACIFIC COAST SALMON TROLL LINE OPERATING UNITS, 1975}

\begin{tabular}{|c|c|c|c|c|c|}
\hline ITEM & ALASKA & WASH INGTON & OREGON & CAL IFORNIA & $\begin{array}{l}\text { TOTAL, EXCLUSIVE } \\
\text { OF OUPL ICATION }\end{array}$ \\
\hline \multirow{3}{*}{ 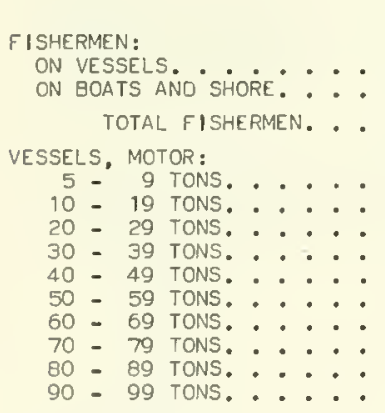 } & \multicolumn{5}{|c|}{ 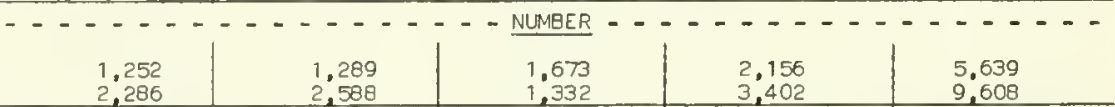 } \\
\hline & 3,538 & 3,87 & 3.005 & 5,558 & 15,247 \\
\hline & $\begin{array}{r}127 \\
317 \\
105 \\
41 \\
21 \\
11 \\
2 \\
2 \\
-\quad 2 \\
-\end{array}$ & $\begin{array}{r}200 \\
515 \\
159 \\
109 \\
44 \\
13 \\
8 \\
1 \\
1 \\
1\end{array}$ & $\begin{array}{r}190 \\
407 \\
112 \\
62 \\
31 \\
16 \\
8 \\
2 \\
5 \\
4\end{array}$ & $\begin{array}{r}201 \\
527 \\
189 \\
87 \\
41 \\
22 \\
10 \\
2 \\
7 \\
2\end{array}$ & $\begin{array}{r}664 \\
1.530 \\
499 \\
258 \\
118 \\
51 \\
23 \\
6 \\
7 \\
7\end{array}$ \\
\hline \multirow[t]{4}{*}{ 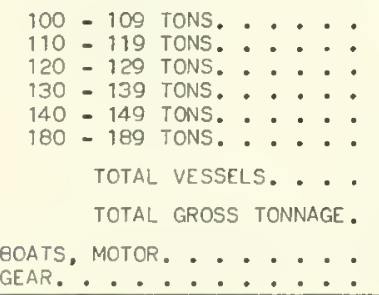 } & $\begin{array}{l}- \\
\overline{-} \\
-\end{array}$ & $\begin{array}{l}- \\
- \\
-\quad 1 \\
-\quad 1\end{array}$ & $\begin{array}{r}2 \\
-\quad 1 \\
-\quad 1 \\
1 \\
1 \\
\end{array}$ & $\begin{array}{l}-1 \\
= \\
- \\
-\end{array}$ & $\begin{array}{l}3 \\
1 \\
1 \\
1 \\
2 \\
1 \\
\end{array}$ \\
\hline & 626 & 1.063 & 837 & 1,078 & 3,172 \\
\hline & 11.060 & 20,087 & 16,267 & 20,428 & 59,114 \\
\hline & $\begin{array}{l}1,143 \\
7.076\end{array}$ & $\begin{array}{r}2,007 \\
13,681\end{array}$ & $\begin{array}{r}1.332 \\
13.014\end{array}$ & $\begin{array}{r}1.701 \\
13.895\end{array}$ & $\begin{array}{r}6.183 \\
45,499 \\
\end{array}$ \\
\hline
\end{tabular}




\section{SALMON LANDINGS BY DISTRICT AND CATCH BY GEAR,'1975}

\begin{tabular}{|c|c|c|c|c|c|c|c|c|c|c|c|}
\hline \multirow{2}{*}{\multicolumn{4}{|c|}{ GEAR ANO SPECIES }} & \multicolumn{8}{|c|}{ ALASKA } \\
\hline & & & & \multicolumn{2}{|c|}{ SOUTHEASTERN } & \multicolumn{2}{|c|}{ CENTRAL } & \multicolumn{2}{|c|}{ WESTERN } & \multicolumn{2}{|c|}{ TOTAL } \\
\hline $\begin{array}{l}\text { PURSE SE INES: } \\
\text { CHINOOK OR KING } \\
\text { CHUM OR KETA. - } \\
\text { PINK. - } \\
\text { REO OR SOCKEYE: } \\
\text { SILVER OR COHO. }\end{array}$ & $\therefore$ & $: \vdots$ & $\therefore$ & $\begin{array}{c}\frac{\text { THOUSAND }}{\frac{\text { POUNOS }}{29}} \\
3,335 \\
13,093 \\
314 \\
480\end{array}$ & \begin{tabular}{|r|} 
THOUSAND \\
OOLLARS \\
15 \\
1,188 \\
4,187 \\
182 \\
273 \\
\end{tabular} & $\begin{array}{r}\frac{\text { THOUSANO }}{\text { POUNOS }} \\
32 \\
1,803 \\
31,056 \\
3,915 \\
744\end{array}$ & $\begin{array}{r}\frac{\text { THOUSANO }}{\text { DOLLARS }} \\
16 \\
703 \\
10,007 \\
1,932 \\
363\end{array}$ & $\begin{array}{c}\frac{\text { THOUSANO }}{\text { POUNOS }} \\
-\quad \\
36 \\
2 \\
102 \\
(1)\end{array}$ & $\begin{array}{c}\frac{\text { THOUSANO }}{\text { DOLLARS }} \\
-\quad 9 \\
1 \\
(1)^{43}\end{array}$ & $\begin{array}{r}\frac{\text { THOUSANO }}{6 \text { POUNDS }} \\
61 \\
5,174 \\
44,151 \\
4,331 \\
1,224\end{array}$ & $\begin{array}{r}\text { THOUSANO } \\
\text { DOLLARS } \\
31 \\
1,900 \\
14,195 \\
2,157 \\
636 \\
\end{array}$ \\
\hline TOTAL. . . & . . & . & . & 17,251 & 5,845 & 37.550 & 13,021 & 140 & 53 & 54,941 & 18,919 \\
\hline $\begin{array}{l}\text { FLOATING TRAPS: } \\
\text { CHINOOK OR KING } \\
\text { CHUM OR KETA. - } \\
\text { PINK. } \\
\text { REO OR SOCKE } \dot{ } \text { ' } \\
\text { SILVER CR COHO. }\end{array}$ & $\therefore$ & $: \vdots$ & $\therefore$ & $\begin{array}{r}(1) \\
11 \\
429 \\
4 \\
3 \\
\end{array}$ & $\begin{array}{r}(1) \\
4 \\
137 \\
2 \\
2 \\
\end{array}$ & $\begin{array}{l}- \\
\overline{-} \\
\end{array}$ & $\begin{array}{l}- \\
\overline{-} \\
-\end{array}$ & $\begin{array}{l}- \\
\overline{-} \\
\end{array}$ & $\begin{array}{l}- \\
- \\
-\end{array}$ & $\begin{array}{r}(1) \\
11 \\
429 \\
4 \\
3 \\
\end{array}$ & $\begin{array}{r}(1) \\
4 \\
137 \\
2 \\
2 \\
\end{array}$ \\
\hline TOTAL. . . & •. & . . & . & 447 & 145 & - & - & - & - & 447 & 145 \\
\hline $\begin{array}{l}\text { GILL NETS, ANCHOR, } \\
\text { STAKE: } \\
\text { CHINOOK OR KING } \\
\text { CHUM OR KETA. } \\
\text { PINK. - } \\
\text { RED OR SOCKEYE: } \\
\text { SILVER OR COHO. }\end{array}$ & $\begin{array}{l}\text { SET } \\
\therefore \\
\vdots\end{array}$ & $\begin{array}{l}0 \\
\vdots \\
\vdots \\
\vdots\end{array}$ & $\therefore$ & $\begin{array}{r}54 \\
32 \\
297 \\
459 \\
358 \\
\end{array}$ & $\begin{array}{r}36 \\
18 \\
101 \\
277 \\
259 \\
\end{array}$ & $\begin{array}{r}118 \\
562 \\
1,998 \\
2,375 \\
1,009 \\
\end{array}$ & $\begin{array}{r}57 \\
208 \\
686 \\
1.455 \\
551 \\
\end{array}$ & $\begin{array}{r}929 \\
9,794 \\
96 \\
2,662 \\
211 \\
\end{array}$ & $\begin{array}{r}380 \\
2.715 \\
28 \\
1.052 \\
72 \\
\end{array}$ & $\begin{array}{r}1,101 \\
10,388 \\
2,391 \\
5,496 \\
1,578 \\
\end{array}$ & $\begin{array}{r}473 \\
2,941 \\
815 \\
2,784 \\
881 \\
\end{array}$ \\
\hline TOTAL. . . & . & . & . & 1,200 & 690 & 6,062 & 2,957 & 13,692 & 4,247 & 20,954 & 7,894 \\
\hline $\begin{array}{l}\text { GILL NETS, ORIFT: } \\
\text { CHINOOK OR KING } \\
\text { CHUM OR KETA. : } \\
\text { PINK. - } \\
\text { REO OR SOCKEYE: } \\
\text { SILVER OR COHO. }\end{array}$ & $\therefore$ & $: \vdots$ & $\therefore$ & $\begin{array}{r}99 \\
3,030 \\
1,484 \\
736 \\
929 \\
\end{array}$ & $\begin{array}{r}67 \\
1.950 \\
504 \\
445 \\
669 \\
\end{array}$ & $\begin{array}{r}505 \\
6,849 \\
1,261 \\
6,789 \\
1,305 \\
\end{array}$ & $\begin{array}{r}388 \\
2,534 \\
418 \\
3,577 \\
751 \\
\end{array}$ & $\begin{array}{r}1,302 \\
3,862 \\
4 \\
25,397 \\
774 \\
\end{array}$ & $\begin{array}{r}533 \\
1,083 \\
1 \\
10,261 \\
266 \\
\end{array}$ & $\begin{array}{r}1,906 \\
13,741 \\
2,749 \\
32,922 \\
3,008 \\
\end{array}$ & $\begin{array}{r}988 \\
5,567 \\
923 \\
14,283 \\
1,686 \\
\end{array}$ \\
\hline TOTAL. . & . . & . & . & 6,278 & 3,635 & 16,709 & 7,668 & 31,339 & 12,144 & 54,326 & 23,447 \\
\hline $\begin{array}{l}\text { LINES, TROLL: } \\
\text { CHINOOK OR KING } \\
\text { CHUM OR KETA. - } \\
\text { PINK. - - : } \\
\text { REO OR SOCKEYE: } \\
\text { SILVER OR COHO. }\end{array}$ & $\therefore$ & 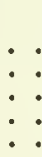 & $\therefore$ & $\begin{array}{r}3,792 \\
23 \\
249 \\
9 \\
1,296 \\
\end{array}$ & $\begin{array}{r}3,761 \\
12 \\
121 \\
6 \\
1,043 \\
\end{array}$ & $\begin{array}{l}- \\
- \\
- \\
\end{array}$ & $\begin{array}{l}- \\
-\end{array}$ & $\begin{array}{l}= \\
=\end{array}$ & $\begin{array}{l}- \\
\overline{-} \\
-\end{array}$ & $\begin{array}{r}3,792 \\
23 \\
249 \\
9 \\
1,297 \\
\end{array}$ & $\begin{array}{r}3,761 \\
12 \\
121 \\
6 \\
1,044 \\
\end{array}$ \\
\hline TOTAL. . . & • $\cdot$ & - . & . & 5,369 & 4,943 & 1 & 1 & - & - & 5,370 & 4,944 \\
\hline $\begin{array}{l}\text { WHEELS: } \\
\text { CHINOOK OR KING } \\
\text { CHUM OR KETA. } \\
\text { SILVER OR COHO. }\end{array}$ & $\therefore$ & $:$ & $:$ & $\begin{array}{l}- \\
\end{array}$ & $=$ & - & - & $\begin{array}{c}13 \\
1,465 \\
(1)^{13}\end{array}$ & $\begin{array}{r}264 \\
(1)^{5} \\
\end{array}$ & $\begin{array}{c}13 \\
1,465 \\
(1)^{13}\end{array}$ & $(1)^{5}$ \\
\hline TOTAL. . . & . . & . . & - . & - & - & - & - & 1,478 & 269 & 1,478 & 269 \\
\hline GRAND TOTAL & . . & . & - . & 30,545 & 15,258 & 60,322 & 23,647 & 46,649 & 16,713 & 137,516 & 55,618 \\
\hline \multirow{2}{*}{\multicolumn{4}{|c|}{ GEAR AND SPECIES }} & \multicolumn{8}{|c|}{ WASHINGTON } \\
\hline & & & & \multicolumn{2}{|c|}{ PUGET SOUND } & \multicolumn{2}{|c|}{ WASHINGTON COAST } & COLUMB IA & RIVER & \multicolumn{2}{|c|}{ TOTAL } \\
\hline $\begin{array}{l}\text { HAUL SE INES: } \\
\text { CHINOOK OR KING } \\
\text { CHUM OR KETA. } \\
\text { PINK. - } \\
\text { SILVER OR COHO: }\end{array}$ & $:$ & $: \cdot$ & $:$ & $\begin{array}{r}\frac{\text { THOUSAND }}{\text { POUNDS }} \\
5 \\
1 \\
56 \\
19 \\
\end{array}$ & \begin{tabular}{|c|} 
THOUSANO \\
OOLLARS \\
$(1)^{5}$ \\
30 \\
16 \\
\end{tabular} & $\begin{array}{c}\frac{\text { THOUSANO }}{\text { POUNOS }} \\
- \\
- \\
-\end{array}$ & $\begin{array}{c}\frac{\text { THOUSANO }}{\text { DOLLARS }} \\
- \\
- \\
- \\
-\end{array}$ & $\begin{array}{c}\frac{\text { THOUSAND }}{\text { POUNOS }} \\
- \\
- \\
- \\
-\end{array}$ & $\begin{array}{c}\text { THOUSAND } \\
\text { DOLLARS } \\
- \\
- \\
- \\
\end{array}$ & $\begin{array}{r}\text { THOUSAND } \\
\text { POUNDS } \\
5 \\
1 \\
56 \\
19 \\
\end{array}$ & $\begin{array}{c}\frac{\text { THOUSANO }}{\text { DOLLARS }} \\
(1)^{5} \\
30 \\
16 \\
\end{array}$ \\
\hline TOTAL. . . & . . & . & . & 81 & 51 & - & - & - & - & 81 & 51 \\
\hline $\begin{array}{l}\text { PURSE SE INES: } \\
\text { CHINOOK OR KING } \\
\text { CHUM OR KETA. } \\
\text { PINK. } \\
\text { RED OR SOCKEY்: } \\
\text { SILVER OR COHO. }\end{array}$ & $\therefore$ & $::$ & $:$ & $\begin{array}{r}1,273 \\
448 \\
5,892 \\
5,081 \\
2,086 \\
\end{array}$ & $\begin{array}{r}1,039 \\
402 \\
2,643 \\
3,889 \\
2,093 \\
\end{array}$ & $\begin{array}{l}\overline{-} \\
\overline{-} \\
\end{array}$ & $\begin{array}{l}\bar{z} \\
\overline{-} \\
\bar{y}\end{array}$ & $\begin{array}{l}- \\
- \\
-\end{array}$ & $\begin{array}{l}- \\
- \\
-\end{array}$ & $\begin{array}{r}1,273 \\
448 \\
5,892 \\
5,081 \\
2,086 \\
\end{array}$ & $\begin{array}{r}1,039 \\
402 \\
2,643 \\
3,889 \\
2,093 \\
\end{array}$ \\
\hline TOTAL. . . & • $\cdot$ & - . & - $\cdot$ & 14,780 & 10,066 & - & - & - & - & 14,780 & 10,066 \\
\hline $\begin{array}{l}\text { POUND NETS: } \\
\text { CHINOOK OR KING } \\
\text { CHUM OR KETA. } \\
\text { PINK. } \\
\text { REO OR SOCKEYE: } \\
\text { SILVER OR COHO. }\end{array}$ & $\therefore$ & : & $\therefore$ & $\begin{array}{r}7 \\
1 \\
22 \\
7 \\
24 \\
\end{array}$ & $\begin{array}{r}6 \\
1 \\
9 \\
1 \\
24 \\
\end{array}$ & $\begin{array}{l}- \\
- \\
-\end{array}$ & $\begin{array}{l}- \\
- \\
-\end{array}$ & $\begin{array}{l}- \\
- \\
-\end{array}$ & $\begin{array}{l}- \\
-\end{array}$ & $\begin{array}{r}7 \\
1 \\
22 \\
1 \\
24 \\
\end{array}$ & $\begin{array}{r}6 \\
1 \\
9 \\
1 \\
24 \\
\end{array}$ \\
\hline TOTAL. . . & . & . & . . & 55 & 41 & - & - & - & - & 55 & 41 \\
\hline
\end{tabular}




\section{SALMON LANDINGS BY DISTRICT AND CATCH BY GEAR, 1975 - Continued}

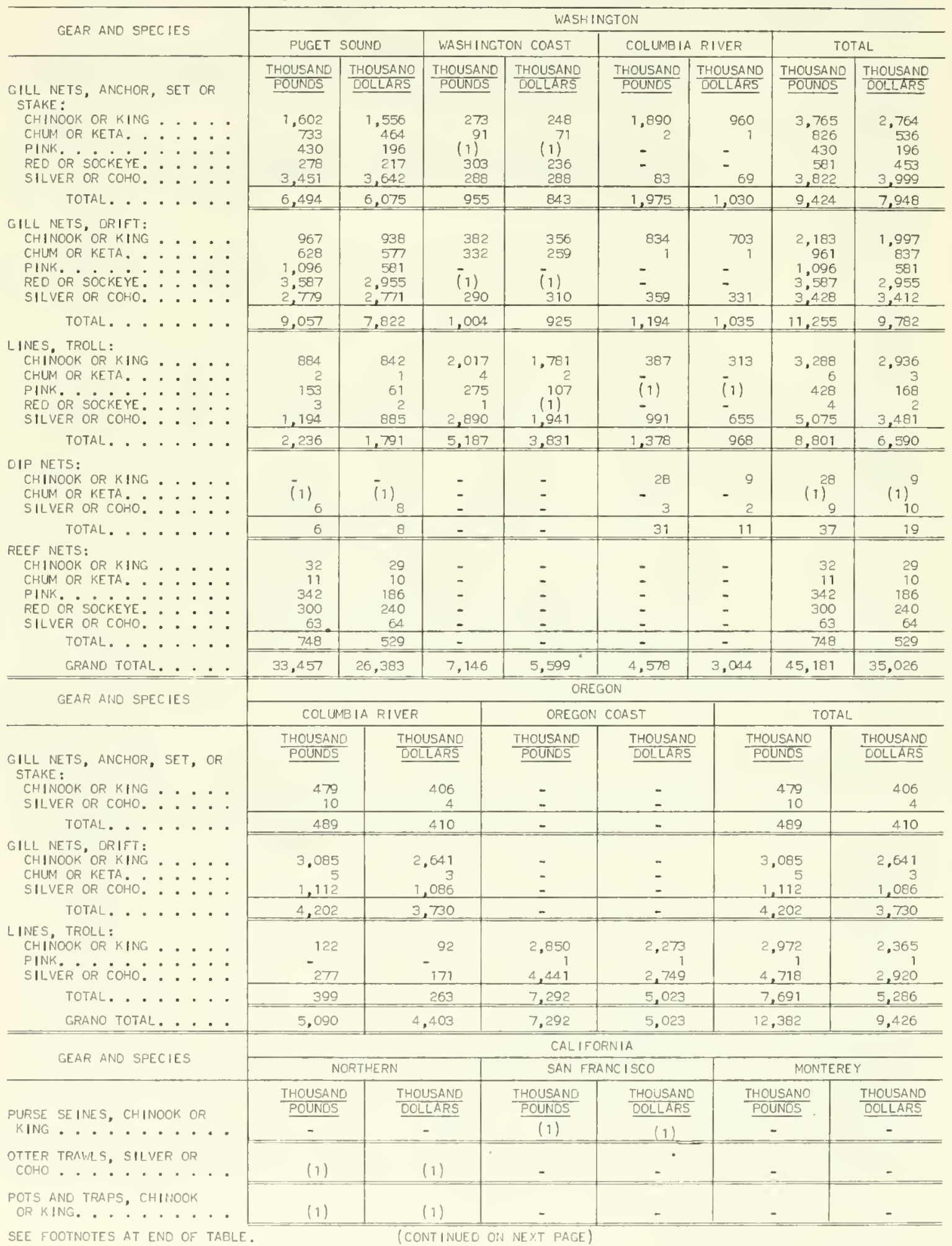




\section{SALMON LANDINGS BY DISTRICT AND CATCH BY GEAR, 1975 - Continued}

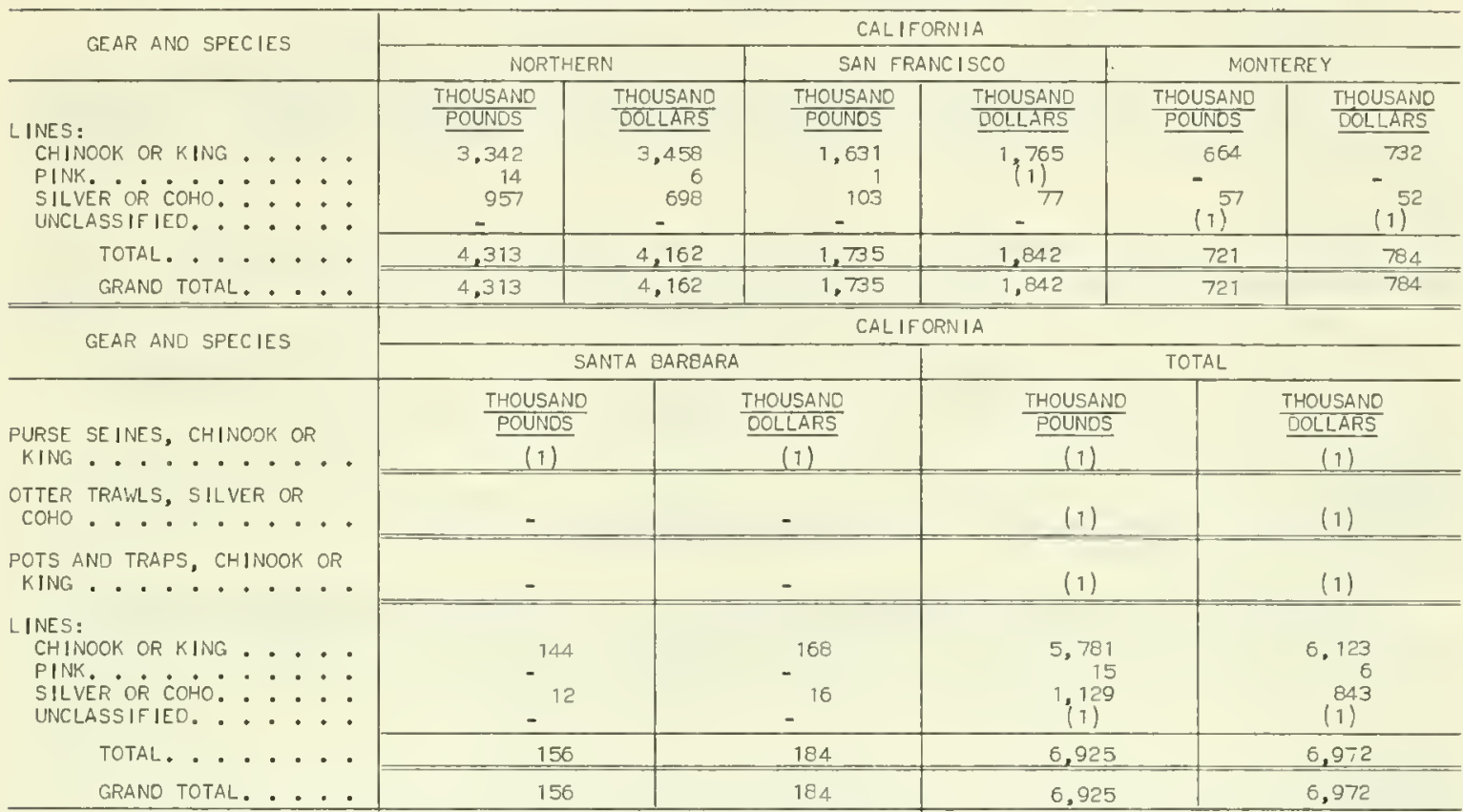

$1 /$ LESS THAN 500 POUNOS OR $\$ 500$.

NOTE: $--I N$ ALASKA, LANDINGS TAKEN EY HAUL SEINES ARE INCLUOED WITH THOSE TAKEN gY PURSE SEINES.

\section{SUMMARY OF SALMON LANDINGS BY DISTRICTS, 1975}

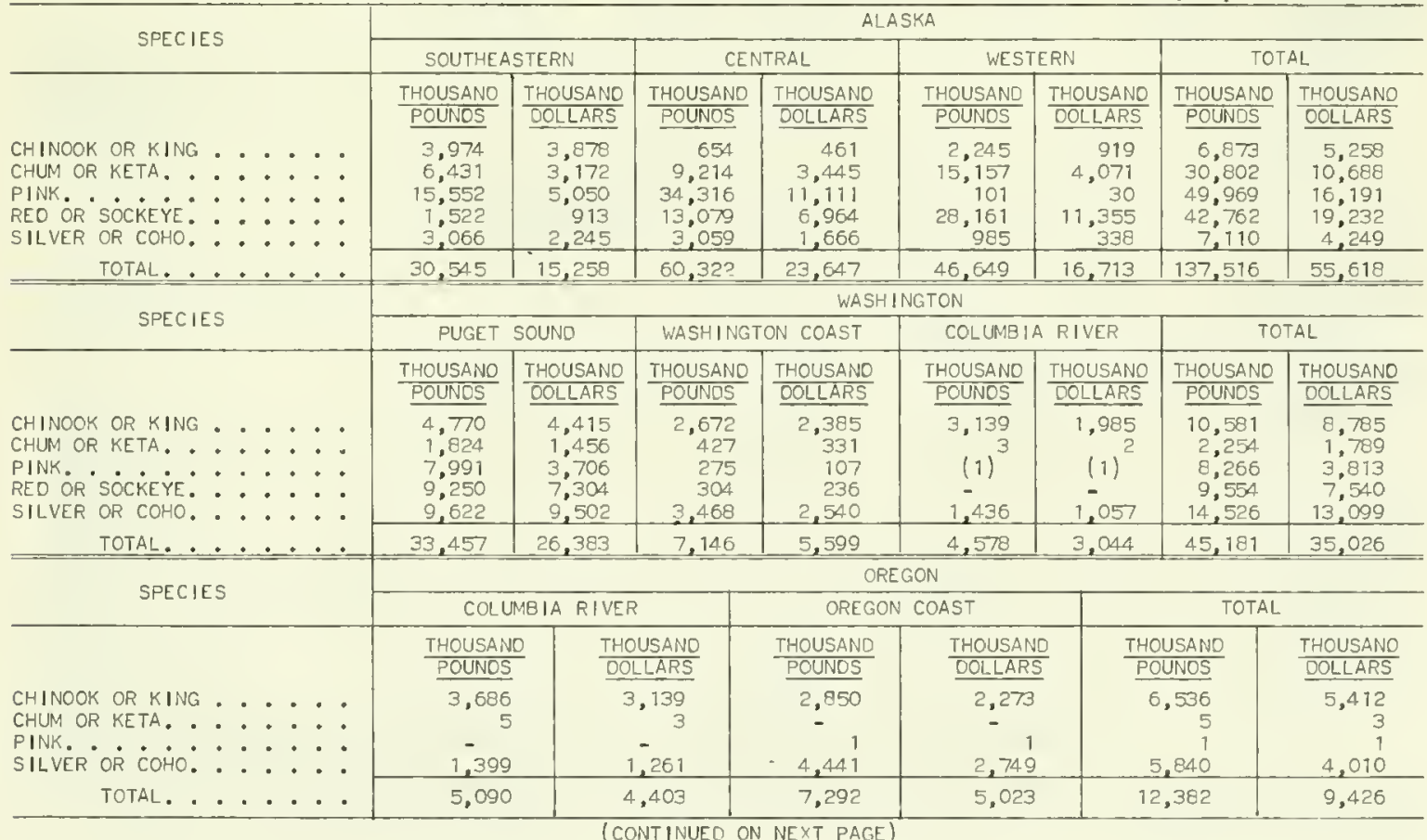




\section{SUMMARY OF SALMON LANDINGS BY DISTRICTS, 1975 - Continued}

\begin{tabular}{|c|c|c|c|c|c|c|}
\hline \multirow{3}{*}{ SPECIES } & \multicolumn{6}{|c|}{ CAL IFDRNIA } \\
\hline & \multicolumn{2}{|c|}{ NORTHERN } & \multicolumn{2}{|c|}{ SAN FRANC ISCO } & \multicolumn{2}{|c|}{ MONTEREY } \\
\hline & $\frac{\text { THOUSANO }}{\text { POUNOS }}$ & $\begin{array}{l}\text { THOUSAND } \\
\text { OOLLARS }\end{array}$ & $\frac{\text { THOUSANO }}{\text { POUNOS }}$ & $\begin{array}{l}\text { THOUSANO } \\
\text { OOLLARS }\end{array}$ & $\frac{\text { THOUSANO }}{\text { POUNOS }}$ & $\frac{\text { THOUSAND }}{\text { DOLLARS }}$ \\
\hline \multirow{3}{*}{ 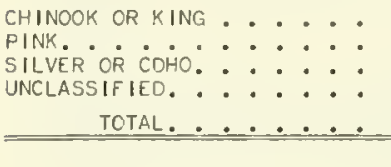 } & $\begin{array}{r}3,342 \\
14 \\
957 \\
-\quad \\
\end{array}$ & $\begin{array}{r}3,458 \\
6 \\
698 \\
\end{array}$ & $\begin{array}{r}1.631 \\
1 \\
103 \\
\end{array}$ & $\begin{array}{l}1,765 \\
1) \\
-77 \\
\end{array}$ & $\begin{array}{r}-564 \\
.11)^{57} \\
\end{array}$ & $\begin{array}{r}-732 \\
(1)^{52} \\
\end{array}$ \\
\hline & 4,313 & 4.162 & 1,735 & 1,842 & 721 & 784 \\
\hline & \multicolumn{6}{|c|}{ CALIFORNIA - CONTINUEO } \\
\hline SPECIES & \multicolumn{3}{|c|}{ SANTA BAREARA } & \multicolumn{3}{|c|}{ TOTAL } \\
\hline & \multicolumn{2}{|c|}{$\frac{\text { THOUSAND }}{\text { POUNOS }}$} & $\frac{\text { THOUSANO }}{\text { DOLLARS }}$ & \multicolumn{2}{|c|}{$\frac{\text { THOUSANO }}{\text { POUNDS }}$} & $\frac{\text { THOUSANO }}{\text { DOLLARS }}$ \\
\hline $\begin{array}{l}\text { CHINOOK OR KING }: \vdots: \\
\text { PINK } \\
\text { SILVER OR COHO: }: \vdots: \vdots \\
\text { UNCLASSIFIEO. }: \vdots:\end{array}$ & 12 & & $\begin{array}{r}168 \\
-\quad 16 \\
-\quad \\
\end{array}$ & \multicolumn{2}{|c|}{$\begin{array}{l}15 \\
1,129 \\
(1)\end{array}$} & $\begin{array}{r}6.123 \\
6 \\
843 \\
(1) \\
\end{array}$ \\
\hline TOTAL....... & \multicolumn{2}{|c|}{156} & 184 & \multicolumn{2}{|c|}{6,925} & 6,972 \\
\hline
\end{tabular}

$1 /$ LESS THAN 500 POUNDS OR \$500.

\section{SUMMARY OF SALMON LANDINGS OF CATCH BY GEAR, 1975}

\begin{tabular}{|c|c|c|c|c|c|c|c|c|c|}
\hline \multicolumn{4}{|l|}{ SPECIES } & $\begin{array}{l}\text { HAUL } \\
\text { SE INES }\end{array}$ & $\begin{array}{l}\text { PURSE } \\
\text { SE INES }\end{array}$ & $\begin{array}{c}\text { DTTER } \\
\text { TRAWLS } \\
\end{array}$ & $\begin{array}{l}\text { POUND } \\
\text { NETS }\end{array}$ & $\begin{array}{c}\text { FLDAT ING } \\
\text { TRAPS } \\
\end{array}$ & $\begin{array}{l}\text { POTS AND } \\
\text { TRAPS } \\
\end{array}$ \\
\hline $\begin{array}{l}\text { ALASKA: } \\
\text { SOUTHEASTERN. } \\
\text { CENTRAL : }: \\
\text { WESTERN : }:\end{array}$ & $\because$ & $\dot{:}$ & $\therefore$ & $\begin{array}{c}-\cdots \\
- \\
- \\
-\end{array}$ & $\begin{array}{r}17,251 \\
37,550 \\
140 \\
\end{array}$ & $\begin{array}{c}- \text { - THOUS } \\
- \\
- \\
\end{array}$ & $\begin{array}{l}\text { UNOS - - } \\
\begin{array}{r}- \\
- \\
-\end{array}\end{array}$ & $\begin{array}{c}\ldots-\cdots \\
447 \\
-\end{array}$ & $\begin{array}{c}\cdots \\
\vdots \\
- \\
\end{array}$ \\
\hline TOTAL. . & - & • & . & - & 54,941 & - & - & 447 & - \\
\hline WASHINGTON, PUGET S & soun & NO - & . & 81 & 14,780 & - & 55 & - & - \\
\hline $\begin{array}{l}\text { CAL IFORNIA: } \\
\text { NORTHERN: } \\
\text { SAN FRANCISCO : } \\
\text { SANTA BARBARA: }\end{array}$ & : & $\dot{:}:$ & $\therefore$ & $\begin{array}{l}- \\
-\end{array}$ & $\left(\begin{array}{l}1 \\
1\end{array}\right)$ & $\begin{array}{l}(1) \\
- \\
-\end{array}$ & $\overline{-}$ & $\overline{-}$ & $\begin{array}{l}(1) \\
- \\
-\end{array}$ \\
\hline TOTAL. . . & - . & . & . & - & (1) & (1) & - & - & (1) \\
\hline GRANO TOTAL & $\therefore$ & . . & $\therefore$ & 81 & 69,721 & (1) & 55 & 447 & (1) \\
\hline SPECIES & & & & $\begin{array}{l}\text { GILL } \\
\text { NETS } \\
\end{array}$ & LINES & $\begin{array}{l}\text { OIP } \\
\text { NETS }\end{array}$ & $\begin{array}{l}\text { REEF } \\
\text { NETS } \\
\end{array}$ & WHEELS & TOTAL \\
\hline $\begin{array}{l}\text { ALASKA: } \\
\text { SOUTHEASTERN. : } \\
\text { CENTRAL : : : } \\
\text { WESTERN: }:\end{array}$ & $:$ & $\therefore$ & $\therefore$ & $\begin{array}{c}\ldots \ldots- \\
7,478 \\
22,771 \\
45,031\end{array}$ & $\begin{array}{r}-\ldots \\
5,369 \\
-\quad 1 \\
\end{array}$ & $\begin{array}{c}- \\
- \text { THOUS } \\
- \\
- \\
\end{array}$ & $\begin{array}{r}\text { QUNOS } \\
= \\
= \\
\end{array}$ & $\begin{array}{c}-- \\
- \\
1,478 \\
\end{array}$ & $\begin{array}{l}\ldots \ldots \\
30,545 \\
60,322 \\
46,549 \\
\end{array}$ \\
\hline TOTAL. . . & - . & . & . . & 75,280 & 5,370 & - & - & 1.478 & 137,516 \\
\hline $\begin{array}{l}\text { WASHINGTON: } \\
\text { PUGET SOUNO } \\
\text { WASHINGTON COAST } \\
\text { COLUMBIA RIVER. }\end{array}$ & $\therefore$ & $: \dot{ }$ & $\therefore$ & $\begin{array}{r}15,551 \\
1,959 \\
3,169 \\
\end{array}$ & $\begin{array}{l}2,236 \\
5,187 \\
1,378 \\
\end{array}$ & $\begin{array}{r}6 \\
-31 \\
\end{array}$ & $\begin{array}{l}748 \\
- \\
\end{array}$ & $=$ & $\begin{array}{r}33,457 \\
7,146 \\
4,578 \\
\end{array}$ \\
\hline TOTAL. $\cdot \cdot$ & $\cdot \cdot$ & $\cdot \cdot$ & - $\cdot$ & 20,679 & 8.801 & 37 & 748 & - & 45,181 \\
\hline $\begin{array}{l}\text { OREGON: } \\
\text { COLUMBIA RIVER. } \\
\text { OREGON COAST. }\end{array}$ & $\therefore$ & $\therefore$ & $\therefore$ & 4,691 & $\begin{array}{r}399 \\
7,292 \\
\end{array}$ & - & - & - & $\begin{array}{l}5,090 \\
7,292 \\
\end{array}$ \\
\hline TOTAL. . . & . $\cdot$ & $\cdot \cdot$ & - . & 4.691 & 7.691 & - & - & - & 12,382 \\
\hline $\begin{array}{l}\text { CAL IFORNIA: } \\
\text { NORTHERN. } \\
\text { SAN FRANCISCO }: \\
\text { MONTEREY. } \\
\text { SANTA BARBAंRA }\end{array}$ & $: \dot{:}$ & : & $\therefore$ & - & $\begin{array}{l}4,313 \\
1,735 \\
721 \\
156 \\
\end{array}$ & $\begin{array}{l}- \\
- \\
-\end{array}$ & $\begin{array}{l}\overline{-} \\
\bar{z}\end{array}$ & $\begin{array}{l}- \\
-\end{array}$ & $\begin{array}{r}4,313 \\
1,735 \\
721 \\
156 \\
\end{array}$ \\
\hline TOTAL. $\cdot \cdot$ & . & $\cdot \cdot$ & - $\cdot$ & - & 6.925 & - & - & $=$ & 6.925 \\
\hline GRANO TOTAL. & 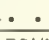 & $\cdot \cdot$ & . . & 100,650 & 28,787 & 37 & 748 & 9.478 & 202.004 \\
\hline
\end{tabular}

$1 /$ LESS THAN 500 POUNOS.

NDTE:--IN ALASKA. LANOINGS TAKEN 8Y HAUL SEINES ARE INCLUOÉO WITH THOSE TAKEN BY PURSE SEINES. 


\section{ATLANTIC COAST TUNA FISHERY, 1975}

Landings of tuna along the Atlantic Coast of 4.9 million pounds valued at $\$ 1.8$ million were up 2.5 million pounds (102 percent) and $\$ 797,000$ (80 percent) over 1974. Larger landings of bluefin tuna in Massachusetts and New Jersey were the reason for the increase in volume. Landings of bluefin tuna in Massachusetts ( 2.2 million pounds) increased 78 percent and in New Jersey ( 2.5 million pounds) increased 188 percent. Fishermen received an average price of 37 cents a pound for bluefin tuna in 1975 compared to 41 cents in 1974.

Purse seines took 72 percent of the harvest; lines, 15 percent; harpoons, 12 percent. An negligible amount was taken by haul seines, otter trawls, midwater trawls, pound nets, floating traps, and gill nets.

\section{SUMMARY OF ATLANTIC COAST TUNA LANDINGS, 1975}

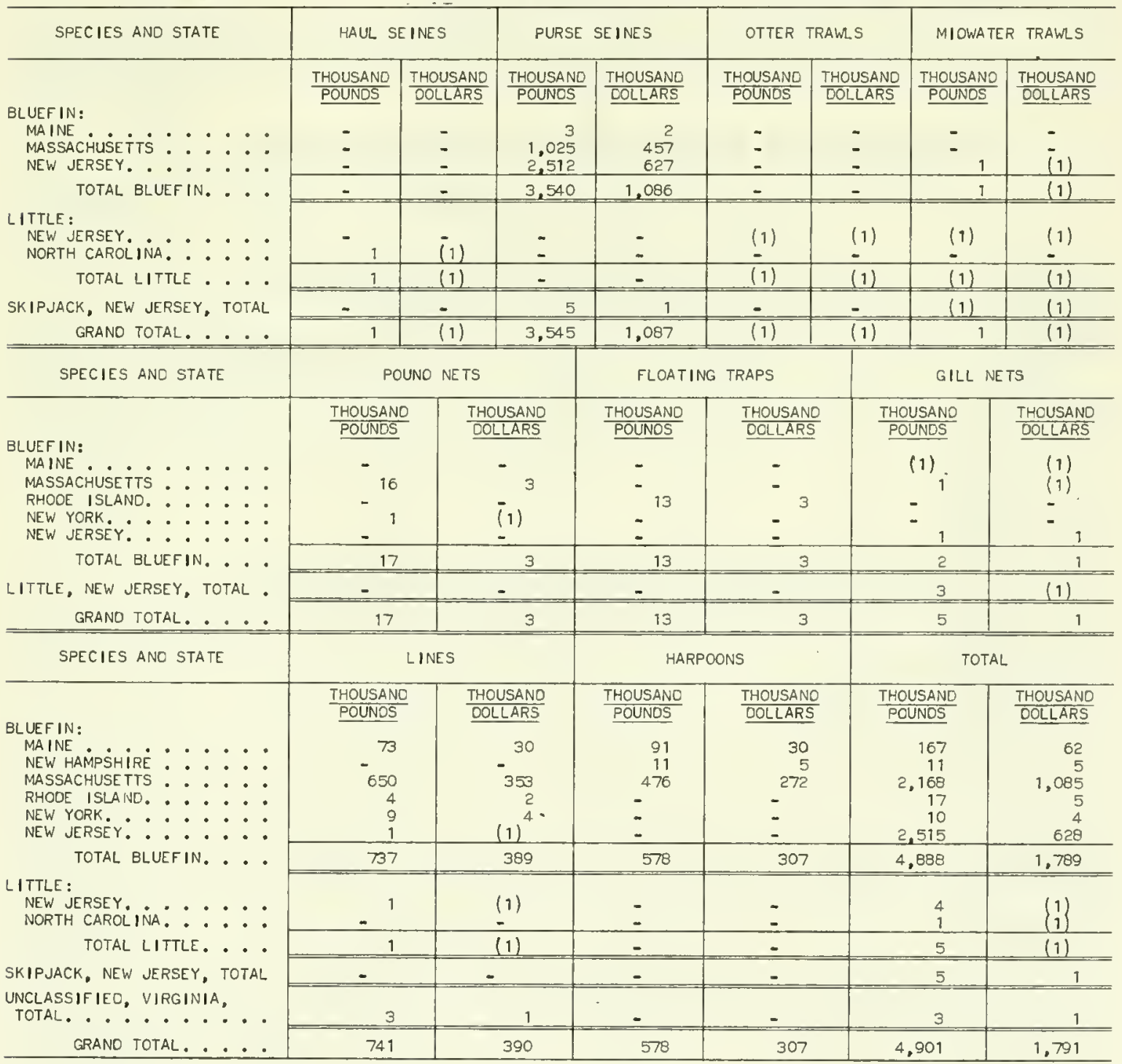

1) LESS THAN 500 POUNCS OR $\$ 500$. 


\section{PACIFIC TUNA FISHERY, 1975}

Domestic landings of tuna at Pacific Coast and Hawaii ports were 387.6 million pounds worth $\$ 105.1$ million, decreases of 2.2 million pounds and $\$ 13.2$ million compared with 1974 . Landings of albacore tuna (49.0 million pounds) ceclined 11 percent and yellowfin $(242.0$ million pounds) declined 5 percent. Landings of bluefin tuna (16.4 million pounds) increased 41 percent and skipjack tuna (79.5 million pounds) increased 16 percent.

The Inter-American Tropical Tuna Commission (IATTC) set an international quota for the yellowfin tuna fishery in the regulatory area of the eastern Pacific Ocean for 1975 of 175,000 short tons with allowances for the increments of 10,000 tons each should data from the fishery warrant such increases. In 1975 the season on yellowfin opened on January 1. The quota was easily reached, and the season was closed March 27. During the closed season the IATTC allowed small vessels ( 400 tons carrying capacity, all member nations) to catch 6,000 tons of yellowfin. The commission also granted permission to one member nation to caich an additional 10,000 tons of yellowfin during the closed season.

Purse seines, the principal gear used in taking yellowfin, skipjack, and bluefin accounted for 81 percent of the landings. Hand and troll lines, used mainly in taking albacore, accounted for almost all the rest. Gill nets and other unspecified gears took a negligible quantity.

\section{SUMMARY OF PACIFIC TUNA OPERATING UNITS, 1975}

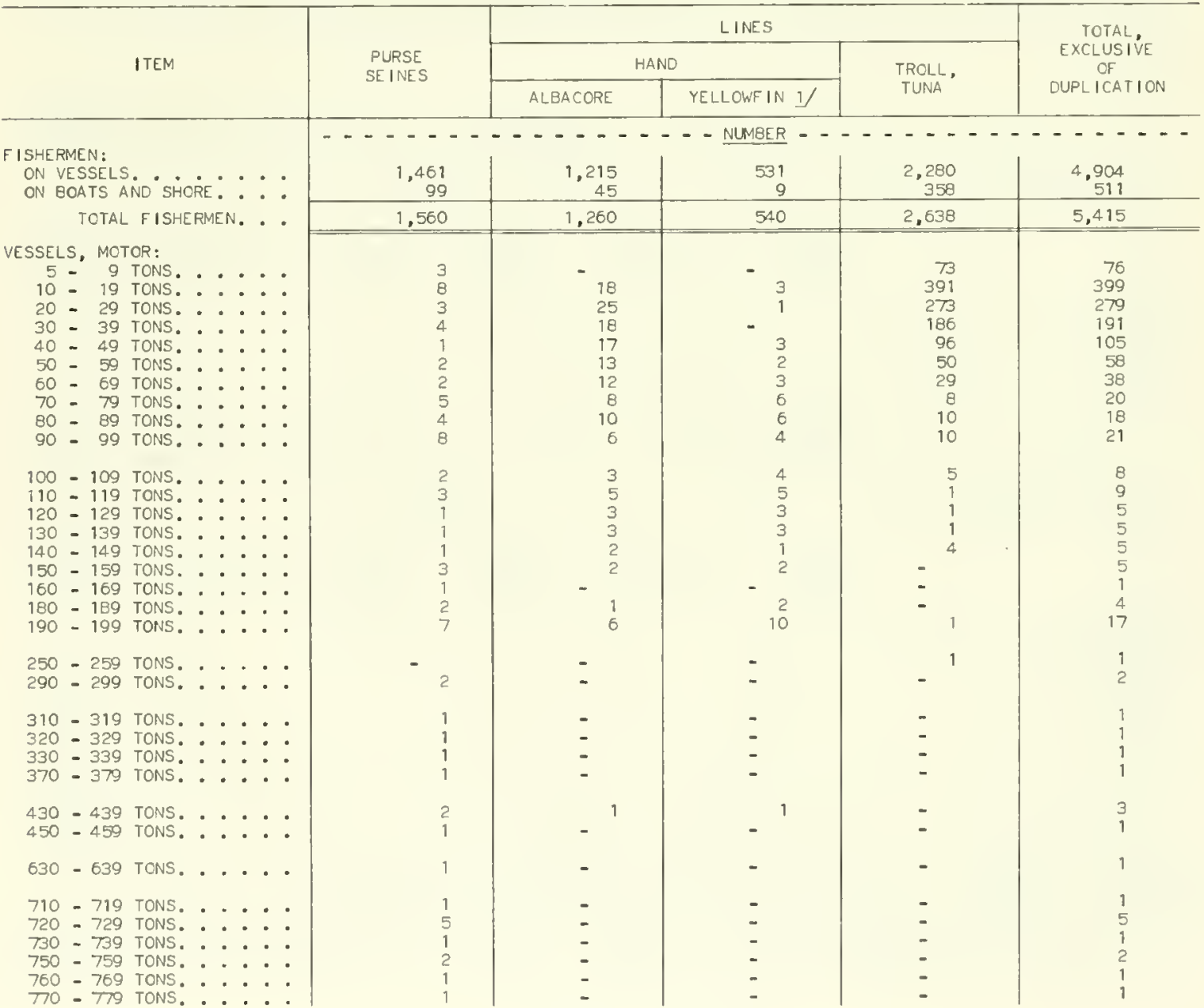




\section{SUMMARY OF PACIFIC TUNA OPERATING UNITS, 1975 - Continued}

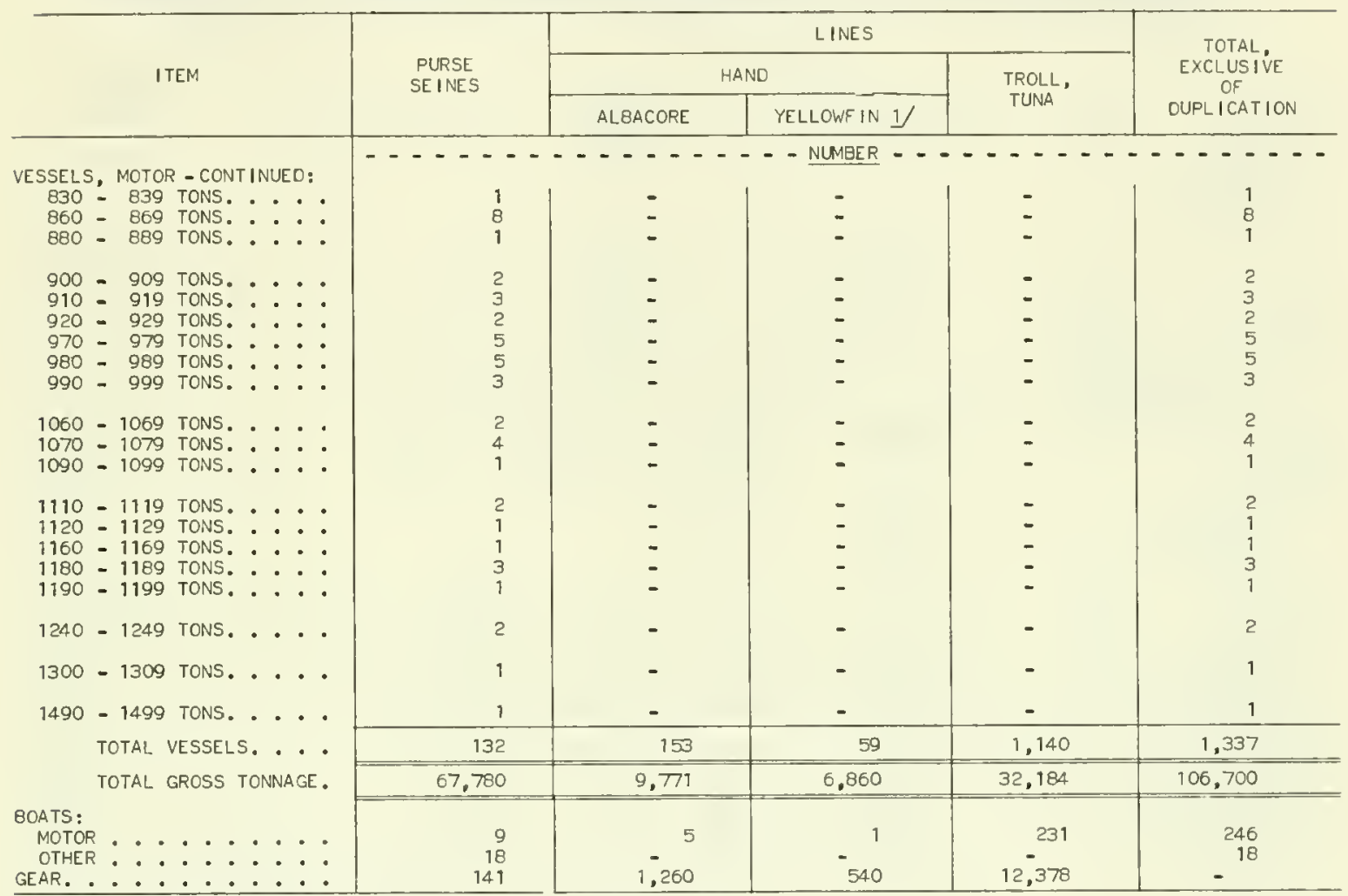

$1 /$ VESSELS OF 50 TONS OR MORE CAPACITY ARE CONSIDEREO CLIPPER CRAFT.

NOTE:--DOES NOT INCLUDE GILL NETS AND UNCLASSIFIED GEAR.

SUMMARY OF PACIFIC TUNA LANDINGS, 1975

\begin{tabular}{|c|c|c|c|c|}
\hline $\begin{array}{l}\text { SPECIES, STATE, } \\
\text { AND DISTRICT }\end{array}$ & \multicolumn{2}{|c|}{ PURSE SEINES } & \multicolumn{2}{|c|}{ GILL NETS } \\
\hline \multirow{4}{*}{ 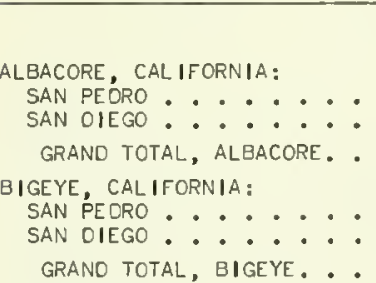 } & $\begin{array}{r}\frac{\text { THOUSANO }}{\text { POUNOS }} \\
84 \\
2 \\
\end{array}$ & $\begin{array}{c}\frac{\text { THOUSAND }}{\text { OOLLARS }} \\
(1)^{27}\end{array}$ & $\begin{array}{r}\frac{\text { THOUSANO }}{\text { POUNOS }} \\
-\quad 1 \\
-\quad\end{array}$ & $\frac{\frac{\text { THOUSANO }}{\text { DOLLARS }}}{(1)}$ \\
\hline & 86 & 27 & 1 & (1) \\
\hline & $\begin{array}{r}344 \\
41 \\
\end{array}$ & $\begin{array}{l}86 \\
10 \\
\end{array}$ & 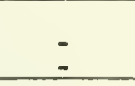 & - \\
\hline & 385 & 96 & & - \\
\hline 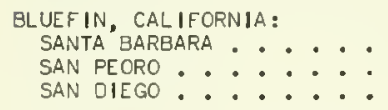 & $\begin{array}{r}362 \\
12,439 \\
3,493 \\
\end{array}$ & $\begin{array}{r}87 \\
3,076 \\
836 \\
\end{array}$ & $\begin{array}{l}- \\
-\end{array}$ & $(1)$ \\
\hline GRAND TOTAL, BLUEFIN . . & 16,294 & 3,999 & 1 & (1) \\
\hline $\begin{array}{l}\text { SKIPJACK: } \\
\text { OREGON, COLUMBIA RIVER. . }\end{array}$ & 256 & 58 & - & $=$ \\
\hline $\begin{array}{l}\text { CALIFORNIA: } \\
\text { SAN PEDRO }: \cdots: \cdots \\
\text { SAN OIEGO }: \therefore .\end{array}$ & $\begin{array}{l}49,432 \\
12,613\end{array}$ & $\begin{array}{r}11,408 \\
2,843 \\
\end{array}$ & 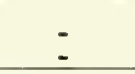 & $=$ \\
\hline TOTAL. . . . . . & 62,045 & 14,251 & - & - \\
\hline 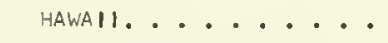 & - & - & (1) & (1) \\
\hline GRANO TOTAL, SKIPJACK. . & 62,301 & 14,309 & (1) & (1) \\
\hline
\end{tabular}




\section{SUMMARY OF PACIFIC TUNA LANDINGS, 1975 - Continued}

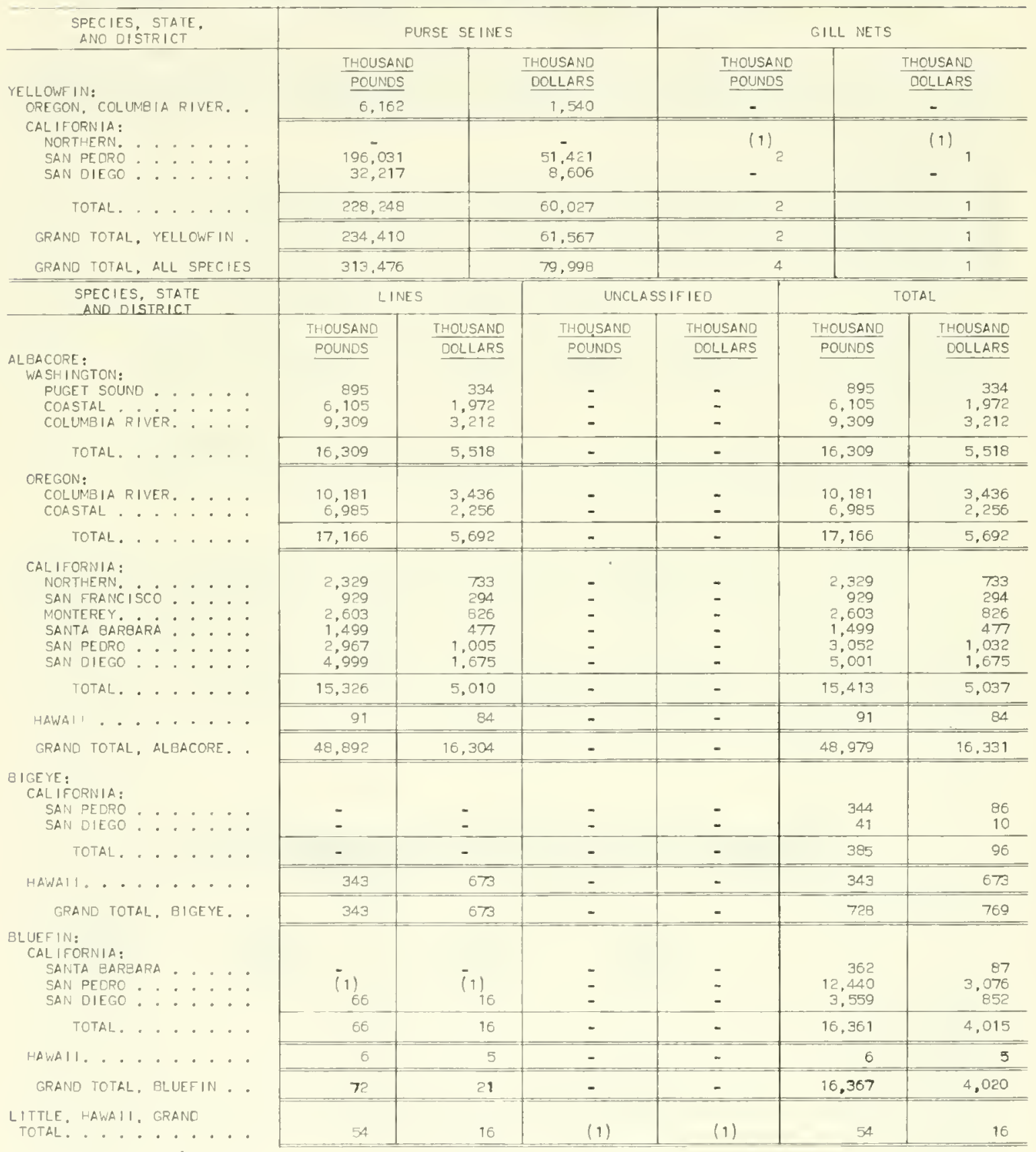

SEE FOOTNOTE AT END OF TABLE.

(CONTINUED ON NEXT PAGE) 


\section{SUMMARY OF PACIFIC TUNA LANDINGS, 1975 - Continued}

\begin{tabular}{|c|c|c|c|c|c|c|}
\hline \multirow{2}{*}{$\begin{array}{l}\text { SPECIES, STATE } \\
\text { AND DISTRICT }\end{array}$} & \multicolumn{2}{|c|}{ LINES } & \multicolumn{2}{|c|}{ UNCLASSIFIED } & \multicolumn{2}{|c|}{ TOTAL } \\
\hline & $\frac{\text { THOUSANO }}{\text { POUNDS }}$ & $\frac{\text { THOUSAND }}{\text { DOLLARS }}$ & $\frac{\text { THOUSANO }}{\text { POUNOS }}$ & $\frac{\text { THOUSANO }}{\text { DOLLARS }}$ & $\frac{\text { THOUSAND }}{\text { POUNDS }}$ & $\frac{\text { THOUSAND }}{\text { OOLLARS }}$ \\
\hline $\begin{array}{l}\text { SKIPJACK: } \\
\text { OREGON, COLUMBIA RIVER. }\end{array}$ & - & - & - & - & 256 & 58 \\
\hline $\begin{array}{l}\text { CALIFORNIA: } \\
\text { SAN PEDRO } \ldots \ldots \\
\text { SAN DIEGD }: \ldots . .\end{array}$ & $\begin{array}{l}7,664 \\
4,536\end{array}$ & $\begin{array}{l}1,793 \\
1,054\end{array}$ & - & $\overline{-}$ & $\begin{array}{l}57,096 \\
17,149\end{array}$ & $\begin{array}{r}13,201 \\
3,897\end{array}$ \\
\hline TOTAL. . . . . . & 12,200 & 2,847 & - & - & 74.245 & 17,098 \\
\hline 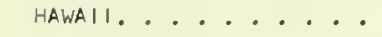 & 5,024 & 2,283 & (1) & (1) & 5,024 & 2,283 \\
\hline GRAND TOTAL, SKIPJACK. . & 17,224 & 5,130 & (1) & (1) & 79,525 & 19,439 \\
\hline $\begin{array}{l}\text { YELLOWF IN: } \\
\text { OREGON, COLLMBIA RIVER. . }\end{array}$ & - & - & - & - & 6,162 & 1,540 \\
\hline $\begin{array}{l}\text { CALIFORNIA: } \\
\text { NORTHERN } \\
\text { SAN PEDRO } \\
\text { SAN OIEGO }\end{array}$ & 4,117 & $\begin{array}{r}-062 \\
475\end{array}$ & $\overline{-}$ & - & $\begin{array}{c}(1) \\
200,150 \\
34,102\end{array}$ & $\begin{array}{l}(1) \\
52,484 \\
9,081\end{array}$ \\
\hline TOTAL. ...... & 6,002 & 1,537 & - & - & 234,252 & 61,565 \\
\hline 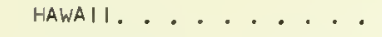 & 1.554 & 1,369 & 3 & 2 & 1,557 & 1,371 \\
\hline GRAND TOTAL, YELLOWF IN . & 7.556 & 2,906 & 3 & 2 & 241,971 & 64,476 \\
\hline $\begin{array}{l}\text { UNCLASSIFIEO, HAWAII, } \\
\text { GRAND TOTAL. . . . . }\end{array}$ & 2 & 2 & - & - & 2 & 2 \\
\hline GRAND TOTAL, ALL SPECIES & 74,143 & 25,052 & 3 & 2 & 387.626 & 105,053 \\
\hline
\end{tabular}

1) LESS THAN 500 POUNOS OR $\$ 500$. 


\section{LANDINGS OF TUNA BY U.S. FLAG VESSELS BY OCEAN OF CAPTURE AND SPECIES, 1960-75}

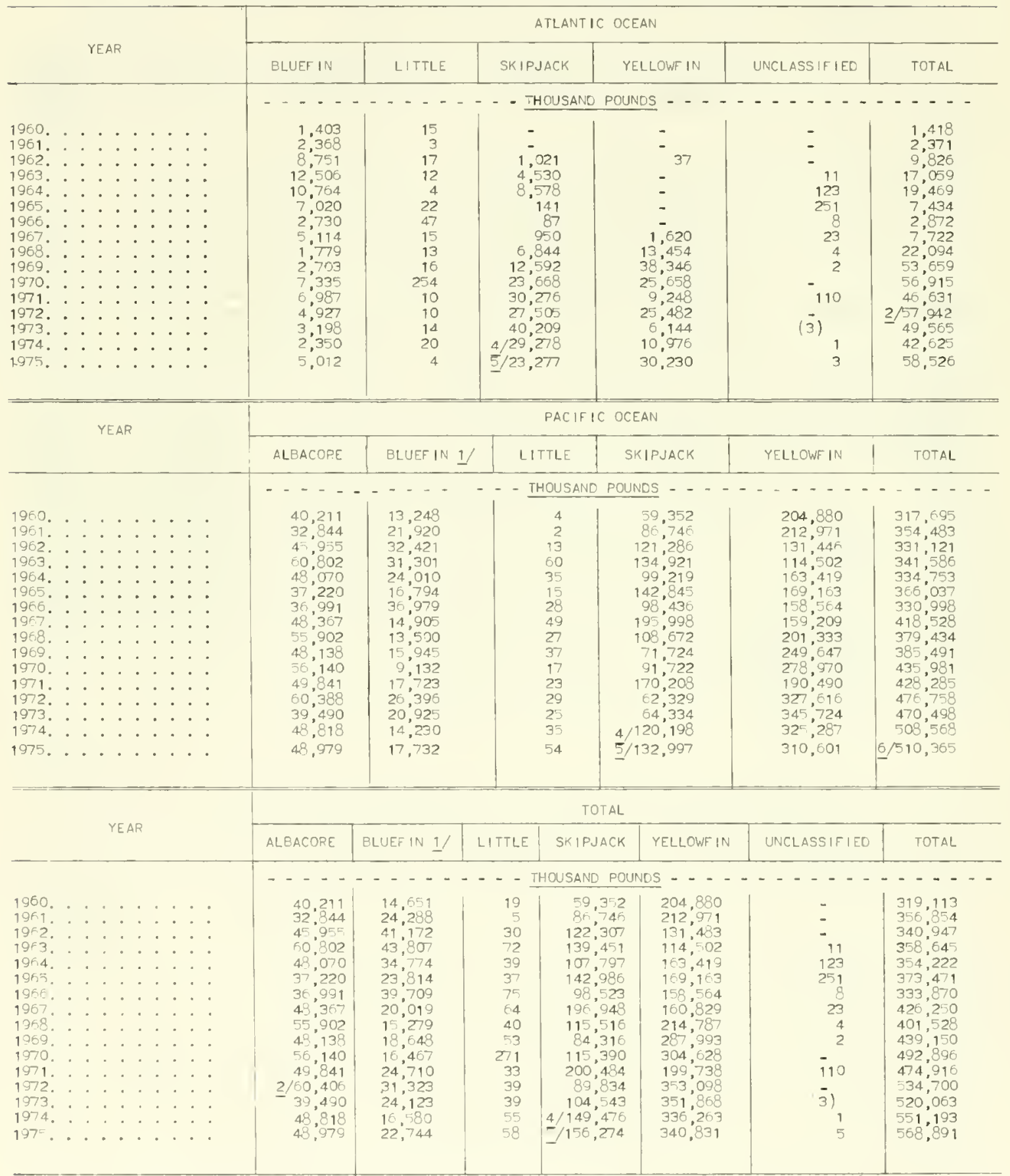

\footnotetext{
1) INCLUDES OATA ON LANOINGS OF BIGEYE TUNA IN HAWAII.
2 INCLUOES 98,000 POUNOS OF ALBACORE TAKEN IN THE ATLANTIC OCEAN.

3) LESS THAN OO POUNOS.

4) INCLUOES 60,000 POUNOS OF BLACK SKIPJACK IN THE ATLAMTIC OCEAN ANO 86,000 POUIIOS IN THE PACIFIC OCEAN.

5, INCLUOES nO, 000 POUNDS OF ELACK SKIPJACK IN THE ATLANTIC OCEAN AND 62,000 POUNDS IN THE PACIFIC OCEAN

6) INCLUDES 2,000 POUNDS OF UNCLASSIFIED TUNA.

HOTE:--INCLUDES LANDINGS IN PUERTO RICN, AMERICAN SAMOA, AND AT FOREIGN PORTS F ZR EXPORT TO FOREIGN COUNTRIES.
} 


\section{U.S. MENHADEN FISHERY, 1975}

Menhaden landings of 1.8 billion pounds worth $\$ 49.3$ million declined 197.8 million pounds and $\$ 17.6$ million compared with 1974 . The sharp drop in value reflects a decline in prices for fish meal and fish oil from the abnormally high levels of 1974 .

Menhaden landings in the Gulf States were 1.2 billion pounds in 1975 , down 99 million pounds compared with 1974, but the third largest on record. Landings of Atlantic menhaden were 606.2 million pounds in 1975, down 98.8 million pounds. The Gulf States accounted for 66 percent of the total landings, followed by the Chesapeake States (18 percent); the South Atlantic States ( 9 percent); the Middle Atlantic States ( 4 percent); and New England States ( 3 percent).

Purse seines accounted for 82 percent of the landings in 1974 . There were 1,906 fishermen, 123 vessels, and 215 boats employed in the menhaden purse seine fishery.

\section{SUMMARY OF MENHADEN PURSE SEINE VESSELS, BY TONNAGE GROUPS, 1975}

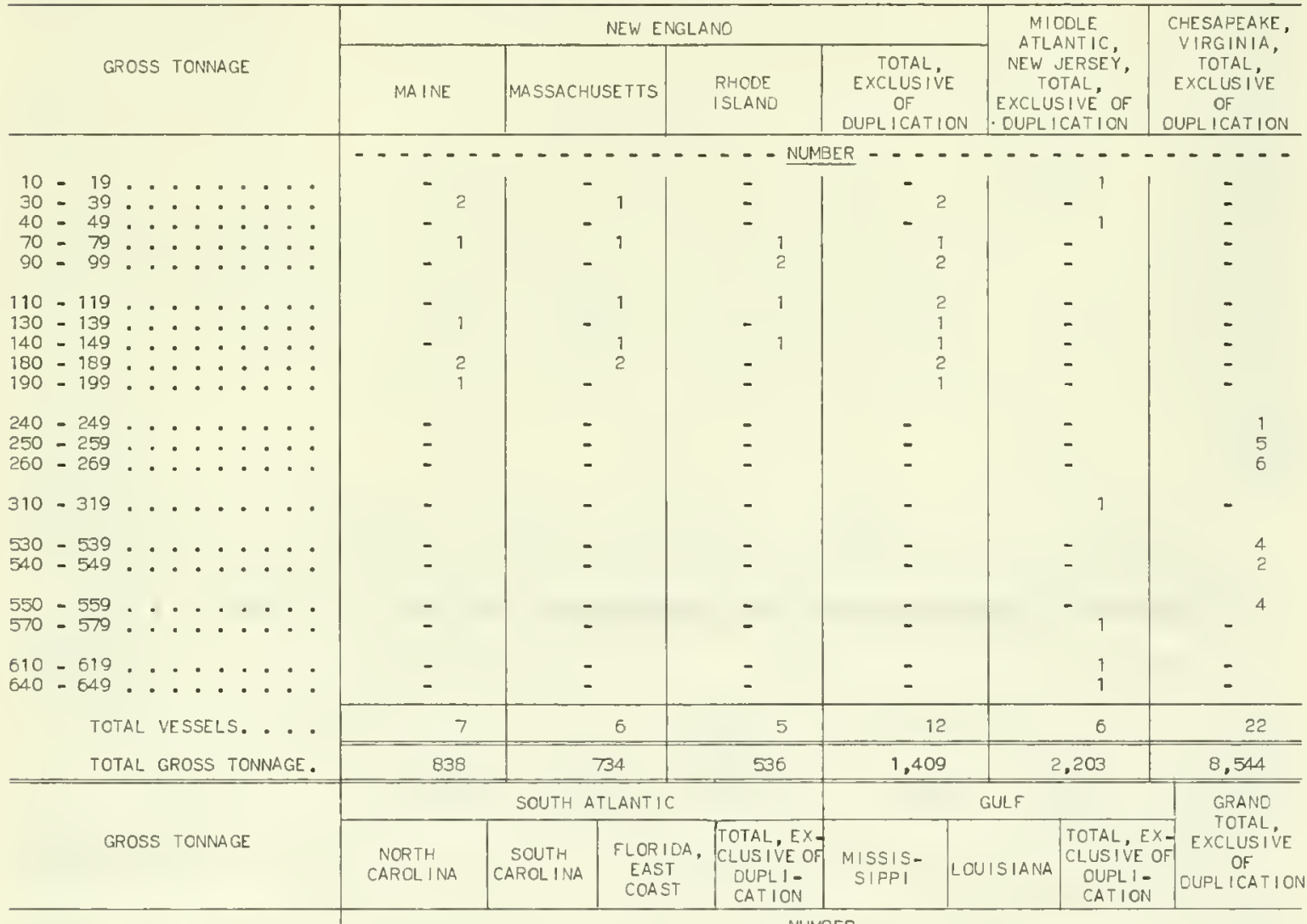

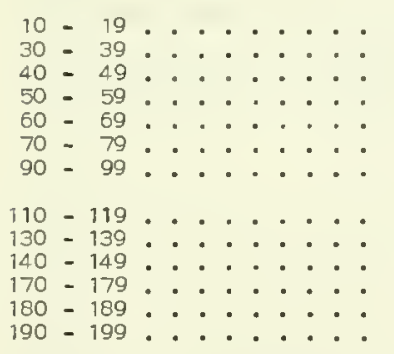

$\ldots \ldots \ldots \ldots$ NUMBER
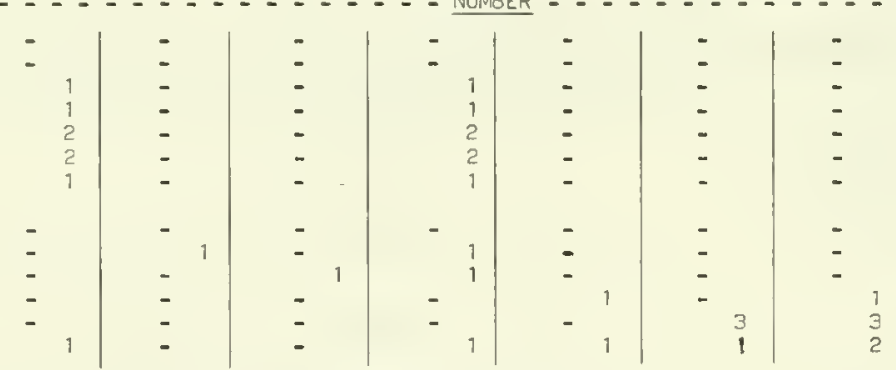

(CONT INUEO ON NEXT PAGE) 


\section{SUMMARY OF MENHADEN PURSE SEINE VESSELS, BY TONNAGE GROUPS, 1975 - Continued}

\begin{tabular}{|c|c|c|c|c|c|c|c|c|}
\hline \multirow[b]{2}{*}{ GROSS TONNAGE } & \multicolumn{4}{|c|}{ SOUTH ATLANTIC } & \multicolumn{3}{|c|}{ GULF } & \multirow{2}{*}{$\begin{array}{l}\text { GRANO } \\
\text { TOTAL, } \\
\text { EXCLUSIVE } \\
\text { OF } \\
\text { OUPLI- } \\
\text { CATION }\end{array}$} \\
\hline & $\begin{array}{c}\text { NORTH } \\
\text { CAROL INA }\end{array}$ & $\begin{array}{l}\text { SOUTH } \\
\text { CAROL INA }\end{array}$ & $\begin{array}{l}\text { FLORIDA, } \\
\text { EAST } \\
\text { COAST }\end{array}$ & $\begin{array}{l}\text { TOTAL, EX } \\
\text { CLUSIVE OF } \\
\text { OULL - - } \\
\text { CATION }\end{array}$ & $\begin{array}{l}\text { MISSIS- } \\
\text { SIPPI }\end{array}$ & LOUISIANA & $\begin{array}{l}\text { TOTAL, EX- } \\
\text { CLUSIVE OF } \\
\text { OUPL I-- } \\
\text { CATION }\end{array}$ & \\
\hline 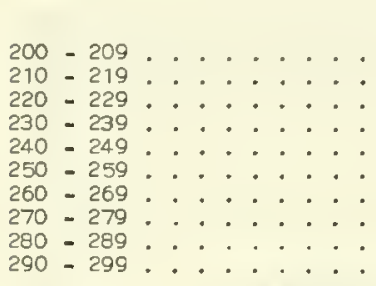 & 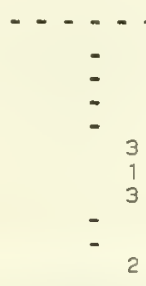 & $\begin{array}{l}\cdots \\
= \\
= \\
= \\
= \\
=\end{array}$ & $\begin{array}{l}\cdots \\
\vdots \\
\vdots \\
\vdots \\
\vdots \\
- \\
-\end{array}$ & $\mid \begin{array}{c}-\cdots \\
- \\
- \\
3 \\
1 \\
- \\
- \\
3\end{array}$ & 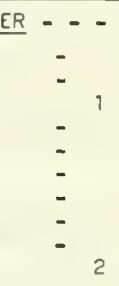 & \begin{tabular}{|c|}
$\cdots$ \\
$\cdots$ \\
2 \\
2 \\
1 \\
3 \\
1 \\
1 \\
1 \\
1 \\
3
\end{tabular} & $\begin{array}{r}\cdots \\
2 \\
3 \\
1 \\
3 \\
1 \\
1 \\
1 \\
1 \\
5\end{array}$ & $\begin{array}{c}\cdots \\
1 \\
2 \\
3 \\
1 \\
6 \\
7 \\
8 \\
1 \\
1 \\
6\end{array}$ \\
\hline 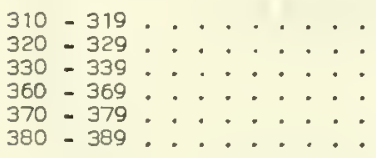 & $\begin{array}{l}\bar{z} \\
\vdots \\
\vdots\end{array}$ & $\begin{array}{l}\bar{\vdots} \\
\overline{-} \\
\overline{-}\end{array}$ & $\begin{array}{l}\overline{-} \\
\vdots \\
-\end{array}$ & $\begin{array}{l}- \\
\vdots \\
-\end{array}$ & $\begin{array}{l}\vdots \\
\vdots \\
\vdots\end{array}$ & $\begin{array}{l}1 \\
1 \\
1 \\
2 \\
2 \\
2\end{array}$ & $\begin{array}{l}1 \\
1 \\
1 \\
2 \\
2 \\
2\end{array}$ & $\begin{array}{l}2 \\
1 \\
1 \\
2 \\
2 \\
2\end{array}$ \\
\hline 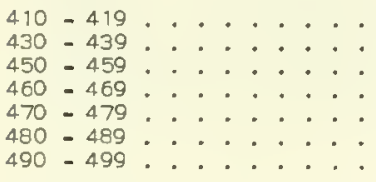 & $\begin{array}{l}- \\
\vdots \\
\vdots \\
-\end{array}$ & $\begin{array}{l}\bar{z} \\
\vdots \\
\overline{-} \\
\overline{-}\end{array}$ & $\begin{array}{l}\overline{-} \\
\vdots \\
\vdots\end{array}$ & $\begin{array}{l}- \\
\vdots \\
\vdots \\
-\end{array}$ & $\begin{array}{l}- \\
- \\
= \\
\vdots\end{array}$ & $\begin{array}{r}2 \\
1 \\
-\quad \\
1 \\
3 \\
2 \\
2 \\
2\end{array}$ & $\begin{array}{l}2 \\
1 \\
1 \\
1 \\
3 \\
2 \\
2 \\
2\end{array}$ & $\begin{array}{l}2 \\
1 \\
1 \\
1 \\
3 \\
2 \\
2 \\
2\end{array}$ \\
\hline 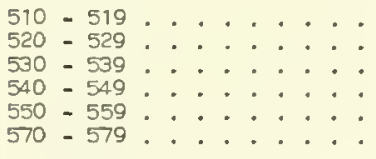 & $\begin{array}{l}- \\
\overline{-} \\
\overline{-}\end{array}$ & $\begin{array}{l}\bar{\vdots} \\
\vdots \\
\overline{-}\end{array}$ & $\begin{array}{l}\overline{-} \\
\overline{-} \\
\overline{-}\end{array}$ & $\begin{array}{l}\overline{-} \\
\vdots \\
-\end{array}$ & $\begin{array}{r}- \\
- \\
-\quad 7 \\
-\quad 1 \\
-\quad 1\end{array}$ & $\begin{array}{r}2 \\
2 \\
11 \\
-\quad 1 \\
-\quad 1\end{array}$ & $\begin{array}{r}2 \\
3 \\
12 \\
-\quad 1 \\
-\quad 1\end{array}$ & $\begin{array}{r}2 \\
3 \\
16 \\
2 \\
2 \\
5 \\
1\end{array}$ \\
\hline 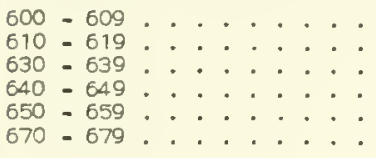 & $\begin{array}{l}- \\
- \\
- \\
- \\
1 \\
1\end{array}$ & $\begin{array}{l}\overline{-} \\
\overline{-} \\
\overline{-}\end{array}$ & $\begin{array}{l}\overline{-} \\
\overline{-} \\
\overline{-}\end{array}$ & $\begin{array}{l}- \\
- \\
- \\
- \\
1 \\
1\end{array}$ & $\begin{array}{l}\overline{-} \\
\overline{-} \\
\overline{-}\end{array}$ & $\begin{array}{r}1 \\
-\quad 1 \\
-\quad 1 \\
-\quad\end{array}$ & $\begin{array}{r}1 \\
-\quad 1 \\
-\quad 1 \\
-\quad 1 \\
-\end{array}$ & $\begin{array}{l}1 \\
1 \\
1 \\
2 \\
1 \\
1\end{array}$ \\
\hline TOTAL VESSELS. . . . & 20 & 1 & 2 & 23 & 16 & 58 & 66 & 123 \\
\hline TOTAL GROSS TONNAGE. & 4,993 & 135 & 348 & 5,476 & 7,001 & 23,314 & 26,014 & 41,770 \\
\hline
\end{tabular}

\section{SUMMARY OF MENHADEN PURSE SEINE OPERATING UNITS, 1975}

\begin{tabular}{|c|c|c|c|c|c|c|}
\hline \multirow{2}{*}{ AREA AND STATE } & \multirow{2}{*}{\multicolumn{2}{|c|}{ VESSELS }} & \multicolumn{2}{|c|}{ BOATS } & \multirow{2}{*}{ FISHERMEN } & \multirow{2}{*}{$\begin{array}{l}\text { PURSE } \\
\text { SEINES }\end{array}$} \\
\hline & & & MOTOR & OTHER & & \\
\hline 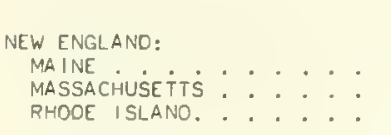 & $\begin{array}{r}\text { AUMBER } \\
7 \\
6 \\
5 \\
\end{array}$ & $\frac{\text { GROSS }}{\text { IONNAGE }} \begin{array}{r}838 \\
734 \\
536\end{array}$ & $\begin{array}{r}-\cdots \\
7 \\
6 \\
10 \\
\end{array}$ & $\begin{array}{r}--1 \\
1 \\
-\quad 6 \\
-\end{array}$ & $\begin{array}{c}R-\cdots \\
38 \\
40 \\
35\end{array}$ & $\begin{array}{r}-\cdots \\
7 \\
6 \\
5\end{array}$ \\
\hline $\begin{array}{l}\text { TOTAL, EXCLUSIVE OF } \\
\text { DUPLICATION ..... }\end{array}$ & 12 & 1,409 & 16 & 2 & 75 & 12 \\
\hline 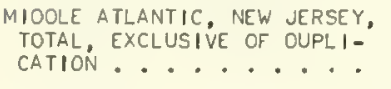 & 6 & 2,203 & 7 & - & 80 & 6 \\
\hline $\begin{array}{l}\text { CHESAPEAKE, VIRGINIA, TOTAL, } \\
\text { EXCLUSIVE OF DUPLICÁTION. }\end{array}$ & 22 & 8,544 & 26 & - & 354 & 22 \\
\hline $\begin{array}{l}\text { SOUTH ATLANTIC: } \\
\text { NORTH CAROL INA.: }: \cdot \\
\text { SOUTH CAROLINA }: \\
\text { FLORIOA, EAST COAST }::\end{array}$ & $\begin{array}{r}20 \\
1 \\
2 \\
\end{array}$ & $\begin{array}{r}4,993 \\
135 \\
348 \\
\end{array}$ & $\begin{array}{r}40 \\
2 \\
4\end{array}$ & - & $\begin{array}{r}334 \\
8 \\
34 \\
\end{array}$ & $\begin{array}{r}20 \\
1 \\
2\end{array}$ \\
\hline $\begin{array}{l}\text { TOTAL, EXCLUSIVE OF } \\
\text { OUPL ICATION } \ldots . \cdots\end{array}$ & 23 & 5,476 & 44 & - & 376 & 23 \\
\hline $\begin{array}{l}\text { GULF : } \\
\text { MISSISSIPPI . . . : } \\
\text { LOUISIANA. } . . . .\end{array}$ & $\begin{array}{l}16 \\
58 \\
\end{array}$ & $\begin{array}{r}7,001 \\
23,314 \\
\end{array}$ & $\begin{array}{r}32 \\
116 \\
\end{array}$ & - & $\begin{array}{l}269 \\
982 \\
\end{array}$ & $\begin{array}{r}16 \\
58 \\
\end{array}$ \\
\hline $\begin{array}{l}\text { TOTAL, EXCLUSIVE OF } \\
\text { OUPLICATION }\end{array}$ & 66 & 26,014 & 132 & - & 1,723 & 56 \\
\hline $\begin{array}{l}\text { GRAND TOTAL, EXCLU- } \\
\text { SIVE OF OUPL ICATION. }\end{array}$ & 123 & 41,770 & 213 & 2 & 1,906 & 123 \\
\hline
\end{tabular}




\section{SUMMARY OF MENHADEN LANDINGS, 1975}

\begin{tabular}{|c|c|c|c|c|c|c|}
\hline AREA ANO STATE & \multicolumn{2}{|c|}{ HAUL SEINES } & \multicolumn{2}{|c|}{ STOP SEINES } & \multicolumn{2}{|c|}{ PURSE SEINES } \\
\hline NEW ENGLAND: & $\frac{\text { THOUSAND }}{\text { POUNDS }}$ & $\frac{\text { THOUSANO }}{\text { DOLLARS }}$ & $\frac{\text { THOUSANO }}{\text { POUNDS }}$ & $\frac{\text { THOUSAND }}{\text { OOLIARS }}$ & $\frac{\text { THOUSANO }}{\text { POUNDS }}$ & $\frac{\text { THOUSAND }}{\text { DOLLARS }}$ \\
\hline MAINE & - & - & - & - & $\begin{array}{l}13,958 \\
20,771\end{array}$ & $\begin{array}{l}196 \\
274\end{array}$ \\
\hline $\begin{array}{l}\text { RHODE ISLANO }: \cdots: \therefore \\
\text { CONNECTICUT: }: \cdots\end{array}$ & -15 & -1 & - & - & 15,433 & -189 \\
\hline TOTAL....... & 15 & 1 & - & - & 50,162 & 659 \\
\hline $\begin{array}{l}\text { MIODLE ATLANTIC, NEW JERSEY, } \\
\text { TOTAL. } . \cdots \cdots \cdot \cdots\end{array}$ & - & - & - & - & 63,864 & 7.626 \\
\hline $\begin{array}{l}\text { CHESAPEAKE: } \\
\text { MARYLAND: }: \cdot: \cdot: \cdot: \\
\text { VIRGINIA: }: \cdot: \cdot: \cdot\end{array}$ & $\begin{array}{r}19 \\
240 \\
\end{array}$ & $(1)_{6}$ & 279,186 & $\overline{6,979}$ & - & - \\
\hline TOTAL. . . . . . & 259 & 6 & 279,186 & 6,979 & - & - \\
\hline 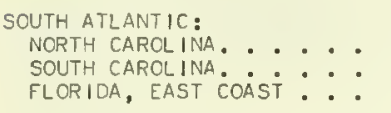 & - & - & $\overline{-}$ & $\overline{-}$ & $\begin{array}{r}153,805 \\
334 \\
11,510 \\
\end{array}$ & $\begin{array}{r}3.259 \\
14 \\
253 \\
\end{array}$ \\
\hline TOTAL. . . . . & 3 & (1) & - & - & 165,649 & 3,526 \\
\hline $\begin{array}{l}\text { GULF: } \\
\text { FLORIDA, WEST COAST }:: \\
\text { MISSISSIPPI }:: \therefore: \\
\text { LOUISIANA }: \cdots:\end{array}$ & 249 & $\mathbf{-}^{8}$ & $\overline{-}$ & $\overline{-}$ & $\begin{array}{r}101 \\
212,071 \\
984,106 \\
\end{array}$ & $\begin{array}{r}3 \\
6,057 \\
29,379 \\
\end{array}$ \\
\hline TOTAL. . . . . & 249 & 8 & - & - & $1,196,278$ & 35,449 \\
\hline GRAND TOTAL...... & 526 & 15 & 279,186 & 6,979 & $1,475,953$ & 47.250 \\
\hline AREA AND STATE & \multicolumn{2}{|c|}{ OTTER TRAWLS } & \multicolumn{2}{|c|}{ MIOWATER TRAWLS } & \multicolumn{2}{|c|}{ POUND NETS } \\
\hline $\begin{array}{l}\text { NEW ENGLAND, MASSACHUSETTS, } \\
\text { TOTAL. } . \cdots \cdots\end{array}$ & $\frac{\frac{\text { THOUSAND }}{\text { POUNDS }}}{-}$ & $\frac{\text { THOUSAND }}{\text { DOLLARS }}$ & $\frac{\frac{\text { THOUSANO }}{\text { POUNOS }}}{-}$ & $\frac{\frac{\text { THOUSAND }}{\text { DOLLARS }}}{-}$ & $\frac{\text { THOUSAND }}{\frac{\text { POUNOS }}{3}}$ & $\frac{\frac{\text { THOUSANO }}{\text { OOLLARS }}}{(1)}$ \\
\hline $\begin{array}{l}\text { MIODLE ATLANTIC: } \\
\text { NEW YORK. }: \vdots: \therefore: \\
\text { NEW JERSEY: }: \vdots:\end{array}$ & -56 & -2 & -71 & -3 & $\begin{array}{r}815 \\
1,890 \\
\end{array}$ & $\begin{array}{l}33 \\
85\end{array}$ \\
\hline TOTAL. . . . . . & 56 & 2 & 71 & 3 & 2,705 & 118 \\
\hline $\begin{array}{l}\text { CHESAPEAKE: } \\
\text { MARYLAND: }: \cdots: \therefore: \\
\text { VIRGINIA: }:: \therefore\end{array}$ & - & $\dot{-}$ & - & - & $\begin{array}{r}5,842 \\
36,318 \\
\end{array}$ & $\begin{array}{l}157 \\
731 \\
\end{array}$ \\
\hline TOTAL. ..... & - & - & - & - & 42,160 & 888 \\
\hline $\begin{array}{l}\text { SOUTH ATLANTIC, SOUTH CARO- } \\
\text { LINA, TOTAL. } . \cdot \cdots \cdot \cdot\end{array}$ & 6 & $(1)$ & - & - & - & - \\
\hline GRANO TOTAL. . . . & 62 & 2 & 71 & 3 & 44,868 & 1,006 \\
\hline AREA ANO STATE & \multicolumn{2}{|c|}{ FLOAT ING TRAPS } & \multicolumn{2}{|c|}{ FYKE ANO HOOP NETS } & \multicolumn{2}{|c|}{ POTS ANO TRAPS } \\
\hline & $\frac{\text { THOUSAND }}{\underline{\text { POUNDS }}}$ & $\frac{\text { THOUSAND }}{\text { DOLLARS }}$ & $\frac{\text { THOUSANO }}{\text { POUNDS }}$ & $\frac{\text { THOUSAND }}{\text { DOLLARS }}$ & $\frac{\text { THOUSANO }}{\text { POUNDS }}$ & $\frac{\text { THOUSANO }}{\text { OOLLARS }}$ \\
\hline $\begin{array}{l}\text { NEW ENGLAND: } \\
\text { MASSACHUSETTS }: . . . \cdot: \\
\text { RHODE ISLANO. }: . . .\end{array}$ & $\begin{array}{r}41 \\
145 \\
\end{array}$ & $\begin{array}{l}1 \\
6 \\
\end{array}$ & $\begin{array}{l}- \\
-\end{array}$ & - & - & $\overline{-}$ \\
\hline TOTAL. . . . . . . & 186 & 7 & - & - & - & - \\
\hline CHESAPEAKE, MARYLAND, TOTAL & - & - & 2 & (1) & 1 & $(1)$ \\
\hline GRANO TOTAL. . . . & 186 & 7 & 2 & (1) & 1 & (1) \\
\hline
\end{tabular}




\section{SUMMARY OF MENHADEN LANDINGS, 1975 - Continued}

\begin{tabular}{|c|c|c|c|c|c|c|c|c|c|}
\hline \multicolumn{4}{|c|}{ AREA AND STATE } & \multicolumn{2}{|c|}{ GILL NETS } & \multicolumn{2}{|c|}{ TRAMMEL NETS } & \multicolumn{2}{|c|}{ TOTAL } \\
\hline & & & & $\frac{\text { THOUSANO }}{\text { POUNOS }}$ & $\begin{array}{l}\text { THOUSAND } \\
\text { DOLLARS }\end{array}$ & $\frac{\text { THOUSAND }}{\text { POUNOS }}$ & $\frac{\text { THOUSANO }}{\text { OOLLARS }}$ & $\frac{\text { THOUSANO }}{\text { POUNDS }}$ & $\frac{\text { THOUSANO }}{\text { OOLLARS }}$ \\
\hline $\begin{array}{l}\text { NEW ENGLAND: } \\
\text { MA INE. } \\
\text { MASSACHUSEंTTSं } \\
\text { RHOOE ISLANO. }\end{array}$ & $: \dot{:}$ & $\because:$ & $\therefore$ & : & $=$ & 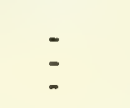 & $\overline{-}$ & $\begin{array}{l}13,958 \\
20,815 \\
15,578\end{array}$ & $\begin{array}{l}196 \\
275 \\
195 \\
\end{array}$ \\
\hline CONNECTICUT - & $\cdot \cdot$ & - · & · & 500 & 24 & - & - & 515 & 25 \\
\hline TOTAL. • & $\cdot \cdot$ & . & . & 500 & 24 & - & - & 50,866 & 691 \\
\hline $\begin{array}{l}\text { MIOOLE ATLANTIC: } \\
\text { NEW YORK.: } \\
\text { NEW JERSEY: } \\
\text { OELAWARE. : }\end{array}$ & $::$ & $: \dot{:}$ & $\therefore$ & $\begin{array}{r}261 \\
53 \\
20 \\
\end{array}$ & $\begin{array}{l}9 \\
3 \\
1 \\
\end{array}$ & - & - & $\begin{array}{r}1,076 \\
65,934 \\
20 \\
\end{array}$ & $\begin{array}{r}42 \\
1,719 \\
1\end{array}$ \\
\hline TOTAL. • & $\cdot \cdot$ & $\cdot \cdot$ & • $\cdot$ & 334 & 13 & - & - & 67,030 & 1.762 \\
\hline $\begin{array}{l}\text { CHESAPEAKE: } \\
\text { MARYLAND. } \\
\text { VIRGINIA: }\end{array}$ & $\therefore:$ & : : & $\therefore$ & $\begin{array}{r}242 \\
39 \\
\end{array}$ & $\begin{array}{l}6 \\
1 \\
\end{array}$ & $=$ & - & $\begin{array}{r}6,106 \\
315,783 \\
\end{array}$ & $\begin{array}{r}163 \\
7,717 \\
\end{array}$ \\
\hline TOTAL. & $\cdot \cdot$ & $\cdot \cdot$ & • & 281 & 7 & - & - & 321,889 & 7,880 \\
\hline $\begin{array}{l}\text { SOUTH ATLANTIC: } \\
\text { NORTH CAROL INA } \\
\text { SOUTH CAROL INA } \\
\text { FLORIDA, EAST }\end{array}$ & COAST & $: \dot{ }$ & $\therefore$ & $\begin{array}{l}- \\
- \\
1,237 \\
\end{array}$ & $\begin{array}{l}- \\
- \\
\end{array}$ & - & - & $\begin{array}{r}153,805 \\
340 \\
12,750 \\
\end{array}$ & $\begin{array}{r}3,259 \\
14 \\
298 \\
\end{array}$ \\
\hline TOTAL. . & $\cdot \cdot \cdot$ & - $\cdot$ & - $\cdot$ & 1,237 & 45 & - & - & 166,895 & 3.571 \\
\hline $\begin{array}{l}\text { GULF: } \\
\text { FLORIDA, WEST } \\
\text { MISSISSIPPI. } \\
\text { LOUISIANA. }\end{array}$ & $\begin{array}{l}\text { COAST } \\
\therefore:\end{array}$ & $: \dot{:}$ & $\therefore$ & $e^{108}$ & -5 & $-^{8}$ & $\begin{array}{l} \\
- \\
-\end{array}$ & $\begin{array}{r}466 \\
212,071 \\
984,106 \\
\end{array}$ & $\begin{array}{r}17 \\
6,067 \\
29,379 \\
\end{array}$ \\
\hline TOTAL. . & . & $\cdot$ & . & 108 & 5 & 8 & 1 & $1,196,643$ & 35,463 \\
\hline GRAND TOTA & TAL. . & . . & - & 2,460 & 94 & 8 & 1 & $1,803,323$ & 49,367 \\
\hline
\end{tabular}




\section{U.S. CLAM FISHERY 1975}

Total U.S. landings of all species of clams in 1975 were 113.4 million pounds worth a record $\$ 43.4$ million. This was 8.3 million pounds less, but $\$ 2.0$ million more than in 1974 , the record year for quantity. The reason for the decline in harvest was the 10 percent or 9 million pounds decline in landings of surf clams.

Surf clams, landed mainly in Virginia and New Jersey, accounted for 77 percent of the U.S. production; hard clams, 13 percent; and soft clams, 8 percent. The remainder consisted of cockle, geoduck, ocean quahog, razor, and mixed clams.

The Middle Atlantic States were the major producers of clams with 47 percent of the catch, followed by the Chesapeake States with 41 percent; the New England States with 10 percent; and the South Atlantic and Pacific Coast States with the remaining 2 percent.

Dredges accounted for 81 percent of the U.S. landings of all species, followed by hoes, 7 percent; rakes, 5 percent; and tongs, 4 percent. The rest were taken by otter trawls, midwater trawls, gill nets, shovels, picks, diving outfits, and by hand.

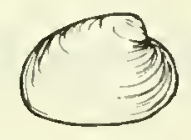

SUMMARY OF CLAM LANDINGS, 1975

\begin{tabular}{|c|c|c|c|c|c|c|c|c|c|c|}
\hline \multicolumn{5}{|c|}{ AREA AND STATE } & \multicolumn{2}{|c|}{ COCKLE } & \multicolumn{2}{|c|}{ GEODUCK } & \multicolumn{2}{|c|}{ HARO } \\
\hline NEW ENGLANO: & & & & & $\frac{\text { THOUSAND }}{\text { POUNDS }}$ & $\frac{\text { THOUSAND }}{\text { DOLLARS }}$ & $\frac{\text { THOUSAND }}{\text { POUNOS }}$ & $\frac{\text { THOUSAND }}{\text { DOLLARS }}$ & $\frac{\text { THOUSAND }}{\text { POUNOS }}$ & $\begin{array}{l}\text { THOUSANO } \\
\text { DOLLARS }\end{array}$ \\
\hline $\begin{array}{l}\text { MA INE } \\
\text { MASSACHUSE TTSS } \\
\text { RHOOE ISLANO. } \\
\text { CONNECTICUT. }\end{array}$ & $: \vdots$ & $\therefore$ & : & : & $\begin{array}{l}- \\
- \\
-\end{array}$ & - & $\begin{array}{l}- \\
- \\
-\end{array}$ & $\begin{array}{l}- \\
- \\
-\end{array}$ & $\begin{array}{r}8 \\
1,110 \\
1,120 \\
120 \\
\end{array}$ & $\begin{array}{r}16 \\
1,759 \\
1,422 \\
100 \\
\end{array}$ \\
\hline TOTAL. . & $\cdot \cdot$ & - $\cdot$ & - & - & - & - & - & - & 2,358 & 3,297 \\
\hline $\begin{array}{l}\text { MIOOLE ATLANTIC: } \\
\text { NEW YORK.: } \\
\text { NEW JERSEY: } \\
\text { OELAWARE. : }\end{array}$ & $:$ & $\therefore$ & : & : & - & - & $\overline{-}$ & - & $\begin{array}{r}8,668 \\
1,620 \\
34 \\
\end{array}$ & $\begin{array}{r}14,301 \\
1,652 \\
32 \\
\end{array}$ \\
\hline TOTAL. . & $\cdot \cdot$ & - . & - & - & - & - & - & - & 10,322 & 15,985 \\
\hline $\begin{array}{l}\text { CHESAPEAKE: } \\
\text { MARYLAND: : } \\
\text { VIRGINIA: : }\end{array}$ & $\dot{.}$ & $\because$ & : & : & - & $=$ & - & $=$ & $\begin{array}{r}74 \\
1,088 \\
\end{array}$ & $\begin{array}{r}57 \\
1,022 \\
\end{array}$ \\
\hline TOTAL. . & $\cdot$ & - . & - & . & - & - & - & - & 1,162 & 1,079 \\
\hline $\begin{array}{l}\text { SOUTH ATLANTIC: } \\
\text { NORTH CAROL INA } \\
\text { SOUTH CAROL INA } \\
\text { FLORIOA, EAST }\end{array}$ & Aं & $\dot{:}:$ & $\dot{\text { : }}$ & : & - & - & - & - & $\begin{array}{r}285 \\
176 \\
73 \\
\end{array}$ & $\begin{array}{r}226 \\
221 \\
90 \\
\end{array}$ \\
\hline TOTAL. • & $\cdot \cdot$ & - . & - & - & - & - & - & $\underline{-}$ & 534 & 537 \\
\hline $\begin{array}{l}\text { PACIFIC: } \\
\text { WASHINGTON. } \\
\text { OREGON. } \\
\text { CALIFORNIA: }\end{array}$ & $\dot{:}$ & $\because$ & : & : & $\begin{array}{l}- \\
- \\
\end{array}$ & $\begin{array}{l}- \\
- \\
\end{array}$ & $\begin{array}{l}783 \\
- \\
-\end{array}$ & $\begin{array}{l}329 \\
- \\
\end{array}$ & $\begin{array}{r}459 \\
1 \\
159 \\
\end{array}$ & $\begin{array}{r}375 \\
1 \\
66 \\
\end{array}$ \\
\hline TOTAL. . & $\cdot \cdot$ & . . & - & - & 2 & 2 & 783 & 329 & 619 & 442 \\
\hline GRAND TOT & TAL. & . & . & . & 2 & 2 & 783 & 329 & 14,995 & 27.340 \\
\hline
\end{tabular}

(CONTINUEO ON NEXT PAGE) 


\section{SUMMARY OF CLAM LANDINGS, 1975 - Continued}

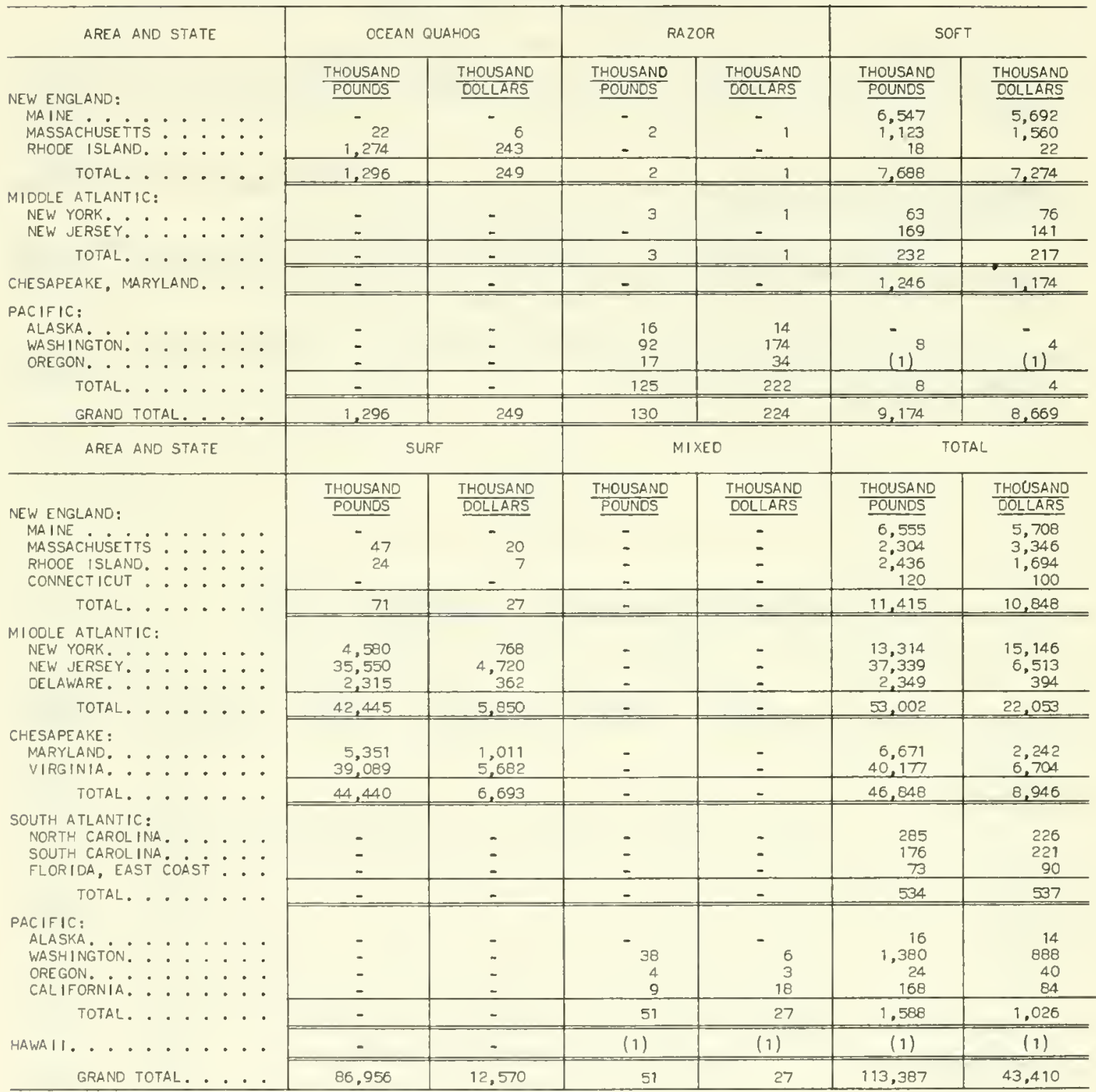

1 LESS THAN 500 POUNDS DR $\$ 500$. 


\section{SUMMARY OF CLAM LANDINGS OF CATCH BY GEAR, 1975}

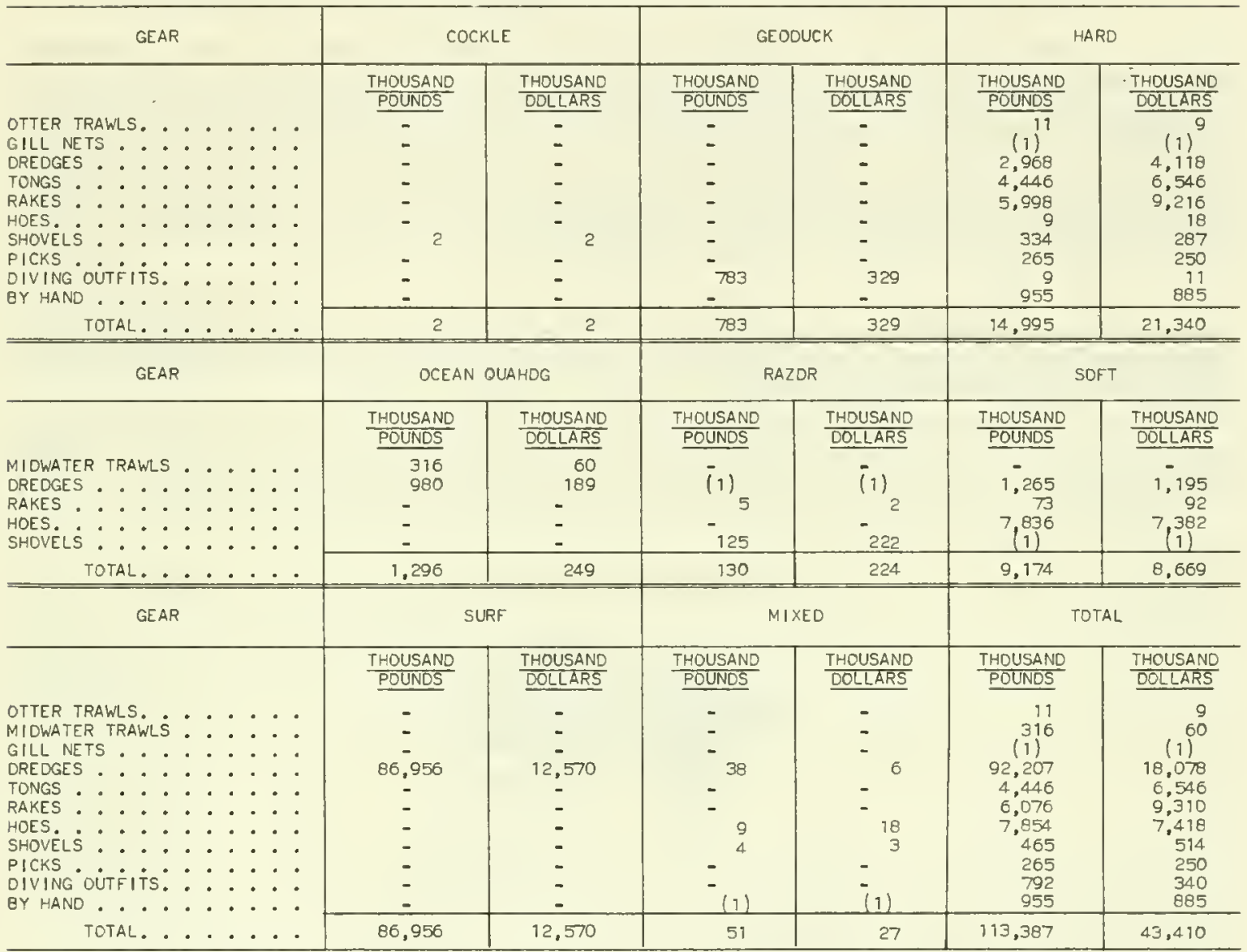

1 LESS THAN 500 POUNDS OR $\$ 500$. 


\section{U.S. CRAB LANDINGS, 1975}

The U.S. catch of crabs was 306.1 million pounds worth $\$ 81.0$ million, decreases of 8 percent in volume and 5 percent in value compared with 1974. All species of crabs declined in volume except for dungeness, king, and rock crabs. However, the principal reason for the lower volume was a 27-percent decline in landings of snow crabs, mainly because of poor market conditions and high inventories in cold storage. Landings of snow crabs (landed only in Alaska) were 46.9 million pounds value at $\$ 7.0$ million in 1975 compared with a record 63.9 million pounds valued at $\$ 13.1$ million in 1974 . A price dispute between fishermen and buyers almost halted snow crab fishing during part of the 1975 fishing season. The average price per pound for snow crabs was 15 cents in 1975 and 20 cents in 1974 . Hard blue crabs with 134.7 million pounds or 44 percent of the total production declined 10 percent.

The Pacific Coast States led in volume with 164.3 million pounds (54 percent of the total), followed by the Chesapeake States, 61.5 million pounds ( 20 percent); the Gulf States, 41.0 million pounds ( 13 percent); and the South Atlantic States, 30.6 million pounds (10 percent). The rest were taken in the New England and Middle Atlantic States, and Hawaii.

Fishermen took 283.2 million pounds (93 percent of the total) with pots and 10.3 million pounds ( 3 percent) with lines. Otter trawls and dredges each took 5.4 million pounds ( 2 percent). The remainder was taken by haul seines, purse seines, pound nets, gill nets, dip nets, lift nets, scrapes, and brush traps.

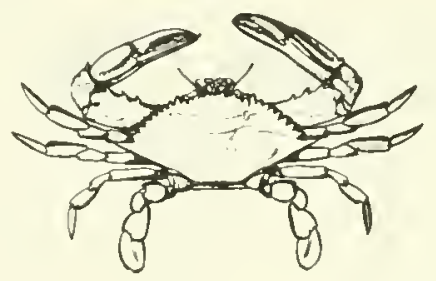

BLUE CRAB

SUMMARY OF CRAB POT OPERATING UNITS, 1975

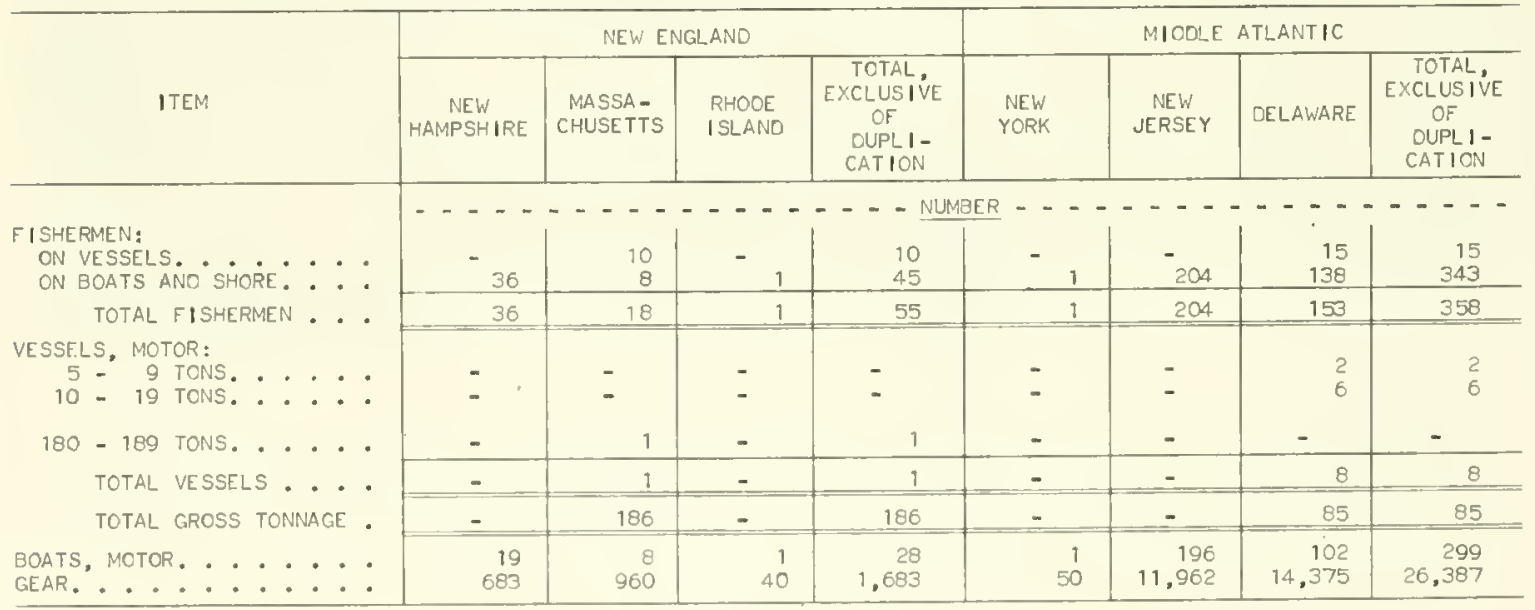

(CONTINUEO ON NEXT PAGE) 
SUMMARY OF CRAB POT OPERATING UNITS, 1975 - Continued

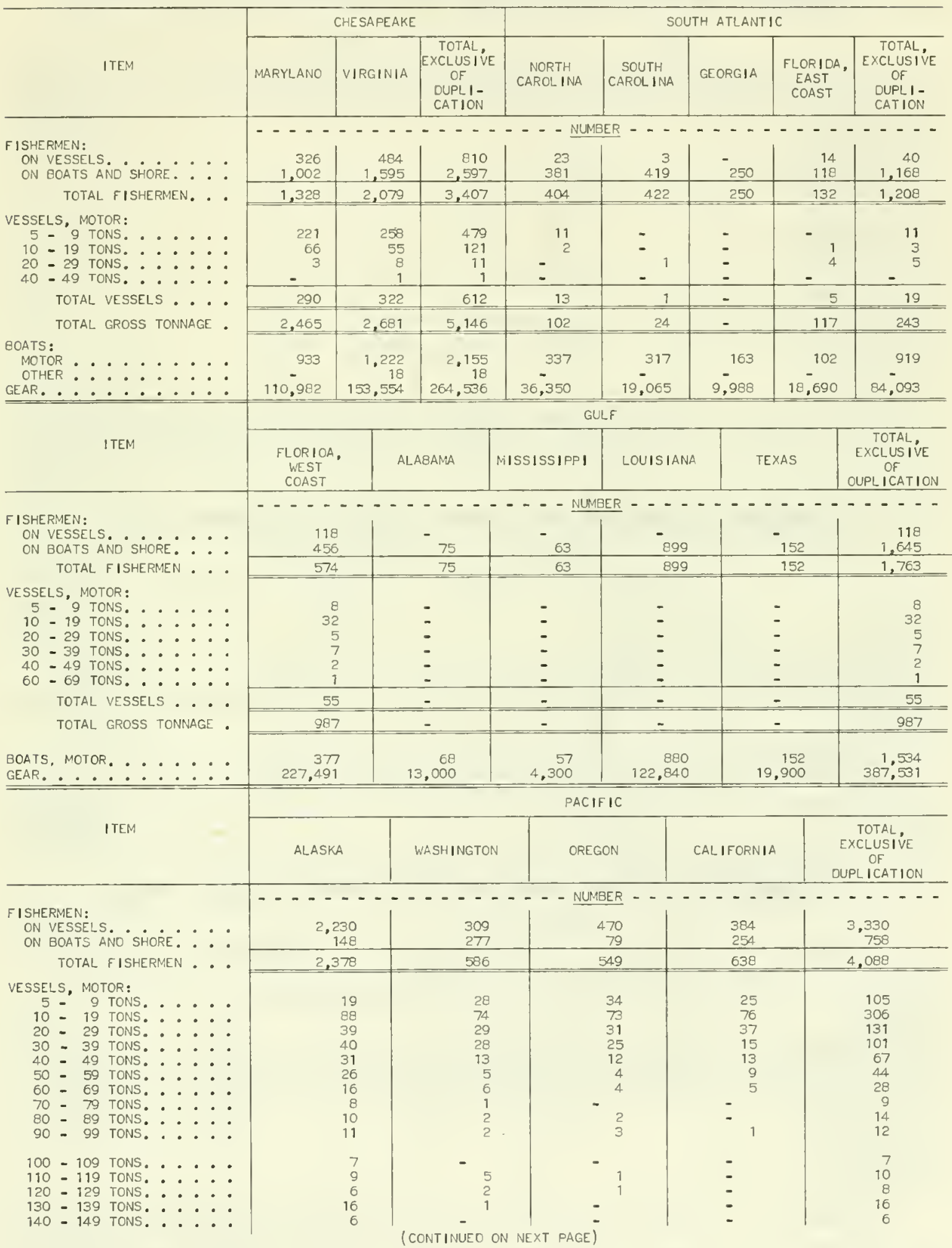




\section{SUMMARY OF CRAB POT OPERATING UNITS, 1975 - Continued}

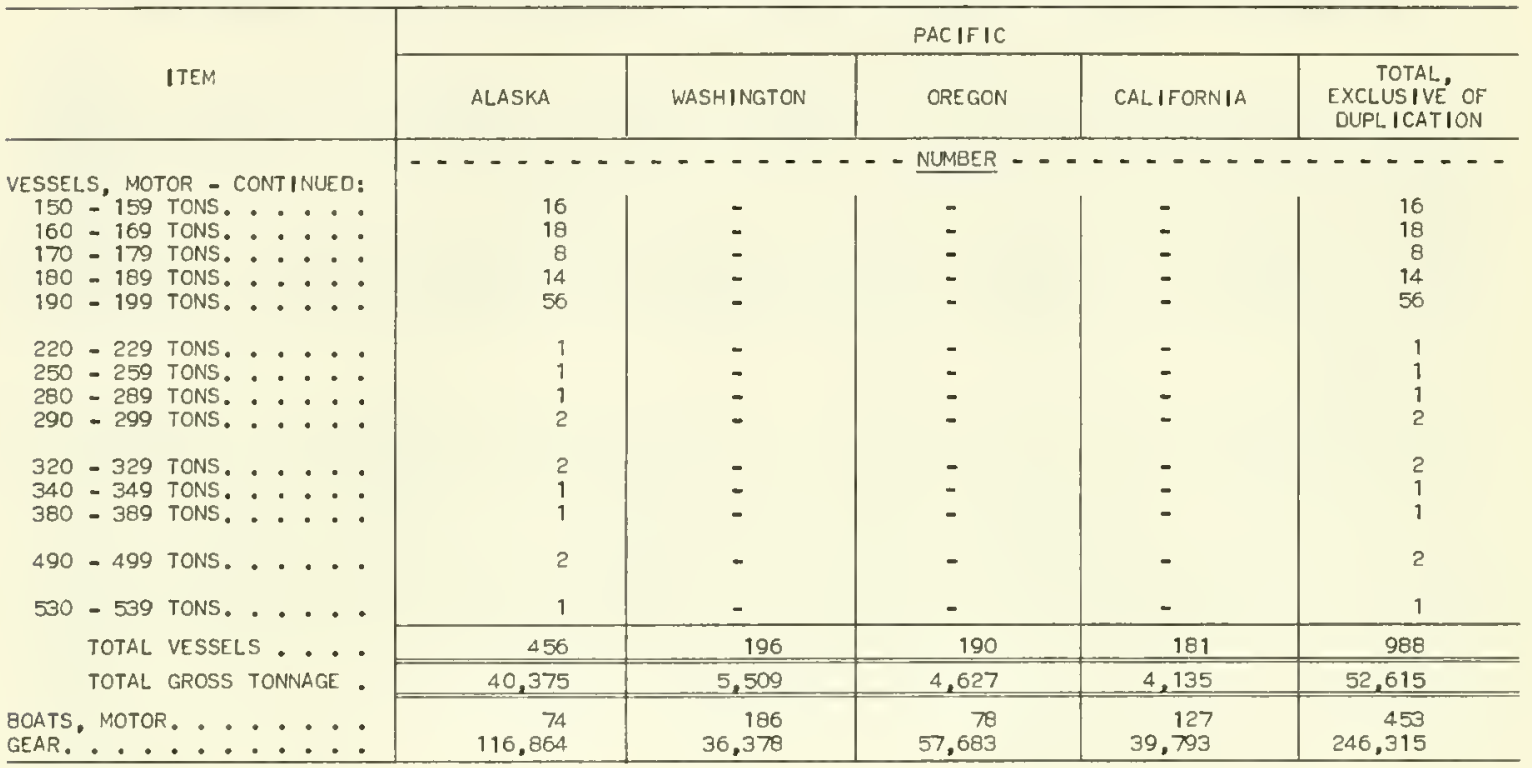

\section{SUMMARY OF CRAB TROT LINE OPERATING UNITS, 1975}

\begin{tabular}{|c|c|c|c|c|c|}
\hline \multirow[b]{2}{*}{ ITEM } & \multicolumn{2}{|c|}{ CHESAPEAKE } & \multirow{2}{*}{$\begin{array}{l}\text { SOUTH } \\
\text { ATLANTIC, } \\
\text { NORTH } \\
\text { CAROL INA }\end{array}$} & \multirow{2}{*}{$\begin{array}{l}\text { GULF, } \\
\text { LOUISIANA }\end{array}$} & \multirow{2}{*}{$\begin{array}{c}\text { TOTAL, } \\
\text { EXCLUS IVE } \\
\text { OF } \\
\text { OUPL ICATION }\end{array}$} \\
\hline & MARYLANO & VIRGINIA & & & \\
\hline $\begin{array}{l}\text { FISHERMEN: } \\
\text { ON VESSELS. } \\
\text { ON BOATS ANO SHORE: }: \vdots\end{array}$ & $\begin{array}{r}325 \\
\quad . .6 \\
9.635\end{array}$ & $\begin{array}{r}\cdots \\
5 \\
3 \\
\end{array}$ & $\begin{array}{r}\text { NUMBER - } \\
2 \\
101\end{array}$ & $\begin{array}{l}-\cdots-\cdots \\
-132 \\
\end{array}$ & $\begin{array}{c}332 \\
9,071 \\
\end{array}$ \\
\hline \multirow{5}{*}{ 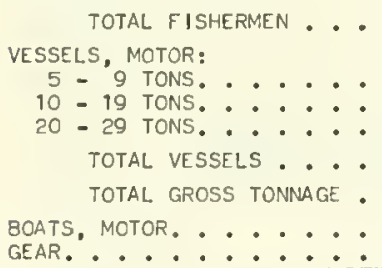 } & 9,960 & 8 & 103 & 132 & 10,203 \\
\hline & $\begin{array}{r}255 \\
52 \\
1 \\
\end{array}$ & $\Sigma^{3}$ & - & $\overline{-}$ & $\begin{array}{r}260 \\
52 \\
1\end{array}$ \\
\hline & 308 & 3 & 2 & - & 313 \\
\hline & 2,404 & 21 & 14 & - & 2,439 \\
\hline & $\begin{array}{l}7,774 \\
9,958\end{array}$ & $\begin{array}{l}3 \\
6\end{array}$ & $\begin{array}{l}73 \\
75\end{array}$ & $\begin{array}{l}132 \\
156\end{array}$ & $\begin{array}{r}7,982 \\
10,195\end{array}$ \\
\hline
\end{tabular}

\section{SUMMARY OF CRAB DREDGE OPERATING UNITS, 1975}

\begin{tabular}{|c|c|c|c|c|}
\hline \multirow{2}{*}{ ITEM } & \multicolumn{2}{|c|}{ MIOOLE ATLANTIC } & \multirow{2}{*}{$\begin{array}{l}\text { CHESAPEAKE, } \\
\text { VIRGINIA }\end{array}$} & \multirow{2}{*}{$\begin{array}{l}\text { TOTAL, EXCLUSIVE } \\
\text { OF DUPLICATION }\end{array}$} \\
\hline & NEW JERSEY & OELAWARE & & \\
\hline \multirow{3}{*}{ 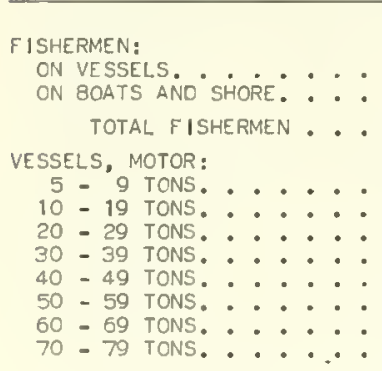 } & $\begin{array}{r}\ldots . \cdots \\
46 \\
\\
35 \\
\end{array}$ & $\ldots-\cdots$ & $\begin{array}{r}\ldots \ldots \\
312 \\
64 \\
\end{array}$ & $\begin{array}{c}378 \\
101 \\
\end{array}$ \\
\hline & 81 & 25 & 376 & 479 \\
\hline & $\begin{array}{r}2 \\
11 \\
-\quad 4 \\
-\quad 1 \\
-\quad 1 \\
-\quad 1\end{array}$ & $\begin{array}{r}- \\
\quad \\
2 \\
2 \\
2 \\
-\quad 1 \\
-\quad \\
-\quad\end{array}$ & $\begin{array}{r}43 \\
55 \\
22 \\
9 \\
3 \\
1 \\
-\quad 2 \\
\end{array}$ & $\begin{array}{r}45 \\
70 \\
28 \\
10 \\
5 \\
1 \\
1 \\
2\end{array}$ \\
\hline TOTAL VESSELS .... & 19 & 9 & 135 & 162 \\
\hline TOTAL GROSS TONNAGE . & 358 & 224 & 2.212 & 2.763 \\
\hline $\begin{array}{l}\text { BOATS, MOTOR }: \therefore \\
\text { GEAR. }\end{array}$ & $\frac{26}{\pi}$ & $\begin{array}{r}2 \\
16\end{array}$ & $\begin{array}{r}28 \\
173\end{array}$ & $\begin{array}{r}56 \\
265\end{array}$ \\
\hline
\end{tabular}


SUMMARY OF CRAB LANDINGS, 1975

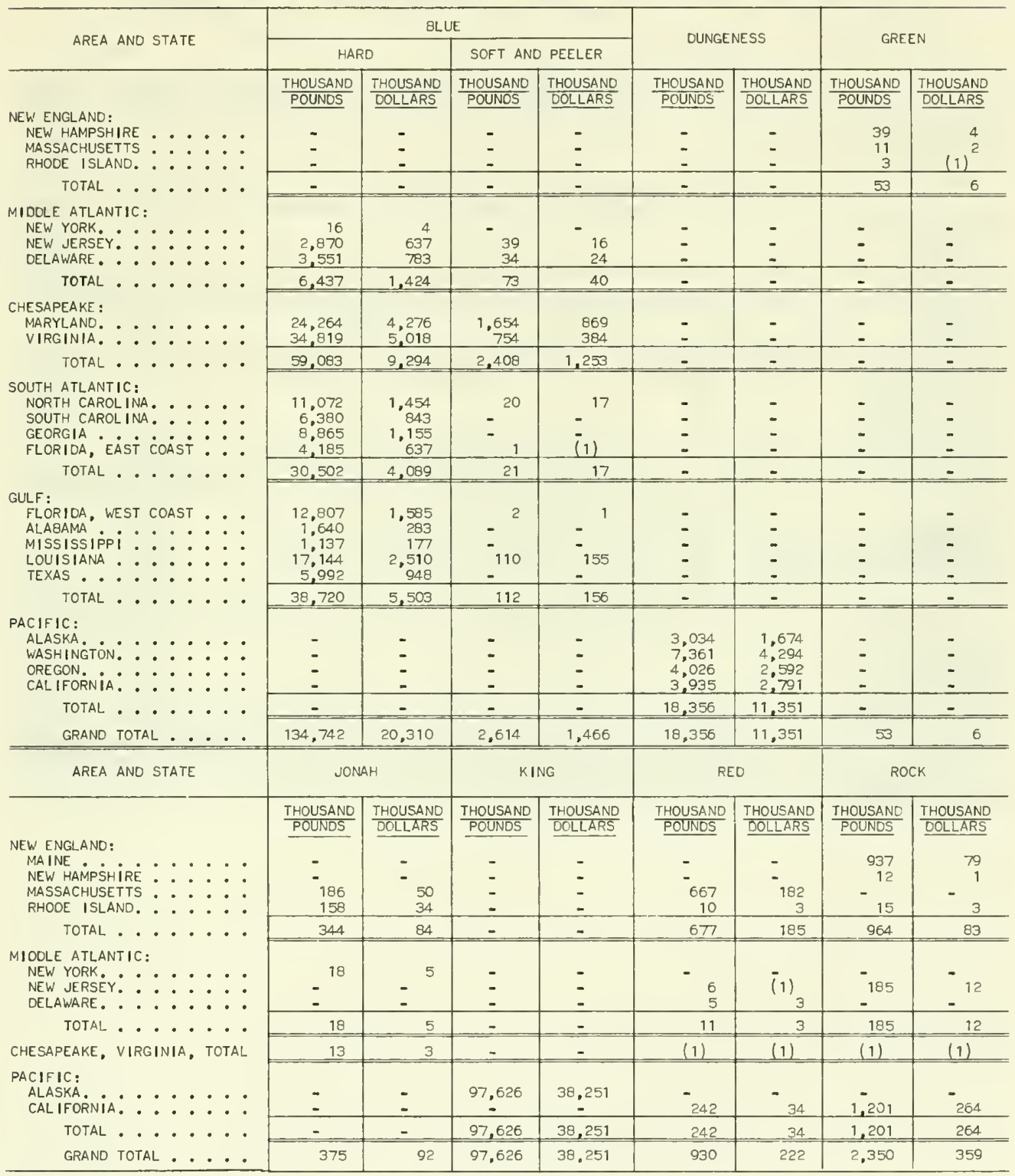

SEE FOOTNOTE AT END OF TABLE.

(CONTINUED ON NEXT PAGE) 


\section{SUMMARY OF CRAB LANDINGS, 1975 - Continued}

\begin{tabular}{|c|c|c|c|c|c|c|c|c|c|c|c|}
\hline \multirow[t]{2}{*}{ AREA AND } & \multicolumn{3}{|l|}{ STATE } & \multicolumn{2}{|c|}{ SNOW } & \multicolumn{2}{|c|}{ STONE } & \multicolumn{2}{|c|}{ UNCLASSIFIED } & \multicolumn{2}{|c|}{ TOTAL } \\
\hline & & & & $\frac{\text { THOUSAND }}{\text { POUNDS }}$ & $\begin{array}{l}\text { THOUSANO } \\
\text { DOLLARS }\end{array}$ & $\frac{\text { THOUSANO }}{\text { POUNDS }}$ & $\frac{\text { THOUSAND }}{\text { DOLLARSS }}$ & $\frac{\text { THOUSAND }}{\underline{\text { POUNOS }}}$ & $\frac{\text { THOUSAND }}{\text { DOLLARS }}$ & $\frac{\text { THOUSAND }}{\text { POUNOS }}$ & $\begin{array}{l}\text { THOUSAND } \\
\text { DOLLARS }\end{array}$ \\
\hline $\begin{array}{l}\text { NEW ENGLAND: } \\
\text { MA INE } \\
\text { NEW HAMPSHIRE } \\
\text { MASSACHUSETTS } \\
\text { RHOOE ISLAND. }\end{array}$ & 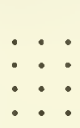 & $\dot{:}$ & : & $\begin{array}{l}- \\
-\end{array}$ & $\begin{array}{l}- \\
- \\
-\end{array}$ & $\begin{array}{l}- \\
- \\
-\end{array}$ & $\begin{array}{l}- \\
- \\
-\end{array}$ & $\begin{array}{l}- \\
- \\
\end{array}$ & 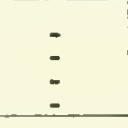 & $\begin{array}{r}937 \\
51 \\
864 \\
186 \\
\end{array}$ & $\begin{array}{r}79 \\
5 \\
234 \\
40 \\
\end{array}$ \\
\hline TOTAL. • & - $\cdot$ & - & - & - & - & - & - & - & - & 2,030 & 350 \\
\hline $\begin{array}{l}\text { MIOOLE ATLANTIC: } \\
\text { NEW YORK.: } \\
\text { NEW JERSEY. : } \\
\text { OELAWARE. : }\end{array}$ & 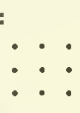 & $\dot{\bullet}$ & : & $=$ & ! & $=$ & - & $=$ & $=$ & $\begin{array}{r}34 \\
3,700 \\
3,590 \\
\end{array}$ & $\begin{array}{r}9 \\
665 \\
810 \\
\end{array}$ \\
\hline TOTAL . & . . & - & - & - & - & - & - & - & - & 6,724 & 1,484 \\
\hline $\begin{array}{l}\text { CHESAPEAKE: } \\
\text { MARYLANO: : } \\
\text { VIRGINIA: : }\end{array}$ & 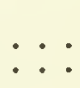 & : & : & - & - & $=$ & $=$ & - & - & $\begin{array}{l}25,918 \\
35,586 \\
\end{array}$ & $\begin{array}{l}5,145 \\
5,405 \\
\end{array}$ \\
\hline TOTAL. • & . • & & - & - & - & - & - & - & - & 61,504 & 10,550 \\
\hline $\begin{array}{l}\text { SOUTH ATLANTIC: } \\
\text { NORTH CAROL INA } \\
\text { SOUTH CAROLINA } \\
\text { GEORGIA . Eं } \\
\text { FLORIDA, EAT }\end{array}$ & $\begin{array}{l}\text { A. } \\
\dot{C} \dot{A} \dot{S} \dot{T}\end{array}$ & $\dot{:}$ & : & $=$ & $\begin{array}{l}- \\
- \\
-\end{array}$ & $\begin{array}{l}- \\
- \\
- \\
-42 \\
\end{array}$ & $\begin{array}{l}- \\
- \\
-\end{array}$ & $\begin{array}{l}- \\
\overline{-} \\
-\end{array}$ & $\begin{array}{l}- \\
\overline{-}\end{array}$ & $\begin{array}{r}11,092 \\
6,380 \\
8,865 \\
4,228 \\
\end{array}$ & $\begin{array}{r}1.471 \\
843 \\
1.155 \\
672 \\
\end{array}$ \\
\hline TOTAL. & . $\cdot$ & & - & - & - & 42 & 35 & - & - & 30,565 & 4,141 \\
\hline $\begin{array}{l}\text { GULF : } \\
\text { FLORIOA, WEST } \\
\text { ALABAMA : } \\
\text { MISSISSIPPI: } \\
\text { LOUISIANA : } \\
\text { TEXAS... }\end{array}$ & $\begin{array}{l}\text { COAST } \\
: \dot{:} \\
: \dot{:} \\
: \dot{:}\end{array}$ & $\dot{:}$ & : & $\begin{array}{l}\overline{-} \\
\overline{-}\end{array}$ & $\overline{-}$ & $\begin{array}{l}2,119 \\
= \\
- \\
\end{array}$ & $\begin{array}{l}1,766 \\
= \\
- \\
-\end{array}$ & $\begin{array}{l}- \\
- \\
-\end{array}$ & $\begin{array}{l}- \\
- \\
-\end{array}$ & $\begin{array}{r}14,928 \\
1,640 \\
1,137 \\
17,254 \\
5,992 \\
\end{array}$ & $\begin{array}{r}3.352 \\
283 \\
177 \\
2,665 \\
948 \\
\end{array}$ \\
\hline TOTAL. . & . & & • & $=$ & - & 2,119 & 1,766 & - & - & 40,951 & 7.425 \\
\hline $\begin{array}{l}\text { PAC IFIC: } \\
\text { ALASKA. } \\
\text { WASHINGTON: } \\
\text { OREGON. } \\
\text { CALIFORNIA: }\end{array}$ & : : : & $\dot{:}$ & : & $\begin{array}{c}46.856 \\
- \\
- \\
\end{array}$ & $\begin{array}{l}7.020 \\
= \\
- \\
\end{array}$ & $\begin{array}{l}- \\
- \\
-\end{array}$ & $\begin{array}{l}- \\
-\end{array}$ & $\begin{array}{l}- \\
- \\
- \\
\end{array}$ & $\begin{array}{l}- \\
= \\
24\end{array}$ & $\begin{array}{r}147,516 \\
7,361 \\
4,026 \\
5,386 \\
\end{array}$ & $\begin{array}{r}46,945 \\
4,294 \\
2,592 \\
3,113 \\
\end{array}$ \\
\hline TOTAL. • & . $\cdot$ & & & 46,856 & 7.020 & - & - & 8 & 24 & 164,289 & 56,944 \\
\hline HAWAII, TOTAL • & . & & - & - & $=$ & - & - & 53 & 85 & 53 & 85 \\
\hline GRANO TOT & TAL. . & $\cdot$ & . & 46,856 & 7.020 & 2.161 & 1,801 & 61 & 109 & 306.124 & 80.987 \\
\hline
\end{tabular}

I) LESS THAN 500 POUNOS OR $\$ 500$. 


\section{SUMMARY OF CRAB LANDINGS OF CATCH BY GEAR, 1975}

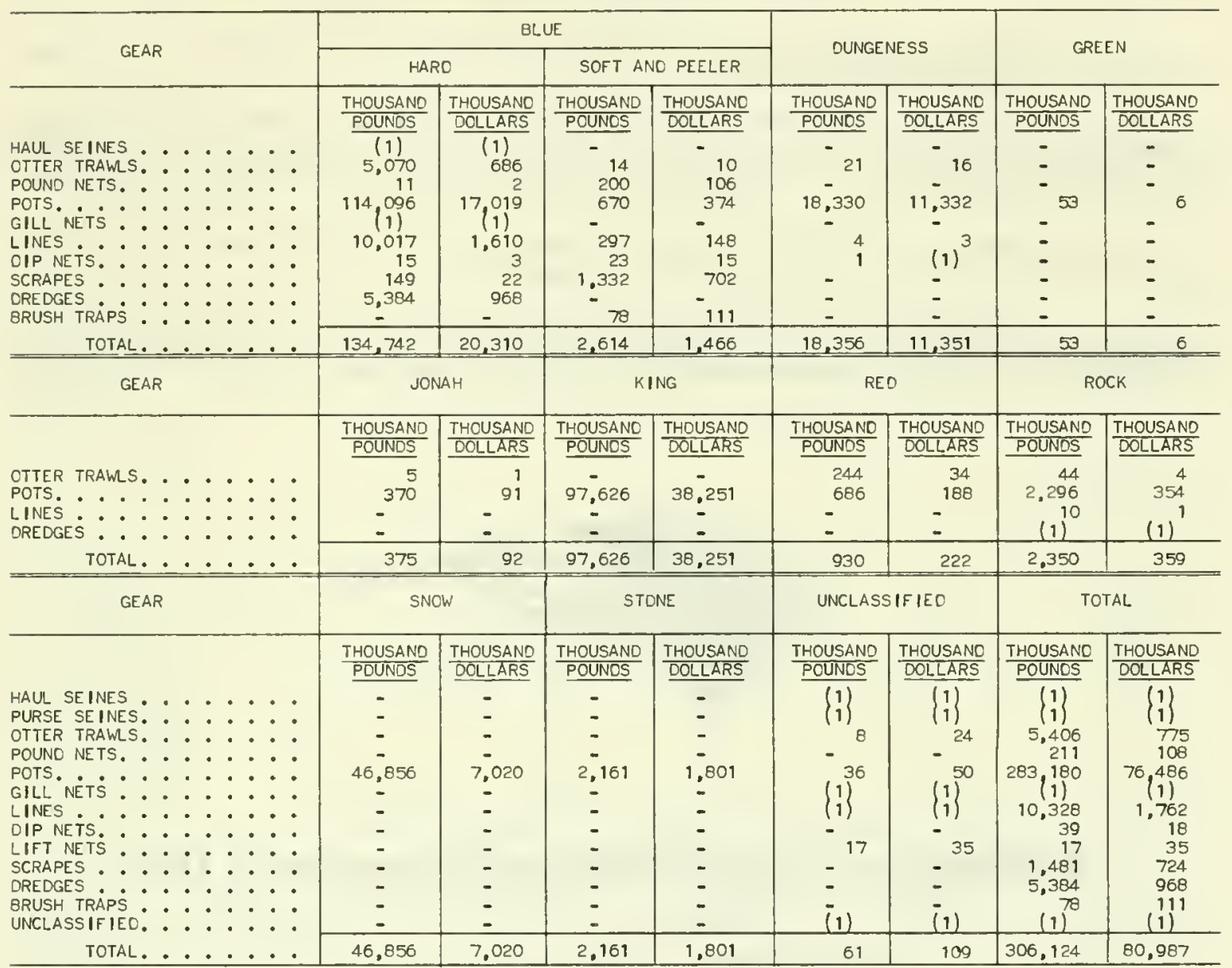




\section{U.S. OYSTER FISHERY, 1975}

The U.S. oyster fishery produced 53.2 million pounds of meats worth $\$ 45.0$ million, an increase of 2.7 million pounds and $\$ 3.7$ million compared with 1974 .

The Chesapeake States led in production with 22.6 million pounds (43 percent of the total), followed by the Gulf States with 19.3 million (36 percent); the Pacific Coast States, 5.8 million (11 percent); and the Middle Atlantic States, 3.3 million pounds ( 6 percent). The New England and South Atlantic States accounted for the rest.

.Dredges took 30.0 million pounds (56 percent) of the oyster landings, and tongs 21.1 million pounds ( 40 percent). The rest were taken by rakes, or gathered by hand.

In Section 13 of this Digest is a table which gives the volume of the bushel measures used for oysters in the various Atlantic and Gulf States and the average yield per bushel. Supplementary shellfish tables appear after the summary table for each Atlantic and Gulf regional section.

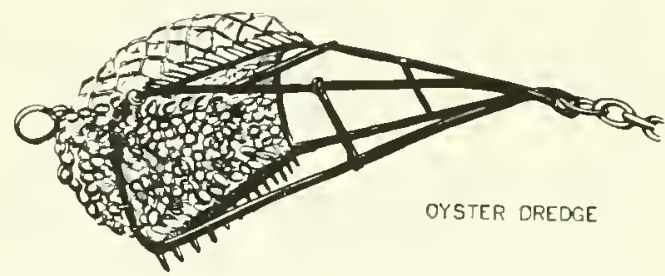

\section{SUMMARY OF OYSTER DREDGE OPERATING UNITS, 1975}

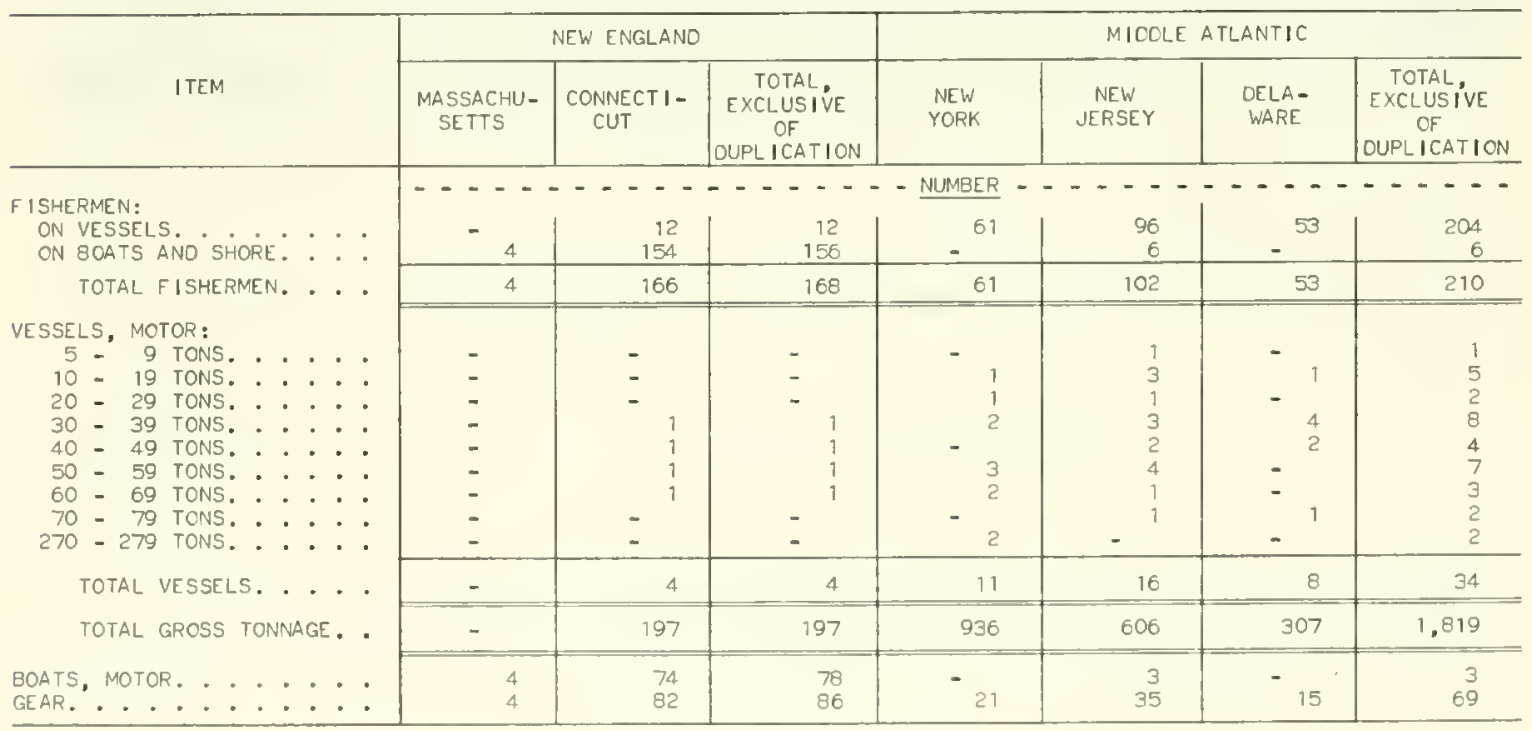

(CONTINUEO ON NEXT PAGE) 


\section{SUMMARY OF OYSTER DREDGE OPERATING UNITS, 1975 - Continued}

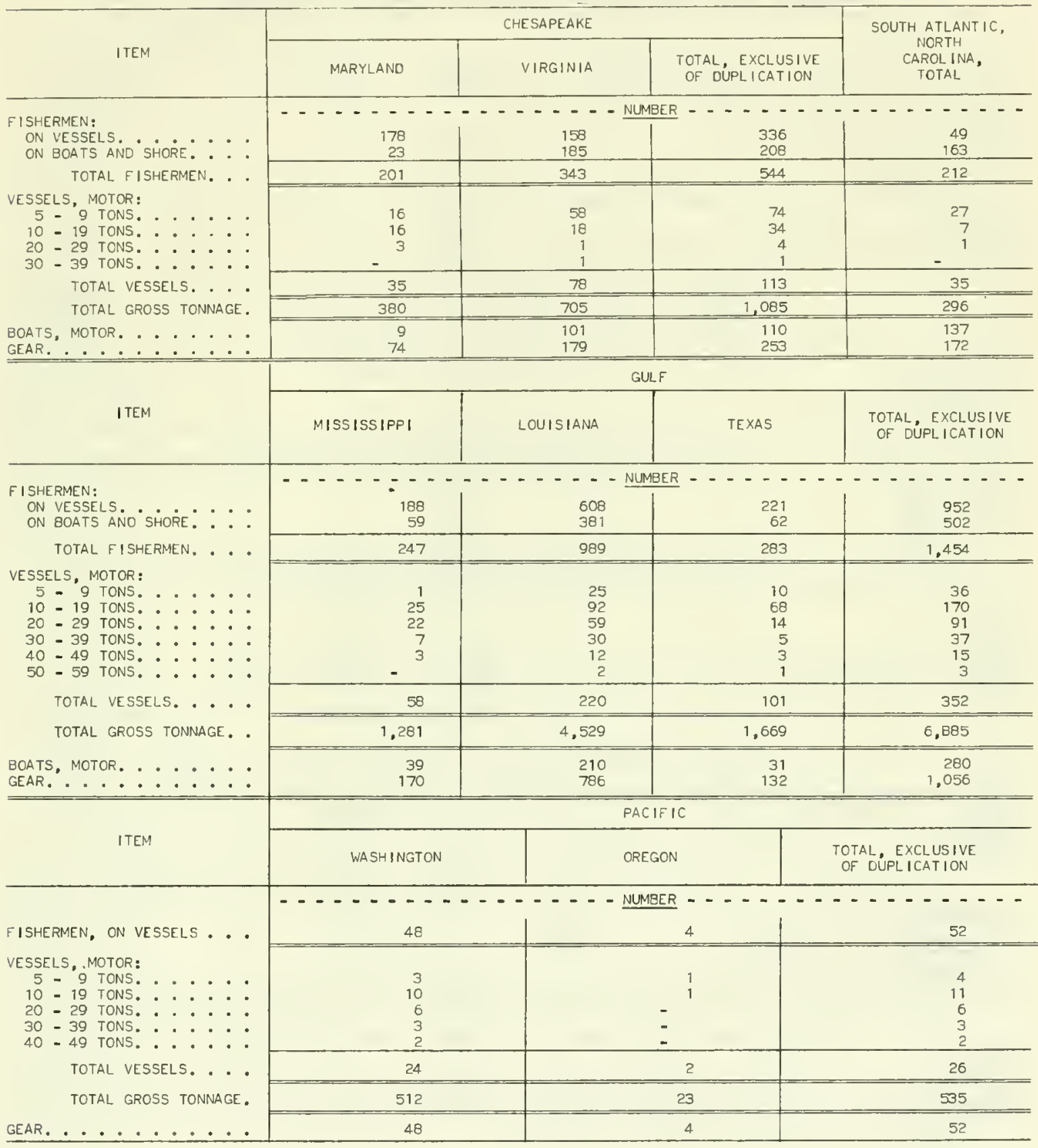




\section{SUMMARY OF OYSTER TONG OPERATING UNITS, 1975}

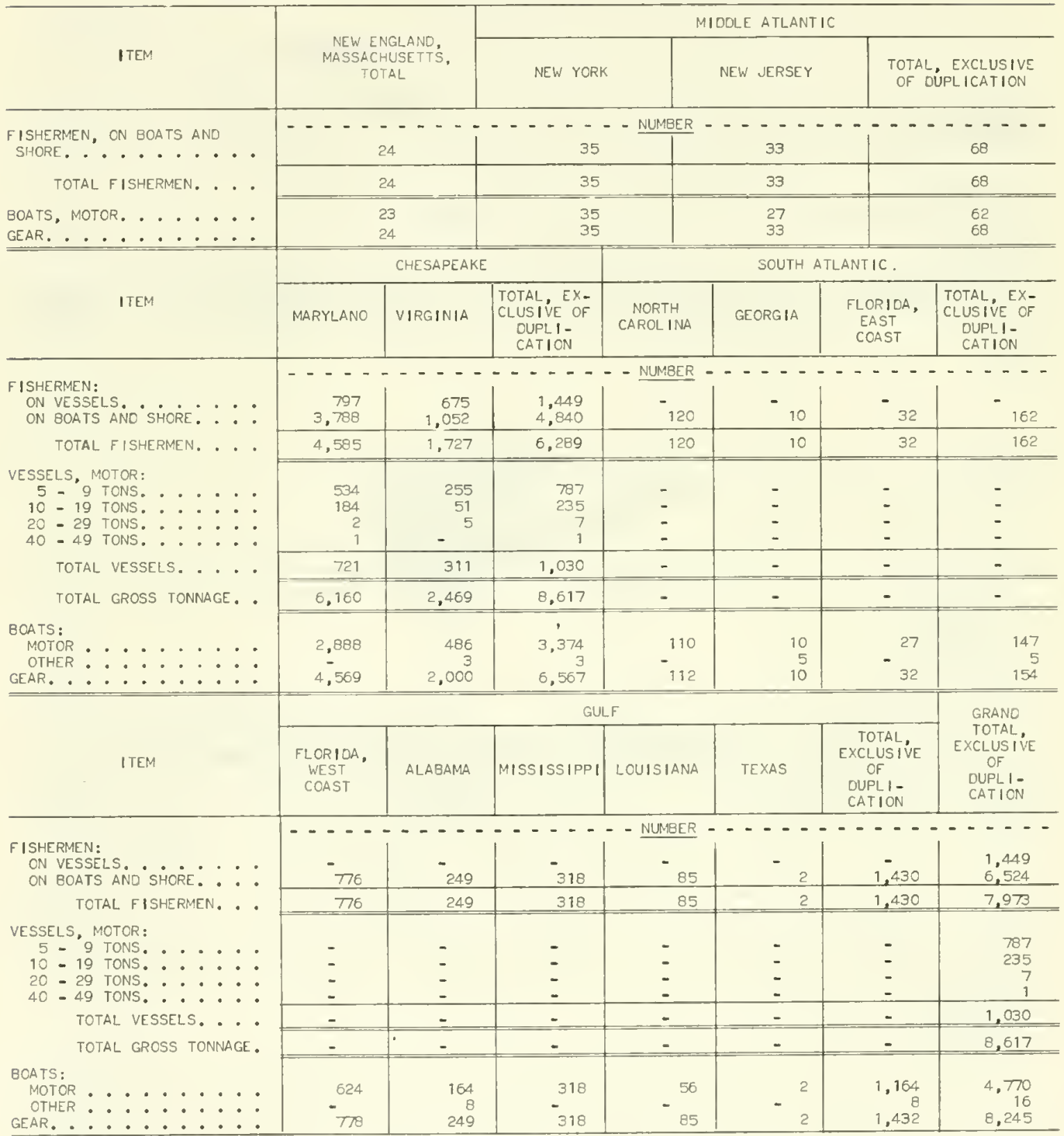


SUMMARY OF OYSTER LANDINGS, 1975

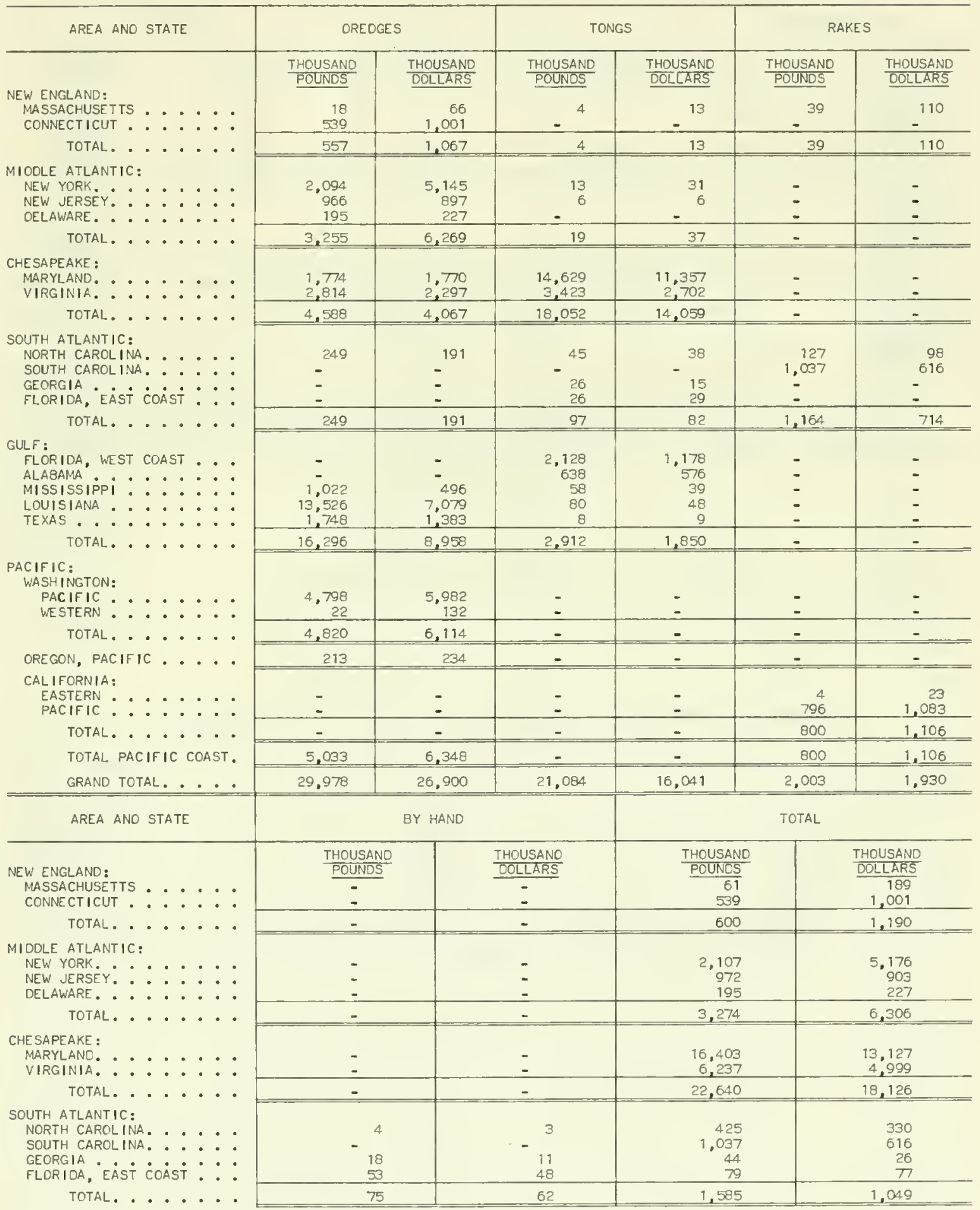




\section{SUMMARY OF OYSTER LANDINGS, 1975 - Continued}

\begin{tabular}{|c|c|c|c|c|}
\hline AREA AND STATE & \multicolumn{2}{|c|}{ BY HANO } & \multicolumn{2}{|c|}{ TOTAL } \\
\hline 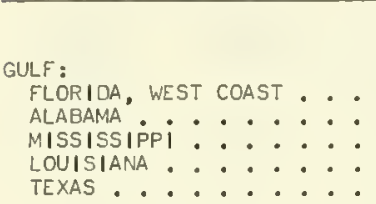 & 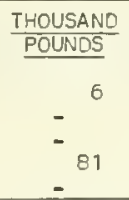 & $\begin{array}{c}\frac{\text { THOUSANO }}{\text { OOLLARS }} \\
-5 \\
- \\
-\end{array}$ & $\begin{array}{r}\text { THOUSANO } \\
\text { POUNOS } \\
2,134 \\
638 \\
1,080 \\
13,687 \\
1,756\end{array}$ & $\begin{array}{c}\text { THOUSANO } \\
\text { OOLLARS } \\
1.183 \\
576 \\
535 \\
7.174 \\
1,392\end{array}$ \\
\hline TOTAL. ................ & 87 & 52 & 19,295 & 10,860 \\
\hline 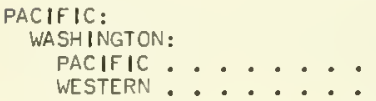 & - & : & $\begin{array}{r}4,798 \\
22 \\
\end{array}$ & $\begin{array}{r}5,982 \\
132\end{array}$ \\
\hline 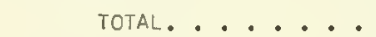 & - & - & 4,820 & 6,114 \\
\hline OREGON, PACIFIC . . . & - & - & 213 & 234 \\
\hline $\begin{array}{l}\text { CAL IFORNIA: } \\
\text { EASTERN } \\
\text { PACIFIC }: \therefore: \therefore:\end{array}$ & - & 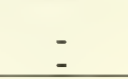 & $\begin{array}{r}4 \\
796 \\
\end{array}$ & $\begin{array}{r}23 \\
1,083 \\
\end{array}$ \\
\hline TOTAL. . . . . . & - & - & 800 & 1,106 \\
\hline TOTAL PACIFIC COAST. & - & - & 5,833 & 7,454 \\
\hline GRAND TOTAL. .... & 162 & 114 & 53,227 & 44,985 \\
\hline
\end{tabular}

NOTE:--LANDINGS OF CATCH BY HANO IN WASHINGTON AND OREGON HAVE BEEN INCLUDEOWITH THE LANDINGS OF CATCH BY DREDGES. 


\section{SUMMARY OF ATLANTIC AND GULF OYSTER LANDINGS, 1975}

\begin{tabular}{|c|c|c|c|c|}
\hline AREA AND STATE & \multicolumn{2}{|c|}{ PUBLIC } & \multicolumn{2}{|c|}{ PRIVATE } \\
\hline $\begin{array}{l}\text { NEW ENGLAND: } \\
\text { MASSACHUSETTS } \ldots: \cdots \\
\text { CONNECTICUT }: \ldots:\end{array}$ & $\begin{array}{r}\frac{\text { THOUSANO }}{\text { POUNOS }} \\
-25 \\
-\end{array}$ & $\frac{\frac{\text { THOUSAND }}{\text { DOLLARS }}}{-68}$ & $\begin{array}{r}\text { THOUSANO } \\
\text { POUNOS } \\
36 \\
539 \\
\end{array}$ & $\begin{array}{r}\text { THOUSANO } \\
\text { DOLLARS } \\
121 \\
1,001 \\
\end{array}$ \\
\hline TOTAL. ...... & 25 & 68 & 575 & 1,122 \\
\hline $\begin{array}{l}\text { MJOOLE ATLANTIC: } \\
\text { NEW YORK } \\
\text { NEW JERSEY }: \therefore \therefore: \therefore \\
\text { OELAWARE. }: \therefore \therefore:\end{array}$ & $\begin{array}{r}13 \\
-\quad 6 \\
\end{array}$ & $\begin{array}{r}31 \\
-\quad 6 \\
\end{array}$ & $\begin{array}{r}2,094 \\
966 \\
195 \\
\end{array}$ & $\begin{array}{r}5.145 \\
897 \\
227 \\
\end{array}$ \\
\hline TOTAL. . . . . & 19 & 37 & 3,255 & 6,269 \\
\hline 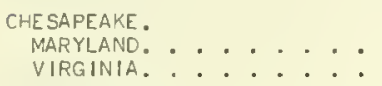 & $\begin{array}{r}15,720 \\
2,992\end{array}$ & $\begin{array}{r}12,325 \\
2,359 \\
\end{array}$ & $\begin{array}{r}683 \\
3,245\end{array}$ & $\begin{array}{r}802 \\
2,640 \\
\end{array}$ \\
\hline TOTAL. . . . . & 18,712 & 14.684 & 3,928 & 3,442 \\
\hline $\begin{array}{l}\text { SOUTH ATLANTIC: } \\
\text { NORTH CAROL INA. } \ldots \\
\text { SOUTH CAROL INA }: \vdots: \\
\text { GEORGIA } \\
\text { FLORIOA, EAंSTं COAंST } \vdots \vdots\end{array}$ & $\begin{array}{l}294 \\
- \\
-\end{array}$ & $\begin{array}{l}227 \\
- \\
- \\
99\end{array}$ & $\begin{array}{r}131 \\
1.037 \\
44 \\
38 \\
\end{array}$ & $\begin{array}{r}103 \\
616 \\
26 \\
38 \\
\end{array}$ \\
\hline TOTAL. . . . . & 335 & 266 & 1.250 & 783 \\
\hline 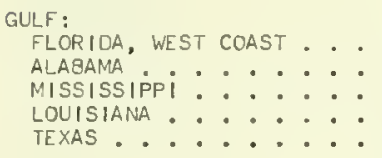 & $\begin{array}{r}2,054 \\
638 \\
909 \\
4,735 \\
1,756 \\
\end{array}$ & $\begin{array}{r}1,142 \\
576 \\
431 \\
2.237 \\
1,392 \\
\end{array}$ & $\begin{array}{r}-80 \\
8,952 \\
-\end{array}$ & $\begin{array}{r}-41 \\
-104 \\
4,937 \\
-\end{array}$ \\
\hline TOTAL. . . . . & 10,092 & 5,778 & 9,203 & 5,082 \\
\hline GRANO TOTAL. .... & 29,183 & 20,833 & 18,211 & 16,698 \\
\hline
\end{tabular}

\section{SUMMARY OF OYSTER LANDINGS BY SPECIES, 1975}

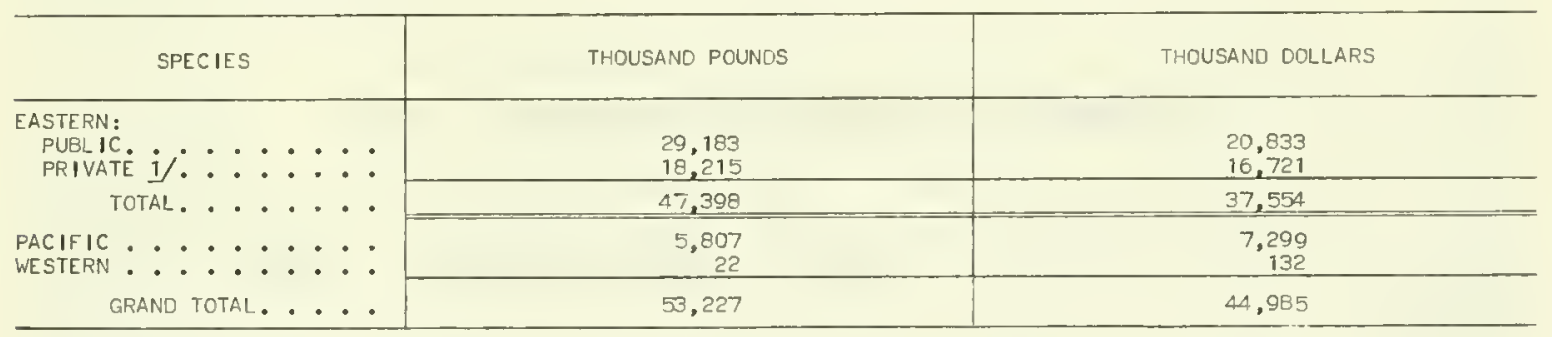

1) EASTERN PRIVATE INCLUDES 4,000 POUNOS OF OYSTERS VALUED AT \$23,000 HARVESTED IN CAL IFORNIA. 


\section{U.S. SHRIMP FISHERY, 1975}

Landings of shrimp at ports in the U.S. were 346.7 million pounds (heads-on) worth $\$ 225.7$ million-a decline of 7 percent in volume, but an increase of 25 percent in value compared with 1974 . Landings declined in all major areas. Landings in the New England States (11.7 million pounds) declined 33 percent; the South Atlantic States (24.9 million pounds) declined 8 percent; the Gulf States (170.1 million pounds) declined 9 percent; and the Pacific Coast States ( 140.1 million pounds) declined 2 percent. Landings in the Mississippi River area ( 9,000 pounds) and Hawaii (5,000 pounds) increased.

The Gulf States accounted for 49 percent of the total landings; Pacific Coast States, 40 percent; the South Atlantic States, 7 percent; and the New England States, 3 percent. The remainder was landed in the Chesapeake States, Mississippi River area, and Hawaii.

Landings of the U.S. shrimp otter trawl fleet were 98 percent of the total harvest. The otter trawl fishery employed 21,331 fishermen on 5,016 vessels and 6,558 boats.

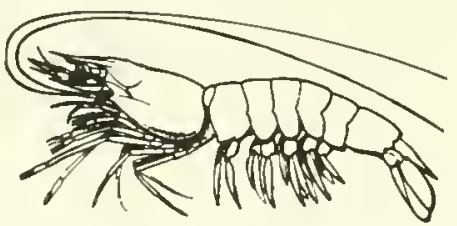

SHR IMP

SUMMARY OF SHRIMP LANDINGS, 1975

\begin{tabular}{|c|c|c|c|c|c|c|}
\hline AREA AND STATE & \multicolumn{2}{|c|}{ BAG NETS } & \multicolumn{2}{|c|}{ BUTTERFLY NETS } & \multicolumn{2}{|c|}{ BEAM TRAWLS } \\
\hline & $\frac{\text { THOUSAND }}{\text { POUNDS }}$ & $\frac{\text { THOUSANO }}{\text { OOLLARS }}$ & $\frac{\text { THOUSANO }}{\text { POUNOS }}$ & $\frac{\text { THOUSAND }}{\text { OOLLARS }}$ & $\frac{\text { THOUSANO }}{\text { POUNOS }}$ & $\frac{\text { THOUSAND }}{\text { OOLLARS }}$ \\
\hline $\begin{array}{l}\text { SOUTH ATLANTIC: } \\
\text { NORTH CAROL INA. }: \cdot: \\
\text { SOUTH CAROL INA. }:\end{array}$ & $\begin{array}{r}202 \\
13 \\
\end{array}$ & $\begin{array}{r}167 \\
7 \\
\end{array}$ & 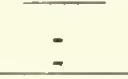 & $=$ & $=$ & - \\
\hline TOTAL. . . . . & 215 & 174 & - & - & - & - \\
\hline GULF, LOUISIANA, TOTAL... & - & - & 2,020 & 902 & - & - \\
\hline $\begin{array}{l}\text { PACIFIC: } \\
\text { ALASKA. }:: \therefore: \\
\text { WASHINGTON: }: \therefore: \\
\text { CALIFORNIA: }: \therefore: \therefore\end{array}$ & $\overline{-}$ & $\begin{array}{l}- \\
-\end{array}$ & $\overline{-}$ & $\begin{array}{l}- \\
-\end{array}$ & $\begin{array}{r}3.039 \\
30 \\
98 \\
\end{array}$ & $\begin{array}{r}422 \\
19 \\
182 \\
\end{array}$ \\
\hline TOTAL. . . . . & - & - & - & - & 3,167 & 623 \\
\hline GRANO TOTAL..... & 215 & 174 & 2,020 & 902 & 3,167 & 623 \\
\hline
\end{tabular}




\section{SUMMARY OF SHRIMP LANDINGS, 1975 - Continued}

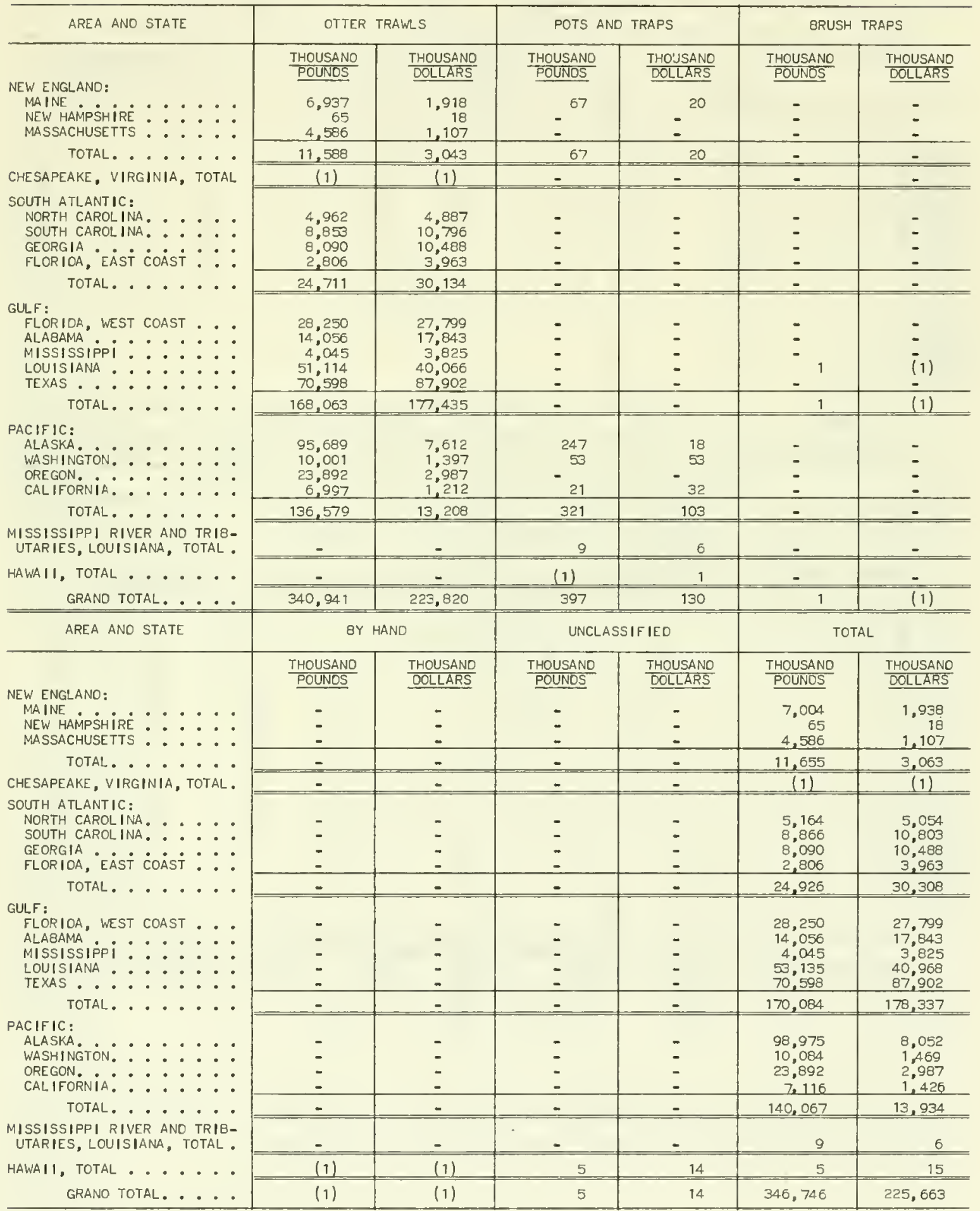

1) LESS THAN 500 POUNOS OR $\$ 500$. 


\section{SUMMARY OF SHRIMP OTTER TRAWL VESSELS, BY TONNAGE GROUPS, 1975}

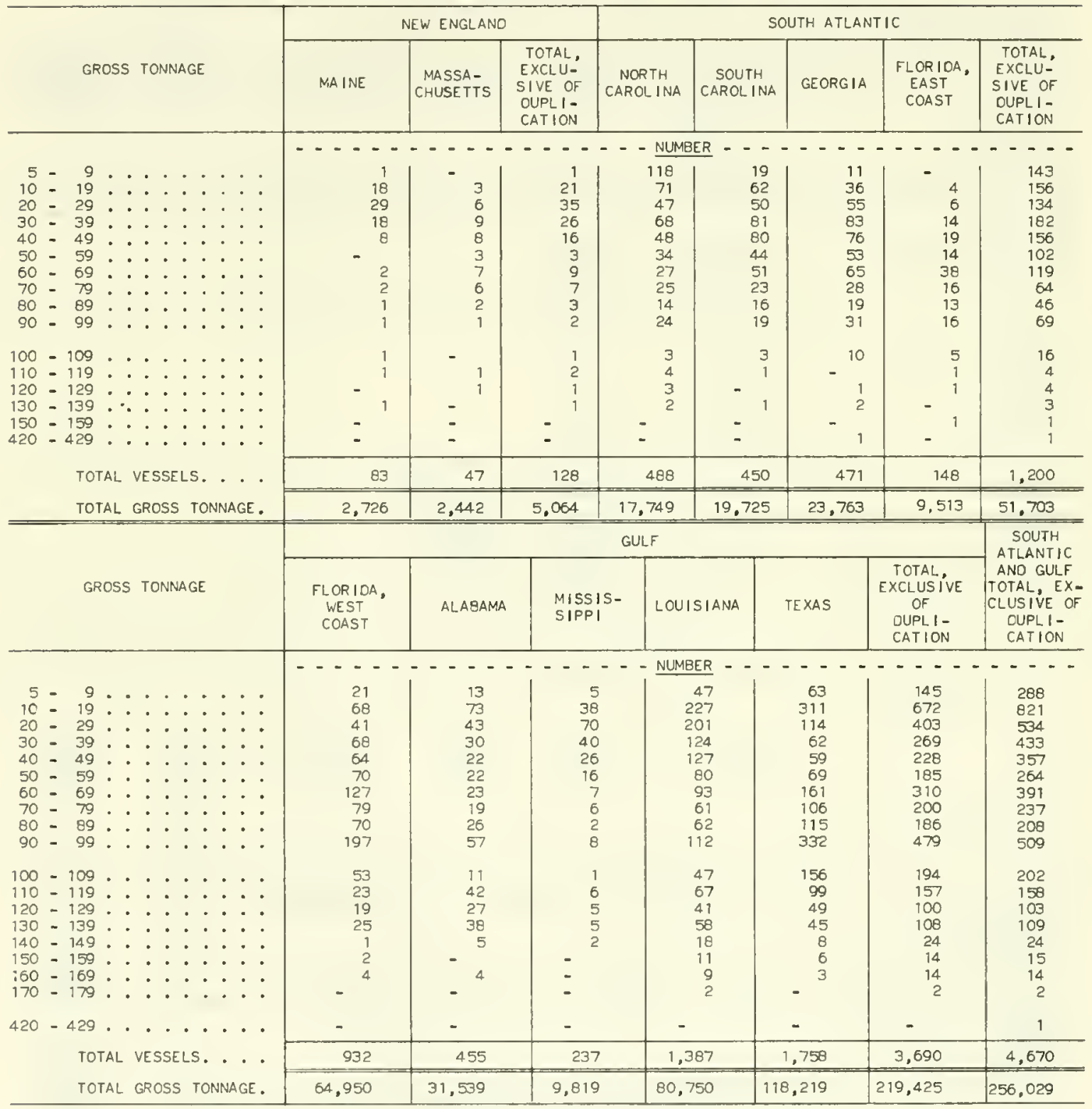




\section{SUMMARY OF SHRIMP OTTER TRAWL VESSELS, BY TONNAGE GROUPS, 1975 - Continued}

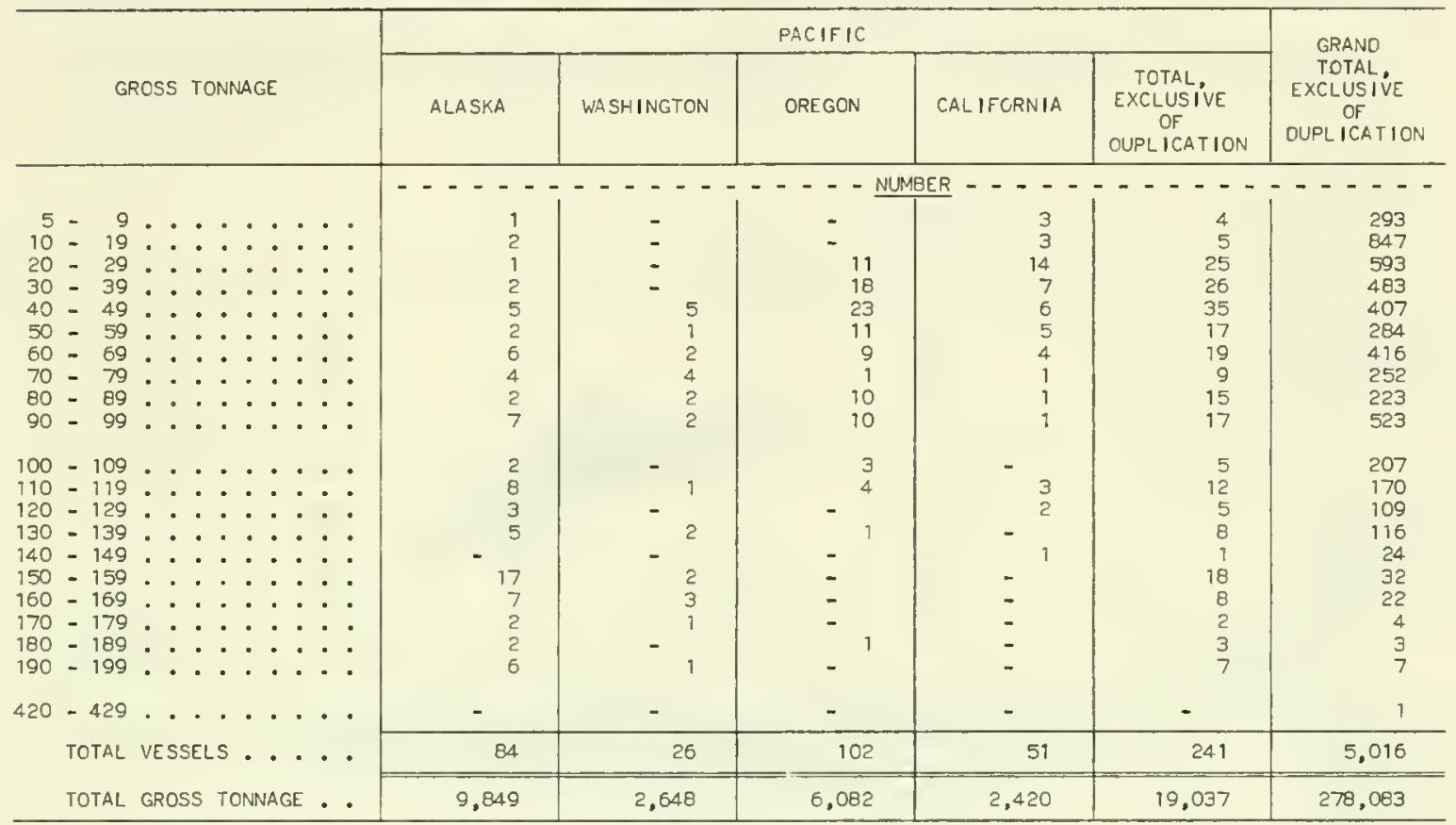

SUMMARY OF SHRIMP OTTER TRAWL OPERATING UNITS, 1975

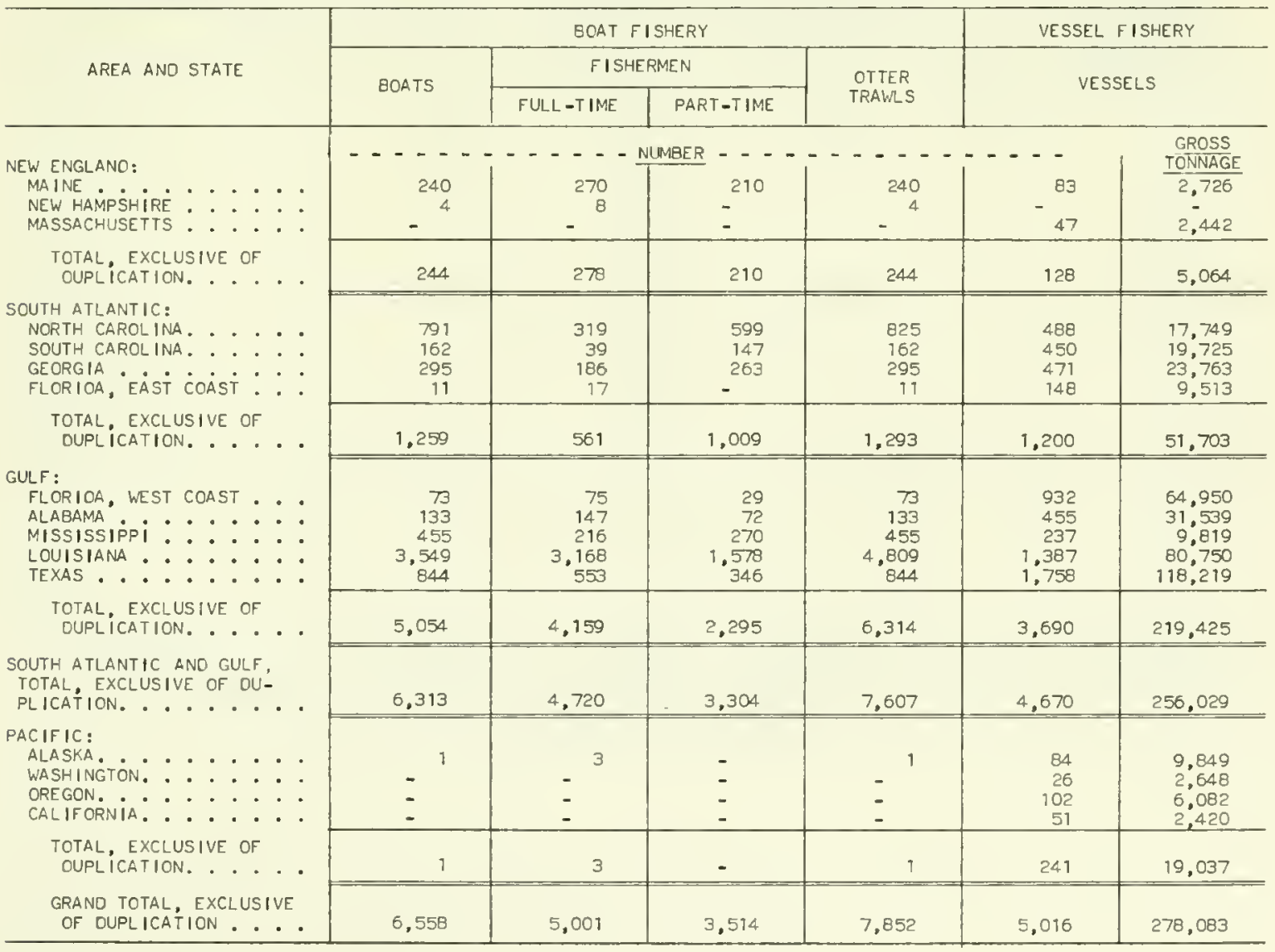




\section{SUMMARY OF SHRIMP OTTER TRAWL OPERATING UNITS, 1975 - Continued}

\begin{tabular}{|c|c|c|c|c|c|}
\hline \multirow{2}{*}{ AREA AND STATE } & \multicolumn{2}{|c|}{ VESSEL FISHERY - CONTINUEO } & \multicolumn{3}{|c|}{ TOTAL (BOAT AND VESSEL FISHERY) } \\
\hline & FISHERMEN & $\begin{array}{l}\text { OTTER } \\
\text { TRAWLS } \\
\end{array}$ & $\begin{array}{l}\text { 8OATS AND } \\
\text { VESSELS } \\
\end{array}$ & FISHERMEN & $\begin{array}{l}\text { OTTER } \\
\text { TRAWLS } \\
\end{array}$ \\
\hline $\begin{array}{l}\text { NEW ENGLANO: } \\
\text { MA INE } \text { NEW HAMPSHIRE }: \vdots: \vdots: \\
\text { MASSACHUSETTS }:: \vdots:\end{array}$ & $\begin{array}{r}\cdots \\
- \\
- \\
2126 \\
\end{array}$ & $\begin{array}{r}\ldots \\
-\quad-\cdots \\
-\quad 47 \\
\end{array}$ & $\begin{array}{r}- \text { NUMBER - } \\
323 \\
4 \\
47\end{array}$ & $\begin{array}{r}-\ldots \\
656 \\
8 \\
212 \\
\end{array}$ & $\begin{array}{r}-\ldots-\cdots \\
323 \\
4 \\
47 \\
\end{array}$ \\
\hline $\begin{array}{l}\text { TOTAL, EXCLUSIVE OF } \\
\text { OUPLICATION } . \cdots\end{array}$ & 383 & 128 & 372 & 871 & 372 \\
\hline 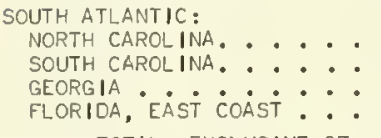 & $\begin{array}{r}1,114 \\
1,032 \\
1,081 \\
332 \\
\end{array}$ & $\begin{array}{l}904 \\
896 \\
941 \\
296 \\
\end{array}$ & $\begin{array}{r}1,279 \\
612 \\
766 \\
159 \\
\end{array}$ & $\begin{array}{l}2,032 \\
1,298 \\
1,530 \\
349 \\
\end{array}$ & $\begin{array}{r}1,729 \\
1,058 \\
1,236 \\
307 \\
\end{array}$ \\
\hline $\begin{array}{l}\text { TOTAL, EXCLUSIVE OF } \\
\text { OUPL ICATION } \cdots\end{array}$ & 2,770 & 2,326 & 2.459 & 4,340 & 3.619 \\
\hline $\begin{array}{l}\text { GULF: } \\
\text { FLORIOA, WEST COAST }:: \\
\text { ALABAMA }: \\
\text { MISSISSIPPI }: \vdots: \vdots: \\
\text { LOUISIANA }: \vdots: \vdots: \\
\text { TEXAS }: \therefore:\end{array}$ & $\begin{array}{r}2,425 \\
1.179 \\
573 \\
3,552 \\
4,751 \\
\end{array}$ & $\begin{array}{r}1,802 \\
815 \\
356 \\
2,498 \\
3,197 \\
\end{array}$ & $\begin{array}{r}1,005 \\
588 \\
692 \\
4,936 \\
2,602 \\
\end{array}$ & $\begin{array}{l}2,529 \\
1,398 \\
1,059 \\
8,298 \\
5,650 \\
\end{array}$ & $\begin{array}{r}1,875 \\
948 \\
811 \\
7,307 \\
4,047 \\
\end{array}$ \\
\hline $\begin{array}{l}\text { TOTAL, EXCLUSIVE OF } \\
\text { OUPLICATION } \cdots\end{array}$ & 9,507 & 6.584 & 8,744 & 15,961 & 12,898 \\
\hline $\begin{array}{l}\text { SOUTH ATLANTIC ANO GULF, } \\
\text { TOTAL, EXCLUSIVE OF DUPLI- } \\
\text { CATION } \cdots \cdots \cdots\end{array}$ & 11,757 & 8,480 & 10,983 & 19.781 & 16,087 \\
\hline $\begin{array}{l}\text { PACIFIC: } \\
\text { ALASKA. } \\
\text { WASHINGTON: }: \vdots: \therefore: \\
\text { OREGON. } \\
\text { CALIFORNIA: }: \vdots: \therefore:\end{array}$ & $\begin{array}{r}252 \\
78 \\
325 \\
153 \\
\end{array}$ & $\begin{array}{r}86 \\
48 \\
164 \\
51 \\
\end{array}$ & $\begin{array}{r}85 \\
26 \\
102 \\
51 \\
\end{array}$ & $\begin{array}{r}255 \\
78 \\
325 \\
153 \\
\end{array}$ & $\begin{array}{r}87 \\
48 \\
154 \\
51 \\
\end{array}$ \\
\hline $\begin{array}{l}\text { TOTAL, EXCLUSIVE OF } \\
\text { DUPLICATION } \cdot \cdots \cdot \cdot\end{array}$ & 742 & 321 & 242 & 745 & 322 \\
\hline $\begin{array}{l}\text { GRANO TOTAL, EXCLU- } \\
\text { SIVE OF DUPL ICATION }\end{array}$ & 12,816 & 8,896 & 11,574 & 21,331 & 16,748 \\
\hline
\end{tabular}




\section{U.S. FISH OTTER TRAWL FLEET, 1975}

The fish otter trawl fleet employed 5,953 fishermen on 1,542 vessels (craft of 5 net tons or more) and 278 boats. One hundred and eighty-three vessels used 2 trawls, which brought the total number of trawls in use to 2,003 .

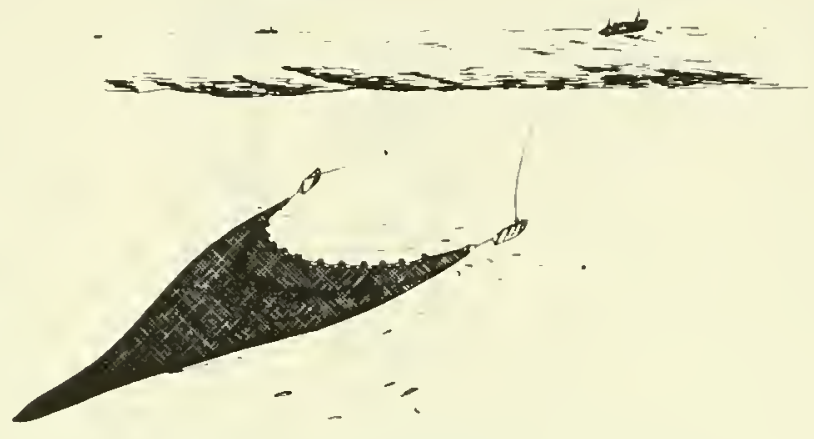

FISH OTTER TRAWL

\section{SUMMARY OF FISH OTTER TRAWL VESSELS, BY TONNAGE GROUPS, 1975}

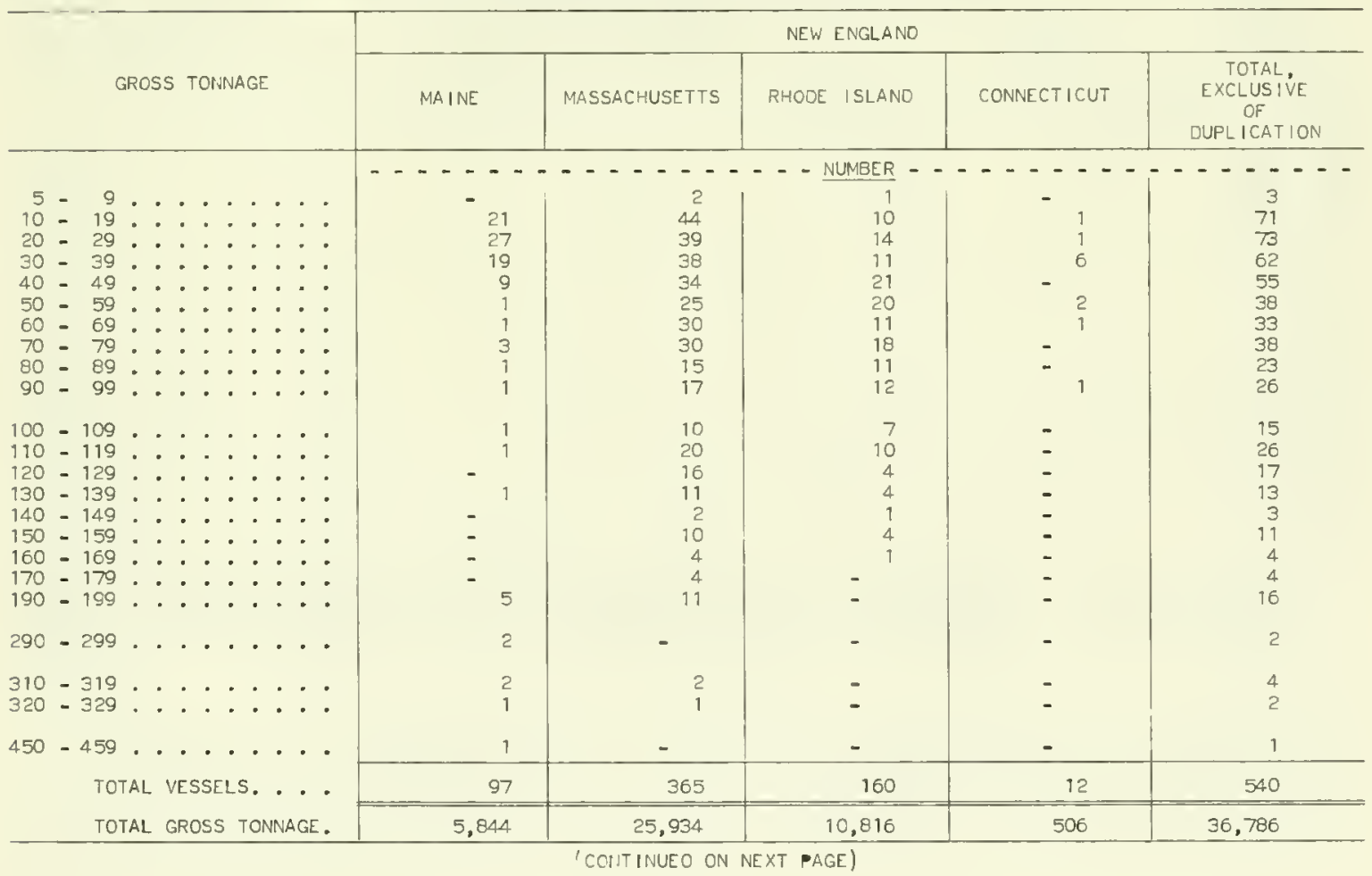


SUMMARY OF FISH OTTER TRAWL VESSELS, BY TONNAGE GROUPS, 1975 - Continued

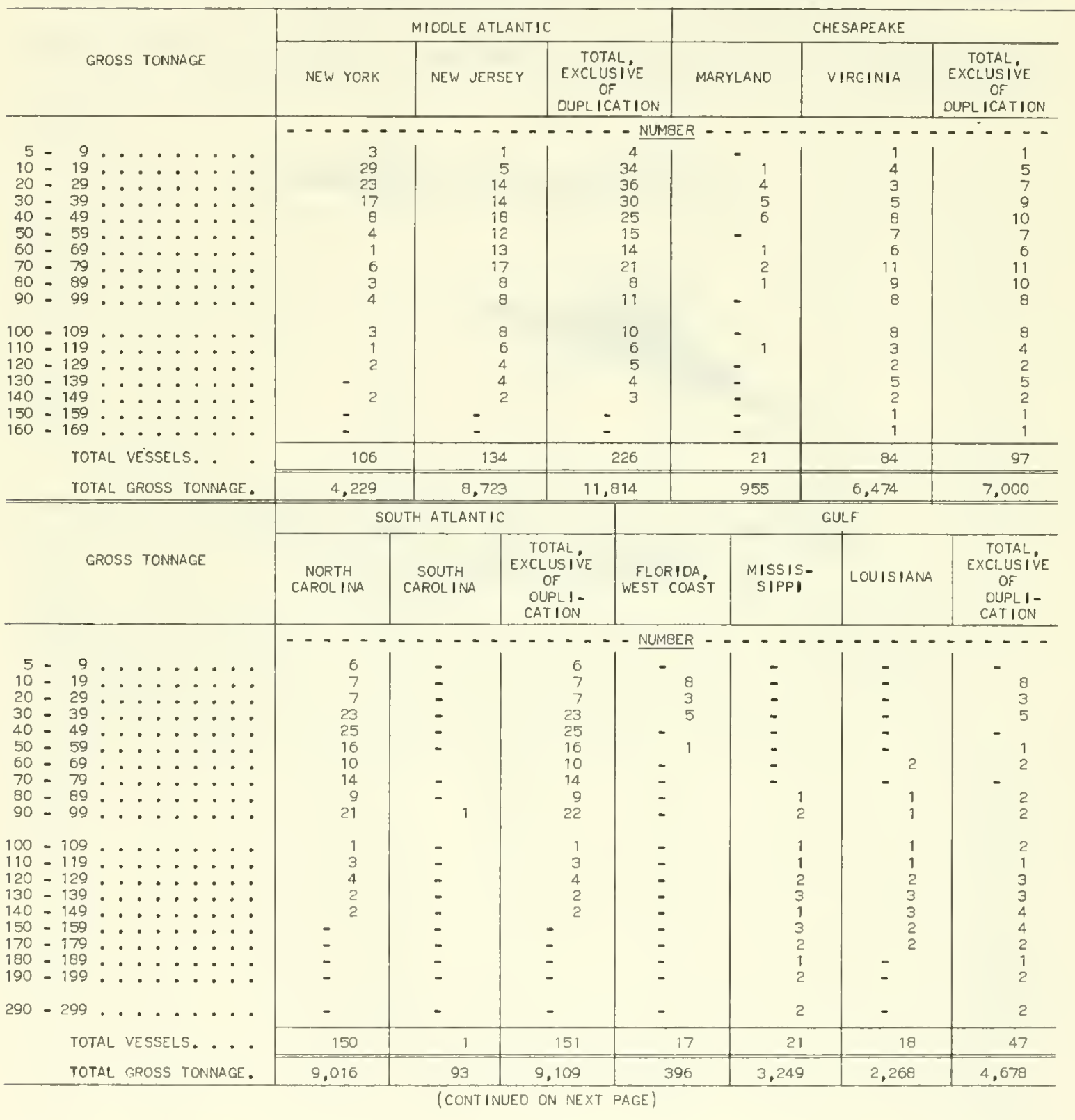


SUMMARY OF FISH OTTER TRAWL VESSELS, BY TONNAGE GROUPS, 1975 - Continued

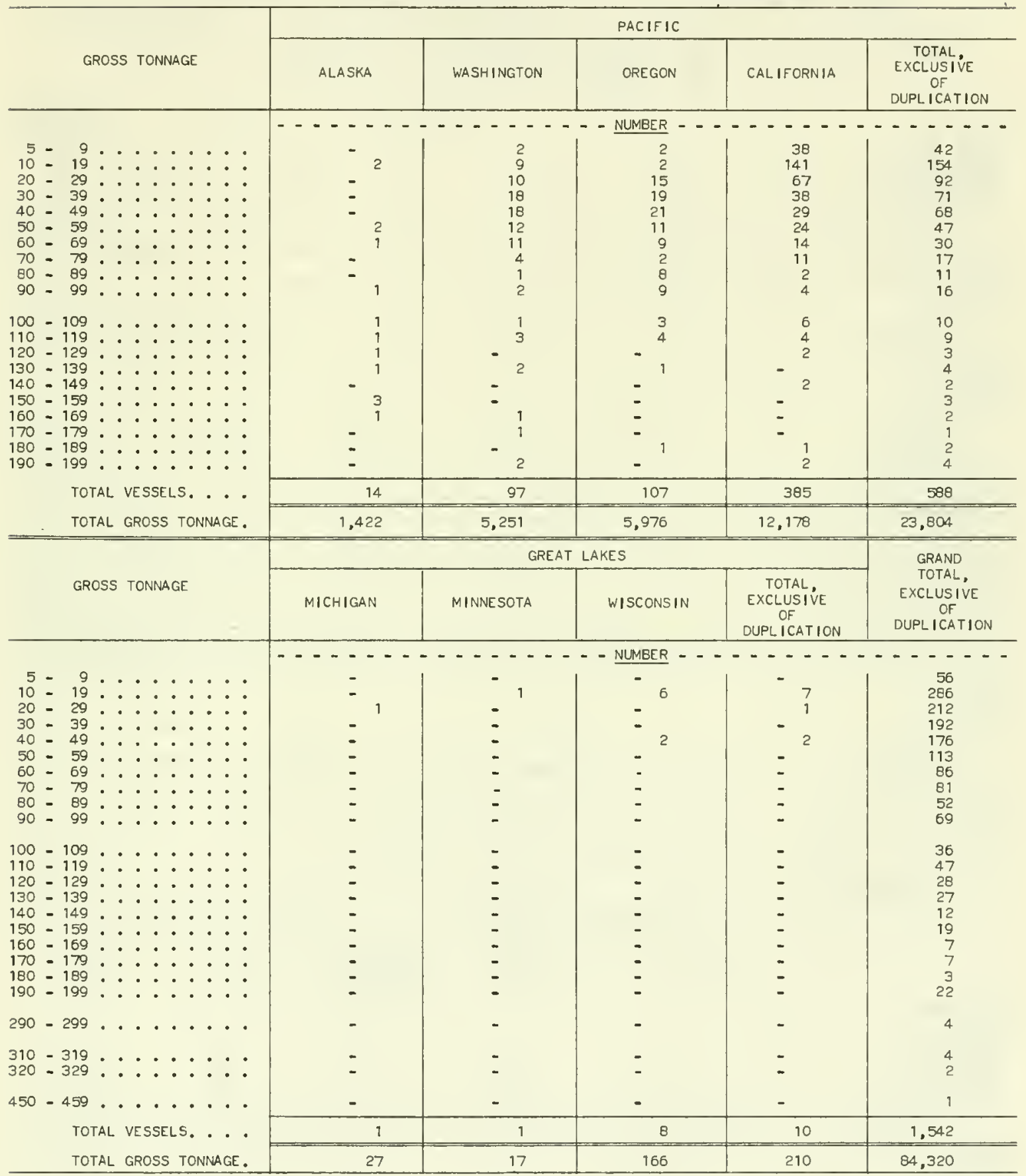




\section{SUMMARY OF FISH OTTER TRAWL OPERATING UNITS, 1975}

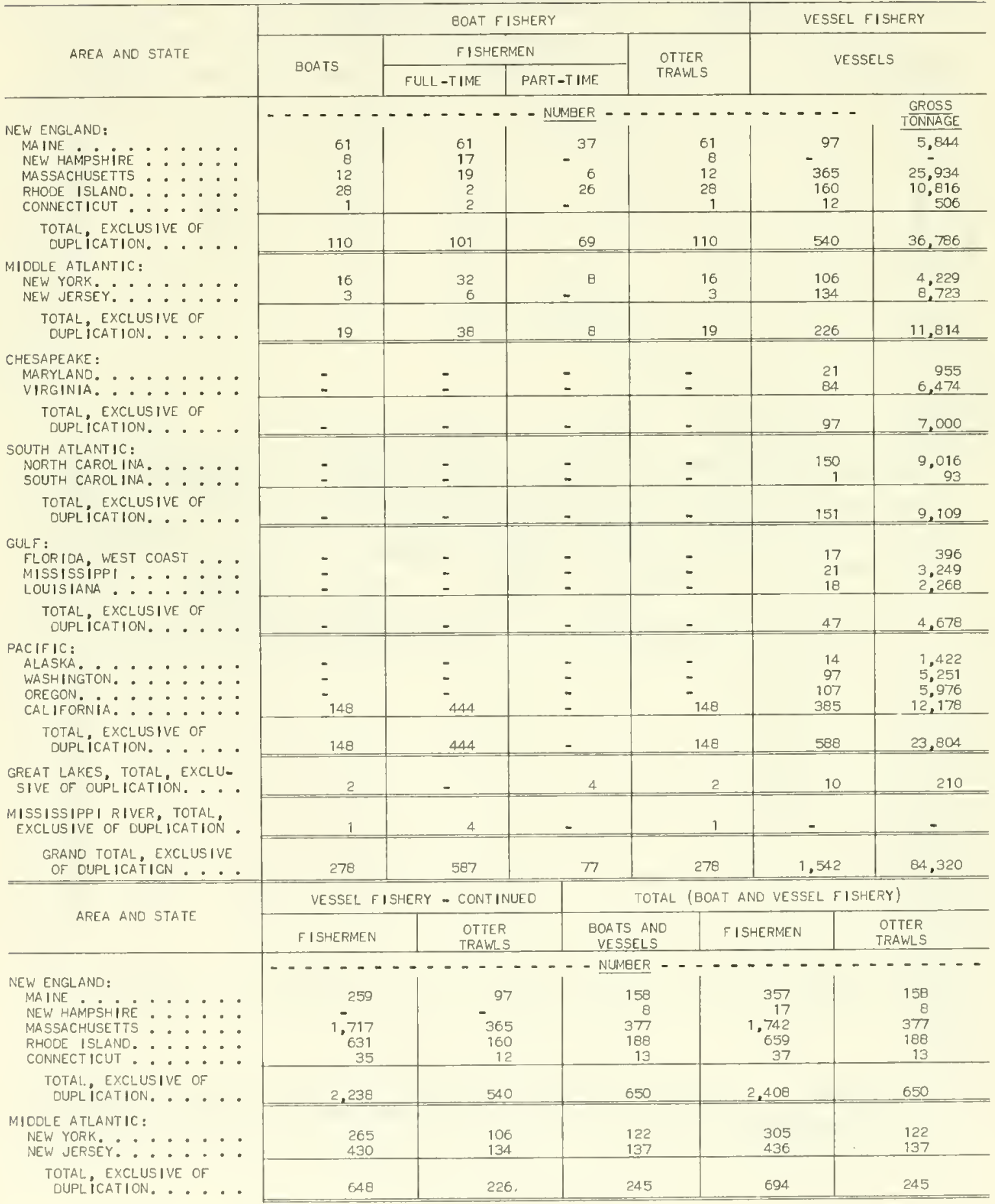

(CONTINUEO ON NEXT PAGE) 


\section{SUMMARY OF FISH OTTER TRAWL OPERATING UNITS, 1975 - Continued}

\begin{tabular}{|c|c|c|c|c|c|}
\hline \multirow{2}{*}{ AREA AND STATE } & \multicolumn{2}{|c|}{ VESSEL FISHERY - CONTINUEO } & \multicolumn{3}{|c|}{ TOTAL (BOAT ANO VESSEL F ISHERY) } \\
\hline & FISHERMEN & $\begin{array}{l}\text { OT TER } \\
\text { TRAWLS }\end{array}$ & $\begin{array}{l}\text { BOATS ANO } \\
\text { VESSELS }\end{array}$ & FISHERMEN & $\begin{array}{c}\text { OTTER } \\
\text { TRAWLS }\end{array}$ \\
\hline 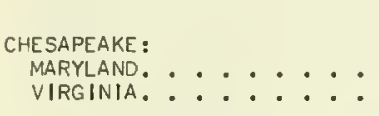 & $\begin{array}{r}\cdots \\
66 \\
353 \\
\end{array}$ & $\begin{array}{r}\cdots \\
21 \\
84 \\
\end{array}$ & $\begin{array}{r}- \text { NUMBER - } \\
\begin{array}{r}21 \\
84\end{array}\end{array}$ & $\begin{array}{r}-\ldots \\
66 \\
353 \\
\end{array}$ & $\begin{array}{l}-\ldots-\ldots \\
21 \\
84 \\
\end{array}$ \\
\hline $\begin{array}{l}\text { TOTAL, EXCLUSIVE OF } \\
\text { OUPLICATION. } . \cdots\end{array}$ & 392 & 97 & 97 & 392 & 97 \\
\hline $\begin{array}{l}\text { SOUTH ATLANTIC: } \\
\text { NORTH CAROL INA. }: .: \\
\text { SOUTH CAROLINA. }\end{array}$ & $\begin{array}{r}457 \\
3 \\
\end{array}$ & $\begin{array}{r}246 \\
2 \\
\end{array}$ & $\begin{array}{r}150 \\
1 \\
\end{array}$ & $\begin{array}{r}457 \\
-\quad 3 \\
\end{array}$ & $\begin{array}{r}246 \\
2 \\
\end{array}$ \\
\hline $\begin{array}{l}\text { TOTAL, EXCLUSIVE OF } \\
\text { OUPLICHTION. . . . }\end{array}$ & 460 & 248 & 151 & 460 & 248 \\
\hline $\begin{array}{l}\text { GULF: } \\
\text { FLORIOA, WEST COAST }: \\
\text { MISSISSIPPI }:: \therefore: \\
\text { LOUISIANA }:: \therefore\end{array}$ & $\begin{array}{l}70 \\
67 \\
54 \\
\end{array}$ & $\begin{array}{l}33 \\
40 \\
36 \\
\end{array}$ & $\begin{array}{l}17 \\
21 \\
18 \\
\end{array}$ & $\begin{array}{l}70 \\
67 \\
54 \\
\end{array}$ & $\begin{array}{l}33 \\
40 \\
36\end{array}$ \\
\hline $\begin{array}{l}\text { TOTAL, EXCLUSIVE OF } \\
\text { OUPL ICATION. . . . }\end{array}$ & 100 & 92 & 47 & 100 & 92 \\
\hline $\begin{array}{l}\text { PACIFIC: } \\
\text { ALASKA } \\
\text { WASHINGTON: }: \therefore: \therefore \\
\text { OREGON. }: \vdots: \therefore \\
\text { CALIFORNIA: }: \therefore: \therefore\end{array}$ & $\begin{array}{r}56 \\
319 \\
357 \\
1.155 \\
\end{array}$ & $\begin{array}{r}20 \\
97 \\
143 \\
385 \\
\end{array}$ & $\begin{array}{r}14 \\
97 \\
107 \\
533 \\
\end{array}$ & $\begin{array}{r}56 \\
319 \\
357 \\
7,599 \\
\end{array}$ & $\begin{array}{r}20 \\
97 \\
143 \\
533 \\
\end{array}$ \\
\hline $\begin{array}{l}\text { TOTAL, EXCLUSIVE OF } \\
\text { OUPLICATION. } . \cdots\end{array}$ & 1,841 & 630 & 736 & 2.285 & 778 \\
\hline $\begin{array}{l}\text { GREAT LAKES, TOTAL, EXCLU- } \\
\text { SIVE OF OUPLICATION. } \cdot \cdots\end{array}$ & 24 & 10 & 12 & 28 & 12 \\
\hline $\begin{array}{l}\text { MISSISSIPPI RIVER, TOTAL, } \\
\text { EXCLUSIVE OF OUPLICATION. }\end{array}$ & - & - & 1 & 4 & 1 \\
\hline $\begin{array}{l}\text { GRANO TOTAL, EXCLUSIVE } \\
\text { OF DUPLICATIION.... }\end{array}$ & 5,289 & 1,725 & 1,820 & 5,953 & 2,003 \\
\hline
\end{tabular}

COAST. 


\section{STATISTICAL SURVEY PROCEDURE}

"Fishery Statistics of the United States" (Statistical Digest) is prepared by the Resource Statistics Division, National Marine Fisheries Service (NMFS), U.S. Department of Commerce, and is a continuation of a series inaugurated by predecessor organizations in the Department of Interior, Commerce, and Commerce and Labor, and the U.S. Fish Commission. The Statistical Digest contains detailed statistics and analytical textual reviews on the commercial fisheries of the United States. Included are data on the quantity and value of the commercial landings of fishery products by States, larger geographic regions and gear; and the number of persons, vessels, boats, and fishing gear engaged in the fisheries. In the sections on the Great Lakes and Mississippi River, the catch is also tabulated by water bodies. The Statistical Digest also contains data on the volume and value of processed fishery products, freezings and cold storage holdings, foreign trade, and other related information.

Following is a brief history of the statistical surveys that have been conducted in the United States and a description of the procedures used to collect the different kinds of data in the various geographical areas of the country.

History--The first comprehensive statistical study of the fisheries and fishery industries of the United States was made for the year 1880 by George Brown Goode, Assistant Director of the U.S. National Museum, and associates, with the cooperation of the Commissioner of Fisheries and the Superintendent of the Tenth Census. Data for specific fisheries or geographic areas for years prior to 1880 , also were collected in the early survey and recorded in Mr. Goode's reports. The survey for 1880 , however, did not include the Mississippi River and its tributaries. Periodic general surveys of a limited number of States or limited areas of the United States were made for the years from 1880 to 1907 and from 1909 to 1928. The first complete statistical canvass of the entire United States was made for 1908 by the Bureau of the Census. The next general survey of the entire United States was not made until 1931, although complete data for all areas, excluding the Mississippi River and Its tributaries, were collected for 1929 and 1930. Complete data on the catch and operating units for these same sections were also collected for 1932. In the latter survey, however, lack of sufficient funds prohibited collection of data on the wholesale and manufacturing operations except those data collected as a part of the canned fishery products and byproducts survey. Various geographic areas were surveyed during the years from 1933 to 1949, inclusive. A complete survey of all sections of the country was made for 1950. Since 1951, all of the coastal areas have been canvassed annually, and catch records have been obtained for the Great Lakes area. Complete operating unit and catch data have been obtained for all areas since 1954, except that only a partial survey of the Mississippi River and its tributaries was made for 1961. Data on the wholesale and manufacturing industries were collected in all of the surveys from 1933 to 1940 , inclusive. In the years from 1941 to 1949 , inclusive, and in 1951 . lack of experienced personnel and budgetary limitations precluded the collection of data on wholesale and manufacturing firms except for those data collected as part of the canned fishery products, industrial products, and packaged fish surveys .

The chart on page 378 indicates the years for which surveys have been made in the various sections. Since the surveys of the fisheries have varied in completeness, three legends have been used for the years shown in the chart to indicate whether complete, partial, or no surveys were conducted in the individual regions. The designation "complete survey" has been used to indicate that basic operating unit and catch data were obtained and that complete information was collected on employment in wholesale and manufacturing establishments and on the production of manufactured fishery products. The legend "partial survey" usually indicates that operating unit 
and catch statistics were collected, but that no information was obtained on employment in wholesale and manufacturing establishments and that only partial data were obtained on the production of manufactured fishery products. In some Instances the designation "partial survey" is used for regions in which only catch statistics were collected. The legend "no survey" indicates that a general canvass was not conducted to obtain operating unit, catch, employment in wholesale and manufacturing plants, and complete manufactured products data. Although the chart indicates that in certain regions no surveys were conducted, some information may be available on the landings at certain important ports. Likewise, information on the catch of certain species, such as menhaden, may be avallable as a result of data collected in connection with the annual canned fish and byproducts survey. Data on the annual production of canned fishery products and byproducts have been collected for all regions since 1921, while information has been obtained on the production of packaged fish for 1926 and annually since 1928.

A bibliography listing the various surveys made since 1880 and the publications in which the results were published appeared in Statistical Digest No. 43. "Fishery Statistics of the United States, 1956." Figures for recent years are available from NMFS in bulletin form, but data for the earlier years are available only in the Fish Commission and Bureau of Fisheries printed reports. These reports are on file in the Department of Commerce library and in many public libraries.

Field Personnel--The statistics contained in this volume have been collected by trained fishery reporting specialists of the National Marine Fisheries Service (NMFS) and, in some cases, by personnel of State fishery agencies. The fishery reporting specialists are assigned to field stations, generally in the principal port within their areas, and travel from that station to conduct their various surveys.

Period Covered--Most of the reporting agents collect statistics on landings for the current year and assemble final operating unit, catch, and processed products data for the previous year. It is usually 3 to 10 months after the end of the calendar year for which they are collecting data before the final figures for the Digest are avallable. The data are tabulated and prepared for publication as soon as possible after the end of the year. The figures are collected and published on a calendar year basis. Prior to 1930, statistics on the catch of oysters in the Atlantic and Gulf States were collected for the oyster season; this is, from September to April, inclusive. Since 1930, they have been collected on a calendar year basis .

Scope--The coastal statistical surveys include canvasses of the commercial fisheries of the oceans, bays, and coastal rivers as far Inland as commercial fishing is important. This usually coincides with the range of commercial fishing for anadromous species. Statistics on the fisheries of the Mississippi River include those of the Mississippi River proper as well as all of its tributaries wherein commercial fishing for either fish, crustaceans, or moliusks is carried on. Statistics on the fisheries of the Great Lakes cover canvasses of the fisheries of the lakes proper, adjacent bays, the International Lakes of northern Minnesota, and rivers which sustain a commercial fishery having outlets into these waters. Statistics on the fisheries of Florida include the commercial fisheries in Lake Okeechobee and other inland lakes. Surveys for statistics of the wholesale and processing fishing industries cover plants located in the coastal, river, and lake areas adjacent to the waters mentioned above.

Methods of Collection--There are several methods used to collect fishery statistics, each of which has been carefully studied to obtain the best results with available personnel and funds. In the preparation of operating units data, field personnel are supplied with a deck of prepunched vessel cards obtained from the Bureau of Customs. These cards indicate the name, official number, rig code, gross tonnage, length, and year built. Field personnel enter the number of crewmen, and number and type of gear used by the vessel. These data are obtained by interview. Data on the craft of less than 5 net tons are obtained from State conservation agencies and by contact with firms purchasing fish or shellfish from fishermen. The data thus obtained are machine processed to ensure accuracy. 


\section{SURVEYS OF THE FISHERIES OF THE UNITED STATES}

\begin{tabular}{|c|c|c|c|c|c|c|c|c|c|c|c|c|c|c|c|c|c|c|c|c|c|c|c|c|c|c|}
\hline $\mathrm{C}$ & Comple & ete $S$ & urvey & & & & & & & Part & tial $\mathrm{S}$ & Surve & & & & & & & & & Surve & & & & & \\
\hline Area & 1800 & '81 & 82 & '83 ' & '84 '84 & 85 & 86 & '87 & $88 \cdot$ & 89 ' & 90 & '91' & '92's & 93 & \begin{tabular}{l|l}
9 &
\end{tabular} & \begin{tabular}{l|l}
95 & 9
\end{tabular} & $96 \mid 9$ & 97 '98 & 98 '9 & \begin{tabular}{l|l}
99 & 19
\end{tabular} & 900 'c & 01 & \begin{tabular}{l|l}
02 & 0
\end{tabular} & $03: 0$ & 04 & 5 \\
\hline New England & c & & & & & & & $\mathrm{P}$ & $\mathrm{P}$ & $P$ & & & & & & & & $\mathrm{P}$ & $P$ & & & & $\mathrm{P}$ & & $\mathrm{P}$ & ? \\
\hline Middle Atlantic & $\mathrm{C}$ & & & & & & & $\mathrm{P}$ & $\mathrm{P}$ & $\mathrm{P}$ & $\mathrm{P}$ & $\mathrm{P}$ & $\mathrm{P}$ & & & & & 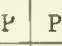 & $P$ & & & $\mathrm{P}$ & & $\mathrm{P}$ & & \\
\hline Chesapeake & $\mathrm{C}$ & & & & & & & P & $\mathrm{P}$ & & $P$ & $P$ & & & & & & $P$ & & & & $\mathrm{P}$ & & $P$ & & \\
\hline South Atlantic & C & & & & & & & $\mathrm{P}$ & $\mathrm{P}$ & $\mathrm{P}$ & $\mathrm{P}$ & & & & & & & $\mathrm{P}$ & & & & & $P$ & & & \\
\hline Gulf & C & & & & & & & $\mathrm{P}$ & $\mathrm{P}$ & $\mathrm{P}$ & $\mathrm{P}$ & & & & & & & $\mathrm{P}$ & & & & & $P$ & & & \\
\hline Alaska & $\mathrm{P}$ & $\mathrm{P}$ & $\mathrm{P}$ & $\mathrm{P}$ & $\mathrm{P}$ & $\mathrm{P}$ & $\mathrm{P}$ & $\mathrm{P}$ & $\mathrm{P}$ & $\mathrm{P}$ & $P$ & $P$ & $\mathrm{P}$ & $P$ & $\mathrm{P}$ & $\mathrm{P}$ & $\mathrm{P}$ & $\mathrm{P}$ & $\mathrm{P}$ & $\mathrm{P}$ & $\mathrm{P}$ & $\mathrm{P}$ & $\mathrm{P}$ & $P$ & 0 & c \\
\hline Wash., Oreg., Calif. & C & & & & & & & & $\mathrm{P}$ & $\mathrm{P}$ & $\mathrm{P}$ & $\mathrm{P}$ & $\mathrm{P}$ & & & $\mathrm{P}$ & & & & $\mathrm{P}$ & & & & $\mathrm{P}$ & $?$ & \\
\hline Great Lakes & c & & & & & P & & & & & $P$ & & & & & & & $\mathrm{P}$ & & $\mathrm{P}$ & & & & $P$ & & \\
\hline Mississippi River & & & & & & & & & & & & & & & $\mathrm{P}$ & & & $\mathrm{P}$ & & $\mathrm{P}$ & & & & P & & \\
\hline Area & 1906 & .07|' & '08 & '09' & '10 & 111 ' & '12' & '13: & $14{ }^{\prime}$ & $\left.15\right|^{\prime}$ & 16 & '17' & 18 . & '19" & $20: 2$ & $21 / 2$ & 22 & $23 \cdot 2$ & $24: 2$ & $25 \cdot 2$ & 26 & $27 ' 2$ & $28 \mid 2$ & 9 & 30 & 31 \\
\hline New England & & & $\mathrm{C}$ & & $\mathrm{P}$ & & & & & & & & & $\mathrm{P}$ & & & & & $P$ & $\mathrm{P}$ & $P$ & $\mathrm{P}$ & c & $\mathrm{C}$ & $c$ & c \\
\hline Middle Atlantic & & & $\mathrm{C}$ & & & & & & & $\mathrm{P}$ & & & & & & $P$ & & & & & $\mathrm{c}$ & & & $\mathrm{C}$ & $c$ & c \\
\hline Chesapeake & & & C & & & & & & & & & & & & $\mathrm{P}$ & & & & & $\mathrm{C}$ & & & & $\mathrm{C}$ & $c$ & $\mathrm{c}$ \\
\hline South Atlantic & & & $\mathrm{c}$ & & & & & & & & & & $\mathrm{P}$ & & & & & $P$ & & & & c & c & C & $C$ & $\mathrm{c}$ \\
\hline Gulf & & & $\mathrm{C}$ & & & & & & & & & & $\mathrm{P}$ & & & & & $\mathrm{P}$ & & & & $\mathrm{C}$ & C & $\mathrm{C}$ & $c$ & $\mathrm{C}$ \\
\hline Alaska & $\mathrm{C}$ & $\mathrm{C}$ & C & C & C & $\mathrm{C}$ & C & $\mathrm{c}$ & $\mathrm{C}$ & c & $\mathrm{C}$ & C & C & C & c & C & C & c & c & C & C & c & c & C & C & C \\
\hline Wash., Oreg., Calif. & & & $\mathrm{c}$ & & & & & & & $P$ & & & & & & & $\mathrm{P}$ & $\mathrm{P}$ & $P$ & $\mathrm{P}$ & P & $\mathrm{P}$ & C & C & c & C \\
\hline Great Lakes & & & c & & & & & $\mathrm{P}$ & $\mathrm{P}$ & $\mathrm{P}$ & $P$ & $P$ & $\mathrm{P}$ & P & $\mathrm{P}$ & $\mathrm{P}$ & $P$ & $\mathrm{P}$ & $P$ & $\mathrm{P}$ & P & $\mathrm{P}$ & $\mathrm{P}$ & C & C & $\mathrm{C}$ \\
\hline Mississippi River & & & c & & & & & & $\mathrm{P}$ & $P$ & & & & & & & $\mathrm{P}$ & & & & & & & & & \\
\hline Area & 1932 & '33' & '34 & 35 ' & 36 & '37. & '38 & 39 & 40 & $41^{\prime}$ & 42 & 43 . & 44. & '45 ' & $46^{\circ}$ & 47.4 & $48^{\circ}$ & $49 \cdot 5$ & $50 \cdot$ & 51 & 52 & 53 & '54'5 & $55 \mid \cdot 5$ & 66 '5 & 57 \\
\hline New England & $\mathrm{P}$ & $\mathrm{C}$ & & c & & c & $\mathrm{c}$ & $\mathrm{C}$ & $\mathrm{C}$ & & $\mathrm{P}$ & $\mathrm{P}$ & $\mathrm{P}$ & $\mathrm{P}$ & $\mathrm{P}$ & $\mathrm{P}$ & $\mathrm{P}$ & $\mathrm{P}$ & $\mathrm{C}$ & $\mathrm{P}$ & $\mathrm{C}$ & C & $\mathrm{C}$ & $\mathrm{C}$ & $\mathrm{C}$ & c \\
\hline Middle Atlantic & $P$ & $\mathrm{c}$ & & $\mathrm{C}$ & & $\mathrm{c}$ & $\mathrm{c}$ & c & $\mathrm{c}$ & & $\mathrm{P}$ & $\mathrm{P}$ & $\mathrm{P}$ & $\mathrm{P}$ & $\mathrm{P}$ & $\mathrm{P}$ & $\mathrm{P}$ & $\mathrm{P}$ & $\mathrm{C}$ & $\mathrm{P}$ & C & C & $\mathrm{C}$ & C & C & C \\
\hline Chesapeake & $P$ & $\mathrm{c}$ & $\mathrm{C}$ & c & C & $\mathrm{C}$ & $\mathrm{C}$ & $\mathrm{c}$ & C & $\mathrm{P}$ & $\mathrm{P}$ & & $P$ & $\mathrm{P}$ & $\mathrm{P}$ & $\mathrm{P}$ & $\mathrm{P}$ & $\mathrm{P}$ & $\mathrm{C}$ & $\mathrm{P}$ & $\mathrm{C}$ & $\overline{\mathrm{C}}$ & $\mathrm{C}$ & $\mathrm{C}$ & $\mathrm{C}$ & $\mathrm{C}$ \\
\hline South Atlantic & $\mathrm{P}$ & & C & & C & C & c & C & C & & & & & $\mathrm{P}$ & & & & & C & $\mathrm{P}$ & $\mathrm{C}$ & c & $\mathrm{C}$ & $\mathrm{C}$ & $\mathrm{C}$ & c \\
\hline Gulf & $\mathrm{P}$ & & $\mathrm{C}$ & & $\mathrm{c}$ & $\mathrm{c}$ & $\mathrm{c}$ & $\mathrm{C}$ & C & . & & & & $\mathrm{P}$ & & & $\mathrm{P}$ & P & $\mathrm{C}$ & $\mathrm{P}$ & c & c & $\mathrm{C}$ & $\mathrm{C}$ & C & C \\
\hline Alaska & C & c & $\mathrm{C}$ & C & $\mathrm{C}$ & $\mathrm{c}$ & c & $\mathrm{C}$ & $\mathrm{C}$ & $\mathrm{c}$ & c & $\mathrm{C}$ & $\mathrm{C}$ & C & $\mathrm{C}$ & $\mathrm{C}$ & $\mathrm{c}$ & $\mathrm{C}$ & C & $\mathrm{C}$ & $\mathrm{C}$ & c & $\mathrm{c}$ & $\mathrm{C}$ & C & $\mathrm{c}$ \\
\hline Wash., Oreg., Calit. & $\mathrm{P}$ & c & $\mathrm{C}$ & $\mathrm{C}$ & c & C & c & C & C & $P$ & $\mathrm{P}$ & $P$ & $P$ & $P$ & $\mathrm{P}$ & $\mathrm{P}$ & $P$ & $\mathrm{P}$ & $\mathrm{C}$ & $\mathrm{P}$ & $\mathrm{C}$ & C & $\mathrm{C}$ & $\mathrm{C}$ & $\mathrm{C}$ & $\mathrm{C}^{-1}$ \\
\hline Great Lakes & $\mathrm{P}$ & $\mathrm{P}$ & C & $\mathrm{P}$ & $\mathrm{C}$ & $\mathrm{C}$ & C & C & c & $\mathrm{P}$ & $\mathrm{P}$ & $\underline{P}$ & $\mathrm{P}$ & $\mathrm{P}$ & $\mathrm{P}$ & \begin{tabular}{l|l}
$\mathrm{P}$ & 1
\end{tabular} & $\mathrm{P}$ & $\mathrm{P}$ & C & $\mathrm{P}$ & $P$ & $P$ & $\mathrm{C}$ & $\mathrm{C}$ & C & $\mathrm{C}$ \\
\hline Mississippi River & & & & & & & & & & & & & & & & & & & C & & & & $\mathrm{C}$ & $\mathrm{C}$ & $\mathrm{C}$ & $\mathrm{C}$ \\
\hline Hawaii & & & & & & & & & & & & & & & $\mathrm{P}$ & P 1 & $\mathrm{P}$ & $P$ & $\mathrm{P}$ & $\mathrm{P}$ & $\mathrm{P}$ & $P$ & $P$ & $\mathrm{P}$ & $\mathrm{P}$ & $\mathrm{P}$ \\
\hline Area & 1958 & 59 & 60 & '61' & 62 ' & '63 ' & '64 & '65 & '66.' & $677^{\circ}$ & 68 & 69 ' & '70' & '71' & 72 ' & $73^{\circ}$ & '74' & 75 & & & & & & & & \\
\hline New England & C & C & C & c & C & C & C & $\mathrm{C}$ & c & c & C & $\mathrm{C}$ & C & C & $\mathrm{C}$ & c & C & $\mathrm{c}$ & & & & & & & & \\
\hline Middle Atlantic & C & C & C & C & C & c & C & C & c & c & C & C & C & c & C & C & C & C & & & & & & & & \\
\hline Chesapeake & c & C & C & c & c & c & C & C & C & C & C & C & $\mathrm{C}$ & c & $C$ & C & C & C & & & & & & & & \\
\hline South Atlantic & c & C & C & c & C & c & C & c & C & c. & C & $\mathrm{C}$ & $\mathrm{C}$ & $\mathrm{C}$ & C & $\mathrm{C}$ & $\mathrm{C}$ & C & & & & & & & & \\
\hline Gulf & c & C & c & c & C & c & $\mathrm{C}$ & C & C & c & C & C & c & c & C & c $c$ & C & C & & & & & & & & \\
\hline Alaska & c & C & c & C & $\mathrm{C}$ & C & C & $\mathrm{C}$ & c & C & C & c & C & $\mathrm{C}$ & C & C & $\mathrm{C}$ & c & & & & & & & & \\
\hline Wash., Oreg., Calif. & C & $\mathrm{C}$ & C & $\mathrm{C}$ & C & C & C & c & c & c & C & C & $\mathrm{C}$ & $\mathrm{C}$ & C & C & C & c & & & & & & & & \\
\hline Great Lakes & C & $\mathrm{C}$ & c & c & $\mathrm{C}$ & C & $\mathrm{C}$ & C & c & C & C & $\mathrm{C}$ & C & $\mathrm{C}$ & C & C & C & $\mathrm{c}$ & & & & & & & & \\
\hline Mississippi River & c & C & $P$ & $P$ & C & $\mathrm{C}$ & C & $\mathrm{C}$ & c & C & C & C & C & $\mathrm{C}$ & c & C 1 & C & C & & & & & & & & \\
\hline Hawaii & $\mathrm{P}$ & C & c & c & c & C & C & c & $\mathrm{C}$ & C & C & C & c & $\mathrm{C}$ & c & c & C & $\mathrm{C}$ & & & & & & & & \\
\hline
\end{tabular}


Data on over 96 percent of the catch are avallable from summaries of monthly landings bulletins and other current records assembled by NMFS or the various States. If complete catch data are not available from central sources, wholesale dealers and manufacturers of fishery products are visited, and data are obtained from them on their purchases of fish and shellfish. It is Impossible for the few Service representatives available for this work to interview each fisherman in a given locallty. However, the more important areas and a sufficient number of areas of lesser. Importance are visited to obtain rellable information on production, the number of fishing craft engaged, the quantity of gear operated, catch by gear and waters, and the number of persons employed as fishermen.

The Service's role with regard to fishery statistics is principally that of coordinating the collection of information and assembling, analyzing, publishing, and disseminating fishery data. The State fishery agencies in a number of States have developed relatively complete statistical systems which greatly facilitate the Service's surveys in these States. In such instances, the Service conducts only such surveys as may be necessary to make the data comparable with those of other States.

NMFS obtains from the records of the State fishery agencies most of the catch statistics for the fisheries of the Great Lakes, the northern Mississippi River area, and the International Lakes of northern Minnesota. To obtaln data on the number of flshermen, boats, vessels, and gear, the Service conducts such personal surveys among the fishermen as may be necessary to supplement the State records.

NMFS statistical personnel are stationed at Seattle, Wash., and Terminal Island, Cal. for the purpose of surveying the fisheries of Washington, Oregon, and Callfornia. They obtain from the records of the State fishery departments figures on the volume of the catch and operating units. The value of the catch is dertved from State and dealers'records. In Washington and Oregon, data for operating units in the offshore fisheries are obtained from the records of various flshery organizations as well as from records of the State fishery agencies. Statistics on the wholesale fishery industry for this section are obtained largely by personal interviews .

In many States, NMFS and the fishery agency of the respective States cooperate in the collection and publication of current monthly and annual data on the catch. These data form the basis of the annual catch figures published in the Digest for the following States: Maine, Massachusetts, Rhode Island, New York, New Jersey, Maryland, Virginia, North Carolira, South Carolina, Georgia, Florida, Alabama, Mississippi, Louisiana, Texas, Ohio, Michigan, and Wisconsin.

In the administration of the Alaska fisheries, the State requires that coples of all receipts for fish and shellfish purchases from fishermen be furnished to the Alaska Department of Fish and Game. The data on these tickets are compiled and made avallable to NMFS. The summary data, by districts, are reproduced in this report.

Statistics on the volume of the catch of fish in the Great Lakes States usually are shown in weights as landed, which may be in the round or drawn condition. Statistics on the volume of the catch of fish taken in the remainder of the United States are usually shown in round welght.

The figures in the tables for shellfish represent the weight of the meats in the case of unlvalve and bivalve mollusks, and round weight in the case of crustaceans and such cephalopods as squid and octopus. 
Shore and Vessel Fisheries--In general, statistics of the shore fisheries collected by NMFS representatives include data on the number of casual and regular fishermen; number of motor and other fishing boats (craft of less than 5 net tons capacity are called "boats"); type and quantity of gear used; and the volume, value, and method of capture of each species for each locality or group of localities. The availability of data collected by some State fishery agencies obviates the necessity of detalled surveys by NMFS personnel.

Statistics on the vessel fisheries include data on the number in the crew; rig of vessels; gross tonnage; kind and quantity of gear used; and volume, value, and method of capture of each species. Craft having a capacity of 5 net tons or over are called "vessels." As in the shore fisherles, the availability of figures collected by State fishery agencles may eliminate the necessity of Service agents collecting these data for individual vessels. Information on the year vessels were built was assembled for 1961, 1966, and 1968 to present.

Statistics on the quantity of gear operated indicate the maximum number of units fished at any one time during the year. Gear carried in reserve for replacement is not reported.

All persons engaged in commerclal fishing operations are included as fishermen. In most areas, fishermen not on vessels have been divided into "full-time" and "part-time." Full-time fishermen are defined as those who receive more than one-half their annual income from fishing, whereas part-time fishermen are those who receive less than one-half their annual compensation from fishing. It has not been possible to separate full-time from part-time fishermen on the Pacific Coast.

Since 1942, the catch of fish and shellfish has been credited to the port at which it was landed. Prior to the survey for that year, it was the practice of NMFS to credit the entire catch of a vessel to the principal port at which fish or shellfish were unloaded, regardless of the actual home port of the vessels. This policy was discontinued since it quite often resulted in inconsistencies by crediting landings of some species to areas far removed from localities in which they are commonly taken. An outstanding example of this is the southern trawl fishery conducted off the New Jersey, Maryland, Virginia, and North Carolina coasts. Some fishing vessels from New England operate in this fishery for 6 to 10 weeks during the winter season. Prior to the survey for 1942, the catch of these vessels, consisting principally of fish common to Middle Atlantic waters, was credited to Massachusetts. Under the present system, this catch is credited to the Middle Atlantic ports where it is landed.

Since 1949 on the Pacific Coast and 1951 for the remainder of the country, craft, fishermen, and gear have been reported for each State in which they fished. A total exclusive of duplication is shown for each section and for the United States as a whole. Prior to the surveys for 1949, each craft on the Pacific Coast was credited to its home port unless it did not fish from that port during the year. In that case, it was credited to the locality where it landed the greatest portion of 1ts catch. Prior to the survey for 1951, each craft on the Atlantic and Gulf Coasts and interfor waters was credited to the port where it landed the greatest portion of its catch during the year. This system was changed to provide more accurate data on the total number of craft operating in a given State. With the increased mobility of the fishing fleet in recent years, the number of vessels fishing in more than one State has increased greatly.

Beginning with data for 1951 , the reporting of unlts of gear was standardized so that nets or lines made up of small units for ease in handling, but fastened together in fishing, were counted as a single unit rather than as a number of smaller units. Prior to 1951, the small units were sometimes counted as Individual pieces of gear even though they were combined for fishing. Th1s rule does not apply to halibut longlines or setlines on the Paciflc Coast. In this flshery, each skate of gear is counted as one line, even though fastened together in fishing, because the International Pacific Halibut Commission uses a skate as a unlt inits studies of fishing intensity. 


\section{STATISTICAL SURVEY PROCEDURE}

Beginning with 1962, only summary data have been shown on the number of fishing gear operated in the Great Lakes and the International Lakes of northern Minnesota. These data appear in the General Review section of the Digest in the table "Summary of Operating Units." In detailed operating unit tables for these lakes, the number and size of gear have been replaced by information on the fishing effort expended in the operation of each gear.

Publication of Data--Statistics on employment in the fisheries, craft and gear engaged, quantlty and value of catch, and certaln data on industries related to the fisherles are summarized according to geographic divisions and publlshed in bulletin form as soon as possible after the completion of each survey. Later, the figures, in more detail, are included in this statistical report .

Data on the operating units (fishermen, fishing craft, and gear) and catch by counties for the Atlantic and Gulf States have been included in these annual statistical reports for the years from 1928 to 1938 except for 1932 . These data have also been published in the digests for the years $1945,1950,1955$, and 1960. County data were collected for the State In whIch surveys were conducted during the years since 1938, except for Maryland. Between 1942 and 1959, only operating unit data by counties have been obtained for Maryland. Complete data were obtained for 1960. County data assembled for the years since 1938 which were not published in the Dlgest are on file in the Washington Office of the Data Management and Statistics Division.

\section{LOCAL AND SPECIAL SURVEYS}

Landings at Certain Massachusetts Ports--Detailed statistics are collected on the landings of aquatic products by individual fishing craft at Boston, Gloucester, New Bedford, Plymouth, Provincetown, and other Cape Cod ports. Data on the landings at Boston and Gloucester have been collected annually since 1893. Information on landings at New Bedford has been collected annually since 1938; and at Plymouth. Provlncetown, and other Cape Cod ports since 1945. NMFS representatives are stationed at the principal ports. They obtain figures on the quantity and value of fish landed dally by fishing craft, the dates of departure and arrival of the craft, the gear used in their capture, the grounds from which the fish were taken, and other related information. The Service's Office of Resource Research cooperates in the collection of these data.

Statistics on landings at the above ports are released monthly and annually in bulletin form, and summary data are published in the annual Statistical Digest.

Shad and Alewife Fisheries--Surveys for statistics on the catch, value of catch, and operating units in the Hudson and Potomac River shad fisherles are made annually. On the Potomac River, similar statistics are also obtained for the alewife fishery. Much of the data required for the se surveys is available from the States' fishery agencies.

Annual data on the shad and alewife fisheries are not published separately in bulletin form. However, a summary is published in various Digests.

Statistics on the Hudson River shad fishery are available for 1896, 1897, 1898, 1901, 1904 , 1910, and continuouslv since 1915. Data for the Potomac River shad fisheryare avallable for 1896, 1901, 1904, 1909, 1915, 1919 to 1942, and 1944 to 1971, inclusive. Statistics on the Potomac River alewife fishery are available for $1896,1909,1915,1919$ to 1942, and 1944 to 1971 , inclusive. 
South Atlantic and Gulf of Mexico Shrimp Fishery--Detailed statistics on quantity and value of shrimp, by variety and size, landed at South Atlantic and Gulf ports, have been collected for the Gulf area since 1956 and the South Atlantic since 1957. Since 1956, NMFS personnel have also obtained daily information on the number of fishing trips, area and depth fished, and time spent fishing for craft landing at U.S. ports in the Gulf of Mexico. Various fishery agencies of the southern States cooperate in the collection of the se data.

Detalled monthly and annual summaries of the statistics on shrimp catch and landings are published in bulletin form and are summarized in the Statistical Digests.

Historical Fishery Statistics--NMFS has in its files and in various reports or publications, a large volume of historical data on fisheries. Beginning with the 1951 Digest, a section entitled "Historical Fishery Statistics," which includes complete historical information on selected species, has been carried. There is published each year a listing of the titles of the series of data appearing in earlier editions.

Review of Certain Major Fisheries--For the years 1942-75, tabulations containing complete data on the catch of certain major species have been included in a section of the Digest entitled "Review of Certain Major Fisheries." Although the data are included in the detalled catch tables of the various States, they are consolidated in this section to provide a single source of data for cod, haddock, menhaden, Atlantic ocean perch, salmon, tuna, oysters, clams, crabs, and shrimp. Data on operating units in the following fisheries have likewise been consolidated in this section: salmon purse seine and troll line, Atlantic and Pacific Coast tuna, menhaden purse seine, fish and shrimp otter trawls.

Canned Fishery Products and Industrial Products--Since 1921, NMFs has made annual sectional surveys for statistics on canned and industrial fishery products. These surveys are started the first week in January of each year for statistics on the production in the preceding year. So far as possible, the Service obtains by mail, statistics on the annual production of each domestic canned and industrial fishery products plant. If it is impossible to obtain the information by mail, the report is secured by a NMFS representative. Inciuded in the data obtained are statistics on the yield and value of the canned products by type of commodity, can size, and area of production. Data on industrial products are obtained by commodity and area of production. The value shown for canned and industrial products is the gross amount received by the packer at the production point. No deductions are made for commissions or expenses.

Annual statistical bulletins are issued on this trade, and detailed data are published in the Statistical Digest. Prior to 1921, canned and industrial products data were not collected for the entire country. However, data on the production of the se products were usually obtained for the areas in which general canvass surveys were conducted.

Fish Meal and Oil--Data are collected monthly on the domestic production of fish meal, body oils and fish solubles. This information is released monthly and annualiy in the Service's Current Fishery Statistics series of bulletins.

Fish Fillets and Steaks--Statistics on the annual production and value of fish fillets and steaks in the United States are obtained in conjunction with the canned and industrial fishery products survey. These data are released annuaily in bulletin form and in the annual Statistical Digest. Statistics on the production of fillets and steaks are available for 1926 and annualiy since 1928, except that no data were collected in California for the years 1941 to 1946, inciusive. 
Fish Sticks and Portions--Quarterly information is collected and published on the production and value of breaded, cooked and raw fish sticks, breaded, cooked and raw fish portions, and unbreaded fish portions. The data are released in the Service's Current Fishery Statistics series of bulletins.

Cold-Storage Holdings of Fish--Information on the monthly freezings and holdings of fishery products is obtained from cold storage warehouses by mall and by NMFS employees. Data are also obtained on the holdings of certain cured fish. Bulletins showing these statistics are issued monthly and annually.

Detailed cold-storage statistlcs also are published in the Statistical Digest. Information regardina cold-storage holdings of fishery products has been published since 1917, while data on the quantity of fish frozen have been released for the years from 1920 to 1925, inclusive, and continuously since 1928 .

Foreign Fishery Trade--Statistics on foreign trade are obtained from compilations made by the Bureau of the Census, Department of Commerce. Statistics on all known imported or exported fishery products have been assembled and published annually since 1926 in the Digest. For earlier years, figures are available in the reports of the Bureau of the Census, Bureau of Foreign and Domestic Commerce, the Bureau of Statistics, the Department of Commerce and Labor, or the Treasury Department.

\section{PRACTICES AND TERMS}

Certain practices and terms used in this report are explained below.

Operating Units - -Operating units include persons employed in the fisheries, and craft and gear engaged in the fisheries.

Vesse1--A craft having a capacity of 5 net tons or over.

Boat--A craft having a capacity of less than 5 net tons.

Days Absent--In computing "days absent" for vessels landing fares at certain Massachuserts ports, the day of arrival, but not the day of departure, is included; thus, a vessel leaving port on the 8 th of the month and returning on the 15 th of the month will be credited with 7 days'absence. Prior to 1944, "days absent" included both the day of departure and the day of arrival.

Days Fished--In computing "days fished" for fishing craft landing shrimp at Gulf of Mexico ports, the total number of hours spent in fishing effort has been divided by 24 . Pisces.

Fish-- The term "fish" as used in this report includes all specles belonging to the class

Shellfish et a l.--A shellfish is an aquatic invertebrate animal having a shell, such as a mollusk or crustacean. However, in order to reduce the classifications appearing in the catch tables, all items not properly listed as "Fish" or "Whale Products" have been included under "Shellfish et al." Accordingly, turtles, frogs, sponges, seaweed, and worms are included under this classification. 
Incidental $\mathrm{Catch}--$ The term "incidental catch" refers to the catch of certain species by a type of gear which ordinarily does not capture such species.

Percentages--Percentages are usually shown as whole numbers. Fractions of percents are dropped if less than five-tenths, an the percentage is raised to the next higher integer if the fraction is greater than five-tenths. If the fraction is exactly five-tenths, odd integers are raised to the next even figure while even integers remain unchanged.

Converting - -Many of the figures shown in the summary tables published herowith have converted to thousands of pounds or thousands of dollars. In making these conversions the sum of the items in a table is raised or lowered to the nearest thousand in accordance with standard statistical procedures. The individual items are adjusted to conform to the total thus obtained.

Confidential Data--The statistical data collected by the Service are confidential, and, unless specific authorization is given, are not released in a manner that would divulge private enterprise.

\section{CONVERSION FACTORS}

It is the pollcy of the Service to show detailed catch figures of all products in pounds for the sake of uniformity and for the purposes of comparison. This represents little difficulty in the case of fish, since in very rare instances are fish reported in units of measure other than pounds. For shellfish, however, the units of measure may be bushels, sacks, barrels, numbers, gallons of meats, etc. So many units make standardization difficult, and when combined with the wide variation in the requirements or definitions of some of these units in the various States, the problem becomes even more complex.

All univalve and bivalve mollusks (except fresh-water mussel shells) are reported in pounds of meats in the detailed catch tables presented in this report. In addition, there are included supplementary tables for most of the sections, which give data on the production in bushels. These supplementary tables also give the production in number of certain other shellfish, such as crabs. There also is included in the General Review section of this report a table containing data on the shell weight of univalve and bivalve mollusks taken.

Oysters--Probably the greatest problem in the presentation of fishery statistics in uniform units of measure is in the case of oysters. Usually the production of oysters on the Atlantic and Gulf Coasts is reported to NMFS personnel in bushels. Prior to the data obtained for the year 1930, bushels were converted to pounds of meats on the basis of a uniform yield of 7 pounds of meats to the bushel. However, it was found that there was considerable variation in the yield of oysters per bushel particularly in Southern States where the yield has ranged as low as half the conversion factor used prior to 1930. There follows a table which gives the measures used for oysters in the various States and the average yields per bushel. The statistical tables in this report are based on these average yields. 


\section{MEASURES AND YIELD OF OYSTERS}

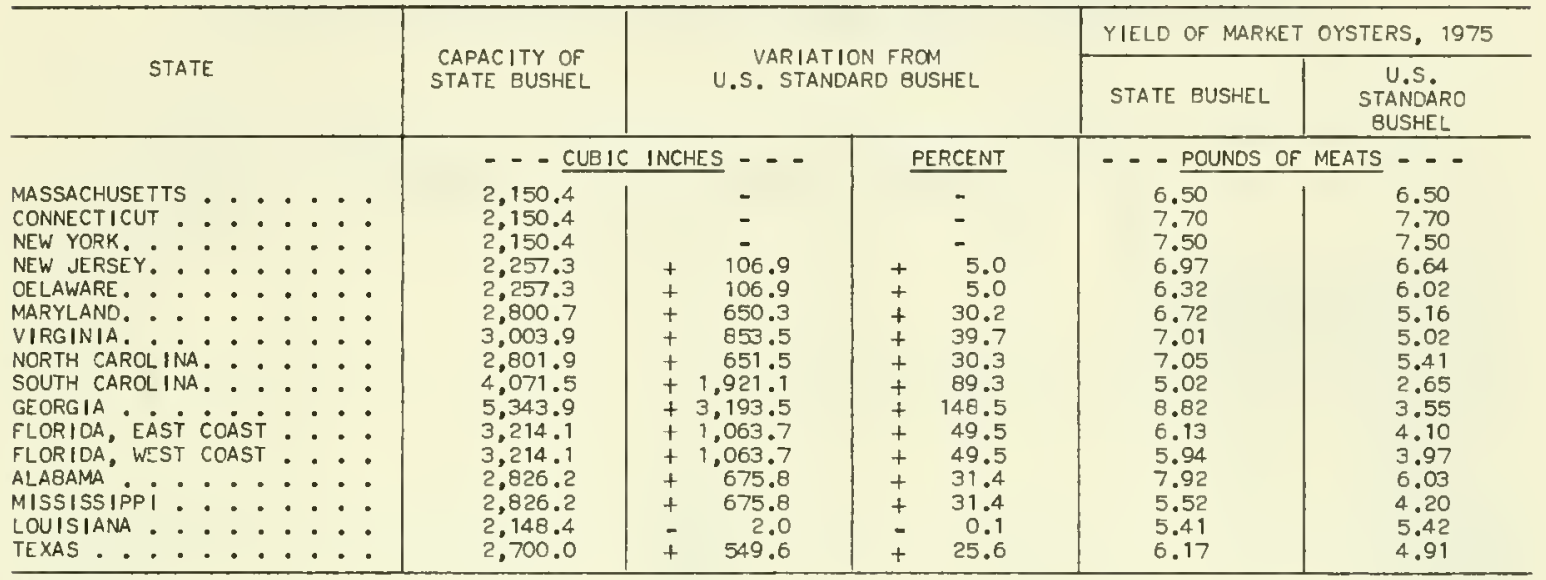

NOTE:--THE CAPACITY OF A U.S. STANDARO BUSHEL IS $2,150,4$ CUBIC INCHES.

AVERAGE YIELD OF CERTAIN MOLLUSKS, 1975

\begin{tabular}{|c|c|c|c|c|c|c|}
\hline \multirow{3}{*}{ STATE } & \multicolumn{6}{|c|}{ CLAMS } \\
\hline & \multicolumn{2}{|c|}{ HARD } & \multirow{2}{*}{$\begin{array}{l}\text { OCEAN } \\
\text { QUAHOG }\end{array}$} & \multirow{2}{*}{ RAZOR } & \multirow{2}{*}{ SOFT } & \multirow{2}{*}{ SURF } \\
\hline & PUBLIC & PRIVATE & & & & \\
\hline 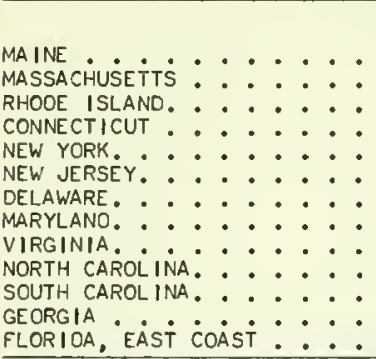 & $\begin{array}{r}\cdots \\
11.00 \\
11.00 \\
12.00 \\
12.00 \\
10.00 \\
8.00 \\
8.00 \\
8.00 \\
8.75 \\
8.75 \\
8.00\end{array}$ & $\begin{array}{c}- \text { POUNO } \\
11.00 \\
12.00 \\
12.00 \\
\vdots \\
\vdots \\
\vdots \\
\vdots \\
-\end{array}$ & $\begin{array}{c}\text { FEATS PER } \\
10.00 \\
10.00 \\
\vdots \\
\vdots \\
\vdots \\
\vdots \\
\vdots \\
-\end{array}$ & $\begin{array}{c}\text { STANOARC } \\
\overline{16.00} \\
\overline{-} \\
16.00 \\
= \\
\overline{-} \\
\overline{-} \\
=\end{array}$ & $\begin{array}{l}15.00 \\
13.00 \\
13.00 \\
-\overline{16} .00 \\
12.00 \\
12.00 \\
= \\
\overline{-} \\
=\end{array}$ & $\begin{array}{l}\cdots \\
11.00 \\
11.00 \\
17.00 \\
17.00 \\
17.00 \\
17.00 \\
17.00 \\
\vdots \\
\vdots\end{array}$ \\
\hline \multirow{2}{*}{ STATE } & \multirow{2}{*}{ CONCHS } & \multirow{2}{*}{$\underset{\text { SEA }}{\text { MUSSELS, }}$} & \multirow{2}{*}{$\begin{array}{l}\text { PER IWINKLES } \\
\text { AND } \\
\text { COCKLES }\end{array}$} & \multicolumn{3}{|c|}{ SCALLOPS } \\
\hline & & & & BAY & CALICO & SEA \\
\hline 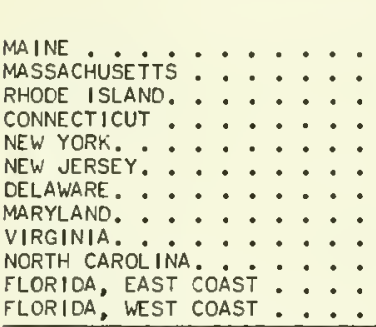 & $\begin{array}{l}15.00 \\
15.00 \\
15.00 \\
15.00 \\
15.00 \\
20.00 \\
20.00 \\
20.00 \\
20.00 \\
14.00 \\
-\end{array}$ & $\begin{array}{c}- \text { POUND } \\
15.00 \\
10.00 \\
10.00 \\
10.00 \\
10.00 \\
10.00 \\
\vdots \\
\vdots \\
\vdots \\
-\end{array}$ & $\begin{array}{c}\text { MEATS PER } \\
18.00 \\
\vdots \\
\vdots \\
\vdots \\
\vdots \\
\vdots \\
\vdots \\
-\end{array}$ & $\begin{array}{l}\text { STANDARD } \\
\overline{6} .00 \\
\overline{-} \\
\overline{6} .00 \\
\overline{-} \\
\overline{5} .50 \\
\overline{4} .52\end{array}$ & 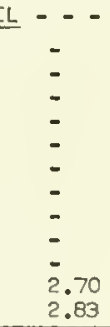 & $\begin{array}{l}-.0 \\
6.00 \\
6.00 \\
6.00 \\
-6.00 \\
6.00 \\
- \\
6.00 \\
6.00 \\
6.10 \\
- \\
-\end{array}$ \\
\hline
\end{tabular}




\section{RECOVERY OF SHRIMP PRODUCTS AND FACTORS FOR CONVERTING THEM TO HEADS-ON WEIGHT}

\begin{tabular}{|c|c|c|c|c|}
\hline ITEM & SOUTH ATLANTIC & ID GULF CATCH & PACIFIC AND NORTH & ATLANTIC CATCH \\
\hline 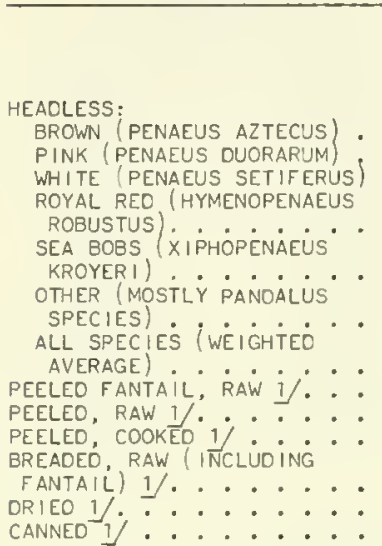 & $\begin{array}{c}\text { PERCENT RECOVERY } \\
\text { FROM HEAOS-ON } \\
\text { WEIGHT } \\
62.1 \\
62.5 \\
64.9 \\
55.6 \\
65.4 \\
- \\
62.9 \\
50.0 \\
49.0 \\
31.9 \\
100.0 \\
13.0 \\
31.2\end{array}$ & $\begin{array}{c}\frac{\text { TO CONVERT TO }}{\text { HEADS-ON WE THHT }}, \\
\text { MULT IPLY BY: } \\
1.61 \\
1.60 \\
1.54 \\
1.80 \\
1.53 \\
- \\
1.59 \\
2.00 \\
2.04 \\
3.13 \\
1.00 \\
7.69 \\
3.21\end{array}$ & \begin{tabular}{c|} 
PERCENT RECOVERY \\
FROM HEAOS-ON \\
WEIGHT \\
- \\
- \\
- \\
- \\
57.0 \\
5.0 \\
28.0 \\
- \\
- \\
16.0
\end{tabular} & $\begin{array}{c}\frac{\text { TO CONVERT TO }}{\text { HEAOS-ON WEIGHT }} \text { ' } \\
\text { MULT IPLY BY: } \\
- \\
- \\
- \\
- \\
1.75 \\
1.75 \\
3.5 \\
- \\
- \\
6.25\end{array}$ \\
\hline
\end{tabular}

1) AVERAGE FOR ALL SPECIES

NOTE:--EFFECTIVE IN 1962, THE CONVERSION FACTORS LISTED ABOVE BECAME THE DATA MANAGEMENT AND STATISTICS OIVISIONS: EACTORS FOR CONVERTING VARIOUS SHRIMP PRODUCTS TO HEAOS-ON (ROUNO) WEIGHT.

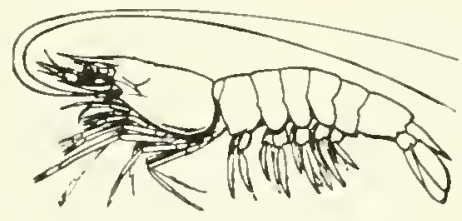




\section{RECOVERY OF PROCESSED SHRIMP PRODUCTS AND FACTORS FOR CONVERTING THEM TO WEIGHT OF RAW BASIC PRODUCT, SOUTH ATLANTIC AND GULF STATES}

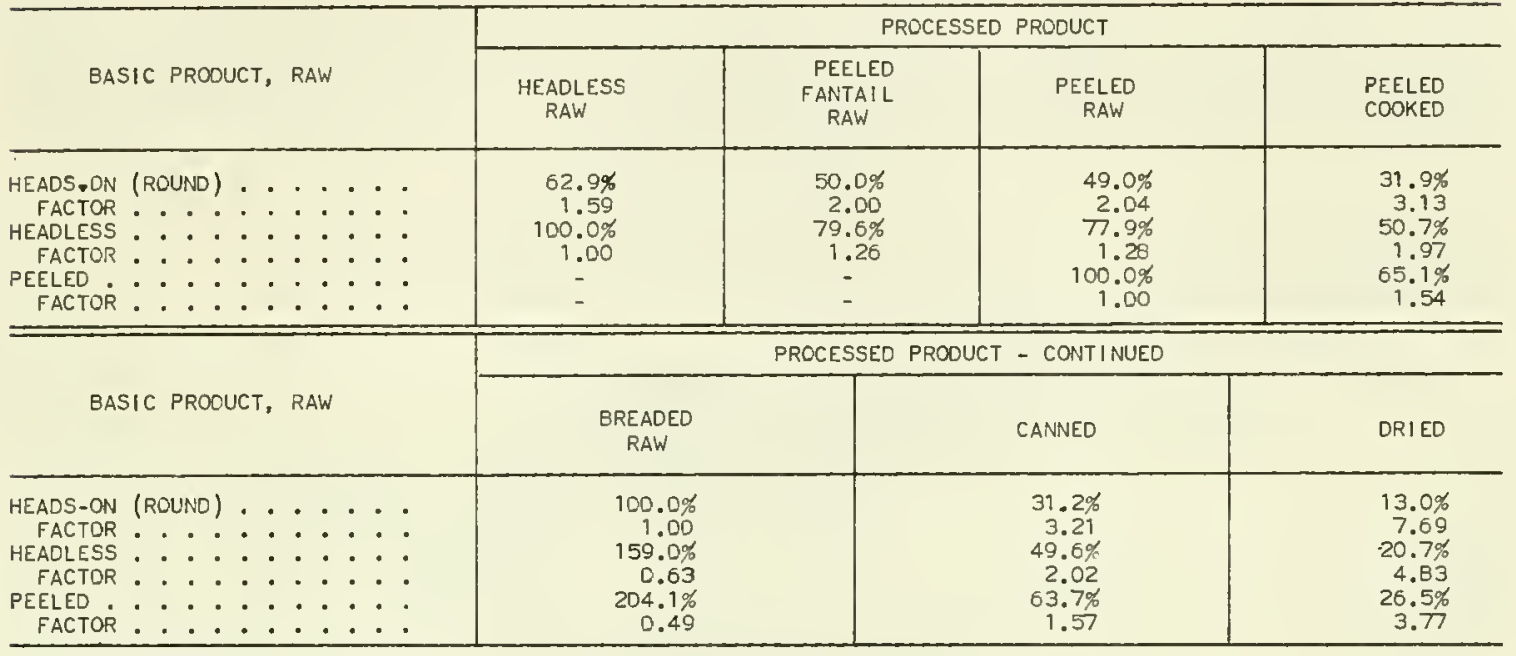

SEE NOTE BELOW FOLLOWING TABLE.

\section{RECOVERY OF PROCESSED SHRIMP PRODUCTS AND FACTORS FOR CONVERTING THEM TO WEIGHT OF RAW PRODUCT, PACIFIC AND NORTH ATLANTIC STATES}

\begin{tabular}{|c|c|c|c|c|}
\hline \multirow{2}{*}{\multicolumn{2}{|c|}{ BASIC PROOUCT, RAW }} & \multicolumn{3}{|c|}{ PROCESSEO PROOUCT } \\
\hline & & $\begin{array}{l}\text { HEADLESS } \\
\text { RAW }\end{array}$ & $\begin{array}{c}\text { PEELED } \\
\text { RAW }\end{array}$ & CANNED \\
\hline $\begin{array}{l}\text { HEADS-ON (ROUND) } \\
\text { FACTOR : } \\
\text { HEADLESS }: \vdots \vdots: \\
\text { FACTOR : }: \vdots \\
\text { PEELED } \\
\text { FACTOR : }: \vdots\end{array}$ & 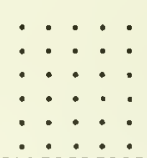 & $\begin{array}{c}57.0 \% \\
1.75 \\
100.0 \% \\
1.00 \\
= \\
-\end{array}$ & $\begin{array}{r}28.0 \% \\
3.57 \\
49.1 \% \\
2.04 \\
100.0 \% \\
1.00\end{array}$ & $\begin{array}{r}16.0 \% \\
6.25 \\
28.1 \% \\
3.56 \\
57.1 \% \\
1.75\end{array}$ \\
\hline
\end{tabular}

NOTE:--THE QUANTITY OF PROCESSEO PROOUCT MULTIPLIED BY THE FACTOR LISTED YIELDS THE WEIGHT DF BASIC PRODUCT REQUIRED TO PRODUCE THE PROCESSED PRODUCT.

OTHER CONVERSION FACTORS

\begin{tabular}{|c|c|c|c|}
\hline ITEM & WHEN REPQRTED AS & TO CONVERT TO: & MULTIPLY BY \\
\hline 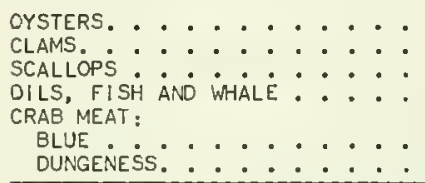 & $\begin{array}{c}\text { GALLONS OF SHUCKED MEATS } \\
" 1 \\
\text { GALLONS } \\
\text { POUNDS }\end{array}$ & $\begin{array}{c}\text { POUNDS DF SHUCKED MEATS } \\
\text { POUNDS } \\
\text { LIVE WEIGHT } \\
\text { "I" }\end{array}$ & $\begin{array}{l}8.75 \\
8.75 \\
8.75 \\
7.75 \\
7.14 \\
4.17\end{array}$ \\
\hline
\end{tabular}


To prevent misunderstanding in the use of common names used in the tables and discussions, the following $118 t$ of common and aclentific names is given for fiah, shellfish, and other aquatic animale and plants taken by U.S. fishermen. The list of sclent1fic names 1s by no means complete and $l_{e}$ intended only as a guide for the identification of the various species under the appropriate common name used in the Statiotical Digest.

Common name used in

Statiotical Digest

Other common names

Sclentific name

\section{IISH}

Alewife................

Amberjack

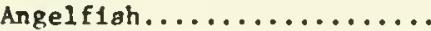

Anglerf $1 a h . \ldots \ldots \ldots \ldots \ldots$

Arct1c char...............

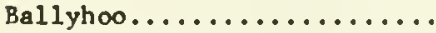

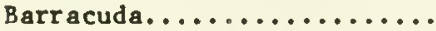

Barracuda, Japanese........

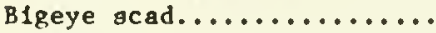

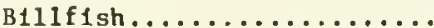

Blackfish (see llardhead)

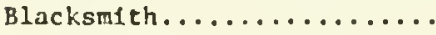

Black sk1pjack (see Tuna)

Bluef $1 \mathrm{sh} . \ldots \ldots \ldots \ldots \ldots . . . .$.

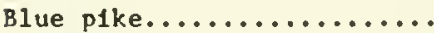

Blue runner...............

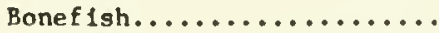

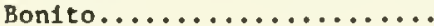

Bowfin................

Brown trout.............

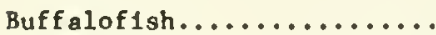

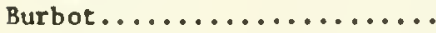

Butterf1ah..............

Cabezon.................

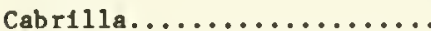

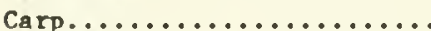

Catf 1 ah and bullheada......

Chubs..................

Cigarf 1ah..............

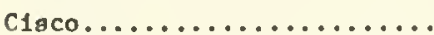

Cobla $(\mathrm{cab1o}) \ldots \ldots \ldots \ldots$

$\operatorname{cod} . \ldots \ldots \ldots \ldots \ldots \ldots \ldots$

Crapple................
B1g-eyed herring, blueback herring, branch herring, glut herring, river herring, shad herring............

Jack, kahala (Hawa11).......

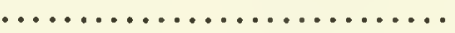
$\ldots \ldots \ldots \ldots \ldots \ldots \ldots \ldots \ldots \ldots$

Allmouth, bellyfish, goose-

f 1sh, headf1sh, monkf1sh....

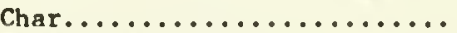

Balso, halfbeak............

Kaku (Hawa11), scooter.......

Kawelea (Hawa11)...........

Akule (Hawa11)............

Needleílsh, saury..........

$\ldots \ldots \ldots \ldots \ldots \ldots \ldots \ldots \ldots$

Blue snapper, skipjack,

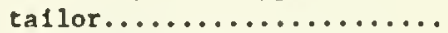

Hard pike, plkeperch........

Crevalle, hardtall, runner...

0'10 (Hawa11).............

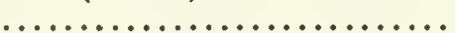

Freshwater dogf $1 \mathrm{sh}$, grindle..

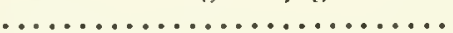
Buffalo, winter carp........

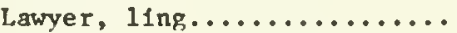
silver dollar..............

Bullhead, marbled sculpin... Rock bass, spotted cabrilla.. German carp, summer carp..... ....................... Blackf in, bluefin, claco, longjaw, tullibee, whitefish

Mackerel scad, opelu (Hawa11), round scad, scad........... Herring, lake herring.......

Black bonfto, coblo, crabeater, lemonfish, ling...... Codf1ah.................

Black crapple, callco crapple, white crappie.....
Alosa aestivalis

A. preudoharengus Seriola species

Engraulidae

Holacanthus and Pomaconthus species

Lophius americonus Salvelinus alpinus Hemircomphus brasiliensis Sphyraena species sphraena helleri Trachurons crumenophthalmus Tylosums species

Chromis punctipinnis

Pomatomus saltatrix

Stizostedion vitreion gloucum

Caranx crysos

Albula vulpes

Sarda chiliensia (Pac1f1c)

S. sarda (Atlant1c)

Amia calva

Salmo tmutta

Ictiobus species

Lota lota

Peprilus triaconthus (Atlant1c)

P. burti (Gulf of Mexico)

Scorpaenichthys marmoratus

Epinephelus analogus

cyprinus carpio

Ictalurus species

Coregonus and Leucichthys

species

Decaptems species

Coregonus artedii

(Lake Erie only)

Rachycentron canadion

Cadus macrocephalus (Pacific)

G. morhua (Atlantic)

Pomoxis annularis

$P$. nigromaculatus 
Common name used in Statistical Digest
Other common names
Sclentific name

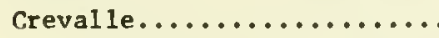

Groaker..................

Cunner.................

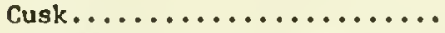

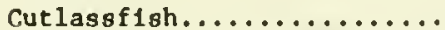

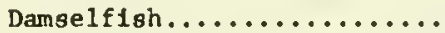

Dolly Varden trout.........

Dolphinftsh

Drum:

Black.................

Red.

Ee1:

Common...............

Conger...............

Moray.................

Flounder:

Atlantic and Gulf Coasts:

Blackback.............

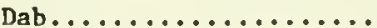

Fluke...............

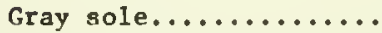

Lemon sole............

Yellowta1l...........

Paclfic Coast:

Arrowtooth halfbut......

Callfornia hallbut......

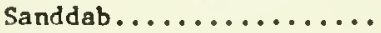

"Sole":

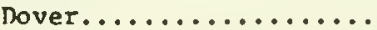

Engl1sh.............

Petrale..............

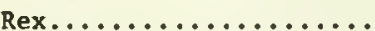

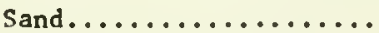

Unclassifled..........

Flylng flah.............

Frigate mackerel..........

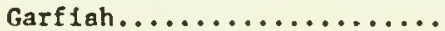

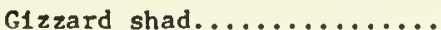

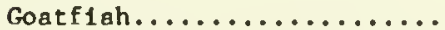

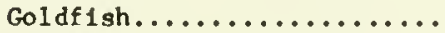

Grenad1er.
Blue cravelle or omflu

(Hawal1), common jack, crevalle jack, hardtall, jack cravelly or ulua, omaka (Hawa11)............ Crocus, hardhead............ Bergall, blue perch, chogset. Torak, tusk............. Silver eel, ribbon fish...... Kuptp1 (Hawa11)............ Bull trout, Dolly Varden, salmon trout.............. Dorado, mah1mah1 (Hawa11), pompano dolphin, dolph1n....

Oyster cracker, oyster drum, ses drum................ Channel bass, redflsh,

spotted bass.............

American eel, silver eel.... Puh1 (Hawa11), wh1te eel....

Puh1 (Hawa11)

Winter flounder (welghing under $3-1 / 2$ pounds each).... American pla1ce, sea dab..... Flounder, Gulf flounder, summer flounder, southern flounder...................

W1tch flounder.............. Blackback (welghing over 3-1/2 pounds each)........

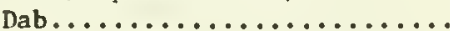

Arrowtooth flounder, French sole, turbot............. Chicken hallbut............. Pactfic sanddab............

Slime aole, shortfinned sole. Lemon sole, Caltfornta sole.. Br111................... Longfinned sole........... Fringe sole..............

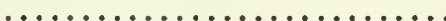

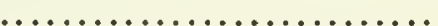

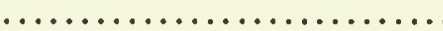
Gar, ses gar............. Mud ahad, nanny shad, winter shad............... Kumu, malu, moano, moelus, weke, weke-ula (Hawa11)..... Gold perch, sand perch......
Caranx hippos

Micropogon undulatus (Atlant1c) Toutogolabrus adspersus Brosme brosme Trichiums lepturus (Atlant1c) Abudefauf sordidus

Salvelinus malma

Coryphaena equisetis c. hippurus

Pogonias cromis Sciaenops ocellata

Anguilla rostrata

Conger oceanicus

C. marginatus

Muraenldae

Pseudopleuronectes americanus Hippoglossoides platessoides

Paralichthys albigutta

P. dentatus

$P$. Zethostigma

Glyptocephalus cynoglossus

Pseudopleuronectes anericanus $L$ imanda fermuginea

Atheresthes stomias Paralichthys californicus Citharichthys sordicus

Micmstomus pacificus

Parophrys vetulus Eopsetta jordani

Glyptocephalus zachims

Psettichthys melanostictus

Bothidae and Pleuronectidae Cypse Lums spectes

Auxis thazard

Lepisosteus specles

Dorosoma cepedianum

Mu111dae

Carassius caratus

Coryphaenoides apectes 
Common name used in Statistical Digest
Other common names

Sea bsss................

Margate, sallorg' cholce....

Grunt

Haddock.................

Hake :

Pacific...............

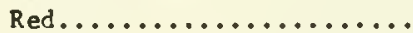

White................

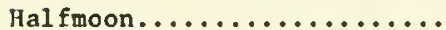

Hal ibut...............

Hardhead................

Harvestflsh.............

Herring:
Lake..............
Sea................

Thresd...............

Hickory shad.............

Hogchoker...............

Hogfish................

Jack mackerel............

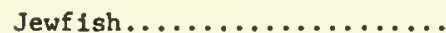

King croaker.............

King whiting or "kingfish". .

Lske trout..............

Lamprey...............

Launce................

Lingcod...............

Mackerel:

Atlantic..............

King.

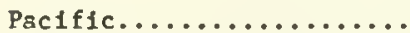

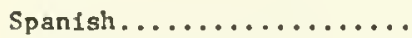

Msckerel scad.............

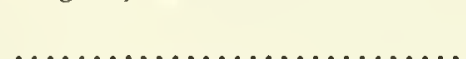

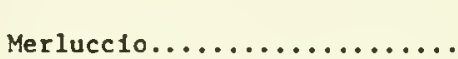

Black hake, ling, mud hake, squirrel, squirrel hake....

Hake...................

Rudderfish, Catalina perch...

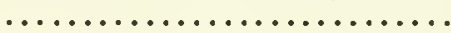

Sacramento blsckfish,

Sacramento rockfish........

Dollarfish, northern

harvestfish, pappyfish, southern harvestfish, starfigh...............

Cisco...................

Sardine................

Halryback................

Autumnal herring, skip,

tallor shad...............

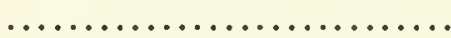

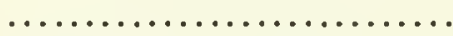

Horse mackerel, Spanish

mackerel................

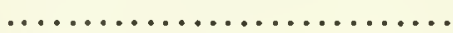

Herring, kingfiah, tomcod,

white croaker.............

Ground mullet, sea mink, sea mullet, whiting. .......

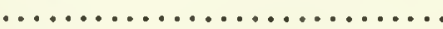
Pacific lamprey, ses lamprey.

American ssnd launce, lant1, sand eel, sand launce....... Blue cod, buffalo cod, cultus cod, ling...............

American mackerel, Boston msckerel................ Cero, kingfish............

Chub mackerel, green mackerel Mackere1................

Opelu (Haws11)............
Sclentific name

Epinephezus and Mycteroperoa species, except E. itajara

Haemulon and

Anisotremus species

Melanogramms aeglefinus

Merluccius productus

Urophycis chuss (Atlantic)

Urophycis tenuis

Medialuna californiensis

Hippogiossus hippoglossus

(At lsntic)

H. stenolepis (Pacific)

orthodon microlepidotus

Pepritus alepidotus

Coregonus artedii

Clupea harengus hargenus (Atlantic)

C. harengus pallasi (Pacific)

opisthonema oglinum (Atlantic)

Alosa mediocris

Trinectes maculatus

Lachnolaimus maximus

Trachumis symmetricus

Epinephelus itajara

Genyonemus ineatus

Menticirrhus species

Salvelinus namaycush

Entosphenus tridentatus (Pacific)

Petromyzon marinus (Atlantic)

Amodytes speciea

ophiodon elongatus

Scomber scombrus

Scomberomorus cavaliza

S. regalis

Scomber japonious

Scomberomorus maculatus (Atlant1.

$S$. concolor (Pacific)

Decapterus macarellus ((Atlantic)

D. pinnulatus (Pacific) 
Common name used in Stat1stical Digest other common names

Mar11n:

Black................

Sa11f1sh..............

Shor tb111.............

silver................

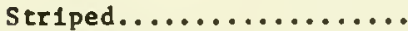

Unclass1f1ed............

Menhaden................

M1lkf1sh.

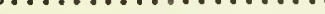

Mojarr8.................

Moonege................

Mountsin bass............ Mud sucker, longj aw.........

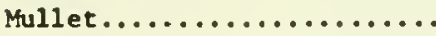

Muttonf1sh..............

Ocesn perch:

Atlant1c.............

Pacific................

Ocean pout...............

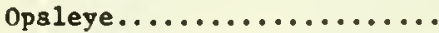

Paddlefish...............

Psrrotf1sh...............

Perch..................

Permit.................

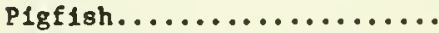

Plke or plckerel..........

Pinflah.................

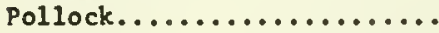

Pompano................

Queenf1sh................

Qu11loach................

Rainbow trout...........

Ratf1sh................

Red bigeye..............

Rock basa.................

Rockf1ahes...............

Rudderflah..............

Runner.
A'u (Hawa11), Pac1fic blue marlin.................

A v (Haws11), lepe......... A'v (Hawa11), shortnosed spesrf1sh................ A'u (Haws11), wh1te marlin... A'u (Hawa11).............. A'u (Hawa11)............... B1geye, bunker, fstback, mossb unker, pogy.......... Awa (Hawa11)..............

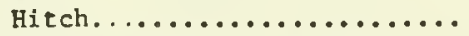
Sand bream, sand perch....... Goldeye, toothed herring.....

Aholehole (Hswa11).........

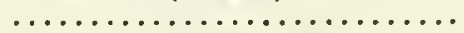
Amaams (Haws11), black mullet, L1za, jumping mullet, ssind mullet, allver mullet, striped mullet, wh1te mullet............. Mutton snapper............

Redf1sh, red perch rosef1oh.. ....................... Eelpout, sea pout.......... Blsck perch............... Spoonbill cat............. Uhu (Hawa11).............. Surff1sh, surfperch......... ...................... Hogf $18 h \ldots . . \ldots \ldots \ldots \ldots \ldots \ldots$ Great Lakes p1ke............ Bream, isltwster bream....... Boston blueflah............

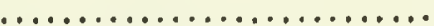
skimf1sh, spearfish......... Steelhead trout............

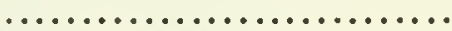
Aweoweo (Hawa11)............ Goggle-eye, groupera, kelp bsss, redeye, sand basa, spotted basa.............

Rock cod, snapper, 1dlot, boccac10................

Bermuds chub, Nenue (Hawa11).

Lae (Hawa11), leatherbsck....
Sc1ent1fic name

Makaira indica

M. rigricans

Istiophorus platypterus

Tetrapturus angustirostris

Tetrapturus albidus

Tetropturus audax

Istiophor1dae

Brevoortia tyrannus (Atlantic)

B. patronus (Gu1f)

Chanos chanos

Cyprinidae

Gerreldae

Hiodon tergisus

H. alosoides

Kuhlia eandvicensis

Gillichthys mirabilis

Mugil species

Lutjanus conalis

Sebastes marinus

Sebastes alutus

Macrozoarces conericanus

Girella nigricans

Polyodon spathula

Scar1dee

Emb1otoc1dae

Trachinotus falcatus

Orthopristis chrysoptera

Esox spec1es

Lagodon rhomboides

Pollachius virens

Theragra chaloograma (Pacific)

Peprilus similimus (Pac1f1c)

Trachinotus carolinus (Atlant1c)

Seriphus politus

carviodes cyprinus

Salmo gairdneri

Hydrolagus colliei

Prlacsnthidae

\section{Ambloplites mpestris}

Paralabrax spec1es (Psc1f1c)

Sebastes species, except

S. alutus (Pacific)

Kyphosus sectatrix (Atlant1c

and Gulf Coasts) $\boldsymbol{R}$. cinerascens

scomberoides sancti-petri 
Common name used in Statistical Digest other common namea

Black cod, butterfish,

Salmon:

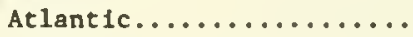

Pactific:

Chinook or king........

Chum or keta..........

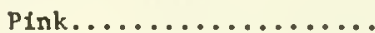

Red or sockeye........

Silver or coho.........

Sand perch...............

Sardine, Pacific..........

Sauger.................

Saury..................

Sawfish................

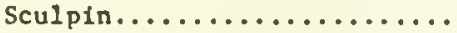

Scup or porgy............

Sea bsss:

Black................

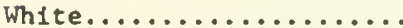

Sea catfish.............

Sea robin................

Sea trout or weakfish:

Gray................

spotted...............

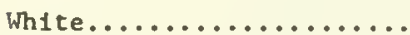

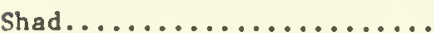

Sharke:

Grayftsh.............

Soupfin...............

Unclassifled...........

Sheef 1 sh................ Sheephead............... Sheepahead:

Freshwater............

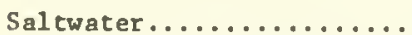

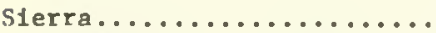
Silveraidea.............. Skates.................. Smelt................. candlef 1 sh..............

Anoptopoma fimbria

Salmo salar

Spring, tyee, tulle, royal chinook, blsckmouth........ Dog, fall, allver bright.... Humpbsck, humpy........... Blueback, kokanee........... Hooknose.................. S1lver perch, yellowta11.... P1lchard, maklawa (Hawa11)...

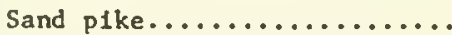
Sk1pper, sour belly.........

Small tooth sawf 1 sh.......... Bullhead, scorpionftsh....... Falr msid, paugy, porgee, whlte snapper............

Blackflah (Atlant1c), black Jewfish (Paclfic), glant sea bass, hapuupuu (Hawa11).

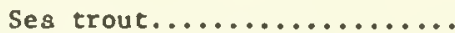
Catflsh, gaff topsall........

$\ldots \ldots \ldots \ldots \ldots \ldots \ldots \ldots \ldots$

Gray trout, squeteague, we akfish............... Speckled trout, spotted seatrout, spotted trout..... Sand seatrout, sand trout, white trout, sllver seatrout American ahad, white ahad....

Dogflah, smooth dog, aplny,

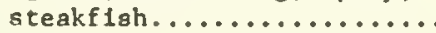

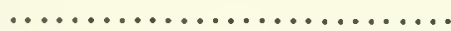
$\ldots \ldots \ldots \ldots \ldots \ldots \ldots \ldots \ldots \ldots$

Inconnu................ California sheephead........

Freshwater drum, gaspergou,

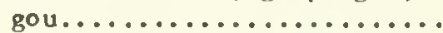
Fathead, humpy, redf 1 sh......

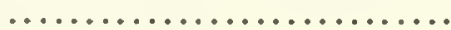
Spearing............... Rajaf1sh, ray............. American smelt, eulachon, ralnbow smelt, allver smelt, capelin................

\author{
Oncorhynchus tshowytscha \\ o. keta \\ 0. gorbuscha \\ 0 . nerka \\ o. kisutch \\ Bairdiezza chrysura \\ Sardinops caemilea \\ Etrumeus micropus \\ Stizostedion canadense \\ Cololabis saira (Pactfic) \\ Scomberesox saums (Atlantic) \\ Pristis pectinata \\ Scorpaenidae \\ Calamus and \\ Stenotomus apecies
}

Centropristis species (Atlantic)

Epinephelus quemus (Hawa11)

Stereolepis gigas (Pactflc)

cynoscion nobitis (Pactf $1 \mathrm{c}$ )

Arius felis

Bagre marinus

Prionotus apecies

Cynoscion regalis

c. nebulosus

c. arenarius

C. nothus

Alosa sapidissima

Mustelus and Squalus species Galeorhimus zyopterus Carcharodon, Carcharhinus,

Lamna, Odontaspis, and

Sphryna species

Stenodus leucichthys

Pimelometopon pulchmon

Aplodinotus grunniens

Archosargus probatocephalus

Scomberomomis sierra

Atherinidae

Raja species

Osmeridae

Mallotus viliosus 
Common name used in Statistical Digest
Other common names

Snapper:

Gray.................

Lane.................

Mangrove...............

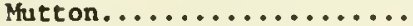

Pink..................

Red

Vermilion...............

Yellowts11.............

Unc lassiffed...........

Snook

Spaniah sardine...........

Splitta11...............

Spot..................

Squirrelfish.............

Steelhesd trout...........

Striped basa.............

Sturgeon:

Common...............

Shovelnose............

Suckers................

Sunfish................

Surgeonf 1sh.

Swellflah..............

Swordflsh..............

Tang :

Convict...............

Orange spot............

Tsutog.................

Tenpounder..............

Thimble-eyed mackerel......

Threadfin..............

Tilapia...............

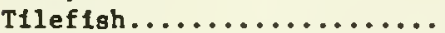

Tomcod.................

Tr1ggerf Ish.
Uku

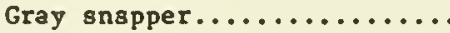

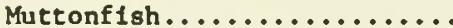

Kalikali, opakapaks (Hawsil).

Ulaula, ulaula koae (Hawa11).

$\ldots \ldots \ldots \ldots \ldots \ldots \ldots \ldots \ldots$

$\ldots \ldots \ldots \ldots \ldots \ldots \ldots \ldots \ldots \ldots$

$\ldots \ldots \ldots \ldots \ldots \ldots \ldots \ldots \ldots \ldots$

Pike, robalo, sergeantfish... Angelfish, Atlantic spadefish

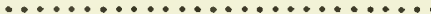

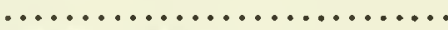

A'awa (Hawsil), goody,

lafayette...............

Alathi (Hawa11)............ Ralnbow trout, salmon trout..

Rock, rockbass, rockf1sh,

str1per................

Atlantic aturgeon, green sturgeon, lake sturgeon, white sturgeon............

Pallid sturgeon............

Bayfish, freshwater mullet, redfin................. Blueg111, bream, perch...... Kala, maiko, palsni, pualu

(Hawa11) .................

Blowf1sh, globeflah, northern puffer, puffer, awell toad..

A'u (Haws11), broadb 111

gwordf $18 h . . . \ldots \ldots \ldots \ldots \ldots$

Manini (Hawg11)...........

Naenae (Hawaft)............

Blackfish, oysterflah.......

Awaawa (Hawa11), bigeyed

herring, ladyfioh..........

Bu1lseye mackerel, chub mackere 1...............

Mo1 (Hawa11)............... Mosquitofish, mouthbrooder...

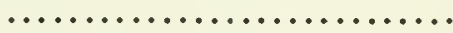

Prost fish..............

Humuhumu (Hawai1)
Scientific name

Lutjonus griseus Aprion virescens Lutjonus synagris

L. griseus

L. conalis

Pristipomoides microlepis

P. sieboldii

Etelis carbunculus, E. marshi, Lutjanus compechanus,

L. purpureus

Rhomboplites curorubens

ocyurus chrysums

Apsilus, Etelis, and

Lutjanus species

Centropomis undecimalis

Chaetodipterus faber (Atlantic)

C. zonatus (Pacific)

Sardinella anchovia

Pogonichthys macrolepidotus

Leiostomus san thumus

Holocentridae

salmo gairdneri

Morone saxatilis

Acipenser apecies Scaphirhymchus platorynchus S. albus

Catostomidae

Lepomis species

Acanthuridae, Naso voicormus

Sphoeroides speciea

Xiphias gladius

Aconthurus sandvicensis

A. olivaceus

Tautoga onitis

Elops howaiensis

$E$. squrus

Scomber japonicus

Polydactylus sexfitis

Tilapia apecies

Lopholatilus chamaeleonticeps

Microgadus proximus (Pacific)

M. tomcod (Atlantic)

Balistidae 


\begin{tabular}{|c|c|c|}
\hline $\begin{array}{l}\text { Common name used in } \\
\text { Ststisticsl Digest }\end{array}$ & Other common names & Sclentific name \\
\hline $\begin{array}{l}\text { Tripleta11 ................ } \\
\text { Tullibee (see chubs) }\end{array}$ & Blsckf1sh, sunf1sh......... & Lobotes surinamensis \\
\hline $\begin{array}{l}\text { Tuns: } \\
\text { Albacore.............. }\end{array}$ & 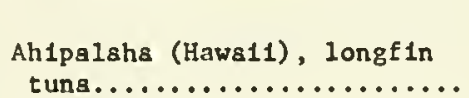 & Thunnus alalunga \\
\hline Bigeye................ & Ah1 (Hows11) $\ldots \ldots \ldots \ldots \ldots \ldots$ & T. obesus \\
\hline Blackfin.............. & $\ldots \ldots \ldots \ldots \ldots \ldots \ldots \ldots \ldots$ & T. atlanticus \\
\hline Black skipjack.......... & $\ldots \ldots \ldots \ldots \ldots \ldots \ldots \ldots \ldots$ & Euthynnus Zineatus \\
\hline 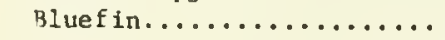 & Hlorse mackerel........... & Thunnus thynnus \\
\hline 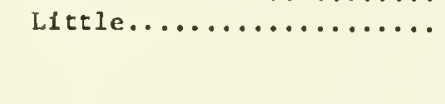 & $\begin{array}{l}\text { Bon1to, false albacore, } \\
\text { kawakawa (Hawai1).......... }\end{array}$ & $\begin{array}{l}\text { Euthynnus alzetteratus (Atlant1c) } \\
\text { and } E \text {. affinias (Hawa11) }\end{array}$ \\
\hline Sk1pjack.............. & 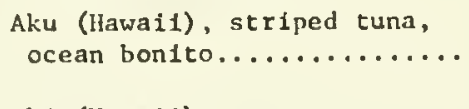 & $\begin{array}{l}\text { E. pelamis and } \\
\text { Katsiawons pelamis (Hawa1i) }\end{array}$ \\
\hline Yellowf1n............. & Ah1 (Hawa11) ............. & Thunnus albacares \\
\hline 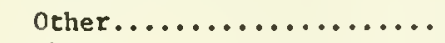 & $\ldots \ldots \ldots \ldots \ldots \ldots \ldots \ldots \ldots \ldots \ldots$ & Euthynnus and Thunnus species \\
\hline 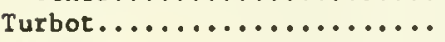 & Alsska pla1ce.............. & Pleuronectes quadrituberculatus \\
\hline Wahoo.................. & Ono (Haws11).............. & Acanthocybium solandri \\
\hline Warsaw............... & Blsck J ewf 1sh, wsrsaw grouper & Epinephelus nigritus \\
\hline White amur............ & 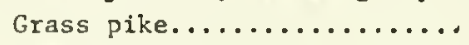 & Ctenopharyngdon idezzus \\
\hline Whiteba1t............. & Smelt............... & Azlosmerus elongatus \\
\hline $\begin{array}{l}\text { White bsss............. } \\
\text { Wh1tefish: }\end{array}$ & White lake bass............. & Morone chrysops \\
\hline Common............... & Lake wh1tef 1 sh............ & Coregonus clupeaformis \\
\hline Menom1nee.............. & Round whitef $18 h \ldots \ldots \ldots \ldots$ & Propsopium cylindracewn \\
\hline Ocesn............... & $\ldots \ldots \ldots \ldots \ldots \ldots \ldots \ldots \ldots \ldots \ldots$ & Caulolatilus princeps (Pacific) \\
\hline White perch............... & $\ldots \ldots \ldots \ldots \ldots \ldots \ldots \ldots \ldots \ldots \ldots$ & Morone americana \\
\hline Whiting $\ldots \ldots \ldots \ldots \ldots \ldots \ldots$ & silver hske............. & Merluccius bilinearis \\
\hline Wolffish.............. & 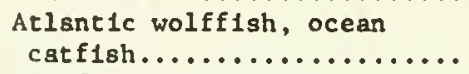 & Anarhichas Zupus \\
\hline Yellow bsss.............. & 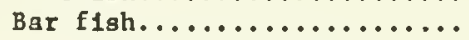 & Morone mississippiensis \\
\hline Yellow perch.............. & Perch, ringed perch......... & Perca flavescens \\
\hline Yellow ptke.............. & Plke perch, wslleye pike..... & Stizostedion vitreum vitreum \\
\hline 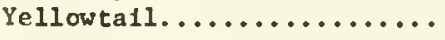 & $\ldots \ldots \ldots \ldots \ldots \ldots \ldots \ldots \ldots$ & Seriola dorsalis \\
\hline
\end{tabular}


Common name uaed in Stat1st1cal D1ge日t
Other common names
Scientific name

\section{CRUSTACEANS}

Craba:

Blue:

llard.................

Soft and peeler........

Dungeness.............

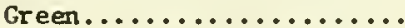

Jonah................

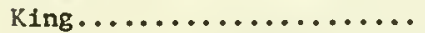

Kona..................

Red...................

Rock.

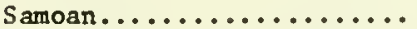

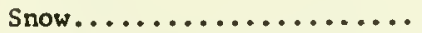

stone.................

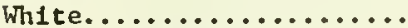

Crawflah, freahwater.......

Horseshoe crab............

Lobster :

American..............

s11pper..............

Sp1ny

Sand shrimp.

\section{Shrimp:}

Saltwater.

Freshwater.
Hard shell crab...........

Soft shell crab..........

Market.................

...................

$\ldots \ldots \ldots \ldots \ldots \ldots \ldots \ldots$

Alaska king crab..........

$\ldots \ldots \ldots \ldots \ldots \ldots \ldots \ldots \ldots$

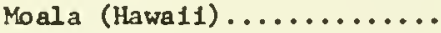

Eelgrags crab...........

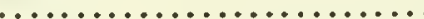

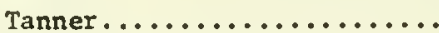

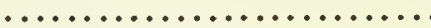

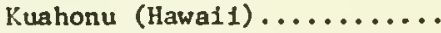

Crab, craw, crawdad,

crayflah...............

Horsefoot crab, ling crah...

Malne lobater, northern

lobster.................

Ulapapapa (Hawai1)........

Bug crawfiah, rock lobster, saltwater crawfiah,

ula (Hawa1i) ..............

Ghost shrimp, blue mud

shr1mp...............

Bay shrimp, hoppers, ocean shrimp, opae (Hawa11), sea bobs, coon stripe,

northern...............
Callinectes sapidus

C. sapidus

Cancer magister

Carcinus maenas

Cancer borealis

Paralithades camschatica

P. platypus

Lithodes acquispina

Ranina ranina

Gemon nivouedens (At lantic)

Podophthalmis viriz (Pactfic)

Cancer irroratus (Atlantic)

C. productus (Pac1f1C)

Scylla serrata (Hawai1)

Chionoecetes bairdi

Menippe mercenaria

Portunus sanguinolentus

Astacus ispecies (Pacific)

Cambarus species (Central and

Eastern)

Limulus polyphemus

Homarus americanus

Paribaccus antarcticus

Scylzarides squamosus

(Hawa11)

Panulimus argus (Atlantic)

P. intermptus (Pacific)

P. penicilzatus (Hawaii)

Callianassa califormiensis

C. gigas

C. affinis

Upogebia pugettensis

Penaeidae, Pandalidae, Crangonidae Penaeus aztecus (brown)

P. brasiliensis (pink)

P. duorarum (pink)

$P$. setiferus (white)

Xiphopenaeus kroyeri (sea bob)

Sicyonia specles (rock)

Hymenopenaeus robustus (royal red)

Pandalus borealis

Macrobrachium specles 
Common name used in Statistical Digest
Other common names
Sclentific name
MDLUSKS, et a1.

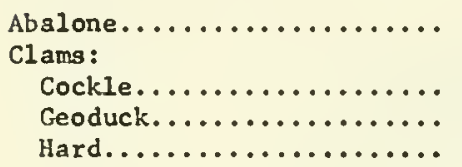

hard.................

Horse................

ocesn quahog...........

Rangia...............

Razor...............

Soft.

Sunray venus............

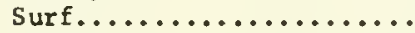

Conchs................

Limpet.................

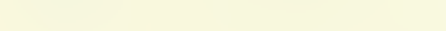

Mussels, ses............

Mussel she11s............

Pesrls and slugs..........

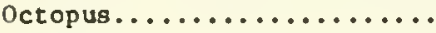

Oysters :

Esstern..............

Pactfic................

Western................

Periwinkles.............

Scallops:

Bay.................

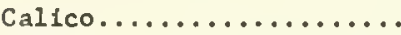

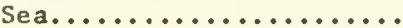

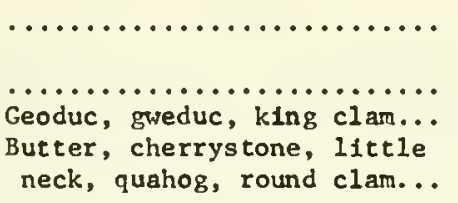

neck, quahog, round clam...

Blue, blue neck, emplre, horseneck clam, gaper......

Black quahog, mahogany qushog................ Freshwster clams..........

Maninose, nannynose, sand clam, soft shell clam, steamer clsm, mud clam....

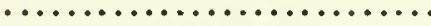
Bsr clam, sea clam, skimmer. Whelks, moonshell, moonsns1l

Coolle hst, hihiwsi, opih1 (Hawsi1)..........

Edible mussel............

Freshwster mussels.........

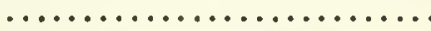
Devilfish, hee (Haws11)....

Amer1csn, cove........... Japanese................ Native, 0lympia...........

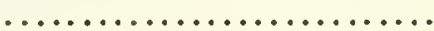
$\ldots \ldots \ldots \ldots \ldots \ldots \ldots \ldots \ldots$

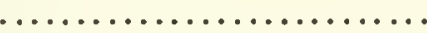

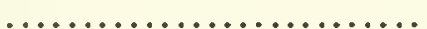

\section{Haliotis species}

Cardium corbis (Pacific)

Panopea generosa

Mercenaria compechiensis

M. mercenaria

Protothaca staminea

Saxidomus giganteus

Tresus capax

T. nuttalzi

Artica islandica

Rangea cuneata (Last and

Gulf coasts)

Ensis directus (Atlantic)

Siliqua patula (Pacific)

Mya arenaria

Macrocallista nimbosa

Spisula solidissima

Busycon and

Strombus specles

Polinices heros

Acmaea digitalis

Helcioniscus argentatus

(saltwater, llawa1i)

Neritina granosa

(freshwater, Hawa11)

Mytilus califomianus (Pacific)

$M$. edulis (Atlantic)

Unionidae

Unionidae

Octopus vulgaris (Atlant1c)

0 . hongkongensis (Pacific)

Crassostrea virginica

C. gigas

Ostrea Iurida

Littorinidae

Argopecten irradians (Northeast Atlant1c)

Pecten dislocatus (South Atlantic)

Argopecten gibbus

Patinopecten caurinus (Alsska)

Placopecten magelzanicus (Atlant1c) 
Common name used in Statiotical Digeat

Squid.

Sea urchina.

Terrapin.

Trepang

Turtles:

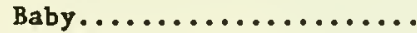

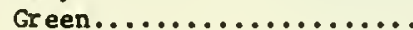

Loggerhead..............

slider................

Snapper...............

Soft-ahell

Froge.................

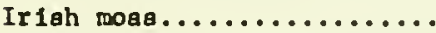

Kelp..................

Seaweed..................

Sponges:

Glove.................

Graвs..................

Sheepswool.............

Bloodworm.................

Sandworm. ...............

Fur seal...............

Other common names

Scientific name

Bone squid, Inkfiah, muhee, taw taw (Hawai1), summer squid.................

Sea egga

Diamondback...............

Lol1 (namako-Hawail), sea cucumber................

$\ldots \ldots \ldots \ldots \ldots \ldots \ldots \ldots \ldots$

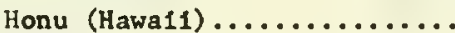

....................

$\ldots \ldots \ldots \ldots \ldots \ldots \ldots \ldots \ldots \ldots$

Alligator turtle, hard shell.

$\ldots \ldots \ldots \ldots \ldots \ldots \ldots \ldots \ldots \ldots$

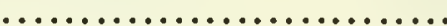

......................

Seaweed .................

Limu.

$\ldots \ldots \ldots \ldots \ldots \ldots \ldots \ldots \ldots \ldots \ldots$

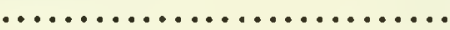

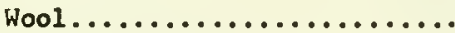

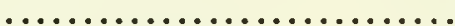

$\ldots \ldots \ldots \ldots \ldots \ldots \ldots \ldots \ldots \ldots \ldots$

$\ldots \ldots \ldots \ldots \ldots \ldots \ldots \ldots \ldots \ldots \ldots$
Loligo opalescens (Pac1f1c)

$L$. pealii (Atlantic)

IZlex species

Strongyzocentrotus droebachiensia (Atlantic)

S. purpuratus (Pacific)

Malaclemys terrapin

Stichopus californicus (Pacific) Thyonebricreus (Atlantic)

Young of freshwater species

Che lydra mydas

Caretta caretta

Pseudemys species

Chelydra serpentina

Macroclemys temincki

Trionyx specles

Rana opecles

Chondmus crispus

Macrocyatis species

Porphyra species

Spongia cheiris

spongia graminea

Hippiospongia lachne

Glycera dibranchiata

Nereis species

Callorhinus ursinus 


\section{SECTION 15 - PICTORIAL SECTION}

As many of the readers of this publication may not be familiar with all of the species of fish and shellfish, etc., taken commercially in the United States, illustrations of many of the varlous species are included in the following pages. The descriptive material appearing with each species includes the areas in which commercial landings are made in the United States and does not constitute the extreme limits in which they occur. Similarly, the gearlisted for each species do not represent the only types of apparatus by which these species are obtained, but represent those types which are normally used in their capture. The gear do not necessarily appear in the order of their importance. Illustrations of species landed in Hawail are not included in this section.

For more detailed information on the nomenclature of the fishery products listed below, the reader is referred to Section 14 of this publication entitled, "Glossary."

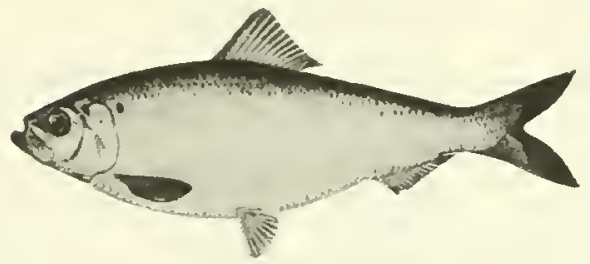

ALEWIFE

RANGE - FLORIDA TO NEW ENGLAND

GEAR - POUND NETS, GILL NETS, WEIRS, DIP NETS, HAUL SEINES, FLOATING TRAPS, FYKE NETS

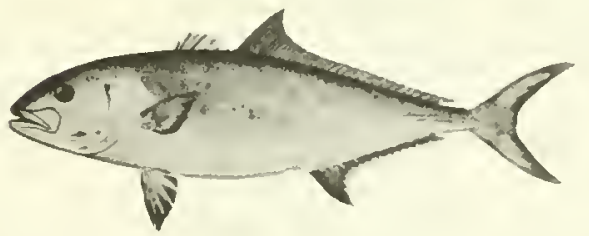

AMBERJACK

RANGE - FLORIOA

GEAR - HANDLINES, TROLL LINES

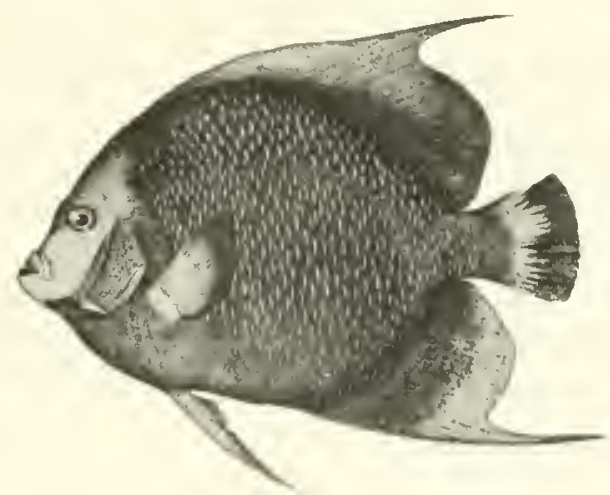

ANGELFISH

RANGE - FLORIOA

GEAR - HAUL SEINES

398

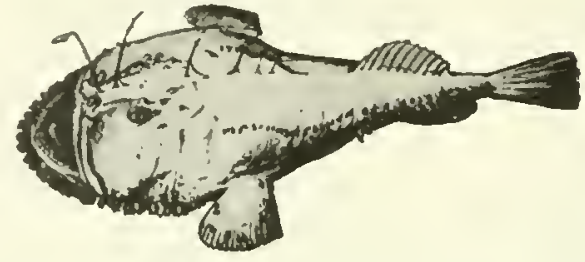

ANGLERF ISH

RANGE - NEW JERSEY TD MASSACHUSETTS

GEAR - DTTER TRAWLS, POUND NETS

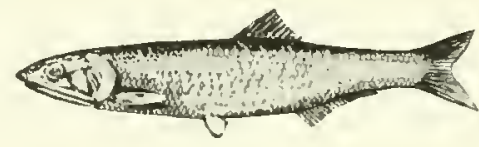

ANCHOVY

RANGE - CALIFORNIA TO WASHINGTON

GEAR - PURSE SEINES AND HAUL SEINES

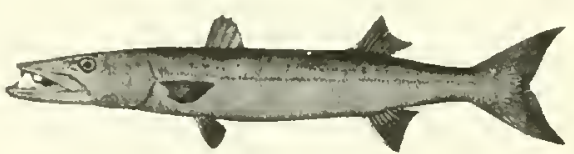

BARRACUDA (ATLANTIC)

RANGE - FLORIDA

GEAR - TROLL LINES, HANDLINES

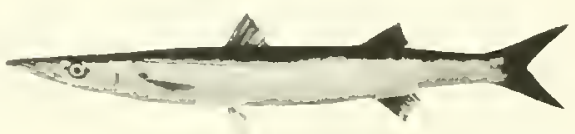

BARRACUOA (PACIFIC)

RANGE - CALIFORNIA

GEAR - PURSE SEINES, LONGLINES, HANDLINES, TROLL LINES, GILL ANO TRAMMEL NETS 


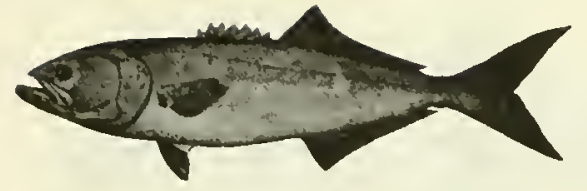

BLUEF ISH

RANGE - GULF OF MEXICO TO NEW ENGLANO

GEAR - HAUL SEINES, GILL NETS, POUND NETS,

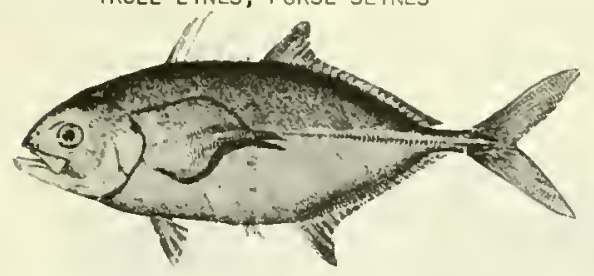

BLUE RUNNER OR HAROTAIL

RANGE - GULF OF MEXICO

GEAR - HAUL SEINES, GILL NETS, POTS

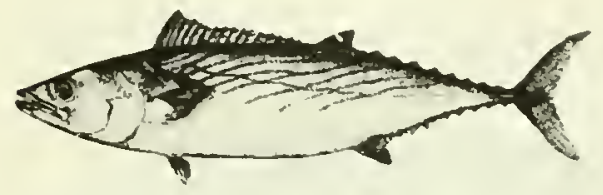

BONITO (ATLANTIC)

RANGE - NORTH CAROLINA TO MASSACHUSETTS

GEAR - POUND NETS, TROLL LINES, GILL NETS

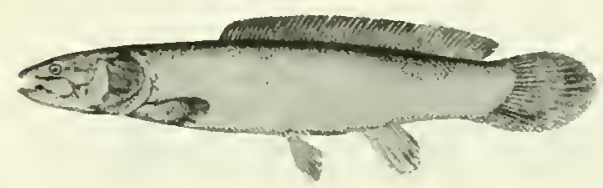

BOWF IN

RANGE - FRESH-WATER

GEAR - HAUL SEINES, TRAP NETS, FYKE NETS

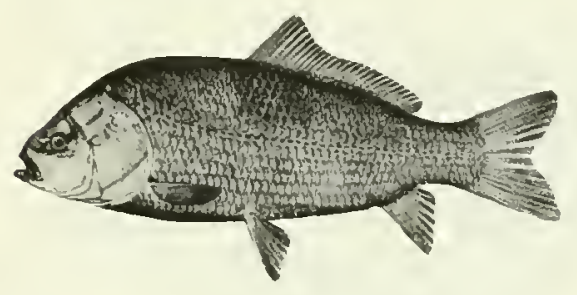

BUFFALOF ISH

RANGE - FRESH-WATER

GEAR - HAUL SEINES, FYKE NETS, TRAMMEL NETS, TROTLINES

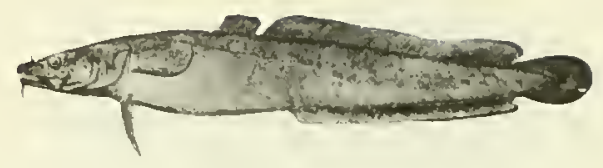

BURBOT

RANGE - GREAT LAKES

GEAR - GILL NETS, FYKE NETS, POUNO

NETS, TRAP NETS

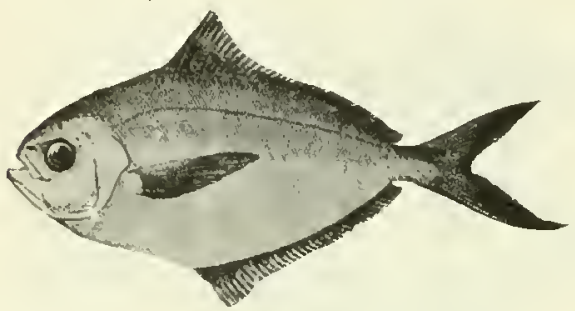

BUTTERF ISH

RANGE - FLORIDA TO NEW ENGLANO

GEAR - POUNO NETS, HAUL SEINES, OTTER TRAWLS

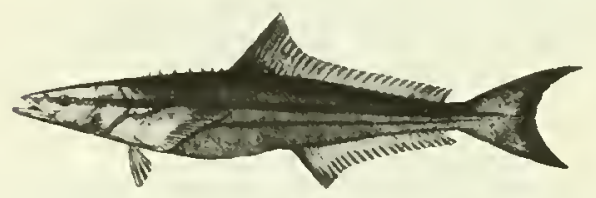

CABIO

RANGE - FLORIDA TO VIRGINIA

GEAR - HANOLINES, POUND NETS

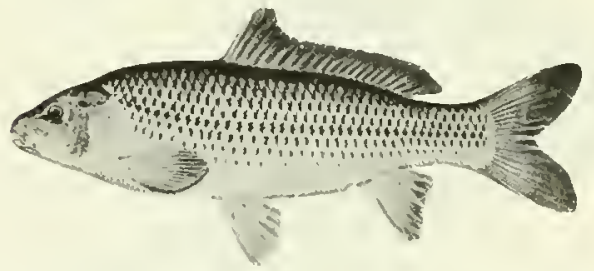

CARP

RANGE - FRESH-WATER

GEAR - HAUL SEINES, GILL NETS, TRAP NETS, FYKE NETS, POUND INETS, TROTLINES

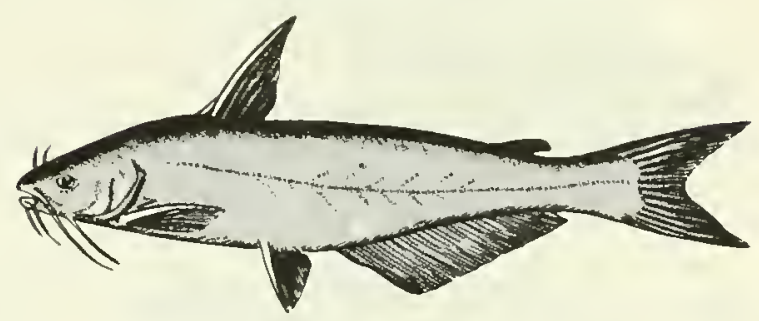

CATF ISH

RANGE - FRESH-WATER

GEAR - HAUL SEINES, TROTLINES, POUND NETS, POTS, FYKE NETS 


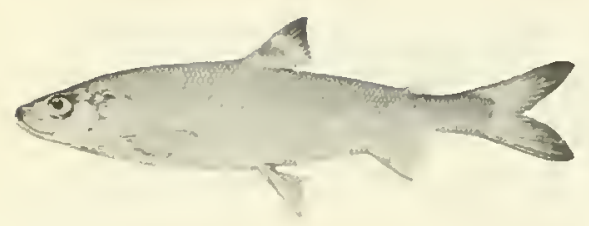

CHUB

PANGE - GREAT LAKES

GEAR - GILL NETS

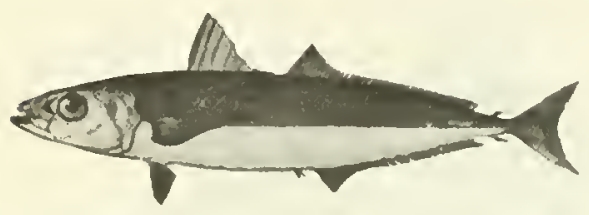

CIGARF ISH

RANGE - FLORIDA

GEAR - HAUL SEINES

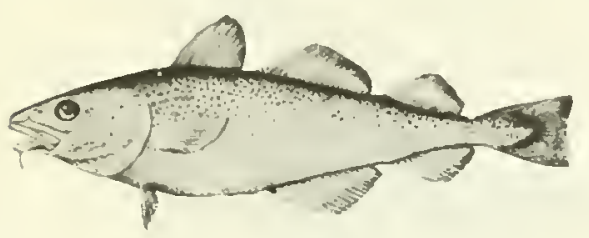

CDO

RANGE - VIRGINIA TO MAINE. WASHINGTON, AND ALASKA

GEAR - OTTER TRAWLS, LONGLINES, GILL NETS

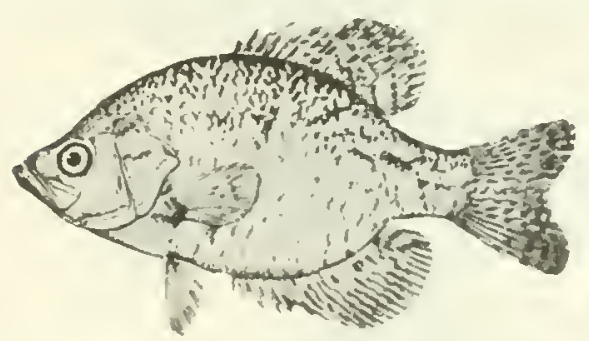

CRAPP IE

RANGE - FRESH-WATER LAKES

GEAR - HAUL SEINES, LINES, POTS

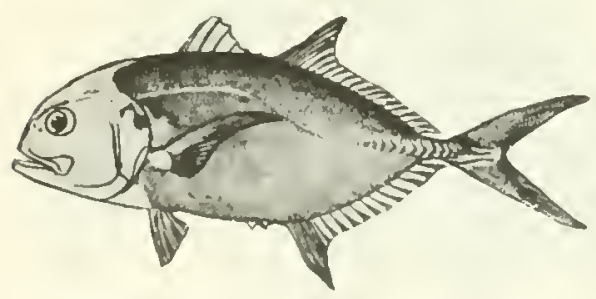

CREVALLE

RANGE - SOUTH ATLANTIC AND GULF STATES

GEAR - HAUL SEINES, GILL NETS, LINES

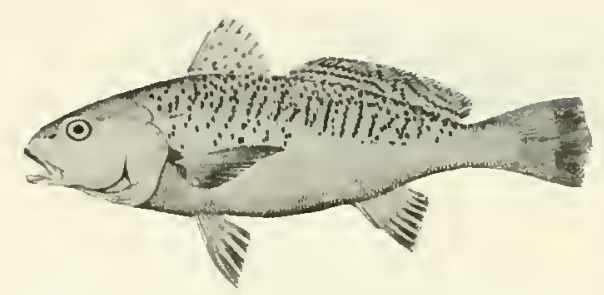

CROAKER

RANGE - GULF OF MEXICO TO NEW YORK

GEAR - POUND NETS, OTTER TRAWLS, HAUL SEINES,

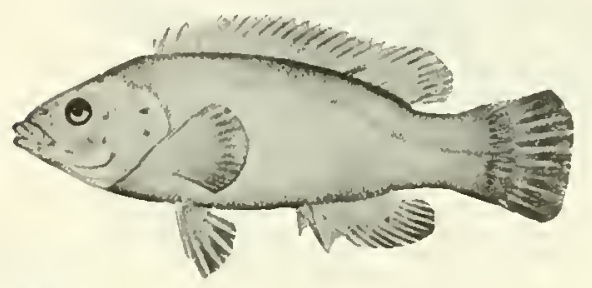

CUNNER

RANGE - NEW ENGLAND

GEAR - OTTER TRAWLS, HANDL INES

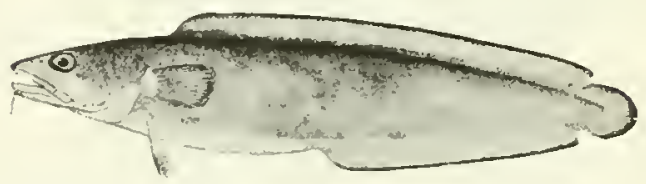

CUSK

RANGE - NEW ENGLAND

GEAR - OTTER TRAWLS, LONGLINES

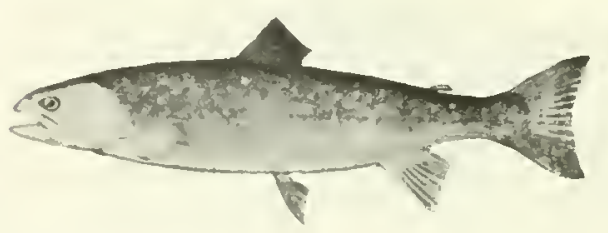

DOLLY VARDEN TROUT

RANGE - PACIFIC

GEAR - POUND NETS, GILL NETS, LINES

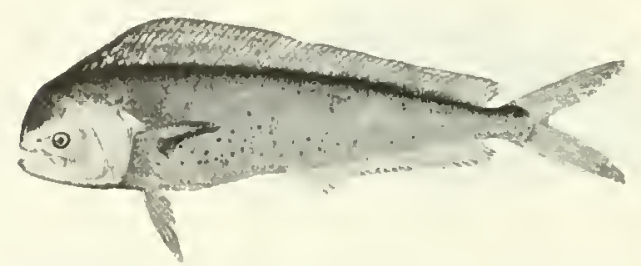

DOLPHIN

RANGE - FLORIDA TO NORTH CAROL INA

GEAR - TROLL L INES 


\section{PICTORIAL SECTION}

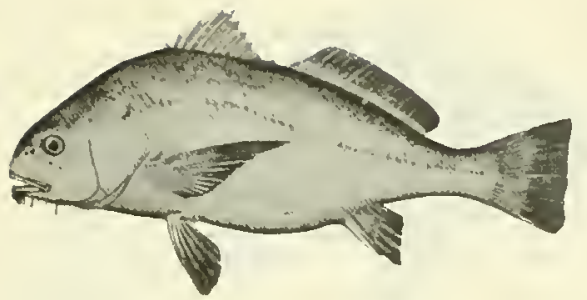

ORUM, BLACK

RANGE - TEXAS TO NORTH CAROLINA

GEAR - HAUL SEINES, POUND NETS, LINES

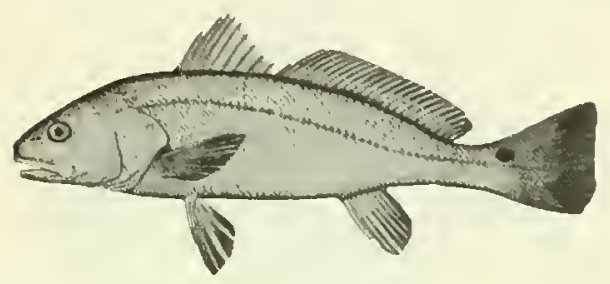

ORUM, RED

RANGE - TEXAS - MARYLAND GEAR - POUND NETS, HAUL SEINES, GILL NETS,

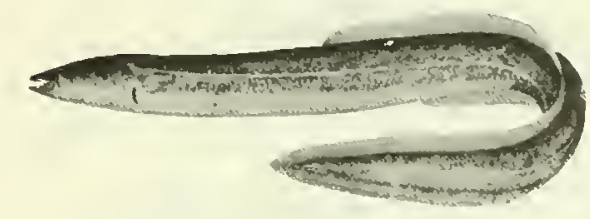

EEL, COMMON

RANGE - FLORIDA TO NEW ENGLANO AND IN

MISSISSIPPI RIVER, LAKE ONTARIO

GEAR - POTS, SPEARS, POUNO NETS

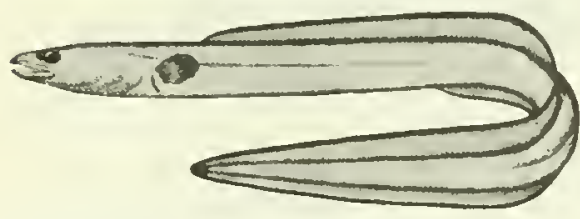

EEL, CONGER

RANGE - FLORIDA TO NEW ENGLAND

GEAR - OTTER TRAWLS

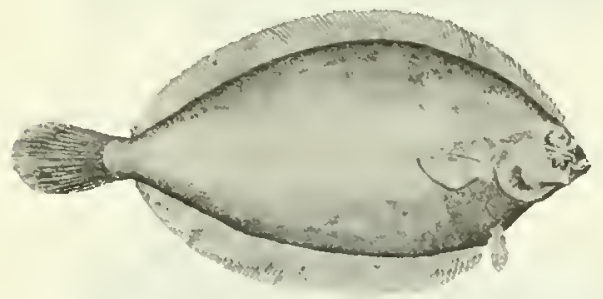

GRAY SOLE

RANGE - MASSACMUSETTS TO MAINE

GEAR - OTTER TRAWLS

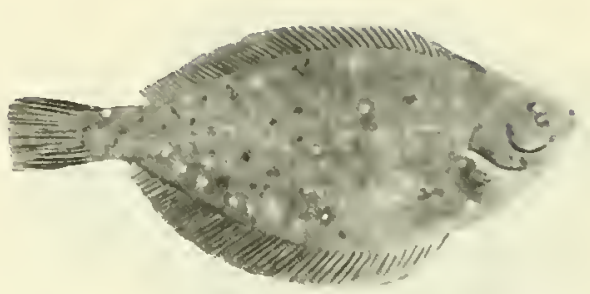

LEMON SOLE

RANGE - NEW YORK TO MAINE

GEAR - OTTER TRAWLS

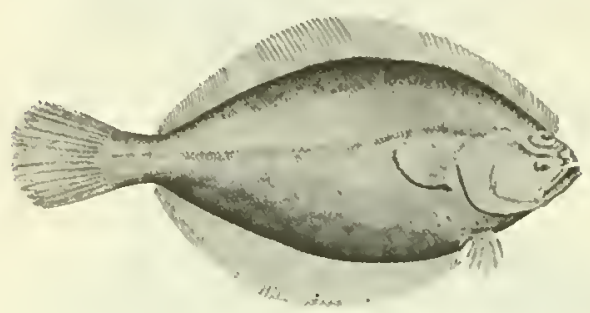

$D A B$

RANGE - MASSACHUSETTS TO NOVA SCOTIA

GEAR - OTTER TRAWLS, LONGLINES

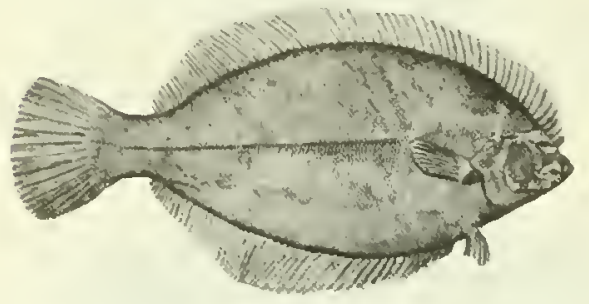

BLACKBACK OR WINTER FLOUNOER

RANGE - NORTH CAROLINA TO MAINE

GEAR - OTTER TRAWLS, POUND NETS, FYKE NETS,
SPEARS, LINES

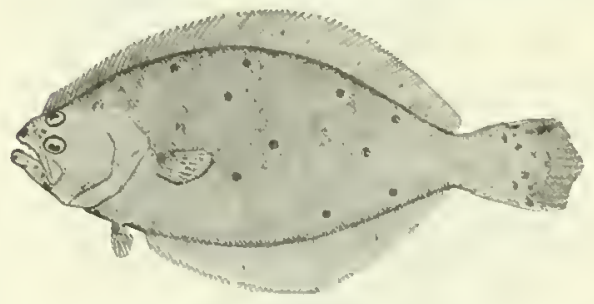

FLUKE

RANGE - TEXAS TO MASSACHUSETTS

GEAR - OTTER TRAWL, SPEARS, LINES

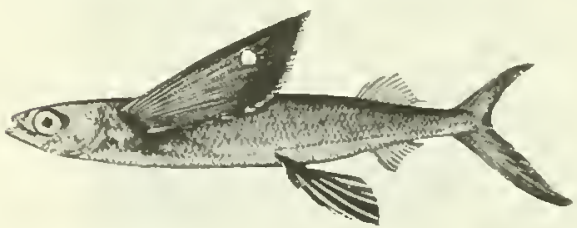

FLYING FISH

RANGE - PACIFIC AND ATLANTIC OCEANS

GEAR - GILL NETS 


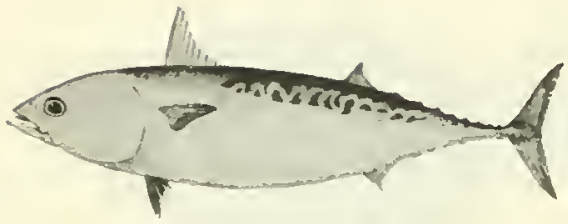

FRIGATE MACKEREL

RANGE - MIDOLE ATLANTIC

GEAR - POUNO NETS

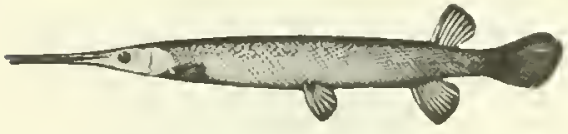

GARF ISH

RANGE - FRESH-WATER

GEAR - HALL SEINES, LINES

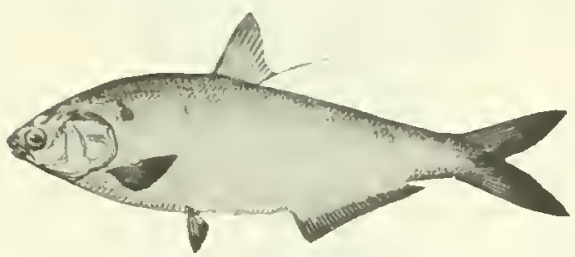

GIZZARO SHAD

RANGE - NORTH CAROL INA TO MARYLAND, GREAT LAKES

GEAR - hAUL SEINES, POUND NETS, GILL NETS

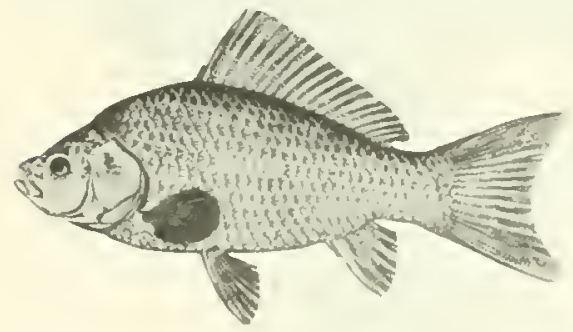

GOLOF ISH

RANGE - LAKES •AND RIVERS

GEAR - HAUL SEINES, TRAP NETS, FYKE NETS

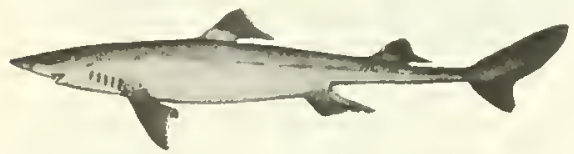

GRAYF ISH

RANGE - PACIFIC

GEAR - LONGLINES, OTTER TRAWLS, GILL NETS

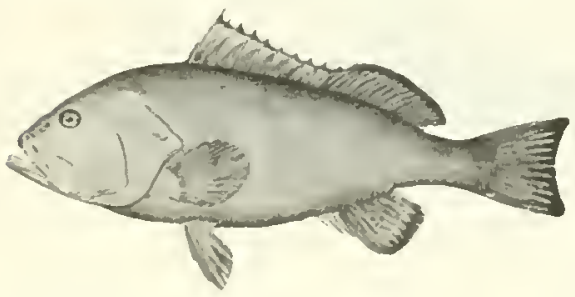

GROUPER

RANGE - TEXAS TO SOUTH CAROLINA

GEAR - HANDLINES, POTS

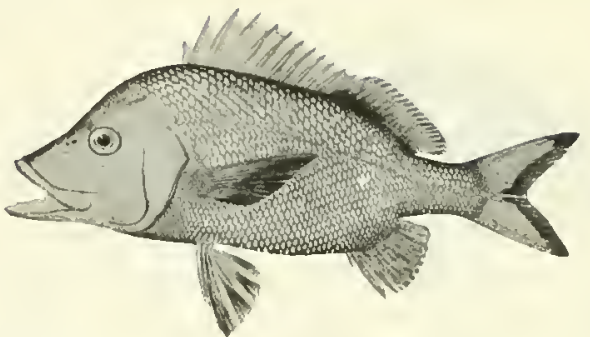

GRUNT

RANGE - FLORIOA

GEAR - POTS, GILL NETS, LINES

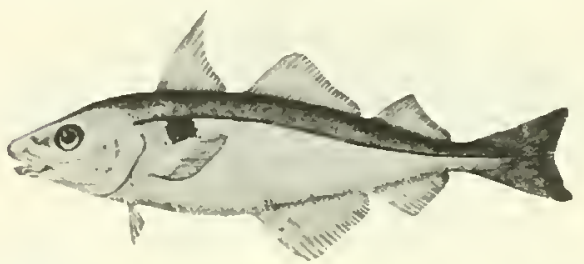

HADOOCK

RANGE - NEW ENGLANO STATES

GEAR - OTTER TRAWLS, GILL NETS, LONGLINES

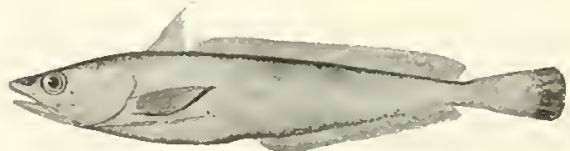

HAKE, RED

RANGE - CHESAPEAKE BAY TO NEW ENGLAND

GEAR - GILL NETS, OTTER TRAWLS, LONGLINES

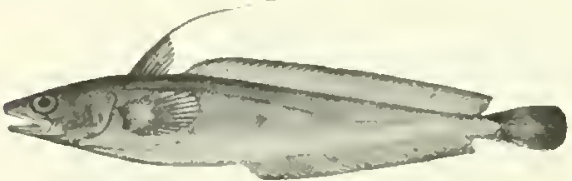

HAKE, WHITE

RANGE - CHESAPEAKE BAY TO NEW ENGLAND

GEAR - GILL NETS, OTTER TRAWLS, LONGLINES

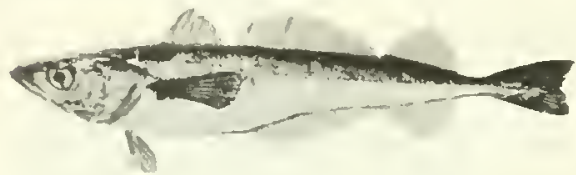

HAKE (PACIFIC)

RANGE - PACIFIC

GEAR - OTTER TRAWLS

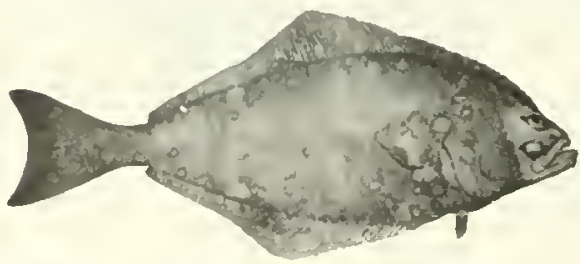

HALIBUT

RANGE - PACIFIC COAST - NEW ENGLAND

GEAR - LONGLINES, OTTER TRAWLS 


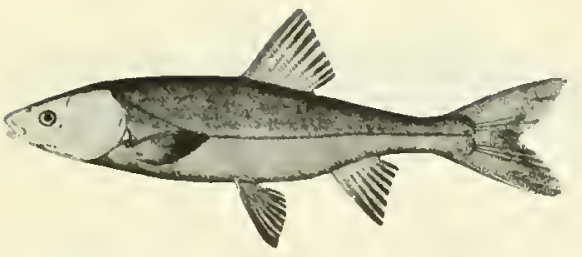

HAROHEAD

RANGE - CALIFORNIA

GEAR - FYKE NETS

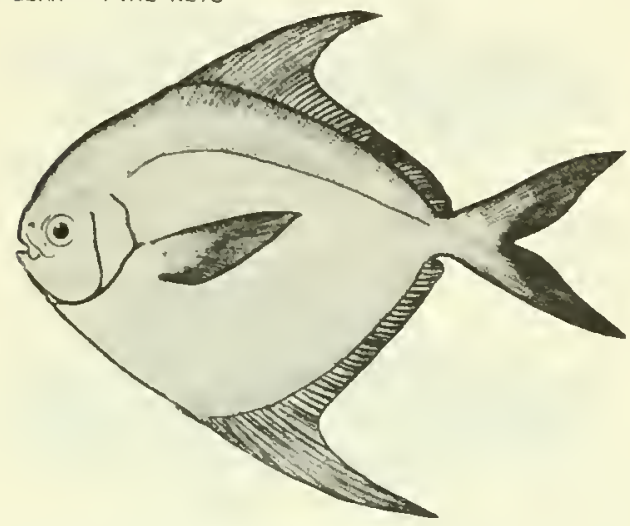

HARVESTF ISH OR "STARF ISH"

RANGE - NORTH CAROLINA TO CHESAPEAKE BAY

GEAR - HAUL SEINES, POUND NETS

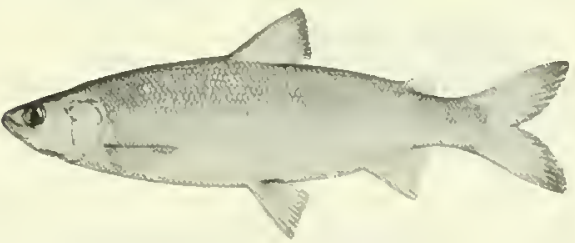

HERRING, LAKE

RANGE - GREAT LAKES GEAR - GILL NETS, HAUL SEINES, POUND NETS,

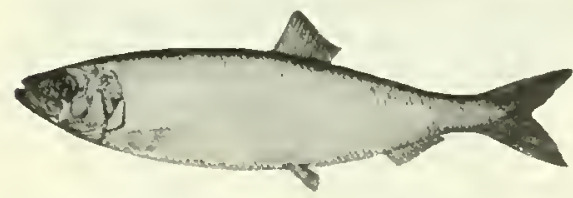

HERRING, SEA

RANGE - NEW JERSEY TO NEW ENGLAND, FACIF IC COAST STATES ANO ALASKA

GEAR - PURSE SEINES, WEIRS, FLOATING TRAPS, STOP SEINES

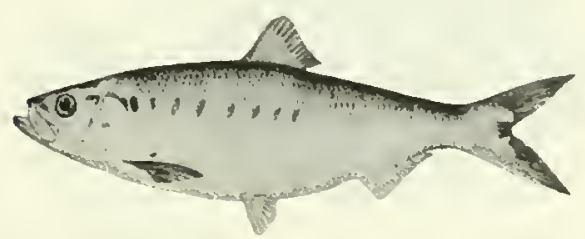

HICKORY SHAD

RANGE - FLORIDA TO RHOOE ISLAND

GEAR - POUND NETS, HAUL SEINES, GILL NETS FLDAT HNG TRAPS

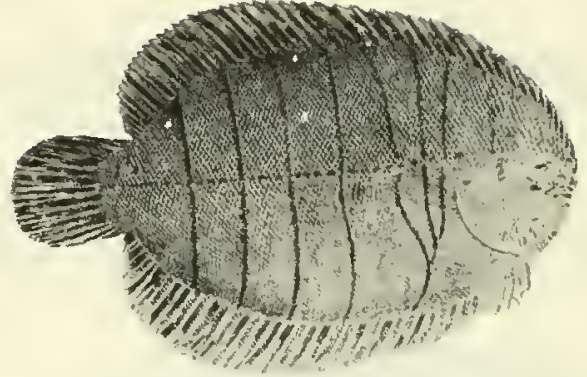

HOGC HOKER

RANGE - CHESAPEAKE BAY

GEAR - POUND NETS, HAUL SEINES

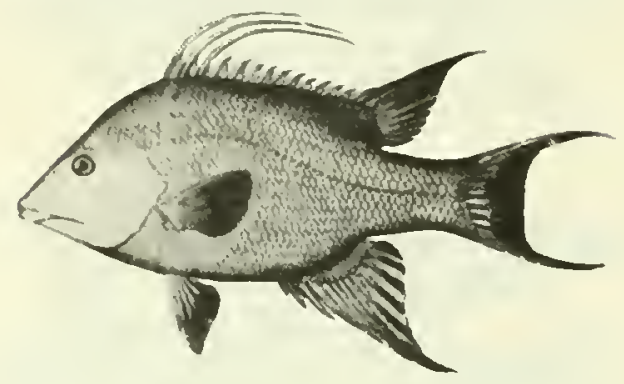

HOGF ISH

RANGE - FLORIDA

GEAR - LINES

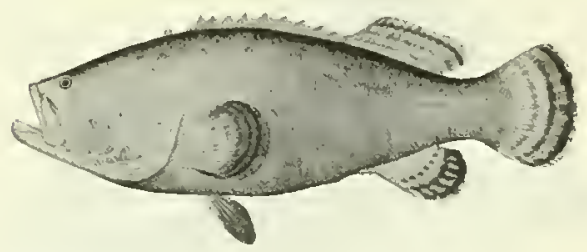

JEWF ISH

RANGE - FLORIOA

GEAR - HANDL INES

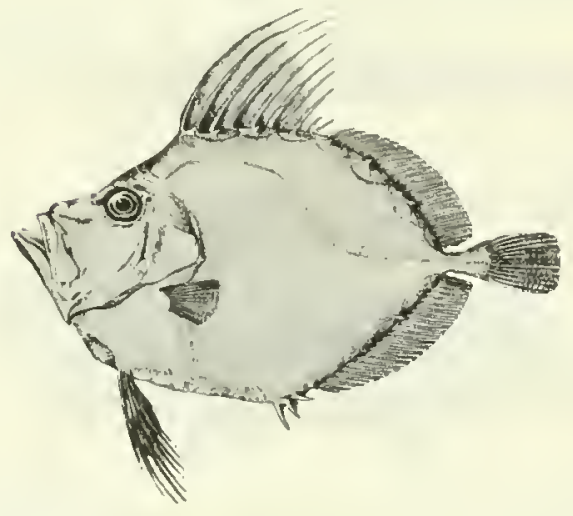

JOHN DORY

RANGE - MIDOLE ATLANTIC STATES

GEAR - OTTER TRAWLS 


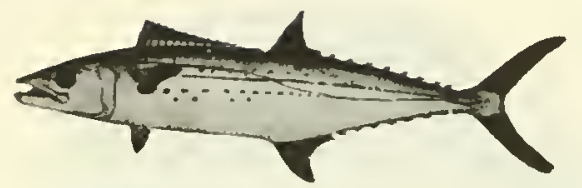

KING MACKEREL

RANGE - TEXAS TO NEW YORK

GEAR - TROLL LINES, GILL NETS, HANOLINES

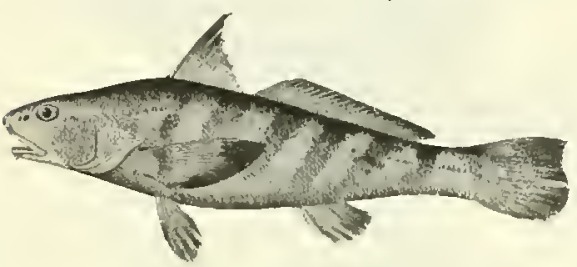

KING WHITING

RANGE - TEXAS TO MASSACHUSETTS

GEAR - OTTER TRAWLS, HAUL SEINES, POUNO NETS

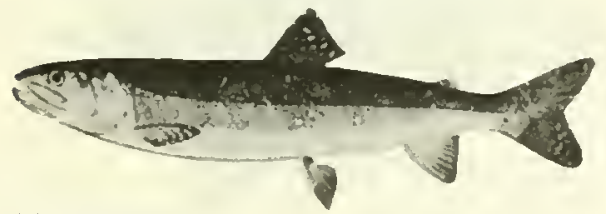

LAKE TROUT

RANGE - GREAT LAKES

GEAR - GILL NETS, LINES, POUNO NETS (TRAP NETS)

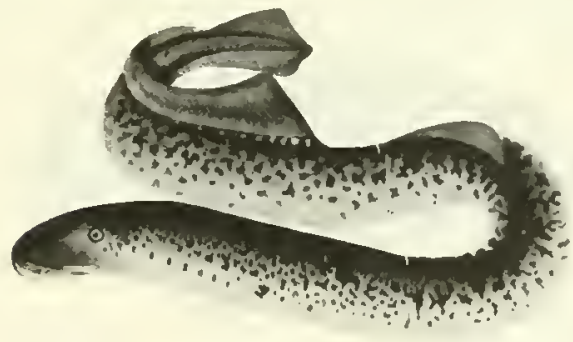

LAMPREY

RANGE - FRESH-WATER

GEAR - POTS, FYKE HETS

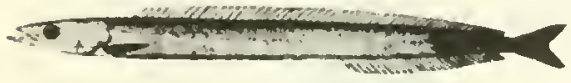

LAUNCE

RANGE - NEW ENGLAND

GEAR - HAUL SEINES

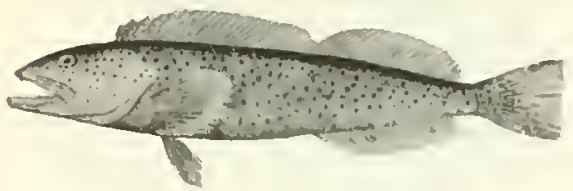

LINGCOD

RANGE - CALIFORNIA TO ALASKA

GEAR - OTTER TRAWLS, LONGLINES, HANDLINES

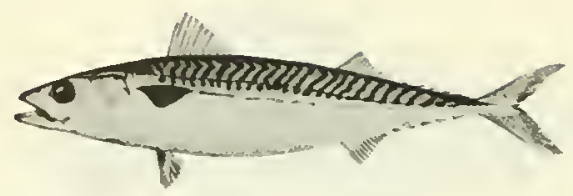

MACKEREL, ATLANTIC

RANGE - CHESAPEAKE BAY TO MAINE

GEAR - PURSE SEINES, GILL NETS, POUNO NETS,

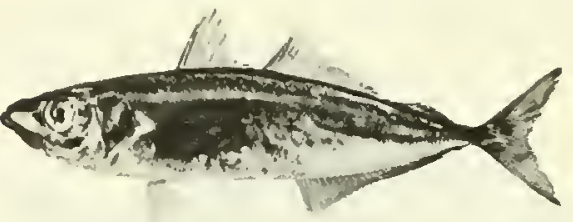

MACKEREL, JACK

R.ANGE - CAL IFORNIA

GEAR - LINES, SEINES, LAMPARA NETS

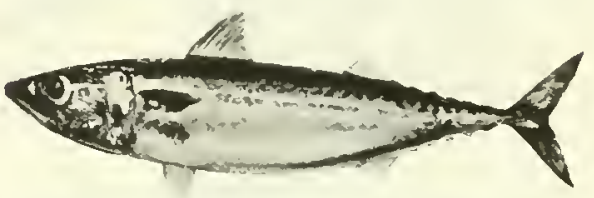

MACKEREL, PACIFIC

RANGE - CALIFORNIA

GEAR - LINES, SEINES, LAMPARA NETS

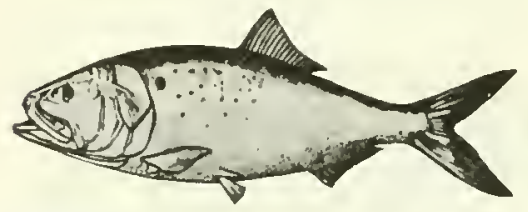

MENHADEN

RANGE - GULF OF MEXICO TO NEW ENGLANO

GEAR - PURSE SEINES, POUNO NETS

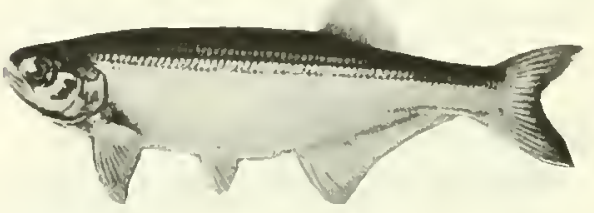

MOONEYE

P.ANGE - GREAT LAKES

GF.AR - HAUL SEINES

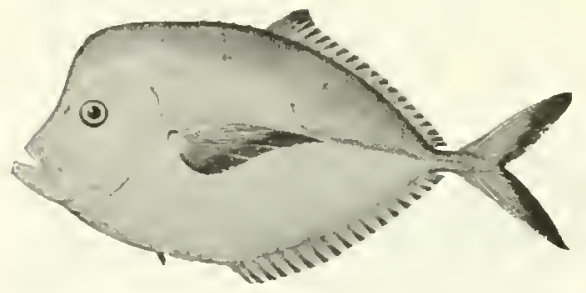

MOONF ISH

RANGE - FLORIDA

GEAR - HANDLINES, HAUL SEINES 


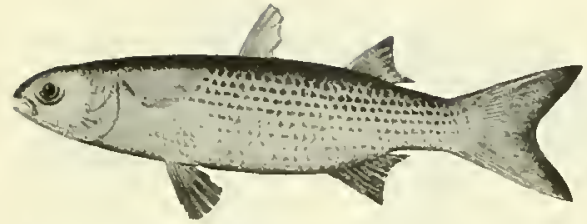

MULLET

RANGE - TEXAS TO NEW JERSEY

GEAR - GILL NETS, HAUL SEINES, POUND NETS, CAST NETS

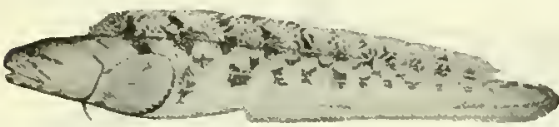

OCEAN POUT

RANGE - NEW ENGLANO

GEAR - OTTER TRAWLS

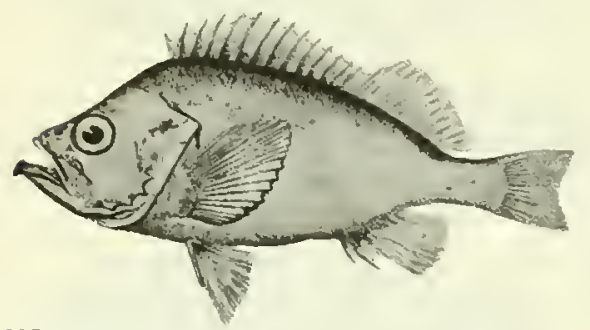

OCEAN PERCH

RANGE - INEW ENGL AND

GEAR - OTTER TRAWLS

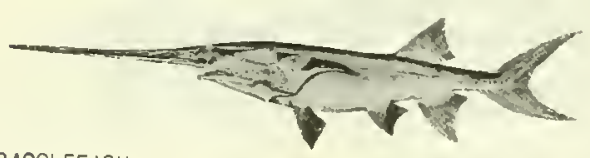

PAOOLEF ISH

RANGE - GULF OF MEXICO, MISSISSIPPI RIVER

GEAR - HAUL SEINES, TROTLINES

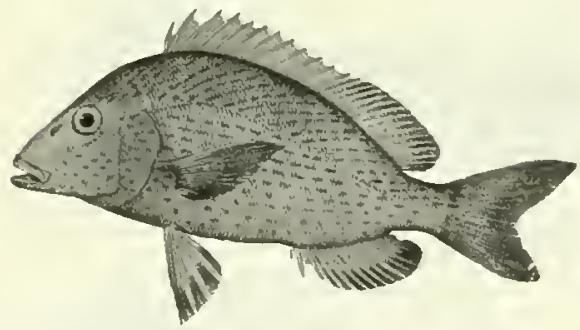

PIGF ISH

RANGE - FLORIOA

GEAR - POTS, HANOLINES, GILL NETS

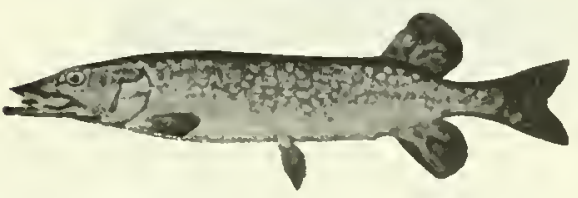

PIKE OR PICKEREI.

RANGE - FRESH-WATER

GEAR - TRAP NETS, FYKE NETS, GILL NETS, POUND NETS, HANDLINES

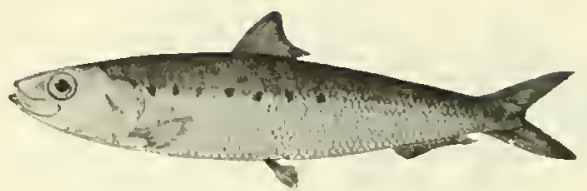

SAROINE, PACIFIC (PILCHARO)

RANGE - CALIFORNIA TO WASHINGTON

GEAR - PURSE SEINES, LAMPARA AND RING NETS, GILL NETS

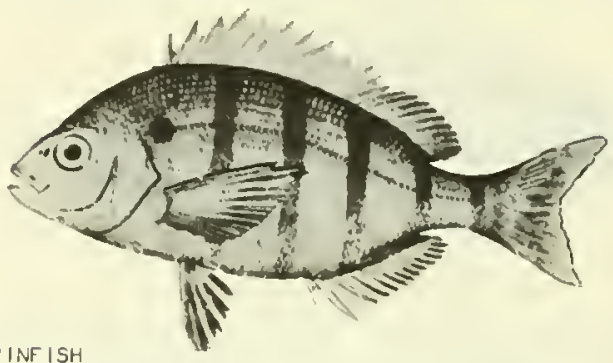

RANGE - FLORIDA TO NORTH CAROL INA

GEAR - HAUL SEINES, GILL NETS

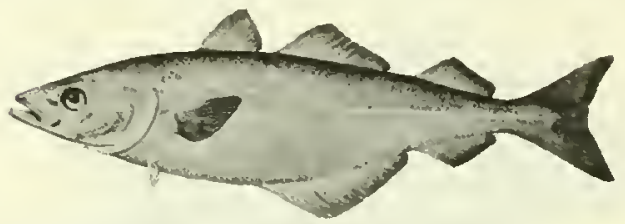

POLLOCK

RANGE - MIOOLE ATLANTIC AND NEW ENGLAND STATES GEAR - LONGLINES, FLOATING TRAPS, POUND NETS, OTTER TRAWLS, GILL NETS

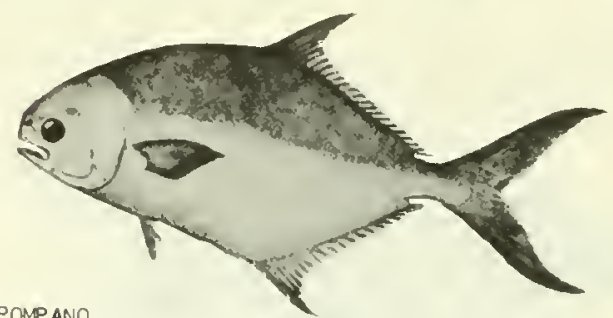

RANGE - TEXAS TO NORTH CAROL INA

GEAR - TRAMMEL NETS, HAUL SEINES, GILL NETS, HANOL INES

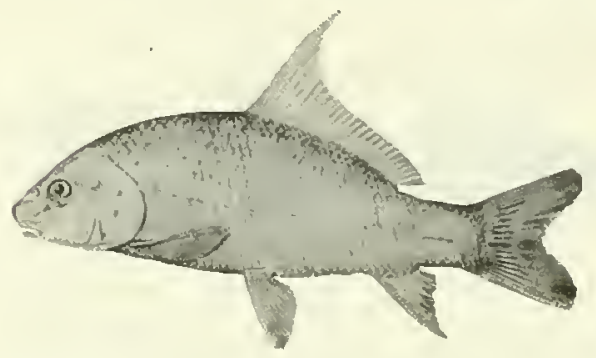

QU ILLBACK

RANGE - FRESH-WATER

GEAR - HAUL SEINES, TROTLINES, FYKE NETS 


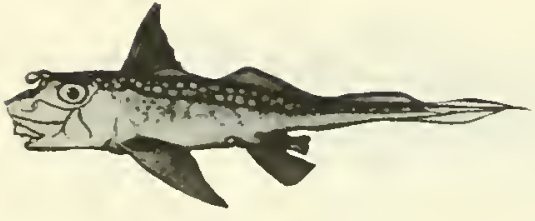

RATF ISH

RANGE - WASHINGTON TO ALASKA

GEAR - BEAM TRAWLS, LONGLINES

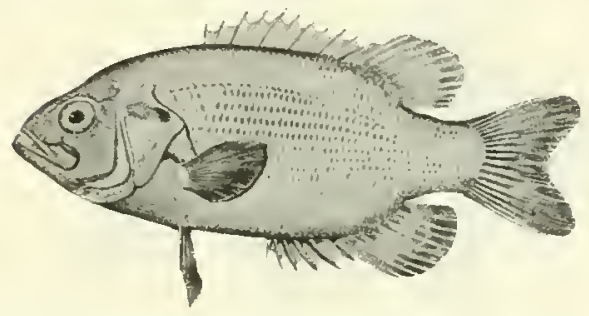

ROCK BASS

RANGE - GREAT LAKES

GEAR - TRAP NETS, FYKE NETS, HAUL SEINES, GILL NETS

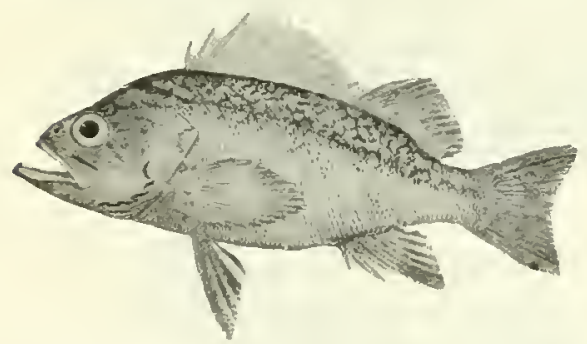

ROCKF ISH

RANGE - CALIFORNIA TO ALASKA

GEAR - LINES, OTTER TRAWLS, PARANZELLA NETS, GILL NETS

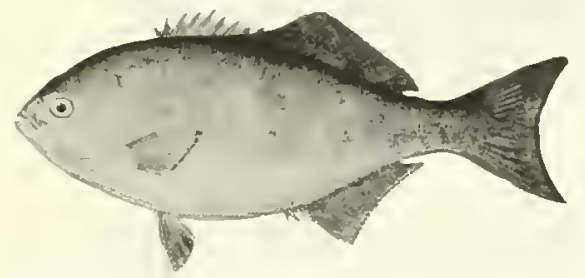

RUDOERF ISH

RANGE - CALIFORNIA

GEAR - LAMPARA AND RING NETS

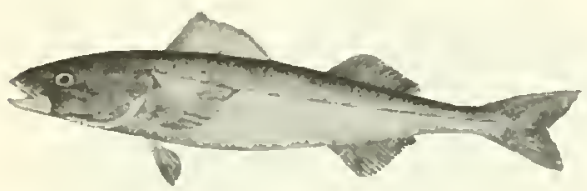

SABLEF ISH

RANGE - PACIFIC COAST STATES ANO ALASKA

GEAR - LONGLINES, OTTER TRAWLS

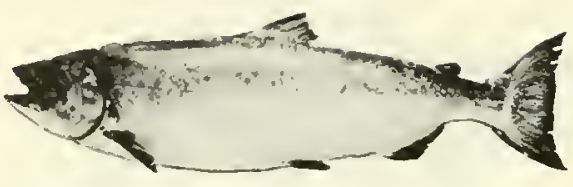

SALMON, CHINOOK OR KING

RANGE - CALIFORNIA TO ALASKA

GEAR - POJND NETS, PURSE SEINES, GILL NETS, HAUL SEINES, TROLL LINES, REEF NETS

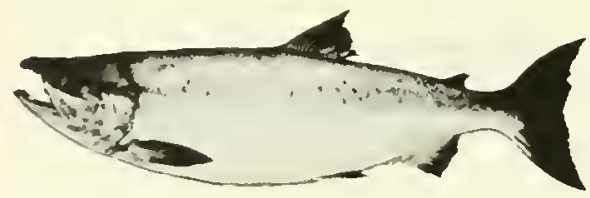

SALMON, CHUM OR KETA

RANGE - OREGON TO ALASKA

GEAR - POUNO NETS, PURSE SEINES, GILL NETS, HAUL SEINES, REEF NETS

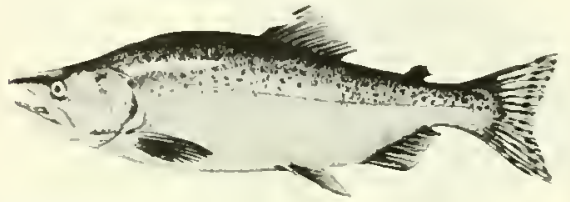

SALMON, PINK

RANGE - WASHINGTON TO ALASKA GEAR - PURSE SEINES, POUNO NETS, GILL NETS
REEF NETS

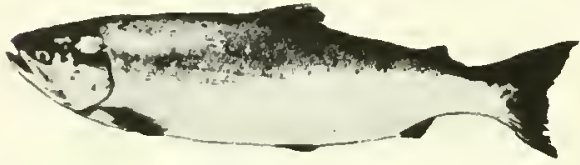

SALMON, REO OR SOCKEYE

RANGE - OREGON TO ALASKA

GEAR - GILL NETS, PURSE SEINES, POUNO NETS,
REEF NETS

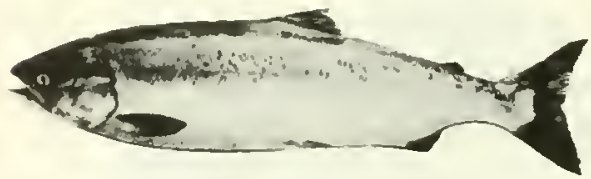

SALMON, SILVER OR COHO

RANGE - CALIFORNIA TO ALASKA

GEAR - HAUL SEINES, PURSE SEINES, GILL NETS, TROLL LINES, POUNO NETS, REEF NETS

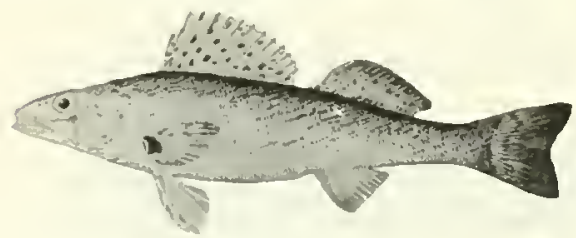

SAUGER

RANGE - GREAT LAKES

GEAR - GILL NETS, HAUL SEINES, TRAP NETS, FYKE NETS 


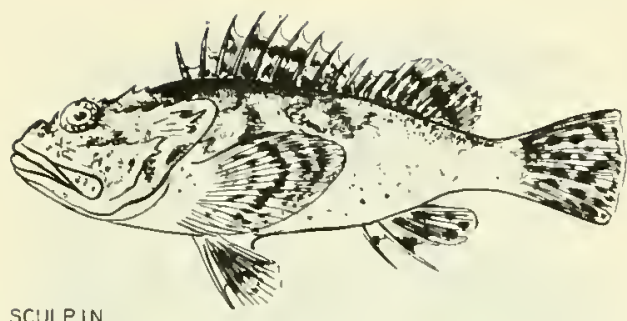

SCULPIN

RANGE - PACIFIC COAST STATES AND ALASKA

GEAR - LINES, GILL NETS, POTS

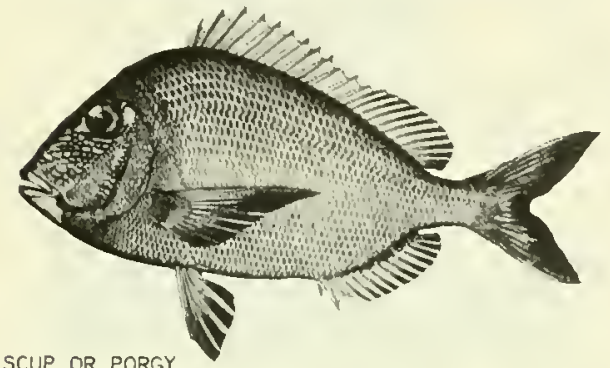

RANGE - FLORIDA TO NEW ENGLAND GEAR - OTTER TRAWLS, POUND NETS

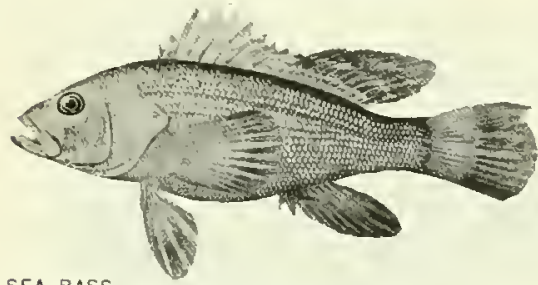

SEA BASS

RANGE - FLORIOA TO NEW ENGLAND

GEAR - OTTER TRAWLS, HANOLINES, POTS

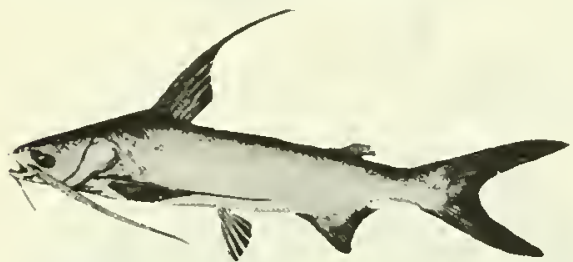

SEA CATF ISH

RANGE - TEXAS TO CHESAPEAKE BAY

GEAR - OTTER TRAWLS, HAUL SEINES, HANOLINES

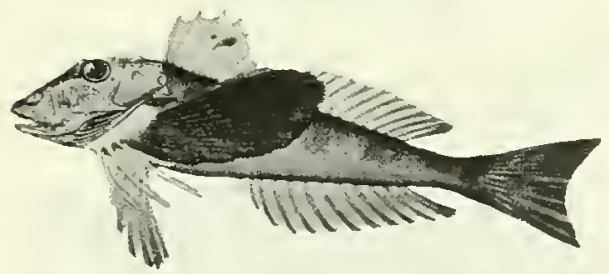

SEA ROBIN

RANGE - CHESAPEAKE BAY TO NEW ENGLAND

GEAR - POUNO NETS, OTTER TRAWLS

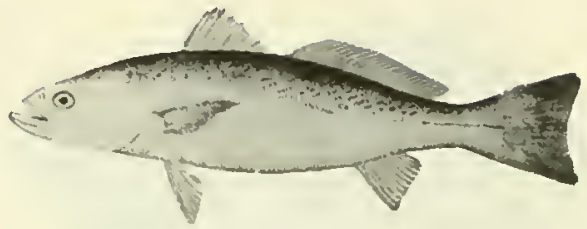

SEA TROUT OR WEAKF ISH, GRAY

RANGE - FLORIDA TO MASSACHUSETTS

GEAR - OTTER TRAWLS, POUND NETS, PURSE SEINES, GILL NETS, HAUL SEINES

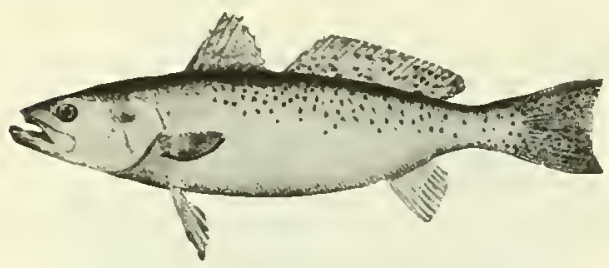

SEA TROUT OR WEAKF ISH, SPOTTED

RANGE - MARYLAND TO TEXAS

GEAR - GILL NETS, TRAMMEL NETS, HAUL SEINES, POUND NETS, OTTER TRAWLS, HANDLINES

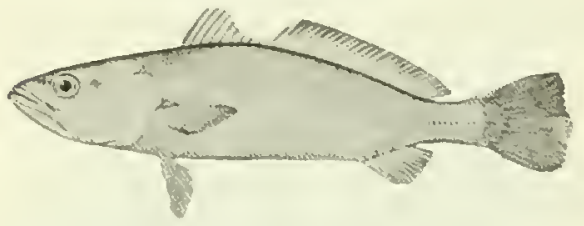

SEA TROUT OR WEAKFISH, WHITE

RANGE - GULF OF MEXICO

GEAR - GILL NETS, HAUL SEINES, HANOLINES

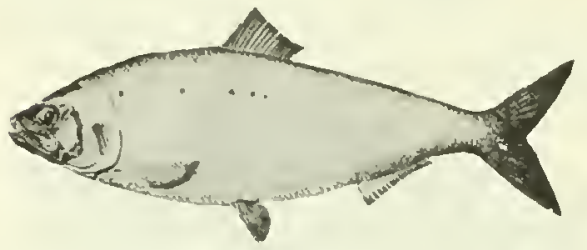

SHAO

RANGE - FLORIDA TO NEW ENGLANO

GEAR - GILL NETS, POUND NETS, FYKE NETS, HAUL SEINES

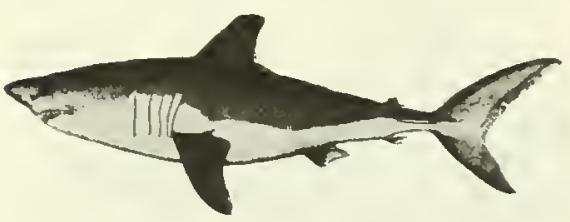

SHARK

RANGE - ATLANTIC COAST, GULF, PACIFIC COAST STATES GEAR - LONGLINES, GILL NETS, OTTER TRAWLS 


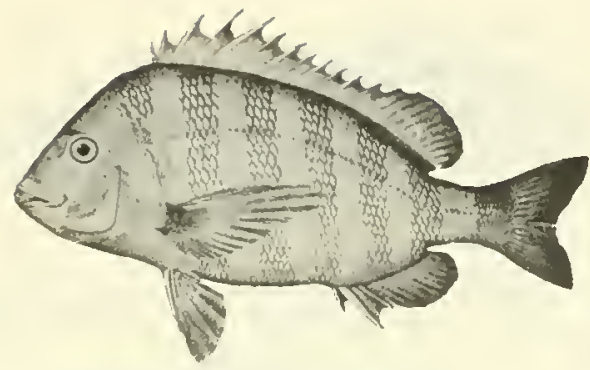

SHEEPSHEAD

RANGE - TEXAS TO CHESAPEAKE BAY

GEAR - HANDLINES, POTS

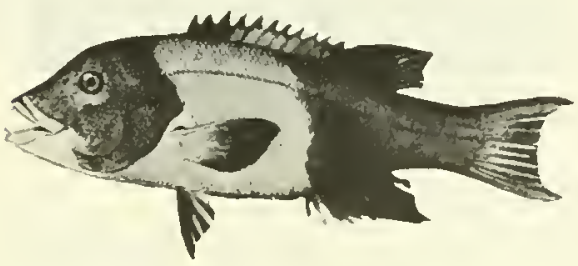

SHEEPSHEAO, CALIFORNIA

RANGE - CALIFORNIA

GEAR - LONGLINES. TRAMMEL NETS

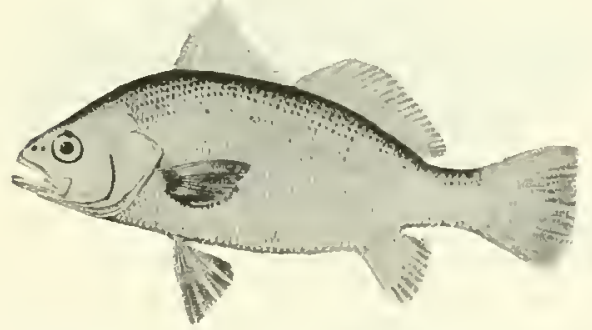

SAND PERCH

RANGE - TEXAS TO NEW YORK

GEAR - HAUL SEINES, GILL NETS, POUND NETS

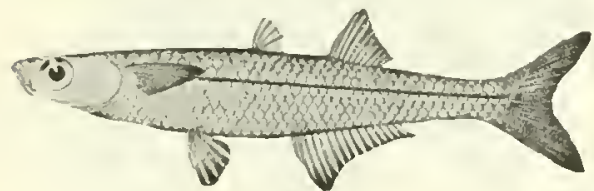

SILVERSIDES

RANGE - NEW YORK

GEAR - HAUL SEINES, OTTER TRAWLS

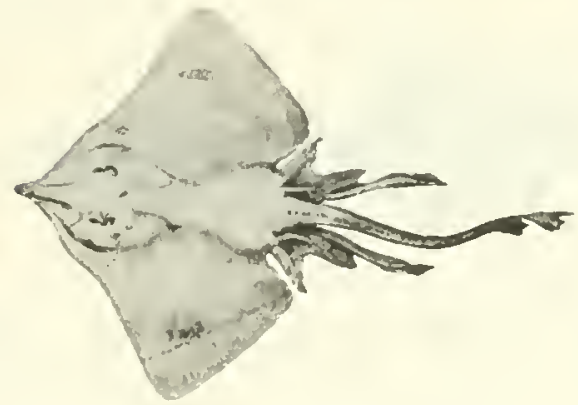

SKATE

RANGE - PACIFIC COAST, CHESAPEAKE BAY TO NEW ENGLANO GEAR - LINES, OTTER TRAWLS, POUND NETS, HAUL SEINES

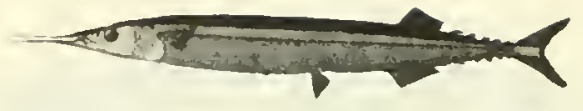

SKIPPER

RANGE - VIRGINIA TO NOVA SCOTIA

GEAR - POUND NETS, WEIRS

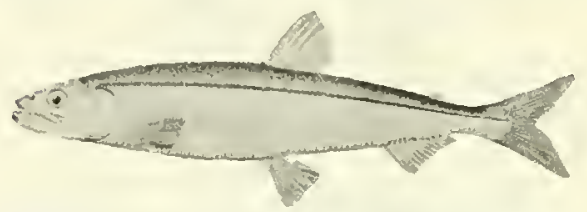

SMELT

RANGE - NEW YORK TO MAINE, PACIF IC OCEAN,

GEAR - POUNO NETS, DIP NETS, GILL NETS, HAUL SEINES

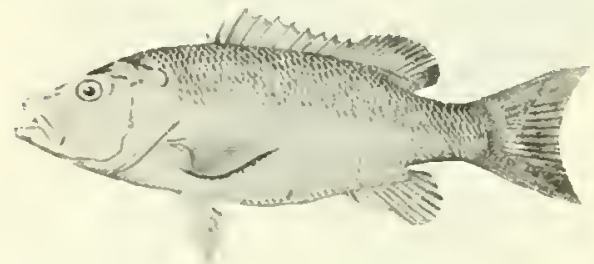

SNAPPER, MANGROVE

RANGE - FLORIDA

GEAR - HANDLINES, GILL NETS

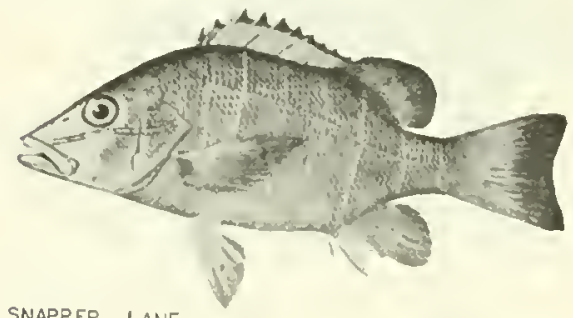

SNAPPER, LANE

RANGE - FLORIOA

GEAR - HANOL INES

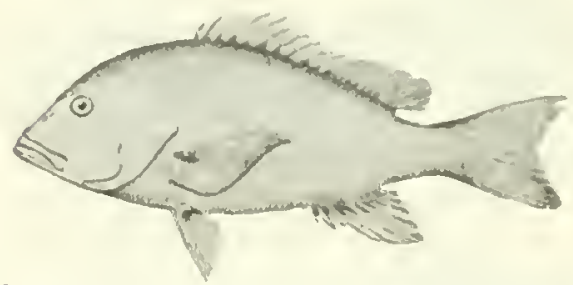

SNAPPER, REO

RANGE - TEXAS TO FLORIOA

GEAR - HANDL INES

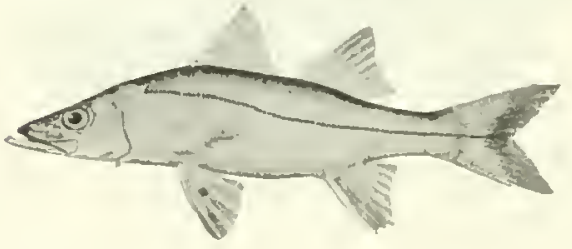

SNOOK

RANGE - TEXAS TO FLORIOA

GEAR - GILL NETS, HANDLINES, HAUL SEINES 


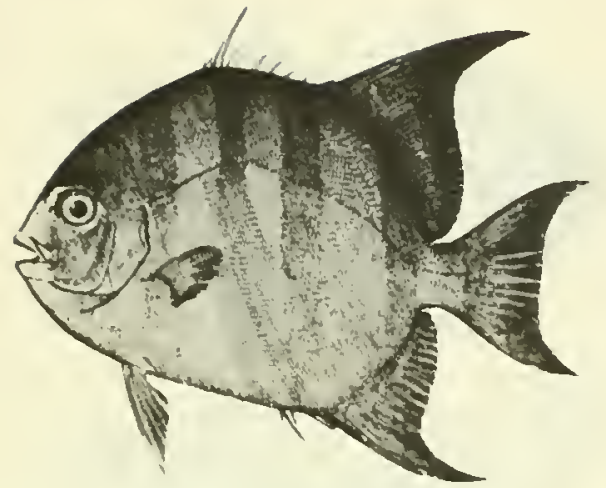

SPADEF ISH

RANGE - FLORIDA

GEAR - GILL NETS, TRAMMEL NETS

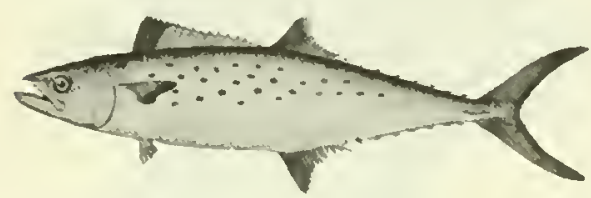

SPANISH MACKEREL

RANGE - TEXAS TO VIRGINIA

GEAR - GILL NETS, LINES, HAUL SEINES

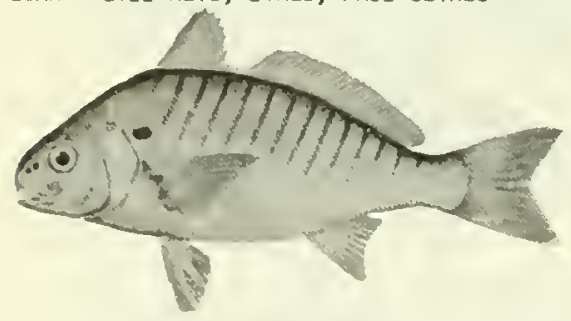

SPOT

RANGE - GULF OF MEXICO TO MIDOLE ATLANTIC STATES GEAR - HAUL SEINES, GILL NETS, POUND NETS, OTTER TRAWLS

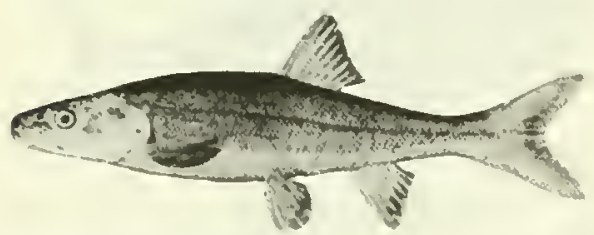

SQUAWF ISH

RANGE - CAL IFORNIA

GEAR - FYKE NETS, GILL NETS

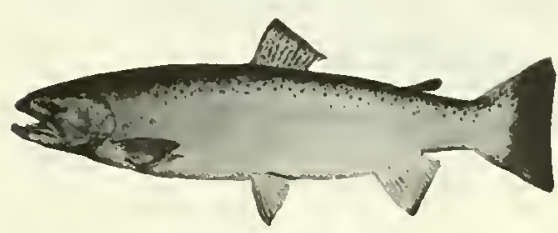

STEELHEAD TROUT

RANGE - OREGON TO ALASKA

GEAR - MAUL SEINES, POUND NETS, GILL NETS, LINES, DIP NETS

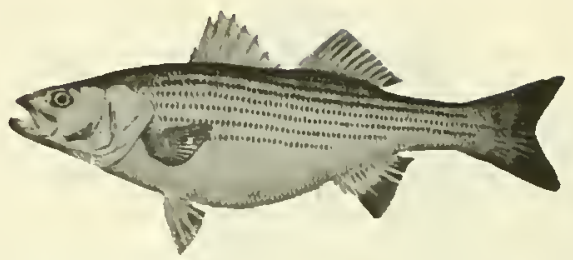

STRIPED BASS

RANGE - NORTH CAROLINA TO NEW ENGLAND, CALIFORNI TO OREGON

GEAR - HAUL SEINES, GILL NETS, POUND NETS, HANOLINES, FYKE NETS

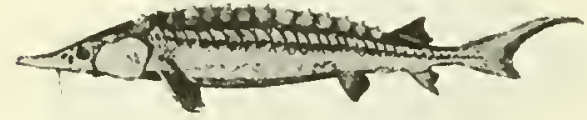

STURGEON

RANGE - COASTAL AND RIVER AREAS

GEAR - GILL NETS, LINES

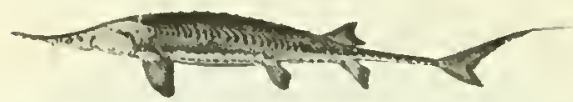

STURGEON, SHOVELNOSE

RANGE - FRESH-WATER

GEAR - HAUL SEINES, LINES, POUND NETS

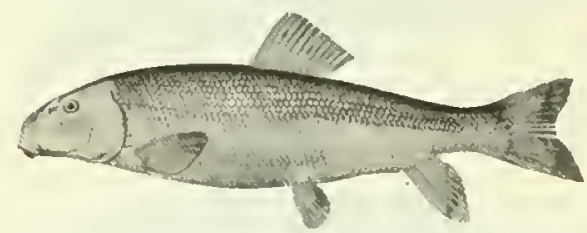

SUCKER

RANGE - FRESH-WATER

GEAR - POUND NETS, FYKE NETS, GILL NETS, HAUL SEINES, TRAP NETS

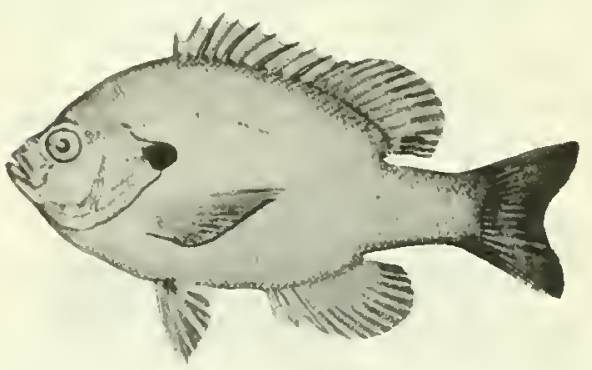

SUNF ISH

RANGE - FRESH-WATER

GEAR - POTS, SEINES, IRAP NETS

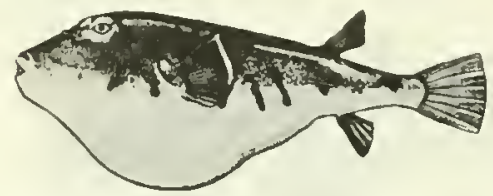

SWELLF ISH

RANGE - CHESAPEAKE BAY TO MIDDLE ATLANTIC

GEAR - POUND NETS, HAUL SEINES, OTTER TRAWLS 


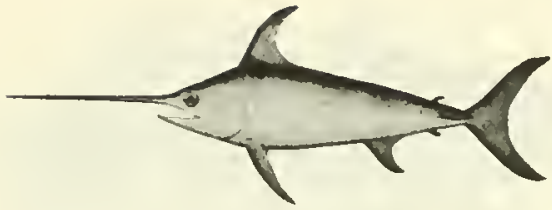

SWOROF ISH

RANGE - NEW ENGLAND AND CALIFORNIA GEAR - HARPOONS

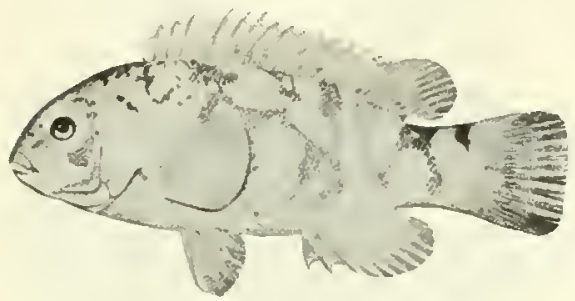

TAUTOG

RANGE - CHESAPEAKE BAY TO NEW ENGLANO GEAR - POUND NETS, HANOLINES, POTS

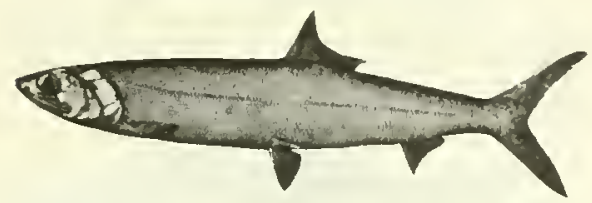

TENPOUNDER

RANGE - FLORIDA

GEAR - HAUL SEINES

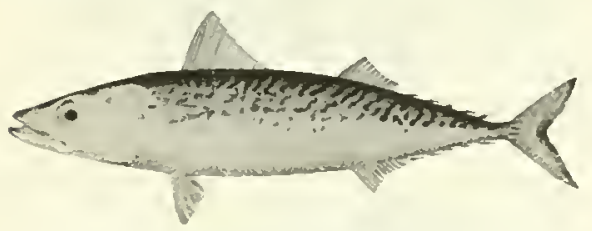

THIMBLE-EYEO MACKEREL

RANGE - CHESAPEAKE BAY TO NEW ENGLAND

GEAR - POUND NETS, PURSE SEINES, OTTER TRAWLS

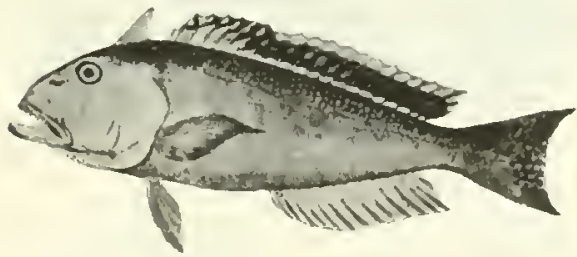

TILEF ISH

RANGE - MIOOLE ATLANTIC AND NEW ENGLAND STATES GEAR - LONGL INES, REEF NETS, OTTER TRAWLS

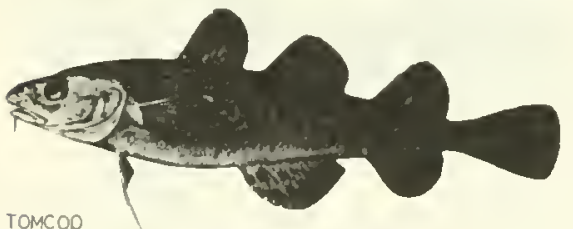

TOMCOO

RANGE - PACIFIC COAST, MIDOLE ATLANTIC AND NEW ENGLAND STATES

GEAR - OTTER TRAWLS, DIP NETS

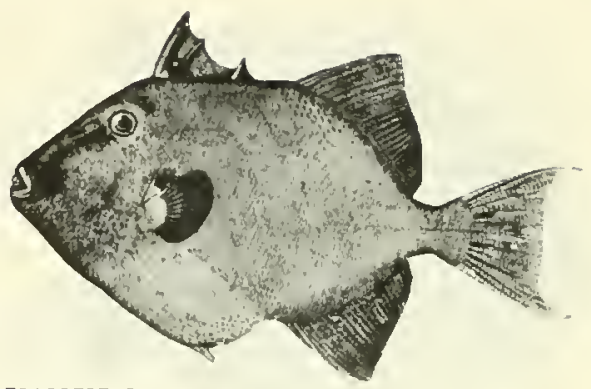

TRIGGERF ISH

RANGE - FLORIDA

GEAR - HANOLINES

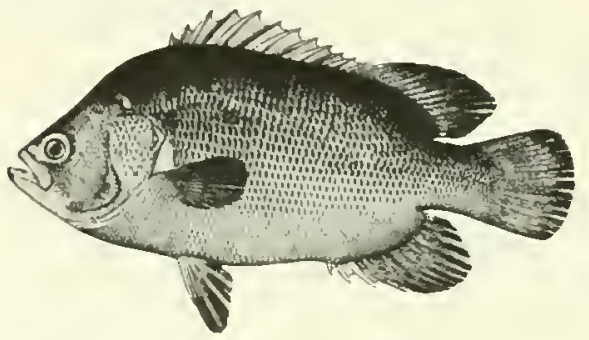

TRIPLETAIL

RANGE - FLORIDA

GEAR - HAUL SEINES, GILL NETS, LINES

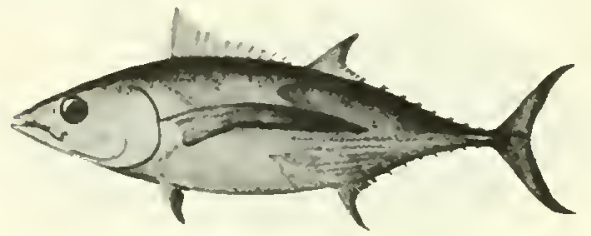

TUNA, ALBACORE

RANGE - PACIF IC COAST

GEAR - LINES

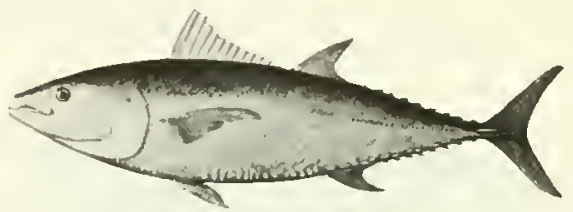

TUNA, BLUEFIN

RANGE - CALIFORNIA, NEW JERSEY TO MAINE

GEAR - PURSE SEINES, LAMPARA NETS, TROLL LINES, POUNO NETS, HARPOONS

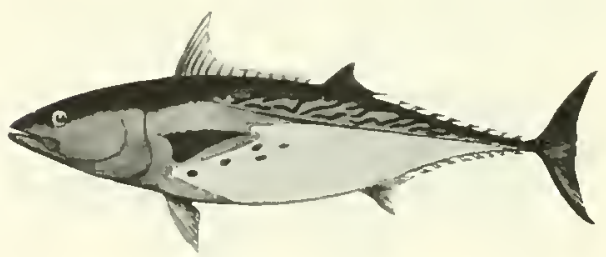

TUNA, LITTLE

RANGE - MASSACHUSETTS TO TEXAS

GEAR - POUND NETS, TROLL LINES, OTTER TRAWLS 


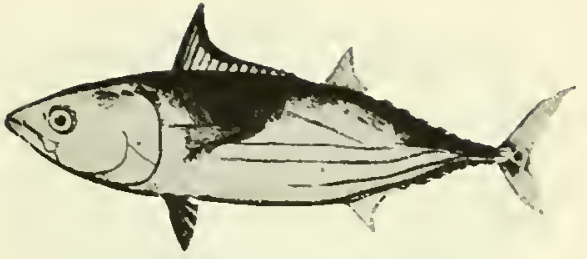

TUNA, SKIPJACK

RANGE - CALIFORNIA

GEAR - LINES AND PURSE SEINES

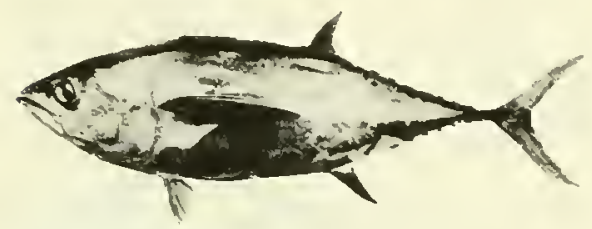

TUNA, YELLOWFIN

RANGE - PACIFIC

GEAR - LINES AND PURSE SEINES

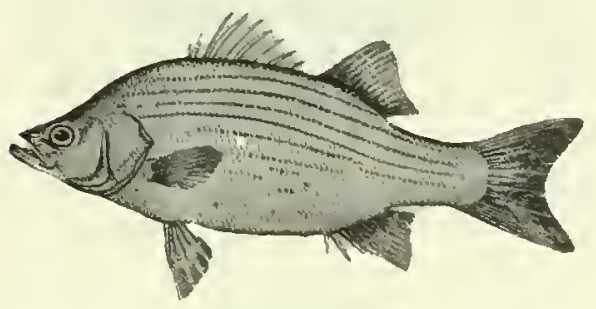

WHITE BASS

RANGE - GREAT LAKES

GEAR - TRAP NETS, FYKE NETS, HAUL SEINES, POUND NETS

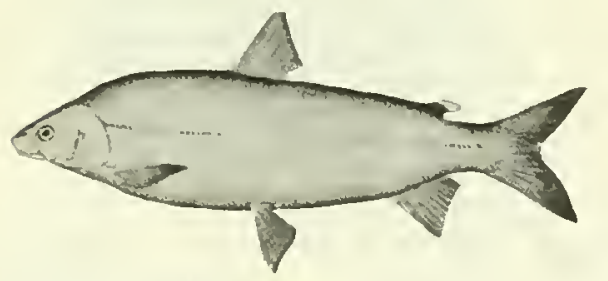

WHITEFISH, COMMON

RANGE - GREAT LAKES

GEAR - GILL NETS, POUND NETS, TRAP NETS

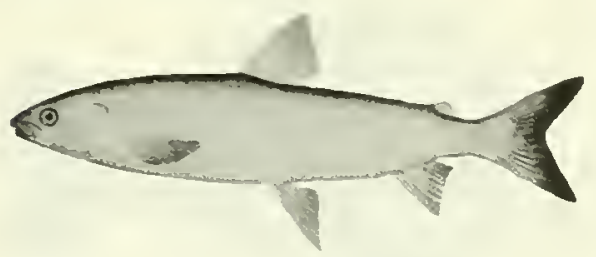

WHITEF ISH, MENOMINEE

RANGE - ALASKA, GREAT LAKES GEAR - GILL NETS, HAUL SEINES, TRAP NETS,
POUND NETS

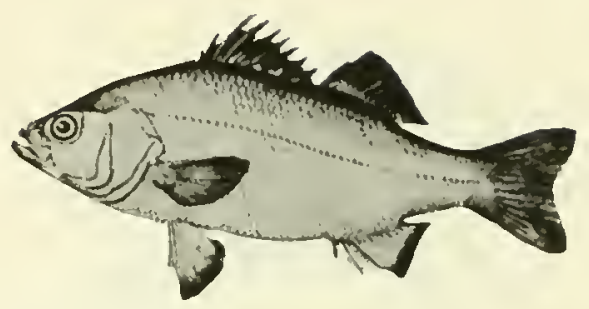

WHITE PERCH

RANGE - NORTH CAROL INA TO MAINE

GEAR - POUND NETS, FYKE NETS, HAUL SEINES

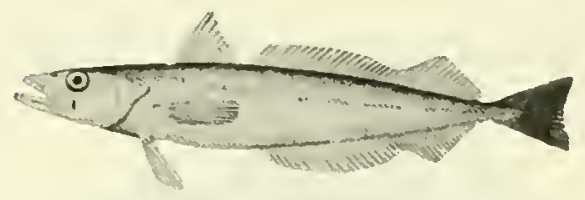

WHITING

RANGE - VIRGINIA TO MAINE

GEAR - OTTER TRAWLS, POUND NETS

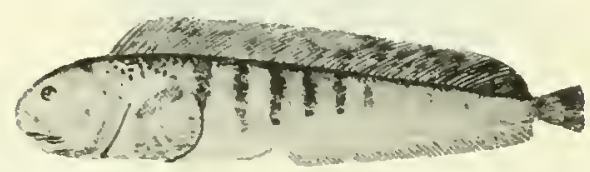

WOLFFISH

RANGE - MASSACHUSETTS AND MAINE GEAR - OTTER TRAWLS, LONGL INES

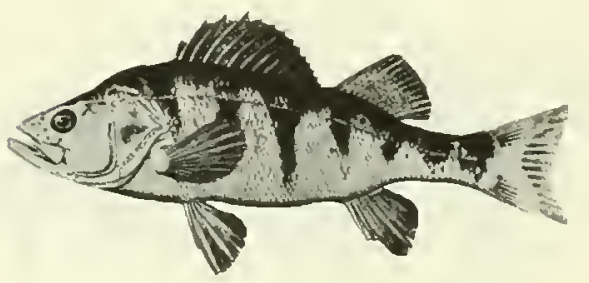

YELLOW PERCH

RANGE - GREAT LAKES, OTHER LAKES

GEAR - GILL NETS, TRAP NETS, POUND NETS, FYKE NETS

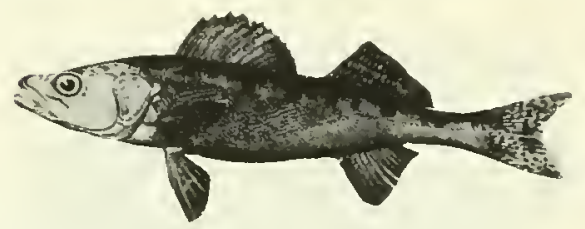

YELLOW PIKE

RANGE - GREAT LAKES

GEAR - POUND NETS, FYKE NETS, GILL NETS, TRAP INETS 


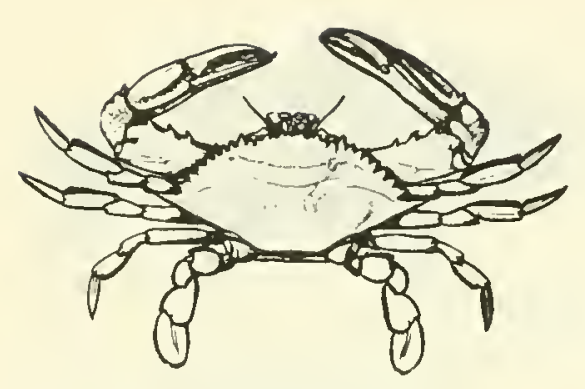

BLUE CRAB

RANGE - TEXAS TO RHODE ISLANO

GEAR - TROTLINES, POTS, FYKE NETS, DIP NETS, SCRAPES, OREOGES

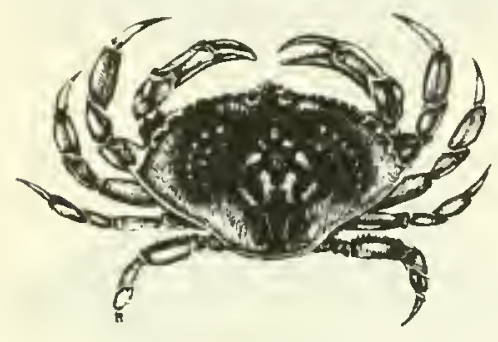

OUNGENESS CRAB

RANGE - PACIFIC COAST STATES ANO ALASKA GEAR - TRAPS

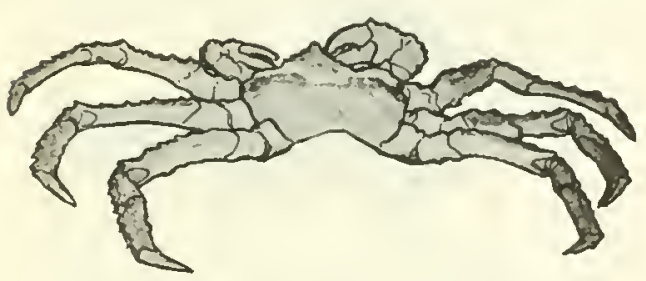

KING CRAB

RANGE - ALASKA

GEAR - POTS

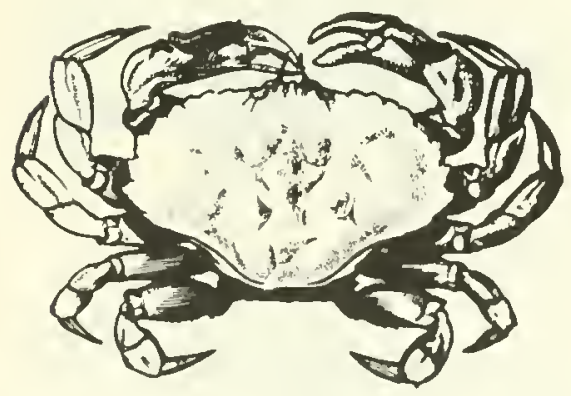

ROCK CRAB

RANGE - NEW ENGLAND

GEAR - POTS

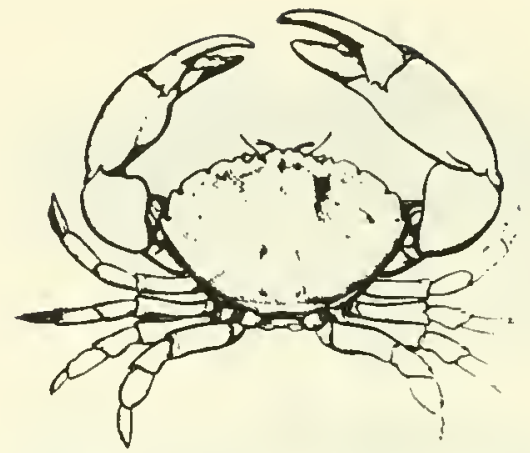

STONE CRAB

RANGE - FLORIOA

GEAR - OIP NETS, CRAB POTS

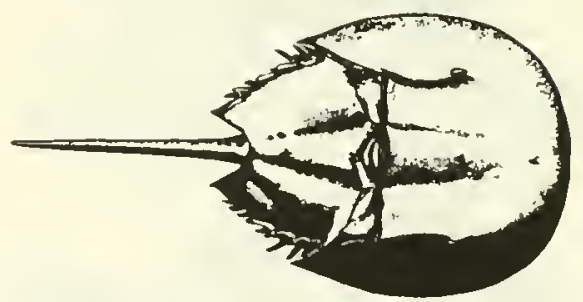

HORSESHOE CRAB

RANGE - MARYLANO TO NEW YORK

GEAR - POUND NETS, WEIRS, BY HANO

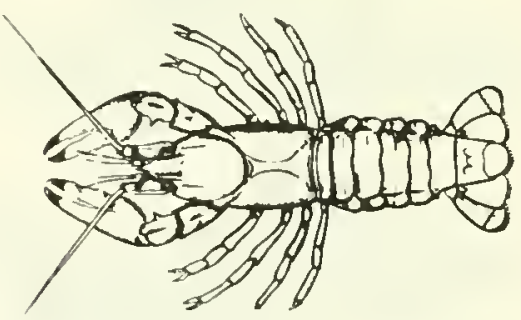

FRESH-WATER CRAWF ISH

RANGE - RIVERS AND LAKES GEAR - POTS

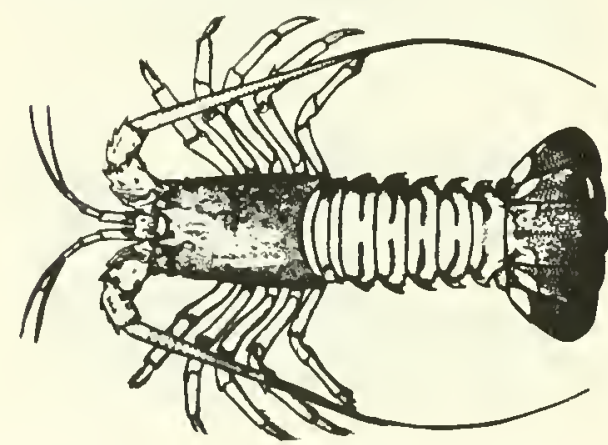

SPINY LOBSTER

RANGE - CALIFORNIA ANO FLORIOA GEAR - OIP NETS, POTS, HOOKS 


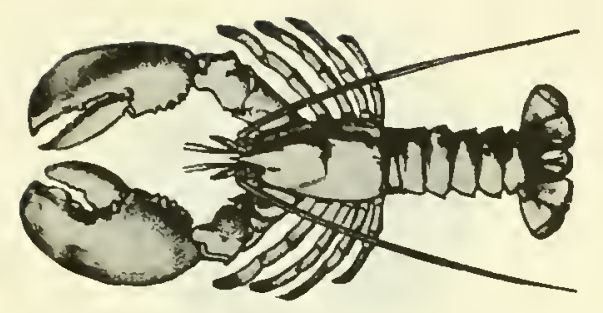

LOBSTER, AMERICAN

RANGE - VIRGINIA TO MAINE

GEAR - POTS, OTTER TRAWLS

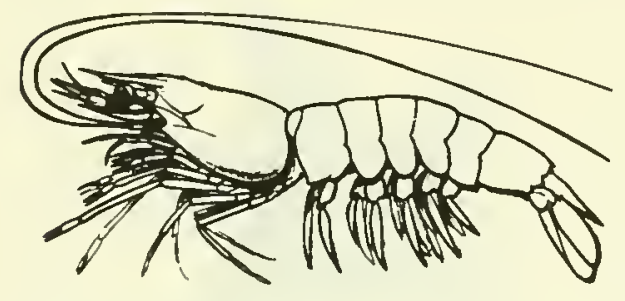

SHRIMP

RANGE - TEXAS TD NORTH CAROL INA, MAINE, GEAR - SHRIMP TRAWLS

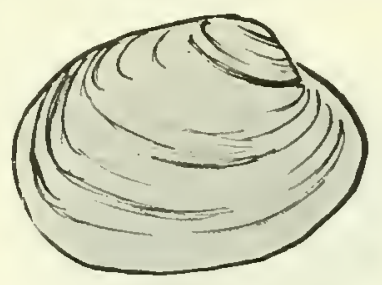

BUTTER CLAM

RANGE - PACIFIC COAST

GEAR - SHOVELS

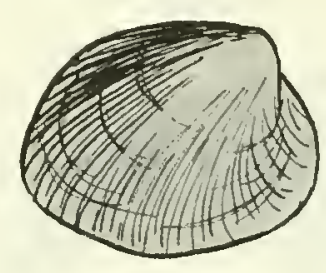

LITTLE NECK CLAM

RANGE - PACIFIC CDAST

GEAR - SHOVELS

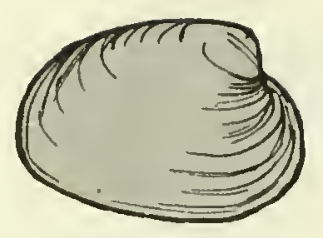

HARD CLAM

RANGE - FLDRIDA TO MAINE

GEAR - HOES, DREDGES, TONGS, RAKES, BY HAND

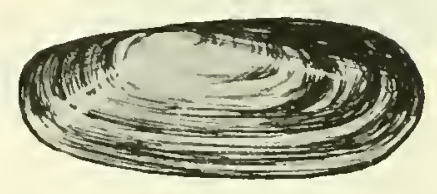

RAZDR CLAM, PACIFIC

RANGE - OREGON, WASHINGTON AND ALASKA GEAR - SHDVELS

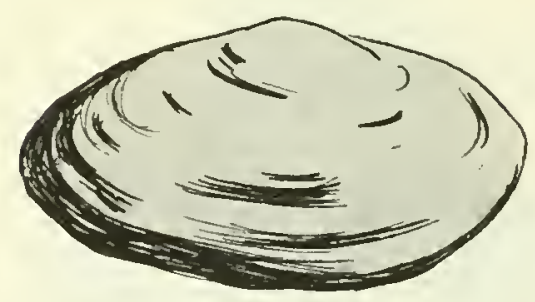

SDFT CLAM

RANGE - MIDDLE ATLANTIC TO NEW ENGLAND, GEAR - FORKS, HDES, RAKES, DREDGES
TACIFIC COAST STATES

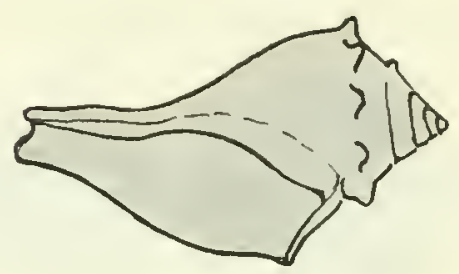

CONCH

RANGE - FLORIDA TO MAINE

GEAR - OTTER TRAWLS, DREDGES, POTS, AND BY HANO 


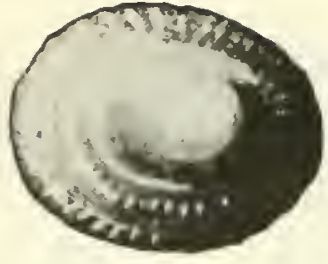

LIMPET

RANGE - NEW YORK AND NEW ENGLAND GEAR - OREDGES

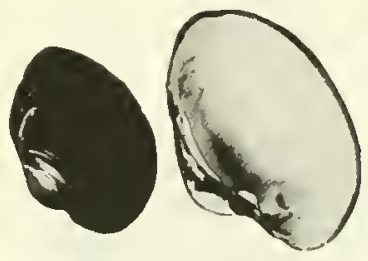

FRESH-WATER MUSSEL

RANGE - FRESH-WATER STREAMS

GEAR - CROWFOOT GARS, PICKS, HANO

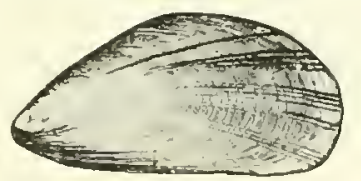

SEA MUSSEL

RANGE - NORTH CAROL INA TO MAINE

GEAR - DREOGES, TONGS, RAKES, HANO

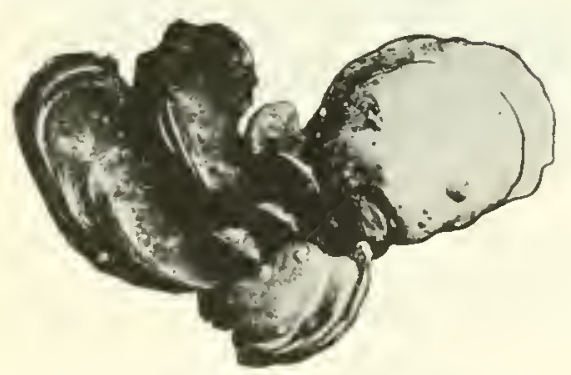

OYSTER

RANGE - TEXAS TO MASSACHUSETTS, PACIFIC COAST

GEAR - TONGS, DREDGES, RAKES, BY HAND

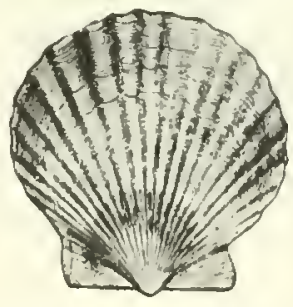

BAY SCALLOP

RANGE - FLORIDA TO MASSACHUSETTS, WASHINGTON

GEAR - DREDGES, SCRAPES, PUSH NETS, TONGS, RAKES OIP NETS

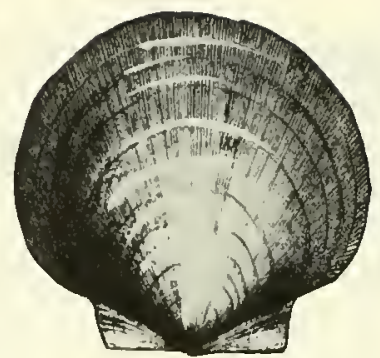

SEA SCALLOP

RANGE - NEW JERSEY TO MAINE

GEAR - OREDGES, OTTER TRAWLS

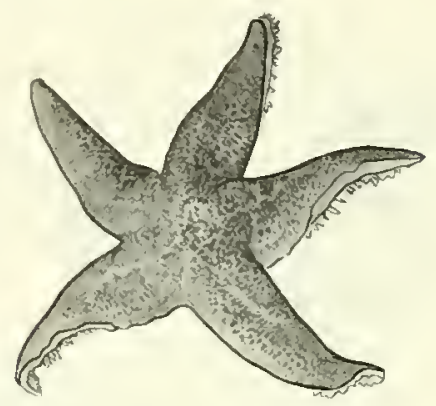

STAET́ I SH

RANGE - ATLANTIC AND PACIFIC COAST

GEAR - HOOKS, SCRAPES, "MOPS"

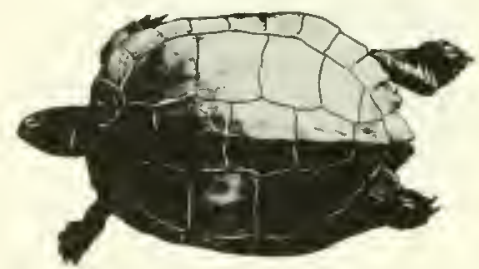

TERRAP IN

RANGE - TEXAS TO NEW JERSEY

GEAR - HAUL SEINES, BY HANO

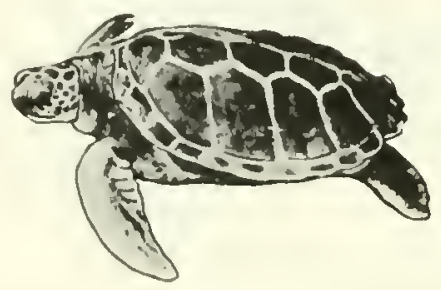

GREEN TURTLE

RANGE - FLORIOA

GEAR - GILL NETS 

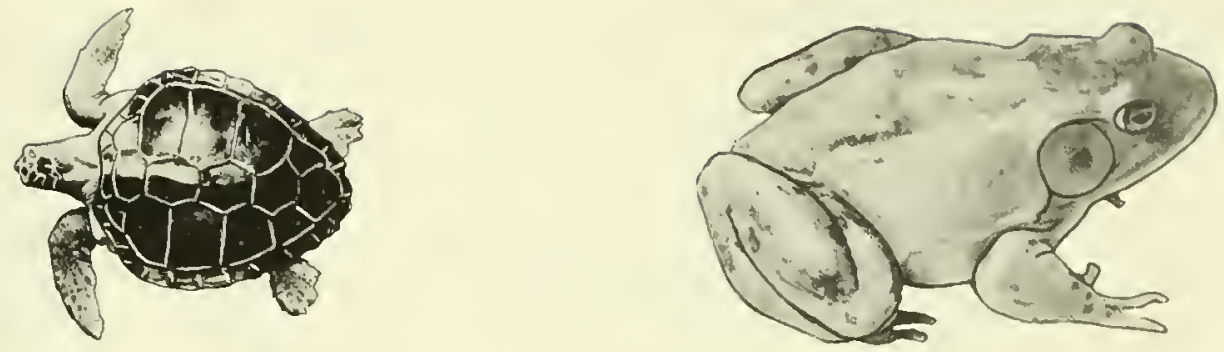

LOGGERHEAD TURTLE

RANGE - FLORIDA TO NEW JERSEY

GEAR - GILL NETS

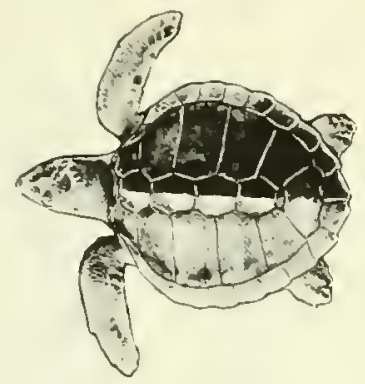

FROG

RANGE - FRESH-WATER, MARSHES, PONO GEAR - SPEARS, GRABS

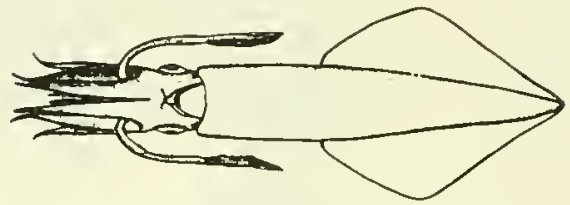

SQUID

RANGE - VIRGINIA TO MAINE, CALIFORNIA AND WASHINGTON

GEAR - LAMPARA NETS, GILL NETS, OTTER TRAWLS, POUNO NETS

HAWKSBILL TURTLE

RANGE - GULF OF MEXICO, AND ATLANTIC COAST TO NEW YORK

GEAR - BY HAND, POUND NETS
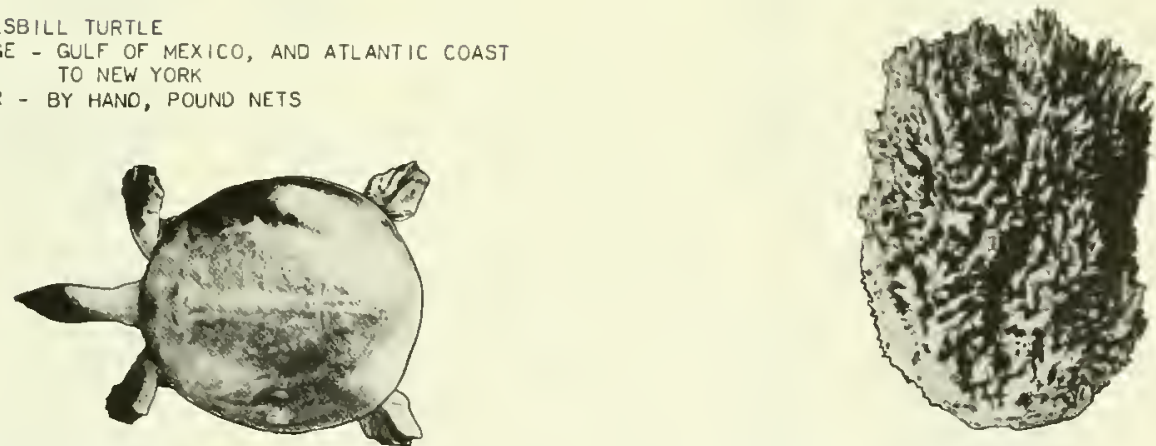

SOFT -SHELL TURTLE

RANGE - LAKES ANO RIVERS

GEAR - HAUL SEINES, FYKE NETS, POTS

SPONGE

RANGE - FLORIOA

GEAR - HOOKS, DIVING OUTFITS

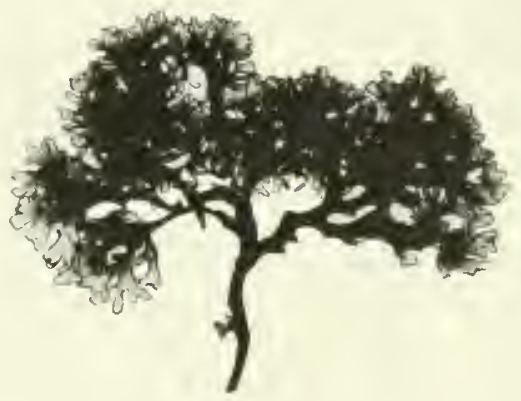

IRISH MOSS

RANGE - NEW ENGLAIND

GEAR - RAKES 
THE FOLLOWING LIST OF PUBLICATIONS INCLUOES ALL REPORTS ISSUED IN THE CURRENT FISHERY STATISTICS (C.F.S.) SERIES DURING 1975 .

C. F. S. NO. TITLE

CATCHES ANO LANOINGS:

\section{NATIONAL SURVEYS:}

6700

6574

6600

6558

6817

6820

6819

6822

6816

6821

6815

6818

\section{7 \\ 6666 \\ 6720 \\ 6685 \\ 6730 \\ 6750 \\ 6769 \\ 6809 \\ 6836}

6628

6788

6855

5875

6477

6497

6517

6537

6558

5587

5607

6627

6545

6665

5719

6645

6654

6718

6683

6728

6748

6767

6786

6807

6834

6853

5873

6892

UNITEO STATES, 1975 REGIONAL SURVEYS:

STATE SURVEYS:

\begin{tabular}{l} 
ALACAMA LANOINGS, \\
\hline OCTOBER 1974 \\
NOVEMBER 1974 \\
OECEMBER 1974 \\
ANNUAL SUMMARY 1974 \\
JANUARY 1975 \\
FEBRUARY 1975 \\
MARCH 1975 \\
APRIL 1975 \\
MAY 1975 \\
JUNE 1975 \\
JULY 1975 \\
AUGUST 1975 \\
SEPTEMBER 1975
\end{tabular}

FLORIDA LANOINGS,

MARCH 1974

APR IL 1974

MAY 1974

JUNE 1974

JULY 1974

AUGUST 1974

OCTOBER 1974

NOVEMBER 1974

OECEMEER 1974

ANNUAL SUMMARY 1974

\section{GEORGIA LANOINGS,}

\section{NOVEMBER 1974}

ANNUAL SUMMARY 1974

JANUARY 1975

FEBRUARY 1975

MARCH 1975

APRIL 1975

MAY 1975

JUNE 1975

JULY 1975

AUGUST 1975

OCTOBER 1975
FISHERIES OF THE UNITEO STATES, 1974

LIET OF FISHERY COOPERATIVES IN THE

PRICES RECEIVED BY FISHERMEN, 1939.74

GULF FISHERIES, ANNUAL SUMMARY 1972

SOUTH ATLANTIC FISHERIES, ANNUAL SUMMARY 1972

CHESAPEAKE FISHERIES, ANNUAL SUMMARY 1973

GREAT LAKES FISHERIES, ANNUAL SUMMARY 1973

GULF FISHERIES, ANNUAL SUMMARY 1973

HAWAII FISHERIES, ANNUAL SUMMARY 1973

MIODLE ATLANTIC FISHERIES, ANNUAL SUMMARY 1973

MISSISSIPP! RIVER FISHERIÉS, ANNUAL SUMMARY 1973

NEW ENGLANO FISHERIES, ANNUAL SUMMARY 1973

SOUTH ATLANTIC FISHERIES, ANNUAL SUMMARY 1973

SEPTEMBER 1974

DECEMEER 1974

SEPTEMBER 1975
C.F.S. NO.

TITLE

LOUISIANA LANDINGS,

6422

6630

6649

6668

6722

6687

6732

6752

6771

6790

6811

6838

6857

687

6409

6636

6655

6709

6674

6693

6739

6758

6717

6798

6825

6844

6864

6883

6414

6641

6650

6679

6698

6744

6763

6782

6803

5830

6849

6869

6888

6637

6656

6710

6675

6694

6740

6759

6778

5799

6826

6845

6865
ANNUAL SUMMARY 1973

OCTOBER 1974

NOVEMBER 1974

DECEMBER 1974

ANNUAL SUMMARY 1974

JANUARY 1975

FEBRUARY 1975

MARCH 1975

APR IL 1975

MAY 1975

JUNE 1975

JULY 1975

AUGUST 1975

SEPTEMEER 1975

MAINE LANOINGS,

ANNUAL SUMMARY 1973

NOVEMBER 1974

OECEMBER 1974

ANNUAL SUMMARY 1974

JANUARY 1975

APR IL 1975

MAY 1975

JUNE 1975

JULY 1975

AUGUST 1975

SEPTEMBER 1975

OCTOBER 1975

$\frac{\text { MARYLAND LAND INGS, }}{\text { ANNUAL SUMMARY } 1973}$

NOVEMBER 1974

DECEMBER 1974

JANUARY 1975

FEBRUARY 1975

MARCH 1975

APR IL 1975

MAY 9975

JUNE 1975

JULY 1975

AUGUST 1975

SEPTEMBER 1975

OCTOBER 1975

MASSACHUSETTS LAND INGS, NOVEMBER 9974

DECEMBER 1974

ANNUAL SUMMARY 1974

JANUARY 1975

FEBRUARY 1975

MARCH 1975

APR IL 1975

MAY 1975

JUNE 1975

JULY 1975

AUGUST 1975

SEPTEMBER 1975
FEBRUARY 1975

MARCH 1975 


\section{F. S. NO.}

\begin{tabular}{ll} 
& MISSISSIPPI LANDINGS, \\
\cline { 2 - 3 } 6421 & ANNUAL SUMMARY 1973 \\
6629 & OCTOBER 1974 \\
6648 & NOVEMBER 1974 \\
6667 & DECEMBER 1974 \\
6729 & ANNUAL SUMMARY 1974 \\
6686 & JANUARY 1975 \\
6731 & FEBRUARY 1975 \\
6751 & MARCH 1975 \\
6770 & APRIL 1975 \\
6789 & MAY 1975 \\
6810 & JUNE 1975 \\
6837 & JULY 1975 \\
6856 & AUGUST 1975 \\
6876 & SEPTEMBER 1975
\end{tabular}

NEW JERSEY LANOINGS,

DECEMBER 1974

ANNUAL SUMMARY 1974

JANUARY 1975

FEBRUARY 1975

MARCH 1975

APR IL 1975

MAY 1975

JUNE 1975

JULY 1975

AUGUST 1975

SEPTEMBER $19^{\circ} 75$

DCTOBER 1975

TITLE

6848

6868

6887

6639

6658

6712

6677

6696

6742

6761

6780

6801

6867

6886

6643

6662

6716

6681

6726

6746

6765

6784

6805

6832

6851

6871

6890

6411

6638

6657

6711

6676

6695

6741

5760

6779

6800

6827

6846

6866

6885

NEW YORK LANDINGS,

NOVEMBER 1974

DECEMBER 9974

ANNUAL SUMMARY 1974

JANUARY 1975

FEBRUARY 1975

MARCH 1975

APRIL 1975

MAY 1975

JUNE 1975

JULY 1975

AUGUST 1975

OCTOBER 1975

NORTH CARDLINA LANDINGS,

NOVEMBER 1974

DECEMBER 1974

ANNUAL SUMMARY 1974

JANUARY 1975

FEBRUARY 1975

MARCH 1975

APR IL 1975

MAY 1975

JUNE 1975

JULY 1975

AUGUST 1975

SEPTEMBER 1975

OCTOBER 1975

RHODE ISLAND LANDINGS,

ANNUAL SUMMARY 1973

DECEMBER 1974

ANNUAL SUMMARY 1974

JANUARY 1975

FEBRUARY 1975

MARCH 1975

APR IL 1975

MAY 1975

JUNE 1975

JULY $\$ 975$

AUGUST 1975

SEPTEMBER 1975

OCTDBER 1975
C. F. S. NO.

TITLE

SOUTH CAROLINA LANDINGS,

SEPTEMBER 1975

NOVEMBER 1974
664

6663

6717

6682

6727

6747

6766

6785

6806

6833

6852

6872

6891

6650

6669

6723

6688

6733

6753

6772

6791

6812

6839

6858

NOVEMBER 1974

DECEMBER 1974

ANNUAL SUMMARY 1974

JANUARY 1975

FEBRUARY 1975

MARCH 1975

APR IL 1975

MAY 1975

JUNE 1975

JULY 1975

AUGUST 1975

SEPTEMBER 1975

OCTOBER 1975

TEXAS LANDINGS,

NOVEMBER 1974

DECEMBER 1974

ANNUAL SUMMARY 1974

JANUARY 1975

FEBRUARY 1975

MARCH 1975

APR IL 1975

MAY 1975

JUNE 1975

JULY 1975

AUGUST 1975

5415

6642

6661

6680

5699

6745

6764

6783

6804

6831

6850

6870

6889

VIRGINIA LAND INGS,

ANNUAL SUMMARY 1973

NOVEMBER 1974

JANUARY 1975

FEBRUARY 1975

MARCH 1975

APRIL 1975

MAY 1975

JUNE 1975

JULY 1975

AUGUST 1975

SEPTEMBER 1975

DCTOBER 1975

SPECIES:

6633

6652

6671

6725

6690

6735

6755

6774

6793

6814

6841

6860

6632

6651

6651
6670

6724

6689

6734

6754

6773

6792

6813

6840

6859

6879

DECEMBER 1974
DECEMBER 1974
GULF COAST SHRIMP DATA,

OCTDBER 1974

NOVEMBER 1974

DECEMBER 1974

ANNUAL SUMMARY 1974

JANUARY 1975

FEBRUARY 1975

MARCH 1975

APR IL 1975

MAY 1975

JUNE 1975

JULY 1975

AUGUST 9975

SEPTEMBER 1975

SHR IMP LANDINGS

OCTOBER Tप74

NOVEMBER 1974

ANNUAL SUMMARY 1974

JANUARY 1975

FEBRUARY 1975

MARCH 1975

APRIL 1975

MAY 1975

JUNE 1975

JULY 1975

AUGUST 1975

SEPTEMBER 1975 
c. F, S, NO.

6701

6403

6635

6654

6673

6692

6738

6759

6776

6797

6824

6843

6863

6882

6704
6736
6795
6861

6653

6706

6672

6691

6737

6756

6775

6796

6823

6842

6862

6881

6926

6702

6708

6705

FROZEN FISHERY PRODUCTS,
COMMERCIAL FISHERIES PRODUCTS REPORTS:

IITLE

CANNEO FISHERY PRODUCTS, ANNUAL SUMMARY 1974

PROCESSEO FISHERY PROOUCTS, ANNUAL SUMMARY 1973

$\frac{\text { FISH MEAL ANO O1L. }}{\text { NOVEMBER } 1974}$.

ANNUAL SUMMARY 1974

JANUARY 1975

FEBRUARY 1975

MARCH 1975

APR II 1975

MAY 7975

JUNE 1975

JULY 1975

AUGUST 1975

SEPTEMBER 1975

OCTOBER 1975

FISH STICKS, FISH PORTIONS, AND
EREAOED SHRTMP,

ANNUAL SUMMARY 1974

JANUARY =MARCH 1975

APRIL-JUNE 1975

JULY-SEPTEMEER 1975

DECEMBER 1974

ANNUAL SUMMARY 1974

JANUARY 1975

FEBRUARY 1975

MARCH 1975

APRIL 1975

MAY 1975

JUNE 1975

JULY 1975

AUGUST 1975

SEPTEMBER 1975

OCTOBER 1975

NOVEMBER 1975

INOUSTRIAL FISHERY PRODUCTS, ANNUAL

SUMMARY 1974

U.S. PRODUCTION OF FISH FILLETS AND STEAKS, ANNUAL SUMMARY 1974

IMPORTS AND EXPORTS OF FISHERY PRODUCTS, ANNUAL SUMMARY 1974
C. F. S. NO.

BASIC ECONOMIC INDICATORS:

6794

CLAMS, 1947-74 


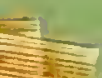

5 
NOAA--S/T 79-111 